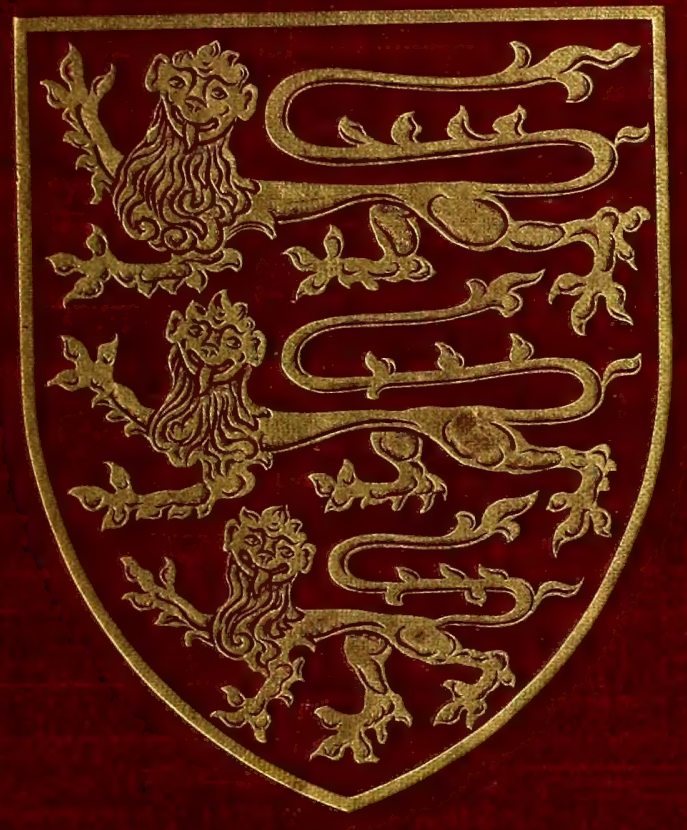




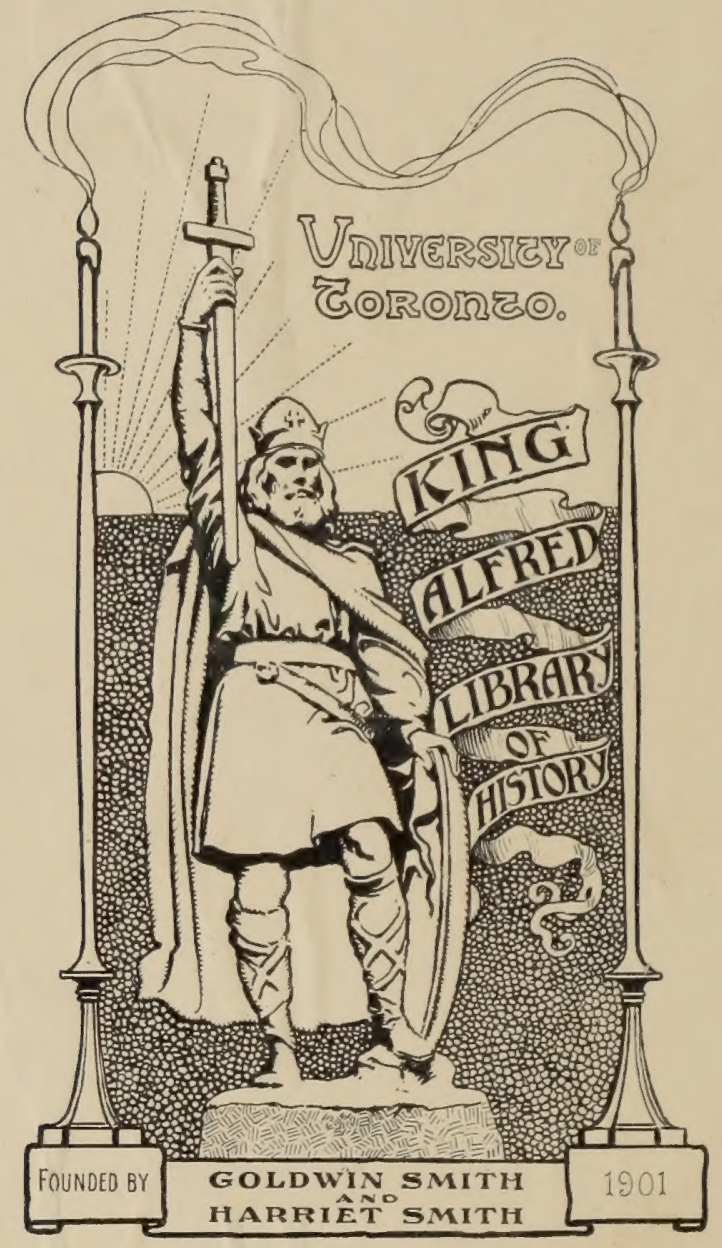



Digitized by the Internet Archive in 2013

http://archive.org/details/victoriahis01page 



\title{
The Victoria Ibistore of the Counties of England
}

\author{
EDITED BY WILLIAM PAGE, F.S.A.
}

A HISTORY OF

\section{SUFFOLK}

\author{
IN SIX VOLUMES \\ VOLU M E I
}




\section{THE \\ VIGTORIA HISTORY \\ OF THE COUNTIES \\ OF ENGLAND \\ SUFFOLK}

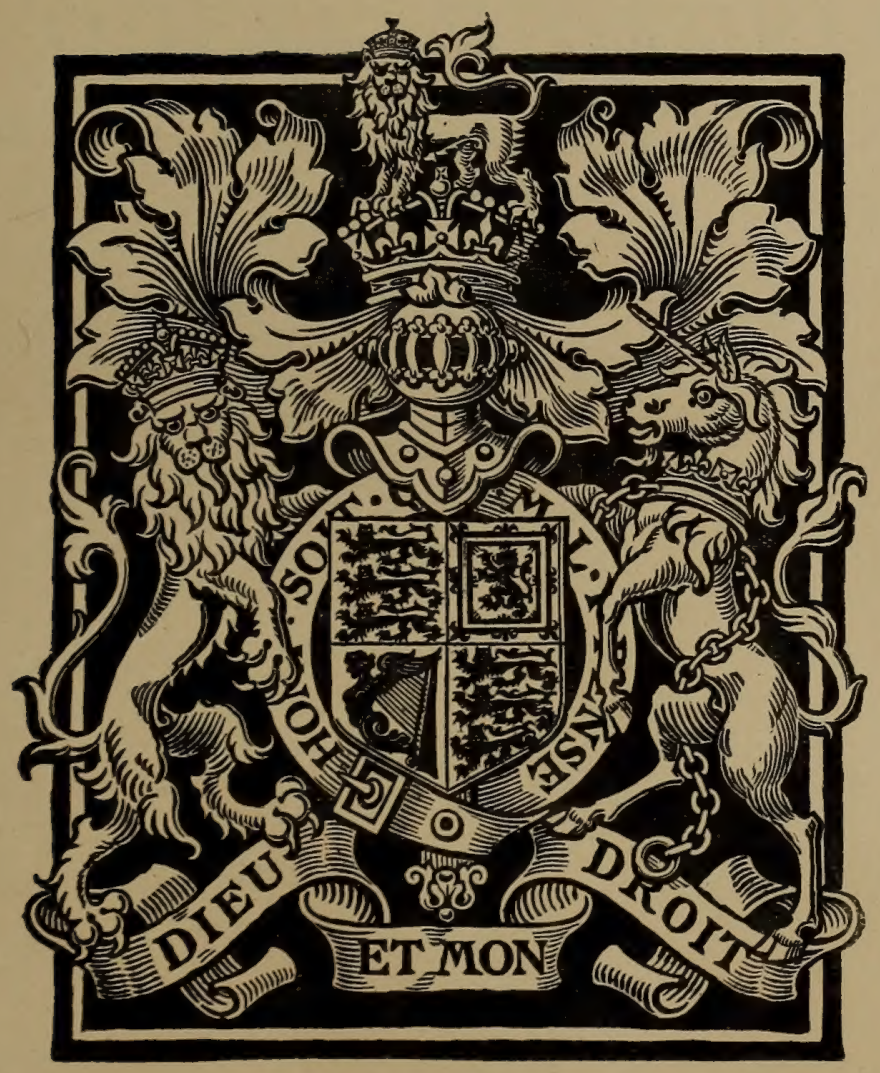

LONDON

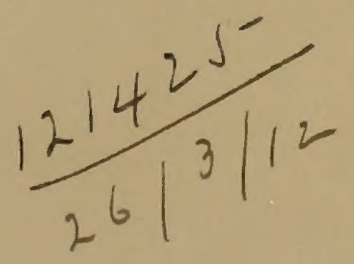

CONSTABLE AND COMPANY LIMITED 
This Hestory is issued to Subscribers only

By Constable \& Company Limited and printed by Eyre \& Spottiswoode Limited H.M. Printers of London 
I N S C R I B E D

TO THE MEMORY OF

HER LATE MAJESTY

QUEEN VICTORIA

W HO GRACIOUSLY GAVE

THE TITLE TO AND

A C C EPTED THE

DEDICATION OF

THIS HISTORY 



\section{THE ADVISORY COUNCIL}

\section{OF THE VICTORIA HISTORY}

His Grace The Lord Archbishop of Canterbury

His Grace The Duke of BEDFord, K.G.

Presidens of the Zoological Society

His Grace The DUKE OF Portland, K.G.

His Grace The Duke of ArgYLl, K.G., K.T.

The Rt. Hon. The Earl of Rosebery and Midlothian, K.G., K.T.

The Rt. Hon. The EarL of Coventry

Late President of the Royal Agricultural Society

The Rt. Hon. The Viscount Dillon

Late President of the Society of Antiquaries

The RT. Hon. The Lord Lister Late President of the Royal Society

The Rt. Hon. The Lord Alverstone, G.C.M.G. Lord Cbief Justice

The Hon. Walter Rothschild, M.P.

Thr RT. Hon. Sir Frederick Pollock, Bart., LL.D., F.S.A., вTC.
Sir Edward Maunde Thompson, K.C.B., D.C.L., LL.D.,F.S.A., ETC.

Late Director of the British Museum

Sir Clements R. Markham, K.C.B., F.R.S., F.S.A.

Late President of the Royal Geographical Society

Sir Henry C. Maxwell-Lyte, K.C.B., M.A., F.S.A., ETC.

Keeper of the Public Records

Sir E. Ray Lankester, K.C.B., LL.D., M.A., F.R.S., eTC. Late Director of the Nat. Hist. Museum, South Kensington

Sir Jos. Hooker, G.C.S.I., M.D., D.C.L, F.R.S., ETC.

Col. Sir Duncan A. Johnstun, K.C.M.G., C.B., R.E.

Late Director General of the Ordnance Survey

Sir Archibald Geikie, LL.D., F.R.S., ETC.

Rev. J. Charles Cox, LL.D., F.S.A., ETC.

Lionel Cust, M.V.O., M.A., F.S.A., ETC.

Late Directer of the National Portrait Gallery

Charles H. Firth, M.A., LL.D. Regius Professor of Modern History,
Oxford
Albert C. L. G. Günther, M.A., M.D., F.R.S., Pн.D.

Late President of the Linnean Society

F. Haverfield, M.A., LL.D., F.S.A.

Camden Professor of Ancient History

Reginald L. Poole, M.A., Ph.D.

University Lecturer in Diplomatic, Oxford

J. Horace Round, M.A., LL.D.

Walter Rye

W. H. Sr. Јонn Hope, M.A.

Among the original members of the Council were

The Late Duke of Devonshire

The Late Duke of Rutland

The Late Mareuess of Salisbury

The Late Dr. Mandell Creighton, Bishop of London

The Late Dr. Stubes, Bishop OF OXFORD

The Late LoRd Acton

The Late Sir William Flower

The Late Col. Sir J. FarquHARSON

Thr Late Sir John Evans

The Late Professor F. York PoWell

General Editor-William PAGE, F.S.A.

\section{GENERAL ADVERTISEMENT}

The Victoria History of the Counties of England is a National Historic Survey which, under the direction of a large staff comprising the foremost students in science, history, and archaeology, is designed to record the history of every county of England in detail. This work was, by gracious permission, dedicated to Her late Majesty Queen Victoria, who gave it her own name. It is the endeavour of all who are associated with the undertaking to make it a worthy and permanent monument to her memory.

Rich as every county of England is in materials for local history, there has hitherto been no attempt made to bring all these materials together into a coherent form.

Although from the seventeenth century down to quite recent times numerous county histories have been issued, they are very unequal in merit; the best of them are very rare and costly ; most of them are imperfect and many are now out of date. Moreover, they were the work of one or two isolated scholars, who, however scholarly, could not possibly deal adequately with all the varied subjects which go to the making of a county history. 
In the VICTORIA HISTORY each county is not the labour of one or two men, but of many, for the work is treated scientifically, and in order to embody in it all that modern scholarship can contribute, a system of co-operation between experts and local students is applied, whereby the history acquires a completeness and definite authority hitherto lacking in similar undertakings.

The names of the distinguished men who have joined the Advisory Council are a guarantee that the work represents the results of the latest discoveries in every department of research, for the trend of modern thought insists upon the intelligent study of the past and of the social, institutional, and political developments of national life. As these histories are the first in which this object has been kept in view, and modern principles applied, it is hoped that they will form a work of reference no less indispensable to the student than welcome to the man of culture.

\title{
THE SCOPE OF THE WORK
}

The history of each county is complete in itself, and in each case its story is told from the earliest times, commencing with the natural features and the flora and fauna. Thereafter follow the antiquities, pre-Roman, Roman, and post-Roman; ancient earthworks; a new translation and critical study of the Domesday Survey; articles on political, ecclesiastical, social, and economic history, architecture, arts, industries, sport, etc.; and topography. The greater part of each history is devoted to a detailed description and history of each parish, containing an account of the land and its owners from the Conquest to the present day. These manorial histories are compiled from original documents in the national collections and from private papers. A special feature is the wealth of illustrations afforded, for not only are buildings of interest pictured, but the coats of arms of past and present landowners are given.

\section{HISTORICAL RESEARCH}

It has always been, and still is, a reproach that England, with a collection of public records greatly exceeding in extent and interest those of any other country in Europe, is yet far behind her neighbours in the study of the genesis and growth of her national and local institutions. Few Englishmen are probably aware that the national and local archives contain for a period of 800 years in an almost unbroken chain of evidence, not only the political, ecclesiastical, and constitutional history of the kingdom, but every detail of its financial and social progress and the history of the land and its successive owners from generation to generation. The neglect of our public and local records is no doubt largely due to the fact that their interest and value is known to but a small number of people, and this again is directly attributable to the absence in this country of any endowment for historical research. The government of this country has too often left to private enterprise work which our continental neighbours entrust to a government department. It is not surprising, therefore, to find that although an immense amount of work has been done by individual effort, the entire absence of organization among the workers and the lack of intelligent direction has hitherto robbed the results of much of their value.

In the Victoria History, for the first time, a serious attempt is made to utilize our national and local muniments to the best advantage by carefully organizing and supervising the researches required. Under the direction of the Records Committee a large staff of experts has been engaged at the Public Record Office in calendaring those classes of records which are fruitful in material for local history, and by a system of interchange of communication among workers under the direct supervision of the general editor and sub-editors a mass of information is sorted and assigned to its correct place, which would otherwise be impossible.

\section{THE RECORDS COMMITTEE}

\author{
Sir Enward Maunde Thompson, K.C.B. \\ Sir HenRy MaXWell-Lyte, K.C.B. \\ W. J. Hardy, M.A., F.S.A. \\ F. MADAN, M.A. \\ C. T. Martin, B.A., F.S.A. \\ J. Horace Round, M.A., LL.D. \\ S. R. Scargill-Bird, F.S.A. \\ W. H. Strevenson, M.A.
}

G. F. W arner, M.A., D.Litt, F.S.A. 


\section{CARTOGRAPHY}

In addition to a general map in several sections, each History contains Geological, Orographical, Botanical, Archaeological, and Domesday maps; also maps illustrating the articles on Ecclesiastical and Political Histories, and the sections dealing with Topography. The Series contains many hundreds of maps in all.

\section{ARCHITECTURE}

A special feature in connexion with the Architecture is a series of ground plans, many of them coloured, showing the architectural history of castles, cathedrals, abbeys, and other monastic foundations.

In order to secure the greatest possible accuracy, the descriptions of the Architecture, ecclesiastical, military, and domestic, are under the supervision of Mr. C. R. Prers, M.A., F.S.A., and a committee has been formed of the following students of architectural history who are referred to as may be required concerning this department of the work :-

\section{ARCHITECTURAL COMMITTEE}

J. BILSON, F.S.A., F.R.I.B.A.

R. BLomfield, M.A., F.S.A., A.R.A. Harold Brakspear, F.S.A., A.R.I.B.A. Prof. G. Baldwin Brown, M.A.

ARTHUR S. Flower, M.A.

J. A. Gотсн, F.S.A., F.R.I.B.A.
W. H. St, John Hope, M.A.

W. H. KNoWles, F.S.A., F.R.I.B.A.

Roland Paul, F.S.A.

J. Horace Round, M.A., LL.D.

Percy G. Stone, F.S.A., F.R.I.B.A.

H. Thackrray Turner, F.S.A. 
The general plan of Contents and the names among others of those who are contributing articles and giving assistance are as follows:-

\section{Natural History}

Geology. Clement Reid, F.R.S., Horace B. Woodward, F.R.S., G. A. Lebour, M.A., J. E. Marr, D.Sc., F.R.S., and others

Palæontology. R. LydekKer, F.R.S., F.L.S., F.G.S.

Contributions by G. A. Boulenger, F.R.S., J. G. Baker, F.R.S., F.L.S., etc., G. C. Drucr, Flora M.A., F.L.S., Waltre Garstang, M.A., D.Sc., F.L.S., Rev. Canon A. M. Norman,

Fauna D.C.L., LL.D., F.R.S., Rev. Canon W. W. Fowler, M.A., D.Sc., F.L.S., F.E.S., Rev. O. Pickard-Cambridge, M.A., F.R.S., Rev. T. R. R. Stebing, M.A., F.R.S., etc., B. B. Woodward, F.G.S., F.R.M.S., etc. and other Specialists

Prehisturic Remains. W. Boyd Dawkins, D.Sc., LL.D., F.R.S., F.S.A., Ggo. Clinch, F.S.A. Scot., F.G.S., John Garstang, M.A., B.LitTr., F.S.A., and others

Roman Remains. F. Haverfield, M.A., LL.D., F.S.A., and others

Anglo-Saxon Remains. C. Hercules Read, LL.D., F.S.A., Regivald A. Smith, B.A., F.S.A., and others

Domesday Book and other kindred Records. J. Horace Round, M.A., LL.D., and other Specialists

Architecture. C. R. Prers, M.A., F.S.A., W. H. St. John Hope, M.A., Harold Braxspear, F.S.A., A.R.I.B.A., and others

Ecclesiastical History. R. L. Poole, M.A., Rev. H. Gee, D.D., F.S.A., Rev. J. C. Cox, LL.D., F.S.A., A. G. LitTle, M.A., and others

Political History. Prof. C. H. Firth, M.A., LL.D., D.Litt., F.S.A., W. H. Stevenson, M.A., J. Horace Round, M.A., LL.D., Prop. T. F. Tout, M.A., Prof. James Tait, M.A., and A. F. Pollard, M.A., F.R.Hist.Soc.

History of Schools. A. F. LEACH, M.A., F.S.A.

Maritime History of Coast Counties. Sir John K. Laughton, M.A., M. Oppenurim, and others Topographical Accounts of Parishes and Manors. By Various Authorities

Agriculture. Sir Ernest Clarke, M.A., Late Sec. to the Royal Agricultural Society, and others

Forestry. John NisBer, D.CEc., and others

Industries, Arts and Manufactures $\}$ By Various Authorities

Ancient and Modern Sport. E. D. Cuming, the Rzv. E. E. Dorling, M.A., and others

Cricket. Sir Homr Gordon, Bart. 



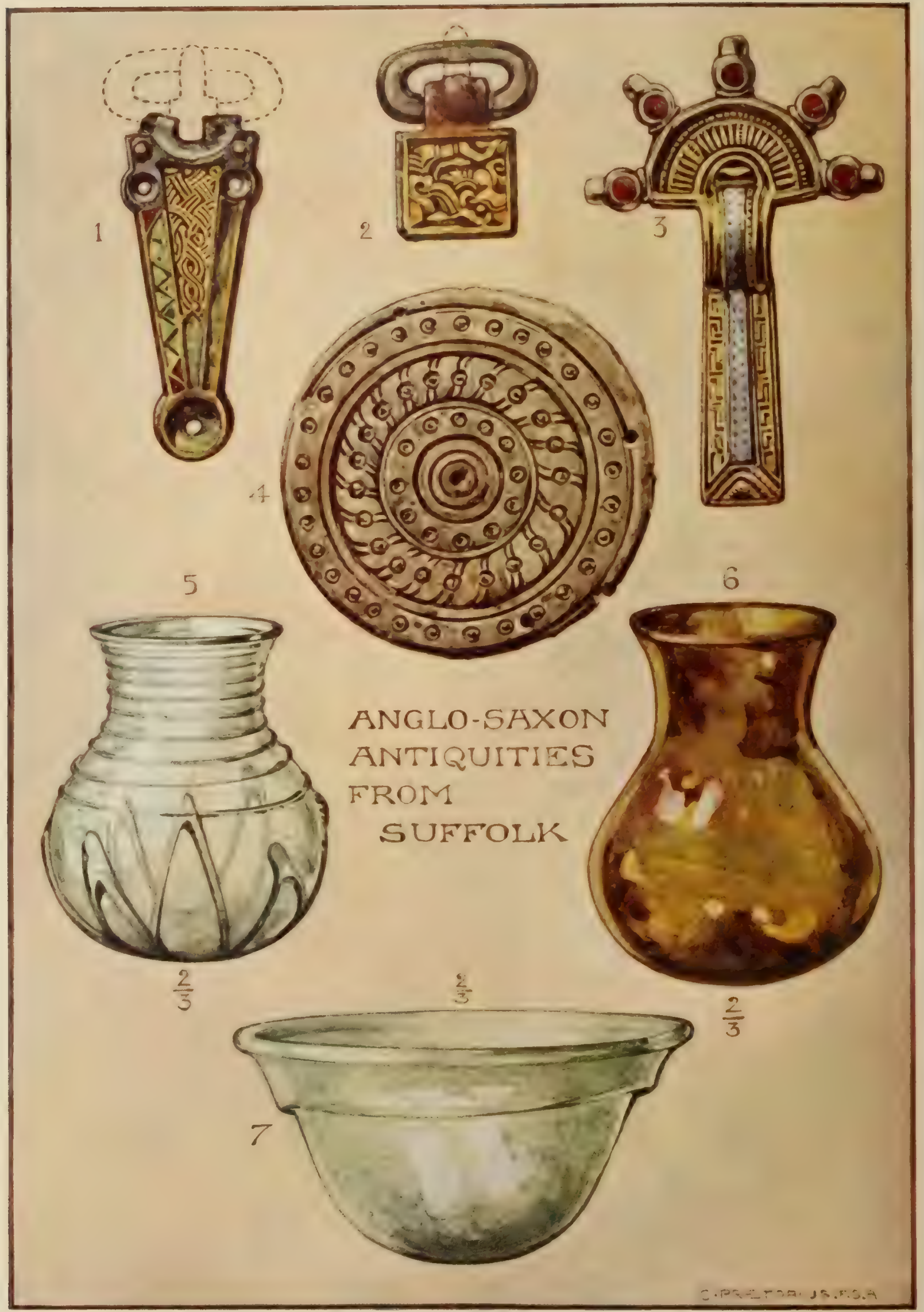




\section{THE}

\section{VICTORIA HISTORY}

OF THE COUNTY OF

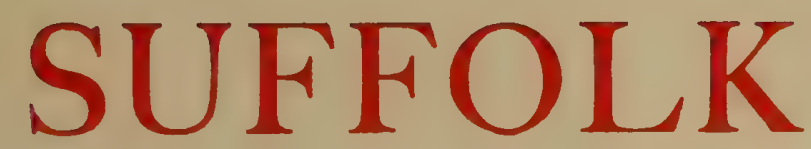

EDITED BY

W I L L I A M A G E, F.S.A.

VOLUME ONE

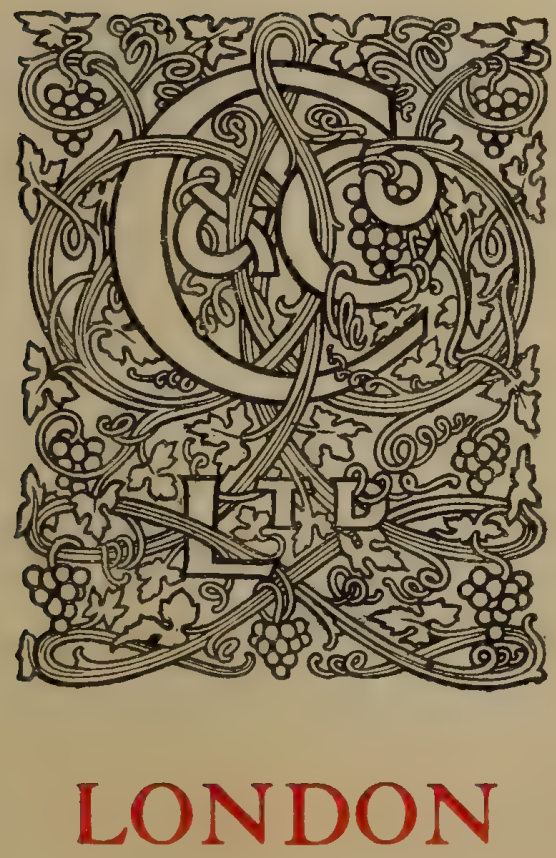

CONSTABLE AND COMPANY LIMITED

I9I I 
DA
670
$59 V_{6}$
V. 1 


\title{
County Committee for Fuffolk
}

\author{
FORMED IN I9O7
}

\section{THE MOST HON. THE MARQUESS OF BRISTOL \\ Lord Lieutenant, Chairman}

His Grace The Duke of Grafton, K.G.

The Rt. Hon. The Earl Cadogan, K.G.

The RT. Hon. The Earl Howe, G.C.V.O.

The Rt. Hon. The Earl of Stradbroke

The Rt. Hon. The Viscount Iveagh, K.P.

The Rt. Hon. The Lord Francis HERVEY

The Rt. Rev. The Lord Bishop of Ely

The Rt. Rev. The Lord Bishop of NORWICH

The Rt. Rev. The Brshop of Thetford

The Rt. Hon. The Lord de Saumarez

The Rt. Hon. The Lord Bateman

Col. The Hon. H. W. Lowry-Corry

The Rt. Hon. Sir William Brampton Gurdon, K.C.M.G., C.B.

The Hon. Stanhope Tollemache

The Rev. Sir William Hyde-Parker, BART.

Sir Ralph Blois, Bart.

Str Thomas Gooch, Bart.

Sir Collingwood Hughes, Bart.

Sir Charles Dalrymple, Bart.

Sir William Dunn, Bart.

Sir Cuthbert Quilter, Bart.

Sir E. Walter Greene, Bar'r.

Sir Ernest Clarke, M.A., F.S.A., F.L.S.

Sir Thomas H. Tacon, D.L.

The Worshipful The Mayor of AldeBURGH

The Worshipful The Mayor of Bury ST. EDMunds

The Worshipful The Mayor of IPsWich

The Worshipful The Mayor of SouthWCLD

The Worshipful The Mayor of SudBURY

W. C. Heaton Armstrong, Esq., M.P.

Col. N. Barnardiston, J.P., D.L.

Edward Beauchamp, EsQ, M.P.
E. F. Bisshopp, EsQ.

EDWARd Brooke, EsQ.

Henry C. Casley, Ese.

The Ven. Archdeacon Chapman, M.A.

T. B. Chevalier, Esq.

A. Townshend Cobbold, Esq.

John D. Cobbold, EsQ. J.P., D.L.

Russell Colman, EsQ.

W. A. Copinger, Ese., LL.D., F.S.A., F.R.S.A.

T. W. Cotman, Eso.

G. Milner-Gibson-Cullum, Eso., M.A., F.S.A.

The Rev. Francis J. Eld, M.A., F.S.A.

The Rev. E. Farrer, F.S.A.

Harry S. Foster, EsQ., J.P., D.L.

H. Rider Haggard, Ese., J.P.

G. A. HaRdY, EsQ., M.P.

The Rev. D. P. Harrison, M.A.

The Rev. J. F. A. Hervey, M.A.

The Rev. E. Hill, M.A.

The Rev. J. Holden, M.A.

J. Sancroft Holmes, Ese., J.P., D.L.

Oliver D. Johnson, EsQ., J.P.

Roger KerRison, EsQ., J.P.

Col. H. Mussenden Leathes

John Seymour Lucas, Ese., R.A.

George Manners, Ese., J.P., D.L.

T. Tindal Methold, EsQ., J.P.

Claude Morley, Esq., F.E.S.

Col. O. H. OAKES

R. H. Inglis Palgrave, EsQ., F.R.S., J.P.

Capt. E. G. Pretyman, J.P., D.L.

F. H. Pretyman, Eso.

CAPT. W. G. Probert

Vincent B. Redstone, EsQ., F.R.Hist.S.

F. S. Stevenson, Esq., B.A., J.P., D.L.

The Rev. Julian G. Tuck, M.A.

The Rev. Canon Warren, B.D., F.S.A.

B. Eaton White, EsQ., J.P.

JoHN Wood, Ese. 



\section{CONTENTS OF VOLUME ONE}

Dedication

The Advisory Council of the Victoria History

General Advertisement

The Suffolk County Committee .

\section{Contents}

List of Illustrations and Maps

Preface .

Table of Abbreviations

Natural History

Geology

Palaeontology

Botany

Introduction

Botanical Districts

List of Phanerogamia

Characeae (Stoneworts)

Musci (Mosses).

Hepaticae (Liverworts)

Freshwater Algae and Diatoms

Marine Algae .

Lichenes (Lichens)

Fungi

Zoology

Marine

Molluscs (Non-Marine)

Insects .

Orthoptera (Earwigs, Grasshoppers, Crickets, etc.)

Neuroptera (Dragon-files, Stonefies, Lacewings, etc.). .

Hymenoptera (Ants, Bees, Wasps, Saw-fies, Gall-fies, etc.)

Coleoptera (Beetles)

Lepidoptera (Butterflies and Motbs)

Diptera (Flies)

Hemiptera (Bugs).

Spiders .

BY H. B. WoodWARd, F.R.S., F.G.S. . . . I

By R. LYdrkKer, F.R.S., F.L.S., F.G.S. . 31

Edited by the Rev. E. N. Bloomfirld, M.A., F.E.S.

By C. E. Salmon

PACE

V

vii

vii

xiii

$\mathrm{xv}$

xvii

$\mathbf{x x i}$

xxiii

By the Rev. G. R. Bullock-Wrastrer, M.A. . . 69

By the Rev. E. N. Bloomfirld, M.A., F.E.S. . 7x

\begin{tabular}{|c|c|c|c|c|}
\hline " & $"$ & " & . & . \\
\hline$"$ & $"$ & " & • & 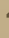 \\
\hline " & " & $"$ & - & . \\
\hline " & $"$ & " & • & 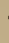 \\
\hline " & " & " & . & 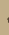 \\
\hline
\end{tabular}

By the late H. C. Sorby, LL.D., F.R.S., F.S.A. - 85

By B. B. WoodWard, F.L.S., F.G.S., F.R.M.S., and

A. Mayfield • • • • . . : 96

By Claude Morley, F.E.S. • • • • . 102

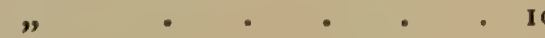

$\begin{array}{llllllll}\prime \prime & M & \cdot & \cdot & \cdot & \cdot & \cdot & 107 \\ \prime & \prime & \cdot & \cdot & \cdot & \cdot & \cdot & 122\end{array}$

By Claude Morley, F.E.S., and the Rev. E. N.

Bloomfirld, M.A., F.E.S. • • • . 128

By Claude Morley, F.E.S. • • • • . I35

" . • . . . $14 \mathrm{I}$ 


\section{CONTENTS OF VOLUME ONE}

Natural History-(continued)

\section{Zoology - (continued)}

Crustaceans

Fishes Reptiles and Batrachian

Birds

Mammals

Early Man

Palacolithic Age .

Neolithic Age

Topographical List of Palaeolithic and Neolithic Localities

Bronze Age

Early Iron Age .

Topographical List of Bronze Age and Early Iron Age Antiquities.

Romano-British Suffolk

Appendix on Santon Downham hoard Anglo-Saxon Remains

Introduction to the Suffolk Domesday .

Translation of the Suffolk Domesday . Ancient Earthworks

Social and Economic History

Part I.

Part II.

Table of Population 1801-1901
By the Rev. T. R. R. Stebring, M.A., F.R.S., F.Z.S. 153

By J. T. Cunningham, M.A. . . . . 163

By G. T. Rope . . . . . . 173

By the Rev. Julian Tuck, M.A. . . . 177

By G. T. Ropr . . . . . . 215

. . . . . . . 235

By W. Allen Sturge, M.V.O., M.D., F.R.C.P. , 235

By W. A. Dutт . . . . . 256

By Grorgr Clinch, F.G.S., F.S.A. (Scot.) • . 263

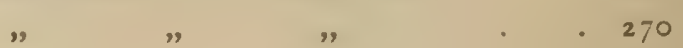

By the late Grorgr E. Fox, M.A., F.S.A. • 279

By Reginald A. Sмith, B.A., F.S.A. . . . 321

" " " " . . 325

By Beatrice A. LeEs, Oxford Honours School of Modern History . . . . . 357

Adapted from the Translation by the late Lord HerveY 418

By J. C. WALl . . . . . 583

. . . . . . . 633

By Professor Grorge Unwin, B.A. . . . 633

By Dorothy Kemp, Oxford Honours School of Modern History . . . . . 660

By Grorge S. Minchin . . . . $68_{3}$ 


\section{LIST OF ILLUSTRATIONS}

Anglo-Saxon Antiquities from Suffolk

PAGB

Early Man :

Plan of Mildenhall District

Sections of the Warren Hill Ridge

Flint Implements.

Plate I

Plate II

, ,

Plate III

,

Plate IV

$\left.\begin{array}{l}\text { Boyton: Gold Torque }{ }_{\text {Lakenheath : Bronze-Age drinking cup }}\end{array}\right\}$

coloured plate, frontispiece

Snape : Cinerary urn

Fornham : Celt

Lakenheath : Ceit

Mildenhall : Celt

Honington : Palstave

Mildenhall : Bronze finger-ring .

Ornament on lid of bronze box .

Westhall : Enamelled bronze harness-ring

Lakenheath : \$-shaped brooch with typical late Celtic ornament

$$
\text { " Small socketed bronze axe }
$$

Mildenhall : Iron bill-hook of the Early Iron Age.

Westhall : Bronze cylinders

Romano-British Suffolk :

Burgh Castle : Plan showing position . . . . . . . . . . 283

" " Plan of Gariannonum . . . . . . . . . . 284

Walton Castle : Plan showing position . . . . . . . . . . 287

Chart of entrance to Harwich Harbour in 1686 . . . . . . . . 288

Walton Castle: Ground plan and ruins

full-page plate, facing 288

Whitton: Fragment of mosaic pavement $\}$.

, " 290

Rougham : Contents of barrow

Barking Hall : Bronze figure

Icklingham : Pewter from the Acton Collection

Coddenham: Mirror case .

Cowlinge: Bronze jar or household god (Hercules)

" " " , (Mercury)

Herringfleet : Bronze vessel

Icklingham : Plan of Roman house, Horselands

Kesgrave: Medallion in terra cotta

Icklingham : Square pewter dish and other pieces.

Martlesham : Base of bronze figure

Melton : Plan of tile kiln 


\section{LIST OF ILLUSTRATIONS}

Anglo-Saxon Remains :

Snape : Cinerary ura . . . . . . . . . . . . 326

, Gold ring wit

Boat in grave-mound

Boat in grave-mound

,

$$
\text { , , " }
$$

Sutton near Woodbridge : Gold front of jewelled brooch 328

Ipswich : Bronze square-headed brooches . . . ? 330

" Square-headed and circular brooches and buckle I

fui:-pige plate, facing 332

Cinerary urns found in Suffolk. Plate III .

Ixworth : Bronze brooch.

Cinerary urns found in Suffolk. Plate IV.

Ixworth : Bronze-gilt disk-head of pin .

Two bronze mounts of sword-scabbard (?)

Akenhain Hall, Ipswich : Pair of long brooches

West Stow Heath : Bronze brooch

Warren Hill, Mildenhall : Bronze badge (?) of fish fo:m

Mitchell's Hill, Icklingham : Gilt-bronze buckle .

Ipswich : Iron axe-head

Mildenhall : Lead weight with bronze-gilt top

" Bronze-gilt broxch with silver mount:

" Part of bracelet-clasp

" Bronze brooch, once enamelled

Felixstowe : Lion brooch of bronze

Bronze brooch in form of bee

Blythburgh : Whale's bone tablet for writing

Ancient Earthworks :

Burgh (near Woodbridge) : Castle Field

Clare: Camp.

Burgh Castle

Chevington Hall Farm

Great Ashfield : Castle Hill

Orford Castle.

Bungay Castle.

Clare Castle.

Eye Castle

Framlingham Castle.

Denham Castle

Haughley Castle

Ilketshall St. John: The Mount

Lidgate Castle

Lindsey Castle

Milden Castle

Otley : Site of Castle

Gisleham Manor House: Moat round Site.

Mettingham Castle.

Wingfield Castle

Lawshall : The Warbanks

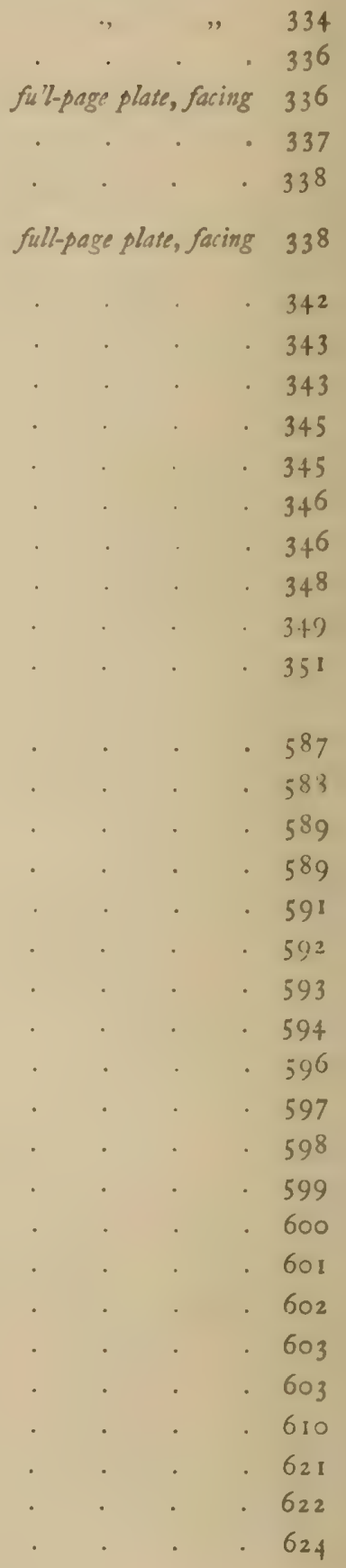




\section{LIST OF MAPS}

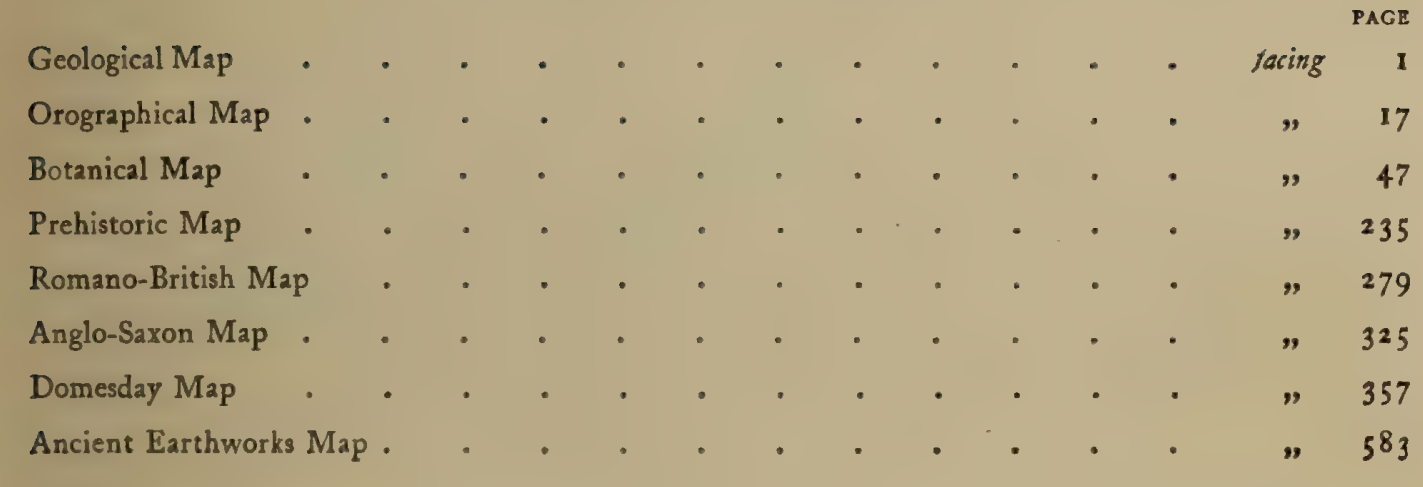





\section{PREFACE}

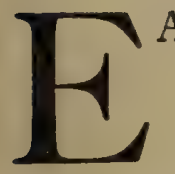

AST ANGLIA exhibits a peculiar difficulty to the county historian on account of the small size, and consequently the large number, of its parishes and manors. This is probably the cause of various unsuccessful attempts to write the history of Suffolk. Some of these efforts have so far matured as to reach the stage of the publication of one or two volumes, while others have not got beyond the stage of preliminary manuscript collections. The first to attempt a county history of Suffolk was John Gage, F.R.S., F.S.A., who, in 1838 , took the name of Rokewode. He published, in 1822, The History and Antiquities of Hengrave, in which parish was the family seat of his father and afterwards of his elder brother. In $183^{8}$ he issued the first volume of his proposed larger work, The History and Antiquities of Suffolk, containing the history of the hundred of Thingoe, the only part of his history which reached publication. His work is careful and exhaustive, and it is much to be regretted that it was not completed. His valuable collections for the continuation of the work are now preserved at Hengrave Hall. The next to take up the history of the county was Alfred Inigo Fox, LL.B., who, in 1820 , took the name of Suckling. He began the publication of his History and Antiquities of Suffolk in 1846, but, like Gage, he only completed the history of one hundred, that of Lothingland. Kirkby's Suffolk Traveller, published in 1848 , and its later edition, with supplement by Augustine Page, published in 1844 , cannot be strictly called county histories, although they contain much useful information. An admirable history of the county was undertaken by the late Mr. W. A. Coppinger, M.A., LL.D., F.S.A., who, in I905, published The Manors of Suffolk, with Notes on their History and Devolution. This volume contains the history of the hundreds of Babergh and Blackburn. In 1908 the second volume, including the hundreds of Blything, Bosmere, and Claydon, appeared. Dr. Coppinger's Materials for the History of Suffolk, containing references to sources for a history of the county, is of great value to all those interested in the topography of Suffolk. Besides the printed histories of the county, there are several manuscript collections for histories, principal among which are those of David Elisha Davy, B.A., which were purchased by the British Museum in 1852 (Add. MSS. 19077-19207); of Davy's friend, H. Jermyn, which were presented to the British Museum by Herbert Gurney in 1830 (Add. MSS. 8168-96); and of Craven Ord, F.R.S., F.S.A., most of whose collections are also now in the British Museum (Add. MSS. 7101-2, 8986-7). 


\section{PREFACE}

During the preparation of this volume the Editor has had to deplore the death of Mr. H. C. Sorby, LL.D., F.R.S., F.S.A., who left the rough draft of his article on the Marine Zoology of the county, the revision of the pronfs of which was generously undertaken by the Rev. Canon Norman, D.C.L. The Editor also greatly regrets the loss of his old and much esteemed friend, Mr. George E. Fox, Hon. M.A., F.S.A., whose profound knowledge of Roman archaeology and kindly sympathy endeared him to a large circle of friends. Mr. Fox died before finally revising the proofs of his article on the Roman Remains of the county, for the correction of which the Editor is responsible. The late Canon Raven was to have written the articles on Early Man and the AngloSaxon Remains of the county, but died before commencing the work.

The Editor has to express his thanks to Lord Francis Hervey for advice and assistance; to the Society of Antiquaries, the Suffolk Institute of Archaeology and Natural History, the British Archaeological Association, the Royal Archaeological Institute, the Prehistoric Society of East Anglia, Mr. C. D. Pridden, M.A., Mr. Frank Woolnough, Mr. W. Allen Sturge, M.V.O., M.D., F.R.C.P., and Miss Nina Layard, for illustrations and information; and to $\mathrm{Mr}$. Vincent Redstone for his ready help in many ways while passing the sheets through the press.

Owing to unforeseen circumstances there has been a delay in the publication of this volume; hence it is possible that works issued during the past year, touching upon the subjects with which it deals, may not have been consulted. 


\section{TABLE OF ABBREVIATIONS}

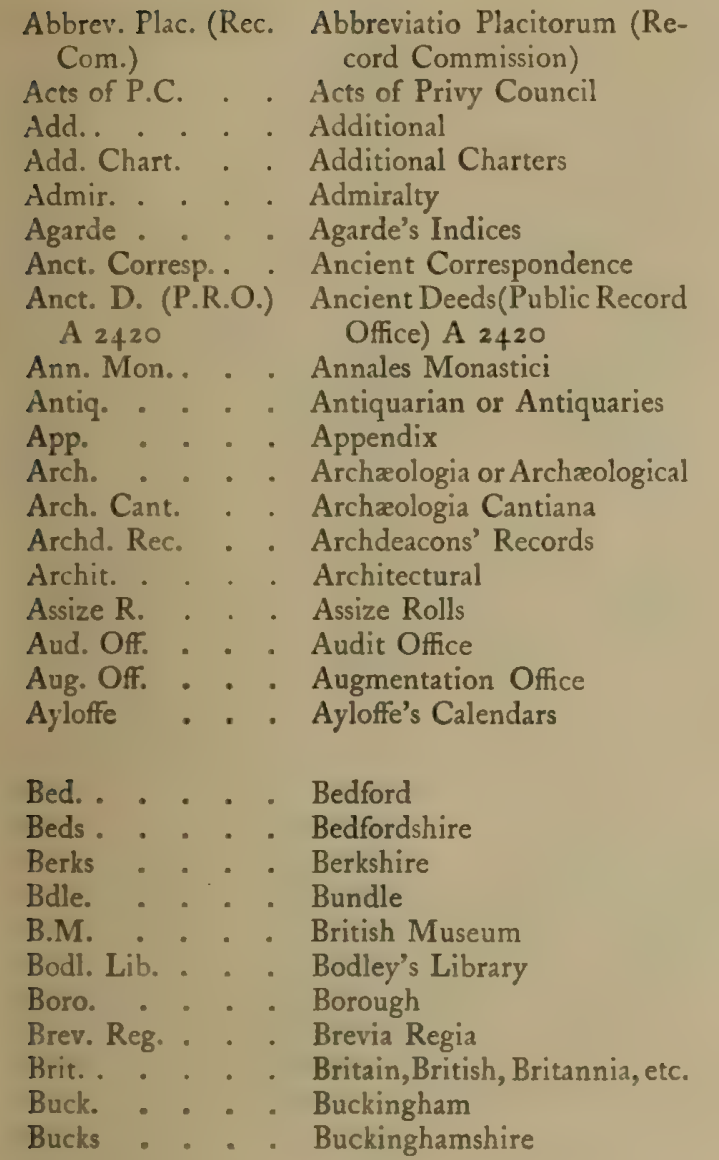

Cal. . . . Calendar

Camb. . . . Cambridgeshire or Cambridge

Cambr. . . Cambria, Cambrian, Cambrensis, etc.

Campb. Chart. . Campbell Charters

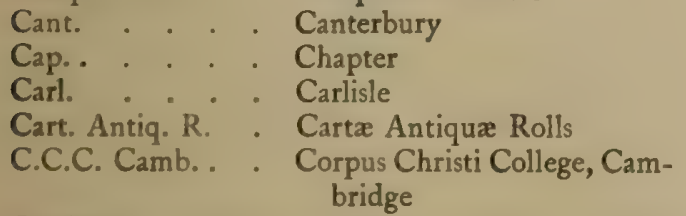

Certiorari Bdles. Certiorari Bundles (Rolls (Rolls Chap.) Chapel)

Chan. Enr. Decree Chancery Enrolled Decree R.

Chan. Proc. Rolls

Chant. Cert.

Chap. Ho.

Charity Inq.

Chart. R. 20 Hen.

III. pt. i. No. 10
Chancery Proceedings

Chantry Certificates (or Certificates of Colleges and Chantries)

\section{Chapter House}

Charity Inquisitions

Charter Roll, 20 Henry III. part i. Number 10
Chartul. . . . Chartulary

Chas. . . . Charles

Ches. . . . Cheshire

Chest. . . . Chester

Ch. Gds. (Exch. Church Goods (Exchequer K.R.) King's Remembrancer)

Chich. . . Chichester

Chron. . . . Chronicle, Chronica, etc.

Close . . . Close Roll

Co. . . . County

Colch. . . . Colchester

Coll. . . . Collections

Com. . . . Commission

Com. Pleas. . Common Pleas

Conf. R. - . Confirmation Rolls

Co. Plac. . . County Placita

Cornw. . . . Cornwall

Corp. . . . . Corporation

Cott. . . . Cotton or Cottonian

Ct. R. . . . Court Rolls

Ct. of Wards . . Court of Wards

Cumb. . . . Cumberland

Cur. Reg. . . . Curia Regis

D. . . . . Deed or Deeds

D. and C. . . . Dean and Chapter

De Banc. R. . . De Banco Rolls

Dec. and Ord : Decrees and Orders

Dep. Keeper's Rep. Deputy Keeper's Reports

Derb. . . . Derbyshire or Derby

Devon . . . Devonshire

Dioc. . . . . Diocese

Doc. . . . . Documents

Dods. MSS. . . Dodsworth MSS.

Dom. Bk. . . . Domesday Book

Dors. . . . Dorsetshire

Duchy of Lanc. . Duchy of Lancaster

Dur. . . . Durham

East. . . . Easter Term

Eccl. . . . . Ecclesiastical

Eccl. Com. . Ecclesiastical Commission

Edw. . . . Edward

Eliz. . . . Elizabeth

Engl. . . England or English

Engl. Hist. Rev, , English Historical Review

Enr. . . . Enrolled or Enrolment

Epis. Reg. . . Episcopal Registers

Esch. Enr. Accts. Escheators Enrolled Accounts

ExcerptaeRot. Fin. Excerpta e Rotulis Finium (Rec. Com.) (Record Commission)

Exch. Dep. . . Exchequer Depositions

Exch. K.B. - . Exchequer King's Bench

Exch. K.R. - Exchequer King's Remembrancer

Exch. L.T.R. . Exchequer Lord Treasurer's Remembrancer 


\section{TABLE OF ABBREVIATIONS}

Exch. of Pleas, Plea Exchequer of Pleas, Plea Roll R.

Exch. of Receipt . Exchequer of Receipt

Exch. Spec. Com. . Exchequer Special Commissions

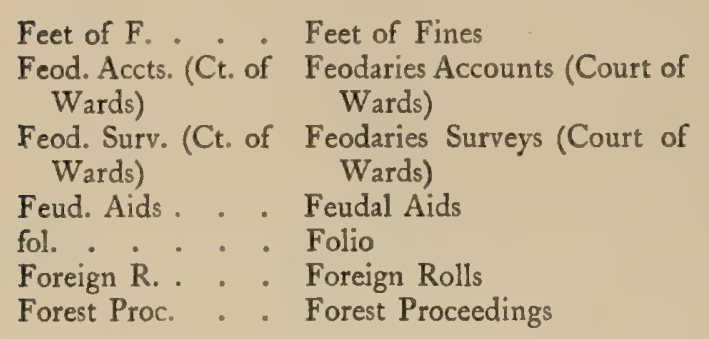

Gaz. . . . . Gazette or Gazetteer

Gen. . . . Genealogical, Genealogica, etc.

Geo. . . . George

Glouc. . . . Gloucestershire or Gloucester

Guild Certif.(Chan.) Guild Certificates (Chancery) Ric. II. Richard II.

\begin{tabular}{|c|c|c|c|}
\hline Hants & . & . & - Hampshire \\
\hline Harl. & . & . & - Harley or Harleian \\
\hline Hen. & . & . & Henry \\
\hline Heref. & . & . & Herefordshire or Hereford \\
\hline Hertf. & . & . & Hertford \\
\hline Herts & - & - & - Hertfordshire \\
\hline Hil. . & . & . & - Hilary Term \\
\hline Hist. & - & - & $\begin{array}{l}\text { - History, Historical, Historian, } \\
\text { Historia, etc. }\end{array}$ \\
\hline Hist. MS & & Com. . & - Historical MSS. Commission \\
\hline Hosp. . & & . & Hospital \\
\hline Hund. R & R. & . & . Hundred Rolls \\
\hline Hưnt. . & . & - & Huntingdon \\
\hline Hunts & . . & - & - Huntingdonshire \\
\hline Inq. a.q.c & d. . & - & - Inquisitionsad quod damnum \\
\hline Inq. p.m. & t. & . & Inquisitions post mortem \\
\hline Inst. . & - & . & Institute or Institution \\
\hline Invent. & . . & . & - Inventory or Inventories \\
\hline Ips. . & . . & . & Ipswich \\
\hline Itin. . . & . & - & Itinerary \\
\hline Jas. . & - & - & - James \\
\hline Journ. & - & - & Journal \\
\hline Lamb. L & ib. & . & . Lambeth Library \\
\hline Lanc. & & . . & Lancashire or Lancaster \\
\hline $\begin{array}{l}\text { L. and } \\
\text { VIII. }\end{array}$ & P. & Hen. & $\begin{array}{l}\text { Letters and Papers, Hen. } \\
\text { VIII. }\end{array}$ \\
\hline Lansd. & & - & Lansdowne \\
\hline Ld. Rev. & Rec & . & Land Revenue Records \\
\hline Leic. : & & . & Leicestershire or Leicester \\
\hline Le Neve' & & & Le Neve's Indices \\
\hline Lib. . & . & . & Library \\
\hline Lich. & - & - & Lichfield \\
\hline Linc. & - & . & Lincolnshire or Lincoln \\
\hline Lond. & .. & - & London \\
\hline m. . & . & . & - Membrane \\
\hline Mem. & - & . & - Memorials \\
\hline
\end{tabular}

Memo. R. . . Memoranda Rolls

Mich. . . Michaelmas Term

Midd. . . . Middlesex

Mins. Accts. . . Ministers' Accounts

Misc. Bks. (Exch. Miscellaneous Books (ExK.R., Exch. chequer King's RememT.R. or Aug. brancer, Exchequer TreaOff.) sury of Receipt or Augmentation Office)

Mon. . . . Monastery, Monasticon

Monm. . . . Monmouth

Mun. . . Muniments or Munimenta

Mus. . . . Museum

N. and Q. . . Notes and Queries

Norf. . . . Norfolk

Northampt. . . Northampton

Northants . . Northamptonshire

Northumb. . . Northumberland

Norw. . . . Norwich

Nott. . . . Nottinghamshire or Notting-

N.S. . . . New Style

Off. . . . . Office

Orig. R. . . Originalia Rolls

O.S. . . . Ordnance Survey

Oxf. . . . . Oxfordshire or Oxford

p. . . . Page

Palmer's Ind. - . Palmer's Indices

Pal. of Chest. . . Palatinate of Chester

Pal. of Dur. . . Palatinate of Durham

Pal. of Lanc. . . Palatinate of Lancaster

Par. . . . Parish, parochial, etc.

Parl. . . . . Parliament or Parliamentary

Parl. R. . . . Parliament Rolls

Parl. Surv. . . Parliamentary Surveys

Partic. for Gts. . Particulars for Grants

Pat. . . . . Patent Roll or Letters Patent

P.C.C. . . . Prerogative Court of Canter-

Pet. . . . Petition

Peterb. . . . Peterborough

Phil. . . . Philip

Pipe R. . . . Pipe Roll

Plea R. . . . Plea Rolls

Pop. Ret. . . Population Returns

Pope Nich. Tax. Pope Nicholas'Taxation(Re(Rec. Com.) cord Commission)

P.R.O. . . . Public Record Office

Proc. . . . Proceedings

Proc. Soc. Antiq. - Proceedings of the Society of pt. . . . Part

Pub. . . . Publications

R. . . . . Roll
Rec.
Recov. R. . . . Records
Rentals and Surv. . Rentals and Surveys
Rep.. . . . Report
Rev. . . . . Review
Ric. . . . Richard




\section{TABLE OF ABBREVIATIONS}

Roff. . . Rochester diocese

Rot. Cur. Reg. . Rotuli Curiz Regis

Rut.... . . Rutland

\begin{tabular}{|c|c|c|}
\hline Sarum . & . $\cdot$ & - Salisbury diocese \\
\hline Ser. . . & . $\cdot$ & - Series \\
\hline Sess. R. . & . & - Sessions Rolls \\
\hline Shrews. . & . . & Shrewsbury \\
\hline Shrops . & - & - Shropshire \\
\hline Soc. . . & . & - Society \\
\hline Soc. Antiq. & - & - Society of Antiquaries \\
\hline Somers. . & . & - Somerset \\
\hline Somers. Ho. & . & Somerset House \\
\hline S.P. Dom. & . & - State Papers Domestic \\
\hline Staff. . & . . . & Staffordshire \\
\hline Star Chamb & b. Proc. & Star Chamber Proceedings \\
\hline Stat. . . & . . . & Statute \\
\hline Steph. . & . & Stephen \\
\hline Subs. R. & . . & Subsidy Rolls \\
\hline Suff. . & - & Suffolk \\
\hline Surr. & .. & - Surrey \\
\hline Suss. . . & $\therefore \quad \therefore$ & - Sussex \\
\hline $\begin{array}{l}\text { Surv. of Cl} \\
\text { ings (Lar } \\
\text { (Chan.) }\end{array}$ & $\begin{array}{l}\text { h. Liv- } \\
\text { mb.) or }\end{array}$ & $\begin{array}{l}\text { Surveys of Church Livings } \\
\text { (Lambeth) or (Chancery) }\end{array}$ \\
\hline
\end{tabular}

Topog. . . . Topography or Topographi.

Trans. . . . Transactions

Transl. . . . Translation

Treas. . . . Treasury or Treasurer

Trin. . . . Trinity Term

Univ. . . . University

Valor Eccl. (Rec. Valor Ecclesiasticus (Record Com.) Commission)

Vet. Mon. . . Vetusta Monumenta

V.C.H. . . . Victoria County History

Vic. . . . . Victoria

vol. . . . Volume

Warw. . . . Warwickshire or Warwick

Westm. . . Westminster

Westmld. . . Westmorland

Will. . William

Wilts . . Wiltshire

Winton. . . Winchester diocese

Worc. . . . Worcestershire or Worcester

Yorks . . . Yorkshire 

A HISTORY OF SUFFOLK 




\section{l}

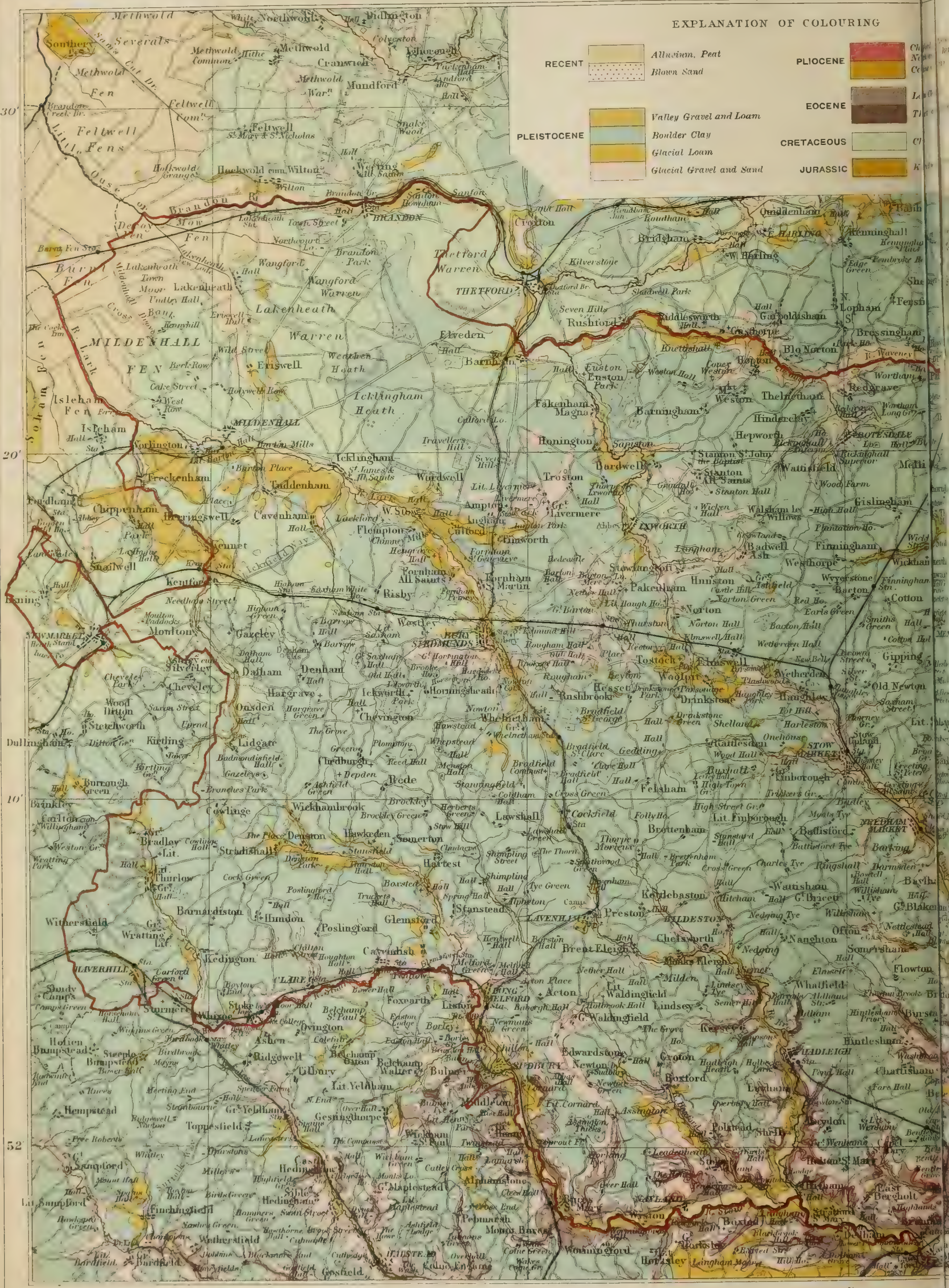



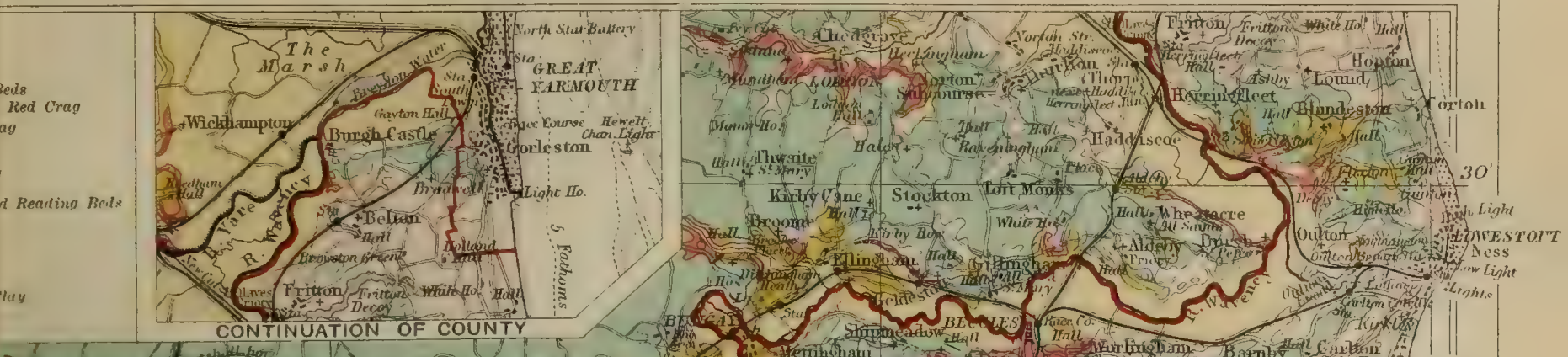

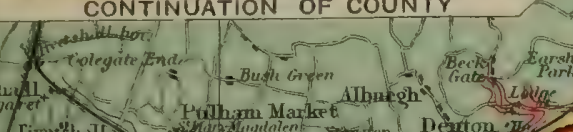

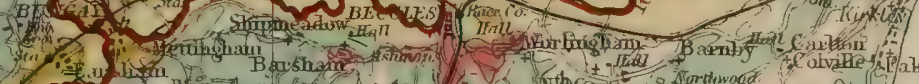

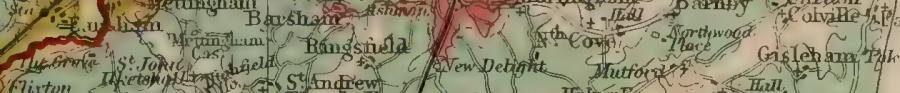

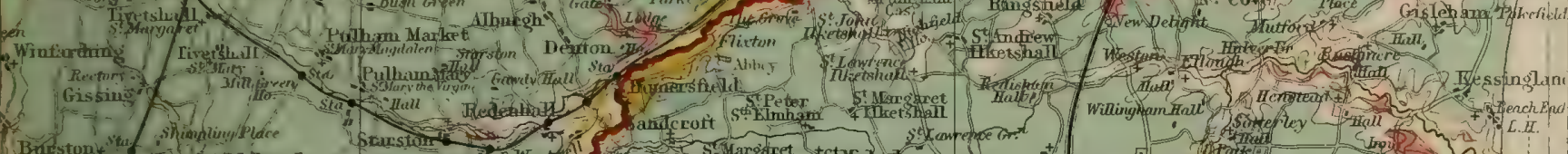

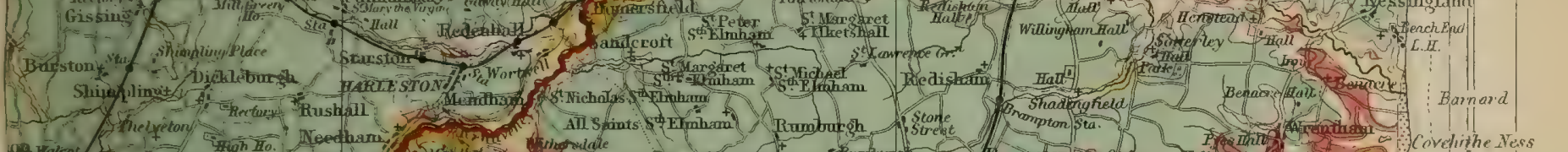

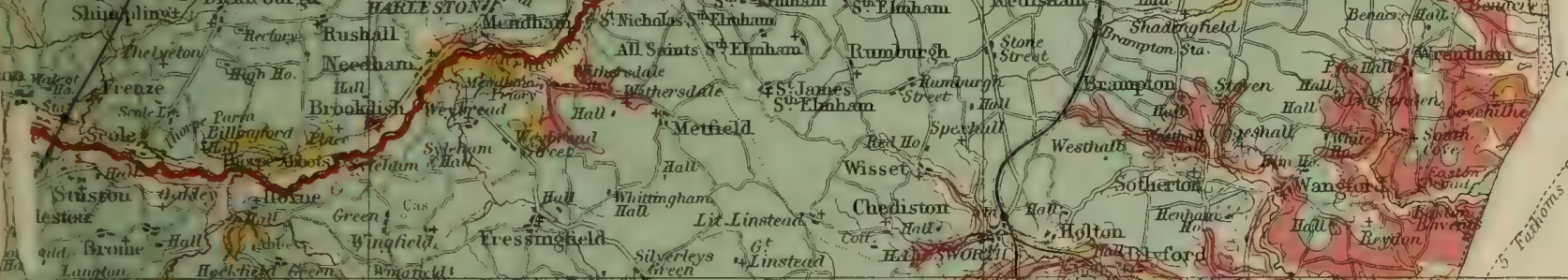

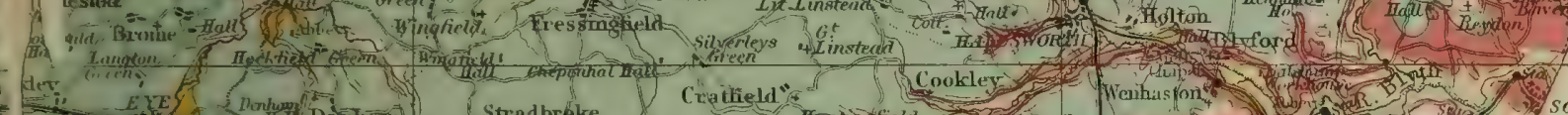

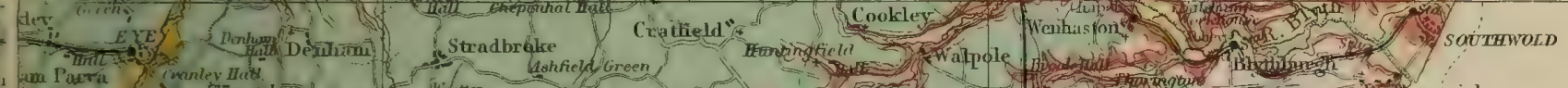

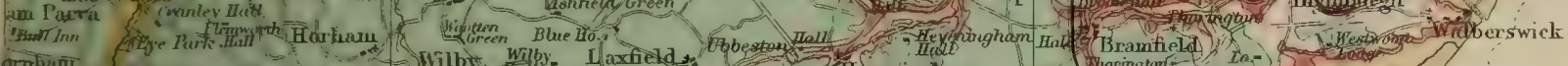

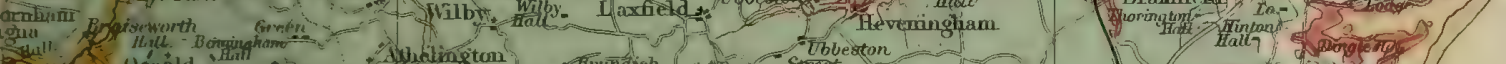

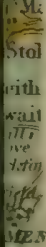

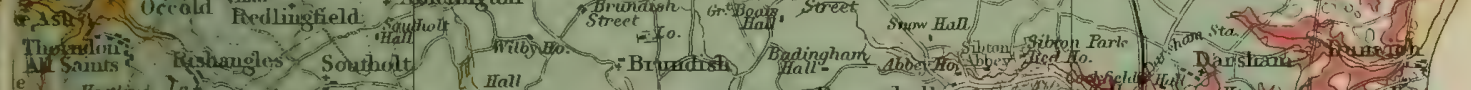

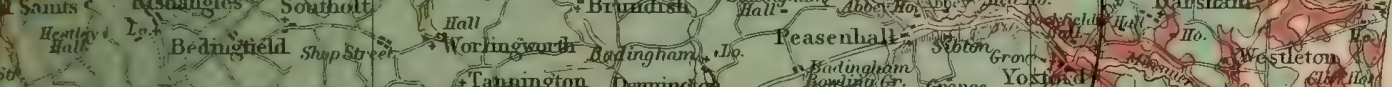

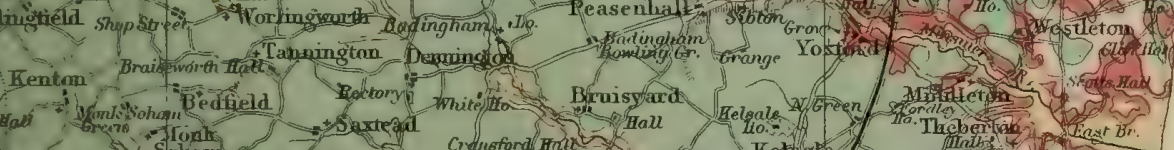

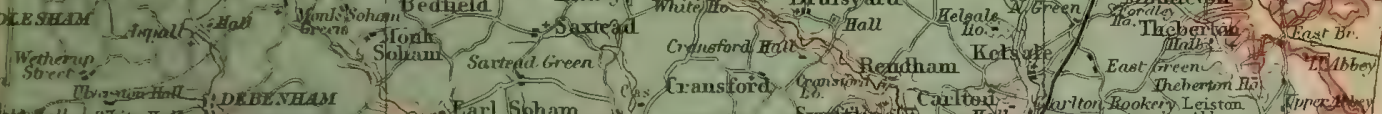

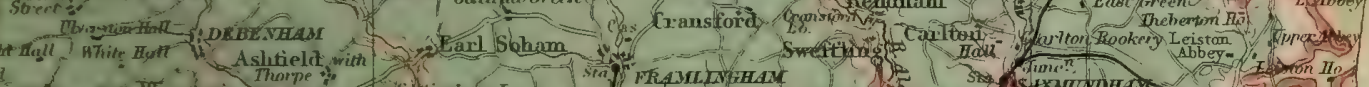

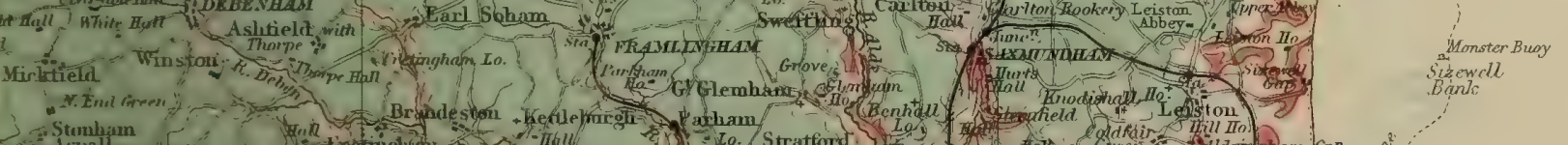

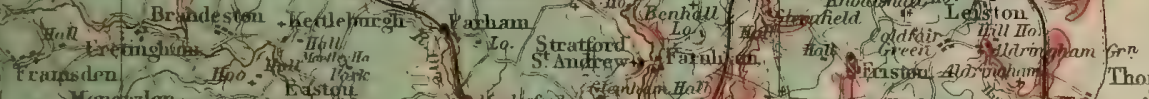

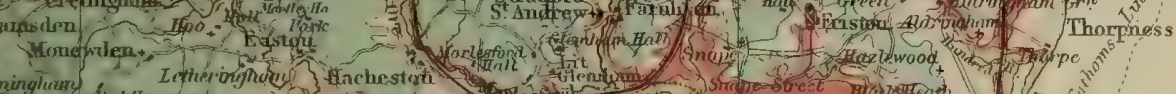

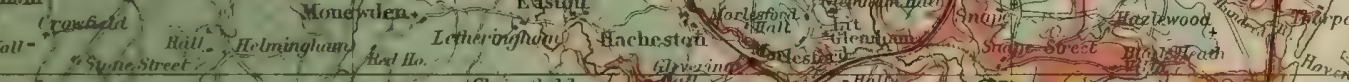

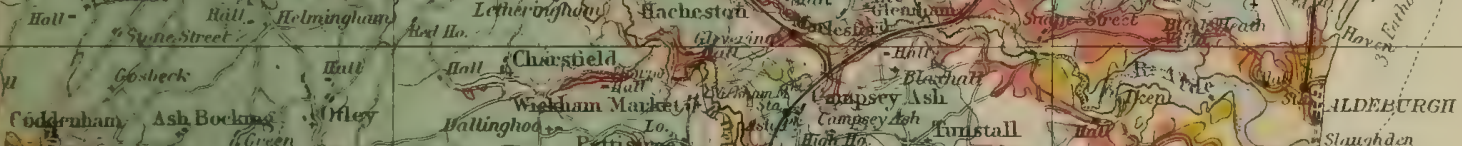

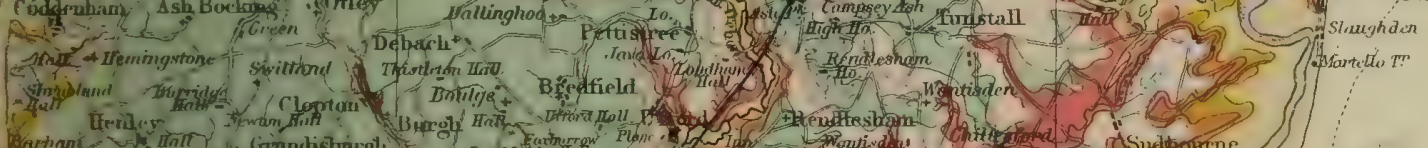

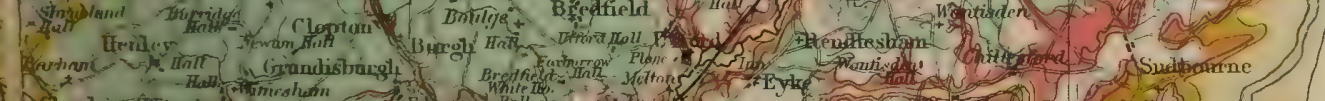

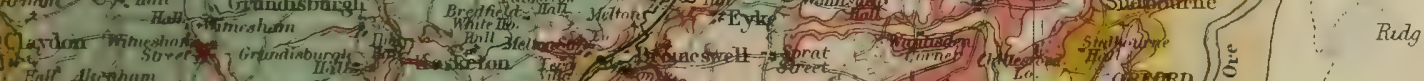

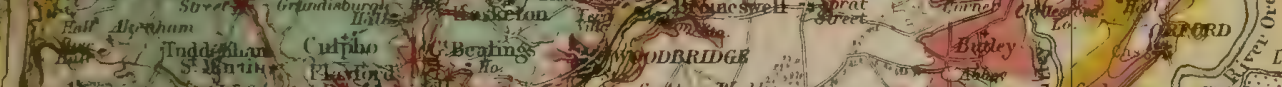

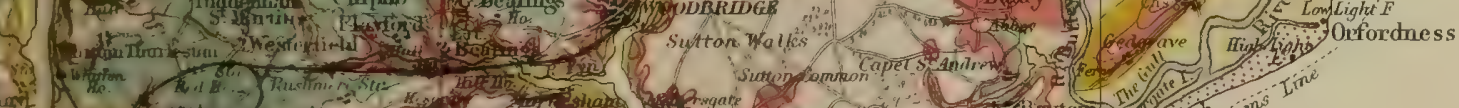

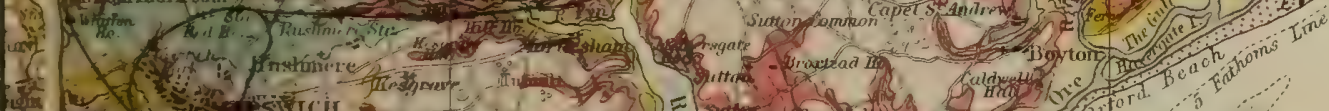

$$
\begin{aligned}
& \text { Whit }
\end{aligned}
$$

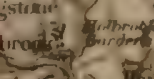

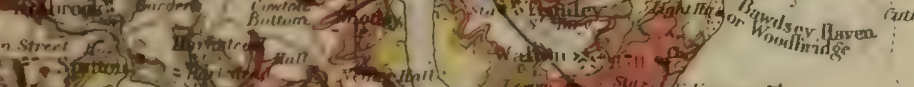

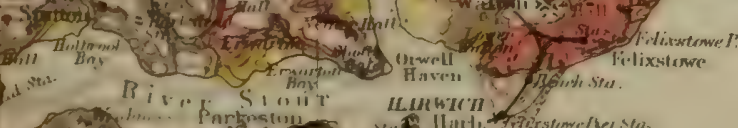





\section{GEOLOGY}

UFFOLK forms part of the East Anglian plain, and consists almost wholly of an undulating region which rarely attains an elevation of 400 feet. The greater portion of the county rises from 80 to 200 feet above sea-level ; there are no prominent hills, and even the district between Stowmarket and Harleston, to which the term 'High Suffolk' has sometimes been applied, lies below 200 feet. The highest ground is between Haverhill and Bury St. Edmunds, and this reaches 4I 7 feet at Rede. The great alluvial tract of the Fenland extends to Mildenhall in the north-western portion of the county, and constitutes a lower plain.

The main features are those of the river valleys, notably along the lower courses, which widen out into the pleasant estuarine waters of the Deben, Orwell and Stour, or expand-as in the case of the Waveney where it joins the Yare-into the brackish water 'broad' known as Breydon Water.

The coast line is nowhere protected by hard rocks, the cliffs being formed of loose sands, gravels and clays, which yield so readily to the combined attacks of land-springs and sea that the losses have been disastrous.

The geological structure of Suffolk is comparatively simple. The Chalk forms the foundation of almost the entire county. Its base would be reached just below the fens of Mildenhall, and it is inclined gently towards the south-east. Thus at Culford near Bury St. Edmunds it has a thickness of 526 feet ; at Stowmarket and to the south-east it is over 800 feet. It forms part of that shallow trough or syncline known as the 'London Basin,' which in the southern and eastern parts of the county where the Chalk is thickest supports a mass of Eocene strata. These appear at the surface at Sudbury and Ipswich, and have been proved in borings at various places, including Southwold and Lowestoft.

Stretching irregularly across the worn surfaces of the Eocene in the southern, and on to the Chalk in the north-eastern parts of the county, are found the several divisions of the Crag formation for which Suffolk is especially famous. Nowhere else in England is there a better huntingground for the collector of fossils than that portion of the Crag district which extends from Felixstow to Aldeburgh and inland to Ipswich and Woodbridge. There in many a pit shells and other organic remains in great abundance and variety may at all times be obtained.

These richly fossiliferous strata have been partially destroyed and 


\section{A HISTORY OF SUFFOLK}

extensively buried up by the succeeding glacial deposits, which form a mantle over by far the greater part of the county. The chalky Boulder Clay occupies much of western and central Suffolk, and the lighter Glacial sands and gravels much of the eastern part. To them the agricultural characters of the land and its scenery are principally due : the strong loam of the Boulder Clay forming arable tracts, and the sands and gravels, together with the Crag series, giving rise to those pleasant, gorse-covered commons which form a marked feature in eastern Suffolk.

Later deposits belonging to old valleys, but some of high antiquity, have attained renown, notably at Hoxne and Brandon, as repositories of the flint implements of Palæolithic man; while the more recent accumulations-marine, estuarine and freshwater-occupy lower levels in the valleys and fringe the coasts.

The chief industries connected with geology are lime-burning and brick-making. The old gun-flint manufactory at Brandon is practically extinct, while the 'coprolite diggings' have been abandoned owing to the introduction of foreign phosphates.

Although the geological structure of the county has been spoken of as simple, the particular relations of many of the sub-divisions in the Pliocene and newer strata have formed the subject of much controversy, and mainly on this account the literature is voluminous.

For some of the earlier records relating to the county we are indebted to the Rev. William Branwhite Clarke, ${ }^{1}$ who was born at East Bergholt, and who ultimately became the 'Father of Australian Geology.' To Searles Valentine Wood of Hasketon and Martlesham, and to his son S. V. Wood, junior ; to Edward Charlesworth, Sir Joseph Prestwich, John Ellor Taylor, Professor E. Ray Lankester, Mr. William Whitaker, Mr. E. T. Newton, Mr. Clement Reid and Mr. F. W. Harmer we are especially indebted for our knowledge of the Tertiary and newer strata and their organic remains. ${ }^{2}$ To Mr. A. J. JukesBrowne and $\mathrm{Mr}$. William Hill we owe our special knowledge of the Chalk. To the publications of the Geological Survey we are likewise indebted, and frequent reference is made to the Memoirs issued by that institution.

The strata or formations known in Suffolk may be grouped as follows, the names in italics referring to those not exposed at the surface.

\footnotetext{
For bibliography see list in Whitaker's 'Geology of the Country around Ipswich, Hadleigh and Felixstow,' Geol. Survey (1885), p. 134; with addenda in 'Geology of Parts of Cambridgeshire and Suffolk,' Geol. Survey (1891), p. I21. See also 'Sketch of the Geology of Suffolk,' by J. E. Taylor, reprinted from the fourth edition of White's History, etc., of the county (1884).
} v. 359 .

1 'On the Geological Structure and Phrnomena of the County of Suffolk,' Trans. Geol. Soc. sec. 2, 


\section{GEOLOGY}

\begin{tabular}{|c|c|c|c|}
\hline Period & Formation & Character of the Strata & $\begin{array}{l}\text { Approximate thick- } \\
\text { ness in feet }\end{array}$ \\
\hline $\begin{array}{l}\text { Recent to } \\
\text { Neolithic }\end{array}$ & $\begin{array}{l}\text { Alluvium, including sub- } \\
\text { merged Forest and Fen } \\
\text { Beds } \\
\text { Blown Sand. . . . . } \\
\text { Shingle Beaches : . . }\end{array}$ & $\begin{array}{l}\text { Mud, silt, clay, peat and } \\
\text { gravel. } \cdot . \cdot \\
\text { Clean sand . . } \\
\text { Chiefly flint pebbles : . }\end{array}$ & $\begin{array}{l}10 \text { to } 50 \\
\text { Io to } 15 \\
\text { up to } 50\end{array}$ \\
\hline $\begin{array}{l}\text { Pleistocene, } \\
\text { Palæolithic } \\
\text { and Glacial }\end{array}$ & $\begin{array}{l}\text { Valley Gravel and Brick- } \\
\text { earth } \\
\text { Boulder Clay . - . } \\
\text { Glacial Sand and Gravel . } \\
\text { Glacial Loam . . . }\end{array}$ & $\begin{array}{l}\text { Sub-angular flint gravel } \\
\text { and loam. - } \\
\text { Chalky clay, with flints } \\
\text { and erratics . . } \\
\text { Shelly sand and gravel . } \\
\text { Loam . . . . . }\end{array}$ & $\begin{array}{l}\text { IO to } 25 \\
\text { up to } 170 \\
\text { I0 to } 100 \\
\text { Io to } 25\end{array}$ \\
\hline Pliocene & $\begin{array}{l}\text { Cromer Forest Bed . } \\
\text { Norwich Crag Series with } \\
\text { Chillesford Clay } \\
\text { Red Crag Series . . . } \\
\text { Coralline Crag . . . . }\end{array}$ & $\begin{array}{l}\text { Gravel, laminated clay and } \\
\text { peaty loam with rootlets } \\
\text { Shelly sand and gravel and } \\
\text { laminated clay } \\
\text { Red and brown shelly sand } \\
\text { Calcareous shelly sand and } \\
\text { sandy limestone. . . }\end{array}$ & $\begin{array}{l}10 \text { to } 25 \\
20 \text { to } 150 \\
10 \text { to } 40 \\
40 \text { to } 60\end{array}$ \\
\hline Eocene & $\begin{array}{l}\text { London Clay . . . } \\
\text { Reading Beds . . . . } \\
\text { Thanet Beds . . . . }\end{array}$ & $\begin{array}{l}\text { Brown and blue clay with } \\
\text { septaria and sandy clay } \\
\text { Mottled clay, sand and } \\
\text { sandstone. . . . } \\
\text { Green clayey sand. . }\end{array}$ & $\begin{array}{l}\text { up to } 130 \\
20 \text { to } 70 \\
10 \text { to } 15\end{array}$ \\
\hline $\begin{array}{c}\text { Upper } \\
\text { Cretaceous }\end{array}$ & $\begin{array}{l}\text { Upper Chalk . . . } \\
\text { Middle Chalk . . . } \\
\text { Lower Chalk . . . } \\
\text { Gault. . . . . . }\end{array}$ & $\begin{array}{l}\text { Soft chalk with nodular } \\
\text { flints . } \\
\text { Harder chalk with few } \\
\text { nodular and tabular flints } \\
\text { Grey and white blocky } \\
\text { chalk with curved joint- } \\
\text { ing and grey marl. } \\
\text { Grey marly clay . . }\end{array}$ & $\begin{array}{l}500 \\
200 \text { to } 220 \\
160 \text { to } 170 \\
50 \text { to } 90\end{array}$ \\
\hline $\begin{array}{l}\text { Lower } \\
\text { Cretaceous }\end{array}$ & Lower Greensand . & $\begin{array}{l}\text { Ferruginous and calcareous } \\
\text { sandstone. }\end{array}$ & 30 to 35 \\
\hline Jurassic & Kimeridge Clay . • . & $\begin{array}{l}\text { Dark shale with bands } \\
\text { and nodules of lime- } \\
\text { stone. }\end{array}$ & 100 \\
\hline Palæozoic & Silurian? (or older) & Slaty rock . . & unknown \\
\hline
\end{tabular}

\section{PALÆOZOIC}

Rocks of ancient date, the age of which cannot at present be determined, have been proved at Stutton in the low ground south of Crepping Hall, on the borders of the Stour.

There at a depth of 994 feet beneath Gault, Chalk and other over- 


\section{A HISTORY OF SUFFOLK}

lying strata certain slaty rocks were entered. In character they resembled beds reached beneath the Gault at Harwich, now believed to belong to the Silurian or an older formation. The enterprise at Stutton, as remarked by $\mathrm{Mr}$. Whitaker, was the first attempt made by the Eastern Counties Coal-boring Association. ${ }^{1}$

An earlier boring at Culford Park to the north-west of Bury St. Edmunds proved dark slaty rock and hornstone beneath the Lower Greensand and overlying rocks, at depths of from $637 \frac{\mathrm{I}}{2}$ to $657 \frac{1}{4}$ feet. $^{2}$

This is all we at present know of the Palæozoic floor in Suffolk.

\section{JURASSIC \\ KIMERIDGE CLAY}

This formation perhaps directly underlies the alluvium in the northern portion of Mildenhall Fen in a very small area in Suffolk, but it may extend beneath the Lower Greensand and Gault and overlying strata towards Newmarket and Mildenhall. Its thickness is not likely to exceed 100 feet, and where exposed beyond the borders of Suffolk it consists of dark shales and clays with nodules and bands of limestone. The occurrence of limestones in the Kimeridge Clay, as at Littleport north of Ely, is interesting, as in other Jurassic formations the development of limestones at the expense of clays occurs in proximity to old land-tracts. ${ }^{3}$ The Kimeridge Clay, if not faulted against the older rocks, must abut against them in the area to the west of Culford.

\section{CRETACEOUS}

\section{LOWER GREENSAND}

In the boring at Culford, previously mentioned, the Palæozoic rock was immediately overlain by greyish-brown ferruginous sandstone and sandy limestone with foraminifera and fragments of echinoderms, mollusca and brachiopods, as well as lignite. These strata occurred beneath the Gault, from 605 to $637 \frac{\mathrm{I}}{2}$ feet in depth, and they have been referred, with doubt, by Mr. Whitaker and Mr. Jukes-Browne to the Lower Greensand, though they mention the possibility of their being Jurassic."

\section{GAULT}

Although the Gault nowhere appears at the surface in Suffolk, it cannot be far below ground over much of Mildenhall Fen, and it probably everywhere underlies the Chalk. It occurs at a depth of 532 feet below Culford, and consists of a mass of grey marl 73 feet thick, in

1 See address by W. Whitaker to Geol. Section, Rep. Brit. Assoc. for 1 895, p. 667, also pp. 436, 693 ; and Geol. Mag. (1895), p. 466.

2 Whitaker and Jukes-Browne, 2uart. Fourn. Geol. Soc. 1. 492.

' H. B. Woodward, 'Jurassic Rocks of Britain,' vol. v. (I895), Geol. Survey, p. I72,

- 2uart. Fourn. Geol. Soc. 1. 493. 


\section{GEOLOGY}

which phosphatic nodules and a few fossils such as Belemnites attenuatus, fish-vertebræ, etc., have been observed. ${ }^{1}$ Its thickness may be greater under Mildenhall Fen, probably as much as 90 feet.

At Stutton the Gault was reached at a depth of 944 feet, and its thickness was about 50 feet. It there rests directly on Palæozoic rock.

No evidence of Upper Greensand has been met with, for although at Combs near Stowmarket the lower part of the Chalk was proved at a depth of 874 feet, and green sandy beds and clays were then reached, these may in part belong to the base of the Chalk, as noted further on. ${ }^{2}$

\section{CHALK}

While the Chalk enters so much into the foundation of the county, it is only in the western parts that it appears to any prominent extent at the surface. Elsewhere it is largely concealed by newer deposits, and on the eastern side it lies more than 200 feet below the surface of Orford marshes, I 26 feet at Saxmundham, and as much as 475 feet at Lowestoft.

The full thickness proved in the deep boring at Stutton amounts to $874 \frac{\mathrm{I}}{2}$ feet, a good deal less than that known to occur in Norfolk. In other localities thicknesses of over 800 feet have been proved, as at Landguard Fort (base not reached), and at Combs near Stowmarket, where the highest beds of Chalk were not present.

The divisions recognized in the Chalk are as follows:-

\begin{tabular}{c|l|l}
\hline & & \multicolumn{1}{c}{ Zones } \\
\hline Upper Chalk & $\begin{array}{l}\text { Chalk with flints : Chalk Rock } \\
\text { at base }\end{array}$ & $\begin{array}{l}\text { Actinocamax quadratus } \\
\text { Marsupites } \\
\text { Micraster } \\
\text { Holaster planus }\end{array}$ \\
\hline Middle Chalk & $\begin{array}{l}\text { Bedded Chalk with few flints : } \\
\text { Melbourn Rock at base }\end{array}$ & $\begin{array}{l}\text { Terebratulina } \\
\text { Rhynchonella cuvieri }\end{array}$ \\
\hline Lower Chalk & $\begin{array}{l}\text { Grey Chalk or clunch : Tottern- } \\
\text { hoe stone at base } \\
\text { Chalk marl }\end{array}$ & $\begin{array}{l}\text { Holaster subglobosus } \\
\text { Ammonites varians }\end{array}$ \\
\hline
\end{tabular}

In the eastern part of the county it is probable that the lowest portion of the Chalk formation is a dark green glauconitic marl a few feet thick, recognized in some deep borings, as at Stutton, and belonging perhaps to the sub-zone of Stauronema carteri. ${ }^{3}$ In the western part of the county it is likely that the Cambridge phosphate bed may occur at the base of the Chalk, as it was proved in a boring at Isleham, and it has been worked near Soham in Cambridgeshire. In this case it would

1 Whitaker and Jukes-Browne, 2uart. Fourn. Geol. Soc. 1. 49 r.

2 Whitaker, Geol. Mag. (1895), p. 465 ; Jukes-Browne, 'Cretaceous Rocks of Britain,' vol. i. (1900), Geol. Survey, pp. 372, 373.

Jukes-Browne, 'Cretaceous Rocks of Britain' vol. i. (I900), Geol. Survey, p. 373. 


\section{A HISTORY OF SUFFOLK}

be found beneath the alluvium of Mildenhall Fen, and perhaps for some distance beneath the levels west of Lakenheath.

The base of the Lower CHALK has nowhere been exposed in the county, and indeed only the higher portions of the grey Chalk marl, which is reckoned to be 60 or 70 feet in thickness, outcrop in the northwest. This marl is surmounted by the Totternhoe Stone, which comprises about 12 feet of grey gritty limestone, largely made up of comminuted fragments of Inoceramus and containing green-coated phosphatic nodules at the base. The beds have been worked for freestone at Isleham, and they probably outcrop to the north-west of West Row. At this locality a band of light red chalk was observed by Mr. Jukes-Browne in the grey chalk which occurs above the Totternhoe Stone. ${ }^{1}$ This higher portion of the Lower Chalk consists for the most part of grey and white blocky chalk or clunch, about 80 feet in thickness, with at top a layer 3 or 4 feet thick of yellow shaly marl and hard chalk, characterized by Actinocamax plenus. These beds extend from West Row eastwards to near Mildenhall, Eriswell and Lakenheath. ${ }^{2}$

The Middle Chalk comprises at its base the Melbourn Rock, a hard sandy nodular layer about 8 feet thick, named from Melbourn in Cambridgeshire. It has been observed near Worlington. The overlying yellowish and somewhat nodular chalk yields Rbynchonella cuvieri, Inoceramus mytiloides and Galerites subrotundus. The beds are exposed in pits east of Mildenhall, to the east and north of Eriswell and to the north-east of Lakenheath. ${ }^{3}$

The higher portion of the Middle Chalk, characterized by Terebratulina, consists of softer white chalk with layers of marl and nodules of flint ; and it extends from Newmarket, east of Mildenhall, to the neighbourhood of Brandon, a region where the Chalk is much hidden by drift sand.

Only in the neighbourhood of Newmarket does the Chalk present its characteristic features of open downs with short, springy turf, such as we find over the well-known training grounds and racecourse." Northwards to Mildenhall and Thetford, owing partly 'to the cappings of Drift as well as to the amount of sand that seems to have been blown over the Chalk, the usual features of a chalk-tract are almost absent. We have no sharp escarpment, no deep valleys, and the flood of sand has given rise, in places, to barren heath-land.' Large plantations of fir and larch have been made, elsewhere much of the ground is 'little else than a gigantic rabbit warren,' although rye, barley and potatoes are grown in places. ${ }^{5}$ In this region, as might be expected, there is a scarcity of surface water.

1 Geol. Mag. (1887), p. 24.

2 Whitaker and Jukes-Browne, 2uart. Fourn. Geol. Soc. xliii. 547, 554; Whitaker and others, 'Geology of South-western Norfolk,' etc., Geol. Survey (1893), p. 29.

3 Jukes-Browne and Hill, Quart. Fourn. Geol. Soc. xliii. $56_{3}, 564$; Jukes-Browne, Stratigraphical Geology (1902), p. 442 .

See F. J. Bennett, 'Geology of Bury St. Edmunds and Newmarket,' Geol. Survey (1 886), p. 2.

- Whitaker and others, 'Geology of Parts of Cambridgeshire and Suffolk,' Geol. Survey (1891), p. 4. 


\section{GEOLOGY}

The UPPER CHALK, consisting of chalk with nodular and tabular flints, underlies the greater part of Suffolk, from Haverhill through Bury St. Edmunds to Brandon, and in the country to the east, where however it is so much obscured by Glacial drift and Tertiary strata that it appears seldom at the surface and few fossils have been recorded.

Chalk with Micraster occurs at Bury St. Edmunds and onwards, probably to Ixworth, Fakenham and Euston Park. At Great Horringer it has been extensively excavated in subterranean workings or galleries.

The Marsupite zone probably extends through the country from near Wickhambrook to Elmswell, Botesdale and Redgrave.

Near Needham Market the Chalk yields Actinocamax quadratus, Inoceramus mytiloides and Ostrea acutirostris. There are Chalk pits at Coddenham, while to the north-east the Chalk appears in the Deben Valley below Debenham and at Earl Soham.

Chalk above the zone of Actinocamax quadratus might have been expected along the borders of the Eocene covering from Sudbury, eastwards to Claydon and Bramford near Ipswich; but at Sudbury no indications of higher beds have been proved, the few fossils found there including Lima boperi and teeth of the sharks Lamna and Oxyrbina. It is to be borne in mind that the thickness of Chalk proved at Combs near Stowmarket is but little less than that below Stutton, where the full local thickness occurs. Along the eastern borders of the county it may be that higher beds occur, but information derived solely from borings is necessarily meagre.

The Chalk is the great storehouse for water, and wells and borings have been carried into it in all parts of the county, excepting into its lowest division of grey marl, which is impervious. Although so much of the Chalk is deeply buried beneath newer strata, which consist largely of impervious clays and effectually keep out the direct rainfall, yet an abundant supply of good water has been obtained at Ipswich, Woodbridge and other places far from the main outcrop. Under such conditions a supply is not always freely obtained, and it may be necessary to penetrate the formation to depths ranging up to 250 feet before a fissure is met with; while along the sea borders, as at Southwold, Leiston, Orford and Landguard Fort, brackish or saline waters have been encountered. In west Suffolk, where the Drift coverings are neither so thick nor so impervious as in central Suffolk, water is more readily obtained. Mr. Whitaker has called attention to an intermittent stream or 'nailbourne' at Coddenham. After much dry weather, when the plane of saturation in the Chalk is low, the brook which flows over Boulder Clay in its higher course sinks into the permeable Chalk, but after long-continued rain there is a continuous flow of water. ${ }^{1}$

The Chalk is burnt for lime at Sudbury, Bramford, near Bury St. Edmunds and other places; and it has been used with an admixture of river-mud for cement making at Waldringfield and Burgh Castle. In

1 'Geology of the Neighbourhood of Stowmarket,' Geol. Survey (1881), p. 18. 


\section{A HISTORY OF SUFFOLK}

a few places, as near Brandon, hard beds have been employed for building purposes.

The most interesting industry connected with the Chalk has been that of the manufacture of gun-flints in the neighbourhood of Brandon. The flint was largely obtained from Lingheath, a tract described by $\mathrm{Mr}$. S. B. J. Skertchly ${ }^{1}$ as completely honeycombed with pits, many of them old, and most of them approached through shafts about 45 feet deep. These occur from Brandon Park on the west to Santon Downham Warren on the east. Good flint has also been obtained at Elvedon, and at one time it was largely extracted from pits on Icklingham Heath. According to the same author the best bed of flint is the 'Floor Stone,' which is the band to which the pits are sunk, and from which most of the gun-flints have been made. It is generally a continuous layer, smooth at the base, and with a somewhat irregular surface. Other layers have been occasionally used for gun-flints, but have been more extensively employed for building purposes, a trade still carried on. About the year 1 835 , when percussion caps were introduced, the gunflint manufactory rapidly declined, the materials subsequently shaped being chiefly for export to Africa.

Dressed flints have been much used in building churches, and fine examples may be seen at Southwold and elsewhere. Flint boulders from gravels have also been largely used for building purposes.

The Chalk is a deep-sea formation made up of calcareous ooze derived from the accumulation and decay of various organisms, notably foraminifera, as well as mollusca and echinoderms. Together with these were sponges, whose siliceous structures have furnished the material which has segregated into the irregular nodules known as flints. These nodules follow the planes of bedding. Other forms of flint occur as tabular layers and as vertical or oblique veins, and these have probably been formed by subsequent infiltration of waters which held silica in solution and deposited it along the more or less vertical and horizontal joint-planes.

That the Chalk extended over the greater part of England is generally admitted, so that on the partial upheaval of the area in Tertiary times Chalk cliffs alone yielded material in its flints for the formation of pebble beds. In Suffolk the Eocene strata do not yield any conspicuous flint pebble beds such as we find in Hertfordshire and other southern counties, but in Pliocene and later times there were great accumulations of flint gravel which tell of the destruction of Chalk-a loss that is likewise manifest from the irregular extension of Pliocene and Glacial drifts across the eroded surface of the Chalk.

This great plain of denudation is by no means a uniformly level tract; it was worn down during successive stages of the Eocene period by encroachment of the sea westwards and northwards, and modified in various ways by the marine, fluviatile and glacial agents of subsequent ages, to which attention will be directed.

$$
1 \text { 'Manufacture of Gun-Flints,' Geol. Survey (1879). }
$$




\section{GEOLOGY}

\section{EOCENE}

\section{THANET BEDS}

The oldest Eocene strata in this country are the Thanet Beds, and their presence in the neighbourhood of Sudbury was made known in 1874 by Mr. Whitaker. Above the Chalk he observed at Ballingdon, a suburb on the Essex side, I 4 feet of green clayey sand, which in all probability represents the Thanet Beds. ${ }^{.}$Traces of the same deposit, sometimes with green-coated flints, have also been observed by him at Cosford Bridge and Kersey Mill in the Brett valley, and at Somersham, Little Blakenham, Claydon, Barham, Bramford and Ipswich.

Nucula and Cardium are the only fossils which have locally been found in the strata.

\section{READING BEDS}

Overlying the thin representative of the Thanet Beds, and otherwise persistent in Suffolk, is the variable group of strata known as the Reading Beds. They comprise alternations of mottled clay, brown and grey clay, grey and green sand, with occasional masses of concretionary sandstone of the nature of greywethers. Black flint pebbles occur here and there, but not in prominent layers; and no fossils have been observed in the strata in Suffolk. The outcrop of the group can be traced by means of pits and borings from Sudbury to Kersey near Hadleigh and the neighbourhood of Ipswich, where the thickness is reckoned by Mr. Whitaker at 37 feet. The thickness however varies like the strata, even within short distances, being from 43 to a little over 60 feet in the neighbourhood of Felixstow, 36 feet at Trimley, 27 to 34 feet near Woodbridge, as much as 70 feet at Southwold, and nearly 80 at Leiston. In these localities our information is derived wholly from records furnished by well-sinkers. The main mass of the Reading Beds extends to Saxmundham and Lowestoft, but not so far inland as Beccles.

The possible occurrence of an outlier of Reading Beds beneath Drift and Crag at Hoxne has been suggested by Mr. W. H. Dalton, and he records the occurrence of 'plastic blue loam' near Halesworth which 'may belong to this series'; but the evidence in both cases is questionable. ${ }^{2}$ In a well made at Brettenham it is possible that Reading Beds occur beneath the Drift, but Mr. Whitaker, who has published the section, does not favour this view. ${ }^{3}$

The Reading Beds having a narrow outcrop and being much concealed by newer strata enter but little into the surface features of the county. The clays are worked for brick-making near Sudbury, Bramford and Ipswich, and the sandy beds are water-bearing.

At Stoke near Ipswich Mr. Whitaker noticed a few feet of sandy

1 2uart. Fourn. Geol. Soc. xxx. 401.

'See 'Geology of the Country around Halesworth and Harleston,' Geol. Survey (1887), pp. 3, $37,38$. 


\section{A HISTORY OF SUFFOLK}

gravel and buff sand, hardened in places into stone, which may belong to the Oldhaven or Blackheath Beds. Again, beneath the London Clay at Leiston, a boring proved 26 feet of loamy sand with flint pebbles and sandstone, which may also represent the same group, and perhaps to some extent the basement bed of the London Clay.

\section{LONDON CLAY}

This formation consists mainly of bluish-grey clay which weathers to a brown clay at and near the surface. It contains selenite, iron pyrites, and also nodular masses of argillaceous limestone or septaria, which were formerly dredged up at the entrance to the Orwell and Stour and burnt at Harwich for Roman cement. Some of these stones were used in old times for building purposes, as in Wrabness and Chelmondiston churches and in the keep of Orford Castle.

The London Clay is exposed beneath the Crag at Felixstow and Bawdsey, and the septaria are said to form rocky ground beneath the sea off the mouth of the Ore. ${ }^{2}$ The clay comes to the surface along the borders of the Deben below Woodbridge, along the Orwell and its tributaries below Burstall and Ipswich, and along the Stour and its tributaries below Boxford and Assington to the north of Nayland.

The basement bed, from 8 to nearly 30 feet in thickness, comprises loamy sand with black flint pebbles and occasional sandstone with casts of shells. One of the most interesting sections was that at Kyson (Kingston) on the banks of the Deben about one mile below Woodbridge, where teeth of the shark Odontaspis ('Lamna'), and also remains of Hyracotherium (formerly regarded as the remains of a monkey) were obtained. ${ }^{3} \quad$ The lower beds have also been exposed at Hadleigh brickyard.

The full thickness of the London Clay is nowhere developed in Suffolk because the formation has suffered extensive erosion. As much as I 30 feet was proved in a well at Orford, about 68 feet at Southwold, and rather less than 50 feet at Leiston, the base of the London Clay occurring in Mr. Whitaker's opinion a little east of Saxmundham. Further south there was proved at Felixstow 64 feet of London Clay, at Trimley $88 \frac{1}{2}$ feet, and at Stutton Hall 7 I feet, the varying thickness being dependent locally on the elevation of the ground. The beds have been worked in places for the manufacture of bricks and tiles.

The fossils of the London Clay include remains of turtles, of the sharks Otodus and Odontaspis, of the eagle-ray Myliobatis, the crab (Plagiolophus) and the lobster (Hoploparia), as well as mollusca such as Nautilus and the boring shell Teredo, brachiopods, pyritized plants and fossil wood. Coprolites have also been met with.

1 ' Geology of the Country around Ipswich,' etc., p. 15 ; 'Geology of South-western Norfolk,' etc., Geol. Survey (1893), p. 163; and Geol. Mag. (1895), p. 463.

2 Capt. H. Alexander, 'Treatise on the Nature and Properties of the Soils of Norfolk, Suffolk and Essex' (1841), p. 15.

3 Prestwich, 2uart. Fourn. Geol. Soc. vi. 272. 


\section{GEOLOGY}

Where exposed at the surface the London Clay would under ordinary circumstances yield a stiff clayey soil, but in Suffolk it is mainly exposed along the borders of valleys and the soil is lightened and enriched by down washes from higher sandy and shelly strata. The soil has therefore been described as a 'rich loam,' and as such it is met with here and there from Hadleigh eastwards to the borders of the Stour, Orwell and Deben.

It is impossible now to say how far the Eocene strata formerly extended over Suffolk. In some areas deep 'pipes' in the Chalk have preserved portions of the strata at a distance from the main mass, but apart from the doubtful evidence furnished by well sections no such relics have at present been proved to occur in Suffolk.

It may be that there was overlap of the successive members of the Eocene series, and that Bagshot Beds formerly extended into the county, yielding materials for some of the Pliocene and Glacial sands and pebble beds. Indeed, S. V. Wood, jun., suggested that the middle Glacial sands might largely have been made up of Bagshot Beds. ${ }^{1}$ The occurrence moreover of Oligocene fossils in the basement beds of the Crag in Norfolk is also a significant fact.

The Chalk surface has been furrowed in places by 'pipes' and traces of clay-with-flints were noticed by Mr. F. J. Bennett in such pipes beneath Boulder Clay near Saxham, ${ }^{2}$ while irregular channels have occasionally been formed in Pleistocene times and filled with Glacial Drift.

Some disturbances have been proved in the Chalk south of Ipswich and at Woodbridge, ${ }^{3}$ while a few small faults have been noticed in the London Clay at Felixstow and Bawdsey.

\section{PLIOCENE}

The Crag Series consists of sands, pebbly gravels and laminated clays, but the characteristic and prominent beds are shelly sands which have for a long period been dug as manure for fertilizing the land and as material for garden walks."

\section{CORALLINE CRAG}

The lowest division, known as the Coralline Crag, owes its name to the fact that much of it is composed of bryozoa. In some places it appears in the form of loose shelly sands; elsewhere it is composed of comminuted shells and bryozoa, locally hardened into stone, the joints

\footnotetext{
1 - Remarks in Explanation of Map of the Upper Tertiaries of the Counties of Norfolk, Suffolk, etc.' (1866), p. 13.

2 'Geology of Bury St. Edmunds,' p. 12.

a Whitaker, 'Geology of Ipswich,' P. roo; and 2uart. Journ. Gecl. Soc. lix.

4 For full particulars of the Pliocene strata, see S. V. Wood, 'The Crag Mollusca,' Palacontograph. Sac.; Prestwich, Quart. Fourn. Geol. Soc. xxvii. I1 1 , 325, 452; F. W. Harmer, ibid. liv. 308, Ivi. 705 ; Whitaker, 'Geology of the country around Ipswich,' p. 32 ; C. Reid, 'The Pliocene Deposits of Britain' (1890), Geol. Survey; and E. T. Newton, 'The Vertebrata of the Pliocene Deposits of Britain' (1891), Geol. Survey.
} 


\section{A HISTORY OF SUFFOLK}

of which are sometimes filled with calcareous veins. Beds of this character have been used for building purposes, as in the tower of Chillesford church; they have been quarried like a freestone, and perhaps on this account the name 'crag' may have been introduced into East Anglia. Blocks also have been obtained from the 'Thorpe Rocks' on the beach near Aldeburgh.

The stone beds do not yield the rich variety of mollusca found in the loose sands, but this, as pointed out by Mr. F. W. Harmer, is owing to the fact that the shells have been largely dissolved away by the action of acidulated water. Consequently the sub-divisions made in the Coralline Crag by Prestwich are not to be regarded as successive zones, but rather as altered local conditions in the strata. In proof of this Mr. Harmer has pointed out that at Brick-kiln farm, Iken, a lenticular patch of the shelly sands occurs in the midst of a mass of the indurated beds. ${ }^{1}$

The Coralline Crag attains a thickness of 50 or 60 feet, and from its pale buff tint it has sometimes been termed the White Crag, in distinction from the Red Crag which overlies it. At some depth below ground all the Crag beds are usually grey in colour. The principal exposures of Coralline Crag are at Tattingstone, south of Ipswich; at Sutton and Ramsholt, south of Woodbridge; and at Gedgrave, Sudbourne, Orford and Aldeburgh. From the abundance of fossils at Gedgrave the formation has been termed the 'Gedgravian' by Mr. Harmer, and characterized as the zone of Mactra triangula.

Among the more abundant and noteworthy fossils are Cardita senilis, Pectunculus glycimeris, Cyprina islandica, C. rustica, Astarte omalii, Diplodonta rotundata, Nucula nucleus, Pecten opercularis, P. tigrinus, Tropbon consocialis, Turritella incrassata, Calypraa cbinensis, Voluta lamberti, etc.

At the base of both Coralline and Red Crag, but chiefly below the Red Crag, there occurs a remarkable nodule and pebble bed which has yielded numerous derived fossils, many of them phosphatized. It is well known as a 'Coprolite bed,' and will be referred to more particularly in reference to the Red Crag. It forms a layer I 2 to I 5 inches thick beneath the Coralline Crag at Sutton, and has there yielded pebbles of quartz, quartzite, flint, septaria from the London Clay, bones of Jurassic saurians, and a large boulder of red porphyry, weighing about a quarter of a ton. ${ }^{2}$ Coprolites were worked at this locality for a short period. The most interesting fossils are those enclosed in rolled fragments of sandstone and known as 'boxstones.' They include Voluta auris-leporis, Conus dujardini, Nassa conglobata and Isocardia cor (and var. lunulata), and these with other forms characterize an older Pliocene deposit, no longer existing in situ in this country. The boxstones, which thus represent remnants of an earlier fauna than the Coralline Crag, have been locally used for road metal. The fauna of the Coralline Crag, as observed by Lyell, indicates a warmer temperature than that of the later stages of the crag. The sea was open to the south, and the mollusca

1 Proc. Geol. Assoc. xv. 436, xvii. 424.

2 Prestwich, Quart. Fourn. Geol. Soc. xxvii. I I 7 ; E. Ray Lankester, ibid. xxvi. 493. 


\section{GEOLOGY}

are of Mediterranean type. The formation as noted by Mr. Harmer was laid down in water of moderate depth as submarine shell-banks with drifted mollusca and with occasional reefs of bryozoa.

\section{RED CRAG}

The Red Crag is a reddish and yellowish brown sand with much oblique and false bedding, with abundant mollusca, some broken and most of them stained red. Rusty brown veins of ironstone and films of ferruginous sandstone pervade the strata. The iron ore, as suggested by J. E. Taylor, may have been derived to some extent from pyrites in the London Clay, but much of it, according to Prestwich, appears to have been introduced subsequently, as the staining and the infiltration bands are very irregularly distributed.

The Red Crag has been opened in places to a depth of 15 or 20 feet, while its full thickness does not appear to exceed 40 feet, if we accept Mr. Harmer's grouping, and regard as Norwich Crag those beds which lie to the north of Aldeburgh.

The Red Crag rests irregularly on the worn surfaces of the Coralline Crag and elsewhere on the London Clay. Lyell described an old cliff in the Coralline Crag at Sutton against which the Red Crag rested, and the two crags have been seen in irregular conjunction at Tattingstone Park and Ramsholt. In opposition to earlier observers Mr. Harmer believes that not many of the Red Crag mollusca have been derived from the Coralline Crag, although he admits that upheaval and some denudation of the older deposit took place, and that its basement bed remained in certain areas to form the foundation of the Red Crag. ${ }^{2}$

It is generally agreed that the older portion of the Red Crag is that of Walton-on-the-Naze, a stage not recognized in Suffolk. In that region it contains most of the characteristic Coralline Crag shells, as well as mollusca which entered the crag basin from areas on the north with which communication had been opened up. Thus Mr. Harmer has come to regard the Red Crag as the marginal accumulations of a sea which gradually retreated northward, so that the deposits as we approach Norfolk yield species more boreal as well as more recent in character.

The oldest layers of Red Crag in Suffolk would be those that occur between the Stour and the Orwell, at Shotley and Erwarton, at Tattingstone and Bentley, and as far west as Stoke and Polstead in the neighbourhood of Sudbury. These beds have not been separately designated by Mr. Harmer, who groups the Suffolk Red Crag into two stages, based on the abundant forms that occur in the districts.

The older he terms the Nerobournian, from Newbourn, south of Woodbridge; it constitutes the zone of Mactra constricta, and includes the well-known Red Crag of Felixstow, which rests on the London Clay in the cliff section, and also the Crag at Trimley, Ramsholt, Sutton and Shottisham.

1 Proc. Geol. Sac. iii. 127 ; Prestwich, 2uart. Fourn. Geol. Soc. xxvii. 339, 342.

2uart. Fourm. Geol. Soc. Ivi. 707, 708, 719, 721 ; Proc. Geol. Assoc. xvii. 428. 


\section{A HISTORY OF SUFFOLK}

The newer division, termed the Butleyan, and known to all collectors in the well-known pit near the Butley Oyster Inn, is characterized as the zone of Cardium grcenlandicum, and is recognized by Mr. Harmer in the cliff at Bawdsey, where the Red Crag overlies the London Clay; also in pits at Alderton, Hollesley, Boyton, Chillesford, Sudbourne and Iken.

The characteristic fossils of the Red Crag are Neptunea (Trophon) antiqua, N. contraria, Purpura lapillus, Natica (several species), Cassidaria bicatenata, Nassa (several species), Turritella incrassata, Tellina obliqua, $\mathcal{T}$. pratenuis, Mactra ovalis, $M$. constricta, Cardium angustatum, Pectunculus glycimeris, Scrobicularia plana (in upper beds), Pecten opercularis, Mytilus, Mya, etc.

The basement bed, to which reference has previously been made, is of considerable interest, as it contains many bones as well as other fossils, and masses of hardened clay or septaria from the London Clay, all rolled and phosphatized, and known commercially as 'coprolites.' The bed is from 6 inches to about 3 feet thick, and the phosphatic nodules or coprolites, which are occasionally dispersed through the formation, have been extensively dug since the middle of last century. In 1847 about 500 tons were raised, in $1854 \mathrm{I} 2,000$ tons, in 1889 5,000 tons, since which date the trade has gradually declined, and was finally abandoned owing to the introduction of foreign phosphates.

Attention was first directed to the nodules by the Rev. J. S. Henslow, ${ }^{1}$ for many years rector of Hitcham, who in 1842 observed the curious nodules in the Red Crag at Felixstow, and afterwards found some which were clearly coprolites. They have been found to yield from 44 to 60 per cent. of phosphate of lime; and have been worked at Walton, Trimley, Falkenham, Foxhall, Bawdsey, Ramsholt, Shottisham, Sutton and Boyton. ${ }^{2}$

Many vertebrate remains have been obtained from the coprolite bed, and notable collections have been made by the Rev. H. Canham of Waldringfield, Messrs. Whincopp and J. Baker of Woodbridge, and Mr. E. Cavell of Saxmundham. Among the remains there occur the ribs and ear-bones (cetotolites) of whales, bones and teeth of mastodon, rhinoceros, tapir, hyæna, etc.

\section{NORWICH CRAG}

To the north of Aldeburgh the place of the Red Crag appears to be occupied by the Norwich Crag. The Crag loses its markedly red colour, and the abundant fossils indicate somewhat more boreal conditions. Whether the whole of the Norwich Crag is newer than any portion of the Red Crag may reasonably be doubted; indeed, the generally accepted view that the upper part of the Red Crag, which is sometimes termed the Scrobicularia Crag, is equivalent to the lower part of the Norwich Crag, has much evidence in support of it. This

1 Proc. Geol. Soc, iv. 28 r.

2 Reid, 'Pliocene Deposits of Britain,' p. 6. 


\section{GEOLOGY}

view, although recently opposed by $\mathrm{Mr}$. Harmer, accords with the general evidence along the East Anglian coast of successively newer stages as we proceed from south to north.

In the Norwich Crag we have a series of shelly sands, orangecoloured and white pebbly sands and gravels, and thin seams and extensive 'jambs' of laminated clay, to the more persistent masses of which the name Chillesford Clay has been applied. It is indeed a great series compared with the Coralline and Red Crags, for it has been found to attain a thickness of nearly 200 feet in places, the thickness increasing from the outcrop, ${ }^{1}$ probably to some extent owing to erosion of the strata during the Pleistocene period.

In 1849 Prestwich described the sections at Chillesford near Orford where the Red Crag with Scrobicularia is exposed in a stackyard, overlain by buff shelly sand and a band of loamy clay, to which the name Chillesford Clay has since been applied. ${ }^{2}$ This clay occurs over some extent of ground near Chillesford and at Iken. Somewhat disturbed and rearranged beds of the clay overlie the Norwich Crag at Dunwich; it is not seen at Southwold, but thinner layers representing it occur in the shelly sand and pebbly gravel at Easton Bavent. It occurs also at Covehithe and Kessingland, at Beccles, near Herringfleet, Somerleyton and Blundeston. It is not to be regarded as the highest portion of the Norwich Crag Series, for in Norfolk it is represented only here and there sometimes overlain by shelly gravel, and elsewhere apparently replaced by the highest stage of the Norwich Crag, known as the Weybourn Crag and Bure Valley Beds. Here we enter the region of controversy, and it will be sufficient to mention that this highest group is succeeded in Norfolk by the Forest Bed Series, which is represented in places on the Suffolk coast.

Following $\mathrm{Mr}$. Harmer we may regard the Norwich Crag as extending from the neighbourhood of Thorpe or Aldringham Common near Aldeburgh to Dunwich, Southwold, Bulchamp and Wangford, and to the Waveney valley near Bungay and Beccles.

These include the most famous localities for fossils, but in many parts of Suffolk, as in Norfolk, we find few or no fossils, as in the Minsmere valley at Darsham and Yoxford, and in the Blyth valley at Thorington, Halesworth and Walpole. In some cases no doubt the shells have been dissolved away. Thicknesses of 105 feet at Saxmundham, 133 at Leiston, 147 feet at Southwold and 80 feet at Beccles have been assigned from the evidence of well borings to the Norwich Crag, without including certain pebbly gravels which at any rate at Southwold and Beccles most likely belong to the series. ${ }^{3}$

1 See Whitaker, Geol. Mag. (1895), p. 464; Harmer, 2uart. Journ. Geol. Soc. lii. 767 ; Proc. Geol. Assoc. svii. 443 .

2uart. Fourn. Geol. Soc. v. 345 ; xrvii. 336, 337. See also Harmer, ibid. liv. 309 ; 1vi. 708 , 721 ; and Reid, 'Pliocene Deposits of Britain,' p. 100.

${ }^{3}$ Reid, 'Pliocene Deposits of Britain,' P. 20 I ; and H. B. Woodward, 'Geology of the country around Norwich,' Geol. Survey (1881), p. 31. See also Prestwich, 2uart. Fourn. Geol. Soc. xxvii. 343, 344 . 


\section{A HISTORY OF SUFFOLK}

The lower portion, the main mass indeed which occurs beneath the Chillesford Clay, where that clay is present, is the more shelly portion, to which the name Icenian has been restricted by Mr. Harmer, and which he regards as the zone of Mactra subtruncata; while the Chillesfordian stage he places as the zone of Leda oblongoides.

The shelly beds of the Norwich Crag yield Ceritbium tricinctum, Turritella terebra, T. incrassata, Purpura lapillus, Neptunea (Tropbon) antiqua, Buccinum undatum, Littorina littorea, Cyprina islandica, Cardium edule, Mya arenaria, Tellina obliqua, $\mathcal{T}$. pratenius, $\mathcal{T}$. lata, Pecten opercularis, Astarte borealis, Nucula cobboldia, fish remains such as Platax woodwardi, occasional coprolites, and bones and teeth of mastodon. The organic remains have been studied by Dr. W. M. Crowfoot of Beccles, Mr. E. T. Dowson of Geldeston and others.

That the Norwich Crag was formed in shallow bays into which streams brought land and freshwater mollusca has been generally admitted. The Chillesford Clay itself has been regarded as of a more estuarine character, its laminated structure and the occurrence of remains of a cetacean to some extent supporting this view. The Chillesford fossils found in the sands beneath the clay at Chillesford are forms met with in the Norwich Crag, but on the whole the assemblage is regarded as rather more boreal in character than the lower or main portion of the Norwich Crag. The species include Turritella terebra, Natica catena, Leda oblongoides, Nucula cobboldia, Cardium edule and $C$. grcelandicum. ${ }^{1}$ Prestwich ${ }^{2}$ has recorded a number of shells from the Chillesford Clay at Easton Bavent, where however the clay is interbedded with much sand and shingle.

The impersistence of the Chillesford Clay and its replacement by beds of sand and pebbly gravel are well-established facts. At Southwold we find the shelly gravel and sand of the crag at the north end of the cliff, with no representative of the Chillesford Clay; and beds of this character, with occasional subordinate seams of clay, extend towards Westleton, where they are overlain by a newer group of pebbly gravels, which appear to be associated with the Middle Glacial Sands. ${ }^{3}$

Northwards we find below the Glacial Drift, along the Waveney valley near Somerleyton, some 20 feet of pebbly gravels; and there are beds as far west as the Stantons, Bardwell and Wattisfield, which may be of Pliocene age. G. Maw noticed shelly gravel between Coddenham and Crowfield, but there the shells were probably derived from Crag beds which are no longer preserved in situ. ${ }^{4}$

The Crag Series forms a water-bearing group, and where it rests on the London Clay or other Eocene clays water is held up and springs are thrown out. Where the Crag rests on Chalk the supply is modified by the relation to the plane of saturation in the Chalk and by the local occurrence of the beds of Chillesford Clay.

1 Harmer, 2uart. Fourn. Geol. Soc. lvi. 721.

${ }^{3}$ Proc. Geol. Assoc, xv. 440.
2 Ibid. xxvii. 345,462 .

4 Geol. Mag. (1864), p. 295. 



\section{GEOLOGY}

\section{CROMER FOREST BED}

Overlying the Chillesford series at Kessingland and exposed also at the foot of the cliffs at Corton is the Cromer Forest Bed-the Cromerian or zone of Elephas meridionalis-a series of freshwater and estuarine deposits, comprising dark peaty clay with seeds and other plant remains, greenish stony clay, and gravel some 10 or 15 feet thick. The dark peaty clay forms a black bed, perhaps an old lacustrine deposit, which lies in hollows above the rootlet bed, and these strata at Kessingland appear generally to occupy an eroded surface of the Chillesford Clay. The greenish stony clay is penetrated by roots, and has been termed the rootlet bed; remains of freshwater shells are found in the Unio bed, a gravelly layer at the base of the black bed, in which occur Unio pictorum and Pisidium astartoides; while remains of elephant, hyæna, rhinoceros and deer are found at different horizons in the Forest Bed Series.

These interesting layers have attracted much attention from John Gunn, J. H. Blake and others, while the organic remains from Corton were specially looked after by J. J. Colman. ${ }^{1}$ The bed with rootlets was first described by S. R. Pattison in $18630^{2}$

It is however a difficult task to clearly make out the sequence along the cliffs from Kessingland to Corton, because not only does the Forest Bed Series rise very little above the sea-level, but a great portion of the cliffs along their base is usually obscured by talus and blown sand. It requires an attentive study on many occasions during successive winter and spring seasons before a clear notion of the relations of the strata can be gained.

The story however has been made out, and Mr. Clement Reid remarks that the Pliocene land fauna and flora is mostly of temperate species. There were forests of oak, Scotch pine, beech, birch, elm, hazel, hornbeam and cornel. The lakes were full of yellow water-lily, water-crowfoot and various existing species of pond weeds; their shores were occupied by thickets of alder and willow, by osmunda, or dense growths of reeds and sedges."

\section{PLEISTOCENE AND RECENT}

\section{GLACIAL DRIFT}

It must be borne in mind that the divisions in geological time are simply convenient groupings. The Pliocene and Pleistocene periods merge imperceptibly whether we consider the physical changes or the strata which furnish the records.

The Glacial Drifts of earlier Pleistocene age were spread irregularly across the entire country, and to this mantle of clays, sands and gravels

1 Blake, 'Geology of the country near Yarmouth and Lowestoft,' Geol. Survey (1890), p. I7 ; Prestwich, 2uart. Journ. Geol. Soc. xxvii. $46_{3}$; E. T. Newton, 'Vertebrata of the Forest Bed Series.'

Geologist, vi. 207.

- Natural Science, vii. 176 ; 'Pliocene Deposits of Britain,' pp. 146, etc. 


\section{A HISTORY OF SUFFOLK}

the agricultural characters and the aspect of the land are most largely due. ${ }^{1}$

\section{GLACIAL LOAM}

The earliest Glacial Drift is a stony loam which underlies the middle Glacial sands and gravels in the cliff between Hopton and Corton, where the sequence in descending order of Chalky Boulder Clay, sands, and loam with occasional boulders, led John Gunn to recognize an Upper and Lower Boulder Clay. ${ }^{2}$

This stony loam, 2 I feet thick, occurs at Blundeston and at Somerleyton, where no doubt it forms a southerly continuation of the ' Contorted Drift' of the Cromer coast. It contains boulders of igneous rock and fragments of marine shells, and may in general terms be regarded as a Lower Boulder Clay, or Lower Glacial Drift. It is used for brick-making.

Higher up along the borders of the Waveney valley there are other beds of loam near North Cove, to the south of Beccles, at Withersdale, Weybread, Stuston, Palgrave and Redgrave. These appear to underlie the main mass of Chalky Boulder Clay (Upper Glacial), but they cannot in all cases be definitely assigned to the Lower Glacial Drift.

The fact must be borne in mind that the Chalky Boulder Clay when much weathered and decalcified becomes a brown stony loam, while in the Middle Glacial sands and gravels there are lenticular masses of laminated loam. Some of these beds, moreover, are rather difficult to distinguish from the earlier Chillesford Clay. Hence there are many difficulties in the identification of particular beds of loam in Suffolk, and such difficulties give rise to divergent opinions. Under these circumstances it will be best to mention briefly the more important beds of loam, without in all cases indicating their relative ages.

The brickyard at Withersdale Cross, south-east of Harleston, showed I 2 feet of laminated brickearth with alternations of sand and gravel, much contorted towards the surface by glacial action. Underlying the brickearth was a considerable thickness of sand and gravel. Somewhat similar beds were noted by Mr. W. H. Dalton to the south of Mendham Priory, where pottery works formerly existed. ${ }^{3}$

More definite evidence of Lower Glacial or Contorted drift occurs in Weybread brickyard, where there is a brown stony loam with fragments of Cyprina and other shells. Here the Chalky Boulder Clay overlies and at one point dovetails into the loam. Similar loam occurs at Sotterly, and sandy loam with streaks of chalky loam underlies the Boulder Clay at Walpole near Halesworth. ${ }^{4}$

1 See 'General View of the Agriculture of Suffolk,' ed. 3, (1804,) by Arthur Young ; and 'Farming of Suffolk,' by Hugh Raynbird, Journ. Roy. Agric. Soc. vii. 26 I.

2 J. Trimmer, Quart. Fourn. Geol. Soc. xiv. 171 ; Rose, Geologist, iii. 137.

3 Whitaker and Dalton, 'Geology of the country around Halesworth and Harleston,' Geol. Survey (1887), p. 16.

Whitaker and Dalton, op. cit. p. 19. 


\section{GEOLOGY}

Mr. F. J. Bennett has described mottled clay and loam at Wattisfield, from which coarse red pottery was formerly made; while at the kiln west of the church at Rickinghall Superior, I 2 feet of dark laminated sandy clay with freshwater shells and plant remains was observed by him beneath the Boulder Clay and Glacial Sand. Again at Knattishall he noticed about I 5 feet of blue and grey clay overlain by 3 feet of sandy loam. ${ }^{1}$

Brickearth also occurs at Reddenhall, Rushbrooke, Wetherden, Stowmarket, Needham Market and Boxford; some beds, as noticed further on, are found in the Middle Glacial Drift, while other deposits are of distinctly later date.

Near Brandon and Santon Downham there are patches of Glacial loam and gravel, the loam being sometimes dug to a depth of 10 feet for brickearth. To these loamy beds, which are more prominently developed on the Norfolk side of the Ouse, Mr. Skertchly applied the name 'Brandon Beds'-they occur in places beneath Boulder Clay, and from some beds which he regarded as equivalent, he recorded the finding of flint flakes and implements. ${ }^{2}$ Boulder Clay was not however to be seen above the loam in which the implements were found, and hence doubt necessarily exists with regard to the high antiquity which he assigned to the implement-bearing deposits. Near Mildenhall the loam furnishes a good soil.

Loam occurs above the Chalky Boulder Clay at Bury St. Edmunds, often merely as weathered and decalcified surface portion of it.

\section{GLACIAL SANDS AND GRAVELS}

The same difficulty which is experienced with the loams is met with in the case of the older Pleistocene sands and gravels. Cases occur where it is difficult to fix the position of some of the deposits. This is natural enough when we bear in mind that gravels are used up again and again at different periods, and that contemporaneous organic remains and the evidence of stratigraphical position are often wanting.

The greater part of the sand and gravel of Suffolk is beneath the Chalky Boulder Clay and belongs to the Middle Glacial division of S. V. Wood, jun. In the eastern part of the county we find a great spread mainly of sands, often very fine in grain and minutely current-bedded. Much of it looks as if it might have been wind-drifted. The beds extend from Gorleston, Bradwell and Belton to Fritton, Herringfleet Hills, Lound and Hopton; they occur at Oulton, Carlton Colville and Kirkley, and further south on the higher grounds over much of the eastern margin of the county, where they rest on the Crag series.

The sands and gravels are from a few feet up to 100 feet in thickness, and they contain in places, especially at Gorleston and Corton, shelly patches somewhat like those of the Crag, and with many broken

1 ' Geology of the country around Diss, Eye, Botesdale and Ixworth,' Geol. Survey (1884), p. I 2.

' 'Geology of South-western Norfolk,' etc., Geol. Survey (1893), Pp. 49-51. 


\section{A HISTORY OF SUFFOLK}

shells such as Cyprina islandica, Cardium edule, Mya arenaria, Mactra ovalis, Pectunculus glycimeris, Turritella incrassata, Purpura lapillus, and many other species. They were looked upon by the earlier observers, amongst whom was C. B. Rose, as re-constructed Crag, and this view is supported by the fact that of more than 100 species, all but two or three are found in the Crag, and that these shells do not occur in the Glacial sands remote from Crag regions. ${ }^{1} \mathrm{Mr}$. Harmer, however, maintains that the fauna is contemporary. ${ }^{2}$

The sands contain a good deal of black carbonaceous matter, or comminuted lignite, that may have been derived from the Estuarine beds of Yorkshire. They contain also grains of chalk and much fine chalky material, especially at and near the junction with the overlying Boulder Clay. On this account by the dissolution of the carbonate of lime and its redeposit as a cement, the sands have been locally hardened into a calcareous sandstone. Beds of this character may be seen near Lowestoft, while curious concretionary columns of sandstone were met with at Mutford Wood, ${ }^{3}$ and large consolidated blocks were observed near Coddenham. ${ }^{4}$ The stone has been locally used for building purposes.

Another feature of interest in the sands is the occurrence of occasional beds of fine loam. A bed of this nature was employed in the manufacture of the once famous Lowestoft china, the works being in existence from $1756-1802 .{ }^{5}$

West of Bury St. Edmunds there are finely-bedded sands, loams and clays, much contorted in places; while near Woolpit there is about 30 feet of brown laminated loam and dark bluish-grey clay, the brown loam being used for the manufacture of red bricks, and the clay for the white bricks for which Woolpit has been famous since the time of Queen Elizabeth. ${ }^{6}$

Of considerable geological interest are the shingle beds or beds of pebbly flint gravel which occur in the sands near Fritton, Oulton, Kirkley and Pakefield, and appear to be the equivalents of the mass of the Westleton shingle on Westleton Common, and in the higher part of Dunwich Cliff. This is one of the controverted questions in geology. It has not been doubted that the pebble gravel at Fritton, Oulton, Kirkley and Pakefield is part of the Middle Glacial; but it has been maintained by Prestwich and others that the mass of shingle at Westleton, Halesworth and Henham is older, and of early Glacial or early Pleistocene age.

There is much gravel somewhat similar in character in the upper part of the Norwich Crag Series, in the subdivision termed 'Bure Valley Beds,' but this is rightly regarded by Mr. F. W. Harmer as distinct

1 H. B. Woodward, Proc. Geol. Assoc. ix. 111.

2 Proc. Geol. Assoc, xvii. 459.

3 H. K. Creed, Proc. Suffolk Inst. iv. (1872), 244.

- G. Maw, Geol. Mag. (1867), p. I 10.

5 J. H. Blake, 'Geology of the country near Yarmouth and Lowestoft,' p. 96.

- Ibid. 'Geology of the neighbourhood of Stowmarket,' p. I 3.

7 H. B. Woodward, Geol. Mag. (1902), p. 27 . (Herein are references to other papers.) 


\section{GEOLOGY}

from the Westleton shingle. ${ }^{1}$ It is a subdivision that may be represented in the Crag Series at Easton Bavent and Southwold, and it may be remarked that the pebble gravel at the northern end of Southwold cliff, regarded by Prestwich as 'Westleton Beds,' ${ }^{2}$ is clearly a part of the Crag Series, which probably extends over the whole of Southwold. We find, in fact, re-arranged Chillesford Clay in the Middle Glacial sands at Dunwich, shingle in the sands at Pakefield and Kirkley, reconstructed Crag in the sands at Gorleston.

As before mentioned, we find on the Chalk tracts in north-western Suffolk much sand of no great thickness, as on Lakenheath Warren. It is a region known as the 'Fieldings,' and noted as subject to sandstorms. As long ago as I 668, Thomas Wright gave a brief description of the devastation caused by the drifting of sand, but the trouble has been exaggerated by subsequent writers owing to the title of Wright's paper, 'A curious and exact Relation of a Sand-floud, which hath lately overwhelmed a great tract of Land in the County of Suffolk., ${ }^{3}$ He remarked that previously the sand had been drifted by the south-west winds over many acres of land, but that it had first reached the bounds of Downham (known as Santon Downham or Downham Arenarum) some 30 or 40 years prior to 1668 , and eventually a number of meadows and pastures were ruined by 'the extream Sandiness of the Soyl, the levity of which, I believe, gave occasion to that Land-story of the Actions that use to be brought in Norfolk for Grounds blown out of the Owners possession.' Until improved by the application of marl this was no doubt the poorest land in the county.

The greatest thickness of sand and gravel (mostly sand) is 100 feet, recorded at Market Weston near Bury St. Edmunds, in which district the beds rest on Chalk. Coarse mixed gravel, often with lumps of Chalk, occurs in places below, in, and above the Chalky Boulder Clay, and is perhaps more intimately connected with the Boulder Clay than the mass of the Middle Glacial sands and pebbly gravels. It may mark places where the débris-laden ice was melted, and its constituents were distributed by torrential streams.

Thus gravel with boulders of limestone, sandstone and grit occurs beneath Boulder Clay at Great Horringer; coarse gravel is likewise found at Gallows Hill, south-east of Needham Market; and a mass of chalky gravel was observed in the Boulder Clay at Halesworth. Some of the patches of gravel now seen on Boulder Clay may have occurred originally in it before the surface had been lowered by denudation. Coarse gravel with large flints occurs at Cockfield and Lavenham, and gravel over Boulder Clay has been exposed to a depth of I 2 to I 8 feet at Tostock, Elmswell, Woolpit and Shelland; a mass of it extends from Great Waldingfield to Cornard Heath, Newton Green and Assington; it is met with also to the north and west of Lowestoft and Gunton, north of Hopton and at Herringfleet Hall. Where the gravel occurs at

1 2uart. Foum. Geol. Soc. Ivi. 724 ; Proc. Geol. Assoc. xvii. 453.

2 Ibid. xxvii. 462 .

Pbil. Trans. iii. (1668), 725. 


\section{A HISTORY OF SUFFOLK}

the surface it is usually decalcified, but where protected by Boulder Clay the Chalk and other calcareous fragments may be preserved.

Sometimes, as near Lowestoft, this newer gravel extends irregularly from higher to lower ground, from Boulder Clay on to the Middle Glacial gravels, and where one gravel rests on another it is often difficult to determine any plane of separation.

Occasionally a large erratic block has been met with, and J. E. Taylor obtained a mass of 'Hertfordshire puddingstone,' weighing about a ton and a half, from the sands near Ipswich.

The Glacial sands and gravels have furnished local supplies of water to many a village and small town. The gravels are employed for road mending, and the larger flints are sometimes used for building purposes.

Speaking generally, the sands and gravels form the less fertile areas in Suffolk, the so-called 'waste' grounds which form the picturesque commons of East Suffolk at Walberswick, Dunwich and Westleton; and the 'Sandlings' which extend southwards from Saxmundham, Orford and Woodbridge. The neighbourhood of Yoxford has sometimes been termed the 'Garden of Suffolk.' Over much of the region mentioned, the Glacial sands and gravels rest on the porous shelly sands of the Crag Series, which are more fertile in character; together they constitute the lighter lands of Suffolk.

\section{BOULDER CLAY}

The Chalky Boulder Clay occupies the surface over the greater part of central and western Suffolk, and it occurs in tracts along the eastern borders. In the central and eastern parts of the county it presents its characteristic features of a tough, bluish-grey, unstratified stony clay, with many small pebbles of Chalk, flints, and stones and fossils from a variety of geological formations, notably from the Secondary strata. Thus Red Chalk, Spilsby Sandstone, Kimeridge Shale and Oxford Clay, Oolites and Lias are represented, and we find Saurian bones, Ammonites, Belemnites, Gryphæa and other fossils. Much of the Chalk and many other blocks of rock, and sometimes fossils such as Belemnites, are scored and scratched, no doubt by sharp fragments, such as shattered flint, that were embedded in the ice to which the Boulder Clay owes its origin.

It attains a thickness of from I 30 to I 50 feet at Wickhambrook, Naughton, Great Thurlow and Hartest, and I 70 feet at Bradfield St. George. Elsewhere, as at Botesdale, St. Margarets Southelmham, Mendlesham, Cockfield, Lavenham and southwards to Assington and Leadenheath, it is from 50 to 100 feet. In western Suffolk, especially about Elvedon and on Icklingham Heath, the Boulder Clay is thinner, more chalky and more sandy, and often not more than 12 feet thick. Much of the Boulder Clay is obscured by a thin sandy soil, which Mr. F. J. Bennett regards as to some extent a decomposition product, and as feeding the sandstorms which arise. ${ }^{1}$

1 'Geology of Diss, Eye, Botesdale and Ixworth,' Geol. Survey (1884). 


\section{GEOLOGY}

Opinions differ with regard to the agent which formed the Boulder Clay. That it was the product of ice-action is not seriously disputed, but whether directly due to a mass, or masses, of land-ice, has been questioned. Ice may have occupied the bed of the North Sea, and spread thence in places inland as maintained by Mr. G. W. Lamplugh. ${ }^{1}$ Ice may also have come from north-eastern parts of England. That the materials came largely from the north-west and north is to be inferred from the Red Chalk, the Jurassic detritus, the carbonaceous fragments which may have come from the Estuarine beds of Yorkshire, and the occasional Carboniferous rocks. The matrix has received attention from the Rev. Edward Hill, rector of Cockfield, and he observes that all the minor materials may have had a westerly origin, and that they are for the most part derived from Secondary strata. ${ }^{2}$

With regard to the question of an ice-sheet, it has been remarked by $\mathrm{Mr}$. Clement Reid that 'we should not forget, however, that an icesheet flowing over a flat country, where the average temperature is near the freezing point, is subjected to conditions entirely unlike those of an alpine glacier flowing down a steep valley into a temperate climate. It is, therefore, only with the ice-sheets of the Arctic regions, or with the wide glaciers of Alaska, that we can profitably compare the ancient glaciation of the North Sea basin.'

The Boulder Clay occurs in patches along the eastern coast at Gorleston, Somerleyton, Corton and Lowestoft, and is nowhere better seen than in the cliffs at Kessingland and Pakefield, where it is about 20 or 30 feet thick and overlies, somewhat evenly and in gentle undulations, the Middle Glacial sands and gravels. Where it rests on sands they often appear to be undisturbed, but in places where stratification is preserved they show marked contortions, as was noticeable in cuttings near Corton and Hopton on the new Yarmouth and Lowestoft direct railway.

More striking evidences of disturbance are met with where the Boulder Clay rests on beds of variable character. It is found indifferently on any of the older formations, occupying slight hollows or occasionally deep channels, the result of prior or contemporaneous erosion. Thus, a deep channel in the Chalk at St. Peter's Quay, Ipswich, noticed by Mr. Whitaker, was filled with I 27 feet of Drift. ${ }^{4}$

Intruded tongues of Boulder Clay have been observed by Mr. F. J. Bennett in the Chalk at Barrow, to the west of Bury St. Edmunds, where a mass, 3 feet thick, extended some 20 feet into the Chalk. ${ }^{5}$ Again at Claydon the Boulder Clay has been thrust beneath the Crag series.

1 Geol. Mag. (1901), p. 142 ; see also H. B. Woodward, ibid. (1897), p. 485 ; Harmer, Proc. Geol. Assoc, xvii. 465 .

2 2uart. Fourm. Geol. Soc, lviii, 179; see also Rev. R. A. Bullen, ibid. Ivii. 285.

3 'Geology of Ipswich,' Natural Science, vii. 177.

- 'Geology of Ipswich,' Geol. Survey, p. 118.

s 'Geology of Bury St. Edmunds,' p. 11.

- Whitaker and others, 'Geology of the neighbourhood of Stowmarket,' p. IO; H. B. Woodward, Geol. Mag. (1897), P. 494. 


\section{A HISTORY OF SUFFOLK}

Near Sudbury the Drifts are intensely contorted, and yet in places they rest on seemingly undisturbed Tertiary strata, a fact explained by Mr. J. E. Marr on the supposition that the naturally soft strata had been frozen into a hard and unyielding condition. At the same time in places the Boulder Clay contained fragments torn off the underlying formations. ${ }^{1}$

Contortions are often prominent where Boulder Clay rests on laminated clays and sands, as to the west of Bury St. Edmunds and at Halesworth Kiln. Disturbances are also met with in the Crag Series at Ipswich, and in the Chalk at Botesdale, where overlain by Boulder Clay.

Some curious and possibly slipped masses of Boulder Clay have been observed in the cliffs at League Hole near Corton. ${ }^{2}$ In connexion with these it may be interesting to mention, on the authority of the late J. H. Blake, that when Sir Morton Peto made the esplanade at Lowestoft he protected the cliff at Kirkley by tipping a lot of Boulder Clay down the face of the cliff.

While the Boulder Clay weathers into a brown stony loam not unlike the loam of the Contorted Drift, it forms the heavier lands (the 'strong loam') of central and south-western Suffolk and of small areas elsewhere. Wheat and beans and also barley flourish on the soil. The district in places is well wooded, and the hedgerows are luxuriant; indeed, the so-called 'woodlands' of High Suffolk form a part of this Boulder Clay tract.

It is not to be regarded as a water-bearing formation, and yet it includes beds of sand and gravel which here and there yield supplies of water, sometimes of an artesian character. Such supplies are apt to fail in seasons of drought.

Ordinary bricks and pottery are in a few places manufactured from the Boulder Clay, as near Ipswich and Burgh Castle, while elsewhere sun-dried bricks are made from the clay mixed with chopped straw.

\section{VALLEY DEPOSITS}

Deposits of gravel and loam of later age than the Boulder Clay occur under two distinct conditions. The older are high level deposits connected with a system for the most part distinct from that of the present drainage, but sometimes initiating it. Some of the coarse gravels which overlie the Boulder Clay are of this character. There are also ancient lacustrine deposits.

Succeeding the main glaciation represented by the Boulder Clay, and when, as Mr. C. Reid points out, the land stood somewhat higher than at present, the streams excavated channels, as at Hoxne, "slightly below that of the present main channel of the river Waveney.' Gradual subsidence turned the Hoxne channel into a shallow freshwater lake,

1 Geol. Mag. (1887), p. 262.

Rev. E. Hill, Quart. Joum. Geol. Soc, lii. 302 , 


\section{GEOLOGY}

which became silted up with clay, and then supported a vegetation whose remains indicate a temperate flora. Later deposits of black peaty earth prove that the climate became colder, indeed Arctic or sub-Arctic; and these were succeeded by somewhat torrential deposits yielding Palæolithic implements. ${ }^{1}$ At St. Cross (Sancroft) near South Elmham a deposit somewhat similar to the bed at Hoxne with temperate flora was found by Mr. C. Candler. It consists of peaty loam and clay evidently deposited in a lake or pool that occupied a hollow in the Boulder Clay. Bones of elephant as well as seeds of plants were obtained. ${ }^{2}$ At Southwold a peaty bed has been exposed at the base of the north cliff, but its age is uncertain. ${ }^{3}$

The gravel and loam or brickearth of the present rivers are found here and there along their margins above the level of the ordinary alluvium. The greater part of these accumulations appear to be of Pleistocene age, as remains of the elephant, rhinoceros and hippopotamus have been found in several localities.

In thickness the deposits vary from a few feet up to about 25 feet. They occur along the Waveney at Homersfield, Wortwell and Reddenhall, at Bungay where the Common is based on a bar of gravel bordered by a loop of the river, and at Beccles racecourse. They fringe the Ouse valley, and by Warren House at Santon Downham curious caves were described by Sir John Evans, some of sufficient magnitude to allow of a man standing inside. They were formed in consequence of the lower beds being let down into hollows of the Chalk, owing to its dissolution by water charged with carbonic acid. ${ }^{4}$

Extensive deposits occur in the Lark valley above Mildenhall, while along the Stour and its tributaries there are gravels at Long Melford, Sudbury, Nayland, Lavenham and Brantham. "Perhaps the most interesting deposit is the brickearth at Stutton, which has yielded Corbicula fluminalis, Hydrobia marginata, Helix fruticum and other mollusca, as well as remains of elephant. ${ }^{5}$

Along the borders of the Gipping and Orwell, at Needham and Sproughton, and along the Deben there are occasional beds of loam and gravel, while at the north end of Southwold a small tract of brickearth yielding remains of elephant was at one time exposed.

Evidence of the antiquity of man was obtained at a very early date in Suffolk, although its significance was not until long after realized. Thus in the year 1797 John Frere called attention to the finding of stone implements at Hoxne, ${ }^{6}$ and this discovery, although briefly referred

1 'The Relation of Palæolithic Man to the Glacial Epoch,' by C. Reid, Rep. Brit. Assoc. for 1896 , 1897, p. 400 ; 'Origin of British Flora,' pp. 52, 77.

2uart. Foum. Geol. Soc. xlv. 504 ; Reid, 'Origin of British Flora,' p. 90.

3 H. B. Woodward, Geol. Mag. (1896), p. 354.

- Geol. Mag. (1868), p. 444.

B. V. Wood, 'Crag Mollusca,' i. and ii. 304, etc. ; Whitaker, 'Geology of Ipswich,' p. 96.

- Archaologia, xiii. 204. See also J. Evans, ibid. xxxviii. 299, and 'Ancient Stone Implements of Great Britain,' ed. 2 (1897), Pp. 543-72 ; Prestwich, Phil. Trans. 1860, p. 304 ; C. Reid, Rep. Brit. Assoc. for 1896 . 


\section{A HISTORY OF SUFFOLK}

to on one or two subsequent occasions, ${ }^{1}$ was practically lost sight of for upwards of sixty years. Attention had then been more prominently drawn to the occurrence of worked flints in the Somme valley, and Sir John Evans recalled to notice the flint implements at Hoxne. The researches made by him and Sir Joseph Prestwich with regard to the relation of the implement-bearing deposits to the Boulder Clay have been confirmed by Mr. C. Reid, who (as before mentioned) has proved that the Palæolithic deposits at Hoxne overlie the Boulder Clay, and are separated from it by layers yielding remains first of temperate and afterwards of arctic plants.

In 1862 Henry Prigg of Bury St. Edmunds (who subsequently changed his name to Trigg) found flint implements in the valley gravel and afterwards in a black peaty layer at the base of loam or valley brickearth at that locality. Later on he found an imperfect fragment of a human skull in loam at Westley near Bury St. Edmunds; but the specimen has since been destroyed. ${ }^{2}$

In the valley of the Little Ouse flint implements were discovered also in 1862 , the first example being obtained at Santon on the Norfolk side, ${ }^{3}$ and many have since been found. In this neighbourhood, as remarked by Mr. S. B. J. Skertchly, "from Palæolithic times to the present day the vicinity of Brandon has been one of the great emporia for flint'; but, as before mentioned, the evidence which he brought forward of implements beneath the Boulder Clay in the neighbourhood of Brandon and Mildenhall has not been deemed satisfactory. His early Palæolithic stage was represented by the Brandon Beds (see p. I 9). These he regarded as older than the Boulder Clay, which in his opinion was intruded into and beneath these loamy beds. He recognized them at Mildenhall, Bury St. Edmunds, West Stow and Culford; ${ }^{4}$ but the deposits may not be all of one age.

Palæolithic implements occur in certain gravels which are newer than the Boulder Clay, and which cap the hills about 70 to I 20 feet above the present Little Ouse river. They have been found at Brandon Field or Gravel Hill, two miles south-west of Brandon, at Lakenheath Hill, and Portway or Marroway (Mareway) Hill east of Eriswell. The gravels are regarded as old valley deposits, and they probably represent lines of drainage independent of the modern courses of streams. At present they must be regarded as the oldest Palæolithic deposits. With them however may be included the beds at Hoxne, and certain deposits lately discovered near Ipswich by Miss N. F. Layard. ${ }^{5}$

According to Mr. S. H. Warren the higher gravels of the Little Ouse and Lark, at Santon Downham and High Lodge near Mildenhall, yield implements of a newer type than those of the earlier drainage

1 R. C. Taylor, 'Geology of East Norfolk' (1827), pp. 14, 27.

2 H. Prigg, Rep. Brit. Assoc. for 1866, sections p. 50; Foum. Anthrop. Inst. xiv. 51 ; and Proc. Norwich Geol. Soc. i. 163 ; E. T. Newton, Proc. Geol. Assoc. xv. 257.

3 J. W. Flower, Quart. Fourm. Geol. Soc. xxiii. 45, xxv. 449.

- 'Manufacture of Gun Flints,' Geol. Survey (1879), p. 65.

5 Nature, May 22, 1902, p. 77. 


\section{GEOLOGY}

system, while in lower levels of the present valleys, at Warren Hill east of Mildenhall and Redhill, both derived and contemporary implements are found. ${ }^{1}$

The consideration of these old valley deposits is a subject which leads on to that of the origin of the present scenery.

The main features over great part of England were sculptured prior to the Glacial period. The main features in Suffolk are of subsequent date.

Thus the Chalk escarpment in pre-Glacial times may have risen in Suffolk to heights comparable with those now found along the Chiltern Hills, the Dunstable and Royston Downs. It has in any case been considerably planed down, and excepting near Newmarket, where the ground rises to $275 \mathrm{feet}$, and at Mildenhall, its distinctive features have been obliterated.

The widespread Glacial Drifts practically overwhelmed the county; ice-action tended to smooth the inequalities of the land, though here and there a deep trough was excavated; and the subsequent features have been carved out of the somewhat irregular accumulations of these erratic deposits, and partially out of the underlying strata.

The melting of the ice led to torrential waters, which marked out some of the earlier valleys, ${ }^{2}$ and distributed masses of coarse gravel here and there. The erosion of the ground has revealed no traces of the earlier scenery; indeed, over a great part of the county the thick drifts have not been intersected. Streams flow over them to join the main river courses which have cut deeply into the land.

Subsequent depression, which took place no doubt slowly, has tended to arrest excavation, and the rivers widen, but, except in the higher courses, no longer deepen their channels. They have become sluggish, and in a few localities the hollows which were formed by estuarine action, or by the serpentine wanderings of the rivers, have been preserved as broads: tracts which are being slowly silted up and narrowed by the growth of marsh plants. Some of the broads, like Fritton Decoy and Oulton Broad, are held up by means of artificial embankments; others, like those of Easton and Benacre, are barred by recent shingle. Small meres sometimes arise in areas where, owing to dissolution of the Chalk, the ground has subsided below the plane of saturation in that formation, as in the case of Barton Mere.

The Alluvium, which forms level meadow or marsh land bordering the rivers, is one of the latest deposits, and may be said to be still in process of formation. It comprises deposits of varied character, but mainly silt and clay with peaty layers and gravel, altogether 20 to 30 feet in thickness.

These low-lying tracts occupy a small area in north-western Suffolk, a part of the Bedford Level, itself a portion of the Fenland; and strips of alluvium fringe the higher courses of the Lark and the Ouse.

1 Geol. Mag. (1902), p. 105.

2 See also Rev. O. Fisher, Quart. Foum. Geol. Soc, xvii. 2. 


\section{A HISTORY OF SUFFOLK}

In the lower reaches of the Waveney, from Beccles to Breydon Water, there are extensive levels which in places lie beneath highwater sea level, and are protected by raised banks along the margin of the river. These marshes are liable to floods, as the sluggish rivers cannot readily convey the water they receive during the heavy rains; but in general the water in the dykes that intersect the marshes is pumped into the river.

Near Burgh St. Peter the alluvial deposits have yielded Cardium edule and Scrobicularia plana in addition to land and freshwater shells. ${ }^{1}$

Lothingland, on which the old town of Lowestoft and Gorleston stand, is now practically an island through the artificial cut which connects Oulton Broad and Lake Lothing, formerly a continuation of the Broad, with the sea. At one time a stream flowed westwards as a tributary of the Waveney, but the sea afterwards formed a channel at Lowestoft gap, which was open during the Roman occupation, but closed by an embankment about the middle of the seventeenth century. It is spoken of by R. C. Taylor as the 'ancient and long abandoned haven of Kirkley.' 2

The marshes near Southwold and Dunwich have been inundated in old times by the sea, and the land on which Southwold is built is practically an island. Further south there are salt marshes near Orford, and there are alluvial islets in the channel of the Ore, based on the London Clay and connected by shingle.

The alluvial tracts, and especially those along the course of the Waveney, furnish the chief meadow and grazing lands.

Peaty beds occur in places on the borders of the Ouse and Lark in their lower courses, also at Lopham, at Easton Broad, over Westwood Marshes near Southwold, and in the estuary of the Deben near Bawdsey. Where such valleys are open to the sea the peaty beds become exposed on the foreshore at low tide and give rise to submerged forests. Thus in the estuary of the Orwell, extending from Ipswich to Pin Mill, a submerged forest was described by J. E. Taylor in $1874 .^{3}$ It contained leaves of plants, hazel nuts, etc., in a peaty bed, which was 9 feet thick in places. The mammoth was obtained, but this doubtless was derived from older deposits.

The depths of the Alluvium indicate that the land stood higher at one time, an elevation which would have enlarged the drainage area and promoted denudation.

The ordinary remains obtained from these deposits are the red deer, wolf, ox, etc., as was the case in Barton Mere."

The coast from near Gorleston southwards is noted for the ravages made by the sea, especially in ancient times at Dunwich, which was an important city in the time of Henry II.

1 J. H. Blake, 'Geology of Yarmouth and Lowestoft,' p. 66.

2 R. C. Taylor, 'On the Geology of East Norfolk' (1827), p. 47 ; and Supplementary Notes, p. 52 ; J. H. Blake, op. cit. pp. 73-5.

${ }^{3}$ Geol. Mag. v. 44I; Rep. Brit. Assoc. for 1875 , sections, p. 82.

- Rev. H. Jones, 2uart. Fourm. Suffolk Inst. (1869), p. 31. 


\section{GEOLOGY}

Of late years the cliffs at Covehithe and Easton Bavent have suffered much, 5 or 6 yards a year having been removed at the former place, and as much as Io yards a year (1889-95) at the latter place. ${ }^{1}$ Southwold, Pakefield aad Kirkley have likewise lost, while at Dunwich there has been less waste during recent years. It is considered likely that Easton Bavent was the most easterly part of England at the time of the Roman occupation.

Felixstow has suffered a good deal of loss, partly owing to the digging in former years of cement stones from the London Clay, a process as detrimental as that of the indiscriminate removal of shingle from Landguard Point.

Excepting in important residential or industrial districts there seems little hope of preserving the coast, for, as remarked by Mr. W. H. Wheeler, when the land is used for agricultural purposes and is of ordinarily fertile character, the cost of the preservation of the cliffs may be greater than the value of the land. ${ }^{2}$

The beach deposits are for the most part shingly, as there are considerable masses of pebbly gravel in the cliffs, and the waste is continually supplying material, the general trend of which is to the south. Sands however occur from Gorleston to Lowestoft, and to a variable extent onwards to Southwold, while shingle occurs mainly to the south. Flint pebbles are most abundant in the beaches, but many carnelians are met with, derived no doubt from the Glacial Drifts.

Land has been gained and lost at Lowestoft. The Ness, now the most easterly point of England, extends in front of an old sea cliff, and comprises hillocks of blown sand and patches of shingle, forming a tract known as the Denes. During recent years this tract has suffered loss. The great shingle beach of Orford Ness extends southwards from Aldeburgh, and has diverted the Ore or Alde some ten miles from its original outlet, Orford Haven, which was nearly opposite the castle in the time of Henry VIII. ${ }^{3}$

Blown sand is not very prominently developed on the Suffolk coast. We find low hillocks between Landguard and Felixstow, also north of Aldeburgh, and others 8 to ro feet high, bordering the marsh of Minsmere Level. Much sand is blown inland from the loose sands in the cliffs between Gunton and Gorleston, and this greatly influences the soil along the sea borders.

Suffolk possesses no remarkable mineral waters. Chalybeate springs have been observed here and there, but none have attained any fame; indeed, the only noteworthy wells are those dedicated to saints. There is perhaps no part of Suffolk from which small supplies of water could not locally be obtained, whether from spring, brook or shallow well. Consequently in early times settlements became scattered all over the

1 Whitaker, 'Geology of Southwold' (1887), pp. 45, 47 ; Capt. H. Alexander, Proc. Geol. Soc. iii. 445 ; J. Spiller, Geol. Mag. (1896), p. 23.

' 'The Sea Coast' (1902), p. 2.

J. B. Redman, Proc. Inst. Civ. Eng. xxili. 186 ; see also Proc. Suffolk Inst. Arch. x. 215. 


\section{A HISTORY OF SUFFOLK}

county. The industries have been mainly those of agriculture and fishing, and the population has grown irrespective of any geological conditions affecting water supply, but rather owing to convenience of position in regard to river or railway, or to the bracing air and other attractions of the seaside. 


\section{PALÆONTOLOGY}

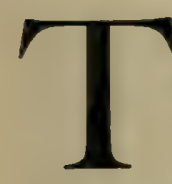

1HE claim of Suffolk to a foremost position among English counties of special interest to the student of vertebrate palæontology is based on the mammalian and other fossils from the Red and Coralline Crags. It is true that remains of many of these Crag species are also met with in the corresponding formations of Essex ; but the majority of them are known only or chiefly from Suffolk. In addition to these Red and Coralline Crag fossils, Suffolk has also yielded remains of vertebrates from the Norwich Crag and the overlying Forest Bed, as well as from superficial strata of still newer age. The great bulk of the vertebrate remains from the Forest Bed and Norwich Crag have however been collected in Norfolk, and since they have been mentioned at some length in the volumes of this work devoted to that county, a brief reference to some of those which occur in Suffolk will suffice in this place.

Before going further, it may be well to mention that many of the vertebrate fossils from the Red and Coralline Crags, especially those found in the so-called nodule bed, exhibit unmistakable signs of rolling by the action of the sea; and some of them have been undoubtedly derived from the breaking up of much older beds. These older derived Crag fossils are treated of in a separate section below. As regards the other fossils, some may quite likely have been washed out of strata a little older than even the Coralline Crag, but the majority, at all events, appear to belong to animals which flourished during some portion of the Pliocene epoch-the epoch in which the Crags themselves were deposited.

From deposits in the county of newer age than the Forest Bed have been obtained remains of a considerable number of the ordinary British Pleistocene mammals. Those of the cave-lion (Felis leo spelaa), the otter (Lutra lutra), and a bear which has been identified with the North American grizzly (Ursus arctus borribilis) have, for instance, been recorded from Ipswich. The skull of a wolf (Canis lupus) dug up from beneath the Norman tower in Bury St. Edmunds is, or was, in the museum of that town. Among the ungulate or hoofed mammals, the great extinct ox or aurochs (Bos taurus primigenius) has left its remains at Lowestoft, and, according to Mr. Norgate of Bury St. Edmunds, at Maid's Cross, Lakenheath. Numerous bones and teeth of the Celtic shorthorn and pig, as well as red deer antlers, were dug up some years ago in a blackish stratum about a couple of feet below the surface at West Stow Heath, in association with Saxon implements. Antlers of red deer, fallow deer 


\section{A HISTORY OF SUFFOLK}

and roe are also stated to have been dug up in the peat of Undley Fen, Mildenhall; while a single roe antler from Burnt Fen, Mildenhall, is in the possession of Mr. Norgate.

From river gravel at Warren Hill, Mildenhall, the gentleman last named records remains of the Pleistocene bison (Bos priscus) in association with those of the mammoth and chipped flint implements. In addition doubtless to many other localities in the county, remains of the red deer (Cervus elapbus) are known from Woodbridge, and those of the giant fallow deer or 'Irish elk' (C. giganteus) and roe-deer (Capreolus capreolus) from Ipswich. Bones and teeth of the wild horse (Equus caballus fossilis) are recorded from Ipswich, Felixstow and Kingston near Woodbridge, and those of the great woolly Siberian two-horned rhinoceros (Rbinoceros antiquitatis) from gravel at Ipswich. Remains of the mammoth (Elepbas primigenius), the Pleistocene representative of the existing Indian elephant, occur in river deposits in many parts of the county, notably Bury St. Edmunds, Hoxne, Icklingham, Ipswich, Orford and Southwold. Mr. Norgate writes that molars and tusks which he assigns to the mammoth and its relative the straight-tusked elephant ( $E$. antiquus) were found some years ago in considerable numbers in gravel at the back of the old gaol at Bury St. Edmunds. The mammoth remains from Icklingham in the valley of the Lark near Bury St. Edmunds were associated with roughly hewn flint implements. ${ }^{1}$ Although no mammalian remains have been obtained from the stratum at Hoxne which yielded the celebrated flint implements described by Mr. John Frere in the year 1806 , bones of red deer, horse and mammoth have been dug up from an underlying bed. ${ }^{2}$ In 1876 the British Museum acquired an associated series of molar teeth and tusks, together with a vertebra, of a small individual of the extinct race of the hippopotamus (Hippopotamus ampbibius major), which had been dug out of a superficial deposit at Lavenham. ${ }^{3}$

Among the mammals recorded from the Forest Bed within the limits of the county are the wolf (Canis lupus) from Kessingland, the cave race of the South African spotted hyæna (Hyana crocuta spelaca), from both Kessingland and Corton, and the great cave-bear (Ursus spelcus). Remains of the red deer and of that race of the giant fallow deer, or 'Irish elk,' commonly known as Cervus verticornis, but preferably designated $C$. giganteus belgrandi, have also been obtained at Kessingland and Pakefield " near Lowestoft. The former locality has likewise afforded evidence of the presence of the wild boar (Sus scrofa ferus), the horse, and the extinct Etruscan rhinoceros (Rbinoceros etruscus). Although not uncommon in the Pliocene deposits of the Val d'Arno, Tuscany, remains of the species last named are rare in Britain, where they have been met with only in the Forest Bed of Norfolk and Suf-

1 See Prestwich, Quart. Fourn. Geol. Soc. xvii. 363, and Lyell, Antiguity of Man, ed. 3, 169.

2 See Lyell, op. cit. p. 167, and Howorth, Geol. Mag. (4) viii. 337 (1901).

3 See Cat. Foss. Mamm. Brit. Mus. ii. 279.

4 Specimens in Norwich Museum. 


\section{PALÆONTOLOGY}

folk, and quite recently in the Pliocene cave at Dove Holes near Buxton, Derbyshire. Of the great southern elephant (Elepbas meridionalis), the Norwich Museum possesses some fine teeth and jaws from Corton and Pakefield. From the Forest Bed of both Suffolk and Norfolk have been obtained remains of an extinct vole, Mimomys intermedius, which has recently been made the type of a special genus ${ }^{1}$ common to the Forest Bed and the Norwich Crag, and characterized by its partially rooted cheek teeth and the presence of an islet of enamel on the worn crown of the last of the series.

The Forest Bed at Pakefield has yielded a cetacean tooth apparently belonging to the existing killer-whale (Orca orca).

Of fishes, remains of the perch (Perca fluviatilis) are recorded from the Forest Bed at Kessingland. More common are the clavicles and so-called 'butterfly bones' (really fin-supports) of the extinct horsemackerel Platax woodwardi, which are also known from the Norwich Crag of Easton Bavent.

Of the few mammalian remains that have been obtained from the Norwich Crag in Suffolk perhaps the most interesting are certain molar teeth of the straight-tusked elephant (Elephas antiquus) from Easton and Southwold. ${ }^{2}$ In many cases this species was a contemporary of the mammoth, but here it occurs in an horizon where the latter animal is unknown. Remains of the otter have been said by Sir R. Owen (British Fossil Mammals and Birds, p. I 2 I) to have been discovered in the Norwich Crag at Southwold, but the statement has not been substantiated by subsequent researches. ${ }^{3}$ Some kind of hollow-horned ruminant is indicated by a bone of the hind-leg (metatarsal) from the Norwich Crag at Easton. Fragments of teeth from the same locality and deposit apparently belong to the mastodon referred to below as Mastodon borsoni. A fragment of the lower part of the (incisor) tooth of a beaver from the Norwich Crag of Sizewell Gap near Southwold was long considered to belong to the living European beaver. According however to Mr. E. T. Newton ${ }^{4}$ it is more probably referable to the extinct Forest Bed genus known as Trogontberium, and possibly to the small $\mathcal{T}$. minus. This specimen is in the collection of the Geological Society of London. From Kyson have been obtained remains of an extinct vole (Mimomys pliocenicus), of which the typical horizon is the Pliocene of the Val d'Arno. ${ }^{5}$

Specimens in the Norwich Museum from the Chillesford Crag beds of Aldeby were identified many years ago by Sir W. H. Flower with the dolphin (Delpbinus delpbis). From the same locality and deposit Sir William also identified remains of the guillemot (Uria troile).

Coming to the carnivora of the Red and Coralline Crags, we find that

1 See F. Major, Proc. Zool. Soc. London, 1902, i. 102.

2 See Newton, 'Vertebrata of Pliocene Deposits of Britain,' Mem. Geol. Survey, p. 47.

3 Ibid. pp. I4, 15.

4 Ibid. P. 49.

S See F. Major, Proc. Zool. Soc. London, 1902, i. 105. M. pliocenicus and the smaller M. newtoni occur in Norfolk, but were not described when the palæontology of that county was written. At that time Mimomys intermedius was known as Microtus intermedius. 


\section{A HISTORY OF SUFFOLK}

a member of the cat tribe agreeing approximately in size with the leopard is represented by a lower carnassial or fiesh-tooth from the Red Crag of Newbourn near Woodbridge. Upon this specimen, which is preserved in the museum at Ipswich, Sir R. Owen ${ }^{1}$ founded his Felis pardoides, but there is no evidence to show that this is really distinct from the leopard ( $F$. pardus), of which it probably represents an extinct race. A second tooth of the same feline subsequently found near Newbourn was also described by Owen. ${ }^{2}$ Although the spotted hyæna is unknown in the Crag, the striped species is represented by certain cheek-teeth from the Red Crag of Felixstow originally described by Professor E. Ray Lankester $^{3}$ as Hycena antiqua; as well as by a right upper carnassial in the Ipswich Museum from the Red Crag of Trimley St. Mary, and a corresponding tooth of the opposite side, preserved in the York Museum, from Woodbridge. The latter specimens present no characters by which they can be satisfactorily distinguished from the corresponding teeth of the existing striped hyæna, but since the Crag representative of that animal probably formed a distinct race, it may be designated $H$. striata antiqua. Remains of the wolf (Canis lupus) have been recorded from the Forest Bed within the county, and the occurrence of the same species in the Red Crag is indicated by three teeth in the York Museum, two of which came from Boyton. The imperfect skull of a fox (C. vulpes) from above the nodule bed at the latter place, now preserved in the British Museum, has been regarded by some as not a true Red Crag fossil, but this opinion was not shared by the late Mr. R. Bell, by whom it was collected. A worn tooth, now in the York Museum, from the Red Crag of Woodbridge, was described by Professor Lankester as Canis primigenius, but, judging from the structure of the enamel, Mr. Newton is inclined to believe that it is really cetacean.

Among the weasel family it is possible that the polecat (Mustela putorius) may have lived in the Crag period, as the British Museum possesses a fragment of the lower jaw of that animal from the Coralline Crag of Orford; it does not appear however to be certain that the specimen is really of Crag age. An otter, provisionally identified with the extinct continental species known as Lutra dubia, is represented by a lower jaw from the Red Crag nodule bed of Foxhall near Woodbridge. $^{4}$

Of far greater interest is a fragment of a lower jaw from the nodule bed of the Red Crag at Felixstow, now preserved in the York Museum, which has been described under the name of Alurus anglicus by Professor W. B. Dawkins. ${ }^{5}$ The genus to which this species belongs is represented at the present day only by the longtailed panda or red cat-bear ( $\not$. splendens) of the eastern Himalaya, and till the identification of the fossil jaw no extinct representative of the group was known. Another fragment of the jaw of the Crag species,

1 Brit. Foss. Mamm. and Birds, p. $169(1846)$.

3 Ann. Mag. Nat. Hist. (3) xiii. 56.

2 2uart. Journ. Geol. Soc. xii. 266 (1856).

1 See Newton, op. cit. p. 12.

5 Quart. Foum. Geol. Soc. xlvi. 451 (1890). 


\section{PALÆONTOLOGY}

also in the York Museum, is known from the nodule bed at Woodbridge; while the Museum of the Geological Survey possesses a complete upper molar from Butley. ${ }^{1}$ The latter specimen serves to indicate that the Crag panda was about a third larger than the living Himalayan species. Panda remains have been subsequently obtained from certain Tertiary strata on the continent, a complete skull forming the type of a distinct genus.

To some extent, perhaps, connecting the pandas with the more typical bears is the extinct Hyanarctus, first described from the Pliocene strata of northern India, but subsequently found in Europe. The only known evidence of the occurrence of this primitive bear-like animal in Britain is afforded by certain teeth from the nodule bed of the Suffolk Red Crag. One of these specimens, an upper molar, was obtained near Waldringfield, and is preserved in the Ipswich Museum, while a second upper molar, from Felixstow, is in the York Museum. The latter collection also contains a lower molar and a tusk, both from Felixstow, which probably belong to the same genus. It is to the late Sir W. H. Flower ${ }^{2}$ that we owe the identification of Hyanarctus in the Red Crag.

Some doubt exists as to whether remains of typical bears occur in the Crag deposits, certain specimens which have been described as such having apparently been misinterpreted. ${ }^{3}$ According however to $\mathrm{Mr}$. Newton, ${ }^{4}$ a tooth from the nodule bed of Woodbridge, preserved in the Museum at York, may possibly belong to the small bear first described from the Pliocene deposits of the Auvergne under the name of Ursus arvernensis. A single tusk, or canine tooth, from the crag of Kessingland, preserved in the Museum at Wisbech, indicates an undetermined carnivore apparently distinct from all the foregoing.

Several of the molluscs met with in the Red Crag indicate the prevalence in Britain at the time of the deposition of these strata of arctic or sub-arctic conditions; and this is confirmed by the occurrence in the nodule bed of the Red Crag of the county of portions of tusks of a large walrus (Odobanus buxleyi), such remains having been first described in I 865 by Professor E. Ray Lankester ${ }^{5}$ as Tricbecodon. Till recently the walrus was known as Trichechus, but the earlier name Odobcanus is now coming into general use.

The Crag being a shore deposit it is only natural to expect that it would contain the remains of seals; and as a matter of fact bones of those animals do occur there, although far from abundantly. Of Suffolk specimens, a bone of the fore-limb (humerus) in the collection of Major E. C. Moor of Great Bealings, from the nodule bed of Foxhall, has been made the type of a species with the name of Pboca moori. There is a similar bone, from the same horizon at Waldringfield, in the Museum of Practical Geology, Jermyn Street. P. moori was a seal of small bodily

\footnotetext{
1 Newton, 2uart. Fourw. Geol. Soc. xlvi. p. 13 (1890).

See Newton, op. cit. p. 15.

2uart. Journ. Geol. Soc, xxi. 226.

8 Ibid. xxxiii. 534 (1877).

${ }^{4}$ Ibid. p. 16.
} 


\section{A HISTORY OF SUFFOLK}

size; but a third Crag humerus from Foxhall, also in the collection of Major Moor, as well as a fourth specimen of the same bone from the Crag, preserved in the York Museum, indicate a still smaller species, which has been provisionally identified with one described on the evidence of remains from the Antwerp Crag under the name of Pbocanella minor. Whether this seal really belongs to an extinct generic type may perhaps be open to doubt.

Passing on to the hoofed or ungulate mammals, it may be mentioned in the first place that teeth and limb bones from the Red Crag of Boyton and other localities in the county undoubtedly demonstrate the occurrence in that deposit of a member of the ox tribe. It has been suggested that the species in question is the Pleistocene bison, but it is perhaps more likely that it is identical with the extinct Etruscan ox (Bos etruscus) of the Pliocene deposits of the Val d'Arno, a primitive species of which the cows were hornless. Cheek-teeth of more than one form of large ruminant are known from the Red Crag nodule bed of Boyton, Sutton, Woodbridge and elsewhere which not improbably belonged to antelopes of several kinds. Two bones of the foot of a small ruminant in the Museum of Practical Geology, said to be from the Coralline Crag of Gedgrave, present a considerable resemblance to the corresponding elements of the skeleton of the musk-deer (Moscbus moschiferus). Antlers and teeth of deer are exceedingly common in the Suffolk Crags, and a large number of so-called species have been based on remains of the former description. Although the number of these nominal species is undoubtedly too large, their reduction is a matter of extreme difficulty, and since it is impossible in some instances to be certain even of the generic position of these Crags, they are but very briefly noticed in this place. Certain fragments of antlers in the British Museum from the nodule bed of the Red Crag have been identified with a fallow deer first described from the Norwich Crag under the name of Cervus falconeri, but the right of the type of the latter to specific distinction is more or less doubtful. The beam of a large antler from the Red Crag of Suffolk was referred by Sir R. Owen ${ }^{1}$ in 1856 to the giant fallow deer or 'Irish elk,' now known scientifically as Cervus giganteus; although, as pointed out by Mr. Newton, ${ }^{2}$ it is most likely that this specimen does not belong to the typical form of that species, it is quite probable that it may pertain to one of the older races of the same, such as the so-called C. verticorris of the Forest Bed of both Norfolk and Suffolk. Of quite a different character are the antlers from the Red Crag nodule bed of Sutton and other localities in the county, on the evidence of which the species $C$. suttonensis was based by Professor Boyd Dawkins ${ }^{3}$ in 1878 . This species was probably allied to the Oriental rusine deer.

Tusks, incisors and cheek-teeth of swine are now and again met with in the nodule bed of the Red Crag of Suffolk, the York Museum

1 2uart. Fourn. Geol. Soc. xii. 226.

3 Quar. Foum. Geol. Soc. xxxvi. 44I.

2 'Vertebrata of Pliocene Deposits,' p. 29. 


\section{PALÆONTOLOGY}

possessing one lower tusk from Waldringfield and a second from Woodbridge, while the Ipswich Museum has an incisor. Cheek-teeth from the Crag indicate the occurrence of two species of wild pig-a larger and a smaller. The larger may be identical with one of the two continental Pliocene forms described as Sus antiquus and S. erymantbius, while the smaller may be the same as $S$. palcoocberus of the German Pliocene.

Of the horses (or perhaps asses or zebras) remains are rare in the Crag, but there is one tooth of an Equus from the Red Crag of Bawdsey in the British Museum, and a second from Felixstow in the York Museum. Less uncommon are cheek-teeth of the three-toed horses of the genus Hipparion, which can be readily distinguished from those of Equus by the pattern on the grinding surface. All the known specimens of these teeth appear to come from the Red Crag nodule bed; the species to which they belong is probably the widely spread $H$. gracilis of the continental Pliocene.

Cheek-teeth of rhinoceroses, often broken, are not uncommonly met with in the Red Crag nodule bed of the county, most of which it was once thought might belong to some of the Pleistocene representatives of the genus. They may however with more probability be assigned to continental Pliocene types, such as the hornless Rbinoceros incisivus and the two-horned $R$. scbleiermacheri of Germany. Tapirs, too, are represented in the Red Crag nodule bed of the county by their teeth, and are perhaps specifically identical with the continental forms described as Tapirus arvernensis and $T$. priscus. The occurrence of these fossil European tapirs, it may be incidentally remarked, is a fact of considerable interest, since they serve to connect the present widely separated habitats-Malaya and tropical America-of this primitive group of oddtoed ungulates.

With the exception of the recently discovered Pliocene cave near Buxton, the Crags of Norfolk and Suffolk are the only deposits in Britain from which are obtained the teeth of those primitive elephants known as mastodons. In these mastodons the cheek-teeth, or molars, are of a much more simple structure than those of the true elephants, being in fact in many respects more like those of gigantic pigs than of the latter. In place of consisting of a great number of closely packed tall parallel plates, the crowns of the molars of the mastodons are formed by a few low columns or ridges, with open valleys between them. Some mastodons have three ridges or rows of columns in each molar save the two front pairs and the last, but in others the number of ridges is four in the teeth in question. Many of the Crag mastodons belong to the species with four-ridged molars originally described from the Auvergne under the name of Mastodon arvernensis, and characterized by the alternating arrangement of the cusps on the crowns of those teeth and the slight prolongation of the front of the lower jaw. Other teeth from the Red Crag belong to a second four-ridged species, the continental $M$. longirostris. One particular molar, with three ridges, from the Red Crag nodule bed near Woodbridge, now preserved in the York Museum, 


\section{A HISTORY OF SUFFOLK}

has been the subject of some discussion. Originally regarded by Professor E. Ray Lankester as the complete tooth of a three-ridged species, it was subsequently considered by the present writer ${ }^{1}$ to be an imperfect tooth of the four-ridged $M$. longirostris. A re-examination of the original specimen showed however that this view was untenable, and Professor Lankester ${ }^{2}$ eventually regarded the specimen as indicating a variety of the three-ridged continental $M$. angustidens, with the varietal name of latidens. Since however there is an Indian species known as M. latidens this nomenclature cannot be adopted; and if the specimen really indicate a race of the aforesaid species, the name $M$. angustidens latior would be appropriate. The writer is however by no means sure that the specimen is not an abnormally formed molar of the aforesaid $M$. longirostrisa species which, by the way, differed from modern elephants in being furnished with tusks in the lower as well as in the upper jaw. Threeridged molars of quite a different type to the foregoing specimen are met with occasionally in the nodule bed of the Red Crag, as well as in the coprolite bed below the Coralline Crag at Sutton and other localities in the county. ${ }^{3}$ Many of these specimens, at any rate, appear to belong to the continental Pliocene species known as $M$. borsoni. It may be added that $M$. longirostris apparently also occurs in the coprolite bed at the base of the Coralline Crag, a fragmentary tooth being reported to have been obtained from that horizon at Sutton. ${ }^{4}$

Doubt was long entertained as to whether remains of true elephants ever occurred in the Crag. The question is however set at rest by portions of two molars in the British Museum ${ }^{5}$ from the Red Crag, one of which was obtained at Felixstow, and the other at Falkenham near Woodbridge. These teeth belong to the southern elephant (Elephas meridionalis), a gigantic species more nearly alied to the living African than to the Indian elephant, whose remains are met with abundantly in the Pliocene strata of the continent and the Norfolk Forest Bed, as well as in a remarkable deposit at Dewlish in Dorsetshire.

A much-worn mammalian skull, now preserved in the museum at Ipswich, from the nodule bed of the Red Crag at Foxhall, was described in 1874 by Sir William Flower, ${ }^{6}$ and identified with an extinct genus of sea-cow, but made the type of a separate species under the name of Halttherium canbami. The genus Halitherium, which is allied to the modern manati, is met with on the continent in strata of Miocene age, so that the Foxhall skull may be somewhat older than the majority of Red Crag fossils.

As would naturally be expected from the small size of most members of the order, remains of rodents, or gnawing mammals, are very scarce in the Crag. Two cheek-teeth from the Red Crag nodule bed (one from Woodbridge), in the Museum of Practical Geology are how-

1 See Cat. Foss. Mamm. Brit. Mus. iv. 62.

See Newton, op. cit. p. 44.

- See Cat. Foss. Mamm. Brit. Mus. iv. II 3.

2 Geol. Mag. (4) vi. 289, (1 899).

- Ibid. 14.

- 2uart. Fourn. Geol. Soc. xxx. I. 


\section{PALÆONTOLOGY}

ever provisionally assigned by $\mathrm{Mr}$. Newton to the existing European beaver (Castor fiber). Certain other beaver teeth from the same horizon at Sutton and other localities in the county have been made the types of a distinct species by Professor Lankester with the name of $G$. veterior. From the characters of the folds of the cheek-teeth, as compared with those of the living beaver, Mr. Newton confirms the distinctness of this species. The type specimens are in the York Museum, but there are others at Ipswich.

Remains of the rabbit have been stated to occur in the Crag, but the evidence on which the statement is made is not forthcoming. $\mathrm{Mr}$. Newton records however a cheek-tooth of some species of Lcpus from the Red Crag.

Remains of whales, porpoises and dolphins are exceedingly common in the Suffolk Crag, as they also are in the Belgian Crag at Antwerp. In the case of the larger whalebone whales, the remains most easy of identification, and also those most commonly found, are the bones of the internal ear, of which one (the tympanic) is hollow and shell-like, while the other (the periotic) is solid and massive. In the beaked whales, on the other hand, the part most commonly preserved is the solid ivory-like rostrum, or beak, from which the group takes its name. Of the larger toothed whales akin to the modern sperm-whale, teeth are the most abundant remains. As early as 1843 Sir R. Owen ${ }^{1}$ named some of these Crag cetaceans on the evidence of ear bones, and others from their teeth. A revision of cetaceans from the Crag was published by the present writer ${ }^{2}$ at a much later date. Tympanic bones from the nodule bed of the Red Crag of the county indicate by their shape so-called ' right-whales,' that is to say species allied to the Greenland whale and southern right-whale of the present seas. To one of these types Owen gave the name Balana affinis; while a second appears identical with the right-whale from the Belgian Crag described by the late Professor Van Beneden as B. primigenia. Certain variations noticeable in the form of the ear-bones of these whales may be due to differences in the age of the individuals to which they belonged. Tympanics of a much smaller right-whale from the Red Crag have been identified with the two Belgian species $B$. insignis and $B$. balcenopsis. The first vertebra of a whale from the Coralline Crag of Sudbourn, in the collection of the British Museum, was referred by Van Beneden himself to the lastmentioned species. It may be well to observe here that as the tympanic and other bones of whales found in the Belgian Crag, belonging to the same species as those from the Red Crag, are not rolled, it is evident that the whales of whose skeletons they formed a part lived in the Pliocene seas, and it therefore follows that the whales of the Red Crag likewise lived about the time when that deposit was laid down. It may also be mentioned that Mr. F. W. Harmer ${ }^{3}$ considers the majority of the remains

1 Proc. Geol. Sac. iv. 283 ; see also Quart. Foum. Geol. Soc. i. 39, and Brit. Foss. Mamm. and Birds.

2 2uart. Fourn. Geol. Soc. xliii. 7, and Cat. Foss. Mamm. Brit. Mus. v. 16.

2uart. Journ. Geol. Sac. lvi. 728 (1900). 


\section{A HISTORY OF SUFFOLK}

of extinct land mammals from the nodule bed of the Red Crag to be derived from older deposits. 'There is indeed,' he writes, 'no more evidence for the existence of Mastodon in England during any part of the Crag era than for that of Hipparion or of the Eocene Hyracotberium.' Against this view may be urged the occurrence of Mastodon arvernensis in the Upper Pliocene deposits of the Auvergne and Val d'Arno, and above all in the British Pliocene cave recently discovered near Buxton.

Other and apparently somewhat less common types of tympanic from the nodule bed of the Red Crag of the county are of a more rounded and shell-like character, and indicate extinct species of those groups of whalebone whales respectively known as humpbacks and finners or rorquals. To a humpbacked whale from the Belgian Crag described by Professor Van Beneden as Megaptera affinis, are apparently referable two tympanics in the Museum of Practical Geology ; the one from the Coralline Crag of Sudbourn, and the other from the nodule bed of the Red Crag near Ipswich. Another species of the same genus, $M$. similis, likewise typically (as is the third) from the Belgian Crag, is represented by a periotic bone in the British Museum from Woodbridge; while a third and smaller form, M. minuta, is known in England by one ear-bone from the Coralline Crag of Suffolk in the Museum at Ipswich, and a second from the nodule bed of the Red Crag at Foxhall in the Museum of Practical Geology.

Of the rorquals, whose tympanic bones are of a more elongated form than those of the humpbacks, two Red Crag species, Balanoptera definita and B. emarginata, were originally described by Owen (as Balana) on the evidence of tympanics from the nodule bed of the county. Two other species, B. goropi and B. borealina, first described from the Belgian Crag, appear to be represented in the nodule bed of the county by tympanics in the collection of the British and Ipswich Museums.

But even these last by no means exhaust the list of Suffolk Crag cetaceans, for certain remains from that deposit have been identified with species of two extinct genera of rorquals named by continental writers Cetotberium and Herpetocetus. One of these species, C. brialmonti, appears to be represented by a vertebra from the Red Crag in the British Museum, and a second, $C$. dubium, by tympanics from the nodule bed in the Museum of the Royal College of Surgeons and other collections. Certain vertebræ from the Red Crag of Suffolk may perhaps pertain to the Belgian species known as $C$. bupschi and C. brevifrons. A tympanic bone in the Museum of Practical Geology from Felixstow, and a second in the Museum of the Royal College of Surgeons, indicate the occurrence in Suffolk of the species described in Belgium as Herpetocetus scaldiensis.

With the last-named species we come to the end of the whalebone whales, and pass on to the toothed group, commencing with the forms allied to the modern sperm-whale. Large teeth of the general type of those of the latter are met with commonly enough in the Red Crag nodule bed of the county, but owing to their damaged condition their 


\section{PALÆONTOLOGY}

specific identification is a matter of difficulty. The earliest name for teeth of this type is Balanodon physaloides, given by Sir R. Owen in 1846, and typified by a Red Crag specimen. It has been considered that other equally large Suffolk Crag teeth belong to the Belgian whale described as Eucetus amblyodon. Teeth of smaller spermwhale-like cetaceans from the Red Crag nodule bed of the county have been tentatively assigned to the continental forms described under the names of Pbyseterula dubusii, Pbysodon grandis, P. fusiformis, Hoplocetus crassidens, H. borgerboutensis, and $H$. curvidens. If an Argentine Pliocene skull be rightly assigned to it, Pbysodon differs from the modern sperm-whale in having a full series of teeth in the upper as well as in the lower jaw.

The occurrence of a whale closely allied to the existing bottle-nose in the Red Crag was made known by the present writer in the following words : 'Hyperoödon is represented by a very perfect right periotic in the Ipswich Museum. This specimen, which has the accessory ossicle still attached, cannot be distinguished from the corresponding bone of the existing $H$. rostratus, and evidently indicates the existence either of that or of a closely allied form in the Pliocene; the occurrence of cervical vertebræ of a member of this genus in the Antwerp Crag has been recorded by Professor Van Beneden.' Since it is practically certain that the Crag bottle-nosed whale is distinct from the existing species it may be appropriately named Hyperoödon taylori, after the late Dr. J. E. Taylor, some time curator of the Ipswich Museum.

Beaked whales, as already said, are very numerously represented by their beaks, or rostra, which in the living species are characterized by their ivory-like appearance and hardness. One type has been referred to a supposed extinct genus, Chonezipbius, of which it has been thought that there are three representatives in the Red Crag, namely $C$. planirostris, C. planus and $C$. packardi. Apparently Chonezipbius is not generically distinct from the existing beaked whale commonly known as Zipbius, and since the latter term is barred by previous usage in another sense, the former name is entitled to stand for the genus. Of the beaked whales belonging to the same genus as the existing Mesoplodon videns (which occasionally visits the British shores) a large number of species have been named on the evidence of Crag specimens, but it is probable that some at least of these are merely nominal. The list is as follows, viz. Mesoplodon longirostris, $M$. tenuirostris, $M$. angustus, $M$. angulatus, $M$. compressus, $M$. floris and $M$. scaphoides, in addition to others which are obviously synonyms. It may be added that one specimen of the periotic bone of a member of this genus is known from the Red Crag nodule bed, preserved in the Museum of Practical Geology.

A totally extinct family of cetaceans, the shark-toothed dolphins, in which the hinder teeth are serrated and double-rooted, is represented by isolated teeth from the nodule bed of the Red Crag of the county. Some of these rare and curious teeth are in the Museum at Ipswich, and others at York. They not improbably belong to the species from the Antwerp Crag described as Squalodon antwerpiensis. 


\section{A HISTORY OF SUFFOLK}

Among the true dolphins and porpoises a species of killer-whale, probably identical with an Italian Pliocene form described as Orca citoniensis, is represented in the Red Crag nodule bed of the county by a tooth in the Ipswich Museum and a periotic in the Museum of Practical Geology. Certain teeth and ear-bones from the nodule bed originally described as Delpbinus uncidens appear generically identical with the socalled blackfish, and are accordingly now known as Globicephalus uncidens. A specimen from the Red Crag nodule bed of the county, supposed to be the swollen base of the aborted tusk of a narwhal, has been considered sufficient to justify the inclusion of the genus Monodon in the Crag fauna. Possibly two Red Crag vertebræ in the Jermyn Street Museum may afford evidence of the occurrence of a species of white whale (Delphinapterus) in the Crag sea. Finally a vertebra from the Coralline Crag of Ramsholt in the British Museum, and two others from the same formation in the Museum of Practical Geology, may be referable to a dolphin of the genus Tursiops.

Very noteworthy is the occurrence in the Suffolk deposits of remains of an albatross, for which the name Diomedea anglica has been proposed by the present writer. ${ }^{1} \quad$ The species is typified by two bones of the foot, now in the Ipswich Museum, found in the sandy bed overlying the Red Crag at Foxhall, and most probably of Red Crag age. Part of a wing-bone (ulna) from the Coralline Crag at Orford, preserved in the Museum of Practical Geology, belongs to the same or an allied species. It may be added that the museum last named also possesses a wing-bone (ulna) of an albatross from the brick-earth of Ilford, Essex.

The fishes of the Crag are for the most part represented by detached teeth. Among these certain smooth and polished molar-like teeth, specimens of which are known from the Red Crag of Woodbridge, Waldringfield and elsewhere, as well as from the Coralline Crag of Gedgrave, indicate a species of sea-bream generically identical with the existing gilt-head (Cbrysopbrys aurata). They do not however admit of specific determination. To the family of the horse-mackerels belongs Platax woodwardi, a species commonly occurring in the Forest Bed and Norwich Crag, but also represented in the Red Crag of Felixstow and elsewhere, and, it is said, in the Coralline Crag. An extinct thunny (Thynnus scaldist), first described from the Antwerp Crag, is known by vertebræ from the Coralline Crag of Aldeburgh and elsewhere. A single tooth in the Museum of Practical Geology from the Coralline Crag of Gedgrave presents no characters by which it can be distinguished from the existing wolf-fish, Anarrbicbas lupus. A wrasse of the genus Labrus is indicated by a specimen of the lower pharyngeal bone from the Red Crag of the county, preserved in the British Museum. Species of cod (Gadus) are indicated by ear-bones (otoliths) from the Coralline Crag of Sudbourn, Broomhill, near Orford and elsewhere; others from

1 Cat. Foss. Birds Brit. Mus. 189 (1891). 


\section{PALÆONTOLOGY}

the Red Crag have been described as a race of the whiting with the name of $G$. merlangus suffolcensis; while yet another form, typically from the Coralline Crag of Gedgrave, has been regarded as indicating an extinct species ( $G$. pseudoeglifinus) nearly allied to the haddock. Fish spines in the York Museum indicate the occurrence of a sturgeon (Acipenser) in the Red Crag; but whether the remains are contemporaneous or washed out of an older deposit does not appear to be ascertained.

The occurrence of species of dog-fishes and sharks in the Suffolk Crag is indicated by numerous remains. Among these two teeth from the Red Crag of Little Bealings near Woodbridge are regarded as belonging to a species nearly related to the common tope (Galeus canis). Certain spines from the Red Crag of Woodbridge and elsewhere were shown by Sir W. H. Flower to be indistinguishable from those with which the 'claspers' of the gigantic basking-shark (Cetorbinus maximus) of modern seas are armed. The largest member of the shark tribe now living, the widely distributed Rondeleti's shark (Carcbarodon rondeletii) is represented by teeth from the Red Crag of Sutton and elsewhere and the Coralline Crag of Orford. Still larger teeth of the same type from the Red Crag of Woodbridge, Felixstow and other places in the county are assigned to the extinct $C$. megalodon, whose remains are met with in later Tertiary strata almost all over the world. Large teeth similar to these fossil specimens were dredged during the Challenger expedition from the depths of the Pacific in such a condition as to lead to the belief that the species was still living at a comparatively recent epoch. Rondeleti's shark is known to attain a length of 40 feet, but the fossil teeth (some of which measure 4 inches across and 5 in height) must indicate a fish half as large again. Shark teeth from the Red Crag nodule bed belonging to forms allied to the porbeagle have been referred to the species known as Oxyrbina bastalis, Odontaspis elegans and O. contortidens. With regard to teeth of the second form Mr. E. T. Newton writes as follows: 'Numerous examples from the Red Crag nodule bed are in the Museum of Practical Geology; some of them are probably derived from older beds, being much rolled and worn; but many of them are beautifully perfect, with the cutting edge quite sharp, and these it is thought must be of a Red Crag age.' Nearly similar remarks will apply to those of the third species. Very characteristic of the Crag are the teeth of a large species of comb-toothed shark, which have been identified by Dr. Smith Woodward with Notidanus gigas, a species typically from the Pliocene strata of Tuscany. According to Mr. Newton remains of this species have been found in the nodule bed of the Red Crag at Woodbridge, Butley, Felixstow and other localities in the county.

Remains of eagle-rays of the genera Myliobatis and Etobatis are not uncommon in the Red Crag of the county ; but the majority of these, as noticed below, are evidently derived from Eocene strata; the name $M$. tumidens has however been applied to a species typified by Red Crag 


\section{A HISTORY OF SUFFOLK}

specimens. Numerous dermal plates from the Coralline Crag of Orford and Gedgrave, as well as from the nodule bed of the Red Crag, are indistinguishable from those of the living thornback skate (Raia clavata), while a single tooth from the Coralline Crag of Gedgrave has been assigned to the common skate $(R$. batis). Other dermal plates, from the Red Crag at Boyton and the Coralline Crag at Gedgrave, are regarded by $\mathrm{Mr}$. Newton as indicating a third (perhaps generically distinct) kind of ray. Finally, a small tooth in the British Museum from the nodule bed of the Red Crag of the county indicates a species of monk-fish (Squatina). A second tooth of similar type has been obtained at Little Bealings, and there is a third in the Museum at York, also from the Red Crag.

Allusion has already been made to the 'derived' vertebrate fossils of Suffolk, or those which are definitely known to have been washed out of older formations. These may now be mentioned somewhat more fully. In $1856 \mathrm{Sir} R$. Owen ${ }^{1}$ described a mammalian tooth from the Red Crag of the county, which he regarded as referable to that primitive group of Carnivora of which the Eocene genera Pterodon and Hyanodon are well known representatives. Although the specimen cannot now be found it is probable that the determination is correct, and that the tooth originally came from the London Clay. That formation is certainly the horizon whence was derived part of a skull of the Eocene mammal Hyracotberium leporinum obtained from the Red Crag of the county and described by Sir R. Owen. ${ }^{2}$ The genus and species in question, it may be observed, were first described from the London Clay of Kent, and form one of the ancestral types of the horse line. Teeth of a much larger size from the Red Crag of the county, some of which are preserved in the Museum at Ipswich and others in the Museum of Practical Geology, belong to Coryphodon eoccenus, another primitive odd-toed mammal typically from the London Clay of Essex. An imperfect skull in the Museum of the Royal College of Surgeons, said to be from the Red Crag of the county, has been described by Sir W. H. Flower, ${ }^{3}$ and provisionally assigned to the genus Xiphodon, under the name of $X$. platyceps, of which it forms the type. As the teeth are wanting the genus to which this curious specimen belongs cannot be definitely determined. Mr. Newton observes that although its exact age is uncertain, yet it approximates most nearly in general appearance to the so-called boxstones of the Suffolk Crag.

The only reptilian remains recorded from the Crag of the county appear to be the skulls of turtles, which have evidently been washed out of the London Clay, and doubtless belong to the forms characteristic of that deposit, such as species of Argillocbelys and Lytoloma.

Fish palates and teeth, likewise mainly of Lower Eocene types, are far from uncommon in the nodule bed of the Red Crag. Among them

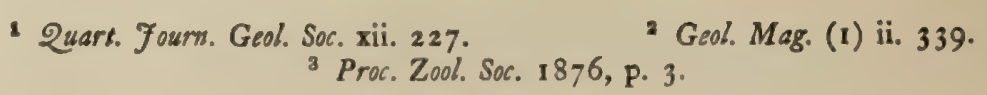




\section{PALÆONTOLOGY}

are specimens of the dentition of the extinct genus Pbyllodus, referable to the three species $P$. speciosus, $P$. bexagonus and $P$. toliapicus. A fragment of a fin-spine from Foxhall is referred by Mr. E. T. Newton to the extinct cat-fish Arius egertoni, whose typical horizon is the Middle Eocene of Sussex. Of the pycnodont ganoids, or those with rounded or oval crushing teeth, specimens from the Crag have been assigned to the genera Pycnodus, Gyrodus, Pisodus and Lepidotus ; those belonging to the first and third being probably derived from the London Clay and the others from still older formations. Dental plates of fishes allied to the living chimæra or king-of-the-herrings are also met with in the Red Crag, and have been assigned to the Eocene genera Edapbodon and Elasmodus. To the same group belongs a fragment of a fish-spine from Woodbridge, now in the British Museum, which has been referred to the Eocene Colorbyncbus rectus.

Allusion to 'derived' teeth of sharks belonging to the genus Odontaspis has been made in an earlier paragraph. In addition to these occur larger teeth belonging to the Eocene shark known as Otodus obliquus. The large roller-like dental plates of eagle-rays of the genus Myliobatis, occasionally met with in the Red Crag, have for the most part been identified with the Eocene species $M$. dixoni and $M$. toliapica. Others belong to the allied genus Atobatis. The Ipswich Museum possesses a few fragments of the well known crushing teeth of the Cretaceous genus Ptychodus, which have been identified with $P$. polygyrus, so abundant in the English Chalk. Lastly, fragments of teeth from Woodbridge indicate a saw-fish (Pristis), doubtless identical with a lower Eocene species.

Of far more interest than the above derived specimens are certain fossils obtained in the year 1839 by the late $\mathrm{Mr}$. W. Colchester of Ipswich in the Lower Eocene sand of Kingston near Woodbridge, some of which are described in Owen's British Fossil Mammals and Birds. Among these a fragment of a lower jaw, showing one entire cheek tooth, has been referred to an opossum with the name Didelphys (?) colchesteri; but the real affinities of the specimen must remain undecided. Another mammal, typified by two cheek teeth of the upper jaw, was named by Owen Hyracotberium cuniculus, as these teeth, although smaller, appeared generically identical with those of $H$. leporinum. A fragment of the lower jaw, with two teeth, of the former species included among Mr. Colchester's collection was at first regarded as indicating a monkey, and accordingly named Macacus eocanus. Another mammalian tooth from Kingston is figured by Owen (op. cit. p. 17), and provisionally regarded as that of some kind of bat.

A fragment of a jaw from Kingston described by Sir R. Owen as Lacerta (?) eocana, appears to be certainly reptilian, although its precise generic determination is probably impossible. Certain fish-scales from Kingston presented to the British Museum by the Rev. J. Middleton in 1854 , are referred by Dr. Smith Woodward to the genus Lepidosteus, now represented by the bony pike of the rivers of North America. From 


\section{A HISTORY OF SUFFOLK}

the same deposit and locality have been obtained teeth of the shark Odontaspis cuspidata. ${ }^{1}$

So far at least as published records are concerned vertebrate remains appear to be exceedingly scarce in the Suffolk Chalk, and no species seem to have been named from that formation in the county. Probably fish teeth have been obtained from some of the chalk pits of the county, but it must suffice to mention that the British Museum possesses some of the well known crushing teeth of the ray-like Ptychodus latissimus from the Upper Chalk of Orford. ${ }^{2}$ As regards fossils from pre-Cretaceous deposits there is a vertebra of Icbthyosaurus thyreospondylus from the Kimeridge Clay of Stanton near Bury St. Edmunds in the collection last named. ${ }^{3}$

1 See Cat. Foss. Fish. Brit. Mus. i. 369.

3 See Cat. Foss. Rept. Brit. Mus, ii. 39.

2 Ibid. i. 149. 
. 


\section{BOTANY}

$\mathbf{A}^{\mathrm{s} \text { the }}$

he Flora of a county is, in a great measure, dependent upon its geological formation and physical conditions, a brief summary of these features of the county of Suffolk seems a necessary preface to an account of its botanical productions.

Chalk forms the foundation of the whole county, with the possible exception of certain tracts beneath the Fenland west of Mildenhall, where the underlying Gault and Kimmeridge Clay may possibly come to the surface.

South of a line (roughly) drawn between Sudbury and Aldeburgh the chalk is covered by Eocene deposits, consisting of Thanet Sands, Reading Beds, and London Clay, the last-mentioned being the most important; these beds, however, are in their turn covered (partially in the south-east part of the county and wholly in the north-east) by the later Pliocene (Crag) deposits, peculiar to the counties of Essex, Suffolk, and Norfolk. The oldest, the Coralline Crag, consisting of a light yellow calcareous deposit with a little sand, is found in an isolated area between Aldeburgh and Boyton and near Shottisham.

The later Red Crag occurs in the south-east part of the county and consists of shelly sands coloured red by oxide of iron, hence the name. In the north-east are found the variable group of sands, laminated clays, and pebbly gravels which make up the Norwich Crag.

All these strata, however, are covered for the most part by Boulder Clay, brick earth, sand, and gravel belonging to the Pleistocene Period, and mainly glacial in origin. The Boulder Clay, the most important of the group, consists chiefly of stiff chalky and stony bluish-gray clay and occupies a considerable area in central, or (as it is locally termed) 'High' Suffolk.

More than two-thirds of the county consists of heavy land; richer districts occur between the Orwell and the Stour, the extreme north-east of the county, and the country between Hopton, Euston, and Newmarket.

Light sandy soils are found in the north-west-a tract known as the Breck District, the most interesting part of the whole county botanically, and fully dealt with under Division I-and again in the extreme east, many species of plants occurring only in the county in these two districts.

In the preparation of the Phanerogamic portion of this article the following gentlemen kindly assisted in various ways, and thanks are due to them :-Messrs. A. Bennett, Rev. G. R. Bullock-Webster (Characex), W. A. Dutt, Rev. E. N. Bloomfield, Rev J D. Gray, Rev. W. M. Rogers. 


\section{A HISTORY OF SUFFOLK}

As a county Suffolk may be said to be comparatively flat, falling away into marshes on the north-west and north-east; what hills there are, are of slight elevation, and for the most part even the higher land is not more than $200 \mathrm{ft}$. above sea level. The greatest elevation occurs about 6 miles south-west of Bury :-Rede ( $420 \mathrm{ft}$.), Ousden ( $405 \mathrm{ft}$.), Depden (404 ft.), and Lawshall (347 ft.) - the River Lark rises at the last-named place.

The coast line, about 50 miles in length, is also low with here and there moderate cliffs or sand dunes, as at Lowestoft Ness (the most easterly point in Great Britain), Kessingland, Easton Bavent, Dunwich, and Bawdsey.

Coast erosion is very prevalent, Pakefield, Southwold, and Dunwich being amongst the chief sufferers.

The principal rivers of this well-drained county are the Little Ouse and Waveney, separating it from Norfolk on the north; the Stowe, dividing it from Essex on the south, and there are also the Gipping (known as the Orwell below Ipswich), Blyth, Deben, Ore, and Lark, all more or less important waterways. All these flow eastward except the Little Ouse and Lark, which find their way into the Wash.

The lakes and broads of Suffolk cannot compare with those of Norfolk either in size or interesting features, and the lakes in the western portion have almost all been artificially enlarged, as Livermere ( 2 miles long) and Redgrave ( 46 acres). Broads of a brackish nature are Breydon Water at Yarmouth, a magnificent stretch of tidal water 5 miles long, and Lake Lothing (also tidal) at Lowestoft, 2 miles long, and separated from Oulton Broad by a lock.

Fresh-water broads, some subject to inroads from the sea at exceptional tides, are Fritton Decoy (500 acres), Barnby, Easton, and Benacre, all small broads, and Barton Mere near Packenham (12 acres). Thorpe Mere near Aldeburgh, formerly a lake of some thousand acres, is now mainly a rush-grown swamp and mud-flat.

East Anglian botany may be well compared with that of low-lying Holland, at one time contiguous and now only separated by a shallow sea. If East Anglian plants are estimated at 1,350 species, and those of Holland at $\mathrm{I}, 480$, about $\mathrm{I}, \mathrm{I} 20$ species are common to both. The more or less Northern types, which are, or have been, found in Suffolk, such as Antennaria dioica, Scirpus rufus, and Carex limosa, occur in Holland, as well as the following species, which are almost, or entirely (*) confined to East Anglia (Norfolk, Suffolk, Cambridgeshire, and Essex) :- ${ }^{*}$ Silene Otites, Holosteum umbellatum, *Medicago falcata, M. minima, *[Lathyrus tuberosus], Tillaa muscosa, Galium anglicum, Peucedanum palustre, *Gnaphalium luteo-album, *Artemisia campestris, *Senecio paludosus, *S. palustris, Soncbus palustris, Melampyrum arvense, *Veronica verna, $V$. triphyllos, *V. spicata, Teucrium Scordium, Primula elatior, Sclerantbus perennis, *Herniaria glabra, Suaeda fruticosa, Atriplex pedunculata, Liparis Loeselii, Stratiotes aloides, * Carex ericetorum, Pbleum phalaroides, *Apera interrupta, *Weingaertneria canescens, and Lastrcea cristata. 


\section{BO'TANY}

Compared with its adjoining counties Suffolk would seem to exceed them all in number of recorded species, with the exception of Norfolk; $\mathrm{I}, \mathrm{I} 80$ appears to be a fair estimate for species in Suffolk, whilst in addition about 90 varieties are known for the county.

Norfolk is credited with I, I97 species and with probably as many varieties or forms as Suffolk; Essex comes next below Suffolk with I,083 species and 44 recorded varieties, and Cambridgeshire (with practically no maritime plants) last with 1,007 species and about 50 varieties.

Suffolk contains a great many interesting species, but as Norfolk or Cambridgeshire can also claim nearly all, Pulmonaria officinalis is left to stand alone as the county's unique production. It is considered by its discoverer, Mr. C. J. Ashfield, the Rev. E. S. Marshall and others to be a true native of Suffolk.

The following species may be noted as being remarkable absentees from Suffolk :-Latbyrus montanus, which occurs in North and South Essex and West Norfolk; Enanthe crocata, growing in South Essex and East and West Norfolk; Vaccinium myrtillus, found in South Essex and East Norfolk ; Narthecium ossifragum, plentiful in East and West Norfolk and Cambridgeshire; and Luzula maxima, seen in all portions of the adjoining counties.

The seeds of the following species, no longer natives of Suffolk, have been found in the county in a fosilized condition :- Trapa natans, Betula nana, Salix myrsinites, S. berbacea, S. polaris, Najas marina, and N. minor.

Betula nana, Salix myrsinites and herbacea are northern British species, and $N$. marina occurs in Norfolk; the others are now ultra-British plants.

An article on Suffolk Botany would not be complete without a few words upon those observers who have resided in the county or contributed to our knowledge of its plants, both in the past and at the present time.

Of botanists resident in the county undoubtedly the first to be mentioned is Sir John Cullum, F.R.S., of Hawstead, who was born in 1733 and died in 1785. His MS. Naturalists' Journal (1772-85) contains much that is interesting, and fully describes the plants of the Bury district, where he first discovered Genista pilosa, Veronica verna, and Muscari racemosum in England. His published History of Hawstead (1774) contains a list of the species to be found in that parish. A very large number of Suffolk species were first reported by this careful observer, including Anemone Pulsatilla, Sisymbrium Irio, Holosteum umbellatum, Dianthus deltoides, Linum perenne, Alchemilla vulgaris, Potentilla verna, Antennaria dioica, Galium anglicum, Gentiana Pneumonanthe, Verbascum Lychnitis, Melampyrum cristatum, Calamintha Nepeta, Hippophae rbamnoides, Orchis ustulata, Opbrys aranifera, \&c.

In 1804-5 Sir T. G. Cullum, F.R.S., brother to the above, enriched the county's flora in a noteworthy manner, adding many new species in Gillingwater's History of Bury, and the Botanists' Guide : these included Medicago sylvestris, Trifolium suffocatum, Lytbrum byssopifolia, Hypochaeris maculata, Herniaria glabra, Rumex maritimus and limosus, Herminium Monorchis, Liparis Loeselii and others. This botanist was born in 1741, practised as a surgeon at Bury, and died at Hawstead in 1831 . In 1774 there appeared a small unfinished work upon British plants from his pen, Florae Anglicae Specimen, which it is said he gave up in favour of his friend Mr. Hudson's well-known book.

Next, in chronological order, appeared George Crabbe, ${ }^{2}$ the poet, born at Aldeburgh in 1754. During the earlier part of his life he resided in Suffolk, and compiled lists of plants

'J. Groves in Proc, Suff. Inst. Arch. and Nat. Hist. 1905, vol, xii, part 2, "Crabbe as a Botanist.' 


\section{A HISTORY OF SUFFOLK}

observed in the various parishes where he held curacies, Aldeburgh, Great Yarmouth, Framlingham, \&c. In later years he held livings in Leicestershire and Wiltshire. Whilst in Suffolk he added to the county, Trigonella purpurascens, Bupleurum tenuissimum, Pulicaria vulgaris, Carduus eriophorus, Galeopsis versicolor, Crocus vernus, Damasonium stellatum, Stratiotes aloides, Spartina stricta, \&c.

Crabbe died in $183^{2}$, and before that date Dawson Turner, a banker in Yarmouth, had attracted attention as a botanist by producing, in conjunction with L. W. Dillwyn, the Botanists' Guide (1805). In this book 'Turner reported for the first time several species from the county, chiefly from the north-east corner, such as Gagea fascicularis, Carex axillaris, $C$. filiformis, \&rc.

Lilly Wigg (1749-1 828) also contributed Suffolk records to the Botanists' Guide; he was trained for a shoemaker, turned schoolmaster, and eventually became a clerk in Dawson Turner's bank at Yarmouth. His mention of localities in the county for Trifolium squamosum, Peucedanum palustre, Pyrola rotundifolia, Verbascum Blattaria, Centunculus minimus, Polygonatum multiforum, Rhyncospora alba, Scirpus pauciforus, and some others, appear to be the earliest notices.

T. J. Woodward (who flourished during the end of the 18 th century), living at Bungay, was the means of adding to the county Helleborus viridis, Pyrus Aria, Schollera Occycoccus, Statice babusiensis, Suaeda fruticosa, Alopecurus bulbosus, and others. He died in 1820 .

D. E. Davy, who also contributed to the Botanists' Guide, residing at Ufford and Yoxford, seems to have been the first to have found the following in Suffolk :-Crambe maritima, Dianthus Armeria, Pyrus torminalis, Erytbraea pulchella, Cyclamen bederaefolium, Verbascum Virgatum, Lastrcea cristata, \&c.

In 1834 there appeared a book, The Natural History of Yarmouth, by two brothers, Charles and James (afterwards Sir James) Paget, the former undertaking the entomological portion and James the rest. The latter became an eminent surgeon in London and was obliged to relinquish his hold upon botany; a bust by Boehm at the Royal College of Surgeons and a portrait by Millais at St. Bartholomew's Hospital are evidences of his popularity. The fresh species to Suffolk in the above-mentioned work include Lepidium birtum, Chenopodium ficifolium, Myrica Gale, Ruppia rostellata, Carex limosa, and Lastraea Oreopteris. Sir James Paget died in 1899 .

The first Flora of Suffolk was that published in I 860 by the Rev. J. S. Henslow and Edmund Skepper, who, besides contributing original matter themselves, included much material gathered from the Phytologist (old series), Old and New Botanists' Guides, English Botany, $\& c_{c}$, and notes from contemporary observers.

The Rev. J. S. Henslow (1796-1861), better known perhaps as Professor Henslow, became the rector of Hitcham in 1837 , and resided there until his death ; his collaborateur, Edmund Skepper, spent the major part of his life at Bury as a druggist. He was a much younger man than Professor Henslow, being born in 1825 , but he only survived the latter six years. The Flora produced by these two botanists did not pretend to be an exhaustive one, but aimed merely to call attention to what little had already been done, and to stimulate others to complete the task. The editors themselves recorded for the county Raphanus maritimus, Erytbrcea littoralis, Allium vineale, Funcus compressus, Potamogeton coloratus, $P$. trichoides, Alopecurus fulvus, Calamagrostis lanceolata, \&c.

The Rev. E. N. Bloomfield, who formerly lived at Glemham and is now rector of Guestling, Sussex, contributed to this Flora, and added Orchis bircina (now probably extinct, as one plant only was found and that in 1847), Scirpus cernuus, Festuca Myurus, \&c.; he also rediscovered for the county, in 1855 , Eryngium campestre in a fresh locality (found by Buddle in the 17 th century in Lothingland), but this is now again lost.

Mention may also be made of F. K. Eagle (discoverer of Sanguisorba officinalis, Gnaphalium luteo-album and Senecio paludosus); the Rev. K. Trimmer, author of the Flora of Norfolk, and the Rev. W. W. Newbould, who found Glyceria Borreri and Apera interrupta in the county, all of whom contributed to the volume.

In 1889 there appeared a new work upon the plants of the county, the Flora of Suffolk by the Rev. W. M. Hind, rector of Honington from 1875 to 1894 . He was born in 1815 in Ireland, studied at Trinity College, Dublin, was appointed curate at Pulverbach, Salop, and then at Pinner, Hertfordshire, until 1875 . The title of LL.D. was conferred upon him in 1870 at the time of his presentation to Trinity College, Dublin, of his large Herbarium.

Although by no means a critical botanist, Dr. Hind showed by his Flora that he was capable of much thoroughness in gathering together material from various out-of-the-way 


\section{BOTANY}

sources, such as the examination of many private herbaria inaccessible to most, and compiling a readable and interesting book, and from it much of this account of Suffolk botanists has been derived. Dr. Hind died suddenly whilst addressing a meeting in 1894, and left a collection of Suffolk specimens, illustrating, in a large measure, his Flora, to the Ipswich Museum. Dr. Hind's Flora and, by the kindness of the museum authorities, the specimens illustrating it, have been of great value in preparing this paper upon Suffolk plants, but it has been found necessary to omit some of the species included in the Flora as the examples representing them in the museum are insufficient or incorrectly named. In compiling material for his work Dr. Hind was very considerably helped by the Rev. Churchill Babington, rector of Cockfield (whose name appears on the title-page of the Flora), who undoubtedly intended to become joint editor, but unfortunately his death in January 1889 prevented this.

Many lists and actual specimens were examined by Dr. Hind, the chief contributors being the following:- Herbarium and lists of Sir C. J. F. Bunbury (1809-86) of Mildenhall and Barton, who found Scirpus rufus and Phleum phalaroides; Mrs. French of Woolpit, who botanized in the south-west of the county and discovered Vicia gracilis, Enanthe fuviatilis, Myosotis sylvatica, and Polygonum maculatum; Rev. G. R. Leathes of Shropham Hall, who found Malaxis paludosa and Allium oleraceum; and lastly, Dr. Hind himself, who added to the county Fumaria densifora, Filago gallica, Mentha gentilis, Luzula Forsteri, and Bromus madritensis.

Botanists of the past have also to be reckoned with in compiling first evidences of the Flora of a county, and it would appear that the earliest mention of a Suffolk plant may be found in Miller's Gardener's Dictionary, ed. 8 (1768), where it records the fact (!) that Lathyrus maritimus sustained the people of Orford during a time of scarcity in 1555 . The passage runs :-

The English Sea Pea is found wild upon the shore in Sussex and several other counties in England. This was first taken notice of in the year 1555 between Orford and Aldborough, where it grew upon the heath where nothing, no, not grass, was ever seen to grow; and the poor people being in distress by reason of the dearth that year, gathered large quantities of these peas and so preserved themselves and families. This is mentioned by Stowe in his Chronicle and Camden in his Britannia, but they were both mistaken in imagining that they were peas cast on shore by a shipwreck, seeing they grow in divers other parts of England and are undoubtedly a different species from the common Pea.

The following botanists, of more than British fame in the olden days and now, should also be noted:- John Caius (alias Key) (1510-73), who again reported Lathyrus maritimus; John Gerard (1545-16I2) of Herbal fame, who noticed Astragalus danicus and Elymus arenarius; William How (1619-56), who mentioned in his Phytologia Britannica that Silene Otites had been found by Mr. Sare; the well-known John Ray (1627-1705), whose Synopsis added Frankenia laevis, Medicago minima, Trifolium glomeratum, Cicuta virosa, and Scleranthus perennis; Adam Buddle, who died in 1715 and for a time had his home at Henley in Suffolk, is credited with finding Medicago falcata, Lathyrus palustris, Eryngium campestre, Equisetum byemale, and Lycopodium clavatum; James Sherard (1666-1 737), who had a remarkable garden at Eltham, Kent, and who is responsible for Helleborus foetidus, Senecio palustris, and Sonchus palustris; J. J. Dillenius (1687-1747), of German nationality, brought to England by W. Sherard (elder brother of above), who included in his edition of Ray's Synopsis, Verbascum pulverulentum, Thesium humifusum, and Urtica pilulifera; T. Willisell, who flourished in Merrett, Ray, and Sherard's days, and collected plants for them all over the United Kingdom, and who found Artemisia campestris and Veronica triphyllos; James Crowe, of Salix fame, who died in 1807 and who reported Daphne Mezereum and Fritillaria Meleagris; Sir J. E. Smith (1 759-1828), the founder of the Linnean Society, who mentioned in his Flora Britannica, Silene conica, Sedum albescens, Diotis candidissima, Chenopotium botryodes, Panicum glabrum, Weingaertneria canescens and Poa bulbosa; and W. Borrer $(1781-1862)$, the Sussex botanist, who found Limosella aquatica and Tolypella intricata.

\section{BOTANICAL DISTRICTS}

Mr. H. C. Watson, in Topographical Botany, has divided the county, for botanical purposes, into East and West Suffolk (vice-counties 25 and 26), the boundary line being I deg. east longitude, but this is (as he himself says) 'not a good division because traceable on maps only, unseen on the ground.' In the Rev. W. M. Hind's Flora of Suffolk, the county was 


\section{A HISTORY OF SUFFOLK}

further sub-divided into five districts corresponding to the divisions representing the county in Parliament, but these do not seem suitable for scientific purposes.

The map therefore attached to this article shows the county separated into five divisions based upon the natural water-basins, the boundary lines obviously following the lines of watersheds. Divisions I and II nearly coincide with Watson's West Suffolk (v.c. 26), and III, IV, and $\mathrm{V}$ with East Suffolk (v.c. 25).

It will be seen, by reference to the map, ${ }^{3}$ that the boundaries of the divisions follow roads and lanes almost invariably, in order that the lines may be accurately traced upon the ground.

\section{Little Ouse}

This division lies on the chalk, mostly overlaid with gravels, clay, and sand, but better exposed in the west, the chalk itself cropping out at Newmarket, Icklingham, Cavenham, \&c. In the extreme north-west of the division fens occur, once the home, doubtless, of Senecio paludosus, S. palustris, Liparis, \&c., an 1 still a most interesting district to the botanist. Of more interest still, perhaps, is a tract of wild heath and moorland country, extending into Cambridgeshire and Norfolk, known as the Breck district, and is referred to below.

This division is watered by the Little Ouse and its tributaries, and the River Lark, which receives the waters of the Kennett.

A small detached portion of Suffolk, about 4 miles by 3, containing Newmarket and Exning, is included in this district, which is coloured green on map.

The Breck district of Suffolk may be said roughly to lie north of the railway from Newmarket to Thurston, and west of the river from Thurston to Euston, and the majority of the 'Breck plants' are included in this area.

The subsoil is chalk, mostly covered with light, loose sand (apt to be wind-drifted, as at Brandon), or gravel, and on the higher land chalk is frequently seen at the surface; there are many gravel and chalk pits. The greater part has probably never been cultivated, but some portions, broken up for growing rye, were called 'Brecks,' hence the name for the district.

There are many wild and open spots chiefly used as sheep walks and rabbit warrens, favoured haunts of Norfolk plover and wheatear; but more recently larch and other plantations have been formed, various inclosures made, and portions now strictly preserved as cover for game, much to the discomfiture of the naturalist. A peculiar point of interest respecting the Breck district is the presence there of distinctly maritime birds, insects, and plants, and by some it is thought that an arm of the sea extended to Thetford from the south coast of Suffolk; others surmise, and this seems the more reasonable idea, that a branch of the Wash reached Thetford from the west, and that the Wash itself extended in the line of the Little Ouse as far as Brandon, Wangford, and Lakenheath, and, further south, to Mildenhall, Icklingham, and Lackford, along the course of the River Lark. Two shallow meres near Roudham Heath, four miles north-east of Thetford, may be relics of this former extension.

Evidence seems to point to an actual range of coast sands near Brandon and Thetford at a comparatively recent stage (geologically speaking) of the Post Glacial Period, whilst the great valley of the Fens was still submerged.

Pottia Heimii, Fürm., a distinctly maritime moss, is found at Wattisfield, and, amongst the Phanerogams, such sea-coast plants as Rumex maritimus and Carex arenaria (chiefly maritime), and Phleum arenarium and $W$ eingaertneria canescens (wholly maritime) occur.

The following plants may be said to be typical of the sandy or chalky fields and heaths of the Breck country, some of them occurring in local abundance :-

$\begin{array}{lll}\text { Anemone Pulsatilla } & \text { Astragalus danicus } & \text { Scleranthus perennis } \\ \text { Silene Otites } & \text { Potentilla verna } & \text { Herniaria glabra } \\ \text { - conica } & \text { Artemisia campestris } & \text { Carex ericetorum } \\ \text { Alsine tenuifolia } & \text { Hypochaeris glabra } & \text { Phleum phalaroides } \\ \text { Genista pilosa } & \text { Veronica spicata } & \text { Apera interrupta } \\ \text { Medicago sylvestris } & \text { - verna } & \text { Festuca ambigua } \\ \text { - falcata } & \text { - triphyllos } & \end{array}$

${ }^{3}$ This has been reduced to such a small scale that many roads cannot be shown, but it should be compared with the Four-Miles-to-One-Inch Map when the object of the irregular lines of the boundaries will be apparent. Owing to an error on the part of the map-makers the whole of Thetford Warren has been left uncoloured, this is a portion of Division I, and the error, no doubt, partly arose from the Government Ordnance Surveys confusing the Parish with the County Boundary. The latter is undoubtedly the Little Ouse river. 


\section{BOTANY}

\section{SPECIEs Worthy of Special Notice}

\section{(Those unique in division in larger type)}

Thalictrum collinum: Lakenheath and several other spots in the Breck district. Further examination of examples of this plant is desirable. Anemone Pulsatilla: Newmarket and near Cavenham and Saxham, but no recent records. A typical chalk plant, growing only where that formation is exposed, of Watson's Germanic (or Eastern) type. Fumaria densiflora grows about Higham and Mildenhall. [Sisymbrium Irio is recorded from Bury and Gazely ; it is called London Rocket, because it sprang up plentifully after the Fire of 1666 , although known in that neighbourhood before that date. Reported from about a dozen counties, but it is perhaps sporadic except about Berwick, Dublin, and in the Channel Isles.] Polygala serpyllacea, var. ciliata, grows at Elveden and Knettishall, a scarce form only occurring elsewhere in Cambridgeshire and Sussex. Diantbus deltoides: Many localities in the Breck district. Silene Otites, a dioecious generally windfertilized plant (unusual in Silene), occurs in many spots in the Breck district and on Newmarket Heath, where it was first recorded for England in 1650. Known only from Suffolk, Norfolk, and Cambridgeshire. S. conica, of Watson's Germanic type, has its head quarters in the county in the Breck district, but also occurs in Division III. Holosteum umbellatum is an interesting species (Germanic) that grows (or grew) upon old walls and thatched roofs at Bury. First noticed there in 1773 , last in 1855 . An extremely rare early flowering species, known only until quite recently from Norfolk and Suffolk, but found in Surrey in I 905 on old walls and sandy places, and it may be overlooked in other spots on account of its being usually quite burnt up by May (see Fourn. Bot. 1905, p. 189). Arenaria tenuifolia grows in many places in the Breck country, and its two varieties, laxa and bybrida occur with it occasionally. Linum perenne, handsomest of all the flax family, is Germanic in type ; it seems confined to the Ixworth and Bury districts. Genista pilosa may be seen in several spots in the Breck district, and was found at Icklingham in I 77I, when it was new to England. Known besides only from Cornwall, Sussex, Kent, and Pembrokeshire. Medicago sylvestris seems to be peculiar to Suffolk, Norfolk, and Cambridgeshire, and was first found in England, near Bury, in 1805. It grows in several other places in the Breck district, and is supposed by many botanists to be a hybrid between sativa and falcata, and its flowers, often green-tinged, seem to be a blend of the purple flowers of the former and yellow of the latter. M. falcata, as a true native, is also quite an East Anglian species, occurring only in the three counties mentioned above ; it is found in many localities in this district, chiefly in the Breck country. M. minima, a species restricted to the south-east of England, and Astragalus danicus occur at Newmarket and in many other places in the Breck district. Lathyrus palustris has been found at Lakenheath and Tuddenham; it is a decreasing plant in England, with a widespread distribution, not reaching, however, higher than Yorkshire (see Trans. Norf. and Norw. Nat. Soc, vii, 472). (L. montanus should be searched for anew in the county; it is reported very doubtfully from Honington, and is known for Essex and Norfolk, but not for Cambridgeshire.) Potentilla verna grows in several spots in a limited area around Cavenham and West Stow. Alchemilla vulgaris: Between Lidgate and Cowlinge. Poterium officinale: Thelnetham and Hinderclay Fens, and at Lakenheath. Geum intermedium : Stanton and Bradfield St. George. Sedum reflexum, var. albescens : A scarce plant of dry hills and heaths; the type naturalized and common, the variety wild at Mildenhall and near Torquay. Drosera anglica: Mildenhall and Redgrave districts; the hybrid D. obovata (anglica $\times$ rotundifolia) occurs at Redgrave. Lytbrum byssopifolia is a rare and uncertain annual, and has not been seen in Suffolk for many years; it formerly grew at Bury, Barrow Bottom, and east of Barton Mere. Peucedanum palustre is an interesting Fen plant, occurring about Mildenhall, with a limited distribution in Britain (Naturalist, I901, p. 267 ; Trans. Norf. and Norw. Nat. Soc. vii, 467). Larvae of the Swallow-tailed Butterfly are very partial to its foliage. Oenantbe silaifolia occurs near Bury. Caucalis latifolia, an uncertain cornfield weed, has not been seen in its recorded stations-Saxham and Newmarket-for many years. Galium anglicum is a scarce delicate annual or biennial found in sandy places and on walls, 


\section{A HISTORY OF SUFFOLK}

as at Thetford, Mildenhall, Bury, \&c. Asperula cynanchica : Watson's Germanic type. A lover of chalk, and frequent in many parts of the district, especially where that formation is exposed. Filago spatbulata has been found near Fornham, Wangford, Icklingham, and Honington, and is doubtless sometimes passed over from its likeness to $F$. germanica. Aster salignus may be seen in Redgrave Fen. Gnapbalium luteo-album was undoubtedly found at Eriswell in the middle of the last century, and as a fragment was sent for identification from Mildenhall in 1896 it may still survive in the district. It is an interesting plant, also found near Wells (recently) and Harling, Norfolk, but now extinct in Cambridgeshire and Sussex; if, indeed, it ever grew in the latter county. Watson's Germanic type. Antennaria dioica is properly a northern species of Watson's Scottish type, but occurs in isolated spots as far south as Cornwall, Devon, and Hampshire, and also in the lowlands of Holland. Its Suffolk localities are Newmarket, Cavenham, and Culford. Artemisia campestris is locally plentiful in certain spots in the Breck district. It grows now only in West Suffolk and East and West Norfolk, but formerly in Cambridgeshire, where its record in 1650 is its first notice for England. A distinct East Anglian or Germanic type. [Senecio paludosus no longer grows, it is feared, in this county nor in England; it formerly grew near Lakenheath. It is a Germanic type of plant, and although specimens exist from East and West Norfolk, North and South Lincoln, and Cambridgeshire, it is probably now extinct in all its localities.] S. palustris: Brandon, Wangford, and Lackford, but not seen recently. A disappearing plant of East Anglia, but it may still exist in East Norfolk. Likely extinct in Sussex, Cambridgeshire, Huntingdonshire, Lincoln, and West Norfolk, where at one time it undoubtedly grew. (For this and former species, see Trans. Norf. and Norw. Nat. Soc. vi, 457.) S. campestris: First record for England, Newmarket Heath, 1660, where it still grows. Hypochaeris maculata: Newmarket and about Cavenham. First discovered in England in 1663 at Newmarket. It is a very local species in England with a decided preference for chalk or limestone (Naturalist, 1902, p. 369). Gentiana baltica: Near Bury. Doubtless passed over occasionally for G. campestris (see Fourn. Bot. 1894, p. 2, and I 904, supp. 124). Primula elatior has a restricted distribution in the county, occurring in many localities between Stowmarket and the western boundary and also in a few isolated spots south of Thetford. It grows only on Boulder Clay here and elsewhere in England, and avoids Chalk, Gault, and Greensand; it only occurs in five other south-eastern counties, and is very local in each (see fourn. Linn. Soc. 1897 (Bot.), xxxiii, 172-201, and Fourn. Bot. 1903, p. 145). Pulmonaria officinalis grows in abundance in Burgate Wood and at Botesdale, where it seems to exist under truly native conditions (see Phytol. I 862 , p. 351). In the wild plant (unlike the garden form) the leaves are unspotted or only very faintly marked. Possibly this is its only native station in England. Verbascum pulverulentum: A true East Anglian species, Norfolk only besides producing it. It grows about Bury, chiefly to the north and south of that town. Limosella aquatica: Barton Mills. Veronica triphyllos: Norfolk, Suffolk, and Yorkshire only. It grows in many places in the Breck district, usually in sandy fields, flowering in April. 'Mervell in Suffolk' (Ray, 1670) is its first record for Britain. V. verna : Norfolk and Suffolk only; truly Germanic. Abundant in many parts of the Breck district, chiefly on the heaths, flowering in May. First found in Britain near Bury in 1775. V. spicata: Newmarket Heath and in two or three spots in the Breck district. Also recorded-but erroneously-from Norfolk, but without doubt found in Cambridgeshire. First found as a British plant in 1660 on Newmarket Heath, and $I$ have a specimen collected there in 1902. One of the scarcest of British plants. Melampyrum cristatum: Absent from the Breck district, but occurs in Burgate Wood and in many localities south of a line drawn from Dalham to Norton. Utricularia intermedia: Thelnetham Fen. Pinguicula vulgaris, of Watson's Scottish type, and rare in most of the southern counties, grows in several places between Redgrave Fen and Hopton, and in the neighbourhoods of Mildenhall and Stowlangtoft. Mentha gentilis: Honington. Scutellaria minor seems to be remarkably scarce in the county; it is recorded from Tuddenham (where recent observers have failed to find it) and one other locality only. Herniaria glabra: Very local, in the Icklingham, Risby, and Higham districts. It is distinctly East Anglian, known only from Norfolk, Suffolk, Cambridgeshire, and Lincolnshire. Var. subciliata occurs on Kentford Heath. Sclerantbus perennis: Many 


\section{BOTANY}

localities in the Breck district. Known at Elden (Elveden) since Ray's time (1677), when it was first noticed as British. Asarum europaeum, a very rare woodland species, has been found at Rougham. Thesium bumifusum, flourishing on a chalky soil, may be found on Newmarket Heath and in the Bury and Brandon districts. Watson's Germanic type. Eupborbia platyphyllos: Hardwick. Malaxis paludosa : Redgrave Fen. Liparis Loeselii: An interesting epiphyte, very uncertain in its appearance year by year, found in spongy bogs as at Redgrave, Thelnetham, Lakenheath, and Tuddenham. Formerly found in Kent and Huntingdonshire, and still growing in Cambridgeshire, Glamorganshire, Carmarthenshire, and Norfolk; I saw it in the last county in 1900 (see Trans. Norf. and Norw. Nat. Soc. vii, 333). Orcbis ustulata : Germanic. Newmarket Heath, Dalham, and near Cavenham. Ophrys aranifera: Germanic. Kennett, and in the Saxham and Sicklesmere neighbourhoods; rare. Herminium monorcbis: Germanic. Around Little Saxham and Sicklesmere. Muscari racemosum: This East Anglian species is only found in a wild state in Norfolk, Suffolk, and Cambridgeshire. First discovered as a British plant at Cavenham and Hengrave in 1805 ; it also occurs in fallows and plantations in a few other stations in the Breck district. Funcus compressus: Livermere Lake and Barnham. Potamogeton zosteraefolius: Ditch near River Lark, 2 miles from Prickwillow. P. trichoides: Tuddenham, Barton Mere, and Wortham Long Green. Carex paradoxa: Near Icklingham St. James and at Market Weston. (For the distribution of this plant, sparing but wide, see Trans. Norf. and Norw. Nat. Soc. vii, 695.) C. ericetorum: A dwarf early-flowering species, only known to occur in West Suffolk, West Norfolk, and Cambridgeshire. It grows at Mildenhall, Icklingham, and near Risby. Panicum glabrum: A local annual of sandy fields, occurring near Bury, though possibly not a true native of the county nor of England. Only found in Suffolk, Norfolk, Hampshire, and Surrey. Germanic. Phleum phalaroides: Germanic type. Found only in six eastern counties. It grows in about half-a-dozen places in the Breck district, as Mildenhall, Lakenheath, \&c. Alopecurus fulvus: Pools near Welnetham. Apera interrupta : Gathered in 1848 near Thetford and then new to England. Subsequently found in many spots in the Breck district, and at Higham, \&c., and also in the counties of Essex, Norfolk, and Cambridge. Weingaertneria canescens : Between Lakenheath and Wangford, and on Lackford Heath. In these localities, and at Homersfield (district 5), it is unique in England as occurring inland; elsewhere in Suffolk and Norfolk (its only other county) it is a true maritime plant. Festuca ambigua occurs in many places in the Breck district, as Thetford, Brandon, Mildenhall, \&c. It flowers in May. Cystopteris fragilis: Old wall near Barton. Equisetum byemale: About Woolpit and in the Bury neighbourhood. Lycopodium clavatum: Tuddenham Heath, very sparingly; known there since 1773. A very scarce species in Suffolk.

\section{StOUR}

This division is in the south-west of the county, is coloured purple on map, and is watered by the River Stour and its numerous tributaries.

The greater part of the division is on a chalk sub-stratum with surface soils of chalky Boulder Clay and patches of sand or gravel; exposed chalk occurs here and there. In the south-east, which may be indicated as lying south of Long Melford, Edwardstone, and Semer, the chalk is overlaid by the Eocene deposits, of which the London Clay is the most important. Still farther to the east these beds are in their turn covered by the red-coloured shelly sands belonging to the Red Crag formation; these sands, however, rarely come to the surface except on the slopes of the valleys intersecting the district, as they are generally covered by the sands and clays of the Glacial series.

A small portion of the banks of the Stour, close to its mouth, produces a few maritime plants. 


\title{
A HISTORY OF SUFFOLK
}

\author{
Species worthy of Special Notice
}

(Those unique in Division in Larger Type)

Vicia gracilis : Washdall Wood, Thurlow, and Nayland. Epilobium roseum: Near Nayland. Alchemilla vulgaris, var. filicaulis, Cockfield. Geum intermedium: Cockfield, Hitcham, and Bergholt. Pulmonaria officinalis: Recorded from Polstead, but with no particulars or evidence to show that it is native there as in Division I (Lithospermum purpureo-caeruleum: 'Bergholt' in Watson's Topographical Botany. This requires investigation, and should not be accepted until confirmed; Mr. H. C. Watson could get no more information.) Veronica triphyllos: Little Thurlow. Melampyrum cristatum : Hitcham and Stanstead. Primula elatior: Many localities, as Cockfield, Rede, Stansfield, west of Hitcham, \&c. Statice Babusiensis : Stutton. Salicornia radicans: Stutton. Urtica pilulifera: Clare. Funcus compressus: Hitcham. Luzula Forsteri: Polstead Wood. Carex strigosa: Brent Eleigh and Nayland. C. laevigata: Near Nayland. Spartina stricta: Stutton. Alopecurus fulvus: Groton. Apera interrupta: Rede. Bromus madritensis : Rede. Equisetum byemale: Hitcham.

\section{ORWELI}

This division, coloured pink on map, is in the south of the county, and includes a small piece of coast line which produces some very interesting maritime species; it is well watered by the River Orwell (called the Gipping above Ipswich) and the Deben with its numerous side streams.

North of a line drawn through Bramford, Ashbocking Green, Otley, Monewden, and Earl Soham this district is on the chalk mostly overlaid with chalky Boulder Clay, with patches of sand or gravel. South of this line the newer ferruginous shelly Red Crag formation crops up, but it is rarely exposed owing to the glacial sands and gravels overlying it; along the rivers the underlying London Clay may be cut into.

An isolated deposit of Coralline Crag occurs south-west of Shottisham, and Coprolite Beds have been worked near by and also at Sutton, Bawdsey, and Trimley, but are becaming worked out. The beds are pebbly, rich in phosphate of lime, and are used as manure.

\section{Species worthy of Special Notick}

(Those unique in Division in Larger Type)

Brassica oleracea: Felixstowe. Lepidium latifolium: By the River Orwell and a pond near Ipswich. Frankenia laevis, a plant typical of Eastern England, grows at Felixstowe. Silene conica: Wherstead. Medicago falcata : Landguard Common and Boulge. M. minima and Trifolium suffocatum grow on Landguard Common and about Bawdsey. Vicia lutea: Between Landguard Fort and Felixstowe. Lathyrus maritimus occurs near Landguard Fort. Alchemilla vulgaris: Woodbridge. Pyrus torminalis: Helmingham. Filago gallica: A rare Germanic cornfield weed, which has been found at Sutton. Essex is the county from which most British Herbaria are supplied, Berechurch and Castle Hedingham being its localities there. It formerly grew in Kent and Buckinghamshire, and in 1867 occurred near St. Martha's Chapel, Chilworth, Surrey. Pulicaria vulgaris: Bramford. [Diotis candidissima, a remarkable plant with woolly leaves and stem, has been found near Landguard Fort, but not recently. It is a decreasing species in England, and almost extinct now ; it possibly lingers in Cornwall, Hampshire, Suffolk, Anglesey, and Jersey, whilst it is still locally plentiful in Ireland (Waterford and Wexford)]. Primula elatior: Finborough. Statice Babusiensis grows at Chelmondiston and Wherstead; at the former spot, S. Limonium grows with it, and the hybrid S. Neumani may be observed (see Fourn. Bot. 1904, p. 36r). Veronica triphyllos: Shottisham and Barham Heath. Melampyrum cristatum: Clopton Park, Rattlesden, and Bramford. Salicornia radicans: Walton and near Landguard Fort. S. appressa : Chelmondiston. Hippophae rhamnoides: I,ane between Shottisham Church and Sutton Heath 


\section{BOTANY}

Leucojum aestivum is plentiful at Little Stonham, and is also found near Great Bealings Church. This is a beautiful plant, and where found in abundance, as by the River Lodden in Berkshire, it whitens the meadows and banks in late April. Gagea fascicularis is known in four places in the Ipswich neighbourhood. Ruppia spiralis and Carex divisa may be found at Bawdsey, Felixstowe, and Walton. Panicum glabrum: Ipswich and Shottisham. Spartina stricta: Ipswich, Ramsholt, and Walton Ferry. Poa bulbosa may be observed on Felixstowe Common and at the mouth of the River Deben. Glyceria Borreri: Walton. Festuca uniglumis : Near Landguard Fort. Lastrea cristata: Bexley Decoy, near Ipswich. This is a decreasing species in England, known from almost a dozen counties, but believed to be extinct now in most; it certainly still occurs in Norfolk in abundance, and probably exists in Nottinghamshire and Yorkshire (see Trans. Norf. and Norw. Nat. Soc. vii, 695).

\section{ORE}

Coloured yellow on map and lies in the east of the county, and includes by far the greater portion of the coast line. It is watered by the River Ore (called the Alde above Aldeburgh), receiving the Butley River near its mouth, and other smaller streams; north of the Ore, in the order named, occur Hundred River (running into Thorpe Mere), Minsmere, Dunwich and Blyth Rivers, and another Hundred River.

The whole coast line is generally flat with occasional unimportant cliffs, and near the shore are found interesting pieces of water known as Benacre, Easton, and Covehithe Broads, all liable to be flooded by the sea at exceptionally high tides; Thorpe Mere, now much grown over by rushes and coarse grass, also occurs in this division. In two or three places near the coast a few of the remarkable 'Breck' plants re-appear.

This division is composed of Crag deposits, but a great part is covered with Drift. The older Coralline Crags (light yellow calcareous deposits consisting chiefly of organic débris with some sands) are found in a small area between Aldeburgh and Boyton, and Coprolite Beds, belonging to this series, have been worked at Butley, Bawdsey, and Boyton.

Red Crag deposits with its usual characteristics are found in the south part of the district, whilst the north part consists of the sands, clay, and pebbly gravels which make up the Norwich Crag.

\section{SPECIES WORThy of SPECIAL Noticr}

(Those unique in Division in Larger Type)

Lepidium latifolium: Blythburgh, Snapebridge, and between Aldeburgh and Orford. Crambe maritima is reported from several places between Aldeburgh and Southwold, and may still survive, but Dr. Hind believed it to be extinct. Frankenia laevis grows about Southwold and Thorpe. [Linum angustifolium, supposed to be now extinct in Suffolk, undoubtedly once grew at Darsham.] Medicago falcata: Dunwich, Orford, and Sudbourne. M. minima occurs in several places near the coast. Trifolium squamosum: Shingle Street, Hollesley. Said by Lilly Wigg to also grow near Yarmouth in former days (district 5). T. suffocatum: Several spots near the coast. Vicia lutea stills grows on Orford Beach, where it was known as long ago as 1775. Latbyrus maritimus was first found in England at Orford in 1555, and is still theré; it also grows at Aldeburgh. Pyrus torminalis: Darsham. [Eryngium campestre is now lost at Dunwich (where it undoubtedly grew in 1856) by the cliffs falling away. It was also found in the $17^{\text {th }}$ century at Lothingland (district 5) by Adam Buddle. It is a plant gradually becoming extinct in England; known from Cornwall, Somerset, Kent, Devonshire, and Northamptonshire, but probably lost now in the last two counties.] Critbmum maritimum: Southwold is the only record for Suffolk, and it has not been observed there in recent years. A decreasing species in England; as 'Samphire' it was formerly in much request for pickling and for using in salads. Inula crithmoides, the golden samphire, is used in the same way. Young shoots of glasswort (Salicornia herbacea) are sometimes substituted for the above and sold as marsh samphire. Pulicaria vulgaris: Framlingham. [Diotis candidissima was found in former days in three or four places on the coast between Benacre and Orford, but has not, I think, been seen there at all recently.] Campanula latifolia: About 


\section{A HISTORY OF SUFFOLK}

Chediston. Pyrola rotundifolia: Near Theberton. Erytbraa littoralis: Sizewell. Verbascum pulverulentum: Dunwich. Veronica verna: Cookley and Thorpe. Its head quarters are in the 'Breck' district. V. triphyllos, another 'Breck' plant, grows at Snape and Aldeburgh. Mentha rotundifolia: Chediston. Scutellaria minor: Friston. Cyclamen bederaefolium: Henham Park, Bramfield (fig. in English Botany), and Abbey Wood, Sibton. One of the rarest of British plants, if indeed a native of this country, which its distribution in Southern Europe is against. Besides Suffolk, it grows apparently wild in woods near Sandhurst, Kent, and Borrer also considered it native near Hastings, Sussex. Statice Babusiensis: Walberswick. Suaeda fruticosa is a scarce plant of Southern England; it occurs about Walberswick and Aldeburgh. Salicornia appressa: Aldeburgh. S. radicans: Orford. Atriplex pedunculata is of Germanic type, and occurs about Walberswick, Shingle Street, and Aldeburgh. It is an uncertain annual of salt marshes, where plants of such duration are extremely rare, in Kent, Norfolk, Lincolnshire, and Cambridgeshire, but probably extinct in the last two counties. It has been reported from Connemara, Ireland (see Trans. Norf. and Norw. Nat. Soc. viii, 40). Hippophae rbamnoides: Thorpe. [Daphne Mezereum formerly grew at Laxfield.] Urtica pilulifera: Thorpe and Aldeburgh. Orchis bircina: A single specimen of this fine orchis was found on gravel at Great Glemham in 1847 , but has not been seen there since. In former years it grew in West Kent (1879) and it has been reported from Surrey and Hampshire; it exists still in East Kent, near Wye, and was found in Sussex in 1907. Polygonatum multiforum: Sternfield. Gagea fascicularis: Great Glemham. [Damasonium stellatum formerly grew at Framlingham.] Ruppia maritima: Aldeburgh and Orford. Scirpus cernuus: Snape. S. rufus grows (or grew) by the edge of the Mere, Aldeburgh, but has not been reported recently. It is quite a northern species, of Watson's Scottish type, and is completely out of its range in Suffolk, where it is much farther south than any other locality in Britain. It occurs also in Holland. Carex divisa may be seen at Southwold, Dunwich, and Hollesley, chiefly growing by the side of brackish ditches. Spartina stricta: Aldeburgh and Orford neighbourhoods. Apera interrupta, one of the 'Breck' plants; grows on Westleton Heath. Weingaertneria canescens occurs in three or four places on the coast between Easton Broad and Pakefield. Poa bulbosa may be observed, early in the year, at Southwold and Aldeburgh. Glyceria Borreri grows between Dunwich and Walberswick. Bromus madritensis : Westleton Heath. Lastrae cristata has been known for many years at Westleton Decoy.

\section{W AVENEY}

This is coloured brown on map, lies in the north-east of the county, and includes all that portion drained by the River Waveney and its tributaries, the Beck, Dove, \&c.

Geologically, by far the greater part of this division is composed of the variable sands, clays, and gravels belonging to the Norwich Crag; westward of Oakley, however, the underlying chalk crops up again.

1 The coast between Lowestoft and Yarmouth includes a range of low hills, grassy denes, and sand dunes.

Interesting fen-lands occur near the Waveney between Beccles and Yarmouth, and produced many a rarity in days gone by ; even now it is a home for many interesting species, such as Latbyrus palustris, Sium latifolium, Peucedanum palustre, Sonchus palustris, [Senecio palustris,] Myrica, Malaxis, Cladium, Carex limosa, C. filiformis, Lastrcea cristata; a number of these only occur elsewhere in the county in the extreme west.

Fritton Decoy, Oulton and Barnby Broads, Lake Lothing, and Breydon Water are in this division.

Of late years the changes round Lowestoft and Yarmouth have destroyed, or caused to become scarce, many species mentioned in Dr. Hind's Flora as occurring in these neighbourhoods; the crumbling away of cliffs, too, between Lowestoft and Kessingland, is another cause of the disappearance of some plants; and Lowestoft Denes, again, are much altered, and many species diminished in numbers by sea incursions, protective and harbour works, golf links, \&rc.

The vegetation around Lake Lothing has altered much in recent years, and very little salt marsh is left; boat-building yards are chiefly responsible for this.

The 'Bogs at Lound,' frequently referred to by Dr. Hind and others, have been much interfered with by the late alterations connected with the Lowestoft Waterworks, and now can scarcely be said to exist. 


\title{
BOTANY
}

Improved drainage is also gradually extinguishing such plants as Lathyrus palustris, Sonchus palustris, and Epipactis palustris.

\section{Species worthy of Special Notice}

\author{
(Those unique in Division in Larger Type)
}

Brassica oleracea : Pakefield, but not seen recently. [Frankenia laevis used to grow in Lothingland.] Holosteum umbellatum is very rare; old walls at Eye and Hoxne are localities, where it was first observed in 1836 and last in 1889. [Linum angustifolium is supposed no longer to grow about Lowestoft, where once it flourished.] Medicago falcata: Lowestoft and Stuston. M. minima : Lowestoft. Trifolium suffocatum grows at Bungay, Lowestoft, and Gorleston. Lathyrus palustris is recorded from many localities in the north-east of this division, such as North Cove, Oulton, Beccles, Blundeston, \&c., and certainly still grows in some of them. Poterium officinale: Palgrave. Pyrus torminalis: Bungay. This is possibly on the Norfolk side of the river, as Stock's list of Bungay plants-on which many records rely -included both counties. 'This fact must be noted also in connexion with other species. Peucedanum palustre: Several localities in the north-east of the division, as North Cove, Fritton, Blundeston, \&c. [Diotis candidissima, now killed by sea encroachments, formerly grew between Lowestoft and Pakefield.] [Senecio palustris, it is feared, is now quite extinct in its old localities at Lothingland, Worlingham, Lound, Haddiscoe, and near Yarmouth.] Sonchus palustris: This formerly grew in five or six localities in marshes not far from the Waveney between Beccles and Yarmouth, and in the Oulton district, and still exists in at least two of them; it is also recorded from Palgrave. Known as the marsh sow-thistle, this fine species is now very scarce, and disappearing in East Anglia; it has not been seen in Essex for some forty years; in Cambridgeshire the last example occurred about 1850; records also exist from Middlesex, Huntingdonshire, and North Lincolnshire. It still grows by the Thames and Medway in Kent, also in Oxfordshire and South Lincolnshire; and was seen in East Norfolk up to 1899 (see Trans. Norf. and Norw. Nat. Soc. viii, 35). Campanula latifolia : About Shipmeadow. Schollera occycoccus : Worlingham Common, near Beccles ; probably extinct now. [Pyrola rotundifolia has not been seen for many years in its old locality near Bradwell, where it is reported that only a single example ever existed.] Erythraea littoralis: Lowestoft and Gorleston; but not reported by recent observers. Gentiana Pneumonanthe : Considered by Dr. Hind and others to be probably extinct in Suffolk, although it had several localities, as Carlton, Hopton, and Corton Heaths; there must be some suitable spots where this beautiful plant should be searched for anew ; it still grows in Norfolk in plenty in similar situations. (Myosotis repens; One doubtful record alone for SuffolkSt. Margaret's. It may be really absent, only reaching as far east as Cambridgeshire.) [Orobanche ramosa. Now extinct. It formerly grew in three or four places as a parasite upon hemp, which is no longer cultivated. It also occurred upon Galeopsis tetrabit in one spot.] Verbascum pulverulentum is said to be now extinct in its two or three known localities between Fritton and - Oulton and at Gorleston, but should be searched for. [Limosella aquatica no longer grows at Lowestoft, local alterations causing this.] Veronica verna has been found at Lowestoft and V.triphyllos at Bungay ; both are more abundant in the 'Breck' district. Mentha alopecuroides grows at Oakley, and its near ally, $M$. rotundifolia, about Withersdale: the former may be known by its longer corolla and calyx-teeth. Cbenopodium botryodes: A very rare and uncertain annual, known from near Lowestoft since 1828 , where it grows near Southtown Marshes. It is an East Anglian species, also occurring in Kent and Norfolk, and reaching Sussex and Hampshire. Atriplex pedunculata is now very rare or else extinct in its recorded localities at Breydon Water and between Yarmouth and Gorleston. Salicornia appressa: Breydon Water. Urtica pilulifera: This, I fear, may no longer be found in East Suffolk, where it had half a dozen localities in this division, as Gorleston, Lowestoft, Bungay, \&c. Malaxis paludosa has been found at Belton and south of Fritton Decoy; it probably no longer occurs in the former locality. Gagea fascicularis grows at Shipmeadow in some plenty. Potamogeton angustifolius: Beccles. Ruppia maritima: Lowestoft and Southtown. Rynchospora alba is possibly now lost at Lound and Belton Bog, owing to drainage. Scirpus cernuus : Lowestoft. Carex limosa: Belton Bog. A very local plant in the south, its head quarters being Northern Britain. It occurs, however, in Norfolk and Holland. Panicum 


\section{A HISTORY OF SUFFOLK}

glabrum: Bungay. Alopecurus bulbosus is known from marshes at Belton, Burgh Castle, Breydon, and Southtown. Apera interrupta: Between Homersfield and St. Cross. Weingaertneria canescens : Lowestoft Denes (from early times) and (more recently) inland at Homersfield, on a bed of post-glacial gravel. Poa bulbosa is still to be found on Lowestoft Denes. Glyceria Borreri: Breydon Water and Lowestoft. Lastrcea cristata: Fritton Decoy. Pilularia globulifera grows at Flixton and is also on record from Hopton Common and Bungay. Equisetum byemale is reported, on somewhat ancient authority, from Lothingland; recent observers have not noted it.

\section{COMPLETE LIST OF SUFFOLK PLANTS}

\section{Explanation of Signs}

[ $]=$ supposed extinct. $(\quad)=$ requires confirming. $t=$ not indigenous. The letters $\mathrm{E}$. or $\mathrm{W}$., following specific names indicates that the species occurs only in that division of Watson's Topographical Botany. The numbers I-5 distinguish species found only in those divisions adopted in this article.

For the sake of convenience the nomenclature is that of the London Catalogue, ed. 9.

\section{PHANEROGAMIA}

\section{Ranunculacear}

Clematis Vitalba, L.

Thalictrum collinum, Wallr. W. I

- Havum, L. a. sphaerocarpum, Lej. $\beta$. riparium, Jord. W. Anemone Pulsatilla, L. W. I

- nemorosa, L.

†- ranunculoides, L.

†- apennina, L. E.

tAdonis autumnalis, $\mathrm{L}$.

Myosurus minimus, L.

Ranunculus circinatus, Sibth

- fluitans, Lam.

- pseudo-fluitans, Bab.

- trichophyllus, Chaix.

- Drouettii, Godr.

- heterophyllus, Web.

- peltatus, Schrank. W. var. penicillatus, Hiern.

- Baudotii, Godr. E. var. confusus, Godr. E.

- Lenormandi, F. Schultz. E.

- hederaceus, L.

- sceleratus, L.

- Flammula, L.

- Lingua, L.

- auricomus, L.

- acris, L. W. var. Boraeanus, Jord.

- repens, L.

- bulbosus, $\mathrm{L}$.

- sardous, Crantz. var. parvulus, L. E.

- parviflorus, L.

- arvensis, $\mathbf{L}$.

- Ficaria, L. var. incumbens, $F$. Schultz.

\section{PHANEROGAMIA (cont.)}

Ranunculaceae (cont.)

Caltha palustris, L. W. var. Guerangerii, Bor

Helleborus viridis, $L$.

- foetidus, L.

$\dagger$ Eranthis hyemalis, Salisb.

Aquilegia vulgaris, $\mathrm{L}$.

†Delphinium Ajacis, Reichb.

\section{Berberideas}

Berberis vulgaris, L.

\section{Nympharacear}

Nymphaea lutea, L.

Castalia speciosa, Salisb.

\section{Papaveracear}

†Papaver somniferum, L.

- Rhaeas, L. var. strigosum, Boenn.

- dubium, L. var. Lecoqii, Lamotte

- Argemone, L.

- hybridum, L.

Glaucium flavum, Crantz.

Chelidonium majus, L.

\section{Fumariacear}

†Neckeria bulbosa, N.E. Br.

t- lutea, Scop.

- claviculata, N.E. Br. E.

Fumaria capreolata, L. E.

- Boraei, Jord. E.

- officinalis, L.

- densiflora, DC. W. I

- parviflora, Lam.
PHANEROGAMIA (cont.)

\section{Crucifrrab}

†Cheiranthus Cheiri, L.

Nasturtium officinale, R. Br. var. siifolium, Reichb. var. microphyllum, Reichb.

- sylvestre, R. Br.

- palustre, DC.

- amphibium, R. Br.

Barbarea vulgaris, R. Br.

†- praecox, R. Br.

Arabis hirsuta, Scop.

- perfoliata, Lam.

Cardamine amara, L.

- pratensis, L.

- hirsuta, L.

- flexuosa, With.

†Alyssum incanum, L. W.

†— calycinum, L.

†- maritimum, L. E.

Erophila vulgaris, DC.

- praecox, DC. W.

Cochlearia officinalis, L. E.

- danica, L. E.

- anglica, L. E.

†Hesperis matronalis, $\mathrm{L}$.

Sisymbrium Thalianum, J. Gay

E. $t[$ - officinale, Scop.

t- pannonicum, Jacq.

- Sophia, L.

[- Irio, L. W. I]

- Alliaria, Scop.

Erysimum cheiranthoides, L.

t- perfoliatum, Crantz.

tCamelina sativa, Crantz.

Brassica oleracea, L. E.

†- Napus, L.

†- Rutabaga, DC.

t- Rapa, L.

- sinapioides, Roth. 
BOTANY

\section{PHANEROGAMIA (cont.)}

Crucifrrar (comt.)

Brassica sinapistrum, Boiss.

- alba, Boiss.

t- Erucastrum, Vill. E.

Diplotaxis tenuifolia, DC.

- muralis, DC. var. Babingtonii, Syme

Bursa bursa-pastoris, Weber

Coronopus Ruellii, All.

Lepidium latifolium, L. E.

- ruderale, L. E.

t- sativum, L. W.

- campestre, R. Br.

- hirtum, Sm.

t- Draba, L.

Thlaspi arvense, $L$.

tIberis amara, L. W.

Teesdalia nudicaulis, $\mathrm{R}$. Br.

†Isatis tinctoria, L.

Crambe maritima, L. E. 4

Cakile maritima, Scop. E.

Raphanus raphanistrum, L.

- maritimus, Sm. E.

\section{ResEDACBAB}

†Reseda alba, L. E.

- lutea, L.

- luteola, L.

\section{Cistingar}

Helianthemum Chamaecistus, Mill.

\section{Violaribar}

Viola palustris, L. E.

- odorata, L.

- hirta, L

f. alba, Lange

- silvestris, Reich.

- Riviniana, Reich.

- ericetorum, Schrader

- lactea, Sm. E. 5

- tricolor, L.

- carpatica, Borbas. W. I

- arvensis, Murr.

\section{Polygaleaz}

Polygala vulgaris, $L$.

- oxyptera, Reichb. W. I

- serpyllacea, Weihe. W. I

var. ciliata, Lebel. W. I

\section{Frankeniaceab}

Frankenia laevis, L. E.

\section{Caryophylleas}

Dianthus Armeria, L. - deltoides, L. W. I $+[$ - plumarius, L. W. I]

\section{PHANEROGAMIA (cont.)}

Caryophyllear (cont.)

†Dianthus Caryophyllus, L. E. tSaponaria Vaccaria, L. E.

- officinalis, L.

Silene Cucubalus, Wibel.

- maritima, With. E.

- conica, L.

- anglica, L.

- Otites, Wibel. W. I

- noctiflora, L.

Lychnis alba, Mill.

- dioica, L.

- Flos-cuculi, L.

- Githago, Scop.

Holosteum umbellatum, L.

Cerastium quaternellum, Fenzl.

- tetrandrum, Curtis

- semidecandrum, $L$.

- glomeratum, Thuill.

- triviale, Link.

- arvense, L.

Stellaria aquatica, Scop.

- media, Cyr. var. Boraeana, Jord. var. major, Koch.W.

- umbrosa, Opiz. W. I

- Holostea, L.

- palustris, Retz.

- graminea, L.

- uliginosa, Murr.

Arenaria tenuifolia, L. var. laxa, Jord. W. I var. hybrida, Vill. W. I

- trinervia, L.

- serpyllifolia, L.

var. glutinosa, Koch. var. leptoclados, Guss.

- peploides, Froel. E.

Sagina maritima, Don. E.

- apetala, L.

- ciliata, Fr.

- procumbens, L.

- nodosa, Fenzl.

Spergula arvensis, L.

a. vulgaris, Boenn.

$\beta$. sativa, Boenn.

Buda rubra, Dum.

- marina. Dum. E. E. var. neglecta, Kindb.

- media. Dum. E.

\section{Portulaceae}

tClaytonia perfoliata, Donn.

Montia fontana, L.

$$
\begin{aligned}
& \text { a. repens, Pers. } \\
& \beta \text {. erecta, Pers. W. }
\end{aligned}
$$

\section{Tamariscinear}

†Tamarix gallica, L. E.

\section{PHANEROGAMIA (cont.)}

\section{HYPERICINEAE}

Hypericum Androsaemum, L.

t-- calycinum, L.

- perforatum, L.

var. angustifolium, Gaud.

- dubium, Leers

- quadratum, Stokes

- humifusum, L.

- hirsutum, L.

- pulchrum, L.

- elodes, L.

\section{Malvaceak}

Althaea officinalis, L. E.

†Lavatera arborea, L. E.

Malva moschata, L.

- sylvestris, L.

- rotundifolia, L.

\section{Tiliaceas}

†Tilia platyphyllos, Scop.

t- vulgaris, Hayne

t- cordata, Mill.

\section{Lingab}

Radiola linoides, Roth.

Linum catharticum, L.

- perenne, L. W. I

[- angustifolium, Huds. E.]

f- usitatissimum, L.

\section{Grraniacear}

Geranium sanguineum, L.

t- phaeum, L.

- pratense, L.

- pyrenaicum, Burm. fil.

- molle, L.

- pusillum, L.

- rotundifolium, L.

- dissectum, L.

- columbinum, L.

- lucidum, L.

- Robertianum, L. var. purpureum, anct. angl. E.

Erodium cicutarium, L'Herit. a. vulgatum, Syme

Oxalis acetosella, L. $\beta$. chaerophyllum, Cav.

†- corniculata, I.

t- stricta, L.

tImpatiens parviflora, DC.

\section{ILICINEAB}

Ilex aquifolium, $\mathbf{L}$.

\section{Celastringar}

Euonymus europaeus, L. 


\section{A HISTORY OF SUFFOLK}

\section{PHANEROGAMIA (cont.)}

Rhamnear

Rhamnus catharticus, L. - frangula, L.

\section{SAPINDACRAB}

†Acer Pseudo-platanus, L. - campestre, L.

\section{Lrguminosab}

Genista anglica, L.

- pilosa, L. W. I

- tinctoria, L.

Ulex europaeus, L.

- Gallii, Planch.

- nanus, Forster

Cytisus Scoparius, Link.

Ononis repens, $\mathbf{L}$. a. inermis, Lange. - spinosa, L.

$\beta$. horrida, Lange.

Trigonella purpurascens, Lam. E.

+Medicago sativa, $L$.

- sylvestris, Fr. W. I

- falcata, L.

- lupulina, L.

- denticulata, Willd.

- arabica, Huds.

- minima, Desr.

Melilotus officinalis, Lam.

t- alba, Desr. W.

t- arvensis, Wallr.

†- indica, All. E.

Trifolium subterraneum, L.

- pratense, L. W

var. parviflorum, Bab.

- medium, L.

- ochroleucum, Huds.

- squamosum, L. E.

†- incarnatum, $L$.

t- Molinerii, Balb. W

- arvense, L.

- striatum, L.

- scabrum, L.

- glomeratum, L.

- suffocatum, L. E.

† - hybridum, L.

var. telegans, Savi.

- repens, $\mathrm{L}$.

- fragiferum, L.

t- resupinatum, L. E.

- procumbens, $L$.

- dubium, Sibth.

- filiforme, L.

Anthyllis vulneraria, L.

Lotus corniculatus, L.

- tenuis, W. \& K.

- uliginosus, Schkuhr.

Astragalus danicus, Retz. W, I

- glycyphyllos, L.
PHANEROGAMIA (cont.)

LEGUMinosab (cont.)

Ornithopus perpusillus, L.

Hippocrepis comosa, L.

Onobrychis viciaefolia, Scop.

Vicia hirsuta, Gray

- gemella, Crantz.

- gracilis, Loisel. W. 2

- Cracca, L.

- sepium, L.

- lutea, L. E.

t- sativa, L.

- angustifolia, L. var. Bobartii, Koch.

- lathyroides, L.

Lathyrus Aphaca, L.

- Nissolia, L.

- pratensis, L.

†- tuberosus, L. W. I

- sylvestris, L.

- palustris, L.

- maritimus, Bigel. E.

(- montanus, Bernh.)

\section{Rosacear}

Prunus spinosa, $\mathrm{L}$.

- insititia, Huds.

t - domestica, L.

- avium, $\mathrm{L}$.

†- Padus, L.

- Cerasus, L.

Spiraea Ulmaria, L.

- Filipendula, L.

Rubus idaeus, L.

- plicatus, Wh. \& N.

- affinis, W. \& N. E.

- Lindleianus, Lees.

- rhamnifolius, W. \& N.

- nemoralis, P. J. Muell. var. glabratus, Bab.

- pulcherrimus, Neum.

- Selmeri, Lindeb. E.

- rusticanus, Merc. $\times$ leucostachys, $\mathbf{E}$.

- macrophyllus, W. \& N. var. Schlechtendalii, Weihe. E. E. var. amplificatus, Lees. pyramidalis, Kalt. E.

- leucostachys, Schleich.

- mucronatus, Blox. E.

- echinatus, Lindl.

- podophyllus, P. J. Muell. W.

- mutabilis, Genev. W.

- foliosus, W. \& N. W.

(- rosaceus, W. \& N.) W. var. hystrix, W. \& N. sub.-sp. infecundus, Rogers. W. sub.-sp. adornatus, P. J. Muell. W.
PHANEROGAMIA (cont.)

Rosacear (cont.)

Rubus Koehleri, W. \& N. W. sub.-sp. dasyphyllus, Rogers

- dumetorum, Weihe. W. var. diversifolius, Lindl. W. var. tuberculatus, $\mathrm{Bab}$. var. fasciculatus, P. J. Muell. W.

- corylifolius, Sm. a. sublustris, Lees W. $\beta$ cyclophyllus,Lindeb.

- Balfourianus, Blox. W.

- caesius, L.

Geum urbanum, L.

- rivale, $\mathrm{L}$. $\times$ urbanum $=$ (intermedium, Ehrh.)

Fragaria vesca, L.

†- elatior, Ehrh. W.

Potentilla Fragariastrum, Ehrh.

- verna, L. W. I

- silvestris, Neck.

- procumbens, Sibth.

- reptans, L.

- Anserina, L.

- argentea, L.

- palustris, Scop.

Alchemilla arvensis, Scop.

- vulgaris, L. W. var. filicaulis, Buser.

Agrimonia Eupatoria, L.

Poterium Sanguisorba, L.

†- polygamum, W. \& K. a. platyphyllum, Jord.

- officinale, Hook, fil.

Rosa spinosissima, L.

- tomentosa, Sm. var. subglobosa, Sm.

- rubiginosa, L.

- micrantha, Sm.

(- obtusifolia, Desv.) var. frondosa, Baker var. tomentella, Leman

- canina, L. var. lutetiana, Leman f. andegavensis, Bast. var. surculosa, Woods var. sphaerica, Gren. var. senticosa, Ach. var. dumalis, Bechst. f. verticillacantha,

Merat. var. urbica, Leman var. dumetorum, Thuill. W. var. arvatica, Baker

(- glauca, Vill.) W. var. subcristata, Baker. 


\section{BOTANY}

\section{PHANEROGAMIA (comt.)}

Rosacrar (cont.)

Rosa stylosa, sp. coll. W.

var. systyla, Bast. W. var. leucochroz, Desv.

- arvensis, Huds.

Pyrus torminalis, Ehrh. E.

- Aria, Ehrh. W. 2

- Aucuparia, Ehrh.

- communis, L.

a. pyraster, L. W

- Malus, L.

a. acerba, DC

$+\beta$. mitis, Wallr.

Crataegus Oxyacantha, L. a. oxyacanthoides,

Thuill.

- monogyna, Jacq.

\section{SAXIFRAGEA:}

Saxifraga Tridactylites, L.

- granulata, L.

Chrysosplenium oppositifolium, L.

- alterniflorum, L.

Parnassia palustris, $\mathbf{L}$.

†Ribes Grossularia, L.

- rubrum, L.

- nigrum, L.

$$
\text { ta. sativum, Reichb. }
$$

\section{Crassulacear}

Tillaea muscosa, L.

Sedum Telephium, L.

t- album, L. W.

t- dasyphyllum, L. W. I

- anglicum, Huds. E.

- acre, L.

t- reflexum, $\mathrm{L}$.

var. albescens, Haw.

W. I

†Sempervivum tectorum, L

\section{Droseracear}

Drosera rotundifolia, L.

- anglica, Huds. I

$\times$ rotundifolia ( $=$ obovata (M. \& K.). E. I

- intermedia, Hayne

\section{Haloragrar}

Hippuris vulgaris, L.

Myriophyllum verticillatum, L. W.

var. pectinatum, DC.

- spicatum, L.

- alterniflorum, DC. W.

\section{PHANEROGAMIA (comt.)}

Halorageas (cont.)

Callitriche verna, $\mathbf{L}$.

- stagnalis, Scop.

- hamulata, Kuetz.

- obtusangula, Le Gall.

\section{LYTHRARIBAB}

Peplis Portula, L.

Lythrum Salicaria, L.

- Hyssopifolia, L. W. I

\section{Onagrarigab}

Epilobium angustifolium, L. E.

- hirsutum, L.

- parviflorum, Schreb.

- montanum, L.

- roseum, Schreb. W. 2

- adnatum, Griseb.

- obscurum, Schreb.

- palustre, L.

†CEnothera biennis, L.

Circaa lutetiana, L.

\section{Cucurbitaceas}

Bryonia dioica, Jacq.

\section{UMBELLIFERAE}

Hydrocotyle vulgaris, L.

Eryngium maritimum, L. E.

[- campestre, L. E. 4]

Sanicula europaea, L.

Conium maculatum, $\mathrm{L}$.

Smyrnium Olusatrum, L.

Bupleurum rotundifolium, L. W.

- tenuissimum, L. E.

Apium graveolens, L.

- nodiflorum, Reichb., fil.

- inundatum, Reichb., fil.

Cicuta virosa, $\mathrm{L}$.

†Ammi majus, L. W.

†Carum Petroselinum, Benth. \& H. $f$.

- segetum, Benth. \& H. f.

t- Carvi, L.

Sison Amomum, L.

Sium latifolium, L.

- erectum, Huds.

Egopodium Podagraria, L.

Pimpinella Saxifraga, L.

- major, Huds.

Conopodium denudatum, Koch.

Chaerophyllum temulum, L.

Scandix Pecten-Veneris, L.

Anthriscus vulgaris, Bernh.

- sylvestris, Hoffm.

†- Cerefolium, Hoffm.

Foeniculum vulgare, Mill.

\section{PHANEROGAMIA (comt.)}

UMBelliferae (cont.)

Crithmum maritimum, L. E.

Enanthe fistulosa, L.

- silaifolia, Bieb. W. I

- Lachenalii, C. Gmel.

(- crocata, L.)

- Phellandrium, Lam.

- fluviatilis, Colem.

Ethusa Cynapium, L.

Silaus flavescens, Bernh.

Angelica sylvestris, L.

†Archangelica officinalis, Hoffm.

Peucedanum palustre, Moench.

- sativum, Benth. \& H. f.

Heracleum Sphondylium, L.

†Coriandrum sativum, L. E.

Daucus Carota, L.

+Caucalis latifolia, L. W. I

- daucoides, L. W.

- arvensis, Huds.

- Anthriscus, Huds.

- nodosa, Scop.

\section{Araliacene}

Hedera Helix, L.

\section{Cornacrae}

Cornus sanguinea, L.

\section{Caprifoliacear}

Adoxa Moschatellina, L.

Sambucus nigra, L.

- Ebulus, L.

Viburnum Opulus, L.

- Lantana, L.

†Lonicera Caprifolium, L.

- Periclymenum, L.

†- Xylosteum, L. W.

\section{Rubiacear}

Galium Cruciata, Scop.

- verum, L.

- erectum, Huds.

- Mollugo, L. a. elatum, Thuill.

$\beta$. insubricum, Gaud.

- saxatile, L.

- palustre, L. W. var. elongatum, Presl.

var. Witheringii, Sm.

- uliginosum, L.

- anglicum, Huds. W. I

- aparine, L.

- tricorne, Stokes

Asperula odorata, L.

- cynanchica, L. W. I

Sherardia arvensis, L. 


\section{A HISTORY OF SUFFOLK}

PHANEROGAMIA (cont.)

VALERIANEAB

Valeriana dioica, L.

- Mikanii, Syme

- sambucifolia, Willd.

t- pyrenaica, L. E.

tCentranthus ruber, DC. W.

Valerianella olitoria, Poll.

- carinata, Loisel. W.

- dentata, Poll.

var. mixta, Dufr.

Dipsaceae

Dipsacus sylvestris, Huds. - pilosus, L.

Scabiosa succisa, $\mathbf{L}$.

- Columbaria, L.

- arvensis, L.

\section{Compositag}

Eupatorium Cannabinum, L. Solidago Virgaurea, L. var. angustifolia, Koch. E.

Bellis perennis, $\mathbf{L}$.

Aster Tripolium, L.

t- salignus, Willd. E. I

†Erigeron Canadense, L.

- acre, L.

Filago germanica, L.

- apiculata, G. E. Sm.

- spathulata, Presl. W. I

- minima, Fr.

- gallica, L. E. 3

Antennaria dioica, R. Br. W. 1

†Anaphalis margaritacea, Benth. \& H.f.

Gnaphalium uliginosum, L.

- luteo-album, L. W. I

- sylvaticum, L.

Inula Helenium, L.

- Conyza, DC.

Pulicaria dysenterica, Gaertn.

- vulgaris, Gaertn. E.

†Xanthium Strumarium, L。 W.

Bidens cernua, L. var. radiata, Sond. E.

- tripartita, L.

Achillea millefolium, L.

- Ptarmica, L.

[Diotis candidissima, Desf. E.]

†Anthemis tinctoria, L.

- Cotula, L.

- arvensis, $L$.

- nobilis, L.

Chrysanthemum segetum, L.

- Leucanthemum, L.

t- Parthenium, Pers.

Matricaria inodora, $\mathrm{L}$ var. salina, Bab. E.

- Chamomilla, L.

Tanacetum vulgare, L.
PHANEROGAMIA (cont.)

Compositae (cont.)

Artemisia Absinthium, L.

- vulgaris, $L$.

- campestris, L. W. I

- maritima, L. E. var. gallica, Willd. E.

Tussilago Farfara, L.

†Petasites fragrans, Presl.

- officinalis, Moench.

E. †Doronicum Pardalianches, $L$.

t- plantagineum, L. E.

Senecio vulgaris, $\mathrm{L}$.

- sylvaticus, L.

var. lividus, Sm. W.

- viscosus, L.

†- squalidus, L. W. I

- erucifolius, $\mathbf{L}$.

- Jacobaea, L.

- aquaticus, Huds.

- paludosus, L. W. I]

- palustris, DC.

- campestris, DC. W. I

[Carlina vulgaris, L.

Arctium majus, Bernh.

- minus, Bernh.

- intermedium, Lange. E.

Carduus tenuiflorus, Curt. E.

- nutans, L.

- crispus, L. var. acanthuides, $\mathbf{L}$.

- lanceolatus, Willd.

- eriophorus, Roth.

- palustris, Willd.

- pratensis, Willd.

- acaulis, Willd.

- arvensis, Hoffm.

Onopordon Acanthium, L.

†Mariana lactea, Hill.

Serratula tinctoria, L. W.

tCentaurea Jacea, L. W.

- nigra, L. E. var. decipiens, Thuill.

- Scabiosa, L.

- Cyanus, L.

- Calcitrapa, L.

† - solstitialis, L.

Cichorium Intybus, L.

Arnoseris pusilla, Gatrtn.

Lapsana communis, L

Picris hieracioides, L. var. arvalis, Jord.

- echioides, L.

Crepis foetida, $\mathbf{L}$.

- taraxacifolia, Thuill.

†- setosa, Hall. W.

- virens, $L$.

- biennis, $\mathrm{L}$.

Hieracium pilosella, L.

t- aurantiacum, $L$.

- murorum, L. W.

- pellucidum, Laest. W. var. lucidulum, Ley.
PHANEROGAMIA (cont.)

Compositae (cont.)

Hieracium vulgatum, Fr. W.

var. maculatum, Sm.

- sciaphilum, Uechtr. W.

- umbellatum, L.

- boreale, Fr.

Hypochaeris glabra, L. var. nana, Dunn. W.

- radicata, $\mathrm{L}$.

- maculata, L. W. I

Leontodon hirtus, L.

- hispidus, L.

- autumnalis, $\mathrm{L}$.

Taraxacum officinale, Web. var. laevigatum,DC. E. var. erythrospermum, Andrz. W. var. palustre, DC. E.

Lactuca virosa, $L$.

- Scariola, L. W. I

- muralis, Fresen.

Sonchus oleraceus, $\mathrm{L}$.

- asper, Hoffm.

- arvensis, L.$$
\text { E. }
$$

var. glabrescens, Hall.

- palustris, L. E. 5

Tragopogon pratense, $L$. var. minus, Mill.

t- porrifolium, L.

\section{Campanulaceab}

Jasione montana, L.

Campanula glomerata, L. W.

- Trachelium, L.

- Jatifolia, L.

†- rapunculoides, L.

- rotundifolia, L.

†- Rapunculus, L.

Specularia hybrida, A. DC.

VACCINIACEAE

Schollera Occycoccus, Roth. E. 5

\section{Ericaceas}

Calluna Erica, DC. var, incana, auct. E.

Erica Tetralix, L.

- cinerea, L.

[Pyrola rotundifolia, L. E.]

\section{MonotropeaE}

Hypopitys Monotropa, Crantz.

Plumbagineas

Statice Limonium, L。 E. E.

f. pyramidalis, Syme.

- Bahusiensis, Fries. E. $\times \operatorname{Limonium}(=$ Neumani, C. E. Salmon.) E.

Armeria maritima, Willd. E. 


\section{BOTANY}

PHANEROGAMIA (cont.)

\section{Primulacear}

Hottonia palustris, $\mathbf{L}$.

Primula acaulis, $\mathbf{L}$.

$$
\text { var. caulescens, Koch. }
$$

$X$ veris (=variabilis, Goup.). E.

- veris, L.

- elatior, Jacq.

Cyclamen hederaefolium, Ait. E.

Lysimachia vulgaris, L.

- Nummularia, L.

- nemorum, L.

Glaux maritima, L.

Anagallis arvensis, L. var. carnea, Schrant.

- caerulea, Schreb.

- tenella, L.

Centunculus minimus, $\mathrm{L}$.

Samolus Valerandi, L.

\section{Oleaceas}

Fraxinus excelsior, L.

Ligustrum vulgare, L.

\section{Apocymackab}

tVinca major, L.

- minor, L.

\section{Grntianear}

Blackstonia perfoliata, Huds. Eryihraa Centaurium, Pers.

- littoralis, Fr. F.

- pulchella, Fr. E.

[Gentiana Pneumonanthe, L. E. 5]

- Amarella, L.

- campestris, L. W.

- baltica, Murb. W. I

Menyanthes trifoliata, L.

†Limnanthemum peltatum, S. P. Gmel. W.

\section{BoragineaE}

Cynoglossum officinale, $\mathrm{L}$.

† Asperago procumbens, L.

Symphytum officinale, L.

var. patens, Sibth.

† Borago officinalis, L.

†Anchusa officinalis, L. E.

t- sempervirens, L.

Lycopsis arvensis, L.

Pulmonaria officinalis, L. E. I

Myosotis caespitosa, F. Schultz - palustris, Re'h. $\mathrm{K}$

var. strigulosa, M. \&

(- repens, G. Don. E. 5)

- sylvatica, Hoffm.

1

\section{PHANEROGAMIA (cont.)}

Boragineas (cont.)

Myosotis arvensis, Lam. W. var. umbrosa

- collina, Hoffm. W. var. Mittenii, Baker.

- versicolor, Reichb.

(Lithospermum purpureo-caeruleum, L. E. 2

- officinale, L.

- arvense, L.

Echium vulgare, L.

\section{Convolvulacear}

Volvulus sepium, Junger. - Soldanella, Junger. E. Convolvulus arvensis, $\mathrm{L}$.

[†Cuscuta Epilinum, Weihe. E.]

- europaea, L.

- Epithymum, Murr.

t- Trifolii, Bab.

\section{Solanaceas}

Solanum Dulcamara, L.

- nigrum, L.

†Lycium barbarum, L.

Atropa Belladonna, L.

+Datura Stramonium, L.

Hyoscyamus niger, $L$.

\section{SCROPHULARINEAB}

Verbascum thapsus, L. $\times$ nigrum

- pulverulentum, Vill.

- Lychnitis, L.

- nigrum, L.

- virgatum, Stokes

- Blattaria, L.

†Linaria Cymbalaria, Mill.

- Elatine, Mill.

- spuria, Mill.

- vulgaris, Mill.

- viscida, Moench.

†Antirrhinum majus, L.

- Orontium, L.

Scrophularia aquatica, L.

- nodosa, $\mathrm{L}$.

t- vernalis, L. W. I

Limosella aquatica, L.

Digitalis purpurea, L.

Veronica hederaefolia, L.

- polita, Fr. W. var. grandiflora, Bab.

- agrestis, L.

- Tournefortii, C. Gmel.

- triphyllos, L.

- verna, L.

- arvensis, L.

- serpyllifolia, L.
PHANEROGAMIA (cont.)

Scrophularineae (cont.)

Veronica spicata, L. W. I

Bab. - officinalis, L.

- Chamoedrys, L.

- montana, L.

- scutellata, L. W.

var. hirsuta, Weber.

W.

- Anagallis, L.

- Beccabunga, L.

Euphrasia nemorosa, H. Mart.

Bartsia Odontites, Huds.

a. verna, Reichb.

$\beta$. serotina, Reichb.

Pedicularis palustris, $\mathrm{L}$.

- sylvatica, L.

Rhinanthus Crista-galli, L.

Melampyrum cristatum, L.

- pratense, L. W.

$$
\text { var. latifolium, Bab. }
$$

\section{Orobanchacear}

†[Orobanche ramosa, L. E. 5]

- major, L.

- elatior, Sutton

- minor, Sm.

\section{Lentibulariear}

Utricularia vulgaris, L.

- neglecta, Lehm. E.

- minor, L.

- intermedia, Hayne. W. I

Pinguicula vulgaris, L. I

\section{VERBENACEAE}

Verbena officinalis, L.

\section{LABIATAE}

Mentha rotundifolia, Huds.

- alopecuroides, Hull. E. 5

- longifolia, Huds.

†- viridis, $L$. var. mollissima, Borkh.

- piperita, L.

- hirsuta, Huds.

E. var. subglabra, Baker.

- sativa, L. W. var. paludosa, Sole.

- rubra, Sm.

- gentilis, L. W. I

- arvensis, L.$$
\text { var. Allionii, Bor. W. }
$$

- Pulegium, L.

Lycopus europaeus, L.

Origanum vulgare, $L$. 


\section{A HISTORY OF SUFFOLK}

\section{PHANEROGAMIA (cont.)}

Labiatar (cont.)

Thymus Serpyllum, Fr.

- Chamoedrys, Fr.

Calamintha Clinopodium, Spenn.

- arvensis, Lam.

- parviflora, Lam.

- officinalis, Moench.

† Melissa officinalis, L. W.

Salvia Verbenaca, L.

†- verticillata, L.

Nepeta Cataria, L.

- Glechoma, Benth.

Scutellaria galericulata, L.

- minor, Huds.

Prunella vulgaris, L.

Marrubium vulgare, L.

Stachys Betonica, Benth.

- palustris, L.

- sylvatica, L. $X$ sylvatica, $L$.

Galeopsis angustifolia, Ehrh.

- versicolor, Curt.

- tetrahit, L. var. bifida, Boenn.

tLeonurus Cardiaca, L.

Lamium amplexicaule, L.

- hybridum, Vill.

- purpureum, L.

†- maculatum, L. var. decipiens, Sonder.

- album, L.

- Galeobdolon, Crantz.

Ballota nigra, L.

(Teucrum Scordium, L. W. I)

- Scorodonia, L.

Ajuga reptans, L.

\section{Plantagingae}

Plantago major, L.

var. microstachys,

Wallr. E.

- media, L.

- lanceolata, L. fil.

var. †Timbali, Reichb.

- maritima, L.

- Coronopus, L.

Littorella juncea, Berg.

\section{IlLecebracear}

Herniaria glabra, L. W. I var. subciliata, Bab. W. I

Scleranthus annuus, L. var. biennis, Reuter

- perennis, L. W. I

\section{Amaranthacear}

†Amaranthus Blitum, L. W.

\section{PHANEROGAMIA (comt.)}

\section{Chenopodiaceae}

Chenopodium polyspermum, L.

- Vulvaria, L.

- album, L.

var. viride, Syme

var. viridescens, St. Am. W

- ficifolium, Sm.

- murale, L. E.

- hybridum, L.

- urbicum, L. var. intermedium, Moq.

- rubrum, L. var. pseudo-botryoides,

H. C. Wats. W.

- botryodes, Sm. E. 5

- Bonus-Henricus, L.

Beta maritima, L. E.

Atriplex littoralis, L。 E. var. serrata, Moq. E.

- patula, L. var. erecta, Huds.

- hastata, L.

- deltoidea, Bab. var. prostrata, Bab.

- Babingtonii, Woods. E.

- laciniata, L. E.

- portulacoides, L. E.

- pedunculata, L. E.

Salicornia herbacea, L, E. E. var. procumbens, Moq.

- stricta, Dum. E.

- appressa, Dum. E.

- radicans, Sm. E.

Suaeda fruticosa, Forsk. E. 4

- maritima, Dum. E. var. procumbens, Syme. E.

Salsola Kali, L。 E.

\section{Polygonaceas}

Polygonum Convolvulus, L.

var. subalatum, V. Hall. W

- aviculare, L. W.

var. agrestinum, Jord. var. vulgatum, Syme. W. W.

var, arenastrum, Bor.

var. microspermum, Jord. W. W.

var. rurivagum, Jord.

var. littorale, Link. E.

- Hydropiper, L.

- minus, Huds. E.

- mite, Schrank
PHANEROGAMIA (cont.)

Polygonaceae (cont.)

Polygonum Persicaria, L. W.

var. elatum, G. \& G.

- lapathifolium, L.

- maculatum, Trim. \& Dyer. W.

- amphibium, L.

- Bistorta, L.

†Fagopyrum esculentum, Moench.

Rumex conglomeratus, Murr.

- sanguineus, L. var. viridis, Sibth.

- maritimus, L.

- limosus, Thuill.

- pulcher, L.

- obtusifolius, L.

- crispus, L.

var. subcordatus, War. ren. E.

var. trigranulatus, Syme. E.

$X$ obtusifolius $(=$ acu tus, L.). W. I

- Hydrolapathum, Huds.

- Acetosa, L.

- Acetosella, L. var

Koch. W.

angustifolius,

\section{Aristolochiacrae}

Asarum europaeum, L. W. I †Aristolochia Clematitis, L.

\section{Thymeiaeaceas}

[Daphne Mezereum, L. E.] - Laureola, L.

\section{Ellaragnacear}

Hippophae rhamnoides, L。 E.

\section{LORANTHACEA}

Viscum album, L.

\section{Santalaceae}

Thesium humifusum, DC. W.

\section{EUPHORBIACBAE}

Euphorbia Helioscopia, L.

- platyphyllos, L. W. I

- amygdaloides, L.

†- Cyparissias, L. W.

- Paralias, L. E.

- Peplus, L.

- exigua, L.

†— Lathyris, L. 


\section{BO'TANY}

\section{PHANEROGAMIA (cont.)}

Euphorbiacear (comt.)

Mercurialis perennis, $L$.

- annua, L.

var. ambigua, L. I.

\section{URTICACEAE}

Ulmus montana, Stokes

- surculosa, Stokes

a. suberosa, Ehrh.

$\beta$. glabra, Mill.

Humulus Lupulus, L.

Urtica dioica, L. W.

var. holosericea, Fries.

var. angustifolia, $\mathbf{A}$. Blytt. W.

t- pilulifera, L.

- urens, L.

Parietaria officinalis, L.

Myricacear

Myrica Gale, L.

\section{Cupuliferas}

Betula verrucosa, Ehrh. - pubescens, Ehrh.

Alnus glutinosa, Medic. Carpinus Betulus, $L$.

Corylus Avellana, L.

Quercus Robur, L.

a. pedunculata, Ehrh.

$\beta$. sessiliflora, Salisb.

+Castanea sativa, Mill.

Fagus sylvatica, L.

\section{SAlicineas}

+Salix pentandra, L. E.

- triandra, L.

var. Hoffmanniana,

Sm. W.

$x$ viminalis ( $=$ undulata, Ehrh.)

- fragilis, L.

f. britannica, F. B.

White. E.

- alba, L.

var. caerulea, Sm. W. var. vitellina, $\mathrm{L}$.

- cinerea, L.

var. aquatica, Sm.

- aurita, L.

var. oleifolia, Sm.

- Capraea, L. $\times$ Capraea

- repens, $L$. $X$ aurita (=ambigua,

Ehrh.). E.

f. incubacea, Syme
PHANEROGAMIA (cont.)

Salicineae (cont.)

†Salix viminalis, $L$. $\times$ Capraea (=Smithiana, Willd.) a. stipularis, Sm. W. B. acuminata, $\mathrm{Sm}$. W.

- purpurea, L. f. Lambertiana, Sm. $X$ viminalis (= rubra, Huds.). W. f. Forbyana, Sm.

Populus alba, L.

- canescens, Sm.

- tremula, L. a. villosa, Lange

t- nigra, L. $\beta$. glabra, Syme

\section{Cekatophylleas}

Ceratophyllum demersum, L. - submersum, L.

\section{Coniferas}

Taxus baccata, L.

†Pinus sylvestris, $\mathrm{L}$.

\section{Hydrocharideas}

†Elodea canadensis, Michx.

Hydrocharis Morsus-ranae, L. Stratiotes Aloides, L.

\section{Orchidrae}

Malaxis paludosa, Sw. E. Liparis Loeselii, Rich. I Neottia Nidus-avis, Rich.

Listera ovata, R. Br.

Spiranthes autumnalis, Rich.

Epipactis latifolia, All.

- media, Fr. W. I

- palustris, Crantz.

Orchis hircina, Scop.

- pyramidalis, L.

- ustulata, L. W. I

- Morio, L.

- mascula, L.

- incarnata, auct. britt. non L.

- latifolia, L.

- maculata, L.

Aceras anthropophora, R. Br.

Ophrys apifera, Huds.

- aranifera, Huds. W. 1

- muscifera, Huds.

Herminium Monorchis, R. Br. W. I

Habenaria conopsea, Benth.

- viridis, R. Br.

- bifolia, R. Br.

- chloroleuca, Ridley

\section{PHANEROGAMIA (cont.)}

IRIDEAE

Iris foetidissima, $\mathbf{L}$.

- Pseudacorus, L.

var. acoriformis, Bor. var. Bastardi, Bor. W.

†Crocus praecox, Haw. W.

t- aureus, Sibth. W.

†- vernus, All.

\section{Amaryllideae}

Narcissus Pseudo-narcissus, L. t- bifloris, Curtis

†- poeticus, $\mathbf{L}$

tGalanthus nivalis, L.

Leucojum aestivum, L. E. 3

\section{Dioscoreas}

Tamus communis, L.

\section{LILIACEAE}

Ruscus aculeatus, L. Asparagus officinalis, L. a. taltilis, L.

Polygonatum multiflorum, All. E.

Convallaria majalis, L.

Allium vineale, $L$.

- oleraceum, L. W.

- ursinum, L.

Muscari racemosum, Mill. W. I

Scilla festalis, Salisb.

tOrnithogalum nutans, L.

- umbellatum, L.

†Lilium Martagon, L. E.

Fritillaria Meleagris, L.

Tulipa sylvestris, L.

Gagea fascicularis, Salisb. E.

Colchicum autumnale, $L$.

Paris quadrifolia, L.

\section{JUNCACEAB}

Juncus bufonius, L.

- squarrosus, L.

- compressus, Jacq. W.

- Gerardi, Loisel. E.

- glaucus, Leers

- effusus, L.

$$
\times \text { glaucus ( }=\text { diffusus, }
$$$$
\text { Hoppe) }
$$

- conglomeratus, L.

- maritimus, Lam. E.

- supinus, Moench. var. fluitans, Lam.

- obtusiflorus, Ehrh.

- lamprocarpus, Ehrh.

- acutiflorus, Ehrh.

Luzula Forsteri, DC. W. $\times$ vernalis ( $=$ Borrer Bromf.). W.

- verna.is, DC. 


\section{A HISTORY OF SUFFOLK}

PHANEROGAMIA (cont.)

JUnCACEAE (cont.)

Luzula campestris, DC.

- erecta, Desv. W.

var. congesta, Lej.

var. pallescens, Koch.

\section{Typhacear}

Typha latifolia, L. - angustifolia, L.

Sparganium ramosum, Huds.

- neglectum, Beeby

- simplex, Huds.

- minimum, Fr.

\section{Aroidear}

Arum maculatum, L. Acorus Calamus, L.

\section{LEMNACEAR}

Lemna trisulca, L.

- minor, $\mathrm{L}$.

- gibba, L.

- polyrrhiza, L.

\section{Alismacear}

Alisma Plantago, L. var. lanceolatum, Afz

- ranunculoides, L.

Sagittaria sagittifolia, L.

[Damasonium stellatum, Pers. E. 4]

Butomus umbellatus, L.

\section{NaIAdacear}

Triglochin palustre, $\mathrm{L}$.

- maritimum, L. E.

Potamogeton natans, L.

- polygonifolius, Pour

- coloratus, Hornem.

- alpinus, Balb.

- heterophyllus, Schreb.

- lucens, L.

var. acuminatus, $F_{\text {s. }}$

- angustifolius, Presl. E. 5

- praelongus, Wulf.

- perfoliatus, L.

- crispus, L.

- densus, L.

f. serratus, Huds.

- zosterifolius, Schum. W. I

- obtusifolius, M. \& K. E. ?

- Friesii, Rupr.

- pusillus, L. var. tenuissinnus, Koch.

- trichoides, Cham. I

- pectinatus, L.

- interruptus, Kit. E.

Ruppia spiralis, Hartm. E.

- rostellata, Koch. E.

\section{PHANEROGAMIA (cont.)}

Natadacear (cont.)

Zannichellia palustris, L. var. repens, Boenn.

- brachystemon, J. Gay

- pedunculata, Reichb. E.

Zostera marina, L. E. var. angustifolia, Fr. E.

\section{Cyperacear}

Eleocharis acicularis, R.Br. E. - palustris, R. Br.

(- uniglumis, Reichb. E.)

- multicaulis, Sm.

Scirpus pauciflorus, Lightf.

- caespitosus, L.

- fluitans, L.

- cernuus, Vahl. E. E.

var. pygmaeus, Kunth.

- setaceus, L.

- lacustris, L.

- Tabernaemontani, Gmel.

- maritimus, L. E.

- sylvaticus, L.

- Caricis, Retz.

- rufus, Schrad. E. 4

Eriophorum angustifolium, Roth.

- latifolium, Hoppe.

Rynchospora alba, Vahl. E. 5

Schoenus nigricans, $L$.

Cladium jamaicense, Crantz.

Carex dioica, $\mathbf{L}$.

- pulicaris, L.

- divisa, Huds. E.

- disticha, Huds.

- arenaria, L.

- teretiuscula, Good.

- paradoxa, Willd. W. I

- paniculata, L.

- vulpina, L.

- muricata, L. W.

var. Leersii, F. Schultz.

- divulsa, Good.

- echinata, Murr.

- remota, L.

- axillaris, Good.

- curta, Good. E.

- ovalis, Good.

- Hudsonii, Ar. Benn.

- acuta, L.

- Goodenowii, J. Gay var. juncella, Fries. W.

- flacca, Schreb.

- limosa, L. E. 5

- pilulifera, L.

- ericetorum, Poll. W. I

- verna, Chaix.

- pallescens, L.

- panicea, L.

- pendula, Huds.

- strigosa, Huds. W. 2
PHANEROGAMIA (cont.)

Cyprracear (comt.)

Carex sylvatica, Huds.

- laevigata, Sm. W. 2

- binervis, Sm.

- distans, L. E.

- fulva, Good.

- extensa, Good.

- flava, L.

var. lepidocarpa,

Tausch. var. minor, Towns.

- filiformis, L.

- hirta, L.

- Pseudo-cyperus, L.

- acutiformis, Ehrh. W var. spadicea, Roth.

- riparia, Curtis

- rostrata, Stokes

- vesicaria, L.

\section{Graminear}

†Panicum sanguinale, $L$.

- glabrum, Gaud.

†- Crus-galli, L.

Setaria viridis, Beauv.

t- glauca, Beauv.

Spartina stricta, Roth. E.

†Phalaris canariensis, $L$.

- arundinacea, L.

Anthoxanthum odoratum, L.

†- Puelii, L. \& L. W.

Alopecurus myosuroides, Huds,

- fulvus, Sm. W.

- geniculatus, L.

- bulbosus, Gouan. E. 5

- pratensis, L.

Milium effusum, L.

Phleum pratense, $\mathrm{L}$. var. nodosum, $\mathrm{L}$.

- phalaroides, Koel. W.

- arenarium, L.

Agrostis canina, L.

- palustris, Huds. var. stolonifera, L. E.

- vulgaris, With. var. pumila, $\mathbf{L}$.

Calamagrostis epigeios, Roth.

- lanceolata, Roth.

Apera Spica-venti, Beauv.

- interrupta, Beauv.

Ammophila arundinacea, Host. E.

Aira caryophyllea, L.

- praecox, L.

Weingaertneria canescens, Bernh.

Deschampsia caespitosa, Beauv.

- flexuosa, Trin.

Holcus mollis, L.

- lanatus, L.

Trisetum pratense. Pers. 


\section{BOTANY}

\section{PHANEROGAMIA (comt.)}

Gramineae (cont.)

Avena pubescens, Huds. W.

- pratensis, L.

† - strigosa, Schreb.

- fatua, L.

Arrhenatherum avenaceum, Beauv. E.

var. nodosum, Reichb.

Sieglingia decumbens, Bernh.

Phragmites communis, Trin.

Cynosurus cristatus, L.

Koeleria cristata, Pers. W. var. gracilis, Boreau.

Molinia varia, Schrank.

Catabrosa aquatica, Beauv.

Melica uniffora, Retz.

Dactylis glomerata, L.

Briza media, L.

Poa annua, L.

- bulbosa, L.

- nemoralis, L.

- compressa, L.

- pratensis, L.

- trivialis, L. var. subcaerulea, Sm. var. glabra, Doell. W.

Glyceria fluitans, R. Br.

- plicata, Fr. var. pedicellata, Towns.

- aquatica, Sm.

- maritima, M. \& K. E.

- distans, Wahl.

- Borreri, Bab. E.

Festuca procumbens, Kunth. E.

- rigida, Kunth.

- rottboellioides, Kunth. E.

- uniglumis, Soland. E. 3

- ambigua, Le Gall. W. I

- Myuros, L.

- sciuroides, Roth.

- ovina, L.

- rubra, L.

var. arenaria, Osb. $\mathbf{E}$. var. fallax, Thuill.

\section{PHANEROGAMIA (cont.)}

Graminear (cont.)

Festuca elatior, L. var. pratensis, Huds.

- arundinacea, Schreb.

Bromus giganteus, L. var. triflorus, Syme. W.

- ramosus, Huds.

- erectus, Huds. var, villosus, Bab. E.

- madritensis, L.

t- tectorum, L. W.

- sterilis, L.

- sscalinus, L.

- racemosus, L.

- commutatus, Schrad.

- interruptus, Druce

- mollis, L. var. glabratus, Doell.

$\dagger$ - arvensis, L.

Brachypodium gracile, Beauv.

Lolium perenne, L. var. titalicum, Braun.

- temulentum, L. var. arvense, With.

Agropyron caninum, Beauv.

- repens, Beauv. var. barbatum, DuvalJouve. $\mathrm{E}$.

- pungens, R. \& S. E. E. var. littorale, Reichb.

- acutum, R. \& S. E.

- junceum, Beauv. E.

Lepturus filiformis, Trin.

Nardus stricta, L.

Hordeum secalinum, Schreb.

- murinum, L.

- marinum, Huds. E.

Elymus arenarius, L. E.

\section{CRYPTOGAMIA}

\section{FILICRS}

Pteris aquilina, L.

Lomaria Spicant, Desv.

\section{CRYPTOGAMIA (comt.)}

Filices (cont.)

Asplenium Adiantum-nigrum, L.

- Trichomanes, L.

- Ruta-muraria, L.

Athyrium Filix-foemina, Roth.

Ceterach officinarum, Willd.

Scolopendrium vulgare, Symons

Cystopteris fragilis, Bernh. W. I

Polystichum lobatum, Presl. var. aculeatum, Syme

- angulare, Presl.

Lastraa Thelypteris, Presl.

- Oreopteris, Presl.

- Filix-mas, Presl.

- cristata, Presl. E.

- spinulosa, Presl.

- dilatata, Presl.

Polypodium vulgare, L. W. var. serratum, Willd.

Osmunda regalis, L.

Ophioglossum vulgatum, L.

Botrychium Lunaria, Sw.

\section{Equisktaceab}

Equisetum maximum, Lam.

- arvense, L.

- palustre, L.

Auct.

var. polystachyum,

- limosum, Sm.

- hyemale, L.

var. fluviatile, L.

\section{LYCOPODIACEAE}

Lycopodium inundatum, L. - clavatum, L. W. I

\section{Marsileaceae}

Pilularia globulifera, L.

\section{CHARACEAE (Stoneworts)}

Suffolk cannot claim to yield a Chara-flora like that of Norfolk, though a more careful and extended examination of its waters may well reveal some unsuspected treasures.

Probably there are few orders of aquatics which demand a more patient and thorough search than the Characeae to secure a full yield of species. A stream which may exhibit no trace whatever of their presence at a given time may yet have been full of excellent specimens three or four weeks earlier. Again, a piece of water which seemed to be wholly destitute of Characeae at one end may prove to possess an abundant supply at the other; whilst again a ditch or pit carefully examined for years without result may only require to be cleaned or re-dug to yield a remarkable crop the following spring.

It will thus be seen that no locality can be regarded as exhaustively worked for Characeae till the examination has covered every piece of water at all times of spring and summer 


\section{A HISTORY OF SUFFOLK}

under varying circumstances and conditions; added to this is the fact that successful Charahunting makes large if not exclusive demands on a botanist. The plants do not appear above the surface of the water, and hence the collector requires to be provided with a drag or rake, sometimes both. They cannot survive exposure to the air, and so necessitate a fairly airtight vasculum; they are exceedingly fragile and brittle, and are thus unfit to be carried in a collecting tin with other plants; they grow in ditches, pools, and marshes, most happily on a rich mud bottom, and so necessitate stout boots, sometimes wading boots, and not seldom a boat where it may be had.

In these circumstances it is not surprising that the Characeae of our counties have not received the attention which is required to supply anything like a complete record of their distribution.

By far the most interesting of the Suffolk Characeae are Chara connivens, Braun, and C. canescens, Lois. The latter was first collected in Suffolk in 1896 by Messrs. E. S. and C. E. Salmon in Easton and Benacre Broads, previous to which its only known habitats were two stations in Cornwall and Dorset, right away in the west of England. Three years later it was found by the Rev. G. R. Bullock-Webster in Hickling Broad in the neighbouring county of Norfolk. C. connivens, an equally rare plant, was only known to have occurred in three stations in Hampshire, Devonshire, and Norfolk, until it was collected by Mr. BullockWebster in Benacre Broad in 1897 . Both these species are brackish-water plants, and the near neighbourhood of Benacre Broad to the sea, with occasional inundations at exceptionally high tides, is favourable to their growth.

Chara contraria, Kuetz., has also been found in Benacre Broad and at Livermere. The latter locality also produces Tolypella intricata, Leonh.; and T. glomerata, Leonh., has been found near Yarmouth South Town.

Lychnothamnus stelliger, Leonh., which occurs so abundantly in the Norfolk Broads, has not so far been recorded from Suffolk, nor yet Nitella tenuissima, Kuetz. or Tolypella prolifera, Leonh., both of which have been collected in the marshes of the Waveney Valley on the Norfolk side, the former near Diss, and the latter near Beccles.

There is evidently much work to be done in Suffolk before anything like a complete record can be compiled.

\section{Characear}

Chara fragilis, Desv. I var. Hedwigii, Kuetz.

W. I

- connivens, Braun. E. 4

- aspera, Willd. var. desmacantha, $\mathrm{H}$.

\& J. G. W. I

- polyacantha, Braun. W. I

\section{Characear (cont.)}

Chara contraria, Kuetz.

- hispida, L.

- vulgaris, L.

var.

var. papillata, Wallr.

- canescens, Loisel. E. 4
Characeab (comt.)

Tolypella intricata, Leonh.W. I

- glomerata, Leonh.

Nitella translucens, Agardh. E. 5

- flexilis, Agardh. E. 5 - opaca, Agardh.

Thus far full lists have been given of the Phanerogams and a portion of the Cryptogams, the Filices, Equisetaceae, \&cc.; there remain the numerous species of the Musci, Hepaticae, Lichens, Algae, and Fungi.

Before enumerating them, however, it will be well to give a short account of what has been done thus far with respect to the Suffolk records in these orders. I believe there are very few, if any, counties where they have been formerly so carefully collected as in Norfolk and Suffolk, and the Suffolk early records will bear favourable comparison with those of almost any county.

At the beginning of the last century there were a good number of botanists in Norfolk and Suffolk who diligently collected these Cryptogams; among the best known of these were Sir James Smith, Sir William Hooker, Rev. G. R. Leathes, and Mr. Dawson Turner, all of whom resided in Norfolk, but who have contributed very many records of Suffolk plants, Cryptogams and others. At the same time there were good Cryptogamic botanists residing in Suffolk, as Sir Thomas Gage, Mr. Woodward, and others. These have recorded their observations in the Botanist's Guide, English Botany, Hooker's British Fungermanniae, \&rc. Even before this time many Cryptogams had been observed by Sir John Cullum of Hawstead, near Bury, and recorded by him in his journal for the years $1772-85$. 


\section{BOTANY}

Somewhat later than the above, Mr. F. K. Eagle of Bury St. Edmunds diligently collected Mosses, Hepatics, and Lichens in the county. His collection is incorporated with that of Sir C. Bunbury, who was also a collector, and whose herbarium is now in the University Botanical Museum at Cambridge.

In $\mathbf{1} 860$ was published Messrs. Henslow and Skepper's Flora of Suffolk, which contains very good and reliable lists of all Orders of Cryptogams. The lists of Mosses, Hepatics, and Lichens were, it is believed, in a great measure by Mr. F. K. Eagle and Mr. Stock of Bungay, who combined their own observations with the records of the Botanist's Guide, and duoubtless other sources, such as Smith's English Botany and Paget's Natural History of Yarmouth. The list of Diatomaceae and Fungi, both of which are very good, were by Mr. Skepper. Little has been done since Mr. Skepper's death in 1867 , but what has been done since that time will be mentioned in the notices of each order.

\section{MUSCI (Mosses)}

In such a county as Suffolk only a very limited Moss flora could be expected, for there are no high hills, much less mountains, and, indeed, a very small part of the county is more than $200 \mathrm{ft}$. above sea level. Again, there are no hard rocks, nor indeed anything worthy of the name of rock, and very little bog. Moreover the annual rainfall is rather scanty, averaging for the county about $25 \mathrm{in}$., and there are no quickly-flowing streams with rocky beds in and by the side of which so many mosses delight to grow. The extensive mud flats and large brackish meres near the coast scarcely produce any species of mosses.

It is not surprising therefore with such conditions that the mosses do not number quite two hundred species, and that the Moss flora taken as a whole is somewhat featureless. With very few exceptions the species are such as occur generally throughout the lowlands of England and central Europe. Among the more noteworthy exceptions are Amblyodon dealbatus, which was discovered by Mr. F. K. Eagle, and Cinclidium stygium, discovered by Mr. Skepper, both at Tuddenham; these species are generally of northern distribution; the latter is scarce in Britain. The cupola-shaped peristome of the Cinclidium is one of the most beautiful objects in British Mosses. It was gathered by Mr. Skepper abundantly in fruit and ?rowing very luxuriantly both in November 1860 and November I862; it is very probable that both these species are now extinct in Suffolk.

On the other hand Tortula cuneifolia and Bryum Donianum are of southern, indeed Mediterranean, distribution, and reach in Suffolk one of their highest northern points. Other interesting species are Bryum lacustre, for a long time known only from Suffolk in the British Isles, and now only recorded for two or three other counties, and Thuidium bystricosum. The latter, though probably only a marked form of the more generally distributed T.abietinum, is striking enough as a form and has only been recorded from a very limited area. Barbula latifolia, which is very rarely fertile, was collected by Mr. F. K. Eagle fruiting freely. Barbula sipuosa from Sweffling was not recognized until lately, and with B. laevipila var. laevipilaeformis, flpm Grundisburgh, and Pterigonium gracile from Icklingham, had not previously been recorded for the county. Several species of the genus Hypnum may also be mentioned: H. Sendtneri var. hamatum at Tuddenham; $H$. rugosum, which is very fine in several places in the Breck district; $H$. falcatum at Gorleston and Tuddenham; $H$. giganteum, not very uncommon in Suffolk; and $H$. elodes, Redgrave Fen, recorded by Mr. E. M. Holmes.

Although the prehistoric deposits do not appear to have yielded such rich results in mosses as those of Norfolk, yet, as recorded by Dr. Hind in his Flora of Suffolk, remains of Hypnum turgescens have been found here and there in local deposits of clay. This, as pointed out by Dr. Hind, is a typically Arctic plant, though it is also found at high elevations in the Alps. It has recently been recovered for our flora in a living state by the Rev. C. H. Binstead, who gathered it high up on Ben Lawers in 1902.

Besides the list in Henslow and Skepper's Flora two papers on the Moss Flora of Suffolk by the Rev. E. N. Bloomfield were published in the Fournal of Botany in 1885 and 1888 . These two papers were combined and many new localities and a few new species added in his 'List of Suffolk Mosses' printed in the Transactions of the Norfolk and Norwich Naturalists Society for I900-I, vol. vii, to which a few corrections were added in the Transactions for 1901-2. To these latter papers we would refer any one who desires detailed information on this subject. 


\section{A HISTORY OF SUFFOLK}

In order to show in some degree the distribution of the Mosses, \&c., the county is divided into the Watsonian districts-E. East Suffolk, and W. West Suffolk; these letters indicate that the species is recorded only for that district.

\section{SPHAGNACEAE}

Sphagnum cymbifolium, Ehrh. var. squarrosulum, N. \& H. E.

- papillosum. var. confertum, Ldb.

- rigidum. var. compactum, Ldb. W.

- subsecundum, Nees. E. var. contortum, Schp. E.

- obesum, Wils. E.

- squarrosum, Pers.

- acutifolium, Ehrh. var. deflexum, Schp.

- fimbriatum, Wils. E.

- intermedium, Hoffm. E.

\section{Polytrichackae}

Catharinea undulata, W. \& M. Polytrichum nanum, Neck.

- aloides, Hedw.

- urnigerum, L. W.

- piliferum, Schreb.

- juniperinum, Willd.

- strictum, Banks. E.

- gracile, Dicks. W.

- formosum, Hedw. W.

- commune, L.

\section{Dicranacrab}

Pleuridium axillare, Ldb. W. - subulatum, B. \& S.

- alternifolium, Rab. W.

Ditrichum flexicaule, Hpe. W.

Seligeria calcarea, B. \& S. W.

Ceratodon purpureus, Brid.

Dicranella heteromalla, Schp.

- cerviculata, Schp.

- crispa, Schp. E.

- rufescens, Schp.

- varia, Schp.

Dicranoweissia cirrhata, Ldb.

Campylopus flexuosus, Brid. var. paradoxus, Husn. E.

- pyriformis, Brid.

- fragilis, B. \& S. E.

Dicranum Bonjeani, De Not.

- scoparium, Hedw.

Leucobryum glaucum, Schp.

\section{Fissidentacear}

Fissidens incurvus, Stke. W

- bryoides, Hedw.

- adiantoides, Hedw.

- taxifolius, Stke.

\section{Grimmiacear}

Grimmia apocarpa, Hedw.

- pulvinata, Sm.

Rhacomitrium canescens, Brid. var. ericoides. B. \& S.

\section{Tortulacear}

Acaulon muticum, C. M. W.

Phascum cuspidatum, Schr.

Pottia recta, Mitt. W.

- bryoides, Mitt.

- Heimii, Furnr.

- truncatula, Ldb.

- intermedia, Furnr.

- crinita, Wils. E

- minutula, Furnr.

- Starkeana, C. M.

- lanceolata, C. M.

Tortula pusilla, Mitt. W.

- lamellata, Ldb. W.

- rigida, Schrad. W.

- alQides, De Not.

- cuneifolia, Roth. E.

- marginata, Spr.

- muralis, Hedw.

- subulata, Hedw.

- mutica, Ldb. (latifolia)

- laevipila, Schwgr. var. laevipilxformis, Limpe. E.

- intermedia, Berk.

- ruralis, Ehrh.

- ruraliformis, Dixon

- papillosa, Wils.

Barbula lurida, Ldb. E.

- rubella, Mitt.

- tophacea, Mitt. W.

- fallax, Hedw.

- rigidula, Mitt. W.

- cylindrica, Schp. E.

- vinealis, Brid. W.

- sinuosa, Braithw. E.

- revoluta, Brid.

- convoluta, Hedw. W.

- unguiculata, Hedw.

Weissia crispa, Mitt. E.

- microstoma, C. M. W.

- viridula, Hedw.

\section{Encalyptaceas}

Encalypta vulgaris, Hedw.

\section{ORTHOTRICHACEAE}

Zygudon viridissimus, R. Br. Ulota crispa, Brid. E.

var. intermedia, Braithw.

\section{Orthotrichacéae (CORt.)}

Ulota phyllantha, Brid. W. Orthotrichum anomalum, saxatile, Milde

- cupulatum, Hoffm. E.

- leiocarpum, B. \& S.

- Lyellii, H. \& T.

- affine, Schrad.

- tenellum, Bruch. W.

- diaphanum, Schrad.

Splachnaceae

Splachnum ampullaceum, L.

\section{Funariacear}

F phemerum serratum, Hpe. Physcomitrella patens, B.\&S. W. Physcomitrium pyriforme, Brid.

Funaria fascicularis, Schp.

- hygrometrica, Sibth.

\section{Meesiacrae}

Amblyodon dealbatus, P. Beau. W.

Aulacomnium palustre, Schwgr.

- androgynum, Schwgr. E.

\section{Bartramiaceae}

Bartramia pomiformis, Hedw.

Philonotis fontana, Brid. var. falcata, Brid. W.

\section{BRYACEAR}

Leptobry um pyriforme,Wils. W. Webera nutans, Hedw.

- carnea, Schp.

Bryum pendulum, Schp. W.

- lacustre, Brid.

- inclinatum, Bland. E.

- pallens, Sw. W.

- bimum, Schreb. W.

- pseudo-triquetrum, Schwgr.

- intermedium, Brid. W.

- caespiticium, L.

- capillare, L.

- Donianum, Grev. W.

- atropurpureum, W. \& M.

- argenteum, L.

- roseum, Schreb.

Mnium affine, Bland. W.

- cuspidatum, Hedw.

- rostratum, Schrad.

- undulatum, L.

- hornum, L.

- serratum, Schrad. W.

- punctatum, L.

- subglobosum, B. \& S. W. Cinclidium stygium, Swartz. W. 


\section{BOTANY}

Fontinalacear

Fontinalis antipyretica, L.

\section{Cryphaeaceal \\ Cryphaea heteromalla, Hedw.}

\section{Neckrracrab}

Neckera complanata, Hubnm. Homalia trichomanoides, Brid.

Leucodontacrae

Antitrichia curtipendula, Brid. E. Leucodon sciuroides, Schwgr. Pterigonium gracile, Swartz.

Porotrichum alopecurum, Mitt.

\section{LRSKeacear}

Leskea polycarpa, Ehrh. E. Anomodon viticulosus, H. \& T. Thuidium abietinum, B. \& S. W. - hystricosum, Mitt. W. - tamariscinum, B. \& S.

\section{HYPNACBAE}

Climacium dendroides, W. \& M. Camptothecium sericeum, Kindb. - lutescens, B. \& S. - nitens, Schreb. W.

Brachythecium glareosum, B.\& S. E.

\section{Hypnaceas (cont.)}

Brachythecium albicans, B. \& S.

- rutabulum, B. \& S.

- rivulare, B. \& S. W.

- velutinum, B. \& S.

- illecebrum, De Not. W.

- purum, Dixon

Eurhynchium piliferum, B. \& S.

- praelongum, Hobk.

- Swartzii, Hobk. W.

- pumilum, Schp. E.

- tenellum, Milde. E.

- myosuroides, Schp. E.

- myurum, Dixon

- striatum, B. \& S.

- rusciforme, Milde.

- murale, Milde.

- confertum, Milde.

Plagiothecium denticulatum, B. \& $\mathrm{S}$.

- sylvaticum, B. \& S. W.

- undulatum, B. \& S. W.

- ? latebricola, B. \& S. E.

Amblystegium serpens, B. \& S.

- filicinum, De Not.

- varium, Ldb. (radicale). W.

Hypnum riparium, L.

- elodes, Spruce. W.

- polygamum, Schp. W. var. stagnatum, Wils. W.

- stellatum, Schreb.

\section{Hypnaceae (cont.)}

Hypnum aduncum, Hedw. W. - Sendtneri var. Kneiffi, Schip.

var. hamatum, Lindb. W.

- fluitans, L.

- exannulatum, Gumb. W.

- uncinatum, Hedw.

- revolvens var. Cossoni, Rem. W. - commutatum, Hedw.

- falcatum, Brid.

- cupressiforme, L. var. resupinatum, Schp. W.

var. fliforme, Brid. W. var. ericetorum, B. \& S. var. elatum, B. \& S.

W.

- molluscum, Hedw.

- palustre, Huds.

- scorpioides, L.

- stramineum, Dicks. E.

- cordifolium, Hedw.

- giganteum, Schp. W.

- cuspidatum, L.

- Schreberi, Willd.

Hylocomium splendens, B. \& S.

- squarrosum, B. \& S.

- triquetrum, B. \& S.

- rugosum, De Not. W.

\section{HEPATICAE (Liverworts)}

If the county is one which is unfavourable for a varied moss flora, it is still more unfavourable for the Hepaticae. We have very few of them, and these few for the most part very common species; even the usually abundant Diplophyllum albicans is not yet recorded, but probably occurs in the county, since it is plentiful in some parts of Norfolk.

The cause of this dearth of Hepaticae is not far to seek. There are no rocks, no swift streams nor waterfalls, scarcely any springs, while the air is very dry, the county of Suffolk having perhaps as little rainfall as any part of England. Besides the scanty supply of rain, the heavy clay soil which covers more than two-thirds of the county, and the thin calcareous soil

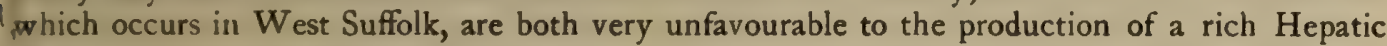
9ora. The late Abbe Boulay, in speaking of the flat, dry, and highly-cultivated district of northeastern France, especially in Champagne, says that 'one may go through many square kilometres without meeting a single species of this class, except perhaps Riccia glauia in neglected fields, or Radula complanata and Frullania dilatata on the trunks of trees,' and there are wide areas in Suffolk of which the same remarks would hold good. It is only in the small and diminishing area of the fen and bog-land, such as Tuddenham Fen and the bogs at Westleton and Belton, that any wealth of species is to be found. It is probable, however, that the Hepatic Flora is slightly richer than the subjoined list would indicate, since many of the species recorded by the older botanists, to whom nearly all the records are due, embrace several forms held to be specifically distinct at the present day. The list of Suffolk Hepaticae published in the Fournal of Botany for 1885 by the Rev. E. N. Bloomfield only enumerates forty species, and of these the greater number only occur in very limited localities. Three species have, however, since been added : Lunularia cruciata, which has been sent from Bungay and Waldringfield - this is doubtless common, but has escaped record as being supposed a form of Marchantia polymorpha ; Kantia Sprengelii, of which a specimen sent to him by Mr. Skepper is figured by Pearson; and Pellia endiviaefolia, 'Various parts o? Suffolk,' Hooker's British Jungermanniae. 


\section{A HISTORY OF SUFFOLK}

Among the more interesting Hepatics recorded for the county are Targionia bypopbylla, discovered by the Rev. W. Kirby, the noted entomologist, at Nayland. It is a species of irregular distribution in Britain, but its head quarters are in the countries bordering the Mediterranean; the figure in English Botany was taken from a specimen sent from this station. Cephalozia Francisci, recorded from wet heaths in Norfolk and Suffolk by Hooker, is considered rare elsewhere, though it is probably often overlooked, and Sphaerocarpus Michelii, a small and interesting species on the borderland between the Marchantiaceae and the Jungermanniaceae also occurs. Like Targionia bypophylla this has a generally southern distribution, and has only been recorded from four other English counties.

Besides these may be mentioned Riccia crystallina, a scarce species gathered by Dr. Hind on Thetford Heath; the curious fringed aquatic Ricciocarpus natans sent by Prof. Henslow from Hitcham with Ricciella fuitans and recorded from Lakenheath, and by Ray from Hadleigh; Cephalozia bifida ( $\mathcal{F}$. byssacea, Hook.), recorded by Hooker as far from uncommon on heaths, \&rc., in Norfolk and Suffolk. No doubt this record refers to the aggregate species, but the plant figured by Hooker is that which is now known as $C$. bifida, which appears to be the rarer of the two species in Britain, and Ptilidium ciliare, not uncommon in the Breck district, and recorded from Lound in the Botanist's Guide.

RicCIACEAB

Riccia glauca, L.

- crystallina, L. W.

- fluitans, L.

Ricciocarpus natans (L.) W.

\section{Marchantiacear}

Targionia hypophylla, L. W. Conocephalum conicum (L.) Lunularia cruciata (L.). E. Marchantia polymorpha, L.

\section{JUNGBRMANIACEAE}

Sphaerocarpus Michelii, Bell

Aneura pinguis (L.) E.

- multifida (L.)

Metzgeria furcata (L.)

Pellia endiviaefolia (Dicks.)
Jungermaniacear (cont.)

Pellia epiphylla (L.)

Fossombronia pusilla (L.). E. Nardia scalaris (Schrad.). E.

Aplozia crenulata (Sm.)

Lophozia inflata (Huds.). W.

- ventricosa (Dicks.)

- excisa (Dicks.)

- incisa (Schrad.) E.

Sphenolobus exsectaeformis (Breidl.)

Plagiochila asplenioides (L.)

Mylia anomala (Hook.). E.

Lophocolea bidentata (L.)

- heterophylla (Schrad.)

Cephalozia bicuspidata (L.)

- connivens (Dicks.)

- Francisci (Hook.)

Cephalozia byssacea (Roth.)

- bifida (Schreb.)
JUngermaniaceae (cont.)

Odontoschisma sphagnı (Dicks.). E.

Kantia trichomanis (L.)

- Sprengelii (Mart.)

Lepidozia setacea (Web.). L.

Ptilidium ciliare (L.)

Scapania compacta (Roth.)

- nemorosa (L.)

- ? undulata (L.)

- irrigua (Nees.)

Radula complanata (L.)

Madotheca platyphylla (L.)

Frullania tamarisci (Lo). W.

- dilatata, (L.)

\section{Anthocerotackal}

Anthoceros punctatus, $\mathbf{L}$.

\section{FRESHWATER ALGAE AND DIATOMS}

Among the data used in compiling this account of these lowly groups of plants, thie following books have been used:- the Flora of Suffolk by Henslow and Skepper, the Old Botanist's Guide, the History of Yarmouth (Norfolk and Suffolk), and through the kindness of the Rev. E. N. Bloomfield, a manuscript of Mr. Skepper's and other data. The list of diatoms is almost entirely due to Mr. Skepper. A collection was made in May I 896 by my late son, Wm. West, jun., B.A., when botanizing on Cavenham Heath, the result being the addition of about ten species, marked *

There is considerable scope for future workers, particularly among the desmids, as very few of this family are recorded. Investigators should be forthcoming in these days, when cheap and good modern microscopes are available. It will be found to be a most interesting study at almost all times of the year, as wherever there is any permanent moisture, algae of some kind are sure to be found, and they require no preparation before examination. Even diatoms can usually be determined without boiling in nitric acid, after being kept in strong spirit for some days. For the preservation of algae for future examination an equal volume of five per cent. formalin shculd be added to the same volume of the water containing the algae; this will preserve the $m$ indefinitely for future examination. It is advisable to make notes as to colour, \&c., before preserving them. A large number of the algae are very 


\section{BOTANY}

minute, and in order to obtain these some advice is necessary as they are not visible to the naked eye; these forms are often found about the stems and leaves of constantly submerged plants, such as Utricularia, Myriophyllum, Nuphar, Nymphaea, Potamogeton, Sphagnum, \&c. To collect from plants like these it is best to remove them (or parts of them) from the water with as little mud as possible and allow them to drain for about a minute, after which they should be gently squeezed over a wide-mouthed bottle. Gatherings made in this way are usually very rich in minute species.

\section{FRESHWATER ALGAE}

Only a moderate number of species have been noted as yet from the county; this is due to lack of local workers during recent times, most of the records being old ones. Excluding diatoms, not more than forty genera and less than seventy species have been recorded. The districts about Tuddenham, Bradwell, Belton, Bury, Lound, and Ipswich, would certainly yield further results if worked. Among these recorded plants is the beautiful netted-purse plant, Hydrodictyon utriculatum, found at Bungay and other places. About ten genera of unicellular plants, excluding diatoms and desmids, are known to occur; these include the pretty coenobial genera Scenedesmus and Pediastrum. Volvox globator is frequent, and $V$. aureus is probably present ; the latter can be distinguished from the former by its smooth spores and smaller size. The Conjugatae are represented by seven genera including the Desmidiaceae, only four genera belonging to the latter being recorded. The genus Vancheria is well represented, by six species, including $V$. dichotoma, which is seldom absent from maritime counties. The beautiful orange-coloured aerial algae, Trentepoblia (Chroolepus) aureum occurs on trees. The two British species of the delicately-branched genus Draparnaldia are frequent. The gelatinous genus Chaetophora is represented by two species. As only two or three species of the Oedogoniaceae are known to occur, it is evident that more work can be done in this group. The remaining genera of the green algae which are known are those of common occurrence.

The blue-green algae usually known as the Cyanophyceae (Myxophyceae is an earlier name) are represented by about fourteen species under eight genera, the genus Oscillatoria being represented by seven species.

The only freshwater algae belonging to the Red Algae that are recorded are Batrachospermum moniliforme and $B$. vagum, both very elegant species, and a species of Lemanea.

\section{DIATOMS}

This well-known group of plants includes both freshwater and marine species, as well as some that are usually only found in brackish water, or sometimes in the latter as well as in freshwater, or, in the case of some species, in either marine or brackish water. These are unicellular plants of very varied form ; they occur wherever water is constantly found ; they differ from all the other algae in having their cell-wall impregnated with silica, which practically renders them-as regards their form and markings-indestructible, hence large fossildeposits of them are found which are used commercially for various purposes, one important one being in the preparation of dynamite. The cell-walls are beautifully and symmetrically sculptured, although they are extremely thin. A fair number of species are known for the county, about 200 species under about fifty genera; this includes the strictly maritime species. The genus Gyrosigma (Pleurosigma), with its finely marked cell-walls, is well represented by twenty species. Under the genus Navicula (including Pinnularia) about forty species are recorded, and for the genus Nitzschia about twelve species. The genera Stauroneis, Gomphonema, and Synedra, are represented by from four to six species each, while the genera Surirella and Epithemia have eight and five species respectively, the genus Amphora also having five. None of the other genera are represented by more than four species, the genera Campylodiscus, Eupodiscus, Coiconeis, and Amphiprora, have each several species. Fewer species are recorded for the genera Cymbella, Coscinodiscus, Actinocyclus, Cyclotella, Tryblionella, Cymatopleura, Cocconema, Doryphora, Podosphaenia, Rbiphidophora, Meridion, Bacillaria, Odontidium, Fragilaria, Achnanthes, Achnantbidium, Rhabdonema, Diatoma, Grammatophora, Tabellaria, Amphitetras, Biddulphia, Podosira, Melosira, Orthosira, Mastogloia, Encyonema, Colletonema, and Schizonema, the species recorded usually varying from one to three. 


\section{A HISTORY OF SUFFOLK}

The following is a list of most of the species known to occur ; a few of the diatoms are those of brackish water :-

\section{Diatomaceab}

Melosira Borreri, Grev.

- varians, Ag.

Cyclotella Kützingiana, Chauvin

- astraea, Kütz.

Cylindrotheca gracilis, Grun.

Tabellaria flocculosa, Kütz.

- fenestrata, Kutz.

Meridion circulare, $\mathrm{Ag}$.

Diatoma vulgare, Bory

- elongatum, Bory

- Ehrenbergii, forma grandis, W. Sm.

Fragilaria capucina, Desm.

- mutabilis, Grün.

- construens,var. binodis, Grun.

Synedra Ulna, Ehren.

- radians, W. Sm.

- pulchella, Kütz.

Eunotia lunaris, Grün.

Achnanthes linearis, W. Sm.

Cocconeis pediculus, Ehren.

- placentula, Ehren.

Navicula serians, Kütz.

- cuspidata, Küz.

- Iridis, var. firma, W. Sm. var. producta, W. Sm.

- elliptica, W. Sm.

-. elegans, W. Sm.

- limosa, var. gibberula, Van Heurck.

- ambigua, Ehren.

- Amphisboena, Bory

- tumens, W. Sm.

- binodis, W. Sm.

- pygmaea, Kutz.

- major, Kütz.

- " nobilis, Kütz.

- viridis, Kütz.

- oblonga, Kütz.

- peregrina, Kütz.

- Tabellaria, var. " acrosphaeria, Raben.

- radiosa, Kutz.

- acuta, Van Heurck.

- gracilis, Kütz.

- digitato-radiata, var. Cyprinus, Van Heurck.

- divergens, Ralfs

- Brebissonii, Kütz.

- Johnsonii, W. Sm.

- mesolepta, Ehren.

- Rabenhorstii, Grün.

- crucicula, Van Heurck.

Vanheurckia rhomboides, Breb.

Stauroneis Phoenicenteron, Ehren.

- anceps, Ehren.

var. linearis, Van Heurck.

Pleurosigma acuminatum, W.Sm.

- attenuatum, W. Sm.

- Spencerii, W. Sm.

\section{Diatomacear (cont.)}

Gomphonema augur, Ehren.

- constrictum, Ehren.

- acuminatum, Ehren.

- olivaceum, Ehren.

Rhoicosphenia curvata, Grun.

Encyonema prostratum, Ralfs

- caespitosum, Kütz.

Cymbella affinis, Kütz.

- cuspidatum, Kutz.

- Ehrenbergii, Kütz.

Cocconema lanceolatum, Ehren.

- cymbiforme, Ehren.

- Cistula, Ehren.

Amphora salina, W. Sm.

- hyalina, Kutz.

- ovalis, Kutz.

var. affinis, Kutz.

var. pediculus, Kutz.

Epithemia turgida, W. Sm.

- sorex, Kütz.

- zebra, Kütz.

- gibba, Kütz.

- ventricosa, Kütz.

Bacillaria paradoxa, Gmel.

Nitzschia sigmoidea, W. Sm.

- linearis, W. Sm.

- sigma, W. Sm.

- spectabilis, Ralfs

- Amphioxys, W. Sm.

- vivax, W. Sm.

- bilobata, W. Sm.

- plana, W. Sm.

- acicularis, W. Sm.

- gracilis, Raben.

- lanceolata, W. Sni.

- constricta, Pritch.

Cymatopleura Solea, W. Sm. var. apiculata, Pritch.

- elliptica, W. Sm.

Surirella biseriata, Bréb.

- linearis, W. Sm.

- gracilis, Grün.

- striatula, Turp.

- Brightwellii, W. Sm.

- minuta, Breb.

- ovata, Kutz. var. salina, W. Sm.

Campylodiscus noricus, var. costata, W. Sm.

- Echineis, Ehren.

The following are marine

diatoms :-

Podosira hormoides, Kutz.

- maculata, Sm.

Melosira nummuloides, Ag.

- sulcata, Kutz.

Hyalodiscus stelliger, Bail.

Coscinodiscus excentricus, Ehren.

\section{Diatomacrab (comt.)}

Coscinodiscus radiatus, Ehren var. concinnus, W. Sm.

Actinoptychus undulatus, Ehren.

Auliscus sculptus, Ralfs

Eupodiscus Argus, Ehr.

Actinocy clus crassus, Van Heurck.

Biddulphiz aurita, Breb.

- pulchella, Gray

- rhombus, W. Sm.

- Smithii, Van Heurck.

- Favus, Van Heurck.

Synedra affinis, Kutz.

- fulgens, W. Sm.

- superba, Kutz.

Achnanthes longipes, $\mathrm{Ag}$.

- brevipes, Ag.

Schizonema eximium, Thur.

- crucigerum, W. Sm.

- Grevillii, Ag.

Cocconeis scutellum, Ehr.

- diaphana, W. Sm.

Navicula Smithii, Ag.

- didyma, Ehren.

- marina, Ralfs

- Hennedyi, var. clavata, Van Heurck.

- Lyra, Ehren.

- directa, W. Sm.

- aspera, Ehren.

Scoliopleura Westii, Grun.

- latestriata, Grún.

- tumida, Rabenh.

Stauroneis salina, W. Sm.

Pleurosigma formosum, W. Sm.

- decorum, W. Sm.

- speciosum, W. Sm.

- rigidum, W. Sm.

- elongatum, W. Sm.

- strigosum, W. Sm.

- quadratum, W.Sm.

- angulatum, W. Sm.

- Aestuarii, W. Sm.

- Balticum, W. Sm.

- Fasciola, W. Sm.

- intermedium, W. Sm.

- acuminatum, W. Sm.

- praelongum, W. Sm.

- tenuissimum, W. Sm.

- littorale, W. Sm.

- Hippocampus, W. Sm.

Doryphora amphiceros, Kutz.

Amphiprora alata, Kutz.

- constricta, Ehren.

- vitrea, W. Sm.

- elegans, W. Sm.

Mastogloia Smithii, Thw.

Rhoicosphenia curvata, var. marina, W. Sm.

Epithemia musculus, var. constricta, W. Sm.

Tryblionella acuminata, W. Sm. 


\section{BOTANY}

Diatomacrar (comt.)

Tryblionella marginata, W. Sm.

Nitzschia angularis, W. Sm.

- longissima, Ralfs

- closterium, W. Sm.

Surirella Gemma, Ehren.

Campylodiscus Hodgsonii, W.Sm.

- parvulus, W. Sm.

Podosphaenia Ehrenbergii, Kütz.

Rhipidophora elongata, Kütz.

- paradoxa, Kutz.

Am phitetrasantediluviana, Ehren.

Grammatophora marina, Kütz.

Rhabdonema arcuatum, Kutz.

- minutum, Kütz.

Among the few other freshwater Algae known to occur are the following :-

\section{RHODOPHYCEAE}

Lemanea torulosa, Ag.

Batrachospermum moniliforme
Ag.
- vagum, Ag.

\section{Chlorophrceas}

Bulbochaete setigera, Ag.

Oedogonium resicatum, Wittr.

Chactophora pisiformis, Ag.

- cornu-damae, Ag.

- tuberculosa, Ag.

\section{Chlorophyceas (cont.)}

Ulothrix zonata, Kutz.

- rivularis, Kutz.

- parietina, Kutz.

Myxonema tenue, Rabenh.

Draparnaldia glomerata, Ag.

Trentepohliz aurea, Mart.

Enteromorpha intestinalis, Link.

Prasiola crispa, Menegh.

- furfuracea, Menegh.

Chaetomorpa linum, Kütz.

Cladophora fracta, Kutz.

- glomerata, Kütz.

Vaucheria sessilis, var. caespitosa, Raben.

- dichotoma, Ag.

- geminata, DC.

- ornithocephala, Hass.

- terrestris, Lyngb.

- Dillwynii, Ag.

Mougeotia genuflexa, Ag.

Spirogyra nitida, Link.

- decimina, Kutz.

- quinina, Kütz.

- pellucida, Kutz.

Zygnema pectinatum, Ag.

- cruciatum, Ag.

- ericetorum, Hansg.

Pleurotaenium *truncatum, Nag.

Closterium *Dianae, Ehren.

- "striolatum, Ehren.

- Kutzingii, Breb.

- Lunula, Nitzsch.

Cosmarium * Botrytis, Meneg.

\section{Chlorophycear (cont.)}

Hyalotheca dissiliens, Bréb.

Volvox globator, Ehren.

Pleurococcus vulgaris, Meneg.

Hydrodictyon utriculatum, Roth.

Scenedesmus quadricauda, Bréb.

Pediastrum Boryanum, Meneg.

Palmella botryoides, Kutz.

Gloeocystis " gigas, Lager

Hydrianum "heteromorphum, Reinsch.

Tetraspora, lubrica, Roth.

Ophiocytium cochleare, A. Br.

Tribonema "bombycina, Derb. and Sol.

\section{MYXophyceAe}

Porphyridium cruentum, Nag.

Tolypothrix distorta, Kütz.

Anabaena Flosaquae, Breb.

Lyngbya ochracea, Thur.

Phormidium autumnale, Gomont.

Oscillatoria tenuis, Ag.

- nigra, Vauch.

- limosa, Ag.

Nostoc sphaericum, Vauch.

- coeruleum, Lyngb.

- commune, Vauch.

- pruniforme, Ag.

- "microscopicum, Carm.

Gloiotrichia natans, $\mathrm{Ag}$.

\section{MARINE ALGAE}

The coast of Suffolk, like that of the neighbouring counties of Norfolk and Essex, is singularly unfavourable to the growth of marine algae. Few if any rocks are accessible even at the lowest tides, and the shifting shingle and sand which form the greater part of the foreshore of the county offer no secure anchorage for marine plants. The larger sea-weeds (e.g. Laminaria byperborea, Saccorbiza polyschides, \&c.) are entirely wanting, whilst the bladder-wiacks (Fuci), which are such conspicuous objects on all our rocky coasts, are found in comparatively sinall quantity, and usually more or less dwarfed and stunted where they occur within the limits of the county. Many brackish-water species are to be met with at the mouth of the River Yare and at the influx of the Stour and Orwell. Great masses of Enteromorphae, Ulvae, Chaetomorphae, \&c., are always to be seen floating in the water or stranded on the mud when the tide recedes; whilst the dreary salt-marshes which fringe the estuaries produce their crop of Oscillatoriae and other Myxophycea, which are of great interest to the algologist, but I fear not very attractive to the ordinary collector.

It is useless to attempt to trace the distribution within the county of the species recorded, for whilst a few of them were gathered from the rocks at Felixstowe and elsewhere, by far the greater number were found amongst the rejectamenta on the beach. No doubt many of them had been detached from submerged rocks in the immediate vicinity of the spot where they were found, but others showed clearly by their battered condition that they had drifted from some more distant locality. The amount of sea-wrack cast up at any point on the Suffolk coast is never very great, and so far as I am aware the farmers of the county do not trouble to collect it for manure, as is usually done in counties where sea-weed is found in abundance. 


\section{A HISTORY OF SUFFOLK}

No attempt has been made in recent years to catalogue the marine flora of Suffolk, the list of sea-weeds in Henslow and Skepper's Flora of Suffolk (London, 1860) (H. \& S.) being the most recent known to me. These authors were doubtless greatly assisted in compiling their list by the account of the Norfolk and Suffolk algae published by Messrs. C. J. and James (afterwards Sir James) Paget in their Sketch of the Natural History of Yarmouth in I 834. Various Suffolk localities are also mentioned in Dawson Turner's Synopsis of the British Fuci, Dillwyn \& Turner's Botanist's Guide (O.B.G.), Greville's Alyae Britannica (Grev.), and Harvey's Phycologia Britannica. I have myself collected at various points on the Suffolk coast, and my friend Mr. George Massee of the Royal Herbarium, Kew, has kindly presented me with a number of specimens collected by him at Felixstowe. The nomenclature used in the present list is that of my Catalogue of the British Marine Algae.

Note.-The writer, the late Mr. E. A. L. Batters, F.L.S., had himself gathered most of the species here recorded for Suffolk, or had seen specimens from it. In other cases the source of information is given.

\section{MYXOPHYCEAE}

Dermocarpa prasina, Born. Hyella caespitosa, Born. Spirulina subsalsa, Ersted. Oscillatoria Corallinæ, Gom. Lyngbya aestuarii, Liebm. - semiplena, J. Ag. Symploca hydnoides, Kütz. Plectonema terebrans, Born. Microleus chthonoplastes, Thur. Calothrix confervicola, Ag.

- scopulorum, Ag.

Rivularia atra, Roth.

Mastigocoleus testarum, Lagerh. Anaboena variabilis, Kütz.

- torulosa, Lagerh.

\section{Chlorospermeat}

Prasiola stipitata, Suhr. Monostroma Grevillei, Wittr. Percursaria percussa, Rosenv. Enteromorpha clathrata, J. Ag. - torta, Reinb.

- compressa, Grev.

- Linza, J. Ag.

- intestinalis, Link.

Ulva lactuca, L.

Ulothrix flacca, Thur.

Endoderma Flustrae, Batt.

Tellamia contorta, Batt.

Urospora isogona, Batt.

Chaetomorpha tortuosa, Kütz.

- linum, Kütz.

- aerea, Kütz.

- Melagonium, Kütz.

Rhizoclonium riparium, Harv.

Cladophora pellucida, Kütz. (H. \& S.)

- Hutchinsiae, Harv.

- rupestris, Kütz.

- hirta, Kütz.

- utriculosa, Kütz.

- glaucescens, Harv.

- fracta, Kutz.

- arcta, Kütz.

Gomontia polyrhiza, Born.

Bryopsis plumosa, Ag.

\section{Fucoidear}

Desmarestia viridis, Lamour.

- ligulata, Lamour (Grev.)

- aculeata, Lamour.

Scytosiphon lomentarius, J. Ag.

Punctaria plantiginea, Grev.

Asperococcus fistulosus, Hook.

Ectocarpus confervoides, Le Jol.

- siliculosus, Kütz.

Pylaiella litoralis, Kjellm.

Arthrocladia villosa, Duby. (Grev.)

Elachistea fucicola, Fries.

Sphacelaria cirrhosa, Ag.

Cladostephus spongiosus, $\mathrm{Ag}$.

— verticillatus, Ag.

Stypocaulon scoparium, Kütz.

Chordaria flagelliformis, Ag. $(\mathrm{H}$. \& S.)

Mesogloia vermiculata, Le Jol. (H. \& S.)

Leathesia difformis, Aresch.

Sporochnus pedunculatus, Ag. (Grev.)

Chorda filum, Stackh. (H. \& S.)

Laminaria saccharina, Lamour. var. phyllitis, Le Jol.

- digitata, Lam. (H. \& S.)

Cutleria multifida, Grev. (H. \& S.)

Fucus spiralis, L.

- vesiculosus, $\mathrm{L}$.

- serratus, L.

Ascophyllum nodosum, Le Jol

Pelvetia canaliculata, Decne. \& Thur. (H. \& S.)

Himanthalia lorea, Lyngb. (H. \& S.)

Halidrys siliquosa, Lyngb.

Cystoseira granulata, Ag. (H. \& S.)

- ericoides, Ag. Turner

- fibrosa, Ag.

Tilopteris Mertensii, Kutz. (H. \& S.)

Dictyota dichotoma, Lamour.

Taonia atomaria, J. Ag. (Grev.)

\section{Floridrae}

Bangia fuscopurpurea, Lyngb. Porphyra umbilicalis, Kütz. var. laciniata, J. Ag.

Acrochaetium Daviesii, Näg. ( $\mathrm{H}$. \& S.)

Scinaia furcellata, Bivona (Grev.)

Naccaria Wigghii, Endl. (H.\& S.)

Chondrus crispus, Stackh.

Gigartina stellata, Batt.

Phyllophora epiphylla, Batt.

- membranifolia, J. Ag.

Ahnfeltia plicata, Fries.

Callophyllis laciniata, Kütz.

Cystoclonium purpureum, Batt.

Rhodophyllis bifida, Kütz. (Grev.)

Gracilaria confervoides, Grev.

Calliblepharis ciliata, Kütz.

Rhodymenia palmata, Grev.

Lomentaria articulata, Lyngb.

- clavellosa, Gail. (Grev.)

Chylocladia ovata, Batt. (Grev.)

Plocamium coccineum, Lyngb.

Nitophyllum ramosum, Batt.

- Gmelini, Grev.

Phycodrys rubens, Batt.

Delesseria sanguinea, Lamour.

- alata, Lamour.

- ruscifolia, Lamour. (Grev.)

- hypoglossum, Lamour. (Grev.)

Bonnemaisonia asparagoides, $\mathrm{Ag}$. (Grev.)

Bostrychia scorpioides, Mont. (H. \& S.)

Rhodometa subfusca, Ag.

- lycopodioides, Ag. (H. \& S.)

Laurencia pinnatifida, Lamour.

Chondria dasyphylla, Ag. (Grev.)

Polysiphonia urceolata, Grev. var. comosa, Ag. var. patens, J. Ag.

- elongata, Grev.

- fastigiata, Grev.

- nigra, Batt.

- nigrescens, Grev. 


\section{BOTANY}

Floridear (cont.)

Brongniartella byssoides, Bory. (H. \& S.)

Heterosiphonia plumosa, Batt. Spermothamnion Turneri, Aresch.

Gritfithsia flosculosa, Batt. Halurus equisetifolius, Kutz. (H. \& S.)

Rhodochorton Rothii, Näg.
Floridear (cont.)

Callithamnion polyspermum, $\mathbf{A g}$. - roseum, Harv.

- Hookeri, Ag.

[- tetricum, Ag. (H. \& S.)]

Plumaria elegans, Schm. Antithamnion Plumula, Thur.

Ceramium rubrum, $\mathrm{Ag}$.

- ciliatum, Ducluz. (H. \& S.)

(acanthonotum ?)
Florideae (cont.)

Halarachnion ligulatum, Kutz. O.B.G.

Furcellaria fastigiata, Lamour. Polyides rotundus, Grev. (Grev.) Corallina officinalis, $\mathrm{L}$

Excluded Specirs

Sargassum vulgare, $\mathrm{Ag}$.

\section{LICHENES (Lichens)}

The list of lichens occurring in the county is more extensive than might have been expected, the want of rocks being partially compensated by the brick and stone walls, some of them of great age, to which many lichens are restricted through the utter absence of rock surfaces. Interesting species are also found on the pebbles, which are scattered over some of our waste and barren land, and also on the ground in like localities. This is more particularly the case with the uncultivated portion of the Breck district, such as Thetford Warren, which is wholly in this county.

Many species of lichens were first admitted into the British flora from specimens collected in Suffolk and Norfolk, and a considerable proportion of these were due to the investigation of $\mathrm{Mr}$. Dawson Turner, who, in conjunction with $\mathrm{Mr}$. Borrer, diligently collected and studied them. A good list of the Suffolk species is given in Henslow and Skepper's Flora. The additions made since are principally due to Mr. C. Larbalestier, who has added much to our knowledge of British lichens, and to whom Leighton's Lichen Flora is dedicated.

All that is known of Suffolk lichens to the present time is recorded by the Rev. E. N. Bloomfield, in the Transactions of the Norfolk and Norwich Naturalists' Society (1904-5), viii, I I 7-37. Here we can only mention a few species.

On walls Lecanora atra and several Lecideei, such as Lecidea canescens, are abundant, while less common are Lecanora parella and sulphurea, Urceolaria scruposa, and Squamaria saxicola at Bury. In the north-west Lecanora arenaria is not uncommon, and the scarce Placodium decipiens has been found at Herringfleet, Framlingham Castle, and Brandon.

On old railngs various species are found, as Parmelia physodes and saxatilis and other Parmeliae, \&c., and rarely Calicium cbrysocephalum, Lecidea ostreata, and Trachylia tigillaris; this latter is a very pretty species, bright yellow, with small black apothecia; it has occurred at Southtown and Little Glemham, and Mr. Larbalestier found it in plenty on some old posts at Felixstowe. T. tympanella is not uncommon on tops of posts and on gates, and stains the fingers touching it, with its sooty spores.

Many species are common on trees, such as various Parmeliae, Parmelia caperata, pulverulenta, stellaris, \&x. P. acetabulum is both local and scarce, and the handsome Physcia ciliaris is not uncommon. Sticta pulmonaria is recorded for Suffolk, but must be very scarce; the curious batswing Collema nigrescens is conspicuous in wet weather on trees, but shrinks up when dry. All these are foliaceous species.

Young ash trees appear as if covered in places with patches like wax; this is due to Verrucaria nitida. There are also various Graphidei, as Opegrapha lyncea on old oaks, Graphis scripta, \&c., and Stigmatidium crassum, a very curious but inconspicuous lichen ; although it well deserves its old name Lichen obscurus, it can be recognized at once by any one accustomed to its peculiar thallus.

On the barren heaths and denes there are various interesting species, as Cladina rangiferina, the reindeer moss; the allied very elegant $C$. sylvatica, the strange looking prickly Cetraria aculeata, and sometimes Lecidea caeruleonigricans. There are also various kinds of the polymorphous Cladoniei, as Cladonia endiviaefolia, cariosa, alcicornis, gracilis, \&c.

The following scarce species are recorded by Mr. Larbalestier from Thetford Warren :Alectoria jubata, var. chalybeiformis; Urceolaria scruposa, var. bryophila ; Parmelia conspersa, var. Mougeotii, Lecanora umbrins-fusca, L. pyreniospora (Conradi) on very old excrements of sheep, 


\section{A HISTORY OF SUFFOLK}

and the rare Squamaria lentigera abundant on the edge of the first deep chalk pit on the lefthand side of the road from Thetford across the warren.

Our list of Caliciei is a good one, comprising fourteen species, some of which have been already mentioned; but there are other scarce species, as Calicium phoeocephalum and Coniocybe furfuracea. Baeomyces roseus and $B$. ichmadophilus are very scarce, $B$. rufus not very uncommon, Strigula Babingtonii, which grows on the leaves of the common laurel, has been found at Cockfield, but is now, I believe, considered to be a fungus.

\section{Collemei}

Collema pulposum, Bernh. var. tenax

- limosum, Ach.

- crispum, Huds.

- cheileum, Ach.

- nigrescens, Huds.

Leptogium microphyllum, Ach.

- tenuissimum, Dicks.

- cretaceum, Sm.

- lacerum, Ach.

- subtile, Schrad.

- sinuatum, Huds.

- palmatum, Huds.

- turgidum, Ach.

- Schraderi, Bernh.

\section{Calicigi}

Sphinctrina turbinata, Pers.

Calicium chrysocephalum, Ach.

- phoeocephalum, Borr.

- aciculare, Sm.

- trichiale,

var. stemomeum, Ach. var. ferrugineum, Borr.

- hyperellum, Ach.

- trachelinum, Ach.

- quercinum, Pers.

- curtum, Borr.

- subtile, Pers.

Coniocybe furfuracea, Ach.

Trachylia tigillaris, $\mathrm{Fr}$.

- tympanella, Fr.

\section{BAEOMYCEI}

Baeomyces rufus, DC.

- roseus, Pers.

- ichmadophilus, Ehrh.

\section{Cladoniei}

Pycnothelia papillaria, Duf.

Cladonia endiviaefolia, Fr.

- pungens, Flk.

- cervicornis, Schaer.

- cariosa, Flk.

- delicata, Flk.

- alcicornis, Flk.

- pyxidata, Fr.

- gracilis

var. chordalis, Ach.

- furcata, Hoffm.

- cornucopioides, Fr.

\section{Cladoniei (cont.)}

Cladonia digitata var. macilenta, Hoffm.

Cladina sylvatica, Hoffm.

- rangiferina, Hoffn.

- uncialis, Hoffm.

\section{STEREOCAULE!}

Stereocaulon paschale, Ach.

\section{USNEEI}

Usnea barbata

var. florida, $L$.

var. hirta, L.

var. articulata, Ach.

\section{RaMALINEI}

Alectoria jubata, L.

Evernia furfuracea, Mann.

- prunastri, L.

var. stictocera, Ach.

Ramalina farinacea, $\mathrm{L}$.

- fraxinea, L. var. ampliata, Ach.

- fastigiata, Pers.

- pollinaria, Ach. var. humilis, Ach.

\section{Cetrariei}

Cetraria aculeata, Fr. var. muricata, Ach.

Platysma sepincola, Ehrh.

- diffusum, Web.

- glaucum, $\mathbf{L}$.

\section{Peltigerei}

Peltigera canina, L.

- rufescens, Hoffm.

- spuria, Ach.

- polydactyla, Hoffm.

\section{Parmeliei}

Sticta pulmonaria, Ach.

Parmelia caperata, L.

- olivacea, L.

- physodes, L.

- perlata, L.

- tiliacea

var. scortea, Ach.

\section{Parmeliei (cont.)}

Parmelia conspersa, Ehrh. - acetabulum, Neck.

- saxatilis, L.

Physcia parietina, L.

- ciliaris, L.

- pulverulenta, Schreb.

- obscura, Ehrh. var. pityrea, Ach. var. virella, Ach. var. ulothrix, Ach. - stellaris, L. var. tenella, Scop. var. caesia, Hoffm.

\section{Pannariri}

Psoroma hypnorum, Vahl.

Pannaria pezizoides var. coronata, Ach.

- microphylla, Sw.

- nigra, Huds.

\section{SQUAMariri}

Squamaria lentigera, Web. _ saxicola, Poll.

Placodium murorum, Hoffim.

- decipiens, Arn.

- citrinum, Ach.

- fulgens, Sw.

\section{LECANOREI}

Lecanora vitellina, Ach.

- candelaria, Ach.

- fuscata, Schrad.

- varia, Ehrh.

_ atra, Huds.

- circinata, Pers.

- sulphurea, Hoffm.

- expallens, Ach.

- subfusca, L.

- galactina, Ach.

- hageni, Ach.

- calcarea,

- gibbosa var. Hoffmanni, Ach.

- parella, L var. porinoidea, Flot. var. Turneri, Sm.

- ferrugines, Huds.

- colobina, Ach.

- cerina, Ehrh. 


\section{BOTANY}

\section{Lrcanorei (cont.)}

Lecanora pyracea var. ulmicola, DC var. holocarpa, Ehrh. var. pyrithroma, Ach.

- 2renaria, Pers.

- sophodes, Ach. var. exigua, Ach. var. roboris, Duf.

- pyreniospora, Nyl.

- haematomma, Ehrh.

- Conradi, Nyl.

- umbrino-fusca, Nyl.

\section{Pertusariei}

Pertusaria dealbata, Ach.

- communis, DC.

- fallax, Pers.

- velata, Turn.

- faginea, L.

- globulifera, Turn.

- leioplaca, Ach.

Phylctis agelaea, Ach.

- argena, Ach.

\section{Thelotremei}

Thelotrema lepadinum, Ach.

Urceolaria scruposa, L. var. bryophila, Ach.

LECIDEEI

Lecidea decipiens, Ehrh.

- ostreata, Hoffm.

- dispansa, Nyl.
LecideEI (cont.)

Lecidea prominula, Borr.

- flexuosa

var. aeruginosa, Borr.

- decolorans, Flk. var. escharoides, Ehrh.

- dubia, Borr.

- quernea, Dicks.

- parasema, Ach. var. elaeochroma, Ach.

- uliginosa, Schrad.

- coarctata var. elachista, Ach.

- contigua, Fr.

- canescens, Dicks.

- myriocarpa, DC. var. chloropolia, Fr. var. pinicola, Ach. var. muscicola, Pers.

- caeruleonigricans, Lightf.

- tricolor, With. var. insignis

- Ehrhartiana, Ach.

- diluta, Pers.

- alboatra, Hoffm. var. epipolia, Ach.

- aromatica, Sm.

- milliaria, Fr. var. syncomista, Flk.

- premnea, Ach.

- rubella, Ehrh.

- bacillifera, Nyl.

- muscorum, Sw.

- effusa, Sm.

- cupularis, Ehrh.

- epigaea, Schr.

\section{Graphiver}

Opegrapha herpetica, Ach. var. rubella, Pers. var. rufescens, Pers.

- atra, Pers.

- Turneri, Leight.

- saxicola,

- varia var. Chevallieri, Leight

var. pulicaris, Lightf.

var. notha, Ach. var. tigrina, Ach

- vulgata, Ach.

- Leightonii, Crombie

- lyncea, Sm.

Stigmatidium crassum, Dub.

Arthonia Swartziana, Ach.

- epipasta, Ach.

- cinnabarina, Wallr.

- pruinosa, Ach.

Graphis scripta, Ach. var. serpentina, Ach.

\section{PyrenocarpeI}

Endocarpam hepaticum, Ach. Verrucaria mauroides, Schaer.

- nigrescens, Pers.

- fuscella, Turn.

- polysticta, Borr.

- viridula, Schrad.

- rupestris, Schrad. var. muralis

- calciseda, DC.

- gemmata, Ach.

- nitida, Weig.

\section{FUNGI}

The first, and until very lately the only list of Suffolk fungi, is that contained in Henslow and Skepper's Suffolk Flora. It is a good and extensive one, and is mostly due to 2 Mr. Skepper, who for several years collected very diligently, especially in 1856 , about Bury, and was very considerably assisted by the Rev. M. J. Berkeley, at that time our great authority on fungi. After the publication of his Flora of Suffolk in 1889, Dr. Hind paid much attention to the larger fungi, thus adding materially to the list of species; many of his specimens were determined or confirmed for him by Mr. G. Worthington Smith, and a few by Dr. Cooke. We are also indebted for records of some of the rarer species to Dr. Badham, author of the Esculent Funguses of England, who resided at East Bergholt, in this county. A list of the species thus far recognized in Suffolk is given by the Rev. E. N. Bloomfield in the Transactions of the Norfolk and Norwich Naturalists' Society (1905-6), viii, 246-64.

Although the fungi are of small economic importance as articles of food, yet on the other hand they are often very destructive in various ways. The only species usually eaten in this country are the common and horse mushrooms, Agaricus campestris and arvensis, which are both wholesome and much esteemed. The morel and truffle are well known and appreciated, but are scarce.

Many other species are esteemed on the Continent, such as the Fairy-ring Champignon, the Cantharelle, \&rc, but are seldom tasted in this country. Many species are very poisonous, even a small piece producing very severe illness or even death. Some of the larger species are very destructive to trees and timber, while many of the small kinds are wellknown pests, such as the potato blight, the corn mildew, hop mildew, smut and bunt in corn, \&r. 


\section{A HISTORY OF SUFFOLK}

It was at one time supposed that the larger fungi, such as some of the Agarics, Polypori, \&c., only attacked dead or decaying trees, but though the spores may only gain access through injuries or decay, the mycelium spreads into the surrounding parts, and thus kills the tree or portions of it.

Another point worth mentioning is the very restricted nature of the matrix on which some alone will grow. Thus Agaricus mucidus only grows on beech, Polyporus betulinus on birch, $P$. dryadeus on oak, Boletus laricinus under larch trees, while many others show a marked preference for one particular species of tree, as $P$. squamosus for ash, $P$. giganteus for beech, $P$. sulpbureus and Fistulina bepatica for oak, while others are not at all particular, but attack many species of trees. The same is true of the smaller fungi.

The north-eastern part of the county, like the adjacent portion of Norfolk, is noted among mycologists for the very rare Trichogastres-Batarrhea and species of Geaster-which have occurred there.

No one since Mr. Skepper's death has paid much attention to the smaller species, which are not given here, but may be found in the Flora of Suffolk.

\section{HYMENOMYCETES}

Agaricini

Amanita virosa, Fr.

- vaginata, Bull

- phallodes, Fr.

- muscaria, L.

- strobiliformis, Fr.

- rubescens, $\mathrm{P}$.

- asper, Fr.

Lepiota procera, Scop.

- rachodes, Vitt.

- acutesquamosa, Wm.

- clypeolaria, Bull.

- cristata, Fr.

- cepaestipes, Sow.

- granulosa, Batsch.

Armillaria mellea, Vahl.

Tricholoma equestre, $\mathrm{L}$.

- nictitans, Fr.

- rutilans, Schoeff.

- vaccinum, P.

- terreum, Schoeff.

- scalpturatum, Fr.

- cartilagineum, Bull

- sulphureum, Bull

- arcuatum, Bull

- acerbum, Bull

- grammopodium, Fr.

- subpulverulentum, Pers.

- nudum, Bull

- personatum, $\mathrm{Fr}$.

Clitocybe nebularis, Batsch. (canaliculatus)

- odora, Bull

- cerussata, Fr.

- candicans, Fr.

- dealbata, P.

- gallinacea, Scop.

- maxima, Fr.

- infundibuliformis, Schoeff.

- geotrupa, Bull

- flaccida, Sow. var. lobatus (fimbriatus, b).

- cyathiformis, Fr.

- fragrans, Sow.

- laccata, Scop.

\section{HYMENOMYCETES (cont.)}

\section{Agaricini (cont.)}

Clitocybe phyllophila, Fr.

Pleurotus ulmarius, Bull

- subpalmatus, Fr.

- fimbriatus, Bolt.

- ostreatus, Jacq.

- acerosus, Fr.

Collybia radicata, Relh.

- longipes, Bull (pudens)

- fusipes, Bull

- maculata, A. \& S.

- butyracea, Bull

- velutipes, Curt.

- confluens, P.

- stipitaria, Fr.

- conigena, P.

- dryophila, Bull.

- exsculpta, Fr.

- tenacella, P.

- esculenta, Jacq.

Mycena pura, $\mathrm{P}$.

- strobilina, Pers.

- lactea, P.

- galericulata, Scot.

- polygramma, Bull

- alcalina, Fr.

- galopus, Schrad.

- epipterygia, Scop.

- corticola, Schum.

- acicula, Schoeff. (clavus)

Omphalia pyxidata, Bull

- umbellifera, L.

- fibula, Bull

Pluteus leoninus, Schoeff.

- phlebophorus, Ditm.

Entoloma sinuatum, Fr.

- sericeum, ? Bull (pascuus)

Clitopilus prunulus, Scop.

Claudopus euosmus, Berk.

- variabilis, P.

Leptonia chalyboea, $\mathbf{P}$.

- incana, Fr. (Sowerbei)

Nolanea pascua, P.

Pholiota praecox, $\mathrm{P}$.

- capistrata, Cooke
HYMENOMYCETES (cont.)

Agaricini (cont.)

Pholiota squarrosa, Müll.

- adiposa, Fr.

- mutabilis, Schoeff.

- pudica, Bull

- heteroclita, Fr.

Hebeloma sinapizans, $\mathbf{F r}$.

- crustuliniforme, Bull

- fastibile, Fr.

- obscurum, P.

- rimosum, Bull

- geophyllum, Sow.

Flammula flavida, Schoeff.

- sapinea, Fr.

Crepidotus mollis, Schoeff.

Naucoria horizontalis, Bull

- melinoides, Fr.

- semiorbicularis, Bull

- siparia, Fr.

Galera tener, Schoeff.

- hypnorum, Batsch.

Tubaria furfuracea, $P$.

Psalliota arvensis, Schoeff. var. villaticus, Brond.

- campestris var, pratensis, Vitt. var. rufescens, Berk.

Stropharia aeruginosa, Curt.

- obturata, Fr.

- stercoraria, Fr.

- semiglobata, Batsch.

Hypholoma sublateritium, Fr.

- fasciculare, Huds.

- lacrymabundum, Fr.

- velutinum, $\mathrm{P}$.

- Candollianum, Fr.

- appendiculatum, Bull

Psilocybe semilanceolata, Fr.

- foenisecii, P.

Panaeolus separatus, L. (semıovatus)

- fimiputris, Bull

- papillionaceus, Bull

Psathyrella gracilis, Fr.

- atomata, Fr. 


\section{BOTANY}

\section{HYMENOMYCETES (cont.)}

Agaricini (cont.)

Psathyrella disseminata, Fr.

Coprinus comatus, Fr.

- atramentarius, Fr.

- picaceus, Fr.

- fimetarius, Fr.

- niveus, $F r$.

- micaceus, Fr.

- radians, Fr.

- radiatus, Fr.

- ephemerus, Fr.

- plicatilis, Fr.

Bolbitius titubans, Fr.

- fragilis, Fr.

Cortinarius purpurascens, Fr.

- collinitus, Fr.

- violaceus, Fr.

- anomalus, Fr.

- hinnuleus, Fr.

Paxillus involutus, $\mathbf{F r}$.

- panuoides, Fr.

Hygrophorus hypothejus, Fr.

- pratensis, Fr.

- virgineus, Fr.

- ceraceus, Fr.

- coccineus, Fr.

- miniatus, Fr.

- puniceus, Fr.

- conicus, Fr.

- psittacinus, Fr.

- vitellinus, Fr.

Gomphidius ? glutinosus, Fr.

- viscidus, Fr.

Lactarius torminosus, $\mathrm{Fr}$.

- turpis, Fr.

- insulsus, Fr.

- blennius, Fr.

- vellereus, Fr.

$$
\text { var. exiuccus, Otto. }
$$

- piperatus, $\mathrm{Fr}_{\mathrm{r}}$

- pyrogalus, Fr.

- deliciosus, Fr.

- pallidus, Fr.

-1- quietus, Fr.

- fuliginosus, Fr.

glyciosmus, Fr.

- volemum, Fr.

- subdulcis, Fr.

Russula nigricans, Fr.

- rubra, Fr.

- foetens, Fr.

- emetica, Fr.

- integra, Fr.

- alutacea, Fr.

Cantharellus cibarius, Fr.

- aurantiacus, Fr.

Marasmius peronatus, Fr.

- oreades, Fr.

- ramealis, Fr.

- androsaceus, Fr.

- rotula, $\mathrm{Fr}$.

- caulicinalis, Fr.

- epiphyllus, Fr.

Lentinus Dunalii, Fr.

\section{HYMENOMYCETES (cont.)}

Agaricini (cont.)

Lentinus lepideus, Fr.

- cochleatus, Fr.

Panus stypticus, Fr.

Schizophyllum commune, Fr.

Lenzites betulina, Fr.

\section{POLYPOREI}

Boletus luteus, L.

- flavus, With.

- flavidus, Fr.

- laricinus, Berk.

- granulatus, L.

- bovinus, L.

- sanguineus, With.

- variegatus, Fr.

- chrysenteron, Fr.

- subtomentosus, L.

- edulis, Bull

- ? aestivalis, Fr. (pachypus)

- Satanas, Lenz.

- luridus, Schoeff.

- scaber, Fr.

- cyanescens, Bull

Polyporus lentus, Berk.

- rufescens, Fr. biennis, Bull)

(Daedalea

perennis, Fr.

- squamosus, Fr.

- varius, Fr.

-- lucidus, Fr.

- giganteus, Fr.

- sulphureus, Fr.

- caesius, Fr.

- adustus, Fr.

- hispidus, Fr.

- cuticularis, Fr.

- dryadeus, Fr.

- betulinus, Fr.

- fomentarius, Fr.

- igniarius, Fr.

- ribis, Fr.

- salicinus, Fr.

- annosus, Fr.

- connatus, Fr.

- fibula, Fr.

- velutinus, Fr.

- hirsutus, Fr.

- versicolor, Fr.

- abietinus, Fr.

- ferruginosus, Fr.

- vaporarius, Fr.

Daedalea quercina, $\mathbf{P}$.

- unicolor, Fr.

Merulius tremellosus, Schrad.

- corium, Fr.

- lachrymans, Fr.

Fistulina hepatica, Fr.

\section{HYDNEI}

Hydnum imbricatum, L.

- repandum, L.

auriscalpium, L.

\section{HYMENOMYCETES (cont.)}

Auricularini

Thelephora caryophyllea, Fr.

- palmata, Fr.

- laciniata, P.

Stereum purpureum, Fr.

- hirsutum, Fr.

- sanguinclentum, Fr.

- rugosum, Fr.

- acerinum, Fr.

Hymenochaete rubiginosa, Lev.

- tabacina, Lev.

Auricularia mesenterica, Bull

Corticium giganteum, Fr.

- laeve, Fr.

- coeruleum, Fr.

- ochraceum, Fr.

- quercinum, $\mathrm{P}$.

- cinereum, Fr.

- incarnatum, Fr.

- nudum, Fr.

- confluens, Fr.

- polygonium, $\mathrm{P}$.

- comedens, Fr.

- sambuci, P.

Cyphella galeata, Fr.

Solenia ochracea, Hoffm. (Peziza anomala)

\section{Clavariei}

Clavaria amethystina, Bull

- fastigiata, DC.

- muscoides, L.

- cristata, Holmsk.

- rugosa, Bull

- abietina, Schum.

- stricta, $P$.

- inaequalis, Müll.

- vermiculata, Scop.

- acuta, Sow.

Calocera cornea, Fr.

Typhula Grevillei, Fr.

\section{TREMELLINI}

Tremella foliacea, $\mathrm{P}$.

- mesenterica, Retz.

- albida, Huds.

- intumescens, Sow.

- viscosa, Berk.

Exidia recisa, Fr.

- glandulosa, Fr.

Hirneola auricula-judae, Berk.

Dacrymyces deliquescens, Dub.

- stillatus, Nees.

Ditiola radicata, Fr.

\section{GASTEROMYCETES}

\section{Hypogari}

Melanogaster ? variegatus, Tul. (T. moschatum) 


\section{A HISTORY OF SUFFOLK}

\section{GASTEROMYCETES (comt.)}

Phalloidei

Phallus impudicus, $L$.

- iosmus, Berk.

Cynophallus caninus, Fr.

\section{TRICHOGASTRES}

Batarrea phalloides, $\mathrm{P}$.

Tulostoma mammosum, Fr.

Geaster coliformis, P.

- fornicatus, Fr.

- striatus, DC.

- Bryantii, Berk.

- limbatus, Fr.

- mammosus, Chev.

- rufescens, Fr.

- hygrometricus, $\mathbf{P}$.

Bovista nigrescens, $\mathbf{P}$.

- plumbea, $\mathrm{P}$.

Lycoperdon giganteum, Batsch.

- caelatum, Fr.

- atropurpureum, Vitt.

- saccatum, Vahl.

- gemmatum, Fr.

- pyriforme, Schoeff.

Scleroderma vulgare, Fr.

- verrucosum, $\mathbf{P}$.

\section{MyXogastres}

Lycogala epidendrum, Fr.

Reticularia umbrina, Fr.

- maxima, Fr.

Aethalium septicum, Fr.

Spumaria alba, DC.

Diderma vernicosum, $\mathbf{P}$.

- spumariodes, Fr.

- globosum, Fr.

Didymium hemisphericum, Fr.

- squamulosum, A. and G.

\section{GASTEROMYCETES (cont.)}

Mrxogastres (cont.)

Didymium farinaceum, Fr.

- nigripes, Fr.

Physarum nutans, $\mathbf{P}$. var. aureum, $P$.

- album, Fr.

Angioridium sinuosum, Grev.

Badhamia hyalina, Berk.

- fulvella, Berk.

- pallida, Berk.

- nitens, Berk.

Craterium minutum, Fr.

- leucocephalum, Ditm.

Stemonitis fusca, Roth.

- ovata, P.

Enerthenema elegans, Bowm.

Arcyria punicea, $\mathrm{P}$.

- incarnata, $\mathrm{P}$.

- nutans, Fr.

Trichia fallax, $\mathrm{P}$.

- clavata, P.

- turbinata, With.

Perichaena populina, Fr.

\section{NidulariaceI}

Cyathus striatus, Hoffm.

- vernicosus, DC.

Crucibulum vulgare, Tul.

Sphaerobolus stellatus, Tode.

\section{ASCOMYCETES}

\section{Elvrlitaczi}

Morchella esculenta, P.

- semilibera, DC.

Helvella crispa, Fr.

- lacunosa, Afz.

- elastica, Bull
ASCOMYCETES (cont.)

Elvellacei (cont.)

Verpa digitaliformis, $\mathbf{P}$.

Spathularia flavida, $\mathbf{P}$.

Leotia lubrica, P.

Geoglossum glutinosum, P.

- glabrum, P.

- hirsutum, P.

- difforme, Fr.

Peziza acetabulum, L.

- tuberosa, Bull

- venosa, P.

- badia, $\mathrm{P}$.

- cochleata, Huds.

- aurantia, Fr.

- repanda, Wahl.

- cerea, Sow.

- cupularis, L.

- lanuginosa, Bull var. Sumneri

- sepulta, Fr.

\section{Tubrracei}

Tuber aestivum, Vitt.

SPhaeriaceI

Torrubia militaris, Fr. (Isaria farinosa)

Claviceps purpurea, Tul.

Epichloe typhina, Berk.

Hypocrea rufa, Fr. (Trichoderma viride)

- alutacea, Fr.

Xylaria polymorpha, Grev.

- digitata, Grev.

- hypoxylon, Grev.

- carpophila, Fr.

Poronia punctata, Fr.

Ustulina vulgaris, Tul.

Hypoxylon concentricum, Grev.

\section{ADDENDA}

Since this list was compiled, the following species and rarieties of flowering plants have bcen recorded for the county :-

Viola ruralis, Jord.

Acer campestire, L. var. leiocarpon, Wallr.

Kubus nitidus, W. and N. E.

$R$. Godroni, L. and L. W.

$R$. radula, Weihe.

Hieracium scanicum, Dahlst. W.

Melampyrum arvense, L. W. Recorded in Henslow and Skepper's 'Fl. Suff.' 1860, and a specimen exists collected in 1773 by Sir J. Cullum, so the plant is something more than a casual in the county as Hind ('Fl. Suff.' 1 889) suggests may be the case.

(Orebanche caryophyllacea, Sm. W.).

O. Picridis, F. Schultz. W. Specimen seen in Hb. Skepper.

Colchicum aurumnale, L. var. album.

Also Erythrae pulchella, Fr. has been found in Suffolk West. 


\section{ZOOLOGY}

\section{MARINE ZOOLOGY}

For more than twenty years I have spent a considerable part of the summer months on board my yacht The Glimpse in the various estuaries of Suffolk, chiefly at Harwich, Mistley, Pinmill, Bawdsey, Woodbridge, Orford, and Aldeburgh, occupying much of my time in trawling and dredging, and in collecting on the surface of the water and on the banks left dry at low tide. I have never been in the district at any other season, and what I say about the marine animals relates only to the warm part of the year, from May to September inclusive. In hot weather the temperature of the estuaries is high owing to the great extent of mud banks left dry at low water, and I have known it as much as $74 \mathrm{deg}$. in the Orwell at Pinmill, whereas in winter the surface is sometimes frozen. I have never been out in the more open sea in very hot and still weather, and the highest temperature I have observed there was 67 deg., but no doubt the water in winter is warmer than in the estuaries. These differences must have a great influence on the kinds of animals met with in the different localities and at different seasons of the year. In some cases even a few weeks make a considerable difference, for some of the animals might be called annuals. There is also a great difference in different years. My observations extended from I 882 to 1903 both inclusive, and in that period there were great changes in nearly all districts. Some animals common at the earlier part were scarce or not foind at the later, and the reverse, but it is impossible to say to what cxtent this was a periodic or permanent change. I hope that the account I now give of the numbers and species found in the above-named years may throw light on this question. At the same time it is important to bear in mind that much depends on the methods used in collecting, living on board a yacht being very different from living on shore with the occasional use of a boat.

\section{Characteristic Features of the Coast}

In giving an account of the marine animals of Suffolk it seems reasonable to include those $\mathrm{I}$ have collected on the southern side of the Stour at and above Harwich, though it really belongs to Essex. This I examined much more because the northern side was farther away and less convenient for landing. I have spent a considerable time in Harwich Harbour and collected on the shore and trawled and dredged inside and 


\section{A HISTORY OF SUFFOLK}

vutside. It is an excellent district for collecting animals like Medusae drifted in by the strong tide from the more open sea. Passing westward up the Stour there are large tracts of mud covered by Zostera marina, in some places as much as a mile wide, left dry at low water, and at a distance looking much like green fields. Dr. Laver of Colchester informed me that many interesting fishes may be caught by trawling over these flats, and possibly some interesting animals may occur in parts I have not been able to examine, as for instance near Wrab Ness. I have spent a good deal of time at Mistley, and have obtained some animals which I have not found elsewhere; but on the whole it is too far up the estuary to be satisfactory.

I have lived many months on the Orwell at Pinmill, and have very often dredged and trawled and collected on the surface and shores in a long series of years. Here also are wide tracts of mud covered by Zostera left dry at low water. In some places the edges of these left dry when the tide is low have yielded a number of rare and interesting animals, several of which I have never found elsewhere, whilst one had not been previously found in England. The character of the deeper water near Pinmill changed remarkably from 1895 to 1902 , and furnished an excellent illustration of the effect of changing condition on the animals living at the bottom. At about 1895 and earlier, before extensive dredging operations were carried on to improve the navigation to Ipswich, the water was remarkably clear and the bottom covered by an unusual variety of living animals, some of which I have seldom or never found elsewhere. Later the deposit of mud caused the bottom in 1897 to be covered by tough material built into imperfect tubes by countless numbers of Amphipods, mainly Fassa pulchella. In 1898 and 1899 the bottom was comparatively clean, and still more so in 1900 , but still even in I90I, when it had become fairly good, most of the interesting animals which had been displaced had not returned, and the ground was almost completely usurped by vast numbers of Ascidiella aspersa. Since then I have not been able to visit the locality and learn how far the original conditions have been restored.

Passing north of Felixstowe are some rocks left dry at low water which, unfortunately, I have examined very imperfectly. The estuary of the Deben is in some respects similar to the Orwell and yet differs materially. I have studied it fairly well all the way to Woodbridge and found in considerable numbers several animals which are rare elsewhere.

North of the Deben the conditions begin to change, and the amount of coarse moving gravel increases much and is most remarkable near the mouth of the Alde, very properly called 'Shingle Street.' I have studied this estuary to a good way above Aldeburgh, where it must often be under the influence of fresh water. Taken as a whole the animals differ considerably from those in the Orwell and Deben.

Passing the mouth of the Alde we come to Ortord Ness and enter the North Sea, where the conditions of the coast differ much from those in the more southern parts of the county. The coast here is more 


\section{MARINE ZOOLOGY}

exposed, and the sand and shingle are little suited for collecting marine animals as they are so apt to be washed away or covered up. I know little of the coast except near Dunwich and Southwold, but both there and at Lowestoft the shore looked so unpromising that I never attempted to dredge, which, moreover, would have been very inconvenient when living on a yacht since there is no available harbour except Lowestoft.

\section{Density of The Water}

The amount of various soluble salts as measured by the density of the water has often such a preponderating influence on the local distribution of many marine animals that it is important to consider it specially. It even seems to have a decided effect when the difference is conparatively small. My observations have extended over a considerable area and for a number of years, but have all been made in the summer months from May to September inclusive, just at the time when the distribution of the animals was studied. In the cold part of the year nearly everything would be different.

First with regard to the more open water along the coast. My observations north-west and south-east of Harwich have been sufficiently numerous, but north of Orford Ness have been confined to only one season, viz. I 886. There is a very decided difference in the means of different years and therefore I compare the densities for that year alone. I then found that the density gradually decreased from the Wallet off the Colne to the North Sea off Lowestoft as follows :-

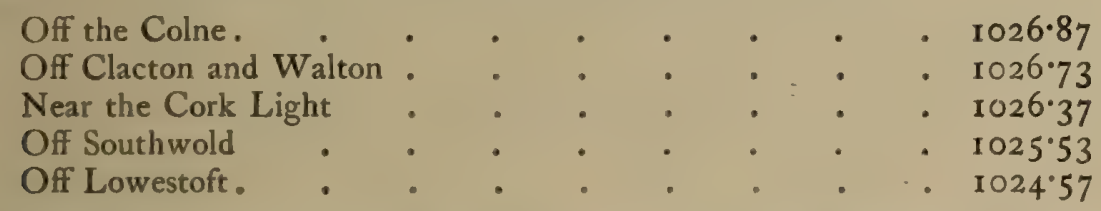

The explanation of this probably is that at the south-west end there is so much more shallow water exposed to evaporation, while at the northcast end the great bulk is of the deeper water of the North Sea. It is, however, very desirable that this conclusion should be confirmed by observations in other years. Judging from what I have learned in the estuaries, such a difference is quite sufficient to materially influence the local distribution of some marine animals.

In comparing the various estuaries one of the most important points to consider is the difference between the mean density of the high and low water in different parts. This alone is sometimes quite sufficient to explain why the animals differ. This difference in density at the lower parts of an estuary depends on a considerable number of circumstances, and may be looked upon as a very good index of the general character of the species found there. To enter into detail would be out of place here, but I may say that the extent of this difference seems to go far to explain the local distribution of many animals as shown in my lists, and on comparing the different estuaries along the coast of 


\section{A HISTORY OF SUFFOLK}

Essex and Suffolk it also seems to show why some are good for the culture of oysters and others unfit, and why they sometimes turn green and in other estuaries lose greenness acquired elsewhere.

\section{Marine and Freshwater Plankton}

When carrying out researches in the Thames in 1882 in connexion with the main drainage of London on behalf of the Board of Works it occurred to me that it was desirable to ascertain the number per gallon of water of such small animals as Cyclops, since their excrements were often so abundant in the mud as to indicate that they might play an important part in destroying the sewage material. Subsequently from the early part of May to the end of September I systematically and regularly carried out similar inquiries in the various estuaries and rivers of Suffolk, Essex, and Kent, and in the more open seawater off the coast. At that time little or no attention had been paid to this subject, which is now looked upon as very important because such small animals form so large a part of the food of larger species.

By the method adopted I obtained in a small bulk of water all the living animals $\frac{1}{10}$ of an inch or more in diameter in a known volume of water, collected near the surface, near the bottom, and half way between. I found it most convenient to give the number per I 0 gallons in order to avoid fractions when dealing with mean results, though as a general rule only $2 \frac{1}{2}$ gallons were collected. No attempt was made to distinguish the species, which would have made the study much more difficult and complicated, but the different groups of animals could easily be recognized by their manner of swimming. The numbers thus found varied enormously from 10 gallons, in fact from only two or three up to 10,000 or more.

One object which I had in view was to ascertain the influence of the varying amount of salts on the kind and number of the small freeswimming animals in passing down the rivers from where the water was fresh till we come to the sea water itself. This is a question of paramount importance in studying estuaries, which in the case of Suffolk have so great an extension. At the same time the results depend not merely on the amount of salts, but also on associated conditions of different kinds. In order therefore to properly elucidate the facts I determined the excess in the weight of the volume of 1,000 grains of rain water. ${ }^{1}$ The rivers and estuaries I studied in I884 were : in Suffolk the Alde, Butley, Orwell, and Stour; in Essex the Colne, Blackwater, Crouche, and Roche; and in Kent the Medway. Since 1884 I have much extended these observations.

1 The late Dr. H. C. Sorby evidently intended to give tables showing the distribution of animals similar to those printed in V.C.H. Essex, i, 74, but no details on this point have been found among the MS. notes relating to his article [Editor V.C.H.]. 


\section{MARINE ZOOLOGY}

\section{Ceratium}

The Orwell is occasionally characterized by the occurrence of a large number of the small Peridinean Ceratium. This multiplies to a remarkable degree in the dock at Ipswich so as to completely alter the colour of the water. In fine sunny weather it rises to the surface and is more or less drifted into the sheltered upper corner, so that the whole looks of a peculiar coffee colour. By careful division and counting I found that near the surface the water may contain several millions per gallon and the bottom only about one-twentieth of that number, and that when cold and dull the surface may contain only 40,000 per gallon. This is the only locality in which I have seen anything of the kind.

\section{PROTOZOA}

Noctiluce miliaris. The number of this per gallon of water varies enormously in different places and in different seasons and in different years. Sometimes they are very few, but on one occasion the average number from top to bottom in Harwich Harbour was about 4,000 per gallon

\section{CALCAREA}

Lescosolenic lacurosa, Johnston. Dredged in the Wallet by Mr. H. W. Unthank

- borryoides, Ellis \& Solander. Found in the Orwell near Pinmill and in the Wallet

Grantia coromato, Ellis \& Sol. - compressa, O. Fabr.
Specimens of G. coronata and compressa, which attain extraordinary size, were procured by Rev. W. B. Clarke in the Orwell (see Bowerbank British Spongiadal), (A.M.N.)

\section{SILICEA}

Chalina oculata, Pallas. In the Orwell near Pinmill and in Harwich Harbour

Halichondria panicea, Pallas. Previous to 1895 this was very abundant in the Orwell near Pinmill, and is more or less common in other places

Isodictya fucorum, Bowerbank. Dredged in the Wallet by Mr. Unthank

- palmata, I Bowerbank. Found in the Wallet by $\mathrm{Mr}$. Unthank

Cliona celata, Grant. Found in oyster shells, into which it bores and does much injury

\section{COELENTERATA (Fellyfish, Sea Anemones, $\mathcal{E}^{c}$.)}

I have not myself collected the more minute species, but $\mathrm{Mr}$. Wm. Cole lent me a collection made by Mr. G. H. Hope in the neighbourhood of Harwich, and the species have been identified by Dr. Walter Garstang.

\section{HYDROZOA}

\section{HydROID ZoOPHYTES}

Coryne vaginata, Hincks. Found by Mr. Hope in June and July

Tubularia larynx, Ellis \& Sol. I have often obtained this from the bottom of my yacht after lying in Suffolk waters

- indivisa, Linn. I am almost certain that $I$ have found this in Suffolk, but it does not appear to be common, and 1 have not seen it lately

\section{HYDROZOA (cont.)}

\section{Hydroid Zoophytes (cont.)}

Obelia gelatinosa, Pallas. I have obtained several fine specimens from the Orwell

Sertularella polyzonias, Linn. Found near Harwich by $\mathrm{Mr}$. Hope

Sertularia pumila, Linn. Mr. Hope says he has found this at all seasons near Harwich

- operculata, Linn. Found by Mr. Hope near Harwich 


\section{A HISTORY OF SUFFOLK}

\section{HYDROZOA (cont.)}

1. HYoroid Zoophytes (comt.)

Sertularia abietina, Linn. Collected by Mr Hope near Harwich

- argentea, Ellis \& Sol. Found near Harwich by Mr. Hope

Hydrallmania falcata, Linn. Collected near Harwich by Mr. Hope

Antennularia antennina, Linn. Found near Harwich by Mr. Hope

Plumularia setacea, Ellis. Specimens bearing gonophores occur in the Orwell near Pinmill

- echinulata, Lamarck. Specimens taken by Mr. Hope in June and October bear gonophores

\section{Medusar \\ (a) Hydromedusa}

I have obtained a number of specimens by means of a tow net, and in sievings of the water; they were not well preserved for indentification, but appeared to be some species of Phialidium. Probably many others could be obtained if specially looked for

\section{(b) Discomedusa}

Shrysaora isosceles, Linn. I have collected more of this in Harwich Harbour than elsewhere. In I 899 I saw an unusually large one at Felixstowe, estimated to have a disc a foot in diameter, and tentacles five or six feet long

Cyanea capillata, Linn. For some years I have seen considerable numbers in Harwich Harbour, in the Orwell, and in the Alde at Orford. They were chiefly of a creamy white, or of a more or less brown orange colour. The amount of solid matter in these animals is surprisingly small. One from which the salt was removed by keeping in dilute formalin was found to contain at least $99 \frac{1}{4}$ per cent. of water

- lamarckii, Peron \& Les. This beautiful blue purple medusa is usually rare, but in September 1884 was fairly common in the Alde near Shingle Street, and possibly I once Jaw it in the Orwell

In 1884 I obtained a medusa in the Orwell, of which I made a coloured drawing, which differed from any of the above species of Cyanea in having the lower appendages of a fine brown colour, but the drawing is not sufficiently detailed to identify the species

\section{HYDROZOA (cont.)}

2. Medusae (cont.)

(b) Discomedusa (cont.)

Aurelia asrita, Linn. This is by far the most abundant of all the medusae. The number in the Orwell is often most remarkable, so that occasionally there appear to be 100 or so in each square yard. I never remember seeing anything like so many in the Stour, Deben, or Alde. Sometimes I have seen specimens in Harwich Harbour 15 in. in diameter. I have an interesting series of more or less rare abnormal varieties, some of which may be due to injuries when young

Rbizostoma octopus, Linn. I have never seen this in any of the estuaries of Suffolk, but have met with a few large individuals in the Wallet, though not so many as farther south-west

\section{CTENOPHORA}

Pleurobrachic pileus, Fleming. Both large and small specimens used to be very abundant in the Stour and Orwell about I 897 , but afterwards seemed to become more and more scarce, and in 1900 and 1901 I obtained very few, though carefully looking for them

\section{ANTHOZOA (Sea Anemones and Corals)}

Alcyonium digitatum, Linn. Found off Harwich outside the harbour, but the specimens are small and not common

Actinoloba diantbus, Ellis. I have often obtained the white and flesh-coloured, but not the dark brown varieties at extreme low water level from the piers at Harwich and Parkston Sagartic troglodites. In the Orwell near Pinmill I have often dredged specimens too small for proper identification attached to large individuals of Ascidiella aspersa

I have been informed that this species occurs on the rocks left dry off Felixstowe, but am not sure the identification wai correct, and it may be the species just noticed

Tealia crassicornis, O. F. Muller. I have collected this many times in the Orwell near Pinmill, and it was very abundant off Harwich at low water level in I 901 . It was also common in the Alde opposite Orford, and may be so now

Halcampa chrysanthellum, Gosse. I have occasionally found this in the mud near Pinmill, but not in later years

\section{NEMERTINEA}

Lineus obscurus, Desor. The only place in which I have found this was in the mud of the Stour near Mistley. It is remarkable for the extent to which it can elongate itself
Amphiporus lactiforeus, Johnston. I have found only one specimen, which was a good many years ago, in the mud of the Orwell at Pinmill 


\section{MARINE ZOOLOGY}

\section{NEMATODA (?)}

Necromema (?). I have seen only one specimen, which was caught when swimming near the surface in Harwich Harbour. It is white, $11 \frac{1}{2}$ in. long, and about $\frac{1}{96}$ in. wide from end to end. When examined with a microscope it is seen to be full of eggs, and is probably a fish parasite which escaped from its host when mature

\section{ANNELIDA}

\section{POLYCHAETA}

Apbrodiva aculeats, Linn. Some years ago I often dredged this in the Stour off Harwich, but I have not obtained it there recently. It is much more abundant in the Wallet

Lepidonosus squamatus, Linn. This occurs in most localities, but not in great numbers

Nereis diversicolor, Mull. Common in the various estuaries in the mud left dry at low water, and in 1901 was very abundant in the Orwell at Pinmill not much below high-water mark. Some specimens are red, from the amount of haemoglobin, others are pale, and some deeply coloured by a peculiar green pigment

- calirifera, Grube. In 1901 this was common in the sandy mud near low-water off Harwich. It can be distinguished at once from the other species by its peculiar manner of swimming

- pelagica, Linn. Before 1901 this was common, and of large size outside Harwich Harbour, being dredged up with masses of the sandy tubes of Sabellaria spinu.osa, but in 1901 this material had been broken up. I found only a few small specimens ur none at all. I have also occasionally dredged it in the Alde off Orford

- longissime. In I90I I obtained from the mud near Pinmill the only specimen of by far the largest Nereis I have ever found in the south-east of England. It is 7 in. long, and above $\frac{1}{4} \mathrm{in}$. thick, and agrees with specimens collected near Queenborough in the Heteromereis collection identified by Dr. E. J. Allen. It was so strong and active that it broke itself in two when put into diluted formalin, which I do not remember to have happened in the case of any other Nereis. On 24 May 1889, when sailing up the Orwell, I saw several specimens of a large Heteronereis swimming near the surface which may have belonged to this species, but none were collected and properly examined

- dumerilii, And. \& M. Edw. Probably common in many places, but often lost out of the dredge. The best specimens I ever obtained were from an old buoy near Pinmill. When kept alive they soon built a semi-transparent branching tube open at both ends, from which they came out to feed on Ulva latissima, and went back again. One which I had kept alive for a considerable time laid in a few minutes eggs carefully estimated at about 10,000 , and had not

\section{POLYCHAETA (const.)}

passed into the Heteronereis condition. I never found it completely changed except when swimming near the surface. Though I have lived so long on the estuaries of Suffolk I saw this only on one occasion, which was in the early morning of 16 July 1898 , when they were so numerous for a few hours in Harwich Harbour that there were probably something like a million. All those caught appear to be males or females containing no ova. The maximum size was about $1 \frac{1}{2}$ in long, which is about one half that of those found at Pinmill, some of which contain ova

Nephthys hombergii, Cuvier. I have obtained many from the mud of the Orwell, and it is fairly common in the other estuaries of Suffolk. It varies considerably in colour, being more or less red or brown

- caeca, Fabr. I have found a few specimens off Harwich and near Pinmill, but it is very much more rare than the other species

Phyllodoce maculata, Mull. Occurs in the sandy mud near low-water level off Harwich, but is comparatively rare

Syllis armillaris, Mull. Obtained from material dredged in the Stour off Harwich, and may be common, but often lost on account of its small size. It is interesting from the manner in which it multiplies by the formation of one or more heads in the length of the body and subsequent division

Nerine foliosa, Aud. and M. Edw. I have found this in the mud of the Orwell, but it appears to be rare

Scolopus armiger, O. F. Müller. All my preserved specimens were collected in Essex, but I think it very probable that I have found it in the sandy mud off Harwich

Cirratulus cirratus, Malm. Though rare elsewhere in the district of the Thames estuary, and I have not found it in any other place in Suffolk, it was most remarkably abundant in 1900 and 1901 in the mudbanks of the Orwell near Pinmill, so that hundreds could be collected in a short time. Though most of them seem to me to be somewhat smaller than they were about 1890 , the species has so greatly increased in numbers that it has probably driven away many other animals that at one time were common. Most of the specimens are of dark colour, but others pale. One that I kept alive laid in a short time 


\section{A HISTORY OF SUFFOLK}

\section{POLYCHAETA (cont.)}

Cirratulus cirratus, Mull. (cont.)

eggs, which by careful division and counting were estimated at about 600,000 , so that it is not difficult to account for increased numbers

- tentaculatus, Flem. Dr. W. Garstang thought that one of my preserved specimens collected about 1890 belonged to this species, but in I 90 I I carefully examined many living individuals, and could not convince myself that there was more than one species

Flabelligera affinis, Sars. About I 890 and earlier this was inconveniently abundant in the Orwell near Pinmill, many objects dredged up being almost covered with it. At the season of reproduction many were seen wriggling about near the surface, and when caught soon deposited eggs, which quickly hatched. In 1899 and 1900 it had become so scarce that I obtained few, and in I 901 none. I never saw it elsewhere

Notomastus latericeus, Sars. Found in sandy mud near low-water level off Harwich, but is apparently not common

Arenicola marina, Linn. Fine specimens are common in the mud of the Orwell and Stour, but in some of the estuaries only small individuals occur

Lanice conchilega, Pall. Fairly common in the mud of the Orwell near low-water level, and probably in many other similar localities

Denophilus (?) tieniatus, Harmer. According to Mr. Harmer this small worm occurs in pools on the shore near Harwich

Amphitrite johnstoni, Malmgren. Before 1901 this was not uncommon in the mud of the Orwell, but was then comparatively rare. One kept alive laid eggs, which by careful repeated division and counting were found to be about two millions in number

Nicolea zostericola, Örst. About I 890 great numbers of this chaetapod crept out of the material dredged up in the Orwell near Pinmill, when it was kept in sea-water, but I have not found any since 1897 , when the character of the bottom became so changed

\section{POLYCHAETA (cont.)}

Polycirrus aurantiacus, Grube. I obtained a very fine specimen from the mud at Pinmill, the body of which was scarcely anything but a mass of eggs. In the course of a day when kept in sea-water, the head end free from eggs detached itself, and seemed still as much alive as ever

Melinna cristata, Sars. Well-grown specimens were common in the mud of the Deben opposite to Ramsholt, and I have found a few small ones near Pinmill and off Harwich

Terebellides straemii, Sars. The occurrence of this in the mud of the Orwell at Pinmill is of much interest, since it had previously never been obtained in England, and only once in Scotland by Dalyell more than a hundred years ago. About the year I 890 I was able to collect quite a number, but have preserved only four mounted specimens, not then knowing that it was so rare. In I90 I I spent much time in looking for it, but was able to find only one

Sabellaria spinulosa, Leuck. Large masses of the sandy tubes built by these worms were common outside Harwich Harbour, but since I 900 they have been broken up and almost disappeared

Sabella pavonina, Sav. Common in the Orwell at the level of low tide, where dark-coloured specimens are more abundant than in most other localities

\section{GEPHYREA}

Priapulus caudatus. In the mud of the Deben near Waldringfrith they were for many years so common near low-water level that I could collect a hundred in a few hours. Many had tails longer than their bodies, and now and then one was found with two tails. At one time large specimens were met with, but after a very cold winter they were comparatively small. During the summer months, when living on the Deben, I never saw any indication of developed eggs

\section{ARTHROPODA}

\section{COPEPODA}

I had collected many of these, but unfortunately the material had been kept too long before it was carefully examined, and had deteriorated too much for the proper identification of the species.

\section{PANTOPODA (Sea Spiders)}

Pycrogonum littorale, Ström. I do not remember finding any in Suffolk, though I can scarcely believe it is absent. At the same time I do not know of any locality similar to that at Burnham in Essex where fine specimens are common

\section{PANTOPODA (cont.)}

Nympbon rubrum, Hodge. By far the best locality I have ever met with for collecting this animal is in the Deben below Woodbridge. When sunny and the water clear, by standing up in a boat they may be seen swimming in a curious sprawling manner, and are easily caught in a sieve fixed to the end of a long stick. The average size is about an inch. I have kept many alive, and it is curious to see how they fold themselves up and lie on the bottom, and when disturbed open themselves out like an umbrella and swim away. 


\section{MARINE ZOOLOGY}

\section{MOLLUSCA}

I have not paid special attention to some groups of these animals, and have recorded only such as attracted my attention when collecting others. I must therefore express my thanks to the Rev. Carleton Greene of Great Barford near St. Neots for the list of shells collected by him, and to $\mathrm{Mr}$. Wm. Cole for a list of those collected by Mr. A. Mayfield of Mendlesham. I have also incorporated the species given by $\mathrm{Mr}$. A. Patterson in his paper on the shells collected by him near Great Yarmouth, published in the Zoologist for 15 May 1903, though no doubt some were obtained just outside Suffolk. In giving the following list I combine all these with my own, and express the authority by the initials, viz. G. for Greene, M. for Mayfield, P. for Patterson, and S. for Sorby.

The nomenclature is that of the Conchological Society in the Fournal of Conchology (Ig0I), No. I, with subsequent corrections by Mr. W. E. Hoyle.

Many of my specimens have been examined and identified by Professor Herdman. ${ }^{1}$

\section{AMPHINEURA}

Craspedochilus cinerenus (G., P.)

- ony: ?

Acanthochites fascicularis,

\section{PELECYPODA (Bivalves)}

Nucula mucleus (G., P., S.)
Anomia epbippium (G., M.)
Mytilus edulis (G., M., P., S.)
Volselle modiolus (G., P.)
Modiolaria marmorata (G.)
- discors (G.)
Ostrea edulis (G., M., P., S.)
Chlamys varius (G., M., P.)
Aquipecten opercularis (G., P.)
Cyprina islandica (G.)
Montacuta bidentato (P.)
Syndosmya nitida (G.)
- alba (G.)
- tenuis (G., M.)
Scrobicularia plana (G., M., P., S.)
Tellina tenuis (G., S.)
- fabula (P., S.)
Macoma balthica (G., M., P., S.)
Donax vituatus (G., P.)
Mactra stuliorum (G., P., S)
Spisula solida (G., P.)
Tapes aureus (S.). In Orwell,
rare
- pullastra (G.)
Cardium exigum (G., P.)
- edule (G., P., S.)
Mya arenaria (G., M., P., S.)
Pbolas dactylus (G., P.)

\section{PELECYPODA (cont.)}

Barnea candida (G., P., S.)

- parva (G.)

Zirphaea crispata (G.)

Teredo navalis (G., P.)

\section{GASTROPODA PROSO-} BRANCHIA (Univalves)

Patella vulgata (G., P.)

Helcion pellucidum (P.)

Acmaea virginea (P.)

Gibbula cineraria (G., M., P., S.)

- umbilicata (G., M.)

Calliostoma zizyphinus (G., M., P.)

Lacuna divaricata (G., M., P.)

- pallidula (G., P.)

Littorina obtusata (G., M., P., S.)

- rudis (G., M., P.)

- littorea (G., M., P., S.)

Rissoa parva (G., M., P.)

- inconspicus (P., S.)

Paludestrina stagnalis (G., M.)

Truncatelle truncata (G.)

Calyptraed chinensis (G.)

Natica catena (G., M., P.)

Bittium reticulatum $(\mathrm{P}$.)

Odostomia unidentata $(\mathrm{P}$.

Turbonilla lactea (G.)

Eulimella commutata (G.)

Turritella communis (G., M.)

Buccinum undatum (G., M., P., S.)

Neptunea antiqua (G., M., P.)

Ocinebra erinacea (G., M., P.)

Purpura lapillus (G., M., S.)

Nassa reticulata (G., M., P., S.)

- incrassata (G., M., P.)

\section{GASTROPODA PROSO- BRANCHIA (cont.)}

Bela turricula (G., M., P.)

- rufa (G., P.)

\section{GASTROPODA OPIS- THOBRANCHIA}

Tetrabranchia

Tornatina truncatula (G., M., P.)

- obtusa (G., P.)

Haminaea bydatis (G.)

Acera bullata (G., S.)

Pbiline aperta (G., M., S.)

\section{Nudibranchia}

Facelina coronata (S.). Orwell

Fiona marina (S.). Orwell and Stour

Acanthodoris pilosa (S.). Stour

Goniodoris castanea (S.). Orwell

\section{CEPHALOPODA}

Sepia officinalis (G., P.)

Sepiola atlantica (S.)

- scandica (P.)

Loligo media (P., S.)

Polypus vulgaris (P.)

About 1890 Sepiola atlantica was much more common in the Orwell and Stour than about 1900 , and the same may be said of Loligo media in the Stour, the numbers of both seeming to decrease year by year.

1 Journ. of Linn. Soc. 'Zoology' xxiii, no. 148 , p. $55^{8}$.

A very remarkable variety of this species was found by Dr. Gwyn Jeffreys in the Deben at Shottisham Creek near Sutton and at Manningtree. It was named by him var. cestwarii, and is described and figured by him in British Concbology, vol. v, p. 205, Pl. ci, fig. 8 (A.M.N.). 


\section{A HISTORY OF SUFFOLK}

\section{POLYZOA}

I have myself paid little attention to these animals, and am obliged mainly to rely on the specimens collected near Harwich by Mr. G. P. Hope, lent to me by Mr. William Cole and identified by Dr. Garstang. The nomenclature is that of Hinck's work on British Marine Polyzoa.

Gemellaria loricata. Harwich (G.P.H.)

Menipea ternata. Harwich (G.P.H.)

Scrupocellaria reptans. Harwich (G.P.H.)

Bicellaria ciliata. Orwell.

Bugula plumosa. Harwich (G.P.H.)

Notamia bursaria. Harwich (G.P.H.)

Flustra foliacea. Met with in the more open water, but not common

- papyracea. Harwich (G.P.H.)

Membranipora lacroixii. Common in old shells, \&c., in the Orwell and elsewhere. The larva (Cyphonantes) is often met with in sievings of the sea water
Membranipora monostachys, Busk, var. fossaria, Hincks. The Ore (Norman)

- pilosa. Harwich (G.P.H.)

Membraniporella melolontha. Dredged in the Orwell (Harmer)

Tubulipora flabellaris. Harwich (G.P.H.)

Alcyonidium gelatinosum. So very abundant in some of the estuaries that the bottom must be covered with it in some places

Vesicularia spinosa. Harwich (G.P.H.)

Amathia lendigera. Harwich (G.P.H.)

Anguinella palmata. Orwell (Harmer). Deben (Norman)

Valkeria uva. Harwich (G.P.H.)

The most interesting species in the foregoing list are $M$. monostachys, var. fossaria and $M$. melolontha, which are, as far as is yet known, confined to the estuaries of the south-east of England (A.M.N.)

\section{ECHINODERMATA}

Echinus miliaris, Linn. This occurs in great numbers in the Stour off Harwich, so as to be the chief feature in the material dredged. It is also common in the Alde some miles below Orford, and was so in the Orwell in I 898

Solaster papposus, Fabr. Occurs in most of the estuaries, but is nowhere abundant

Ophiura ciliaris, Linn. Dredged in Harwich Harbour, and is probably fairly common in many other places

Ophiothrix fragilis, O. F. Muller. Some years ago this was abundant in the Orwell twisted about inside and outside sponges, but was not common in later years. I have also occasionally dredged it in Harwich $\mathrm{Har}$ bour

Synapia inhaerens, O. F. Müller. For a number of years I was able to obtain many excellent specimens of this interesting animal from the mud near low water on the south-west side of the Orwell, a short distance below Pinmill, but it had become comparatively scarce in 1900 , possibly on account of the greatly increased numbers of Cirratulus cirratus. This local abundance of Synapte is remarkable, for I do not remember finding a single specimen in any other locality in the district of the Thames estuary

Cucumaria (?). A fairly fine Holothurian was moderately common in the Stour off Parkeston about 1890 , but I have not found one for some years, though I have carefully dredged for it. Unfortunately no entire specimen was preserved, and those portions which I mounted as a lantern slide are inadequate to prove what species it was

Thyone fusus, O. F. Muller. Found in the Orwell and Stour, but only single specimens in each estuary, and these somewhat small

\section{TUNICATA (Simple Ascidians)}

Styelopsis grossularia, Van Beneden. More or less common in the lower part of the estuaries and more open water, attached to stones, shells, and algae. Common in the Deben near Waldringfield

Polycarpa comata, Alder. Sometimes very abundant in particular places in the Orwell near Pinmill, and less so in the other estuaries of Suffolk. It is usually so covered with attached sand as to look like a sandy concretion
Polycarpa pomaria, Savigny. Was and may still be very abundant in the Deben a little below Martlesham Creek in a part where scarcely any other animal was found. I obtained a number in the Orwell near Pinmill in 1901, though I had not seen any before

Ascidiella aspersa, O. F. Muller. In 1901 this was most remarkably abundant in the Orwell below Pinmill, the bottiom in some places being covered by small ones, and large masses being found like bunches of 


\section{MARINE ZOOLOGY}

Ascidiella aspersa, O. F. Muller (cont.) white grapes. Lower down large and excellent specimens were obtained. Fairly common in the lower parts of all the estuaries. The great number of the larvae in the water is shown by the fact that we have sometimes cleaned off the bottom of the yacht so many young individuals mainly of this species that I estimated them at about 100,000 which must have attached themselves within no considerable period of time - virginea, O. F. Muller. Compared with the above-named species this is rare

Ascidia plebein, Alder. Found in the lower part of the Stour, but is not common
Ascidia producta, Hancock. In Igor this was fairly abundant in the lower part of the Orwell, often much attached along its side to dead shells and other objects

Ciona intestinalis, Linn. In 1890 unusually good specimens could be obtained by dredging at 'the Rocks' in the Deben above Ramsholt, but not in later years. It occurs in most of the other estuaries and in the open water outside, but is not common, and often very dirty

Clavelina lepadiformis, O. F. Muller. I do not remember finding this actually in Suffolk, but cannot believe it is absent, since it is fairly common within a few miles in Essex

\section{COMPOUND ASCIDIANS}

Some of these are conspicuous and attractive objects, and some very obscure and of little interest, except for microscopic observation.

In the later months of summer the banks of the Orwell near Pinmill at extreme low water are an excellent locality for the study of Botrylli, but this is made somewhat difficult by the fact that they so soon die and decompose in hot weather, even when kept in a large aquarium, so that it is almost impossible to compare living specimens collected on different days. The individual colonies differ very greatly in colour from dark blue and dark grey to flesh colour and yellow, and the difficulty is to make out how far this is due to difference ir species or to extreme variation. This fact is fully recognized by Professor Herdman in his paper on the classification of the Tunicata in the Fournal of the Linnean Society. ${ }^{3}$

After many trials I found that it was possible to preserve the specimens mounted in Canada balsam, so that they could be compared in subsequent years with lower or higher magnifying powers. The only important change is that the formalin used in the preparation soon alters the blue pigment of some varieties into a brownish red one, similar to, if not identical with, that which occurs naturally in the closely allied genus Botrylloides. On examining these specimens it was soon seen that not only the well-preserved colour varies from a more or less brown red to pale yellow, but there is much variation in its distribution, and a very great difference in the general character of the individual animals. The difficulty, however, is that these differences are not those taken notice of in the published accounts of the different species, so that, although it is easy to recognize what may be specific differences, it is difficult to assign the proper names. It was soon seen that independent of colouring they could be separated into three groups which differ so much that one feels constrained to look upon them as species until a more extensive series of specimens furnishes connecting links. One of these groups, however, shows great differences, and one must conclude that there is either a single very variable species or else three or even four closely-related species, which differ mainly in the extent and manner in which the colour is distributed. One of these possible species seems to correspond with Botryllus scblosseri, and another may be what has been called $B$. polycyclus, but the difficulty of corroborating the observed structures with published descriptions seems to show that much remains to be learned before anything more can be said than that, though there may be several true species there is very great variation in some members of the group, and it is difficult or impossible to say whether the characters are or are not of specific value.

Botrylloides rubrum, M. Edw. I have found a few specimens on the pier at Harwich and in the Orwell, but it is far from common

- leachii, Sav. Previous to 1900 good specimens could be dredged in the Orwell below Pinmill, but after that they were inferior, mainly owing to the muddy state of the water

Polyclinum aurantium. I have dredged a few specimens in the Orwell, but since the water has been muddy they have been inferior in colour

Didemnum; Leptoclinum; Diplosoma. These occur in the Orwell, but the species have not been studied in a satisfactory manner

Appendicularia (Chamisso). Specimens of these animals are common in the sievings of sea water along the coast

'Aug. 1891, xxiii, 606. 


\section{MOLLUSCS}

\section{(NON-MARINE)}

That Suffolk, despite the apparent lack of diversity in its physical features and the covering of drift with which the greater part of its surface is masked, is a county favourable to the development of molluscan life is attested by the large number of species that make it their habitat.

Not that they are at all evenly distributed. In the middle of the county they are far from abundant, while the Breck district is the poorest. Some species are absent from certain localities while common in others. Thus Hygromia rufescens, one of our commonest snails, is extremely rare in the most easterly part of the county, but common and abundant in all parts farther west. On the other hand Helicella Cantiana (the Kentish snail) is the commonest road-side snail in the east, but rare to the west. While near Mendlesham that agricultural pest, Agriolimax agrestis, the grey slug, is said to be far from plentiful.

Out of the 145 or so species that are known to inhabit the British Islands, no fewer than I 6 have been recorded as occurring within the area, and to this number not more than a bare half dozen are ever likely to be added.

Four records have had to be rejected. Clausilia biplicata, which appears to have been an error of either observation or determination: Sphaerium rivicola, which rests on specimens in the Ipswich Museum doubtfully referred to that neighbourhood, though no examples have been met with by recent collectors despite careful search: Pisidium fontinale and $P$. pusillum, the specimens so named proving on investigation to belong to other species.

The Pseudamnicola anatina, recorded from Oulton Broad in 1904 as new to Britain, was considered by Dr. Boettger, who identified it from dead specimens, to be doubtfully distinct from Paludestrina confusa, and Mr. E. A. Smith, I.S.O., of the British Museum (Natural History), after a careful observation of living specimens lately procured from the same spot, states that the mollusc in question cannot be differentiated from the latter form, pointing out in addition that there is considerable doubt as to what shells were meant by the two separate authors who severally employed the trivial name 'anatinus.' Mr. Smith's conclusion has been adopted in the appended list.

The occurrences in Suffolk estuaries of the two forms Paludestrina confusa and the recently discovered Assemania Grayana, hitherto known 


\section{MOLLUSCS}

in these Islands only from the estuary of the Thames, is of great interest, inasmuch as it adds another link to the chain of evidence that the Thames and the East Anglian rivers were formerly connected with each other and the Rhine in the broad valley now beneath the waters of the North Sea.

Assemania has been found on the other side of this old valley in Belgium and Denmark. Paludestrina confusa on the other hand is known in the fossil state at West Wittering and Stone on the Sussex and Hants seaboards.

Faminia triplicata, another recent discovery, though considered by some competent malacologists to be merely a variety of $\mathcal{F}$. muscorum, is retained as a valid species.

The pretty little molluscs referred to the genus Vertigo seem very partial to Suffolk, all the British species save $V$. alpestris, which is a northern form, being represented. Of these the latest addition has been $V$. Moulinsiana, and though its claim to be considered a Suffolk shell at present rests on the presence of a single, recently dead, shell, there can be no doubt of its existence in some one of those swamps in which it loves to dwell and into which the ordinary collector does not love to penetrate. The species is now known in nine English counties from Derby to Devon, as well as in Galway, and occurs besides in several post-tertiary deposits, so that it is widely spread but probably largely overlooked on account of its uninviting habitat.

The Roman snail (Helix pomatia) here attains the furthest northeasterly limit of its distribution in England. Originally thought to have been introduced by the Romans, whence its popular name, it has now been proved an old inhabitant by its occurrence in a deposit of pre-Roman age near Reigate.

In a Pleistocene deposit at Stutton the following species that no longer live in the British Islands have been found:-Eulota fruticum, Paludestrina marginata, Unio littoralis, Corbicula fluminalis, and Pisidium astartoides. The first three still live on the Continent; Corbicula dwells to-day in the Nile; while the last seems entirely extinct.

A Holocene deposit at Knettishall has yielded a continental form, Planorbis vorticulus, no longer living in Britain.

The literature dealing with the mollusca of Suffolk is not extensive. The most important papers are:-One by the Rev. Carleton Greene (Proc. of the Suff. Inst. of Arch. and Nat. Hist., vii, 275; Additions, xi, 424), and two, one on East, one on West Suffolk, by Mr. A. Mayfield (Fourn. of Conchology, $\mathrm{x}, 295$; xi, 333).

From these, with the assistance of stray notes and the Records of the Conchological Society, the appended list has been compiled. 


\section{A HISTORY OF SUFFOLK}

\section{A. GASTROPODA}

\section{PULMONATA}

a. STYLOMMATOPHORA

Testacella baliotidea, Drap. Blaxhall; Bury St. Edmunds; Dallinghoo Rectory; Woolverstone; Martlesham, near Woodbridge

- scutulum, Sby. Campsey Ash (A. S. Kennard)

Limax maximus, Linn.

- favus, Linn.

Common

- arborum, Bouch.-Chant. Locad : Mendlesham; Wetheringsett ; Haughley ; Rattlesden; Brandon

Agriolimax agrestis (Linn.). Only too common

- laevis (Mull.). Plentiful in damp places

Milax $[=$ Amalia $]$ Sowerbyi (Fér.). Woodbridge ; Mendlesham; Bramford; Ipswich

- gagates (Drap.). St. Margaret's, Ipswich

Vitrina pellucida (Müll.).

Vitrea crystallina (Müll.).\} Common

- lucida (D̂rap:). Ipswich

- cellaria (Müll.). Common everywhere

- Rogersi, B. B. Woodw. [ = glabra, Brit. Auct.]. Common

- alliaria (Miller). Rare : Brandon; Mendlesham

- nitidula (Drap.). Very common in districts

- pura (Alder). Rare: Gt. Fakenham; Haughley; Mendlesham; Thornham; Bramford; Sproughton

- radiatula (Alder). Rare: Haughley; Brandon; Lowestoft; Mendlesham; Wickham Skeith

Zonitoides nitidus (Müll.). Rather rare: Gt. Fakenham; Wyverstone; Brandon, nr. Lake Lothing; Lowestoft ; Needham Market; Sproughton

- excavatus (Alder). Hardwick

Euconulus [Vitrea] fulvus (Müll.). Uncommon: Drinkstone; Knettishall; Tuddenham; Mendlesham; Bramford

Arion ater (Linn.). Common

- intermedius, Norm. Local: fairly distributed

- hortensis, Fér. Common

- fasciatus, Nils. [ = circumscriptus, John.]. Woodbridge; Mendlesham; Thwaite; Needham Market

Punctum pygmaeum (Drap.). Drinkstone; Haughley; Gt. Fakenham; Rattlesden

\section{PULMONATA (cont.)}

a. Stylommatophora (cont.)

Sphyradium edentulum (Drap.). Rare at Walsham-le-Willows; plentiful in Mendlesham Churchyard; Hopton

Pyramidula rotundata (Müll.). Common everywhere

Fairly common Helicella virgata $(\mathrm{DaC}$.$) throughout, ex-$ - itala (Linn.).

- caperata (Mont.). Common

- Cantiana (Mont.). Not common, local, plentiful where it does occur

- Cartusiana (Müll.). One dead specimen at Little Glemham; another at Gt. Fakenham; a flourishing colony on a chalky hedge bank at Needham Market

Hygromia fusca (Mont.). Cockfield; Felsham

- granulata (Alder). Local

- bispida (Linn.). Common. The true $H$. sericea, Drap., appears to have been confounded with this species, and it is thought will prove common in Suffolk

- rufescens (Penn.). Common

Acantbinula aculeata (Müll.). Haughley; Drinkstone; Gunton; Mendlesham; Ipswich

Vallonia pulchella (Müll.). Mendlesham; Bramford; \&c.

- excentrica, Sterki. Knettishall; Westhorpe; \&c.

- costata (Müll.). Hengrave; Tuddenham

Helicigona lapicida (Linn.). Local

- arbustorum (Linn.). Rare: Mildenhall; Oulton; Somerleyton

Helix aspersa, Müll. Very common everywhere

- pomatia, Linn. Found in 1897 by Mr. Claude Morley in a chalk pit at Bramford, but whether it had been introduced there or not seems uncertain; a colony was introduced at Blaxhall in part from Normandy in 1882 , and in part from Surrey in 1884 , but does not appear to have bred

- nemoralis, Linn. Common

- bortensis, Müll. Commoner than the preceding

Ena $[=$ Buliminus $]$ montana (Drap.). Local: in places south-west of Bury St. Edmund's. The species, however, appears to be dying out 


\section{MOLLUSCS}

\section{PULMONATA (cont.)}

a. StYlommatophora (cont.)

Ena obscura (Mull.). Not common: locally and widely distributed

Cocblicopa lubrica (Müll.). Common

Azeca tridens (Pult.). Friston; plentiful in the Mendlesham district; Wickham Skeith; Thwaite

Caecilioides [= Caecilianella $]$ acicula (Müll.). Mendlesham; Aldeburgh; Ipswich; Old Newton; Ixworth Thorpe

Faminia $[=$ Pupa cylindracea Loca $]$, bu t (DaC.).

- muscorum (Linn.). widely dis-

- triplicata (Stud.). Brandon; Barton Mills

Vertigo minutissima (Hartm.). One specimen on the wall of Burgh Castle, Gt. Yarmouth

- antivertigo (Drap.). Rare : near Lake Lothing ; Lowestoft ; Brandon; Mildenhall; Needham Market; Knettishall

- substriata (Jeff.). Thornham; Hopton

- pygmaea (Drap.). Haughley; Tuddenham; Herringswell ; Lowestoft ; Mendlesham; Wetheringsett

- Moulinsiana (Dupuy). Rejectamenta of Little Ouse at Knettishall

- pusilla, Mull. Near Woodbridge; Thwaite - angustior, Jeff. Aldeburgh

Balea perversa (Linn.). Rare : Walsham-leWillows; Mendlesham; Wickham Skeith

Clausilia laminata (Mont.). Rare : Haughley; Hitcham ; Mendlesham

- bidentata (Ström). Common : a white variety was also found at Gislingham

$\left.\begin{array}{l}\text { Succinea putris (Linn.). } \\ \text { - elegans, Risso. }\end{array}\right\}$ Fairly common

\section{b. BASOMMATOPHORA}

Carychıum minımum, Mull. Very common

Phytia $[=$ Alexia $]$ myosotis (Drap.). Coast from Dunwich to Southwold

Ancylus fuviatilis, Mull. Rare : Brandon; Mildenhall; Bramford; Needham Market

Acroloxus [=Velletia $]$ lacustris (Linn.), Rare: Gt. Fakenham; Knettishall (dead shells); Sudbury; Mendlesham; Ipswich

Limnaea auricularia (Linn.). Local

- pereger (Mull.). Common everywhere

- palustris (Mull.). Local

- truncatula (Mull.). Fairly common
I. PULMONATA (cont.)

b. Basommatophora (cont.)

Limnaea stagnalis (Linn.). Common

- glabra (Mull.). 'Suffolk' (Leach)

Amphipeplea glutinosa (Müll.). Mildenhall ; two specimens at Needham Market

Planorbis corneus (Linn.). I Local, but widely

- albus, (Mull.). $\}$ distributed

- crista $[=$ nautileus $]$ (Linn.). Rare: Mendlesham

- carinatus, Müll.

- umbilicatus, Müll. [ = mar- Local, but ginatus, Drap.]. $\quad$ wide ly

- vortex (Linn.). $\quad$ dist r i-

- spirorbis (Linn.). buted

- contortus (Linn.). $\quad$ fontanus (Lightf.). Very local, but widely distributed

Segmentina nitida (Müll.) $[=$ Planorbis lineatus (Walker)]. Rare : Mildenhall; Needham Market

Physa fontinalis (Linn.). Local, but widely distributed

Aplecta [ = Physa $]$ bypnorum (Linn.). More local, but also widely distributed

\section{PROSOBRANCHIA}

Paludestrina confusa (Frau.). Oulton Broad; Blythburgh

- Fenkinsi (Smith). Oulton Broad; Walberswick ; Aldeburgh; River Orwell

- ventrosa (Mont.). Aldeburgh; Southwold; Woodbridge; Lowestoft; Breydon

- stagnalis (Bast.). Woodbridge and estuaries all down the coast

Bithynia tentaculata (Linn.). Common

- Leachii (Shepp.). Local, but widely distributed

Vivipara vivipara (Linn.). Near Oulton Broad ; Ipswich ; Bramford

- contecta (Millet). Oulton Broad; several localities in West Suffolk

Valvata piscinalis (Müll.). Widely distributed - cristata, Mull. Very common

Assemania Grayana, Leach. Blythburgh; Aldeburgh; River Orwell

Pomatias elegans (Mull.). Lavenham; Sudbury ; Bramford

Acicula lineata (Drap.). Ipswich; Sudbury; Oulton

Neritina fuviatilis (Linn.). Rare: Brandon; Mildenhall; Bramford 


\section{A HISTORY OF SUFFOLK}

\section{B. PELECYPODA}

Dreissensia polymorpha (Pall.). Breydon

Unio pictorum (Linn.). Gt. Fakenham; near Mildenhall; near Oulton Broad
Anodonta cygnaea (Linn.). Local, but widely

Pisidium Henslowianum (Shepp.). Mildenhall; distributed

Sphaerium corneum (Linn.). Common

- lacustre (Müll.). Gt. Fakenham; Walsham-le-Willows; Mildenhall ; Barton Mere; Sudbury; Mendlesham

Pisidium amnicum (Müll.). Widely distributed Needham Market

- subtruncatum, Malm. Mildenhall

- pulchellum, Jenyns. Mildenhall

- obtusale, Pfr. Wyverstone; Mendlesham; Lowestoft

- nitidum, Jenyns. Wetherden; Mendlessham; Mildenhall

- Gassiesianum, Dupuy. Santon Downham; Lowestoft

\section{NOTE}

Since the compilation of the above list a flourishing colony of Helisi pomatia has been discovered in a large chalk pit at Rickinghall in the north of the county. 


\section{INSECTS}

Not erroneously has Suffolk been termed 'that best of entomological counties,' for I firmly believe that there is not another in Britain, with the possible exception of Surrey, which lacks the sea-coast species, to compare with it in the number and variety of its insect-fauna ; and if its list of atpresent discovered kinds is not equal to that of other districts the fact must be attributed to lack of observers rather than to paucity of material. It is not my province to set forth the very varied geological and floral features which go so far to influence its insects' presence, but it is only fit that those localities which may most advantageously be visited by the entomologist and their peculiar treasures should be indicated in order; and this will explain the constant recurrence in the following account of some dozen of them with, I trust, unnauseating frequency. The visitor leaves the railway at Bentley station, and, after a glance at the crag-pits at Tattingstone and the Brantham Dale on the east, strikes off west and begins his hunt at the Bentley Woods, where for twelve years I collected weekly or oftener, and on my last visit took a new Psocid! It is a wood locality with oak on the one side, fir on the other, and a marshy meadow between. The Raydon Woods, still keeping westward, are similar though less wild; and, farther on, Assington Thicks is part of the same ancient forest-track, and its fauna has, perhaps, been less disturbed through the ages. Then comes an unprofitable track through Sudbury and Melford to Haverhill in the south-west corner of the county, which is all heavy land, and with the single exception of Stanstead Wood, of little use to us. Turning north we are soon on the chalky slopes about Newmarket, which should yield many new things, though I have always been disappointed there. Some ten miles to the east is Bury St. Edmunds and Tostock, where Mr. Tuck has found many good things in the broad woods, though it is all heavy land. But straight ahead we come to Tuddenham and Herringswell, which once formed part of the great fen level, and we still find such inn-signs as 'The Anchor' there. This is the best marshcollecting in the county: the Angelica grows $8 \mathrm{ft}$. high, one falls over tussock-grasses hidden by herbage, and on the southern side are scattered woods of alder merging into birch, with broad open tracks of wild heather and rabbits' warrens; while on the north it is bounded by the sluggish and weedy Lark River, on the banks of which, a little farther west, is good collecting at Barton Mills and Mildenhall. The chalk at Worlington is worth a visit from the latter town. Continuing northward we come to the best heath collecting in the county ; between Eriswell and Brandon there is heath, as far as the eye can reach nothing but heath-and rabbits. Maidcross Hill at Lakenheath is worth a visit - it is all sand; and Palmers' Heath between it and Brandon is also productive. We are now at Brandon, 


\section{A HISTORY OF SUFFOLK}

and south, east, and west, and along the Ouse River on the north, are all most prolific; but especially Town Street, the island by the Staunch (which is not strictly in Suffolk), and the high sandy fields by the waterworks. It is all grand collecting on the sandy Thetford Warren, to Elveden and Wordwell ; many good things were found in the old days at Livermere, and then we get back to the greasy heavy lands about Mendlesham, Debenham and Monk Soham, or keep along the northern rivers, Little Ouse and Waveney. The latter is good for insects at Wortham and Bungay, and at Beccles begins to broaden out into the Suffolk Broads, which at Barnby and Oulton are in no way inferior to those larger ones of Norfolk. Continuing north-east we find the coast at Corton cliffs prolific; and it is one of the best localities for Aculeates in Britain-through Lowestoft, Kessingland, Benacre and Covehithe and Easton Broads to glorious Southwold. Southwold is an island: to the north are sandhills and sandy heaths; to the south are salt marshes along the River Blyth, the valley of which is all sweeping sandy heath; and this light soil stretches out southward to Westleton, Dunwich, Snape, and Aldeburgh ; and yet farther south to Bromeswell, Butley, Orford, Hollesley and Alderton: anywhere in this 40-mile coast, or within from 5 to Io miles of it inland, good things are constantly turning up, and at Staverton is a genuine primeval forest, well worth a visit. Felixstowe is no better than the rest of the coast, though oftener visited, and its brackish ditches yield well to the water-net. The whole peninsula of which it forms the apex, with its bases at Woodbridge and Ipswich, is sandy land, and the heaths at Nacton, Martlesham, and especially Foxhall, have added species to the British list. The valley of the Gipping is worth a final excursion, for here is where Kirby took most of his classic bees at Barham; Claydon Bridge, Bramford, Great Blakenham and the chalk-pits at Little Blakenham are all productive of their particular marsh and chalk insects. ${ }^{1}$ Roughly we may say that the county is noted for its marsh insects at Tuddenham and Barton Mills in the west, Oulton and Barnby in the north-east, and the salt marshes at Benacre, Southwold, and Felixstowe; for its heath or 'breck' insects about Brandon, Elveden, and Icklingham, which are very different from the ordinary heath insects of the coast sands and Foxhall; and, in a less degree, for its forest insects at Bentley, Assington, Tostock, and Staverton. It is just this variety of wooded heavy land in the south, chalk in the west and south-east, sandy valley-gravels in the north-west, and light heathy coast line with its external salt marshes, that enables us to enrol six and a quarter thousand different kinds of insects in the list for Suffolk.

\section{ORTHOPTERA}

\section{Earwigs, Grasshoppers, Crickets, Cockroaches, \&c.}

Even if we include the Dermaptera or earwigs, there are only about forty different kinds of these voracious and interesting insects in Britain, so it is hardly surprising to find that just half this number have been found to inhabit Suffolk. Of our forty kinds several were not originally natives, but have, at various more or less remote periods, been introduced in ships plying between English and Eastern ports. Some of them are of such extremely rare occurrence as to be regarded as only casual visitors; and others so nocturnal and retiring in their habits as to be but rarely seen, 


\section{INSECTS}

even where they exist in numbers. Several kinds were observed about Yarmouth by the Pagets; and a few on the coast by the Rev. E. N. Bloomfield and Mr. E. Saunders, but there are no notable records of them in periodical literature.

The little earwig, Labia minor, is of general distribution, and is not uncommonly found singly, flying in the sunshine in June, July, and September, as well as upon the damp mud at the margins of ponds, at Bentley, Claydon Bridge, Walton, Wickham Market, Framlingham, Tuddenham Fen, and, Paget says, about Yarmouth. ${ }^{1}$ Our only other earwig is the ubiquitous Forficula auricularia, which I have frequently seen fiying to the light of street lamps, beneath which, if one did but look, they often congregate in great numbers; by day they hide away beneath stones, \&c., but may occasionally be seen assimilating the nectar from Angelica and ragwort flowers; and upon one occasion my hand received quite a sharp pinch from the forceps, usually supposed only capable of folding away the wings. I have noticed the variety forcipata, Steph., on nettles at Belstead; and Paget mentions its occurrence on the Yarmouth sandhills. Only two of the four smaller cockroaches have been noticed, of which the first, Phyllodromia germanica, has established a footing in Ipswich houses; the latter is Ectobia Panzeri, and is common upon the coast sandhills among the marram grass from Felixstowe to Corton; Saunders found it at Lowestoft in August, and the larvae are equally common in June and July. In the Hope Museum at Oxford there is one specimen of this species labelled 'Rev. W. Kirby, lapponica,' which was very likely taken in Suffolk nearly a century ago. ${ }^{2}$ Paget says the common or household cockroach, Blatta orientalis, was to be found in most Yarmouth houses in 1834 , and it is doubtless only too common throughout the county, though it would be interesting to know if this imported species has yet penetrated to the more rural districts; we have none at Monk Soham. In June I 894 I took a male which appeared to have been attracted by, and was crawling beneath, an electric light in the middle of Ipswich. B. Australasiae is not infrequently imported in linseed, \&rc., from abroad.

Among the grasshoppers, Mecostetbus grossus has been found in several Norfolk localities, and appears to be the species referred to by Paget under the name Locusta flavipes, which he says was common in Belton Bog, Suffolk. All the Stenobothri, except $S$. lineatus, have been observed here; $S$. viridulus is not uncommon in marshy spots about Beccles, Barnby Broad, Southwold, and Tuddenham Fen. Some doubt must be entertained regarding the record of $S$. rufipes, which I took at Beccles in 1892 , but am now unable to remember upon which side of the Waveney. Bloomfield has found S. elegans in July at Southwold; it has occurred to me in Tuddenham Fen, and not uncommonly in the marshes at Burgh Castle in August. S. bicolor and S. parallelus are abundant everywhere; one day my attention was called to two males of the former which were apparently courting a single female at Foxhall by the unusually dull note they were both emitting; and on another occasion at Southwold I found an example on a first-story window, which was a curious circumstance in so low-flying a species. Of Gomphocerus I have only noticed the common G. maculatus, which is widely distributed about Foxhall, Corton sandhills, Southwold, and on the Breck sands at Lakenheath and Brandon. The remainder of the short-horned grasshoppers, with two exceptions, cannot be termed indigenous since they are but casual visitants. Both these exceptions are members of the genus Tettix; T. bipunctatus, which appears to be the Acridium bipunctatum, taken commonly about Yarmouth by Paget, is an extremely abundant kind and, unlike most Acridiodea, hibernates in the perfect state, the larvae being found in August. $\tau$. subulatus is very local in Suffolk, where I have met with it only among the dwarf sallows in the Poor Fen at Tuddenham in June.

Of the long-horned grasshoppers, Leptophyes punctatissima is generally distributed ; it sometimes occurs upon 'sugar' in the Bentley Woods, and has been observed at Felixstowe, Bramford, Assington, Farnham, Dennington, and Monk Soham. The pretty green Mecomma varium is not rare on oaks and frequently visits sugared trees at Ipswich, Bentley Woods, and Tostock, but is rarely seen in its earlier stages. Throughout the fen and broads districts the lovely chocolate and green Xiphidium dorsale is to be swept from reeds: I first saw it not uncommonly in Barnby and Benacre Broads in August, occasionally upon the flowers of Angelica, and it has subsequently turned up in Tuddenham Fen and the salt marshes about Southwold; it does not appear to obtain maturity till the end of July, and is quite possibly the Acrida aptera which Paget records as common in damp places in Lound Wood in September. The great green Locusta viridissima is occasionally not uncommon on the banks of the Gipping at Sproughton; and in the same neighbourhood I have found it licking the stylopods of Angelica sylvestris at Claydon in September ; Mr. Tuck has taken it at Bury St. Edmunds, Mr. Maynard at Orford, and there are specimens in Wheel's collection from Assington. Thamnotrizon cinereus is mainly nocturnal in its habits, and is very frequently attracted by 'sugar' in the Bentley Woods; it has also occurred at Bungay and Wherstead. Among the

It was flying in great numbers in my garden at Monk Soham on I May 1908.

' Cf. Ent. Rec. 1900, p. 98. 


\section{A HISTORY OF SUFFOLK}

crickets we can only boast of Gryllus domesticus, which is often heard shrilling in bake-houses in Ipswich and Yarmouth, though rarely seen; it is said to be an immigrant from northern Africa, appears to be confined to such warm situations as the above, and has, at least in Suffolk, never been found in the open country. Mr. Tuck tells me he has found Gryllus campestris about Tostock, in Mid-Suffolk; and it is extremely probable that the Mole Cricket (Gryllotalpa vulgaris) also lives in the county, since Kirby and Spence record it from Ickleton, in Cambridgeshire.

\section{NEUROPTERA}

\section{Dragon-fies, Stone-fies, Lacewings, Caddis-fies, छc.}

Under this head I shall, for the sake of convenience, group all the heterogeneous families that have at various times been allowed to pass as possible members of this order of insects since, in a work like the present, it is good to give as comprehensive a conspectus as can be set out. Among the dragon-flies we find many species have been recorded from Suffolk in The Entomologists' Annual of 1861, Entomologists' Monthly Magazine, and The Entomologist, in Evans' British Libellulidae, MacLachlan's Trichoptera, and Lucas's recent work; Paget refers to a few, and Winter collected some nice things in the neighbourhood of Aldeby near Beccles, which are mentioned in the Entomologists' Weekly Intelligencer, vol. ix. Personally I have never been able to raise the enthusiasm in these insects necessary to their thorough investigation, but have picked up a goodly number at odd times by casual collecting ; the present list forms a fair basis for future work, but can scarcely be considered thoroughly representative of, nor to do justice to, our fine stretches of both running and stagnant water. My sluggishness in this direction is the more inexcusable, since Mr. MacLachlan had hoped great things from our broads of the north-east.

The Thysanura have, with little justification, been included in this Order, and may be treated of here, since but two species have been noticed. I have no doubt that the Silver Fish, Lepisma saccarina, so common in the store-cupboards of old houses, occurs here in plenty, though I have met with it only in my own house and in Monk Soham Church. The other species, of which I shook two examples out of a grass-sod at Hitcham, Prof. Henslow's parish, early in October 1899, is Campodea staphylinus, and is said by Lord Avebury to represent the ancestral type of insect. These Thysanura undergo no metamorphoses, and never develop wings; they consequently fall into the ametabolic section of the Insecta. The Plecoptera, Ephemeridae, and Odonata, on the contrary, do undergo transformations of a modified form, that is to say, that, although the larva, pupa, and imago differ from one another, there is no quiescent stage in their lives. To the former also belong the Collembola or 'spring-tails,' of which a great many species are extremely common, though they have never been adequately collected, in Suffolk. In I904 I put a few specimens of this curious group in spirits while collecting other insects in the Ipswich district; they proved to belong to eight species: Orchesella cincta, Linn.; O. pilosa, Geof.; Tomocerus plumbeus, Linn. ; Templetonia crystallina, Müll.; Seira domestica, Nic.; S. Buskii, Lub.; the rare Lepidocyrtus curvicollis, Bour.; and DeGeeria Nicoletii, Lub. Among the Pseudo-neuroptera, Atropos divinatoria is sometimes quite a pest in my collections, and radical measures become occasionally necessary for its extermination. I have taken at Sproughton, Ipswich, and on gorse in the Bentley Woods, Clothilla picea, or the rural book-louse. Of the pretty genus $P$ socus, $P$. longicornis is widely distributed on trees in the Bentley Woods, Barham, and Barnby Broad; $P$. nebulosus is not rare in the former locality in the autumn; I have taken $P$. fasciatus at Barton Mills and Brandon in June, and $P$. bifasciatus, recorded from Suffolk by Hagen, in Tuddenham Fen in September. Hagen also records $P$. variegatus, which has occurred to me at Freston, and $P$. morio from our county. Stenopsocus cruciatus is common in the Bentley Woods, Staverton, Ipswich, and Monk Soham ; S. immaculatus and S. stigmaticus are also found here, the latter at Foxhall and Brandon. Caecilius pedicularius seems to be attracted by light since I have taken it in my study at night; once it occurred to me commonly in a dead calf at Foxhall $;^{1}$ it is doubtless abundant, and C. favidus has been observed on the banks of the Gippingat Ipswich in September, and at Tuddenham, Wherstead, Freston, and Foxhall ; C. piceus was swept from reeds at Southwold in September 1907, and C. fuscopterus was very common in Bentley Woods in September 1904. In October I 899 I was so fortunate as to sweep a specimen of the extremely rare $C$. atricornis in a small marshy wood at Bramford ; ${ }^{2}$ this would appear to have been little more than the second known specimen; and in September 1907 another turned up in a ditch at Mildenhall at the other extremity of the county. Mr. J. J. King took about twenty examples of $C$. Kolbei, Tetens, the first in Britain, on 16 August 1892, just within the entrance to Tuddenham Fen, by sweeping the dry stems of ragwort, in the vicinity of Scots fir. ${ }^{3}$

${ }^{2}$ Cf. Ent. Mo. Mag. 1899, p. 273.

Ibid. 272.

'Ibid. v, 244. 


\section{INSECTS}

Elipsocus unipunctatus is not uncommon at Brandon, Whitton, and the Bentley Woods ; E. byalinus at Monk Soham, Bentley Woods, and Tuddenham Fen; E. Westwoodi has occurred to me at Boxford and Tuddenham in July; and $E$. abietis is everywhere common on fir trees, upon which four specimens of $E$. cyanops, Rost., are recorded from Tuddenham Heath at the end of June 1880.4 Recently $E$. flaviceps and $E$. consimilis, both from Foxhall, have been added to our list, together with Ectopsocus Brigsii from Wherstead and the Bentley Woods in March, as well as Peripsocus alboguttatus in September and August in Tuddenham Fen, and P. phaeopterus at Brandon. Much remains to be done among the Perlidae, of which the record of even Chloroperla grammatica is not positive, though I believe I took it here in 1893 . Leuctra fusciventris has been swept at Foxhall and Wherstead, where L. Klapaleki is not rare on alder in the autumn; and L. geniculata has been found at Brandon Staunch in September. Nemoura variegata is common, especially in the early spring, at Bentley and Aspall Woods, Sotherton, Barham, Ickworth, Sudbury, and Tuddenham. N. cinerea has once been found about Ipswich, but $N$. inconspicua occurs in the Bentley Woods and Bixley Decoy annually in April, and sometimes again in September, when $N$. praecox may also be found in the latter locality. Mayflies are often common, but there appears to be but very small variety among them; Ephemera vulgata is very rarely as abundant here as in other counties where I have observed it; Leptophlebia marginata has only turned up once, on the banks of the Gipping in May, though quite possibly it constantly occurs there; L. submarginata is rarely noticed at Foxhall in the same month. Clöeon dipterum is by no means uncommon in Southwold, Assington, Shrubland Park, and $\mathrm{Mr}$. Chitty once took C. simile at Brandon in June; though the ubiquitous Baetis Rhodani is everywhere met with.

Among the Odonata, or dragon-flies, we are able to instance most of the commoner kinds as of indigenous occurrence. Sympetrum striolatum is common, $S$. flaveolum flies in Tuddenham Fen in August, but has not been seen elsewhere; Platetrum depressum is not very common, though widely distributed; Libellula quadrimaculatum has occurred to me in the marshes at Beccles, to Prest near Lowestoft, and to Paget rarely at Lound. Of the very rare and local L. fulva I captured an example in the marshes at Beccles in 1892,5 another in Barnby Broad in July 1905 ; and Paget records it from Lound. Orthetrum caerulescens I saw abundantly on the outskirts of Henham Park, Covehithe, and at Hulver Bridge in 1900; and $O$. cancellatum is nearly certain to be found in the broads of the north-east, since I have noticed it in Wroxham Broad in Norfolk. Cordulia aenea is said to be rare in Fritton Wood in May, and has several times been mentioned from Martlesham Heath ; Brachytron pratense is recorded by Lucas from the Lowestoft Broads, and I found it at Henstead in 1905. Harwood has found the rare Aeschna mixta flying over the Stour at Wiston, and I took an example in a Beccles house in $1892 ;{ }^{6}$ another has occurred to me in an Ipswich garden in October; and it is very probable that Paget's $A$. varia, Curt., is also referable to this species. Aesibna cyanea and $A$.grandis are both quite common. ${ }^{7}$ Both kinds of Calopteryx have turned up and Fitch reports great numbers of $C$. virgo near the source of the Stour. ${ }^{8}$ 'The smaller dragon-flies have been much neglected. Lestes sponsa at Westleton, Claydon, Oulton, and Barnby Broads; Platycnemis pennipes at Blakenham, Claydon, Bentley Woods, Sproughton, and Bures; with the common Pyrrhosoma nymphula and Ischnura elegans have been noted. Erytbromma najas, at present uninstanced, certainly only requires a little searching in June to put in an appearance. Agrion pulchellum at Brandon, Lowestoft, and Tuddenham Fen, and A. cyantbigerum at Blakenham, Claydon, and Barnby Broad are uncommon, though $A$. puella swarms everywhere from Lakenheath and Wortham to Nayland and the coast salt-marshes.

The Neuroptera-plannipennia, regarded by Prof. Miall as the true representatives of the Order, are in very fair profusion in Suffolk, where Sialis lutaria swarms. The curious snake-fly, Raphidia notata, occurs sparingly in Belstead Wood and Assington Thicks, which, though 30 miles apart, have a wonderfully analogous fauna; upon one occasion I bred this species from a larva found in burrows in a solid holly stem. $R$. xanthostigma has occurred to me singly at Brandon, and in a very wet part of Tuddenham Fen in June. Sisyra fuscata is often common by running water; Micromus variegatus occurs at Stanstead, Tuddenham, and BentleyWoods, where, as well as at Wherstead, $M$. paganus has been found. The pretty genus Hemerobius is well represented by $H$. nitidulus on pine trees in Bentley Woods, $H$. bumuli commonly, $H$. lutescens at Belstead and Harleston, $H$. limbatus common from Brandon to Ipswich, $H$. stigma abundant in Belstead Woods, and beaten from pine-hedges at Elveden and Tuddenham in August, $H$. subnebulosus occasionally at electric light, \&c., about Ipswich and Lowestoft; $H$. nervosus once found at Bentley in May, and $H$. concinnus beaten from fir in the same locality at the end of June. At Kessingland I have swept $H$. micans among marram grass.

Ent. Mo. Mag. xvii, 2 1, 71 .

Ibid. 1897 , p. 106.

'Ibid.

- Lucas says Aeschna isosceles used to be common near Yarmouth, but there is no direct evidence of it having occurred on our side of the border, though five specimens were taken and many seen near Stalham in the Norfolk Broads in 1903.

Entom. 1879, p. 288. 


\section{A HISTORY OF SUFFOLK}

Of the twelve British Chrysopae, all but $C$. abbreviata have been observed by me here; the large C. vittata was flying in Bentley Woods in June; C. flava, flavifrons, tenella, septempunctata, and the widely distributed $C$. phyllochroma are all attracted to electric light in Ipswich; $C$. alba was taken about Lowestoft; $C$. prasina and $C$. ventralis in Bentley Woods (Mr. Gimingham has also found the latter recently at Dunwich); $C$. vulgaris and $C$. perla are generally distributed, the former often occurring on reeds in salt-marshes. The pretty scorpion-flies Panorpa communis and P.germanica are very widely spread; and the rarer $P$. cognata occurs in Barnby Broad in July. I have once or twice noted Coniopteryx psociformis in the Bentley Woods in July ; C. lactea at Brandon, Foxhall, and Freston in June, and C. aleyrodiformis on elms and sallows at Wherstead and Foxhall.

The water flies, caddis worms, or Trichoptera, are the only section of the Neuroptera, with the exception of the Plannipennia, which undergoes complete transformations, and is consequently known as holometabolic. The large and handsome Phryganea grandis, which I have bred from its larva at Ipswich, is not infrequent; $P$. striata has turned up in my house at Monk Soham in May ; and Mr. A. Gibbs has taken several $P$. varia at sugar in the marshes at Orford. Neuronia ruficrus and Agrypnia Pagetana (which Curtis named after our Yarmouth observer) are uncommon; I have taken the latter once or twice in the broads about Lowestoft, and Winter says that a fine specimen was captured by the River Waveney, near Beccles, in 1860. Colpotaulius incisus is common, and Grammotaulius atomarius with Glyphotaelius pellucidus not rare. We have most of the extensive genus Limnophilus in Suffolk; L. rbombicus, marmoratus, lunatus, politus, affinis, and sparsus are all common and widely distributed. L. nigriceps once occurred to me not uncommonly on the banks of the Gipping near Ipswich in October. ${ }^{9}$ Mr. MacLachlan tells us $L$. borealis once turned up in some abundance in the Suffolk Broads. ${ }^{10} \quad L$. auricula has been found at Beccles, Brandon, and Tuddenham; $L$. flavicornis and $L$. centralis in my garden at Monk Soham; and $L$. extricatus once in July at Ipswich. L. birsutus is probably abundant in the broads in June; I have taken it at Mildenhall ; L. fuscicornis is not uncommon on sugar, and Anabolia nervosa often a perfect pest. Phacopteryx flew in to light at Monk Soham House in September 1906. Stenophylax permistus, sequax (also taken at Monk Soham), and stellatus rarely put in an appearance about Ipswich, where, at electric light, on 23 April 1895, I caught the only British specimen of Mesophylax aspersus. ${ }^{11}$ Halesus radiatus and Chaetopteryx villosa are quite common; but Sericostoma personatum has only occurred to me at Farnham, on the banks of the Alde, and on those of Belstead Brook at Wherstead. Notidobia ciliaris and Göera pilosa are widely distributed, though I have taken but one Lepidostoma birtum near Ipswich in July, in which month Agraylea multipunctata has been attracted to artificial light at Southwold.

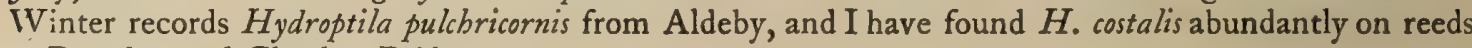
at Brandon and Claydon Bridge.

Of the Leptoceridae, Molanna angustata is common and, with Leptocerus fulvus, senilis, cinereus, and aterrimus, may be seen flying low on the surface of the Gipping and Little Ouse. I have observed Triaenodes bicolor at Oulton Broad and Walberswick; and T. conspersa has been attracted to electric light in the middle of Ipswich. The pretty little Mystacides nigra and azurea are not rare at Brandon and Ipswich; I took $M$. longicornis in Beccles in September 1907, and I have since confirmed what MacLachlan thought ${ }^{12}$ was probably a mangled Oecetis lacustris at Blakenham, while Adicella reducta has turned up in June at Tuddenham Fen, and Setodes tineiformis in August in Barnby Broad. Hydropsyche angustipennis and $H$. guttata are probably common, Tinodes waeneri being abundant everywhere from Brandon to the Gipping. Lype phaeopa has occurred by sweeping at Belstead and on the banks of the Little Ouse and of the Gipping ; and Plectrocnemia conspersa occasionally flies to sugar in Ipswich, Tuddenham Fen, and Bentley Woods. I have only seen Polycentropus flavomaculatus at Nayland, Icklingham, and Brandon, though Holocentropus picicornis seems to have a wide range about Bramford, Barnby Broad, Southwold, and Lowestoft. Towards the end of April 1897 I was so fortunate as to make the third British capture of $H$. stagnalis, Alb., in the Bramford marshes $;^{13}$ there was no sign of it in the same locality at the beginning of May 1898 ; but on the gth of that month in 1899 it swarmed upon the water-weeds of one particular pond there, and I captured a fine series. Of the rest, Cyrnus trimaculatus is not uncommon from Ipswich to Blakenham, often upon Scrophularia; Agapetus fuscipes and Berea pullata are found at Foxhall, though the former appears to be uncommon there ; and in July 1903 I swept $B$. maurus in Tuddenham Fen.

From the above account of the Neuroptera, in the broadest sense of the term, which have been actually observed in Suffolk, it is evident that there are but $\mathrm{I}_{4}$ species, including Hydroptila pulchricornis, which Winter records as having been abundant on the railway bridge across the Waveney, near Aldeby, which connects this county with Norfolk. This is indeed a small total for our wellwatered county, when we consider that nearly 450 kinds have been found in Britain.

Cf. Ent. Mo. Mag. 1898, p. 21.

"Cf. Ent. Mo. Mag. Nov. 1895 .
${ }^{10}$ Trans. Ent. Soc. 1865 , p. 39.

12 Ibid. 1897, p. 266. 106 


\title{
INSECTS
}

\section{HYMENOPTERA}

\author{
Ants, Bees, Wasps, Saw-fies, Gall-fies, Ichneumons, \&
}

The classification of this Order has always been a difficult subject owing to the dissimilarity exhibited by the great number of families, \&c., into which the vast variety of its species has been divided. This is by no means the place to enter into the subject, of which I shall only say that those kinds noted in Suffolk have, in the following brief account, been grouped more or less in the three-fold manner propounded by Konow in the Deut. Ent. Zeit. of 1890 , and followed by me in the Ichneumonologia Britannica, though the minor groups stand, in some instances, as placed by Ashmead in the Proceedings of the U.S. Nat. Museum of 1900 , which was in the first place a dichotomous system. The three sub-orders of which the whole is composed are :-The Vespoidea, or Aculeata with Chrysididae; the Ichneumonidea, including all the entomophagous (as well as the phytophagous Cynipidae) kinds; and the Tenthredonidea, or sawflies and Siricidae.

\section{VESPOIDEA}

\section{Chrysididae}

Of the twenty-one species recorded from Britain by Morice, ${ }^{1}$ we find that twelve have been observed in Suffolk. All these have been quite recently noted with the single exception of Cleptes pallidipes, which Paget says used to be common on the Yarmouth sand-hills in I834; Mr. R. C. L. Perkins tells me he has seen it about Brandon, and I have myself found it on flowers by the Gipping in June; C. nitidula, recorded from Suffolk by Smith, ${ }^{2}$ has occurred to me at Bramford, Mildenhall, and upon Chaerophyllum in Brantham Dale. We owe the inclusion of Notozus Panzeri and Elampus auratus to Perkins, who noted them in the Breck district in 1899, together with $E$. aenea, which I have once captured upon tansy in the Bramford marshes in the middle of July. Hedychridium ardens has turned up about Mildenhall, and Morice records the very rare $H$. integrum from the same locality. ${ }^{3}$ I was so fortunate as to take a couple of the lovely Hedychrum nobile upon the flowers of Heracleum at Bramford in 1901, one with a blue, and one with a green, thorax, and both with brilliant red-gold body. Of the ten British species of Chrysis, we can boast but four, though $C$. birsuta and $C$. viridula, which have been found in Norfolk, probably inhabit the county. $C$. cyanea may often be seen about the borings of Fossors at Bentley and Assington Woods, Brantham Dale and Tuddenham Fen; C. ignita, the ruby-tail, is even commoner at Finborough, Ipswich, Hollesley, Bealings, Brantham, Dodnash, and Bentley Woods; Perkins has found C. Ruddii in the Breck district; and one or two examples of the rare C. succincta occurred to me on Heracleum in the Bentley Woods in 1894 , though I have not seen it there since that time. So few localities appear to be honoured by the presence of this last species that I may be forgiven for mentioning my capture of an example at Oxshott in Surrey, I0 July 1901. C. fulgida should also occur with us, since it is found in the fens at Wicken, in Cambridgeshire.

\section{Aculeata}

In treating of this group it will be best to follow the nomenclature generally in vogue among British students at the present time, in which the ants hold first place, followed by the fossors and wasps, the bees being grouped at the end of the sub-order. In the last, we in Suffolk, take preeminence in historical interest by virtue of the Rev. William Kirby's fundamental work upon the British species, his Monograpbia Apum Angliae, which was published in Ipswich in 1802 ; in it we learn a great deal concerning the local entomologists of that date:-Nicholas Gwyn, M.D., of Ipswich; Rev. Peter Lathbury, of Woodbridge ; Rev. James Coyte, of Ipswich ; Rev. Revett Sheppard, B.A., curate of Nacton, \&cc., \&c. Many additions, as well as notices of the other three divisions, were brought forward by the Pagets, Curtis, and Parfitt; Fred Smith in his Catalogues of Fossors, and Bees, and in the Entomological Annual, 1859-68; Rothney, Morice, and Tuck in the Entomologist's Monthly Magazine, Kirby in Transactions of the Linnean Society, and Ransom in the Entomologist. Bridgman, R. C. L. Perkins, A. Piffard, Harwood, and others have also collected here. Mr. W. H. Tuck published a very full list of the species observed by him about Tostock in the Transactions of the Norfolk Naturalists' Society in 1 895 ; and early in 1898 I brought forward a similar one for the Ipswich district in the Entomologist. Mr. Edward Saunders has found many rare

Ent. Ann. 1862, p. 85.

${ }^{3}$ Ent. Mo. Mag. 1900, p. 108. 


\section{A HISTORY OF SUFFOLK}

kinds about Lowestoft, which are mentioned in his Aculeata of the British Islands. From this mass of material I was enabled to draw up in I 899 , my 'Aculeata of Suffolk,' ${ }^{4}$ and in it to enumerate 282 species out of a total of 374 in all Britain; and yet a few of the commoner fossors had not been met with. Since that time only thirteen species, of which four were for the first time known to inhabit Britain, have been added, bringing the total to 295 different kinds-the longest county list, I believe, in England, with perhaps one exception. It will, consequently, be unnecessary in the following summary to refer to the insects in detail, and I shall indicate only those kinds which are of special interest, of historical note, or individual rarity.

Regarding the ants, we find in the Proceedings of the Entomological Society, 1834, xxv, that Formica rufa is sometimes quite troublesome in the county, but it has now become rare and very local. Smith, in his Fossorial Hymenoptera tells us that Kirby sent Formica emarginata to Latreille, though no example of it existed in the former's collection. Smith further states ${ }^{5}$ that a female, $F$. brunnea, the only British specimen, had been captured on the coast at Pakefield; this was probably referable to Lasius umbratus. He also once took the very rare Myrmecina Latreillei at Southwold in 1859. Stenamma Westwoodi has been found in a bees' nest at Tostock and in moss in the Bentley Woods; and the interesting little Monomorium Pharaonis, always found in shops and houses, where it is imported in foreign produce, once occurred to me by sweeping a hedge-bottom at Wherstead, at least a mile from any shop, \&c. Mutilla europaea used to be found at Southwold and upon Lound Heath, which I am informed is now reduced to a very small area, practically only a clay-pit, and few know it by its old name. In the Entomological Annual, 1866, Smith records the rare Methoca Icbneumonoides from Suffolk; and Tipbia femorata is everywhere abundant in the Breck district upon Angelica and carrot flowers in August, as well as upon the coast. The fourth British specimen of Pompilus unicolor was captured at Pakefield in 1858; and Perkins has turned up $P$. bicolor, niger, and spissus about Brandon. Salius obtusiventris has been found at Needham Market and Tostock, whence Tuck sent me a single male, probably the first of that sex noticed in Britain, in July 1900. Kirby, in erecting the genus, records Ammopbila sabulosa, birsuta, and lutaria, which have all been since found here, from Suffolk. Spilomena troglodytes is not uncommon about Brandon; and in an Ipswich garden I have several times taken Stigmus Solskyi among Aphides upon Heracleum, which fact appears to clear up the doubt expressed by Saunders as to its larva's pabulum. Pemphredon Wesmaeli and P. morio, till lately one of our very rarest British species, have both been found by Tuck at Tostock; the latter has also occurred to him at Rougham in August, and locally to Perkins in the Breck. Curtis records Mimesa atra from Suffolk; there are several in Kirby's collection, and Smith once saw it on a flower at Lowestoft. The rare Didineis lunicornis has been found by Smith at Carlton Wood, by Piffard near Felixstowe, and I once met with a male in the act of sucking honey from Smyrnium Olusatrum on the cliffs there in August. The interesting genus Crabro is represented by twenty-three species, of which $C$. tibialis is certainly uncommon at Stanstead Wood, Monk Soham, and Alderton; C. capitosus has been bred from bramble stems at Ipswich by Rothney ; $C$. varius, anxius, and $W$ esmaeli are uncommon ; Tuck says $C$. lituratus is rare at Tostock, and I have only once detected it in the vicinity of Ipswich.

Hornets, though occasionally observed in our woods, are not unpleasantly common in Suffolk, and the social wasps do not occur with the frequency of the southern counties; they are sometimes attracted into street lamps by the flies which have come to the light at night; the males of Vespa rufa may sometimes be freely found upon Angelica flowers, and Mr. Tuck has observed nests of $V$. sylvestris built, like a martin's, beneath house eaves in August. The rare $V$. norvegica has been noticed nesting at Aldeburgh, Tostock, and twice at Lowestoft in recent years; it constructs nests in trees and bushes, often in gardens, of the size of a cricket ball. Of the Odyneri, the usually common $O$. spinipes is certainly rare here, having been found only about Brandon, and quite recently about Copdock, by the late Rev. J. H. Hocking; O. pictus is very local; O. trimarginatus is confined to the coast (it has not occurred at Tostock); and the handsome $O$. antilope is uncommon about Bury St. Edmunds and in the Breck district.

To turn to the bees, we find $\mathrm{I}_{4}$ kinds recorded out of a British total of about 204. Of Colletes, we cannot claim $C$. cunicularia, which seems to be nearly confined to the Liverpool and Chester districts; $C$. marginata, Perkins says, is not uncommon on the Breck sands. Prosopis pictipes is found in the same district and has once occurred at Tostock to Tuck, who has also noticed Sphecodes longulus in May at Drinkstone. S. rubicundus was first brought forward as British in 1895 , and during the following year it was found to be not uncommon at Tostock by Tuck; it has also been taken about Ipswich by Hocking and myself. Only five localities appear to be known for Halictus quadricinctus, one of which is Little Blakenham in Suffolk, as is indicated in a MS. note in Kirby's interleaved copy of his Monographia. His record of $H$. xanthopus from Barham has recently been confirmed by the capture of examples at Brandon, Tostock, and Copdock; but

- See The Hymenoptera of Suff. pt. i.

${ }^{5}$ Op. cit. 224. 


\section{INSECTS}

Kirby's $H$. laevigatus and $H$. sexnotatus, originally described from their author's parish of Barham, have not been since met with in Suffolk. H. prasinus has been found about Brandon and Bury St. Edmunds, and in the latter locality $H$. pauxillus occurs rarely in flowers of Inula dysenterica. Of $H$. laevis, Saunders writes in 1896 , 'the only British exponent of this species was taken at Nacton, Suffolk, as recorded by Kirby in his Monographia'; Kirby says simply 'Barhamiae semel capta, iterum in Nacton, Suffolciae'; this certainly refers to two distinct specimens which, if I be not mistaken, both still exist in Kirby's collection in the British Museum. There are some fifty species of Andrena in Britain, and forty have been found in this county; $A$. pilipes is widely distributed; $A$. thoracica and $A$. cineraria are distinctly rare; and the only occurrence of $A$. forea is that of a female on Rubus flower in the Bentley Woods in August in 1896 . Though A. nigriceps is common enrugl, from July to August, Kirby's record of it, 'Barhamiae. Aprili ineunte, 1800,' must surely be an error or refer to a distinct kind. Mr. Hocking tells me that he has confirmed Kirby's record A. tridentata, at Melton and Barham, by the capture of an example in Suffolk in I90I; it occurs upon ragwort and appears to have been elsewhere observed only at Bournemouth, Christchurch, and Norwich. A. coitana, named after Coyte of Ipswich, is often in the utmost profusion on Heracleum flowers at Southwold, \&c. ; and the very rare $A$. proxima has turned up singly at Barham, Copdock, and Great Blakenham. ${ }^{6} \quad A$. fulvago, not a rare species in most parts of Britain, still rests in our county list upon Kirby's record of 1799; he says he has usually found it scarce about Barham at the beginning of June, but that in I 799 it was very plentiful. I once found A. similis in the Bentley Woods ; it was beaten from a white poplar in the middle of June.

Panurgus calcaratus has only been found at Martlesham Heath by Kirby; but Paget, Smith, and Piffard have all taken $P$. ursinus. Nomada fucata and $N$. Lathburiana have not been observed for over a hundred years; and $N$. lineola seems very scarce. In May 1897, I was so fortunate as to capture the second British example of $N$. guttulata, sitting upon a composite flower in Belstead Woods; the first, without locality, is in Mr. Edward Saunders' collection. ${ }^{7}$ Perkins has found $N$. bifida about Brandon, and Tuck $N$. borealis at Tostock in April. Coelioxys vectis has occurred at Lowestoft (but not at Tostock) ; $C$. rufescens has turned up in several localities, and its variety umbrina at Lowestoft. Megachile maritima is still common, with $M$. argentata in its original locality near Landguard Fort at Felixstowe, and has also been found inland at Rougham, Bungay, and Brandon. $M$. versicolor was once bred by Tuck at Tostock, ${ }^{8}$ and is widely distributed in the Breck district. We have all the British Osmiae, excepting $O$. parietina, which is confined to Wales and the North; the local $O$. pilicornis has occurred at Lowestoft, Copdock, and once to me in June (not September) in Brantham Dale. $O$. xanthomelana from Somersham and $O$. aurulenta from Henley, still stand upon Kirby's records, though that of $O$. spinulosa from Witnesham and Little Blakenham has been confirmed by Tuck, who annually found it at Tostock. The three species of Stelis frequent the Breck sands; and I have recently taken Anthidium manicatum commonly at Southwold at flowers of Petasites officinalis. For six years my single female of Anthophora retusa was the only known Suffolk specimen ; then Tuck took one at Thurston, and subsequently fair quantities from two colonies at Bungay in June $190 \mathrm{r}$, the males occurring at Geranium pyrenaicum and Lotus corniculatus : lately it has again been found at Bentley Woods and Copdock. Sarapoda has not been found for a century, nor, indeed, has Bombus Cullumanus; but B. Smitbianus is widely distributed and not uncommon about Brandon, and the common humble bees are frequent everywhere.

I shall conclude the Aculeata with a list of the only thirteen species which have been added to the county catalogue since it was published by me in 1899; and indeed with so full a list one cannot expect to have much new information to impart in this respect.

\section{AdDITIONS, 1900-1907}

Tiphia minuta. Males singly on Angelica sylvestris flowers at Brondors and Tuddenham Fen, and upon Heracleum sphondylium at Lackford Bridge, in Aug. 1900

Calicurgus hyalinatus. Found upon young poplar singly in Assington Thicks, in July 1902

Psen unicolor. Taken in a marshy spot at Tostock by Mr. Tuck

Gorytes laticinctus. Taken at Barton Mills in August 1901 (A. H. Hamm)

Crabro anxius. A female on parsley at Tostock in Aug. (cf. Norf. Trans. 1897)

- Cf. Ent. Mo. Mag. Lxxxiii, 265.

- Cf Trans. Norf. and Norwo. Nat
Odynerus bifasciatus. Several found by Tuck at Tostock (cf. Ent. Mo. Mag. 1902, p. 106)

Prosopis palustris. First described from Suffolk in Ent. Mo. Mag. xxxvi, 49; I have found it in the utmost profusion in Tuddenham Fen, as well as at Brandon, Icklingham, and the Nerw Forest

- cornuta. A single female was taken at Timworth, near Bury St. Edmunds, in July (cf. Ent. Mo. Mag. 1907, p. 67)

Halictus zonulus. One found at Hollesley early in Aug., by Mr. Hocking

7 Ibid. xxxiii, 280. 


\section{A HISTORY OF SUFFOLK}

\section{Addrtrons, 1900-1907 (continued)}

Halictus breviceps. Two females taken near Copdock in 1899 .

Andrena niveata. Probably not uncommon; taken at Brandon in May by Perkins, and on parsleyflowers at Tostock in June and July, by Tuck

Andrena hattorfiana. Two males on Knautia arvensis at Copdock in July, by Hocking

Nomada sexfasciata. There was only indirect evidence of this species' occurrence till one was taken at the burrows of Eucera longicornis at Copdock

\section{ICHNEUMONIDEA}

\section{Evanitdar}

Only seven species of this family had been found in Britain in 1872 , since which time I am aware of the addition of but one kind. ${ }^{9}$ Only two of these species appear to be at all common in Britain; and these are parasitic upon Aculeata, Chelostoma, \&cc, but do not prey, like the typical genus Evania, upon the egg-capsules of cockroaches. Both these species appear to be abundant throughout Suffolk, since Perkins in the Breck district about Brandon, and Tuck about Bury St. Edmunds have observed them, but only one of the remaining five has been recorded hence. The first of these, Foenus jaculator, has not been noticed about Ipswich, though I have found it upon carrot flowers at Tuddenham St. Mary in August ; the second, $F$. assectator, is common every where in July, and has occurred to me upon flowers of Heracleum sphondylium, \&c., at Ipswich, Bramford, Bentley Woods, and Tuddenham Fen, but especially at Barham, where it is to be met with freely. Evania appendigaster was first found in Britain by the Rev. James Coyte of Ipswich, in Suffolk; ${ }^{10}$ it is very rare, and even now regarded as being hardly permanently established in our Islands.

\section{Chalcididae}

No group of British insects is more in want of elucidation than the pretty little members of this extensive family, which are abundant everywhere upon herbage and flowers. Walker's works upon them are indeed 'love's labour lost,' for they are quite unintelligible to the modern systematist ; and I believe Wood's ambitious attempt at listing the whole of the British insects to contain the only catalogue-a quite valueless one-of them in existence. I have from various sources obtained the names of a very few of my numerous captures in this group, but until some student arises to propound a feasible classification, we shall for the most part have to content ourselves with the mere compilation of specimens and the observation of their interesting economy, which is considerably complicated, since the majority are hyperparasites. Nevertheless the following notes may be of some little value as regards the distribution of the Chalcididae in Suffolk, though only some fifteen species have been determined.

I once found Chalcis minuta, Linn., on umbelliferous flowers by the Gipping at Sproughton ; and Smicra sispes, Linn, which is said to prey upon Stratiomyid Diptera, is not uncommon in Oulton Broad; Tuck has found it at Finborough and in Benacre Broad, and Paget records it as rather common in marshes at Gorleston during August, in 1834, under the name Clavipes, Fab. The handsome Perilampus ruficornis, Fab., is often common in the spring in Bentley and Assington Woods among the undergrowth. I have taken Torymus nobilis, Boh., at Bentley, and several times bred Torymus regius, Nees, from the marble galls of Cynips Kollari at Bentley, where T. erucarum has occasionally been noticed; and the pretty little Micromelus pyrrbogaster is by no means rare at Bramford in the autumn. Claeonymus depressus has turned up at Little Blakenham, with Eupelmus excavatus, Dalm., in September. On the window of a house at Bentley I took an example of the strange Caratomus megacephalus, Fab., of Stephens' Illustrations, on I July 1903; it resembles nothing so much as the hammer-headed shark. Megastigmus dorsalis, Fab., has been swept at the Loweseoft denes in August. Callimome lasioptera appears widely distributed; and at Felixstowe the apterous Cerocephala formiciformis, Westw., has been found upon the book I was reading at the end of May. Eurytoma rosae, Nees, has occurred at Burgh Castle in August, and in the

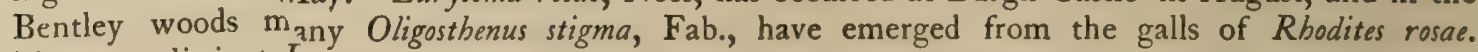

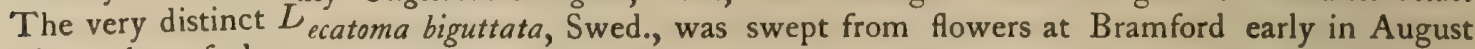
1897 ; but of the re t, though they comprise members of the genera Eulophus, Isosoma, Callimome, \&c., I have utterly falied to obtain reliable identifications, excepting Cheiropachus quadrum, Fab., once found commonly at Sotherton and once at Belstead; and Cerapterocerus mirabilis, which Saunders took at Southw' ld in July 1877. Comys Swederi, Dalm., too, has turned up at Wherstead and Tuddenham.

${ }^{\circ}$ Cf. Entom. 1880, p. 8!

${ }^{20}$ Donovan, Nat. Hist. of Brit. Insects, x, pl. 329. 


\section{INSECTS}

Since the above paragraph was written I have been doing some desultory work on this family, and consider the determination of the following local species sufficiently satisfactory for publication :Eucharis adscendens, Fab., the only British exponent of its family, was swept in Tuddenham Fen on 6 May 1907. Males of Eurytoma aterrima, Sch., at Brandon on 27 September 1907, and of $E$. nitida, Walk., at Barton Mills on 12 June 1900. Isosoma longicornis, Walk., at Bentley Woods on 2 I June I 901 ; I. brevis, Walk., at Southwold on 3I May I905; I. angustipennis, Walk., at Bentley on 13 May 1900, and in Tuddenham Fen on 6 May 1907; I. minor, Walk., at Belstead on 23 May 1896; I. elongata, Walk., at Foxhall on 27 May 1907; I. angustata, Walk., at Barnby Broad on 5 July 1906; $I$. depressa, Walk., swept from grass at Nacton 26 May 1900 ; and $I$. attenuata, Walk., at Wortham on 9 June 1900 . Callimome curtus, Walk., was beaten from birch in the Bentley Woods on 4 May 1895 , and is frequently common on the underside of lime leaves in my garden here at Monk Soham; C. flavipes, Walk., was found on Angelica flowers at Claydon Bridge on 10 August 1899 ; and C. chloromerus, Walk., in the Bentley Woods on 13 May 1900. Mr. Tuck has taken at Tostock several specimens of the interesting Monodontomerus nitidus, Newp., which lives in bees' nests. Two species of Chalcids were described by Rev. W. Kirby, ${ }^{10 a} M a-$ croglenes penetrans and Eulophus damicornis.

I have recently been engaged upon the compilation of a Catalogue of British Chalcididae, shortly to be published by the Entomological Society, and find that upon the closest scrutiny there appear to be $I, 408$ species in our isles.

\section{Cynipidae}

Of this family we have a much more representative, though still quite an elementary, list, and one which could with ease be extended with a little attentive working. Though a large proportion of these insects are phytophagous in their habits, they have nothing in common with the Tenthredonidea structually, and many are known to be parasitic upon Aphides. The majority, however, construct galls upon the leaves and roots of herbage and trees which were for long, and still are by the vulgar, supposed to be of vegetable origin; many are inquiline in the galls of their relatives; and several harbour commensals which play no part in the galls' construction. I am much indebted to Mr. G. C. Bignell for assisting me in the determination of the following thirty-three spicies, of which only one was noticed by the older collectors.

'The curious and distinct species of Figites, Kleditoma, and Eucoela are not uncommon from June to November; Figites scutellaris, Rossi., has been found at Marlesford, and Anacharis tincta, Walk., in Tuddenham Fen; Kleditoma nigra, Htg., in the Bentley Woods; and Aegilipes rufpes, Westw., by Tuck about Tostock, and by Platten in Ipswich. The extensive genus Eucoela is represented by $E$. nigricornis, Cam., common at Mildenhall, Claydon, and Bury on carrot flowers; E. proxima, Cam., at Framlingham in June; $E$. diaphana, Htg., at Burgh Castle and Bentley; E. crassiscornis, Westw., found about Bury by Tuck, and $E$. gracilicornis, in the Bramford marshes. What are, perhaps, E. rapae, Westw., and E. testaceipes, Cam., have been seen respectively at Bentley and Foxhall. The large and very rare Ibalia cultellator, Fab., was first taken in Britain by Mr. W. H. C. Edwards, who captured a male flying in his garden at Bungay; this specimen is figured by Curtis; ${ }^{11}$ and is said to be parasitic upon Sirex juvencus. The galls of Cynips kollari, Htg., are common everywhere upon oak trees; but Andricus radicis, $F_{a b}$, is more often met with in the perfect state and frequently swept from herbage in Bentley Woods; the galls of $A$. fecundatrix, Htg., may be commonly observed in the same locality, where I once found A. Sieboldi, Htg., and probably also A. gemmatus, Adl.; Synergus Reinhardi, Mayr, inquiline upon $C$. Kollari, is very common; S. Hayneanus, Htg., occurred to me at Foxhall in June 1895 ; S. incrassatus, Htg., inquiline upon Aphilotbrix corticus, Htg., is common, the pretty males having been found at Bentley and about Bury; and both $S$. vulgaris, Htg., and S. melanopus, $\mathrm{Htg}$, are common. The imagines of Apbilothrix quadrilineatus, $\mathrm{Htg}$., occur in Bentley Woods, where I have met with Trigonaspis megaptera, Panz. Biorrbiza terminalis, Fab., is found at Belstead and Ipswich in November, and both Neuroterus lenticularis, Oliv., and N. aprilinus, Gir., are abundant, but $N$. tricolor, $\mathrm{Htg}$, has only once been noted in the Bentley Woods, where I have seen galls of N. numismatis, Oliv., Andricus ostreus, Gir., and Dryophanta divisa, Htg. The woolly bedeguar galls of Rhodites rosae are not uncommon about Bentley and Wrentham; and I have taken the much rarer $R$. nervosus, Curt., at Framlingham in June. Allotria pedestris, Curt., and A. megaptera, Cam., were found at Brandon in June 1903; I have observed galls of Diastrophus rubi on blackberry at Debenham, and Mr. Rasor has sent me those of Aulax glechomae, Htg., from Woolpit.

103 Trans. Linn. Soc. 1800 , p. 109, and 1825 , p. 112.

"Brit. Ent. xxii. 


\section{A HISTORY OF SUFFOLK}

\section{ICHNEUMONIDAE}

Of this extremely interesting family, the species of which are often large and brightly coloured, always preying upon insects of all orders, as well as upon spiders and false-scorpions, there were 1,186 different kinds known in Britain in 1872 , which number had risen to 1,719 in 1901, when my paper upon the subject was read before the Entomological Society. The determination of these insects, however, is fraught with so much difficulty that the family has been almost entirely neglected in our isles, with the consequence that in Suffolk there have been but few observers. Paget, Curtis, and Rev. E. N. Bloomfield have recorded a very few of the commoner and more striking kinds; there are one or two in the British Museum found about Lowestoft by F. Smith; and others have been noticed by Bedwell, Tuck, and Ransom. In my Ichneumons of Britain ${ }^{12} \mathrm{I}$ have recorded a goodly number of the first two sub-families from the county; and in working upon my second volume I have noticed many Cryptids; but the remaining three sub-families are very poorly represented, because, although I possess some thousands of Suffolk specimens, opportunity has not yet been found for working out the correct names of the great majority. Hence we find that but little over four hundred species can with accuracy be referred to in the following précis, which, as nothing has at present appeared upon the general subject, is dealt with in some detail.

Taking the five sub-families in their usual order, we find among the Ichneumoninae Hoplismenus albifrons has been captured on flowers at Walberswick and Brandon; Automalus alboguttatus from Bury St. Edmunds, in the late Mr. Alfred Beaumont's collection; that we can include the tawny Trogus lutorius, on the strength of specimens bred from poplar hawk-moths at Yarmouth by Paget and from Delephila galii by Mr. Peek at Aldeburgh, with $\mathcal{T}$. exaltatorius and Protichneumon fuscipennis on the Rev. A. H. Wratislaw's authority; $P$. laminatorius is a common parasite of the elephant hawk-moth at Ipswich and Sudbury, and was once bred from the bedstraw hawk at Aldeburgh. Coelichneumon lineator is sometimes found in the Bentley Woods, C. liocnemis at Brantham and C. castaneiventris at Ipswich and Assington; while of the genus Stenichneumon, S. trilineatus is very often seen hibernating beneath the bark of pine and aspen trees in winter, and swept from reeds in the Southwold marshes. Cratichneumon rufifrons is common in the Bentley Woods, Staverton Thicks, and Brandon; C. nigritarius was recorded from Covehithe at the end of June by Curtis and is still not rare on the undergrowth in our woods; $C$. fabricator and $C$. annulator are abundant everywhere in the late spring, and I have found $C$. fugitivus at Ipswich with the variable $C$. coruscator. The Rev. A. H. Wratislaw took $C$. Gravenborsti near Bury St. Edmunds, and both C. lanius and C. varipes occur on low bushes in the Bentley Woods, though the latter is certainly rare there. Melanichneumon leucomelas has been taken by Bedwell at Oulton Broad, Platten in Ipswich, and Beaumont near Bury; the marsh-fiequenting $M$. bimaculatorius was swept by Elliott at Covehithe Broad in October 1900 ; I have found $M$. saturatorius in the same place, as well as at Brandon, $M$. perscrutator on carrot flowers at Tuddenham, and the rare $M$. sanguinator once flying in the sunshine at Bentley in July. Of the genus Barichneumon we can claim $B$. anator, $B$. vestigator, and $B$. derogator, which have been found about Bury by Mr. Tuck; $B$. incubitor and $B$. lepidus from Tuddenham $F e n$ in August; $B$. angustulus from Copdock by Hocking, and $B$. albicinctus is common in marshy places at Ipswich and Barton Mills; Tuck has, moreover, once captured $B$. bilunulatus in Finborough Park. We next come to the long and difficult typical genus Ichneumon, which comprises over fifty British kinds, and of which we only have I. xanthorius at Tostock, Bentley, and Ipswich, often at roots of Aira caespitosa in the winter; I. sarcitorius, common at Claydon, Aldeburgh, Lowestoft, Ipswich, Barham, and Westleton, upon flowers in August and September; a female of the very rare $I$. lautatorius was once found by Bedwell on the sandhills at Kessingland. I. latrator and I. subquadratus are common among grass in the winter, and the males in autumn on flower-heads; I. molitorius has been found at Sproughton, Foxhall and, Paget says, commonly about Gorleston; I. suspiciosus at Tostock, Bramford, and Henstead on Angelica blossoms, and $I$. extensorius is common everywhere; but of $I$. primatorius only one male example has occurred to me upon the flower of Angelica sylvestris in Barnby Broad, and at the end of August 1902, I took the first British specimen of $I$. gradarius (which I have since that time received from Ireland) from the same kind of flowers in Tuddenham Fen.

Chasmias motatorius is abundant in grass-tufts and beneath pine bark in the winter, and its males are found on flowers in September; the linear Limerodes arctiventris is occasionally found among marram grass and Matricaria on the coast at Lowestoft and Southwold. I have bred Ctenichneumon castigator at Ipswich in 1893 , and Beaumont has obtained C. funereus from the Rev. A. H. Wratislaw's collection, found about Bury St. Edmunds. In the British Museum is an example of $C$. messorius from Suffolk, where C. divisorius is widely distributed and to be seen on various flowers in August. Spilicbneumon occisorius occurs at roots of grass in the Bentley Woods in winter; but the

${ }^{12}$ Claude Morley, F.E.S., \&c., Ichneumonologia Britannica (2 vols. 1903 and 1907; vol. iii in Press). 


\section{INSECTS}

usually abundant Amblyteles palliatorius has never been noted in the county; though $A$. vadatorius on Angelica flowers and $A$. castanopygus (which is parasitic upon Dasypolia templi $i^{13}$ on reed-stems) sometimes turn up in Tuddenham Fen. We also have noted $A$. negatorius at Claydon Bridge and the Southwold cliffs; $A$. subsericans at Tostock with, once only, the universally abundant $A$. armatorius; and $\mathrm{Mr}$. Wratislaw took $A$. uniguttatus at Bury St. Edmunds in the 'sixties. Bridgman named Hepiopelmus leucostigmus from Tostock, where Mr. Tuck has also found both sexes of Probolus alticola. We have only four of the eighteen species of Platylabus; $P$. pedatorius is rare in the Bramford marshes and Tuddenham Fen, $P$. nigricollis occurs sparingly in the Bentley Woods, and $P$. phaleratus, with $P$. albinus, in Tuddenham Fen on dwarf-sallow bushes. Coming now to the Phaeogenides, we find our catalogue somewhat fuller with Stenodontus marginellus on Vicia sativa in the Bentley Woods; Herpestomus brunnicornis on fir trees in the spring at Tostock, and Phaeogenes argutus commonly in grass-tufts about Bentley during the winter. $P$. stipator hibernates, and has occurred to me on umbelliferous flowers at Ipswich in September; $P$. semivulpinus once or twice to Tuck at Tostock; P. melanogonus in May and October in the Bentley Woods, where P. infimus is common in the spring upon fir trees. $P$. ophthalmicus is not infrequent in August in the Lowestoft Broads and at Henstead; and I have taken the only known British example of $P$. eques on the undergrowth in Assington Thicks towards the end of May. $P$. ischiomelinus has been found about Lury by Tuck; $P$. maculicornis on fir trees at Bentley and Foxhall, with $P$. stimulator; $P$. callopus and $P$. fulvitarsis are recorded from Aldeburgh, Tostock, and Bentley Woods ; P. rusticatus, too, has been noted in June in Tuddenham Fen. Two kinds, which I have doubtfully referred to $P$. socius, Holmgr., and P. macilentus, Wesm. (Ichn.Brit. i, Appendix), have been noticed at Foxhall and Rushford respectively. Of Diadromus, we only have $D$. troglodytes, which is not uncommon in Bentley Woods, with $D$. subtilicornis from Brandon, and $D$. collaris from the Coniferae at Finborough, Tostock, Bramford, and Foxhall. All the five British species of the difficult genus Aethecerus are found here; Ae. longulus once on the banks of the Gipping at Ipswich; Ae.placidus at Burgh Castle, Ae. nitidus about Barton Mills in June, Ae. discolor in the autumn in Bentley Woods, and Ae. dispar at Dunwich. Dicaelotus pumilus and Colpognatbus divisus are abundant, with the much rarer Centeterus opprimator in winter moss. In 1895 I was so fortunate as to breed the first British specimen of Hemichneumon elongatus at Ipswich, and to take Melanomicrus Elliotti, a species new to science, in the Bentley Woods. I could give a long list of localities for Alomyia debellator in Suffolk, where it is frequent in the late summer upon umbelliferous flowers, but will only instance Barnby Broad, where it is especially common and ranges from the pale form, known as semiflava, to the very dark one, called nigra.

The second sub-family, the Cryptinae, have never been noticed from Suffolk, and I have consequently striven to collate all the material at present available which bears upon them. Of the typical genus Cryptus, we find C. tarsoleucus commonly at Tostock, Copdock, and Sudbury ; the distinct $C$. viduatorius at Felixstowe, Barnby Broad, and Farnham; $C$. obscurus has been bred from the pupa of Taeniocampa instabilis in Ipswich, and is common everywhere upon hedges; $C$. albatorius has been found by Hocking at Copdock and by Tuck at Tostock; I have, too, once taken $C$. tuberculatus at Ipswich. Habrocryptus porrectorius is often beaten from oak trees in the Bentley Woods, and Pycnocryptus peregrinator occurs in the spring at Belstead and about Tostock. Agrothereutes batavus, which is the brachypterous form of Spilocryptus incubitor, is found about Ipswich in September, and S. cimbicis occurs commonly in the hedge cocoons of Trichiosoma at Westerfield and Debenham. S. abbreviator, which is now considered identical with $S$. Hopei, is not rare at Ipswich and the Bentley Woods; and I have several times bred Gambrus ornatus from Burnet cocoons on the grass-stems in Oulton Broad in July. The handsome Aritranis carnifex is sometimes swept in the marshes of Brandon, Oulton Broad, and by Elliott in Tuddenham Fen; while the delicate A. signatorius may be beaten from poplar trees at Foxhall and Tostock, where it preys upon the social wasps. The very rare Nematopodius formosus, which was only known as British by one unlocalized specimen in the British Museum, turned up in my house at Monk Soham, on the upper windows in July 1905. Among the Phygadeuonides, we find that Plectocryptus digitatus occurs around Ipswich, Cratocryptus stomaticus in the Bentley Woods and the Bramford marshes, $C$. subpetiolatus at bees' nests in the former locality, and $C$. parvulus at Henstead and Barnby Broad in August. The curious aquatic Trichocryptus cinctorius has been dredged out of the ditches at Barnby and Oulton Broads, and Microcryptus graminicola found in Holbon Marsh near Beccles. M. rufipes and $M$. perspicillator are uncommon in Bentley Woods, $M$. abdominator and $M$. nigrocinctus turn up everywhere; $M$. basizonius has been noticed only in Dodnash Wood, and $M$. bifrons only at the roots of Funcus in a swampy meadow at Wherstead. The very distinct Acanthocryptus flagitator is found at Harkstead, Tostock, and Barton Mills; $A$. quadrispinosus in tufts of grass during the winter in the Bentley Woods, and $A$. nigricollis on Heracleum flowers by Tuck at Tostock. Glyphicnemis vagabunda

is See Newman, Moths, 279. 


\section{A HISTORY OF SUFFOLK}

and G. profligator, which are very closely related species, are abundant on umbelliferous fowers throughout the county in July ; Tuck has once taken Phygadeuon Gravenborsti in the nest of Bombus bortorum near Bury St. Edmunds; I have caught $P$. variabilis in Shrubland Park; $P$. bercynicus is common about Lowestoft in August; $P$. brevitarsis has been turned up in Bentley Woods, where $P$. fumator is abundant during hibernation, while the closely allied $P$. dimidiatus once fell to my net in Barnby Broad. The elegant genus Panargyrops is only here represented by two species, $P$. pellucidator and $P$. tenuipes, both of which have been sent to me frnm Tostock by Mr. W. H. Tuck, M.A.

Last autumn I worked out the sixty-nine British species of the genus Hemiteles, and I am now able to say that $H$. fulvipes, which is a common hyperparasite of the white butterflies, occurs at Southwold and Ipswich; H. varitarsus I bred from a spider's nest in the Reydon marshes, and found on flowers at Claydon Bridge; $H$. necator, H. bicolorinus, and the omnivorous $H$. areator are abundant, and I have often found $H$. cingulator on windows at Butley and Monk Soham in June. $H$. inimicus inhabits the Brandon marshes and Monk Park Wood, $H$. pedestris the Bentley Woods, in which both $H$. subzonatus, of which I have taken the undescribed male, and $H$. niger hibernate. $H$. similis is common at Kenton, Southwold, \&c.; as also is $H$. tristator. $H$. laevigatus occurs at Alderton and in Tuddenham Fen; $H$. incisus in Finborough Park; $H$. distinctus about Brandon; Tuck has found $H$. gracilis at Tostock, and $H$. aestivalis is plentiful throughout the county. Orthopelma luteolator preys extensively upon the bedeguar galls of $R$ bodites rosae, locally known as 'robins' pin cushions,' and I have received Cecidonomus Westoni from Tuck, found at Tostock. In revising the British Stilpnides, I found that Stilpnus gagates had occurred at Blakenham; S. deplanatus in Finborough Park, $S$. pavoniae at Witnesham, and the rare $S$. Dryadum at Barton Mills in June. The genus Atractodes, which is now placed in this group of the Cryptinae, is here represented by A. gravidus at Southwold, and $A$. piceicornis at Foxhall, while $A$. vestalis and $A$. exilis are common. A. bicolor, whose economy is not yet known, is occasionally found in carrion; $A$. croceicornis rarely at Barton Mills and $A$. gilvipes at Brandon, as well as at Tostock by Tuck, who also turned up $A$. foveolatus at Aldeburgh in September 1899. We have all the four species of Exolytus, which I consider to be stable in Britain; the extremely abundant $E$. laevigatus, the common $E$. scrutator; $E$. splendens at Ipswich and Mildenhall, and $E$. petiolaris, which is but recently recorded from Britain, found at Foxhall.

To this list of Cryptinae I am now able to add considerably through quite recent investigation among my specimens. One of the only two known British specimens of Trichocryptus aquaticus was taken by Tuck in Finborough Park; and he found several Cubocephalus oviventris at Benacre Broad in 1899 . Males of Microcryptus arridens, $M$. galactinus, and $M$. leucostictus are common on flowers, with, more sparingly, those of $M$. erytbrinus, $M$. sperator, and $M$. labralis. I introduced $M$. tricinctus as British on the strength of a to taken in the Bentley Woods, where both sexes of $M$. brachypterus and. $M$. micropterus have also been found. Acanthocryptus Hopei and Glyphicnemis Suffolciensis are species new to science found by me here, with G. brevis, G. erythrogastra, and $G$. senilis. Several more Phygadeuones have also been noted:- $P$. rufulus, $P$. speculator, and $P$. sodalis are rare; and only one $P$. nyctemerus has been seen, flying about the burrows of Hylesinus crenatus in an ash at Ashfield in September 1907. $P$. vagans and $P$. leucostigmus are not uncommon about Southwold in autumn; and I took the second known specimen of $P$. Scoticus in the Bentley Woods. $P$. brachyurus and $P$. flavimanus seem rare, but $P$. assimilis, $P$. dumetorum and $P$. exiguus are frequently met with, though $P$. mixtus, $P$. inflatus, and $P$. scaposus are infrequent. Spinolia fulveolata and Hemiteles varicornis are common among reeds; my new $H$. brunneus is also found here, and Cecidonomus xylonomoides, Morl., is described from an example found in Bentley Woods. Cremnodes atricapillus, Stilpnus blandus, and Goniocryptus titillator are not at all common.

The majority of the British Pezomachoides have occurred in the county, and are interesting as a group on account of their apterous condition and the great variety of their hosts, which include spiders, braconids, moths, and beetles! Pezomachus aquisgranensis, $P$. Kiesenwetteri, and $P$. zonatus are found in moss in Bentley Woods in winter; $P$. costatus at Kessingland, $P$. rufipes in grass-tufts, and $P$. aemulus are uncommon; $P$. acarorum, $P$. festinans, and $P$. nigritus appear local species. Oulton Broad produces $P$. micrurus, and Bentley Woods both $P$. formicarius and $P$. Mülleri; $P$. attentus, $P$. antbracinus, and $P$. timidus are somewhat rare; but $P$. vagans, $P$. fraudulentus, and $P$. modestus are abundant. By sweeping at dusk in September quantities of $P$. corruptor and $P$. carnifex may be obtained, with a rare $P$. comes and $P$. geochares. $P$. instabilis and $P$. intermedius are very common, but $P$. nigricornis distinctly rare, on fir trees in the spring; the most ubiquitous of the whole genus, however, is $P$. fasciatus, which turns up everywhere.

This brings us to the third sub-family, the slender-bodied Ophioninae, of which I have found Henicospilus ramidulus commonly on reeds in the salt marshes, as well as at light at midnight at Southwold; $H$. merdarius preys on Dianthaecia irregularis at Tuddenham; Ophion minutus is rare in Assington Thicks in May, but both $O$. obscurus and $O$. luteus are very common at street lamps and 


\section{INSECTS}

electric light in Ipswich; sometimes too they are attracted by sugar in the Bentley Woods, and Paget says that the latter was frequently met with in Yarmouth in 1834. Anomalon ruficorne and A. perspicuum have been found about Ipswich, Agrypon flaveolatum at Lavenham, and A. tenuicorne at Alderton. Paget once bred Opheltes glaucopterus from the chrysalis of Cimbex varians, which he instances at Lound Wood, and I possess an example taken near Bury St. Edmunds by Mr. Wratislaw, probably in Tuddenham Fen, where I have myself beaten it from birch bushes. Paniscus cephalotes, the well-known parasite of the puss-moth, was not uncommon here in $1894 ; P$. virgatus has been bred by Ransom at Sudbury from Melanippe fluctuata; $P$. testaceus is often attracted to light at night; in the Bentley Woods I have once found $P$. tarsatus, and at Leiston $P$. cristatus once. Several kinds of Campoplex are common, but I can only refer to $C$. angustatus and $C$. tenuis with any degree of certainty ; and in the extensive, though at present inadequately worked, genus Limneria but few species have been satisfactorily determined. I have met with $L$. annulata about Lowestoft in August ; L. chrysosticta at Bramford and Claydon Bridge ; $L$. crassicornis not uncommonly at Oulton and Barnby Broads, and Henstead ; $L$. exareolata and $L$. Faunus also in the marshes at Henstead; $L$. fulviventris at Dunwich and Brandon; $L$. fenestralis at Barnby Broad and in a fungus at Ipswich; L. borealis at Burgh Castle and on the banks of the Orwell ; L. clavipennis not uncommonly in the Lowestoft district: L. litoralis at Barnby Broad; L. rufipes at Burgh Castle, and $L$. rufiventris on the banks of the Gipping. I have, however, over seven hundred specimens of this genus from which most of the British species may with all probability be recorded. Cremastus interruptus has occurred to me at Claydon bridge and the Felixstowe cliffs upon flowers. Porizon hostilis and $P$. harpurus are common upon Angelica flowers in the autumn. Plectiscus zonatus has been found by Tuck at Tostock. Mesochorus pectoralis has been swept from thistles in the Bentley Woods in November; $M$. confusus found on fennel flowers at Alderton; $M$. vittator in Barnby Broad in August, and Tuck has found $M$. tetricus at Bury St. Edmunds. Thersilochus versutus has. been taken at Ipswich, where $\mathcal{T}$. moderator is often bred from the pink larvae of Orchesia micans in Boleti on trees. Curtis took both sexes of Collyria calcitrador in Suffolk, ${ }^{14}$ and it is still abundant at Tostock, Bentley, Lavenham, \&c., doubtless doing much good since it preys upon the Cephus pygmaeus, which is so injurious to wheat. Exetastes cinctipes is common in Ipswich and Woodbridge gardens, devouring the caterpillars of the cabbage moths; I have captured $E$. illusor on the banks of the Orwell in July ; $E$. guttatorius has been observed in Finborough Park, and is doubtless widely distributed. Smith found the very rare Arotes albicinctus near Lowestoft, ${ }^{15}$ and both Wratislaw and Curtis ${ }^{16}$ have noticed Banchus pictus, which occasionally turns up in Bentley Woods, in the county. I have found $B$. variegatus sparingly about Ipswich, and $B$. falcator in the greatest profusion on Heracleum sphondylium flowers by the sea at Easton Bavents. ${ }^{17}$

The Tryphoninae are by no means well represented in our list, though we can instance over eighty kinds, and a great deal of heterogeneous material awaits elucidation. The pretty Mesoleptus cingulator is common on Scrophularia in the Bramford marshes, Tuddenham Fen, and at Tostock; $M$. typhae has occurred in Bentley Woods, where $M$. testaceous is uncommon; $M$. melanocephala occasionally falls to the beating stick in Tuddenham Fen in August; $M$. paludicola and $M$. sulphuratus, together with what I believe to be $M$. furax, have been taken in Oulton Broad, whence Bedwell has given me Euryproctus geniculosus. E. nemoralis has turned up upon Angelica flowers at Barton Mills, and Tuck has found $E$. atomator in Finborough Park. Catoglyptus fortipes is common, and I have once captured $C$. fuscicornis in the Bentley Woods. Perilissus praerogator is abundant everywhere on flowers in the late autumn, with $P$. filicornis in Tuddenham Fen. Prionopoda glabra lives at Southwold in July, and Thymaris compressus at Tuddenham. Megastylus cruentator has been noted about Tostock and Lowestoft ; $M$. mediator at Wherstead in the end of October, and $M$. borealis in Staverton Thicks in June. Mesoleius sanguinicollis and $M$. virgultorum are found in the Bentley Woods ; $M$. caligatus in Herringswell Fen, $M$. aulicus at Foxhall, $M$. armillatorius with $M$. insolens at Brandon, and $M$. semicaligatus not rarely in the marshes about Beccles. Of the

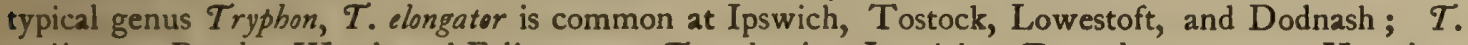
rutilator at Bentley Woods and Felixstowe; T. vulgaris at Ipswich; T. trochanteratus on Heracleum at Moulton; $\mathcal{T}$. signator at Tostock by Tuck; T. assimilis in Barnby Broad ; $\mathcal{T}$. bicornutus at Claydon, Tostock, and Foxhall; and I once swept the handsome $\mathcal{T}$. scotopterus in some numbers in Stanstead Wood, where also has occurred an example of Grypocentrus lativentris. G. albipes has been found at Barton Mills, and G. basalis is very abundant in our woods in the spring. Trematopygus albipes has occurred to Tuck at Benacre Broad, and in the Bentley Woods Eumesius crassicornis is found sparingly in May. The larviparous Polyblastus varitarsus and $P$. cotburnatus are not rare on flowers in the autumn; and I have once found $P$. mutabilis in Tuddenham Fen in June, and $P$. pinguis once upon the Southwold cliffs. $P$. calcar is attracted to fennel-flowers at Alderton, $P$. Westringi inhabits Barton Mills, and $P$. carinator is not uncommon. Erromenus brunnicornis is

"Cf. Form Insects, 257.
Brit. Ent. 588.
${ }^{15}$ C. Ent. Ann. 1859 , p. 112.

1 Cf. Ent. Mo. Mag. 1903, p. 157 . 


\section{A HISTORY OF SUFFOLK}

common at Westleton and Tostock, E. frenator at Fordley and Kenton, and I have taken both Acrotomus lucidulus in Tuddenham Fen and Cteniscus succinctus in the Bentley Woods. The distinct Exyston cinctulum has been once or twice noticed about Bury and Aldeburgh.

Among the Prosopi have been observed Exochus mansuetor, commonly on the windows of Monk Soham House, E. flavomarginatus at Assington in May, E. consimilis, and at Lowestoft E. nigripalpis. Chorinaeus cristator has occurred to me at Henstead and Burgh Castle; C. funebris at Covehithe; and, in April, Tuck has sent me C. talpae from Tostock. The Schizodontes ${ }^{18}$ are somewhat more fully represented by Bassus laetatorius, which abounds from Lackford bridge to Slaughden beach; $B$. albosignatus rare at Southwold; $B$. annulatus and $B$. varicoxa at Monk Soham, and both $B$. tricinctus and $B$. multicolor are common locally. Zootrephus bolmgreni is not uncommon about Tuddenham Fen and Barton Mills, with Z. rufiventris from Brandon and the Lowestoft Broads. Homoporus cinctus and H. bizonarius occur sparingly at Tostock, Finborough Park, and the Bentley Woods; $H$. graculus at Barnby Broad and Tuddenham Fen; $H$. porectorius at Assington Thicks and Tuddenham $\mathrm{Fen} ; H$. tarsatorius and $H$. flavolineatus in woods in the spring; $H$. fissorius appears to be very rare on Angelica flowers at Foxhall in September; H. ornatus is abundant in the coast marshes at Southwold, and $H$. dimidiatus everywhere in August; $H$. longiventris and $H$. crassicrus were first taken in Britain in Suffolk; $H$. pumilus at Tostock and Brandon; the only specimen of $H$. strigator was taken on flowers in Henstead Marsh in August 1898; H. signatus is common in July at Monk Soham; Tuck has found the widespread $H$. elegans at Bury, and $H$. xanthaspis first occurred in England in Tuddenham Fen in August 1905, with the commoner $H$. bygrobius. Promethus sulcator, $P$. festivus, and $P$. pulchellus are also abundant; one $q$ of $P$. laticarpus has turned up at Henstead, and I have $P$. dorsalis from Monk Soham, Brandon, and about Lowestoft, and $P$. cognatus from Southwold, Brandon, Clare, and Barnby Broad. Paget says Metopius micratorius used to occur in Yarmouth gardens, sometimes abundantly; and Curtis records it from Southwold, where Mr. Tuck recently found it. ${ }^{19}$ I have once seen it in the Bentley Woods, but it is certainly now quite rare in Suffolk.

The last sub-family, the Pimplinae, comprises such handsome insects as Rhyssa persuasoria, the parasite of the wood-wasp, which measures 4 inches over all; this giant has been taken in Ipswich by Baylis and by Tuck at Bury and Rushbrooke. Ephialtes imperator is said to have been common about Yarmouth by Paget, who may, however, have referred to $E$. carbonarius, which has occurred to Tuck at Tostock and to me at Bramford; and I once found a male of the exclusively marsh Acaenitus arator on Angelica flowers in Tuddenham Fen. Perithous mediator and $P$. varius, parasites of fossors, are not uncommon. Of the genus Pimpla we can record the common $P$. instigator, which I have bred from Smerinthus tiliae at Beccles and from Arctia menthastri at Ipswich; $P$. examinator and $P$. turionellae commonly in June; $P$. rufator at Ipswich in $1893 ; P$. flavonotata, not uncommon upon reeds in the Southwold salt marshes; $P$. brevicornis, $P$. scanica, always abundant with $P$. pomorum and the handsome $P$. diluta, upon Coniferae in the spring; $P$. alternans bred from a moth's pupa in Barnby Broad; $P$. oculatoria and $P$. graminellae not uncommon; $P$. calobata at Ipswich, and $P$. didyma, of which I once bred two dozen examples of both sexes from a single larva of Odonestis potatoria. $\boldsymbol{P}$. robusta occurs about Lowestoft in August, $\boldsymbol{P}$. sagax at $\boldsymbol{F i n -}$ ningham and Eye, $P$. strigpleuris at Aldeburgh and Tostock in September, and $P$. detrita is common everywhere upon flowers in August. Iscbnocerus rusticus has been found at Copdock, and Clistopyga incitator at Ipswich by Platten and at Tostock by Tuck. The interesting genus Glypta is well represented by G. bicornis, G. pedata, and G. annulata in Barnby Broad; G. nigrina on windows of Monk Soham House; G. ceratites and $G$. bifoveolata are generally distributed; $G$. trochanterata and $G$. incisa at Ipswich; G. sculpturata at Sibton Abbey; G. parvicornuta in Tuddenham Fen; G. elongata at Dunwich; G. pedata at Lackford Bridge; G. elongata at Southwold; G. haesitator at Belstead in early June; G. scalaris at Burgh Castle; G. femorata at Stanstead; G. resinanae at Tostock with G. mensurata and G. lugubrina, while G. flavolineata and $G$. annulata are common on the flowers. I have found Schizopyga analis at Barton Mills; and Stilbops vetula, with Colpomeria inanis, abundantly in all our woods in May. Lissonota maculatoria has occurred to Tuck at Tostock ; $L$. verberans at Brandon, $L$. variabilis at Foxhall; $L$. bellator and $L$. commixta are common everywhere in August, with L. sulphurifera and L. cylindrator on flowers. Meniscus murinus is often abundant upon blackthorn blossom in April ; $M$. catenator occurred to me in Barnby Broad in July I 906 , and $M$. setosus was found at Bury by Wratislaw. Phytodictus segmentator has turned up at Stoke by Clare, $P$. coryphaeus at Dunwich, and Oedemopsis scabriculus is locally common on flowers in August. The curious and widely distributed Xylonomus pilicornis has only once been seen in Suffolk, in the marshes near Wortham Ling in June.

In recently working out material for the third volume of my Ichneumons of Britain, I found the following Pimplinae to also inhabit our county:-Pimpla arundinator is common in marshy

${ }^{10}$ Cf. Trans. Ent. Soc. 1905, pp. 419-38.

${ }^{13} \mathrm{Cf}$. Trans. Norf. and Norro. Nat. Sac. vii, 14. 


\section{INSECTS}

places; $\boldsymbol{P}$. roborator, Grav., has been taken by Platten in Woodbridge ; $\boldsymbol{P}$. punctiventris, Thoms., is not rare, though mixed with $P$. calobata, Grav.; $P$. nucum, Ratz., has been found in Monk Park Wood in June; and Mr. Tuck has once taken P. ornata about Tostock. I bred a female of Polyspbincta multicolora, Grav., from a spider in my garden last year; its larva is an external parasite, and lies like a muffler round its host's neck. Schizopyga podagrica, Grav., has also occurred in Monk Soham. The handsome Lycorina triangulifera, Holmgr., once fell to my beating-stick in the Bentley Woods in June 1902. Cryptopimpla calceator, Grav., and C. errabunda, Grav., have been met with singly at Foxhall and Lowestoft, but are rare. Lissonota is an extensive genus, and we can now also claim $L$. leucogona and $L$. nitida on flowers at Monk Soham, L. trochanterata commonly at Marlesford, \&cc.; Mr. Tuck has found $L$. deversor at Tostock; and L. segmentator once occurred to me in Assington Thicks, L. nigridens on Angelica flowers at Harkstead in September, L. dubia at Brandon in June, and L. errabunda, Holmgr., in the Bentley Woods. Meniscus plantarius was once found by Mr. Wratislaw about Bury St. Edmunds, and Collyria puncticeps is a common species. Phytodietus obscurus occurs in Bentley Woods, and I have described Thymaris fenestralis, Morl., from specimens taken on the windows of Monk Soham House in July.

From the above account of the Suffolk Ichneumonidae, which is the best at present obtainable, it will be seen that the sub-families are very unequally represented, and that they may be thus summarized :-

\begin{tabular}{|c|c|c|c|c|c|c|c|c|c|c|c|c|c|}
\hline Ichneumonina & & - & • & • & • & • & - & - & - & • & • & \multicolumn{2}{|c|}{92 species } \\
\hline Cryptinae & - & - & - & . & - & - & - & - & - & • & - & I 39 & " \\
\hline Ophioninae & . & - & - & - & • & - & - & - & - & • & * & $4^{8}$ & $"$ \\
\hline Tryphoninae & - & - & - & - & - & - & . & - & - & • & • & 89 & $"$ \\
\hline Pimplinae & . & - & - & . & - & • & . & . & • & • & . & 87 & , \\
\hline
\end{tabular}

\section{BRACONIDAE}

In Suffolk but little attention has been paid to this extensive family, so closely resembling in structure and economy the Ichneumonidae, from which, however, its members may be known by the possession of only one recurrent nervure in the fore-wing, or, in such as be apterous, by the chitinous abdomen. One species is recorded hence in Wood's Insects at Home, and a few were first described by Curtis from this county in his British Entomology; but for the most part I have had to rely upon my own intermittent efforts at collecting and determination for the representation of the following species, which in all probability constitute about one half of the number actually occurring with us.

The typical genus Bracon is fairly well represented ${ }^{20}$ by $B$. minutator, found occasionally 2bout Tostock by Tuck; $B$. fulvipes found here by Bedwell and myself; $B$. variegator, of which Tuck bred one from a spider's nest in April $1902 ; B$. stabilis, common; $B$. fuscicoxis, about Brandon; $B$. guttiger, at Nacton in May; B. satanas, rarely ; $B$. fraudator and B. epitriptus, at Monk Soham in July; $B$. practermissus, at Oulton Broad, and $B$. discoideus, on flowers at Brandon and Claydon; $B$. regularis, at Bramford and Foxhall; $B$. variator and $B$. osculator are common; $B$. obscurator has once occurred at Wherstead, and B. antbracinus once on herbage in the Bentley Woods. Rhyssalus indagator once occurred to me at Assington in the middle of June, and Tuck took Spathius rubidus at Tostock in September 1902. The common S. exarator, which preys most beneficially upon the death-watch beetle, has turned up in Dodnash Woods, and at Tuddenham, where also Hecabolus sulcatus is found in August. Doryctes imperator was taken, flying in the sunshine, at Ipswich in June 1896 ; and Tuck has given me D. spatbiiformis, which he bred from a spider's nest at Tostock. Clinocentrus excubitor inhabits the Bentley Woods and Heterogammus dispar was swept in Herringswell Fen in August 1905. The ubiquitous Rhogas circumscriptus has been met with at Foxhall, Belstead, Bury St. Edmunds, and Barnby Broad; ${ }^{21} R$. armatus and $R$. dimidiatus occur about Ipswich; $R$. irregularis in the Lowestoft district, Tuddenham, and Herringswell Fens; the rare $R$. nigricornis has once turned up in Barnby Broad in July, and Curtis ${ }^{22}$ describes his $R$. subucola from Suffolk in the middle of May. Respecting the interesting Cryptogastres, cf. Entomologist, 1907, p. 879, where I have recorded from Suffolk Phanerotoma dentata from Tuddenham Fen; Chelonus inanitus, of which Wood says ${ }^{23}$ that F. Smith took fifty at Lowestoft, is common throughout the county ; C. carbonator, not rare at Bramford, Foxhall, Blythburgh, and Westleton; $C$. secutor, from Brandon; $C$. sulcatus, common at Barton Mills, Claydon, and Brandon; and a single C. dispar at Foxhall in September. Several species of Ascogaster are also mentioned: A. rufipes from Tuddenham, A. rufidens from Bildeston, A. variipes from Henstead, and $A$. quadridentatus at Tostock, Grundisburgh, and the Bentley Woods. Of the nine British Sigalphi, only four have been noted here: S. luteipes at Benacre Broad, Aldeburgh, and Kenton;

${ }^{2}$ Cf. Ent. Mo. Mag. 1906, p. 106.
Brit. Ent. 5 I2.
"I Ibid. 1902, p. 10.

Op. cit. 325 , pl. x, fig. 6. 


\section{A HISTORY OF SUFFOLK}

S. caudatus at Aldeburgh, Needham, and Claydon; S. floricola at Southwold, and S.obscurellus, which was taken by Tuck at Aldeburgh in September 1899.

In 1906 I paid some little attention to the Microgasterides, so beneficial in destroying the white butterfly caterpillars on cabbages. ${ }^{24}$ In the extensive genus Apanteles, I have swept $A$. ferrugineus at Barton Mills and in Tuddenham Fen; taken A. limbatus about Ipswich in 1893 ; seen $A$. glomeratus everywhere on Pieris rapae and brassicae; received $A$. spurius from Platten at Ipswich; captured $A$. geryonis in the Bentley Woods; instanced $A$. zygaenarun from Felixstowe and Brandon; bred ten $A$. caiae from Chelonia caia at Ipswich; received $A$. nothus from Rothschild, who bred them from Anticlea sinuata, at Tuddenham; and eleven $A$.difficilis from Tuck, who bred them at Bury St. Edmunds; $A$. falcatus occurs in Barnby Broad in August; $A$. decorus in the Bentley Woods and Benacre Broad; $A$. obscurus at Oulton Broad and Brandon; $A$. coniferae in the Walberswick salt-marshes; $A$. fuliginosus at Claydon on Angelica flowers in August; $A$. astrarches at Lakenheath and the Bentley Woods; $A$. bicolor in the Southwold salt-marshes in August ; and the common $A$. fulvipes at Wortham, Tuddenham Fen, Barton Mills, and Stanstead Wood in June. The allied genus Microplitis is not so well represented by $M$. spinolae at Southwold in August ; $M$. tristis, which Tuck has bred here from Diatbecia cucubali; $M$. dolens on Angelica flowers at Claydon in $1899 ; M$. spectabilis, a common species about Ipswich; M. mediana at Claydon, late in September; and $M$. tuberculifera at Ipswich and the Bentley Woods. The typical genus Microgaster is treated of in the Entomologist for 1906, and mention is made of $M$. alvearius at Ipswich; $M$. connexus at Bungay; $M$. tiro at Henstead in August; $M$. suffolciensis, Morl., from such distant places as Bury St. Edmunds and Locarno, though in both it was bred from Notbris verbascella; $M$. subcompletus has occurred at Alderton in September; $M$. sticticus at Tostock and Barnby Broad; and both $M$. globatus and $M$. tibialis are very common. The review of the section Areolarii is completed in the Entomologist, 1907, p. 217, where I have instanced the capture of a new British species, Microdus nugax, on meadow-sweet flowers at Foxhall in August 1902; $M$. clausthalianus at Barton Mills in June; and $M$. tumidulus at Foxhall and Claydon Bridge. Earinus nitidulus has been swept in Tuddenham $F$ en and $E$. gloriatorius beaten from birch-bushes in the Bentley Woods in May; Orgilus obscurator occurs in Tuddenham Fen and the Bentley Woods; and I have described a species new to science, $O$. micropterus, which was first taken on the flowers of Angelica at Foxhall on 12 September 1898.

This brings us to the confusing Polymorphi, among which the Euphorides are here represented by Euphorus pallidipes and E. picipes, both common in May, the former at Stanstead, Belstead, Brockdish (Norf.), Brandon and Barton Mills, and the latter in Tuddenham Fen. Microctonus splendidus has turned up at Southwold in August, and Perilitus rutilus is common among turnips at Ipswich and Monk Soham. Meteorus albiditarsis has been taken by Elliott in the Bentley Woods; I have beaten $M$. caligatus from plum at Barham in May; $M$. chrysophthalmus at Freston early in September; Mr. Sparke has found $M$. deceptor at Tuddenham Fen; $M$. pallidipes is common at Wherstead, Assington, and Monk Soham; M. obfuscatus is common about Boleti on elms, since it preys upon the larvae of beetles feeding therein; $M$. atrator has occurred on the windows of Monk Soham House, with $M$. scutellator, in August ; $M$. rubens has been found by Mr. Piffard on the Felixstowe sandhills, and $M$. fragilis is common at Tuddenham, Halesworth, Needham, and Moulton; $M$. punctiventris occurs at Southwold; $M$. filator was once found ovipositing in a dead rabbit in the Bentley Woods; and $M$. pulchricornis is common about Ipswich. Blacus armatulus is not rare in bracken refuse in the Bentley Woods, together with $B$. ruficornis; ${ }^{25}$ and $I$ have found $B$. bumilis at Claydon Bridge. Curtis ${ }^{26}$ records the beautiful Proterops nigripennis, Wesm., under the name Bracon denigrator, Linn., as having been taken by the Rev. William Kirby, probably at Barham; and in the Entomologists' Monthly Magazine, I900, p. I74, I have confirmed Helcon annulicornis as a British insect on the strength of an example captured in Brantham Dale, apparently in search of some ivy-feeding beetle. Macrocentrus marginator is a very common kind on flowers and reeds at Lowestoft, Brandon, Monk Soham, Southwold, and Herringswell ; $M$. thoracicus occurs at Ipswich and in Assington Thicks; $M$. abdominalis is abundant throughout the county; $M$. infirmus has been noted at Monk Soham, Southwold, Aldeburgh, and Barton Mills; and $M$. collaris under plants of Erodium cicutarium at Brandon in August. Diospilus oleraceus is common at Assington, Bentley, Tostock, and Monk Soham; and Pygostolus sticticus not rare at Brandon in June. The rare and very aberrant Pachylomma buccata was found on my study window at Monk Soham early in July 1905; but the Aphidiides are very poorly represented by Aphidius cardui on fennel flowers on the Felixstowe cliffs, A. granarius bred at Monk Soham from Siphonophora sonchi in 1907, A. avenae and $A$. pini in the Bentley Woods, where also Ephedrus lacertosus has appeared; besides these only Trioxys aceris can be named, though a great many species which I have recently bred from aphides in my garden

* Cf. Entom. 1906, pp. 99-105.

${ }^{28}$ Cf. Ent. Mo. Mag. 1900, p. 288 ; 1901, p. 17.

${ }^{20}$ Brit. Ent. lxix. 


\section{INSECTS}

await determination. The rare Polemon liparae has been swept in the marshes at Barton Mills in the middle of June, and Dale also tells us that it has been bred from the dipterous Lipara lucens at Beccles in 1861.97

The Pezomachoid Chasmodon apterus is found at Wherstead and Blythburgh; and Aphaereta ceppalotes in the Bentley Woods and ovipositing in dipterous larvae in dung at Southwold. Goniarcina lucicola occurs among autumnal fungi at Bramford and Foxhall ; and Diaspasta contracta in a damp wood in the former locality in mid-October. The typical Alysia manducator is frequently found ovipositing in dipterous larvae amongst carrion at Claydon, Foxhall, Henstead, Barnby Broad, and Tuddenham Fen; the allied Homophyla pullata I have seen in a horse-trough in Ipswich, Pbaenocarpa conspurcator ovipositing in dog's droppings, Aspilota ruficornis in Stanstead Wood and Tuddenham Fen, and once I found several specimens of what the Rev. T. A. Marshall said was A. maculipes in a fungus at Assington Thicks in June. At the same locality Oenone ringens has also been taken; and the curious Chaenon anceps is not uncommon at Tostock, Tuddenham, and Lowestoft. Coelinius niger occurs frequently in marshes at Felixstowe, Dennington, and Barton Mills; C. gracilis at Brandon; and $C$. elegans is doubtless common in the Broads district. Rhizarcha stramineipes has several times been taken in the Bentley Woods, and Dacnusa abdita once or twice at Nacton.

\section{Proctotrypidae}

Very little is known of the British Proctotrypidae, which have never been adequately monographed; and consequently I am greatly indebted to the late Rev. T. A. Marshall, whose contribution on this subject was, I believe, to have appeared in Andre's great Species des Hyménoptéres d'Europe, for kindly examining and naming the fifty kinds enumerated in the following list, only two of which had been previously recorded hence by Curtis. These interesting little creatures are, for the most part, parasitic upon the eggs of other insects and, since more than one often find sustenence in a single moth's egg to supply the whole of their larval appetite, the minute size of these 'Fairy Flies' may be easily imagined; but their beautiful and varied structure is only to be appreciated through the microscope. Their classification is still to a great extent in a state of chaos, from which it may be expected to emerge on the completion of Dr. Kieffer's perhaps too elaborate European Monograph. We are indebted to Mr. A. J. Chitty for the revision of our species, and those not here bearing a distinctive name will shortly be described by him.

In the subfamily Proctotrypinae, the typical genus is represented in Suffolk by Proctotrypes niger, which has occurred to me in Tuddenham Fen and to Tuck at Tostock; its var. $a$ was swept at Needham Market, and the var. $\beta$ taken on umbelliferous flowers on the coast at Felixstowe. Tuck has also taken P. ater, Nees, at Tostock in May and P. buccatus, Thoms., in September; I have found the latter at Whitton and Dodnash. The first of Mr. Chitty's new species was also taken by Tuck in an old beehive in Bury St. Edmunds, and I discovered the second in a dead rabbit in the Bentley Woods. ${ }^{28}$ P. longicornis, Nees, is common, and has turned up at Bentley Woods on fir trees, at Felixstowe, Claydon, and Aspall Wood. P. brevipennis, Latr., was once swept at Westleton by Mr. Elliott, and I caught it running on Foxhall Plateau in July I904. The handsome P. gravidator, L., is not uncommon at Foxhall, Brandon, Herringswell, Belstead, and on the Kessingland cliffs; whilst an allied species-Chitty's third-was in my sweep-net in Tuddenham Fen on 23 August 1905. P. pallidipes has only been found at Wherstead and Barton Mills; and $P$. viator, which destroys wireworms, at Ipswich and Tostock. P. calcar, Hal., is also found at Tostock and Barton Mills; but $P$. laricis, Hal., is confined to the Ipswich district, Bentley Woods, Bramford, and Bourne Bridge. It is $P$. parvulus, Hal., that destroys the larvae of Orchesia micans in fungi on elm, in the same locality. Chitty's fourth species I swept in a little alder wood at Bramford; ${ }^{29}$ and his fifth occurred to me on long grass at Wortham early in June 1900 . Codrus apterogynus, Hal., and Lagynodes pallidus, Boh., are not infrequent, the former at Southwold, Corton cliffs, Sproughton, and Claydon, the latter in the Bramford marshes and amongst moss. Trichosteresis nitida, Thoms., has been taken at Nacton; T. Försteri, Kief., swept at Southwold in August 1904; Megaspilus alutaceus, Thoms., on the cliffs at Corton; $M$. balteratus, Boh., in the Bentley Woods; $M$. rufipes, Nees, among moss at Ipswich ; and the apterous form of $M$. thoracicus, Nees, in a marshy wood at Bramford. The interesting and perhaps fossorial Bethylus fuscicornis, Jur., is recorded by Curtis, under the name $B$. punctatus, ${ }^{30}$ from rushes on the beach at Covehithe, and it is common at Ipswich, Bentley Woods, and Oulton Broad; its for-long-intermixed cousin, B. cephalotes, Först., has been taken at Brandon in the north and Sudbury in the south. Of the Dryininae, Chitty has recorded ${ }^{31}$ Gonatopus striatus, Kief., from Brandon in May, and G. sepsoides, Westw., from Lowestoft. To the genus Antacon he has paid considerable attention, and has just published

"Cf. Ent. Mo. Mag. I893, p. 115.

2 Ibid. I 900, p. 42.
${ }^{30}$ Brit. Ent. $\mathbf{7 2 0}$.

Ibid. I 907, p. 50.

31 Ent. Rec. 1907, p. 81. 


\section{A HISTORY OF SUFFOLK}

deseriptions of new species. His A. barbatus I took at Bentley in May 1902; A. arcuatus, Kief., I found in the same locality in July 1904, and A. imberbis, Kief., in Assington Thicks in May 1899. Chitty's A. Kiefferi was floating on a horse-trough in Ipswich in May 1895. A. Gaullei, Kief., occurs on flowers in the Bramford marshes and on fumatory at Tattingstone in July; while A. Morleyi, Chitty, affected the flowers of meadow-sweet at Foxhall in August 1902. I have also taken $A$. vicinus, Kief., by the Alde at Farnham and $A$. fusiformis, Kief., in a swamp at Reydon.

Of the very rare Pedinomma rufescens, Westw., I captured the second or third British example in a chalk pit in Barking on 6 October 1898 ; Mr. Marshall, to whom I gave it, first discovered the $\delta$, also an apterous insect, in I90I. The second of Curtis's records refers to Helorus anomalipes, Panz., which he says the Rev. William Kirby had observed in Suffolk, ${ }^{32}$ where, indeed, it is fairly common everywhere, though especially so at Aldeburgh and Sibton Abbey. Among the Belytinae we have fifteen ill-defined species : an undescribed Acropiesta occurred to me at Blakenham in May 1897 ; and in the genus Belyta, B. validicornis, Thoms, was taken at the same time and subsequently at Brockdish (Norf.). B. depressa and B. abrupta, Thoms., have been found respectively at the Kessingland cliffs in July and Stanstead Wood in the middle of June. The fourth and fifth species were taken flying in the Bentley Woods 27 May 1900 ; and B. dorsalis, Thoms., was once swept in Dodnash Woods in September. I have taken Pantoclis brevis, Nees, in moss at Ipswich, and a species of the same genus or Anectata in the Bentley Woods on 22 September 1899. A new species of Aclista was also swept there on the same day, as well as A. brachyptera, Thoms., on 28 September 1895 . Single specimens of Ismarus favicornis, Thoms., at Southwold, Oxylabis armata, Curt., at Bentley Woods, and of a species of Xenotoma at Stanstead Wood in June, have also been noted. Turning now to the Diapriinae, we find that Spilomicrus stigmaticalis has been swept from herbage at Little Blakenham; S. nigripes, Thoms., is common at Tuddenham Fen, Ipswich, and Barnby Broad; and that S. integer has occurred at Wherstead on 27 October, 1903. Aneurrbynchus galesiformis, Westw., has been found in Bentley Woods, A. pentatomus, Thoms., at Stanstead Wood and Knight's Dales, and $A$. nodicornis, Marsh., has also put in an appearance. Galesus fuscipennis, Curt., occurs at Bentley and Belstead, and its variety was taken in the former woods on II July I902. Basalys antennata, Nees, has once been taken at Foxhall in September; and a new species of Paramesius beneath the bark of a willow tree at Sproughton on 3 September 1897 . The genus Loxotropa is represented ty L. tritoma, Thoms., in Dodnash Woods; L.tripartita, Marsh. (or dispar, Nees), on the banks of the Orwell at Wherstead; L. abrupta, Thoms., in a marshy wood at Bramford; ${ }^{33}$ and Galesus brevicornis or obliquus, Thoms., at Bentley. The typical genus Diapria is represented by D. conica, Fab., in the Bentley Woods, at Southwold and Claydon; Mr. Chitty's first new species is not Suffolcian, but the second was found in the centre of Framlingham; $D$. verticillata, Latr., has occurred at Claydon, and the third new species in the Bramford marshes; D. nigra, Nees, is common at Easton Broad, Foxhall Decoy, and perhaps at Barren Heath, near Ipswich; D. suspecta, Nees, on brackish mud at Aldeburgh, at the roots of ragwort at Brandon, and of stonecrop at Tuddenham. A fourth kind has appeared in flood refuse by the Gipping and on firs in the Bentley Woods. Monelata petiolaris, Nees, has been found in damp moss in the same locality in the autumn, together with the minute Leptacis scutellaris, 'Thoms., which sometimes lives in ants' nests. Late in September 1905 my wife discovered on a white table-cloth, Alaptus minimus, Walk., one of the most minute of our indigenous insects, measuring one-fiftieth of an inch in length.

\section{TENTHREDONIDEA}

The nomenclature of the sawflies is just now in a state or transition from that employed in Cameron's British Phytophagous Hymenoptera to the more scientific system evolved by Pastor Konow, as at present being set forth by the Rev. F. D. Morice in The Entomologists' Monthly Magazine; and although Mr. Morice's nomenclature has not yet nearly fully appeared, and is still quite unfamiliar to British students, it is thought advisable, in the following résumé of the Suffolk species, to adopt for the most part the newer, more correct but less familiar names, which will shortly be the only ones in general use. The sawflies of the county have been comparatively fully worked during the past ten years, though never systematically, and new kinds are still constantly turning up as more and more of the Broads, Breck, woods, and marsh-lands are explored entomologically.

The curious little Xyela jullii occurs, though sparingly, on pine trees in Bentley Woods, where Pamphilus sylvarum has once been taken and $P$. sylvaticus is of periodical appearance. The Cephina are rather well represented by Fanus cynosbati, which Mr. Chitty took at Brandon; ${ }^{34}$ Trachelus tabidus from Boxford and Claydon; Cepbus pilosulus from Stanstead and Barton Mills; C. pallidipes from Moulton and Tuddenham; and $C$. pygmaeus, which is only too common everywhere, and very

38 Brit. Ent. 403.

* Cf. Ent.Mo. Mag. 1900, p. 42.

${ }^{34}$ Ibid. 1903, P. 277. 


\section{INSECTS}

destructive to the wheat crops. The Siricdidae or horntails, which used to be considered distinct from the Tenthredinidae, have recently been placed here, and are well-represented in Suffolk. Of this small family, Xiphydria prolongata has occurred in some numbers to me at Mildenhall in one oak post ${ }^{36}$ and the handsome Sirex gigas occasionally appears throughout the county, ${ }^{36}$ and was found in Ipswich in $1903 ; S$. noctilio is of much less frequent observation, and is only recorded from Tostock, Bury, Great Glemham, and Battisford. The large and handsome Cimbicina are but poorly worked in the county at present; Cimbex sylvarum used to be common at Lound in Paget's time, and C. femorata has only once been found, by the late Mr. E. G. J. Sparke, who dug up the cocoon near Bury St. Edmund's; there is also but one example of $C$. lutea, which was taken at Bury many years ago by the Rev. A. H. Wratislaw. In August 1904 I beat a larva of $C$. connata from alder in Freston Woud. ${ }^{37}$ Trichiosoma lucorum was found feeding on birch by Paget; but $\mathcal{T}$. tibialis is quite common on whitethorn at Sudbury, Debenham, and about Ipswich, being often destroyed by

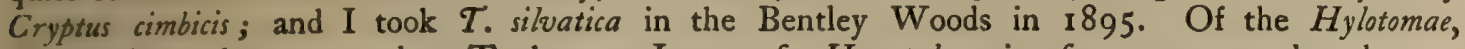
$H$. coerulescens has occurred to Tuck near Lowestoft, $H$. ustulata is often common though very local, $H$. cyanocrocea is rare at Tostock, Wherstead, and Ipswich, and I have turned up $H$. fuscipes in Assington Thicks in May. Abia sericea is much commoner with us than the usually more widely distributed $A$. fasciata, which only lives in the Bentley Woods; and fifty years ago the Rev. E. N. Bloomfield found a Lophyrus, which was probably pini, defoliating the fir-trees at Easton. Larvae of Arge rosae are very destructive to rose-trees; I took them at Tuddenham in 1906.

Turning to the Nematina, we find Hemichroa crocea in the Brandon and Freston marshes, and H. alni at Bentley and Lackford Bridge, while Dineura nigricans is common in the Bentley Woods and in Assington Thicks; D. stylata has turned up at Brandon, and Mesoneura verna at Belstead in May. Priophorus padi, Cladius pectinicornis, and Trichocampus viminalis are abundant; T.ulmi extends from Ipswich to Tostock and from Leiston to Lowestoft, and Priophorus tristis is found at Bentley. Mr. Norgate has discovered Croesus septentrionalis in north Suffolk, and it would appear, from the old records of Curtis, Paget, and Westwood, ${ }^{38}$ to have been widely distributed at that time; I took it at Brandon in 1906, but it is certainly rare there, occurring in August. Fifty species of the now sub-divided genus Nematus have been noticed:-Micronematus monogyniae is found in the Bentley Woods, Phyllotoma vagans at Brandon, Lygaeonematus compressicornis in Barnby Broad, and Cryptocampus saliceti is quite common. Pristiphora shows $P$. fulvipes and ruficornis at Bramford, Aletcheri at Ipswich, Felixstowe, and Sudbury, pallidiventris and westoni common in Tuddenham Fen, subbifida at Aldeburgh, and $P$. pallidipes in the Reydon alder carr. Nematus, as now restricted, contains only five Suffolcian kinds : $N$. crassus once at Tuddenham, aurantiacus by Tuck at Bungay, acuminatus in the Bentley Woods, luteus rarely at Brandon, and N. consobrinus at Ipswich in 1893 . Of Pteronus we have a dozen species, the Ipswich district contributing $P$. virescens, curtispina, bergmanni, bortensis, croceus, and pavidus; the gooseberry pest, $P$. ribesii, appears much less prevalent here than in most places, though it is recorded from six or seven parishes; $P$. myosotidis is everywhere abundant, $P$. oligospilus has been found at Tuddenham and Ipswich, $P$. brevivalvis at Foxhall, $P$. melanaspis rarely at Henstead marsh and Bentley Woods, and once I found males of $P$. polyspilus common at Brandon. Pachynematus adds $P$. vagus and trisignatus commonly, $P$. einersbergensis, clitellatus and turgidus at Barnby Broad, $P$. albipennis at Ipswich, $P$. apicalis and xanthocarpus in the-Bentley Woods, $P$. obductus at Tuddenham, and $P$. rumices at both Dunwich and the Reydon alder carr in June. Holcocneme lucidus is fairly common, but $H$. caeruleocarpus has only been taken by Tuck at Tostock. The willow-feeding Pontaniae are $P$. salicis and leucosticta, which are both common, $P$. salicis-cinereae at Tuddenham, $P$. gallicola at Ipswich, $P$. bipartita at Walberswick and Dunwich, and $P$. viminalis in the Reydon alder carr. The last of these sub-genera is Amauronematus, which includes $A$. viduatus from Brandon and Tuddenham, $A$. vittatus from the latter locality, and $A$. fallax taken by me at Ipswich in 1895 and in Tuddenham Fen in 1907.

The pretty Eriocampa ovata is recorded ${ }^{39}$ plentifully from Lowestoft, $E$. annulipes has been found at Brandon, $E$. varipes at Walberswick and in the Bentley Woods, $E$. testaceipes at Tostock, and the destructive $E$. limacina is fortunately rare, as also would appear to be the rose pest, $E$. aethiops which I have only seen in the Bawdsey marshes. Suffolk can claim many of the Blennocampae, of which B. tenuicornis and aterrima, with Monophadnus geniculatus, have only occurred at Ipswich, $M$. albipes at Foxhall and in Tuddenham Fen, B. melanocephalus in the Bentley Woods, and Pareophora nigripes only at Lavenham and Foxhall in May. Scolioneura vicina, S. nana, and S. betulaeti are beaten from birch in woods in September, May, and June respectively; Blennocampa alternipes and assimilis at Bramford, B. pusilla at Bungay and Assington, while Tomostethus luteiventris, dubius, and fuliginosus are all widely distributed. Hoplocampa ferruginea and crataegi are frequent in hedges, $H$. pectoralis has occurred to me at Barton Mills, and $H$. rutilicornis in the Bentley Woods, where

${ }^{3}$ Ent. Mo. Mag. 1899, p. 190.

ss Proc. Ent. Soc. 1840 , p. v.

$$
{ }^{36} \text { Ibid. 1898, p. } 213 . \quad{ }^{37} \text { Ibid. 1905, p. } 214 .
$$




\section{A HISTORY OF SUFFOLK}

Harpiphorus lepidus is sometimes seen. In the genus Emphytus we are rather poor, only being enabled to claim $E$. togatus at Bentley, $E$. serotinus at Bungay and Bramford in October, and $E$. grossulariae rarely in Assington Thicks and Finborough Park; but $E$. calceatus and tener are somewhat common, and $\mathrm{Mr}$. Tuck has recently added $E$. cinctus and tibialis from Tostock. Fenella nigrita is rare at Belstead, Fenusa melanopoda local at Barnby Broad and Tostock, $F$. pygmaea at Bramford and Brandon, and $F$. betulae at Barton Mills. I took Kaliosysphinga ulmi at Foxhall in May 1907. Athalia annulata is the only unobserved kind of the genus, for $A$. rosae abounds everywhere, $A$. spinarum is recorded by Curtis in his Farm Insects as most destructive about Covehithe, and I have recently found it there, as well as in the Breck district; $A$. ancilla is local, A. scutellariae has only been taken in Tuddenham Fen and $A$. lugens is represented by a single female captured at Southwold by Mr. Tuck. Selandria serva is abundant, $S$. stramineipes local at Ipswich, Brandon, and Assington; $S$. morio widely distributed and $S$. aperta only noticed at Barton Mills, Lowestoft, Brandon, and Ipswich. Strongylogaster cingulatus is common among bracken, including two of the rare male ; and I have taken Stromboceros delicatulus rarely in both Assington and Staverton Thicks. At Dodnash, Tuddenham, and Lowestoft Taxonus equiseti, which is certainly not common, has been met with; T. glabratus is, however, abundant with Poecilosoma excisa at Henstead and Reydon. $P$. luteolum occurred to me at Southwold in 1900, P. immusa at Barton Mills and in Bentley Woods in June, with $P$. pulveratum once at Foxhall, and $P$. tridens once at Barnby Broad. Of $P$. longicornis I took a single male in Reydon marshes in June 1905.

Of the difficult Dolerina we have Loderus palmatus at Tostock and Bramford, Dolerus madidus at Ipswich and Tostock, D. palustris widely distributed but not common, D. liogaster at East Bridge, $D$. baematodes at Foxhall and Tostock, D. nigratus at Monk Soham, D. rugosulus at Blakenham, $D$. ravus at Stoke-by-Clare and Lavenham in the south, D. fissus in the Bentley Woods, with $D$. coruscans and picipes; while D. pratensis, gonager, anthracinus, aeneus, and Loderus vestigialis are widely distributed and most of them common. Tenthredopsis campestris, litterata, dorsalis, and coqueberti are frequently met with in the spring; $T$. tiliae is not rare at Tostock and Bentley, T. ornata is recorded from near Yarmouth by Paget, and has turned up at Belstead, Lavenham, \&c.; and Mr. W. H. Tuck has found T. dorsivittata at Tostock. Rhogogastera lateralis, aucupariae, and viridis are all common and widely distributed. Pachyprotasis rapae is abundant, but $P$. antennata, so common in the south of England, has not occurred with us. Of the handsome genus Macrophya, the marsh-loving $M$. I2-punctata is even commoner than $M$. neglecta, $M$. blanda and rufipes have occurred at Copdock, M. rustica at Bungay and Woolpit in July, while at Brandon I once found $M$. albicincta, and once at Belstead $M$. ribis. Allantus scropbulariae and arcuatus are abundant, though $A$. marginellus is rare, and $A$. cingulum doubtfully Suffolcian. In the typical genus Tentbredo, four kinds-livida, rufiventris, bicincta, and mesomela-are abundant in the woods; $\mathcal{T}$. velox, T. solitaria, and $\mathcal{T}$. maculata are all very rare indeed at Bentley, though $\mathcal{T}_{\text {. atra }}$ is occasionally met with there, and $\mathcal{T}$. punctulata has only been seen in Assington Thicks; at Brandon alone $\mathcal{T}$. picta has occurred to Mr. Chitty and me in some numbers.

In all one hundred and ninety-one species have been noticed in Suffolk out of the nearly four hundred which inhabit Britain.

\section{COLEOPTERA}

\section{Beetles}

At the time of the publication of Canon Fowler's recent work on the beetles of the British Islands, very little indeed appeared to be known of the Suffolk species; but a careful and systematic study of various books and periodicals issued during rather more than the last hundred years reveals the fact that it was only in comparatively recent times that they had been neglected. In the very first British book on beetles, the Entomologia Britannica of Marsham, which appeared in 1802, we find some twenty species recorded from Suffolk, mainly upon the authority of the Rev. William Kirby, M.A., F.R.S. The earliest of these records takes precedence, perhaps, of any in Britain, and refers to Scarabaeus (Geotrupes) vernalis, L., which was found commonly near Woodbridge in 1795. And in the same year the rector of Barham gave his classical Monographia Apum Angliae with a local mention of the curious Stylops which bears his name and has since been adopted as the permanent seal of the Entomological Society. During the following twenty years John Curtis collected extensively in various parts of the county and many of his better captures are brought forward in the British Entomology of 1823-40. Denny enumerates several of Kirby's Pselaphi and Scydmaeni in his Norwich Monographia of 1825 ; and nine years later many beetles are recorded, though without author's names, from the north-east corner of the county by the Pagets. Stephens's Manual in 1839 condenses the records set forth in the same author's Illustrations, with many additions; and 


\section{INSECTS}

others are contained in the Annals and Magazine of Natural History and in the Zoologist of 1844 and 1849 respectively, by Walton and Prof. Henslow. The venerable William Kirby died in 1850 , and in Mr. Freeman's account of his life, published in 1852, several of his more noteworthy beetles are referred to, as well as many of his interesting Suffolk wanderings in search of them. Dawson has new material in his Geodephaga Britannica of 1854 , where several full accounts of those of the older writers may be found. The Naturalist of 1858 and the Entomologists' Weekly Intelligencer of I 859 to 1861 contain some most useful lists of captures by Leeds Fox, Dr. Garneys, and Tyrer, who went to live at Eye in April of the former year. Curtis supplements his earlier notes by others in his Farm Insects in 1860. The old numbers of the Entomologists' Monthly Magazine contain several county records from the pens of Rye, Saunders, Walker, Barrett, and the Rev. A. H. Wratislaw of Bury School, who also wrote on the subject in the Transactions of the Suffolk Archaeological Society of 1870 . Power seems to have collected here very little, but is interesting in the Entomologist of 1865 and 1866. Then comes the gap. Till 1894, when I attacked the beetles of the Ipswich district, nothing was done, but since that time notes have flowed in broadcast from Messrs. Bedwell, Baylis, Butler, Chitty, Cottam, Champion, F. Fox, Keys, Norgate, Tomlin, and Tuck.

In 1899 I summed up all that was then known of our beetles, enumerating 1,763 species in my Coleoptera of Suffolk; and we can now show that from 1795 to a few months ago, when a species not previously known among the three and a quarter thousand in Britain was here discovered, the county, despite its paucity of observers, has always held its own as a prolific and happy hunting ground.

An account of the more ubiquitous kinds would occupy far too much valuable space to no good purpose, and I propose to give simply a brief summary of those species which, from their local distribution, almost exclusive attachment to our peculiar supersoils, or their individual rarity, appear to be worthy of especial consideration in a county history, particularly since full lists have already been printed in my work above referred to.

One of the most handsome, as well as rarest (for it is thought to be hardly indigenous), of our British insects is Calosoma sychophanta, which was first discovered about I 820, at Aldeburgh, on the Suffolk coast, by the poet Crabbe, who was undoubtedly a good naturalist or he could not have written such a splendid resume of the fauna of Belvoir as is published in Nichols' History of Leicester. ${ }^{1}$ This insect has probably occurred more frequently here than elsewhere in Britain, since we have also records of it from Southwold, by a lady, and several times at Lowestoft, one as late as 1857 , of which some were said to have been floating on the sea. Several continental beetles appear to have reached our coast in this way, since Licinus cassideus, which is certainly not British, has been found at Aldeburgh according to Dawson, who also says that Chlaenius sulcicollis, which has a wide range through Germany, Sweden, \&c., was once picked up near Covehithe about 1825. It is a curious coincidence that these visitants should have all occurred within a few miles of each other. There are other records of continental species occurring in Suffolk, but the majority of these are very unreliable, since they were brought forward before our fauna was adequately investigated and its species determined. Such marsh-frequenting kinds as Dromius sigma and D. longiceps, Odacantha melanura, which occurs near Manningtree as well as in Benacre and Oulton Broads, and Bradycellus placidus, are by no means uncommon among rejectamenta left on the banks after a flood; and I have enumerated 152 different species found in one bag of it on the margins of the River Gipping near Ipswich in February, which included two dozen of the very rare Trachys troglodytes. ${ }^{2}$ In May 1897 Mr. E. A. Elliott, F.Z.S., and I discovered Harpalus Frölichii upon the Foxhall plateau, which species had not before been found in Britain, and it was by no means rare in this one restricted locality, where it occurred in company with $H$. discoideus, ignavus, consentaneus, Medon castaneus, \&cc., during 1898. Then it appeared to unaccountably die out; only one example being found in 1899 , and it was feared that it had entirely disappeared; ${ }^{3}$ but it has again turned up, though very sparingly, in its old haunts. ${ }^{4}$ Upon the Breck sands in the neighbourhood of Brandon is the only locality in Britain where Harpalus anxius is found inland, and almost the only one inland for $H$. picipennis, though on the coast the former is common, with Amara consularis, Lymnaeum nigropicum, Lionychus quadrillum, and the Pogoni. The first British capture of Polystichus vittatus was effected by Hewitson in 1828 near Southwold; and many other interesting Geodephaga also occur. The last I shall refer to is Anchomenus gracilipes, which is nowhere found in our islands outside this county, though the Rev. W. F. Johnson records it from Donegal; this latter is, however, owned to be an error in Mr. Johnson's recent List of the Beetles of Ireland. The first specimen was taken at the Wisbeach Canal at Lowestoft in 1831 ; a second at Southwold in 1859 ; two at Lowestoft in June 1861 ; and the last by Mr. Bedwell at the base of the Corton cliffs in June $1898 .^{\circ}$

\footnotetext{
'Vol. i, pp. crc-cciii (1795).

Cf. Ent. Mo. Mag. April 1897.

'Ibid. 1898 , p. 84 ; 1901 , p. 64 ; East Go. Mag. ii, No. 5 .

- Cf. Ent. Mo. Mag. 1903, P. 205.

${ }^{3}$ Ibid. Oct. 1898.
} 


\section{A HISTORY OF SUFFOLK}

The water-beetles, both carnivorous and phytophagous, offer little of note, and much yet remains to be done concerning them, since, considering the great extent of brackish and fresh water, there is no reason why all the very rarest, which occur in our latitude, should not be found here. Mr. E. A. Newbery has recently introduced Haliplus immaculatus, Gerh., into the British fauna, on the strength of specimens taken at Bury St. Edmunds by Mr. W. H. Tuck, M.A. The fenloving Hydroporus halensis was first captured in Britain at Haughley; and subsequently at Stowmarket and Bungay; I have found it commonly in a little rain-pool in the Foxhall crag-pits, and once or twice in the Bramford marshes. Illybius subaeneus is also said to have occurred in the Waveney near Beccles, though the record appears open to doubt. Marsham noticed Cercyon littoralis on the banks of the Orwell near Ipswich, and it is still extremely abundant in the same locality, with Aleochara algarum, \&c. The Brachelytra are represented by some four hundred species; and many of Stephens's records cannot be incorporated for lack of synonymy. Microglossa marginalis has once occurred to me at Martlesham, and the rare Myrmedonia collaris is not unusually found at Oulton Broad and near Beccles, by sifting the refuse of marsh-hay stacks. Vellius dilatatus has several times turned up in some numbers; Prof. Henslow, writing to the Zoologist, says he took thirty or forty examples in 1848 ; and in $1896 \mathrm{Mr}$. Tuck found several in the nests of hornets and wasps at Bury St. Edmunds. In bees' nests the latter found the first British Quedius nigrocaeruleus, which was also taken by Bedwell at Kessingland in July $1905 .{ }^{6}$ Ocypus cyaneus is found about Bury, where it has occurred several times; and one or two Philontbus lucens have turned up in the Bentley Woods, in moss. Stilicus fragilis was once found in abundance in Aspall Wood by Dr. Garneys, but seems to have died out, since I have been unable to rediscover it there. Rye wrote so fully of the Suffolk Steni that the genus is well represented with us; its best exponents, perhaps, being Stenus ater, incrassatus, circularis, nigritulus, Erichsoni, pallidipes, and fornicatus. Oxyporus rufus is often common in summer fungi; and I once took two females of Bledius taurus flying to electric light in the middle of Ipswich at night. ${ }^{7}$ Prognatha quadricornis is another species first found in Britain by Kirby near Barham; it has since occurred to Mr. Tuck at Bury St. Edmunds, and to me at Lakenheath.

Several of the extensive and heterogeneous genera of the Clavicornia merit especial notice. The first two, which constituted the subject of Denny's Monograpbia, are somewhat poorly represented, primarily on account of their small size, retiring habits, and general rarity; Batrisus venustus was first found in Britain near Barham, and subsequently by Mr. Waterhouse near Glemsford in an old stump. Curtis figures a Suffolk specimen of Silpha opaca-possibly that taken at Aldeburgh by the Rev. F. W. Hope-in his British Entomology; and I have dug up the rare Hister maginatus at the base of an oak tree near Ipswich. Saprinus virescens has occurred to me at Belstead, and Teretrius picipes to Garneys near Bungay. - All the common ladybirds are very freely met with, though Coccinella I3-punctata has only been found, and then very rarely, near Bungay and Ipswich. Scymnus pulcbellus is practically confined to the vicinity of Barham, one specimen only being recorded from Kent in the Entomologists' Annual, 1864, p. 72. 'There were but two old specimens in Kirby's collection; and it was not till May 1894 that F. Fox rediscovered it at Coddenham, upon one side of one particular pine tree. I have taken Rbizophagus parallelocollis at Blakenham; and recently turned up Ortbocerus muticus, which had not been taken here for twenty years, upon the wind-swept heaths of the Breck, near Mildenhall. Aglenus brunneus is a well-known British insect, and there is no need to doubt the accuracy of Dr. Garneys' record of it from Bedingfield. ${ }^{8}$ The last Clavicorn worthy of note is Heterocerus obsoletus, Curtis, which its author found on the salt marshes in Suffolk the beginning of May; here it is still met with in no inconsiderable numbers, burrowing in the mud at the ditch-sides and flying freely in the sunshine. Mr. E. C. Bedwell has recently found that several unsuspected species of this group, including the rare Silvanus surinamensis, live in our Suffolk flour-mills. The Lamillicorn, Copris lunaris, was also found by Curtis at Bungay; and I have taken one specimen, apparently attracted by light, in a street lamp on the outskirts of Ipswich. Of the extensive and interesting genus $A$ phodius, we have noted twenty-five species, of which $A$. constans, not noticed since Stephens's record, $A$. porcus, by no means rare, and $A$. quadrimaculatus, which Mr. Fox informed me he had once found at Bawdsey and is now found near Ipswich, are the best. Odontaeus mobilicornis has once been recorded from the county; as also have Ischnodes sanguinicollis and Ludius ferrugineus.

Of the Malacoderma, the fen-loving Silis ruficollis occurs commonly in July along the valley of the Waveney, extending as far west as Brandon; together with Anthocomus rufus and Axinotarsus ruficollis. Psilotbrix nobilis, which ranges no farther north than Norfolk, is rarely met with in flowers of Glaucium flavum on the coast; and I have once swept Phlooophilus Edwardsi in Dodnash Woods. Larvae and imagines of Ptinus germanus were very common in an old gate-post at Wenham in April 1 899, having been previously taken once or twice at Bungay, where Dr. Garneys

${ }^{6}$ Cf. Ent. Mo. Mag. Mar. 1896 ; Dec. 1898 ; 1905, p. 279.

'Cf. Entom. Nov. 1895.

${ }^{8}$ See Claude Morley, Coleoptera of Suff. 58. 


\section{INSECTS}

found $P$. sexpunctatus in his house in May 1861 . A letter, describing the damage done to an oak beam in Barham Church by Xestobium tessellatum, from Mr. Spence, was read before the Entomological Society in 1847 . The Longicornia of the county could probably be augmented by a systematic working of the ancient woods around Fakenham and Staverton, which former I have never visited; most of the commoner kinds are, however, recorded. The lovely and aromatic musk beetle occurs year after year not uncommonly about Mildenhall, as was at first pointed out to me by Dr. Sharp ; it resembles a great emerald as it sits upon the white fluffy heads of the Angelica, sipping their nectar and protesting with loud stridulations to the pressure of one's fingers, with which it is easily captured; when flying it looks like a small bird, with its wide-spread elytra, legs, and flowing antennae. Hylotrupes bajulus from Frostenden, and Callidium alni from Bungay, have not been met with for many years. Curtis once took ' a considerable number' of Clytus arcuatus near the latter town, and I have recently rediscovered Rhagium bifasciatum, which is not rare in most parts of England. Acanthocinus aedilis, Monochammus sutor, and Phytaecia cylindrica have all occurred sparingly; the last, which has been recorded from Eye and Coddenham, has recently been found about Bury by Mr. Tuck.

In the Phytophaga - so called, I suppose, because the species of this division are only a small part of the plant-feeding beetles!-we are very rich, more especially, as was remarked by Rye, ${ }^{9}$ in the leaping species, which include the Turnip 'Fleas.' Sixteen of the nineteen British Donaciae have been noticed, of which $D$. dentipes is only known to live at Oulton Broad and Henstead Marsh, and $D$. cinerea only in Barnby Broad, where it is confined to a single clump of Arundo phragmites, though first turned up many years ago by Curtis; and $D$. impressa has not been found in Suffolk for seventy years. Cryptocephalus sexpunctatus has only once been found: I beat an example from birch in the Bentley Woods in May 1895 , and though the spot has since been constantly searched no more have appeared. Crysomela carnifex is another instance of a continental species found on the Suffolk coast, this time at Covehithe in April, by Mr. Curtis, who often collected in that neighbourhood; and there is hardly room to doubt the correctness of this record when we find that in June 1897 a specimen of the continental $C$. gloriosa, var. superba, was taken alive on the cliffs at Southwold, only a couple of miles farther south, and was carefully examined and undoubtedly correctly named. It is somewhat uncommon on the Continent, extending from the Maritime Alps, through Switzerland and Saxony, to the confines of Poland ; there is, however, no evidence to show that it has ever occurred in north-west Germany, it is unknown in Holland, and its mode of arrival upon our coast is entirely open to discussion. It may have been imported with garden produce, since it feeds upon the umbelliferous Laserpitium glabrum, in which case one would rather have looked for it in a town like Lowestoft, where Carabus auratus, Dawson says, has occurred, than on the open cliffs of Southwold. ${ }^{10}$ Phytodecta rufipes, Crytocephalus lineola, and Haltica coryli are common in the Bentley Woods; and Crepidodera nitidula is another rare kind, occurring not uncommonly upon young white poplars in Assington Thicks. Microzoum tibiale was taken by Kirby and Marsham at Barton Mills, where it is still often seen, in 1797 ; the former once took Diaperis boleti in 'considerable numbers' from a fungus near Barham in June, and it has not since been found in Britain. Cteniopus sulphureus is usually considered to be a coast insect, but in Suffolk we find it throughout the county-at Belton, Brandon, Tuddenham, Bramford, \&c. That interesting beetle whose larva always lives in wasps' nests, Metaecus paradoxus, is not by any means uncommon here, fifty examples having been found in one year near Bury by Mr. Tuck; and I anticipate that its supposed rarity would disappear if collectors cared to more frequently attack its strongholds. Cantharis vesicatoria is said by Westwood to have appeared in the county in 'immense profusion' about 1837 . It was recorded from Tuddenham and Icklingham by Wratislaw; and has lately been taken, locally abundant, in Essex and Cambridgeshire; in 1906 it was common at Newmarket.

Kirby first described the curious and anomalous Choragus Sheppardi from Offten ' in Suffolcia' in $1818,{ }^{11}$ and named it after the Rev. Revett Sheppard, who was curate of Nacton during the three years following 1804 , and a great friend of his; it is not a rare species here, though always occurring singly. An inexplicable case of 'distribution' is furnished by the occurrence of Rhinomacer attelaboides upon the pine trees in the Bentley Woods early in 1898 ; this species had never been found south of Ripon before, and no new timber had for a great many years been imported. ${ }^{18}$ Suffolk is rendered classical ground for the charming genus Apion by Kirby's 'Monograph' upon it in the Linnean Transactions, and some sixty different kinds are noted from the county, among which $A$. laevigatum is extremely rare, having been taken in only one other (now destroyed) locality in Britain.13 Kirby writes of it 'in arenario quodam prope Gippovicum a Dom. Sheppard bis lectum'; it is said to feed in galls upon the terminal shoots of Gnaphalium gallicum. A. affine, limonii, Gyllenbali, astragali, and flavimanum are also recorded by the older authors, but

- Cf. Ent. Ann. 1865 , p. 40 .

1 C. Linn. Trans. xii, 447 .

${ }^{13}$ C. Proc. Ent. So: 184 I, p. 32 ; Ent. Rec. viii, 2451.
${ }^{10}$ E. Anglian Daily Times, 15 Dec, 1898.

1 Cf. Ent. Mo. Mag. xxxiv, 166. 


\section{A HISTORY OF SUFFOLK}

have not been taken here for a considerable period. Though several of our three hundred species of weevils are rare, few claim special notice here. Dorytomus validirostris, generally a scarce insect, is very abundant with us beneath the bark of aspen trees during the winter; I have upon occasion taken a hundred examples beneath a single small piece of bark! Two specimens of Bagous diglyptus, of which only two others have been found in Britain, have at different times occurred to me on the banks of the Gipping near Ipswich; and the late G. C. Barrett found the larva of the very rare Gymnetron linariae at the roots of toadflax at Brandon, where it has recently again turned up sparingly. Stephens' ancient record of Cryptorrbynchus lapathi has recently been confirmed by the capture of fresh specimens by Mr. E. A. Elliott and others, at Barton Mills and Tuddenham Fen.

The above epitome will show, I think, how many rarities may be found in one county by assiduous collecting. The results of much of my own-some 8,500 specimens-were presented a short time ago to the Bury St. Edmunds Museum and form a fairly representative illustration of the local fauna of this group. I will conclude with a catalogue of those species which have been added to the 1,763 ennumerated in my Coleoptera of Suffolk, since its appearance in May 1899 until Oct. 1907, many of which had already been forecasted as of probable, though uninstanced, occurrence in the footnotes. A full list is given, since the majority are rare kinds.

\section{AdDitrons, 1899-1907}

Harpalus serripes. At roots of plants on crag cliffs at Felixstowe

Lemostenus complanatus. Three beneath bark of felled tree at Ipswich; Felixstowe

Anchomenus oblongus. Bentley Woods, in grass tufts

Bembidium doris. On margin of ditch in Tuddenham Fen in July

Demetrias monostigma. Not rare on banks of Little Ouse River at Brandon

Dromius longiceps. Swept by Mr. Chitty by the Ouse at Brandon, in May 1906

Brachinus crepitans. Fourteen examples near Landguard Fort, Felixstowe

Haliplus immaculatus. Several captured upon one occasion in the borough of Bury St. Edmunds, in June 1903 (cf. Ent. Mo. Mag. 1907, p. 4)

Deronectes depressus. Barmby Broad; Bury St. Edmunds; and Bungay

Hydroporus discretus. Two at Tostock in July

- bilineatus. Two slightly doubtful females at Tostock in July

Rhantus bistriatus. Tostock and Bury St. Edmunds; not rare

- grappii. Found singly at Oulton Broad and Tostock

Dytiscus circumcinctus. One dimorphic female at Tostock in May.

- punctulatus. Bungay and Bury St. Edmunds; very scarce

Hydaticus transversalis. One male at Barnby in April

Helochares punctatus. Curiously rare; only found at Wherstead in 1904

Limnebius nitidus. Taken at Brandon by the Ouse in June

Helophorus mulsanti. Found at Tostock, 23 May 1902

Ochthebius exaratus. One in a brackish ditch at Bawdsey

Cercyon terminatus. Found at Tostock in May 1902

Aleochara cuniculorum. Lowestoft, Staverton and Brandon; common in rabbit-holes

- spadicea. 'Taken in moles' nests at Ipswich by Prof. Beare

Oxypoda misella. Not rare in rabbit-holes about Brandon (cf. Ent. Mo. Mag. I904, p. 60)

Ischnoglossa prolixa. Found at Oulton Broad (cf. Ent. Mo. Mag. 1906, p. 12)

Ocyusa incrassata. Once found in Oulton Broad in December
Ocyusa maura. Probably common; Bixley Decoy in refuse in spring

- picina. Brandon and Bixley Decoy, in damp spots

- nigrata, Fairm. Levington, in martin's nest. New to Britain (cf. Ent. Mo. Mag. 1904, p. 251 )

Ilyobates propinquus. One specimen found at Ipswich in April

Callicerus rigidicornis. One specimen taken with the last

Thamiaria hospita. In a cossus tree at Oulion Broad in Aug.

Homalota caesula. In rabbit-holes about Brandon and Tuddenham

- cuspidata. Not rare under bark, Bentley Woods in Feb.

- hepatica. Once found about Mercurialis in Bentley Woods

- immersa. In rotten wood; Trimley Marshes and Bentley Woods

- intermedia. A somewhat doubtful specimen at Oulton Broad

- mortuorum. Swept singly at Tostock in June

- ravilla. Found in an old wasps' nest at Tostock in March

- vilis. Two males in Tuddenham Fen in June 1903

Tachyusa atra. Taken by the Little Ouse at Brandon in June

Xenusa uvida. One beneath seaweed by the Orwell at Wherstead

Lamprinus saginatus. Taken at Foxhall in April

Hypocyptus seminulum. One swept in Tuddentam Fen, Aug. I 905

Megacronus inclinans. One in dead leaves in Woolverstone Park

Quedius longicornis. Found in a mole's run in garden of Monk Soham House, Mar. 1905

Staphylinus fulvipes. One flying in Bentley Woods in June

Philonthus fulvipes. Taken in Tuddenham $F \in n$ in middle of June

- fumarius. In flood refuse at Benacre Broad

Cryptobium fracticorne. Several in reed refuse at Oulton Broad

Paederus fuscipes. Easion and Covehithe Broads, not uncommon

Evaesthetus ruficapillus. By the river at Brandon in June 


\section{INSECTS}

\section{Adprrions, 1899-1907 (continued)}

Stenus argus. Found with the last species

- atratulus. With the last

- fuscipes. Swept in marshes at Tuddenham Fen and Brandon

- morio. Very rare at Brandon and Lakenheath in June

- solutus. Found singly at Brandons and Bixley Decoy in spring

Bledius spectabilis. A male upon Felixstowe beach in May

Trogophloeus foveolatus. Abundant on mud of brackish ditch at Bowdsey

Lestiva muscorum. Found in flood refuse at Oulion Broad in Apr.

Omalium riparium. Taken by the Orwell at Nacton in Apr.

- testaceum. Roots of plants at Witnesham (cf. Ent. Mo. Mag. 1903, p. 281)

Phloeocharis subtilissima. Taken at Brandon in June

Euplectus sanguineus. One in an Ipswich garden in June

Euconnus hirticollis. Root of a thistle, Pannington Holl, Wherstead

Agathidium nigripenne. Swept in Bentley Woods in June

Liodes humeralis. Taken at Brandon in June and May

Anisotoma ovalis. Found at Brandon in early June

Choleva anisotomoides. Singly at Felixstowe and Foxhall in Apr.

- fusca. A male at Oulton Broad in June

- wilkini. Found about Bury St. Edmunds in 1900

- sericatus. Ipswich and Bentley Woods; probably common

Hister bimaculatus. One flying in the sunshine at Wickham Market in July

- merdarius. A few beneath oak bark at Brandon

- purpurascens. Ipswich; both type and var. niger at Brandon

Paromalus flavicornis. Rare at Brandon, beneath oak bark

Onthophilus sulcatus. Not rare in Brandon rabbitholes (cf. Ent. Mo. Mag. 1903, p. 204)

Ptenidium punctatum. Taken on banks of Orwell at Nacton in Apr.

Sericoderus lateralis. Two at Glemsford in June

Phalacrus hybridus. Found at Felixstorve (cf. Ent. Mo. Mag. 1907, p. 224)

Meligethes rotundicollis. Taken by sweeping at Kessingland

Aglenus brunneus. Omitted from the original list

Lemophloeus ater. In gorse stem at Brandon in July

Corticaria crenulata. Taken beneath Chenopodium at Felixstowe

Melanophthalma fulvipes. Probably common; on the coast of Felixstorve

- similata. Swept at Tostock in June

Silvanus surinamensis. Abundant in a flour-mill in Lowesioft

Telmatophilus typhae. In reed refuse at Bixley Decoy, Foxhall

Cryptophagus populi. Barmby Broad and Tostock (cf. Trans. Norfolk Soc. 1902, p. 332)

Atomaria basalis. Abundant in haystack in Oulton Broad

- Berolinensis. One in a fungus in the Bentley Woods
Litargus bifasciatus. Found very rarely at Mildenhall (cf. Ent. Mo. Mag. July 1899)

Dermestes undulatus. One captured at Brandon in early June

Aspidiphorus orbiculatus. One swept in Cutler's Wood at Freston

Limnius troglodytes. Swept by Mrs. Morley on the banks of the Ouse at Brandon

Aphodius depressus. A couple at Oulton Broad in Sept.

- tristis. Not uncommon in rabbit-holes about Brandon

Diastictus vulneratus. The only British specimen on Brandon Heath (cf. Proc. Entom. Soc. 19 Sept. 1902)

Elater lythropterus. Found in Tuddenham Fen in 1889

Cyphon coarctatus. Captured near Bury St. Edmunds in 1903

Telephorus figuratus. Not rare at Brandon and Tudderham Fen

- thoracicus. Tuddenham Fen, Barton Mills, and Oulton Broad

Malthodes atomus. Foxhall, Bentley Woods, and Glemsford, singly

Malachius viridis. Hemley salt marshes in 1904

Ptinus tectus. Abundant in a flour-mill at Lowestoft

Lasioderma serricorne. One specimen on my study window, Monk Soham.

Anobium paniceum. A few in a flour-mill at Lowestoft

Coenocara bovistac. Brandon in Aug. (cf. Ent. Mo. Mag. 1904, p. 87)

Rhizopertha pusilla. Abundant in malt in Bury St. Edmunds

Sphindus dubius. Found in fungus, Foxhall (cf. Ent. Rec. 1900, p. 78)

Cis festivus. Common in a fungus at Wherstead

- fuscatus. In a post at Barnby Broad in Sept.

- vestitus. Under pine bark in Bentley Woods

Ennearthron cornutum. Mildenhall, Barton Mills, Bixley Decoy, and Foxhall

Donacia thalassina. Two found in Oulion Broad in July

Zeugophora flavicollis. Found once on white poplar in Assington Thicks

Chrysomela graminis. Swept from reeds at Brandon upon several occasions

Plagiodera versicolora. On the banks of the Waveney at Beceles

Hydrothassa aucta. Taken at Oulion Broad in Sept.

Luperus rufipes. Found in Tuddenham Fen on birch in June

Galerucella calmariensis. Wang ford St. Martin, Henstead, and Beccles

Longitarsus anchusae. Common on Cynoglossum at Shrubland Park

- castaneus. In Oulton Broad rarely in Mar.

- dorsalis. Not uncommon beneath ragwort at Brandon in June

- aeruginosus, Foud. Darshem, Kessingland, and Southwold, overlooked

Aphthona herbigrada. Locally common in Aug. in Tuddenham Fen

Epitrix pubescens. On Solanum dulcamarae; local at Brondors and Tuddenhum

Chaetocnema Sahlbergi. Oulton Broad (Ent. Mo. Mag. 1905, p. 68) 


\section{A HISTORY OF SUFFOLK}

\section{Additions, I 899-I907 (continued)}

Cassida vittata, Vill. Grass-tufts ; Bentley Woods and Bagous nodulosus. In dykes at Beccles in June and East Bergholt

Blaps Gages, Linn. The only British specimen at Bury (cf. Ent. Mo. Mag. 1903, p. 174)

Tribolium confusum. In vast numbers in a flourmill in Lowestoft

Mycetochares bipustulata. Staverton Thicks in June, one only

Latheticus oryzae. Abundant in the Lowestoft flourmill in Aug.

Anthicus instabilis. On Chenopodium, both sexes, at Felixstowe

Rhynchites interpunctatus. On sallow in Bentley Woods in May

Apion ononidis. On Ononis spinosa in Blakenham chalk pits

- dissimile. Swept from trefoil, Bentley Woods (cf. Ent. Rec. 1900, p. 78)

- sanguineum. Once said to have occurred at Brandon (cf. Ent. Mo. Mag. 1904, p. 87)

Otiorhynchus raucus. On Felixstowe cliffs in June

Trachyphloeus spinimanus. Sparingly at Foxhall and Tuddenham

Phyllobius viridicollis. Common in June at Brandon; Tuddenham

Limobius mixtus. Captured at Brandon in early June

Hypera suspiciosa. One female at Oulton Broad in Mar.

- trilineata. Singly in Bramford marsh and Shrubland Park

Orchestes decoratus. Swept from dwarf sallow in Tuddenham Fen, Aug. 1905

Liparis coronatus. Bramford Road, Ipswich; probably imported with chalk

Erirrhinus scirpi. One in reed refuse at Benacre Broad in Sept. Aug.

Tychius tibialis. Found at roots of ragwort at Brandon in June

Sibinia potentillae. One found on the Corton cliffs in Aug.

Gymnetron collinus. Brandon, one in June 1903

Ceuthorhynchus ericae. Hollesley Heath and Tuddenham Fen, local

- euphorbiae. At Brandon and Glemsford in June

Ceuthorhynchideus Dawsoni. Once in June at Brandon

- horridus. In a chalk pit at Brandon, very rare

- mixtus. One swept at Wherstead (cf. Ent. Mo. Mag. 1900, p. 287)

- posthumus. Singly at Mildenhall and Foxhall Plateaus

Litodactylus leucogaster. Apparently rare; Oulton Broad and Southwold

Balaninus rubidus. Brandon, and not uncommon in Tuddenham Fen

Codiosoma spadix. One 'on coasts of Suffolk' in Capron's collection ; and at Southwold, by myself

Bruchus affinis. On Angelica at Claydon Bridge in Aug.

- pectinicornis. One female on Angelica flower at Foxhall in Aug.

Megacronus cingulatus. Beaten from a birch bush in Tuddenham Fen early in May 1907

Quedius obliteratus. Wherstead, Ipswich, Bury, and Westleton

- vexans. Taken by Prof. Beare in moles' nests at Ipswich in the spring

Oxypoda longipes. Also found in moles' nests at Ipswich by Prof. Beare

These additions go to show how much there yet is to be done in the local kinds, and how very far we still are from the perfect knowledge or catalogue of them, in spite of our 1,930 species; though, in the compilation of this extensive list, we have had the advantage of visits from nearly all the best British coleopterists.

\section{LEPIDOPTERA}

\section{Butterfies and Moths}

The handsome butterflies and moths have always come in for the lion's share of attention among insects, and Suffolk has not been behind the majority of counties in the investigation of her indigenous species; so much so has this been the case that of late years local collectors have been to a great extent relieved of the pressure of their study, which circumstance probably accounts for the comparatively full catalogues of the more neglected orders of insects which the few resident collectors have been enabled to compile. The first list issued by the Rev. E. N. Bloomfield was dated I 888, when, during the compilation of a county catalogue, he found a very much greater mass of information respecting the Macro- than the Micro-Lepidoptera, and was induced to bring out a preparatory account of the latter in order that it might be augmented to something approaching the perfection to which the former had already attained. The result is seen in the very full Lepidoptera of Suffolk he published in 1890 , and supplemented in 1900, mainly from the records of Canon Cruttwell, Revs. J. H. Hocking and A. P. Waller, Messrs. Claude Morley, E. Baylis, and the late C. A. Pyett. The Victoria County lists of Lepidoptera have often run to such length that only a general outline of those of Suffolk will be given, with especial reference to such species as are peculiar to, or especially prevalent in, the county or generally rare.

Considering the proximity of Suffolk to both Cambridgeshire and Norfolk, it is curious that the Swallow-tail butterfly (Papilio Machaon) is so rare with us as to leave considerable doubt whether it ever breeds here at all ; it is said that years ago it used to be constantly and consistently found in 


\section{INSECTS}

the north-west, and one was positively caught there (and most laudably liberated) so recently as 1901; but in the other districts it is doubtful whether the single records refer to anything more than mere escapes, such as is mentioned in The East Anglian Daily Times, 16 and 20 August 1900. Leucophasia sinapis has not been seen for over twenty years, and appears to have become extinct ; as also curiously enough has Salyrus aegeria, which used to be common; and Pieris crataegi is recorded, but probably in error, by Curtis. 'The Bath White (Pieris daplidice) was taken at Felixstowe and Aldeburgh in 1872 , but has not been since seen. Our two species of Colias are, as elsewhere, periodical, though $C$. edusa may be noted singly in most autumns; its variety belice being much rarer. Argynnis Lathonia has occurred at long intervals at such widely-spread localities as Aldeburgh, Ipswich, Lavenham, Icklingham, Stoke-by-Nayland, and Bradwell; its last appearance being in 1866. 1. Niobe, var. eris, has once occurred at Monk Park Wood in 1879, about six miles south of Bury St. Edmunds; it is the only British specimen of this insect. ${ }^{1}$ Melitaea artemis has been found at Stowmarket, Beccles, and various places in the north-west, where it is still to be met with, though apparently becoming very local; Mr. Wratislaw says in the early numbers of the Entomologist it was formerly common there; $M$. athalia is only doubtfully indigenous in the county. Vanessa c-album is very rare, but has been taken at Bury, Needham, and Bungay, while $V$. antiopa, though usually very rare, has been taken in many places; it was almost common in 1872 . The lovely White Admiral occurs annually in several of our woods, and in some years most horrible slaughter of this innocent is made, the collectors (who cannot be called entomologists) gleefully bring one or even two hundred specimens home at a time; but the grand Purple Emperor is still very much rarer, and has hardly been seen of late, though recorded from around Ipswich, Beccles, Stowmarket, and Sudbury. Arge galathea is extinct, though it was found at Needham before 1850; but Satyrus semele abounds on all our heaths with all its commoner congeners. Thecla rubi and $\tau$. quercus are very common, and $\mathcal{T}$.w-album is frequently met with in the south-east; $\mathcal{T}$. pruni was once taken at Brandeston by the Rev. J. Green, and T. betulae has occurred at Ipswich, Saxham, and Raydon, but is very rare. The rarest of all butterflies, the long-extinct Large Copper, is said by Stephens to have at one time occurred on the coast at Benacre Broad, but this was a record of the 'thirties. All the common Blues occur sparingly ; Lycaena corydon is, owing to the scarcity of chalk, by no means common; $L$. acis was taken in $186 \mathrm{I}$ at Foxhall, and $L$. adonis is only doubtfully Suffolcian, though in Miss Jermyns's curious Butterfy Collector's Vade Mecum, ${ }^{2}$ Moulton and Dalham are instanced as localities for the 'Clifton Blue'; it has, however, been taken at Newmarket, but this may have been in Cambridgeshire. L. alsus and Hesperia lineola are very rare, the former being confined to the neighbourhood of Newmarket, and the latter hitherto found only at Bures; but Nemeobius lucina is by no means uncommon in woods at Bentley, Raydon, Needham, and Freston. Altogether we have fifty-eight out of the sixty-six British butterflies, and of the remainder only one, Hesperia paniscus, is at all likely to be found here.

All the hawk-moths, too, have been taken in the county, which is especially celebrated as the British head quarters of Sphinx pinastri, first found near Waldringfield in I 875, since which time its range has gradually spread to Ipswich, Aldeburgh, Campsey Ash, Saxmundham, Aldringham, and Southwold; it is now firmly established, and specimens have been taken almost every year, and the larva has even been found feeding upon the Cedar of Lebanon. S. convolvuli is periodically common, and the coast sands have produced Deilepbila euphorbiae, though this species has never been adequately sought after in Suffolk. The rare C. celerio has turned up singly at Stowmarket, Beccles, Newmarket, Orford, Ipswich, \&c., and the very rare $C$. nerii was taken in Southtown, Yarmouth, in August 1872, by the Rev. J. W. Colville. The two species of Macroglossa, fusiformis and bombiliformis, are scarce, especially the latter. Among the clear-wings, Sesia myopiaeformis is very local, S. culiciformis not uncommon, S. formiciformis was once found freely at Stoke-by-Nayland; $S$. ichneumoniformis occurred among flowers near Norton Wood to Tuck in July I $899 ; S$. cynipiformis and $S$. bembeciformis are local ; and $S$. tipuliformis, with $S$. apiformis, common, the last being so abundant that the aspens throughout the county bear marks of their depredations. The curious little Limacodes testudo is found at Eaton, Playford, and Beccles; about Ipswich its larvae are common on oak in September and October. Procris statices and Zygaena trifolii are not uncommon in the broads of the north-east, but $Z$. lonicerae is very rare. Nola cuculatella and $N$. confusalis are common; but $N$. strigula is rare, though it has been taken by several collectors at the Bentley Woods and at Felixstowe; N. centonalis was found at Hemley in 1904. Lithosia muscerda, found elsewhere only in Norfolk, is recorded from Lakenheath in Mr. Eedle's Fenland, and was taken among alders in Barnby Broad in August 1898 by the writer; $L$. aureola, L. quadra, and $L$. rubricollis are all more or less rare in Suffolk; and $L$. belvola is doubtfully also recorded. The interesting Deiopeia pulchella has been taken singly at Rougham, Finborough, Rickinghall, Foxhall, Aldeburgh, Ipswich, and was last turned up by Mr. Mera at Felixstowe in June 1892 ; and Callimorpha dominula is very

${ }^{1}$ Cf. Ent. Mo. Mag. 1900, Pp. 41, 89.

Published at Ipswich in 1827. 


\section{A HISTORY OF SUFFOLK}

rare, being confined to the marshes of the north-west, where Euthemonia russula is common on the heaths. Arctia plantaginis has been found at Bentley, Spilosoma fuliginosa and $\mathcal{S}$. mendica are uncommon; and S. urticae very rare, though it has appeared at Tuddenham, Beccles, and Gorleston. Orgyia fascelina and $O$. gonostigma are both rare, the latter only once taken, at Bentley; but Liparis monacha and Demas coryli may be found upon oak-trunks about Ipswich. Trichiura crataegi and Eriogaster lanestris are both rare, for though the latter is said to be common, it does not appear to have been found in the county for a great many years. Bombyx castrensis has often been bred from larvae found in the extensive salt marshes at Aldeburgh; but $B$. trifolii, which is said by Hele, in his history of Aldeburgh, to have been found in the same locality, is probably a mistake. Endromis versicolor, which used to be found about Ipswich, has not been seen for many years, though Saturnia carpini is widely distributed. All the Hooktips, excepting Platypteryx sicula, which is probably wrongly reported as having been taken at Stowmarket, are found with us; $P$. falcula is abundant, and $P$. lacertula rare, in the Bentley Woods; and $P$. unguicula beaten commonly from beech-trees about Bury St. Edmunds. All the Kittens are rare, and the Lobster moth has only been noticed at West Stow, Holbrook, Bentley, and in 1903 at Needham Market; but Petasia cassinea is widely distributed. We have also all the British Prominents, though Notodonta cucullina and N. trilophus are very rare, and $N$. carmelita doubtful ; $N$. chaonia and $N$. dictaeoides are occasionally attracted to electric light in Ipswich town; $N$. dodonea was found not uncommonly by the Rev. Joseph Green. Clostera curtula and reclusa are widely distributed, though not common.

We next come to the Noctuae, and here we find the lovely Thyatira batis and $T$. derasa somewhat commonly attracted to 'sugar' on tree-trunks, and all the British Cymatophorae represented with the single exception of $C$. fuctuosa, though $C$. or and $C$. flavicornis are scarce. Bryophila glandifera is very rare at Needham and Gorleston, but the handsome Dipthera orion is to be met with annually at Bentley, where it was at one time not rare. Acronycta leporina and A. ligustri have been taken in many places, but $A$. alni is confined to but few ; and Simyra venosa has turned up at Lowestoft, Fritton, and Needham Market. Our list is fairly full in the marsh-loving Leucaniae and Nonagriae. Of the former genus $L$. extranea has only once occurred at Leiston in August 1878 ; $L$. obsoleta at Needham Market; L. litoralis only at Lowestoft and Kessingland; L. pudorina used to be found at Ipswich alone, but it has recently been discovered by the late Mr. E. G. J. Sparke at Tuddenham; L. straminea at Ipswich and recently at Hemley and Needham; and L. phragmitidis should be common, if adequately worked, in the Suffolk Broads. Leucania albipuncta has recently ${ }^{3}$ been added to our list by Mr. Waller, who took it, and both the red and light varieties of $L$. flavicolor, in the marshes at Hemley. Senta ulvae is another rare species at Ipswich and Lowestoft, and a varied series was secured at Hemley in 1905. Many localities are instanced for Nonagria despecta, both in east and west Suffolk; and $N$. lutosa is commonly attracted to light in Ipswich; but $N$. neurica is rare at Lakenheath, Needham, and Lowestoft, and $N$. sparganii has been bred at Hemley. Hydraecia petasitis is certainly not uncommon, near Needham, though rarely seen in the perfect state; and both $X$ ylophasia sublustris and $X$. scolopacina are local and widely distributed. The rare $X$ lomiges conspicillaris has occurred, it is said, at Ipswich, but has not been seen for a great many years, though Neuria saponariae is very widely distributed. Another recent addition to our list is Aporophyla australis, several examples of which are recorded from Felixstowe in 1895 by Lord Rendlesham; it was also seen both there and at Kessingland in 1902. Luperina caespitis is often frequent at street-lamps in Ipswich. Mamestra abjecta, anceps, and albicolon are all uncommon; the last occurs occasionally in numbers upon the Breck sands of the north-west, as well as upon the east coast. Apamea fibrosa is local; but $A$. ophiogramma, which used to be considered a great rarity, has been several times taken recently at light in Ipswich. In Suffolk Agrotis valligera is by no means confined to the coast, having been taken on the Breck sands, as well as at Needham and Beccles; $A$. puta is very common, but $A$. saucia is local; $A$. ripae and $A$. cursoria occur on the coast, and though local are sometimes in plenty, with $A$. praecox, which is less abundant, and they are also found in the Breck district. A. agathina is probably common on the heaths, but $A$. ravida is very rare at Bury and Brandon. All the Triphaenae occur here, the only rare species, $T$. subsequa, having been met with at Ipswich, Waldringfield, Bury, Brandon, and Tuddenham, though $T$. fimbria is also somewhat uncommon.

The writer has taken all the fourteen species of Noctua that occur in Suffolk in the course of a couple of seasons, so perhaps none should be accounted rare : the best are $N$. neglecta at Brandon and Ipswich; $N$. rhomboidea, which is scarce at sugar in the Bentley Woods, \&c., in east Suffolk; and the generally rare but here locally abundant $N$. Dablii. Most of the Taeniocampae, except the northern $T$. opima, are here found more or less commonly, though $T$. leucographa and $T$. miniosa are very local, the former having only once been taken near Stowmarket. The generally rare Orthosia suspecta may be sometimes secured in plenty on sugar near Ipswich, together with $O$. macilenta ; and 


\section{INSECTS}

O. upsilen is not common, though widespread. Anchocelis lunosa and Xanthia aurago are uncommon at respectively light and ivy blossom; but $X$. gilvago and citrago are of frequent occurrence, and $X$. ocellaris has of late been taken at Ipswich, Copdock, Waldringfield, and Bungay. At light Cirrboedia xerampelina is sometimes taken, usually singly, from Ipswich to Beccles; and both the Tetheae have been found, though $T$. retusa is still very rare, occurring only at Ipswich and Bungay. Dicycla oo rests upon the single specimen taken at Tuddenham by Wratislaw a good many years ago ; and Cosmia pyralina continues to be one of the possibly obtainable rarities. Widely distributed but certainly rare is Eremobia ochroleuca; and only quite recently has Dianthaecia conspersa been found in the county at Bungay, Kessingland, Oulton Broad, and Ipswich. One of our most exclusive species is $D$. irregularis, which was rediscovered as British by Rev. A. H. Wratislaw at Tuddenham; this species is nearly confined, in Britain, to the Breck district of Suffolk, whence it has found its way into most cabinets from the local collectors, who capture great numbers of its caterpillars ; it has also occurred at Elveden, Brandon, Eriswell, and Icklingham in the same district, and is often netted at dusk fying to the flowers of the Spanish Campion (Selene otites). Aplecta occulta is only recorded from the Bentley Woods and Beccles, and Hadena adusta, contigua, and genistae are local; $H$. suasa occurs at Brandon and about Aldeburgh, and the rare $H$. atriplicis singly at Brandon, Playford, and Stowmarket. Calocampa exoleta and vetusta are both rather rare in the county, where Xylina semibrunnea has only occurred at New market and Stowmarket. In 1895 the Rev. J. H. Hocking took at Copdock the third or fourth British specimen of $X$. lambda, var. zinkenii, ${ }^{4}$ and Cucullia scrophulariae is also very rare at Lakenheath and in the Bury district. C. lycbnitis has only been found at Woolpit and Beccles, C. asteris at Aldeburgh, C. absynthii at Erwarton and Orford, and C. chamomillae at Southwold, Stowmarket, Needham, Ipswich, and Tuddenham. The interesting genus Heliothis is well represented in the Breck district, where $H$. marginata and $H$. dipsacea are not uncommon, though $H$. peltigera and $H$. armigera are very rare at Brandon; the former also at Lowestoft and the latter at Needham Market. Acontia luctuosa, Hydrellia unca, and Agrophila sulphuralis are not infrequent in the Breck district, where the latter was first discovered in Britain, and it is still hardly found anywhere else, though it is said to have occurred in plenty in Shrubland Park. Erastia fuscula and Brephos notha are very widely distributed, but local; Plusia orichalcia, so much sought after in Cambridgeshire, has only been found at Middleton once, in 1857; Toxocampa pastinum is local but not rare. The beautiful Catocala fraxini has occurred in various placesLowestoft, Aldeburgh, and Ipswich-and in August IgOI Mr. J. F. Green took a perfect specimen in Benacre Park ; ${ }^{6}$. promissa is extremely rare about Bentley, and $C$. sponsa has probably become extinct, though recorded from the same locality. Opbiodes lunaris is recorded ${ }^{6}$ from the Lowestoft lighthouse in 1832, the example being in Captain Chawner's collection. The last Noctua worthy of mention is Phytometra aenea, which is very local at Tuddenham, Herringfleet, \&c.

So many of the Geometrae are common that it is only necessary in this family to note that Ellopia fasciaria, Silene lunaria, S. illustraria, and Ennomos erosaria, though local, are widely distributed; and that $E$. fuscantaria is unusually abundant annually at light. Cleora viduaria is only of doubtful occurrence, as also are Boarmia roboraria and consortaria, recorded from Bentley, though none of the British Tepbrosiae are uncommon. $\mathcal{T}$. consonaria has been found only at Stowmarket and Bentley. Ephyra orbicularia was once taken at Lowestoft, and Hyria auroraria is only found in the Fens at Oulton and Tuddenham. Several nice Acidaliae have turned up here; thus $A$. perochraria at Aldeburgh, A. trigemminata common at Bentley, Hemley, \&c., A. rusticata singly at Stowmarket and Felixstowe, $A$. emutata and $A$. inornata very local, $A$.ornata at Brandeston, Tuddenham, and Southwold, and above all $A$. rubricata, a species nearly confined to Suffolk, but occurring in the west at Brandon, Thetford, and Tuddenham, and in the east at Leiston, Southwold, and Aldeburgh. Aleucis pictaria was added to our list by Mr. Hocking in April 1898, and Minoa euphorbiata is very rare at Stowmarket and Needham. The pretty Fidonia conspicuata used to be quite common about Ipswich half a century ago, but it has only been thrice noticed during the last fifteen years, and may now be extinct; and Sterrba sacraria has only once put in an appearance, in 1863. Aldeburgh is the only known home of Pacbycnemia bippocastanaria, which was taken there by Wratislaw. All the Hybernidae are common, but Cheimatobia boreata was first noticed, though it is common, in 1897. Several nice Pugs, such as Eupithaecia succentureata, plumbeolata, albipunctata, valerianata, dodoneata, and togata occur here, the last at Brandon and Southwold; though others, e.g. E. consignata, exiguata, coronata, and debiliata are very rare; and $E$. pusillata, with $E$. innotata, have only recently been added to the list. Thera juniperata has occurred among juniper at Dalham, Hypsipetes ruberata at Bury and Ipswich, Melanippe hastata commonly at Bentley; but $M$. galiata, probably owing to our small outcrop of chalk, is very rare indeed, having been taken singly only at Bentley and Chelmondiston. Anticlea rubidata and

- Cf. Ent. Mo. Mog. I895, p. 279.

- Cf. Knowledge, 1901, p. 231.

Entom. 1872 , p. 147. 


\section{A HISTORY OF SUFFOLK}

A. berberata are found annually at Bury, but Coremia propugnata is by no means common, and Camptogramma fluviata has occurred once to Major Nurse in Bury, and once to the writer at light in Ipswich. The only uncommon Cidariae are $C$. psittacata and C. sagittata; and Eubolia bipunctaraia is still doubtfully a Suffolk species; E. lineolata and Chesias obliquaria are local; and Lithostege griseata is found in few British localities outside the Breck sands, where, however, it occurs somewhat freely.

Owing to the smaller number of lepidopterists who are interested in the Micros our list of them is less complete, and species are still being constantly added to it by even superficial collectors; this becomes very plain when we see that against thirteen additions to the Macros up to 1900 there are 116 among the smaller kinds since 1890 . Among the Deltoides, Hypena crassalis and the two Hypenodes are distinctly rare; the former is recorded, perhaps by mistake, at Brandeston by the Rev. Joseph Green, the two latter mainly at Beccles; several of the Herminiae are also uncommon, as is the curious Aventia flexula, which, however, once occurred plentifully at Brandeston. Pyralis fimbrialis is abundant, Cledeobia angustalis somewhat scarce, and Aglossa cuprealis very rare at Bramford and Whitton. The three Pyraustae are seldom met with. Ennychia octomaculalis has occurred singly at Stowmarket, and $E$. anguinalis near Tuddenham, while Diasemia literalis has but once turned up in the former locality. All the British Hydrocampidae are common, Acentropus niveus being frequently met with in the coast broads. The very rare Botys nubilalis has been taken at Felixstowe by Gibbs. B. pandalis is doubtfully recorded from the county ; Ebulea verbascalis is rare at Ipswich and Brandon; $E$. stachydalis at Bentley; and $\mathrm{Mr}$. Sparke has recently turned up Pionea margaritalis in some numbers upon one occasion at Tuddenham. Spilodes sticticalis is almost confined to the same district, but is abundant there. Mecyna polygonalis was once taken at Bury by Wratislaw in 1869; Scoparia lineola is found at Brandon and on the coast; and the following species are all local :- $S$. basistrigalis, crataegella, coarctalis, and pallida. Nineteen species of Pterophori are recorded; the writer added Agdistes Bennettii to the list at light at Ipswich in I 895, and it has since been found to be not uncommon at Southwold and Hemley; Platyptilia gonodadactyla is local, Aciptilia tetradactyla from Barton Mills, and Leioptilus osteodactyla is local at Ipswich. These last two are quite recent additions, as is also Mimaeseoptilus phaeodactylus from Felixstowe, and Leioptilus Lienigianus has been taken in several localities near the coast. Three species have recently been added to the eighteen Crambidae originally recorded from Suffolk: Crambus alpinellus from Hemley, C. salinellus from Aldeburgh, and C. fascelinellus from Felixstowe; the last is of special interest, as it was only previously known from Norfolk in the vicinity of Yarmouth. Our four Chilidae are all rare or local; Sehaenobius gigantellus has been taken only at Needham Market and Santon Downham.

The interesting Phycidae are well represented by twenty-nine kinds, but most of these are of rare occurrence. Anerastia Farrella was taken at Lowestoft lighthouse in 1840 , but $A$. lotella is common at Felixstowe; five species of Homacosoma are all more or less scarce, the last addition being $H$. nimbella from Southwold; Nyctigretes achatinella has been taken at Benacre and Felixstowe, and would appear not to be so rare as formerly ; Cryptoblabes bistriga, recorded from Woolpit, ${ }^{7}$ has not since been noticed. Other species worthy of mention are Gymnancyla canella near Leiston, Phycis betulae at Copdock, and Dioryctria splendidella at Southwold. ${ }^{8}$ The genus Rhodophaea includes seven species; $R$. formosa, consociella, advenalla, suavella, and tumidella are local; but $R$. marmorea has only been taken at Aldeburgh; and $R$. rubrotibiella at Brandon. Three species of Galleriidae are only too common, two of these feeding on the comb of the honey-bee and ruining the hives, but the rare and interesting Melanoblaptes bipunctanus has only been found at Felixstowe, where Mr. A. E. Gibbs took a nice series. Of the three beautiful species of Cymbidae, Halias prasinana may be seen and heard stridulating at Bentley and other woods; $H$. quercana is local, and $H$. cblorana seems rare, and is only recorded from Ipswich and Beccles.

\section{TORTRICES}

The large genus Tortrix is well represented, and most of the species are common; T. icterana is local, and $\mathcal{T}$. crataegana, with $\mathcal{T}$. diversana, have been but recently noticed, the former at Bentley and the latter at Hemley. Peronea cristana has but once occurred, near Ipswich ; and $P$. comparana and $P$. comariana have been lately added. Of the genus Pentbina, the best are $P$. sellana from Tuddenham, Aldeburgh, and Southwold; $P$. picana and P. praelongana at Bentley Woods, and $P$. fuligana at Aldeburgh; the pretty Anthithesia salicella seems scarce, and Spilonota neglectana is local. Of the genus Sericoris, the more uncommon are S.litoralis, conchana, and micana; Mixodia ratzburgbiana is found among Scotch fir. We have all the species of Orthotaenia, though none seem

${ }^{7}$ Ent. Ann. 1866 .

- Ent. Mo. Mag. Sept. 1891. 


\section{INSECTS}

common; $O$. purpurana at Bentley and $O$. ericetana at Orford, while $O$. antiquana and $O$. striana are recorded from several localities in the east; Phtheochroa rugosana has been taken at Aldeburgh, Chelmondiston, and Felixstowe; and the rare Sciaphila sinuata at the latter place; and we have also S. communane and S. chrysantheana; while Clepsis rusticana occurs at Tuddenham. Of the pretty genus Phoxopteryx none seem to be common unless it is $P$. lundana; $P$. unguicana at Brandon and Copdock, $P$. inornatana at Tuddenham, $P$. comptana at Leiston, and $P$. lactana at Brandon, Bentley, and Assington, are all local; while the rare $P$. upupana has been taken at Bentley Woods. Of the numerous species of Grapholithidae may be mentioned Bactra furfurana at Lowestoft, Grapholitho nigromaculana at Brandon, Elveden, and Aldeburgh; Phloodes immundana at Leiston, Paedisca bilunana with $P$. occultana at Orford and Felixstowe; $P$. oppressana at Brandon, Ipswich, and Lowestoft; Olindia ulmana, Semasia ianthinana, S. rufillana, and Hensimeme fimbriana are all local. The rare Coccyx ochsenheimeriana was taken by $\mathrm{Mr}$. Warren at Brandon; the pretty Stigmonota regiana is not rare, $S$. roseticolana is found near Ipswich, and $S$. redimitana and $S$. weirana at Bentley; and Carpocapsa grossana at Flixton. C. funebrana, of which the larvae are common in plums, is rarely met with in the perfect state; Dicrorampha saturnana, $D$. plumbagana, and $D$. simpliciana are local, as are also Catoptria juliana, C. expallidana, and $S$. candidulana, the last at Southwold; while Trycheris mediana is everywhere abundant. Of the Conchylidae the best are Eupoecilia nana, notulana, and $E$. rupicola; $E$. roseana, first taken in Suffolk at Bungay in 1905, and $E$. vectisana, which occurs plentifully in salt-marshes; $E$. DeGreyana and $E$. anthemidana are very local, and have only been taken at Brandon; Argyrolepia Subbaumannia at Tuddenham and A. zephyrana at Felixstowe. Of the interesting genus Conchylis, C. Francillana, C. dilucidana, $C$. Smeathmanniana, and $C$. inopiana are all local, while $C$. beatricella was introduced into the British list from specimens bred near Leiston by the Hon. Beatrice de Grey.

\section{TINEA}

We can only mention a few of the rarer and most interesting species of this group.

\section{Psychidae}

Five species, of which $P$ syche radiella has been taken both in the east near Ipswich and west at Lakenheath; $\boldsymbol{P}$. reticella at Hemley and Easton Broad in 1905.

\section{TINRIDAE}

Of this family there are forty-one species; and three of the interesting genus Ochsenheimeria have occurred, though none seem common; $O$. vaculella was recorded by Kirby, and has since been taken in several localities, O. birdella at Thetford and Barnby Broad, O. bisontella at Tuddenham and Bentley Woods. Of the destructive genus Tinea some are very common, but $\mathcal{T}$. imella has

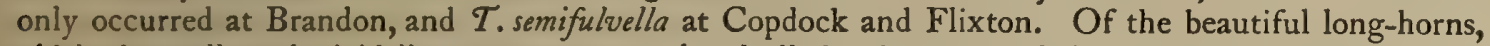
Adela degeerella and viridella are common; $A$. sulzella has been recorded by Curtis from Wrentham, A. rufimetrella taken by the writer at Barnby Broad in 1905, and A. fibulella is occasionally met with. Nemotois fasciellus does not seem to be rare, having been taken at Orford and several times both at Ipswich and Aldeburgh, but $N$. minimellus only in Barnby Broad.

\section{HYPONOMEUTIDAE}

These comprise twelve kinds, of which Hyponomeuta evonymellus occurs at Thorpe and Orford, H. virgiratipunctatus and Anesycbia decemguttella at Bungay.

\section{Plutrllidae}

Of the eleven species, Cerostoma sequella and $C$. silvella are scarce, Eidophasia messingiella has been taken by Lord Walsingham at Copdock, Plutella porrectella at Hemley; and Theristis caudella would seem to be not uncommon at Bentley, though not met with elsewhere.

\section{GrLechimae}

Of these we have about one hundred and eight species, but few of them can be noticed Of the twenty-four kinds of Depressaria the following are scarce:-D. umbellana among gorse, 


\section{A HISTORY OF SUFFOLK}

D. cnicella on Eryngium at Southwold, D. chaerophylli on Chaerophyllum temulum, D. granulosella on Anthriscus vulgaris, D. badiella and D. ciliella. Of the sixty species of the old genus Gelechia, G. gerronella, G. celeraella, G. pictella, G. Lyellella, G. Hermannella, G. sequax, and G. alacella are all scarce. The little Cleodora cytisella has lately been proved to feed on the brake-fern, among which it is usually taken. To these we may add Hypsilophus fasciellus at Tuddenham, Notbris verbascella at Bury on Verbascum pulverulentum, Dasycera olivierella at Stratford St. Mary and Felixstowe. Oecophora lunaris is rather common about Ipswich, and the larger $O$. lambdella, whose larvae feed in the stems of gorse, has been taken at Aldeburgh, Leiston, and Southwold; the very rare Butalis cicadella has occurred singly at Brandon and Tuddenham; $\boldsymbol{B}$. grandipennis also feeds on the furze bushes in the latter locality.

\section{Glyphipterygidar}

Of our nine species we need only mention Roslerstammia erxlebenella from Ipswich, and the rare Perithia obscurepunctella from Copdock.

\section{ARGYRESTHIIDAE}

Of the sixteen species scarcely any are rare; Cedestis Gysselinella, which used to be considered a northern species, is now not uncommon in the Breck district, and Zelleria hepariella was taken at Leiston by the Hon. Beatrice de Grey.

\section{Gracilaridae}

Of the eleven species, several hibernate and are found in the spring; Gracillaria stigmatella is then seen not uncommonly; the larvae of G. tringipennella mine the leaf-stalks of the ribwort plantain, G. elongella is found among poplar, and the larvae of Coriscium Brongniartellum lives beneath the cuticle of oak-leaves, causing extensive bladdery mines.

\section{COLEOPHORIDAE}

Lord Walsingham records the rare Coleophora inflatae from Brandon, where occurs the very local $C$. saturatella. None of the larger species seem common, but $C$. anatipennella is found at Aldeburgh and Bentley Woods, C. palliatella at Copdock, $C$. currucipennella at Aldeburgh, C. siccifoliella makes its case of a dead leaf at Lowestoft, and C. favaginella occurs at Kessingland. We have, in all, about twenty-seven species of this family.

\section{Elachistidar}

The thirty species include the curious and very local Stathmopoda pedella, Bachtrachedra pinicolella, the brilliant Cosmopteryx eximia, Laverna lacteella, and the pretty Stephensia Brunnichella, all of which are rare and local.

\section{LITHOCOLLETIDAE}

Most of our fifteen species are common, but Lithocolletis bortella and L. scopariella, both from Brandon, are scarce and rarely met with, and L. stettinensis was first found at Foxhall, among alders, by the writer in 1907 .

\section{LYONETIDAR}

Of the ten species we need only mention Opostega saliciella and Bucculatrix Boyerella, both from Southwold.

\section{Nepticulidae}

These tiny moths have been much neglected, only twenty species being recorded; they include Nepticula basiguttella and $N$. viscerella, both from Tuddenham, $N$. trimaculella from Brandon, and Bobemannia quadrimaculella from Lowestoft and Fritton. 


\section{INSECTS}

This rough summary will give the better kinds of those moths and butterflies which have been noticed in Suffolk, the full figures representing the time-honoured groups are :-

Rhopalocera :
Sphinges :
Bombyces :
Noctuze :
Geometrae :
Deltoides :
Pyralides :
Pterophori :
Crambi :
Tortrices :
Tineze

\begin{tabular}{|c|c|c|c|c|c|c|c|c|}
\hline - & - & • & - & • & • & - & $5^{8}$ & pecies \\
\hline • & - & - & - & - & . & . & 25 & " \\
\hline • & . & . & • & • & 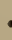 & . & 89 & " \\
\hline - & - & • & • & . & . & . & 235 & $n$ \\
\hline - & . & . & . & • & , & , & 215 & " \\
\hline - & • & • & • & . & 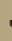 & 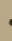 & II & " \\
\hline - & . & . & . & • & 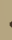 & 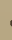 & 50 & " \\
\hline - & . & . & . & . & 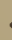 & 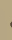 & 19 & " \\
\hline . & . & . & . & . & 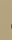 & 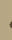 & 59 & " \\
\hline - & • & . & . & . & 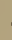 & 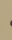 & 199 & $"$ \\
\hline • & . & • & . & 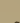 & & & 331 & " \\
\hline
\end{tabular}

\section{DIPTERA}

\section{Flies}

From the time of Kirby, who paid considerable attention to the destructive wheat midge, and Paget, who effected a few very interesting captures of these insects round Yarmouth about 1830 , to the present time, the two-winged flies have received quite as much attention in Suffolk as in most parts of England. Of late years the local collectors have been of that satisfactorily omnivorous kind which collects all Orders, with the result that, despite the well-known difficulty always attending the determination of Diptera, we are able to record I,I I I different species from the county. When it is remembered that considerably over 3,000 kinds have been observed in Britain, this total d hes not appear large, though the variety of circumstances, local and otherwise, which go to impede 2 clear knowledge are so numerous that even this number could only have been compiled by the co-operation of all those who have collected here. In this respect we have been fortunate in the selection by Mr. G. H. Verrall, of a Suffolk residence at Newmarket-his house and garden, though adjacent to Cambridgeshire, being entirely in Suffolk - and in the summer visits at various times of other dipterists, the Hon. N. C. Rothschild, Rev. E. N. Bloomfield, Messrs. A. Piffard, E. A. Elliott, \&c., who have helped to swell the list. Curtis, in his British Entomology, records several species from the vicinity of Covehithe and Wrentham; Mr. W. H. Tuck of Bury St. Edmunds has collected about Tostock, Aldeburgh, Bungay, Southwold, and Lowestoft; Mr. E. A. Fitch of Maldon has found a few species here ; and others are noticed by Messrs. Verrall, ${ }^{1}$ Collin, Henslow, Freeman, Bedwell, Gibbs, Ransom, and others. These scattered notes being all that have appeared upon the subject, it becomes necessary in the following account to briefly refer to the individual species which have been noted, though a work like the present is hardly the place to introduce those interesting details of economy and habits of the species which go to show how varied are the earlier stages of this extensive and, in some respects, most humanly beneficial family.

The fleas are treated in Mr. Verrall's List of British Diptera (ed. 2, 1901), the nomenclature of which has been here adopted, as an aberrant family of the Diptera, but they have received but little attention in Suffolk. Nevertheless, Pulex canis, the dog flea, P.erinacei, which was once taken abundantly from a newly dead hedgehog in Bentley Woods, and $P$. leporis upon rabbits, have been noted; while $P$. irritans, Trichopsylla fasciatus and $\mathcal{T}$. agyrtes occur in houses. $\mathcal{T}$. birundinis and T. gallinae are abundant in martins' nests and on fowls, and $\mathcal{T}$. sciurorum, which once turned up in a fungus, in those of squirrels. The field-mouse flea, Typhlopsylla gracilis, and that of the mole, Hystrichopsylla talpae, are by no means rare in the Ipswich district. A flea new to science has recently been described ${ }^{2}$ from a wood-pigeon's nest at Mildenhall, and called Ceratophyllus Farreni. The destructive Cecidomyidae, of which the Hessian fly is a familiar example, have been entirely overlooked locally, and only five species can be instanced. The late Mr. H. Goss exhibited a number of puparia of Cecidomyia destructor from various places in Suffolk at a meeting of the Entomological Society on 5 October 1887 , and in the Transactions of the Linnean Society, iv, 237, the Rev. William Kirby refers to his Diplosis tritici as doing considerable damage to the wheat crops in the neighbourhood of Barham; $D$. buxi is recorded from Suffolk by Fitch. ${ }^{3}$ Recently Collin has found Rhabdophaga salicis in woody galls on sallow at Bradley, and Perrisia crataegi is abundant in my garden at Monk Soham. The Mycetophilidae are represented by Sciara Thomae and $S$. carbonaria, which with other species of the genus are common everywhere; and S. bilineata occurs

\footnotetext{
'Ent. Mo. Mag. 1882, 1886, 1887, 1888, 1894; Monographs of Brit. Syrphidae, Dolichopodidae, \&c.

Ibid. 1905 , p. 255.

${ }^{3}$ Entom. 1880 , p. 149.
} 


\section{A HISTORY OF SUFFOLK}

in Newmarket. Cordyla flaviceps has been found at Tuddenham, both $C$. crassicornis and C. brevicornis at Newmarket, with Dynatosoma fuscicorne. Mycetophila luctuosa is found with $M$. obscura at Tuddenham, $M$. punctata, cingulum, and lineola are common in the Bentley Woods; $M$. bimaculata in Ipswich; unipunctata has been found at Tuddenham, $M$. dimidiata, xanthopyga and spectabilis at Newmarket. Rbymosia trunctata has occurred in Mr. Verrall's study, and Exechia interrupta, $E$. spinigera, $E$. fungorum, and $E$. tenuicornis in his garden; E. lateralis is not uncommonly beaten from yew trees in Bentley Woods in February. Mycothera dimidiata, Brachycampta alternans, B. bicolor, $B$. griseicollis, and $B$. serena are all found at Newmarket, the last also at Exning; Docosia sciarina has been noted at Coddenham and $D$. valida is often abundant at Bentley Woods on oak-trunks in May. Pbronia Girschneri is recorded from Newmarket, Collin has taken Sceptonia nigra at Tuddenham in September, and I have presented Zygomyia pictipennis, from the Bentley Woods in February on fir trees, to the British Museum, as it was previously doubtfully British. Z. notata, Z. vara, Z. valida and Acnemia nitidicollis occur at Newmarket. I have taken Sciophila marginata in the Bentley Woods and at Blakenham; and hear from Mr. Collin that S. occultans, S. incisurata, and $S$. fimbriata all occur at Tuddenham, with $S$. tumida at Newmarket. Glaphyroptera fasciipennis affects flowers at Bramford and Foxhall ; and both G. winthemii and $G$. fasciola are found at Newmarket, together with Lasiosoma birtum and $L$. luteum. The genus Platyura is represented by $P$. marginata at Ipswich, $P$. atrata at Bildeston, $P$. cincta and $P$. nana at Newmarket, and the $P$. intincta of Shiner at Henstead. I have caught Ceroplates tipuloides in Staverton Thicks; and Mycetobia pallidipes on exuding sap at Brandon. Macrocera fasciata, lutea, centralis, stigma, phalerata, pusilla, and crassicornis all occur in Newmarket, with Bolitophila fusca, and at Tuddenham $B$. cinerea. Mr. Tuck confirmed Ditomyia fasciata as British by the capture of a specimen at Tostock. ${ }^{4}$

The typical genus of the Bibionidae is well represented, but of the others we only have Anarete candidata, Scatpse clavipes, albitarsis, recurva, and S. brevicornis at Newmarket, S. notata at Coddenham, S. balterata abundantly at Foxhall, and S. Aavicollis, which I once found ovipositing in a fungus in Tattingstone Park; both Dilophus albipennis and $D$. febrilis are plentiful. Among the fifteen species of Bibio in the British list only $B$. ferruginatus, venosus, and lacteipennis yet remain to be found here. Simulium ornatum has occurred to me at Foxhall, $S$. reptans and $S$. (?) argyreata are abundant in the Breck district, and Verrall has found $S$. nanum at Tuddenham. The extensive families Chironomidae and Psychodidae are represented for the most part by specimens from Newmarket-understood hereinafter-and elsewhere in Mr. Verrall's collection, where I have seen Chironomus dorsalis, tentans, chloris, and albimanus. I have found C. plumosus at Oulton Broad and Ipswich, $C$. riparius at Wherstead and Whitton, $C$. rufipes at Claydon, and $C$. dispar in my study in Ipswich in 1895 . Verrall has Cricotopus molitator, bicinctus, and annulipes, Camptocladius aterrimus, byssinus, and minimus; Orthocladius variabilis and stercorius; with Diamesa obscurimanus. At Ipswich I have found Metriocnemus fuscipes at light, and Tanypus varius; T. nebulosus turns up at Bramford in May, and T.choreus, carneus, melanops, and pygmaeus are in Verrall's collection. Ceratopogon myrmecophilus is the proper name of the species recorded from Bentley Woods $;{ }^{5}$ C. pulicaris is common in Suffolk, with $C$. femoratus in marshy places; and Verrall has $C$. piceus, ciliatus, frutetorum, varius, pictipennis, and niger. Among the Psychodidae Verrall has recorded Pericoma nubila and $P$. fusca from Fritton; $P$. ocellaris and $P$. auriculata are also in his collection. I have often swept the common $P$ sychoda phalaenoides from reeds, and $P$. albipennis, $P$. sexpunctata, and $P$. humeralis occur at Newmarket, with Trichomyia urbica. Of the mosquitoes Anopheles bifurcatus occurs at Foxhall, Mildenhall, and Wherstead; the common A. maculipennis at Newmarket, Southwold, Bury, Halesworth, Wickham Market, Blakenham, Bawdsey, and Newbourn. Of the gnats Culex annulatus, and pipiens are only too common; but $C$. dorsalis, the Aldeburgh biting gnat, said to have been originally imported in ships from Norway, is decidedly local at that place and at Southwold ; ${ }^{6}$ and C. bicolor is rarely attracted to sugar on trees in the Bentley Woods. Verrall adds Corethra fusca, and the Dixid Dixia nebulosa. Ptychoptera contaminata, albimana, and scutellaris are all common near streams, and $P$. paludosa occurs at Exning in August. Among the Limnobidae I have seen Limnobia bifasciata abundantly on sugar in the Bentley Woods; L. quadrinotata, nubeculosa, and analis about Ipswich ; L. nigropunctata abundantly in woods at Assington and Bentley, and $L$. favipes at Wherstead. Verrall has $L$. tripunctata, Dicranomyia sericata, and Rbipidia maculata from Newmarket, with $D$. modesta from Mildenhall, $D$. didyma and $D$. dumetorum from Barton Mills; $D$. lutea often dances in crowds in Ipswich and Southwold, $D$. chorea occurs in Ipswich houses, and I once found D. morio in a sand-pit. Both Empeda nubila and Goniomyia tenella, with Acyphona maculata, are found in Newmarket, and Cbilotricha imbuta at Exning. Molophilus appendiculatus, bifilatus, and obscurus have been found by Verrall, and $M$. propinquus occurs at Mildenhall in September. I have taken Rbypholopus lineatus on willows in Bentley Woods, and Curtis tells us he once took $R$. nodulosus

\footnotetext{
'Cf. Ent. Mo. Mag. 1902, p. 110.
}

${ }^{5}$ Ent. Mo. Mag. 1897, pp. 49, 90.

'Ibid. 1895, pp. 227-9. 


\section{INSECTS}

commonly in a Suffolk garden. $R$. baemorrboidalis is rare, with Erioptera trivialis at Exning; I have taken $E$. faviescens by the Gipping at Ipswich, $E$. lutea at Dunwich, and Curtis records E. fuscipennis from our county. Symplecta sticitica, S. punctipennis, Ephelia marmorata and Dactylolabis Frauenfeldi are all uncommon, but several of the Limnophilae, such as L. dispar, ferruginea, ochracea, and discicollis are common, though $L$. lineola is only reported from Exning in July. The winter gnats are of course abundant, and Trichocera biemalis and regelationis may often be seen dancing about bare hedges, with, in September, T. annulata. Ula pilosa and Amalopis immaculata are not common, but the large and handsome Pedicia rivosa, which was recorded from Lound Wood by Paget, is sometimes seen at Tuddenham, Hemley, and Foxhall. The crane fies are well represented by eight species of Pachyrrbina, including the beautiful $P$. crocata from Whitton, and eighteen Tipulae, some of which, as T. nigra, signata, lutescens, and vittata, appear local ; Dictenidia bimaculata has been captured in Stanstead Wood in May. The last family of the Nematocera, the Rhyphidae, is abundant in Rhyphus fenestralis and $R$. punctatus.

The Brachycera have been much more carefully worked, and the first family, the Stratiomyidae, is somewhat fully represented. Pachygaster ater is often abundant on bracken at Foxhall, and I have once found $P$. Leachii at Farnham in July; Nemotelus pantherinus and N. uliginosus occur at Felixstowe, the latter being widely distributed and recorded by Curtis from Thetford; $N$. nigrinus has been noticed at Ipswich, Bramford, and Barton Mills. The pretty genus Oxycera is represented by $O$. pygmaea at Tuddenham, $O$. formosa not uncommonly at Foxhall in August, $O$. pulchella taken here by Piffard, and $O$. trilineata first noticed by Paget. Stratiomys potamida is found about Ipswich and Lowestoft, S. riparia not rarely on umbels at Felixstowe, Benacre, and Southwold; $S$. furcata is common in the Broads, and I have taken one $S$. longicornis by a brackish ditch at Wherstead; Odontomyia angulata is recorded by Verrall from Tuddenham, $O$. tigrina was once swept by me at Drinkstone, and $O$. viridula is everywhere abundant on the coast. The beautiful Chrysonotus bipunctatus has been captured at Foxhall, Great Glemham, and Tostock; Sargus flavipes occurs at Tostock and Lowestoft, S. cuprarius singly at Monk Soham and at Tostock, together with $S$. iridatus at the latter locality. Chloromyia formosa, Microchrysa polita and $M$. favicornis are common, as also are Beris clavipes, vallata, chalybeata, and Chorisops tibialis. Xylomyia marginata has occurred at Exning in September. One is not inordinately worried by the bellicose Tabanidae, if we except Heamatopota pluvialis; $H$. crassicornis is distinctly rare at Brantham, Felixstowe, and Ipswich; Therioplectes tropicus, as well as its variety bisignatus, attacks one in the woods at Bentley, Raydon, and Barton Mills, and T. solstitialis is not rare in the Broads. Paget records Atylotus futous, under the name Tabanus alpinus, as having been rare at Belton Bog; the only members of the latter genus at present found are $T$. autumnalis at Southwold and $\mathcal{T}$. bromius at Felixstowe; Chrysops relicta is even commoner with us than $C$. caecutiens. Some of the elegant Leptidae are abundant, especially Leptis scolopacea, which sits head downwards on tree-trunks, L. tringaria, L. lineola, and Chrysophilus auratus; C. aureus is local at Tostock, Bentley Woods, and Bramford. The insectivorous Asilidae are common in June, Leptogaster cylindrica, Dioctria oelandica, rufipes, and Baumhaueri occurring everywhere, though $D$. atricapilla is local at Tostock and Wortham, and D. favipes only met with in Assington Thicks. Isopogon brevirostris has occurred at Newmarket in July, and Tuck took Laphria marginata in the Bury district in August 1897 ; the handsome Asilus crabroniformis is widely distributed; Philonicus albiceps occurs on the coast at Felixstowe and Corton; Epitriptus cingulatus and Neoitamus cyanurus are common; Machimus atricapillus has turned up in the Bentley Woods, \&rc. ; and Dysmachus trigonus is often abundant on the Lowestoft and Felixstowe denes, as well as at Brandon.

Of the hirsute Bombylidae Antbrax Paniscus is widely distributed but uncommon, and Curtis records $A$. bottentota (probably referable to the above species) among rushes near the sea-shore at Covehithe early in July I 822 ; he also gives us a long and interesting account of Phtbiria pulicaria, which he first found in Britain in the same locality and presented to the British Museum. Bombylius discolor and $B$. major are common, but doubt exists as to the capture of $B$. minor by $\mathrm{Mr}$. Tuck at Tostock in 1897 , and perhaps $B$. canescens, Mik., is the species inferred. The Therevidae comprise

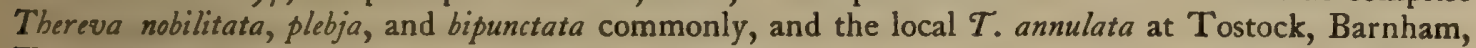
Tuddenham Fen, and Brandon. Scenopinus fenestralis is found at Thetford, Tostock, Orwell, and Monk Soham; and S. niger is said to have been taken at Tostock in May I898. I have only once met with the rare Oncodes gibbosus at Barnby Broad in July; and Acrocera globulus once on birch in Tuddenham Fen. Few species of the voraceous Empidae can be referred to, though both kinds of Hybos, ten of Rhamphomyia, and sixteen of Empis, have been noted; of the latter we may mention Empis opaca at Tostock, $E$. nigritarsis at Wherstead, $E$. pennaria at Oulton, and $E$. pennipes in the Bentley Woods. Pachymeria femorata is common, and $P$. palparis has occurred in Barnby Broad; Hilara cilipes, pilosa, maura, clypeata, and pinetorum can be instanced, with Ocydromia glabricula, Leptopeza favipes, Clinocara stagnalis, two Trichinae, and Microphorus vetulinus. There is an example of Ardoptera irrorata from Tuddenham, in the British Museum; Lepidomyia melanocephala 


\section{A HISTORY OF SUFFOLK}

occurs commonly at Bentley, Stilpon lunata at Foxhall, with Tachypeza nubila at Oulton and Newmarket ; Tachista connexa is abundant, as was once Chersodromia cursitans on Malva on the beach at Slaughdon; Tachydromia albiseta, by Verrall, at Brandon, $\mathcal{T}$. flavipes at Needham, $\mathcal{T}$. maculipes at Foxhall, and $\tau$. femoralis at Claydon Bridge, have also been observed. Several recent additions include Oreogeton flavipes, Leptopeza flavipes, Hemerodromia unilineata, Ardoptera guttata, Thamnodromia vocatoria, Drapetis assimilis, Tachista arrogans, and Elaphropeza ephippiata. The beautiful Dolichopodidae have recently come in for a good deal of attention, and we can enumerate four species of Psilopus, Neurigona quadrifasciata, Eutarsus, aulicus and Hygroceuleuthus diadema, the last from Moulton in June. The typical genus Dolichopus is represented by sixteen species, of which many are only recorded from the Broads of the north-east or Fens of the north-west. The handsome Poecilobotbrus nobilitatus often occurs on my house-windows at Monk Soham; Argyrae with silver bodies flit about streams; Macbaerium maritimae is common by the salt-water Orwell; Scellus notatus may be swept from reeds in our salt marshes, and the curious little Medeterus are seen sitting abundantly on tree-trunks, \&cc. I have recently added Dolichopus griseipennis, D. trivialis and $D$. acuticornis from Monk Soham, $D$. lepidus and $D$. planitarsis from Tuddenham Fen, $D$. clavipes from Southwold, $D$. ungulatus from Barham, Reydon, and Easton Broad, Xiphandrium monotricbum from Southwold, and Hercostomus nigripennis from Henstead. In all seventy-three species of this family have been noticed in the county. Of the last family of the orthorrhaphous diptera, the Lonchopteridae, we have all the British kinds but Lonchoptera punctum and L. fuscipennis; they are common, often turning up even during the winter months.

The first three families of the cyclorrhaphous diptera, the Platypezidae, Pipunculidae, and the Syrphidae, are now well known on account of Mr. Verrall's fine work, which treats of them, and in which, too, many Suffolk records are enumerated. Callimyia speciosa has occurred at Newmarket, and $C$. amoena at Brandon; Platypeza atra was once found by me in the Bentley Woods ; ${ }^{7}$ both $P$. dorsalis and $P$. infumata can be mentioned, the former from Newmarket, and the latter taken by Mr. Piffard at Felixstowe; Chalarus spurius is recorded from Verrall's garden, and Verrallia aucta from Suffolk. Thirteen species of the extensive and distinct genus Pipunculus have been noticed here, but others are sure to turn up, of these the following seem worth recording: Pipunculus balteratus at Tuddenham, which is the only British locality, $P$. varipes at Bentley Woods and Tuddenham, and $P$. pratorum in Newmarket. I have captured Paragus tibialis at Oulton Broad and Bramford, and $P$. bicolor on the banks of the Gipping. Pipizella virens and Pipiza noctiluca are common, $P$. luteitarsis and $P$. bimaculata are recorded from Newmarket, and I took a male of $P$. lugubris about Ipswich, in 1894. Cnemodon vitripennis is recorded by Verrall, Orthoneura nobilis has occurred about Ipswich, and we can include all the species of Liogaster and Chrysogaster except $C$. macquarti. Of Chilosia we have seventeen species; of the rarer kinds may be noticed $C$. longula from Barton Mills, $C$. bonesta at Ipswich in $1893, C$. grossa which is widely distributed, C. albipilla singly at Bentley and Raydon in March, $C$. impressa common at Barnby Broad, and $C$. Bergenstammi at Tuddenham. And of Platychirus eight are recorded; the best are $P$. scambus from Aldeburgh and Southwold, $P$. fulviventris from Brandon and Bramford, and P. angustatus from Aldeburgh and Bentley. Pyrophaena granditarsa is not uncommon, and $P$. rosarum has also been met with; of Melanostoma we have not yet noticed $M$. dubium, though the fine Xanthandrus comtus occurs at Copdock, Leucozona leucorum usually a common species bred from nests of Bombus terrestris by Tuck at Tostock, and I once captured Ischyrosyrphus laternarius at Bramford in August. Catabomba pryastri is common; and Gibbs took C. selenetica at Orford in 1903. Twenty-two species of Syrphus have been identified from the county, of which may be mentioned $S$. tricinctus at Lackford and the Bentley Woods, $S$. annulatus, S. triangulifer, S. punctulatus from Newmarket, and $S$. labiatarum from Barton Milis and Tostock; as well as the three Sphaerophoria and both species of the handsome genus Xanthogramma. Baccha elongata is local, but Ascia podriagrica and foralis occur freely; $A$. dispar is also said to have been found here. The rare Bracbypoda bicolor has twice been captured by me at so distant localities as Belstead and Brandon; Rbingia campestris, Volucella bombylans, and $V$. pellucens are common, and I once found $V$. inflata in the Bentley Woods. We have not found Eristalis cryptarum nor rupium, but the other members of the genus are of frequent occurrence, $E$. aeneus being often abundant on the coast. Myiatropa florea and Helophilus pendulus are a nuisance on flowers, though $H$. trivittatus in various localities, $H$. bybridus at Cornard by Harwood, $H$. transfugus at Walberswick, $H$. lineatus about Ipswich, and $H$. vittatus (the Ruddii of Curtis) from Breydon marshes, never seem to be met with in any numbers. Merodon equestris occurs at Bury, and I have found it in an Ipswich house, and Tropidia scita is abundant in the fens and marshes. Criorrbina berberina is noticed in Bentley Woods, $C$. oxyacanthae at the same locality and at Bungay, ${ }^{8} C$. floccosa is bred at Tostock by Tuck, with the rare and handsome Pocota apiformis. I have captured Xylota nemorum at Barham, $X$. segnis at Foxhall, $X$. lenta has been found at Copdock, and $X$. sylvarum at Tostock and 


\section{INSECTS}

Bungay. Syrita pipiens is abundant; Eumerus sabulonum was captured by Piffard near Landguard Fort, and $E$. strigatus is not very uncommon. Chrysotoxum sylvarum, C. bicinctum, and $C$. festivum are common; I have found $C$. elegans at Southwold, and Tuck has bred $C$. octomaculatum at Tostock in 1896 and 1897 . Paget records Sericomyia borealis as occasionally common at Lound Heath, though not now met with for many years, and I took the fine Criorrbina asilica in Bentley Woods in 1904 .

The interesting family Conopidae is well represented in Suffolk. Of the typical genus Conops, C. Aavipes, quadrifasciata, and ceriiformis are not uncommon, and Tuck has bred the variety vitellinus at Tostock. Physocephala rufipes and Oncomyia atra are also ubiquitous, but $O$. pusilla and Zodion cinereum are very rarely met with, the former at Dodnash Woods and about Bury, the latter once only at Foxhall in August, and once at Brandon in June. Sicus ferrugineus is often seen on ragwort flowers in the autumn; Myopa buccata is recorded hence by Curtis, and more recently from the Bury district, \&zc.; $M$. testacea was bred at Tostock by Tuck in May 1898 , and $M$. fasciata, which I have captured at Foxhall, was found at Ipswich by Freeman about 1887. Among the bot-fies, the Oestridae, we can only positively claim two species, though Hypodermae are sure to occur; these are Gastroptilus equi, of which Mr. Tuck took several specimens at Tostock in August 1898 , and others at Bungay in July; and Oestrus ovis, the sheep-fly, which he also found in the former village in July. Many of our parasitic flies of the family Tachinidae have not yet been determined, but we may mention Meigenia egens from flowers near Ipswich, Ceromasia machairopsis about Ipswich, $C$. sordidisquama and $C$. juvenilis common in Bentley Woods in May, C. senilis from Felixstowe, by Piffard (in the British Museum), and Dodnash Woods, C. stabulans about Ipswich and Lowestoft, and C. spectabilis on birch in Assington Thicks in June. Exorista vetula is found at Assington and Bentley, E. fimbriata and $E$. apicalrigria occur here (the latter being in the British Museum), $E$. perturbans is common on oak-trunks; Mr. Ransom has bred $E$. jucunda at Sudbury from Liparis salicis, and Tuck found $E$. notabilis at Aldeburgh. Epicampocera succincta is common at Little Blakenham; I have Blepharidea vulgaris bred from Pieris rapae and Abraxas grossulariata; Myxexorista fauna has been captured in the Bentley Woods, where Botbria caesifrons and Phorocera serriventris are not rare; Blepharipoda atropivora has been noticed at Bramford, and Sisyropa bortulana in Bentley Woods; $S$. lucorum I have bred from lepidopterous pupae at Ipswich in July. Chaetolyga amoena occurs about Bury St. Edmunds, Tachina grandis in the Bentley Woods, T. erucarum at Felixstowe, and $\mathcal{T}$. rustica with $\mathcal{T}$. agilis about Ipswich ; Gonia divisa was captured in 1894, and at Foxhall in May I have taken G. ornata with G. lateralis. Monochaeta leucophaea and Thelymorpha vertigosa are rare about Ipswich; Aporomyia dubia is abundant in the Bentley Woods; Somobia rebaptizata widely distributed, and Pelatachina tibialis once occurred to me at Mildenhall in June. In the Bentley Woods Macquartia grisea, Degeeria medorina, Demoticus Plebejus and D. frontatus, Myiobia pacifica, Micropalpus pudicus (with the type of Meade's Nemoraea quadraticornis), all occur with more or less frequency. Ptilops chalybeata has turned up at Bramford, Antbracomyia nana at Hensstead and Tostock, Micropalpus pictus at Claydon Bridge, $M$. vulpinus is certainly uncommon at Felixstowe and Tostock, but Thelaira leucozona and Erigone radicum are common enough. Tuck has taken $E$. rudis about Bury, and I have found $E$. vivida near Ipswich; Echinomyia grossa has occurred to me at Barton Mills, and E. fera to Hocking at Copdock; Plagia ruralis occurs in the Bentley Woods and $P$. trepida at Assington. Piffard says Phorichaeta carbonarius was abundant at Felixstowe in 1896 , and presented it to the British Museum ; Discochaeta muscaria is rare at Assington, but Roeselia antiqua is generally distributed, as also are Digonochaeta spinipennis and D. setipennis. Thryptocera crassicornis and T. bicolor, with the two Siphonae, have been noted. Early in I897 I took what Dr. Meade said was Exorista (Blepharomyia) amplicornis on oak-trunks in the Bentley Woods, and with it occurred what he considered a new species and named Phorocera incerta, a cotype of which is in the British Museum; ${ }^{9}$ these Verrall synonymizes. I was also so fortunate as to add Phasia Rothi (Xysta cana) to the British list, ${ }^{10}$ having found it in the vicinity of Ipswich, where Alophora pusilla is sparingly met with. Few of the remaining sections of the Tachinidae, the Trixinae, Sarcophaginae, and the Dexinae, require particular mention; in the first we have twelve species, including Trixa oestroidea, ${ }^{11}$ Tryphaera umbrinervis, and Dialyta atriceps; in the second fourteen species, several of the typical genus Sarcophaga and the fine northern fly Cynomyia mortuorum from Orford and Tuddenham, the bee-parasite called Miltogramma punctatum, Hereronychia chaetoneura, and the interesting little Spbixapata conica from Bramford and Felixstowe ; in the last only four species, of which Dexiosoma caninum is found sitting commonly on bracken with, rarely, Dexia rustica in the Bentley Woods, and D. vacua at Worlington, and Prosena sybarita on the Breck sands, taken by the Hon. N. C. Rothschild, in August.

Of the ubiquitous Muscidae, we have found all the Stomoxys, Pollenia, Myiospila, Musca, Morellia, Mesembrina, Pyrellia excepting P. cyanicolor, Protocalliphora, Calliphora, and Euphora;

Cf. Ent. Mo. Mog. 1897, p. 223 ; 1898, p. 35.

${ }^{10}$ Ibid. 1896, p. $212 ; 1898$, p. 39 .

"C. Trans. Norf. Nat. Soc. 1901, p. 157. 


\section{A HISTORY OF SUFFOLK}

Graphomyia maculata and Cyrtoneura stabulans are abundant; $C$. pabulorum has been bred at Tostock from nests of Vespa vulgaris; Lucilia caesar and $L$. serica are common on flowers, and I once took a doubtful L. illustris at Blakenham. The Anthomyidae are equally common; of these we have the two usual Polietes, eighteen species of Hyetodesia, in addition to $H$. obscurata taken at Exning in July; Alloeostylus flaveola and A. simplex; six species of Mydaea, twelve of Spilogaster, two of Limnophora, eleven of Hydrotaea, four of Hydrophoria, fourteen of Hylemyia, seven of Chortophila, twelve of Phorbia, and five of Pegomyia. Sphecolyma inanis has been bred by Tuck from nests of Vespa germanica; Melanochila riparia occurs at Foxhall; Ophyra leucostoma and Drymia hamata are

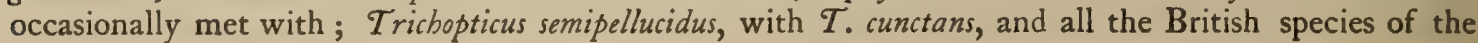
genus Antbomyia are also recorded, the rare $A$. albicincta having been taken once at Tostock. Mycophaga fungorum has been found about Bury St. Edmunds and the rare Chirosia abbitarsis at Foxhall. We have recently added Lasiops Roederi, ctenoctena, and $L$. Meadii from Newmarket. Among the Homalomyinae we have fourteen species of the typical genus and five Azelia, three Lispe, two Caricea, two Coenosia, together with Piezura pardalina, Coelomyia mollissa, Hoplogaster mollicula, and Fucellia maritima. The marsh-loving Cordyluridae are represented by Cordylura pudica at Henstead, C. pubera at Brandon, $C$. ciliata at Beccles and Claydon, and the common C. umbrosa; Parallelomma albipes at Foxhall and Bentley Woods, Cnemopogon apicalis at Barton Mills, Amaurosoma tibiella at Oulton Broad, Norellia spinimana, N. liturata, and N. spiniger, Trichopalpus fraternus, and Spathiophora bydromyzina; eight species of Scatophaga, Ceratinostoma ostiorum on the banks of the Orwell and the Gipping, and Coniosternum obscurum at Harleston. Helomyza rufa and H. ustulata, Blepharsptera ruficauda, and $B$. serrata are common; $H$. Zetterstedtii, montana, and $H$. pallida occur about Newmarket, and I took Allophyla atricornis at Brandon in 1903 ; Heteromyza atricornis and Tepbrochlamys rufiventris are frequent, $\mathcal{T}$. favipes is found in the Bentley Woods, and $\mathcal{T}$. pallescens was taken in Ipswich in 1896 . Trigonometopus frontatus is our only representative of the Heteroneuridae; it occurs in some numbers on dead rushes at Foxhall in March, and doubtless hibernates among them.

The Sciomyzidae in so well-watered a county as Suffolk are abundant; Mr. Tuck has taken Actora aestuum at Aldeburgh in September, and both Dryomyza analis and D. faveola are everywhere common; of Sciomyza we have noted nine species, including S. Schoenherri near Ipswich, S. simplex at Barton Mills, and $S$. albocostata at Foxhall ; and ten of Tetanocera, of which mention may be made of $T$. sylvatica at Barnby Broad, $T$. punctata commonly, and $T$. umbrarum in reed refuse at Oulton Broad, Limnia marginata at Barham and Ipswich, and L. obliterata at Tostock and Aldeburgh. Elgiva dorsalis and $E$. rufa are common; I took $E$. lineata at Tuddenham in 1906, and Tuck has found E. albiseta at Tostock in July. The carrot-fly Psila rosae is too common, I have taken $P$. fimetaria at Ipswich and Tuddenham, and both $P$. nigricornis and villosula are found at $\mathrm{New}-$ market. Chyliza atriseta occurs at Bramford, C. leptogaster in Tuddenham Fen, and in June 1902 Tuck took $C$. vittata, which was new to Britain, at Bungay; Loxocera aristata and L. albiseta are generally distributed, and I once beat $L$. sylvatica in the Bentley Woods. Micropeza lateralis is rare upon dry heath grasses at Foxhall, $M$. corrigiolata common with Calobata ephippium; $C$. petronella occurs commonly in Ipswich gardens, and Verrall took $C$. cibaria at Fritton in 1881. Of the Ortalidae, the only British specimen of Tanypeza longimana was captured at Tostock by Tuck in July $1899 ;{ }^{12}$ Dorycera graminum is not rare, nor also probably is Ptilonota centralis. Pteropaectria frondescentiae is frequent on rushes, and $P$. afficta and $P$. nigrina have been met with here; Ceroxys pictus is abundant in the coast salt marshes and $C$. crassipennis in all the broads and fens. Platystoma seminationis is often a pest in June, with Rivellia syngenesiae; Seoptera vibrans is local at Theberton, Southwold, Monk Soham, and Tuddenham Fen; Ulidia erythropthalma is not uncommon, but Chrysomyza demandata is rare. Comparatively little attention has been paid to the pretty little Trypetidae, and we can only instance the celery-fly, Acidia heraclei and A. lychnidis, Gonyglossum Wiedemanni at Blakenham and Newmarket, Spilographa Zoe at Tuddenham on birch, Trypeta jaceae at Yoxford; $\mathcal{T}$. onotrophes and $\mathcal{T}$. forescentiae are common, $\mathcal{T}$. cornuta has occurred at Ipswich, T. tussilaginis at Oulton Broad, and $T$. serratula at Farnham. Urophora solstitialis and U. stylata. with Sphenella marginata, are frequent; Ensina sonchi has been taken at Southwold, Urellia stellata at Foxhall, and six species of $\mathcal{T}_{\text {ephritis comprise our list-T }}$. plantaginis abundant about Southwold, T. formosa at Bentley and Tostock, and the widely-distributed $\mathcal{T}$. bardanae. Of the Lonchaeidae, $L$. vaginalis is abundant, $L$. chorea found near Needham, $L$. tarsata bred by me from a Tortrix pupa at Foxhall; and I also took upon thistles in the Bentley Woods, 1895, what Dr. Meade called L. fumosa, Egger. Palloptera ustulata, P. umbellatarum, and $P$. arcuata are common, but I have only found $P$. saltuum at Southwold, and Toxoneura muliebris has been taken at Bramford, \&c. Peplomyza Wiedemanni occurs at Barton Mills, Sapromyza marginalis, fasciata, inusta, decempunctata, biumbrata, rorida, praeusta, and plumicornis are all recorded from the county, with $S$. lupulina from Wherstead,

${ }^{18}$ Cf. Ent. Mon. Mag. 1904, p. 60. 


\section{INSECTS}

Lauxania Elisae, $L$. aenea, and, at Oulton Broad by Tuck, L. byalinata. Balioptera tripunctata is abundant, though not so $B$. combinata; Opomyza germinationis and $O$. forum are of general distribution; and at Shotley I have found Pelethophila lutea and P. fava at Tostock.

The long-legged Sepsidae are somewhat fully represented, the typical genus comprising Sepsis pectoralis at Felixstowe, S. nigripes, violacea, cynipsea, and S. pilipes at Newmarket; Nemopoda cylindrica and $N$. stercoraria are common about Ipswich ; Henicita Leachi and H. annulipes are recorded; and at Tuddenham Verrall has taken Mycetaulus bipunctatus in September. The three Themira, putris, superba, and minor occur in Newmarket, with Saltella sphondylii and S. nigripes. The cheese-mites, Piophila casei, with five more of the same genus, are of course abundant, and the pretty Madiza glabra occurs at Ipswich and Southwold. Six Geomyzidae are noticed in Anthomyza flavipes at Felixstowe, and A. gracilis in Newmarket; Geomyza obscurella has occurred to me at Aldeburgh, Diastata nigripennis at Foxhall with $D$. unipunctata, and D. punctum at Kessingland. The Ephydridae have been recently much augmented by Mr. Verrall's Suffolk captures, and we now boast of Notiphila venosa and $N$. dorsata from Aldeburgh, with five common kinds of the genus; Trimerina madizans from Bentley Woods in the winter; Psilopa leucostoma and nitidula, with Hydrellia griseola, commonly. Collin has found Discocerina obscurella at Tuddenham and Philhygria stictica at Newmarket. Hyadina scutellata and $H$. guttata occur, and Paget took Ochthera mantis at Lound Heath; two Parbydrae are common with Ephydra riparia and Caenia palustris; but the curious tiny Scatellae, of which we have four kinds, are never in great profusion. Among the Drosophilidae, Scaptomyza graminum and Aulacigaster rufitarsis are rare, though few of our six species of Drosophila are uncommon. The handsome little Chloropidae have received considerable attention from Mr. Collin, so our list comprises Lipara lucens, common by the River Lark, Platycephala planifrons in profusion in all the Broads, four kinds of Meromyza, with Centor cerceris and C. myopinus among reeds. Anthracophaga strigula has occurred to me at Bawdsey, Diplotoxa messoria at Beccles, and D. inconstans at Claydon Bridge ; our list is augmented by seven species of Chlorops, two of Chloropisca, and five Oscinus, which, with the common Elachyptera cornuta and abortive E. brachyptera, conclude this family. Cacoxenus indagator, from Newmarket, represents the Milichidae; Agromyza lutea at Claydon and Schoenomyza litorella at Foxhall, the next family; Phytomyza elegans from Tuddenham and Chromatomyia affinis, a third; while the fourth, the Astiadae, adds only Astia amoena, which abounds in bracken refuse in the winter. It becomes necessary to somewhat fully deal with our Borboridae since no other county has so good a list, thanks to the assiduity of Mr. Collin. The typical genus Borborus has eleven representatives, of which $B$. nitidus has occcurred to me at Bramford, $B$. pedestris at Ipswich and Brandon, $B$. longipennis on my study window, and $B$. geniculatus in the Bentley Woods; Collin has also found $B$. suillorum at Bradley, with $B$. Roseri, $B$. sordidus in a Newmarket paddock, and he described $B$. notabilis from Bradley. ${ }^{13}$ Sphaerocera monilis, pusilla, vaporariorum, scabricula, and Collin's new S. eximia are all found at Newmarket; while I have seen $S$. subsultans at Claydon. Of the extensive genus Limosina we have twenty-seven kinds, among which I have taken $L$. frontinalis at Bentley, L. sylvatica at Felixstowe, L. ochripes at Ipswich, with $L$. scutellaris, L. erratica at Freston, $L$. spinipennis at Felixstowe, and $L$. roralis at Brandon; all the remainder have fallen to Collin's net, and they comprise $L$. ferrugata, lutosa, limosa, vagans, lugubris, melania, atomus, acutangula, fungicola, vitripennis, coxata, punilio, clunipes, beteroneura, nigerrima, crassimana, fuscipennis, and minutissima, together with his two new species, $H$. Halidayi and L. mirabilis, from Newmarket. ${ }^{14}$ In the Phoridae we are not so good, and only possess Conicera similis, Trineura aterrima, six species of Phora including Verrall's new $P$. formicarum. ${ }^{15}$ The last family, the Hippoboscidae is represented by four kinds: Ornithomyia avicularia which Tuck took at Tostock in 1897 ; Stenopteryx hirundinis, captured by Dr. Wood at Woolpit; Oxypterum pallidum, recorded by Paget from the Yarmouth district, and still a very rare fly; and the Sheep-fly, Melophagus ovis, which has occurred to the Rev. E. N. Bloomfield at Great Glemham and to me at Monk Soham.

\section{H E M I P T E R A}

Bugs

\section{HETEROPTERA}

Concerning the Heteroptera of Suffolk, little or nothing has until quite recently been published, and it will be advisable to here deal somewhat fully with the subject. Little is to be learned from modern literature, and nothing whatever (but one or two records in Curtis's British Entomology, and a few more or less unreliable ones in Paget's Natural History of Great Yarmouth) from the older authors. Mr. Saunders has done some collecting about Southwold, and Mr. E. A. Butler around 


\section{A HISTORY OF SUFFOLK}

Corton near Lowestoft and at Felixstowe; Mr. Thouless brings forward a few kinds in the Transactions of the Norfolk Naturalists' Society, and Mr. J. J. Walker mentions one or two from the vicinity of Brandon. But for the majority of the species-especially the commoner sorts, which go so largely to swell the proportions of a county list, though of little value in themselves, except for purposes of 'distribution'-I have had to rely mainly upon my own efforts and upon those of Mr. Tuck, who has found several species in the neighbourhood of Bury St. Edmunds.

Odontoscelis fuliginosus has been found at Lowestoft, Felixstowe, and Mildenhall ; it occurred to me upon the Foxhall Plateau not uncommonly in 1904. Podops inuncta, Gnathoconus albomarginatus, Sebirus bicolor, and S. biguttatus are widely distributed, the last being often found in moss during the winter. Aelia acuminata is decidedly local, though common on dry grasses at Brandon and Lowestoft ; Bedwell has recently taken it at Kessingland, and I have once swept it at Barham. On 25 May I90I I was so fortunate as to beat the fourth localized British specimen of Peribalus vernalis from young poplar trees in the Bentley Woods, near Ipswich; elsewhere it is only known from Weston-super-Mare, Cumberland, and Sussex. ${ }^{1}$ Pentatoma prasina is common in the same locality, and P. baccarum has been taken singly by Elliott, Bedwell, and myself at Benacre and Oulton Broads and Barton Mills. Piezodorus lituratus, Tropicoris rufpes, Podisus luridus, Acanthosoma haemorrboidale, dentatum, and interstinctum are all common, though Picromerus bidens is certainly rare, having been taken once only by Baylis at Foxhall Heath in 1895, and once by Bedwell at Herringfleet. Of the Coreidae, I have found in some numbers the rare Spathocera Dalmani, not before seen north of the Thames, crawling upon the bare, sandy Foxhall Plateau in May and September. Syromastes marginatus and Pseudophloeus Fallenii have been taken sparingly, the former at Fritton, Lound, Bungay, and Westleton, the latter upon several occasions uncommonly on the Breck Sands, though locally abundant at Brandon beneath cranesbill. Coreus denticulatus, Corizus parumpunctus, and Myrmus myriformis are not uncommon; and Chorosoma Schillingi was found at Lowestoft and Southwold by Saunders, and has occurred to me at the latter locality. In May 1903 Tuck captured Verlusia rhombea, which was more frequent at Brandon in 1906, at Bury St. Edmunds, and there is an example of Corizus capitatus in the Cambridge Museum from Mildenhall. Of the curious Neides, $N$. tipularius has been taken singly by Mr. Newbery and myself about Ipswich, $N$. crassipes by Thouless about Lowestoft, and by Bedwell at Barnby Broad; N. minor is common, and has been found in the nests of Bombus muscorum by Tuck; $N$. signoreti occurred in a gravel pit at Claydon in July; N. montivagus at Southwold and Hadleigh in moss. Metacanthus puncticeps is very abundant at the roots of marram grass on the Kessingland sandhills, and also occurs at Lowestoft and Kentford.

Of the Lygaeidae, the ubiquitous Nysius thymi, Ischnorbynchus resedae, I. geminatus, and Cymus glandicolor are abundant, though $C$. claviculus appears to be confined to the Bentley Woods. The local Heterogaster urticae occurs in some numbers at Lakenheath, Brandon, Tuddenham, Bungay, Lowestoft, Aldeburgh, and Hollesley; Rhoparochromus dilatatus and $R$. chiragra are not rare, and $R$. praetextatus is recorded from Thetford Warren by Curtis. The usually common Chilacis typhae is only found at Fritton and Ischnocoris angustulus beneath heather everywhere. Macrodema micropterum, Plintbisus brevipennis, and the three Stygni have all been found here; and I took one specimen of the very rare Lasiosomus enervis at Southwold in July 1897; Acompus rufipes swarms in all the true fen country, from Mildenhall and Brandon to Oulton. Peritrechus luniger and P. geniculatus, Trapezonotus agrestis, Aphanus pedestris, Scolopostethus affinis, S. decoratus, Notochilus contractus, Drymus sylvaticus, and D. brunnea are all quite common; though Peritrecbus nubilus is distinctly scarce at the roots of grass on the Kessingland sandhills and in Bentley Woods, as well as in marsh-hay in Oulton Broad; Aphanus lynceus has but twice occurred to me, in moss at Barton Mills in August and in a grass-tuft at East Bergholt in April ; Scolopostethus neglectus, sometimes fully developed, is found at Tostock, Stoke by Nayland, Lavenham, and Oulton Broad; and both Gastrodes have been recorded by Paget, though that his 'abietis, L.' refers to that species is open to doubt; G. ferrugineus is common at Brightwell Heath, Mildenhall, Battisford, \&c. Jennings took Drymus confusus at Brandon $;^{2}$ and Curtis tells us that many Pyrrbocoris apterus have been found at Beccles in May.

Among the leaf-like Tingididae, both species of Piesma are found, $P$. quadrata in profusion beneath Chenopodium at Felixstowe by $\mathrm{Mr}$. Newbery, and $P$. capitata widely distributed. Serenthia laeta is very local at Tuddenham, Mildenhall, Brandon, and Kessingland. Orthostira parvula, Monantbia ampliata, $M$. cardui, and $M$. bumuli are very common. Dictyonota crassicornis has been found at Bentley Woods, Felixstowe, on the banks of the Gipping, and in an ants' nest at Covehithe Broad; D. strichnocera on mullein at Westleton in July; and Derephysia foliacea has occurred to Butler at Herringfleet and to me in a dead rabbit in the Bentley Woods. Monanthia ciliata and $M$. dumetorum are scarce, the former at Belstead and the latter on whitethorn in Shrubland Park. 


\section{INSECTS}

The flat Aradus depressus is often common among pine chips, and Aneuris laevis sometimes socially abundant in moss on old stumps at Bentley. The two hydrophilous Hebri occur not uncommonly in flood refuse at Oulton Broad, and Velia currens, of which I captured a developed form in the Bramford marshes in September 1895, Hydrometra stagnorum, Gerris thoracica, G. gibbifera, and G. lacustris, are all common. Microvelia pygmaea is fairly abundant at Oulton Broad, and also occurs in the Bramford marshes; Gerris najas has once been taken by me in some numbers in a millstream at Nayland, and I once captured an example of the very rare G. rufoscutellata in an inundated cart-rut in the Bentley Woods in 1903. Bedwell has found G. argentata in Oulton and Barnby Broads. Both species of Ploiaria have been beaten from a faggot-stack at Tuddenham in August, and $P$. vagabundus is also rare on holly in the Bentley Woods. The large Reduvius personatus, which clothes itself in dust, and is said to prey upon bed-bugs, has several times occurred at Sudbury, Bury, Brandon, and flying to light in an Ipswich house in November; Coranus subapterus is somewhat common, with Nabis ericetorum, beneath heather throughout the county. All the British Nabes have been found in Suffolk; $N$. lineatus at Fritton, where it is not rare, Southwold, Oulton Broad, Henstead, and Herringfleet ; $N$. boops is supposed to be a very rare species, of which Butler took one specimen on the sandhills near Lowestoft, ${ }^{3}$ and in 1902 I took it beneath heather at Foxhall, where I should expect it to be not uncommon if thoroughly searched for. Among the littoral Saldae much remains to be done, since $S$. pilosa, saltatoria, pallidipes, pilosella, opacula, orthochila, littoralis, lateralis, and cincta are all that have been noticed here at present.

Cimex lectularius is of course only too common in our towns; and there is a local superstition that these insects are spontaneously evolved from wall-plaster or the paste with which its paper is affixed! Ceratocombus coleoptratus, Piezostethus galactinus, and P. curisitans, Lyctocoris campestris, and Temnostethus pusillus have all been noted. The three common Anthocores, with Tetraphleps vittata, Triphleps nigra, T. minuta, and T. majuscula are reported; and I have lately taken Anthocoris sarothamni at Brandon and the two Acompocores on fir trees in Barnby Broad. Saunders took two Brachysteles parvicornis in 1877 beneath a low elm hedge near Walberswick, which is the only known British locality for this species excepting Kessingland, where I captured one in 1904. The rare Cardiastethus fasciiventris has turned up at Monk Soham, Nayland, Raydon Great Wood, and Coddenham in April and May; as well as Xylocoris ater and Microphysa elegantula. I made the second British capture of Xylocorridea brevipennis in the dry moat of Framlingham Castle on 8 April I 901 , having first found the species in Britain in Richmond Park. ${ }^{4}$ Saunders records both Myrmedobia tenella and $M$. inconspicua from Southwold, and both sexes of the latter at roots of grass on the Lowestoft sandhills. Bedwell has recently turned up the former at Oulton Broad; and Microphysa pselaphiformis has been found at Mildenhall and Tuddenham by Dr. Sharp and Mr. Chitty.

We now come to the great family Capsidae, of which Pithanus Maerkeli, Miris laevigatus, $M$. calcaratus, Megalocera erratica, M. ruficornis, Leptopterna ferrugata, L. dolobrata, and Monalocoris filicis are quite common. Acetropus Gimmerthalii is said to be rare, but occurs annually upon Walberswick Heath and sometimes in the Bentley Woods ; Megalocera longicornis has been found in several localities; and Teratocornis antennatus in Easton and Covehithe Broads. Pantilius tunicatus lives about Brandon and Thetford, Tostock, and Bentley Woods, and Gibbs has found it at Orford; Lopus flavomarginatus is very common at Bentley, where I have twice found the variety superciliosus of L. gothicus. Miridius quadrivirgatus appears to be confined to the south and south-east coasts of Britain, Lowestoft constituting its most northern limit. Seven species of the slender-legged genus Phytocoris and seven of the stouter Calocoris, as well as Oncognathus binotatus, have been observed here, none of which are of especial note, unless it be the unusual rarity of $C$. fulvomarginatus. In 1904 I added Dicbrooscytus rufipennis, from the Bentley Woods and Kessingland, and Plesiocoris rugicollis, from Foxhall, to our county list. Of the genus Lygus we have eleven kinds, none, however, appearing uncommon except the variety nigronasutus of $L$. lucorum, which has only been recorded from Corton by Mr. Butler, and Lygus atomarius, which Edwards alone had taken off silver firs at Stratton Strawless in Norfolk till Mr. W. H. Tuck sent a specimen for identification to Mr. E. A. Butler, taken at Tostock near Bury St. Edmunds in 1896 or 1897 . Zygimus pinastri occurs at Lowestoft, Corton, Fritton, Somerleyton, and Bramford; Poeciloscytus unifasciatus sparingly in Tuddenham Fen ; P. nigritus very rarely in Cutlers Wood at Freston; and P. Gyllenbalii is common, as also are Liocoris tripustulatus, Capsus lanarius (which is capable of inflicting a painful puncture), and Rhopalotomus ater. Camptobochis lutescens is much rarer here than about London; I have only seen it from Tostock, Lavenham, Shrubland Park, Henstead, and Tuddenham Fen. In the lastmentioned locality Mr. E. A. Elliott has taken Pilophorus cinnamopterus singly on the flowers of Spiraea at the end of August; and Butler has found Allodapus rufescens at Lowestoft (where it turned up commonly in 1905) and Herringfleet. Halticus apterus, $H$. luteicollis, rarely on hazel at Freston, 


\section{A HISTORY OF SUFFOLK}

Orthocephalus saltator, and, at Lowestoft, $O$. mutabilis have been noticed here. Six kinds of Dicyphus (of which $D$. pallidicornis is confined to Digitalis purpurea at Freston), Campyloneura virgula, and the two species of Cyllocoris are all common on their respective food-plants. Aetorbinus angulatus is often attracted to light at night; and I have captured Globiceps flavomaculatus, G. dispar, and Mecomma ambulans. Butler has taken a macropterous specimen of Cyrtorrbinus flaveolus at Fritton, ${ }^{5}$ I have found $C$. caricis at Wherstead, and $C$. pygmaeus has occurred to Thouless at Fritton. Eleven species of the genus Orthotylus have been found in Suffolk, of which $O$. prasinus, taken by Saunders at Southwold in $1877, O$. tenellus at Freston, and O. rubidus on Artemisia maritima are the only uncommon ones. Hypsitylus bicolor, Heterocordylus tibialis, Onychumenus decolor, and Oncotylus viridiflavus are uncommon, and Heterotoma merioptera abundant on nettles. Loxops coccineus has only been seen at Kentford, with Malacoris cblorizans in the Bentley and Dodnash Woods. The two common Macrocolei and both the Macrotyli are met with; Conostetbus roseus is abundant upon Foxhall Plateau and Harpocera thoracica on oaks everywhere. Amblytylus affinis, Byrsoptera rufifrons, the three Phyli and Atractotomus magnicornis occur sparingly, though $A$. mali has only been found at Bungay upon one occasion in 1903. Eleven species of Psallus, among which $P$. alnicola at Freston and P. Rotermundi at Brandon are very local, and six of Plagiognathus, of which $P$. albipennis is found on Artemisia maritima all along the coast, have been noticed. Butler took Asciodema obsoletum at Lowestoft in I891; I have recently also turned it up about Ipswich.

Many of the interesting aquatic Cryptocerata await discovery, and few unusual kinds have been noticed. Naucoris cimicoides is said by Paget to have been very common in ditches about Yarmouth in 1825 ; it occurs at Oulton Broad, Ipswich, in brackish water at Bawdsey, and swarms in the Tostock ponds. Nepa cinerea, the water-scorpion, is generally common; but the handsome Ranatra linearis stood on the authority of a single specimen taken many years ago at Battisford by Baker, till Tuck took several in one pond in the middle of a field at Drinkstone in October $1901 .^{6}$ Notonecta glauca is abundant, and its variety furcata is referred to by Paget; Plea minutissima occurs in all the ponds about Ipswich. Of the extensive genus Corixa, comprising the lesser waterboatmen, we have only fifteen kinds as far as is at present ascertained; all these are fairly widely distributed, though $C$. fallenii is represented by only two individuals taken respectively in 1893 and 1904, C. coleoptrata and $C$. venusta are restricted to Bixley Decoy and Oulton Broad, and $C$. limitata is very rare and local. $C$. lugubris often occurs, mixed with $C$. pracusta, in the utmost abundance among shrimps, in the brackish ditches at Bawdsey, the net becoming weighed down with a dark mass of them.

From this short résumé of the Heteroptera it will be seen that some two hundred and eightyfour species have been noticed in Suffolk. Considering that I captured over a hundred in 1897 alone, and that less than that number have been added during the following eight years, it is sufficiently obvious that collecting of late has fa!len into neglect, and that assiduous working might show up many new kinds.

\section{HOMOPTERA}

\section{Cicadidae}

In this group we have had even less observations to draw from than was the case in the Heteroptera. Mr. Butler noted a few about Lowestoft in $189 \mathrm{I}, \mathrm{Mr}$. Edwards mentions one or two kinds from Southwold and Brandon, and Curtis records, I think, two from the county. It cannot, therefore, be wondered at that I have been able to include little more than exactly half the British kinds; but, with our extensive marsh country, to which many of those insects are restricted, quite another fifty or sixty kinds should turn up if systematically sought in favourable situations and upon their particular food plants, for these, like the last group, are entirely phytophagous in their economy.

The curious Centrotus cornutus is a common species on bushes in the woods about Ipswich, Bury St. Edmunds, and Lowestoft in June; but Gargara genistae is very local at Tostock and Ipswich, though Mr. Norgate has taken it commonly on broom at Barnham and Downham in the north-west. Issus coleoptratus has only occurred singly at Ipswich in I 894 and I904, and in a wasps' nest in a holly bush near Bury; Cixius pilosus and C. nervosus are common, though $C$. cunicularis is decidedly local at Tostock and Assington Thicks in July. The thick-horned Asiraca clavicornis was first found by Curtis at Henstead near Wangford, and more recently by myself among coniferae in Bentley Woods, it is not uncommon about Brandon; I have also found Delphax pulchella to be somewhat common on reeds in Benacre and Herringfleet Broads in the middle of August. The extensive genus Liburnia requires much more full investigation than it has hitherto received; of the

'Ent. Mo. Mag. 1891 , p. 277.

${ }^{6}$ Cf. Trans. Norf. Nat. Soc. 1902, p. 333. 


\section{INSECTS}

fifty British species only eighteen have been observed, amongst which $L$. notula occurs on reeds in Oulton Broad, L. lineola in Dodnash Woods, and on the banks of the Orwell, L. longipennis in tufts of Carex paniculata at Foxhall in the winter ; L. vittipennis is abundant in Tuddenham Fen, where Elliott has taken $L$. fuscovittata in some numbers; and $L$. punctulum with $L$. pellucida and $L$. scotti about Lowestoft, where it was found by Butler, as well as at Claydon Bridge and Foxhall. Mr. Edwards tells us ${ }^{7}$ that $L$, or Chloriona, glaucescens, Fieb.-formerly thought to be $C$. unicolor, H. S. - has been found by him commonly on reeds in the coast marshes at Southwold in August. L. leptosoma and L. limbata are common, and L. elegantula local at Foxhall, Kentford, and Tuddenham; but $L$. speciosa, which does not appear to have been taken in Britain for many years, has been but sparingly met with by Mr. Elliott and myself in marshes at Ipswich, Barton Mills, Brandon and Tuddenham Fen. The remaining species are Liburnia difficilis, discolor, exigua, Fairmairei, and lineata, whose distribution is not yet fully known.

Of the rest of the Delphacidae, I have seen Dicranotropus hamata from Foxhall to Tuddenham, and Stiroma pteridis common on bracken, $P$. albomarginata at Bentley and Tuddenham, $P$. affinis once swept at Freston in 1904. The extremely handsome Triecphora vulnerata is by no means uncommon upon young poplars and flying in the sunshine in the Bentley Woods, Assington Thicks, and Holbrook Park in June; both species of Aphrophora live about Ipswich and Bury ; and all the British Philaeni, or 'Cuckoo-spits,' are common, though $P$. lineatus appears somewhat local, and several forms of $P$. spumarius have not been met with. Ledra aurita is uncommon on oaks in the Bentley Woods, at Tostock and Battisford; Ulopa reticulata often swarms beneath heather; and Megophthalmus scanicus is very common. Among the pretty family Bythoscopidae, we have a much better percentage of representatives. Macropsis lanio is often beaten from oak trees; Bythoscopus alni rarely met with on the banks of the Gipping and in Bentley Woods, where as elsewhere $B$. flavicollis abounds; the rare $B$. rufusculus has occurred singly in Tuddenham Fen and the Bentley Woods in 1904. Pediopsis scutellatus, $P$. tibialis, $P$. impurus, and $P$. ulmi all occur with fair frequency, and last year I discovered $P$. cereus in Tuddenham Fen and $P$. fuscinervis at Foxhall, both in August; $C$. virescens, too, has lately turned up at Tostock, Kentford, and Barham. Idiocerus adustus, $I$. populi and $I$. confusus are not infrequent upon poplars and willows; an example from Farnham appears referable to I. fulgidus; and I have also recently found here I. lituratus in Tuddenham Fen and 1 . distinguendus in Assington Thicks, which latter Mr. Tuck took at Aldeburgh ; ${ }^{8}$ I. albicans is local at Freston, Tuddenham, and Brandon, and a single I. tremulae has occurred in Bentley Woods. Agallia puncticeps and $A$. venosa both occur, the latter being widely distributed at Claydon, Southwold, and Brandon. Evacanthus interruptus, upon ragwort, and E. acuminatus are both found in the Bramford chalk pits; and Tettigonia viridis is often a pest in marshes throughout the county. We possess all the British Acocephali, the only uncommon one being $A$. flavostriatus, which Butler has turned up in Fritton Decoy and I have seen at Kessingland. Eupelix cuspidata has only been noticed on the Breck sands and Foxhall Plateau; but Doratura stylata and Paramesus nervosus, of the former of which I captured a specimen of the macropterous form at Ipswich in 1896, are common. I also beat a single Glyptocephalus proceps at Barren Heath near Ipswich in July 1904.

The Jassidae leave much to be desired; the only common Athysani being A. brevipennis, communis, sordidus, obsoletus, and obscurellus; Butler has found $A$. grisescens at Lowestoft. Twelve kinds of Deltocephalus are enumerated, of which five-D. pascuellus, coronifer, distinguendus, sabulicola, and punctum-were first taken by Butler about Lowestoft; Edwards records D. Normani from Fritton, and I have seen $D$. argus in the Westleton lamb-pits and at Foxhall, where $D$. citrinellus, ocellaris, and striatus also occur. D. Flori and $D$. pulicaris appear to be rare at Freston. ${ }^{9}$ Allygus mixtus, Limotettix antennata, and $L$. quadrinotata are common, as also probably is $L$. sulphurella, though I had not met with it till last August, when the rare $L$. aurantipes occurred to me at Foxhall and Bramford marshes. Of our six species of Thamnotettix, Tuck met with $T$. splendidula at Tostock in October I899; and I beat a couple of $\mathcal{T}$. Torneella from birch in the Bentley Woods in May and June 1902, from bushes through which I have beaten with no sign of this insect for ten consecutive years; it is rare in Britain, but has a wide range from Rannoch to the New Forest. T. attenuata first turned up, and then commonly, at Foxhall late in September 1904. Edwards has found the rare Cicadula fasciifrons at Southwold; and I have once or twice met with $C$. septemnotata, which is much rarer here than $C$. sexnotata; Gnathodes punctatus is local at Bentley Woods and Foxhall. Alebra albostriella has been observed, and, in Tuddenham Fen, in June 190I, I took three examples of an allied insect, which was common there on birch, though apparently hitherto unrecognized in Britain. Dicraneura variata is abundant and D. flavipennis common. The

Ent. Mo. Mag. 1898 , p. 60.

- Cf. Trans. Norf. Nat. Soc. 1902, p. 332.

- Since the above was written I have been so tortunate as to capture somewhat commonly Deltocephalus formosus, a species not hitherto noticed in Britain, in a marshy wood at Brandon, on the banks of the Little Ouse, which forms the north-west boundary of the county (CF. Ent. Mo. Mag. 1908, p. 59).-C. M. 


\section{A HISTORY OF SUFFOLK}

pretty green $K y$ bos smaragdulus lives not uncommonly in all our marshes ; Chlorita flavescens occurs at Southwold, where it is attracted to lamplight in July; and C. viridula is always abundant in the spring at Bentley and in Ipswich gardens. Of the slender and fragile genus Eupteryx, we have twelve kinds, all common and widely distributed except $E$. melissae from Foxhall, E. abrotani in salt marshes at Southwold, and E. signatipennis, which occurs abundantly, but solely, on Spiraea ulmaria in the Freston Woods. Only ten species of Typhlocyba have at present been noted, amongst which T. sexpunctata, ulmi, Douglasi, rosae, and quercus are common; $\mathcal{T}$. tenerrima occurs at Ipswich and Carlton Colville, gratiosa at Southwold, geometrica sparingly on alder and nitidula once only on beech at Foxhall. Zygina flammigera has been found at Wherstead, Z. parvula at Bramford and Foxhall, where also Z. scutellaris has occurred, and I have once swept the rare Z. byperici from a mass of Hypericum birsutum in the Bentley Woods in the middle of September.

\section{Psyllidar}

The difficulty of determining the Psyllina has greatly contributed to their being passed over in the field, consequently there are comparatively few records. Livia juncorum is certainly rare at Bramford and Foxhall in the autumn, though it is said to be universally abundant at the roots of rushes; on I9 August 1904 I swept the two first British specimens of $L$. limbata, in Tuddenham Fen. Psyllopsis fraxinicola is abundant on ash trees everywhere, but $P$. fraxini has only been seen at Assington and Barham. Aphalara caltbae is not rare, but A. exilis has only occurred at Foxhall once. Of the clear-winged genus Psylla, we have twelve species, few of which claim especial attention excepting to point out that many may be beaten from coniferae in the winter: thus $P$. pruni has been found in the Bentley Woods, with $P$. pineti, in March; $P$. melanoneura has been taken by Chitty at Foxhall in the same month, and $P$. buxi lives in my garden here at Monk Soham till quite late in the autumn on box-trees. $P$. visci Curtis described from specimens found at Rougham, near Bury St. Edmunds, but it has not since been reported from the county. Trioza urticae, galii, and remota are probably, like Arytaena genistae, all abundant; but $T$. crithmi has only once occurred to me, in some numbers in August in the coast salt marshes at Southwold.

\section{APHIDIDAE}

For the purpose of adding some account of the green flies of the county to this History, I began to collect them last May, and succeeded so well in their identification, with the aid of Buckton's Monograph of the British Aphides, published by the Ray Society, I876-83, that I am able to present a very representative account of them. By slavishly following this work I have been enabled to name nearly every specimen taken upon its own food-plant, and can only regret that so little interest is shown in this most interesting family in Britain, where I know of no one who pretends to any knowledge of the subject since the author's death. Except where stated the following species were taken in the garden of Monk Soham House during 1907.

The first species of the Aphidinae, and one of the most prevalent, was Siphonophora rosae, which was seen upon the young shoots of both wild and cultivated roses throughout the summer, as well as upon the leaves of adjacent Aquilegia vulgaris at the end of July. I did not look for S. granaria till the middle of August, but harvest had hardly begun, and I at once found both the imaginal forms commonly on some adventitious ears of wheat in my garden and a few females on barley in neighbouring fields. S. bieracii were very rare beneath flower-heads of Hieracium early in August, associating with a few females of Aphis rumicis. As early as I June larvae of $S$. millefolii appeared on the Hower-stalks of Chrysanthemum segetum, and in early August both winged and apterous imagines were fairly common on the stems of both that plant and Acbillea millifolium, becoming abundant by the middle of the month; it also occurs at Brandon. At the end of July I found S. pisi not very commonly on my garden peas and its larvae on Bursa bursa-pastoris; in I903 I took it near Ipswich in October. S. rubi was not observed till the first week in August, when both imaginal forms were seen on the leaves of Rubus fruticosus with Aphis urticariae. S. urticae has been scarce; I took only one apterous female, still attached to her pupal skin, on nettle early in August. The distinct $A$. avellanae also appears rare, since of this I have also found but one apterous female on Corylus avellanae in early June. Larvae, pupae, and apterous forms of S. tanaceti abounded in a dandelion in the middle of August. On Tusilago farfara numerous dead S. tussilaginis were found early in the same month; and a diligent search revealed but two winged forms. $S$. sonchi, in its apterous forms, is one of our commonest species on Centurea nigra at Monk Soham, Southwold, and Brandon. Larvae, pupae, and apterous imagines of $S$. cichorii occurred upon a plant of chicory near Easton Park on 17 August; and I saw it also at Dunwich in the middle of September. Five S. olivata were taken on Cnicus palustris in the Bentley Woods in August 1904 . 


\section{INSECTS}

The small Phorodon bumuli was abundant on the underside of hop leaves near Easton Park in August; and a protracted examination of Lamium album in my garden revealed a solitary winged $P$. galeopsidis, on the under side of the leaf, in the same month. On 7 June a score of Myzus cerasi in all their stages, though only two winged, were found on cherry; and in early August I took M. ribis rarely on Ribes rubrum. Quite suddenly on 4 August, Drepanosipbum acerina appeared commonly beneath maple leaves and those of adjacent hazel and dogwood. Apterous females, larvae, and pupae of the distinct and presumably rare Megoura viciae were found very commonly feeding upon the pods and stems of Latbyrus pratensis in a damp meadow near Easton Park on 17 August. Early in June Rhopalosiphum ribis was found in hundreds in all its stages in rolled leaves of Ribes nigrum; and it is certainly the same species that Kirby referred to nearly a century ago when he wrote: 10 'Last week I observed the top of every young shoot of the currant trees in my garden (at Barham) curled up by myriads of these insects.' $R$. nymphae was abundant on the stalks of Alisma plantago in July and Nymphaea alba in August, in the moat which surrounds my house, but among thousands of the apterous form I could detect but one winged specimen. A very few winged females and pupae only of $R$. ligustri were taken early in August on privet leaves. Exclusively winged forms of Siphocoryne pastinaceae were found on wild carrot both here and in the adjacent parish of Bedfield in August. S. xylostei is a great pest on honeysuckle over the house-windows. S. capreae occurs commonly on the leaves of willow and, like $S$. xylostei, extends throughout the summer. $S$. foeniculi has only been seen on fennel at Dunwich in the middle of September.

The genus Aphis is an extensive one, and many of its species are common. A. brassicae was forming large powdery masses on the flowers of cabbages on 9 June, and was still abundant up to the end of August; but I have seen no winged forms. About the same time I found a little cluster of four apterous $A$. crataegi on a leaf of whitethorn in Framlingham Castle moat; and A. subterranea was very common on a carrot, just below the ground, at the end of August. On whitethorn at Bedfield early in the same month $A$. edentula was not uncommon in all its forms on terminal shoots. Mallow failed to produce 1 . malvae, but it occurred abundantly beneath the flower-heads of yarrow in early August. On I June winged $A$. mali were somewhat common, with a few scattered pupal skins on the leaves of the apple trees; and on the $3^{\text {rd }}$ the apterous females and larvae were found to be abundant in their curled leaves; the whole pest had, however, quite vanished by the end of July. A. urticaria was very common on the stems of nettle early in June; and in curled leaves of Prunus spinosa, $A$. pruni was prevalent at the same time, with a proportion of one winged to every score of apterous forms. A. atriplicis occurred on the sea lavender and Aster tripolium in the salt marshes about Southwold early in September. A. bieracii was first seen very rarely on leaves of Heracleum sphondylium on 9 June, by the middle of July it was common, and at the beginning of August extremely abundant on the stems of hogweed ; it also appeared at Southwold. A single plant of the hairy willow herb, among many, produced a dozen larvae and one of both forms of the female of $A$. epilobii in the middle of August. $A$. bederae is only too common on the ivy around the house. A. rumicis is one of the commonest kinds here, and bewilderingly omnivorous; I first took the winged form singly on the young leaves of Rumex acetosa; it abounded on broad beans throughout the summer, also attacking Cnicus arvensis, Petasitis officinalis, beet, and Hieraceum. Thirteen of the very distinct larvae of $A$. papaveris were clustered togethet on a leaf of scarlet poppy on $30 \mathrm{July}$; and all the forms of $A$. pyri were abundant in curled leaves of pear early in June. Hyalopterus arundinis was so numerous on reeds in the salt-marshes about Southwold in September as to appreciably weigh down the sweep-net ; and Bucton records H. melanoceppalus from Brandon.

At the end of May, Chaitophorus aceris was very numerous beneath the leaves of maple, mingling later with Drepanosiphum. Early in August I succeeded in securing three examples of the winged form of $C$. salicivorus, among myriads of the apterous one, which were scattered all over the leaves of sallow; later $I$ also saw the species at Southwold. In the middle of August $C$. leucomelas was not uncommon in its curious blisters on aspen leaves at Monk Soham, Debenham, and Easton Park. Buckton also records Cryptosiphum artemisiae from Brandon. Callipterus betuleticola is excessively abundant on birch in Tuddenham Fen and at Mildenhall; $C$. coryli occurred commonly, though singly and sparsely, here on hazel leaves in August. It was common in Easton Park in the middle of the month, together with $C$. quercus, which I first found on oak leaves in my garden on 4 June. On 27 August 1906 C. casteneae was swept from rough heath grass in Tuddenham Fen; and this year I also found it at Brandon. Pterocallis juglandicola turned up on a walnut tree at Sibton Abbey in the middle of September; and, on the leaves of alder near Easton Park, winged $P$. alni were not rare, though only one apterous imago and but a few larvae were present in the middle of August. I have twice captured $P$. tiliae flying in July at Ipswich and Kessingland; here the winged form is solitarily abundant on the under side of lime leaves. Phyllaphis fagi was.

${ }^{10}$ Introd. 80 Entom. (7th ed.), 152. 


\section{A HISTORY OF SUFFOLK}

abundant in all stages on the leaves of both old and young beeches at the beginning of June, but soon disappeared.

Of Lachnus, the presumably rare $L$. agilis was commonly beaten from pines in the middle of August, though but three winged forms were seen. Many winged $L$. macrocephalus were beaten from spruce at Foxhall on 4 July 1904 ; and Kirby and Spence say ${ }^{11}$ that L. pini used to be common in the garden of Mr. Sheppard, who was curate of Nacton, 1804-7. I have captured winged $L$. pinicolus in the Bentley Woods in July and at Easton Broad in June; and in the middle of August beaten the apterous form abundantly in my garden here, where were no winged individuals. Three hibernating winged females of the large $L$. viminalis were found beneath willow bark by the Gipping at Ipswich during the winter of ${ }^{1894-5}$. Kirby says ${ }^{12}$ that he has taken Aphis radicum (= Trama troglodytes) in the nest of Lasius flarus-most probably in this county. Of the Schizoneurinae, Schizoneura lanigera is only too common here and at Brandon on apple bark; I have, however, seen none winged; they were still on the trees 22 October 1907. Apterous S. fuliginosa are equally abundant in downy masses, one behind the other, on the pinnules of Scots fir in August ; the earliest winged ones appeared last year on 22 October. Perhaps the ubiquitous $S$. corni, more appropriately called vagans, was the species said by Kirby to have occurred in incredible numbers in Ipswich in 1814 ; it is, at all events, often abundant there, at Wherstead, and Barren Heath, as well as at Monk Soham, Reydon, Tuddenham, Eriswell, and Brandon, first appearing on 22 August in 1907. Of the remaining small families I can at present only mention Chermes laricis, of which I found eggs, larvae, and winged females abundantly on larches at Foxhall at the end of May, and a big oviparous female here in June; and Forda formicaria, which Mr. Chitty took near Brandon in the nest of Tetramorium caespitum early in May.

\section{Aberrant Hemiptera}

Under this heading I shall notice the extremely few species of all those various families which have at different times been thought to possibly belong to this Order, because little or nothing has been ascertained respecting them in Suffolk, and they appear to have appealed very little to the collecting instincts of our entomologists. I have, for instance, very often seen Coccidae, or Scale Insects, on bushes and have passed them by on the other side; once I did send what I thought to be a Coccid to Mr. Newstead, but he returned it as the pupa of a Psyllid! Mr. Tomlin has found fluffy Coccids on bushes in the Bentley Woods, and I have no doubt Mytilaspis, Aspidiotus, and the rest of the pests are only too common with us, but I wot not of them. The only three species of the family I can refer to are the currant scale, Pulvinaria ribesiae, Sign., which I saw on my currant bushes this year, Aspidiotes crataegi on hawthorn, and a white coccid, which simply covered the bark of a tall beech in my garden last August, but its name I do not know. Only two kinds of Aleurodidae have been mentioned by Mr. Douglas, ${ }^{13}$ both taken that year by Mr. Bonnewell ; Aleurodes proletella, Linn., on celandine at Coddenham on 7 November, and $A$. brassicae, Walk., on savoys in an Ipswich garden on the $14^{\text {th }}$ of the same month; the latter species occurred in my garden at Monk Soham on 3 June and again in October 1906. Of the Mallophaga, too, those apterous parasites of birds which have no suction-tube with its circle of hooks at the base, but a biting mouth, only three kinds can be instanced, though a very great many certainly occur, since each bird is supposed to possess a peculiar one. The first appears to be Laemobothrum laticolle, Denny, who says it is found on the genus Falco; this was certainly taken, with many more of the same species, upon a hawk which a fowler had caught in his net near Ipswich in November 1900; and in October $1903 \mathrm{Mr}$. W. A. Dutt sent me apparently the same kind, found on a hobby hawk ( $F$. subbuteo) at Lowestoft. Two domestic fowl lice, Goniocotes hologaster and Menopon pallidium, have been found in my hen-house at Monk Soham. The Pediculidae raise more aversion than interest, and the only three kinds at present under notice are Pediculus capitis, Nitz; that so often found on pigs, Haematopinus suis, Leach, and the dog louse, H. piliferus, Burm. Nor can we claim any authentic Thripsidae, though abundant everywhere and in July often sweeping over the neighbourhood in myriads, entering picture-frames in such numbers as to necessitate remounting, and tickling everyone's flesh; the commonest kind here is probably Limothrips cerealium, Hal., so destructive to corn.14 A second species, Coleothrips fasciata, Linn., has been somewhat doubtfully recorded from Monk Soham by Prof. Poulton. ${ }^{15}$

In 1905 I published The Hemiptera of Suffolk, which brings the total of Heteroptera noted here up to 281 species, and the Homoptera, of the families Cicadidae and Psyllidae, to 162 species,

"Introd. to Entom. (7th ed.), $185 . \quad$ 18 Ibid. 336.

14 C. my notes in E. Anglian Daily Times, 7 Aug. 1906.

${ }^{15}$ Trans. Ent. Soc. 1906, p. 409.

${ }^{13}$ Ens. Mo. Mag. 1895, p. 68. 


\section{INSECTS}

which numbers may be taken to very fairly represent the fauna of the county, though especial attention to these groups would doubtless reveal many more; and indeed $I$ am already able to add :-

Asopus punctatus. Beaten from rose, Tuddenham $F e n$, Aug. 1905, by E. A. Elliott, F.Z.S.

Sehirus morio. Found in sand at Brandon, May and June, by A. J. Chitty, M.A., and myself

Gerris argentata. Oxiton and Barmby Broads, early Apr. 1903, by E. C. Bedwell, F.E.S

Phytocoris Reuteri. I beat one from white poplar at Brondon, in Aug. 1906

Systellonotus triguttatus. At Brandon, in Aug. 1906, by E. A. Elliote and myself

Corim venusta. Four specimens in a swamp at Bixley Decoy, Foxball, in Mar. 1897

Libornia forcipata. I swept this in an alder carr at Reydon early in June 1905

Idiocerus varius. Beaten from trees at Brandon, in the middle of Aug. 1906
Allygus modestus. One swept from marsh plants in Tuddenbam Fen, in autumn of 1906

Deltocephalus socialis. Captured at Brandon and Tuddenham Fen, in Aug. 1905

Deltocephalus formosus. A new British species, which I swept at Brandon, Aug. 1906

Limotettix stactogala. Found commonly on tamarisk at Southwold, Sept. 1907

Cicadula metria. Swept from reeds near Brandon Stanch in the early autumn of 1906

Dicraneura similis. Two specimens were swept in Tuddenham Fen, in Aug. 1905

Aphalara nervosa. One only, taken on ragwort in my garden, Monk Soham House, 1907

\section{A Summary OF THe Insects OF SUffolk, October 1907}

\begin{tabular}{|c|c|c|c|c|c|c|c|c|c|c|c|}
\hline OLEOPTERA:- & & & & Suffolk & Britain & NEURoptera :- & & & & Suffolk & Britain \\
\hline Adephaga. & . & . & . & 277 & 444 & Thysanura . & & . & . & 10 & 60 \\
\hline & . & . & & 74 & 95 & Pseudo-neuropt & tera & . & . & 40 & 111 \\
\hline Brachelytra. & . & - & & 44 & 777 & Odonata & & . & . & 20 & 42 \\
\hline Clavicornia. & . & . & & 343 & $68 I$ & Subnecromorph & rotica & & . & 32 & 56 \\
\hline Lamellicornia & . & - & . & & 90 & Trichoptera & & . & . & 62 & 174 \\
\hline $\begin{array}{l}\text { Stern } \\
\text { Mala }\end{array}$ & · & · & . & 35 & 76 & & Totar & & - & $\overline{164}$ & $\underline{443}$ \\
\hline erma & $\dot{.}$ & 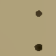 & • & $\begin{array}{l}5 \\
3\end{array}$ & $\begin{array}{l}91 \\
57\end{array}$ & & & & & & \\
\hline Long & . & . & . & $\begin{array}{l}5 \\
3\end{array}$ & $\begin{array}{l}57 \\
57\end{array}$ & LEPIDOPTERA & - . & - & - & 1,290 & c. 2,100 \\
\hline phaga & & . & - & 187 & 256 & HYMENOPTERA :- & & & & & \\
\hline Heteromera & - & - & - & 73 & 118 & Chrsyididae & & . & - & 12 & 2 I \\
\hline Rhynchophora & . & - & - & 320 & 526 & ata. & & . & • & 295 & 380 \\
\hline & Total & - & . & 1,930 & 3,268 & Evaniidae & - & . & - & 3 & \\
\hline EMIYTEI & & & & & & Ichne & & & : & 137 & $\begin{array}{r}1,688 \\
596\end{array}$ \\
\hline & - & • & & 287 & & aidae & $\cdot$ & & . & $\begin{array}{r}137 \\
74\end{array}$ & 373 \\
\hline & . & . & & 17 & & idae. & . & . & . & 36 & $1,408^{11}$ \\
\hline & . & . & . & 66 & 18 & & & . & . & 38 & $180^{18}$ \\
\hline Other Groups & - & . & $\cdot$ & 13 & c. $299^{16}$ & Tenthredinidae & . & & . & 191 & c. $350^{19}$ \\
\hline & Total & - & - & 537 & 1,233 & & Total & & . & $1,24 I$ & 5,004 \\
\hline RTHOPTERA . & . $\cdot$ & - . & . & 22 & 53 & Diptera . • & & - & & - 1,171 & $2,577^{20}$ \\
\hline
\end{tabular}

GRANd Total . . Suffolk, 6,355. Britain . . 14,678

${ }^{26}$ This is Dale's computation, and is probably much too low; he says, Thripsidae, 46; Coccidae, 18 (c. Newstead); Aleyrodidae, 10; Pediculidae, 14; and Philopteridae, 211.

${ }_{17}$ Walker, Haliday, and Westwood are stated to have described 1,274 by Kirchner (Cat. Hym. Europ.) ; I have found the above total to be correct by the closest scrutiny.

16 Marshall says (Ent. Ann. 1874) that he has trebled Curtis's number-56; there is no British list, and the above total is that of the species described by Cameron, 1893 .

${ }_{10}$ We cannot tell the total till Rev. F. D. Morice has completed his present work on this family (Ent. Mo. Mag. 1903 et seq.).

Excluding all the doubtfully British species in Mr. Verrall's List.-C. M 


\title{
A HISTORY OF SUFFOLK
}

\section{ARACHNIDA}

\author{
Spiders, Harvestmen, False Scorpions, and Mites.
}

No specialist, so far as I am aware, has ever worked at the Arachnida in Suffolk. Many years ago, while entomologizing in the neighbourhood of Lowestoft and of Bury St. Edmunds, I observed numbers of the commoner species of Araneidea, but at that time-1849-50-I had not seriously begun to pay special attention to this group, and unfortunately have no records of the species met with. Both the districts referred to were evidently such as would abundantly repay careful working. The following list has been drawn up almost entirely from various collections of spiders sent to me for identification between 1901 and 1904 by Mr. Claude Morley of Monk Soham, Suffolk, and collected by him during his entomological researches in different parts of the county. The list contains one hundred species of Araneidea (True Spiders), seven species of Phalangidea (Harvestmen), three species of Chernetidea (False Scorpions), and two of Acaridea (Mites). This is but a meagre representation of the British spiders (whose numbers as at present recorded amount to about 550 species). Among those now recorded for Suffolk some few are local and rare, and one ( $T$ meticus commodus) appeared to me to be undescribed at the time I received it ; but the greater number are among the species more commonly and generally distributed. Seven of the Phalangidea are represented out of twenty-four recorded British species, and only three of the twenty or so recorded British Chernetidea (False Scorpions); while of the Acaridea (Mites) only two can be named.

For further information upon the systematic arrangement, nomenclature, synonyms, and other details of the species in the subjoined list, I may refer to the following English publications :- $A$ History of the Spiders of Great Britain and Ireland, by John Blackwall (Ray Soc. 1861-4); Spiders of Dorset, with an Appendix containing short descriptions of those British species not yet found in Dorset, by the Rev. O. Pickard-Cambridge, M.A. (Dorset Nat. Hist. and Antiq. Field Club, 187981); papers on 'Spiders and other British Arachnids,' by the Rev. O. Pickard-Cambridge, M.A., \&c. (being papers supplementary to 'Spiders of Dorset' [supra cit.], Proc. of the Dorset Nat. Hist. and Antiq. Field Club, 1882-1908); List of British and Irish Spiders, by the Rev. O. Pickard-Cambridge, M.A., F.R.S., \&c., \&c., pp. I-84, and other papers therein quoted ; (Sime \& Co., Dorchester, Dorset, 1900); 'Monograph on the British Species of Phalangidea or Harvestmen,' by the Rev. O. Pickard-Cambridge, M.A., F.R.S., C.M.Z.S., \&c. (Proc. of the Dorset Nat. Hist. and Antiq. Field Club, xi, 1890); 'Monograph on the British Species of Phalangidea or Harvestmen,' by R. H. Meade, F.R.C.S. (Ann. and Mag. of Nat. Hist. June 1855); 'Monograph on the British Species of Chernetidea or False Scorpions,' by the Rev. O. Pickard-Cambridge, M.A., F.R.S., C.M.Z.S., \&c. (Proc. of the Dorset Nat. Hist. and Antiq. Field Club, xiii, 1892); 'The Genus 'Tapinocyba,' by A. Randell Jackson, M.B., M.Sc. (Trans. of the Nat. Hist. Soc. of Northumb. Dur. and Newcastle-upon-Tyne (new ser.), i, pt. 2, pl. vii, viii, 1905); The Spiders of Tynedale, by A. Randell Jackson, M.B., M.Sc., loc. cit. i, pt. 3, 1906 ; 'A Contribution to the Spider Fauna of the County of Glamorgan,' by A. Randell Jackson, M.B., M.Sc. (Cardiff Nat. Soc. Trans. vol. xxxix, 1907); 'On some rare Arachnids captured during 1906,' by A. Randell Jackson, M.B., M.Sc. (Proc. of the Chester Soc. of Nat. Sc. Lit. and Art, pt. 6, no. I, pl. I, May 1907); 'The British Spiders of the Genus Lycosa,' by Frank P. Smith (Fourn. of the Quekett Micros. Club, April 1907, pl. 1-4).

\section{ARANEIDEA (True Spiders)}

\section{DYSDERIDAE}

Segestria, Latreille.

Segestria senoculata, Linnaeus.

DysDera, Latreille.

Dysdera Cambridgii, Thorell.

Harpactrs, Templeton.

Harpactes Hombergii, Scopoli.

\section{DRASSIDAE}

Drassus, Walckenaer.

Drassus lapidosus, Walckenaer. Includes Drassus cupreus, Blackwall, which appears to be certainly a variety only of $D$. lapidosus.

Prosthesima, L. Koch. Prosthesima Petiverii, Scopoli.

- Latreillii, C. L. Koch.
DRASSIDAE (continued)

Clubrona, Latreille. Clubiona reclusa, Cambridge.

- bolosericea, De Geer. - brevipes, Blackwall.

Micaria, C. L. Koch. Micaria pulicaria, Sundevall.

Zora, C. L. Koch.

Zora maculata, Blackwall.

Anyphazna, Sundevall. Anyphaeno accentuata, Walckenaer.

Agroeca, Westring. Agroeca brumnea, Blackwall.

\section{DICTYNIDAE}

Dictrna, Sundevall.

Dictyna uncinata, Westring. 


\section{SPIDERS}

\section{DICTYNIDAE (continued)}

Lethia, Menge.

Lethic humitis, Blackwall.

Amauronius, C. L. Koch. Amaurobius similis, Blackwall.

- femestralis, Stroem.

\section{AGELENIDAE}

Arcrnonera, Latreille. Argyromeso aquatica, Latreille.

Tegenaria, Latreille.

Tegenaria parietina, Fourcroy. Local, Woodbridge.

Agruens, Walckenaer. Agelena labyrintbica, Clerck.

\section{THERIDIIDAE}

Theridion, Walckenaer.

Theridion vistatum, C. L. Koch.

- sisyphium, Clerck.

- varians, Hahn.

- bimaculatum, Linnaeus.

Pногсомма, Thorell.

Pbolcomma gibbum, Westring. Ipswich district. Local and rare.

Phrlonethis, Thorell.

Pbyllonethis lineata, Clerck.

Lithyphantes, Thorell.

Litbyphantes corollotus, Linnaeus. Between Brandon and Elveden. Local and rare.

Crustulina, Menge.

Crustuline guittate, Wider.

Laseola, Simon.

Laseola coracina, C. L. Koch. Ipswich. Local and rare.

LinXPHia, Latreille.

Linyphia montana, Clerck.

- triangularis, Clerck.

- bortensis, Sundevall.

- clasbrata, Sundevall.

Leptyphantes, Menge.

Leptyphantes Blackwallii, Kulczynski.

- ericaes, Blackwall.

Bathyphantes, Menge.

Bathyphantes concolor, Wider.

- dorsalis, Wider.

Porrномма, Simon.

Porrbomma egerio, Simon. Blakenham (H. Donisthorpe). Rare and local.

TMrTicus, Menge.

Tmeticus rufus, Wider.

- commodus, Cambridge. (The only example yet recorded of this species.)

Microneta, Menge.

Micronese vioria, Blackwall.

Goncrudivm, Menge.

Gongylidium fuscum, Blackwall.

- retusum, Westring.

- dentatum, Wider.

Erscone, Savigny.

Erigone atra, Blackwall.

Nerienz, Blackwall. (Sensu restricto.)

Neriene rubens, Blackwall.

- rubella, Blackwall.

Eмroin, F. P. Smith. (Dicyphus, Menge.)

Enidia bituberculata, Wider.

\section{THERIDIIDAE (continued)}

Diplocephalus, Bertkau

Diplocephalus fuscipes, Blackwall.

Wideria, Simon.

Wideria antica, Wider.

\section{MIMETIDAE}

Ero, C. L. Koch.

Ero thoracica, Wider.

\section{EPEIRIDAE}

Terragnatha, Latreille.

Tetragmatha extensa, Linnaeus.

- Solandrii, Scopoli.

- obtusa, L. Koch. Local

Pachygnatha, Sundevall.

Pachygnatha Degeerii, Sundevall.

- Clerckii, Sundevall.

Meta, C. L. Koch.

Meta segmentata, Clerck.

- Merianae, Scopoli

Crclosa, Menge. Cyclosa conica, Pallas.

Cercidia, Thorell.

Cercidia prominens, Westring. Bentley Woods. Local.

Epeira, Walckenaer

Epeira gibbosa, Walckenaer.

- pyramidata, Clerck. Ipswich. Local and rare.

- diademata, Clerck.

- cucurbitina, Clerck.

- triguttata, Fabricius.

- Redii, Scopoli.

- umbratica, Clerck.

- cornuta, Clerck.

\section{THOMISIDAE}

Misumena, Simon.

Misumena vatia, Clerck.

Xysricus, C. L. Koch.

Xysticus cristatus, Clerck.

- pini, Hahn.

- lanio, C L. Koch

- erraticus, Blackwall.

- ulmi, Hahn. Ipswich district. Rare and local

Oxyptila, Simon.

Oxyptila atomaria, Panzer.

- praticola, C. L. Koch.

- trux, Blackwall.

- fexa, Cambridge. Rare

Philodromus, Walckenaer.

Pbilodromus aureolus, Clerck.

- dispar, Walckenaer.

Tibellus, Simon.

Tibellus oblongus, Waickenaer. Bramford. Local

PISAURIDAE

Pisaura, Simon.

Pisaura mirabilis, Clerck.

\section{LYCOSIDAE}

DoLomedes, Latreille.

Dolomedes fimbriatus, Clerck

Pirata, Sundevall.

Pirata piraticus, Clerck.

- bygrophilus, Thorell. Local. Ipswich district.

- latitans, Blackwall. Local. Ipswich district. 


\section{A HISTORY OF SUFFOLK}

\section{LYCOSIDAE (continued)}

Trochosa, C. L. Koch.

Trochosa ruricola, De Geer.

- terricola, Thorell.

- picta, Hahn. Local. Southwold.

Tarentula, Sundevall.

Tarentula andrenivor a, Walckenaer.

Lrcosa, Latreille.

Lycosa amentata, Clerck.

- nigriceps, Thorell.

- pullata, Clerck.

- lugubris, Walckenaer.

- monticola, C. L. Koch.

\section{SALTICIDAE}

Epiblemum, Hentz.

Epiblemum scenicum, Clerck.

Heliophanus, C. L. Koch.

Heliophanus cupreus, Walckenaer.

Ballus, C. L. Koch.

Ballus depressus, Blackwall. Not common. Bentley Woods.

Arrus, Walckenaer.

Attus saltator, Simon. Tuddenham. Rare.

Hasarius, Simon.

Hasarius falcatus, Clerck.

\section{PHALANGIDEA (Harvestmen)}

\section{PHALANGIIDAE}

Lrobunum, C. L. Koch. Liobunum Blackwallii, Meade.

Phalangrum, Linnaeus. Pbalangium opilio, Linnaeus.

Platybunus, C. L. Koch. Platybunus corniger, Hermann. - triangularis, Herbst.
PHALANGIIDAE (continued)

Origorophus, C. L. Koch. Oligolophus agrestis, Meade. - tridens, C. L. Koch.

\section{NEMASTOMATIDAE}

Nemastoma, C. L. Koch. Nemastoma lugubre, O. F. Müler.

\section{CHERNETIDAEA (False Scorpions)}

Chthonius, C. L. Koch. Chthonius Rayi, L. Koch. Orisium, Leach. Obisium muscorum, Leach.
Chernes, Menge. Chernes dubius, Cambridge.

\section{ACARIDEA (Mites)}

\section{GAMASIDAE}

Sub-fam. UropodinaE

\section{GLYPHOPSIS.}

Glyphopsis coccinea, Michael.

- Bostockii, Michael. (In nest of an ant, Lasius flavus; Monk Soham.) 


\section{CRUSTACEANS}

For studying this class of animals, characteristically though not exclusively aquatic, Suffolk makes kindly provision. It includes among its natural advantages a wealth of waters helpful to this purpose. Several slow-flowing rivers at various points form lake-like expansions. Little winding brooks feed the more important streams. Watercourses wide or narrow frequently intersect the land to regulate its drainage. Ponds and wells and marshes are not wanting. In all directions aquatic plants are present to feed, to shelter, or sometimes to entrap innumerable crustacean tenants. A considerable sea-board allows the species of the North Sea to approach the eastern border of the county. Fleets of trawlers bring to its harbours a vast variety of fishes, on which a due proportion of parasitic Entomostraca are always sure to be lurking. Nevertheless, in the past the carcinology of Suffolk, in regard to several orders and tribes, has been much neglected. To this neglect the creatures themselves contribute by their prevailing love of concealment. In the fishing industry the hard necessities of business leave men little time for paying attention to the intrusive fish-lice and sea-fleas, which are practically their competitors in the same trade. For the more or less popular pursuit of shore-hunting, the coast-line of Suffolk is not wholly satisfactory. Much of it is too exposed and unindented to favour the immediate approach of shelter-loving animals. At Yarmouth the ebb and flow from the north coinciding with the flow and ebb from the south by their counteraction give to the rise and fall of the tide a very restricted range. Hence any one whose field of exploration is between tide-marks finds there but little encouragement.

The earliest notices of Crustacea observed in this county seem to be those which occur in the earliest writings of Dr. William Elford Leach, who, while quite a young man, nearly a hundred years ago won distinction for himself and for English science by his scientific treatment of this class. As will be shown in due course, he mentions from this coast four species of Malacostraca. Then followed an interval of some fifty years, during which apparently no further records were forthcoming, until a new epoch opened with Dr. G. S. Brady's important monograph on Recent British Ostracoda, published by the Linnean Society in I 868. It is rather surprising that this work did not more largely stimulate the collection of entomostracans in a district so admirably fitted to supply them in variety and abundance. It may perhaps have revealed only too clearly that to facility of collecting succeeds no little difficulty of discriminating these minute objects. Except for renewed researches by Dr. Brady himself, in company with his friend, the late David Robertson of Cumbrae, little effort was made to bring the micro-fauna of Suffolk into greater prominence. In 1875 the report of Dr. Aug. Metzger, on the invertebrates dredged by the German vessel Pommerania in the North Sea, added several malacostracans to the hitherto scanty list accredited to this county. Soon afterwards Dr. Brady, in his Monograph of the Copepoda of Great Britain, published by the Ray Society, recorded a few species of that order from Suffolk localities.

Although the Malacostraca that have to be named are comparatively few, the species are distributed over many genera, families, and orders. They are pretty equally divided between the Podophthalma or stalk-eyed section, which have pedunculate movable eyes, and the sessile-eyed Edriophthalma, in which the eyes are fixed, without stalk or articulation. To the former section belong the crab, the lobster, the crayfish, the prawn, and the shrimp, within which alliance the popular idea of this class is often strictly confined. In the other section are included the woodlouse and the sandhopper, with many other forms in endless variety, united by the firmest bonds of relationship to the shrimp and the crab. Mankind are fastidious and, as a rule, eat only those crustaceans that can waggle their eyes, whereas almost all marine animals and many birds feed on sessile-eyed species without reluctance. Among the Podophthalma the highest place is generally conceded to the Brachyura or short-tails, because in their organization the ganglionic chain is most concentrated, and because the actions of many among them are, or seem to be, in no small degree intelligent and purposeful. Between a naked savage and the well-dressed gentleman of to-day an intermediate state of civilization is represented by the Indian in his feathers and war-paint. The tribe of the Oxyrrhyncha, or crabs with sharpened beaks, behave much like the Indian. They do not indeed try to make themselves terrible in aspect, but by 


\section{A HISTORY OF SUFFOLK}

borrowed plumes and scraps of clothing they seek to efface themselves. Not only do they allow weeds and sponges and other zoophytes to grow upon their carapaces, but of their own accord carefully affix them. What thus they don, they can also at their pleasure doff. To this tribe, in the family Inachidae, belongs the species Macropodia rostrata (Linn.), which Mr. Claude Morley in 1893 observed in the Ipswich Museum, the place of capture being recorded as Southwold. Mr. Morley laments that at a later date the record of locality had been removed from most of the crustacean specimens in this museum. The nearly related species $M$. tenuirostris (Leach) is reported by Metzger ${ }^{1}$ as taken by the Pommerania in 23 fathoms depth, south-east of Yarmouth. In the same tribe Hyas araneus (Linn.), of the family Hyadidae, is recorded by Mr. Morley as brought in by Southwold fishing-boats, and it may be added that in May I907 a dead specimen was picked up on the north beach at Lowestoft. Among the characters which serve to distinguish these species one from another, it may be noted that in the genus Hyas the tail-part or pleon is divided into seven segments, a number never exceeded in any malacostracan pleon, though it is often enough apparently not attained. In Macropodia the number is only six, owing not to any real loss of a segment, but to a coalescence which has taken place between the sixth and the seventh. In this genus also the eyes have no proper orbits, but are salient and non-retractile, whereas in Hyas there is a cup-like hinder portion of the orbit into which the eye can be deflexed. Between $M$. rostrata and $M$. tenuirostris one mark of difference is that the two closely adjacent arms of the rostrum in the former are shorter, and in the latter species longer, than the peduncles of the second antennae. In both the rostrum is more slender than in Hyas. For both the generic name Stenorynchus, Lamarck, 1818, was long accepted, but Macropodia was instituted by Leach for the same species three years earlier. $M$. tenuirostris of Leach was for some time supposed to be a synonym of Inacbus longirostris (Fabricius). The latter form, however, has now been shown by Miss Rathbun to be a synonym of $M$. rostrata, so that $M$. tenuirostris takes rank as an independent species.

Less interesting to the intellect but more welcome to the palate is Cancer pagurus, Linn., the well-known representative of the Cyclometopa, or arch-fronted crabs. It belongs to the family Cancridae, and for mere purposes of recognition would not need to be described. It may, however, be noticed that technically the front of a crab is the part of the carapace between the orbits, but when we speak of cyclometopous or circular-fronted crabs, we refer to the segment of a circle including with the true front and the orbits also the two marginal spaces, which are commonly divided each into five teeth. These spaces in the great eatable crab form, in place of five dents, nine bluntish lobes. The supply of this species at Lowestoft in the spring of 1907 did not appear to be especially plentiful. Mr. Claude Morley notes that the Ipswich Museum possesses an abnormal claw of a specimen from Aldeburgh. In the same institution he observed Portunus marmoreus, Leach, brought in by Southwold fishing-boats, and Carcinus maenas (Linn.), which he speaks of as doubtless abundant. A dead specimen was noticed in 1907 at Lake Lothing, and incidentally the species is mentioned as occurring in the river at Yarmouth in 1869 . While waiting for the tide to turn, - Robertson and Brady sat down by the side of a little stream, where a great many shrimps were playing or hunting for prey under a little cascade. There was a little shore-crab, Carcinus maenas, stationed at the corner, making many a grab at the shrimps, but they eluded each and every attempt he made by bounding backwards with wonderful dexterity.'2 The genera Carcinus and Portunus both belong to the family Portunidae or swimming crabs, and agree in regard to the pleon, which in the female is fully segmented, but in the male has only five segments, the middle three in that sex being coalesced into a single piece. In Portunus the last joint of the last legs (fifth pair of peraeopods) is far more expanded than in Carcinus. Really the audacious C. maenas is so much given to walking about in the open air that a specially paddle-shaped toe for natatory purposes would be an inconvenient piece of equipment.

The Oxystomata, or sharp-mouthed crabs, owe their name not to any rostral prolongation, but to the narrowing forwards of the buccal or mouth area. From this tribe Metzger reports Ebalia cranchii, Leach, as taken in 23 fathoms, south-east of Yarmouth, and E. tumefacta (Montagu) in 23 fathoms, east-south-east of the same town. ${ }^{3}$ They belong to the family Leucosiidae, in which the afferent channels to the branchiae open at the antero-lateral angles of the endostome or buccal cavity, and the efferent channels traverse it in the middle line. The branchiae are fewer than nine in number on each side. According to Leach, Montagu's species has only three tubercles on the carapace, while his own has five. He further specifies that in Montagu's species the pleon of the male has not only the third to the fifth segments coalesced, but also the sixth and seventh, the latter two apparently being separate in $C$. cranchii. To an eye unsophisticated by

\footnotetext{
'Nordseefabrt der Pommerania (Jahresbericht comm. zur wissenschaftlichen Untersuchung der deutschen Meeres in Kiel, 1875$), 294$.

'The Naturalist of Cumbrae (1891), 256.

- Nordseefahrt der Pommerania, 293.
} 


\section{CRUSTACEANS}

study these little crabs with their legs folded up look more like small rudely-chipped bits of stone than animals high in the scale of organic life.

Passing from the true crabs to the 'hermits,' which are only crabs by courtesy, we have among the Macrura anomala, in the family Paguridae, the familiar Eupagurus bernhardus (Linn.). Mr. Morley reports this as represented in the Ipswich Museum, and adds his own opinion that it is 'doubtless abundant.' From the same division Metzger reports, in the family Galatheidae the species Galathed squamifera, Leach, and G. intermedia, Lilljeborg, both taken south-east of Yarmouth at the depth of 23 fathoms. From the 'hermits' these little lobster-like animals are distinguished by having the pleon symmetrical. Between the two species here named there is a distinction not immediately obvious. A little examination will show that the appendages of crustaceans are sometimes branched and sometimes simple. It is not uncommon for the first joint to carry an accessory branch known as the epipod, and for the next joint to have a branch called the exopod. The Brachyura and Macrura agree in having five conspicuous pairs of limbs, spoken of as legs, or technically as peraeopods, though the diversity of functions they fulfil sometimes makes any common name for them rather inappropriate. Often the first pair are grasping organs, or chelipeds. Now, in Leach's 'scaly Galathea' the chelipeds and two following pairs of legs carry epipods, which in G. intermedia are confined to the chelipeds. To explain the name of the 'intermediate Galathea' we must notice a third species, G. strigosa (Linn.), in which none of these limbs have epipods. Thus Lilljeborg's species stands between a species with three pairs and a species without any. It would be interesting if some of our experimentalists could ascertain whether these differences are co-ordinated with any differences in the habitual life of the creatures, and whether the simplification of structure should be regarded as an advance or an inferiority.

The genuine Macrura have a familiar representative on the coast of Suffolk in the common lobster, Astacus gammarus (Linn.), of the family Nephropsidae. The neighbouring family Potamobiidae supplies the river crayfish, Potamobius pallipes (Lereboullet). According to Mr. Claude Morley, the Ipswich Museum has a specimen of it, taken from the River Gipping at Stowmarket. Mr. Cooper, sadler at Kirkby, Lowestoft, assured us that in his schooldays crayfishes were common in the River Waveney, near Yarmouth. The crayfish eats animal food, but combines with this a vegetable diet. Especially it is said to be fond of the Characeae or stone-worts which abound in the East Anglian Broads. The lime with which these plants incrust their delicate stems and leaves supplies what is needed for hardening the chitinous skeleton of the crustacean.

The tribe Caridea, embracing so many of the species popularly known as shrimps, is moderately well represented on this coast. In the family Crangonidae Crangon vulgaris, Fabricius, the common shrimp, justifies to some extent its specific name and English epithet, although there is another species also commercially prominent in this part of the world. In the same family Metzger reports Crangon trispinosus, Hailstone, and $C$. nanus, Kröyer, both from 22 fathoms, south-east of Yarmouth. ${ }^{4}$ From the same locality he records in the family Hippolytidae Hippolyte pusiola, Kröyer, at 23 fathoms, ${ }^{5}$ and Virbius fasciger, Gosse, at 16 fathoms, and in the Pandalidae Pandalus brevirostris (Rathke), at 23 fathoms. ${ }^{6}$ To this group must be added Pandalus montagui, Leach, and in the Palaemonidae Palaemonetes varians (Leach). Some of these species, however, in the progress of science during the last hundred years, have undergone various changes of nomenclature, owing to successive discoveries as to their structure and true systematic position. The first family is distinguished from the others by the subchelate character of the first legs. They are not fully formed chelipeds. The sixth joint, or hand, is not produced into a thumb opposable longitudinally to the seventh joint or finger. The clasping effect is produced by the widened distal margin of the hand, across which the finger closes more or less obliquely. In the families Hippolytidae and Pandalidae the second legs have the fifth joint, or so-called wrist, divided into several secondary articulations, which is not the case in the Crangonidae or Palaemonidae. But whereas the Hippolytidae have the first legs clearly didactyle, in the Pandalidae these limbs are either simple or only microscopically chelate. The species cited by Metzger as Crangon trispinosus was placed by Kinahan in a new genus, Cherapbilus, to which also $C$. nanus was referred by Sars. The name Cheraphilus, being open to objection, has since been changed to Pbilocheras, ${ }^{7}$ and, Kröyer's species having been identified with Westwood's earlier Crangon bispinosus, the name should now be written Philocheras bispinosus (Westwood). In the genus Crangon the second pair of legs are subequal in length to the rest, but they are much shorter than the rest in Philocheras. Recently Dr. Calman has recalled attention to the fact that in Crangon vulgaris there are six pairs of branchiae, the arthrobranchia of the third maxilliped having sometimes been overlooked, which, he says, 'although small, is not at all difficult to see.' ${ }^{8}$ He refers to Huxley's recognition of this feature given in the Proceedings of the Zoological Society for $1878,{ }^{\circ}$ but does not notice the misleading contradiction which has there slipped into

- Loc. cit. 291.

Ibid. 286.

Ibid. $28 \mathrm{~g}$.

- South African Crustacea (1900), pt. i, p. 48.

- National Antarctic Expedition, Nat. Hist. (1907), ii, 6, 'Crustacea'

Op. cit. $7^{83}$. 


\section{A HISTORY OF SUFFOLK}

Huxley's statement. That celebrated writer says, 'In Crangon none of the maxillipedes bear gills,' but in the very next paragraph adds, 'I can find only one arthrobranchia on the ninth somite.' This ninth somite is that which carries the third maxillipeds. The respiratory arrangements of the Podophthalma admit the theoretical possibility of four pairs of branchiae to each of the three pairs of maxillipeds and the five succeeding pairs of limbs. These breathing-organs are distinguished as podobranchiae when attached to the first joint of the appendage, as front and hind arthrobranchiae when on the connecting membrane between the limb and side-plate, and as pleurobranchiae when attached to the side-plate itself. The full number is never found, and, owing to the crowding together and easily detachable nature of these organs, they are often miscounted by the careless or unwary. There are sometimes extraordinary differences between forms in many respects nearly related. Thus Pandalus montagui agrees with $P$. brevirostris in having five pairs of pleurobranchiae and one pair of podobranchiae ; but it has six pairs of arthrobranchiae, of which the latter species has only two. ${ }^{10}$

In the Hippolytidae it is now acknowledged that Virbius fasciger is synonymous with Hippolyte varians, Leach. It was only distinguishable from it, as Metzger observes, ${ }^{11}$ by the transverse dorsal tufts of plumose setae, which readily fall off. These more probably mark some stage of the individual life than any specific or even varietal difference. Hippolyte pusiola, Kröyer, has now been transferred to the very extensive genus Spirontocaris, Bate, in which the mandibles have a palp, and the second pair of legs have the wrist seven-jointed, whereas in Hippolyte this wrist is three-jointed and the mandibles are without palp.

In regard to the type species of Leach's genus Pandalus it is interesting to compare that author's own statements. In the article 'Crustaceology' of the Edinburgh Encyclopaedia, after defining the genus, he writes :- 'Sp. I Montagui. Rostrum turning upwards, with many teeth above, and the apex emarginate, with six teeth beneath; antennae ringed with white and red alternately. Pandalus Montagui, Leach, Malacos. Brit. Pandalus, Tab. A, named in honour of its first discoverer, Montagu, by whom it was called Astacus maculatus. The Rev. J. Fleming took this species in Zetland, whose successful labours in that country speak more than we can do in words., 12

But in the Malacostraca Podophthalmata Britanniae ${ }^{13}$ Leach gives the name as Pandalus annulicornis, and writes:- 'This highly interesting species was discovered in Zetland, and in St. Andrew's Bay, Scotland, by the Rev. Dr. Fleming, who most kindly gave me the specimens I originally described in the Edinburgh Encyclopaedia. It was observed also by Montagu, who found it on the coast of Devon ; and by Mrs. D. Turner it was noticed at Yarmouth, and pointed out to Mr. J. D. C. Sowerby as distinct from the common prawn. It is used at Yarmouth as an article of food, and is at that place so much esteemed for the table as to afford constant employment during the summer season to several fishermen, who take it in abundance at a considerable distance from the shore, and name it from that circumstance the sea-shrimp.'

By the common prawn is no doubt intended Leander serratus (Pennant), an early record of which in Suffolk may therefore be credited to the acute observation of Mrs. Dawson Turner. Why Leach discarded the name maculatus given by Montagu, and the name montagui given by himself, to the first species of Pandalus, must be left to conjecture. Possibly maculatus was thought inappropriate, and annulicornis especially appropriate, but according to modern ideas the name montagui found with the earliest description of the species must prevail. Leach described the first pair of feet as adactylus or fingerless, meaning that they had a simple stiliform ending. In 1899 Dr. Calman pointed out that they are in fact microscopically chelate, and at the same time instituted a new genus Pandalina for Rathke's $P$. brevirostris. This is distinguished from the preceding species by a much shorter rostrum, by a much less subdivided wrist of the second legs, as well as by the branchial formula above described. When the British Association met at Ipswich in 1 895, during an excursion, Pandalus montagui was taken abundantly in the River Stour. What diminution in the salinity of the water this 'sea-shrimp' can put up with does not appear to have been ascertained. Palaemonetes varians (Leach) makes itself at home in water that is quite fresh, as well as in the sea. It was originally placed in the genus Palaemon by Leach, who speaks of it as "common at Yarmouth,' 14 and 'very common on the Devonshire, Glamorgan, and Norfolk coasts, where it is taken as an article of food.' ${ }^{15}$ It is distinguished, by having no palp to the mandibles, from Palaemon and Leander, in which there is a three-jointed mandibular palp.

The Schizopoda, called cleft-footed because the legs have two branches, are here represented according to Metzger by Mysis inermis (Rathke) and Gastrosaccus sanctus, van Beneden, both taken at 16 fathoms depth south-east of Yarmouth. ${ }^{16}$ The family Mysidae, to which these belong, is remarkable as having no proper branchiae. M. inermis is often referred to White's genus Macromysis,

${ }^{10}$ Calman, Ann. Nat. Hist. (1 899), Ser. 7, iii, $30,37$.

"Op. cit. (1814), vii, 432 .

"Nordseefabrt Pormm. 305.

"Edinb. Encycl. vii, 432 .

3olac. Pod. Brit. (1 May 1816), text to pl. xliii, figs. 14-16.
${ }^{3}$ Mp.

${ }^{16}$ Nordseefahrt Ponm. 288, 289. 


\section{CRUSTACEANS}

1847, but that is itself a synonym of the much earlier Praunus, Leach. Metzger quotes Mysis spinifera, Goës, as a synonym of Gastrosaccus sanctus, but it is now known that these two species are distinct, G. spinifer having the concave hind margin of its carapace prettily fringed with eight sharp denticles, which are not present in the other species. From Praunus this genus is distinguished by the very great development of the side-plates in the first pleon segment. All the three species mentioned agree in having the telson apically divided. Thus they are separated from a fourth species in the same family, Siriella armata (Milne-Edwards), of which a specimen was found by Mrs. T.R.R. Stebbing, cast up among hydroids on the north beach, Lowestoft, in May 1907. This species has a very long sharply-pointed rostrum, agreeing in this respect with S. frontalis (Milne-Edwards), but separated from it by the scale of the second antennae, which in $S$. armata is distally much narrower, and by the armature of the telson, wherein the marginal spines are less unequal and the larger are separated from one another by less numerous small ones. The apical spinules are three or four in number.

The Edriophthalma or sessile-eyed Malacostracans offer a few points of interest in the fauna of Suffolk. In the order Isopoda, tribe Flabellifera, family Sphaeromidae, Mr. Claude Morley reports Sphaeroma longicauda, Leach, from brackish water, Trimley Marshes. Leach, in establishing a second species, S. hookeri, at first speaks of it as 'discovered by Mr. W. J. Hooker on the Norfolk coast,' 17 but later writes, "Habitat in Suffolciâ ad littora maris; color cinereus aut rufescens, punctulis nigris sparsus. Cum copiâ crustaceorum benignissime communicavit amicus W. J. Hooker, cujus nomen gerit.' ${ }^{18}$ It is tantalizing to think of the light which might have been thrown on the carcinology of this county by the families of Dawson Turner, James de Carle Sowerby, and William Jackson Hooker, had not their passing interest in it been diverted to other branches of natural history. As to the two species it is no longer quite certain that they ought to be retained in the genus Sphaeroma, and it is a little uncertain whether they should be specifically separated one from the other. In the same tribe the family Limnoriidae contains the widely distributed gribble, which Leach in 1814 called Limnoria terebrans. He says of it, "This new and highly interesting species was sent to Dr. Leach by Mr. Stevenson, from the Bell Rock, in logs of wood, which it perforated in the most alarming manner. He has since received it from the coast of Suffolk.' ${ }^{19}$ Kirby and Spence in their Introduction to Entomology, published in 1815, had already paid much attention to injurious insects, but without any notice of the gribble. For this, which they evidently considered a serious omission, they endeavoured to atone at great length in an Appendix issued the very next year. Therein it is stated, 'The Linnean order Aptera furnishes another timber-eating insect, a kind of woodlouse (Limnoria terebrans of Dr. Leach), which in point of rapidity of execution seems to surpass all its European brethren, and in many cases may be productive of more serious injury than any of them, since it attacks the woodwork of piers and jetties constructed in salt water, and so effectually as to threaten the rapid destruction of those in which it has established itself. In December last I was favoured by Charles Lutwidge, esq., of Hull, with specimens of wood from the piers at Bridlington Quay which woefully confirm the fears entertained of their total ruin by the hosts of these pygmy assailants, that have within a few years made good a lodgement in them, and which, though not so long as a grain of rice, ply their masticatory organs with such assiduity as to have already reduced great part of the woodwork into a state resembling honeycomb.' ${ }^{2}$ Further on the writer says, 'The inhabitants of Bridlington Quay believe that this insect was left there, a few years ago, by an American vessel, with what foundation I know not: but that it is an imported insect, and, like the Teredo navalis, not originally an European animal, seems very probable, from the fact that I can find no description of any species of Oniscus at all resembling it prior to that of Dr. Leach, who seems first to have given it a name (Linn. Trans. xi, 37 1), and it appears highly improbable that, if it had been an European species, it should not long since have attracted attention and been described.' ${ }^{21}$ It was rather late in the day for these distinguished entomologists to be treating this creature as an insect. As a matter of fact it had been described in 1799 by J. Rathke as Cymothoa lignorum, the generic name clearly indicating that it was known on the Continent to be a marine crustacean. Three kindred species from various parts of the world have since been described. How and when Limnoria lignorum was first introduced into Great Britain it might not be easy now to ascertain. It is unsafe to argue that it was not living and working among us, because no one had said anything about it till the combined efforts of Robert Stevenson and Dr. Leach made it notorious.

In the tribe Valvifera the family Astacillidae contains Astacilla longicornis (Sowerby) of which a specimen dredged off Yarmouth was given me several years ago by Dr. G. S. Brady. In the family Idoteidae Metzger reports Idotea tricuspidata, Desmarest, from Yarmouth Harbour. ${ }^{22}$ By this name is probably intended I. balthica (Pallas), which is everywhere common on our coasts.

"Edinb. Encycl, vii, 433 .

Op. cit. 17 .
13 Trans. Linn. Soc. (1815), xi, 369.

"Ibid. 19.
1" Edinb. Encyel. vii, 433.

$n$ Nordseefahrt Pomm. 285. 


\section{A HISTORY OF SUFFOLK}

I. viridis (Slabber), a much more slender species, with the pleon apically much less clearly tridendate, was sent to me by the late Dr. Sorby, F.R.S., from the mouth of the Orwell. In the tribe Asellota, family Asellidae, the universally distributed freshwater species Asellus aquaticus (Linn.) was found abundant in a wide ditch near Oulton and in Kirkley Run, Lowestoft. The tribe Epicaridea is one in which nature, like the giants piling Pelion upon Ossa, plants shrimps upon shrimps. It contains only crustaceans parasitic or semi-parasitic upon crustaceans. In Suffolk the abundant Pandalus montagui frequently harbours under its abdomen or pleon the lop-sided prolific Hemiarthrus abdominalis (H. Rathke) with her closely attached, small, symmetrical mate. This isopod is said to frequent impartially ten or eleven different species of shrimps or prawns. Metzger records it under the preoccupied name Phryxus as taken in 23 fathoms south-east of Yarmouth on Hippolyte pusiola. ${ }^{23}$ By some oversight he does not include this locality among the places of capture for the host itself, which, as already explained, is now called Spirontocaris pusiola.

In the tribe Oniscidea, Messrs. Webb and Sillem ${ }^{24}$ record only three species from Suffolk. With another three here added the total assuredly falls far short of the number which will eventually be found in the county. In the family Oniscidae the extremely common Porcellio scaber, Latreille, was taken at Sparrow's Nest Park, Lowestoft, and near Oulton Broad. The smooth $P$. laevis, Latreille, with long-branched uropods, is recorded by Mr. Webb from Ipswich. The large and common Oniscus asellus, Linn., is reported from the same place by Mr. Claude Morley, and has also been taken at Lowestoft. At the latter locality the much smaller and more shining Pbiloscia muscorum (Scopoli) was found. The straight-fronted Metoponortbus pruinosus (Brandt) has been taken at Ipswich by Mr. Webb, who further records from the same locality Armadillidium vulgare (Latreille) of the family Armadillidiidae. This so-called pill-woodlouse, which is not always so common as its specific name suggests, was taken variously coloured at Oulton Broad, and in one instance alive on the sands between tide-marks at south beach, Lowestoft.

The Amphipoda, like the Isopoda, have sessile eyes, and between the headpiece and the pleon have seven segments of the trunk articulated and uncovered by any carapace. Unlike the Isopoda they have their breathing organs, not in the pleon, but connected with the limbs of the central trunk or peraeon. In the tribe of Amphipoda Gammaridea the pleon is almost always strongly developed, its first three segments as a rule carrying each a pair of pleopods, each pleopod having two many-jointed branches, and each joint of the branches being furnished with a couple of plumose setae. To these swimming-organs succeed on the next three segments three pairs of uropods, in which the branches are stiff, not many-jointed, the terminal segment or telson being as usual without appendages. From this vast tribe Metzger reports Amatbilla sabinei (Leach), as taken in I6 fathoms south-east of Yarmouth. ${ }^{25}$ This species, which belongs to the family Gammaridae as now restricted, was named Gammarus sabini by Leach in 1819 , but it has borne several other names, earlier and later than those given by Leach, and should now be called Gammarellus bomari (Fabricius). ${ }^{26}$ By its carinate body and feebly emarginate telson it may be distinguished from the common fresh-water amphipod Gammarus pulex (Linn.), which has the body not carinate and the telson cleft. The latter occurs in Kirkley Run, as in almost all similar situations throughout the kingdom. From the Gammaridae the Talitridae are distinguished by having no palp to the mandible and by having the third uropod usually single-branched. Talitrus saltator (Montagu), the sandhopper, though not specially recorded for Suffolk, may be trusted to occur on all our sandy coasts. A much more rarely observed species, Talorchestia brito, Stebbing, proved to be plentiful at south beach Lowestoft, in May 1907. The relationships of these genera are rather intricate. The male and female of Talitrus and the female of Talorchestia have the first legs simple and the second feebly chelate. The female of the shorehopper Orchestia has the first legs subchelate and the second feebly chelate. The males of Talorchestia and Orchestia have the first legs subchelate and the second also subchelate, but in a much more powerful degree. Hence a new species in these genera cannot easily be assigned to its proper genus unless both sexes are known. In the young male of Talorchestia brito the first legs or gnathopods are still simple like those of the female, while the second gnathopods undergo various changes before reaching their final form. Corresponding changes have been described in detail for the young male of Talorchestia deshayesii (Audouin), one or two specimens of which occurred on the same beach at Lowestoft, distinguishable by their dark eyes and (when alive) by the rows of spots on the pleon. ${ }^{27}$ Of neither species were full grown males captured. The eyes of $\mathcal{T}$. brito are white, with dark pigment showing through the centre, the body colouring, purple markings on a ground of pale orange and white, making this little skipper difficult to see when it settles on the sand, after its many long and rapid leaps, first in one direction and then in another. It was first observed in North Devonshire, and has since been recorded from Gironde in France. From the family Jassidae, which are not burrowing but domicolous, Fassa

${ }^{3}$ Nordseefahrt Pomm. $285 . \quad$ The British Woodlice (1906).
${ }^{3}$ Das Tierreich, Amph. Gamm. (1906), 2 1, P. 287.

158
${ }^{25}$ Nordseefahrt Pomm. 281.

$"$ Ibid. 546. 


\section{CRUSTACEANS}

pulcbella, Leach, has been obtained by Dr. Sorby in the River Orwell. For a long time the genus Fassa of Leach was confounded with his Podocerus, established at the same time, but really belonging to a different family. ${ }^{28}$ Lastly, for the family Corophiidae a record is supplied by the Rev.E.N. Bloomfield, who, writing in August I902, says, ' in a very interesting letter from Dr. Harmer, F.R.S., of Cambridge, among various creatures met with by him in the salt water ditches near Aldborough, he mentions the very remarkable amphipod Corophium grossipes.' This species should rather be called $C$. volutator (Pallas). All round our coasts it forms its tubular galleries in the mud of tidal swamps. From $C$. crassicorne (Bruzelius), which has been taken in almost fresh water in Norfolk, $C$. volutator is separated by a rather uncommon feature of distinction, the latter species having the fourth, fifth, and sixth segments of the pleon normally articulated, while in the former they are coalesced into a single piece.

The Entomostraca form three principal groups, Branchiopoda, Ostracoda, Copepoda, each with various subdivisions. In the first only the Cladocera now need our attention. Of these the following examples may be specified. From a small pond near Oulton on I4 May 1907, a specimen of Daphnia pulex (De Geer) was taken, corresponding with the figure given by Lilljeborg of a young male taken at Upsala, not in the spring but early in September, and described as Mas junior autumnalis. 29 To the same family Daphniidae belongs Simosa vetula (O. F. Muller), of which specimens were obtained from a ditch near Oulton, 13 May 1907. These agree perfectly with Lilljeborg's account and figures of the femina adulta vernalis. ${ }^{30}$ The veteran Swedish anthor states that the female of this species, like Daphnia pulex, is largest in the spring, being about $3 \mathrm{~mm}$. long, and having then the largest number of eggs in the brood cavity, its shape broad oval, strongly narrowed in front. In this genus it may be noted that the four-jointed branch of the second or swimming antennae has one of the apical setae shorter than the other two, minutely uncinate and thereby prehensile. On the hind body $S$. vetula has two processes, the anterior standing nearly upright, the other smaller, bent forward. Behind the caudal setae the upper margin of the tail-piece runs to an angle, between which and the ungues a very sinuous border carries from nine to ten spines. The ungues are distinguished from those of other species in the genus by the microscopic fineness of their spinules. The name vetula, as given by Müller, may originally have included more than one species. As defined by Schoedler in 1858 it is now generally accepted for the form here described. A male specimen was obtained, as well as several of the other sex. In the family Chydoridae, at the same time and place with S. vetula one example of Eurycercus lamellatus (O.F.M.) was taken. This family differs from the Daphniidae by having both branches of the swimming antennae instead of only one of them three-jointed, and by having the intestine with instead of without a loop. Eurycercus agrees with the Daphniidae in that the intestine has in front two caecal appendages, which are not present in other members of the Chydoridae. E. lamellatus has the first antennae thick, with the sensory seta placed near the middle of their single joint. Lilljeborg gives the length of the female as ranging between 3 and $4 \mathrm{~mm}$, the size somewhat larger in spring and summer than in autumn, less in brackish water than in fresh. ${ }^{31}$ Under the microscope the tail-piece is a pleasing object with its fringe of 100-120 spinules. These gradually increase in size as they pass from the caudal setae to an angle which is separated from the ungues by a deep sinus. Near the ungues the sinus also carries spines and spinules. Chydorus sphaericus (O.F.M.), a tiny dwarf in comparison with the two preceding species, is abundant at Lowestoft, as it appears to be in suitable waters all over the globe. The sexual differences in this species are well marked, the rostrum of the female being acute, that of the male obtuse, and the tail of the male being strongly emarginate at the anal fissure, instead of shallowly as in the female.

For the Ostracoda of Suffolk, the paper by G. S. Brady and David Robertson, published in the Annals and Magazine of Natural History for July $1870,{ }^{32}$ is the leading authority. The authors say: 'The Entomostraca of the tidal rivers of Norfolk, Suffolk, and the Cambridge fen-district constitute so remarkable a group that it seems best to speak of them separately, and in so doing we shall call the area to which we refer the East Anglian District, understanding by that term the whole tract drained by the rivers Nene, Cam, Bure, Yare, and Waveney. The drainage tract of the adjoining rivers on the south, Ald, Deben, Stour, \&c., is separated by rising ground, and appears to be zoologically distinct.' Speaking of the Broads of Norfolk and Suffolk in general, they say that they may be considered as expansions of the various tidal rivers, though situated at such distances from the sea as to be but slightly influenced by tidal ebb and flow. As to those with which we are here more especially concerned, they write: 'Lake Lothing is a tidal expanse separated from Oulton Broad, at its western extremity, by an embankment, through which canal boats pass by means of a lock. In this way some slight communication exists between the waters of the two basins, but the true outlet of Oulton Broad is by the River Waveney, which from this point takes a circuitous

"Das Tierreich, Amph. Gamm. (1906), 21, pp. 654, 739.

Ibid. 67 , pl. xxiv, figs. 8-18. *ladocera Suecioe, pl. xii, fig. I 2. ${ }^{3}$ Op. cit. $1-33$, pls. iv $-\mathrm{x}$. 


\section{A HISTORY OF SUFFOLK}

course of about 15 miles to Breydon Water. The western end of Lake Lothing has quite a marine appearance, its stones being coated with the usual Algae of the upper littoral zone. Our gatherings are from the soft black mud of the channel beyond low-water mark. The sea was once known, on the occasion of an unusually high tide, to break over the top of the bank into Oulton Broad.' Breydon Water itself they describe as a large tidal basin about 4 miles long by a mile broad, to the west of Great Yarmouth, receiving the waters of the rivers Bure, Yare, and Waveney, and having a large proportion of its surface left dry at low water. From the Deben or the Stour, or both, they give the following species: In the family Cyprididae, Cypris pratensis, Brady and Robertson, at that date a new species, C. compressa, Baird, C. laevis, O. F. Muller, C. gibba, Ramdohr ; Cypridopsis obesa, Brady and Robertson, Candona candida (O.F.M.), C. lactea, Baird, C. albicans, Brady; in the Cytheridae, Cythere castanea, G. O. Sars, C. porcellanea, Brady, C. lutea, O.F.M., C. viridis, O.F.M., C. villosa (Sars), C. fuscata, Brady, Limnicythere inopinata (Baird), Cytheridea torosa (R. Jones), Xestoleberis aurantia (Baird), Loxoconcha impressa (Baird), L. elliptica, Brady, L. pusilla, Brady and Robertson, then new, Cytherura nigrescens (Baird), C. robertsoni, Brady, C. gibba (O.F.M.); in the Paradoxostomatidae, Paradoxostoma variabile (Baird), P. fischeri, Sars; in the family Darwinulidae, Polycheles stevensoni, Brady and Robertson, a new genus and new species. To this list must be added from Oulton Broad, Lake Lothing, or Breydon Water, and in most cases from all three, in the Cyprididae, Cypris ovum (Jurine), C. reptans (Baird), Cypridopsis aculeata (Liljeborg), C. newtoni, Brady and Robertson, a new species, Candona compressa, Koch, C. kingsleii, Brady and Robertson, a new species; in the Cytheridae, Metacypris cordata, Brady and Robertson, genus and species both new, Cythere pellucida, Baird, C. cicatricosa, Sars, C. antiquata, Baird, Limnicythere monstrifica (Norman), Cytheridea torosa, var. teres, Cytherura flavescens, Brady, C. striata, Sars; Cytheridea subulata, Brady; Sclerochilus contortus (Norman), with var. abbreviatus; Paradoxostoma abbreviatum, Sars, $P$. ensiforme, Brady. Of the species taken in the rivers above mentioned only Cythere villosa and Cytherura gibba were missing from the expanded waters. From other researches may be added Cypria ophthalmica (Jurine) and Cyclocypris serena (Koch), obtained at Lowestoft in 1907 and submitted to Dr. Brady for identification, also Cytheridea elongata, Brady, and Cytherura clathrata, Sars, recorded by Brady in 1868, as dredged off Yarmouth by Mr. D. O. Drewett. Moreover, Paradoxostoma normani, Brady, appears to have been taken by Dr. Brady in Breydon Water, though at first considered to be a variety abbreviatus of Sclerocbilus contortus. ${ }^{33}$

To deal with this long series of genera and species so as to make intelligible their numerous and important but often microscopic differences, would demand a treatise to itself. It must suffice to allot them to their proper places under the rapid advances of modern classification, and to comment on a few forms in which this county may claim exceptional interest. All the species belong to the division Podocopa, in which the little animals are without a heart, and which is distinguished in general from the other division, the Myodocopa, by having no rostral sinus to the shell-valves. The four families among which these species are distributed cannot be at once known apart by any single character. But as a rule the Cytheridae have a hard shell with uneven surface, while the shell in the other three families is thin and smooth. In the Cyprididae the second antennae usually have a brush of long plumose natatory setae, not found in the other families, and only the last two pairs of appendages are leg-like, instead of the last three as in the others. The so-called poison-gland and its duct, formed by the setiform flagellum on the basal joint of the second antennae, structures found in the Cytheridae and Paradoxostomatidae, are wanting in the Darwinulidae. The Cytheridae are mostly marine, and cannot swim. The Paradoxostomatidae are distinguished by their slender, stiliform mandibles, adapted for piercing instead of biting.

Cypris pratensis, according to Sars, should be called Cyprinotus pratensis, the change of genus in part depending on the strange circumstance that species of Cypris are found to be in many places never, or hardly ever, anything but parthenogenetic, while species of Cyprois and Cyprinotus are more connubial. ${ }^{34}$ Cypris compressa, Baird, is now identified with Cypria ophthalmica (Jurine). ${ }^{35}$ C. laevis (O.F.M.) and C. ovum (Jurine), must be transferred to the synonymy of Cyclocypris laevis.

The species Cypris serena, Koch, which since its institution has borne half a dozen different names, is now to be called Cyclocypris serena. Referring to this species and C. laevis, Brady and Norman, after re-defining their genus Cyclocypris, say: 'Professor G. O. Sars was certainly quite right in removing the two preceding species into the genus $C y c l o c y p r i s . ~ O u r$ figures, pt. I, pl. xi, figs. 15, 16, were not correct as regards the setae of the limbs drawn, of which we now give correct descriptions in the character of the genus. ${ }^{36}$ It should be observed that figs. $15-16$ have reference to Cyclocypris globosa (Sars), a species to which I was inclined to refer my Lowestoft specimens. These minute ostracods are tumid in shape, brown in colour; the second antennae of the female

ss An. Nat. Hist. (1868), Ser. 4, iii, 372.

M Brady and Norman, Trans. Roy. Dublin Soc. (1896), Ser. 2, v, 720.

${ }^{26}$ Ibid. (1889), Ser. 2, iv, 69. $\quad$ Ibid. (1896), v. ?18, 7 19. 


\section{CRUSTACEANS}

have ungues of great length, not exceeded by the natatory setae of the antepenultimate joint, but much exceeded by a solitary seta issuing apparently from the proximal part of that joint. This striking feature does not appear to have been recorded by our authorities. Dr. Brady, having kindly examined a specimen, writes: 'In comparing my mounted dissections of $C$. serena, I find that they agree with yours as to setose armature of antennae-one (or two) long setae and a few short ones.' On the caudal rami of these specimens the dorsal seta was not perceived, but is not necessarily absent; there is a minute seta in front of the ungues, which are strong, unequal, curved at the apex, and the dorsal margin of the rami is finely pectinate.

The large and common handsomely-coloured Erpetocypris reptans (Baird) occurs freely at Kirkley Run, Lowestoft. As to Cypris gibba, Ramdohr, it is thought probable that two species have been confounded under one name. These are now called Ilyocypris gibba (Ramdohr), and I. bradyi, Sars, with a reserve in favour of calling the latter I. biplicata (Koch). Whether Cypridopsis obesa should retain its generic name or be transferred to Pionocypris, and whether it should be accounted a distinct species or only a variety of $C$. or P. vidua (O.F.M.), are questions of transcendental learning. C. aculeata should, it seems, be attributed not to Lilljeborg, but to O. G. Costa, who independently and earlier chose the same specific name. To the localities for Candona candida may be added a broad ditch near Oulton. As to this species, Brady and Norman remark that the ordinary form 'occurs commonly in ponds and ditches; and the variety tumida is most common in rivers and dykes subject to tidal influence, as in the fen district of Norfolk and Suffolk., ${ }^{37}$ In this genus the second antennae are without a brush of natatory setae, and in fact the animals have no swimming power. Candona kingsleii, named in honour of the well-known novelist and naturalist, Canon Charles Kingsley, has been transferred to a new genus, Candonopsis, by the Hungarian author Vávra. ${ }^{38}$ Candona albicans is now thought not to be an independent species, but to represent the young of $C$. compressa and probably other species. ${ }^{39}$

Polycheles stevensoni, after twice lighting upon a preoccupied generic name, is now established as Darwinula stevensoni, in a distinct family Darwinulidae. Brady and Norman say, 'This is perhaps the most characteristic Entomostracan of the East Anglian Fen district, where it is widely spread, and often occurs in considerable abundance.' 40

Metacypris cordata hovered at first between the Cyprididae and Cytheridae, but is now settled in the latter family. ${ }^{41}$ For the relations between Cythere pellucida, Baird, C. castanea, auctorum, and $C$. confusa, Brady and Norman, the monograph by the two latter authors should be consulted, ${ }^{42}$ and similarly for those between $C$. lutea and C. viridis, ${ }^{43}$ C. cicatricosa is insecure; Loxoconcha elliptica is now regarded as a synonym of L. viridis (O.F.M.); Cytherura robertsoni becomes a synonym of C. gibba (O.F.M.); C. flavescens of C. sella, Sars, and C. gibba, Brady, of the same author's C. cornuta. ${ }^{4}$

Turning from this prolific branch of Suffolk carcinology to the Copepoda, which may be equally abundant, we find the records less ample. It is evident, however, that here as elsewhere the family Cyclopidae, in the tribe Cyclopidea, offers not a few species of Cyclops. This is a genus almost confined to fresh water. It is perplexing by the number and general similarity of the species. The first antennae are to a certain extent helpful by the varying number of the joints. But this character must be used with caution; for while in adults the number of joints may vary from six to eighteen according to the species, it may vary from five to eleven in juvenile stages of a single species. In Cyclops vernalis, Fischer, the highest number of joints is attained; but almost all the eighteen except the first are very short, even the two last being of very moderate length. This species, which has been taken at Lowestoft, is called $C$. elongatus by Claus, and Brady in 1891 uses that name for it. C. albidus (Jurine) has the first antennae 17 -jointed. The first, fourth, seventh, and the last three joints are longer than the rest. The terminal joint has a microscopically serrated ridge. In the second antennae the antepenultimate joint is pectinate, and the two following joints are elongate. C. fuscus (Jurine) also has 17-jointed first antennae, more slender, and without pectination of the terminal joint; the antepenultimate joint of the second antennae setulose instead of pectinate, and the penultimate joint not elongate. Both these forms occur at Lowestoft. By Brady they are united as one species under the name C. signatus, Koch. C. viridis (Jurine), also with 17 -jointed antennae, for which Brady in 1878 accepted the name C. gigas, Claus, includes both that species and Claus's $C$. brevicornis. Brady found it plentifully in the Broads of Norfolk and Suffolk. ${ }^{45}$ C. serrulatus, Fischer, has the antennae 12-jointed. Both sexes were found at Lowestoft. There also a male specimen of C. affinis, Sars, was obtained, agreeing with the figures of the anterior antennae, fifth foot, and caudal ramus given by Brady, ${ }^{46}$ and

${ }^{27}$ Brady and Norman, Trans. Roy. Dublin Soc. (1889), iv, 99.

"Ibid. iv, 101.
"Ibid. $128,185,188$.

${ }^{6}$ Monograph of Brit. Copepoda (Ray Soc.), i, 106.
${ }^{39}$ Ibid. (1896), v, 731.

"Ibid. 123.

"Ibid. 140, $185,192$.

Ibid. $126-7$.

${ }^{46}$ Ibid. pl. 24B. 


\section{A HISTORY OF SUFFOLK}

with Uljanin's figure. ${ }^{47}$ On the basal joint of the first antennae in the male there is in the Lowestoft specimen a seta widened near the base, with the border of this widened part pectinate. In this species the first antennae of the female are I I-jointed. C. fimbriatus, Fischer, which is perhaps the same as $C$. crassicornis, O.F.M., has 8-jointed first antennae. The Lowestoft specimen agrees with Uljanin's figures of the first antennae and labrum. ${ }^{48} \quad$ C. aequoreus, Fischer, with 6-jointed first antennae, is recorded by Brady from brackish pools of salt marshes, among other places at 'Manningtree (Suffolk).' 49 Manningtree itself is in Essex, but so near to Suffolk that the species mentioned is no doubt common to both counties. As to C. belleri, Brady, which that author in 1878 reported from Oulton Broad, among species with 10-jointed first antennae, in 1891 he says, 'It is perhaps more than probable that the types [now lost] represented one of the stages of development of a I 7 -jointed species, and under this impression it seems best for the present to regard the species as one of doubtful validity.' 50

In the tribe Calanidea and the family Temoridae, instituted by Sars in 1903, Eurytemora velox (Lilljeborg) is reported by Brady as occurring 'in several of the broads of Norfolk and Suffolk,' and 'in pools near the River Stour at Manningtree.' For the synonymy of this species, which involves various perplexities, the reader should consult the works of Dr. Brady and Mr. Scourfield. Both writers agree that it thrives in fresh water, and also flourishes in that which is brackish. Brady says, in brackish pools fully exposed to the rays of the sun it seems to luxuriate, often fairly swarming in such places. ${ }^{51}$

In the tribe Arpacticidea, and the family Tachidiidae, Tacbidius brevicornis (O.F.M.) is recorded by Brady from Oulton Broad and Lake Lothing, in brackish marsh-pools. ${ }^{62}$ By Norman and Scott, in The Crustacea of Devon and Cornwall (1906), this species is said to be $\mathcal{T}$. discipes, Giesbrecht. From the family Canthocampidae Canthocampus minutus (O.F.M.) has been taken at Lowestoft. It has been pointed out by Canon Norman that 'Jurine himself quotes Muller's Cyclops minutus as a synonym for his own Monoculus staphylinus,' so that the latter specific name must give way to its predecessor. ${ }^{53}$ C. palustris, Brady, was taken by that author in brackish pools by the River Stour, at Manningtree, and in Oulton Broad (Suffolk). ${ }^{54}$ The variable species Dactylopusia tisboides (Claus), referred by Sars to the family Thalestridae (Crustacea of Norway (1905), v, I 25), is reported by Brady from 'brackish pools near the River Stour, at Manningtree, Suffolk.' ${ }^{55}$ Lastly, concerning Platychelipus littoralis, Brady, in the family Nannopidae, at its institution in 1880 , the often-quoted author remarks, 'several examples of this very distinct species were noticed in a gathering from between tide-marks at Lake Lothing, Suffolk, where the water of Oulton Broad finds its way to the sea. Though the gathering was made among the fronds of Fuci the water would no doubt be brackish.' ${ }^{56}$

A hundred years ago, so far as appears, the carcinology of Suffolk was a simple blank. Its chronicles are still extremely incomplete. No mention, for instance, has been made of cirripedes, although none of our coasts are left unfrequented by species of that group. For these and an indefinite number of other crustacean families, it is assuredly not the representative creatures that are wanting, but in some cases observers, and in others the published record of observations.

${ }^{47}$ Crustacea of Turkestan, pl. xi, fig. 4 .

${ }^{49}$ Mon. Brit. Copepoda, i, I 20.

${ }^{48}$ Ibid. pl. viii, figs. 9-16.

${ }^{\text {so }}$ Tians. Nat. Hist. Soc. Nortbumb. xi, 92.

${ }^{51}$ Ibid. xi, 105; Fourn. Quekett Microsc. Club (1903), 533.

${ }^{6}$ Mon. Brit. Copepoda (1880), ii, 20.

st Mon. Brit. Copepoda, ii, 54 .

${ }_{53}$ Fourn. Quekett Microsc. Club (1903), 536.

${ }^{65}$ Ibid. 108.

${ }^{36}$ Ibid. 104. 


\section{FISHES}

The coast of Suffolk extends from Harwich to Yarmouth and includes only three estuaries of considerable size, namely the Stour, the Orwell, and the Deben. Besides these there is only one harbour of importance, that of Lowestoft. The shore consists of sand and shingle, and slopes gradually seawards to the 20-fathom line; beyond this there is a narrow depression running parallel to the coast and deepening to 25 and 27 fathoms. On the other side of the depression are the shallow grounds extending to the Dutch coast, the more northern part of which is known to the Lowestoft trawlers as the Brown Ridges. The rivers of the county are of no great size, and there is only one considerable lake, Oulton Broad near Lowestoft.

Scarcely any special accounts of the fishes of Suffolk have been published, and except at Lowestoft very little attention seems to have been paid to the ichthyology of the county. In Norfolk there have been many zealous naturalists and among them good ichthyologists, but the study of natural history has been rather neglected in the sister county. The notes in the following list are chiefly based on records contained in the 'List of Norfolk Fishes' by Dr. John Lowe, 'Transactions of the Norfolk and Norwich Naturalists' Society, 1873-4, the additions to that list in the same Transactions, vol. iii, I 884 and later volumes, and the writer's own observations made at Lowestoft and on board Lowestoft fishing boats in 1895. A few notes have been taken from Mr. Nicholas Fenwick Hele's interesting little book, Notes or Fottings about Aldeburgh, published in 1870 . The records in the Natural History of Yarmouth, by C. J. and James Paget, published in I 834, have been incorporated in Lowe's list.

Since 1902 Lowestoft has been the centre for the English portion of the International Fishery Investigations in the North Sea. The English researches have been carried out on behalf of the Government by the Marine Biological Association, which has maintained a laboratory, a scientific staff, and a research steamer at Lowestoft, and has also carried on hydrographical researches from its laboratory at Plymouth. The researches at Lowestoft have been principally applied to the trawl fishery and have consisted of investigations of the distribution, movements, and growth of the fishes which are taken by the trawl, especially of the plaice. The migrations of the fishes have been followed by the method of marking large numbers of specimens and setting them free again at different localities. These experiments have also thrown light on the rate of growth of the fish. One of the most interesting discoveries made in the course of the International Investigations is that the age of a plaice is 


\section{A HISTORY OF SUFFOLK}

indicated in the structure of its otoliths; the latter are calcareous bodies of flattened oval shape contained in the cavities of the ears, and they increase in size by the addition of new deposits on the surface. The successive layers deposited in successive years can be distinguished by differences of transparency in the deposits of different seasons, and so the number of years in the age of the fish can be ascertained. Other calcareous structures of fishes show similar annual rings, for instance the scales and the bones, but usually they are less distinct than the rings of the otoliths.

An asterisk prefixed to a name denotes a fresh-water species; two asterisks indicate occurrence in both fresh and salt water.

\section{TELEOSTEANS}

\section{ACANTHOPTERYGII}

*1. Perch. Perca fuviatilis, Linn.

Common in the rivers and in Oulton Broad.

**2. Sea Bass. Morone labrax, Linn. (Labrax lupus, Day).

Doubtless occurs occasionally off the coast and in the estuaries, but only as a summer visitor. Has been taken on the Norfolk coast.

*3. Ruff or Pope. Acerina cernua, Linn.

Not so common as in Norfolk.

4. Shade-fish. Sciaena aquila, Lacép.

A specimen over $5 \mathrm{ft}$. in length and weighing $84 \mathrm{lb}$. is recorded by Hele to have come ashore at Thorpe near Aldeburgh in August $1868 . .^{1}$ Another specimen was taken near Yarmouth in November 1 875 , as recorded by $\mathrm{Mr}$. Tregelles of Brompton in the Times of I November of that year. It was $4 \mathrm{ft} .9 \mathrm{in}$. in length and weighed $75 \mathrm{lb}$.

5. Common Sea-bream. Pagellus centrodontus, De la Roche.

Probably occurs occasionally but rarely; has been recorded for Norfolk.

\section{Gilt-head. Pagrus auratus, Linn.}

Very rare: a specimen recorded at Pakefield by $R$. Leathes in April 1829. ${ }^{2}$

\section{Scorpaena dactyloptera, De la Roche.}

A specimen $5 \frac{3}{4} \mathrm{in}$. in length taken off Yarmouth by a shrimper obtained by Mr. A. Paterson 29 April $\times 894$ is recorded in Lowe's third list under the name Sebastes norvegicus. In the fourth list this specimen is identified as Scorpaena dactyloptera, and Mr. Paterson saw a second specimen at Lowestoft in December I 895 which measured 8 in.

\footnotetext{
1 Notes and Fottings about Aldeburgh.

${ }^{2}$ Lowe, Fishes of Norf.
}

8. Red Mullet. Mullus barbatus, var. surmulletus, Linn.

Occurs occasionally. In Paget's Natural History of Yarmouth it is stated that 10,000 were sent in one week in May 1831 to the London market. Mr. Gurney believed that the red mullet of the eastern coast were plain red mullet, but this seems unlikely, and Lowe considers that the plain variety occurs but rarely; it has not been proved to occur at all.

\section{Ballan Wrasse. Labrus maculatus, Bloch.}

A young specimen about 8 in. long was taken with hook and line in the outer harbour of Lowestoft in August 1852.

\section{Cook or Cuckoo Wrasse. Labrus mixtus,} Linn.

A specimen under the name $L$. larvatus is recorded by Lowe, ${ }^{3}$ probably from Norfolk.

*11. Miller's Thumb. Cottus gobio, Linn.

Occurs in the Yare, probably also in the $\mathrm{Wa}$ veney and other rivers.

I 2. Father-lasher, Short-spined Bull-head. Cottus scorpius, Linn.

Common on the coast.

13. Long-spined Bull-head. Cottus bubalis, Euphr.

Probably occurs.

14. Grey Gurnard. Trigla gurnardus, Linn.

Common on the Lowestoft trawling grounds; numbers are landed in the trawl market. The grey gurnard in its young stages, when under $9 \mathrm{in}$. in length is of a uniform reddish colour without spots, but not so bright a red as Trigla cuculus. In its adult condition it has bright yellow spots.

$$
{ }^{3} \text { Proc. Zool. Soc. } 1859 \text {, p. } 249 .
$$




\section{FISHES}

15. Tub, Latchet, or Sapphirine Gurnard. Trigla birundo, Linn.

A considerable number are taken on the Lowestoft trawling grounds in September and October.

16. Red Gurnard or Elleck. Trigla cuculus, Linn.

Common on the trawling grounds.

17. Streaked Gurnard. Trigla lineata, Linn.

Examples not seldom brought in by trawlers at Yarmouth and Lowestoft. One landed at Lowestoft on 9 March 1896 was said to have been taken near the port."

\section{Pogge or Armed Bull-head. Agonus cata-} phractus, Linn.

Common on the Newcome Sand and along the coast.

19. Lump-sucker. Cyclopterus lumpus, Linn.

Has been taken off Yarmouth and occurs occasionally off the Suffolk coast. Hele states that an enormous specimen weighing over $15 \mathrm{lb}$. was captured at Aldeburgh in March I 868 ; its length was $22 \frac{1}{2} \mathrm{in}$., its greatest breadth $13 \frac{1}{2} \mathrm{in}$.

\section{Sea-snail. Liparis vulgaris, Flem.}

21. Montague's Sucker. Liparis montagui, Cuv.

Both these species are recorded as occurring on the Norfolk coast, and it is probable that they occur in the Suffork district, but they have not been recorded.

\section{Two-spotted Goby. Gobius ruthensparri, Euphr.}

The Gobius unipunctatus of Yarrell and the G. pusillus of Lowe, recorded for Norfolk, are considered by recent authorities as synonyms of this species. It may occur on the Suffolk coast, but as it swims among Laminaria and Zostera it may be rare, the shores of Suffolk consisting chiefly of shingle with little weed.

\section{Freckled Goby. Gobius minutus, Gmel.}

Common on the Newcome Sand and probably on other sandy ground along the coast. Taken in considerable numbers in shrimp trawls.

\section{John Dory. Zeus faber, Linn.}

Probably occurs sometimes, as it has been taken off Yarmouth (Paget). I saw none taken on the trawling grounds in September 1895 . A specimen $8 \frac{1}{4} \mathrm{lb}$. in weight, taken in drift nets with herring on 2 October 1896 , is mentioned in Lowe's fourth list.

\section{'Lowe's fourth list.}

25. Boar-fish. Capros aper, Linn.

Has been recorded as found at Harwich, and therefore may occur within the Suffolk limits occasionally. Southwell mentions a specimen found on a shrimper at Yarmouth, July I $88 \mathrm{I}$, and another dead on Yarmouth beach in May 1882 .

\section{Mackerel. Scomber scombrus, Linn.}

There is a regular fishery for mackerel off the Suffolk coast in summer, May and June, and again in autumn in September and October. There is reason to believe that they come from the English Channel and return thither in winter. In Lowe's supplementary list a quotation is given from a letter of $\mathrm{Mr}$. Massingham, harbour master of Lowestoft, to Mr. Southwell. The letter is dated 9 November 1875 and comments on the unusual fact of a large number of mackerel having been taken at that late season of the year, as they were usually only caught on that coast in May and June. It would appear from this that the presence of mackerel in autumn was previously unknown to the fishermen, or at least to the harbour master; but it is improbable that mackerel only began to visit the Suffolk coast in autumn in the year 1875 .

\section{Tunny. Thynnus thynnnus, Linn.}

In the Norwich Museum is a specimen $3 \mathrm{ft} .6$ in. long taken off the Suffolk coast, probably near Southwold. Another, $6 \mathrm{ft}$. 9 in. long, weighing $224 \mathrm{lb}$, was taken at Yarmouth in October I870. According to Paget small specimens are not infrequently taken during the mackerel fishery.

\section{Plain Bonito. Auxis rochei, Risso.}

Two taken in June 1839 off Yarmouth, and a third at the same place in 1847 .

\section{Sword-fish. Xiphias gladius, Linn.}

Specimens have been taken on the shores of Essex and Norfolk. One was captured at Lowestoft about November I 882 and another is mentioned in Lowe's fourth list on the authority of Paterson as landed at the same place in September 1897 .

\section{Ray's Bream. Brama raii, Bl. Schn.}

Two specimens recorded by Dr. Lowe from Yarmouth, one of which is in the Norwich Museum.

\section{Opah or King-fish. Lampris luna, Gmel.}

Two specimens recorded by Paget as taken at Yarmouth in 1823 and 1828 . This fish reaches a large size, specimens having been taken which measured from $4 \mathrm{ft}$. to $6 \mathrm{ft}$. in length and weighed 


\section{A HISTORY OF SUFFOLK}

upwards of I cwt. It is remarkable for its brilliant colours. It is an oceanic fish, but not probably an inhabitant of the great depths. It is frequently seen on the coast of Norway, and in Britain the greater number of specimens have been taken in the north. It evidently enters the North Sea from the north, as it has not been recorded on the English coast between Suffolk and Cornwall.

\section{Scad or Horse-mackerel. Caranx trachurus, Linn.}

Common off Lowestoft in the mackerel season, and taken in mackerel nets.

\section{Pilot-fish, Naucrates ductor, Linn.}

The only record seems to be that of $\mathrm{Mr}$. Gurney, who informed Lowe that many years before I 873 he saw a specimen which had been recently caught off the Suffolk coast.

\section{Greater Weever. Trachinus draco, Linn.}

Extremely abundant on the trawling grounds off Lowestoft (Brown Ridges). Numbers are frequently seen with red and grey gurnard in heaps in the trawl market, for sale as food.

\section{Lesser Weever. Trachinus vipera, Cuv. and Val.}

Common on the shrimping grounds, such as Newcome Sand, and also on the trawling grounds, but too small to have any market value. It is remarkable that Lowe in his Fishes of Norfolk scoffs at the 'erroneous idea,' which he says was still held by the fishermen, that a wound inflicted by the dorsal fin is poisoned. It may be true that the spines of the dorsal fin are not poisonous, but it is certain that the fish possesses a venomous sting in its opercular spine. The present writer has had painful experience of the effects of a prick from this spine, and can testify that the venom acts as an irritant to the nerves. It produced the most intense pain, extending from the wound in the thumb up to the shoulder, and lasting for about five minutes, but did not have any other effects. The wound did not become inflamed or festered, and the pain, although almost unbearable while it lasted, soon subsided completely. The involuntary experiment was made on board a Lowestoft shrimping boat, and can easily be repeated by anyone who desires further proof.

\section{Dragonet or Skulpin. Callionymus lyra, Linn.}

I saw several specimens taken in the trawl on one of the Lowestoft trawlers in September 1895. Probably the species is common on the trawling grounds, as, the fish being small and slender, many would escape through the meshes.
The male and female in this species are very different and were formerly supposed to be distinct species, the former being known from its brilliant colouring as the gemmeous dragonet and the latter as the sordid dragonet. The male is adorned with vivid blue and yellow markings and has the first dorsal fin greatly elongated. The fishes perform an elaborate process of courtship when breeding, which was very completely studied by Mr. E. W. L. Holt and described by him in the Proceedings of the Zoological Society for 1898 .

\section{Cat-fish or Wolf-fish. Anarrbichas lupus, Linn.}

Is recorded by Paget from Yarmouth and therefore probably occurs occasionally.

\section{Butterfish or Gunnel. Centronotus gunnellus, Linn.}

Recorded at Yarmouth.

\section{Viviparous Blenny. Zoarces viviparus,} Linn.

Gurney says that adult specimens are found near the beach at Lowestoft, and in the later summer months young ones about an inch in length are abundant in the upper part of the inner harbour, where they frequent the mud banks.

40. Angler, Fishing-frog, or Monk-fish. Lopbius piscatorius, Linn.

Recorded by Paget at Yarmouth. According to Lowe's fourth list quite a number were captured by the mackerel boats at Lowestoft in the autumn of 1897 , but he does not explain how a purely ground fish like this came to be captured in drift nets; it is usually taken by the trawl.

\section{ANACANTHINI}

\section{Cod. Gadus morrbua, Linn.}

Occurs but is not very abundant. It was not taken in the trawl in the voyage which I made in a Lowestoft smack, but appears occasionally in the records of the International Investigations from Lowestoft grounds.

\section{Haddock. Gadus aeglefinus, Linn.}

Considerable numbers of haddock are landed at Lowestoft, but they are chiefly obtained from the deeper water to the north. On the Brown Ridges where the depth is mostly from 10 to 15 fathoms I saw none, and they are not mentioned in the records of the International Investigations as occurring on the grounds off the Suffolk coast. 


\section{FISHES}

43. Bib or Pout. Gadus luscus, Linn.

Occurs at Lowestoft according to Mr. Gurney in Dr. Lowe's list. I did not notice it on the Brown Ridges in September I 895, but it is recorded from the deep water off Lowestoft and from other grounds in the neighbourhood, in the International Investigations.

\section{Whiting. Gadus merlangus, Linn.}

Abundant both inshore and on the trawling grounds. They are caught with hook and line from the piers of Lowestoft Harbour in autumn and large numbers are landed by the trawlers. Many small specimens are taken by the shrimpers and also by the large trawlers; in fact I did not see any over 13 in. long. The trawlers often throw overboard all the whiting caught at the beginning of a voyage and save only those taken in the last hauls, as they are of little value after being in ice for several days.

\section{Coal-fish. Gadus virens, Linn.}

Plentiful at Yarmouth according to Paget, but this probably refers only to fish landed by the trawlers, for the coal-fish belongs to more northern waters; in the records of the International Investigations it is only occasionally recorded from grounds about the Dogger.

\section{Ling. Molva vulgaris, Flem.}

At Yarmouth according to Paget; is recorded once or twice from the Lowestoft deep water (Intern. Invest.).

*7. Burbot. Lota vulgaris, Cuv.

Occurs in the Waveney.

48. Five-bearded Rockling. Motella mustela, Linn.

At Yarmouth according to Paget.

\section{PLEURONECTOIDEI}

\section{Halibut. Hippoglossus vulgaris, Flem.}

The halibut being a northern deep-water fish is not commonly taken off the Suffolk coast, but a specimen $5 \mathrm{ft}$. 4 in. long was mentioned in the Norwich papers of 15 February 1873 as taken off Yarmouth; Buckland records another, $6 \mathrm{ft}$. long weighing $161 \mathrm{lb}$, from the same place in 1867 ; a third, above $7 \mathrm{ft}$. in length and weighing over $300 \mathrm{lb}$., is recorded in the Norfolk Chronicle of 29 April 1876 as taken from the deep sea off the eastern counties.

\section{Turbot. Rhombus maximus, Linn.}

Mr. Gurney obtained a large specimen at Lowestoft which was caught in the deep channel opposite the esplanade, and he heard that two had been taken at the head of the inner harbour just below Mutford Lock. Turbot are fairly plentiful on the Lowestoft trawling grounds and of considerable size.

\section{Brill. Rhombus laevis, Linn.}

Taken with the turbot in about equal numbers on trawling grounds.

\section{Scald-fish or Scald-back. Arnoglossus laterna, Walb.}

I saw several specimens of this fish taken in the trawl on the Brown Ridges in September. I have shown that the male of this fish when mature has the anterior rays of the dorsal fin elongated. This was formerly considered to be a distinct species and named $A$. lophotes; I have not seen this form in the North Sea, it is known to live in deeper water than the young specimens.

\section{Plaice. Pleuronectes platessa, Linn.}

Abundant on the trawling grounds and forms one of the most valuable parts of the catch of the trawlers. I found that the plaice on the Brown Ridges were mature at a smaller size than those from more northern grounds such as the Dogger Bank, all over 13 in. being mature, while of the more northern plaice the limit is about 17 in. The smallest mature on the Brown Ridges are 9 in. long, while on the northern grounds none are mature under 13 in.: these figures refer to females, the males being mature at a somewhat smaller size. In this respect the Lowestoft plaice are similar to the Channel plaice studied at Plymouth. The naturalists of the International Investigations have studied by means of the rings of the otoliths the relation between age and size on different grounds, but have not yet published a full account of the relation between age and maturity. They find that on shallow grounds like those off Lowestoft, as well as on both sides of the North Sea farther to the north, plaice are much smaller at the same age than those from deep water or from the Dogger Bank. According to Dr. Garstang the lower rate of growth on shallow grounds is due to overcrowding and consequent scarcity of food, but other conditions, such as temperature, probably have an influence on the growth. The marking experiments of the International Investigations show a marked general tendency in plaice in this part of the North Sea to migrate southwards in winter and northwards in summer.

\section{Lemon Dab. Pleuronectes microcephalus, Donovan.}

This fish, called usually lemon sole by fishermen and dealers, is very scarce on the Brown Ridges where the water is shallow, but more plentiful in the deeper water off the Suffolk coast. 


\section{A HISTORY OF SUFFOLK}

55. Dab. Pleuronectes simanda, Linn.

Plentiful.

56. Flounder. Pleuronectes flesus, Linn.

Common in the estuaries at Lowestoft, Harwich, etc. and in the sea in the spring when it is spawning.

\section{Sole. Solea vulgaris, Quensel.}

Fairly plentiful on the trawling grounds. The young $I \frac{1}{2}$ in. to 3 in. long are taken in considerable numbers by shrimpers on the Newcome Sand opposite Lowestoft, together with others from $6 \mathrm{in}$. to $10 \mathrm{in}$. in length. Those taken by the large trawlers are from $8 \mathrm{in}$, to $18 \mathrm{in.}$ in length.

58. Solenette. Solea lutea, Risso.

Common on the Brown Ridges.

\section{PLECTOGNATHI}

59. Sun-fish. Orthagoriscus mola, Linn.

Three specimens are on record as taken at Yarmouth, one in Sir Thomas Browne's list written in 1662 , one in 1835 , and one in $1843 .^{\circ}$

\section{PERCESOCES}

60. Thin-lipped Grey Mullet. Mugil capito, Cuv.

At the mouth of the Orwell (Gurney).

6r. Atherine. Atherina presbyter, Jenyns.

At Lowestoft according to Gurney.

62. Larger Launce or Sand-eel. Ammodytes lanceolatus, Lesueur.

Dr. Lowe reverses the English names of these species, calling lanceolatus the lesser, tobianus the larger launce. He states that lanceolatus occurs in the Norfolk Estuary, but it probably occurs also on the Suffolk coast.

63. Lesser Launce, or Sand-eel. Ammodytes tobianus, Lesueur.

Common at Yarmouth and Lowestoft.

\section{Gar-fish. Belone vulgaris, Fleming.}

Taken regularly in small numbers by the mackerel nets off Lowestoft in October. Dr. Lowe gives some interesting notes on the occurrence of the Hemirhampbus europaeus of Yarrell, which is in all probability the young of this species. $\mathrm{He}$ observed them in the Ouse below Lynn in July 1868.

- Paget op. cit. and Zool. 1843.
65. Saury Pike, or Skipper. Scombresox saurus, Bl. Schn.

Occurs at Yarmouth according to Gurney.

\section{HEMIBRANCHII}

**66. Three-spined Stickleback. Gasterosteus aculeatus, Linn.

\section{Common.}

*67. Ten-spined Stickleback. Gasterosteus pungitius, Linn.

Probably occurs.

68. Fifteen-spined Stickleback. Gasterosteus spinachia, Linn.

Rare at Yarmouth according to Paget.

\section{LOPHOBRANCHII}

69. Broad-nosed Pipe-fish. Siphonostoma typhle, Linn.

Occurs at Yarmouth and Lowestoft.

70. Greater Pipe-fish. Syngnathus acus, Linn.

Probably common.

71. Sea-horse. Hippocampus antiquorum, Leach.

Is included in Paget's Yarmouth list, but there is no record of its having been taken on the Suffolk coast.

\section{HAPLOMI}

*72. Pike. Esox lucius, Linn.

Common in the Norfolk Broads, probably occurs in Suffolk.

\section{OSTARIOPHYSI}

*73. Carp. Cyprinus carpio, Linn. Probably occurs.

*74. Gudgeon. Gobio fuviatilis, Flem.

Common.

*95. Roach. Leuciscus rutilus, Linn. Common.

*76. Dace. Leuciscus dobula, Linn. Conimon.

*77. Rudd. Leuciscus erytbrophthalmus, Linn. Common.

*78. Minnow. Leuciscus phoxinus, Linn. Common.

*79. Tench. Tinca vulgaris, Cuv. Common. 


\section{FISHES}

*8o. Bream. Abramis brama, Linn.

Common.

*81. White Bream. Abramis blicca, Bloch. Probably occurs.

*82. Loach. Nemacbilus barbatula, Linn. Probably occurs.

\section{MALACOPTERYGII}

**83. Salmon. Salmo salar, Linn.

The salmon does not seem to occur in the Suffolk rivers, although in Sir T. Browne's time it was said to be taken in the Waveney. It is recorded that a specimen weighing $25 \mathrm{lb}$. was captured off Lowestoft in a trawl net in May 1879 , and that this was only the second instance since $18490^{\circ}$ A specimen of $13 \frac{1}{2} \mathrm{lb}$. weight is recorded in Lowe's fourth list as taken in a drawnet at Gorleston, 17 May 1898.

**84. Salmon Trout. Salmo trutta, Linn.

Lubbock states that the salmon-trout is taken in the Waveney. Considerable numbers are taken in the mackerel nets off Lowestoft in October. One which I examined in 1895 was $14 \frac{3}{4}$ in. long. Although great variation occurs in the proportions of the head, in the shape of the preoperculum, and in the number of the coecal appendages, these differences are not constant enough to distinguish permanent varieties.

*85. Trout. Salmo fario, Linn.

According to Lubbock there are no trout in the $W$ aveney and they are not mentioned as occurring in the rivers of Suffolk.

**86. Smelt. Osmerus eperlanus, Linn.

Common in all the estuaries, at Lowestoft, in the Alde, the Deben, the Orwell, and the Stour. Hele in Notes and Jottings about Aldeburgh mentions an indenture of 1608 in the town-hall of that town, agreeing that a reduced payment should be made to the Priory of Our Lady of Snape for every boat fishing for sperling in sperling time. These fish never leave the estuaries entirely, but they ascend almost to the limits of the tide to spawn, and deposit their eggs in fresh water. The ova are adhesive and attach themselves by a flexible membrane to piles and piers or other objects in the water ; but many of them become detached and move to and fro with the tide at the bottom of the channel.

\section{Anchovy. Engraulis encrasicholus, Linn.}

Paget records a specimen found on the beach at Yarmouth in 1830 , and Lowe states that they

- Colman, Land and Water, 10 May 1879. are frequently caught in the Ouse at Lynn in Norfolk. Although there are no actual records for Suffolk they probably occur in the sea off the coast in autumn, as they are abundant in the Zuyder Zee in Holland in summer and migrate southwards through the English Channel in the autumn.

\section{Herring. Clupea harengus, Linn.}

Immense shoals of herrings arrive off the coasts of Suffolk and Norfolk at the beginning of October, and from that time to the end of November a great fishery is carried on at Lowestoft and Yarmouth, in which not only hundreds of local boats take part, but large numbers of Scotch boats. The herrings spawn in November, and soon after spawning all depart again. Herrings are also on the Suffolk coast from March to July, and in all probability another spawning takes place some time within that period. No special study however has been made of these spring herrings, but there is evidence from other parts of the coast that herrings spawn at the beginning of the year as well as in autumn. There is reason to believe that the fish of the two seasons are not the same, but perfectly distinct, and that they form separate races. The autumn herrings are larger and come from the deep sea, while the spring herrings spawn nearer shore and do not migrate to so great a distance.

\section{Sprat. Clupea sprattus, Linn.}

Caught off the coast with small-meshed driftnets from the beginning of November to the middle of January. This fishery is carried on at Lowestoft, Southwold, Thorpe, and Aldeburgh, while at Harwich sprats are caught with stownets in the estuary. In Lowe's Fishes of Norfolk $\mathrm{Mr}$. Dowell is quoted as stating that though he had seen vast quantities of sprats caught, he never saw one with roe. This fact can now be explained, for it has been proved that sprats spawn at some distance from the coast in summer, and that during the sprat fishery in autumn and winter, when they are in the estuaries or near the coast, their roes, although of course present, are not developed. Ripe specimens with large roes have been obtained occasionally in the trawl, and the eggs, which are buoyant, are found in the sea from February to May or June. The young, soon after hatching, approach the shore and enter the estuaries, where they are caught as whitebait.

\section{Pilchard. Clupea pilchardus, Walb. Artedi.}

According to Paget a few specimens are taken every year in the herring-nets at Yarmouth, but usually they are rare. In some years at the end of the 18 th century, according to the same authority, these fish were abundant. They have also been recorded at Harwich. 


\section{A HISTORY OF SUFFOLK}

**91. Allis Shad. Clupea alosa, Linn.

Not abundant. According to Paget not uncommon with the herrings at Yarmouth. 'Two specimens recorded by Gurney as taken at Lowestoft in May 1840, a male of $3 \frac{1}{4} \mathrm{lb}$. and a female of $4 \frac{1}{4} \mathrm{lb}$.

\section{**92. Twaite Shad. Clupea finta, Cuv.}

Not uncommon at Yarmouth according to Paget. A specimen over $2 \mathrm{lb}$. in weight was caught with hook and line at Lowestoft in June I 867 (Lowe).

\section{APODES}

**93. Eel. Anguilla vulgaris, Turton.

Common in the rivers and estuaries. A quotation by Day in his British Fishes states that Mr. Gurney used to find sharp-nosed eels along the coast at Lowestoft, sometimes nearly a mile from the harbour mouth. These were doubtless males, in which the snout is narrower and sharper than in the females. Both sexes however may be taken in the sea, since all eels migrate to the sea in order to spawn. It has now been proved that the spawning of the eel takes place and the young are hatched in the open Atlantic to the west and south of the British Isles, in the neighbourhood of the 500 fathom line. The larvae are ribbon shaped and perfectly transparent, and were formerly known as a species of Leptocephalus under the name $L$. brevirostris. The identification of this species as the larva of the eel was made by Grassi and Calandruccio at Catania in Sicily in 1893 , and in 1905 specimens of this larva were taken in considerable numbers off the entrance to the English Channel, just beyond the 500fathom line, by the Danish naturalist Johannes Schmidt on the Danish investigation steamer Thor. The spawning eels were not obtained, but the presence of the larvae shows that the spawning takes place not far off; the larvae were not taken at the bottom, but within about 50 fathoms of the surface. Thus all the eels which live in fresh waters in England or elsewhere in north-western Europe are originally hatched in the open Atlantic and migrate thence to the rivers. Eels spawn only once in their lives; those which descend to the sea never return, but die after shedding their eggs and milt.

\section{Conger. Conger vulgaris, Cuv.}

Not uncommon at Yarmouth according to Paget. In October 1895 I saw four specimens landed at Lowestoft by a trawler which had been fishing in the deep water off the town. The larva of the Conger is Leptocephalus morrisi, which has occasionally been taken in shallow water, but there is no doubt that spawning takes place in deep water. Like the eel the conger spawns only once in its life. All the large specimens taken are females, the males never exceeding $2 \mathrm{ft}$. $6 \mathrm{in}$. in length.

\section{GANOIDS}

**95. Sturgeon. Acipenser sturio, Linn.

Dr. John Lowe mentions a specimen taken off the Suffolk coast which was $12 \mathrm{ft} .2 \mathrm{in}$. long and weighed only $156 \mathrm{lb}$. In Mr. Hele's little book on Aldeburgh he writes 'Mr. G. T. Rope of Blaxhall, Tunstall, has furnished the following interesting particulars concerning the capture of a sturgeon many years ago. The incident is well remembered by his father, now (1870) in his 90 th year. The fish was taken in the river Alde at Rendham, according to $\mathrm{Mr}$. Rope senior between the years 1836 and 1840 . The capture occurred on the property of the grandfather of the Rev. E. N. Bloomfield of Guestling Rectory near Hastings, and that gentleman in a letter to $\mathrm{Mr}$. Rope gives the following account of the event :- " There had been a flood, but the water had gone down, so that the sturgeon was left in a hole of the river and could not get away. A boy who had been sent from the Grove, Glenham, where my grandfather lived, to the farm at Rendham, saw as he supposed a pig in the river. He therefore told them at the farm what he had seen. The head man at once went with a halter to pull the pig out and so captured the sturgeon. It was a very fine one and was exhibited at Saxmundham. I think the sturgeon must have been taken some time before $1835 . "$ 


\section{CHONDROPTERYGIANS}

96. Blue Shark. Carcharias glaucus, Linn.

Mentioned by Paget as seen occasionally at Yarmouth with the herring. Mr. Gunn records a specimen $5 \mathrm{ft} .4 \mathrm{in}$. long stranded on the beach at Yarmouth in 1866, which Lowe suggests might have been a tope. Hele records the capture of a specimen at Aldeburgh, and a second stranded specimen $6 \mathrm{ft}$. long at Yarmouth is recorded in the Zoologist in 1867 .

\section{Tope. Galeus vulgaris, Flem.}

I identified a specimen taken in the trawl when I was on board a Lowestoft trawler on the Brown Ridges in 1895 . It was a female 25 in. in length.

\section{Hammerhead. Zygaena malleus, Risso.}

A specimen is on record as taken at Yarmouth in November 1829 .

99. Smooth Hound. Mustelus vulgaris, Muller \& Henle.

A specimen 12 in. long was taken during my voyage on the Brown Ridges in 1895 . I also saw a small specimen taken in the shrimp trawl on the Newcome Sand. The men calied it a Sweet William, a name given by Dale in his Antiquities of Harwich, published in 1830 , to Galeus vulgaris.

100. Rough Hound or Small-spotted Dog-fish. Scyllium canicula, Linn.

At Lowestoft according to Gurney.

I0I. Nurse Hound or Large-spotted Dog-fish. Scyllium catulus, Cuv.

At Yarmouth according to Paget.

102. Porbeagle. Lamna cornubica, Gmel.

Two specimens taken at Yarmouth (Paget). Southwell in his Notes to Sir Thomas Browne's list states that a specimen $7 \mathrm{ft}$. long was taken it Lowestoft in October 1900, in drift-nets.

I03. Thresher. Alopias vulpes, Gmel.

This species was first described by Dr. Caius in 1570 from a specimen stranded between Lowestoft and Pakefield. Southwell mentions specimens at Lowestoft on II and 29 September 1897. Another occurred at the same place in November 1898 which was $14 \mathrm{ft}$. long. It is not infrequent in the mackerel season; it preys on the mackerel and is entangled in the driftnets.

\section{Basking Shark. Selache maxima, Gmel.}

Paget states that several have been taken at Yarmouth at different times.
105. Picked Dog-fish or Spur-dog. Acanthias vulgaris, Risso.

I saw a small specimen caught in the shrimp trawl on the Newcome Sand, but none on the Brown Ridges. It is probably common at times, but being a mid-water swimmer is usually caught in the drift-nets or by hook and line.

106. Greenland Shark. Laemargus microceptalus, Bl. Schn.

Southwell records a male specimen $12 \frac{1}{2} \mathrm{ft}$. long taken off Kessingland in February $1875^{\circ}$

107. Angel-fish or Monk-fish. Rbina squatina, Linn.

A specimen was exhibited by fishermen on the beach at Lowestoft in August 1874 ( $T$. Southwell).

108. Torpedo or Electric Ray. Torpedo nobiliana, Bonap.

In Lowe's supplementary list a fine specimen of $\mathcal{T}$. vulgaris is stated to have been trawled at Lowestoft in December 1883 . It was in all probability this species.

I09. Common Skate. Raia batis, Linn.

Probably occurs in the deep water. I did not see any caught on the shallow grounds when I was at Lowestoft.

110. White Skate, Burton Skate. Raia alba, Lacép.

A fine example is mentioned by Day as taken off Yarmouth in October 1883 , the first for twenty-five years according to the Eastern Daily Press at the time.

III. Thornback Ray. Raia clavata, Linn.

Common. I saw three young specimens taken in the trawl on the Brown Ridges in 1895; they were about 12 in. in width.

112. Spotted Ray or Homelyn Ray. Raia maculata, Montagu.

Probably occurs, as it is common off Norfolk according to Lowe.

113. Sting Ray. Trygon pastinaca, Linn.

Mr. Gurney in Lowe's list mentions one weighing about 2 stone which he saw taken off Kessingland in 1856 and which had a double spine. T. E. Gunn records one from Yarmouth $3 \mathrm{ft}$. 6 in. long which weighed 4 stone.

114. Eagle Ray. Myliobatis aquila, Linn.

One found dead on Lowestoft beach in June 1867.

$$
\text { 'Zool. } 1875 .
$$




\section{A HISTORY OF SUFFOLK}

\section{CYCLOSTOMES}

**115. Sea Lamprey. Petromyzon marinus, Linn.

According to Lowe this species is abunciant in the Yare in April and May, when numbers ascend the river to breed; it probably occurs also in the Waveney, and perhaps in other Suffolk rivers.
*116. Lampern or River Lamprey. Petromyzon fuviatilis, Linn.

Occurs in Norfolk in the Ouse, and perhaps in Suffolk rivers, but is not recorded.

* I 7. Planer's Lamprey. Petromyzon branchialis, Linn.

Occurs in Norfolk according to Lowe and therefore probably in Suffolk, but not recorded. 


\section{REPTILES \\ AND BATRACHIANS}

Four species only of reptiles and five of batrachians can with certainty be enumerated for this county. Of the former all have apparently decreased in number during the last century, especially the latter half of it; three in particular, the common ringed snake, viper and slow-worm, being no longer found in many of their former haunts. The face of the country has undergone such changes through a higher system of cultivation, enclosure of wastes, drainage and other causes, that much of it has become unfitted for the requirements of these creatures. On the other hand, the shelter provided by numerous railway cuttings and embankments may, it is to be hoped, serve to retard, and perhaps prevent, the utter extermination of these and other persecuted members of the British fauna.

As regards batrachians, the natterjack (Bufo calamita) is found in several places near the coast. The Norfolk and Cambridgeshire colonies of the edible frog (Rana esculenta) do not appear to have spread into this county. A single specimen, doubtless an escaped one, was found in a garden at Felixstowe in August 1882 (see note by A. B. R. Battye, Zoologist, I 883, p. 226). Several of these frogs brought from Normandy were turned out at Blaxhall in 1882 , and a further supply, obtained from London, in 1892 ; but owing to improper packing a large number died. A few were seen and heard through the summers of 1893 and 1894 , and one, in the adjoining parish of Farnham, in 1895 , since which time none have been observed.

The palmated newt (Molge paımata) has not, as far as I am aware, been met with in this county, but as it has been found both in Norfolk and Essex it seems not unlikely that its presence may eventually be detected.

Eleven examples of the European water tortoise (Emys lutaria) were placed in a pond at Blaxhall in 1889 , but most of them soon wandered away in different directions. During the three following years specimens were from time to time found about the village, and in 1894 two were discovered in a marsh ditch about a quarter of a mile off, another in the river (Alde) at about the same distance in an opposite direction, and a third in a ditch at Iken Cliff, more than two miles off. During the years 1894 and 1895 forty-nine of these tortoises were turned into ditches and ponds at Blaxhall. A few were at the same time liberated in some water adjoining a garden at Little Glemham. 


\section{A HISTORY OF SUFFOLK}

These latter appeared regularly near the same spot for several summers in succession, but have now ceased to do so. In all cases the tortoises remained in a healthy and thriving condition, but no young ones have been seen.

\section{REPTILES}

\section{LACERTILIA}

1. Common or Viviparous Lizard. Lacerta vivipara (Jacq.)

Fairly common in some parts of the county on dry banks facing south or south-east. About the heaths of east Suffolk it used to be most abundant; but in those parts best known to the writer, where pheasants now abound, lizards have become very scarce. Over a large extent of heath land in the parishes of Blaxhall and Tunstall, much of it common ground, these little creatures were within the recollection of the writer extremely abundant, notwithstanding that kestrels were at that time much more numerous than at present, and harriers not uncommon. Since however the preservation of game has been extended to this tract of ground, and pheasants have greatly increased in number, the lizards have almost if not entirely disappeared.

As regards the western part of the county, Professor A. Newton writes, 'According to my experience the viviparous lizard was very scarce and extremely local in west Suffolk. At Elveden I knew of only one place where it was ever to be seen, and even there one could not be sure of always meeting with it.'

\section{Slow-worm. Anguis fragilis, Linn.}

This harmless and interesting little reptile is pretty generally distributed, but reports from various districts show it to te less common than it used to be. It is unfortunately looked upon by many people as a noxious and dangerous creature, and is therefore destroyed by them if possible whenever met with. In many parts of east Suffolk it is now but seldom seen. About Thetford also it is considered by Mr. W. G. Clarke to be 'rather rare.'

The increased attention paid to roads and roadside banks and hedges may perhaps partly account for the disappearance of this animal from some of its former haunts, the surface of the banks being seldom allowed to remain long undisturbed, and the hedges kept so low and narrow as to afford little or no shelter or concealment.

In Earl Soham churchyard slow-worms have been noticed by the Rev. R. Abbay to be abundant; and communications received from other parts of the county seem to de- note a particular partiality or these little reptiles for churchyards in general. In such situations they would probably have a better chance of remaining undisturbed than elsewhere, and be less exposed to persecution from men and boys.

\section{OPHIDIA}

\section{Common or Ringed Snake. Tropidonotus natrix, Linn.}

Throughout the whole county this species is much less numerous than it was thirty or forty years ago, and from many districts where it was formerly not uncommon it has now totally disappeared. It is doubtful indeed if it can anywhere be called plentiful at the present time. The much 'cleaner' system of farming now adopted, involving the abolition of the old rough banks and wide straggling hedges of former times, the drainage of swamps and enclosure and cultivation of waste corners, have long been encroaching upon and gradually restricting the former haunts of the ringed snake. In those woods and waste grounds where it still maintains a struggle for existence every man's hand is against it ; the gamekeepers destroy it as 'vermin,' and the country people generally, believing this harmless animal to be a venomous creature dangerous to mankind, consider it a meritorious action to kill every one they meet with. In the neighbourhood of Ipswich there are woods and heaths where the common snake is still occasionally seen. Mr. H. Miller of Ipswich and other observers have met with examples at Bentley, Foxhall, Raydon and Brantham. About Needham Market specimens have frequently been observed by Mr. H. Lingwood. In the Beccles district Mr. W. M. Crowfoot reports it to be still not uncommon, while about Herringfleet, a few miles further north, it appears to have become rare. Reports from the neighbourhood of Bury St. Edmunds and west Suffolk generally, mostly agree as to the increasing scarcity of snakes, though these reptiles still exist in some places. The Rev. J. G. Tuck, writing from Tostock near Bury, refers to the ringed snake as getting rare in that part of the county. About ten years ago he used to come across specimens often enough. In a later communication to the writer he mentions two snakes having been 


\section{REPTILES AND}

seen on the railway bank at Elmswell on 9 April I903. Just over the Cambridgeshire border at the 'Devil's Dyke' a large snake was observed by a friend of Mr. F. Norgate's in September 1892 .

One reason given by $\mathrm{Mr}$. Bateman ${ }^{2}$ for the greater scarcity of this species as compared with the viper, is that the eggs of the former, often deposited in manure heaps and similar situations, are very liable to injury and often prevented from hatching, while the more prolific "viper produces at one time from thirty to fifty little viperlings, all ready and able to fight their way in the world.'

For an interesting account of the curious behaviour of some sparrows and a robin in the presence of a snake, see the Zoologist for I 869 , p. I 9 I8.

\section{Common Viper or Adder. Vipera berus, Linn.}

Very much scarcer than it used to be, but still found in many parts of the county. On the irregular strip of heath land which runs more or less parallel to the coast, extending in places several miles inland, it was up to thirty or forty years ago fairly common. Here it probably subsisted principally on the lizards which then abounded on the same ground. At that time vipers were not unfrequently carried into the neighbouring farmyards, among loads of furze, brakes (bracken) and heather brought from the heath. Of

\section{BATRACHIANS}

late years Mr. H. Miller has met with examples at Nacton and Alnesbourne, as well as in woods at Bentley, Raydon and Brantham, and Mr. Hudson has until lately found this reptile common at Foxhall near the decoy. From the heath about Blaxhall, Tunstall and Iken, it has almost entirely disappeared. At Gedgrave one was lately killed by a waggoner with his whip while it was crossing the road, and was preserved by $\mathrm{Mr}$. Hudson of Ipswich. Vipers were formerly common about Blythburgh, Westleton and Dunwich, but according to various observers their numbers have greatly diminished. Indeed intelligence received from several parts of the county agrees with respect to the increasing scarcity of this reptile in comparison with former times. In very few districts does it still appear to be at all abundant. Mr. W. M. Crowfoot considers it not uncommon in the neighbourhood of Beccles, and has found the red variety in Worlingham Park. He was also told by Colonel Leathes of Herringfleet Hall, some 4 or 5 miles from Beccles, that they were a great deal too common in that parish. Mr. H. Lingwood, in a letter to the writer, states that it is frequently met with in the neighbourhood of Needham Market, also that he has known it take the water like the common snake. Mr. F. Norgate killed two vipers at Tuddenham St. Mary near Mildenhall in May 1893 , and has occasionally met with them there in previous years.

\section{BATRACHIANS}

\section{ECAUDATA}

1. Common Frog. Rana temporaria, Linn. Locally, Fresher or Freshy.

Plentiful in low and moist situations in all parts of the county. A handsome variety is sometimes met with, in which the upper parts are of 2 rich chestnut with darker spots or blotches, the under parts yellow, splashed and sprinkled with light scarlet or blood red. This occurs about Blaxhall, Farnham and the surrounding district. The writer has also seen a specimen near the river Stour at Bures, and it is probably to be found in other parts of the county.

2. Common Toad. Bufo vulgaris, Laur. Locally, Hopping-toad.

Common. Breeds abundantly in many ponds and ditches (though by no means in

1 The Vivarium, by the Rev. Gregory C. Bateman, A.K.C., P. 222. all of them) throughout the county. Great numbers both of toads and frogs are destroyed and partly devoured at the commencement of the spawning season by rats.

\section{Natterjack Toad, Bufo calamita, Laur.}

This very local species occurs in more than one part of the county, showing as elsewhere a decided partiality for the sea coast. It is found at Belton near Yarmouth, Herringfleet, St. Olaves, Southwold and Walberswick. From thence, following the coast line in a southerly direction, we come to Aldeburgh, where in August 1882 the Rev. H. A. Macpherson observed examples in warm

2 At Herrirgfleet it has been observed by Mr. H. Miller of Ipswich, as well as by Colonel Leathes, who has also seen specimens at St. Olaves. Both Mr. Miller and Mr. E. R. Cooper have met with this species at Southwold, and at Walberswick it has been noticed by Mr. Cooper and the present writer. 


\section{A HISTORY OF SUFFOLK}

sunshine quite close to the beach. ${ }^{1}$ Further south $\mathrm{Mr}$. H. Miller has noticed this species in a garden at Alderton. At Bawdsey, an adjoining village at the mouth of the river Deben, a colony of natterjacks has long been known to exist. Through the kindness of Mr. W. H. Tuck I am enabled to record an inland locality for this interesting little batrachian. At Tostock, a village situated about midway between Stowmarket and Bury St. Edmunds, there is a pond which forms one of the sources of the little river Thet. This particular pond, one among several in that neighbourhood, has long been frequented in the breeding season by natterjacks. Mr. Tuck states that they leave the water in July. These animals used to spawn annually at Coldfair Green, about 3 miles north-west of Aldeburgh. A small stream here crosses the green, connected after heavy rains with several shallow depressions in the ground, which then become pools of water; remaining in that state sometimes for many months. Here, within a stone's throw of several cottages, the natterjacks used to deposit their spawn, and at the end of April and beginning of May their loud ringing cry could be heard for a considerable distance. From some unknown cause they have now deserted this spot. On 17 June 1903 the

$$
\text { 2 Zoologist, 1882, p. } 465 \text {. }
$$

Rev. J. G. Tuck saw a half grown natterjack on Wortham Common near Diss.

\section{CAUDATA}

\section{Great Crested Newt. Molge cristata, Laur.}

Inhabits ponds in various parts of the county, particularly those upon a clay soil. It is less numerous than the common smooth newt, but the two are not unfrequently found together, the warty newt sometimes making a meal of its smaller relative.

5. Common Newt. Molge vulgaris, Linn. (Triton punctatus, Latr.)

Plentiful in many ponds and pools of stagnant water, particularly those in which the shining pondweed (Potamogeton lucens) grows, upon the under side of the leaves of which the female often deposits her eggs. The common newt is sometimes found hibernating in cellars, but more frequently under stones, logs, etc. The young after their transition from the tadpole state, instead of increasing, appear for a time to diminish considerably in bulk. It is not unusual to find hibernating on land, newts which have attained the perfect or adult stage, so extremely small as to be less than half the size of examples in the larval condition, living in the water and still retaining their branchiæ.

\section{ADDENDUM}

European Water Tortoise. Emys lutaria. Some of the water tortoises turned out at Blaxhall and Little Glemham during the years I 894 and I 895 still survive in both parishes. Three large specimens have been seen together during the spring of 1908, in a ditch at the latter place. 


\section{B I R DS}

If the list of the birds of Suffolk falls short of the Norfolk list by about thirty species, it is not because the former county has been less attractive to birds than its northern neighbour, but because Suffolk has not been so productive of resident naturalists who have made a special study of local birds. The fifty miles of Suffolk coast-line with its tidal rivers, as well as the marshes and broads of the east and the fens of the north-west, must have been literally teeming with bird-life in the eighteenth century. Latham seems to have had some knowledge of the birds of Suffolk, but it was not till I 824 that the Rev. Revett Sheppard (a Suffolk man) and the Rev. William Whitear jointly produced their Catalogue of Norfolk and Suffolk Birds, with Remarks. In I 846, when the Rev. Alfred Suckling published The History and Antiquities of the County of Suffolk, he was assisted by Mr. T. M. Spalding, who furnished him with a List of Birds rarely and occasionally met with in the County of Suffolk (vol. i. Introduction pp. xxxv.-ix.). This list contains I I 6 species, some of which are ordinary summer migrants, such as the wheatear and wryneck, both of which are accorded a place. In 1859 the late Mr. Nicholas Fenwick Hele, a Devonshire man, went into practice as a medical man at Aldeburgh, where he remained till his much-lamented death in 1892. The two editions of his Notes and Fottings about Aldeburgh, published respectively in 1870 and 1890 , contain much interesting information on the birds of the district, and his fine collection of local birds, many of them shot, and nearly all mounted by himself, is now preserved in the Ipswich Museum. In 1886 the late Dr. Churchill Babington, rector of Cockfield, published The Catalogue of the Birds of Suffolk, with an Introduction and Remarks on their Distribution, an octavo volume of nearly 300 pages, illustrated by photographs taken from mounted specimens of some of the rarest species; and in $\mathrm{I} 8 \mathrm{gI}$ the present writer furnished a list of Suffolk birds for Mr. William White's History, Gazetteer and Directory of Suffolk.

At the present time about ninety species of birds habitually breed in the county, and some few others may breed or attempt to do so from time to time, though they can hardly be considered to do so regularly. These are the Dartford warbler, white wagtail, crossbill, short-eared owl, Montagu's harrier, hobby, garganey, pochard, quail, spotted crake, oystercatcher and woodcock; and then follows a rather melancholy list of birds which are known to have formerly bred in the county, some of them in large numbers, but which do so no longer, and with the possible exception of the bearded tit there is little hope of their ever doing so again. This catalogue includes the bearded tit, raven, buzzard, pere- 


\section{A HISTORY OF SUFFOLK}

grine falcon, cormorant, spoonbill, great bustard, avocet and black-headed gull, to which perhaps may be added the Sandwich tern and the roseate tern, and there can be little doubt that in days now long gone by many other species resorted to the woods, fens and marshes of Suffolk in the nesting season. No record seems to exist of Savi's warbler, the marsh-harrier, hen-harrier, honey-buzzard, kite, bittern, grey-lag goose, crane, ruff, black-tailed godwit, curlew and black tern having bred in the county, but from what we know of their habits in other parts of England in former times, and on the continent of Europe at the present day, it seems quite reasonable to believe that such was the case.

The birds seen or obtained on Breydon Water, which for some three miles forms the boundary between Norfolk and Suffolk, may fairly be considered to belong in an equal degree to both counties, and several species have no other claim to a place in the Suffolk list than their occurrence 'on Breydon.'

In the following list, when a species is described as a 'resident' it is intended to convey the meaning that some individuals of that species may be found in the county all the year round, but not in all cases the same in winter as in summer. Two very well known birds, the songthrush and the chaffinch, may be taken as typical examples. Very few thrushes pass the winter in Suffolk, even though that season may be an exceptionally mild one, and for every one that does so we have at least a dozen pairs of breeding birds. On the contrary swarms of migratory chaffinches come to us with the bramblings in late autumn and early winter, and for every pair which breed here we have twenty or more 'foreigners' in winter. The blackbirds which come to our holly trees in December with the fieldfares and redwings are probably not the same birds which throng our fruit gardens in June; the 'plovers' eggs' so eagerly sought by schoolboys in the Easter holidays are not laid by the same lapwings which may be seen flocking in our fields in November ; and the snipe whose 'drumming' above our marshes and meadows is one of the most welcome signs of the coming of spring will be far away when the snipe-shooter goes over the same ground later in the year. It would seem in fact that most birds which breed with us leave us in the late summer or autumn and move on to the south ; their places are filled, and in the case of the sky-lark and wood-pigeon filled ten times over, by others of the same species which come to us from the north. The migration of ' resident' species can be seen by any one who passes a few days at Southwold or Aldeburgh about the middle of October, when sky-larks, starlings, rooks and jackdaws can be watched as they come in over the sea.

By a 'summer migrant' is meant a bird which comes to us in spring, remains with us some months, rearing one or perhaps two broods here, and leaving again in autumn never spends the winter in this country. Of this class we have about thirty species, of which the redbacked shrike, swift, wryneck, turtle-dove, stone-curlew, common tern and lesser tern may be mentioned as examples. 


\section{BIRDS}

A ' winter migrant' on the other hand is a bird which comes to us in autumn, remaining with us till the return of spring calls it back to its breeding haunts in more northern regions. The fieldfare, redwing, brambling, hooded crow, with the great majority of the woodcocks, are examples of this class, and having no inducement to remain long in one place, their movements are more irregular and uncertain than those of the summer migrants.

The term 'visitant' is applied to a species which comes to us on its passage from north to south, or vice versa, remaining only for a few weeks or days, perhaps but for a few hours, for the purpose of resting. Many of the waders, like the grey plover, greenshank, knot and bar-tailed godwit, come to the Suffolk coast and to Breydon Water in May on their migration to their northern breeding grounds, and make a return visit in August and September when the young birds of the year are numerous, but at mid-summer or mid-winter none are to be found. Under the heading of 'visitants' must also be included those birds the occurrence of which in the county is more or less irregular and accidental.

A good deal of bird protection has been accomplished in Suffolk both by private effort and recent legislation. Within the limits of jurisdiction of the West Suffolk County Council all species of owls, the kestrel, the kingfisher, and the great bustard (the last-named for special reasons) are now protected throughout the year, and the taking or destroying of their eggs, with those of the nightjar, heron, stonecurlew, redshank and many other species is prohibited. In east Suffolk that portion of the coast on which the terns and other birds breed is now a 'protected area,' and here, where a single raid used formerly to produce eighty or a hundred 'cobs' eggs,' protection exists not only in name but in actual fact. Breydon Water also is well looked after in the close time by the members of the Breydon Protection Society and their agents, so that spoonbills frequently come there, remain for some days, and depart in safety. The extension of the close time in Norfolk and east Suffolk from I August to I September has also been of great value in preventing the wanton destruction of the terns and black-headed gulls.

It seems desirable to add the local or colloquial names of each species so far as it has been possible to obtain them. Natural history 'object lessons' now form a part of the instruction given in village schools, and the teaching must often be given by those whose knowledge of their subject has been gained from books and illustrations rather than from actual out-door experience. The children will thus be taught to speak of the various birds by what must be admitted to be their proper names and to discard the familiar ' mavis' and 'King Harry' which have come down from generation to generation in our villages, so it seems possible that in the course of time these names may become obsolete.

In drawing up this list the second edition (1899) of Mr. Howard Saunders' Illustrated Manual of British Birds has been adopted as the guide both to the order in which the species are given, and the name 


\section{A HISTORY OF SUFFOLK}

under which each one is mentioned. Following the example of that excellent authority, the purple gallinule, the Canada goose and the Egyptian goose are excluded from the list as birds which have escaped from captivity or semi-captivity, and the 'parrot-crossbill' and 'Polish swan' are not treated as distinct species. 384 species of British birds are described in the Manual, of which 282 find a place in this list.

Space will not permit individual acknowledgment of all the valuable assistance received, but the writer's cordial thanks are due to Mr. Frank Norgate, who has most kindly read through the MS. and the proof-sheets; to the Rev. F. C. R. Jourdain and Mr. G. T. Rope for the use of their private notes; and to Mr. L. Travis for his unvaried courtesy during the last fifteen years in affording opportunities for the inspection of the birds sent to him for preservation and also in giving information of their localities.

1. Mistle-Thrush. Turdus viscivorus, Linn.

Locally, Mistler or Mistle-bird.

A resident, breeding early, and as a rule rearing only one brood in the year. It does not frequent fruit gardens in the summer, but goes away with its young into meadows and fields.

\section{Song-Thrush. Turdus musicus, Linn. Locally, Mavis.}

A resident, though, as previously stated, a thoroughly migratory species. An early breeder, sometimes having eggs in February, and nesting at least twice in the season.

\section{Redwing. Turdus iliacus, Linn.}

A typical 'winter migrant,' often found in company with the fieldfare, and, like that species, never under any circumstances remaining to breed here.

\section{Fieldfare. Turdus pilaris, Linn.}

Locally, Fulfer or Dow-Fulfer (=Dove Fieldfare,) probably from the dove colour on its back.

A winter migrant, which in hard weather abandons its 'field-faring' habits, and comes into gardens to feed on holly-berries. During a short but severe frost in February, 1902, over forty fell in one day to one gun, a slaughter only excusable from the fact that the fieldfare in good condition is an excellent bird for the table.

\section{Blackbird. Turdus merula, Linn.}

Resident and common, but a bird whose migratory habits are plainly shown by the frequent casualties with which it meets on the lanterns of lighthouses and lightships. It breeds twice or thrice in the season, the first clutch of eggs rarely exceeding four, while in
May or June five are often and six occasionally found. Varieties with more or less white in the plumage are not uncommon. The blackbird much appreciates being fed in winter, and a few apples, worthless for the table or kitchen, are a great boon to it in severe weather.

\section{Ring-Ouzel. Turdus torquatus, Linn.}

A spring and autumn visitant, probably occurring every year. One got into a net and was captured in a garden at Icklingham in the summer of Ig0I. There seems to be no satisfactory record of its nesting here, though several heaths and commons in Suffolk are well suited to its habits.

\section{Wheatear. Saxicola cenanthe (Linn.) \\ Locally, Stone-chuck.}

A typical 'summer migrant' and one of the earliest, arriving on the east coast about the last week in March. 'The sea-blue bird of March' is to be seen on rabbit-warrens, heaths and waste grounds, where it builds its nest in rabbit-burrows, rearing two broods in the year. During the last few years no less than three new species of wheatear have been added to the British bird list, of which it may be said that any one who finds himself the possessor of a rather small wheatear with a black or mottled patch under the throat has a very valuable prize, and that, if these rare visitors occur at all, the locality will probably be near the coast, and the time that of the autumn migration.

\section{Whinchat. Pratincola rubetra (Linn.)}

Locally, Furze-chuck.

A summer migrant, breeding in rough grass meadows and on furze commons throughout the county. 


\section{BIRDS}

\section{Stonechat. Pratincola rubicola (Linn.)}

Locally, Furze-chuck.

A resident, though more numerous in summer, and only nesting on furze commons. It breeds twice in the year, building a nest so well concealed in the thickest part of a furze bush that its discovery is almost impossible unless the bird is seen to go to it or suddenly flushed from it.

\section{Redstart. Ruticilla phanicurus (Linn.) \\ Locally, Fire-tail or Red-tail.}

This pretty species is well known as a summer migrant throughout the county.

II. Black Redstart. Ruticilla titys (Scopoli)

Though a regular winter migrant to some parts of England, in Suffolk this bird is a decidedly rare winter visitant, usually found near the coast. If a redstart is seen in the eastern counties after September, it is pretty certain to be one of this species.

12. Red-spotted Bluethroat. Cyanecula suecica (Linn.)

A very rare spring and autumn visitant, of which Dr. Babington mentions the occurrence of seven specimens, and no more seem to have been recorded. The bluethroat is unlikely to be found except near the coast, and in the plain plumage of the first year might easily be overlooked.

\section{Redbreast. Erithacus rubecula (Linn.)}

The title 'robin' is so often applied to this bird that it can hardly be given as a local name. Though a common resident, there are numerous records of its migrations on the east coast and elsewhere, even on the Shetland Islands. Wherever the custom of feeding birds in the winter is practised the robin is always well to the front, and often comes so late in the afternoon that his colouring cannot be seen. In April, 1903, a pair hatched off in a garden at Bury, of which the cock would take meal-worms from the hand and carry them to the young brood. An old kettle with the lid removed and placed on its side in a bush or in ivy on a wall is a favourite nesting place. Occasionally a clutch of perfectly white eggs is found, and the second nest of the robin is in Suffolk frequently selected by the cuckoo for the reception of its egg.

\section{Nightingale. Daulias luscinia (Linn.)}

About the middle of April this well known summer migrant arrives in Suffolk in large numbers, and those who know it well by sight often recognize it before it makes its presence known by its song. Its nest-of which oak leaves always form a part-and eggs are both unlike those of any other bird nesting in Great Britain, though the eggs vary a good deal. Perhaps a circle with a ten mile radius and the Norman tower at Bury for its centre would contain as many nightingales in May as any district of equal area in this country, and they indirectly enjoy the benefit of the protection of the gamekeeper, who likes his woods 'kept quiet' in the breeding time. Only one brood is reared in the season, and as soon as the young are hatched the song of the cock ceases, so when it is heard after the first week in June it is usually due to the fact that the first nest has been taken or destroyed.

\section{Whitethroat. Sylvia cinerea (Bechstein)} Locally, Hay-jack.

This lively little summer migrant is common everywhere, and its nest, usually built in what is known in Suffolk as the 'brew' of a ditch, is often disclosed by the bird darting out at the feet of any one passing by.

16. Lesser Whitethroat. Sylvia curruca (Linn.)

A much less abundant summer migrant than its larger congener, building a very small neat nest in hedges, generally two or three feet from the ground.

\section{Blackcap. Sylvia atricapilla (Linn.)}

A summer migrant whose song is only inferior to that of the nightingale. The fact of the cock being often seen on the nest has sometimes given rise to the mistaken idea that both sexes are alike, whereas the 'cap' of the hen is reddish brown.

\section{Garden-Warbler. Sylvia bortensis (Bech- stein) \\ Locally, Hay-jack.}

This summer migrant shares the above local name with the whitethroat from the dry grass used in the building of their nests. Its eggs often much resemble those of the blackcap, but the garden-warbler is a much later breeder, and the nest is larger, while the eggs never show any trace of the beautiful red tint sometimes seen in a clutch of blackcap's eggs.

\section{Dartford Warbler. Sylvia undata (Bod- daert)}

The discovery of the breeding of the Dartford warbler in Suffolk is due to the late Sir Edward Newton, whose observations are re-orded in the Birds of Norfolk (iii. $3^{87}$ ). It 


\section{A HISTORY OF SUFFOLK}

may perhaps be classed as a resident, as a few pairs probably still breed on some of the furze commons.

20. Goldcrest. Regulus cristatus, K. L. Koch Locally, Teapot, possibly from the shape of its nest.

A resident, receiving large additions in autumn. There is nothing more interesting in the autumn migration than the crossing of the wild North Sea by this 'shadow of a bird,' as Gilbert White called it. On 15 October, 1883 , fourteen were killed by striking the lantern of the Shipwash lightship, which lies about five miles south-east of Orford. Dr. Babington seems to have been very doubtful about the claim of the firecrest ( $R$. ignicapillus) to a place in the Suffolk list, and as there appear to be no further records the species is omitted here.

\section{Chiffchaff. Phylloscopus rufus (Bechstein)}

The local names of 'ground oven' and 'oven bird' are common to this species and the willow-warbler from the shape of their nests. The chiffchaff is a summer migrant, arriving in March and announcing its presence by the often repeated note from which it takes its name.

\section{Willow - Warbler. Pbylloscopus trocbilus} (Linn.)

A summer migrant, building a domed nest lined with feathers like that of the chiffchaff, but the eggs can be distinguished by their pale red markings, while those of the chiffchaff are spotted with purple or claret colour.

\section{Wood-Warbler. Phylloscopus sibilatrix} (Bechstein)

A much more uncommon summer migrant. The bird is larger and greener than either of the two species just mentioned, its nest contains no feathers, and the eggs are much more closely marked with dark red or purple.

\section{Reed-Warbler, Acrocephalus streperus (Vieillot)}

A local summer migrant, restricted to places where the reeds afford it shelter and also the requisite support for its beautiful nest. It is plentiful in the reeds which fringe and in some places completely cover the river Waveney. The very similar marsh-warbler (A. palustris), which has occurred in Norfolk, will doubtless be sooner or later identified in Suffolk, and any basket-like nest found in an osier-bed, or suspended from the stalks of the meadow-sweet, should be carefully watched with this object in view.

\section{Sedge-Warbler. Acrocephalus phragmitis}

(Bechstein)

A very common summer migrant, which seems to be especially fond of the sound of its own voice, as it may be heard before daylight and after dusk. A rare kindred species known as the aquatic warbler ( $A$. aquaticus) has been obtained in Norfolk, and 'the conspicuous buff streak down the middle of the crown of the aquatic warbler is an unfailing mark of distinction between this species and the sedge warbler' (Saunders' Manual, p. 88)

\section{Grasshopper-Warbler. Locustella nevia} (Boddaert)

A local summer migrant, much more often heard than seen, which builds a nest so well concealed in rough grass or a low bush that very few nest-hunting boys have ever seen its red-mottled eggs, or even know of the existence of the bird. The grasshopperwarbler looks very dark in colour when flushed from her nest, and as she goes off spreads her tail to its fullest extent, so that when once seen under these circumstances she can always be recognized again.

27. Hedge-Sparrow. Accentor modularis (Linn.)

Locally, Hedge-Betty.

A common resident, though many are also migratory. Its moss-built, hair-lined nest and lovely blue eggs are well known to every one. As in the case of the blackbird, five eggs are rarely found till the second nest is built.

28. Alpine Accentor. Accentor collaris (Scopoli)

This very rare visitant has never been obtained in the county, but has been twice seen by excellent observers, the first time in 1824 at Oulton by the Rev. R. Lubbock, and again in September, 1894, at Gorleston Pier by Mr. Patterson (Zoologist for 1900, p. 400)

29. Dipper. Cinclus aquaticus, Bechstein

This species, though common enough in many parts of England, is a very rare visitant to Suffolk. Dr. Babington also records the occurrence of the northern form, which has a black breast.

30. Bearded Reedling or Tit. Panurus biarmicus (Linn.)

Norfolk appears to be the only county in the British Islands in which this beautiful little bird is now (1903) a resident. It was 


\section{BIRDS}

once by no means rare in several localities, chiefly in east Suffolk, but is now only an autumn and winter visitant. Two were recorded in the Field as having been seen near Ipswich in the autumn of 1902 .

31. Long-tailed Tit. Acredula caudata (Linn.) Locally, Pudding-poke, Bum-barrel, from the shape of its nest.

A resident and an early breeder, often commencing to build its curious nest in March, when it is easily found in the bare thorn hedges.

32. Great Tit. Parus major, Linn. Locally, Black-cap.

A common resident species, which becomes very tame where it is fed in the winter, and will always go to suitable nest-boxes provided for its accommodation. It has a curious habit of covering up its eggs till the full clutch is laid, and the sitting hen will allow the lid of the box to be removed and replaced without leaving her nest. Where traps baited with cheese are set for mice in gardens great tits, blue tits and nuthatches are almost certain to be caught unless the traps are covered or sprung during the daytime. Among the early signs of spring is the note of the great tit, of which country people remark that ' $\mathrm{He}$ 's a sharpin' his saw.'

\section{Coal-Tit. Parus ater, Linn.}

A resident, not so common as the last, but very similar in its habits, except that of roosting in haystacks, which none of the other tits do.

\section{Marsh-Tit. Parus palustris, Linn.}

Also a resident, but not abundant. Its favourite nesting-place seems to be an old rotten birch or alder stump, in which it often bores for itself a neat little nesting-hole like that of a woodpecker, and builds a small nest chiefly made of down. As a rule it lays eggs marked with larger and darker spots than those of the other tits.

\section{Blue Tit. Parus ceruleus, Linn. Locally, Blue-cap, Tom-tit, Pick-cheese.}

A common resident, well known to every one, and the word 'impudent' suits it better than 'tame.' In Suffolk all the tits appear to breed but once in a year, and as the family sometimes consists of ten or a dozen they increase as rapidly as many birds which rear two broods. A nest-box with a small hole placed on a garden wall is pretty certain to attract a pair of blue tits, and they more than pay their rent by the number of caterpillars which they destroy when feeding their young.

\section{Crested Tit. Parus cristatus, Linn.}

Mr. Hele saw one in his garden at Aldeburgh in the summer of 1861 , and as he possessed a good knowledge of birds combined with excellent eyesight there can be no doubt as to the identity of the bird. A second was shot at Melton in 1873 and seen by Dr. Babington (Zoologist, I 890 , p. 2 I I )

\section{Nuthatch. Sitta casia, Wolf.}

A resident in the strict sense of the word, as there appear to be no records of its migration anywhere in England, and it does not find a place in the list of nearly 400 species seen or obtained on Heligoland. It has a singular habit, unique among British birds, of plastering up the entrance to its nesting-place with clay, leaving only a hole just large enough to allow it to pass in and out, and it also uses an unusual material for its nest, which is simply a heap of the scales of the Scotch fir. Like the great tit it will readily take advantage of a nesting box, and will also come to a window for food. No bird is more amusing to watch than a nuthatch when feeding, and no bird can take better care of itself, as even the sparrow stands in awe of the long sharp bill which can 'hack' a hole in the shell of a hazel nut. 'The name 'nuthatch' means the ' hacker of nuts,' and the bird is often miscalled a 'tree-creeper' or a 'woodpecker.'

38. Wren. Troglodytes parvulus, K. L. Koch.
Locally, Tittereen or Magareen, which may
be corruptions of Titty Wren and Maggie
Wren.
A hardy little resident, which seems able to find food even in hard winters, as it never comes to be fed. Records of its migratory movements have been received from the Corton and Shipwash light-vessels, and also from the Orford lighthouse.

\section{Tree-Creeper. Certbia familiaris, Linn. \\ Locally, Creep-tree; Dr. Babington also gives Bark-runner.}

This little bird is almost as much a resident as the nuthatch, and is fairly common throughout the county wherever trees suitable to its habits are to be found. It usually builds behind a loose piece of bark on an elm, and has often been known to use an artificial site of this kind. Two nests, both containing eggs, have been seen in places thus constructed on opposite sides of the same elm tree. The eggs of the tree-creeper much resemble those 


\section{A HISTORY OF SUFFOLK}

of the smaller tits, but the nest is quite unlike that of any other bird.

\section{Pied Wagtail. Motacilla lugubris, Tem-} minck.

Locally, Washtail or Penny-Wagtail, the latter perhaps from Penelope, like Jenny Wren.

In mild winters a few pied wagtails may remain to pass the whole year in Suffolk, but this pretty bird is practically a summer migrant. It is very fond of tennis courts and croquet grounds, where it may often be seen busily engaged in the pursuit of insects. The pied wagtail sometimes uses the old nest of another bird as the foundation of its own, and usually rears two broods in the year.

41. White Wagtail. Motacilla alba, Linn.

This bird is the continental form of the pied wagtail, and its migrations extend as far north as Iceland, where it breeds regularly. It is doubtless often seen and not recognized, and may be a regular summer migrant. On more than one occasion it has been known to interbreed in Suffolk with the pied wagtail, while at least one nest has been found of which both the parents were white wagtails. The adult bird is easily recognized by its light grey back, sharply contrasting with the glossy black of the head, but its habits, nest and sparrow-like eggs all resemble those of the more common species.

\section{Grey Wagtail. Motacilla melanope, Pallas.}

A rather rare winter visitant, never breeding in the county, though it has been known to do so in Lincolnshire. A wagtail showing any trace of yellow in its plumage which is observed in the winter is certain to belong to this species.

\section{Blue-headed Yellow Wagtail. Motacilla flava, Linn.}

A rare summer visitant, which from its habit of frequenting marshes and meadows may easily be overlooked, and if it breeds in the county the nest and eggs cannot be distinquished from those of the yellow wagtail, but the male in full plumage can be recognized by the colour of his head.

\section{Yellow Wagtail. Motacilla raii (Bona- parte)}

A summer migrant. Common enough in localities suited to its habits, where it breeds on furze commons, marshes and in rough meadows. The nest is very difficult to find, as the hen steals quietly off her eggs at the approach of an intruder, though in wet cold weather, like most birds, she sometimes sits very closely.

\section{Tree-Pipit. Anthus trivialis (Linn.)}

A common summer migrant, always nesting on the ground, and rearing two broods in the year. The nest is frequently found in hayfields and on railway banks, and the eggs, with the single exception of the guillemot's, vary more than those of any other British bird.

\section{Meadow-Pipit. Anthus pratensis (Linn.) \\ Locally, Tit-lark, a name often given also to the tree-pipit.}

The great majority of the meadow-pipits which are found in Suffolk are summer migrants, though some remain throughout the year. This species frequents furze commons rather than meadows, and its nest is usually placed on or very near the ground in a low furze bush. The eggs are much duller in tint than those of the tree pipit, and never show any of the red mottling or purple or greenish blotches so often seen in those of that species.

\section{Tawny Pipit. Anthus campestris (Linn.)}

This very rare visitant has occurred once near Lowestoft, where one was caught alive on 2 September, I 889 (Zoologist, I890, p. 57). Dr. Babington has admitted Richard's pipit (A. richardi) to his Catalogue, as' it has been shot a few times near Yarmouth, and is said to have been once seen near Hadleigh. No Suffolk specimen is known to exist, though there can be little doubt that it has visited the county, and with a view to its future recognition it may be described as the largest pipit known, in size nearly equal to a sky-lark, and possessing a long curved hind claw.

\section{Rock-Pipit. Anthus obscurus (Latham)}

A winter visitant to the coast, where it frequents salt marshes and the muddy banks of tidal rivers. It has never been known to breed in the eastern counties. Two other species of pipit are figured and described in Saunders' Manual, and any bird of this family about which there exists any doubt should be submitted to the inspection of an expert.

49. Golden Oriole. Oriolus galbula, Linn.

An occasional spring and summer visitant, more frequently found in east Suffolk than further inland. As it has more than once nested in Kent it is by no means impossible that it might also do so in other counties if the same protection were extended to it, but the brilliant yellow colouring of the cock oriole's 


\section{BIRDS}

plumage renders him liable to attract notice, and this usually results in his being shot.

\section{Great Grey Shrike. Lanius excubitor,} Linn.

A regular autumn and winter visitant, met with every year, and a bird likely to attract notice from its colouring. The northern form known as Pallas's grey shrike, which has more white on the wings, also occurs.

$$
\begin{aligned}
& \text { 51. Red-backed Shrike. Lanius collurio, } \\
& \text { Linn. } \\
& \text { Locally, Butcher-bird. }
\end{aligned}
$$

A well-known summer migrant, nesting plentifully in mid-Suffolk, and returning to the same locality year after year with great regularity. A late comer, it is also a late breeder, making its nest about the end of May in a thorn hedge, and usually choosing one which divides two grass fields. If the cock bird is seen perched on a telegraph wire, it may be taken for granted that the nest is not far away. The eggs, though they vary a good deal, are not likely to be mistaken for those of any other bird which breeds in the British Islands, and the variety zoned with deep red and purple is very beautiful. This type however is not found in more than one nest in a dozen. The name of 'butcher-bird' has been given to this species from its curious habit of impaling bees and small birds on furzebushes or thorn fences.

\section{Woodchat Shrike. Lanius pomeranus, Sparrman}

A very rare summer visitant, which has only occurred three or four times, the last record being in 1860. Three specimens of the lesser grey shrike (Lanius minor), a bird intermediate in size between the great grey and red-backed species, have been obtained in Norfolk, and as it is a southern bird it may on some future occasion be met with in Suffolk.

\section{Waxwing. Ampelis garrulus, Linn.}

A most erratic winter visitant, in some seasons dispersed all over the county, and sometimes not occurring once in a long cold winter. There was a considerable immigration in 1849-50 and another in 1866-7; during the frost of $1890-1$, which lasted eight weeks, no waxwings were recorded either in Norfolk or Suffolk; but in the early months of 1893 a good many were obtained, and a keeper near Ixworth shot five in one day. Most local collections contain one or two specimens, and the waxwing is so striking in its appearance that the most unobservant gunner could not pick up one without noticing that his victim was not a common bird.

54. Spotted Flycatcher. Muscicapa grisola, Linn.

Locally, Wall-bird.

This well-known summer migrant derives its local name from its habit of building its nest on the bough of a fruit tree or rose trained against a wall. The young birds, when they leave the nest, are as boldly spotted on the back as the young of the mistle-thrush.

\section{Pied Flycatcher. Muscicapa atricapilla,} Linn.

A rather rare spring and autumn migrant, which does not breed in Suffolk. The cock bird, with his jet-black and pure white plumage, is easily recognized, but the female and young might easily escape notice. Another small species, the red-breasted flycatcher ( $M$. parva), has occurred three or four times in Norfolk, and the male in full plumage rather resembles the robin.

\section{Swallow. Hirundo rustica, Linn.}

$A$ beautiful and very common summer migrant, appearing about the middle of April, and gladly welcomed by all lovers of nature. A few days of very cold weather with severe hailstorms about the middle of May, I89I, caused the death of many swallows, and several were taken to a bird-stuffer in Bury, who was told by the boys who brought them that ' they kept on dropping down.' As a rule birds suffer far more in hard winters from scarcity of food than from actual cold, but there can be little doubt in this case that the swallows were simply paralyzed by the damp chilly atmosphere. The congregating of swallows and martins before their departure must have been noticed by everybody who takes an interest in bird life, and it is not unusual to see the roof of a church or the top of a house literally covered with them. The southward migration of the swallow extends much farther than is usually supposed, and probably a very few, if any, pass the winter in Europe.

\section{House-Martin. Chelidon urbica, Linn.}

A summer migrant, rather later than the swallow, whose nests can be seen under the eaves of one or more houses in almost every village. These are usually left undisturbed, as it is said that 'the martins bring luck to a house,' and it is also supposed to be 'unlucky' to molest them. The worst enemy of these birds is the house-sparrow, who often 


\section{A HISTORY OF SUFFOLK}

evicts them from their nests and takes possession. Gilbert White of Selborne seems to have been the first to notice this, as he writes : -When the house-sparrows deprive my martins of their nests, as soon as I cause one to be shot, the other, be it cock or hen, presently procures a mate, and so on for several times following.' Young martins, doubtless the third brood, are sometimes seen in the nest as late as October.

\section{Sand-Martin. Cotile riparia (Linn.) Locally, Pit-Martin.}

Also a summer migrant, arriving before the swallow, and breeding in large colonies in gravel-pits and sand-pits, also in the sides of railway cuttings. Near Brandon it has been known to excavate its nesting-holes in a very large heap of sawdust (F. Norgate).

\section{Greenfinch. Ligurinus chloris, Linn. Locally, Green Linnet.}

A common resident, breeding everywhere, and congregating in large flocks during the winter on stubbles and in stack-yards.

6o. Hawfinch. Coccothraustes vulgaris, Pallas.

A resident, not uncommon, and perhaps breeding more numerously in the vicinity of Bury than in any other part of the county. The nest, much resembling that of the bullfinch, but larger, and always containing more or less grey lichen, is usually found in thorns, apple trees, or on the branches of firs at some distance from the trunk. Few eggs are more beautiful when fresh, but the delicate tints of olive and purple soon disappear when they are blown. The hawfinch is easily recognized when flying by the display of white on the wings and tail, and is a troublesome bird in kitchen gardens, where (as an old gardener used to say), 'they play hack wi' the peas.' This bird sometimes comes quite up to a house for food, and at Tostock a few years ago a fine old male was killed by a cat close to the front door of the rectory, but too much damaged to be of any use as a specimen.

61. Goldfinch. Carduelis elegans, Stephens. Locally, King Harry, Redcap and Thistle Finch.

This lovely little bird is a resident, though less common than it used to be. Being much in request as a cage-bird many are taken by bird-catchers and many nests robbed of the young.

\section{Siskin. Carduelis spinus (Linn.)}

A winter migrant, usually frequenting alder trees. In the summer of 1902 the siskin was observed in west Suffolk under circumstances which suggest that it may have bred.

\section{Serin Finch. Serinus bortulanus, K. L. Koch.}

A very rare summer visitant, which has only occurred two or three times. In colouring and size it is not unlike the siskin, but has a stouter bill, and is never likely to be met with in the winter.

64. House-Sparrow. Passer domesticus (Linn.)

A too common resident, which might be numbered among the 'extinct breeders' without causing general regret. Destructive alike in gardens and cornfields, blocking up troughs with its untidy nest, doing much damage to thatch, and (as before stated) the enemy of the martin, there is little to be said in its favour. 'Introduced, like the rabbit, through officious ignorance, in Australia, New Zealand and the United States, it has become such a curse that special legislation has been loudly invoked for its destruction' (Saunders' Manual, p. I 80). The only methods of reducing the numbers of the sparrow without the destruction of other birds seem to be by netting it in stacks and ivy, and by taking every nest which can be got at when the young are hatched, not when there are eggs. The use of poisoned grain is illegal, and also attended with serious risks not only to other birds, but also to poultry, pigs and cats; while if a shot is fired into the great flocks of birds which assemble in stack-yards in hard weather after corn has been thrashed out, robins, tits and other harmless birds will usually be killed with the sparrows. Birds like the hedgesparrow, whose usual food consists of insects, will often pick up grain in the winter, possibly for purposes of digestion as well as for food. The house-sparrow often builds in colonies in the branches of trees, and when these are bare in winter the nests convey the idea of a small rookery.

65. Tree-Sparrow. Passer montanus (Linn.)

A pretty little resident, as harmless as its larger relative is destructive. In addition to those which breed here, many tree-sparrows come 'over the water' to the east coast in autumn. The nest is usually built in holes of trees, and has often been found in a nestbox. Fresh eggs have been found as late as August, and a clutch nearly always contains an 'odd egg' very lightly marked in comparison with the others. A cross between this bird and the house-sparrow was shot in a farm-yard at Tostock in 1894 , which was 


\section{BIRDS}

examined in the flesh by the late Lord Lilford, and exhibited after it was mounted at meetings of the Linnean and Norfolk Naturalists' Societies.

\section{Chaffinch. Fringilla ceelebs, Linn.}

This charming bird is a resident, but, as previously pointed out, very many come as winter migrants with the bramblings. It is often spoken of simply as the 'finch.'

67. Brambling. Fringilla montifringilla, Linn.

A winter migrant, sometimes so numerous that the beech woods are literally alive with them. When a flock of small birds feeding on beech-mast is disturbed, the bramblings are easily recognized as they fly up by their white backs. It has no local name, but allusion is often made to 'them little foreign finches.' The brambling sometimes remains till the middle of April, when the cock birds begin to assume the black head and back of the summer plumage, and occasionally a bird is shot with more or less black on the throat. It has never been known to nest in England except in captivity, and is a handsome addition to an aviary.

\section{Linnet. Linota cannabina (Linn.)} Locally, Grey Linnet, Red Linnet.

A common resident, breeding abundantly on furze commons, also in road-side hedges and even in gardens. It breeds at least twice in a year, and sometimes lays perfectly white eggs.

69. Mealy Redpoll. Linota linaria (Linn.)

A rather scarce winter migrant, larger and greyer than the lesser redpoll.

70. Lesser Redpoll. Linota rufescens (Vieillot)

$A$ resident, though its numbers are increased in winter, when it is often to be seen on alders in company with siskins. It builds an exquisite little nest lined with willowdown, and its eggs are easily recognized by their small size and blue ground-colour.

71. Twite. Linota flavirostris (Linn.)

A winter migrant, sometimes occurring near the coast in large flocks. It is a smaller bird than the linnet, with more yellow on the bill, and no red on the head.

\section{Bullfinch, Pyrrbula europaca, Vieillot. Locally, Olf.}

The cock bullfinch, often called a "bloodolf' from his bright red breast, is one of our handsomest small birds. This resident species is often seen in pairs during the winter, and in early spring is rather troublesome in gardens, but a few explosions of powder in an old muzzle-loader will often keep it away altogether, while a charge of shot fired at a bullfinch in a plum or apple tree will do far more damage than the bird itself. It is a strong hardy bird, quite well able to bear severe weather, as it can always find buds of some sort and is one of the few birds which feed on 'hips,' as the berries of the dog-rose and sweet-briar are called. No bird is a greater favourite as a cage-bird with cottagers, and a brood of young 'olfs' is reared with the greatest care. There is a large northern race or species of bullfinch ( $P$. major), of which the cock has a paler grey back and a still brighter red breast than our bird. It has once been shot in Norfolk, and once plainly seen in Suffolk, but 'Russian bullfinches' are now imported in such numbers that there is at least a likelihood of both these being escaped birds.

Dr. Babington records for what they are worth a few occurrences of the pine grosbeak ( $P$. enucleator), but adds that "the above quoted instances appear to be doubtful' and his remark seems to be much to the point.

\section{Crossbill. Loxia curvirostra, Linn. \\ Locally, Robin-Hawk.}

A well known species whose migrations are almost as irregular and uncertain as those of the waxwing. In some years, as in $1867-8$, and again in $1888-9$, the bird-stuffers shops have been full of crossbills in every variety of plumage, but a man who brought some into Bury in 1888 remarked that he had seen none for twenty years. In 1889 several nests were found containing eggs, of which full details are given in the Birds of Norfolk (iii. 390, 391). There was a smaller migration in 1898 in the late summer, and some were shot in Norfolk as early as August, the birds being so tame that in one place they were killed with a catapult. The crossbill is a very early breeder, having eggs in March even in Scotland, where it breeds regularly. The "large, stout-billed race, formerly distinguished as the parrotcrossbill (Loxia pityopsittacus),' mentioned incidentally by Mr. Saunders (Manual, p. 202), has occurred in Suffolk more than once. A very fine red male of this form shot near Bury in December, 1888, measured nearly $7 \frac{1}{2}$ inches in length in the flesh, and is in the Tostock rectory collection.

74. Two-barred Crossbill. Loxia bifasciata (C. L. Brehm)

A very rare visitant from the north-east. 


\section{A HISTORY OF SUFFOLK}

A cock bird, shot at Drinkstone in May, 1846 , is now in the Norwich Museum, and another cock, in full plumage, was shot at Burgh Castle September, 1889 , in which year others were obtained in Yorkshire, Bedfordshire and Surrey. This species derives its name from the two white bars on the wing, and was formerly known as the "European white-winged crossbill.'

\section{Corn-Bunting. Emberiza miliaria, Linn. Locally, Bunting-lark.}

A resident, not very common, but found all over the county. It is essentially a bird of the fields, and only comes into stackyards in severe weather. This bird almost always nests on the ground, and is a late breeder, seldom having eggs before June, while they have been 'cut over' in August. 'The eggs are often splendidly blotched with rich dark brown, and if not very carefully blown the colouring matter is liable to be rubbed off.

76. Yellow Hammer. Emberiza citrinella, Linn.

Locally, Yellowham or Yellowhammet.

A common resident, sometimes seen in large flocks during the winter. A beautiful variety of this bird was killed at Great Barton about November, 1902, the entire plumage of which was almost as yellow as that of a canary. The yellow hammer sits close, and goes off her nest in a manner which at once discloses the exact spot, so very many nests are robbed by boys. It is rare to find more than four eggs, and sometimes a spotless variety is met with, much resembling pale eggs of the wheatear. Further evidence seems desirable before adding the cirl bunting (E. cirlus) to the Suffolk list, as although two were caught 'on Breydon marshes' early in 1888 , of which the identity is beyond question, they may have been taken in either Norfolk or Suffolk. In size the cirl bunting is a trifle smaller than the yellow hammer, the cock has a black throat, and both sexes are without the warm rusty red on the lower back.

\section{Ortolan Bunting. Emberiza bortulana,} Linn.

A very rare visitant, of which a specimen killed near Lowestoft in May, 1859, seems to be the only record.

\section{Reed-Bunting. Emberixa schoeniclus, Linn. \\ Locally, Water-Sparrow.}

This prettily-marked species is a resident, common enough in marshes, rough meadows and reedy dykes, where the cock, with his handsome plumage and lively movements, is a conspicuous little bird. The reed-bunting usually builds in sedge or other herbage close to the water, less frequently in a low thornbush or in furze on a common, and the eggs are much darker in colour than those of any other bunting which breeds in England.

\section{Snow-Bunting. Plectrophenax nivalis (Linn.)}

A regular winter migrant to the coast, sometimes appearing in large numbers. $\mathrm{Mr}$. Hele used to find it at Aldeburgh ' frequenting the Haven Sands and generally along shore.' It breeds in small numbers in Scotland, but has never been known to do so south of the border.

\section{Lapland Bunting. Calcarius lapponicus (Linn.)}

A rare winter visitant, of which perhaps six specimens have been obtained in the county. There was a large autumn migration of Lapland buntings in Norfolk in 1892 , but very few reached Suffolk. In colouring this bird rather resembles the reed-bunting, but is easily known by the long and nearly straight hind claw.

\section{Starling. Sturnus vulgaris, Linn.}

A common resident, breeding wherever it can find suitable holes in church towers, old trees, and thatched buildings. It has been known to enlarge the entrance hole of an old weather-beaten nesting-box till it could gain admittance, and can be as easily attracted to a box as the great tit. Though, it is fond of cherries, and sometimes adds to the damage already done to thatch by sparrows, it devours an enormous quantity of insects and grubs, and a group of starlings at work on the grass with the spring sun shining on their glossy plumage is a very charming piece of bird-life. Multitudes cross the North Sea in autumn, and Mr. Hele during two hours' observation of in-coming migrants at Aldeburgh on an October morning noticed thirteen arrivals of starlings. As many as fifty have been killed in a night by striking the glass of one of the Norfolk lightships.

\section{Rose-coloured Starling. Pastor roseus} (Linn.)

A rare visitant, of which there does not seem to be an occurrence since I 868 . The young bird is very plainly coloured, and might easily be passed over alive or dead without being recognized as a rarity.

The following interesting paragraph appears 


\section{BIRDS}

in the Zoologist for 1888 (p. 185): 'Probable occurrence of the Chough in Suffolk. In a migration schedule received this morning (April I4th) from Mr. Owen Boyle, of the Landguard Lighthouse, is the following entry : - "April 2nd, 1888. Two Crows put in an appearance, $7.30 \mathrm{a} . \mathrm{m}$., larger than Jackdaws ; they had red beaks and legs, and went northwest." JoHn CORdeaux.' This seems hardly sufficient to warrant the inclusion of the chough in the Suffolk list, but Mr. Cordeaux, who made a special study of migration, and perhaps did more than any man to interest the keepers of lightships and lighthouses in the subject, appears to have thought the incident worthy of record.

\section{Nutcracker. Nucifraga caryocatactes} (Linn.)

A very rare visitant to England, which has once at least occurred in Suffolk, one having been shot at Gorleston in October, 1864 .

\section{Jay. Garrulus glandarius (Linn.)}

This handsome bird is a resident, common enough where it can find woods and copses suitable to its habits. It is not a favourite with gardeners or gamekeepers, and it certainly does a good deal of damage to green peas, but probably the eggs of wood-pigeons and of the various thrushes are much more liable to be eaten by it than those of game birds.

\section{Magpie. Pica rustica (Scopoli)}

Though common enough in many parts of England, the magpie is a rare bird in Suffolk, and almost extinct as a breeding species.

\section{Jackdaw. Corvus monedula, Linn.}

A rather local resident, breeding in hollow trees and church towers. Thorpe Morieux church, near Lavenham, used to provide shelter for a large colony of jackdaws, but the tower has recently been put in order and the holes stopped which contained the nests. Young jackdaws brought up from the nest and allowed perfect liberty with uncut wings make delightful pets, and become extremely tame, but they are liable to be decoyed away by wild birds at the time of the autumn migration. At this season these birds are often seen literally in swarms, and the oftrepeated calls of ' jack' from a flock passing overhead have rather a pretty effect.

\section{Raven. Corvus corax, Linn.}

This splendid bird is now quite extinct as a resident, and very rare even as a visitant. All the ravens' nests in the county of which any record exists were built in trees, as there are no cliffs of sufficient height on the coastline nor any inland rocks. In the western division of Suffolk it formerly bred at Drinkstone Park, Icklingham, Elveden, and Santon Downham, also at Stutton, Gedgrave and Middleton in the eastern part of the county, the last occupied nest being at Elveden about 1863 (Ootheca Wolleyana, p. 578). At Middleton a tree is still (1902) standing which used to be resorted to every year, and a former owner of the property caused the 'raven-tree' to be fenced round for the protection of the nest. On one occasion some young ravens from the Gedgrave nest were taken to Leiston, a distance of at least eleven miles, but the old birds found them out and fed them in their new home (G. T. Rope). At Lindsey, near Hadleigh, there is a farm called 'Ravens' Hall,' which may have been thus named from its being an old haunt of this species, though the title may be derived from the surname of a former owner. Mr. Hele used to see and hear ravens from time to time at Aldeburgh, but never obtained a specimen, and the last occurrence seems to have been that of one shot by a keeper at the Tuddenham in west Suffolk about 1888 or 1889 , which was not preserved (F. Norgate).

\section{Carrion-Crow. Corvus corone, Linn.}

In the 'sixties' this bird was sufficiently common to be known by the local name of 'carroner,' but it seems probable that in the next list of Suffolk birds it will be numbered among the extinct breeders, as no bird is more detested by gamekeepers, and, it must be added, with good reason. The Rev. James Oakes, who was rector of Tostock from 1796 till I86I, was very fond of a pair or two of carrion crows which bred on his property, and never allowed them to be destroyed, though doubtless the young poultry on his home farm suffered from their depredations. This bird is sometimes seen on the sea-shore, and there are records of its migrations. Viewed from below, the nest of the carrion crow is exactly like that of the rook, but is more warmly lined with wool and fur, and the eggs are rather larger, and as a rule, more richly coloured. In a full clutch of five crow's eggs there is usually an 'odd egg,' much lighter in colour than the rest, and sometimes a nestful of eggs is found much resembling large eggs of the jackdaw.

\section{Hooded Crow. Corvus cornix, Linn. Locally, Royston Crow.}

Near the coast this bird is a common winter migrant, which may often be seen in 


\section{A HISTORY OF SUFFOLK}

October coming in over the water, and the boldly-contrasted black and grey of its plumage make it an easy bird to identify. It soon makes itself at home in its winter quarters, and frequents the sea-shore along the tide-line, where food of some sort is always to be found. Mr. Hele mentions two instances of its breeding near Aldeburgh in 1872 and 1873 , and an egg marked in his handwriting ' Royston, Hazelwood,' is in the museum collection at Ipswich. This bird is sometimes spoken of as the 'carrion-crow.'

\section{Rook. Corvus frugilegus, Linn.}

Many of the Suffolk farmhouses and parsonages, as well as the large country mansions, have their rookery, these colonies varying in size from a dozen nests to ten or twenty times that number. Rooks are in their way as migratory as starlings, and numbers cross the North Sea in autumn, sometimes striking the light-vessels. This bird is almost omnivorous, and in dry seasons will eat any eggs that come in its way, especially those of ducks and other water-birds, while its fondness for grain makes the employment of "bud-scarin" (bird-scaring) boys a necessity on farms near a rookery. Still it devours a vast number of worms and insects, and like the bullfinch deserves to be frightened away with powder rather than slaughtered with shot, for there is hardly any bird more closely connected with country life in East Anglia.

\section{Sky-Lark. Alauda arvensis, Linn.}

A resident, breeding as early as the middle of April and as late as the end of July, in cornfields, meadows, marshes and commons. In winter, sky-larks collect in vast flocks on the Stubbles, and multitudes cross the North Sea during the autumn migration. Perhaps more of these birds perish from striking the lights than any other species, and the number picked up is sometimes sufficient to provide the crew of a lightship with a substantial meal.

\section{Wood-Lark. Alauda arborea, Linn.}

A very local resident, which seems only to have been found breeding on the western side of the county near the Norfolk border. Comparatively few people know of its existence, but those wishing to add to their knowledge will find an admirable account of the bird and its habits in Suffolk in Yarrell's British Birds (ed. 4, i. 625-31). It is a smaller bird than the sky-lark, with a shorter tail and a conspicuous streak over the eye.

\section{Short-toed Lark. Alauda brachydactyla,} Leisler.

One was shot 'near South Breydon Wall,
Great Yarmouth' on 7 November, 1889 (Zoologist, 1890, p. 77), which would claim a place in the Suffolk rather than the Norfolk list.

\section{Shore-Lark. Otocorys alpestris (Linn.)}

The shore-lark used to be considered a great rarity, and was not known as a British bird till 1830 , when the first recorded specimen was obtained in Norfolk. Mr. Hele first met with it at Aldeburgh in November, I 864 , by the merest chance, as having shot at two birds on the ground to obtain food for a tame hobby, he picked up a fine cock shorelark, which is still in the Ipswich Museum, and the second bird, which was wounded at the time, was brought to him a few days later. In the second edition of his book ( 1890 ) he was able to describe it as 'by no means uncommon.' In matters relating to birds it is easier to state facts than to give an explanation of them, and the cause of the great increase in the number of shore-larks which now come to the east coast of England as winter migrants has yet to be made known. In 1896 two were obtained near Needham Market, an unusually long distance from the sea (Lingwood).

\section{Swift. Cypselus apus (Linn.)}

Locally, Deviling, Shriek-Devil, Rain-bird, Shriek-Owl and Screech-Owl.

Whoever bestowed on the swift the first two of the local names given above must have imagined that there was something 'uncanny' about the dusky colour, rapid flight and piercing cry of the bird. But it is a charming and interesting creature, and one which should never be destroyed or disturbed. The swift is a late summer migrant, seldom arriving before May, though Professor Newton was able to record in the Field the appearance of one at Lowestoft on 26 March, I897, which was plainly seen by himself and his brother. All the Suffolk swifts nest in buildings of some kind, and there has always been a flourishing colony in the tower of Elmswell church, but there is at least one place in East Anglia where these birds still retain what must be regarded as their original habit of breeding in a cliff. One singular habit of the swift is that of gathering into bands towards the close of the day and dashing about at lightning speed, all the birds at intervals squealing in chorus. This performance appears to be gone through simply for exercise or amusement, and the birds seem to enjoy it thoroughly. The name of "rainbird' has been forwarded by an observer near Woodbridge, and is in accordance with $\mathrm{Mr}$. 


\section{BIRDS}

Saunders' remark (Manual, p. 262) that 'the swift seems to revel in the storm.' In Suffolk the name of 'swift' is applied to the common water-newt.

\section{Alpine Swift. Cypselus melba (Linn.)}

A very rare visitant from the continent of Europe which has only occurred two or three times. On 8 September, 1870, two were seen at Aldeburgh, and one flew into a room at the Brudenell Hotel, where it was captured and killed. It was for some time in the possession of the late Mr. H. Greenwood, who kindly gave several of his friends the opportunity of seeing it in the flesh. The alpine swift can be recognized by its white under-parts and large size, having a wing expanse of quite eighteen inches.

97. Nightjar. Caprimulgus europaus, Linn. Locally, Night-hawk, Night-reel or Eve-jar.

The above-given local names, like the orthodox 'nightjar,' are derived from the bird's nocturnal habits and singular note, and the absurd and misleading name of 'goatsucker' is happily almost obsolete. This bird is a summer migrant to Suffolk, frequenting heaths and commons throughout the county. Arriving about the first week of May its eggs may be found about a month later, and the blending of delicate grey and rich brown on a fresh clutch of nightjar's eggs is very beautiful, but the delicate colouring soon fades when the eggs are blown. The two eggs are laid on the ground without any pretence of a nest, and the young, which are well covered with down when hatched, soon begin to move from place to place. Many interesting photographs of young nightjars have been obtained, and more than one artist has been successful in getting a picture of the hen on her eggs. There is no more harmless bird than the nightjar, as its food consists entirely of insects, and it is to be regretted that it is sometimes wantonly shot by rabbit-shooters on summer evenings when in pursuit of its prey.

98. Wryneck. lÿnx torquilla, Linn.

Locally, Cuckoo-leader, Cuckoo's mate or Barley-bird.

The wryneck's well known note is usually heard quite early in April, and the name of ' barley-bird' appears to be derived from the arrival of the bird at about the time of sowing spring barley. It is a 'masterful' bird, and has been known to eject not only the great tit but even the sparrow from a nest-box which it coveted for its own use. When disturbed on its eggs, which are usually laid in a hole in a tree, it protests with a hissing noise which can be almost exactly imitated by dropping a lighted match into cold water. No nest is made, the eggs being laid on scraps of wood, and when the tree is very soft and decayed the wryneck will enlarge the hole. A few years ago three clutches of nine, eight and six eggs were taken from an old appletree near Bury, all of which were undoubtedly laid by the same bird in one season.

99. Green Woodpecker. Gecinus viridis
(Linn.)
Locally, Woodsprite, probably the 'sprite' or
'spirit' of the wood, from its loud
laughing cry being heard when the bird
was unseen.
A beautiful resident species, which like the nuthatch seems to remain in the same locality all the year. Its domestic arrangements are often upset by starlings, which take possession of the holes bored by the woodpecker when completed, and thus often cause it to postpone the laying of eggs till the end of May or even till June. The elm is its favourite tree, but its nest-holes have been noticed in Suffolk in the birch, alder, willow, white poplar, oak, ash, beech, silver fir and even in an old dead holly, of which part is still standing in Hessett churchyard. Fresh eggs of the green woodpecker are very lovely, the yolk giving an exquisite pink tint to the glossy white shell. A beautiful pair of these birds, in the Tostock rectory collection, were picked up dead during a very severe frost in February, 1895, the cock at Elmswell and the hen near Bury, which had evidently died of cold and hunger, as no trace of injury could be found on either. This woodpecker sometimes comes into gardens and searches the grass for ants and other insects.

\section{Great Spotted Woodpecker. Dendrocopus major (Linn.)}

This bird is also a resident, but neither so common nor so conspicuous as the green woodpecker. It is also more migratory, and at times crosses the sea in some numbers. In spring the cock makes a very loud vibrating noise by rapidly hammering a branch or the trunk of a tree with his bill, and this, as it is never heard in winter, is probably his method of attracting the attention of the hen. Being a later breeder than the green woodpecker it suffers less from the molestation of starlings. A nest in an old dead birch at Tostock contained four slightly sat on eggs on 2 June, 1900, which were much less glossy than those of the green woodpecker, and the hen sat very close. These birds roost in old nest-holes. 


\section{A HISTORY OF SUFFOLK}

IOI. Lesser Spotted Woodpecker. Dendrocopus minor (Linn.)

This is much the smallest of the three British woodpeckers, and is a resident as common as the great spotted, but seldom seen. It is difficult to say whether the local names of 'wood-jar,' 'wood-nail' and 'grain-bird' are meant for this bird or the larger species, as the singular noise alluded to above and suggested by the names is common to both. 'Grain-bird' may have some connection with the 'grain' of the wood, and was given by an intelligent old labourer who accurately described the sound. The tiny nesting-hole of the lesser spotted woodpecker is usually bored in dead wood at some height above the ground, so that to examine the nest and its contents involves some risk. The eggs much resemble those of the wryneck, but are slightly smaller.

The large black woodpecker (Picus martius) is reported to have been seen in Suffolk, but as its claim to be even a British bird is very doubtful, nothing but the production of a specimen in the flesh in so fresh a state as to show beyond a doubt that it was not imported from Norway or Sweden will ever satisfy critical naturalists.

102. Kingfisher. Alcedo ispida, Linn.

This richly-coloured little bird is a resident, breeding in the banks of streams and sometimes in the side of a crag-pit (Zoologist, 1870 , p. 2,022). It seems also to a certain extent to be migratory, as many are observed about dykes and rivers near the coast in the autumn, and one was killed by striking the Orford lighthouse on 25 March, 1884 , which suggests that the bird had wintered in the south, and was returning to breed in Suffolk. The kingfisher bores a hole for itself, and fresh 'whitewash' at the entrance is a pretty sure sign that the eggs are laid. It is an early breeder, as even in the north of England a full clutch of seven eggs has been found by the middle of April. Occasionally the nest is spoiled by heavy rains flooding the stream and causing the water to rise above the entrance hole, an instance of which occurred near Woolpit in the early summer of 1889. Few birds suffered more than the kingfisher in the frost of 1890-1, which lasted eight weeks and caused the death of many, some from being shot and others from actual starvation. There were six in the flesh in a shop at Bury on 17 December.

103. Roller. Coracias garrulus, Linn.

This splendid bird has occurred a few times in the eastern part of the county on its spring and autumn migrations, the last recorded having been obtained at Burgh Castle in September, I 892.

104. Bee-Eater. Merops apiaster, Linn.

A far rarer visitant to England than the roller, and there are only two or three records from Suffolk.

\section{Hoopoe. Upupa epops, Linn.}

A Suffolk man reporting the appearance of a hoopoe would probably describe it as 'a wholly pretty bird with a topple-crown,' and any one who has once seen it alive is certain to recognize it again. Perhaps it is hardly common enough to be called a regular summer visitant, but most outdoor naturalists in East Anglia have come across it at least once in their career. Near Lowestoft no less than thirteen were obtained in the April and May of 1859 , and $\mathrm{Mr}$. Hele used to meet with it from time to time at Aldeburgh. There is no record of it having attempted to breed in the county.

\section{Cuckoo. Cuculus canorus, Linn.}

The year 1894 was a 'record year' for early cuckoos throughout the country, and in Suffolk Colonel Butler observed two at Brettenham Park on 4 April. At Tostock the cuckoo was seen and heard on 9 April, but these dates are a good fortnight in advance of the usual time for the arrival of this summer migrant. The following rhymes were lately taken down at the fireside of a cottager, who said he had heard the first 'more than sixty year ago':-

In April he show his bill,

In May he sing night and day,

In June he change his tune,

He wait till July, away he fly,

If he wait till August away he must-go.

The cuckoo is a pretty bird, he sing as he fly, $\mathrm{He}$ bring us good tidings and tell us no lie.

To the latter another authority adds :

He suck the pretty birds' eggs to make his voice clear,

And the more he sing 'cuckoo' the summer draw near.

This well known bird is found all over Suffolk, and its eggs which are laid from May to July are most often deposited in the nests of the robin, sedge-warbler, reed-warbler, hedge-sparrow, pied wagtail and meadow-pipit. Taking the county through it is probable that more cuckoos' eggs are placed in the nest of the hedge-sparrow than of any other bird, and that the meadow-pipit would come in a 'good second.' The greenfinch, linnet and yellow bunting are less frequently chosen as foster- 


\section{BIRDS}

parents, and the egg of the cuckoo has been found in Suffolk in the nests of the songthrush, blackbird, nightingale, whitethroat, blackcap, willow-wren, yellow wagtail, treepipit, red-backed shrike, spotted flycatcher, chaffinch, bullfinch and reed-bunting, making twenty-two species in all, while doubtless other nests have been chosen which have not been recorded or discovered. It is very rare to find more than one cuckoo's egg in a nest, but in May, I902, a meadow-pipit's nest was taken near Diss, containing three eggs of the owner and two of the cuckoo, the two cuckoos' eggs being quite unlike each other. The cuckoo's egg has been found in a nest with no other egg, and with from one to six eggs of the foster-parent. Though the old birds take their departure in July, a nestling has been seen in August, and the young birds sometimes remain till late in September. The song from which the cuckoo derives its name is familiar to every one, but it has another note believed to be peculiar to the hen, which resembles the spluttering sound produced by pouring water from a bottle. The taking of young cuckoos from the nest with the idea of rearing them is not to be encouraged, as they are troublesome to feed, uninteresting in their ways, and usually die in a few weeks. Mr. Hele tried his luck with several, but never succeeded, and where so skilful and patient a naturalist failed others are not likely to succeed.

107. White or Barn-Owl. Strix flammea, Linn.

Lacally, White Owl.

As previously mentioned the West Suffolk County Council has issued orders for the protection of all species of owls throughout the year, and if owners and occupiers of land would not only strictly forbid their keepers to kill these birds, but also make it understood that they wished to see and hear owls about their place, these wholesale destroyers of rats and mice would have a fair chance of doing their work. All owls cast up the fur and bones of their prey in pellets, and these can be easily analyzed by putting a few in a basin and pouring warm water over them, when the bones of various small rodents will be seen. A farmer whose knowledge of birds enabled him to speak from experience once said that 'any one who kills an owl ought to get six months,' and the barn-owl is certainly one of the most useful members of a highly respectable county family. It is a resident breeding in old trees, barns and church towers, but migrants arrive in autumn. These 'Scandinavian barn-owls' are usually darker in colour than the resident birds, and a remarkably good specimen, with the entire breast of a warm fawn colour, was obtained near Lowestoft in February, 1898 , which is now in the Tostock rectory collection.

\section{Long-eared Owl. Asio otus (Linn.)}

Locally, Horned Owl.

A resident, far from common, but breeding every year. It frequents fir plantations, and generally uses an old squirrel's nest on which to lay its eggs, though the nest of a crow or other bird is sometimes chosen.

rog. Short-eared Owl. Asio accipitrinus (Pallas)

Locally, Woodcock Owl or Sedge Owl.

This winter migrant derives its local names from its arrival on the east coast in October, when the woodcocks come, and from its being often aroused from sedge or rough grass. Shorteared owls vary a good deal in plumage, and any one seeing a small pale specimen side by side with a large dark one might easily imagine them to belong to different species. Like the woodcock, the short-eared owl occasionally breeds, and a nest found at Tuddenham (west Suffolk) in 1882 is recorded in the Zoologist for that year. The nest, such as it is, is invariably on or near the ground, and the white eggs cannot be distinguished from those of the long-eared owl. A beautiful photograph of a nest containing seven eggs is given in Kearton's Rarer British Birds.

I I0. Tawny Owl. Syrnium aluco (Linn.) Locally, Brown Owl.

This handsome owl always makes its presence in a locality known by its loud hooting cry, which on a clear frosty night can be heard at some distance, and possesses a great charm for bird lovers. It is a resident, breeding in hollow trees, and often has a full clutch of eggs before the end of March. When the young are hatched it becomes bold and even aggressive, and the following incident recorded shortly after its occurrence in the Zoologist of 1890 by the present writer may be of sufficient interest to justify its quotation here : - A few days ago I had a novel and somewhat unpleasant experience of the way in which the tawny owl resents an approach to its nest. About three weeks ago I found in an old dead elm a nest containing three young and two eggs, which we much hoped would not be disturbed, as till last year this bird was not known to breed here. One bright moonlight night I was standing close to the trunk of the tree, watching for the return of the birds with food for their young. Presently one of the parents perched on a tree a few yards away, 


\section{A HISTORY OF SUFFOLK}

uttering a peculiar whining cry, and in a minute or two dashed straight at my head. The blow inflicted was very like that of a moderately hard snowball, and putting up my hand I found my forehead bleeding freely in several places, while my cap (a soft grey woollen one) was carried off as a trophy, and found the next morning under a tree about 70 or 80 yards away. Since then I have given my protégés a wide berth after sunset.'

\section{Ix. Tengmalm's Owl. Nyctala tengmalmi (J.F. Gmelin)}

A rare autumn and winter visitant from Scandinavia and Lapland, of which about half a dozen Suffolk occurrences are recorded. Two were caught alive and uninjured at Southwold in the autumn of I 901 , both of which lived for some time in confinement. Tengmalm's owl and the little owl could be distinguished even in the dark by their legs, which in this species are covered to the claws with thick downy feathers, while in the little owl the toes are nearly bare.

\section{Little Owl. Atbene noctua (Scopoli)}

Little owls have been turned out in England on several occasions and have bred in a state of perfect liberty, so it is difficult to decide whether those which are met with from time to time are genuine migrants. The late Mr. Bilson of Bury had one in the flesh in February, 1865 , which was shot at Hengrave, and a very perfect specimen was caught at Cavenham about 22 April, 1902, which was stuffed by Mr. Travis of Bury.

I I3. Snowy Owl. Nyctea scandiaca (Linn.)

This splendid northern species is very rare in East Anglia, and only occurs in winter. One, now in the Norwich Museum, was shot near Bungay in February, I 847 , which was for a long time in Mr. Spalding's collection, and a second is reported to have been shot near the Languard lighthouse 9 February, 1886, but its possessor is not known. A third was seen by Colonel Leathes within 20 yards on a tree near Fritton Lake, 30 September, 1902 (Leathes).

\section{14. Scops-Owl. Scops giu (Scopoli)}

This, the smallest of the British owls, is a very rare visitor, but there seems to be a genuine record of one shot at Haughley in 1865. It can be at once recognized by its ear-tufts. Like the little owl this species is very often imported alive from the continent, and can usually be obtained through the London dealers.
I I . Marsh-Harrier. Circus aruginosus(Linn.)

The marsh-harrier is the largest of the three British harriers, and has for many years been the most uncommon in Suffolk. There can be no reasonable doubt that it formerly bred in more than one locality, but all endeavours to establish a definite record have been unsuccessful. One was picked up dead near Aldeburgh in May, I 869, but Mr. Hele was never able to procure a specimen, and the one in his collection in the Ipswich Museum, which is cased up with a peregrine and a roughlegged buzzard, came from Norfolk.

\section{16. Hen-Harrier. Circus cyaneus (Linn.)}

Females and young males of this species occur in the county almost every year, but the old male in his grey and white plumage is practically unknown. It doubtless bred till the early part of the last century, but the nest found on Cavenham Heath in 1871 , in which there were three broken eggs, but no bird belonging to which was seen (Babington's Catalogue, p. $3^{8}$ ), was far more likely to have been that of Montagu's harrier. A fine young male was shot on the outskirts of Bury in October, I 899 , which was said to have just killed a partridge.

\section{7. Montagu's Harrier. Circus cineraceus} (Montagu)

A spring and autumn visitant, of which there are no records of the breeding since 1889. In that year two nests were found, each containing three eggs, one at Westleton, the other on Dunwich Common, of which somewhat melancholy details are published in the Zoologist for I 890 (p. 77). Montagu's harrier is the smallest of the three species, in colour more resembling the hen-harrier than the marsh, and occasionally an almost black variety is met with, a specimen of which is in the Dennis collection at the Bury Museum.

\section{8 . Buzzard. Buteo vulgaris, Leach.}

The local name of 'puttock, which really belongs to this species, is applied in Suffolk to any large hawk. The buzzard is now only a visitant, usually occurring in autumn, but it used to breed in the county. The last eggs taken and preserved were probably a clutch taken at Tostock about 1853 in a wood well known to hunting men as 'Cindron Hills,' but buzzards bred in Monk's Wood near Felsham in 1874, where Dr. Babington saw the nest. One of the birds was shot and thrown away for the foxes, and in the following year the hen was wounded on the nest (Catalogue, p. 33). Like the ravens, the buzzards bred in trees for want of suitable rocks, and the 


\section{BIRDS}

Tostock nest was in all likelihood an old carrion-crow's, as these birds used to frequent the place where it was found.

119. Rough-legged Buzzard. Buteo lagopus (J. F. Gmelin)

A winter migrant, almost as irregular as the waxwing, as in some seasons a good many have occurred, and in many winters not one has been recorded. 1876 and 1891 were rough-legged buzzard years, the former year especially, when these birds were met with all over the county. They vary in plumage a good deal, but are usually lighter in colour than the common buzzard, and ' $a$ bird in the hand 'can be recognized at once by the feathered legs. The rough-legged buzzard has not been known to breed in the British Islands.

120. Spotted Eagle. Aquila maculata (J. F. Gmelin)

Of eleven British specimens of this bird two belong to Suffolk, both of which were obtained in the autumn of $189 \mathrm{r}$. The first was shot at Sudbourne near Orford early in November, and beautifully set up for its owner by Messrs. Pratt of Brighton; the second at Reydon near Southwold in December, details of both being recorded in the Field at the time of the occurrences. The spotted eagle is a small eagle with feathered legs and more or less spotted with white on the upper parts.

121. White-tailed Eagle. Haliaëtus albicilla (Linn.)

An occasional autumn and winter visitant, often recorded as the golden eagle. The young golden eagle has a good deal of white on the tail, while the young white-tailed eagle has a dark brown tail, but the two birds can be distinguished at a glance by the legs, which in the golden eagle are feathered to the toes and in the white-tailed eagle are bare to the joint. Many collections contain a local specimen of the latter, but there is no satisfactory record of the occurrence of the golden eagle in Suffolk, and it is very rare to meet with it south of the Scottish border.

122. Goshawk. Astur palumbarius (Linn.)

A very rare autumn and winter visitant, of which the last occurrence was at Somerleyton in March, 1894. The goshawk may be described as a gigantic sparrow-hawk, with proportionately shorter and stouter legs, and like that species has bright orange-yellow eyes.

123. Sparrow-Hawk. Accipiter nisus (Linn.)

A resident, breeding throughout the county, but rarely allowed to bring off its young, as it bears an evil repute as a destroyer of young game. The nest is sometimes built by the birds themselves and sometimes an old one belonging to some other bird, but is invariably on a tree, never in rocks or buildings. Few birds lay more beautiful eggs, and a clutch well covered with chestnut-red blotches is an ornament to any collection. There are many records of the sparrowhawk's migration on the east coast.

\section{Kite. Milvus ictinus, Savigny.}

This magnificent bird is now very rare, but Dr. Babington's statement that it 'formerly bred' is doubtless quite correct, as there are many places in the county suited to its habits. The last kite obtained in Suffolk was one at Frostenden in February, 1901 (W. M. Crowfoot). In the autumn of I 88 I large birds of prey were met with in unusual numbers, and a female kite was picked up dead, but perfectly fresh, on the shore near Aldeburgh, of which particulars are given in the Zoologist for $188_{4}$ (p. I).

125. Honey-Buzzard. Pernis apivorus(Linn.)

A summer visitant, which has often nested in other parts of England, the New Forest especially, but there is no mention of its ever having attempted to do so in East Anglia. The honey-buzzard varies a good deal in plumage, but the long wings and rather small but brilliant yellow eye are always distinguishing marks. A very fine old female shot near Bury on II June, I888, which had been feeding on unfledged birds and blackbirds' eggs, is now in the Tostock rectory collection.

\section{Greenland Falcon. Falco candicans (J.F.} Gmelin)

Dr. Babington (Catalogue, p. 230) gives details of three occurrences, all in east Suffolk.

\section{Gyr-Falcon. Falco gyrfalco, Linn.}

An immature specimen was shot at Orford in October, 1867 , an excellent photograph of which is given in Dr. Babington's Catalogue. Suckling, in his History and Antiquities of the County of Suffolk mentions (ii. 236) that King John in return for his grant of certain privileges received from the inhabitants of Dunwich ten falcons and five gyr-falcons, in addition to a payment of money.

\section{Peregrine Falcon. Falco peregrinus, Tunstall.}

Almost every autumn and winter one or two peregrines are sent into Bury to be stuffed, and they are certainly the least rare of the large hawks. The great majority of those 


\section{A HISTORY OF SUFFOLK}

obtained are females, and a perfect old male is a rarity. A splendid specimen came to grief against the telegraph wires near Aldeburgh in March, I864, and was brought to Mr. Hele in a terribly damaged condition, but he managed to make a good bird of it. A hen bird was caught near Bury in May, 1890 , which is an unusual date. Peregrines vary a good deal in colour, some being much darker than others. The only mention of the breeding of this bird in Suffolk is made by the Rev. R. Lubbock, who in his Fauna of Norfolk says that 'during the time that the late Mr. Downes practised falconry near Yarmouth a pair of these birds used to breed in the steeple of Corton Church. The nestlings were taken and trained to the chase, the clerk having a regular retaining fee for their preservation' (ed. I879, p. 29). This would probably be some time between 1800 and 1820 . The book referred to contains (pp. 224-39) an article by Professor Newton on 'Hawking in Norfolk,' in which there are some interesting references to the same sport in Suffolk, especially to the pursuit of the kite in the neighbourhood of Thetford.

\section{-129. Hobby. Falco subbuteo, Linn.}

This beautiful little falcon is now a rare summer migrant, and must be classed among the 'doubtful breeders.' A very perfect male was shot at Rougham in June, 1898 , which may have been one of a pair nesting in the vicinity, and in the 'sixties' Mr. Hele had a tame hobby for some years, which was taken from a nest near Woodbridge. She was kept in the garden during the summer and brought into the house for warmth in the winter, but at last made her escape, with the usual sequel of being shot, and is now one of a group of hawks and owls in the Ipswich Museum. The hobby is said never to build a nest, but always to use an old one, most frequently a crow's, and is the latest breeder of all the hawks, not laying till June. Three eggs are usually laid, like those of the kestrel, but rather larger and paler in colour.

130. Merlin. Falco asalon, Tunstall.

The merlin is a winter migrant, never remaining to breed, but not uncommon near the coast, where it has been shot as early as the first week in September. Its small size enables it to be easily recognized.

\section{I3I. Red-footed Falcon. Falco vespertinus,} Linn.

The only record of this very rare southern species is that of one shot at Somerleyton in
July, 1862, which was for many years in the late Mr. H. Stevenson's collection.

\section{Kestrel. Falco tinnunculus, Linn.}

The kestrel like the owls is supposed to be protected by law throughout the year in west Suffolk, but (also like the owls) is often shot by those who ought to know better. It is the most common of all the hawks, breeding throughout the county, frequently in church towers, but also in hollow trees and old nests of other birds. Its richly-coloured eggs can hardly be mistaken for those of any other bird nesting in Suffolk, and the young birds, which are easily reared, make delightful pets, becoming almost as tame as jackdaws, but if allowed perfect liberty the migratory instinct calls them southwards in early autumn. The food of the kestrel consists chiefly of mice, and the damage it is often accused of doing to young game if not imaginary is greatly exaggerated. The lesser kestrel ( $F$. cenchris) has not yet been found in Suffolk, and can be identified by its small size and white claws.

\section{Osprey. Pandion haliaëtus (Linn.)}

A rare spring and autumn visitant, more often occurring near the coast than inland. Several have been shot on Breydon, two of which are in the Bury Museum, and two or three near Aldeburgh, one of which, shot near Thorpe Haven in October, 1874 , is in the museum at Ipswich. The bold contrast of dark brown above and white below in the osprey's plumage, and its extent of wing, which often exceeds five feet, combine to render it an easy bird to recognize.

\section{Cormorant. Phalacrocorax carbo (Linn.)}

The often-quoted record of Mr. Lubbock (Fauna of Norfolk, ed. 1879, p. I 73) that 'cormorants have in some seasons nested in the trees around Fritton decoy in some number ; in other years there has not been one nest' must once more be cited, and from a note in the Birds of Norfolk (iii. 288) the date appears to be about 1825 . The cormorant is now only a visitant, usually in late summer and autumn.

\section{Shag or Green Cormorant. Phalacro- corax graculus (Linn.)}

A visitant much rarer than the cormorant, and a more strictly marine species, never known to have nested in the county. In December, 1900, one was shot when perched on the roof of a house at West Stow near Bury, which is quite thirty miles from the sea. 


\section{BIRDS}

136. Gannet or Solan Goose. Sula bassana (Linn.)

A rare autumn and winter visitant to the coast, sometimes driven inland by rough weather. Most of those obtained have been young birds in the spotted plumage, and an old white bird is quite a rarity.

\section{Common Heron. Ardea cinerea, Linn.} Locally, Harnser or Heronshaw.

From a fancied resemblance of its cry to the word, the heron is often alluded to as 'Frank' or 'Old Franky.' It is a resident having several colonies in the county, of which those at Orwell Park near Ipswich and Blackheath on the river Alde were the largest. Recent inquiries have elicited that both these heronries are sadly diminished, as in 1902 neither had more than about six nests. In 1893 and 1894 the herons at Blackheath were much disturbed by rooks, which persistently sucked the eggs and left the ground under the trees strewn with shells (Rev. F. C. R. Jourdain). These two seasons were unusually dry and the rooks possibly had difficulty in obtaining food. There are however more recently established but flourishing heronries at Broke Hall near Ipswich and at Walberswick, both of which may be offshoots from the older ones. Herons formerly bred at Herringfleet, but not for many years past, though there is a fine heronry at Reedham, just over the Norfolk border, where the birds are strictly protected (Col. Leathes). There were sixteen nests in April, 1903, at Flixton Hall near Bungay, where the herons are also well looked after (Sir Fredk. Adair). In west Suffolk there is one at Cavenham (Rev. E. A. Jones) and in 1902 a few pairs nested at Chimney Mills near Bury on the Culford estate (Mr. L. Travis). In winter herons are scattered all over the county, too often to fall victims to the prowling gunner, and are sometimes seen displayed as 'show-birds' in the game shops. In west Suffolk the heron is protected under the Wild Birds' Protection Act and also its eggs, so it is to be hoped that so fine and interesting a bird will always hold its own and never be numbered among the 'extinct breeders.'

\section{Purple Heron. Ardea purpurea, Linn.}

A rare visitant, hitherto only recorded from the eastern side of the county and usually in autumn. Those which occur are in most cases young birds which have probably gone astray when migrating from their breeding grounds in Holland. A fine pair in the Ipswich Museum were brought in the flesh to a bird-stuffer in that town (Babington), but it does not follow as a matter of course that they were killed in Suffolk or even in England.

139. Squacco Heron. Ardea ralloides, Scopoli.

A very rare summer visitant, of which the only record for perhaps half a century is that of a female shot in Thorpe Mere near Aldeburgh on 14 June, 1882. $\mathrm{Mr}$. Hele had it in the flesh and writes, 'It had been feeding on the Pandalus annulicornis or grey shrimp, also small eels. It was in most perfect plumage. The ovary contained impregnated eggs ' (Notes about Aldeburgh, ed. 1890, p. 82).

140. Night-Heron. Nycticorax griseus (Linn.)

A rare visitant which has been obtained a few times, the last occurrence being in June, 1883 (Babington).

141. Little Bittern. Ardetta minuta (Linn.)

Several little bitterns have been shot in the county, and many more may have come and gone without being noticed, as its small size and habit of frequenting reed-beds often enable it to escape observation. Most of those recorded have been summer visitants, and there can be little doubt as to its having formerly bred in the eastern counties.

\section{Bittern. Botaurus stellaris (Linn.)}

Though eggs of the bittern were taken in Norfolk as recently as 1868 there is no positive record of its having bred in Suffolk, but it was probably a resident both in the fenland near Mildenhall and also in the vicinity of Lowestoft. Hardly a winter passes without one or more being shot, and like other winter migrants they are much more numerous in some seasons than in others. Early in February, 190r, a bittern was caught by a dog at Ampton and conveyed to the Zoological Gardens, but it soon died and was returned to the donors, for whom it was preserved by Mr. Travis of Bury. It was a small bird but in beautiful plumage.

143. White Stork. Ciconia alba, Bechstein.

A rare summer visitant which has not been obtained or seen for upwards of thirty years. There is one in the Ipswich Museum shot at Sudborne in 1830 and given by the late Sir Richard Wallace, and one was seen in the meres near Aldeburgh on several occasions in the spring of 1875 .

144. Black Stork. Ciconia nigra (Linn.)

Even rarer than the white stork, but two or three have been recorded. One shot on 


\section{A HISTORY OF SUFFOLK}

Breydon in June, 1877 , was bought at $\mathrm{Mr}$. Stevenson's sale for the Norwich Museum, and Dr. Babington mentions having seen another which was shot at Stoke-by-Nayland in 1881 .

145. Glossy Ibis. Plegadis falcinellus (Linn.)

Only one bona-fide Suffolk specimen of this accidental visitant has been obtained, an adult female shot at Blundeston near Lowestoft in May, 1850 (Birds of Norfolk, ii. 193).

146. Spoonbill. Platalea leucorodia, Linn.

'The platea or shovelard, which build upon the tops of high trees. They formerly built in the heronry at Claxton and Reedham; now at Trimley, in Suffolk. They come in March, and are shot by fowlers, not for their meat, but for the handsomeness of the same ; remarkable in their white colour, copped crown, and spoon or spatule like bill.' 'This most interesting note of the Norfolk naturalist Sir Thomas Browne is quoted by the author of the Birds of Norfolk (ii. 184), who assigns to it the date of 1688 . The spoonbill is now by no means one of the rarest spring and summer visitants, and its pure white plumage and long legs make it a conspicuous bird. In the 'sixties' and 'seventies' it was frequently seen about the river and meres near Aldeburgh, and the Hele collection at Ipswich possesses two local specimens. In the Zoologist for I $90 \mathrm{I}, \mathrm{Mr}$. Patterson was able to write from Yarmouth : 'Scarcely a day has passed since early April to this day of writing (June 2Ist) but what one or more spoonbills have been in sight on Breydon. First one was seen on April Ioth, twelve on April 27 th, and five more next day - seventeen in all ! Seven observed on May 7 th ; I saw two on May I6th quite near my houseboat, and I sailed up to a couple on May 17 th.' No bird has profited more by the watchful oversight now exercised on Breydon than this, as it can be seen through the watcher's glass a mile or more away. These and other spring visitants probably reach Breydon viâ Suffolk.

I 47. Grey Lag-Goose. Anser cinereus, Meyer.

Though this is the only goose breeding in the British Islands, and the only one known ever to have done so, it is in Suffolk the rarest of the four grey geese and quite an uncommon winter visitant. In September, 1870, three frequented the meres near Aldeburgh and associated with the geese kept by the cottagers at Thorpe. One of them was shot and proved to be a very fine old gander slightly marked with black on the under parts (Ipswich Museum).

\section{White-fronted Goose. Anser albifrons} (Scopoli)

A rather uncommon winter migrant, though Mr. Hele mentions that in the winter of $1870-1$ enormous 'skeins' visited the Aldeburgh neighbourhood. Some of the old birds are very richly marked with black on the breast and belly, and like the grey laggoose this species has a white nail on the tip of the beak.

149. Bean-Goose. Anser segetum (J. F.
Gmelin)
This is the common 'wild goose' of Suffolk, and a flock seen flying over in west Suffolk during the winter may safely be said to be bean-geese. 'On some of the farms near the coast and river at Sudbourne and Gedgrave wild geese came in such numbers to feed on the young growing corn that the farmers had to employ boys to scare them away. One farmer used to have yarn stretched between sticks all over the fields frequented by them. This was probably about sixty years ago and my father recollects it well' (G. T. Rope). The rearing of geese on a large scale was formerly a recognized industry in East Anglia, and in 1902 more than a thousand geese brought over from Holland when quite young were turned down on some fields at Tostock, many of which showed plain traces of bean-goose ancestry.

\section{Pink-footed Goose. Anser brachyrbyn- chus, Baillon.}

Next to the bean-goose, which it resembles in having a black nail on the beak, this is the most common grey goose, being in some years the more abundant of the two. It is of course a winter migrant, and at Aldeburgh has been seen in flocks of eighty or a hundred in the marshes south of the town (C. C. Clarke in litt.).

\section{Barnacle-Goose. Bernicla leucopsis (Bech- stein)}

A decidedly rare winter visitant of which two were obtained in the river near Aldeburgh 20 September, 1887 (Hele). This is an unusually early occurrence.

\section{Brent Goose. Bernicla brenta (Pallas) \\ Locally, Prussian Goose or Brant.}

In hard winters this marine goose is quite abundant, though it is never obtained in the same numbers as in Essex. It has been noticed on migration from the Corton lightship as early as July (Zoologist, 1880, p. 184). 


\section{BIRDS}

The omission of the Canada goose and of the Egyptian goose has been already explained.

\section{Whooper Swan. Cygnus musicus, Bech- stein.}

$1870-1$ and $1890-1$ were both great 'swan years,' in the former of which more than twenty whoopers were shot near Aldeburgh, and in the latter a good many were obtained. One gunner shot five in the river Alde at one discharge of his punt gun, and another shot three swans, of which the species was not recorded, at one shot with a shoulder gun. A fine old cock whooper will often turn the scale at over $20 \mathrm{lb}$. and there seems always to be a sale for swans of any kind in the London market. Probably all are utilized for food in some form or other.

\section{Bewick's Swan. Cygnus bewicki, Yar- rell.}

This bird shares with the whooper the popular name of 'wild swan,' and though not so common as its larger congener, when whoopers arrive in unusual numbers Bewick's swan may always be expected. An adult in the Tostock rectory collection was shot in the river Alde as late as March, I89I, and before it was skinned the bright yellow of the bare skin round the eyes (technically called the orbit) was very conspicuous. Bewick's swan is a much smaller bird than the whooper, and ${ }_{3} \mathrm{lb}$. is a good weight even for an old male.

155. Mute Swan. Cygnus olor (J. F. Gmelin)

Though many mute swans stray from private waters and lose their lives $\mathrm{Mr}$. Saunders has suggested (Manual, p. 417) that it does not follow that all which are shot are escaped birds, "for the mute swan still breeds in a perfectly wild state at no greater distance from us than Denmark and the south of Sweden, whence it is forced by cold to migrate in winter.' These countries it may be pointed out are a good thousand miles nearer the east coast of England than any known breeding-place of Bewick's swan. Swan-breeding has never been carried on in Suffolk on so large a scale as in Norfolk, and the fattening of cygnets for the table has not often been attempted. The late Rev. W. G. Tuck, who as a Norfolk man well knew the edible value of the swan, had one or two young ones fattened and killed in the early 'sixties,' and though the experiment was entirely successful from an edible point of view it was hardly so as a matter of expenditure and result.
156. Common Sheld-Duck. Tadorna cornuta (S. G. Gmelin)

Locally, Burrow-Duck.

This fine wildfowl is a resident breeding in rabbit holes in several localities near the coast, though the birds which remain all the year are few in number compared with the winter migrants. Of these Mr. Hele says (Notes about Aldeburgh, ed. 1870, p. I51): 'Almost every winter many shieldrakes visit us, they fly together in large flocks, and most beautiful they appear. The white of the wings reminds one strongly of a patch of the purest possible snow having fallen upon their backs.' Being entirely shore and mudfeeders they are utterly valueless for the table, and it is a pity to shoot such interesting and ornamental birds unless they are required as specimens. The eggs, which are white and glossy, are sometimes as many as twelve in number, and the drake and duck are much alike.

\section{Ruddy Sheld-Duck. Tadorna casarca (Linn.)}

Till 1892 a single bird shot in the mere near Aldeburgh in July, 1886, was the only Suffolk specimen of this rare south-eastern duck, but in the summer of 1892 a remarkable migration occurred of which Mr. F. M. Ogilvie has given full details in the Zoologist for that year (pp. 392-8). Three more were then shot in the meres near Aldeburgh and others seen, but there is no record of any having been obtained or even observed since that date.

\section{Mallard or Wild Duck. Anas boscas, Linn.}

Locally, Wild Duck, Grey Duck.

A resident throughout the county, breeding in marshes, on heaths, and occasionally in a place as high and dry as the head of an old pollard tree. The resident birds pair in February and often have eggs in March, and these should be spared after 10 February at the latest. Many 'foreigners' come over in winter, which are smaller and slimmer birds than the resident race. At least three decoys are still worked in Suffolk, of which one is at Fritton Lake near Lowestoft and another at Iken near Aldeburgh. In the former 2,765 fowl were taken in the season of $1900-1$ and about half that number in the following year, but some sixty years ago when decoys were worked at both ends of the lake the numbers were from twelve to fifteen thousand annually (Col. H. M. Leathes). The present owner of the Iken decoy (Mr. A. H. E. 


\section{A HISTORY OF SUFFOLK}

Wood) has kindly furnished details of the number of fowl taken from I878-9 to I $901-2$, the total for the twenty-four seasons amounting to 43,318 , which includes fowl shot on the estate and adjoining tidal waters. Of the total 20,382 were wild ducks, 17,169 teal, and 5,464 wigeon, the balance being made up of 'various.' The number of fowl in the season of $1902-3$ was 3177 , which beat the previous record of 2,964 in $1899-$ 1900 (A. H. E. W. in litt.). The third decoy is on the Orwell Park estate near Ipswich, and yields an average of about 2,000 fowl in a season.

159. Gadwall. Anas strepera, Linn.

This game-duck breeds regularly in Norfolk but the nest has not yet been found in Suffolk, though in May, 190I, a clutch of ten eggs was taken near Diss within a mile of the boundary river and put under a hen. In Suffolk it is a rather uncommon winter migrant. During a short period of hard weather in February, 1902, a female was shot at Bardwell and preserved by Mr. Travis of Bury. The gadwall can be recognized by its yellowish legs and white wing-spot.

160. Shoveler. Spatula clypeata (Linn.)

For beauty and variety of colouring the shoveler drake is excelled by no British waterfowl. This bird is a resident and 'about ten or twelve couple breed annually in one district in east Suffolk where I have seen four or five nests. Sometimes they are to be found among dead reeds : at other times high up on commons among gorse and bracken and right away from water. One nest contained eleven shoveler and three pheasant eggs' (Rev, F. C. R. Jourdain). The broad bill is a distinguishing mark of this bird in any plumage.

\section{Pintail. Dafila acuta (Linn.)}

Locally, Sea-Pheasant.

A winter migrant sometimes arriving in September and occasionally remaining as late as I3 May (Zoologist, 1875, p. 4536), but never breeding in England.

162. Teal. Nettion crecca (Linn.)

A resident which "breeds in fair numbers in east Suffolk. I have seen the nest in woods as well as on the commons' (Rev. F. C. R. Jourdain). $\quad 1879-80$ was a great teal year, and 1,661 were captured or shot at Iken out of a total of 2,846 fowl (A. H. E. Wood).

163. Garganey. 2uerquedula circia (Linn.)

This summer migrant is now so rare that the local name of 'summer-teal' is practically obsolete. In the 'seventies' Mr. Hele found it breeding in the marshes near Aldeburgh, and $\mathrm{Mr}$. G. T. Rope in the reedland at Leiston (Zoologist, 1874, p. 4036, for details of the latter), but there are no more recent records. In 1872 several young birds were shot near Aldeburgh during August, and there are one or two local eggs in the Ipswich Museum. The duck in hand can be distinguished from the teal by the absence of the bright green wing-spot.

\section{Wigeon. Mareca penelope (Linn.)}

A common winter migrant of which many are taken in the decoys and also shot. The record of wigeon in the Iken decoy was 771 in 1900-1 (A. H. E. Wood). They have been seen paired in the Aldeburgh meres in May, and Mr. Hele thought they occasionally bred, having once had a duckling brought to him still partly in the down, but it is perhaps possible that this may have been a gadwall.

\section{Red-crested Pochard. Netta rufina} (Pallas)

A very rare visitant from the south of which Dr. Babington records one perfectly satisfactory specimen shot at Easton Broad by Mr. Spalding 'some years before 1 864.' It was a drake in full plumage, and at $\mathrm{Mr}$. Spalding's sale was secured by the late Mr. H. Greenwood (Catalogue, p. 245).

\section{Pochard. Fuligula ferina (Linn.)}

A winter migrant sometimes plentiful enough and believed to have nested once at least near Aldeburgh (Hele). Some eggs were taken and from them were hatched ducklings with very large feet, but they died and were not preserved. 'I have seen a few in the spring with other duck and believe them to breed, though I have not found the nest' (Rev. F. C. R. Jourdain).

\section{Ferruginous Duck. Fuligula nyroca (Güldenstädt)}

A rare visitant which has only been obtained a few times in Suffolk and not very recently.

\section{Tufted Duck. Fuligula cristata (Leach)}

This is a bird whose nest, like that of the pochard, could probably be found if searched for, as it breeds abundantly in Norfolk and its range as a resident species is extending throughout the country. As a winter migrant it is very well known on the coast and in the rivers. 


\section{BIRDS}

169. Scaup-Duck. Fuligula marila (Linn.)

A sea-duck seldom met with inland, never breeding in England and only very rarely in Scotland, but common enough on the coast in winter. The name is probably derived from its feeding on mussel 'scalps.'

x 70. Goldeneye. Clangula glaucion (Linn.) Locally, Goldeneye Daver (= Diver).

A winter migrant of which young birds and females are not uncommon, but a good old drake is quite a rarity.

\section{7x. Long-tailed Duck. Harelda glacialis} (Linn.)

A rather irregular winter migrant of which Mr. Hele states that it 'has occurred in flocks during excessively cold winters.' An old drake in summer dress was obtained near Orford about 23 July, 1872 (Ipswich Museum), in which plumage it is extremely rare in Britain.

172. Common Eider Duck. Somateria mollissima (Linn.)

A rare winter visitant, but one which will perhaps be more often met with in East Anglia now that its breeding grounds on the Farne Islands are so strictly protected. The very rare king-eider (S. spectabilis) has been obtained more than once in Norfolk, and if all eiders killed in Suffolk are examined by a competent authority it may sooner or later be recognized. It is a slightly smaller bird than the common eider.

173. Common Scoter. Edemia nigra (Linn.)

This winter migrant is an essentially marine bird and very rarely seen inland. A few, which are probably birds which have not begun to breed, are sometimes observed flying alongshore in the summer months. In July, I89I, large flocks were attracted to Sizewell Bank to feed on the barley washed out of a steamer sunk there (F. M. Ogilvie in Zoologist, 1892, p. 109).

\section{Velvet-Scoter. Edemia fusca (Linn.)}

Though much less frequent than the lastnamed species young velvet-scoters are not uncommon in winter, but old drakes in the handsome adult plumage are scarce. A very perfect one was shot at Cockfield, which is quite twenty-five miles from the sea, 26 November, 1892. The colouring of the legs and beak was very bright.

175. Goosander. Mergus merganser, Linn.

Females and young birds are not uncommon winter migrants, but a perfect male is always a prize and an ornament to any collection.

\section{Red-breasted Merganser. Mergus ser- rator, Linn.}

Locally, Saw-bill or Saw-bill Daver.

This species shares with the goosander the local name of 'saw-bill,' and the same remarks apply to it, though it is perhaps the more common of the two.

177. Smew. Mergus albellus, Linn.

A rare winter visitant, which occurs as a rule only in very severe winters. A fine drake was shot near Ixworth during the frost of 1890-1. The Ipswich Museum (Hele collection) possesses splendid old males of this and the three last-named species, all obtained at or near Aldeburgh in 1870 and $187 \mathrm{I}$.

\section{Ring-Dove or Wood-Pigeon. Columba palumbus, Linn.}

A common resident breeding twice if not three times in the year, and often appearing in enormous flocks in winter. Many are shot by waiting for them in 'dow-houses' (dove is usually 'dow' in Suffolk), which are huts roughly constructed of boughs in which the shooter waits for the birds as they come to the woods for the acorns and beech-mast. On 9 February, 1903, a man was shooting them in this manner near Ipswich and killed a fine young white-tailed eagle which flew down on a dead bird set up as a decoy (Zoologist, 1903, p. 107). In the Newmarket neighbourhood wood-pigeons swarmed in December, 1902, and a local paper stated that a punt gun was brought to bear on them so effectually that in one case nineteen were killed at a shot. These great flocks probably come from Scandinavia, as they have been seen crossing the North Sea, and there is a record of one having been killed by striking a lighthouse at Orford (Migration Report for 1884 , p. 59).

\section{Stock-Dove. Columba anas, Linn. \\ Locally, Stock-Dow.}

A resident never seen in flocks like the ring-dove, but more numerous now than in former years. It derives its name from its habit of nesting in the 'stocks' or trunks of hollow trees, but it also breeds freely in rabbit burrows on the warrens and sometimes in church towers. The eggs, smaller and more creamy-white than those of the ring-dove, have been found as early as April and as late as September. A nest with two almost fresh eggs was found in the tower of Tostock church, 26 August, 1900. The smaller 


\section{A HISTORY OF SUFFOLK}

size and entire absence of white in the plumage distinguish this bird from the ringdove, and it does not ' coo,' but utters instead a singular grunting note.

I 80. Turtle-Dove. Turtur communis, Selby.

A summer migrant arriving about May Day and easily encouraged by feeding. For some years past they have come daily to the garden at Tostock rectory in the summer months, feeding on maize thrown down for the tame pigeons, and though they do not pass the winter north of the Mediterranean there can be little doubt that the same birds return to their old haunts year after year. They are very fond of salt, and when seen in kitchen gardens they come there with no worse intent than to peck about on the saltimpregnated soil of the asparagus beds. The beauty and harmlessness of this bird well merit the protection ordered in west Suffolk both for itself and its eggs.

181. Pallas's Sand-Grouse. Syrrhaptes paradoxus (Pallas)

Suffolk was visited by this Asiatic species both in the immigration of 1863 and the second and much larger one in 1888. Mr. Hele records (Notes about Aldeburgh, ed. I 890 , p. 79) that on $28 \mathrm{May}, 186_{3}$, seven were seen to come in from the sea, which alighted on the shore at Thorpe. A female (Ipswich Museum) was shot and brought to him, and many others were afterwards seen. Dr. Babington (Catalogue, pp. 236-8) has given a very careful record of the first visitation with illustrations of a cock and hen. The pioneers of the second visitation appeared in Suffolk about the end of May, 1888, when one was obtained at Mildenhall and another picked up on the beach at Lowestoft. Several were shot near Aldeburgh, some of which were taken to $\mathrm{Mr}$. Hele, and a fine pair in the Tostock rectory collection were kindly sent by him in the flesh. The birds soon spread all over the county, and many passed on to the midlands. Some remained till the end of the year, but no attempt at breeding appears to have been made in Suffolk. In 1889 "there was a beautiful single male Pallas's sand-grouse killed at Thorpe Haven the very end of January. It was peculiarly marked about the breast, being very dark. "The primaries of the wings and elongated feathers of the tail were most perfect. The bird weighed thirteen ounces. I should say about the best example obtained ' (N. F. Hele in litt.). Dr. Babington died in January, I 889 , having been for some time in failing health, which prevented him from going thoroughly into the visitation of $\mathbf{I} 888$, and perhaps the last addition to his fine collection of birds was a male of this species shot at Lowestoft I 3 June, I888. It is impossible to give any idea of the number visiting the county or of those killed, but a local paper stated that on 27 August a flock of two or three hundred birds passed over Eriswell, and it is pretty certain that all those which were shot were not recorded.

182. Pheasant. Phasianus colchicus, Linn.

Though thousands of pheasants are annually reared and shot in Suffolk, it would now be a difficult matter to obtain a specimen of the pure old English form. The great majority of cocks show more or less of the white ring on the neck derived from the Chinese $P$. torquatus, and as the Japanese pheasant and Reeves' pheasant have also been turned down in various places, cross-bred birds in great variety have been shot. Pied or even white varieties are common enough, and about the end of 1898 two hybrids between the pheasant and common fowl were sent to Bury to be preserved. Colonel Butler records (Zoologist, I901, p. 477) a black grouse and pheasant hybrid shot near Woodbridge, and it seems hardly needful to add that the presence of the black grouse in Suffolk is due to some having been turned down.

\section{Partridge. Perdix cinerea, Latham.}

Suffolk has long been regarded as a stronghold of this favourite game bird, which is often spoken of as the 'pattridge.' They are expected to be paired by Valentine Day and to have hatched by Midsummer Day. Varieties of plumage occur from time to time.

\section{Red-legged Partridge. Caccabis rufa} (Linn.)

Locally, French Partridge or Frenchman.

Towards the close of the eighteenth century these birds were introduced into England 'by the Marquis of Hertford and Lord Rendlesham, each of whom had eggs procured on the Continent, carefully brought to England, and placed under domestic fowls; the former at Sudbourn, near Orford in Suffolk, one of his shooting residences; the latter on his estates at Rendlesham, a few miles distant from Sudbourn. From these places the birds have been gradually extending themselves over the adjoining counties' (Yarrell, ed. 4, iii. I I6). The 'Frenchman' is now dispersed all through the county, and is perhaps as common in the neighbourhood of Diss as anywhere. Young birds of this species in 


\section{BIRDS}

the speckled plumage have often been mistaken for hybrids with the common partridge.

\section{Quail. Coturnix communis, Bonnaterre.}

A rather irregular summer migrant, more plentiful in some years than in others. The nest has been occasionally found.

\section{Corn-Crake or Land-Rail. Crex pra-} tensis, Bechstein.

In Suffolk people usually shoot the 'landrail ' but hear the 'corn-crake,' as the latter name appeals more to the ear. This bird is a rather late summer migrant, nesting in meadows and cornfields, where it makes its presence known by its oft-repeated 'crakecrake.' Comparatively few people know it by sight, and a beautiful specimen which struck the telegraph wires near Bury in May, I90I, was a puzzle to a gang of railway workmen, not one of whom could name it.

187. Spotted Crake. Porzana maruetta (Leach)

One or two pairs may nest in the county still, but this bird is chiefly an autumn visitant. Mr. G. T. Rope has found it nesting at Leiston, 'where in the marshes on the Lower Abbey Farm there was a large reed-bed or "reedland," since drained and done away with. The Spotted Crake bred there in 1872 and my brother and $I$ found the nest, or more strictly speaking our dog found it. The young were on the point of hatching and an addled egg and a drawing of one of the chicks were sent to the Field office' (G. T. R. in litt.). In the summer of 1866 the naturalists at Aldeburgh were much perplexed by the call of a bird repeatedly heard in the mere nearest the town, and there is little doubt that the 'weet-weet' was produced by the spotted crake (Hele).

188. Little Crake. Porzana parva (Scopoli)

A very rare visitant, which has doubtless often escaped notice from its small size and skulking habits. One was killed on Oulton Broad in 1830 , which Dr. Babington considered the "only one which can with certainty be counted on as having occurred in Suffolk.'

\section{Baillon's Crake. Porzana bailloni (Vieillot)}

The records of this rare visitant do not appear to be very satisfactory or very recent, but as Dr. Babington has admitted its claim and Mr. Saunders states that 'Baillon's crake has occurred in Suffolk' (Manual, p. 513) it is included here, especially as there are several good records from Norfolk, and it is believed to have nested in that county. It may be roughly described as a very small spotted crake.

190. Water-Rail. Rallus aquaticus, Linn.

A resident breeding in marshes and reedbeds, but not common except in winter, when the numbers are increased by the arrival of migrants.

I91. Moor-Hen. Gallinula chloropus (Linn.)

A common resident, also known as the water-hen, breeding on the edges of lakes, rivers and ponds, and even in ditches, where its nest may be found from early in April till late in June, as it rears two broods in a season. During a flood in the Norton meadows in June, 1902, which must have destroyed many hundreds of eggs, a sitting moorhen raised her nest and eggs with sedge and reeds to a height of about 18 inches above the original site of the nest and kept them high and dry. In a long frost these birds suffer severely, and in the intense frost of February, 1895 , some were found dead at Tostock in rabbit burrows into which they had evidently crept for shelter.

\section{Coot. Fulica atra, Linn.}

A resident far less common than the moorhen but breeding both in marshes near the sea and on inland waters. Bartonmere, before it had shrunk to its present condition, was a favourite haunt, and in I90I several pairs nested on Drinkstone Park water. 'There are a few women in the town who are regularly employed to prepare the coot for cooking. It appears the down under the feathers is so close and thick as to necessitate its removal after the bird is plucked. This is done by first rubbing the surface with powdered resin, afterwards dipping the entire body into hot water. By this means the resin becomes dissolved and mingling with the down allows it to be removed with tolerable ease' (Hele, Notes about Aldeburgh, ed. 1890 , p. 86).

\section{93. Crane. Grus communis, Bechstein.}

Though it is quite possible that the crane may have bred in the fens of Suffolk long ago there are only two records of its occurrence in recent times, both of them in the Lowestoft district. One was shot at Kirkley in a barley field in April, 1845 (Babington, Catalogue, p. 157), and the other at Benacre in the last week of June, 1893 , which was preserved for Sir Alfred Gooch by Mr. Bunn of Lowestoft. 


\section{A HISTORY OF SUFFOLK}

\section{Great Bustard. Otis tarda, Linn.}

Much has been written on the great bustards of Suffolk, but as this fine old county family became extinct about 1830 it is pretty certain that there is no one now living who can claim a personal acquaintance with them, and $a$ writer in the twentieth century must fall back on information previously published. The history of the Norfolk and Suffolk bustards has been most carefully recorded in the Birds of Norfolk (i. I-42, and iii. 396407), and Dr. Babington (Catalogue, pp. I I I-3) has taken great trouble to preserve a record of the occurrences in this county. This superb game bird had its headquarters in the north-west on the warrens or brecks about Elveden, Eriswell and Icklingham. Mr. W. Bilson, for many years a bird-stuffer at Bury, who was born in 1808 and died in I 894, well remembered the Icklingham bustards, and on one occasion saw as many as six at once. This would probably be about I824. Only four specimens of the old native race seem to be in existence, and none of them remain in the county. There is one in the Cambridge Museum from Icklingham; one in the Norwich Museum obtained at Elveden in 1815 ; one in the collection of Mr. Lucas of Burgh in Norfolk, killed at Eriswell about 1829 ; and one was for many years at Riddlesworth Hall, which was killed at Cavenham, and at the Riddlesworth sale in I 894 passed into a private collection. All these are females. Dr. Babington mentions also the particulars of four Suffolk eggs which were intact when he wrote in 1886 . After the old race had become extinct Suffolk remained for about forty years unvisited by bustards, but in January, 1876, a fine male appeared at Feltwell in Norfolk, where he remained for a month and was subsequently seen at Eriswell and Elveden (H. M. Upcher in Zoologist, 1876, p. 4882, where full details are given). During the winter of $1890-1$ several hen bustards were killed in England, one of them in Mildenhall Fen on 5 February, I891. Mr. Howlett of Newmarket met a fen-man with the bird in his hand and at once purchased it. He mounted it and afterwards sold it to Mr. Walter Rothschild of Tring Park, in whose museum it still remains. An attempt was made some ten years later to re-establish the bustard on the Elveden estate where seventeen birds imported from Spain were turned down. The experiment unfortunately was not successful as the majority of the birds disappeared, and in December, I90I, only four remained, of which one had a damaged wing (J. H. Gurney in Zoologist,
1902, p. 84). Two of the birds strayed to Finningham, where they were shot by a keeper in June, I90I, and though the shooter was prosecuted and fined for killing game out of season the mischief was done. These two birds, a hen and a young cock, were presented to the Ipswich Museum. In the autumn of 1902 one of the four survivors was shot just over the Cambridgeshire border and all hope of the birds increasing was at an end, though a cock and hen were alive and well in April, 1903, of which the hen had laid two infertile eggs in 1902 (Mr. W. Hill).

\section{Little Bustard. Otis tetrax, Linn.}

There is no reason to believe that this bird was ever anything but the rare visitant to Britain that it is now. Nearly all the Suffolk examples have been met with in autumn or winter, but the only one obtained since the 'seventies' is a remarkable exception. This was a fine male shot at Kessingland on 30 May, 1898 , which was in perfect breeding plumage, and in this respect unique as a British specimen. An illustration reproduced from a photograph with details will be found in the Zoologist for $1899, \mathrm{p} .120$.

\section{Stone-Curlew. Edicnemus scolopax (S. G.} Gmelin)

Locally, Culloo or Cullew.

A summer migrant arriving about the end of March and still fairly common in those parts of the county which were once the haunt of the bustard. There are also some on the commons and in the fields adjoining the coast, and in May, rgor, a clutch of eggs was found near Southwold. The two eggs often differ a good deal in shape, one being much rounder than the other, and this was the case with a clutch remarkable for the minute freckles on both eggs found near Mildenhall in 1902. 'Many of the first clutches are broken by harrowing and rolling. It is a curious fact that keepers who have excellent opportunities of observing these birds state that they see them occasionally during every month of the winter' (Rev. F. C. R. Jourdain). One was picked up alive near Bury in November, 1902, apparently nipped by the cold, but it soon recovered and was eventually sent to an aviary in Yorkshire. In January, 1889 , one was shot at Barrow, and as a note made at the time mentions that it was in poor plumage and condition it may have been a wounded bird. This bird is also known as the great plover, Norfolk plover and thick-knee. The large bright yellow eye is very beautiful in the living bird, and indicates the nocturnal habits of the species. 


\section{BIRDS}

197. Cream-coloured Courser. Cursorius gallicus (J. F. Gmelin)

Dr. Babington mentions one occurrence of this very rare straggler to England, stating that one was shot at Friston in 1828 (Catalogue, p. 239).

198. Dotterel. Eudromias morinellus (Linn.)

An uncommon spring and autumn migrant, but it is quite possible that in the plain plumage of the first autumn many have been shot and eaten without being recognized. In the spring of 1880 one in perfect summer dress was brought to Mr. Hele which had 'made a job of itself' (Suffolk for suicide) against the telegraph wires so effectually that it could not be mounted. The dotterel breeds no nearer to Suffolk than the mountains of the English lake district.

199. Ringed Plover. Egialitis biaticula (Linn.)

Locally, Stone-hatch, inland ; Stone-runner, on the coast.

The graceful flight and mellow whistle of this pretty bird must be familiar to every one who has walked along the shingly beaches of Suffolk. It is a resident breeding on the coast and also inland at Barnham, Elveden, Lakenheath and on Thetford Warren. Mr. W. G. Clarke has given (Zoologist, 1897, pp. 502-4) full details of the inland nestingplaces, stating that the birds arrive in March and sometimes have eggs by the end of the month, adding that they leave about midAugust and are said to 'go with the cuckoos.' Young birds unable to fly are sometimes seen in August, which indicates that two broods are reared in the year. A rather smaller form with darker mantle occurs on migration, but the real little ringed plover (E. curonica) has not been recognized in Suffolk.

200. Kentish Plover. Egialitis cantiana (Latham)

A rare spring and autumn migrant, the breeding grounds of which are confined in England to a very limited area on the coasts of Kent and Sussex. It is smaller than the ringed plover and can be identified at any age by its black legs. A very perfect male in the Ipswich Museum was shot near Aldeburgh in June, 1869 .

201. Golden Plover. Charadrius pluvialis, Linn.

A winter migrant often met with inland but rarely remaining late enough to assume its summer plumage. In May, 1891, one was shot at Tuddenham (west Suffolk) with a very perfect black breast, which is still in the possession of Mr. Travis of Bury. Its nearest breeding grounds are on the Derbyshire hills. The lesser golden plover (Charadrius dominicus) has lately been added to the British list, and any one shooting a small golden plover near the coast will do well to obtain the opinion of an expert before consigning it to the larder.

202. Grey Plover. Squatarola belvetica (Linn.)

A typical spring and autumn visitant much more numerous in the latter season. Young birds in first plumage have a yellowish tinge on the back, but the grey plover can be recognized in any plumage by possessing a hind toe. The splendid specimens in the Ipswich Museum were shot near Aldeburgh in 1866 or 1867 .

203. Lapwing. Vanellus vulgaris, Bechstein. Locally, Peewit, Horn-Pie.

A resident breeding in rough meadows, on commons and also on arable land throughout the county. In the very early spring of 1894 a full clutch of eggs was found at Tostock on 30 March. Many eggs are taken for eating, but if the first nest is safely hatched only one brood is reared. Early in July the Suffolk-bred birds congregate in flocks, and there are large additions of ' foreigners' in late autumn, of which there are many records from lightships and lighthouses.

204. Turnstone. Strepsilas interpres (Linn.)

A spring and autumn migrant and a bird easily recognized from its black and white plumage. The young birds begin to arrive in August and are sometimes so tame that they will allow a shore-shooter to walk almost up to them. The turnstone frequents the beach and is often seen feeding quite close to the tide-line. Dr. Babington had no records from west Suffolk.

205. Oyster-catcher. Hamatopus ostralegus, Linn.

Locally, Olive (Rev. F. C. R. Jourdain); Mere-Pie.

The great flocks of oyster-catchers which frequent the shores of the Wash are unknown in Suffolk, though Mr. Hele says that they were 'formerly much more abundant than now and used to breed in large numbers about the mere-land at Thorpe.' No eggs came into his possession between 1860 and 1890 , when in the second edition of his book he wrote of the once abundant birds: 'A few of these are generally to be found during May, both at Thorpe and about the river side,' referring to those which occurred on migration. In 


\section{A HISTORY OF SUFFOLK}

I 89 I the present writer classed the oystercatcher with the extinct breeders, but on 3 June, I893, the Rev. F. C. R. Jourdain found a nest on the Suffolk coast with three eggs just hatching, and on 5 June saw a pair evidently breeding on one of the rivers, adding that in 1894 they were certainly breeding again on the shore, and that a boy told him he had more than once found the nest of the 'olive,' as he called it (F. C. R. J. in litt.). This is an interesting case of birds returning to old breeding grounds, and this handsome species may perhaps be described as a resident though very scarce and local.

\section{Avocet. Recurvirostra avocetta, Linn.}

This bird has been extinct as a breeder in the British Islands for more than half a century, but Mr. Hele was able to write in $\mathbf{1} 870$, 'I have been informed by a trustworthy old gunner since dead that he could distinctly remember this species, called by the local name of the awl-bird, breeding not infrequently in the mere-lands at Thorpe.' The death of the informant must have taken place some time between 1859 and 1870 , and he might have been a bird-nesting boy at any time between 1800 and 1820 , so it seems reasonable to believe that the avocet continued to breed in Suffolk as long as it did in Norfolk, where it is known to have bred till about I 822 or I824. There could hardly have been a place in England better suited to its habits than the mere and fen at Thorpe before the railway was made and when all the district was quiet, but there were probably other places both north and south of Thorpe in which it bred. Mr. T. M. Spalding about 1846 wrote of the avocet, 'Now very rare; has been killed at Orford and Easton Broad.' The avocets which bred in Suffolk were undoubtedly summer migrants, and when any occur now they usually appear in spring. A pair visited the old haunts at Thorpe in April, I 878 , of which the hen was shot, and on 4 May, 1887, five out of a flock of six were shot on Breydon, where they now have the benefit of careful protection.

\section{Black-winged Stilt. Himantopus candidus, Bonnaterre.}

There is a rather ancient specimen of this bird in the Bury Museum (Dennis collection) said to have been 'shot at Orford but not known in what year.' Mr. Dennis was so careful to preserve full 'data' of the birds he stuffed that such a rare bird would have all particulars affixed to the case, and he probably bought it already mounted. In the Zoologist for 1875 (p. 4634) Mr. Stevenson records one shot in July of that year on Outney Common near Bungay, and if the locality is correct this bird was killed just within the Suffolk boundary. Dr. Babington mentions one or two more shot 'at Yarmouth' or 'on Breydon' many years ago (Catalogue, p. 239).

\section{Grey Phalarope. Phalaropus fulicarius} (Linn.)

Not very uncommon on the coast as an autumnal visitant, but never met with on its northward journey in spring. In winter plumage it rather resembles the sanderling at the same season, but is easily recognized by the lobed membranes of the feet.

\section{Red-necked Phalarope. Phalaropus byper- boreus (Linn.)}

Though this species breeds in Orkney and Shetland, and the nearest breeding grounds of the grey phalarope are in Iceland, it is much the rarer of the two in Suffolk, and years often pass without its occurrence. Mr. Hele had to wait twenty years before a specimen came into his hands.

\section{Woodcock. Scolopax rusticula, Linn.}

A woodcock's nest in Suffolk is quite a rare thing, but Dr. Babington (Catalogue, p. 146) mentions ten places where it is believed to have bred once at least. To these may be added Monk's Wood at Bradfield, where four young ones were hatched early in April, 1897, and three eggs taken in the following year, and Rattlesden, where there was a nest with four eggs in 1900. But the bird is practically a winter migrant, arriving about the middle of October. In October, 1865 , one struck the weather-vane on St. Mary's Church at Bury and was picked up under the tower with the neck torn open. Woodcocks have been seen at Aldeburgh on several occasions coming in over the sea, usually directly against the wind, and after the fatiguing effort of the migration flight have been known to drop into gardens or even on the bare shingle under cover of a fishingboat (Hele). In Suffolk as elsewhere they vary a good deal in colour and size, and a small red bird shot at Tostock in December, 1893 (rectory collection) weighed barely Io oz., while a large dark specimen will often run up to $13 \mathrm{oz}$. or more. The woodcock usually rises in silence, but one flushed at Tostock on 17 March, 1894, uttered a cry like 'cack-cack-cack.' It is an early breeder and even in Scotland often has eggs in March. 


\section{BIRDS}

211. Great Snipe. Gallinago major (J. F. Gmelin)

The solitary snipe, as this bird is often called, is an autumnal visitant usually appearing in August and September, but never remaining through the winter and very rarely occurring in spring. Mr. Bunn of Lowestoft has more than once picked up a specimen in the game shops there, and dozens have doubtless been shot and eaten. Mr. Hele once shot in the dusk at something running on the ground in the marshes just south of Aldeburgh and picked up a great snipe.

\section{Common Snipe. Gallinago caelestis (Frenzel)}

A resident which sometimes has eggs in March. Many of the early nests are destroyed when the meadows are rolled, but the hen soon lays again, and the same bird has been known to lay three full clutches of four eggs in a season. The fresh eggs are often very handsomely marked but vary a good deal both in size and colour. A clutch of five was found at Tostock on 28 May, I 892, from which the bird was flushed, and a sitting snipe will sometimes almost allow herself to be trodden on. The birds which breed as they do in suitable places all over the county return to the same haunts with great regularity, and their arrival is soon announced by the 'drumming' of the cock, which is sometimes heard quite late in the evening when the Easter moon is at the full. Many come as winter migrants, and one at least has been killed by striking the Orford lighthouse.

213. Jack Snipe. Gallinago gallinula (Linn.)

This is the smallest and by far the handsomest of the British snipe and is a winter migrant arriving in September and leaving in March or April. Its nest has never been found in the British Islands.

\section{Broad-billed Sandpiper. Limicola platy- rbyncha (Temminck)}

A very rare visitant from north-eastern Europe which has been obtained on Breydon three times in spring and once in autumn.

\section{Pectoral Sandpiper. Tringa maculata, Vieillot.}

This rare visitant from the other side of the Atlantic has been shot four times near Aldeburgh and always in the autumn. One shot by Mr. Hele is in the Ipswich Museum, and another shot by the present writer in Thorpe Mere 14 September, 1872 , was recorded in the Zoologist for that year (p. 3307) as follows: 'To-day I was lucky enough to shoot a pectoral sandpiper in the north mere. Three birds skimmed past me within a longish shot and I shot at them and killed this one, thinking that they were curlewsandpipers. It is evidently a bird of the year from the light-coloured margins to the feathers; the sex I could not ascertain with certainty owing to the shot marks. The legs and base of lower mandible were light yellowish brown and irides dark brown; the body was loaded with fat. The wind had been blowing rather freely from the west for some days and I fancy that this bird must have been blown over to the coast of Norway or Iceland, and then have joined a flock of knots or curlewsandpipers on their way southward.'

216. Siberian Pectoral Sandpiper. Tringa acuminata (Horsfield)

This is the old world representative of the last-named species, and recently added to the British list, a specimen having been shot on Breydon 29 August, 1892, of which full details are given in the Zoologist for 1892 (pp. 356-8).

\section{Dunlin. Tringa alpina, Linn.}

Locally, Oxbird.

The commonest wader on the coast but never breeding in Suffolk, though it does so regularly in many English counties. The young birds arrive quite early in August and in winter it is sometimes seen in great flocks.

\section{Little Stint. Tringa minuta, Leisler.}

A spring and autumn migrant sometimes rather common. When curlew-sandpipers are abundant this species usually comes in fair numbers, but never in large flocks, and in spring it is always rare.

\section{Temminck's Stint. Tringa temmincki, Leisler.}

Also a spring and autumn migrant, rarer than the little stint. In plumage it much resembles the common sandpiper and has yellowish legs, those of the little stint being black.

\section{Curlew-Sandpiper. Tringa subarquata (Güldenstädt)}

This species is sometimes common enough in autumn, when as many as six have been killed at a shot in the Aldeburgh meres. In the handsome summer dress, which resembles that of the knot at the same season, it is much rarer, but a good many have been obtained both on Breydon and near Aldeburgh. The long down-curved bill from which the name is derived enables it to be recognized in any 


\section{A HISTORY OF SUFFOLK}

plumage when shot, and on the wing the white rump is conspicuous.

221. Purple Sandpiper. Tringa striata, Linn.

An autumn and winter visitant and one of the tamest of the waders on its first arrival. Like the grey phalarope it misses the east coast on its homeward journey in spring and is unknown here in breeding plumage.

\section{Knot. Tringa canutus, Linn.}

Locally, Silver Plover in winter.

The migrations of the knot are much like those of the curlew-sandpiper but it appears in autumn and winter in much larger flocks, and some remain throughout the winter. Its remarkably extensive geographical range has been carefully worked out by Mr. Saunders (Manual, p. 596), but no eggs have ever been found. From the vast numbers of birds which come to England in autumn and winter the nests must abound in some yet undiscovered breeding-place.

\section{Sanderling. Calidris arenaria (Linn.)}

A spring and autumn migrant of which a few remain through the winter. Though the plumage varies a great deal according to age and season it can be always known by the absence of a hind-toe.

\section{Ruff. Machetes pugnax (Linn.)}

The ruff bred in Norfolk till late in the 'eighties' and there can be no reasonable doubt that it bred in Suffolk in earlier times in more than one locality, although no record of its having done so exists. Young birds are not at all uncommon in autumn, and in July, I 872, an adult male was shot near Aldeburgh showing traces of a recently-shed white ruff (Ipswich Museum).

\section{Buff-breasted Sandpiper. Tringites ru- fescens (Vieillot)}

A very rare North American species of which three specimens have been shot on Breydon, the last in 1843 . All three occurrences were in autumn.

\section{Common Sandpiper. Totanus bypoleucus (Linn.) \\ Locally, Summer Snipe.}

This species is not at all uncommon as a spring and autumn visitant, frequenting tidal rivers and dykes in the marshes. Its nest and eggs have once been found in Norfolk, but there is at present no certain proof of its having bred in this county.

227. American Spotted Sandpiper. Totanus macularius (Linn.)

A specimen of this American sandpiper was shot near Mildenhall early in 1869 (Zoologist, I87 I, p. 2684) and stuffed by Mr. Bilson of Bury. Dr. Babington when engaged on his book was unable to trace it and seemed somewhat doubtful about it, but adds in his appendix (Catalogue, p. 276): 'I now believe that there was no reason to question the Mildenhall example.'

\section{Wood-Sandpiper. Totanus glareola (J.} F. Gmelin)

A spring and autumn migrant which has often been obtained in the eastern part of the county especially in the Aldeburgh meres. On 14 June, 1889 , a flock of five was seen in the mere adjoining the North Field (Zoologist, 1889, p. 313).

229. Green Sandpiper. Totanus ochropus (Linn.)

Some birds of this species remain through the winter, and Dr. Babington (Catalogue, p. 132) had records for all months but February, March and November. It is a striking bird on the wing, looking as black and white as an oyster-catcher when flying low over the water, and the very loud shrill note it utters when alarmed is certain to attract attention, and it is a less sociable bird than the wood-sandpiper, being usually met with singly or in pairs. The eggs have never been found in the British Islands, though it is quite possible it may have bred, as its habit of laying in old nests of other birds built in trees was unknown till about fifty years ago. Should the eggs ever be found in England the discovery will probably be made in one of the counties bounded on the east by the North Sea.

\section{Redshank. Totanus calidris (Linn.) \\ Locally, Tu-tu (Rev. F. C. R. Jourdain).}

A resident breeding in marshes near the coast and also in several localities in west Suffolk, but the autumn and winter migrants far exceed in number the resident birds. In its nesting-grounds it is an attractive bird with bold dashing flight and loud mellow whistle, and though the anxiety of the parents may plainly indicate that the eggs are near they are difficult to find, being usually well concealed in a tuft of grass and the hen does not sit very closely. The eggs are often sold as 'plovers' eggs' but are rather smaller and lighter in colour.

231. Spotted Redshank. Totanus fuscus (Linn.)

An uncommon visitant at any time, and in the black summer dress is quite a rarity. One in this plumage was shot at Stanningfield in May, 1871 , and preserved by Mr. Bilson. 


\section{BIRDS}

Young birds occur from time to time in autumn, and two were shot at Aldeburgh in January, 1871, rather an unusual date, one of which is in the Ipswich Museum. It is a larger bird than the common redshank, with longer legs and beak in proportion to its size, and has no white on the wing.

232. Greenshank. Totanus canescens (J. F. Gmelin)

A spring and autumn visitant, the young birds often fairly plentiful in autumn. In I $880 \mathrm{Mr}$. Charles Clarke took an egg between the martello tower and the Orford lighthouse believed to have been a greenshank's, both from the character of the egg itself and from his description of the birds, which were very white underneath and kept up a shrill whistling overhead. This bird breeds in fair numbers in the north of Scotland.

\section{Bar-tailed Godwit. Limosa lapponica (Linn.)}

A spring and autumn migrant arriving on passage about the middle of May, when Mr. Patterson has seen hundreds on Breydon (Zoologist, 1901, p. I04). The young birds come in August and September and are often easily approached and shot, as perhaps they never see a human being at close quarters till they reach the British coast. They are excellent eating and often sold in numbers by game dealers. Most of those which come in autumn move on after a short stay, but some remain through the winter, and in January, I 903 , a considerable number were shot.

\section{Black-tailed Godwit. Limosa belgica} (J. F. Gmelin)

Though there is ample evidence of this bird breeding in East Anglia till about 1847 no record has been kept of its having done so in Suffolk. It is now only a rare visitant in late summer or autumn, the last occurrence being one shot on the Orwell 8 October, 1902, by Mr. Hudson of Ipswich, who recorded it in the Field. Many are imported from the continent both alive and dead, and sometimes unblown eggs can be bought in Leadenhall market.

\section{Common Curlew. Numenius arquata (Linn.)}

Some curlews remain on the coast all the year but none breed in the eastern counties, though they do so numerously in the north of England. There is plenty of common land in east Suffolk well suited to their habits in the breeding season, and it is quite possible that they bred here formerly. Many come in autumn, and from reports forwarded from various light-stations the glare of the lantern seems to have more attraction for them than for most birds, as 'many round lantern' is a frequent entry. Their loud whistle is often recognized as they pass over on migration at night, and Mr. Travis has heard them going over Bury. Curlews vary a good deal in size and weight as well as in length of bill.

236. Whimbrel. Numenius pheopus (Linn.) Locally, May-bird or Bream.

Its regular appearance in May will account for the first local name given for this spring and autumn migrant, but to explain the latter, which Mr. G. T. Rope gives as 'Brame' (Zoologist, 1878 , p. 290), is difficult. The whimbrel frequents the coast, tidal rivers and marshes near the sea and is rarely met with inland except on migration. Its only breeding places in the British Isles are in Orkney and Shetland.

\section{Eskimo Curlew. Numenius borealis (J.} R. Forster)

A very rare American species of which $\mathrm{Mr}$. Hele writes: 'One shot some years ago on the river by Capt. Ferrand, but unfortunately not preserved. A specimen in very similar dress was obtained on the Woodbridge river and was in the collection of the late Mr. Hilling of that town' (Notes about Aldeburgh, ed. 1890, p. 98). There is no record of any other in England.

238. Black Tern. Hydrochelidon nigra (Linn.)

This is another species which doubtless bred in Suffolk a century ago, and it is now not rare as a spring and autumn visitant. It sometimes comes to inland waters, where its singularly graceful flight and dusky colouring cannot fail to attract notice, while its tameness renders it an easy and most interesting bird to watch. One was seen on Bartonmere for some hours on 20 April, I 895, hawking for insects over the water like a swallow, and it seems in spring to be almost entirely an insect feeder. As many as forty have been seen on Breydon during the migration in May (Patterson, Zoologist, 1901, p. 105). The young birds which appear in September are greyish-brown above and white below, and can be recognized by having the feet only half-webbed.

\section{White-winged Black Tern. Hydrocbeli- don leucoptera (Schinz)}

This rare southern species has only been recognized as a British bird since $184 \mathrm{I}$, and was not known to have visited Breydon till I 87 x, when the late Mr. E. T. Booth killed 


\section{A HISTORY OF SUFFOLK}

four at one shot, which are in the Dyke Road Museum at Brighton. A flock of eight was seen on Breydon 22 April, 1901 (Zoologist, $190 \mathrm{I}, \mathrm{p} .88$ ), and this bird is perhaps now an annual summer visitant there, but it has only once been identified on the Suffolk coast or inland waters, when two were seen on Fritton Lake in the year mentioned above (Leathes).

240. Gull-billed Tern. Sterna anglica, Montagu)

A rare summer visitant of which there is no record except from Breydon, where eight or nine have been shot, the last occurrence being on 5 September, 1896 (Zoologist, I 897, p. I32). A Breydon specimen shot in April, 1849 , is in the Bury Museum. On the wing it would be difficult to distinguish this bird from the more common Sandwich tern.

\section{I. Caspian Tern. Sterna caspia, Pallas.}

$\mathrm{Mr}$. Yarrell states that three or four of this species were once seen at Aldeburgh and one of them shot. As a rare summer visitant it has occurred several times on Breydon, where one was seen on two successive days in July, I 901 (Zoologist, 1902, p. 91), and another 24 July, 1902 (Zoologist, 1903, p. 132). The geographical range of this fine species is very extensive both in the old and new world (Saunders' Manual, p. 642).

\section{Sandwich Tern. Sterna cantiaca (J. F. Gmelin)}

This is the largest of the five species of terns which still breed in Britain, but in Suffolk it is now only a visitant, though there is some evidence that it used to breed. Bewick quotes from Latham that 'it is pretty common on the Suffolk and Kentish coasts in the summer months, breeds there in the month of June,' and this would be towards the close of the eighteenth century. About fifty years later in 1846 or thereabouts $\mathrm{Mr}$. T. M. Spalding in his Catalogue previously referred to mentions it simply as "summer visitor,' using precisely the same words for the wryneck. It formerly bred near the Kentish port from which its name is derived, and still breeds abundantly on the Farne Islands and less numerously in other places in England. As there could hardly be a locality better suited to it than the Orford beach, with a tidal river on one side and the sea on the other, it is quite possible that like the oystercatcher it may return to its old breedinggrounds, especially as it enjoys the benefit of the strictest protection on the Farne Islands and also of the extension of the close-time to
I September, so with the increase in its numbers new colonies may be formed. The Sandwich tern can be recognized by its large size, black legs and perfectly white underparts, and its very beautiful eggs are unlike those of any other British bird.

\section{Roseate Tern. Sterna dougalli, Mon- tagu}

In Mr. Spalding's list just referred to he simply mentions 'Roseate Tern. Orford.' This seems to indicate that he regarded that locality as a rëgular haunt, and he was so careful an observer, and the bird is one so easily recognized alive or dead, that there need be no hesitation in admitting the bird to the Suffolk list. It probably bred, and is believed to have done so in Norfolk recently (Patterson). Mr. Booth saw one on Breydon, 26 May, 1871 (Birds of Norfolk, iii. 300).

\section{Common Tern. Sterna fuviatilis, Nau- mann.}

Locally, Cob, Sea-swallow.

This lovely bird is a summer migrant, breeding in fair numbers on the now 'protected area' of Orford beach, where it is on the increase. Thirty or forty years ago the nests used to be mercilessly robbed by people who went down with dogs trained to find the eggs, and as recently as 1878 over one hundred were taken in a day. Mr. Hele states that they used also to breed at Thorpe. The Orford terns have been seen to mob a hare which ran across their breeding ground (C. J. Palmer).

245. Arctic Tern. Sterna macrura (Naumann)

A spring and autumn visitant which may have bred, but there is no absolute proof of its having done so. It is very like the common tern, but has a longer tail, shorter legs, a smaller bill and underparts of a darker grey. The young of the year are not easy to distinguish, and the legs are the best guide, being pinkish in this species and yellowish-brown in the common tern.

\section{Little Tern. Sterna minuta, Linn. Locally, Reek or Ric, from its cry.}

This graceful little bird is a summer migrant, arriving early in May and breeding on the Orford beach. There is also a colony on a shingle bank near Southwold (Rev. F. C. R. Jourdain). Few birds have benefited more by the protection extended to eggs and parents during the last few years than the terns of the east coast. Both the common and lesser terns are occasionally met with inland at the time of the spring migra- 


\section{BIRDS}

tion, and one of the latter was picked up in a pond at Tostock 28 April, 1897.

\section{Sabine's Gull. Xeme sabinii (Joseph Sabine)}

This small fork-tailed gull, which seems like a link between the terns and gulls, is a very rare visitant from arctic America. Two were shot on Breydon in October, $188 \mathrm{I}$, and a third at Lowestoft 18 October, I901 (Zoologist, 1902, p. 93), all of which were young birds.

248. Little Gull. Larus minutus, Pallas.

In the winter of $1869-70$ there was a considerable migration of little gulls to the east coast, and it is now not very rare as an autumn and winter visitant. An exceptional occurrence was recorded in the Field of 1867 by Mr. Hele, who shot 'on May 22 a little gull in the Thorpe Mere in immature but very handsome plumage. It was in company with several little terns and tolerably easy of approach. The bird (a male) had been feeding upon the slender dragon-fly so common hereabouts. The flight of the little gull almost exactly resembled that of the little tern.' This specimen, with an old bird in winter dress shot in 1870 , is in the Ipswich Museum. One was shot at Thorpe 26 September, I 87 I (Hele).

249. Black-headed Gull. Larus ridibundus, Linn.

Locally, Peck-mire, Coddy-moddy.

This is the only gull which is known ever to have bred in East Anglia, and there is only one record of a 'gullery' in Suffolk, of which Professor Newton furnished the particulars for the Birds of Norfolk (iii. 323). 'The extinct Brandon gullery was on a small mere perhaps half-a-mile from the Brandon and Mildenhall road, and so close to the Wangford boundary that in one place the Wangford warren-bank may be said to have touched the water-indeed, in a wet season, I have seen the water come through on the Wangford side. On the gth April, 1853 , Gathercole, who had been warrener on Wangford for twenty-two years, told my brother and myself that the "coddy-moddies" left off breeding there several years ago." The bird is still common enough, especially the young in autumn.

250. Mediterranean Black - headed Gull. Larus melanocephalus, Natterer.

As its name suggests this is a southern species, of which a single bird wandered to Breydon and was shot on 26 December, 1886 (Zoologist, 1887, p. 69).
25I. Common Gull. Larus canus (Linn.)

Locally, Cob, Sea-cob, Sea-crow (inland).

The presence of this and other gulls on the east coast at all times of the year may be accounted for by the fact that these birds do not assume full plumage for some years, and do not breed till they assume it. Hence there are birds of any age from one to four years with nothing to keep them in one place for a week at a time, and they may be seen on the coast any day. The common gull is often seen flying over inland, and the appearance of a flock is supposed to foretell stormy weather, though when they are flying towards the north or east the exact opposite is the case. Most gulls seen inland are of this species, which is not known to breed anywhere in England or Wales.

\section{Herring-Gull. Larus argentatus (J. F. Gmelin)}

This fine bird, of which the nearest breeding places are on the Yorkshire cliffs, is not uncommon as an autumn and winter visitant, especially in the sprat season.

253. Yellow-legged Herring-Gull. Larus cachinnans, Pallas.

Like $L$. melanocephalus only one specimen of this bird has been obtained. It was shot on Breydon 4 November, 1886 , but not fully identified or recorded for some years. (Zoologist, I897, p. 572).

254. Lesser Black-backed Gull. Larus fuscus, Linn.

Locally, Saddle-back or Black-back.

Fine old birds of this species often occur in July and August on migration, and the young, which are very similar to those of the herringgull, are common. It does not appear to remain on the east coast in winter, and is practically a summer migrant to England.

255. Great Black-backed Gull. Larus marinus, Linn.

Locally, Saddle-back or Black-back.

No English winter is too severe for this magnificent sea-bird, which frequents our coast all the year. In the perfect black and white plumage which it is said not to assume for four or five years it is rather rare, but young birds are common enough.

256. Glaucous Gull. Larus glaucus, O. Fabricius.

This large gull is a winter visitant from the far north, and not uncommon in hard winters. In January, 188I, nearly thirty were obtained near Yarmouth, of which only 


\section{A HISTORY OF SUFFOLK}

seven were adults (Babington). It has no black on the wings or tail at any age, and the young birds are mottled all over with light brown on a dull white ground.

257. Iceland Gull. Larus leucopserus, Faber.

The Iceland gull is one of the rarest winter visitants. One was shot in Thorpe Mere in January, 1874 (Ipswich Museum), and in the Zoologist for 1892 (p. I14) Mr. F. M. Ogilvie gives particulars of another shot in January of that year, both of which were immature. This species resembles the glaucous gull in colour, but is much smaller, and has far longer wings in proportion to its size.

\section{Kittiwake. Rissa tridactyla (Linn.)}

This gull is a rather irregular winter visitant, but sometimes appears in fair numbers in the sprat fishing time. After some heavy gales in February, 1894, an adult bird was picked up in a yard at Bury, and another was found exhausted near Bury in March, 1903, after a westerly gale.

\section{Great Skua. Megalestris catarrbactes (Linn.)}

A very rare winter visitant to the coast. An unusually light-coloured specimen in the Ipswich Museum was picked up dead on the beach at Thorpe in January, 1864 , and one was shot at Lowestoft in the memorable storm of I 8 January, I 88 I (Zoologist, I882, p. 429). It is essentially a sea-rover, rarely approaching the shore.

\section{Pomatorhine Skua. Stercorarius poma- torbinus (Temminck)}

An irregular autumn and winter visitant. There was an exceptional immigration all along the east coast in October, 1879, when several were obtained near Aldeburgh (Hele).

26I. Arctic or Richardson's Skua. Stercorarius crepidatus (J. F. Gmelin)

This is in Suffolk by far the most common of all the four skuas and a regular autumn visitant, sometimes appearing as early as August. It has been obtained in all stages of plumage, and there are several good local specimens in the Ipswich Museum.

\section{Long-tailed or Buffon's Skua. Stercora- rius parasiticus (Linn.)}

A rare autumn visitant which has been obtained a few times on the coast and once near Newmarket, where one was found dead in November, 189I. All the skuas seem to make the return journey to their northern breeding-places by a different route in the spring, as they are never seen at that season on the east coast.

\section{Razorbill. Alca torda, Linn.}

This bird is not uncommon as an autumn and winter visitant, and in late summer quite young ones are seen with their parents, having strayed from their breeding-haunts on the Yorkshire cliffs. Early in 1872 there was a strange mortality among these birds, which Mr. Hele described in the Field. 'An extraordinary advent of and mortality amongst razorbills, numbers of which have been washed ashore. From whence all these individuals have strayed I know not, but imagine that as starvation appears to be in each and every case the actual cause of death they had been in attendance upon some shoals of smal fish-probably sprats-which had suddenly taken to deeper water through the generally rough condition of the sea. Certain it is that all the birds I have examined are more or less mature with good and sound plumage. In my walk this morning my dog brought me no less than eleven specimens, and I hear of very many more having been found.' This mortality was not limited to Aldeburgh or even to Suffolk.

\section{Guillemot. Uria troile (Linn.)}

A visitant at any time of the year except the height of the breeding season, and sometimes found inland. One was picked up alive and uninjured at Rougham on I 3 March, I 896, and sent to the Zoological Gardens.

\section{Black Guillemot. Uria grylle (Linn.)}

Though a regular breeder in the Orkney and Shetland Islands, the black guillemot is a very rare winter visitant, and the immature bird obtained at Aldeburgh by $\mathrm{Mr}$. Hele in 1863 (Ipswich Museum) is perhaps the only Suffolk specimen in existence.

\section{Little Auk. Mergulus alle (Linn.)}

This little arctic sea-bird is not rare as a winter visitant, and more often found inland than any other bird of its kind. There was an extraordinary visitation early in 1895 , and little auks were picked up all over the county, though less numerously than in Norfolk. Mr. Howlett of Newmarket had more than forty (W. Howlett in litt.).

\section{Puffin. Fratercula arctica (Linn.)}

The quaint-looking puffin is not common enough in Suffolk to be known by its Yorkshire name of 'sea-parrot,' and is a decidedly rare bird. Mr. Hele has given (Notes about Aldeburgh, ed. 1870, p. 164) details of a fine 


\section{BIRDS}

old bird brought to him alive in March, I 869 (Ipswich Museum). About 20 November, 1893, the Suffolk coast was visited by a terrific north-easterly gale, and many storm driven sea-birds were picked up, among them an adult puffin within the bounds of Bury. It was found alive and unhurt by some boys, who took it to $\mathrm{Mr}$. Travis, who kept it alive; but it refused the fish provided for it, and died at the end of a week.

268. Great Northern Diver. Colymbus glacialis, Linn.

This fine bird is a winter visitant from the north, and is usually only met with on the coast in hard weather. All those obtained have been in immature plumage.

269. White-billed Northern Diver. Colymbus adamsi, G. R. Gray.

This rare arctic species, which is even larger than the great northern diver, has only recently been added to the British list. The first British specimen was shot at Pakefield in the early spring of 1852 (Saunders' Manual, p. $7 \mathrm{II}$ ) and is in Mr. Gurney's collection.

270. Black-throated Diver. Colymbus glacialis, Linn.

A rare winter visitant, but one which might easily be overlooked in the plain grey and white plumage in which it usually occurs in England. Mr. Gurney has a Lowestoft specimen in nearly full breeding plumage (Birds of Norfolk, iii. 270).

271. Red-throated Diver. Colymbus septentrionalis, Linn.

Locally, Sprat-Loon.

This bird is much the most common of the divers, and may be called a regular winter migrant. Specimens are sometimes obtained in autumn in almost perfect summer dress, with the chestnut-red patch on the throat from which the name is derived. None of the divers breed in England, but the blackthroated and red-throated breed in fair numbers in the north of Scotland and on the adjacent islands.

\section{Great Crested Grebe. Podicipes crista- tus (Linn.)}

This splendid bird is a resident breeding in fair numbers on Fritton Lake, where it is carefully protected (Col. Leathes). In west Suffolk it breeds on Ampton Water, and used to do so on Bartonmere when there was sufficient water. The pike is its worst enemy, and this voracious fish devours many young grebes during the early days of their exist- ence. In winter the crested grebes go to the sea and tidal rivers.

\section{Red-necked Grebe. Podicipes griseigena} (Boddaert)

A rather rare winter visitant, and in Suffolk almost entirely a marine species.

\section{Slavonian Grebe. Podicipes auritus (Linn.)}

This species, which breeds abundantly in Iceland, is not uncommon as a winter visitant to the east coast, but has not been recorded from Suffolk in its very handsome summer plumage.

\section{Eared Grebe. Podicipes nigrtcollis (C.} L. Brehm)

A southern species, only occurring in the spring and summer months. On 3 August, 1878 , a fine male was shot near the martello tower at Aldeburgh. In winter dress it much resembles the Slavonian grebe at the same season, but is smaller and has a slightly up-turned bill.

\section{Little Grebe or Dabchick. Podicipes fuviatilis (Tunstall) \\ Locally, Dabchick, Deve-dobbler ; Dobchicken} (Rev. F. C. R. Jourdain).

A common resident, which breeds not only on large pieces of water, but also on ponds and even in meadow dykes. Its nest with the eggs covered might easily be taken for a mass of weeds, and this has been well illustrated by Mr. Kearton's photographs, which he obtained in east Suffolk. The dabchick is an early breeder, having eggs by the end of April, and as the young in down have been found late in August (Zoologist, x 873, p. 3798) it must sometimes breed twice in a year. The eggs of this and all the other grebes are protected in west Suffolk.

\section{Storm-Petrel. Procellaria pelagica, Linn.}

This tiny sea-bird is an autumn visitant, and is well known to the lighthouse and lightship keepers, as in its ocean wanderings it frequently strikes the lanterns, and more than one has been thus obtained at the Languard station. Storm-petrels are occasionally picked up inland, and after the gale mentioned above in the note on the puffin one was found at Livermere. Except in very rough weather it rarely approaches the land.

\section{Leach's Fork-tailed Petrel. Oceanodro- ma leucorrboa (Vieillot)}

This species is easily recognized by its larger size and forked tail, and is much rarer 


\section{A HISTORY OF SUFFOLK}

than the storm-petrel. Most of the specimens recorded have been obtained in autumn, and one in the Tostock rectory collection was picked up alive but quite exhausted on the ground near Lowestoft pier early in October, 1897 .

279. Wilson's Petrel. Oceanites oceanicus (Kuhl)

Mr. Hele has recorded in both editions of his book a specimen of this very rare wanderer obtained in the Aldeburgh neighbourhood many years ago, which belonged to the late Colonel Thellusson.

\section{Great Shearwater. Puffinus gravis} (O'Reilly)

Only one specimen of this casual visitant has been obtained in Suffolk, which was brought into Lowestoft by a fishing-boat in November, 1898 (Zoologist, 1899, p. 31), and this bird may have been procured some distance out at sea. Mr. Hele mentions having seen one passing alongshore in December, 1869 (Notes about Aldeburgh, ed. 1870, p. 175).
281. Manx Shearwater. Puffinis anglorum (Temminck)

A rare autumn visitant which has occurred a few times in September. It is sometimes found inland, and Dr. Babington possessed a specimen which was taken alive at Fornham in a harvest field I September, I 882 (Catalogue, p. 225). In September, 1891 , a shearwater was shot by a visitor to Aldeburgh, which was either an unusually small example of this species or some very rare stranger. Several new species of petrel have been added to the British list within the last twenty years, which are figured in Saunders' Manual, and in two instances a small bird picked up dead on the beach has proved to be a very valuable prize; the moral of which is that any petrel of which there is the slightest doubt as to the species should be carefully preserved, and either submitted to an expert or compared with the series in the national collection.

\section{Fulmar. Fulmarus glacialis (Linn.)}

A rare autumn and winter visitant, usually keeping well out at sea. One caught alive at Sizewell in September, 1862 (Hele) is in the Ipswich Museum.

\section{ADDENDA}

137. Common Heron. In May, I 908 the Orwell Park and Blackheath heronries were reported as entirely deserted ( fide head-keeper on both estates). About two pairs breed at Euston (Rev. R. B. Caton). The colony at Broke Hall is still in existence, and seventeen nests were counted at Flixton Hall in 1908.

I59. Gadwall. This species bred at Euston in 1903 , and Rev. R. B. Caton reports several pairs breeding there in 1908 .

165. Red-crested Pochard. A pair were shot in Thorpe Mere I6 January, I904 (Zool. I 905, p. 90). A flock of thirteen visited Breydon 4 September, I 906, of which nine were shot (Zool. 1906, p. 394).

167. Ferruginous Duck. Two were shot on Culford Lake by the Hon. Lewin Cadogan in January, 1906 (Field,3 February, 1 906).

191. Moor-Hen. A specimen of the rare and curious variety, 'hairy' in plumage and sandy in colour, was caught by a dog near Bury in January, 1905 and preserved by the late Mr. Travis.

206. Avocet. Nine visited Breydon 14-17 June, I 905 (Zool. 1906, pp. 129-30).

242. Sandwich Tern. A nest with one egg was photographed near Orford Haven in
1906, the bird flying about near the operator. An adult bird was killed about the same time by striking the telephone wire (G. P. Hope).

244. Common Tern. The protection order has unfortunately been rescinded after being in force five years. In 1907 almost every egg was taken as soon as laid. The terns all came back, but in reduced numbers, this year (1908), and it will not be long before they all leave off breeding on the north weir (G. P. Hope).

246a. Sooty Tern. Sterna fuliginosa, J. F. Gmelin. In the spring of 1900 one was picked up dead at Santon Downham, which was not identified till more than three years later. Through the good offices of Messrs. W. A. Dutt and W. G. Clarke, by whom it was recognized, the bird was taken to Norwich for inspection, and its identity confirmed by the naturalists there. This is the fourth British specimen (Saunders' Manual, ed. 2, p. 655).

249. Black-headed Gull. During the hard weather early in 1907 these gulls were flying about near the houses in Fonnereau Road, Ipswich. 


\section{A M M A LS}

The mammals, reptiles and batrachians of Suffolk have hitherto received very little attention. As far as $\mathrm{I}$ am aware no list embracing the whole area of the county has ever been published. Several histories of separate towns and villages have from time to time appeared, but few of these contain any remarks on the animal life of their respective districts, and in the rare exceptions to this rule only slight sketches, confined principally to the birds and insects, are given.

Over the greater part of the county game preserving is almost the universal custom, and all carnivorous animals meet with ceaseless persecution, including species which are not only harmless but even beneficial to the interests of those who destroy them.

Unfortunately it is in those very districts which still remain uncultivated, and whose natural features are most favourable to the preservation of such animals as the badger, marten, etc., that the destruction of so-called 'vermin' is most strenuously carried on. Moreover having become rarities, their skins are of value for stuffing, so that any stray wanderer finding its way to the woods and heaths of Suffolk stands a very poor chance of remaining long in peace and security.

Rather more than a quarter of a century ago there were beavers in this county, living in a state of partial liberty in Sotterley Park; but, as I am informed by Mr. Ling, agent on that estate, they soon strayed away and were in a short time all lost or killed. These animals were brought from Canada by the late Colonel Barne, about the year I 868, and were of course of the American species Castor canadensis (Kuhl), which is considered to be specifically distinct from the European beaver.

About the year 1873 or 1874 a number of alpine or Irish hares (Lepus variabilis, Pallas) from Ireland were turned down by the late Sir Richard Wallace at Iken, on the Sudbourn Hall estate. They bred freely and spread in various directions, specimens having been observed at Gedgrave and other places in the neighbourhood. They appear however to have gradually died out, none having been seen now for some years past. The keeper on whose beat these animals were liberated described the young ones as being very stupid and helpless, often falling into the marsh ditches and getting drowned. He has found as many as three or four dead leverets in the water in one morning. No hybrids between this species and the common hare were observed by this man.

As regards the Cetacea, it is very probable that examples may from time to time have been stranded on the beach, or caught in herring 


\section{A HISTORY OF SUFFOLK}

nets off the Suffolk coast, which have never been seen or identified by a naturalist. Where animals of this order are caught at sea, more or less opposite to the boundary line between two counties, as for instance off Yarmouth, ${ }^{1}$ it is by no means easy to decide to which county they should be assigned, nor is it perhaps a matter of much consequence. Some of the specimens enumerated by Mr. Patterson in his Mammalia of Great Yarmouth, which are not mentioned here, may have been captured off the Suffolk coast.

Except in the case of a few occurrences taken from the above mentioned valuable list, the writer is indebted for the short account of Suffolk cetaceans given below to Mr. T. Southwell, F.Z.S.

The writer's sincere thanks are especially due to Mr. T. Southwell, Dr. Laver and the Rev. J. G. Tuck for much valuable advice, and for the great amount of assistance which they have spared neither time nor trouble to afford. $\mathrm{He}$ is also greatly indebted to $\mathrm{Mr}$. F. Norgate, Mr. W. M. Crowfoot, Mr. H. Miller, the Rev. F. C. R. Jourdain, Mr. W. G. Clarke, Mr. H. Lingwood, Mr. W. H. Tuck, Mr. H. C. Hudson and many others, too numerous to mention separately, for the trouble they have taken in procuring information on the mammals, reptiles and batrachians of this county.

\section{CHEIROPTERA}

\section{Long-eared Bat. Plecotus auritus, Linn.}

With the exception of the pipistrelle, and in some districts perhaps of the noctule, this appears to be the commonest Suffolk bat, and it is certainly one of the prettiest. By day it hides in hollow trees, nooks and crannies in old buildings, and similar retreats. The writer has observed it in a cellar at Blaxhall. Messrs. C. J. and James Paget (Sketch of the Nat. Hist. of Yarmouth and its Neigbbourbood, published in 1834) refer to this species as 'common in old houses in and about the town.' In the neighbourhood of Thetford, on the Norfolk boundary, Mr. W. G. Clarke considers it to be rare. Mr. Hudson, taxidermist, Ipswich, lately informed me that in taking down an elm tree at Holy Wells, on the outskirts of that town, a very large number of long-eared bats were found in the cavity of a large rotten branch. The man who found them remarked that when he put his hand and arm into the hole, the place felt quite warm. On the evening of 7 June I 888 several small bats, believed to have been of this species, were noticed by the writer about some oaks at the edge of Iken Wood. They were threading their way amongst the branches with great ease and dexterity, never appearing to touch a twig with their wings; and were feeding apparently on small moths, and possibly also on caterpillars, for they certainly took food of some sort at times from the leaves. This is one among several species of bats observed in the Stour valley by $\mathrm{Mr}$. H. Laver of Colchester.

2. Barbastelle. Barbastella barbastellus, Schreber.

Bell-Barbastellus daubentonii.

Professor Alfred Newton (Zoologist, 1857 , p. 5420) records the occurrence of this bat in Suffolk. Mr. Southwell, in an article on the Mammalia and Reptilia of Norfolk, ${ }^{2}$ referring to the barbastelle, says : ' $\mathrm{Mr}$. Crowfoot found one on a wall at Ellingham' (on the Norfolk side of the river Waveney), ' on 2 November 1870 , and believes this species to be common in the neighbourhood of Beccles.' In a letter to the writer, Mr. Crowfoot mentions a specimen he took some years ago from a tree in Worlingham Park. About the year 1900 a bat, believed to have been of this species, was taken by the writer from a hole, rather low down, in the trunk of a large and very old cherry tree in a garden at Little Giemham ; but before a careful examination could be made, it freed itself by a sudden effort, and escaped. The dark colour of the fur (near'y black

1 Southtown, a part of Great Yarmouth, is in Suffolk.

2 Read before the Norfolk and Norwich Nat. Soc. and printed in their Transactions, i. (18:70-1), 71. 


\section{MAMMALS}

on the upper parts), and singular aspect of the face, occasioned by deeply sunk nostrils and a peculiar formation of the ears, at once arrested attention, recalling Bell's figure of this species.

\section{Great or White's Bat. Pipistrellus noctula, Schreber. \\ Bell-Scosopbilus noctula. \\ White-Vespertilio altivolans.}

The Messrs. Paget, ${ }^{1}$ writing in 1834 , refer to this animal as being 'rather rare' in the neighbourhood of Yarmouth, which includes a portion of Suffolk; and about Thetford, Mr. W. G. Clarke considers it to be rather scarce at the present time. In most parts of the county however it is a common species. In the east it is especially numerous, and its vigorous and somewhat snipe-like flight often attracts attention as at sunset its dark form comes into bold relief against the glowing colours of the western sky. Flying usually at a considerable elevation, it will sometimes, in hot pursuit of its prey, dash obliquely downwards almost to the earth. In east Suffolk it is generally first seen on the wing about the second or third week in April. During a period of seven or eight years, the earliest appearance noted by the writer is 2 April at Leiston, in the year 1873 . It does not as a rule retire to its winter quarters till the latter part of October, and on two occasions, in unusually mild weather, I have noticed it abroad near Snape Bridge in November ; in one instance as late as the 28 th of that month. In the year 1894 the Rev. F. C. R. Jourdain saw one near Halesworth, flying at mid-day in bright sunshine, as early in the season as 26 March. In I901 a noctule was observed by the writer, apparently hawking for insects over a sandpit at Blaxhall on 21 January at 4.45 p.m. The Rev. J. G. Tuck informs me that these large bats take possession of the nestboxes placed about his garden at Tostock near Bury St. Edmunds for the benefit of the birds, and that he has found as many as ten in one box. The noctule is particularly partial to our river valleys; those of the Blythe, the Alde and the Stour being especially attractive to it.

\section{Pipistrelle. Pipistrellus pipistrellus, Schre- ber. \\ Bell-Scotopbilus pipistrellus.}

Abundant. Often seen abroad in midwinter during mild weather. It not unfre-

I A Sketch of the Nat. Hist. of rarmouth and Neigbbourbood, C. J. and James Paget. quently hawks for insects in the daytime, both in summer and winter. I have several times noticed this little bat so engaged in December and January at hours varying from 9 a.m. to 2 p.m.

\section{Natterer's Bat. Myotis nattereri, Kuhl. Bell-Vespertilio nottereri.}

Professor Newton ${ }^{2}$ has recorded the occurrence of this bat at Elveden near Thetford, and $\mathrm{Mr}$. H. Laver of Colchester has also met with it in the Stour valley. On several occasions during the years 1882 and 1883 some examples of the present species were found by the writer in the interior of a plaster figure on the wall of a summer-house at Blaxhall, most of them being males. On 12 April I884 four of these bats, two of each sex, were discovered in the same retreat, and on 18 March 1885 a single female was the only occupant. They ran with considerable agility upon the ground, and their flight was strong and vigorous. A pair were discovered in the same place in May 1903.

\section{Daubenton's Bat. Myotis daubentoni, Leisler. \\ Bell-Vespertilio daubentonii.}

In an article on this bat in the Zoologist for I 889 , Mr. J. E. Harting, then editor of that journal, states (p. 163) that it has been observed by Doubleday flying over the river Stour at Sudbury. Mr. H. Laver of Colchester has since met with this species in the Stour valley. About the year 1878 a bat was shot within the boundaries of the parish of St. Clement's, Ipswich, near the present site of the sewer outlet works, which at that time had not been constructed. Mr. H. C. Hudson, taxidermist of that town, who was present when it was killed, observing that it was no common species, went with the person who shot it to the Ipswich Museum, to try and ascertain its species. Unfortunately Dr. Taylor, curator at the time, was away. After however consulting several books, $\mathrm{Mr}$. Hudson came to the conclusion that it was a specimen of $V$. daubentonii. It was soon afterwards sent to London, and came into the possession of a Mr. Betts, who has since died.

[Vespertilio dasycneme. Boie (Isis, I 825 , p. 1200).

Mr. J. E. Harting ('Remarks on British Bats,' Zoologist, 1887 , p. 162 , in which is given the classification, with distinguishing characters of the families and genera, of all

- Zoologist, 1853 , p. 3804 . 


\section{A HISTORY OF SUFFOLK}

the species found in these islands) refers to $V$. dasycneme as 'reported to have been captured on the banks of the Stour.'] ${ }^{1}$
7. Whiskered Bat. Myotis mystacinus, Leisler. Bell-Vespertilio mystacinus.

Mr. H. Laver has met with this species in the Stour valley.

\section{INSECTIVORA}

\section{Hedgehog. Erinaceus europaeus, Linn.}

This animal is certainly far less common than it used to be, and in many parts of the county it has become quite scarce. As pointed out by the late Rev. F. Barham Zincke, in his interesting history of the parish of Wherstead, ${ }^{2}$ the clearing away of the large banks and wide rambling hedges once so prevalent has deprived certain of our reptiles and smaller mammals of secure and convenient retreats, and has done much towards reducing their numbers. Among these the hedgehog may certainly be included. It has besides many enemies to contend with in its struggle for existence. The gamekeeper persecutes the poor hedgepig most relentlessly for occasional misdemeanours, and others blindly follow his example, killing every one they meet with, regardless of its services as a destroyer of snails, beetles and young field mice. Rabbit-trapping too involves the destruction of many of these animals, which often lie up by day in a rabbit burrow, and gipsies with their dogs keep a sharp look-out for them for culinary purposes. The old deep-rooted prejudice against the hedgehog, on account of its supposed habit of sucking cows, still lingers in this county. In some recent correspondence on this subject in the 'East Anglian Miscellany,' ${ }^{3}$ instances were brought forward of the animal's supposed guilt.

\section{Mole. Talpa europeea, Linn.}

Common everywhere. On the light sandy soil towards the coast, as well as in other parts of the county, moles are found in astonishing numbers, fields and meadows being almost covered with their hillocks. Game-preserving is so universal here, and is carried to such extremes, that most of the creatures appointed by nature to keep down the number of such animals as these and the smaller rodents, have been well nigh exter-

1 'Cf. Buckton, Proc. Linn. Soc. 1853 , p. 260 , where the species is treated as a variety of $V$. daubentonii. Tomes (Zoologist, 1854, p. 436r) considered it to be dasycneme.'

2 Some Materials for the History of Wherstead, by

F. Barham Zincke, vicar of Wherstead.

${ }_{3}$ Published once a week in the columns of the East Anglian Daily Times. minated. The Rev. F. C. R. Jourdain informs me that near Sibton he has seen four or five hundred moles hung out on some wire fencing, near where mole-catchers have been at work. When the marsh lands are flooded, the moles are sometimes forced by the rising waters to assemble in such spots as are slightly above the general level. Here they attract the attention of the herons, which on such occasions clear off a good many, and numbers of the 'castings' of these birds may be found composed almost entirely of the bones and skins of moles. On some marshes on the coast between Dunwich and Sizewell the writer has seen two or three great blackbacked gulls (Larus marinus) waiting for days together about these small temporary islands, the castings or pellets thrown up by these birds affording conclusive evidence of the nature of their diet. Long continued droughts in summer are fatal to large numbers of moles. The worms then descend probably to such a depth that their enemies cannot follow them. At such times these animals often come out upon the surface of the ground, and after searching about for food cannot again penetrate the hard crust, and soon die. Several cream-coloured moles have been caught near Sudbourne Church, and Mr. W. G. Clarke informs me that the same variety has occurred both at Elveden and on Barnham Common, and that specimens whose fur was of a yellowish tint have been taken at Fakenham. Of late years quite a demand has arisen for mole-skins for converting into furs, and the price has gone up considerably. They were recently (1903) advertised for in the East Anglian Daily Times at 3s. per dozen.

\section{Common Shrew. Sorex araneus, Linn.}

Locally, Ranny (applicable also to the other two British shrews).

This little animal is met with throughout the county in a great variety of situations. It frequents woods, hedge-banks, cornfields, dry heaths, upland pastures and low wet marshes. After the marsh ditches have been cleaned out, the shrews drive small tunnels in all directions through the mud which has been thrown out, in order to get at the rich feast of aquatic insects and other forms of animal life contained in it. They also burrow through 


\section{MAMMALS}

the dry patches of cow-dung in the meadows to feed on the grubs beneath. In some wet swampy meadows near Minsmere sluice, which many years ago were more or less flooded every winter, sometimes as late as March, shrews used to be very numerous. After a sudden rise of water a great many might be seen congregated upon small patches of higher ground. Even where the surface was covered with water they could then be seen running up and down the broken-down stems of reeds and other plants, while at times they seemed to be actually running upon the water, the scum upon the surface with various floating odds and ends which had collected there being buoyant enough in places to support their weight. In these marshes I have found their nests by the sides of ditches; the occupants on being disturbed taking to the water quite readily, and swimming well. Individuals having white tips to their tails are frequently met with as elsewhere. On 14 March I 883 I caught a pied shrew at Farnham. A broad band of white almost entirely encircled the body at the loins, the edges being sharply defined. One side of the head and neck was of a silvery grey tint. Specimens having a few scattered white hairs on the forehead are not uncommon. The ravenous and insatiable appetite possessed by both moles and shrews is well known. If a common shrew just caught be held in one hand, and a beetle or woodlouse offered it with the other, it will at once seize and devour it. The writer once placed two of these little animals in a cage with a good supply of worms and insects. The next morning only one could be found, and that dead, the body looking unnaturally distended. After a close search one foot and some of the fur of the other was found. One of these shrews had evidently killed and eaten its companion, paying for this act of cannibalism with its own life.

\section{Pigmy Shrew. Sorex minutus, Pallas. Bell-Sorex pygmaus.}

Two skulls of this little animal have been found by the Rev. Francis C. R. Jourdain in owl pellets at Huntingfield, in the eastern part of the county, and one at Great Thurlow in the west, and have been identified by Mr. Lionel E. Adams. On 23 December 1892 Mr. F. Norgate of Bury St. Edmunds saw a specimen of $S$. pygmaeus dive into a narrow crevice three quarters by one quarter of an inch wide between the bricks of his porch floor, and setting a trap close to the spot caught the animal in the following March. I have on several occasions come upon shrews of this species, both living and dead, at Blaxhall; in more than one instance from noticing a cat or kitten playing with one, and do not think it can be very uncommon. Owing to its extremely diminutive size and inconspicuous colour (harmonizing perfectly with the dead leaves, dry sticks, etc., among which it lives), it no doubt often escapes notice. All three of our British shrews are subject to that mysterious mortality which in the case of $S$. araneus has so often attracted attention, but never I believe been satisfactorily accounted for. $\mathrm{Mr}$. Edward Bidwell has an albino of this species from Thetford (Trans. Norf, and Nor. Nat. Soc. iii. 667).

\section{Water Shrew. Neomys fodiens, Pallas.}

$$
\text { Bell-Crossopus fodiens. }
$$

This pretty and interesting little animal is widely distributed in the county, though I know of no locality where it can be called abundant. Its habits and the nature of its haunts alike tend to shield it from observation in spite of its rather conspicuous and strongly contrasted colours. In the north-east, towards the Norfolk boundary, its occurrence is recorded by Mr. Southwell ('Mammalia and Reptilia of Norfolk,' Zool. 1871, p.2753), who refers to a specimen from Oulton, Suffolk, seen by Mr. Gurney. At Fritton Decoy Mr. F. Norgate has watched these little animals diving for their prey. The Rev. E. $T$. Daubeny informs me that he has once or twice observed this species at Market Weston near Thetford. About Wilby the Rev. H. S. Marriott has met with it in some numbers, more particularly in the early spring. The Rev. F. C. R. Jourdain obtained a skull of the water shrew at Huntingfield, near Halesworth, and another at Great Thurlow in west Suffolk. Both these skulls were taken from pellets of the barn owl (Strix flammea), and were examined by Mr. Lionel E. Adams. About Needham Market this animal has not unfrequently been observed by Mr. H. Lingwood, and the late Dr. Churchill Babington, author of the Birds of Suffolk, has taken it at Cockfield. In the neighbourhood of Blaxhall it is not uncommon, and the writer has seen it 'fishing' in a pond surrounded by trees in that parish, and also in a ditch near Dunningworth Hall, Tunstall. Elsewhere in that district he has occasionally met with examples both living and dead, some of the latter at a distance from water. It has also been observed at Leiston. In September I886 I picked up a dead one at Stratford St. Mary, on the banks of the river Stour, which here forms the southern boundary of the county, and Mr. H. Miller informs me that this 


\section{A HISTORY OF SUFFOLK}

species has also been observed at East Bergholt, a mile or two further down the river, by Mr. C. Whiting. Cats not unfrequently kill this animal, as well as the other British shrews.

The Oared Shrew (Sorex remifer, Bell), formerly considered to be specifically distinct, but now looked upon as a variety of $C$. fodiens, also occurs in the county. The under parts in this animal are almost as dark as the back, and the general colour much resembles that of the mole. On 5 September 1900, in a meadow at Blaxhall, I met with one of these big dark-coloured shrews. It was a pregnant female, and so large that before picking it up I took it for a half-grown mole. Hoping to have leisure to examine it carefully on the morrow, I placed it in a large cage with earth, water, a bed of dry grass and a plentiful supply of earthworms, one of which it at once seized and devoured. But in the morning it had disappeared most unaccountably. This shrew was certainly larger than a fullgrown house mouse $(M$. musculus). Its climbing powers were considerable, for it not only easily ascended the upright wires of the cage, but even made its way along the top, clinging, back downwards, to the wires. The fact of its being with young at this season seems to denote that more than one litter may be produced during the year. Many years ago one was seen by the writer on the bank of a pond in the same parish which he believes to have been still larger.

\section{CARNIVORA}

\section{Fox. Vulpes vulpes, Linn. Bell-Vulpes vulgaris.}

In Suffolk foxes are not often met with far from the hunting districts, which are situated (broadly speaking) in the central, southern and extreme western parts of the county, hunted respectively by the Suffolk, Essex and Suffolk, and Newmarket and Thurlow foxhounds. From time to time one of these animals makes its appearance among the game preserves in other parts of the county, where it does not always receive a very hearty welcome. On the Campsea Ashe estate, which for many years has been occasionally visited by these animals, one was shot in the autumn of 1902 at a fir plantation on Tunstall Heath, and another was killed at Ramsholt in December of that year. About the same time a fox was known to frequent the neighbourhood of Pettistree. The late Mr. Hele of Aldeburgh ${ }^{1}$ gives an instance of a dead fox having been found floating in the river near that town in 1864, and in the same year of an old and decrepit vixen having been trapped on a warren close by. Formerly these animals must have been generally distributed throughout the county, and their frequent depredations in the poultry yard and among the young lambs led to a reward being offered in many parishes for their destruction. In the churchwardens' accounts for the parish of Freston near Ipswich there are several entries of sums paid during the latter part of the eighteenth century for the destruction of foxes, the amount varying at that time from Is. to $2 s .6 d$, per head.

\section{Fottings about Aldeburgh, by N. F. Hele, 1870 .}

14. Pine Marten. Mustela martes, Linn. Bell-Martes abietum.

In a part of the country where the destruction of every beast or bird supposed to be in any way harmful to game goes on unceasingly year after year one can hardly expect to find many carnivorous mammals still surviving. The larger species are usually the first to disappear, and that beautiful and graceful animal the marten, the largest of our British weasels, has long been extinct as a resident species. Yet as lately as the year 1889 a marten was shot on 29 May in a Scotch fir plantation at Sutton near Woodbridge, and another is said to have been seen at the same time. According to a report of this occurrence in the Field of 13 July 1889 , p. 45 , the animal destroyed was a male, measuring 27 inches in length and weighing a trifle over $4 \mathrm{lb}$. When shot it was carrying in its mouth a full-grown young wood-pigeon. It was stuffed by Mr. Asten of Woodbridge. As it is probably not less than sixty or seventy years since the marten became extinct in Suffolk it is difficult to account for its reappearance after so long an interval. If these two individuals could possibly have wandered from any existing habitat of the species, they did well to escape detection, considering the distance they must have travelled. Remarking on some similar occurrences of this animal in Norfolk in comparatively recent times Mr. Southwell (Trans. Norf. and Nor. Nat. Soc. ii. 668) writes as follows: "That these were escapes I have no doubt, although unable to trace them. To show how easily this may occur, I was informed by a friend (Prof. Newton) that some years ago an un- 


\section{MAMMALS}

dergraduate at Cambridge surprised him by stating that from time to time a considerable number of live martens had been sent to him from Ireland, several of which had escaped and were then living at large in his neighbourhood in the south of England; the same thing may well have happened in Norfolk (or Suffolk) without its being suspected.' In the Norwich Mercury of 21 December 1811 is the report of the 'Suffolk Gamekeepers' Annual Meeting' held at Bury St. Edmunds on 9 December of that year, at which a prize was given to one Sharnton as the most successful gamekeeper. This man had the overlooking of 4,000 acres, and among the 'vermin' destroyed by him in the preceding year are enumerated three martens. ${ }^{1}$ The Messrs. Paget refer to the marten as occurring ' formerly at Herringfleet and Tofts; ${ }^{2}$ now extremely rare.' A specimen was now and then captured in Ubbeston Wood during the first quarter of the last century, and the writer's father remembers having seen one in that parish nailed upon a barn.

\section{Polecat. Putorius putorius, Linn. Bell -Mustela putorius.}

There is abundant evidence to show that this animal was formerly common in most parts of the county, and until about the middle of the last century it does not appear to have been considered rare. The late Rev. H. T. Frere, writing in the Zoolog ist for 1849 , p. 2493, states that 'the polecat is to be found on most rabbit warrens. In some parts of Suffolk it is far too common.' The continual persecution however to which its predacious habits have always rendered it liable, together with the greatly increased area devoted to game preserving, in time began to make an appreciable reduction in the numbers of this animal, and its almost complete extirpation from the greater part of the county has gradually been effected. In the west and north-west the polecat appears to have held its ground longer than elsewhere. In the

- See an article entitled 'Martens in Suffolk,' T. Southwell, Zool. 1877, p. 338, where the number is stated, as given by Mr. Gurney in his communication to the Norf. and Nor. Nat. Society's Trans. ii. 224, 23 'forty-three' ! - 2n error which has been extensively copied. Mr. Southwell has since been at considerable pains to get at the original newspaper report, which he ultimately discovered in the Norwich Mercury of 21 December 18I1, where, as above stated, the number of martens is 'three' and not 'forty-three.' It is impossible now to say how the original error arose.

Probably Toft Monks near Aldeby, which is in Norfolk.
Mildenhall district, and especially about the fen country between that town and Ely, it is still frequently met with. A gamekeeper from whom the Rev. B. P. Oakes obtained a specimen captured at Beck Row, a hamlet of Mildenhall, about the year 1897, told him that he had killed thirty-eight! including young ones, in the course of the year, and that he believed polecats to be common in the fens towards Ely, and that they worked up to Beck Row along the dykes. In 1898 Mr. Travis, the Bury St. Edmunds taxidermist, received one from Cavenham, some 7 or 8 miles north-west of that town, and also one from Mildenhall in the same year, both these examples being killed during February, on the $3^{\text {rd }}$ and $15^{\text {th }}$ respectively. Three others obtained in the Mildenhall district during the same year were seen and examined by the Rev. J. G. Tuck. The following curious capture of a polecat is from the Ipswich fournal of 23 February 1895: 'At Isleham in the Cambridgeshire fens ${ }^{1}$ a polecat has been found by the lockkeeper with its feet frozen to the top of the lock gate. It had evidently stopped on the gate to watch some object of prey:' In the same journal of the date of 28 March 1888 one of these animals is reported to have been caught at Mildenhall in a trap set for an otter. Mr. W. G. Clarke, in a letter to the writer, refers to the capture of one of these animals about the year 1898 at Lakenheath, and also to its former occurrence both at Fakenham and Euston. At Barnham in the same district Mr. F. Norgate started a very big polecat from a rabbit hole on 2 I August 1890. As regards the north-eastern part of the county, the last polecats known by $\mathrm{Mr}$. W. M. Crowfoot of Beccles to have been killed in his neighbourhood were trapped at Worlingham about the year 1859 or 1860 . A very large male was exhibited at a dealer's stall at Yarmouth market in November 1867. It was said to have been killed somewhere in the neighbourhood, but whether in Norfolk or Suffolk was not specified. ${ }^{2}$ The late Rev. H. T. Frere, writing to Mr. Southwell in December 1870 , referring to a period about twenty years previous to that date, mentions this species as being 'common enough about Diss.' He further stated, 'They seem to leave the lower grounds about October, and when I lived at Roydon Hall we were sure to catch several about that time under the roots of a particular pollard oak, through

1 The river Lark at Isleham forms the boundary between Suffolk and Cambridgeshire.

T. E. Gunn, Zoologist, 1869, p. 1925. 


\section{A HISTORY OF SUFFOLK}

which there was a run. I once caught seven, two old and five young ones, in a barn there. On two or three other occasions I have turned out burrows on the fen, which have contained eels and frogs generally half decomposed.' In the Zoologist, 1888, p. 222, Mr. Frere writes: 'I have seen their tracks in the snow not many years ago, and now I hear that there was one this winter within two hundred yards of my house.' Roydon and Diss are both in Norfolk, but have only the river Waveney between them and Suffolk. I am indebted to Captain Page of Woolpit for the particulars of a strange incident which occurred at the old rectory of that parish, which is situated in the west central part of the county. The house was one of the old parsonages built in Queen Elizabeth's time, having no cellar beneath. In June 1852 the inmates were driven from their drawing-room by a most evil and unaccountable smell. At length it was supposed the nuisance must be caused by some dead animal, and the carpenter was sent for to take up the floor boards when a living polecat was found comfortably ensconced underneath them. Mr. H. Lingwood has a specimen from Bricett near Bildeston obtained in 1847 . In the neighbourhood of Letheringham in east Suffolk it was also not uncommon at that time, and lingered until several years later. Polecats inhabited Ubbeston Wood near Halesworth (then unpreserved for game) within the memory of the writer's father, who also recollects seeing the mouths of their burrows strewn with bones and feathers. This would probably be from about 1824 to 1830 or later. A gamekeeper informed Mr. C. Whiting that while living at Crowfield about $2 \frac{1}{2}$ miles from Coddenham, between 1860 and 1872 , he caught about fourteen polecats. ${ }^{1}$ During the last two years of that period only one or two were killed, and he believes these animals to be now extinct in that neighbourhood.

\section{Stoat. Putorius ermineus, Linn. Bell-Mustela erminea.}

In the neighbourhood of Tostock in west Suffolk, the Rev. J. G. Tuck has often heard the local name of 'miniver' used for this animal. The Rev.E.T. Daubeny, too(Nature Notes, October 1903, p. 213), in a list of local names in use in the neighbourhood of Market Weston near Thetford, says : 'In winter the stoat is a "minifer." In the eastern part of the county it is, or used

1 For this information I am indebted to $\mathrm{Mr}$. H. Miller of Ipswich. frequently to be, called the 'weasel,' while the true weasel has another name given it. No animal is more universally detested by gamekeepers than this bold, determined little marauder; and its numbers have been so much reduced by traps, guns and other means, that it is far less common than it was thirty years ago. In the game-preserving districts of east Suffolk, one rarely gets a chance now of watching the stoat hunting along the side of a hedge or ditch, and admiring the grace and elegance of his movements as he comes bounding along, full of life and animation, now and again raising himself to his full height, in order to extend his horizon. In spite of its bad reputation, this animal is an excellent and accomplished ratcatcher, and so atones for many of its misdeeds. The advantage it possesses through its ability to follow its prey into their holes, combined with remarkable strength, agility and courage, makes it a formidable foe to the rat. Stoats haunt the banks of rivers and streams, especially where there are beds of reeds or osiers, preying upon rats, water voles, waterhens, etc. On the beach, sand hills and rough ground between Sizewell and the Dunwich cliffs, where they were comparatively safe from the keepers, both stoats and weasels used to be fairly common. They also visit at times the river 'walls,' in pursuit of the rats and moles which there do much damage; but even here their relentless enemy follows them, setting baited traps for their destruction. The stoat takes the water boldly, swimming very fast, and with a good deal of its body above the surface. Where rabbits abound, these animals are soon attracted to the spot. Mr. W. G. Clarke informs me that in the year I 893,200 stoats were trapped upon Thetford warren in six weeks. Up to the early part of the last century, this animal must have been very common. In the list of vermin killed in a single year ( $18 \mathrm{I} \mathrm{I}$ ) by a gamekeeper in Suffolk (quoted in the account given here of the marten) the number of stoats destroyed is 416. Every winter, whether severe or otherwise, a few white or rather nearly white specimens find their way into the bird-stuffers' shops, most of them retaining a few patches of colour, especially round the eyes and along the spine, the black tip of the tail being of course always present. One in perfect winter dress, killed in Suffolk, was exhibited by Dr. Crisp at a meeting of the Zoological Society in $18600^{2}$ The extraordinary audacity so characteristic of the weasel family is very conspicuous in the stoat, who will sometimes

2 Zoologist, 1860, p. 6913. 


\section{MAMMALS}

dispute, even with man, the possession of any animal he may have killed. See the Zoologist of 1890, p. 380 , where some very curious experiences with this animal are described.

17. Weasel. Putorius nivalis, Linn. Bell-Mustela vulgaris.

Locally, Whitethroat (male); Mousehunt or Mousehunter (female).

Like the stoat, this useful and elegant little animal is systematically destroyed by gamekeepers, and its numbers have been sadly reduced. In some parts of the county it has become the rarer animal of the two ; and in places where not long ago it was fairly common, one may now keep a sharp look-out for a year or more without seeing a single individual; besides which the old rough banks and wide bushy hedges which formerly provided it with both shelter and productive hunting grounds have disappeared. From its diminutive size and flexible snake-like form, the weasel can follow a mouse into its hole, or thread its way among the sheaves in a wheat stack with the greatest ease; and with the exception perhaps of the barn owl is the most valuable and efficient mouser we possess. Its value in keeping down mice, voles, and even rats and moles is well known and appreciated by many farmers, who would feign protect and encourage it if possible. Repeated observations have shown that while such prey is to be had, the weasel does very little harm among game or young chickens; certainly far less that the rats it helps to keep down. ${ }^{2}$ A curious habit of this little animal came under the notice of Mr. A. M. Rope of Leiston. Driving over Westleton 'Walks,' he noticed on a bare sandy spot of ground a strange-looking object moving along in a peculiar undulating manner. It was some 2 feet in length and very narrow; and he at first took it for a snake. A nearer approach showed it to be a female weasel, with a litter of young ones following close behind her in single file. The dam carried her head and neck high above the ground. When she saw that she was observed, she took one of the cubs in her mouth and bore it off to some place of safety, returning very soon for another, which she served the same; and there is little doubt that had she been watched longer she would not have rested until every one of the cubs had been removed and placed out of danger. A family of young weasels following closely behind their mother in one long unbroken line has also been noticed near Orford. A weasel was once seen by the

2 See Zoologist, 1894, p. 422, twelve lines from bottom. writer swimming across the river Alde, not far from Langham bridge, and carrying in its mouth a young one, almost if not quite as large as itself. Not one of our few remaining wild animals is more graceful and agile in all its movements or more entertaining to watch than the weasel. It is a great pity that in the war of extermination waged against so many of our interesting native animals, this useful and beautiful little creature at least should not be spared.

\section{Badger. Meles meles, Linn. Bell-Meles taxus.}

Except as an occasional wanderer from a distance the badger can no longer, I fear, be included in a list of Suffolk mammals. From time to time however a specimen still turns up here and there. A few may have been introduced for the purpose of making earths for foxes, while some of the more recent examples may possibly have escaped from confinement, and perhaps in rare instances have bred in the county. Formerly however they must have been common in many parts of Suffolk. At the time the Messrs. Paget wrote $(1834)$ these animals had already been exterminated in the Yarmouth district, though stated by them to have been common thirty years earlier, especially about Bradwell and Browston. In some parts of the county badgers appear to have lingered till nearly half a century later. In the winter of . $846-7$ one was killed at Cavenham, and another supposed at the time to exist in that neighbourhood, as recorded by Professor A. Newton (Zool. 1849, p. 2379). Mr. F. S. Griffiths of Dedham, in a communication to the East Anglian Miscellany of 9 March 1901, writes as follows: "Some fifteen or sixteen years ago a fine female badger was taken alive-not shot-by Mr. Robert Partridge of Stratford St. Mary, while cutting grass. It was afterwards sold, I think, to Mr. H. N. Dunnett, but soon died. Dissection proved it to contain, I think, three young ones. It was supposed to have been an escaped specimen; but I have heard from two very old inhabitants of Stratford St. Mary ... that in their youth they frequently undertook to dig badgers out in the Commons and Bush Hills, two preserved woods near the meadows spoken of.' About Ubbeston there were a few badgers during the first quarter of the last century, Ubbeston Wood being then unpreserved. Mr. S. Levett, in the East Anglian Miscellany of 9 March 1901, states that he has seen one which had been caught on the Stratton Hall estate in 1852 ; and that another has since 


\section{A HISTORY OF SUFFOLK}

been taken by a ratcatcher at Kirton Hall. $\mathrm{Mr}$. Levett has been told badgers used to breed at Fagbury Cliffs at Walton and Trimley. The three localities last named are situated in a rather isolated part of the county, lying between the rivers Orwell and Deben. In the same publication, under date 4 May I $901, \mathrm{Mr} . \mathrm{T}$. W. Thurston refers to one of these animals having been caught at Norton near Bury St. Edmunds, about four or five years previous to that time. Mr. T. E. Gunn of Norwich in the Zoologist of 1869 , p. I 926 , records the capture of a female and two cubs in Suffolk, close to the Norfolk boundary, in 1865 . Mr. C. Whiting, in a letter to Mr. H. Miller of Ipswich, gives an account of a curious capture of one of these animals about the year I 865 or 1866 on the Dial farm, Coddenham, by a man named Jessop. He had shot at and wounded a rabbit which his dog, as he thought, had followed to a hole. Reaching in with his arm, he pulled out a badger, which fortunately did not bite him. Having somehow managed to get a wire snare over its leg, he drew it into a sack and secured it. He kept it some little time shut up in a shed, but it afterwards escaped. About a week or ten days after this, a badger (doubtless the same animal) was captured close by and sold to a man living near Chelmsford. About the year 1885 or 1886 a male badger was unfortunately destroyed at Chillesford, where it had first been noticed drinking at a pond in the village. This, there is little doubt, was one which had made its escape two or three years before from Blaxhall, about four miles distant, and which came originally from Oxfordshire. Since its escape it had lived for a time in a rabbits' burrow in that parish. A badger caught at Stratford St. Andrew by a man named Cuthbert was sent to $\mathrm{Mr}$. Asten, taxidermist at Woodbridge, in May 1891. Mr. W. M. Crowfoot of Beccles, in a letter to the writer, states that the last badger he has heard of in his district was dug alive out of a burrow in a small plantation at Carlton Colville, known as the 'Grove.' After having been exhibited in the neigbourhood it was killed and stuffed, and was purchased in 1894 by a gentleman living at Lowestoft. The last Suffolk badger of which I can find any notice is one killed in the Cliff Hill Wood on the Sudbourne estate, on I March I 895 , recorded by Mr. S. O. Heywood of Glevering Hall, in the East Anglian Miscellany of 9 March 1901 . It is unaccountable that an interesting and inoffensive animal like the present species, well known to do little harm to game, should almost invariably be killed wherever it makes its appearance, instead of being welcomed and protected. It does excellent service in searching out and destroying wasps' nests. For a most entertaining account of the successful introduction and establishment of a colony of badgers by a gentleman in Leicestershire, see the Zoologist of $1888, p .6$. Since writing the above I have received a letter from Mr. C. H. Hill, gamekeeper (to whom I had been kindly referred by Mr. Laver of Colchester). This man lately lived at Stanway in Essex, where a few badgers are still, I believe, in existence. The following is an extract: "I have seen their work in the parish of Sproughton. They (drew) an earth in the latter part of March in a hedge-row bank upon the Valley farm, I believe for young. Unfortunately the hedge was cut down and the earth exposed, causing them to forsake it. I have not the slightest doubt that it was done by badgers, as I have seen their work at Stanway Hall. I have not heard of any being turned down here.'

Tidings have just arrived of the capture during the present year of one of these animals in this county. In a letter from Mr. A. E. Elliott, Estate Office, Elveden, forwarded by the Rev. J. G. Tuck, mention is made of a badger caught last January in a belt called 'Napthens' in that parish. It was a fine male measuring 3 feet 9 inches in length.

\section{Otter. Lutra lutra, Linn. Bell-Lutra vulgaris.}

For the last thirty years or so the number of otters frequenting the rivers and streams of this county, in spite of the treatment they generally receive, is greater than has previously been the case for a considerable period. The Messrs. Paget, writing of the Yarmouth district in 1834 , refer to this species as 'now seldom seen on any of the broads, where it was once not uncommon,' and up to more recent times it has been considered a rare animal in Suffolk. At present however so many instances of the capture or wanton destruction by gun, trap or other means, of this interesting and comparatively harmless animal annually come to light, that it would be difficult as well as unnecessary to enumerate them. From the Waveney and Little Ouse in the north to the Stour on the southern boundary, there are few streams that are not occasionally visited by this nocturnal wanderer. In the extensive marshes near the coast and the low meadows of the river valleys otters hunt the ditches for eels, frogs, freshwater mussels (Anodonta cygnea), and coarse fish, lying up temporarily in reed beds, alder cars or any suitable retreat they can find. The 


\section{MAMMALS}

presence of a town of considerable size on the banks of a river frequented by these animals by no means prevents their passage up and down stream. At Ipswich the curious whistling call of the otter has been heard at night, where the river Orwell passes through the town. Mr. Hudson, the Ipswich taxidermist, who at the time had several otters in his shop, informed the writer of a curious incident which took place a short time before. While the passenger steamer Merrimac was lying at Ipswich, a man proceeding to clean one of her paddle-boxes found an otter inside it, which I am sorry to add he destroyed. In the local museum there is a large otter labelled 'Killed in Stoke Park,' which is just outside the town. The Essex Otterhounds, on 27 August 1902, killed three otters near Stowmarket, weighing respectively 24 , Is and 7 lb. In May 1879 a fine male entered one of the marsh draining mills on the Minsmere level, where it was shot by the man in charge of the mill. The marshes in that neighbourhood are much frequented by otters. On one occasion, close to a thick plantation bordering upon these marshes, $\mathrm{Mr}$. A. M. Rope had in sight two of these animals at the same moment and was able to watch them for some time. In the spring of $188_{3}$ they seem to have been quite numerous in the Waveney. Among others destroyed, a female and her cubs were 'done to death' near Bungay. It seems indeed to be thought a heroic and praiseworthy deed to take the lives of these graceful creatures, whose presence so greatly enhances the interest and attractiveness of the places they haunt. Otter cubs are, as is well known, born at various seasons, and not, like the young of most wild animals, in the spring and summer only. ${ }^{1}$ On 10 March r 885 two young otters were caught in a farmyard at Stratford St. Andrew by means of a running noose on the end of a pole. They were at the time not quite half grown, and were probably born during the previous autumn. A small cub killed by a dog on the Abbey farm at Snape on 5 December 1892 appeared to be then about eight or nine weeks old. In severe winters, when neither frogs, eels nor fish of any sort are any longer to be had, the otter is forced to subsist on whatever it can get, preying upon waterhens, rabbits, etc. During the winter of 1891-2 near Leiston, Mr. A. M. Rope followed the track of one of these animals in the

1 Mr. Southwell's observations show this animal to be, in Norfolk at least, a late autumn and winter breeder. snow, which left the river and led across some fields. Here it appeared to have tried to seize a hare in its seat, but only succeeded in getting a mouthful of fur.

\section{Common Seal. Phoca vitulina, Linn.}

Almost every year a few seals visit different parts of the Suffolk coast, sometimes entering the rivers in pursuit of their prey. The Messrs. Paget refer to this animal as follows: - Occasionally has been seen in the Roads, or been thrown upon the beach; one weighing 14 stones killed March 1822. They seem formerly to have been much more common.' Mr. N. F. Hele, ${ }^{2}$ writing thirty-six years later than the Pagets, mentions the occurrence of four seals at Aldeburgh and Thorpe, between 1863 and 1869 . He remarks that : 'It is probable that these animals come from the north, and follow the shoals of herrings. In every instance of capture or otherwise, the seals have always appeared off Thorpe, to northward of us, before arriving here.' Mr. T. Southwell, in an article on the 'Mammalia of Norfolk,' ${ }^{3}$ has drawn attention to a colony of these animals inhabiting sandbanks in the Wash. It seems only reasonable to suppose that those seen from time to time on the coasts of Suffolk and Essex are wanderers from these sandbanks. Two seals were observed in the Stour, between Harwich and Manningtree in 1854 , one of which was shot by a puntsman. A beautiful specimen lately on view at the shop of Mr. Hudson of Ipswich had been shot in the Deben on 22 February 1902. For a very long period these creatures have from time to time made their appearance on the beach at Orford, particularly about the shifting shingle at the mouth of the river, and it is supposed by some that the traditional 'wild man' of Orford, shut up for a time in the castle, was in reality a seal. In November 1872 one of these animals was observed several days in succession in the river at Orford, sometimes opposite the quay. On one occasion it was seen with a fish in its mouth between the quay and a vessel lying close by. According to $\mathrm{Mr}$. C. Rope of that town, the time that seals most frequently make their appearance there is from the latter part of November to the end of December, but in 1902 two were observed in July. One was seen at Felixstowe by a night watchman in October I 900 (East Anglian Daily Times, 22 October

2. Jottings about Aldeburgh, N. F. Hele.

3 Trans. Norf. and Nor. Nat. Soc. i. (1870-1), 71.

- Mammalia of Essex, H. Laver, F.L.S., p. 55. 


\section{A HISTORY OF SUFFOLK}

1900), and another killed near Bawdsey ferry on 7 September 1891 . Some years ago a young seal was killed on the steps of the landing-place at Walberswick ferry near Southwold. Another young one was shot on 9 September 1878 while lying on the end of the Minsmere sluice between Dunwich and Sizewell. It is gratifying to be able to give a single instance where one of these beautiful and intelligent animals met with kind treatment instead of serving as a mark for a rifle bullet. Mr. T. Southwell (Zool. x 890, p. 384) writes as follows: ' On the 8 th August I went to Corton to see a seal which had been caught on the beach there, I believe, the same morning; this was nearly full grown, and so won the hearts of the ladies at Cliffe House by its mild beseeching looks, and evident discomfort, that Mrs. Colman bribed its captor to liberate it, and we had the pleasure of seeing it swim off to sea.'

\section{2x. Hooded Seal. Cystophora cristata, Erxle- ben.}

'The first fully identified British example of this seal, and for a long time the only one known, was killed in the river Orwell on 29 June 1847 . It was preserved in the Ipswich Museum, but on my last visit to that institution I was unable to identify it; the stuffed seals were without labels, and the then curator did not seem aware of the treasure he should have in his charge.'

To the above account of this rare British animal, for which the writer is indebted to Mr. T. Southwell, F.Z.S., the following particulars, taken from Mr. H. Laver's Mammalia of Essex, p. 56, may be added: 'The capture of this specimen was recorded by Mr. W. B. Clark in the Zoologist for 1847 , p. 1870 , where a full description of it is to be found. It was presented to the museum by Mr. Ransome.'

\section{RODENTIA}

\section{Squirrel. Sciurus leucorus, Kerr. Bell-Sciurus vulgaris.}

Inhabits woods, parks and plantations in most districts, and was at one time very abundant in the Scotch fir belts about Mildenhall. It is however destroyed on some estates as an enemy to game, and is probably much less numerous in Suffolk than in many English counties. In sparsely wooded districts squirrels make long journeys from wood to wood, taking advantage as much as possible of roadside trees and hedges. On 4 November 1872 , in a wide stretch of marshes near Leiston, which, with the exception of a very few scattered pollard willows, are quite bare of trees, a squirrel was caught by a dog in a clump of sedge at the very edge of a ditch, only just clear of the water, and on the same open marshes in December 1873 one was seen and chased by a man at work near by. A large and handsome example, of a pale fawn or cream colour throughout, for at least two years frequented a garden and plantation at Blaxhall. In the Field of 22 November 1902 will be found an interesting note on the squirrels in Christchurch Park, Ipswich, whose gambols among the branches of the fine old oaks and chestnuts add greatly to the attractions of the place.

\section{Dormouse. Muscardinus avellanarius, Linn. \\ Bell-Myoxus avellanarius.}

The distribution of the dormouse in England, and especially in East Anglia, is very curious, and difficult to understand. Though found in many parts of Essex, it appears to be absent from a large portion of the neighbouring county of Suffolk, amounting perhaps to more than half of it, while in Norfolk it is only known to occur in one locality, restricted to some three or four adjoining parishes. As regards the eastern half of the county of Suffolk, from the Waveney in the north to the Stour in the south, no instance has, as far as I am aware, been recorded of the dormouse having been met with except in the neighbourhood of Ipswich and the wooded country about Belstead and Bentley. This little animal appears to be commonest in the west central district lying to the south-west of the railway connecting Bury St. Edmunds with Haughley and extending as far as Long Melford on the Essex border. No recent information has been received of its occurrence in west Suffolk further north than Thurston. The Messrs. Paget however refer to it as 'occasionally seen in small woods, etc.', about Yarmouth in their time (1834). Mr. W. G. Clarke, in reply to an inquiry on this subject, writes as follows: 'I have never met with the dormouse in the Thetford district, nor is there any record of its occurrence, although this may be due to lack of systematic observation.' Mr. Travis, the Bury St. Edmunds taxidermist, considers this animal as by no means rare in the neighbourhood of that town, and Mr. W. H. Tuck informs me that it is ' not uncommon about Tostock.' The Rev. J. G. 'Tuck, rector of that place, found one in a birds' nest-box on an elm tree, some 


\section{MAMMALS}

12 feet from the ground. There was no nest. The following localities were given in a letter from the late Dr. Babington to the writer in 1885 : 'Bull's Wood, Cockfield (dormice, as well as many of their nests containing young, found during September about two years ago), Rougham, Thurston, Beyton, Bradfield St. George and Rushbrook. Not at all uncommon in the neighbourhood.' The late Dr. Bree, in a letter to Mr. H. Laver of Colchester, dated from Long Melford, Suffolk, says : 'The dormouse is well known about here ... Two "sleepers" were quite recently caught by a man while at work in a large wood near Lavenham.' As regards the Ipswich district, Mr. H. Miller of that town has on more than one occasion during entomological excursions met with dormice in the woods at Belstead and Bentley, and once possessed a specimen which had been found in its nest near the Gold Road in the parish of Stoke, a suburb or hamlet of Ipswich. As recently as the year 1899 he found a pair of dormice and their nest in the Old Hall Wood, Belstead.

24. Brown Rat. Mus decumanus, Pallas.

In consequence of the systematic destruction of its natural enemies by gamekeepers this noxious and omnivorous animal has become excessively abundant. During the summer great numbers of rats live out in the marshes, burrowing into the sides of ditches and also into the river 'walls,' sometimes to such an extent as to endanger their stability. Undermined and weakened by the numerous excavations of the rats and moles, these embankments can no longer resist the weight and pressure of the water, and giving way before the incoming tide occasion extensive floods. The woods too harbour great quantities of these animals, which multiply there to an alarming extent, feasting upon the maize and other food intended for the pheasants. Towards winter they make their way to farm premises, corn stacks and buildings, where they make great havoc among farm produce of various sorts, and especially later on among the early broods of ducklings and chickens, carrying off at times a whole brood in a single night. So numerous have they become that in many districts the ratcatcher with his dogs and ferrets can no longer keep them in check, and the farmers have for years past been forced to resort to the objectionable practice of laying down poison, whereby unfortunately not only the rats are destroyed, but also those very creatures which if more numerous would far more effectually keep down the numbers of these rodents. It is more than probable that many weasels, stoats, owls and other useful ratcatchers find and devour the poisoned rats with fatal results to themselves. Even on the sea coasts colonies of rats establish themselves among the faggots sunk in the shingle as a protection to the beach. The sea itself provides them with a constant supply of food, such as shellfish, dead fish, crustacea and other marine animals, and occasionally corn and other stores washed ashore from wrecks. On some parts of the coast this is supplemented in spring and summer by the eggs and young of terns, ringed plovers and other birds. Some years ago after the wreck of a herring boat the beach between Sizewell and Dunwich was for a long distance strewn with these fish, many of which were carried by rats a long distance across the marshes to an ancient isolated building in ruins known as the 'Chapel,' 1 and were there found stored in their holes under the crumbling walls. Mr. Southwell informs me that on Lowestoft pier he has seen the rats seize and run off with the bait lying by the side of the anglers from the pier. The brown rat varies a good deal in size, and where food is plentiful will attain to dimensions far exceeding those of ordinary individuals. Some big rats have been met with in this county, and curiously enough the two heaviest examples of which I have come across any record were caught in the same parish (Tunstall). One of these, which weighed $2 \mathrm{I}$ ounces, was recorded by $\mathrm{Mr}$. J. D. Jackson in the Field of 13 August 1881. The other, weighing 23 ounces, was killed on the Dunningworth Hall farm by Mr. R. A. Girling. The occurrence was noted in the same publication under date IO February 1883 . These weights however have in several instances been exceeded, notably in the case of a specimen mentioned in the Field of 9 January 1897 , which is stated to have weighed $2 \frac{3}{4} \mathrm{lb}$. In a species so abundant as $M$. decumanus occasional deviation from the normal colouring would naturally be expected. Several rather striking varieties have occurred in this county. In the Zoologist for 1889 , p. I44, a fawn coloured specimen, white underneath and with pink eyes, is recorded by Mr. E. W. Gunn of Ipswich as having been trapped at Holbrook. In January 1890 a pied rat, brown and white, which had been killed at the Burnthouse farm, Farnham, was seen by the writer. Several others, more or less marked with

1 This ruin is all that now remains of the abbey of Premonstratensian canons, founded in 1182 . See Hist. of Suffolk, Rev. J. J. Raven, D.D., p. 87. 


\section{A HISTORY OF SUFFOLK}

white and belonging perhaps to the same litter, were observed there at about the same time. Albinos are not very uncommon, and have several times been met with in the county. A white rat with black eyes was shot by Mr. G. Cornish on the banks of the Gipping at Ipswich about the year 1868 or 1869 , and in February 1903 an adult which was of a smoky black colour all over was to be seen in the shop of Mr. Asten, taxidermist of Woodbridge. It had been caught at Boyton.

\section{Black Rat. Mus rattus, Linn.}

Black rats have occasionally been reported to have been caught in old houses in Ipswich. Mr. H. C. Hudson of that town lately told the writer that when living in Fore Street, he used now and then to catch examples of this species, with which he is well acquainted, sometimes as many as three or four in a year. The last captured was in the summer of $189 \mathrm{I}$. One was caught in a house in Brook Street, Ipswich, about the year 1863 or 1864 . Mr. Frank Norgate, in a letter to the writer, gives particulars of a black rat killed in January I $89 \mathrm{I}$ at a pea stack at Little Welnetham. His description of this animal, carefully taken down at the time of capture, agrees in most details with that given by Bell (Hist. Brit. 2uad.) of $M$. rattus, excepting that the tail was 'well covered with hair,' whereas in that species it is usually nearly naked. Through the kindness of the owner of this specimen, Willoughby Josselyn, Esq., the writer was allowed to examine it, but could not arrive at a decided opinion as to its species. Without having seen Mr. Norgate's notes referred to above, and taking into consideration the place of capture, one would I think be inclined to label this rat ' $M$ us decumanus (black variety).' Its form and appearance had probably undergone considerable alteration through and since the process of stuffing, especially as regards the shape of the muzzle; and both tail and ears seemed rather short for $M$. rattus. The animal being mounted by itself in a small glazed case, it was impossible to get a clear view of the feet. At Yarmouth the black rat seems to have increased rather than diminished in numbers since the Messrs. Pagets' list was published. It is there stated that 'This species still remains here, though its numbers are gradually decreasing; it is now seldom found, except in the ceilings and upper stories of old buildings.' Mr. A. Patterson ('Mammalia of Great Yarmouth and its Immediate Neighbourhood,' Zoologist, I 898, p. 305) writes: "Than at the present moment the black rat was never more numerous at
Yarmouth.' He further states that in 1895 , when its numbers appeared to be increasing, it confined itself chiefly to the south-western part of the town, much of which is in the county of Suffolk. Mr. Patterson received over a hundred examples within a few months. Traffic with foreign ports tends here to keep up a supply of black rats, and prevents the species from dying out.

\section{[Alexandrian Rat. Mus alexandrinus, D( Selys.}

On 9 May 1903 I received a black rat which had been caught on the premises of Messrs. Paul of Ipswich, corn merchants and importers of foreign grain. It was an adult female in good condition, with glossy shining fur. Mr. T. Southwell, who examined this animal, pronounced it to be a specimen of $M$. alexandrinus, the continental form of our $M$. rattus; in colour however it resembled the latter. The great length of the tail (nearly 9 inches), in comparison with that of the head and body, was very striking. Some of the hairs of the whiskers, which were very abundant, reached $2 \frac{1}{2}$ inches. The manager of the above-mentioned firm, to whom I am indebted for this specimen, stated that black and slate-coloured rats were not unfrequently caught in their warehouses and granaries.]

\section{House Mouse. Mus musculus, Linn.}

Abundant everywhere, and, like the brown rat, always ready to adapt itself to any change of circumstance or situation. Thus in the matter of nest building, it turns to account any material it finds available. In a stack hay or straw is used, in the carpenter's shop shavings serve its purpose equally well, and in the house paper or rag of any kind is soon converted into soft and comfortable bedding. A nest found in a fowl house at Blaxhall was composed entirely of the bright buff feathers or some Pekin bantams. Scarcely any animal multiplies faster than this species. The writer has records of three mouse's nests in Suffolk, containing respectively fourteen, seventeen and thirty-two young ones. In the last case more than one female had probably used the same nest as a nursery. In thrashing a wheat stack at Blaxhall in April 188 I a white mouse was killed with a litter of young ones, all of which were white, and like the mother had black eyes, and were therefore not albinos. Some of the young had both ears of a greyish colour, while in others only one ear was coloured. Most of them had also a small spot or two of the same tint at the root of the tail. In the spring of I 903 several mice of a cinnamon colour 


\section{MAMMALS}

were observed by Mr. E. J. Rope in a barn at Little Glemham.

27. Wood Mouse or Long-tailed Field Mouse. Mus sylvaticus, Linn.

Very abundant everywhere, frequenting woods, hedge banks, fields and gardens. I have seen it among the tall marram grass on the sea beach between Dunwich and Sizewell. It sometimes enters houses, and especially dairies, from its fondness for milk; but does not permanently take up its abode there. Owing to its partiality for newly sown peas, beans, and corn of all kinds, it is not a favourite with farmers and gardeners.

\section{Yellow-necked Mouse. Mus favicollis, Melchior.}

In March 1903 a fine adult female of this large and handsome variety of Mus sylvaticus was captured at Tostock Rectory, near Bury St. Edmunds, by the Rev. J. G. Tuck. It was trapped inside the house, having first betrayed its presence by biting the door mat in the hall. Mr. Tuck was kind enough to forward it to the writer, who afterwards sent it on to Mr. Southwell of Norwich. It was ultimately examined by Mr. Oldfield Thomas of the British Museum, who pronounced it to be a clearly marked example of the large form of Mus sylvaticus, i.e. Mus sylvaticus quintoni, Barrett-Hamilton. Previous to this occurrence Mr. Barrett-Hamilton had received specimens from Suffolk, but possesses no record of the exact locality. In the Zoologist for April 1903 will be found an interesting article by Mr. Southwell on this large race or subspecies of $M$. sylvaticus. Mr. Tuck informed the writer that he believed a second specimen had been caught in another house in his parish. Besides its superior size and more brilliant colouring, this animal differs from a typical specimen of the long-tailed field mouse, in the shape and extent of the breast spot or collar. In the latter this is a mere spot or streak of fawn, rather variable in size and shape, on the silvery white fur of the under parts ; in the former it is developed into a well marked band across the breast; the middle portion of this band being produced so as to form a streak, running backwards for a short distance towards the tail, and also projecting slightly forwards, thus producing a somewhat cross-like figure. $\mathrm{Mr}$. Southwell informs me that a second female example from Tostock was sent him by $\mathrm{Mr}$. Tuck on 18 April 1903. On 18 June Mr. Tuck sent two more specimens, which had been caught by his cat, to the Norwich Museum.
29. Harvest Mouse. Mus minutus, Pallas.

This beautiful little animal is not uncommon in Suffolk, though perhaps nowhere particularly abundant. Owing to its diminutive size, as well as to a want of interest in matters of natural history among those most likely to come in contact with it, its presence is apt to be overlooked; and it is probably more generally distributed than is commonly supposed. The harvest mouse is not included in the Messrs. Pagets' Sketch of the Natural History of Yarmouth, published in 1834 , but in more recent years has been found to inhabit some parts of the Yarmouth district. Mr. W. M. Crowfoot has found its nest among the coarse herbage growing on the Norfolk bank of the Waveney at Gillingham, and also in the marram-grass on the beach at Kessingland, almost within reach of the sea-spray. ${ }^{1}$ At Haddiscoe in Norfolk, just over the Suffolk boundary, Mr. Last Farman reports finding these mice in quantity in the bottom of barleystacks. ${ }^{2}$ The writer has often met with this species at Leiston, and also at Blaxhall, where it is certainly far from uncommon, though, as elsewhere, uncertain and erratic in its appearance. Harvest mice have also been observed at Little Glemham, and at Gedgrave near Orford. About Bury St. Edmunds $\mathrm{Mr}$. Travis, taxidermist of that town, considers them common, and at Tostock, between Bury and Stowmarket, they are stated by Mr. W. H. Tuck to be not uncommon. At Market Weston near Thetford the Rev. E. T. Daubeny has seen two nests, and in the neighbourhood of Needham Market Mr. H. Lingwood has, some thirty years ago, many times come across both the mice and their nests. Mr. E. C. Moor of Great Bealings, in a communication to the Zoologist for 1884 , p. 190, writes as follows: 'During the autumn of 1883 , especially harvest time, several nests of the harvest mouse, $M u$ s messorius, were taken by myself, mostly from barley-fields, being placed upon the laid barley. Almost all contained young ones, numbering from six to eight, and it was surprising to see how eight fair-sized mice could possibly live in a nest hardly as large as an orange.' In a letter to the writer dated I January 1903 , Mr. Moor refers to this little animal as being rather common at Bealings, and generally observed when threshing in the winter. Harvest mice are indeed seldom seen except during the threshing of corn stacks, when

\footnotetext{
1 'Mammalia and Reptilia of Norfolk,' T. Southwell, Zool. 1871 , p. 2756.

' 'The Mammalia of Great Yarmouth,' A. Patterson, Zool. 1898 , p. 305.
} 


\section{A HISTORY OF SUFFOLK}

numbers are sometimes found congregated together in the lower part of the stack. After the corn is gone, they often remain throughout the winter in the straw left on the spot. On one occasion a pair were observed by Mr. Moor in a stack of tares. The writer has seen the nest of this little animal built in tall reed-like grass, in the midst of a thin whitethorn hedge beside a ditch at Snape ; among straggling blackthorn bushes in a similar situation at Leiston, and in a plant of the common broom at Washbrook. A nest built among standing barley was presented by Mr. E. C. Moor to the Ipswich Museum.

30. Water Vole. Microtus amphibius, Linn. Bell-Arvicola ampbibius.

Common in suitable situations in most parts of the county. From its inoffensive habits it is less persecuted by man than most of our British rodents, and the presence of this busy little creature gives an additional interest to most rivers, streams and ponds. It is less shy than many animals, and as its range of vision seems to be rather limited, it can by careful stalking be very closely approached, especially when feeding. The Rev. F.C.R. Jourdain has observed that the water vole is very rarely preyed upon by owls, though our two smaller voles are often devoured by these birds. The writer has more than once seen it feeding on the leaves of the common blue forget-me-not.

The black variety of this animal, common in some parts of Scotland, and also found in Norfolk and Cambridgeshire, occurs in a few districts. Professor Newton has reported it to be common in the neighbourhood of Thetford on the Norfolk boundary, ${ }^{1}$ and the Rev. J. G. Tuck in February 1898 received a good specimen of this variety, in the flesh, killed at the stables of Hopton Rectory, about a mile from the Little Ouse. ${ }^{2}$ The specimen is still in his possession. Mr. H. Lingwood, in a letter to the writer, states that he has not unfrequently seen the black variety of the water vole in the river Gipping, near his house, at Needham Market. A specimen about the colour of $M$. decumanus, but having a pinkish tinge, was seen some years ago by Mr. A. M. Rope near Leiston.

31. Field Vole. Microtus agrestis, Linn. Bell-Arvicola agrestis.

Local name, 'Meadow Mouse.' About Thetford it is called the 'Bog Mouse.' ' Very

1 A History of British 2uadrupeds, Thos. Bell, F.Z.S., ed. 2 (1874), p. 322.

2 Zoologist, 1898 , P. 122.

W. G. Clarke in litt. common in meadows and marshy ground, but from its protective colouring, and burrowing and tunnelling habits, it usually attracts little notice. On the salt marshes near the coast, and the river walls, it abounds and grows to a large size. It also makes its appearance on arable land when cropped with clover, lucerne and other forage plants. It is very prolific, and continues breeding through more than half the year. In Suffolk the writer has found nests of the field vole containing young, sometimes as many as ten in one litter, from 9 March till I3 October. Some of the earlier of these contain fur, plucked from rabbits or any other dead animals available; that of its own species being sometimes used for this purpose. In cutting grass, these nests, built on the surface of the ground, generally in some slight depression, not unfrequently get entangled among the knives of the mowing machine and impede its progress. This little animal takes the water quite readily. If surprised at the water's edge, it swims out boldly like a miniature water vole, and can easily cross most ditches, but if the width is too great for its liking it soon turns back. The writer once saw a rather small field vole cross the river Alde, against a strong current, at a spot where it is between 30 and 40 feet wide (measured). This species is sometimes found on the sea shore at low tide, close to the surf, apparently searching for animal food among the seaweed. The writer once surprised one of these voles, thus engaged, on the sand under the cliff at Iken, at the brink of the water. It at once swam straight out from the shore, but soon returned. In November 1872 an albino field vole was caught alive at East Bergholt and brought to Mr. W. S. Calvert of that place, who recorded the occurrence in the Field of 30 November 1872.

A perfectly black female suckling a litter of young ones of the normal colour was captured in a clover field at Blaxhall on 25 June 1886. Its fur was of a rich shining black, long and abundant. This specimen is now in the Ipswich Museum. In an adjoining pea-field, a second black female was caught alive on 7 August in the same year, and was sent to the Zoological Gardens, Regent's Park. This species is much sought after by weasels, kestrels and owls, the short-eared or woodcock owl in particular.

32. Bank Vole. Evotomys glareolus, Schreber. Bell-Arvicola glareolus.

This pretty little animal is common in many parts of the county, and is probably much more generally distributed than is often supposed, frequenting old rough banks, woods, 


\section{MAMMALS}

gardens and orchards. It is no doubt often confounded by superficial observers with the last mentioned species, but may easily be distinguished from it, not only by its teeth, but by its larger eyes, longer tail and ears (the latter showing well beyond the fur), and by the warm ruddy tint on the back of adult examples. It is also more lively and rapid in its movements. In the autumn it climbs about the hedges with the greatest ease in search of ripe haws, and the writer once noticed one early in May perched high up in a tall hedge at Farnham, feeding on the tender young leaves of the hawthorn. In the winter the bank vole sometimes enters outhouses where seeds, bulbs, etc., are kept, and especially buildings used for storing apples and pears, from which it is sometimes difficult to exclude it. In an apple-house in the midst of a plantation at Blaxhall, several examples are caught almost every season. A few years ago several were found in a heap of mangolds or beetroot (locally a 'beet clamp') at Leiston. They had made a nest among the litter with which the roots were covered before being banked up with earth. This little animal is easily tamed, and is very amusing in its ways. One kept for two years at Blaxhall would feed quite readily from the hand. This, as well as several others kept there at different times as pets, had been rescued when quite young from the jaws of a cat. The Rev. F. C. R. Jourdain found twelve skulls of this species in pellets of the barn owl (Strix flammea) at Huntingfield.

33. Common Hare. Lepus europaus, Pallas. Bell-Lepus timidus.

Common, but not so abundant as it was thirty or forty years ago. At that time, on some of the large estates towards the coast, an enormous stock of hares was kept up, resulting in a considerable proportion of undersized and diseased animals. Some curious varieties have occurred from time to time. Mr. Alexander Clark-Kennedy (Zool. I 869, p. $155^{8}$ ) states that a hare with white and iron grey markings was shot near Easton by the late Duke of Hamilton, in November 1868. The head, ears and part of the neck were white, mingled with grey ; the legs, feet, with part of the chest and of the back, white.

A grey female is reported by Mr. T. E. Gunn (Zool. 1868, p. 1 129) as having been killed near Wangford in January 1868 . In this example the whole surface of the coat was of a silver greyish hue, suffused with a pale reddish tinge on the head, ears, neck and flanks.
Mr. H. C. Hudson, taxidermist of Ipswich, informs me that a pale sandy variety, approaching white, was shot in or close to the parish of Woolverstone in January 1893.

In the Zoologist for 1843, p. 342 , there is a notice of a black hare killed at Glemsford, then to be seen in the Sudbury Museum. ${ }^{1}$ A perfectly black specimen shot at Brome, on the estate of the late Sir Edward Kerrison, Bart., in January 1 855 , was for nearly half a century a conspicuous object in the Ipswich Museum, but has at last apparently vanished from mortal ken. A third black hare killed at Denham, near Bury St. Edmunds, is mentioned by Mr. Southwell in an article on the 'Mammalia and Reptilia of Norfolk' (Zool. 1871, p. 2757), on the authority of the late Mr. J. H. Gurney. ${ }^{2} \quad$ Yet another example of this rare variety has been obtained at Belchamp St. Pauls in Essex, just beyond the Suffolk boundary. The occurrence was recorded by Mr. G. W. Eagle in the Field, the exact date of which I am unable to supply. That hares are good and bold swimmers is well known. They have now and then been seen crossing the river Ore, below Orford, to and from the long narrow strip of beach between that river and the sea, and have been caught in the water on their passage.

\section{Rabbit. Lepus cuniculus, Linn.}

Abundant everywhere, but especially so in the 'Breck' district in the north-west, and on the light sandy soil stretching along the coast.

The silver sprig or silver grey variety flourished exceedingly on Thetford Warren from the year 1837 to about 1888 ; after which time the skins appear to have declined in value. In the middle of the last century 20,000 were annually sent to London from this warren alone. ${ }^{3}$ In 1883 Mr. F. Norgate counted on Thetford Warren sixty silver greys in sight at the same time, besides many other rabbits. Mr. S. R. Lingwood, in a letter dated 16 February 1903, writes: 'At the present time their skins are of no more value than the ordinary grey, hardly so much. Some 40 or 50 years ago the skin was of more value than the carcase.' The variety appears to be dying out, from repeated crossing with the normal type. A black variety is not uncommon in many districts; sandy coloured rabbits are also occasionally met with, some of them of a beautiful bright tint inclining

1 This museum is no longer in existence.

2 Trams. Norf. and Nor. Nat. Soc. 1869-70, p. 26.

3 For this information the writer is indebted to Mr. W. G. Clarke of Norwich. 


\section{A HISTORY OF SUFFOLK}

to orange. Albinos, among pure bred wild rabbits, are rare. In an article on the 'Mammalia and Reptilia of Norfolk' (Zool. 187 I, p. 2757), Mr. Southwell refers to a very curious variety shot by Mr. J. H. Gurney on Corton Denes, Lowestoft, which was decorated with alternate black and grey markings like a cyprus $^{2}$ cat.

\section{UNGULATA}

35. Red Deer. Cervus elaphus, Linn.

Among the eleven Suffolk deer parks enumerated by Whitaker in his list, published in $1892,{ }^{1}$ two only are mentioned as containing red deer, viz. Helmingham Park ( 72 head) and Somerleyton Park (20 head).

Judging by the number of antlers which have been found, this must formerly have been a common animal in this county. Several of these have been dredged up from the beds of the Orwell and the Alde, and there are now in the Ipswich Museum specimens from the former river in various states of preservation. Mr. Norgate has seen antlers of the red deer, stated by their owner to have been obtained from Undley Fen, Mildenhall.

\section{Fallow Deer. Cervus dama, Linn.}

The following herds of fallow deer are mentioned in Mr. Whitaker's list, published in $1892:-$

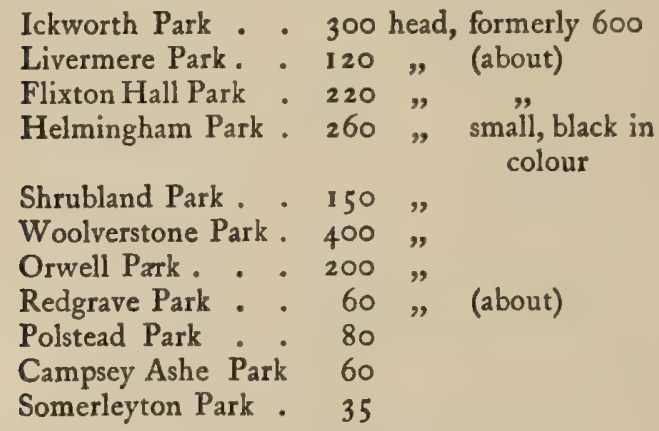

Besides the above, Ampton Park also con- tains a herd of fallow deer. Some were kept in Christchurch Park, Ipswich, until some forty or fifty years ago. The 'dappled herd" of Euston Park, immortalized by Robert Bloomfield in the Fakenham Ghost, disappeared from there, as I am informed by Mr. W. G. Clarke, about the year 1845 or 1846 .

\section{Roe Deer. Capreolus capreolus, Linn. Bell-Capreolus caprea.}

Though this animal has long been extinct in Suffolk, its remains, found in more than one part of the county, show it to have been formerly not uncommon. ${ }^{3}$ It has in one district been re-introduced, and there are at the present time roe deer living at large and breeding within the Suffolk boundary. Mr. Heatley Noble, in an interesting article entitled 'The Birds and other Animals of Thetford Warren' (Zool. April 1903, p. 157), quotes a letter from the owner of the warren, W. Dalziel Mackenzie, Esq., where it is stated that 'Roe Deer obtained from Wurtemberg have been turned down in the young Warren woods, and have increased considerably.' Mr. Noble, in a letter dated 30 April 1903, has been good enough to supply the following additional information: 'Queen's Wood, where the deer were turned out, was planted by Mr. Mackenzie. It is about 800 acres in extent, and runs down to the river." " He further adds: ' $I$ have not heard of one on the Norfolk side yet.'

\section{CETACEA}

38. Common Rorqual. Balanoptera musculus, Linn.

'A much decayed specimen was cast ashore at Kessingland about the 29th of October 1899.' (This was seen and identified by Mr. Southwell.) The Rev. J. G. Tuck, in an article which appeared at the time in Land and $W$ ater recording this occurrence, says :

The village of Kessingland was in a state of excitement, the whale having been cast upon the shore there and left high and dry, exhaling an

1 Descriptive List of the Deer Parks and Paddacks of England, Joseph Whitaker, F.Z.S. (1892). odour which almost made the neighbourhood unbearable. The local authorities decided to cremate it, and this with some difficulty was at last effected.

\section{Lesser Rorqual. Balanoptera rostrata, Fab.}

'A female was captured in the river at

2 In East Anglia tabby cats are almost universally so called, the two words 'tabby' and 'cyprus" having a similar origin.

${ }_{3} \mathrm{Mr}$. F. Norgate possesses 2 horn from the peat at Burnt Fen, Mildenhall, and has been shown others, stated by their owner to be from Undley Fen, Mildenhall.

- The Little Ouse, which here divides Suffolk from Norfolk. 


\section{MAMMALS}

Gorleston on the 8th of June 1891,' Of this specimen Mr. Patterson observes: ${ }^{1}$ 'It was drawn into the life-boat shed and exhibited, afterwards being preserved and taken on tour to various parts of the country.' Mr. Patterson also records ${ }^{1}$ an adult specimen stranded on Gorleston beach on 8 December 1896.

40. Grampus. Orca gladiator, Lacépède.

Mr. Patterson reports ${ }^{1}$ an example $7 \mathrm{ft}$. $6 \mathrm{in.} \mathrm{long,} \mathrm{taken} \mathrm{into} \mathrm{Lowestoft} \mathrm{harbour} \mathrm{on}$ 12 November 1894.

41. Porpoise. Phocana communis, F. Cuvier.

'Small schools of this, the most frequently met with of the Cetaceans in our waters, are

2 - The Mammalia of Great Yarmouth and its Immediate Neighbourhood,' Arthur Patterson, Zool. I898, P. 309. frequently seen passing at sea, and individuals are occasionally captured in the herring nets and landed at Lowestoft.'-T. Southwell.

42. Bottle-nosed Dolphin. Tursiops tursio, Fab.

Bell-Delphinus tursio.

The late Sir William Flower, in a letter to Mr. T. Southwell, referring to a recent visit to Felixstowe, observes: "besides common porpoises frequently, we saw on the afternoon of July 27 th [1873] a pair of Delphinus tursio going south.'

43. White-beaked Dolphin. Delphinus albirostris, J. E. Gray.

Among several examples which have come under the notice of Mr. Patterson at or near Yarmouth is one measuring 7 feet, taken at Gorleston on 17 April 1890.

\section{ADDENDA}

19. Otter. Two young otters were found by a lady on 23 May 1908, in a deep cart rut in the marshes near the 'King's Fleet,' not far from the mouth of the Deben. Three and a half hours later a man visiting the spot found them still lying there, one, however, being dead. They were taken to Mr. Hudson of Ipswich (to whom I am indebted for this information), who, on examining the dead cub, found in its head two deep tooth marks, making it appear that its death had been caused by the bite of some animal. He managed to get the other young otter to take some milk, and eventually succeeded in rearing it. The dam had probably been killed.
30. Water Vole. On 14 February 1908 a female of the black variety, killed at Barnham, near Thetford, was received for preservation by $\mathrm{Mr}$. H. C. Hudson of Ipswich.

An albino of this species was caught 27 April 1908 near the water-mill at Little Glemham. It was about three parts grown, the fur being of the purest white all over, long, soft, and abundant ; the eyes red. This specimen has been sent by Mr. E. J. Rope to the Ipswich Museum.

36. Fallow Deer. The number of fallow deer in Flixton Hall Park, as I am informed by $\mathrm{Mr}$. C. S. Joy, is at the present time (1908) about 260. 


Prehistoric MaP

of

SUFFOI K

O

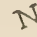

O $\therefore$ Lakerheath wahgrona 0 Orhethord

$P$

方

?d

เ

$$
\bullet
$$

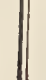

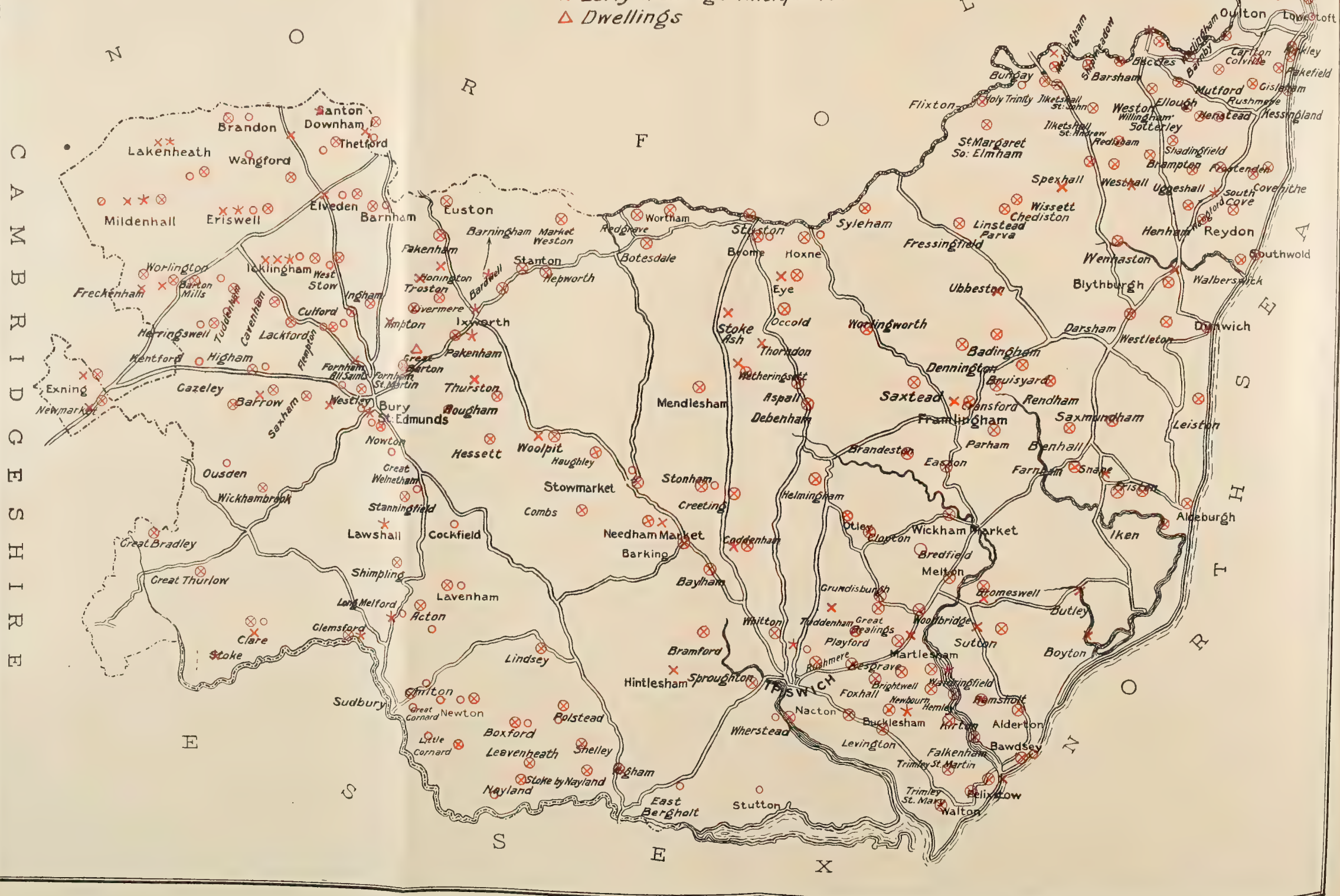

\section{Reference}

- Palaolithic Implements

Q Neolithic Implements

* Bronze Age Antiquities

* Early Iron Age Antiquities

$\triangle$ Dwellings

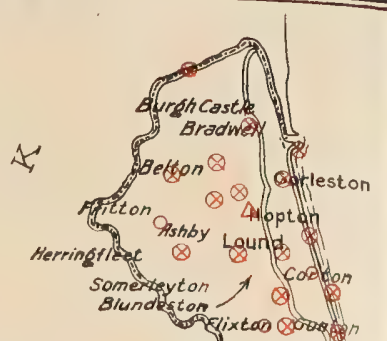




\section{EARLY MAN}

$\mathrm{T}^{\mathrm{\mu}}$

HE county of Suffolk offers the nearest approach to an epitome of the Stone Age of man that is probably to be found in the whole world. In this respect it holds to the Stone Age much the same relation that the county of Gloucester does to geology. Probably nowhere in the world is there such a concatenation of geological periods to be met with in a relatively small area as in Gloucestershire. Similarly nowhere probably are so many periods and sub-periods of the Palaeolithic and Neolithic Ages represented as in Suffolk, and more especially in the northwestern part of the county. It is true that one important division of the Palaeolithic Period is absent : viz. the Magdalenian, so splendidly represented in Central and Southern France. But this is probably due to the absence of caves in the county. In the Neolithic Period there is an absence of the megalithic monuments so characteristic of the later stages of that period in certain parts of this and of other countries. Absence of the necessary prime material would account for this. But with these two exceptions the whole panorama of the Stone Age is exhibited with extraordinary fullness, and under conditions which raise hopes for the solution of some of the many obscure problems associated with it. To treat of the whole county in detail would require a volume rather than an article. It will therefore be better to confine the main portion of this article to one division of the county, leaving the rest to be described more briefly in the topographical index at the end. For this purpose the north-western section, comprised within the limits of a line drawn from Thetford to Bury St. Edmunds, thence to Mildenhall, Lakenheath, Brandon, and back to Thetford, has been selected. Within this line are comprised some of the richest deposits of the Palaeolithic Age in England, if not in the world, and within it have probably been found a larger number and greater variety of neolithic implements of beautiful workmanship and of fine material than in any other part of the world of equal area.

\section{The Palaeolithic Age}

It will be well to begin with the earlier main division of the great Palaeolithic Age commonly known as the 'Drift' Period. The name 'drift' is derived from the fact that with very few exceptions the implements of this period, so far as England and the western half of Europe are concerned, are found in gravels which have been formed at one or more epochs of vast diluvial action, by which the stones lying on the surface of the land have been washed down to form deposits of gravel in valleys; which valleys may still exist as such, or may by subsequent changes of the surface have ceased 


\section{A HISTORY OF SUFFOLK}

to be valleys, may, indeed, be converted into hill-tops. Though the fact that such implements are almost invariably found in gravels has been universally recognized, yet it would seem that insufficient stress has been laid upon the extraordinary nature of the floods that must have cleared the surface of the ground, over very wide areas, of all stones lying upon it at the time. For were the ground not so cleared we should find implements belonging to this period lying on or near to the surface independently of gravels. Yet this is never the case except under quite exceptional circumstances. ${ }^{1}$ It is further worthy of note that since the close of the 'Drift' Period floods on the scale necessary for such complete sweeping of the surface seem not to have taken place; for though the Palaeolithic Age lasted for a long time after the 'Drift' Period had come to an end, there is no evidence of later gravels containing the implements of later palaeolithic man. Later gravels occur, it is true, but they would not seem to have resulted from so generalized a sweeping of the surface of the earth as was the case with the older gravels in which the 'drift' implements are found.

It must not be thought however that all gravels of the earlier quaternary period yield implements. This is by no means the case, not even the majority of them do so. These diluvial periods seem to have been repeated time after time. Sometimes man had existed in the district and had made his weapons since the last diluvial period, and these weapons appear in the gravels resulting from the next ensuing floods. Sometimes man had been absent in the interval between two such periods, and no implements lay on the ground to be incorporated in the gravels. But that these diluvial periods recurred many times, and that man disappeared from the scene and reappeared many times during the long series of centuries involved, is clear from the occurrence in a comparatively small area of country of gravels at different levels, some of them with implements, some without a trace of them; whilst of those with implements there are, in gravels in near proximity to one another, wide differences of type and of patination, ${ }^{2}$ such as would be impossible if the gravels had been laid down at the same time, and if the floods giving rise to them had swept the surface of implements made by the same race of man and belonging to the same period.

This is very clearly seen in North-west Suffolk and the adjacent parts of Norfolk, where a large number of implementiferous gravels have been discovered. It would require more space than can be here allotted, and more knowledge than is perhaps at the disposal of anyone at present, to deal with all these gravels in a scientific way. It is proposed therefore to consider certain gravels which occupy what is now a ridge, running for several miles from south to north from a point about 2 miles east of the little town of Mildenhall, to a point about three-quarters of a mile east of the village of Lakenheath. This ridge is a mere fragment

'There are two conditions under which this may occur: (I) Where palaeolithic man was living on a ridge, as on the present North and South Downs of southern England. Here the physical conditions are such as to prevent the gathering force of any large body of water. On these Downs 'drift' implements are not unfrequently found on the surface. (2) Where an old implementiferous gravel has been cut through by a river of later date, and its contents scattered over the lower course of the river ; in this case 'drift' implements may be found in the alluvial soil of the newer river. Occasionally also 'drift' implements were buried to a considerable depth in brick-earth or other deposits, and thus protected from later changes.

'The word 'patination' is used to indicate the changes of surface of hard materials such as stone or bronze resulting from age. 


\section{EARLY MAN}

of what it must have been originally, much of it having been destroyed by river action of later times; and both north and south ends are abrupt and without any present connexion with the neighbouring higher ground. Nor is the ridge continuous from end to end. At some time in its history it has been cut across at right angles by streams coming from the east. There are at least three such breachès of continuity which will be described more fully presently. And these three breaches are by no means the only evidences of the past destructive forces to which this area of ground has been exposed. The very fact that to-day it exists as a ridge speaks eloquently of its past history. All along the top of the ridge are gravels, most of them implementiferous, and at least two of them teeming with the handiwork of man. When these gravels were laid down what is now the ridge must have been a valley, all traces of the boundaries of which have now disappeared. To the west the ridge slopes down to the flat expanse of the chalk plain of Cambridgeshire and the Fen country; whilst to the east it is bounded by a valiey, in many parts a mile wide, running parallel to the ridge from north to south, which valley must have been

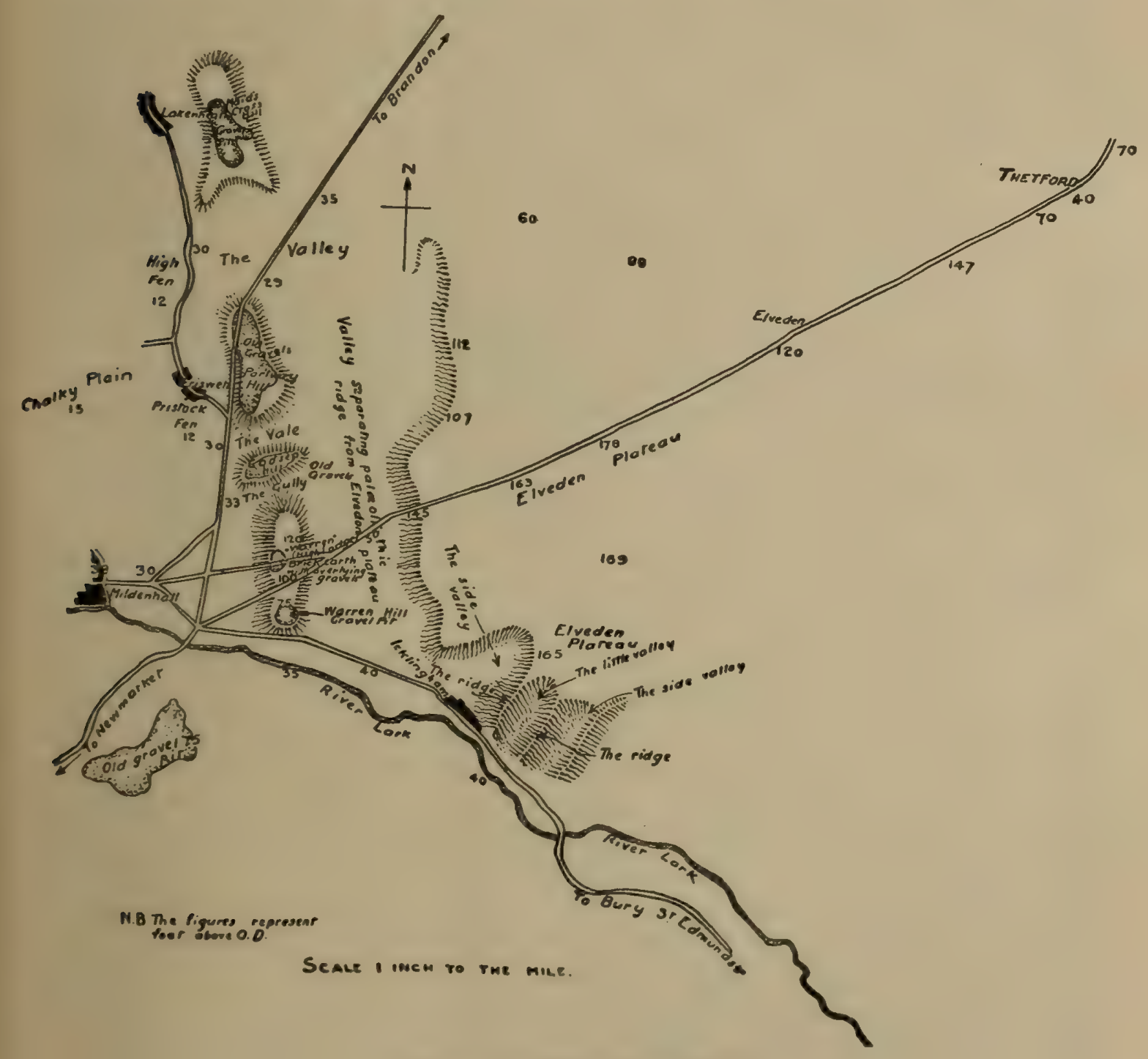

Plax of the Mildenhall District 


\section{A HISTORY OF SUFFOLK}

scooped out since the gravels were deposited on the top of the ridge. This valley ends in the wider valley of the River Lark, a river running from east to west; a river now of small size, but whose valley at this point is about 2 miles wide. The Lark runs at right angles to the ridge and cuts right through it, so that the southern end of the ridge appears as a low escarpment bordering the Lark Valley. No one who stands on this escarpment and looks southward across the valley of the Lark can have any doubt that this valley has been formed since the gravels which cap the ridge were laid down; and that the present river system of this part of Suffolk has little or nothing in common with that which obtained at the time the gravels were formed.

To sum up the evidence brought forward up to this point; we see that since the gravels were laid down in a river running from south to north, one side (the west) of the valley containing the river has entirely disappeared, being replaced by a flat plain at an average level of about $80 \mathrm{ft}$. below the level of the gravels; whilst the other side (the east) has been cut out by water until the ancient river boundary is replaced by a valley averaging some $60 \mathrm{ft}$. below the level of the gravels and about a mile wide.

As has been stated the ridge is capped by gravels for nearly its whole extent ; and in at least four different places these gravels have yielded humanlyworked implements. These four gravels are not, however, all at the same height above the Ordnance datum. Thus the upper surface of those situated at the south end of the ridge-known as the Warren Hill gravels-is about $70 \mathrm{ft}$. above the Ordnance datum, whereas the corresponding surface of the others lies at or above the hundred-foot level. And as they differ in height so do they differ in the character of the implements found in them. The four gravels referred to are known from south to north as:-(I) The Warren Hill gravels (just mentioned); (2) the High (or Warren) Lodge gravels; (3) the Portway Hill gravels; (4) the Maid's Cross Hill (Lakenheath) gravels. The Warren Hill pits have produced the largest number of implementscertainly over a thousand ; the Maid's Cross Hill pits have been the next most prolific-probably some hundreds; then the High Lodge gravels, the conditions of which are very peculiar and to which further reference will be made presently. The gravels at Portway Hill have not hitherto yielded many implements, and it is therefore difficult to speak very definitely about them.

In comparing a large series of Warren Hill implements with a series from Maid's Cross Hill, the sharp distinction between them in type and appearance becomes at once evident. The striking characteristic of the series from Warren Hill is that the ovate implement, brought to a more or less sharp edge all round, shows marked predominance over other forms. At Maid's Cross Hill the pointed implement with a massive upper end is in equally marked predominance-a pointed implement of special type. Then again the predominant patina, or colour change due to age, of the Warren Hill implements is a peculiar spotted blue and yellow, very rarely met with elsewhere ; whilst that of the Maid's Cross Hill implements is a light yellowish white with perhaps bluish marbling. It is thus, in the case of the great majority of implements, perfectly easy to recognize at a glance from which of the gravels they have come. The implements from the High Lodge gravels, though more or less distinct in form and colour from those from Warren 


\section{EARLY MAN}

Hill, somewhat resemble the latter and are wholly different from those from Maid's Cross Hill. Of implements from Portway Hill a sufficient number has not been examined to learn their leading characteristics.

This marked difference in the appearance of implements found in gravels relatively near to one another points to the gravels having been formed at quite different periods, the man whose implements are found in the later gravels having appeared and occupied the country after his predecessors' handiwork had all been swept down and buried in the earlier gravels. Which then of the two gravels, the Warren Hill or the Maid's Cross Hill, is the earlier? This question will be discussed when the gravels and their contained implements have been examined in rather more detail.

As has been seen, the Warren Hill gravels cap the southern end of the ridge where the little escarpment slopes rapidly down to the Lark Valley. Their upper surface lies at an average of about $70 \mathrm{ft}$. above the Ordnance datum and between $30 \mathrm{ft}$. and $40 \mathrm{ft}$. above the River Lark. They are certainly between $30 \mathrm{ft}$. and $40 \mathrm{ft}$. thick, and the base has never apparently been reached. They are soft in structure, with much sand. As before said, the river that gave rise to them ran at a right angle to the course of the present River Lark, which has washed away a considerable, probably the larger, portion of the original gravel. On the opposite side of the Lark Valley -here 2 miles wide-are gravels lying at about the same height as those of Warren Hill and containing flint implements of very similar types, which were probably continuous with the Warren Hill gravels.

It has been pointed out that the predominant type of implement at Warren Hill is the ovate with sharp edges all round ; the Warren Hill ovate is indeed familiar to all collectors of flint implements. An interesting and rather surprising fact is that this sharp ovate is rarely found in the Thames Valley. This valley from above Oxford to the Nore teems with implementiferous gravels, and many thousands of implements have come out of them. In the writer's collection there are some three thousand specimens from the Thames Valley; yet amongst this large number there is only one sharp ovate at all comparable to those which occur in such large numbers at Warren Hill. A few ovate implements occur, but they are of wholly different type from the bulk of those in the Suffolk gravel. What does this mean? It can hardly be a question of local distribution; for, on the one hand, gravels within a very few miles of Warren Hill contain nolarger proportion of sharp ovates than do those of the Thames Valley ; whilst, on the other hand, sharp thin ovates, strictly like those from Warren Hill, are found in various other parts of England, as well as in France and in other more distant parts of the world. It would seem therefore that in the Thames Valley gravels and in the Warren Hill gravel we are dealing with two very distinct periods. The Thames Valley Period is, it is true, represented, though only in a meagre degree, at Warren Hill; whilst the Warren Hill Period is scarcely represented in the Thames Valley. French archaeologists divide their 'drift' period into two main divisions ; one named from Chelles in the department of Seine et Marne, thence called Chelléen; the other from St. Acheul near Amiens, whence called Acheuléen. The classification is a rough one only, but has been almost universally accepted. The Thames Valley implements belong in the main to the Chelléen; the Warren Hill implements to the Acheuléen. There seems 


\section{A HISTORY OF SUFFOLK}

to be no doubt that the Chelléen period preceded the Acheuléen in time. Hence therefore the Thames Valley gravels are older than those at Warren Hill ; the absence of the later types from the Thames Valley gravels pointing to the probability that during the period of the civilization represented at Warren Hill the Thames Valley was under water, and therefore not habitable.

This Warren Hill Period must have been of immense length. The ovates which have been found in such large numbers are by no means uniform in shape or appearance. Some are much more finely made than others; and they vary also very largely in patina, the more finely made tending to be less patinated than those of coarser shape--some indeed being scarcely patinated at all. The great majority, however, are more or less deeply patinated; and as already stated there is one type of patina, exceedingly common in implements from Warren Hill, which is rarely met with elsewhere-a curious mottling of surface, yellow or white spots on a blue ground, or blue spots on a yellow ground.

Not only is the predominant patina special to Warren Hill, but there are two other peculiarities which occur in implements from that gravel which are rarely met with anywhere else. The first is that a very considerable proportion of them are differently patinated on the two sides of the ovate. Sometimes this difference is merely one of degree of change of colour, but in not a few cases the difference is more than this, one side being deeply patinated-with very marked colour change, whilst the other side is quite unchanged, and presents the original colour of the freshly chipped flint (which is in nearly all cases black). What does this mean? In the first place it means that the patination had taken place before the stone reached its present position in the gravel; for it is not possible that in a number of instances a stone lying in a sandy gravel should have had one side protected in such a way as not to undergo the same change as the other; whereas it is easily understood that a stone lying on the ground for a long period of time will have its upper surface, exposed to all the varying conditions of weather and light, patinated; whilst the under surface, protected as it is, will be much less changed - or even quite unchanged. The phenomenon is familiar to all who have examined flint implements from the African deserts. Here the stones have lain for countless ages with one side exposed to the hot African sun, whilst the other has been protected by the shade of the stone itself. So it must have been with these stones from Warren Hill, and we have thus specific proof that the patination took place before the stones were washed into the gravel. With regard to the length of time thus indicated we can only say that no neolithic stones, not even the very oldest of them, have a patina at all approaching that of the bulk of Warren Hill stones for depth and variety of colour. Yet we shall see presently that there are reasons for believing that the more ancient neoliths are of much greater age than they have hitherto been credited with. It would therefore seem that the Warren Hill implements-at any rate the older specimens amongst them-must have been lying on the ground for an immense-almost immeasurable-length of time before they were washed down into the gravels in which they are found.

There is another remarkable point in connexion with implements from Warren Hill. In a large proportion of them the edges present chips varying 


\section{EARLY MAN}

in size from a split pea up to a five-shilling piece, or even larger, which chips are apparently due not to human agency, but to accidental violence. The surface of these chips in no way resembles that of the implements themselves, but has undergone a change from the natural blackness of the newly-chipped flint to a porcelainous white, quite irrespective of the patina which the humanly-worked surfaces of the flint may have taken on. This chipping is a very remarkable and very instructive phenomenon. It means that at some time in the past history of these flints, after they had received their patination, they were subjected to some exceedingly rough usage, not by man but by nature; a knocking about greater than that to which the stones of any other implementiferous gravels have been subjected; for this curious chipping is practically confined to Warren Hill. Then these newly-chipped surfaces have undergone a fresh patination, but probably not in the gravels in which they are now found. In the first place the Warren Hill gravels are very sandy-so much so that they are often referred to as sand pits rather than gravel pits. They are one of the loosest and softest gravels that the writer is acquainted with; the least likely of any therefore to show signs on the stones of extensive knocking about, in their course down to the gravels. The chipping would thus seem to be due to some previous journey under flood conditions, the last journey into their present position being a later episode in their history. And this view is borne out by the fact that implements with slight patination, which are generally of finer make, show less signs of rolling than those of more marked patination; and have none of the chipping round the edge. They have in fact been fabricated after the tumultuous floods which chipped the older implements, and have therefore been subjected only to the milder diluvial conditions which gave rise to the present sandy gravels.

But further, there is good reason for believing, contrary to the general view, that flints do not, in most cases at any rate, undergo staining in gravels. At Warren Hill the evidence already adduced is in favour of this view; many of the implements being patinated on one side only, and the accidental chips being white rather than the colour of the original patina. The most cursory examination of palaeolithic gravels will show that in them the true palaeolithic patinations are rare amongst the stones composing the gravels. These true palaeolithic patinations are of various kinds; but all of them are quite different from the prevailing patination of the gravels. This does not refer to humanly-worked stones only, but to all the flints in the gravels of true Palaeolithic Age, for the patinas on the humanly-worked stones do not differ from those on the accidentally split or chipped surfaces of the unworked stones of the same period. Yet, the point bears repetition that flints with palaeolithic patinations, whether human or non-human, in most gravels are in a very small minority, not more perhaps than one in a thousand. How then can they have got their staining in, at any rate, the present gravels? Moreover, if the gravels be carefully examined it will be seen that there are flints in them which have evidently been broken in their course down into the gravel; and the broken surfaces of these flints are quite black-wholly unpatinated. Therefore, to go back to the accidental chippings on many of the Warren Hill ovates with their porcelainous white patination, there is every reason to believe that these chippings date, not from the last diluvial action to which they have been exposed, but to some 


\section{A HISTORY OF SUFFOLK}

long anterior action, which probably ended by scattering them over a wide surface of land rather than gathering them into a gravel, and that they thus had a second long exposure to atmospheric conditions before arriving at their present resting-place. Our ovates, themselves probably divisible into several sub-periods, belong to a period of palaeolithic life which is unrepresented in the Thames Valley, teeming as this latter does with remains of 'drift' man. After being made they were exposed on the surface of the earth for a time sufficient to induce colour changes, far beyond anything that we see in the oldest neolithic flints. Then they were subjected by nature to some very rough usage which markedly chipped their edges. They then lay exposed to the air and the elements for a further period long enough to induce white porcelainous patination of the chipped surfaces. Then came the diluvial conditions which washed them into their present resting place at Warren Hill; since which time many great changes in the earth's surface have occurred, including the vast denudation which gave rise to the Fen district; and later on (as we shall see) the scooping out of the valley of the present River Lark and its affluents. This gives us some hint of the vast periods involved in the consideration of 'drift' man.

We will now pass to the next series of gravels on the ridge, viz.: those at High (Warren) Lodge, ${ }^{3}$ by the side of the Mildenhall-Thetford road. They lie about three-quarters of a mile north of Warren Hill, and the summit of the ridge is about $\mathrm{I} 20 \mathrm{ft}$. above the Ordnance datum, and therefore about $50 \mathrm{ft}$. higher than the present upper limit of the Warren Hill gravels. The situation of the High Lodge gravel is, however, a very remarkable one, and is worthy of careful description and study.

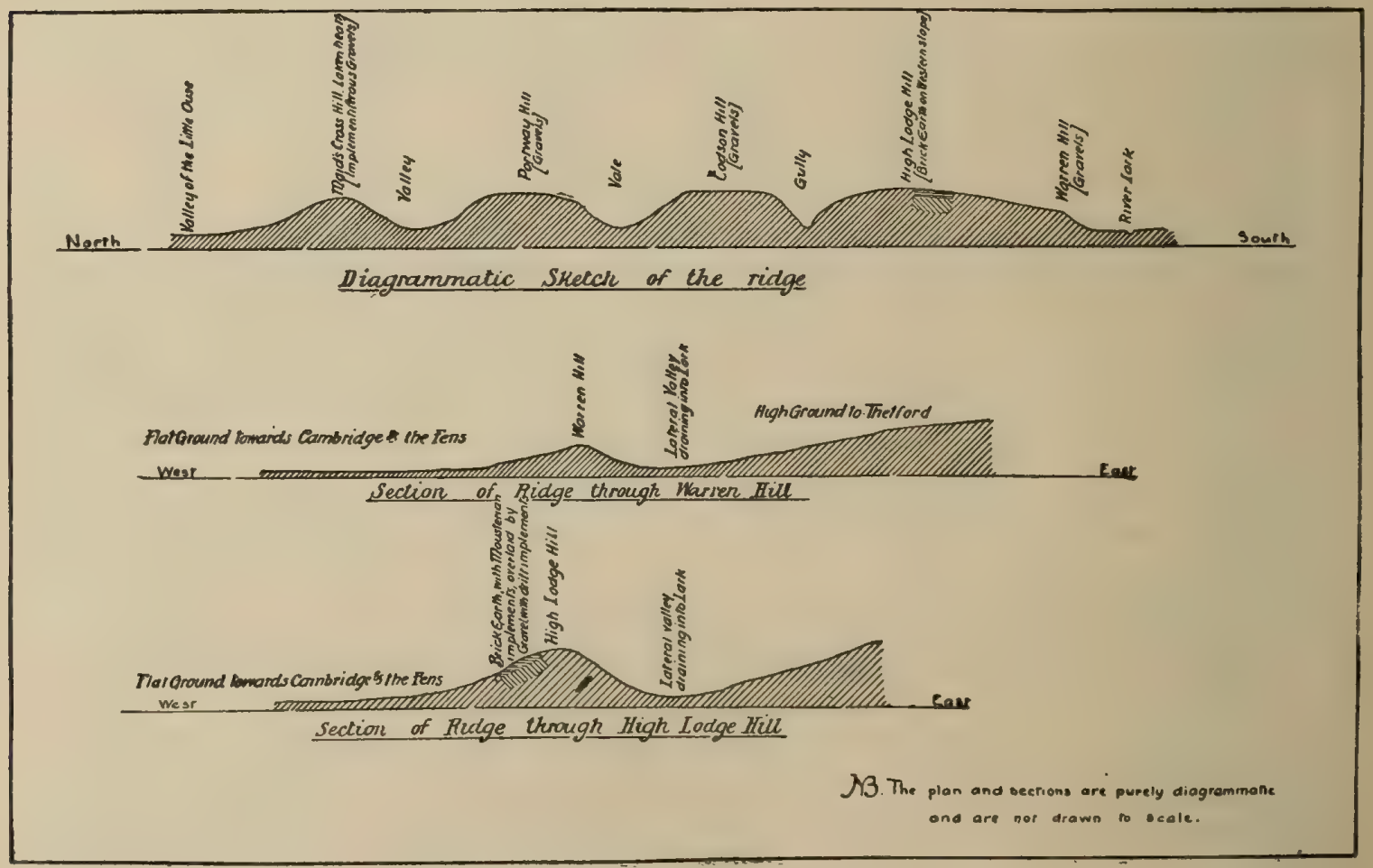

Sections of the Warren Hill Ridge

${ }^{3}$ This name is given to avoid confusion with another 'High Lodge' about 2 miles away on the EriswellElveden Road. 


\section{EARLY MAN}

It has been stated that the ridge on which lie the various gravels with which we are dealing runs from south to north; is bounded on the east by a side valley of the Lark river-system, and on the west slopes down to the plain of Cambridgeshire and of the Fens. This plain was obviously excavated after the deposit of the gravels; and after this excavation the whole district must have gone under water, probably that of a lagoon; for a deep hollow which was made in the side of the ridge where High Lodge now stands became filled with brick-earth, which during the past forty years has been worked for commercial purposes. The brick-earth would seem to have been of slow formation, and during this period the banks of the lagoon were inhabited by a race of men who made their implements on the spot where they are now found, the implements being subsequently buried in the slow deposit from the water of the lagoon, and there they have remained to this day. That the implements are lying where they were dropped by their makers and users seems clear from the fact that they are as sharp and fresh as the day they were made; and having been protected from atmospheric conditions they are for the most part wholly unpatinated-as black and as dull as if made yesterday; so much so that archaeologists unacquainted with the circumstances have found it difficult to believe that they are not modern forgeries. This view that the implements have never been moved since they dropped from the hands of their makers is borne out by the fact that in addition to the perfect implements there are in the brick-earth large numbers of flakes and rough pieces, just as one would expect to find on the site of a workshop of flint implements, all of them as sharp and as fresh and as unpatinated as the implements themselves. But now comes the interesting point. These implements are not 'drift' implements. They are wholly unlike the implements found in the neighbouring gravels, or in fact in any gravels. On the other hand they resemble in the closest possible way the implements found in such large numbers in the rock-shelter of Le Moustier in the valley of the Vézère in Dordogne, which have become the prototypes for the great 'Mousterian' division of palaeolithic time. Implements of definite 'Mousterian' type have now been found in various parts of Europe and elsewhere ; the latest great discovery of the kind having been in the 'Grottedu-Prince' at Mentone, where more than 60 vertical feet of deposits of this age were carefully excavated. To show the vast length of time that this particular civilization must have lasted, reference need only be made to the fact that in the lower strata of the 'Grotte-du-Prince' the Mousterian implements were associated with the bones of sub-tropical animals-a sub-tropical elephant and rhinoceros and the hippopotamus; whilst in the upper strata the same class of implement was associated with the bones of sub-arctic animals-a sub-arctic elephant the mammoth, a sub-arctic rhinoceros, and the reindeer. We need not be surprised, then, that our Mousterian man at High Lodge lived on the side of our ridge for a time sufficient for the level of the lagoon waters gradually to rise, slowly burying the handiwork of generation after generation until the brick-earths had accumulated to a depth of more, probably much more, than $30 \mathrm{ft}$., implements being found at all depths in the brick-earth.

It is a curious fact that except for this rich deposit at High Lodge, the Mousterian Age is practically unrepresented in England; and the deposit 


\section{A HISTORY OF SUFFOLK}

therefore is, if only for this reason, one of the greatest interest and importance. But this is not the only reason why it should be carefully studied ; for the conditions in which the deposit has been made are such that it can throw light on the Mousterian Period such as no other deposit-not even the great deposit of the 'Grotte-du-Prince,' splendidly worked and studied as it has been under the auspices of the Prince of Monaco-has hitherto been able to do. For we now come to the most extraordinary part of the story. When the workmen were digging on the side of the ridge to get at the brick-earth just mentioned-the pit being sunk well to the westward of the top of the ridge, and at an elevation some $20 \mathrm{ft}$. below the highest pointthey found that they had to pass through a layer of gravel $8 \mathrm{ft}$. or $\mathrm{I} \circ \mathrm{ft}$. thick, before reaching the brick-earth, the gravel thus lying above the brickearth, and like it at the side, and not on the top of the ridge. From the geological point of view this in itself was a strange state of things; but what made it still stranger was that this gravel contained very considerable numbers of 'drift' implements-implements of typical 'drift' shapes and of finely coloured patination. This was a discovery well calculated to puzzle both archaeologist and geologist. If anything is certain in prehistoric archaeology, it is the priority of the 'drift' period to the Mousterian; yet here we have typical Mousterian implements lying under a deposit of 'drift' gravels. The explanation of this strange anomaly is comparatively simple and exceedingly instructive.

When first describing the ridge it was stated that it is now no longer continuous, but is cut through in several places. There is, to begin with, the valley of the Lark, which has separated the ridge from the higher ground to the south, whence the valley now represented by the ridge originally came. Next, at a distance of about $I_{\frac{1}{2}}$ miles to the north of Warren Hill, which now forms the escarpment bounding the ridge towards the Lark valley, is a V-shaped gully cutting the ridge from east to west, and forming a clear passage from the bounding valley on the east of the ridge to the fen country on the west of it. This, which may be called 'the Gully' is about roo yds. wide at its lowest part. Then, at about a mile still farther north, the ridge is again cut through by another V-shaped aperture, which is about $\frac{1}{3}$ of a mile wide at its lowest part, and which also opens free communication between the eastern bounding valley and the fen country to the west. This may be called 'the Vale'which is, indeed, the name given to it on the Ordnance map. About another mile to the north the ridge ends, only to reappear a mile farther on as Maid's Cross Hill, Lakenheath. This breach is therefore a mile wide; but it has quite obviously been made by water flowing from east to west, for here, as in the case of the other breaches, and of the lateral side valley to the east with which they communicate, the final bed of the stream as it diminished in size to nothingness can quite clearly be seen. Neither in the lateral valley nor in the breaches does any water flow now, nor can it have done so for a long time, as the roadways of the present day are carried across them on causeways in which not even a culvert has been made. This wide breach it is proposed to call ' the Valley.'

The interpretation of this state of things may be taken with some confidence to be as follows. Before the Lark river-system had been established, 


\section{EARLY MAN}

which we have seen was clearly after the deposit of the gravels at Warren Hill and other parts of the ridge, the ridge was continuous towards the east with the high ground which extends to and beyond Elveden about 5 miles away. The western boundary of the valley in which these ridge gravels were deposited had already disappeared in the general denudation which gave rise to the present fen districts and the surrounding low-lying chalky plain. On the slope resulting from this denudation Mousterian man lived and made his implements, which were successively buried in the brick-earth in which they are now found. When at some subsequent period the diluvial conditions arose which gave rise to the present river-system of this part of the country, great floods of water poured over from the higher ground in the neighbourhood of Elveden and rushed down over the ridge (not yet separated on its eastern side) and so into the low-lying country beyond. The great main drain of the district was meantime forming, and is now represented by the River Lark. This would tend to draw towards itself the minor drains of the system, and amongst these would be that represented by the valley which has cut the ridge off from the high ground to the east. This valley would, however, not be formed all at once. It would be shorter and narrower, to begin with, than it subsequently became. But as it cut its way back northwards it would tap first one and then another of the streams which up till then had been rushing from the high ground to the east towards and over the gravel-topped land which now constitutes our ridge. These streams flowing from east to west would in ordinary course be cutting their way down through the gravels and underlying strata, and with time would deepen and widen their beds. The tapping process described would deflect the water first of the 'gully,' then of the 'vale,' and finally of the 'valley.' The 'gully,' as we have seen, had attained a bottom width of roo yds., when its further progress was thus stopped; the 'vale' a width of about a third of a mile, when it ceased to carry further water; whilst the 'valley' was a mile wide before it was finally tapped.

Here, then, we must look for the explanation of the superposition of 'drift' gravels to 'Mousterian' brick-earth. Not only were there these three breaches made in the ridge by the rush of waters from the east, but a fourth breach was begun half-way between our 'gully' and the Lark. The water had time to push the gravels capping the ridge at this point over on to the side of the ridge to the west, when the valley which the waters were excavating to the east of the ridge tapped the source of this flow, and here the gravels have remained to this day. The paradox in prehistoric archaeology thus caused comes as an aid to geology in clearing up a very curious problem.

A comparatively simple confirmation of the account here given may be obtained. If it be the case that large portions of the ridge with its implementiferous gravels have been carried away by the Lark and by the streams that gave rise to the breaches here described, then there ought to be some signs of the resulting débris in the valley of the Lark below the ridge and in the country to the west of the ridge; and such evidence is forthcoming. A certain number of typical Warren Hill implements have been found at or near the surface of the ground at various spots in the lower Lark Valley; and implements of pure 'drift' types, and with typical 'drift' patination, have been picked up on fields opposite each of the breaches described at 


\section{A HISTORY OF SUFFOLK}

distances of from one to three miles from the breach. It is not very probable that any large number of such implements will be found, as most of them will be buried too deep for agricultural operations to reach them. The few that have been found, however, speak eloquently of the causes that have moved them to their present positions.

We will now pass to the gravels capping Maid's Cross Hill at Lakenheath, the isolated northern extremity of the ridge. These gravels are of great thickness, and their upper surface lies at about $100 \mathrm{ft}$. above the Ordnance datum-considerably higher, therefore, than those at Warren Hill. The ovate implement is here much less predominant; the type which occurs in large numbers and which may be said to give a special cacbet to these gravels being a peculiar form of pointed implement with a cross section approaching the triangular or rectangular shape. This class of pointed implement is different from that found in the Thames Valley, and so far as is known is almost special to this part of Suffolk. It is not altogether confined to Lakenheath, for specimens sometimes occur from other gravels in the district; but in no other gravel with which the writer is acquainted is it so distinctive a type as there. Then again, as has been said before, the patina of the implements from Lakenheath is markedly different from that of the implements from Warren Hill.

Thus we see that the gravels at Warren Hill and at Lakenheath, although evidently lying in the same old river-valley, and although separated from one another by less than half a dozen miles, contain implements that are sharply defined from one another in type and in patina, and obviously must have been deposited at quite different times. Can we, then, form any idea as to whether the higher gravels (Maid's Cross Hill) were deposited before or after the lowerlying gravels (Warren Hill) ? For reasons too long to go into on the present occasion there can be but little doubt that the higher gravels are the later. This is the opposite of what obtains in the Thames Valley and in other valleys of greater depth and scooped out in harder strata than those in Suffolk. In these the higher gravels on the sides of the valleys are the older. But in Suffolk the valleys have filled up, and then after extensive denudation an entirely different set of valleys has been produced ; the stumps of the older ones have been left, as in the case of our ridge; and the deposits show in the order of their deposition, the higher ones being the later. This is borne out by the fact that though the implements from the gravels of our ridge present so sharp a contrast to those from the Thames Valley, yet gravels occur in the neighbourhood which contain typical Thames Valley types; and in every case with which the writer is acquainted these gravels lie at a lower level than our ridge gravels. The best known of these gravels is that at Shrub Hill, a few miles. on the other side of the Norfolk border. This gravel teems with implements of Thames Valley types; yet although it is called a 'hill,' the gravel really lies on an island of gault in the middle of the fens, at a few feet only above the level of the sea. The gravels which must have overlain the present Warren Hill gravels to allow of the flow of water which laid down the higherlying Maid's Cross gravels, were doubtless swept away when the Lark Valley was made.

Special attention must be called to the implications arising from the differences of period indicated by the differences of type and of patina in 


\section{EARLY MAN}

implements from neighbouring gravels such as these. They prove beyond any doubt that there were several-probably many-different periods of human occupation in the 'drift' age, separated from one another by periods of vast diluvial action. The earth was swept clean of its implements by one great set of floods; then man reappeared, and bis implements in turn were swept down into gravels, and so on. How many times this process was repeated it is impossible to say; but as it is difficult to believe that each recurrence of habitable conditions with the alternating flood conditions was other than of very long duration, the total length of time thus adumbrated for the whole 'drift' period must have been immense-far beyond anything that has hitherto been tentatively assigned to it.

We are now in a position to sum up the knowledge gained from this discussion of the geological conditions of the ridge.

I. The first and most important point is the evidence just brought forward that the whole 'drift' period was made up of sub-periods during which the land was alternately habitable and under diluvial conditions.

2. That the 'drift' period must have been of sufficient length to include not only the vast deposits of the Thames Valley, but also large and important deposits in Suffolk which are not represented in the Thames Valley.

3. That the patina of 'drift' implements, certainly in Suffolk and probably everywhere else, was formed before they got into their present positions in the gravels. There is every reason to believe that this formation of patina on flints of good quality is of very slow growth ; for no neolithic implement has ever been found presenting anything like the ochreous patination so distinctive of a large proportion of ' $\mathrm{drift}$ ' implements. Yet even at the most moderate computation neolithic implements are several thousands of years old.

4. This being so, the very varied and in many cases the very deep patination of many of the Warren Hill ovates points to the period represented by them as having been very long, probably greatly exceeding anything that we can allow for the whole Neolithic Age, including the time that has elapsed since it came to an end. Yet this Warren Hill period is merely one of many sub-periods of the great 'drift' age. We begin here to get a glimpse of the vast extension of palaeolithic time.

5. Passing on from the lessons taught as to the 'drift' period we come to the next great division of palaeolithic archaeology, the 'Mousterian.' After the 'drift' age had passed away, and before the Mousterian was established, we saw that a wholly new distribution of geological forces took place by which the valley and the river in it were changed from their original character. The river disappeared, and the land to the west of the valley was shaved down to its present relative level; the lowering process being carried right up to the western side of our ridge, which then formed a bank sloping down from the higher ground to the east to the newly excavated lower ground to the west. And on this bank, the shore probably of some lagoon, lived 'Mousterian' man, whose implements are found buried in the brick-earth deposited by the muddy waters of the gradually rising lagoon. This is probably the only instance where we get a glimpse of the order of time that elapsed between the 'drift' epoch and that of 'Mousterian' man. Here we have the sequence : ovates of Warren Hill ; their patination; their accidental chipping and its patination; the flood conditions that washed them into the gravels; recurrence 


\section{A HISTORY OF SUFFOLK}

of similar conditions giving rise to the Lakenheath implements; destruction of the valley, with excavation of the fen district; and finally 'Mousterian' man sitting on the side of the hill thus formed. When the conditions are appreciated the vast periods involved are almost beyond our comprehension.

6. After the implements of 'Mousterian' man had been buried by the gradual accumulation of the $30 \mathrm{ft}$. (or more) of brick-earth, a recurrence took place of diluvial action, with the result that the present river-system represented by the Lark and its affluents was established. The old river-valley with its gravels, the western side of which had already been destroyed, was now cut off from the high ground to the east, and its ridge-like character finally determined. The ridge itself was at the same time cut into sections, and the beginning of such a cutting process at High Lodge swept the gravels capping the ridge at this point over the brow of the hill on to the top of the lower-lying but much more recently deposited brick-earth with its contained Mousterian implements.

Before passing to the consideration of the Neolithic Period a few words must be said about the hiatus of time that is presumed to have existed between the end of the Palaeolithic Period and the beginning of the Neolithic. There is a general consensus of opinion that in North-west Europe, at any rate, there was a lapse of time of indeterminate length, during which, for some reason not yet explained, large areas of Europe, including the British Isles, were uninhabited, and therefore presumably not habitable, by man. There has been a tendency amongst some archaeologists to call certain groups of implements which do not appear to find a place in any of the recognized periods ' Mesolithic;' that is to say, between the Palaeolithic and Neolithic Periods. But the connotation of the word is so very large that it would require evidence of a far more convincing character than anything that has hitherto been brought forward to admit of its acceptance in scientific archaeology. For the present therefore we are justified in postulating the existence of a hiatus; the Palaeolithic and Neolithic Ages being sharply defined from one other. During this hiatus man must have lived somewhere ; but as to the conditions of his existence we shall have to wait for knowledge until we have learnt a great deal more than we know at present of the Stone Age of the subtropical and tropical regions of the earth.

\section{The Neolithic Age}

If the Palaeolithic Period has presented us in North-west Suffolk with novel problems of great interest, the Neolithic Period in no way yields to it in the importance and the interest of the problems which it offers us. Here it is not, however, to the position in which the implements lie that we must look for the main factors of the case. Neolithic implements all lie on the surface or in the surface soil ; hence it is only exceptionally that we shall get help from position. It is the stones themselves that must be our study, their forms and especially their surfaces - the patination or other changes that have taken place on these surfaces. In stones from the gravels we saw that the study of patina might be of considerable service in clearing up problems; but in their case the patina is only of secondary value, the chief element being the geological 


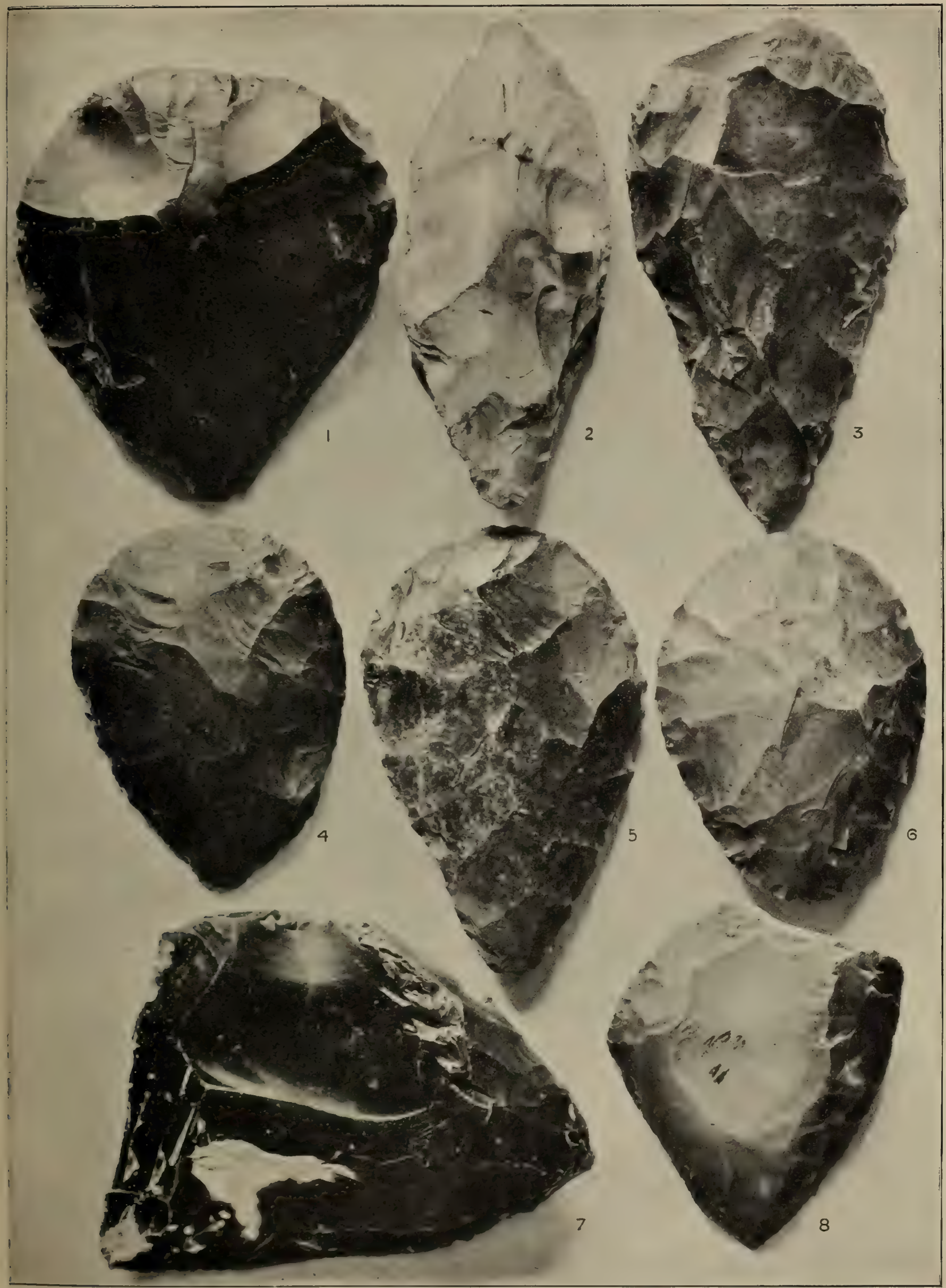

Fint I MPLEMENTs, Plate I. (Scale about $\frac{3}{4}$.)

From (1) Warren Hill (the other side of this piece is white). (2) Elveden. (3) Brandon Fields. (4) Herringswell. (5) Warren Hil:. (6) Lakenheath. (-) Mousterian 'racloir.' (8) Mousterian 'pointe.' The two last are from the Mousterian brick-earth deposit it High Lodge, Mildenhail. 



\section{EARLY MAN}

position of the gravels or brick-earths in which they are found. Prehistoric archaeologists have hitherto rated the significance of patina changes at too low a value. Certain patinas, it is true, are not of great value, for instance, the chalky-white patina that forms on many flints that have been exposed to the action of easily decomposed limestone, such as chalk and the softer oolites. But where flints have been lying in contact with the harder limestones, with soils other than limestone, and especially with sand, the surface changes become of the greatest help in determining relative age. In North-west Suffolk the ground is covered, over very large tracts of country, by sand which in most places protects the flints from the action of the underlying chalk, where the latter is not also covered by great thicknesses of boulder clay. By this means the large numbers of neolithic flints found in this part of the county are protected from the more or less rapid decomposition induced by the presence of carbonic acid in considerable quantity; and the changes produced in the flint by prolonged exposure to moisture, sun, and air are allowed to show themselves uncomplicated by other considerations. Reasons will be presently given for believing that these changes take place in flint of good quality with extraordinary slowness; and that in such flint a high degree of patination predicates great age.

It is proposed to take for the discussion of neoliths a little valley in the parish of Icklingham which forms a part of the Lark system of drainage (see plan, p. 237). As with the valleys referred to in the first part of this article, so here there is now no water in the valley, and there is no sign of there having been any within the historic period.

The valley in question is about a mile in length and runs from the plateau of Elveden straight down to the main valley of the Lark, which it enters at a right angle. The valley is in the shape of a wide and shallow $\mathrm{V}$; the highest points of the $\mathrm{V}$ being about half a mile apart ; and the perpendicular depth of the valley about $50 \mathrm{ft}$. to $60 \mathrm{ft}$. The plateau where the valley starts is about $170 \mathrm{ft}$. above the Ordnance datum and the River Lark at the point where the valley debouches is about $40 \mathrm{ft}$. above the same datum. The lateral boundaries of the valley consist on each side of a ridge about 300 yds. wide; each ridge descending on its opposite side into a wider and longer valley, which two valleys also sweep down from the plateau into the main valley of the Lark.

When we consider the matter, it is rather strange that so short a valley as this should have such great relative width; that it should start flush from the plateau with no sign of any special collecting ground; and that it should enter the main valley at a right angle, with no sign that the water, which presumably hollowed it out, made any attempt to swirl round in the direction of the current of the main stream, as is usually the case at the junction of rivers. We will, however, not follow these points further just now, but proceed to the examination of the valley.

From the neolithic point of view the valley is probably one of the richest districts in the world. Though its area includes not more than some 300 acres, many thousands of implements have already come out of it ; and there probably remain quite as many yet to be found. The implements are by no means all of high quality, the majority indeed are rough; but none the less are they full of instruction. Many patinas are represented, too many to be described in detail. But they may be summed up as follows:-(I) A deep 


\section{A HISTORY OF SUFFOLK}

lustrous blue; (2) a lighter less lustrous blue ; (3) a deep and highly lustrous blue-black ; (4) a less lustrous black ; (5) a dull non-lustrous black ; (6) a thick more or less lustrous porcelainous white; $(7)$ a thin slightly lustrous white. And in addition to the more ordinary types of flint which undergo changes of surface in course of time, there are a considerable number of implements and flakes made of fine chalcedonic or jasperoid flint which decomposes with extreme difficulty. In most cases these have come down to us with little or no change, though there may be other evidence of their being of equal age with some of the most highly patinated of the implements made of ordinary flint.

What evidence is there that pieces of different patinations, or different degrees of the same patination, are of different ages? In answer to this it is only necessary to bring forward another feature frequently met with in this valley as elsewhere, viz. the occurrence on the same implement of the work of men of two different ages. In the best examples an implement of fine make which has undergone patination of a marked description has been carefully re-worked at some subsequent period; and the re-worked surfaces are either unpatinated or have patination quite evidently less ancient than that on the original working. More often an implement of early Neolithic Period has been simply re-used at a later period without any care as to re-making. In such a case the old and patinated implement shows all round the edges the chips that have been detached when it was re-used ; such chips being either unpatinated or having a different degree of patination from that on the original work. Sometimes more than two types of patination of human work are present on the same implement. From a study of a large series of such doubly patinated implements, much may be learnt as to the relative age of patinations.

We now come to the most important point in connexion with the implements from this valley, and one which is wholly novel. This is the presence, on great numbers of them, of scratches of various kinds-'striae' to use the more scientific term. The importance of this phenomenon is very great. When we consider that flint is of a very high degree of hardness, even when of poor quality ; when we consider that most of the implements found in Northwest Suffolk are formed of flint of especially good quality, many of them being made of translucent chalcedonic or jasperoid flint; when we find that flint of this quality will scratch with ease flints of less fine varieties, whereas nothing softer than quartz will scratch it; and when we find that flints of this fine quality are themselves often scratched all over-the fact that this is so tends to excite our astonishment and make us ponder deeply on the causes that can have produced such a result.

It will not be possible here to go into the abstruse questions which an inspection of these scratched surface-flint implements brings before the mind; nor would an article in a county history be the proper place to enter on the highly controversial lines of investigation which would be necessary for their discussion. It will be well therefore to give only a short account of these striated implements, which, though occurring by thousands in this particular valley, are by no means confined to it ; they are found not only widely scattered over North-west Suffolk, but also in many other parts of England and elsewhere.

Just as there are many varieties of patination of surface-flint implements - which can, however, be referred for the most part to six or eight main 


\section{EARLY MAN}

categories-so there are many varieties of striated implements, which can similarly be referred to six or seven categories.

I. The most ancient class of neolithic implements would appear to be represented by a group of exceedingly rough pieces, the humanly-made surfaces of which are scratched all over; in typical specimens the scratches are so numerous and so criss-crossed over the whole surface that it would be difficult to put more than the point of a pin between them.

2. The next class in apparent age is mainly composed of deep blue or deep blue-black highly lustrous pieces. The scratches though less numerous than in Class I are yet very well marked, generally large and deep; and striae thus made go right into the substance of the flint and are more or less of uniform depth. The bulbar side of the implement or flake is the one chiefly affected, and the bulb is especially liable to be scratched, apparently as being the part that is most prominent. Implements of this class are generally rough in make, but they are quite different in shape from those of Class $I$. Occasionally an implement of Class 2 has been made from one of Class 1 . In that case the two periods of work on the same stone are sharply defined from one another by quality of workmanship, by patina, and by the kind of scratching on the surfaces.

3. This class resembles Class 2 in its main features; but differs from it in degree of patination, in the smaller number and depth of the scratches, and in the greater variety of forms and greater delicacy in the make of the implements.

4. This is a numerous class, composed of implements in which the patina is much less developed than in either of the preceding classes; or of implements without colour patina but on which a lustred surface of a high degree of intensity has been produced. These implements are scratched in a different way from those in the first three classes. The scratches are large, but instead of being of the same colour as the surrounding flint they stand out white, and are prominently visible when seen at a distance of some feet. There is a strong tendency to parallelism in these white scratches. In the scratching of the first three classes, though parallelism is sometimes seen, yet on the whole it is not a striking feature. In the white scratches of this class the parallelism is one of the points that at once attract attention. Examination with a lens will reveal the cause of the whiteness. The scratches will then be seen to differ from those on stones of the first three classes in this respect : it has been remarked that in those classes the scratches go with fair uniformity into the substance of the flint from end to end of the scratch. These white scratches will be seen to be composed not of a single straight furrow on the flint, but of a number of little digs into the flint separated by minute intervals of unbroken surface; or if the surface be broken throughout, the scratch is by no means of uniform depth, and the surface of the scratch is bruised rather than cut cleanly through. It is to this lack of uniformity of depth, combined with the bruising of the flint, that the whiteness of the scratch is due.

5. This class, which is very curious but quite well defined, is met with less frequently in the valley itself than in some of the neighbouring districts. The characteristic of the scratching on the implements is that instead of large scratches the surfaces show a number of very fine hair-like scratches. These fine scratches occur in groups of from four or five up to forty or fifty; the 


\section{A HISTORY OF SUFFOLK}

scratches of the group being strictly parallel to one another and frequently running for an inch or more across the surface. There may be one group or several on the same stone, the groups not being necessarily parallel to one another. It is difficult to look at these groups of fine parallel scratches, bearing in mind the extreme hardness of the fine flint surfaces on which they have been engraved, without the conviction that they have been made by the dragging of fine sand (quartz grains) across the surface under pressure.

6. The last class into which scratched implements fall is the most numerous of all. It consists of implements, with slight patinas, but generally sub-lustrous, on which there are two or three slight and, in most cases, fine scratches, generally less than $\frac{1}{3}$ in. long, which suggest to the observer that whatever may have been the conditions which gave rise to the scratches on all the various classes of stones just enumerated, these conditions have been present in much less degree in this our last class. As the variety and delicacy of make of implements gradually increased, as we advanced from one class to another, so here we reach the highest point in these respects attained by scratched implements. Even the more delicate arrow-heads are represented by a few specimens. The vast majority of arrow-heads belong however to the great class of unpatinated, unscratched, and highly-finished implements.

The above are the six great classes into which the scratched flints may be divided. It is quite certain that the classes are not contemporary with one another, but that there is a sequence in their relative ages ; and it is practically certain that the sequence in which they are placed above is the correct oneClass I being the earliest and Class 6 the latest. Proof of this is to be found in a careful study of the large series of doubly patinated pieces where two classes are represented on the same stone. As the result of this definite sequence, the stones composing the earlier classes must have existed during the subsequent periods when the later kinds of scratching were acquired, and therefore ought to present all the varieties of scratching, not only that of their own period, but those of all subsequent periods. As a matter of fact this is very commonly the case ; nevertheless it is by no means rare for an implement to show nothing but the scratching belonging to its own special period - to have come down true, so to speak. At first sight this seems rather surprising. There is, however, a quite simple explanation of the phenomenon ; but as this explanation is closely connected with the general theory of the causation of the scratches it is not possible to go into it here.

The question may be asked: Are these scratched implements really neolithic; or do they represent some late phase of the Palaeolithic Period; or perhaps even an intermediate period? The answer is that with the exception of the first class, a few examples of each class have been found with parts of their surfaces polished. Care must of course be taken in such cases not to confuse the scratches due to artificial polishing with the scratches due to some quite outside cause. There is really no difficulty in making the distinction between the two, as there is practically no resemblancc between them. In certain instances the 'natural' scratches, if they may be called so, run right athwart the 'artificial' scratches; and the contrast between them becomes at once evident.

With regard to the distribution of these scratched flints, as has already been stated, they abound in the little valley, but they equally abound in the 


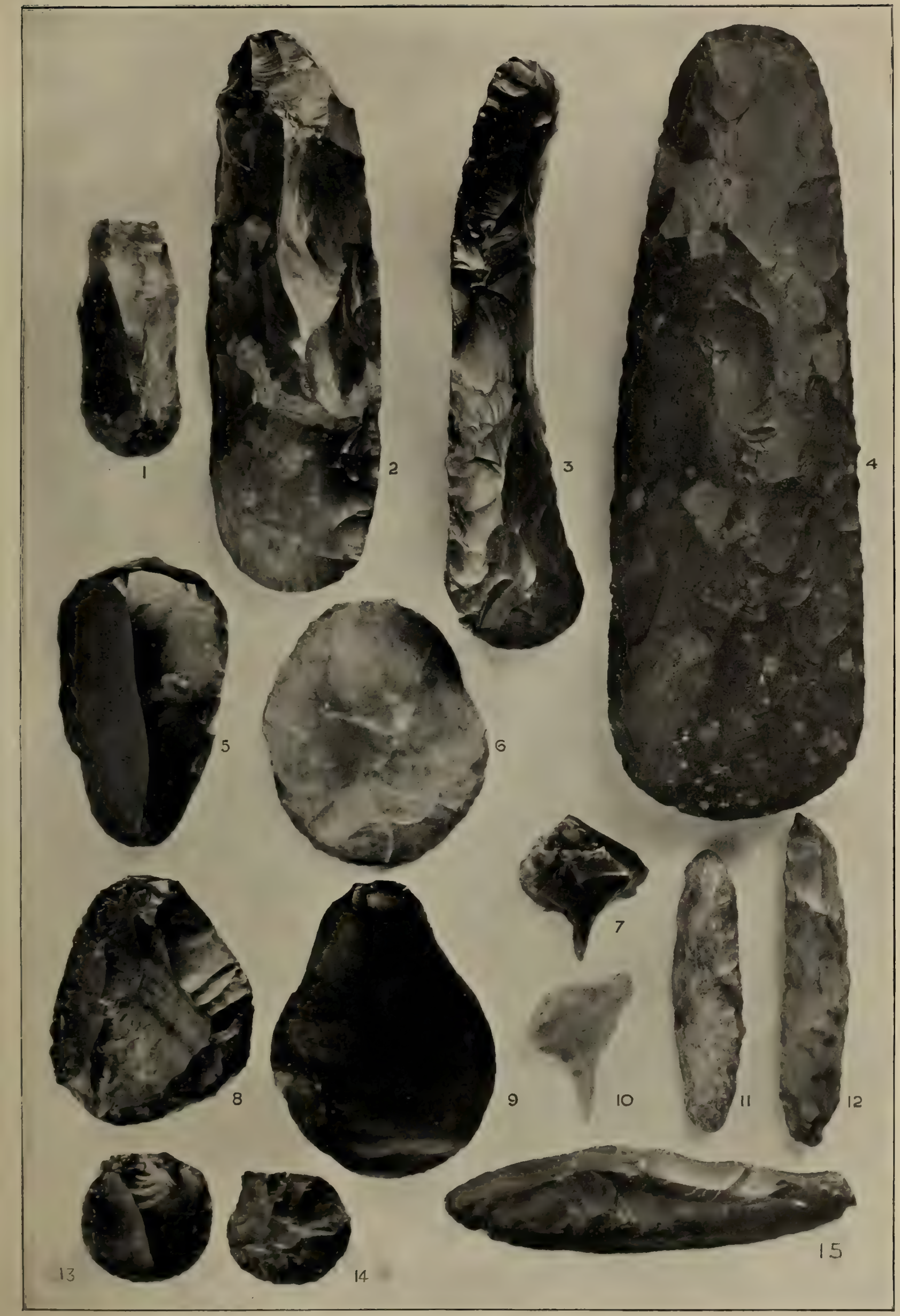

Fuiv Implements. Plate II. (Scale atout $\frac{3}{4}$.)

Fon in , Mi:ienhall (2) Midenh, I Fen. (i) Kenny Hill, Mildenhall. (4) Mi:denhall Fen. (5,6,8) Mildenhall. 1) Kenny Hill, Midienha!l. $(7,10,11,12)$ Icklingham. (13, 14$)$ Mildenhal!. (15) Burnt Fen, Mildenhall. 



\section{EARLY MAN}

fields which border the valley-on the two ridges, that is to say, which separate the little valley from the larger neighbouring valleys. These ridges are about 300 yds. wide, and are connected directly with the main plateau, from which they slope very slightly away, being on the average not more than $6 \mathrm{ft}$. or $8 \mathrm{ft}$. below its level. As the plateau is the highest ground in the district it cannot be claimed that the scratched flints have been watercarried, and that the scratches have been produced by their knocking against one another in the process. There is moreover this curious fact to be noted in connexion with the distribution of scratched flints on these ridges, viz. that no sooner has one begun to descend the side of either ridge opposite to the little valley, so as to pass into the neighbouring larger valleys, than the scratched stones become more and more scarce, until after walking a few hundred yards down the side of the larger valleys, they disappear altogether. This peculiarity is so marked that it calls for some explanation ; for it is a strange thing that these two ridges should themselves be covered with scratched implements; that these implements should be found in large numbers down the sides of the little valley; but that when we pass down the opposite side into the larger outside valleys they should disappear. The explanation appears to be this: the two outside valleys though both are now quite empty of water, have in past times, when the water to be carried off has been on a large scale, acted as the drains for the plateau. The little valley in the middle has therefore at such times been relieved of any function of the kind. It is in fact a repetition of what has been stated as having taken place at High Lodge. The little valley at first took its share in draining the plateau, but eventually was relieved of its work by the opening out of the larger side valleys. Since then it has been left in exactly the condition at which it had arrived in those distant times, so far at any rate as the action of water is concerned. In the side valleys, on the contrary, large flows of water continued to take place, and ancient implements lying in them would either be washed away or buried deep in the detritus brought down by the streams. The subject however here touches delicate ground, as the full explanation of this curious fact must necessarily form part of a full discussion of the problem of the scratches. But the fact of this curious distribution of the scratched flints is one that ought to be noted here.

This concludes a strange story in so far as it can be dealt with here. It is for the future to determine its true meaning. It may however be said that no true account of the late Pleistocene Age can be given until the questions involved have been fully answered; and that no geologist will have mastered this part of his subject who has not given full attention to the lessons to be learnt from this obscure little valley in North-west Suffolk.

The variety of the neolithic implements found in Suffolk is very great ; and the beauty of them not to be surpassed in the British Isles. Almost every type described by Sir John Evans in his classical work on The Ancient Stone Implements of Great Britain is to be found in Suffolk. Chipped celts occur in considerable numbers, especially in the fen districts of the northwestern part of the county. Some of these resemble in shape the general type of polished axes; and the best of them are examples of the highest skill 


\section{A HISTORY OF SUFFOLK}

in chipping obtained by early man, if we except the finest of the Danish and Egyptian pieces. The majority, however, are long and narrow, with sides approximately parallel. Chipped celts of this description are met with in large numbers in three districts of England: the South Downs of Sussex, and especially in the neighbourhood of Eastbourne; the River Thames and its affluent the Lea, from the beds of which some hundreds have been dredged; and the Fen districts. The South Downs are near to the sea; the Thames is the most important waterway of the south of England; whilst the Fens were at that time probably a chain of lakes leading to the sea. It seems probable therefore that these long chipped axes had as their main use the hollowing out of canoes. Canoes were probably made by lighting fires along the upper side of trunks of trees felled for the purpose. When the wood was sufficiently charred axes of this kind would be admirably adapted for stubbing out the half-burnt wood; and by repetition of the process the canoe would be made.

Polished axes, of which many have been found in Suffolk, differ from those found in many parts of the country, in that owing to the abundance, large size, and fine quality of the flint found in the county, this material has been much more widely used for axes than elsewhere. Where flint is scarce or of inferior quality neolithic man took great pains to obtain fine hard stones other than flint to make into polished axes. Where he could not obtain a suitable stone in his own district he imported it from a distance ; and there is evidence of barter on a considerable scale, whether of the raw material or of the finished article. There was little necessity for this in Suffolk; for though flint is a somewhat intractable substance to work into shape and to polish, nothing could be better for the end in view when once the necessary labour had been gone through.

In all districts where flint is easily obtained and where neolithic man has left his traces, scrapers are found in large numbers-so common indeed are they that there is a tendency amongst collectors to despise these humble but highly useful little tools. Nowhere have they been found in such large numbers as in Suffolk; and nowhere are they found of such real beauty, both of material and of workmanship, as in the north-western part of the county. They vary in size from a split pea up to great implements $4 \mathrm{in}$. or 5 in. long. And they are of all shapes-circular, oval, spoon-shaped, duck'sbill, oblong with the corners rounded off, and many other forms. Many of them are made of very fine material ; translucent chalcedonic flint, red jasperoid flint, rich brown flint, variegated and striped flint. And the natural beauty of the stone is often increased by the changes that time has produced on the surface. This may be brilliantly lustrous; or the natural colour of the flints may have been intensified or altogether changed under the influence of the surroundings in which for countless centuries they have lain. More especially is this the case with those found in the fen districts, where the wet soil, largely made up of rotting vegetation, stains the flint of a beautiful red-brown colour unmistakable when once seen. A picked collection of Suffolk scrapers may almost be compared to a collection of precious minerals. Indeed, those who are not familiar with neolithic objects from this district would hardly helieve what very beautiful things they are in themselves, apart from the interest attaching to them from the human and archaeological point of view. 


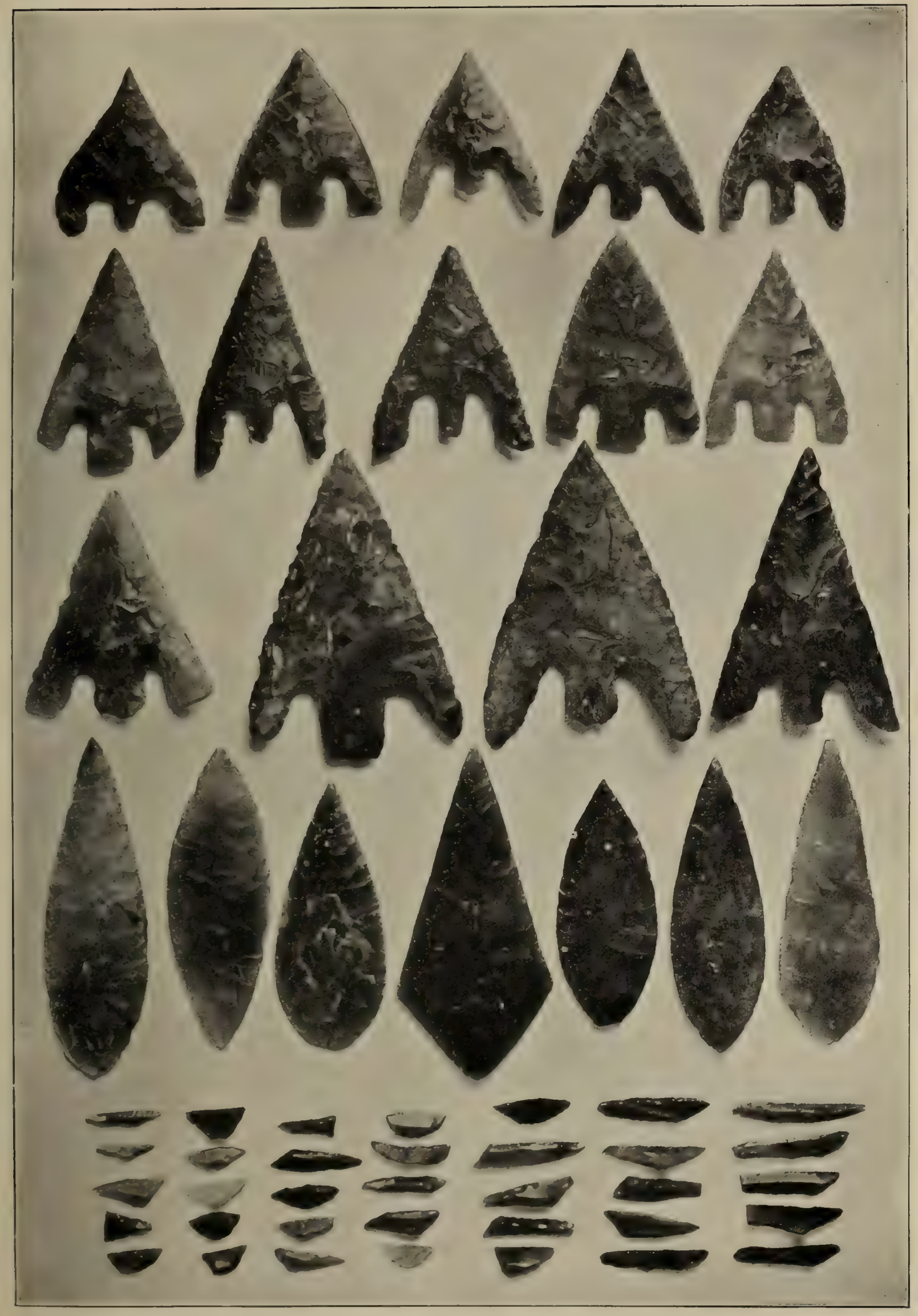

Flint Implements. Plate 1II. (Scale j.)

Anowheads from the neighbourhood of Mildenhall and Icklingham. Pigmy implements from Wangford Warren, near Brandon. 



\section{EARLY MAN}

And so with the arrow-heads. Of these there are three main varieties: the leaf-shaped; the lozenge-shaped; and the barbed and tanged. Two great divisions met with elsewhere are almost wholly wanting : the tanged without barbs, and the barbed without tang-the hollow-based. The former is common in Italy and Egypt ; the latter in Ireland, Denmark, Egypt, and Japan. The types present in Suffolk may be divided into many sub-types, and they occur in very large numbers. They are frequently of the greatest beauty, and the variety of material is as great as in the case of the scrapers. One may repeat of the arrow-heads what was said of the scrapers, that a picked collection is worthy to rank with a collection of jewels.

Space prevents the consideration of all the many varieties of neolithic implements so richly represented in Suffolk : the javelin-heads and spear-heads, the knife-daggers, and knives of many sorts; the 'fabricators' and chisels; the axe-hammers and hammer-heads. Suffice it to say that for the most part they yield in nothing to those found elsewhere. There is, however, one class of implement found in great abundance in certain places in the county which must not be passed over in silence. This is the 'midget' or 'pigmy' flints. Those who have followed the course of prehistoric archaeology during the past few years will be aware of the great importance which the study of these tiny implements has assumed. They seem to occur almost everywhere where neolithic man was firmly established; though it is especially in sandy places that the majority have been found-probably from the much greater ease with which they can be discovered in wind-blown sand than in heavy agricultural ground. Their first discovery in England was made not in sand, but under a thick coating of peat, by Dr. Colley March, on the Lancashire moors. In Suffolk, however, it has been on sandy heaths that they have been chiefly found; and the same is true of the great find at Scunthorpe in Lincolnshire, and in other places in England. Out of England they have been found in Belgium, in many parts of France, in Italy, Algiers, Tunis, Egypt ; whilst one of the most notable finds was that of the late Mr. A. C. Carlyle in caves in the Vindhya Hills of Central India, whence have come the most beautiful of any that have been anywhere found. Many types occur, but the strange thing is the resemblance of the types from all these widely scattered places. And the types are not simple, but highly evolved and worked out with great delicacy and precision. This resemblance is so striking that it seems impossible that they should not have had a common origin. Not only are the implements highly finished, but they are almost always made of flint or other varieties of silica specially selected for their beauty ; indeed, those from India are largely made of precious stones ; jasper, chalcedony of the finest quality, agate, moss-agate, cornelian, and many other beautiful stones. In size they are astonishingly small; a highly-finished little implement will be no larger than the paring of a little finger nail. Little is known about them. They are neolithic, probably belonging to some early phase of the period. Wherever found, they usually occur in large numbers, and they are rarely mixed with the larger and more generally recognized neolithic implements. As to their use, many suggestions have been hazarded; but it is doubtful whether any of these suggestions have much probability of truth in them. Though their neolithic origin seems certain, yet minute implements, not very dissimilar, occur in certain palaeo- 


\section{A HISTORY OF SUFFOLK}

lithic deposits. Thus they are found in the later deposits of the well-known caves of Mentone, which are believed to belong to a civilization following the Mousterian described in the first part of this article. And they have been met with in large numbers in certain caves in central France, the deposits of which belong to one phase of the great Magdalenian Age; in both these cases being associated with the remains of extinct animals. As with many other branches of prehistoric archaeology much remains to be found out about these 'midgets,' whether palaeolithic or neolithic. Thus far their discovery has added one more to the many fascinating problems attaching to the study of the great science of the evolution of the civilization of mankind.

\section{Topographical List of the Palaeolithic and Neolithic Localities in SuffolK}

(Where references are not given, the discovery has been made by the compiler of this list, or the information has been communicated to him privately. For valuable assistance in making the list as complete as possible, he is especially indebted to Dr. W. Allen Sturge, Dr. J. S. Holden, the Rev. J. D. Gray, and Messrs. F. J. Bennett, W. G. Clarke, A. E. W. Baker, and E. R. H. Hancox.)

Acton.-Palaeolithic implements have been found here by Mr. F. J. Bennett, the Rev. J. D. Gray, and Dr. J. S. Holden.

Aldeburgh.-Neolithic scrapers, flakes, \&c., occur on the Golf Links; also below high water in the bed of the Alde.

Alderton.-Neolithic polished stone celt [Evans, Stone Imp. (2nd ed.), 102].

AsHBY.-Neolithic flakes and implements occur in fields west of the church.

AsPallo-Neolithic scrapers.

BADingham.-Neolithic scrapers and flakes.

BARDWELL.—Neolithic perforated felstone celt [Evans, Stone Imp. (2nd ed.), 192].

BARKING.-Neolithic scrapers.

BARNBY.- Neolithic implements of rude types.

Barnham St. Gregory.-Palaeolithic implements [Geol. of Cambs. and Suff. 80]. Two neolithic polished stone celts [Trans. Norf. and Norw. Nat. Soc. viii, 29]; ground fabricator [ibid. 30]; fire-marked fints, bones, and pebbles [ibid. 27]. Polished axe [Field Club, iv, 165]. Neolith c arrow-heads, scrapers, flakes, \&c., in Cambridge Museum of Archaeology.

Barrow.-Neolithic limestone disc [Evans, Stone Imp. 439]. Neolithic arrow-heads.

Barsham.-Neolithic scrapers, \&c. [Waveney Valley in the Stone Age, 18].

Barton Mills.-Palaeolithic implements [Geol. of Cambs. and Suff. 78 ; Proc. Norw. Geol. Soc. i, 164]. Palaeolithic implements from here are in the Cambridge Museum of Archaeology. Neolithic arrow-head [Evans, Stone Imp. 390]. Other arrow-heads have been found.

BAwDSEY.-Palaeolithic implements [Proc. Norw. Geol. Soc. i, 164]. Neolithic quartzite hammer with natural hole artificially smoothed. Neolithic scrapers.

Baylmam.-Neolithic implements [Proc. Suff. Inst.Arch. vii, 209-II]. Partly ground axe and chisel ground at both ends.

Bealings, Great.-Neolithic polished flint celts, perforated hammer, flint cores, and scrapers.

Beccless.-Polished stone axe [Norw. Mus.]. Neolithic scrapers, \&c. [Thetford Mech. Inst.].

Beck Row.-See Mildenhall.

Belton.-Neolithic flint knives, scrapers, and flakes [Waveney Valley in the Stone Age, 18, 19]; Neolithic 'button' scrapers [ibid. 38]. Polished stone axes [Norw. Mus. Proc. Suff. Inst. Arch. xi (3), 2 ; Norf. Arch. iv, 312].

Benhal.L.-Mr. J. Chambers, of this parish, has a neolithic ground celt of basalt, found on Benhall Green.

Bergholt, EAst.-There is a pointed palaeolithic implement labelled 'East Bergholt' in Colchester Museum.

Blundeston.-Neolithic curved knife [Waveney Valley in the Stone Age, 19]. Neolithic scrapers, flakes, \&c.

BLYTHBURGH.-Neolithic scrapers and choppers.

Botrsdale. - Neolithic polished celt [Evans, Stone Imp. 100]. Flat-sided polished flint celt [ibid. $1 \times 0]$. 


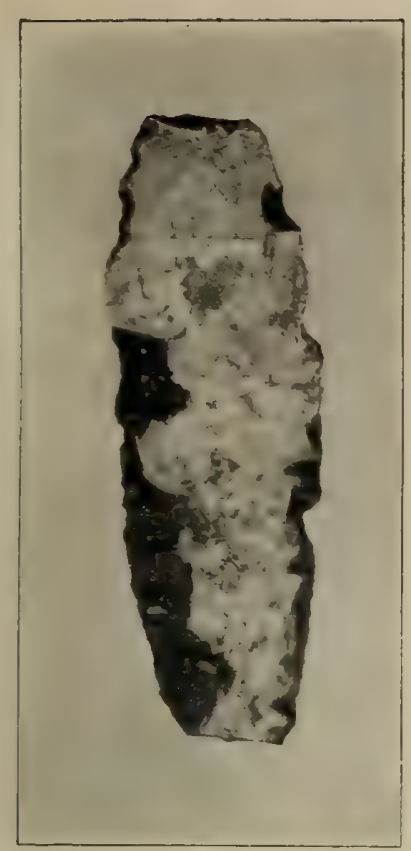

Fincly chipsed knife with two periods of working. The older patinited work is of the same yishity as the later unpatinated wor's.
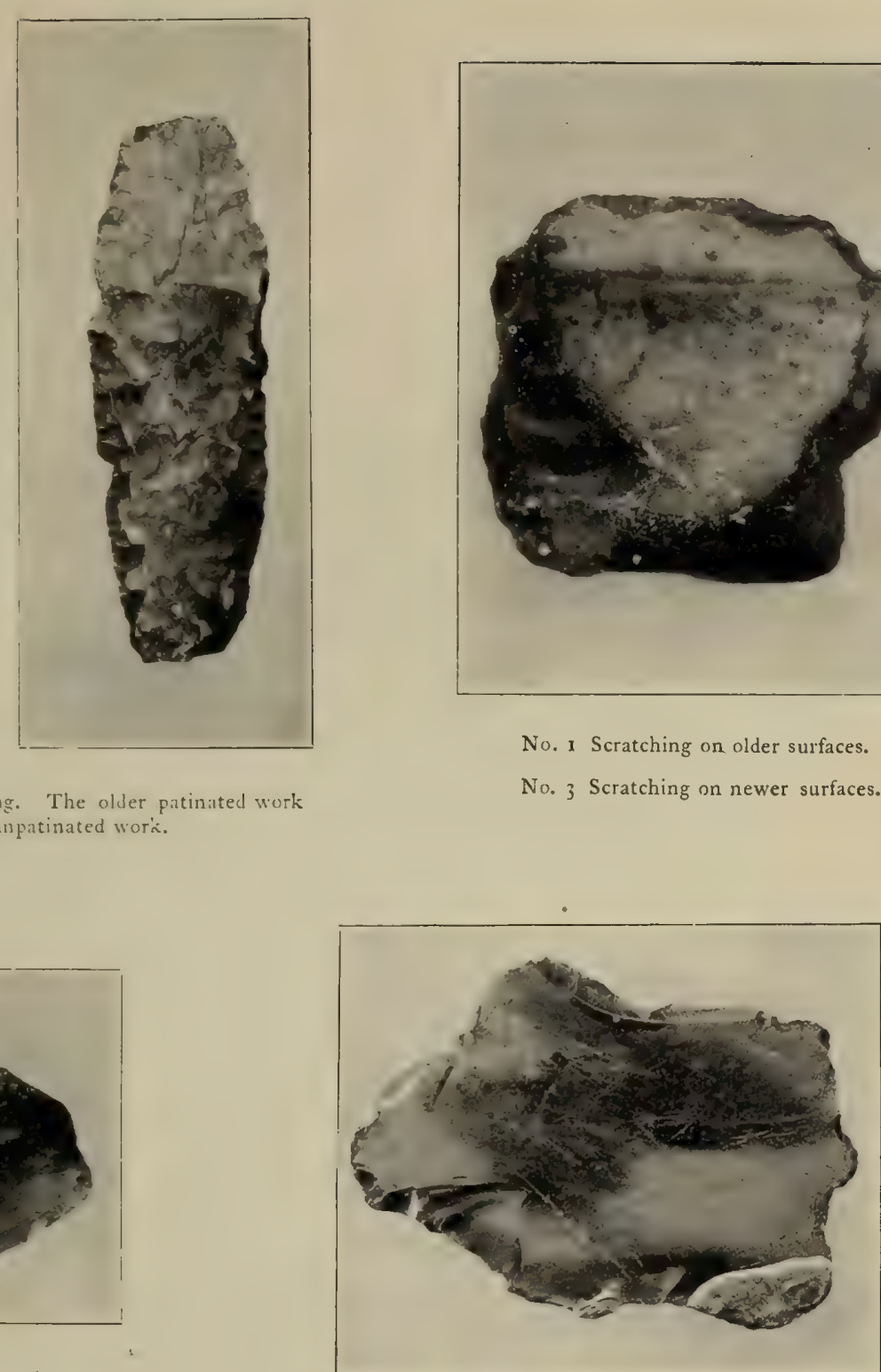

No. 3 Scratching.

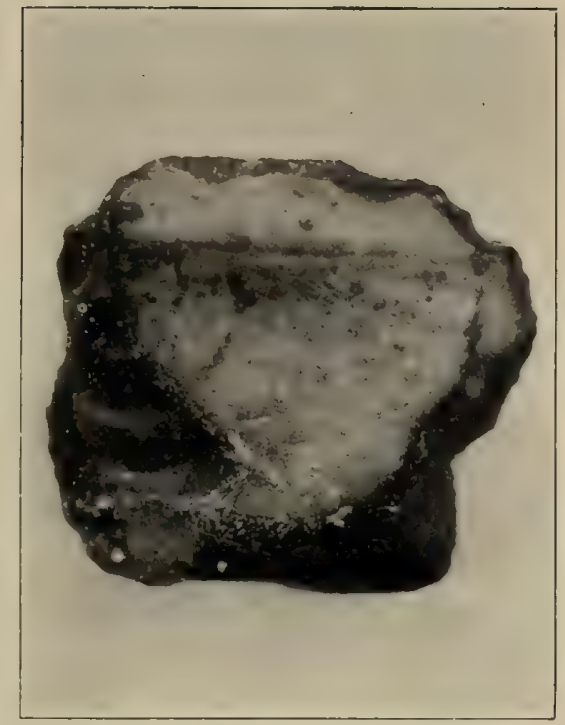

No. I Scratching on older surfaces.

No. 3 Scratching on newer surfaces.

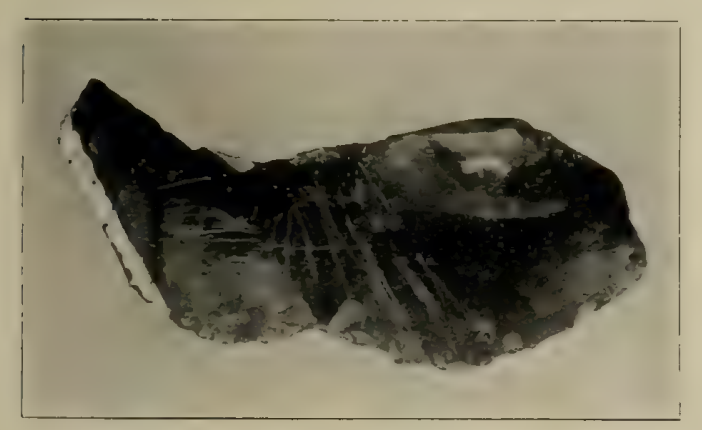

No. + Scratching. 



\section{EARLY MAN}

BOXFORD.-Palaeolithic implements found here by Mr. F. J. Bennett. Neolithic chipped flint axe.

Bradify, Great.-Neolithic arrow-heads.

BRADWELL. - Several neolithic flakes and implements.

BRAMFORD.-Neolithic scrapers.

BRAMPTON.-Neolithic scrapers and flakes.

Brandeston.-Neolithic flint borer in Ipswich Museum.

Brandon.-Supposed inter-glacial implements [Evans, Stone Imp. 568 ; Proc. Cambs. Phil. Soc. iil, 285; Geol. Surv. Mem. 'On the Manufacture of Gunflints,' 68; Prehistoric Europe, 263; Miller and Skertchley, Fenland, 546 et seq. ; Brit. Mus. Guide to the Stone Age, 2 I]. Palaeolithic implements [Quart. Fourn. Geol. Soc. xxv, 449; Evans, Stone Imp. 562, 565 ; Brit. Mus. Guide to the Stone Age, 8 ; Proc. Norw. Geol. Soc. i, 164; Norw. Mus. ; Camb. Mus. of Arch.]. Neolithic polished axes in Cambridge Museum of Archaeology. Neolithic arrowheads and scrapers.

BredField. - Palaeolithic implements in Ipswich Museum. Neolithic polished and unpolished flint celts, scrapers, \&c. Some are in Ipswich Museum.

BRIGHTWELL.-Neolithic ground-edged celt, barbed and leaf-shaped arrow-heads, knives and scrapers.

Brome (near Diss).-A pointed palaeolithic implement found here is in the possession of Mr. G. Spalding of Norwich. Neolithic polished axe of yellow flint.

Bromeswell.-Neolithic arrow-heads and scrapers.

BrUISYARD.-Neolithic scrapers, choppers, \&c.

BUCKLESHAM. - Neolithic polished flint celt and scrapers.

Bungay.-Palaeolithic implement [Antiq. Feb. 1908, p. 64; Man, viii, 41, 42]. Neolithic polished flint axe, triangular flint knife, scrapers, \&c. [Waveney Valley in the Stone Age, 21-5]. At a meeting of the Norwich Geological Society held on 26 April 1864, Mr. B. B. Woodward mentioned the finding of neolithic implements at Bungay. Pigmy flint implements [Nature, 5 Dec. 1907].

Burgh Castre.-Neolithic scrapers, choppers and flakes [Waveney Valley in the Stone Age, 26].

Burnt Fen.-See Mildenhall.

Bury St. Edmunds.-Palaeolithic implements [Evans, Stone Imp. 540-2; Flint Chips, 43]. Palaeolithic human skull [Evans, Stone Imp. 656; Brit. Mus. Guide to the Stone Age, 7]. Ground-edged flint celt [Evans, Stone Imp. 91] ; flint chisel [ibid. 174]. There are palaeolithic implements from Bury in the Blackmore Museum, Salisbury, and neolithic implements in the Cambridge Museum of Archaeology.

Cardwell.-See Lakenheath.

Carlton Colville. - Neolithic scrapers, \&c. [Proc. Suff. Inst. Arch. xi (3), 4]. Partly polished axe.

Cavenham.-Palaeolithic implements [Geol. of Cambs. and Suff. 78]. Polished greenstone celt [Evans, Stone Imp. 142]. Neolithic arrow-heads, polished axes, scrapers, \&c., found here are in the Cambridge Museum of Archaeology, Bury St. Edmunds Museum, and several private collections.

Chediston.- Three neolithic chipped fint axes.

Chilton,-Palaeolithic implements found here by Mr. F. J. Bennett.

Clare.-Palaeolithic implements found by Dr. J. S. Holden. Neolithic perforated quartzite hammer [Evans, Stone Imp. 229].

Cropton.-Polished flint celt.

CockFirld.-Palaeolithic implements found by Dr. J. S. Holden.

Coddenham.-Neolithic scrapers and flakes.

Combs.-Neolithic flint dagger, in Ipswich Museum.

Cornard, Great.-Dr. J. S. Holden has found palaeolithic implements here associated with teeth and tusks of Elephas primigenius.

Cornard, Litrue.-Palaeolithic implements have been found here by Mr. F. J. Bennett. Neolithic scrapers and flakes.

Corton.-Palaeolithic implements [Antiq. Feb. 1908, p. 63]. Neolithic fint knife [Arch. Fourn. xxii, 75 ; Proc. Soc. Antiq. (Ser. 2), iii, 19; Evans, Stone Imp. 356-7]. Neolithic lance-head, scraper, and borer [Raven, Hist. of Suff. $1 \mathrm{I}$ ]. Broken polished flint axe.

CovehitHE.-Neolithic scrapers, chopper, and flakes.

CRANSEORD.-Neolithic scrapers.

Creeting.-Neolithic flakes and scrapers.

Culford.-Palaeolithic implements [Geol. of Cambs. and Suff. 51, 81 ; Fourn. Anthrop. Inst. vii, 162 ; Brit. Assoc. Rep. 1879 ; Brit. Mus. Guide to the Stone Age, 9]. Neolithic ground-edged celt [Evans, Stone Imp. 88]. Neolithic implements found here are in the Cambridge Museum of Archaeology. 


\section{A HISTORY OF SUFFOLK}

Darsham.-Neolithic flint core.

Debenham.-Neolithic ground-edged flint celt [Evans, Stone Imp. 91]. Neolithic flakes and scrapers.

Dennington.-Neolithic scrapers and borer.

Dunwich.- Neolithic flakes, scrapers and choppers, and polished axe.

EAston.-Neolithic flakes and scrapers.

Ellougr.-Neolithic flakes, scrapers, \&c., are plentiful in fields near the church. Neolithic fiint core.

Elveden,-Palaeolithic implements [Miller and Skertchley, Fenland, 346). Palaeolithic implements found here are in the Cambridge Museum of Archaeology and the collections of Mr. F. Rix (Thetford), and Mr. F. H. Haward (Norwich). Neolithic polished axes, also scrapers, \&ic, are in the Cambridge Museum of Archaeology and the Thetford Mechanics' Institute.

Eriswell.-Palaeolithic implements [Evans, Stone Imp. 550; Geol. of Cambs. and Suff. 74]. Palaeolithic implements found here are in the Cambridge Museum of Archaeology. Neolithic arrow-heads and polished and unpolished celts from this place are also at Cambridge. Among recent discoveries has been that of one of the so-called 'star-shaped' implements with flat base, ridged back, and rounded points. These implements, which occur elsewhere in the Breck district, resemble a well-known Egyptian form.

Euston.-Neolithic implements [Trans. Norf. and Norw. Nat. Soc. vi, 35].

ExNING.-Neolithic arrow-heads.

EYE.-Neolithic perforated jasper hammer [Evans, Stone Imp. 229]. Neolithic fabricator. Other implements from Eye are in the Ipswich Museum.

FaKENHAM.-Neolithic scrapers.

Falkenham.-Neolithic scrapers, and flakes.

FARNHAM.-Neolithic flakes, scrapers and cores.

Felixstowe.-Neolithic perforated quartzite axe [Evans, Stone Imp. 207, 218]. Neolithic scrapers.

FLEMPTON.-There is a palaeolithic implement labelled 'Flempton' in Bury St. Edmunds Museum. Neolithic implements, now in the Cambridge Museum of Archaeology.

Flixton (near Bungay).-Neolithic broken polished chert axe [Introd. to Galpin's Flowering Plants of Harleston, 18].

Flixton (near Lowestoft).-Neolithic scrapers, knives, \&c. [Waveney Valley in the Stone Age, 29, 30 ; Proc. Suff. Inst. Arch. xi (3), 31]. Neolithic flint choppers [ibid. 6].

Fornham All S.AinTs.-Palaeolithic implements [Evans, Stone Imp. 542]. There is a palaeolithic implement labelled 'Fornham' in Bury St. Edmunds Museum.

Fornham St. Martin.-Neolithic implements, now in Bury St. Edmunds Museum.

FoxнALl.-Many well-worked neolithic scrapers, arrow-heads, and knives have been found on the heathland of this parish.

Framlingham.-A flint implement (no. 307) in the Museum and Art Gallery, Beaumont, Plymouth, was found here. Mr. E. E. Lowe (curator) states that it appears to be palaeolithic. Neolithic implements, rudely worked.

Freckenham.-Neolithic arrow-heads.

Fressingfield.-Neolithic implements [Proc. Suff. Inst. Arch. vii, 36].

FrISTON,-Neolithic scrapers and flakes.

FrITtON.-Neolithic flakes and implements, including discoidal and pick-like implements [ $W$ aveney Valley in the Stone Age, 32 ; Proc. Suff. Inst. Arch. xi (3), 9]. Neolithic 'button' scrapers and needle scrapers [ibid. $3,4,7$ ]. A flint axe is recorded to have been found on the edge of Fritton Lake in 1865 [Norf. Arch. vii, 351].

Frostenden.-Neolithic implements, rather rudely fashioned, occur in fields near the church.

GazELEY.-Neolithic arrow -heads have been found at Needham Street, in this parish.

Gisleham.-Neolithic implements have been found in considerable numbers on Bloodmoor Hill in this parish, among them being a well-worked flint knife, and a broken chipped axe.

GlemsForD.-Neolithic scrapers and flakes.

Gorleston.-Neolithic implements [Proc. Suff. Inst. Arch. xi (3), 4].

Grundisburgh.-Neolithic polished flint celt [Evans, Stone Imp. IOO]. Neolithic perforated flint hammer in British Museum [ibid. 223].

Gunton.-Neolithic implements [Proc. Suff. Inst. Arch. xi (3), 4].

HAUGHLEY.-Neolithic barbed and leaf-shaped arrow-heads, scrapers, \&c.

Helmingham.-Neolithic flint flakes [Arch. Fourn. xxi, I 72 ; Evans, Stone Imp. 28o].

HeMLEY.-Neolithic scrapers, \&c., have been found in good numbers.

Henham.-Neolithic scrapers and flakes.

HENSTEAD. - Neolithic implements of rude workmanship. 


\section{EARLY MAN}

HePWORTH.-Neolithic polished flint celts [Evans, Stone Imp. 100, 102].

HerringfleEt.-Palaeolithic implements [Antiq. Feb. 1908, pp. 60-4]. Neolithic implements of very finished workmanship have been found here, including some interesting combination tools, such as double-ended convex scrapers and combined convex and concave scrapers.

Herringswell.-Palaeolithic implement [Evans, Stone Imp. 539]. Neolithic polished axes, arrowhead, \&c.

Hessett. - Neolithic polished axe.

Higham (near Bury).-Palaeolithic implements [Windle, Remains of the Prehistoric Period, 64]. Neolithic arrow-head and scrapers.

Hrgham (near Haderigh), - Neolithic trimmed flakes.

Holywell Row.-See Mildenhall.

Hopton.-Neolithic scrapers, knives, \&c., of delicate workmanship [Proc. Suff. Inst. Arch. xi, (3), 329].

Hoxne. - Palaeolithic implements [Arch. xiii, 204; ibid. xxxviii, 298 ; Evans, Stone Imp. 573-7; Lubbock, Prehistoric Times (4th ed.), 353-4; Geologist, iii, 347 ; ibid. iv, 19; Phil. Trans. (1860), 277, 307 ; ibid. (1864), 247 ; ibid. cl, 304-9; ibid. cliv, 283; Skelton, Meyrick's Armour, r1. xlvi ; Lyell, Antiq. of Man, 166; Quart. Fourn. of Science (1876), 289-304; Reid and Ridley, Rep. Brit. Assoc. (1888), 674; 'Appointment of Committee to examine Hoxne Beds' (1895), 679; Rep. of Com. (1896), 400; Essex Naturalist, ix, 245; Geol. of Country around Halesworth and Harleston, 27-31; Quart. Fourn. Geol. Soc. xxxvi, 497, and xxxviii, 669; Proc. Norw. Geol. Soc. pt. ii, 62; Geol. of Engl. and Wales (2nd ed.), 515 ; Brit. Mus. Guide to the Stone Age, 1, 7-8, 20; Geikie, Textbook of Geol. (4th ed.), I 358; Proc. Suff. Inst. Arch. vii (I), p. xxviii]. Neolithic arrow-head [Arch. Fourn. xvii, 261 ; Evans, Stone Imp. 373]; arrow-head [ibid. 390]. Neolithic flakes and scrapers [Waveney Valley in the Stone Age, 34].

Ickingham.-Palaeolithic implements [Phil. Trans. (1864), 253; Quart. Fourn. Geol. Soc. xvii, 364; Arch. xxxviii, 302, and xxxix, 63; Lyell, Antiq. of Man, 169; Evans, Stone Imp. 543-7; Geol. of Cambs. and Suff. 79-80; Brit. Mus. Guide to the Stone Age, 21 ; Proc. Norw. Geol. Soc, i, 163]. Thousands of neolithic implements have been found in the two Icklingham parishes, including polished and unpolished axes, triangular knives, arrow-heads, perforated hammers, and leaf-shaped, lunate, and ground-edged knives. Some of these are figured and described in Evans, Stone Imp. Icklingham flint implements are preserved in the British Museum, in the Museum of the Society of Antiquaries of Scotland, in the Cambridge Museum of Archaeology, Blackmore Museum (Salisbury), Norwich and Ipswich Museums, Thetford Mechanics' Institute, and many private collections.

IKEN.-Neolithic scrapers and flakes.

Il KeTShall St. ANDREW,-Neolithic chopper.

Ilketshall St. John.-Neolithic broken polished flint axe [Waveney Valley in the Stone Age, 26]. Neolithic implements, rudely fashioned, are frequently found here.

INGHAM. - Neolithic implements found here are in the Thetford Mechanics' Institute.

IPswICH.-Palaeolithic implements [Fourn. Anthrop. Inst. xxxiii, 4I-3; ibid. xxxiv, 306-10]. Neolithic deer-horn pick [Fourn. Anthrop. Inst. i, 73; Evans, Stone Imp. 34]. Neolithic polished flint axe [ibid. 100]. Perforated quartzite celt [ibid. 193]. Neolithic flint dagger [ibid. 353]. Neolithic knife [Proc. Suff. Inst. Arch. xi, 203].

Kenny Hill. - See Mildenhall.

KEnTrORD.- There are palaeolithic implements labelled ' Kentford' in the Cambridge Museum of Archaeology.

Kesgrave.-Neolithic polished flint celt [Evans, Stone Imp. 100]. Neolithic scrapers and arrowheads.

Kessingland.-Neolithic scrapers, knives, choppers, borers, \&c., are plentifully distributed over the fields in this parish, and they have also been found among the sand dunes on the beach.

KrRKLEY.-Neolithic polished flint axe [Proc. Suff. Inst. Arch. xi (3), 2; Waveney Valley in the Stone Age, 36]. Neolithic scrapers and flakes have been found below high-water mark in Lake Lothing, and a partly ground axe and a well-worked flint knife were picked up on Black Heath.

KIRTON.-Neolithic scrapers and flakes.

LACKFORD.-Neolithic flat-sided, polished fint axe [Evans, Stone Imp. 112]. Arrow-heads.

Lakenheath. - Palaeolithic implements [Evans, Stone Imp. 566; Geol. of Cambs. and Suff. 74; Quart. Fourn. Geol. Sac. xxv, 450-1; Brit. Mus. Guide to the Stone Age, 8 ; Proc. Norw. Geol. Soc. i, 164]. This parish has produced a very great number of neolithic implements, including polished and unpolished axes, chipped and ground flint knives, arrow-heads, scrapers, \&rc. Many of these implements are described and figured in Evans, Stone Imp. In the Cambridge Museum of Archaeology there are about 250 arrow-heads from this parish, while a recent 


\section{A HISTORY OF SUFFOLK}

addition to that museum is a perforated celt from Lakenheath Fen. This is also a locality for pigmy flint implements [Trans. Norf. and Norw. Nat. Soc. viii, 32]. Sir J. Evans [Stone Imp. 550] records the finding of a palaeolithic implement on the surface of the ground at Cardwell in this parish.

Lavenham.-Palaeolithic flakes associated with a tusk of Hippopotamus major and a molar of Rbinoceros leptorbinus [Geol. of the Neighbourbood of Stowmarket, 17]. Neolithic chipped axe.

LEAvenheaTh.-Neolithic polished axe.

LEISTON.-Neolithic scrapers and flakes.

Levington.-Neolithic scrapers, knives, \&c., of delicate workmanship.

LINDSEY.-A very fine neolithic axe was found here in 1889 . It was embedded in a wall about 200 years old, into which it had been built with other flints [Proc. Suff. Inst. Arch. xi (2)]. This axe is $I \frac{1}{2}$ in. in length and weighs $3 \frac{1}{4} \mathrm{lb}$.

Linstead Parva.-Two stone axes were found in a garden here in 1867.

Livermere. - Neolithic polished greenstone celt [Evans, Stone Imp. 116].

Lound.-Several polished and unpolished neolithic axes have been found here in the course of excavations in connexion with the Lowestoft Waterworks. They were met with on the bank of an arm of Fritton Lake, under a peaty deposit resting on what appeared to be an old sandy shore of the lake [Proc. Suff. Inst. Arch. (2); Waveney Valley in the Stone Age, 31-2; Longe, Lowestoft in Olden Times]. These axes, which were accompanied by a grinding or polishing stone, are preserved in the offices of the Gas and Water Company at Lowestoft. Other neolithic implements, including scrapers, choppers, borers, \&c., have been found in this parish, and recently another well-chipped axe has been discovered.

LowestoFt.-Palaeolithic implements [Antiq. Feb. 1908, pp. 60-4]. Leaf-shaped arrow-heads [Waveney Valley in the Stone Age, 35]. Neolithic ground fint axe [ibid. 36]. A large number of finely-chipped neolithic implements have been found near the shores of Lake Lothing, while in the fields around Lowestoft implements of ruder workmanship are numerous.

Market Weston.-Neolithic polished flint celt [Evans, Stone Imp. IOO].

Martiesham.-Neolithic ground-edged celt [Evans, Stone Imp. 89]. In a field here, known as Bloodfield, several axes and arrow-heads have been found. Several private collections contain axes and arrow-heads picked up in this parish, among them being a small greenstone celt found on a stone heap.

Melford, Long.-Palaeolithic implements [Evans, Stone Imp. 578 ; Proc. Norw. Geol. Soc. i, 164]. Other implements, associated with remains of Elephas primigenius, have been found by Dr. J. S. Holden. Palaeolithic implements found here are in the Norwich Museum and the collection of Mr. F. J. Bennett. Neolithic implements also occur.

MeLton.-Neolithic partly polished flint pick [Evans, Stone Imp. 174]. Delicately worked neolithic implements have been found here, including a partly ground arrow-head.

Mendersham.-Neolithic implements in Ipswich Museum.

Mettingham. - Neolithic implements of rude workmanship are plentiful in some of the fields.

Mildenhall.-Palaeolithic implements [Evans, Stone Imp. 548-50, 643, 685; Geol. of Cambs. and Suff. 55-7, 74, 81, 84; Phil. Trans. cliv, 253 ; Brit. Mus. Guide to the Stone Age, 9, 1 3, 27, 28 ; Brit. Assoc. Rep. 1879 ; Miller and Skertchley, Fenland, 548 ; Proc. Norw. Geol. Soc. i, 163; Neolithic Man in N.E. Surr. 14]. A most interesting palaeolithic locality in this parish is High or Warren Lodge, where a brick-earth occurs, containing implements of types resembling those from the cave of Le Moustier. At West Row and Holywell Row, two hamlets in Mildenhall, palaeolithic implements occur in the surface soil ; this is also the case in some of the neighbouring parishes. There are many palaeolithic implements from Mildenhall in the Cambridge Museum of Archaeology; also some in the British Museum, Ipswich Museum, Blackmore Museum (Salisbury), and the Museum of the Society of Antiquaries of Scotland. Neolithic implements : Flint knife or dagger [Evans, Stone Imp. 337], flint adze or hoe [ibid. 78], flint saw [ibid. 73, 75], unpolished axes [ibid. 67-8, 73, 75], ground-edged celts [ibid. 88, 91, 93], polished celts [ibid. 104, I10], perforated quartzite hammer [ibid. 229], perforated greenstone hammer [ibid. 230], ground flake [ibid. 291], oval chipped knife [ibid. 336-7], ground flint knife [ibid. 341]. Mildenhall, like Icklingham, Lakenheath, and several other parishes in North-west Suffolk, has produced an immense number of neolithic implements, examples of which are to be found in many museums, while great numbers are in the hands of private collectors. Arrow-heads are frequently found. Beck Row, Burnt Fen, Kenny Hill, West Row, West Row Fen, and Holywell Row, all hamlets in this parish, have produced many neolithic implements, including arrow-heads and polished and unpolished axes.

MUTFORD.-Neolithic scrapers, knives, choppers, and flakes. 


\section{EARLY MAN}

NACTon.-Neolithic hatchet and borer [Proc. Suff. Inst. Arch. xi (3)]. This parish is one of the most prolific in South-east Suffolk so far as neolithic implements are concerned. Several sites of settlements have been identified by Mr. E. R. H. Hancox, and axes, arrow-heads, spear-heads, chisels, knives, symmetrically worked scrapers, borers, hammer-stones, and trimmed flakes have been found. Numerous pyramidal cores and literally thousands of flakes mark the sites of the settlements.

Nayland.-Mr. F. J. Bennett and Dr. J. S. Holden have found palaeolithic implements in the drift sands and gravels of this neighbourhood. The Rev. J. D. Gray has also found palaeolithic implements here. Neolithic implements have been found in considerable numbers, including convex and concave scrapers, borers, fabricators, chisels, knives, \& c.

NeEdham Market.-Neolithic scrapers and flakes.

NEWBOURN.- Neolithic implements of delicate workmanship in considerable numbers.

Newmarket.-Neolithic polished axes, arrow-heads, \&c., have been found here; but in some instances they were probably found in that part of Newmarket which is in Cambridgeshire.

Newton.-Mr. F. J. Bennett and Dr. J. S. Holden have found palaeolithic implements here. Neolithic implements also occur.

North Stow.-See West Stow.

NowToN.-Palaeolithic implements [Evans, Stone Imp. 542].

OccolD. - Neolithic scrapers, borers, flakes, \&c.

OTLEY.-A neolithic polished axe found here is in the Norwich Museum.

Oulton.-Palaeolithic implement [Antiq. Feb. 1908, p. 63]. Neolithic polished fint axe [Waveney Valley in the Stone Age, 40]. Various neolithic implements [Proc. Suff. Inst. Arch. xi (3)].

OUSDEN.-Palaeolithic scraper-like implement [Geol. of Cambs. and Suff. IOg].

PAKefield. - Neolithic implements of rude workmanship are abundant in this parish. The Rev. R. Ashington Bullen collected 719 neolithic implements and flakes on a farm here, including a hoe, a hand-hatchet, a hand-hammer, several small saws, and a tanged and winged arrowhead of pale chalcedonic flint.

Pakenham.-Neolithic flakes, implements, and 'pot-boilers' [Proc. Suff. Inst. Arch. x, 169].

Parham. - Several rudely-shaped neolithic implements.

PlaYFord.-Neolithic polished flint celt [Evans, Stone Imp. IOI].

Polstead.-Palaeolithic implements have been found on the surface of the ground. Neolithic axe and flint cores.

RAMSHOLT,-Neolithic scrapers and other worked flints.

Redgrave.-Neolithic polished flint celt [Evans, Stone Imp. I10]; perforated quartzite hammerhead [ibid. 228].

Redisham.一Rudely worked neolithic implements.

Rendнam.-Neolithic flakes and implements, rudely fashioned.

REYDON.-Neolithic scrapers and flakes.

Rougham.-Dr. W. Allen Sturge has palaeolithic implements that were found here, apparently from brick-earth.

RUSHMERE ST. ANDREW.-Neolithic polished axe.

RUSHMERE (near LOWESTOFT). - Rudely-fashioned neolithic implements.

Santon Downham.-Palaeolithic implements [Evans, Stone Imp. 550, 552, 556-560, 647, 660 ; Geol. Mag. v, 443 ; Proc. Soc. Antiq. (Ser. 2), iv, 124; Brit. Assoc. Rep. 1886 ; Miller and Skertchley, Fenland, 551 ; Proc. Norw. Geol. Soc. i, 164; Brit. Mus. Guide to the Stone Age, 16, 21]. Palaeolithic implements from this place are in the British Museum, Blackmore Museum (Salisbury), Norwich Museum, and several private collections. Neolithic implements: Rough chipped flint adze [Evans, Stone Imp. 70]; ground-edged flint celt [ibid. 92]; polished flint celt [ibid. 99]; ground-edged blue flint knife and fragment of circularground knife [T rans. Norf. and Norw. Nat. Soc. viii, 30] ; finely worked pear-shaped scraper [ibid. 34]. Santon Downham has been very prolific of neolithic implements, many of which are of very finished workmanship. Among them are some of the peculiar 'star shaped 'implements (see ERrswelL). Good examples of Santon Downham neoliths are in the museums at Cambridge, Norwich, and Edinburgh.

Saхнам.--Neolithic implements found here are in the Cambridge Museum of Archaeology.

SAXMUNDHAM. - Neolithic scrapers.

SAXTRAD. - Neolithic scrapers and flakes.

SHADINGFIELD. - Neolithic scrapers and flakes.

Sherlez. - Neolithic polished celt [Evans, Stone Imp. 106]; another found here is in the possession of Mr. J. Payne, of Hadleigh.

SHimplis. - Rudely-worked neolithic implements have been found in and around the earthworks known as 'War-banks.' 


\section{A HISTORY OF SUFFOLK}

ShIPMEAdow.-Neolithic scrapers and flakes.

Sicklesmere. - See Welnetham Magna.

SNAPE. - Neolithic scrapers and worked flakes. Flint flakes found in barrow [Hele's Notes about Aldeburgh, 26]. Mr. J. Chambers (Benhall) has a neolithic polished flint celt from this parish.

Somerleyton.-Neolithic scrapers of fine workmanship [Proc. Suff. Inst. Arch. xi (3)].

SOTTERLEY.-Neolithic flakes and cores.

South COVE.-Rudely shaped neolithic implements.

South Elmham St. Margaret. - Neolithic polished flint axe and portions of two others [Galpin, Flowering Plants of Harleston, 17, 18]; neolithic chipped axe, spear-heads, arrow-heads, and scrapers [ibid. 18, 19].

SoutHWOLD, - Neolithic arrow-head and other implements.

SPEXHALL.-Rudely worked neolithic choppers and scrapers.

Sproughton.-Neolithic greenstone celt [Evans, Stone Imp. 126].

STANNINGFIELD. - Neolithic perforated hammer [Evans, Stone Imp. 228].

Stanton.-Neolithic arrow-head [Evans, Stone Imp. 389].

STOKE-BY-NAYLAND.-Neolithic perforated hammer and other implements.

Stonham [? Stonham Earl].-Mr. G. Spalding of Norwich has a palaeolithic implement inscribed 'Stonham,' found in 1887. Neolithic flint flakes [Evans, Stone Imp. 281 ; Arch. Assoc. Fourn. xxiv, 182].

STOWMARKeT.-A fine palaeolithic implement, said to have been found at Stowmarket, was exhibited recently in a dealer's shop at Ipswich. Neolithic polished celt [Arch. xvi, 364; Evans, Stone Imp. I I O ]. Other neolithic implements found here are in Ipswich Museum.

Stusron.-Neolithic flakes and scrapers [Waveney Valley in the Stone Age, 4I].

Stutron,-Palaeolithic flake [Evans, Stone Imp. 578].

Sudbury.-Palaeolithic implements [Evans, Stone Imp. 578]. Mr. F. J. Bennett and Dr. J. S. Holden have also found palaeolithic implements here. Neolithic polished whin-stone celt [ibid. II 7]. Two other polished axes and numerous other neolithic implements.

Sutron.-Neolithic polished flint celt [Evans, Stone Imp. III]; perforated quartzite hammer [ibid. 23I]. A considerable number of neolithic arrow-heads, scrapers, and other worked flints have been found on Sutton Heath, in the neighbourhood of round barrows. Some of these are in the Ipswich Museum. The whole district is described as being strewn with neolithic flakes and chips.

SYLEHAM. - Neolithic implements of rude workmanship.

THETFORD.- This town is a well-known palaeolithic site; but the palaeolithic gravels are on the Norfolk side of the Little Ouse. Neolithic chipped flint celt [Evans, Stone Imp. 74] ; two partly ground axes [Trans. Norf. and Norw. Nat. Soc. viii, 29,30]; ground triangular graver [ibid. 30] ; hollow-based javelin-head [ibid. 32] ; re-chipped fabricator [ibid. 33]. The heaths and warrens around Thetford have produced a great number of neolithic implements.

Thurlow, Great.-Neolithic polished flint axe.

Thurston.-Neolithic ground-edged celt of mica-schist [Evans, Stone Imp. 97].

TRIMLEYs. - Neolithic implements of delicate workmanship have been found in these parishes.

Troston.-Neolithic ground-edged celt of micaceous grit [Evans, Stone Imp. 97]; another polished celt [ibid. 128] ; polished limestone celt [ibid.]. Neolithic implements found here are in the Thetford Mechanics' Institute.

Tuddenham St. Mary.-There are palaeolithic implements from this parish in the collection of Dr. W. Allen Sturge. Neolithic axes, arrow-heads, etc., some of which are in the Cambridge Museum of Archaeology and the Ipswich Museum.

UGGESHALI. - Neolithic fabricator, borer, and scrapers.

UNDLEY.-A hamlet in the fen part of Lakenheath. Implements found here are often described as having come from the hamlet of Undley Common, which is in Mildenhall, and vice versa. They include neolithic arrow-heads and polished axes.

Undley Common.-See Mildenhall.

W ALBERSWICK.-A considerable number of rude neolithic implements, including many of grey cherty flint.

WaldRINGField.-Neolithic flint chisel [Proc. Suff. Inst. Arch. xi, 4]. Well-chipped scrapers are plentiful in this parish, and some good flint knives have been found.

W ALTON-CUM-FELIXSTOWE.-Neolithic scrapers.

Wangford (near Brandon).-Palaeolithic implements [Brit. Mus. Guide to the Stone Age, 21 ]. Neolithic arrow-heads [Evans, Stone Imp. 389; Arch. Fourn. x, 354]. This parish has produced many well-worked neolithic implements, including polished and unpolished axes. Great numbers of pigmy implements have also been found.

W ANGFORD (near SOUTHWOLD).-Neolithic implements of rude workmanship. 


\section{EARLY MAN}

Warren Lodge. - See Mildenhall.

Welnetham Magna (Sicklesmere).-Palaeolithic implements [Evans, Stone Imp. 542 ; Brit. Mus. Guide to the Stone Age, 9, 2I; Proc. Suff. Inst. Arch. vii, 216; Miller and Skertchley, Fenland, 548 ; Proc. Norw. Geol. Soc. i, 163].

WENHASTON.-Neolithic flakes and scrapers.

IVesthall.-Neolithic rubbed flint pebbles [Evans, Stone Imp.442;Arch.xxxiv, 456]. Neolithic scrapers.

Westleton.-Neolithic white flint gouge [Evans, Stone Imp. 179]; neolithic quartzite hammerhead [Proc. Norw. Geol. Soc. i, 30]. Also many rudely worked neolithic implements.

Westley.-Palaeolithic human skull [fourn. Anthrop. Inst. xiv, 51 ; Man the Primeval Savage, 280; Evans, Stone Imp. 542]. Palaeolithic chopper [ibid. 543]. Neolithic spear-heads and other implements [Proc. Suff. Inst. Arch. vii, 2 I 4 ].

WEsTON.-Rudely worked neolithic implements.

West Row.-See Mildenhall.

WEST Stow.-Palaeolithic implements [Evans, Stone Imp. 542; Brit. Assoc. Rep. I897; Miller and Skertchley, Fenland, 548 ; Brit. Mus. Guide to the Stone Age, 9]. Neolithic implements : Polished flint celt [Evans, Stone Imp. 100]; thin ground adze [ibid. 92]; flint chisel [ibid. 176]; arrow-heads [ibid. 389 ; Proc. Suff. Inst. Arch. vii, 216]. Many other neolithic implements have been found here, some of which are in the Museum of Archaeology at Cambridge. In North Stow, in this parish, neolithic fint chisel [Evans, Stone Imp. 176]; curved knife and horse-shoe-shaped ground flint knife [ibid. 342, 356] ; ground-edged chisel [Proc. Suff. Inst. Arch. xi, (2), 203].

WeTHERINGSETT. - Two neolithic polished axes, picked up by schoolboys, are preserved in the village school.

Wherstead.-Palaeolithic implements [Proc. Norw. Geol. Soc. i, 164]. Neolithic implements in Ipswich Museum.

WhITTON.-Neolithic flakes and scrapers.

Wickhambrook. - Neolithic polished axe in Bury St. Edmunds Museum.

Wickham Market.-Neolithic implements of rude workmanship.

WILLINGHAM. - Neolithic chopper and scrapers.

WOODBRIDGE.-Finely worked neolithic flint knife, polished axe, and many other well-worked implements.

WooLPIT.-Neolithic arrow-head in British Museum.

WorLINGHAM.-Neolithic flakes, choppers, and scrapers.

WORLINGTON.-Neolithic polished axes, arrow-heads, and many other delicately worked implements. Some are in the Museum of Archaeology at Cambridge.

WORLINGWORTH. - Neolithic implements of rude workmanship.

WorthaM.-Neolithic polished axe in Norwich Museum.

\section{The Bronze Age}

A convenient division which may be made of prehistoric antiquities is that which separates the stone ages from the metal ages, the Palaeolithic and Neolithic Periods from those of bronze and iron. The beginning of the Bronze Age in Britain is archaeologically very important for more than one reason. It marks a great advance in culture, and it proves the coming of a new race to our shores.

In certain countries the age of stone appears to have been succeeded by a period in which the only metallic tools and weapons were those made of copper, but before the Goidelic Celts came to Britain they had arrived at the Bronze Age of culture, a distinct advance on the Copper Age.

There are many problems in connexion with the early working of bronze in this country into which it is unnecessary to enter in this place ; but a few words on the general question of the Bronze Age are perhaps desirable in order to indicate the value and precise significance of some of the discoveries of antiquities in Suffolk about to be described.

The chief source of information on certain phases of prehistoric civilization and prehistoric customs is found in sepulchral remains. This 


\section{A HISTORY OF SUFFOLK}

is as true of the Bronze Age as of later parts of prehistoric time. The introduction of bronze into Britain was marked by an almost entire change in the burial customs of the people. The neolithic burial-places consisted of megalithic structures, and long or oval barrows sometimes containing chambers built up of rough stones. The dead bodies were buried sometimes with and sometimes without previous burning or partial burning, and also in some cases after the skeleton had been bereft of its flesh. The bronzeusing people, on the other hand, habitually burnt their dead and inclosed the remains in either ( $\mathrm{I}$ ) a cist formed of comparatively small stones, (2) a cinerary urn of rough pottery, inclosing also smaller sepulchral pottery, or (3) in an excavated hole in the ground, which was then covered by a mound. They reared low mounds, generally circular in plan, over the remains, which usually consisted of the much charred or entirely calcined fragments of bone accompanied by a few articles of either bronze or worked flint.

Although burial by inhumation still continued to be practised during the Bronze Age, cremation was adopted for the first time, and constitutes one of the most characteristic features of Bronze-Age burial. The survival of the practice of inhumation affords, as the late Mr. J. Romilly Allen has clearly shown, ${ }^{1}$ an indication that the Bronze-Age race, or Goidels, amalgamated with the neolithic aborigines rather than exterminated them. The unburnt bodies were usually buried in a doubled-up position, and sometimes an urn was placed near the dead body ; but with the burnt interments of the Bronze Age ornamented pottery was generally deposited, and this affords ample material for studying the art of the period.

This pottery derived from round barrows, which can now be examined in the more important museums of the kingdom, exhibits a remarkable variety of forms, which for the purpose of definite classification have been divided into the following classes:-

I. Cinerary urns.

2. 'Food-vessels.'
3. 'Drinking-cups.'

4. 'Incense-cups.'

Of these terms, perhaps the first alone may be regarded as really descriptive of the use to which that type of vessels was put. The cinerary urn, which was used as a receptacle for the remains of burnt human bones, stood from 6 in. to $3 \mathrm{ft}$. in height. It was sometimes placed upright, and sometimes in an inverted position on a flat stone. Round the top of the vessel was usually a thick rim the purpose of which was probably to impart strength.

'Food-vessels' are urns with fairly wide open mouths. By some authorities they are believed to have been used to contain food which was placed near the human remains in unburnt Bronze-Age burials.

'Drinking-cups' are vessels of beaker-like form, the surfaces of which are ornamented by interesting incised designs. They are hardly ever associated with cremated burials, and are generally found placed near the shoulders of the skeleton of the dead.

'Incense-cups,' unlike the two types of pottery just referred to, are never found in association with unburnt burials; they invariably accompany crema- 


\section{EARLY MAN}

tion, and are sometimes found contained within cinerary urns. The purpose of this kind of vessel, which is sometimes furnished with a lid or cover, is a question which has given rise to much speculation among antiquaries, but the point remains unsettled. The use indicated by the name appears improbable, but there is another suggested use which certainly seems reasonable, namely, that these vessels were used for conveying fire to the funereal pyre, as part of the ritual accompanying cremation; but this theory requires confirmation.

Much important information as to the casting of bronze articles, the trading in bronze implements, and the evolution and contemporaneity or otherwise of forms of bronze implements, has been derived from certain deposits or hoards of metal. These originally were hidden in the soil by the possessor and not recovered until modern times, when by some chance excavation they have been brought to the light of day.

Hoards of bronze antiquities comprise a considerable variety of new and old implements, ingots of rough metal or cakes of copper, \&c., but they fall conveniently into three main groups or classes, viz :

(a) Personal hoards, containing the personal property of individuals who had buried the metallic objects underground for security, and presumably forgotten the site, or at any rate, for one reason or another, never recovered the treasure;

(b) Merchants' hoards, comprising the stock of newly cast implements or weapons ready for use, and probably carried about from place to place for exchange; and

(c) Founders' hoards, consisting of broken or disused weapons, implements, \&cc. collected for the purpose of re-melting and often accompanied by moulds for the making of fresh castings in bronze.

The evidence of accumulations of this character for the diffusion of Bronze-Age population and the activity of Bronze-Age commerce is of the greatest archaeological value.

Another point upon which bronze hoards afford valuable evidence is the succession of stages in the development of the form of implements, etc. Within certain limits they prove what objects are contemporary. They show, for example, that tanged implements of any kind are rarely found with socketed celts; that flanged celts and palstaves are sometimes found together, but that palstaves are often found with socketed celts; and that both metal moulds and rough lumps of copper are generally associated with hoards in which socketed celts are found.

Knife-daggers and early flat celts are found only very rarely in hoards; but they occur with some frequency in association with interments in BronzeAge barrows. From this it seems safe to infer that in the earliest periods of the British Bronze Age (to which flat celts and knife-daggers belong) metallic tools were esteemed very highly ; indeed, they may have been regarded with superstition; or they may have been buried with the dead to serve as the most useful objects for life in a future state ; or possibly the art of melting down the old metal tools and casting new ones was unknown.

It is clear, after a careful study of many hoards of Bronze-Age antiquities, that flat celts, and tanged implements generally, belong to the early part of the Bronze Period, whilst palstaves, socketed celts, and socketed articles generally are of later date. 


\section{A HISTORY OF SUFFOLK}

Suffolk :-

The following are brief particulars of these Bronze-Age hoards found in

Clare, Poslingford Hall.-This hoard, ${ }^{2}$ which was discovered by labourers in or about 1845 , comprised 19 bronze flanged celts of various sizes, the largest weighing $\mathrm{I} \frac{1}{2} \mathrm{lb}$. and the smallest rather less than I $\mathrm{lb}$. Several of them were ornamented with engraved lines, punctures, and zigzag patterns. Some of these interesting objects were subsequently presented to the British Museum.

Felixstowe.-This hoard, which subsequently passed into the collection of the late Sir John Evans, contained the following objects, 24 in all :-

\begin{tabular}{|c|c|c|c|c|c|c|c|c|c|}
\hline Rough metal & & - $\quad$ - & - & - & - & - & - & - & \\
\hline Fragments of tools & an & weapons & . & . & . & . & . & . & - \\
\hline Heads and runners & . & .. & - & . & • & - & . & - & - \\
\hline Knives or daggers & . & . & . & . & . & . & . & . & . \\
\hline Socketed celts & . & . & . & . & . & . & . & . & - \\
\hline Gouge . . & . & . & . & . & . & . & . & . & . \\
\hline Spear-heads & - & - & - & . & - & - & • & - & - \\
\hline Saw . . & . & . & . & . & . & . & . & . & . \\
\hline Scabbard end. & . & . & . & . & . & . & . & . & . \\
\hline
\end{tabular}

Thorndon.-The hoard of Bronze Age antiquities found at this place comprised a spearhead, hammer, knife, gouge, awl, and one or two socketed celts. The hammer, as the late Sir A. Wollaston Franks ${ }^{3}$ pointed out, is of a curious and rare type. It resembles a socketed celt, but instead of tapering off at the point, the lower end is cut off square and is of solid character. The knife is provided with a socket into which the handle was fixed by two pins. The gouge is of the ordinary type.

The hoard must have been made late in the Bronze Age, all the articles having reached their highest, or at any rate, latest stage of developinent. The socketed hammer is suggestive of the type having been derived from a much worn-down celt. The objects are now preserved in the British Museum.

Exning.-An interesting hoard, probably of Roman date, but containing several objects of purely Bronze-Age character, was discovered in Exning in the year I 832. Mr. (afterwards Sir) A. W. Franks exhibited the objects at a meeting of the Royal Archaeological Institute 4 in 1852 , and drew attention to the more important points of the antiquities. The articles included a bronze pendant object bearing some resemblance to a bulla, formed of thin metal filled with baked clay; socketed celts; spear-heads; a gouge; and a curious pin with a chain, all of bronze. Near this hoard were two urns the form of which was very similar to Roman vessels, but the material was coarse and badly baked, suggestive of a rather earlier period.

The art of the Bronze Age in Britain is traceable, to a large extent, to a Mycenaean origin. ${ }^{5}$ The forms it takes throughout Europe, comprise (I) the swastika, (2) the triskele, (3) the cup and ring, (4) the ship, (5) the axe, and (6) the wheel. In England we have only a few of these forms, among which the swastika is rare, and cups and rings fairly abundant, particularly in the north of England.

One of the chief forms employed on the pottery of the Bronze Age in this country is the cheveron in various combinations. Parallel horizontal lines are largely used, singly or otherwise, so as to cut up the body of the vessel into zones, which as a general rule, are alternately plain and ornamented.

An urn of the 'drinking-cup' type round at Lakenheath, and now preserved in the British Museum, illustrates this kind of Bronze-Age ornament in an admirable manner. In this urn the whole of the external surface is covered with ornament, the general effect of which is distinctly pleasing, although the forms employed are quite simple and elementary.

Proc. Soc. Antiq. (Ser. I), 1, 83.

- Arch. Journ. ix, 303 ; x, 3.
Arch. Fourn. x, 3.

- J. Romilly Allen, Caltic Art, 2 I. 


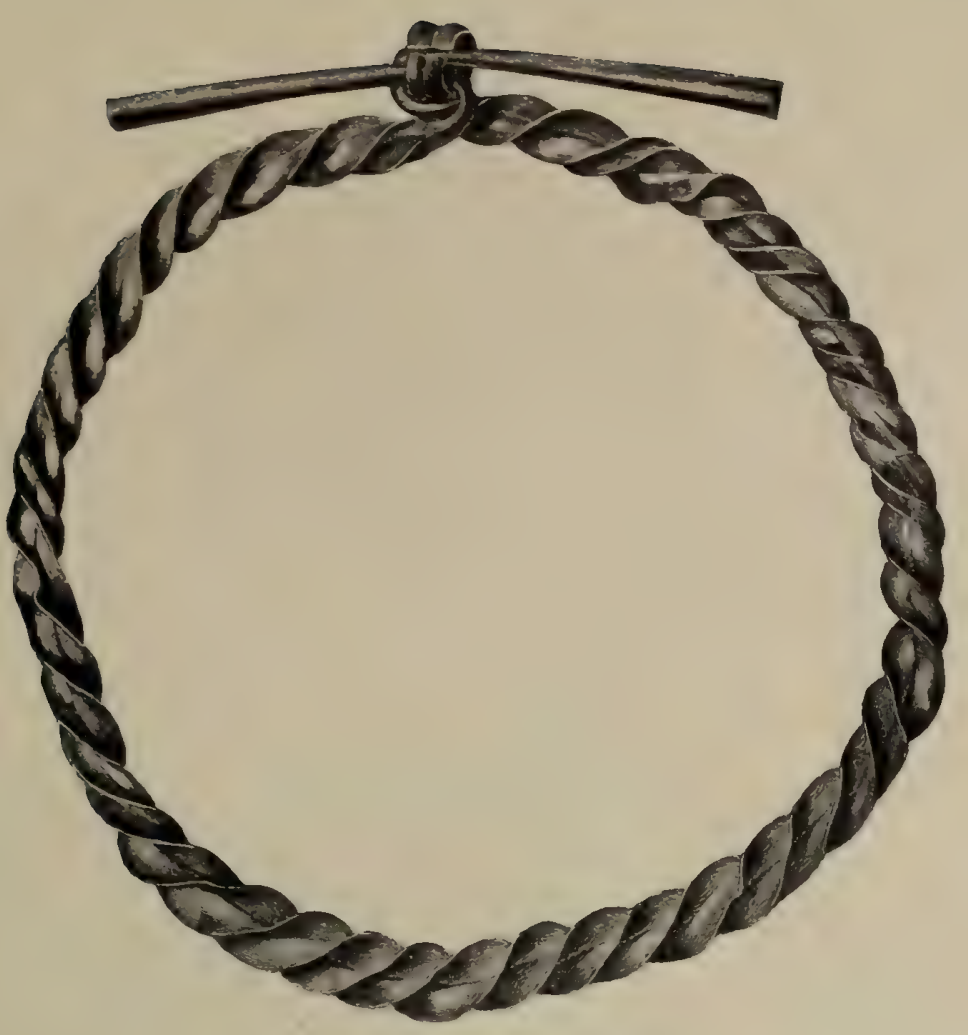

Gold TORque Found at Boyton

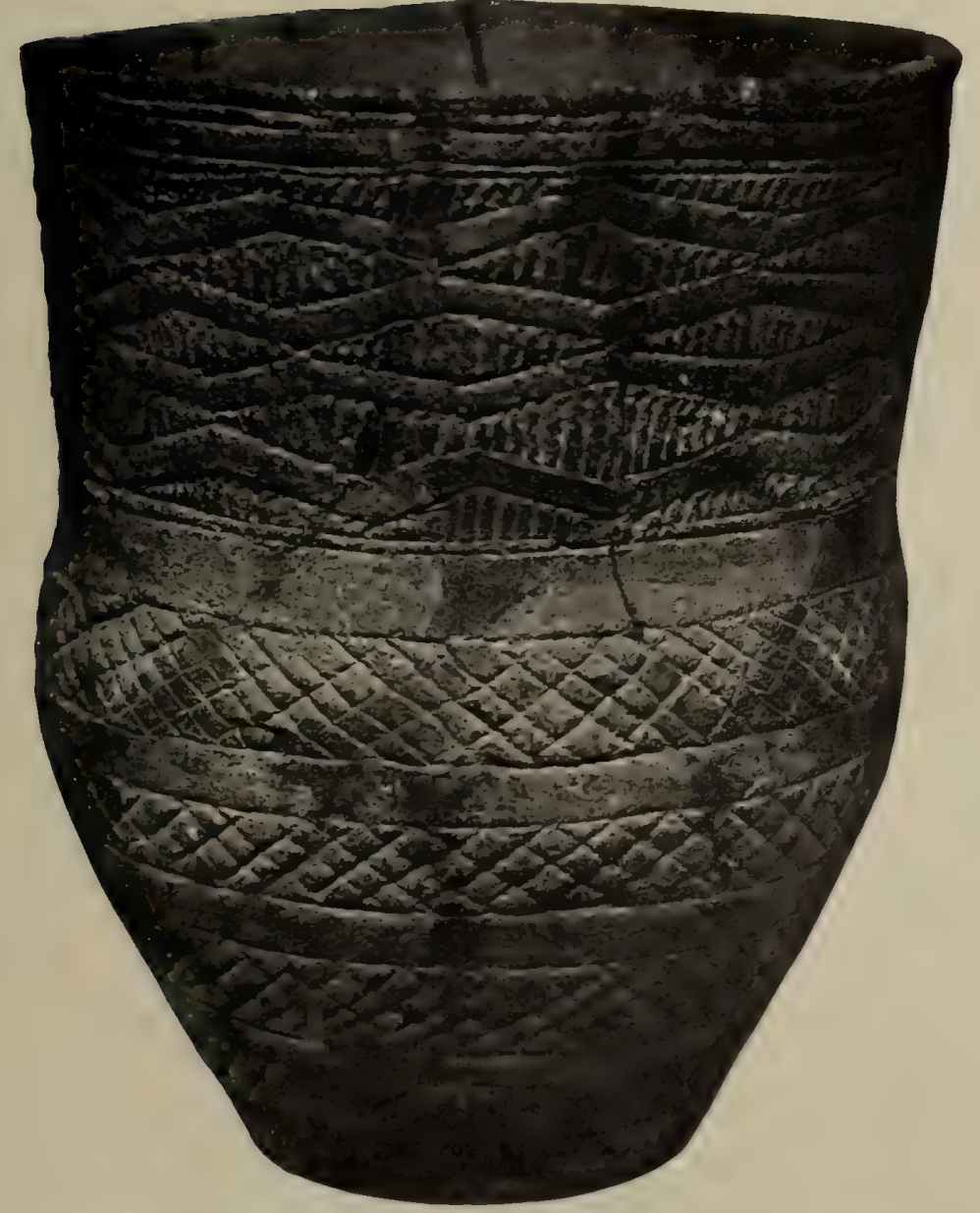

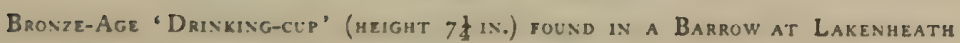
(Now in the British Museum)

Bronze-Age Antiquites found in Suffolk 



\section{EARLY MAN}

It will be observed that straight lines only are employed. Spiral forms, which gave such beauty to Late Celtic art, are here entirely wanting, and, with the exception of the circles found on the bottoms of some of the incense cups, curves form no part of the decoration of Bronze-Age pottery. Although the incisions are somewhat irregular they are evidently intended for, and must be regarded as, straight lines.

One of the characteristics of the Bronze-Age beakers or 'drinking-cups' of Essex is the use of parallel horizontal lines.

A cinerary urn of the regular Bronze-Age type with over-hanging rim was found at Snape (see annexed illustration).

There are a few pieces of Bronze-Age pottery of some interest, which were probably found in Suffolk, now preserved in the archaeological museum at Ipswich. One is a vase, or urn, of drinking-cup form, about 5 in. high, decorated with a rather

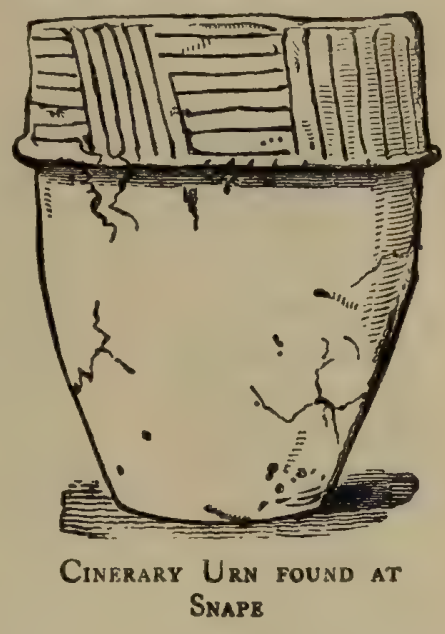
coarse series of dots arranged in the form of horizontal lines between which, in alternate zones, are dotted lines in the form of lattice-work with diamondshaped openings. Another similar vessel is beside that just described. Both are somewhat mutilated by hard wear.

There is a third vessel of flatter, smaller, and more globular form. It is ornamented with incised horizontal lines.

There are certain ornamental features on some of the cast-bronze implements found in Suffolk which give distinctly valuable illustrations of the kind of artistic efforts made by the worker in bronze of this early period of time. These differ essentially from the styles of ornamentation found on sepulchral pottery of this period. In the pottery we have many different combina-

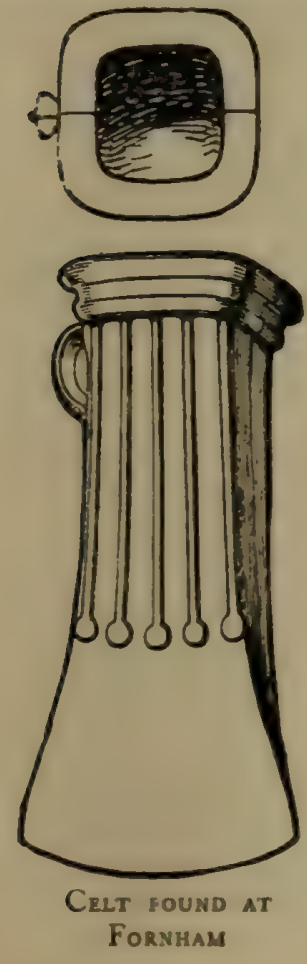
tions of horizontal, perpendicular, and oblique lines, generally forming some kind of cheveron design. Everything of the nature of a regular curve is wanting. If a line approaches a curved form it is almost certainly the result of carelessness or accident. In the objects formed of cast bronze, however, as will be observed from the accompanying illustrations, this is not the case. Here we have, in the case of the socketed celt from Fornham, a series of five flattened circular pellets or roundels arranged across the celt at about the point where the hollow socket ends and the solid, business-part of the implement begins. Raised lines, or ribs, connect the roundels with the welldeveloped moulding which surrounds the socket end of the celt. The area near the cutting edge, it will be noted, is kept quite free from ornament.

The use to which implements of this type were applied is a matter of some uncertainty, but the fact that they have often been found broken just at the small end of the socket suggests that they were employed for levering, prising, or splitting wood, or some such use. If this is 


\section{A HISTORY OF SUFFOLK}

true the ornament in the form of pellets and ribs on the sides may have been a method of strengthening the implement at the point where it specially required rigidity.

Another socketed celt, found at Lakenheath, has on the sides three lines of rather oval pellets, terminating in ring ornaments. Between them are plain

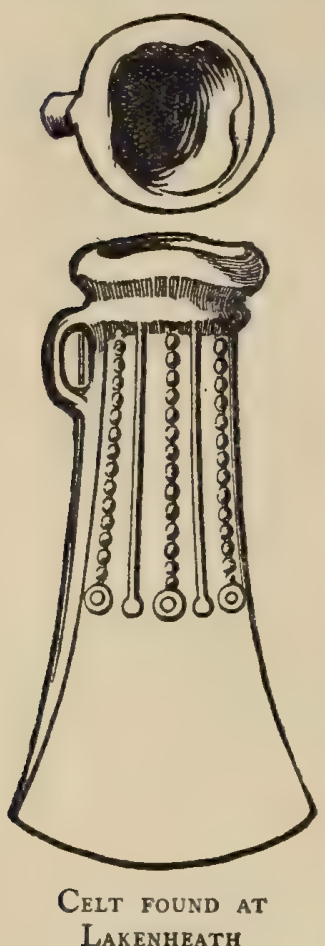
ribs terminating in small circular pellets. This specimen is in the British Museum.

The celt from Mildenhall here shown has three curved ribs on each side arranged in a way which suggests survival in form of the bent-over flanges or wings of the earlier types of implements.

A palstave found at Honington is ornamented with a kind of shield. In some cases this shield is divided into two halves by a line carried through it from apex to base, but in the Honington example this line is not present. It is a curious feature, but comparative study shows that it is related to the vertical ribs which are found on many palstaves. A fragment of a similar palstave, labelled ' part of a bronze spear-head,' is in the Museum at Ipswich, and presumably it was found in Suffolk.

Two leaf-shaped swords found at

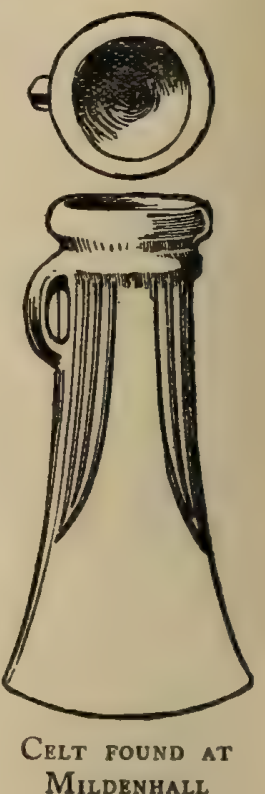

Barrow, ${ }^{6}$ near Bury St. Edmunds, are of particular value from the fact that they were found under circumstances which indicate, if they do not prove, association with a burial. The discovery was made in 1850 or $185 \mathrm{I}$ by workmen. The swords, one of which measured $261 \mathrm{in}$. in length, lay two or three feet below the surface. The evidences go to show that the associated burial was unburnt. Of these two swords, one is now in the

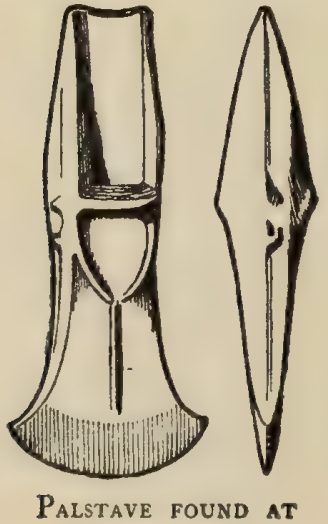

Honington
Museum at Bury St. Edmunds.

The bronze swords procured at Barrow show a good deal of refinement of form. There is in the Cambridge Museum of Archaeology a fragment of another fine leafshaped sword-blade found at Mildenhall.

In the Archaeological Museum in Christchurch Park, Ipswich, there are socketed spear-heads of bronze from Felixstowe and Nacton Heath, and palstaves and socketed celts from Mildenhall (several), Baylham, Bromeswell, Hadleigh, and Stowmarket. One bronze celt in this collection which is of special interest from its thick, unornamented form (a characteristic of the early part of the

- Proc. Bury and W. Suff. Aich. Inst. vi, 185-6. It is worthy of note that another leaf-shaped bronze sword was found buried about $2 \mathrm{ft}$. 6 in. deep under similar circumstances, and doubtless in connexion with an interment, at Chippenham (in East Cambs.), quite close to Barrow. The Rev. Canon Greenwell, F.R.S., to whom this discovery has been referred, feels considerable doubt as to the suggested association of the swords with a burial. 


\section{EARLY MAN}

Bronze Age), is unfortunately unlabelled with any more definite locality than 'Suffolk.'

A perfectly preserved gold torque, measuring about 5 in. in external diameter, was discovered at Boyton ${ }^{7}$ in the year 1835 . The torque, as one might expect from its name, is twisted, whilst the ends, which are made of straight pieces of thick gold wire or bar, are turned sharp back, so as to produce acute hook-like fastenings. The total weight, including a link of gold ring money attached, as an additional security, to the fastening, is $2 \mathrm{oz} .4 \mathrm{dwt}$. The torque was found in a loam-pit embedded in the soil $12 \mathrm{ft}$. below the surface, and unfortunately in washing it one of the pieces of ring-money (there were originally two) was lost. The other is now in the British Museum.

The period of this beautiful specimen of personal ornament is probably somewhat late in the Bronze Age. The charming effect produced by the twisting of the gold is due to the fact that the bar of metal was built up into a kind of rod or wire of a cruciform section.

There does not appear to be much available evidence as to the forms of human dwellings during the Bronze Age. In times of civil or tribal strife, possibly also in very severe weather, the Bronze-Age folk retired to caves and other natural fortresses, just as at a much later period the Scottish Covenanters fled to caves and forests during the persecutions which they underwent.

The antiquities discovered in Heathery Burn Cave, in the county of Durham, furnish evidence of the presence of human residents extending over a considerable period, but residence was probably intermittent and interrupted. In other parts of the country rock shelters as well as caves may have been made use of for dwelling purposes. It is significant, however, that the small clay sepulchral receptacles known as hut urns, found in Italy, which are of the Bronze-Age, are shaped exactly like small wooden houses or huts with square plan, gabled roofs, timber-rafters, and rectangular or nearly rectangular windows and doors. We may possibly conclude from this that the houses of the Bronze Age in Britain, as elsewhere, were constructed of shaped timbers. The tools formed of bronze would doubtless be equal to the work of cutting, cleaving, and shaping the timbers necessary for the building of such houses.

Certain remains of Bronze-Age houses in this country have been found, although they are distinctly rare. On Dartmoor, where stones for the purpose are abundant, there are several low circular walls or foundations of habitations which belonged to this period. In other parts of the kingdom where rivers, lakes, or marshy land were available, the dwellings were constructed upon piles driven into the bed of the stream or lake. These pile-dwellings, whilst perhaps having certain disadvantages arising from dampness, afforded valuable protection from wolves as well as from human enemies.

There is every reason to believe that there are still existing below the soil, in places where lakes and marshes have been dried up or river-courses have been diverted, several remains of pile-dwellings of the Bronze Age. Possibly there are some such in Suffolk, a county which presents many of the requisite physical conditions for structures of this character.

At least one spot where remains of pile-dwellings have been found in Suffolk is recorded; this is in Barton Mere, at Great Barton. Here, it is pretty 


\section{A HISTORY OF SUFFOLK}

clear that the houses had been constructed on piles driven into the bottom of the lake. Large blocks of stone were found round the piles, which from the associated socketed bronze spear-heads were evidently the work of the Bronze Age.

\section{The Early Iron Age}

The use of iron in prehistoric times succeeded the use of bronze. This division of time, or rather stage of culture, as it may more conveniently be considered, began with the first introduction of iron into Britain, and ended with the coming of the Romans to our shores. The term Early Iron Age, which is sufficiently descriptive for all practical purposes, must not, however, be taken to mean that iron was the only metal in use, because during the whole period, and indeed subsequently to it, bronze continued to be used for the hilts and scabbards of swords, for horse-trappings, and a variety of other articles in which durability and slow oxidation were more desirable qualities than the capacity for receiving a keen edge or a sharp point. There was, in fact, quite a long period of transition and overlapping, during which bronze and iron were employed in the manufacture of weapons and domestic implements of all kinds.

The employment of the exact admixture of metals to produce the hardest bronze proves that both copper and tin were thoroughly well understood during this period. To the metals iron, copper and tin, we may add gold, the latter having been extensively employed for the making of personal ornaments in the Bronze Age as well as the Early Iron Age. The extraordinary skill displayed by the inhabitants of Britain at this early period in the working of different metals is eclipsed by the artistic excellence of the ornamental forms, and by the use of variously coloured enamelling, employed especially on articles for personal wear, such as brooches, bracelets, collars, \&c. Suffolk has furnished a few metallic objects of this period which may be placed amongst the very finest of their class. These will be described in this article in due course.

There are reasons for thinking that the first iron used in Britain was not obtained from an indigenous source, but was imported, being brought probably by the Brythons, a branch, like the Goidels or Bronze-Age people, of the Celtic family. A point of very great interest about this subject is that the chief of the British Islands received its name from that of the new race which, at the beginning of the Early Iron Age, made its appearance on our shores. To this race, therefore, Britain is indebted for the first knowledge of iron, for her wonderful metallurgical skill, her name, and much of the blood which has made her famous amongst the great nations of history.

An Early Iron-Age burial deposit of great interest was discovered in or about the year 1888 at Elveden. Dr. Arthur Evans, ${ }^{1}$ who had an early opportunity of examining the objects found, draws attention to the striking resemblance of this Suffolk burial to those found at Aylesford, Kent.

The objects found at Elveden comprised a two-handled bronze-plated wooden tankard adorned with repoussé medallions, and presenting the closest parallel to a tankard made of bronze found in one of the Aylesford graves. The Elveden tankard is remarkable on account of the purity of the Late 


\section{EARLY MAN}

Celtic curves introduced into its ornamental circular discs, and also on account of the general form of the vessel, ${ }^{2}$ which reminds one very forcibly of the Aylesford example.

The Elveden sepulchral deposit also contained three earthenware vessels of excellent quality and belonging unquestionably to the same class of ware as that found at Aylesford, which, as Dr. Arthur Evans has demonstrated, is a fashion introduced from the region about the northern end of the Adriatic Sea. One of these was a reddish colour, and, though more globular in form, resembled the most delicately finished of the Aylesford vases in the double row of undulating striae that ornamented its body. Calcined bones found amongst the earth in which these relics lay evidently formed part of the funeral deposit placed here, as at Aylesford, some little depth below the surface of the ground.

A bronze brooch of great beauty, of the type known as $\mathbf{S}$-shaped, was discovered at Lakenheath, Suffolk, some years ago, and is now in the possession of Mr. S. G. Fenton. ${ }^{3}$ The late Mr. J. Romilly Allen, who published an account of this brooch in The Reliquary of January 1907, points out that the form of this class of brooch seems to have been suggested by a dolphin, a sea-horse, or some kind of nondescript dragonesque creature, and although the shape has been modified by successive copying and making the two ends symmetrical, the eye, which is the most prominent feature, has survived in nearly all cases.

The Lakenheath brooch was found on a skeleton, so there can be no doubt that it was buried as part of the personal ornaments of the dead. The bronze is well preserved, and the kind of ornamental forms introduced into the brooch can be seen precisely. The main outlines are in the form of broad, sweeping curves. At the terminations are curved trumpet-like expansions. In the open part of what may be called the thick part of the letter $S$ is a circular-pierced ornament ingeniously produced by a combination of two trumpet-shaped pieces. The pin by which the brooch was attached to the garment still remains in a practically perfect state of preservation.

The accompanying photograph shows the scheme of the ornament, which, it will be seen, is purely Late Celtic in character. The vigour of the whole design affords sufficient proof that we have here a charming piece of British jewellery in which no trace of Roman influence is to be found.

In later forms of $\mathbf{S}$-shaped brooches the ornament is more generally carried out in enamels of red, yellow, blue, \&c., rather than by beauty of form, as in the Lakenheath example. Some beautiful examples were found

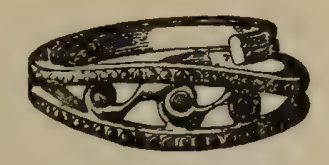

Bronze Finger-RING found NeAR MrLDENHALL (enlarged)

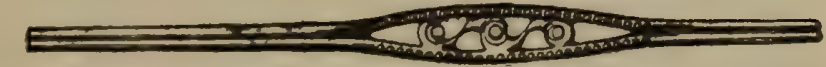

Diagram of Broize Ring Extended (full size)

\footnotetext{
- For these reasons it has been repeatedly figured as a pure type of Late Celtic art before there was any admixture of Roman influence.

${ }^{3}$ The writer is indebted to Mr. Fenton for permission to examine this brooch, and take the accompanying photograph.
} 


\section{A HISTORY OF SUFFOLK}

many years ago in the Victoria Cave, Settle, Yorkshire. In one of these, which represents a dragon, the eye is made of red enamel.

Other Early Iron-Age brooches found in Suffolk are now in the Museum of Archaeology at Cambridge.

Mr. Fenton also possesses a charming little bronze finger-ring displaying strong Celtic influence in the scroll-work, which ornaments and partially fills a longitudinal opening extending for about an inch. On either side of this opening there are lines of beaded ornament pointing, perhaps, to Roman influence. The Late Celtic scroll-work, however, is quite definite enough to prove its close relation to native British art. The ring is quite small and clearly intended for a lady. It was found in the neighbourhood of Mildenhall.

An interesting group of Early Iron-Age objects was discovered in 1854 , during the process of draining a field at Westhall, a Suffolk village situated about 3 miles north-east of Halesworth. Details of the discovery were communicated to the Society of Antiquaries of London by Mr. Henry Harrod, F.S.A., in 1855, and this paper, published in Arcbaeologia, ${ }^{6}$ is the authority for the following account :-

A farmer engaged in draining Millpost Field caused the trenches to be carried to a depth of between $2 \mathrm{ft}$. and $3 \mathrm{ft}$. below the surface, revealing a stiff, clayey soil. In the lowest part of the field, adjoining a water-course, it was observed that there was an area of about 2 acres of much darker soil than that of the other part of the field. This peculiarity was visible when the field was turned up by the plough, but when the drained trenches were cut, much burnt earth and many fragments of pottery were discovered.

Near the centre of this dark patch of earth, and about $2 \mathrm{ft}$. below the surface, the workmen came upon a number of bronze rings and other fragments, which the farmer gave to Mr. Hylton, a Norfolk farmer. The discovery led to the careful examination of the site, and upon digging over the surface with a spade it was found that throughout the blackened area the soil contained evidences of the action of fire to a depth below the surface varying from $\mathrm{Ift}$. $6 \mathrm{in}$. to $3 \mathrm{ft}$. The soil also contained much charcoal and very many fragments of broken pottery, all of the commonest and plainest kind, but in great variety. All the pottery was broken, but so abundant were the fragments that each spadeful of earth contained a dozen fragments of a dozen different urns. Mr. Harrod found a solitary fragment of a plain Samian patera, but he seems to have been convinced that all the rest was of 'Roman-British manufacture.'

The more important objects were contained in a bronze vessel, of which the bottom and part of the side remained. Over them was found a thin bronze plate or cover which was of ruder workmanship than the other

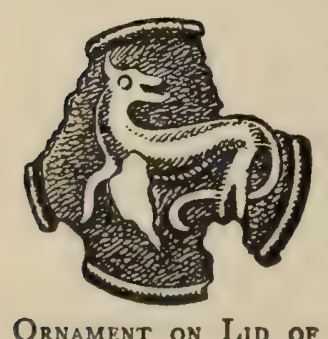

BronzB Box bronzes, and it had, in its centre, a circular plate or disc embossed with an animal recalling the forms found on the Late Celtic bucket from Aylesford. The cover itself, although considerably damaged, appears to have been ornamented with a species of elongated cross patée, between the limbs of which were conventional branches of palm, the whole inclosed in (I) a circle of oval projections arranged diametrically, and (2) five concentric

- See Boyd-Dawkins, Cave Hunting, 98.

s Op. cit. xxxvi, 454-6. 


$$
\begin{aligned}
& 0.9 \\
& 81
\end{aligned}
$$





\section{EARLY MAN}

raised ridges. The precise character of some of these ornamental features, which are somewhat complex, will be best understood from the accompanying drawing.

The objects contained in the case were of great importance, comprising the ornamental boss from the harness of a horse, and three rings, also associated with horse accoutrements, of bronze ornamented in dark-red enamel designs of late and rather debased Late Celtic forms. These three rings appear to have been suspended from a strap, or, like the modern terrets, may possibly have been fixed upright into the saddle. In ancient times, as at present, they seem to have been intended as guides and supports for the leather driving reins. The ornamental decoration of these rings or terrets comprises the characteristic curves and returning spirals of Late Celtic art, whilst in the case of the smallest example we have a debased representation of two fishes or dragons placed head to head.

In addition to the above pieces of horse trappings, or rather harnessfurniture, the deposit contained no less than six hollow bronze cylinders about $I \frac{8}{2}$ in. in length, three of them with the larger end open, and the others having a square aperture. The fourth

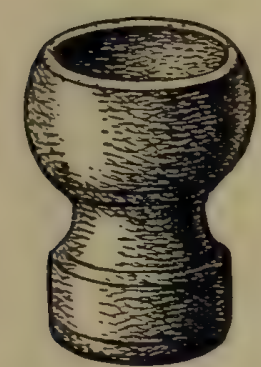

Bronze Cylinder FROM WESTHALL specimen was found in a damaged condition and containing a mass of iron. The fifth was blocked up with iron, and the sixth seemed to possess no square hole at all. These six objects were probably either the heads of linch-pins or the terminations of the axles of chariot wheels, probably of three different chariots. It is significant in view of this that there were three different 'terrets' or harness-rings found.

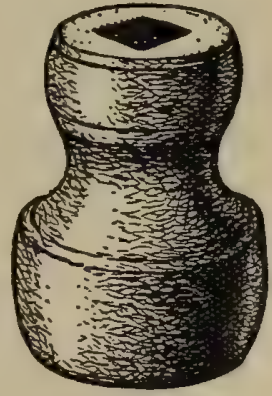

Bronze Cylinder FROM WESTHALL

Other objects in the find included some small pieces of bronze, one riveted over another, a small blue glass bead, a corroded brass coin, said to be of Faustina, and a typical Roman lamp of bronze.

The fact that these objects were found inclosed within a bronze case indicates that they were buried in the earth as a hoard for future use, but it does not preclude the possibility of several of the articles having been obtained from a chariot burial, which was a method of interment in use during the Early Iron Age, as is shown by the remains found in Yorkshire and other parts of England.

The great Fen district, which extended from the Wash for more than 60 miles to the south, was an important physical barrier which tended to isolate almost completely what are now known as Norfolk and Suffolk. This isolation of the eastern counties is illustrated in several ways. We see it, to some extent, reflected in the character of the antiquities, in the direction of the roads, and in the inscriptions on the coins.

The ancient British tribe of the Iceni appears to have inhabited the district on the eastern side of England now represented by the counties of Norfolk and Suffolk, and probably portions of adjacent counties. On some of the ancient British coins found in this part of the country the inscription ECEN Occurs, and this obviously refers to the name of the tribe. Even in the case of uninscribed coins from this district, certain well-marked peculiarities 


\section{A HISTORY OF SUFFOLK}

have been observed which distinguished them as the currency of an independent tribe. ${ }^{6}$

We have another interesting trace of this ancient British tribe in the name Icknield Street (anciently Icenhilde Weg), a road which, in pre-Roman as well as Roman times, connected the southern and central parts of the kingdom with the territory of the Iceni.

Tacitus and Ptolemy, among classical writers, described the Iceni under different designations, and furnish very little definite information as to the extent of the tribe, or the names of its princes or rulers; but here again we get a little light from such numismatic evidence as is available. The inscriptions ANTD and ANTED on ancient British coins are believed to be, contractions for Antedrigus, which, there is reason to suppose, was the name of a prince who originally ruled over the Iceni until the defeat of that tribe, about A.D. 50, by the Romans under the leadership of Ostorius. Coins bearing the inscriptions just given have been found in the west of Britain, and it seems probable that Antedrigus became a prince there, either over some remnant of his people who accompanied him in his flight to the west, or by election over a native British tribe in that district.

A map of England, marked in such a way as to show the distribution of the various types of ancient British coins, affords ample confirmation of the fact that the tribes inhabiting what was afterwards known as East Anglia were severed from the rest of Britain by something more than mere distance. The predominance of purely local coins over coins from other, but not very distant, districts is, however, shown more clearly in the contents of hoards found at Freckenham and Santon Downham.

In the former hoard about ninety coins of rather base gold were found in an earthen pot buried in the soil.

The Santon Downham hoard, which was found in 1869 , contained 109 coins. Of these twelve bore the inscription ECEN; nineteen the inscription ECE ; four the inscription AESV ; fourteen the inscription ANTED; twenty-nine did not show their legends; the same number (twenty-nine) were uninscribed; and two were coins of Roman date and make. The identity of the prince or other person or even town represented by the inscription AEsv has not been clearly determined. Sir John Evans suggested that it indicated either Asutagus, ${ }^{7}$ or else some British town of the Iceni. ${ }^{8} \quad$ But the preponderance of coins either (I) bearing legends which may be regarded as indicating the tribe and one of the princes of the Iceni, or (2) of types which are known to be characteristic of this district, is remarkable.

Numerous individual coins found separately in different parts of Suffolk may also be assigned to the Iceni, either on the ground of inscription or likeness of type. The precise localities are given in the topographical list at the end of this article.

One interesting coin was found at Newmarket bearing an inscription of Addedomaros, a prince whose dominions probably either joined those of Cunobelinus, or were included within them.

We should naturally expect to see in the ancient coinage of Suffolk definite traces of the influence of Cunobelinus, a powerful and famous ruler

Evans, Anct. Brit. Coins, 375.

${ }^{8}$ Anct. Brit. Coins, 386.

'Numis. Ghron. (new ser.), ix, 326. 


\section{EARLY MAN}

whom Shakespeare refers to under the familar Cymbeline. Cunobelinus, whose period probably extended from about 5 B.C. to about 43 A.D. was king of a large part of south-east Britain. His seat of government, probably, and the mint whence his gold coins emanated, were both at Colchester. The coins of this prince usually bear very brief inscriptions consisting of the abbreviations cvNo, CAMv, or other similar forms. CAMV is an abbreviation of Camulodunum, which had been originally a town of the Britons. This the Romans occupied, and in due course they extended the name to a Roman colony.

In Suffolk coins bearing the inscriptions of Cunobelinus have been found at Coddenham, Glemsford, Ipswich (2), Lawshall, and Melford (2).

Uninscribed coins of gold, silver, copper, and tin, of the Ancient British Period, have been found in various parts of the county, whilst at Icklingham a contemporary forgery was found in the shape of a silver-plated copper coin.

\section{Topographical List of Bronze-Age and Early Iron-Age Antiquities FOUND IN SUFFoLK}

Ampton.-Bronze-Age cinerary urn and incense cup, in the British Museum.

Bardwell (near Bury St. Edmund's). - Several tin coins found [Evans, Coins, 485].

BARROw.-Flanged bronze celt, ornamented with curved transverse ridges on the lower half of the

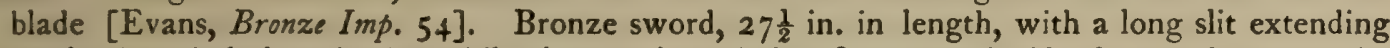
nearly the whole length of the hilt-plate, and ten holes, five on each side, for attachment to the hilt [Evans, Bronze Imp. 277]. Bronze leaf-shaped sword, in Bury St. Edmunds Museum.

Barton, Great.-Pile dwellings associated with Bronze-Age spear-heads, found in Barton Mere [Dawkins, Early Man in Britain, 352].

Becct.es.-Uninscribed copper coin with winged Pegasus [Evans, Coins, 479].

Blythвurgh.-Bronze socketed celt, in Bury St. Edmunds Museum.

Boyton.-Bronze-Age torque of gold fastened by means of a piece of ring-money, now in the British Museum [Arch. xxvi, 471].

BRANDON.-Bronze-Age drinking cup.

BROMESWELL.-Winged bronze celt, $6 \frac{1}{2} \mathrm{in}$. long [Evans, Bronze Imp. 90].

Buckiesham.-Uninscribed gold coin [Evans, Coins, 432].

Burnt Fen.-See Mildenhall.

Bury St. Edmunds.-Early Iron-Age pin [Brit. Mus. Guide to Early Iron Age Antiq. 147]. Ancient British gold coin inscribed with the name of Antedrigus [Evans, Coins, 490]. Coin of the Iceni [ibid. 583]. Several uninscribed silver coins [Evans, Coins, I13, I15, 353].

Buthey.-Hoard of nineteen bronze celts discovered about i 845 [Arch. xxxi, 496]. Bronze fibula, now in British Museum.

Clare (Poslingford Hall).-Hoard of bronze implements, \&cc. [Proc. Soc. Antiq. (Ser. 1), i, 83]. Also four ornamented bronze celts were found, and are now in the British Museum. Four flanged celts, found at Poslingford, are in Bury St. Edmunds Museum.

Coddenham.-Coin of Cunobelinus [Evans, Coins, 342].

Elveden. - Late Celtic antiquities found here, see pp. 270-I.

ERISWelL. - Two bronze celts, in British Museum; three bronze celts, in Bury St. Edmunds Museum. Two Late Celtic bronze brooches, now in the possession of Mr. W. C. Wells.

ExNing.-Plain bronze celt, bronze pins, twisted armlet, armillae, jet armillae, bronze buckles, bronze penannular armillae, and bronze ornament, all now in the British Museum. Hoard containing some objects of the Bronze Age [Arch. Fourn. ix, 303; x, 3].

Eyr: ABbey FARM. - British burial-ground (probably of the Bronze Age) [W. Bury and Suff. Trans. ii, 117 ; Gent. Mag. Aug. 1818, p. 132].

Felixstowe.-Hoard of Bronze-Age antiquities [Proc. Soc. Antiq. Lond. xi, 8-12]. Bronze-Age implements, now in Norwich Museum.

Fornham.- Socketed bronze celt, the aperture or socket approaching a square form. The sides have interesting ornamentation [Evans, Bronze Imp. 122]. Silver British coin of the Iceni [Evans, Coins, 587].

Framuingham.-Bronze palstave. 


\section{A HISTORY OF SUFFOLK}

Freckenham.-Hoard of ninety coins of rather base gold [Evans, Coins, 578]. Gold British coins attributed to the Iceni [Evans, Coins, 578, 579, 580, $58 \mathrm{r}, 5^{8} 3$ ].

Glemsford.-Coin of Cunobelinus [Evans, Coins, 559].

Hintlesham.-Bronze tanged spear-head, or dagger-blade, now in the British Museum.

Honington.-Bronze palstave with interesting ornamentation [Evans, Bronze Imp. 91].

Icklingham.-Bronze-Age spear-head and drinking-cup in Bury St. Edmunds Museum. Numerous other Bronze-Age antiquities are now in the Museum of Archaeology at Cambridge. Numerous coins of the Iceni and of Cunobelinus, \&c. [Evans, Coins, I1 8, \&c.]. The late Mr. Romilly Allen also recorded the discovery of a late Celtic bronze sword-sheath [Arch. Camb. (Ser. 5), xiii, 327]. In the River Lark, near this place, was found a leaf-shaped BronzeAge sword [Evans, Bronze Imp. 282].

IPSWICH.- Two rings and portions of semi-cylindrical cauldron, and beaded brackets through which they passed, now in the Ipswich (Christchurch Park) Museum [Evans, Bronze Imp. 411]. Coin of Addedomaros and others of Cunobelinus and of the Iceni [Evans, Coins 374, \&c.].

Ixworth.-Several ancient British coins, including those of Cunobelinus, the Iceni, \& $\mathrm{rc}$. [Evans, Coins, 316, 321, 397, 398, 433]. Coin of Cunobelinus [W. Bury and Suff. Trans. i, 75].

LAKEnhEATH. - In the collection of the late Sir John Evans there are several important Bronze-Age antiquities found at Lakenheath [See Evans, Bronze Imp. 80, I25, 320, 322, 330]. Bronze socketed celt, now in the British Museum. Palstaves, socketed celts, rapier-blade, \&c.; of bronze, in the Museum at Bury St. Edmunds and the Museum of Archaeology at Cambridge. Bronze S-shaped brooch of late Celtic design, also small bronze socketed axe of Italian (?) work, in the collection of Mr. S. G. Fenton; and bronze rings (Late Celtic) in the possession of Mr. W. C. Wells. At Undley, in this parish, was found a socketed gouge of bronze, of unusual length, measuring nearly 6 in. [Evans, Bronze Imp. 175].

LARK (River).-See IcKLIngham.

Lawshall.-Gold coin of Cunobelinus [Evans, Coins, 298].

Lound.-Traces of what are believed to have been lake dwellings have been found here [E. Anglian (new ser.), ii, 1111$]$.

MarTlesham.-Hoard of bronze objects, including socketed celt, gouge, knife, and a large quantity of lumps of copper [Evans, Bronze Imp. I I 9, 129, I 74, 206, 424]. There are certain Bronze-Age antiquities from Martlesham in Norwich Museum.

Merford, Long.-Ancient British coins of Cunobelinus [Evans, Coins, 569, 572].

Mettingham.-Bronze palstave, now in the Museum of Archaeology at Cambridge.

Mildenhall. -Numerous Bronze-Age antiquities in bronze [Evans, Bronze Imp. 46, 78, 127, 306]. Iron bill, or chopper, possibly of the Early Iron Age, found here and now in the possession of Mr. S. G. Fenton. Beautiful bronze finger-ring of late Celtic design, in collection of Mr. S. G. Fenton. Silver and gold coins of the Iceni [Evans, Coins, 397, 58r]. Coarse cylindrical object of pottery (late Celtic), now in the British Museum. Other Bronze-Age antiquities are in the Museum of Archaeology at Cambridge. At Burnt Fen, in this parish, were found two bronze celts, now in the British Museum.

NeEdham Market.-Bronze-Age 'drinking cup,' now in the British Museum.

Newmarket.-British coin of Addedomaros [Evans, Coins, 577]. Bronze socketed spear-head [Proc. Bury and W. Suff. Arch. Inst. x, I69].

Pakenham.- Silver coins of the Iceni [Evans, Coins, 397, 586].

Poslingford Hall. - See Clark.

Santon Downham. - Important hoard of 109 Ancient British coins, some being those of the Iceni [Numis. Chron. (new ser.), ix, 326].

SNAPE. - Bronze-Age cinerary urn, 15 in. high, found in tumulus on Snape Common near Anglo-Saxon remains [Proc. Soc. Antiq. (2nd Ser.), ii, I 79].

STOKE.-Uninscribed gold coin [Evans, Coins, 50].

Stoke Ash.-British (Bronze Age?) cinerary urn [W. Bury and Suff. Trans, ii, ror].

Suffolk.-Bronze celts (locality not stated) [W. Bury and Suff. Trans. ii, 204]. The late Sir John Evans had in his collection a flanged bronze celt from some unknown locality in Suffolk [Evans, Bronze Imp. 48].

SuTron.-Long chisel-like palstave of bronze, and bronze looped palstaves [Evans, Bronze Imp. 84, 87]. Bronze-Age urn, now in the British Museum.

TheTford.-Socketed Bronze-Age celt and spear-head with two loops [Evans, Bronze Imp. 123, $321]$.

THORndon.-Important hoard of Bronze-Age antiquities [Arch. Fourn. x, 3]. Bronze socketed dagger, spear-head, gouge, socketed hammer, and bradawl, now in the British Museum. Bronze. Age cinerary urn, now in Bury St. Edmunds Museum. 


\section{EARLY MAN}

ThuRston.-Six annular and two pennanular bronze bracelets e igraved with diagonal and curved lines. Now in possession of the Mr. W. C. Wells.

Troston Heath. - Bronze-Age 'food-vessel,' now in the British Museum.

Tuddenham.-Bronze-Age 'drinking cup,' now in the British Museum. Bronze-Age implements in the Museum of Archaeology at Cambridge.

UbBeston.-Bronze palstaves, with vertical ribs on blades [Evans, Bronze Imp. 93].

UNDLEY.-See LAKENHEATH.

WaLdRINGFIELD, - Uninscribed gold British coin [Evans, Coins, 60]. Small lanceolate bronze object, possibly a javelin-head; now in the possession of Mr. W. C. Wells.

W ANGFORD.-Silver coin of the Iceni, bearing the representation of an animal resembling a boar [Evans, Coins, 398].

Westhall.-A hoard containing several important Early Iron-Age antiquities found here (and now in the British Museum), including bronze bridle ornaments and other objects; also bronze lamp, mirror, embossed plates, fragments of bowl and cylindrical vessel, Roman coin, flint pebble, and fragments of Samian ware and flue-tiles.

WestleY.-Bronze-Age cinerary urn, now in Bury St. Edmunds Museum.

WetheringsetT. - Leaf-shaped Bronze-Age sword found $14 \mathrm{ft}$. deep in clay. There is a long slot in the hilt-plate [Evans, Bronze Imp. 274, 282].

Wissetr.-Bronze celt [Arch. Inst. Norw. vol. (1 847 ) xxiv].

Woolpit.-Socketed spear-head, or lance-head [Evans, Bronze Imp. 328]. Clay amulets (prehistoric ?) in Bury St. Edmunds Museum. Bronze sword-blade [Arch. Inst. Norw. vol. (1847) xxvi].

Worlington,-Bronze-Age 'drinking cup,' now in the British Museum. 




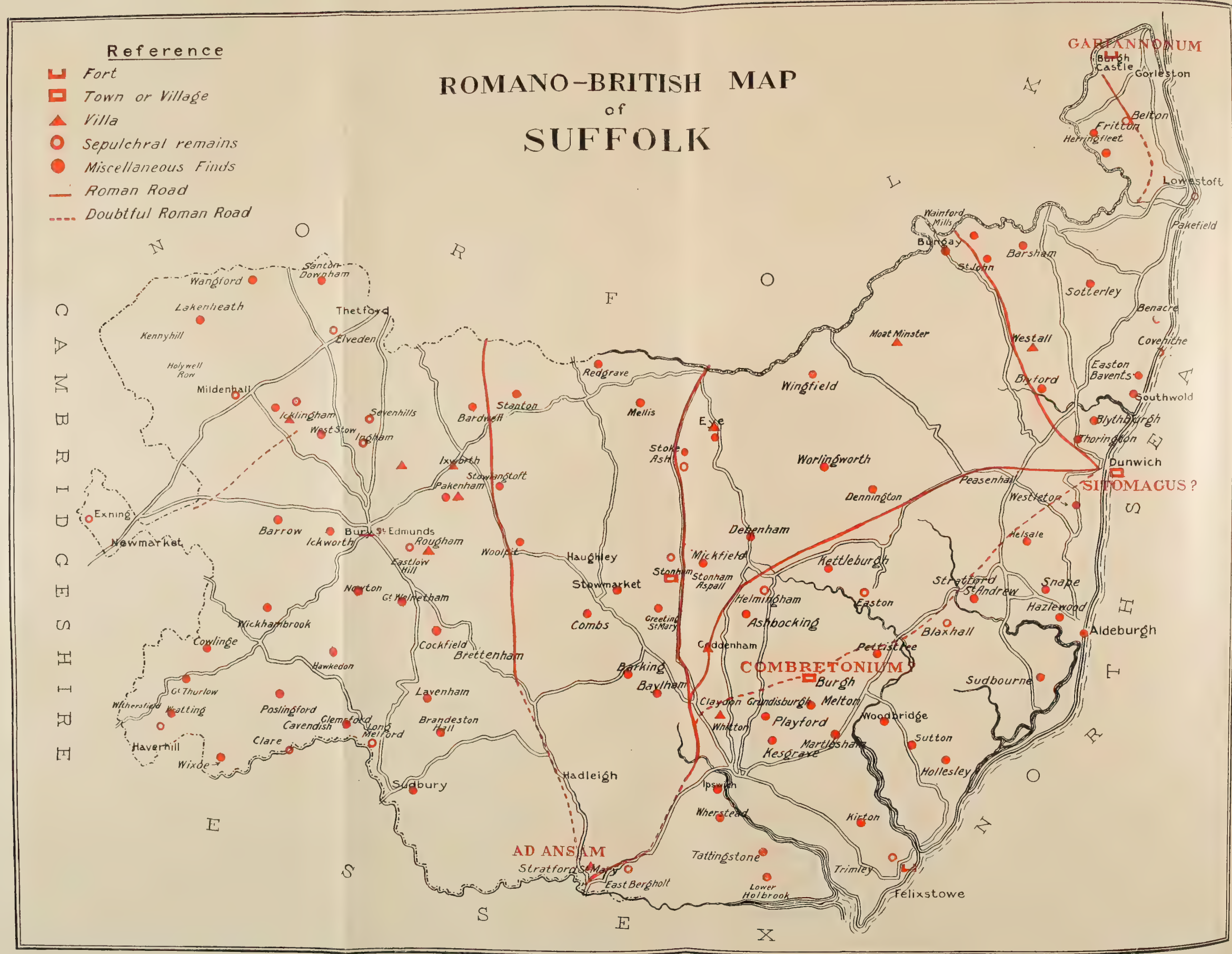




\section{ROMANO-BRITISH SUFFOLK}

70 give any idea of what the district which we now name Suffolk was like in the Roman period it will be useless to have recourse to the pages of ancient writers, for only one recorded event, the great revolt against Rome under Boadicea, Queen of the Iceni, can in any way be connected with the land with which we are dealing. Its inhabitants suffered doubtless in the struggle, and more so from the vengeance of the conquerors, which may have resulted in deserted homesteads and untilled fields for many years. One other event deducible from an ancient document which left a more permanent mark here than any consequences of the great rebellion was the erection on the coast of Suffolk of certainly one, and almost certainly two, of the fortresses called 'the forts of the Saxon Shore,' from the fact of their having been built to defend the east coast from the attacks of the Saxon sea-rovers, which during the decline of the Roman power towards the end of the 3 rd century had become intolerable. We shall have more to say on this subject when the remains of these fortresses are examined.

In default of anything like history we have a source from which we can at least make out some picture of the lives of those who lived on the soil of Suffolk during the ages of Roman dominion. This, as Dr. Raven well says, ' is the great unwieldy mass of unwritten testimony: coins, and medals, pottery, traces of domestic life and colonization, roads and forts, arguments fairly deducible from the soil and the set of the country, etc.' Into this mass we propose to penetrate and give the results of such researches.

The county of Suffolk lies for the most part compactly within natural boundaries. On the north the Waveney and the Little Ouse divide it from Norfolk, and on the south the Stour through all its length parts it from Essex. The little streams of the Lark and the Linnet help to separate it from Cambridgeshire and the fens, whilst the German Ocean for ever gnaws away its eastern side and chokes its river mouths with shifting sands. All its principal rivers fall into the North Sea, and three of them are distinguished by one peculiarity in common, which had a decided influence on the choice of position of the sea fortresses at Burgh near Yarmouth (Gariannonum) and Walton. The peculiarity in question is that on approaching the coast the rivers do not discharge themselves directly into the sea, but at no great distance from the beach they make a turn to the south and pursue a course for miles in a direction roughly parallel with the shore line, before falling into the ocean. This is the case

'See the Notitia Dignitatum, 'an official directory and army list' probably made up in the early years of the 5 th century. 


\section{A HISTORY OF SUFFOLK}

with the Waveney and its associated Norfolk rivers, and was formerly so with the Blyth, which has been led by a direct cut into the sea. The Alde, or Or, which bears the latter name in its lower half, is more decided in the strangeness of its wanderings. It makes for the sea till just behind Aldeburgh, where it expands into a considerable sheet of water, from the eastern end of which it takes a southern direction not far from, and sometimes quite close to, the shore, and so continues for about ro miles before it finally falls into the ocean. The next river travelling south, the Deben, has a direct exit, but the waves are gradually heaping up the sands at its mouth, and so forcing the current downwards till in time it will no doubt resemble its sisters. The same on a much larger scale may be said of the estuaries of the Stour and the Orwell in their devious courses. These rivers are accompanied by belts of marsh land, which have behind them extensive heaths, a very paradise of the bee when the heather and the gorse are in bloom. The tract altogether forms a wide belt on this eastern side of the county which may be distinguished under the title of 'the light lands.' Probably, although a greater and more careful cultivation has altered somewhat its general conditions, it retains much of the aspect it wore in Roman times, when it must have been a district not of agriculturists, but of hunters and fishers. The marshes of the east coast are matched by the fen land on the west side of the county, and the country about Brandon and Thetford on the north repeats the light lands of the east coast. A larger and more settled population of natives or colonists occupied the fertile wheat-producing portions of the more central area. They may have contributed by their industry to the export of grain from Britain of which we hear in the later Roman period. There was only one port on the coast, and as to its identity there are some doubts. Some antiquaries call Dunwich -or rather the town of that name now beneath the waves of the North Seathe ancient Sitomagus. Supposing them to be right, then the grain ships for the Continent were probably loaded along its quays; but if not, the road, certainly Roman, through central Suffolk would be used by long trains of wagons loaded with corn toiling southward to Camulodunum, where the empty ships ready for their arrival lay along the wharfs by the Colne. But leaving conjecture there can be no question that traces of the inhabitants of the Roman period are dotted all over Suffolk, and it will be our task to point them out, or at least the most prominent of them, in the following pages.

The Roman antiquities of the county, for the sake of clearness, will be best described under two heads, viz. Military and Civil. The first section is by far the more important, as it touches the subject of the defence of the east coast from invasion.

\section{Remains of Military Occupation}

Referring to the Ordnance Survey maps, there will be noticed many places marked 'camp' or 'camp field,'" and others, 'rectangular inclosure formed by moats,' some with, some without banks of earth on the inner side, most of which are usually erroneously referred to the Roman period.

\footnotetext{
'Consult the New Engl. Dict. edited by J. A. K. Murray, vol, ii, C, where is found the following : 'Camper (obs. or dial.), a player at Camp or football,' and quotes '1573 'Tusser, Husb. (1878) 60,' Get 'Campers a ball to Camp therewithall,' and 'In medow or pasture to growe the more fine, Let Campers be camping in any of thine."
} 


\section{ROMANO-BRITISH SUFFOLK}

Some county histories vouch for the existence of an inclosure at a quarter of a mile north-west of the village of Stratford St. Mary. This is an important point, for it is fairly certain that a Roman road from Colchester passes the Stour at this point, going northwards. Nothing seems to have been found in the inclosure, but cinerary urns have been dug up in the parish. From its distance from the ford it is scarcely likely to have had any military character about it; but, if Roman at all, one is tempted to see a farmstead, fortified in troublous times, perhaps the last quarter of the $3^{\text {rd }}$ century, sufficiently to resist any sudden attack from the sea-rovers who by chance might ascend the river. ${ }^{3}$

Another quadrangular inclosure of similar kind is to be found at South Elmham. Within the bank this measures about 4 acres, and it contains the ruins of a Saxon church called 'the Old Minster.' Fragments of Roman brick, and it is said even of flue tiles, were used up as material in the building of the church. It may possibly be that a Roman homestead of some consequence stood originally on the site, and that the bank and ditch had been drawn round it for protection in the later years of the Roman occupation, whilst, at a later period still, the ruins of the house and its dependencies served as a quarry in building the church whose remains are still to be seen. There are great discrepancies in the accounts given of this site by antiquaries. One (Suckling) speaks of 'urns with burnt bones and ashes' having been ploughed up frequently within the inclosure; another (Woodward) states 'that though the Minster Yard (the inclosure in question) has been cultivated by all the most approved methods of modern husbandry, ploughed, subsoiled, and even drained; although the moat has been searched and cleared ... no traces of anything that could be called antique has been found.'

There is no need to give here any description of various vague traces of banks and ditches which have been called Roman, as they will be dealt with at sufficient length in the Topographical Index to this article and in the section upon earthworks.

Burgh near Woodbridge. - The twilight becomes less obscure as we come to the next site to be described, one which shows plain marks of Roman occupation. This is at Burgh near Woodbridge. Dr. Raven, ${ }^{4}$ whose studies on Roman roads in East Anglia are well known, sees at Burgh a fortified post, and considers it to be the Combretonium of the IXth Iter of Antonine. The aspect of the site might bear out this supposition. In fields gently sloping to low land through which flows a little stream, and close beside the road from Woodbridge, lie the scarcely distinguishable lines of a mound and fosse, forming a quadrangular inclosure whose dimensions may be guessed approximately at $800 \mathrm{ft}$. by $500 \mathrm{ft}$., although nothing but careful excavation and measurement could ascertain its exact size. The greatest length of this inclosure is from north-west to south-east. The eastern end is traversed by a considerable depression or valley running to the low ground, down which a road called 'Drabs Lane' has been carried to meet that from Woodbridge. Near the angle where the two ways join are

' Such a protected farmstead has presumably been found at Cwmbrwyn in Carmarthenshire; see Arcb. Cambr. Apr. 1907.

- Raven, Hist. of Saff. (1895), 30 et seq. 


\section{A HISTORY OF SUFFOLK}

situated the church and churchyard of Burgh, placed astride the centre of the south-west side of the inclosure. The north-east angle of the entrenchment can still be made out, and perhaps that of the north-west also. The line of fosse and bank of the south-east end is fairly visible, and crowns the slope of the valley down which runs Drabs Lane. All the ploughed land within the vague lines of this inclosure shows fragments of Roman brick and roof tiles, and in the field in which stands the church red-tile tesserae have been picked up, a sure sign of the former existence of Roman buildings. Excavations were made in November 1900 by Mr. Walter Brooke and Mr. E. St. F. Moore. The objects found are now in the Ipswich Museum.

Here again we may perhaps see something similar to the two moated inclosures previously mentioned. It may be conjectured that some extensive homestead was hastily fortified against the too probable attacks of the Teutonic sea-rovers from the neighbouring ocean, or it may not be impossible that a small congregation of houses within the inclosing banks may have formed the much-disputed site of Combretonium.

Burgh Castle.-We emerge into clear daylight when the next two stations and the last to be noted are reached, viz. those of Burgh Castle near Yarmouth and Walton near Felixstowe, of which the latter is now submerged beneath the waters of the North Sea. But before describing these stations something must be said as to the causes of their origin.

By the last quarter of the $3^{\text {rd }}$ century the Romano-British fleet, on which no doubt dependence had been placed for the protection of the east and south coasts from raids by plundering bands of rovers from over the seas, had evidently failed to afford that protection. Whether it was that the fleet was not numerous enough or for whatever reason, the Roman government determined to supplement its first line of defence by a second, and this was achieved by the erection of forts capable of holding from 500 to I,000 men each, on points of the coast-line extending from the mouth of the Wash to Pevensey on the coast of Sussex. The coast-line indicated received the name of Litus Saxonicum, and the nine fortresses which guarded it are called 'the forts of the Saxon Shore.'

The repeated attacks on the east coast by the Danes and Northmen at a time later than the Roman period show with sufficient clearness the plan adopted by them in their raids, and from it we may easily deduce that their predecessors the Angles and Saxons were their masters in the art of invasion. Their endeavour was to enter the rivers and by so doing to recch an inner and more populous region to plunder rather than to ravage the coast. The way to check the carrying out of this plan was to place a sufficient guard over the mouths of such rivers as might appear to offer too easy an access to the better inhabited districts, and there is strong presumption that this was what was attempted by placing these Roman forts in the positions they occupied. In nearly every instance, but in none so plainly as at Burgh Castle, are they placed on or near the mouths of important rivers. We shall see how the two forts in question will fall in with the view put forward. A consultation of the map (plan I) will show that at the extreme north-east corner of the county lies a sheet of water called Breydon Water, which forms at this point the limit of the county. Into the western end of Breydon flow two rivers, the Waveney and the Yare; another, the Bure, a Norfolk river, 


\section{ROMANO-BRITISH SUFFOLK}

flowing into it on the north. Of these the Waveney makes a great bow or curve from north to south a little above its mouth in Breydon, and then, changing its direction, proceeds westward. Breydon is practically landlocked, for the access to the sea of its waters and those of the rivers entering it is now only by a channel 2 miles long to the south of the town of Yarmouth.

This has probably always existed, but the chief outfall of the rivers was at another point, and one of more importance. In Roman times, and for countless ages previously, the tides rushed in and out of Breydon through a great opening in the huge sand bank on which Yarmouth came to be built in the I Ith century. This gap, through which the Norfolk and Suffolk rivers flowed to the sea, in course of ages became blocked by shifting sands, and by the time of Elizabeth had become entirely effaced. In the Middle Ages it was known by the euphonious name of Grubbs Haven, and its position lay between the north end of Yarmouth and

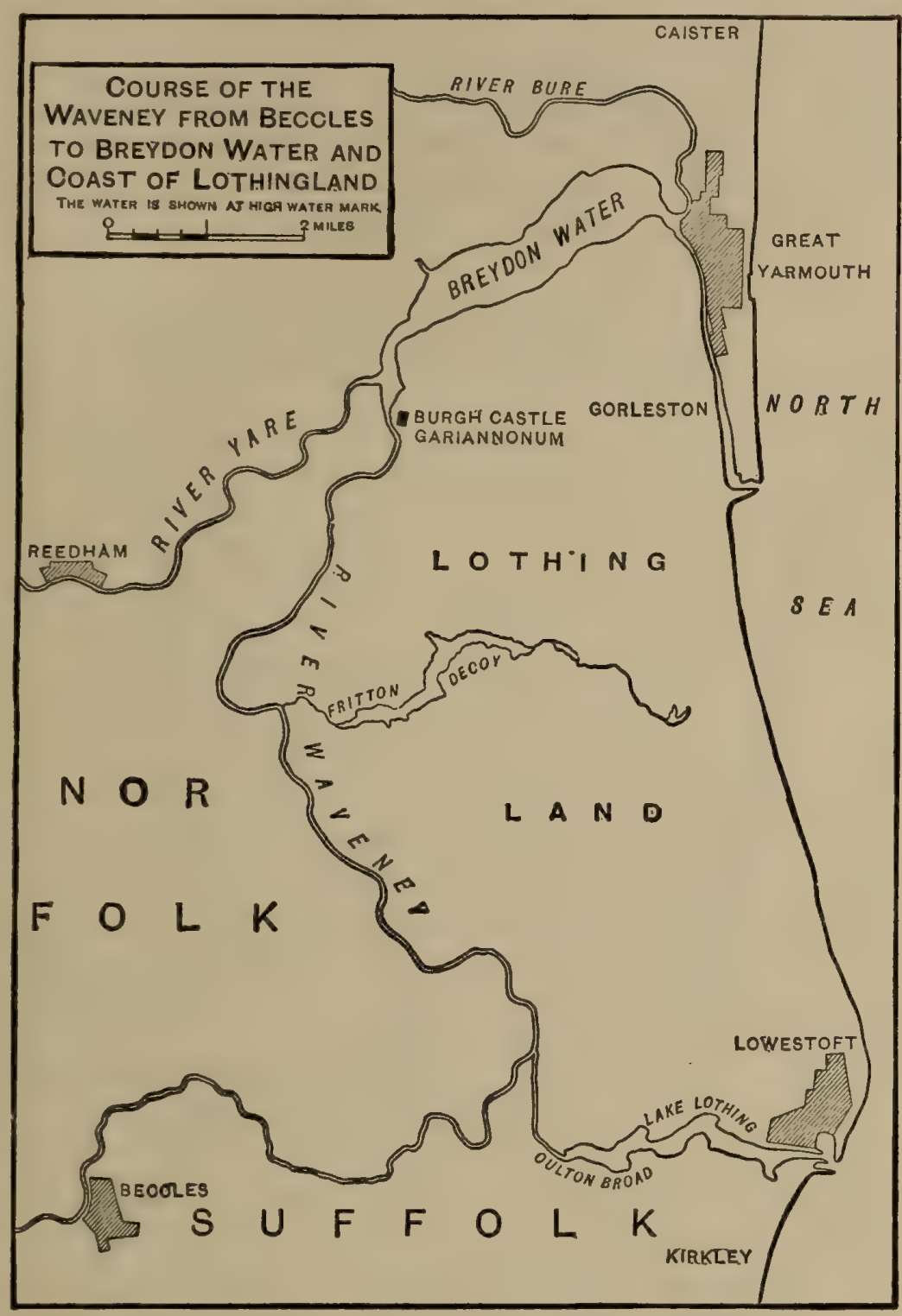

Plan I.-Plan showing Position of Burgh Castle a spot still farther north called Caister. Close to this village was certainly a small Roman settlement which may well have overlooked the passage of the sea into Breydon. It is now covered by the Yarmouth Water Company's waterworks.

One other point must be mentioned, as it affects the position of the camp at Burgh. At Lowestoft, as will be seen by reference to the map (plan I), there is a communication between the sea and the Waveney, first by a sheet of water called Lake Lothing, and further by a broad called Oulton Broad, whence a long channel runs west and north to the Waveney. Much of this waterway, however, is artificial and modern. The definite junction 


\section{A HISTORY OF SUFFOLK}

of Lake Lothing with the sea was effected when the harbour at Lowestoft was formed; before that the narrow strip of land between the two waters was breached and filled and breached and filled again and again, and the connexion too between Lake Lothing and Oulton Broad seems to have been uncertain. That there was any way at all practicable for vessels along this line in Roman times cannot be believed, as it would have rendered the fortress useless, by allowing an entrance to the river far above it. The south bank of Breydon, unlike its other margins, was not marshy, and fairly high land can be traced along its full extent. Towards the north of the Waveney it rises somewhat, and at the spot chosen for the fortress of Gariannonum (Burgh Castle) ${ }^{5}$ it presents a high bank to the west with a

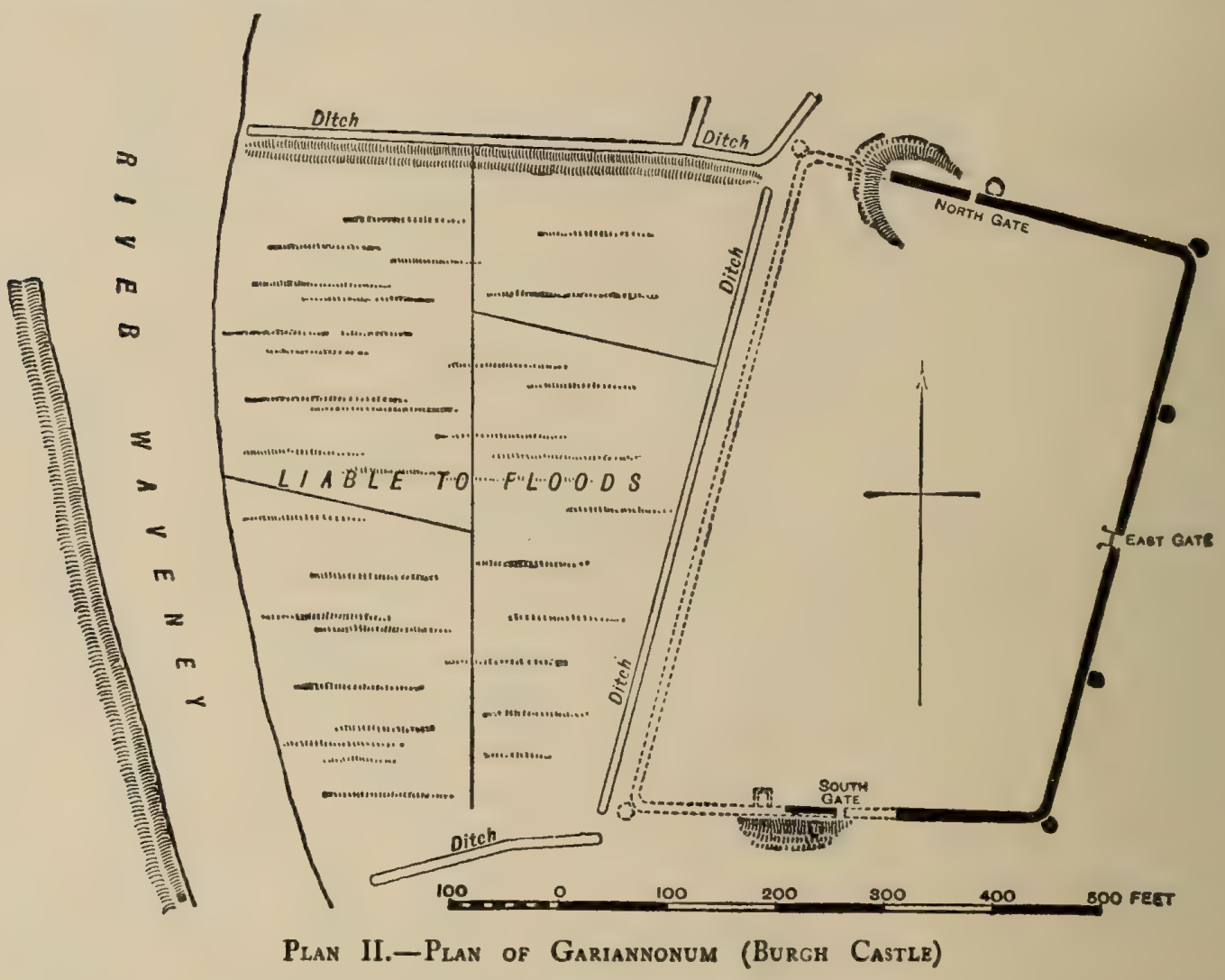

steep incline to the river, which flows at its foot with a broad strip of marsh intervening (plan II).

Like all Roman fortresses, at least in this country, all that remain above ground are the walls of enceinte surrounding a space of quadrangular shape, in this instance roughly $640 \mathrm{ft}$. long by $4 \mathrm{r} 3 \mathrm{ft}$. wide. The thickness of the walls is $9 \mathrm{ft}$., with a foundation $\mathrm{I} 2 \mathrm{ft}$. thick; each angle is rounded and is buttressed by a solid round bastion. Two other bastions occur on the east side, and one each on the north and south sides, these not being in the centre of each side, but rather west of it. Each of the bastions has a hole in the top $2 \mathrm{ft}$. deep by $2 \mathrm{ft}$. in diameter, possible indications of some sort of turntable on which a small ballista could be planted. There is another peculiarity respecting them. From their bases for $7 \mathrm{ft}$. up they are not bonded into the wall, but from that point for the rest of the height, originally

- Norf. Arch. 1 859, v, 126 et seq. 


\section{ROMANO-BRITISH SUFFOLK}

no doubt from $16 \mathrm{ft}$. to $20 \mathrm{ft}$., they form one mass with it. It seems probable that the builders decided on the additional defences when they had partly carried up their wall, and that the bastions were then added, their upper portion becoming one with the wall behind them. The wall and bastions were of the usual construction for such work, a core of rubble with a facing of faced flints (in this case) with, at short intervals, lacing courses of brick. Occasionally the mortar appears coloured with brick-dust, which is used capriciously, and it is doubtful if there was any particular reason for its use.

The greater portion of the area of the fortress was on high level ground, but west of the gates in the north and south walls it sloped rather steeply, as has been said, to the river. The walls named were carried down this slope to join the west wall, which adjoined the river whose waters perhaps then ran nearer this wall than at present. Of this wall nothing is visible. The remains of its foundations were however uncovered in 1859 by that able antiquary the late Henry Harrod, and the existence of a wall similar to the others sufficiently proved. ${ }^{6}$ It was pushed as far forward towards the river as the marsh would allow. How it disappeared is clear enough, for it was used as a quarry, being easy to get at, during the Middle Ages. Tiles from it may be found in the fabric of the church at Reedham on the Yare, not more than two miles from Burgh, and no doubt in other places.

The south wall of the fortress will be seen by a reference to the plan (plan II) to be at an obtuse angle with the east one. This looks like an intention to get the south-west angle of the inclosure as near the river bank as possible. The distance between the banks at this south-west corner is roughly $330 \mathrm{ft}$., at the corresponding north-west angle it may be $600 \mathrm{ft}$. The distances here named are by no means beyond those attainable by the darts of the larger ballistae used by the Romans in the field, and there is nothing improbable in supposing that such ballistae might have been planted on platforms backing the river wall, of such power as effectually to command the passage of the river opposite the fortress. ${ }^{?}$

The gates are three in number, as has been said, but of the south gate only a trace remains. Those in the north and south walls were only $5 \mathrm{ft}$. wide and offer no peculiarities of construction. The eastern gate, the principal one, in the centre of the eastern wall, is commanded by bastions on either side. In a line with the inside face of the wall across the gateway a trench was found in the soil 15 in. wide, a clear indication of the former existence of a timber threshold. Inside the gate on either hand were the remains of a low wall with a return at a distance of $10 \mathrm{ft} .7$ in. from the threshold. It is possible these were vestiges of the walls of the guard-houses. The gateway was no doubt a single arch, the rampart walk passing over it, and it was c'osed by a door of two valves in the usual fashion.

As in other fortresses of the same date there seems little trace of any ditch. Along the east front there is no sign of such a feature. Some signs of this

- See Norf. Arch. $1859, v, 146$ et seq.

'See for such a platform an inscription in Corpus Inscr. Brit. Latinae, vii, no. 1045. The French have made experiments as to these engines. In one of the halls of the Musée des Antiquités Nationales de St. Germain near Paris may be seen full-size working models of ballistae of several sizes, restorations made from the plans of General de Reffye. All are presumably for use in the field, and the largest can throw a dart, according to the weight, for a distance from 150 to 310 metres. Larger and more powerful engines of the sort might have carried bolts with effect to still greater distances than those named. 


\section{A HISTORY OF SUFFOLK}

defence appear on the north and south sides, but they are more like natural depressions of the ground than artificial excavations.

The walls do not appear to have been backed by any mound, though Harrod, who thoroughly knew the ground, considers there was one. It would unquestionably have strengthened the defences; but its existence must remain an open question. At other fortresses of late date, Richborough and Pevensey, there is no mound, which is a frequent feature of earlier fortifications (Ist and 2 nd centuries), but with these latter the scheme of defence differs from that adopted for the forts of the Saxon Shore. Unhappily there is but little chance of making further discoveries in the inclosed area, as the ground has been dug over for gravel and clay for many years, and the greater part of the central space has been carried away. No excavations would now reveal traces of the officers' quarters; the barracks for the men, the granaries, the stables, the treasury, or the shrine for the standards, all are gone without any record except perhaps one slight trace of the baths. Ives, a writer of the I 8 th century, describing the ruins in his day speaks of a mound within the walls near the south gate, apparently of considerable size. By the time of Harrod's explorations so much digging appears to have been done hereabouts that a doubt exists as to the existence of this hill. However, Harrod cut a trench across what remained of it, and at a pcint some distance to the west of where the south gate of the station formerly stood came upon the foundations of a small chamber, the south side of which was formed by the wall of the station. It was $16 \mathrm{ft}$. 6 in. square, and had along its south side a flue formed of flanged tiles with some indication of a furnace outside at the southeast corner. One fragment of the west wall remained with signs of plastering upon it, and there was nothing further to be discovered. It is quite possible that the chamber was one forming part of the baths of the station.

The cemetery of the fortress, which has never been properly explored, is supposed to have occupied the field outside the eastern wall. Out of three or four cinerary urns said to have come from Burgh two figured by Ives are distinctly Anglian. There is little more to be said of finds. In levelling part of the hill about 1770 Ives reported the uncovering of a stratum of quantities of ashes and broken vases and a silver spoon, just the contents of a dust heap. ${ }^{8}$ It must be noted that the coins turned up are mostly those of the later emperors.

One or two other matters require attention before quitting the neighbourhood of Gariannonum. If this fortress was intended, as conjectured with very good reason, to have been built where it stands for the purpose of closing the waterway of the Waveney, it seems impossible that the sister river close by could have been left with no defence. Roman remains have been found at Reedham, 2 miles up the Yare from Breydon, which might indicate a small post for watching and signalling purposes. On a hill close to the river (the Yare) mounds showed an inclosure, and the foundations of a tower were discovered, a tower from which signals could be transmitted to the big station beside the Waveney, ${ }^{9}$ for it must not be overlooked that the course of the Yare, though of less importance, required watching as well as the Waveney,

${ }^{8}$ Ives, Garian. (2nd ed.), 1803.

${ }^{9}$ Norf. Arch. iv $(1855), 3 \mathbf{I}^{-1}$. The mounds mentioned have long since vanished, with anything that stood on or by them carted away for gravel. 


\section{ROMANO-BRITISH SUFFOLK}

There might also be a look-out and signalling station at Caister, north of Yarmouth, where Roman remains have been found. From it there would be a wide view both over the North Sea and the passage into Breydon. Nor must we forget the fleet. To be of any service there must have been a certain number of vessels for the defence of the coast and harbours near each station, and Breydon offered a good anchorage for Gariannonum. From : he Notitia Dignitatum, compiled it is believed in the $5^{\text {th }}$ century, it appea $s$ that the fortress was garrisoned by a body of cavalry, the Stablesian Horse. The land for many miles south of the station was flat and in places high above the sea, and well adapted for any work cavalry would have to do ; an $\downarrow$ from this point on the Waveney as far as Dunwich a Roman port, presumably walled, could be easily patrolled when necessity arose. ${ }^{10}$

Walton.-Travelling southward, at the south corner of the county and upon its coast line (plan III) will be found the companion fortress to the one just described. But before giving any account of what is known of it the district which it was erected to guard must be noticed, or the reason for the need of its existence will not be apparent.

At this southern corner of Suffolk there are three waterways, two of which penetrate far into the land. The first and most easterly, the Deben, so called from the little stream which flows into it, runs up as far as Woodbridge, and a short distance beyond this town is Burgh, already mentioned. Farther south come the estuaries of the Orwell and the

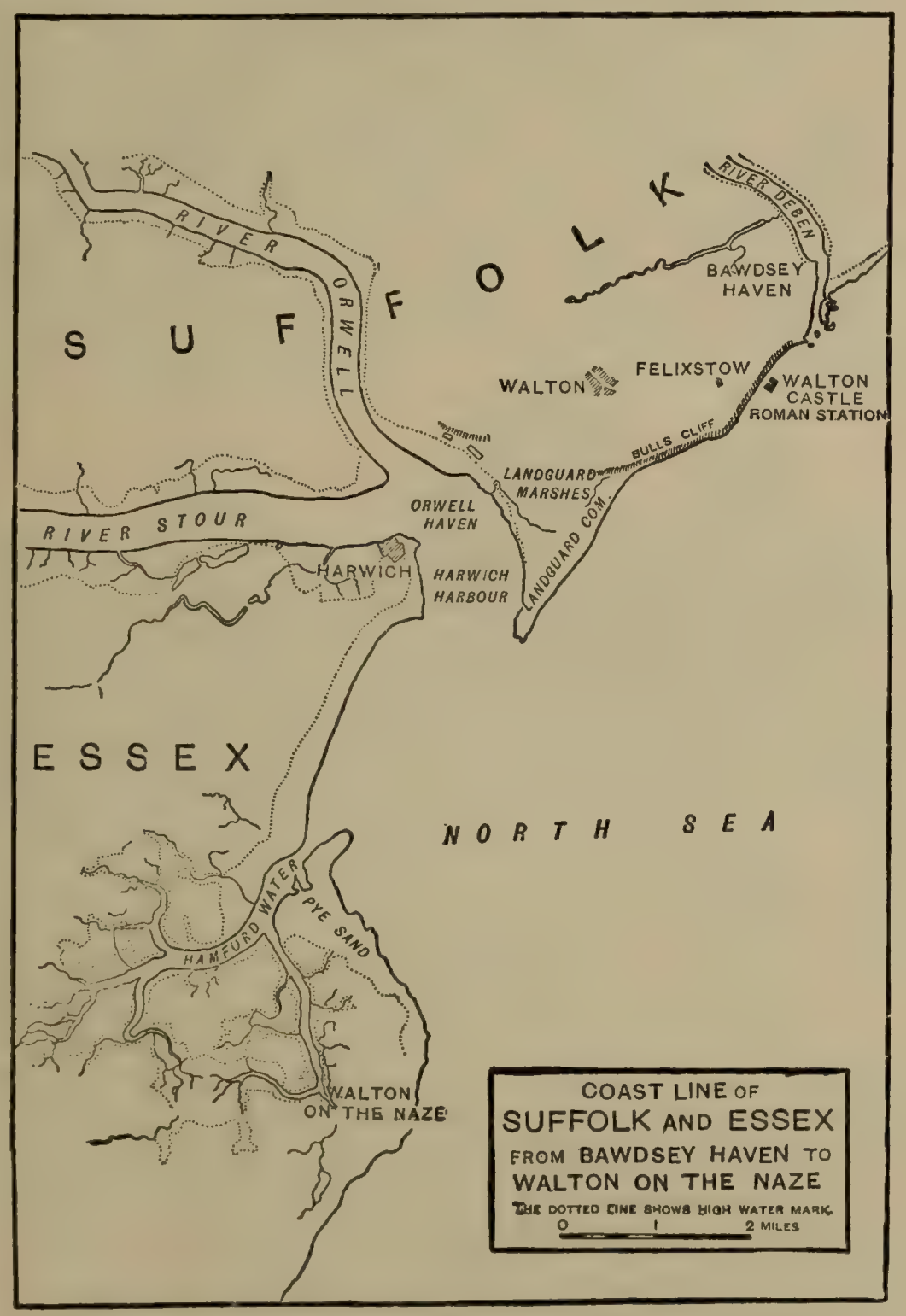

Plan III.-Plan showing Position of Walton Castle

"Mag. Brit. (1730), v, 191 ; Soc. of Antig. Min. Bk. (1758), viii, 67 ; Suckling, Hist. of Suff. (1848), ii 262 ; Arch. Journ. $(18 ; 8), x v, 155$. 


\section{A HISTORY OF SUFFOLK}

Stour, which unite now in the harbour of Harwich. This harbour, as seen on the map (plan III), has a considerable width, but it has only one deep channel into it, close beside the end of Landguard Common. The sea is shallow, and there were, if there are not still, considerable sand banks in front of the harbour, as may be seen on the map (plan III). A plan (IV) of the port was made in 1686 by Capt. Grenvil Collins and dedicated to Pepys. It is a well-known fact that the North Sea has, even in historic times of no distant date, largely affected the eastern

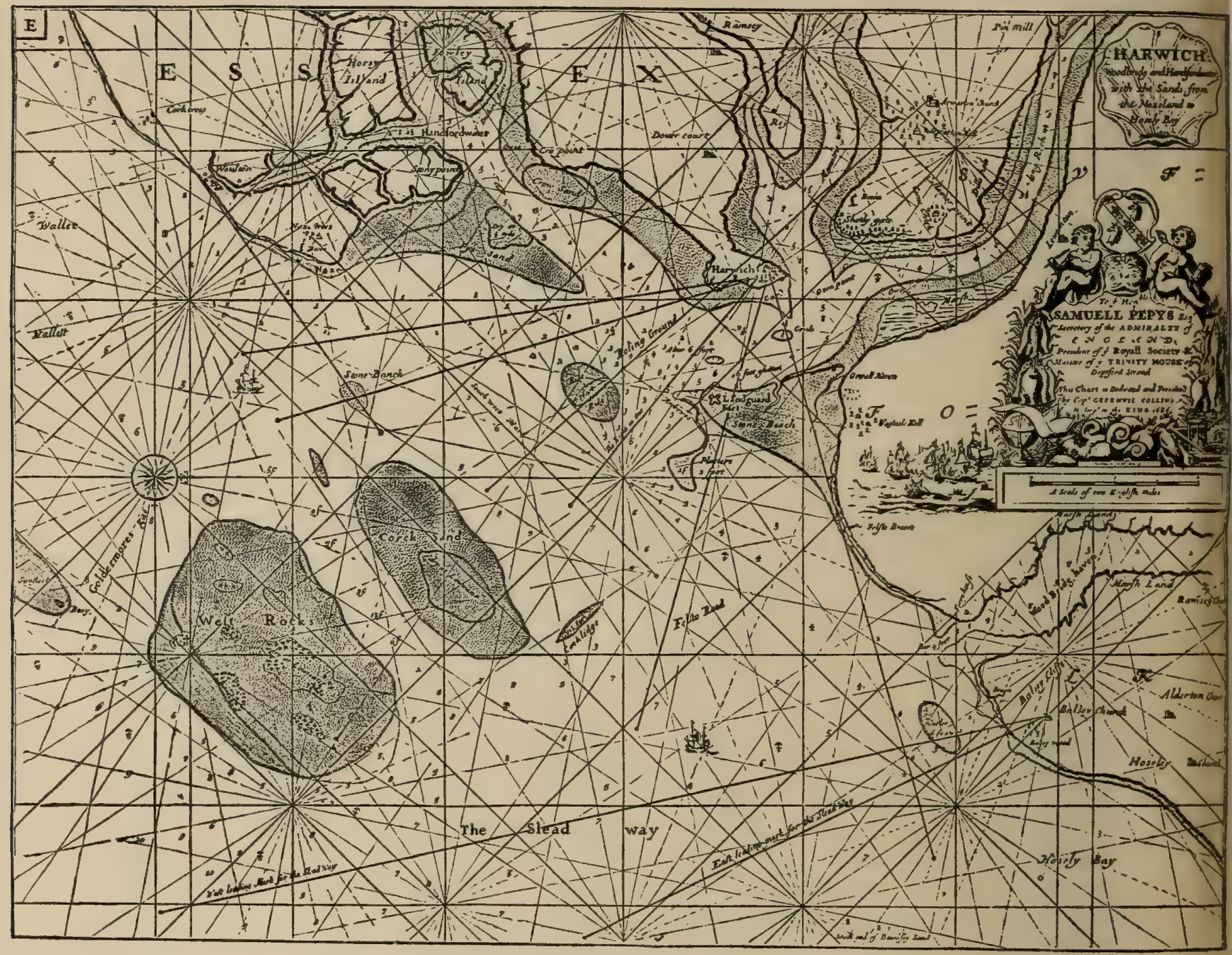

Plas IV.-Chart of Entrance to Harwich Harbour in 1686

coast-line of Britain, and very especially portions of Suffolk. Along this line of coast from the Deben to the Stour it has been advancing with some rapidity, and in the course of nineteen centuries considerable alterations in the disposition of land and water may have taken place, and so much is this the case, that it is permissible to conjecture, that in the Roman period a tract of salt marshes and sand banks stretched across the present opening of Harwich Harbour, forming a lagoon something like Breydon, from which the united waters of the Stour and Orwell poured themselves into the sea by a passage running at the foot of high land called at its eastern end 

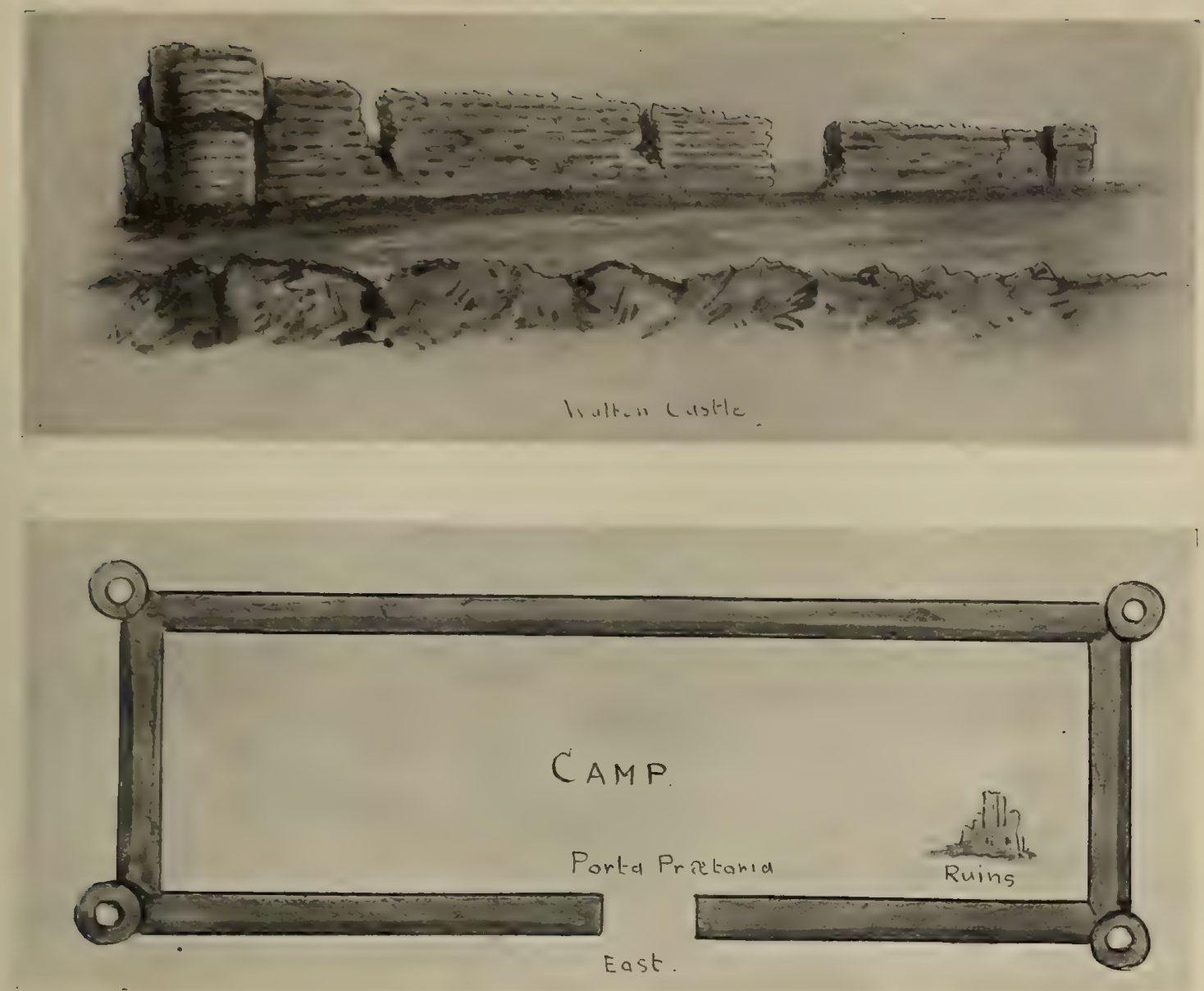

Walton Castle: Ground Plan and Ruins

(From a drawing made in 1623 )

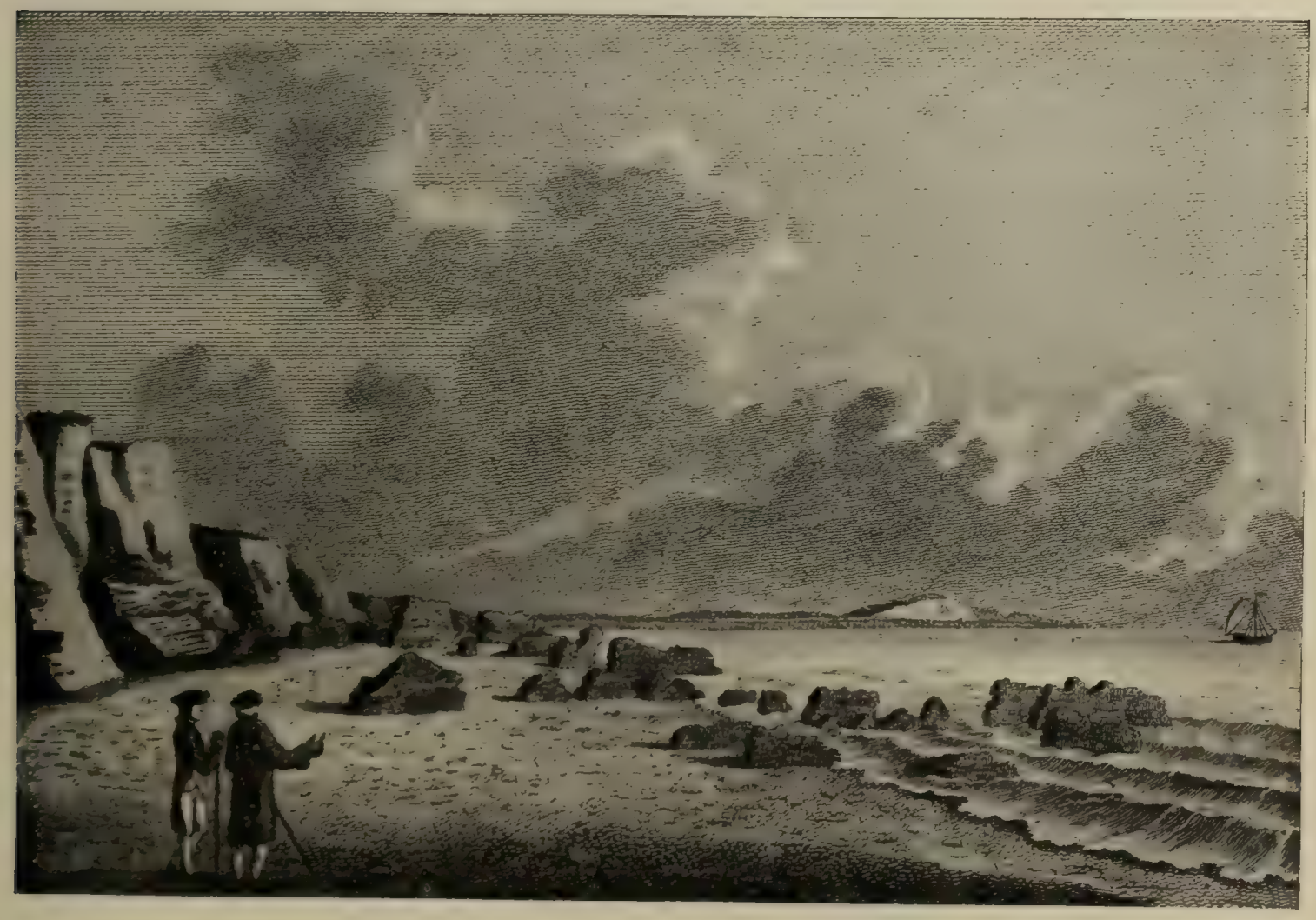

Walton Castle : Ruins

(I rom a dlaruing maite in 1700) 



\section{ROMANO-BRITISH SUFFOLK}

Bulls Cliff, at Felixstowe. Marshes at the foot of this high land, and the traces of a waterway in the marshes, in fact, seem to point out the line on which the united waters of the Stour and Orwell reached the sea in very early times. Between the Deben and these other estuaries lay a broad flat tract of land some miles in extent, a sort of peninsula. In the Roman period this tract projected farther into the North Sea than it does now. On a site on this land about a mile south of the mouth of the Deben, but possibly then at some distance from the sea-shore, stood the fortress whose history, scanty as it is, is still worth tracing. Of the walls not a fragment remains above the waves, which undermined the last relics of them in the 18 th century. Now and again when the tide is at its lowest two or three weed-covered masses may be seen, but that is all there is to show that a Roman station once stood on the spot. Fortunately the memory of it has been preserved in letters and drawings which show clearly enough the character of the buildings. The place was known in the 17 th century, and probably much earlier, by the name of Walton Castle, no doubt from some traces remaining within the inclosure of the Roman walls of a keep and other structures of the 12 th century, built by the rebel earl Hugh Bigod, whose castle here was destroyed by the king (Henry II) after the suppression of the rebellion in which the earl had been engaged."

However this may be, it is not until the 18 th century that it is possible to speak with any certainty as to the remains called Walton Castle, and then the descriptions show them to be clearly Roman. The first in date is the following, which occurs in vol. $\mathrm{i}$ of the Minute Books of the Society of Antiquaries under date 28 November 1722 , in a letter from Dr. Knight. It runs thus:-

Some distance East of this town (i.e. the neighbouring village of $W$ alton) are the ruins of a Roman Wall situate on the Ridge of a cliff next the Sea between Languard ffort and Woodbridge River (the Deben) on Bawdsey haven. 'Tis 100 yards long, five foot above ground 12 broad at each end and turned with an angle. Its composed of Pepple and Roman bricks in three courses, all round footsteps of buildings, and several large pieces of Wall cast down upon the Strand by the Seas undermining ye Cliff all which have Roman brick. At low water mark very much of the like is visible at some distance in the Sea. There are two entire Pillars with Balls, the Cliff is roo foot high.

The next notice that can be given is from Kirby's Suffolk Traveller (1735), where it is stated under the head of Walton :- 'For the neighbouring Parish of Felixstowe on the Colnes side of Woodbridge (Bardsey) haven, still appear the ruins of a quadrangular castle, advantageously situated'; and further and more fully in the second edition of his book, published in 1754 , he says :

He that would look for the Site of this Castle (i.e. of Walton) within the bounds of Walton strictly taken will never find it; but upon a high Cliff in Felixstowe, at the distance of about one mile from the mouth of Woodbridge River (the Deben) and two miles from Orwell Haven, Part of the Foundation of the West Side of it, is still to be seen : being now One Hundred and Eighty-seven yards in Length, and nine feet thick; it is called by the Country People, Stone-Works. How much larger it was we cannot judge. Part of the South end being washed away: and the Sea, which is daily gaining upon this coast having swallowed up the ruins. Such was the condition of it about the year 1740: but since then the Sea hath washed away the remainder of the Foundation. There can be no doubt but $W$ alton Castle was a Roman Fortification as appears from the great Variety of Roman Urns, Rings, Coins, etc, that have been found there, etc.

"On the Pipe Roll of 22 Hen. II, $2 n, 1176$, is the amount of the costs involved in its destruction. The Norman additions to the Roman fortress would find a parallel in those made within the Roman walls of Pevensey (Anderida), another of the 'forts of the Saxon Shore.' 


\section{A HISTORY OF SUFFOLK}

A page further on contains the following paragraph, which seems to identify the place: 'In a Survey of the Manor of Felixstowe Priory made in 16 I 3 we find a Close of Arable land called Great Long-Dole, in which Close are the ruins of Walton Castle.' The close is still known by its ancient name, and its position may be seen on the Ordnance Survey maps. It lies close against the sea. Grose, in his supplement to the Antiquities of England and Wales, published in 1787 , gives a view of the wall in question, which by that time had fallen on the beach. He says: "Its remains in 1766 when this view was drawn, were only visible at near low water, the sea having gained so considerably on this coast as to wash away the cliff on which it stood. A gentleman now living remembers the ruins of the castle to have stood at least fifty yards within the extremity of the cliff.' Thus the only remaining fragment of Roman inclosure had fallen beneath the waves in 1766 . The wall unquestionably formed part of a station of the same class as the one by the Waveney, though perhaps not covering quite so large an extent of ground. Kirby speaks of it as standing on a ridge. This was the southern edge of a wide depression, scarcely a valley, which, wide upon the shore, gradually narrowed as it ran westward to the ancient village of Felixstowe. Both slopes of this shallow valley appear to have been used as the cemetery of the station; a boarded well has been discovered; and perhaps some few scattered houses, judging from the building material found, may have existed here. On the north side of the valley, where a fall of the cliff occurred in 1853 , two skeletons were uncovered. These had bronze armlets, which were placed with the bones in the museum at Ipswich. ${ }^{12}$

From a report ${ }^{13}$ in the Proceedings of the Society of Antiquaries (1885) we learn that 'during the progress of works carried on in what is known as the Park, situated a short distance from Felixstowe Church (close to, if not actually part of, the field known as the Great Long-Dole), the men in their search for Coprolites came upon many most interesting relics of the Roman occupation.' Amongst the list of objects turned up occur 'coins of Severus, Gordianus, Gallienus, Victorinus, Constantinus, Arcadius' \&c. Of more consequence than the miscellaneous finds were the cinerary urns found, 'containing bones and ashes and either closed with a cover or with a stone only.' The discovery of these last showed the situation as part of the cemetery.

From what has preceded it is clear that there was on this spot of the Suffolk coast a Roman station, approximating in size and details of construction to those noted for the defence of the east coast. It occurs at a most important point for the protection of this coast, and its omission would have caused a dangerous gap in the line of defence. On the cliff $100 \mathrm{ft}$. above the sea it commanded a full view of both the Stour and the Orwell and of the Deben, the harbour at whose mouth, called Bawdsey Haven, scarcely a mile away, would have held the auxiliary ships of the fleet. It seems strange that the site should be so little known by antiquaries, perhaps owing to its disappearance early in the 18 th century and the very little interest shown by them in the later Roman fortresses in comparison with those which are more obvious and earlier.

\footnotetext{
is For an account of other views representing the ruins of the Roman station called Walton Castle see Topographical Index under Felixstowe.

13 Proc. Soc. Antiq. Lond. (Ser. 2), 1885, xi, 12, 14.
} 


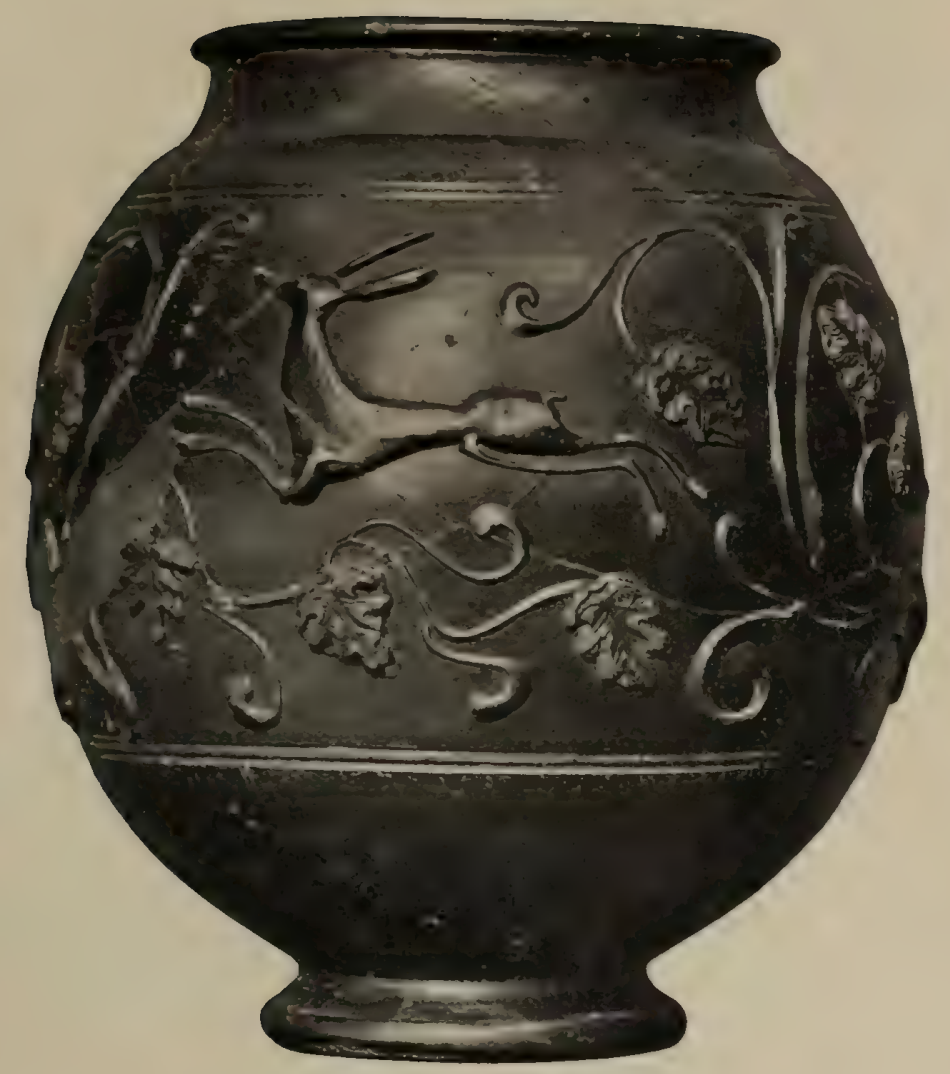

Vase from Walton Castle Cemetery (British Museum)

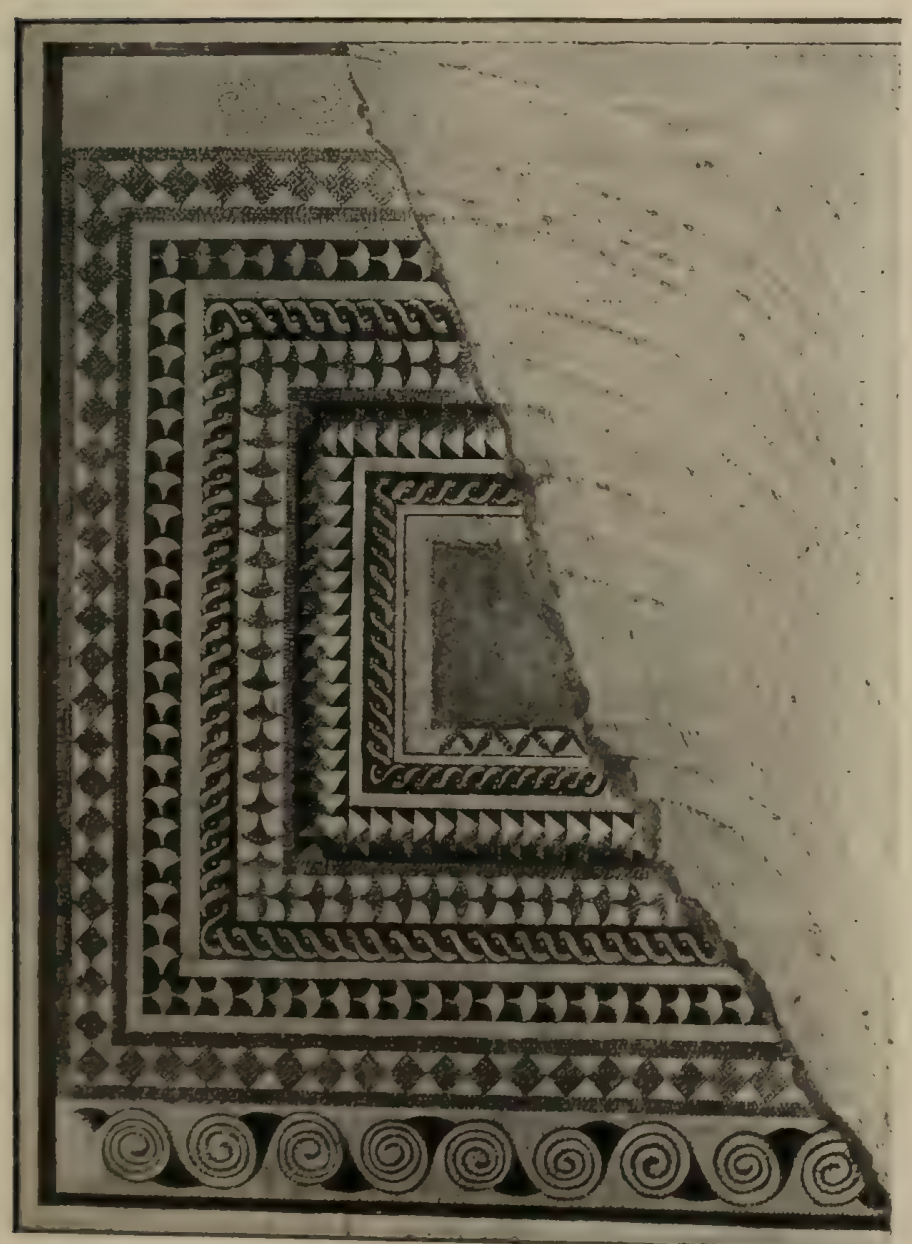

Fragment of Mosaic Pavement from Whitton 



\section{ROMANO-BRITISH SUFFOLK}

It is a curious fact that though eight of the 'forts of the Saxon Shore' have been identified with all probable correctness, the place of one of them has never been settled with general assent. This is the Portus Adurni. The station has been supposed to have been situated on the Adur, a stream flowing into Shoreham Harbour, in Sussex, the name being given to it from that of the stream; but this has been shown to be an error, as the little river in question had no certain name till the 17 th century, when that name was bestowed upon it. ${ }^{14}$ Portchester has also been suggested for its site, as a large Roman station of the late class still exists there at the head of Portsmouth Harbour. There is, however, no river or stream here whose name might be associated with that of the port. From the most westerly of the identified ports of the Saxon Shore, Pevensey (Anderida), round to Brancaster on the Wash, in Norfolk (Branodunum), the sites of the stations have been found and named, yet here at Walton on the most important point in the whole line lies a station as important as Gariannonum, which station it is suggested was Portus Adurni. If we knew the Roman name of the Stour such a suggestion would be settled.

In the Notitia Dignitatum Portus Adurni is spoken of as garrisoned by a body of exploratores; that is, in modern phrase, mounted scouts. No better troops could be selected for such a fort as that at Walton. There seems not very much doubt that if all the facts connected with the site could be fairly arrayed the name given above would with little hesitation be bestowed upon it and the last gap in the list of the Notitia would be satisfactorily filled.

\section{Remains of Civilian Occupation}

The civil side of our subject does not perhaps offer matter of as much interest as that just treated; not so much on account of the want of its importance as on account of the imperfect remains it has to show. Yet Suffolk quite equals other counties in the number of such remains. It is needless to dwell on the minor antiquities, which will be found fully treated in the Topographical Index. The essential object is to note all traces discoverable of the dwelling-places of the inhabitants of the district in question, for from them alone it is possible to guess at the social condition of settlers or of the Romanized Britons occupying the land. From the paucity of stone and the abundant supply of wood from the forests the houses must have been of halftimbered construction, the spaces between the timbers being filled with a plastering of clay upon a ground-work of laths or reeds, the whole built on a footing, some $2 \mathrm{ft}$. high, of rubble or brick, and roofed with reeds which grew plentifully along the course of the rivers. Such dwellings sufficed, but in those of any size, the comforts or elegancies of life, such as tessellated pavements and painted walls and warmed winter rooms, were not entirely lost sight of. The principal settlements which have been found may here be noted, beginning with such sites as are discoverable by building and other material, scattered in the soil, and passing on to actual foundations marking out a definite plan. At Great Welnetham, Gough in his edition of Camden reported the ploughing up of many fragments of pottery early in the 18 th centurys

"Haverfield, Proc. Soc. Antig. 1893 (Ser. 2), xiv, 112 , 1 I6. 


\section{A HISTORY OF SUFFOLK}

including specimens of so called-Samian ware, urns, ashes, bones of animals, etc., and amongst other things a kitchen chopper of no unusual form, which he calls a sacrificial knife. ${ }^{15}$ At Coddenham ${ }^{16}$ again in 1826 , in an inclosure near the banks of the Gipping, much broken pottery, and Roman bricks, tiles, and ashes were discovered. An ancient road crossing a ford passed through this inclosure. Further, at Westhall near Halesworth in a field called Mill Post Field, beside a small stream, an area of 2 acres was thickly strewn with broken pottery, and the earth for a depth of $\mathrm{I} \mathrm{ft} .6 \mathrm{in}$. showed signs of burning. ${ }^{17}$

The inclosure of Burgh with its scattered remains of building material has already been noted, but another site as noteworthy as Burgh must be mentioned. This lies in the Stonham parishes, and, if the record of it is not exaggerated, suggests the former existence of a village. In a valley crossing the boundaries of the parishes of Earl Stonham and Little Stonham excavations were carried on in 1867 over an area of several acres, and it was reported that these showed that houses had occupied the north side of the valley, while opposite on the south side the cemetery could be traced by many cinerary urns, often covered with a tile. From the presence of flue tiles on the north side of the valley, the deduction was clear that hypocausts had existed there, and afforded a proof that houses of some importance once occupied the spot. But there were no traces of foundations to be made out. ${ }^{18}$

Other sites, however, indicate the former presence of houses. At a place called Red Castle Farm near Ixworth ${ }^{19}$ a mosaic pavement, afterwards destroyed, was discovered in the 18 th century. Again at Rougham, in the vicinity of a group of Roman sepulchral tumuli (of which more presently), a floor was observed of which the following account was given in 1843 to the Gentleman's Magazine. 'In a field occupied by Mr. Levett, about 250 yards south-east of the tumuli, the plough struck on some vestiges of buildings. About the middle of the field we ourselves observed the plain remains of a Roman floor constructed of pounded tiles and mortar, and a stratum of fine white calcareous stucco on the surface.' A somewhat similar instance occurred at Whitton near Ipswich, where in laying the foundations of a new farm-house in 1854 in a field called Castle Field great quantities of Roman bricks were dug up and a fragment of mosaic pavement of somewhat singular design was also uncovered. This latter was saved from the usual destruction attending such things and presented to the Ipswich Museum.

More definite traces of habitations than those already given can be cited, as, for instance, at Eye. ${ }^{20}$ There being a tradition that buildings had once stood in a field called Camp Field to the north of the town, the owner of the ground determined to test its truth and in an excavation made in 1857 came upon what seems to have been a Roman hypocaust with its furnace. Little was done, or possibly much more might have been revealed, and the discovery was very imperfectly recorded. Another hypocaust with its furnace complete was found in 1835 at a spot about half a mile south of Ixworth ${ }^{21}$ on the way to Stowlangtoft. The same fate befell this relic as that cited at Eye. Little beyond the opening up of this hypocaust appears to have been attempted,

${ }^{15}$ Camden, Brit. (ed. Gough), 1789 (Add.), 4, 8 I.

${ }^{18}$ Gent. Mag. 1825, pt. i, 291-3.

"Arch. I 855 , xxxvi, 454 et seq. It was in this field that bronze enamelled objects of Celtic character were found mixed with others of Roman date.

18 Gourn. Brit. Arch. Assoc. 1868, xxiv, 184-5. $\quad{ }^{10}$ Gent. Mag. 1843. pt. ii, 524-8.

20 East Angl. Notes, $1864, \mathrm{i}, 249$.

"Proc. Suff. Inst. Arch. ', 77-8. 


\section{ROMANO-BRITISH SUFFOLK}

though doubtless more might have been found if further search had been carried out.

The third and last example of the remains of buildings to be cited here is one found at Icklingham in 1877 , situated in a field called the Horselands. Its discoverer, Mr. Henry Prigg, says of it, 'So far as one can judge from the portion already explored the general plan of the building was that of a parallelogram directed north-west and south-east, having its principal apartments at the west, and the minor ones grouping around a central courtyard. The only portion explored was one large chamber at the west end, $25 \mathrm{ft}$. by $17 \mathrm{ft}$., divided into two by a transverse wall and warmed by a hypocaust ;' which he proceeds to describe very fully. It differs in nothing from the usual type of pillared hypocaust. Nothing more than the exploration of this hypocaust seems to have been attempted, and the rest of the traces of the house still have to be explored.92

The last resting-places of the inhabitants wherever discovered point to their dwellings in life in close vicinity. Near to any village or group of houses the cemetery will be found, and every isolated dwelling has its little burial-ground; only in our generally haphazard methods of research one or other, house or interment, is missed. Instances of various cinerary urns have been dug up : at Coddenham, a site already mentioned, and at Stratford St. Mary. At Wangford, ${ }^{23}$ near an ancient ford over the Waveney, calcined bones and Roman pottery (the latter probably the broken urns which had held the human ashes) were turned up in 1856 . At Stoke Ash 'some vessels containing calcined bones were found inverted on a square tile,' and at Easton ${ }^{24}$ in 1850 in a gravel pit five urns, and a sixth in the following year, were dug out. Later a group of seven or eight were turned up, only one of which had been used to hold ashes. Lastly, close to the site of the villa at Whitton previously referred to, one of those large globular ampborae not uncommon in this county was discovered in digging for gravel in 1894 . It was filled with ashes, probably from the funeral pile, in which no doubt had been buried the cinerary urn. Amphorae of similar character and containing cinerary urns have been dug up elsewhere. In all cases, as in this, the handles and neck have been removed so that the urn holding the ashes could be placed within.

The most remarkable, however, of the Roman tombs found in Suffolk are the four tumuli at Rougham, the remains in which were unquestionably those of the possessors of the mansion in their close neighbourhood. These barrows were ranged in a line, one being larger than the others and called Eastelow Hill. The most northerly on being levelled in 1843 was found to contain a cist of brick $2 \mathrm{ft}$. square covered by a layer of flat tiles. In it was an iron lamp and a thick square jar of green glass holding bones and ashes. The next tumulus to this one was destroyed in the same year. A cist of brick of the same character as that just mentioned lay in the centre at a depth slightly lower than the ground level. A large globular vase of glass contained human ashes and bones, and amongst them lay a lachrymatory, also of glass, with a bronze coin. Various vessels of different wares were

\footnotetext{
$n$ Foum. Brit. Arch. Assoc. 1878, xxxiv, i2 et seq.

s Proc. Bury and West Suff. Arch. Inst. 1863, iii, 413 et seq.

" Goum. Brit. Arch. Assoc. I 853 , viii, 159, 160.
} 


\section{A HISTORY OF SUFFOLK}

with the vase, and possibly a small casket in fragments. From one side an iron spike projected from the brickwork, sustaining an iron lamp.

The third and last of the smaller tumuli was practically worn down by the passage of a road across it, but the fourth and largest was intact when opened in 1844 by Professor Henslow, who had examined all the others previously. The interment had differed entirely from the others in that it was by inhumation. On a floor of flints at the original level of the ground was built up a chamber of rubble and tiles, a sort of little house with roofing of tiles. At the north end was a small projection, but for what purpose could not be made out. Inside, in a leaden coffin probably originally inclosed in one of wood, lay the skeleton of a man. Nothing else was found in the tomb. The interment seems to have been of comparatively late date, and may have been Christian. ${ }^{25}$

Turning now to more extensive sepulchral deposits, the first which may be named was discovered in the parish of Pakenham, next to that of Ixworth, early in the I gth century whilst digging for gravel. The man who came upon it described it as a square place full of pots set in rows. There were many, but he could not tell the number. The urns were of dark colour, and some had covers. No care was taken to preserve any of them, and these few words record all that is known of them..$^{26}$

Of more importance is a cemetery found in 1873 in a field called 'The Cowpath Breck,' close to the road to Thetford, when the railroad was in course of construction between Bury St. Edmunds and Thetford. As the cuttings progressed no less than nineteen interments were noted. There was only one vessel containing ashes, a vase of red ware covered with white slip, all the other burials were in coffins of which only the nails remained. Most of the coffins had an east and west position; in tile second burial the head, however, was to the north. There seems to have been some pottery with the coffins, and in one having an east and west position was a vase of Durobrivian ware and some horses' teeth; in another a second vase of Durobrivian ware of a red colour. ${ }^{27}$

Not far from these interments a group of rubbish pits occurred. They had the usual contents, animal bones and broken pottery. Wherever such pits are found it is a sure sign of the presence of habitations not far off. Thus, though the cemetery has been discovered, the village of which it was the burial-ground has yet to be found, unless indeed it has utterly disappeared. ${ }^{28}$

Less satisfactory because more disturbed was a cemetery recorded to have been found between Haverhill ${ }^{29}$ and Withersfield, not far from the castle at the former place. Here in 1759 , in digging for gravel, complete skeletons were unearthed and many cartloads of human bones removed from the spot. These would not have been conclusive evidence of Roman burials if such had not been proved by the presence of urns of glass, paterae of so-called Samian ware,

Proc. Suff. Inst. Arch. 1874 , iv, 257 et seq.

${ }^{27}$ For further details see under Ingham in the Topographical Index.

29 The mention of rubbish pits leads to that of wells. Some few of these have been found in Suffolk, especially along the coast where at Covehithe near Southwold the fall of the cliffs disclosed a certain number. They all seem to have shown the usual construction of square Roman timber-framed wells in this country, made of boards, standing in sections one on another and strengthened at the angles with short cross picces. The wells are noted here because when they became dry, they were generally used as rubbish pits, and from them as from the pits many and various objects have been obtained.

${ }^{50}$ Coles MS. v, 31, fol. $92-3$, and for drawings of some of the objects, fol. $916,92 b$. 


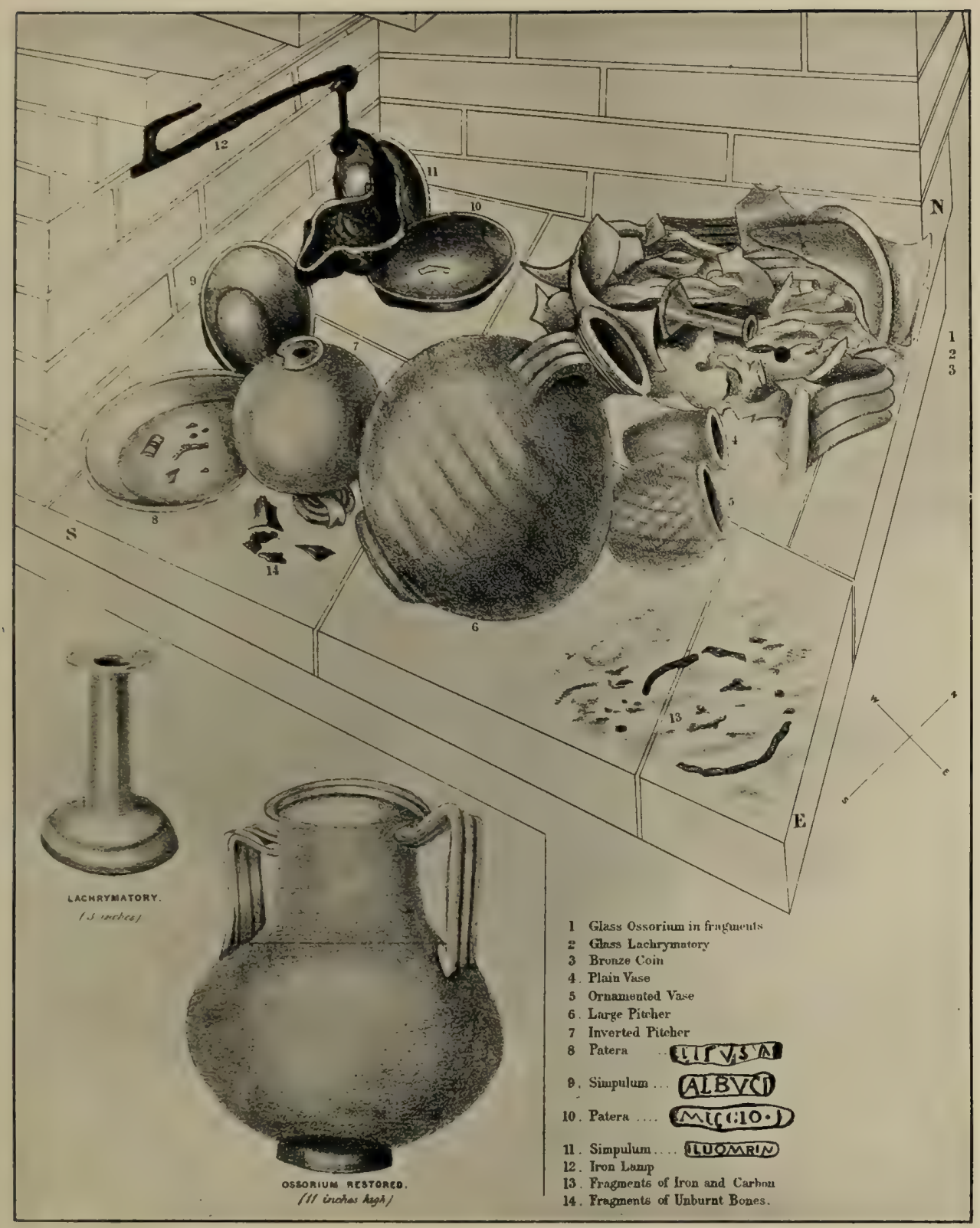

Contents of Barrow opened at Rougham in $18+3$

(From Proce. Suff Insto Arch, Iv.) 



\section{ROMANO-BRITISH SUFFOLK}

urns of white ware, a lump of red earth, and many shards or cinerary urns. Near, and probably originally within the largest of the glass vessels, was a white glass lachrymatory, one of those small perfume bottles sometimes buried amongst the ashes in the cinerary urns. In both cemeteries just mentioned the two methods of burial seem to have been practised, thus indicating a comparatively late date in the Roman period. To complete this list of cemeteries the one already noted in the Stonham parishes may be called to mind.

Another indication of dwelling-places or their near vicinity is to be seen in the hoards of coins which have been disclosed from time to time. Either these must have been buried plunder or the treasure of an individual who had deposited it in some spot within his observation. Such hoards of Roman coins have been turned up in various places in Suffolk. One of bronze coins is recorded to have been discovered in Ickworth, ${ }^{30}$ and another of the same metal at Lakenheath. ${ }^{31}$ A small collection of British coins was found at Santon Downham ${ }^{32}$ in the year 1870 . It is named here because it included two second brass of the Emperor Claudius. An important find was made in the year 1874 at Lavenham, ${ }^{33}$ in a field near Lavenham Lodge, where a labourer ploughing turned up from about a foot underground a rude earthen vessel, filled with silver denarii, 197 in number; 187 of these were saved. The earliest in date, as far as could be ascertained, were three of Mark Antony (B.C. 44-30), the latest twenty-eight of Trajan (A.D. 98-I I 7). A still larger hoard of upwards of 900 silver pieces was discovered when a new turnpike road was being made through the parish of Benacre in $1786 .^{34}$ It is said that none of these were earlier in date than Vespasian (A.D. 69-79). Not far from the site of the interment at Mildenhall, ${ }^{35}$ previously mentioned, were found in 1833 two vessels of clay and the remains of a third containing coins rusted into a mass. A much earlier find was made, viz. in 1764 , of ' a pot full of Roman coins of the Lower Empire' at Stowlangtoft. ${ }^{36}$ Again, in 1870 , at Sutton, another deposit, of two urns containing coins of the period of Constantine (A.D. 307-337), was turned up; and later, in 1874, a labourer ploughing a field on land called Dix's Charity land at Icklingham ${ }^{37}$ discovered a hoard of silver pieces numbering in all probability about 400. Those which were preserved and examined showed a range of date from Constantine I (A.D. 307-337) to Honorius (A.D. 395-423).

Regarding only the value of the metal, the most remarkable of these Suffolk hoards was that discovered near Eye, ${ }^{38}$ on Clint Farm, in 1781 . This consisted of several hundred gold coins (600 it was said) in good preservation, inclosed in a leaden cist, ranging in date from Valentinian (A.D. 364-375) to Honorius (A.D. 395-423). There appears to have been an interment close by the site of this find, as was also the case near that made at Mildenhall. In both instances the treasure may have been deposited in burial-places attached to private houses. Finally, the mention of a hoard of the latest period, not an unimportant one, may close this list of finds

2 Camden, Brit. (ed. Gough), 1789, Add. ii, 81.

* Arch. Fosm. 1870 , xxvii, 92 et seq.

" Gent. Mag. cvi, pt. i ( 1786$), 472-3$.

* Camden, Brit. (ed. Gough), 1789 (Add.), ii, 81.

u Journ. Brit. Arch. Assoc. 1880, xxxvi, 104.

$n$ Proc. Suff. Inst. Arch. 1874 , iv, 414 et seq.

is Archoeologia, 1839, xv, App. 609.

19 Iprevich Joum. of Loroestoft, 1790, p. $38 \mathrm{n}$. 


\section{A HISTORY OF SUFFOLK}

of coins. In the year 1812 , a collection of minimi to the number of a thousand was ploughed up on land beyond the limits of the common at Bungay. ${ }^{39}$

As an example of manufactures carried on within the county, the potters' kilns discovered near the village of West Stow ${ }^{40}$ may be cited. Five of these have been uncovered, the first in 1879 , and there is reason to believe that many more have either been destroyed or yet remain beneath the soil; in fact that there was a little community of potters settled on this spot. The kilns were small but of the usual form. Shards of pottery lay about them, but they were empty save that in one ampullae of a buff ware had been fired. From the ashes of this last kiln two small brass coins of Constantine were turned up, an indication perhaps of the date when the kilns were in working order.

Another more rare, if not unique find was made near Byng $\mathrm{Hall}$, in Pettistree, ${ }^{41}$ in Melton, in 1846 . This had the appearance of a brickfield, stacks of burnt and unburnt bricks of Roman character being brought to light. Flanged tiles also and some hundreds of others of the usual form helped to show the nature of the find. But unfortunately the excavations were not continued; little was done, and we have only an incomplete record of what was seen.

Before entering on another section of this paper, viz. the Roman roads in and through Suffolk, some mention must be made of the miscellaneous antiquities of the period. To go through any detailed list of these would occupy too much space, nor are they, for the most part, so unlike much to be found elsewhere as to need special remark. Some, however, of the more remarkable are here cited.

Amongst these, the statuette in bronze dug up at Barking $\mathrm{Hall}^{48}$ before the year I 800 may well take the first place. The figure measures 22 in. in height, and is believed to represent an imperial personage in full armour. It is the details of this armour which give the figure its character and distinction, for the surface of the cuirass is completely covered with fine niello work of a quality and completeness of design rare in this country. The statuette was considered so important a specimen of its kind that it was engraved and described in the fourth volume of Vetusta Monumenta of the Society of Antiquaries. It now forms one of the chief ornaments of the RomanoBritish collection at the British Museum.

Fragments of two statuettes of a very different style from the preceding, but of equal interest archaeologically, were found at Hawkedon, ${ }^{48}$ in 1880 , in an amphora which had probably contained a cinerary urn. Only the heads and busts of these statuettes remained. The material of which they were composed was pipeclay. As an indication of size, it may be noted that the: head of one measured $I$ in. and of the other $I \frac{1}{2}$ in. in height. Both represented a nude type of the goddess Venus. Such figures are well known in France, but are much less common in this country. What makes their discovery worthy of notice is that they may perhaps be looked upon as objects of popular worship. The two specimens here mentioned may have had a place in the domestic shrine

${ }^{39}$ Proc. Suff. Inst. Arch. 1863 , iii, 414.

10 Gourn. Brit. Arch. Assoc. 1881 , xxxvii, 152 et seq.

"Davy, Suff. Coll. B.M. MSS. xxxvii, 19113, fol. 194 a, b. See diagram of find in Topog. Index.

12 Vetusta Monumenta (Soc. Antig.), iv, pl. xi, xv. Proc. Suff. Inst. Arch. vi, i 888-9. 


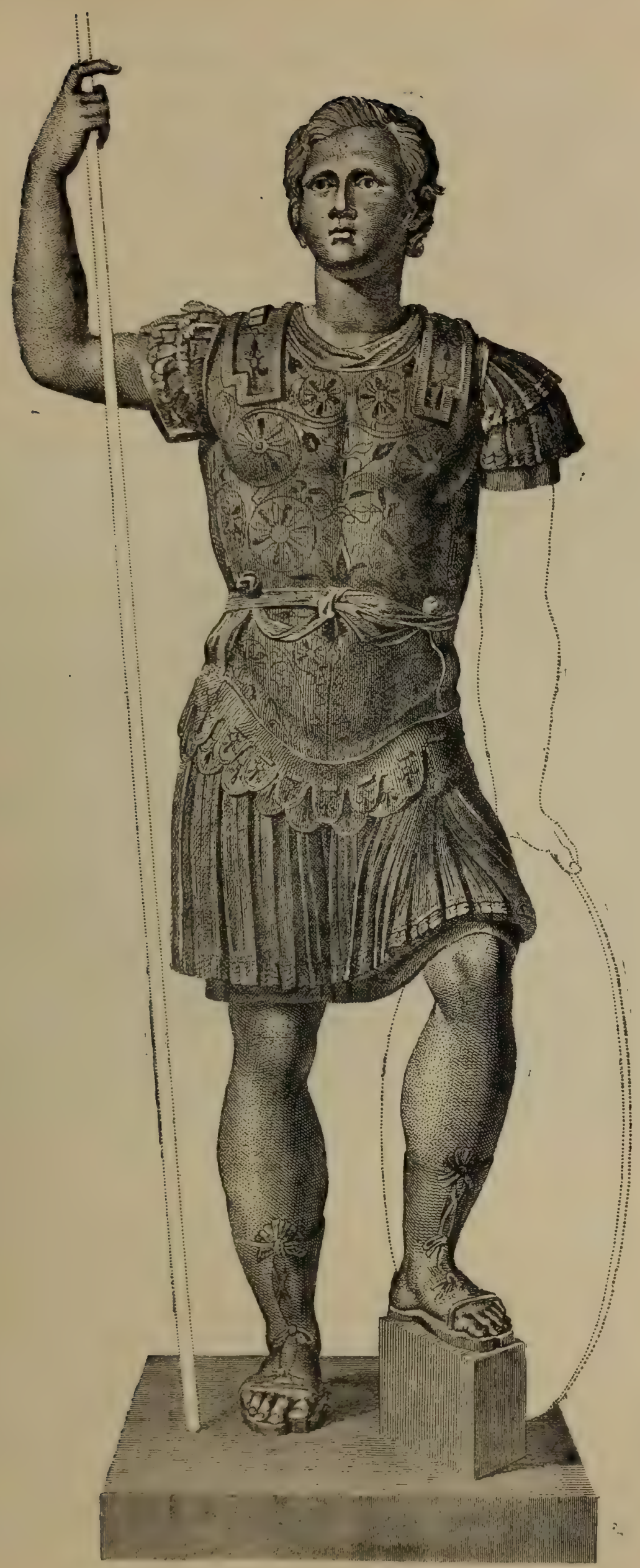

Bronze Figure (height, 22 in.) from Barking Hall 


\section{A HISTORY OF SUFFOLK}

of some dwelling not far from the spot where they were found. These objects are now deposited in the museum at Bury St. Edmunds.

The last of the more notable finds which we need name here was that of a whole service of pewter vessels, dug up at Icklingham ${ }^{44}$ in 1839 , remarkable from the fact that the discovery helped to swell a list of similar finds in the eastern counties already larger than can be made out in any other district in England. The pieces of this set are well preserved, the larger proportion taking the form of shallow paterae. They are now in the British Museum.

\section{ROADS}

It is needless here to give any account of the authorities concerning the Roman roads in Britain. It suffices to name the principal one and that most relied upon, namely the Antonine Itinerary, which is a road book of the Roman empire, whose compilation is variously dated from $200 \mathrm{~A} . \mathrm{D}$. to early in the $4^{\text {th }}$ century. The portion of this book relating to Britain is divided into fifteen sections or 'Iters,' showing in each the route between the stations which begin and end the Iter.

For Iter V, running from London through Colchester and Lincoln to Carlisle, no satisfactory course has been made out through Suffolk. The direction is uncertain and no sites have yet been identified with any certainty. All that can be said is that Villa Faustini and Icinos must have been somewhere within the county.

Iter IX, which passes from Caister St. Edmunds in Norfolk to London, is less hopeless, and affords room for probable conjecture, but with this there are difficulties. For instance, the distance between Colchester (Camoludunum) and Caister St. Edmunds (Venta Icinorum) is given as 75 Roman miles instead of 55 miles, which it would be by a direct route. ${ }^{45}$ The positions of the intermediate stations (Combretonium and Sitomagus) are also vague. To account for the discrepancy in the distances named it is supposed that the road was deflected either eastward or westward. Camden imagined that it ran the westward course by Brettenham and Thetford though without any valid reason. The late Dr. Raven preferred an eastern deflection. The stations on Iter IX from London to Colchester are fairly well determined, even as far as Stratford St. Mary (supposed to be Ad Ansam of the Itinerary), where the road coming north from Colchester crosses the Stour. It has been traced beyond this, going northward and so faintly onward, till just beyond the little River Gipping it is again clearly discoverable. From hereabouts begins the deflection by which it is supposed to pass Burgh, near Woodbridge (possibly Combretonium), and thence onwards by Stratford St. Andrew, Saxmundham, and Kelsale to Dunwich, which may be the Sitomagus of the Itinerary. From this point all is clear. The road passes in a north-westerly direction, over the River Blyth, by Halesworth, past Mettingham Castle to a ford at Wangford over the Waveney, and so onwards to Venta Icinorum, thus completing the Iter. ${ }^{46}$ A recent writer on Roman roads in Britain lays down another route for the section between the Gipping

$$
\begin{aligned}
& \text { 4 Arch. 1842, xxix, App. 389. } 5 \text { T. Codrington, Roman Roads in Britain, } 228-9 . \\
& { }^{40} \text { Rev. J. J. Raven, D.D., Hist. of Suff. iii, } 28 \text { et seq. } \\
& 208
\end{aligned}
$$




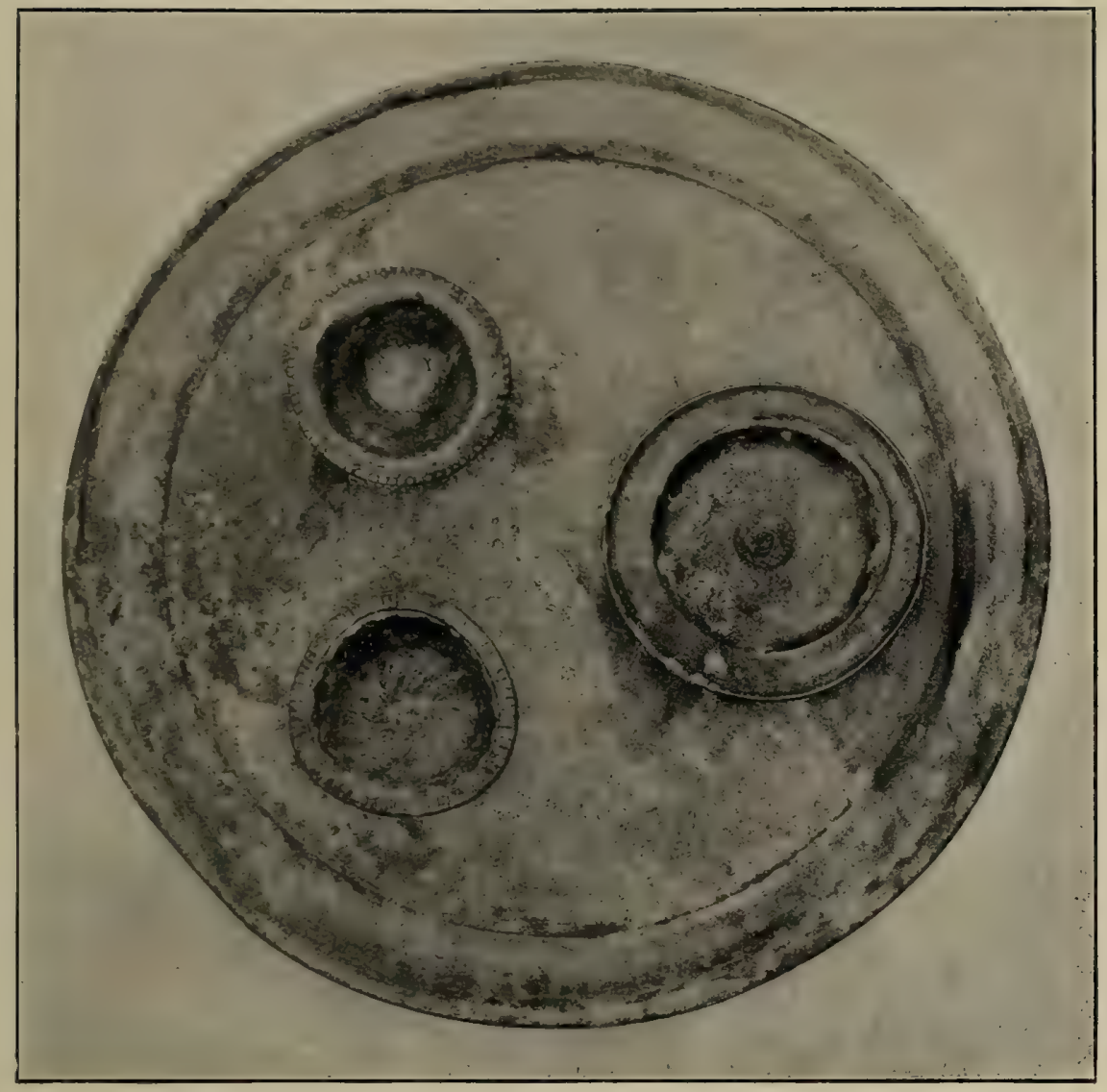

Pewter from the Acton Collection, found at Icklingham 



\section{ROMANO-BRITISH SUFFOLK}

and Dunwich, making it run by Coddenham, East Soham, and by Sibton Abbey, and so to Dunwich. There is one objection to this route, that it passes by no site with so many Roman remains as at Burgh, which might well be taken for the Combretonium of the Itinerary. ${ }^{47}$ No line of communication has yet been discovered between Walton Castle and the routes here mentioned. It is impossible that there should not have been such a line. As for Gariannonum (Burgh Castle), a road starts from that fortress southwards, which is supposed to have passed by Hopton and towards the end of Oulton Broad. It cannot be traced farther, if as far. Possibly the road continued till it joined the line from Dunwich to Wangford; or perhaps, crossing the Waveney at Burgh St. Peter, it may have passed on to join this same line near Ditchingham station in Norfolk; but this is mere conjecture. ${ }^{48}$

The most direct road from the south to Venta comes from Stratford St. Mary (Ad Ansam), and as far as the Gipping is the same road as that spoken of as part of Iter IX. From thence, proceeding in a nearly direct northern course, it runs by the Stonhams to Stoke Ash, and so to Scole, where it passes into Norfolk on its way to Venta Icinorum. Though by far the most direct route to the last-named station, it cannot be identified as belonging to the Antonine system. 'The Peddars Way,' one of the most remarkable of the Roman roads on the eastern side of Britain, is likewise omitted from the Antonine Itineraries. Its supposed starting-point was Colchester, but for I 6 miles through Suffolk there are no signs of it. Not until the village of Hitcham is passed do traces of it appear. From Hitcham it goes on to Woolpit, from thence to Stowlangtoft, and so on past Thetford, where crossing the county boundary about 5 miles east of that town it enters Norfolk. It crosses the west side of Norfolk to find an ending at an obscure village, Holm on the Sea, at a point where the Wash is narrowest from the opposite coast of Lincolnshire, and 4 miles west of Brandon (Branodunum), the first of the forts of the Saxon shore. A writer, previously cited, says of it, from Stanton 'this remarkable road can be traced for 45 miles to the north coast of Norfolk. It has been called British, but it has all the characteristics of Roman laying out, and is, indeed, the best-preserved Roman road in East Anglia.' And, again, Peddars Way has been said to pass through neither town nor village, and it is true that from Ringstead (in Norfolk) 'southwards as far as it can be traced, about 45 miles, Castle Acre' (a possible Roman station) ' is the only village upon it, and those near it are small.' 4

One other road requires to be mentioned, viz., the Icknield Way, which shows faintly on the western border of Suffolk, passing the county boundary at Kentford, and running on less and less visibly towards Lackford, but vanishing beyond that place.

1. T. Codrington, Roman Roads in Britain, 220-I.

- Ibid. 222. The writer apparently here confuses a place on the Waveney called Burgh St. Peter with the great fortress at that river's mouth, or he may have been led into error by the vain imaginings of local antiquaries, one of whom at least has endeavoured to fix the site of Gariannonum on this spot in order to bolster up a theory, unfortunately too much credited, of the existence in Roman times of a huge estuary separating Norfolk from Suffolk and running far up into the former county. There are no signs of any Roman fortress at Burgh St. Peter, nor have any Roman remains been found there.

* T. Codrington, Roman Roads in Britain, 224 et seg. 


\section{A HISTORY OF SUFFOLK}

\section{TOPOGRAPHICAL INDEX}

AldzBURgr.-Between Aldeburgh and Orford small Roman coins of the Lower Empire were found in great quantities on the sea shore [MS. Min. Soc. Antiq. 1743, iv, 190]. (See Hazlewood.)

Ashbocking.-At a spot on a farm in this parish, lying between two mounds and inclosed with ditches, a considerable quantity of scattered broken pottery was found [Davy, Suff. Coll. B.M. MSS. viii, 19084, fol. 3 0].

BARDWELL. - Near a gravel pit $330 \mathrm{yds}$. south of the village 'Roman Pottery was found in 1840 ' [O.S. 6-in. xxxiv, NE.]. A bronze enamelled diamond-shaped fibula was found in May 1869 [fourn. Brit. Arch. Assoc. xxvii, 258-9].

BARKING.-A bronze statuette was found near Barking Hall towards the end of the 18 th century, buried about $12 \mathrm{ft}$. below the surface of the ground. It is $22 \mathrm{in}$. in height, and represents an imperial personage in full armour, but bareheaded. The left arm is lost, the right is raised, the fingers of the hand being bent, an indication that they once grasped a spear. Besides the quality of the workmanship, the figure exhibits a fine instance of metal inlay and niello work, the cuirass being covered with scrolls and leaves of the latter work, interspersed with flowers and leafage formed by thin laminae of white metal. The bronze serving as a ground to this ornamentation was of a fine golden colour. The figure was found on land belonging to the Earl of Ashburnham, who presented it to the British Museum in 1813 [MS. Min. Soc. Antiq. xxviii, $13(1800)$; Vet. Monum. iv]. A bronze handled bowl was found at Needham Market in this parish [Chart, Watling Coll. in possession of Miss Nina Layard]. A bronze bowl (Anglian) and another (Celtic) with a coarse buff earthenware pot, which contained coins dating from Antoninus Pius (A.D. I $3^{8-61}$ ), were found at Gatesford [Chart, Watling Coll. in possession of Miss Nina Layard; and note by Mr. H. Watling, Reliq. and Illus. Arch. vi, 244].

BarRow.-A Roman key found here is now in the Museum, Bury St. Edmunds.

BARSHAM.-A gold ring was found about 1816 near Barsham Hall engraved with a figure holding a standard [Suckling, Hist. Suff. i, 44].

Baylham.-Near 'the Great Road' supposed to be Roman have been found so-called Samian pottery, painted white ware, and other remains, together with coins, one of which was a first brass of Hadrian (A.D. I17-38). A considerable number of coins found had been sold to different people [Fourn. Brit. Arch. Assoc. xxv, 387-8]. A knife with bone handle and a ring of bronze were found here with Roman urns [Suffolk Illustrations (Fitch Coll. in Lib. of Suff. Inst. of Arch. Bury St. Edmunds), vol. xiii ; Proc. Suff. Arch. Inst. v, 117$]$. Amongst the pottery found was a piece of figured so-called Samian, part of a vase of early type, three flanged basins, the rim of one painted with white scrollwork, all three of the same ware; pans of so-called Samian; different sizes of brown and pale buff ware, and two ollae, one pale red, the other brownish buff ware, and a one-handled bottle, with short small neck, of black ware. There is also in the Watling Coll. in possession of Miss Nina Layard a plan of the site showing the track of the Roman road, and with it a note where a bronze box was found.

Belton.-Pottery from a tumulus was found here [Proc. Arch. Inst. Norw. 1847, xxviii],

BENACRE. - 'A few days ago, as the workmen were making a new turnpike road at Benacre . . . one of them struck his pickaxe against a stone bottle which contained about 920 pieces of silver coin' [Ipswich Fourn. 27 May 1786]. A further reference to this find says: 'The coins alluded to were in good preservation, and included a large series (some few before Domitian [A.D. 81-96]). They are all about the size of a sixpence, nine of them weighing an ounce. . . . Sir Thomas Gooch purchased near 700. Some were bought by different persons, and the remainder sold to a Jew, who retailed them at a low price in the neighbourhood. Impressions of Aurelian [B.C. 270-5], Germanicus [B.C. 15-A.D. 19], and Trajan [A.D. 98-117] are in my possession; drawings of which I have sent...-R.L.' [Gent. Mag. lvi (1), 472-3]. In Excursions in the Co. of Suff. ii, 130-1, it is stated that none of the coins in this hoard were prior in date to Vespasian (A.D. 69-79). In Benacre Park is a clump of trees near the road from Lowestoft called 'Money tree clump' [O.S. 6-in. xix, SW.].

Bergholt, EAst.-A number of urns, evidently sepulchral, from the ashes they contained, was found in 1838 in digging foundations for a house in a field about a quarter of a mile north of the church, on a hill towards Stratford. They lay in a circle with a diameter of about $\mathbf{1} 2$ or I 4 yds., and were much broken. Those in the centre were of fine earth inclining to white, the outer ones were of a coarse red earth. The necks of some were entire, and about the size of a common bottle [Note from E. Dunthorne, Sept. 1838; Davy, Suff. Coll. B.M. MSS. xxviii, 19104, fol. 134]. 


\section{ROMANO-BRITISH SUFFOLK}

Blaxhall. - In a field near Grove Farm were found in $186_{3}$ Roman coins, urns, \&c., and in the same parish, on Blaxhall Heath, a 'tumulus with Roman urns was found in $1827^{\text {' }}$ [O.S. 6-in. lix, SE.].

BLYFORD. - A bronze statuette of a nude Venus, 6 in. high, holding a dove in the right hand, was found in a field near Blyford Bridge. It was originally in the possession of the late Rev. S. B. Turner. Between Blyford and Sotterley was found an urn of buff ware [Chart, Watling Coll. in possession of Miss Nina Layard].

BLythBurgh.-The following entries record the discovery of Roman remains : 'Not many years ago there were Roman urns dug up here among old buildings' [Lysons, Mag. Brit. (1730), v, 193]. From Grose we have the statement, 'A number of Roman urns dug up here about the year 1678' [Grose, Antiq. of Engl. and Wales, iii, 1775]. Suckling says that after a fire which damaged the village in 1676 , the labourers in clearing the ground for fresh buildings found several Roman urns and coins [Suckling, Hist. Suff. ii, 142].

Brandeston.-A Roman coin, large brass, was found here [fourn. Brit. Arch. Assoc. x, 90].

Bungay.-In sinking a well in Earsham Street, near the castle, in 1826 , a coin, first brass, of Marcus Aurelius (A.D. I6I-80) and a second brass of Faustina (A.D. I38-41) were found. The next year a coin of Gordian III (A.D. 238-44) was turned up in a garden near Duke's Bridge [Suckling, Hist. Suff. i, 130]. 'Part of Trinity parish lies by the side of the old Roman road called Stone Street at the distance of about 5 miles from the town' [ibid. 133]. Bronze coins of Nero (A.D. 54-68), Antoninus (A.D. I38-6I), Aurelius (A.D. 161-80), Faustina the younger (A.D. 147-76), and Carausius (A.D. 286-93), were dug up in the town, and more than 1,000 minimi were ploughed up outside the common in 1812 [Proc. Suff. Arch. Inst. iii, 414]. A coin of Nero (A.D. 54-68), second brass, was turned up from the railway cutting on the common in 1862 (?) [East Angl. N. and Q. i, 249]. A coin of Clodius Albinus (A.D. I96-7), first brass, was dug up in Mr. Lait's garden at the 'back of the hills,' and another of Vespasian (A.D. 69-79), with incuse reverse, was found near the town [Raven, Hist. Suff. 30].

A trench across the neck of the common is marked in the O.S. maps 'Roman remains,' and about the centre of it 'Roman coin found 1862.' The Stone Street, running in a north-west direction, makes an angle in the town, and after crossing the River Waveney starts again due north. It crosses the marches north of the river at about their narrowest part, and passes about a quarter of a mile south-east of the bank called 'Roman remains' [O.S. 6-in. viii, SE.]. A road, called 'Stone Street,' also runs in a north-west direction through the parishes of Spexhall and Ilketshall St. Lawrence, between Bungay and Halesworth [O.S. 6-in. xviii, SW.].

BuRGH. - Near Woodbridge: 'A bout a mile to the south-east of Clopton.' The church 'stands within the enclosure of a Roman station' [Excursions in Suff. ii, I 9, 46]. Coins have been found on the site; one, possibly of Tiberius [A.D. 14-37), another of Crispus (A.D. 317-26), with a second, illegible, probably of the same period, and a minim of Constantine II (A.D. 33740) [Proc. Suff. Arch. Inst. ix, 335]. 'Burgh churchyard is well scarped to the south and west, and at about $200 \mathrm{yds}$. to the south the remains of a trench now filled in may be clearly seen. This, at a point east-south-east of the church, turns northward, and between the two churches (Burgh and Clopton, a mile away) westward, till it meets the scarp. The name Castlefield is still preserved, and the late Major Rouse of Woodbridge could remember the ruined walls. Here, a few years ago, a gold Roman bracelet was found, and at the further end of Clopton in 1883 a boy named John Gardiner found a gold Roman coin, which he sold to a watchmaker in Woodbridge. Fictile remains are found strewn on the ground' [Raven, Hist, Suff. 30 et seq.]. In 1901 excavations at this place yielded 'very interesting rubbish,' tiles, potsherds, painted wall-plaster, a coin or two, and other relics of a possible Roman villa [Antiq. xxxvii, 342, (1901) 'Quarterly Notes,' by Prof. Haverfield]. On the O.S. Map [6-in. lviii, SW.] the field in which the church stands is marked 'site of camp', though the traces of the fosses are not given.

Burgh Castle. - Near Yarmouth. A walled station. [For early description and plans, see Sir Henry Spelman, Icenia (ed. 1723), 155; Camden, Brit. (ed. Gough), ii, 77, 90 ; Ives, Garian. (ed. 1803); King, Munimenta Antiqua, ii, 52n-5, I16 et seq.] The following details may be added to the general description of this station previously given. The body of the walls is of flint rubble concrete, with lacing courses of tiles, six of which may yet be seen. These courses run two tiles deep into the wall, and are three tiles in width. The spaces between these courses vary from I ft. $8 \mathrm{in}$. to $2 \mathrm{ft}$. 1 in. in width, showing a dressed flint facing. The walls are faced on the inside, but the lacing courses are irregular and fewer than on the outside, and the flint facing is ruder also. The mortar employed in the outer facing is pink with coarsely-pounded tile. There is no regular rule in the employment of it 


\section{A HISTORY OF SUFFOLK}

throughout the walls, but if anything it is associated with the tile courses. At the broken west end of the north wall, where the high land slopes to the water meadows, there are some indications of a stepped line in the tile courses to meet the last of those in the west or river wall. Where the wall is fractured there is a drop in the tile courses which shows in the section. The west wall, that next the river, was founded on piling, the piles being I $\mathrm{ft}$. apart, and the interspaces filled with clay and chalk stones strongly rammed down. If all the bastions of the station had foundations like that of the tower on the south side it would appear that they were founded on a bed of timber planking. The tower referred to has fallen over, and on its base could be seen, in 1774, the imprint in the mortar of the planking on which it had been built. The best and most complete account of the station is that given by Harrod [Norf. Arch. v, I 46 et seq. ; see also Proc. Soc. Antiq. iii, 227].

With respect to the supposed cemetery of the station, Ives says [Garian., 34-5], 'The field adjoining the eastern wall of Gariannonum was the place allotted for depositing the ashes of the dead. . . . Here a great number of Roman urns have been found. . . . They are made of a coarse blue clay brought from the neighbouring village of Bradwell; illformed, brittle, and porous. In the year 1756 a space of $5 \mathrm{yds}$. square was opened in this field, and about $2 \mathrm{ft}$. below the surface a great many fragments of urns were discovered, which appeared to have been broken by ploughs and carts passing over them. These and the oyster shells, bones of cattle, burnt coals, and other remains found with them, plainly discovered this to have been the Ustrina of the garrison. One of these urns, when the pieces were united, contained more than a peck and a half of corn, and had a large thick stone operculum on the top of it ; within was a considerable number of bones and ashes, several fair pieces of Constantine, and the head of a Roman spear.' The illustrations given by Ives [Garian., 34] show the head of a spear, a Roman fibula, and two urns which are Anglian, not Roman [see also MS. Min. Soc. Antiq. i, $195(1726-7)]$. Two cinerary urns were found in the same field, called Brick Kiln Piece, in December 1843 , at a depth of $2 \mathrm{ft}$. They were partly filled with bones, and one contained four iron nails [Suckling, Hist. Suff. 333; Suff. Illus. (Fitch Coll.), vol. iii]. A vase of dark brown Durobrivian ware, decorated with white scrolls in slip and with a female mask at the mouth, was found between the station and the church in 1851 [Norf. Arch. iii, 415; Dawson Turner Coll. B.M. Add. MSS. 23062, fol. 95]. In a field, the position of which is not specified, a number of circular pieces of stone (?) were discovered "flat on one side and slightly convex on the reverse; of a dingy black colour interspersed with dull red spots.' These were possibly spindle-whorls of pottery [Suckling, Hist. Suff. 333]. According to Ives [Garian, 30-1] no coins were found earlier than those of Domitian (A.D. 8I-96), and most of them much later, of the Lower Empire. Few were of any other metal than bronze, though Ives had a silver one of Gratian (A.D. 375-83). It was said that a considerable number of silver, as well as two of gold, had once been ploughed up. The coins, which were in the possession of the late Sir Francis G. M. Boileau, bart., F.S.A., the owner of the site, range from Gallienus (A.D. 253-68) to Arcadius (A.D. 383-408). There is one silver piece of Arcadius.

Other objects from this station in the possession of the late Sir Francis G. M. Boileau in 1889 were:-Fragments of iron nails, one with a flat square head and 4 in, of shank remaining, together with pieces of flat iron bands found within the east gate, in 1847 ; a small flat square of bronze with a man's head on it in low relief within a circle ; a harp-shaped fibula of bronze $1 \frac{1}{2} \mathrm{in}$. long, with remains of blue enamel about the head and a sinking for the setting of stones, found in 1847 ; a very small fragment of a thin glass vessel, one fragment of so-called Samian ware with ornament in white painted on it, found in 1850 ; other pieces all plain, one showing a flanged rim; a small globular bottle of buff-coloured ware, 2 in. high, with a very small neck; one perfect urn and fragments of another, of coarse grey ware, found in 1848 ; a pan of the same coarse ware; pieces of flue and roof tiles, and horns of deer with portions sawn off them. In the Museum at Norwich are fragments of a vase found in 1852 , presented by Mr. G. J. Chester, and fragments of bronze buckles and other small objects, presented by Mr. W. Squire. One of these so-called bronze buckles is a portion of a Saxon fibula. In the British Museum are a bronze ball and a small hollow cylinder of the same metal from Burgh [O.S. Norf. 6-in. I I, NW.; 25-in. 5 and 9, lxxviii ; descriptions of the place are also given in Fourn. Brit. Arch. Assoc. xxxvi, 98-9; Proc. Suff. Arch. Inst, xi, 311 ].

Bury St. Edmunds. - A 'glass unguentarium' was found near a skeleton on the site of Mr. Farrow's house in the churchyard [Proc. Suff. Arch. Inst. i, 343]. There are several Roman coins from the Botanic Garden [ibid. ii, 28], and the head of a one-handled vase of red ware covered with a cream-coloured slip was found in $184_{c} 8$ [Acton Coll. Suff. Illus. (Fitch Coll.), vol. xvii]. Two coins of Carausius (A.D. 286-93) and Allectus (A.D. 293-6) were also found here [Numis. Fourn. i, 264]. 

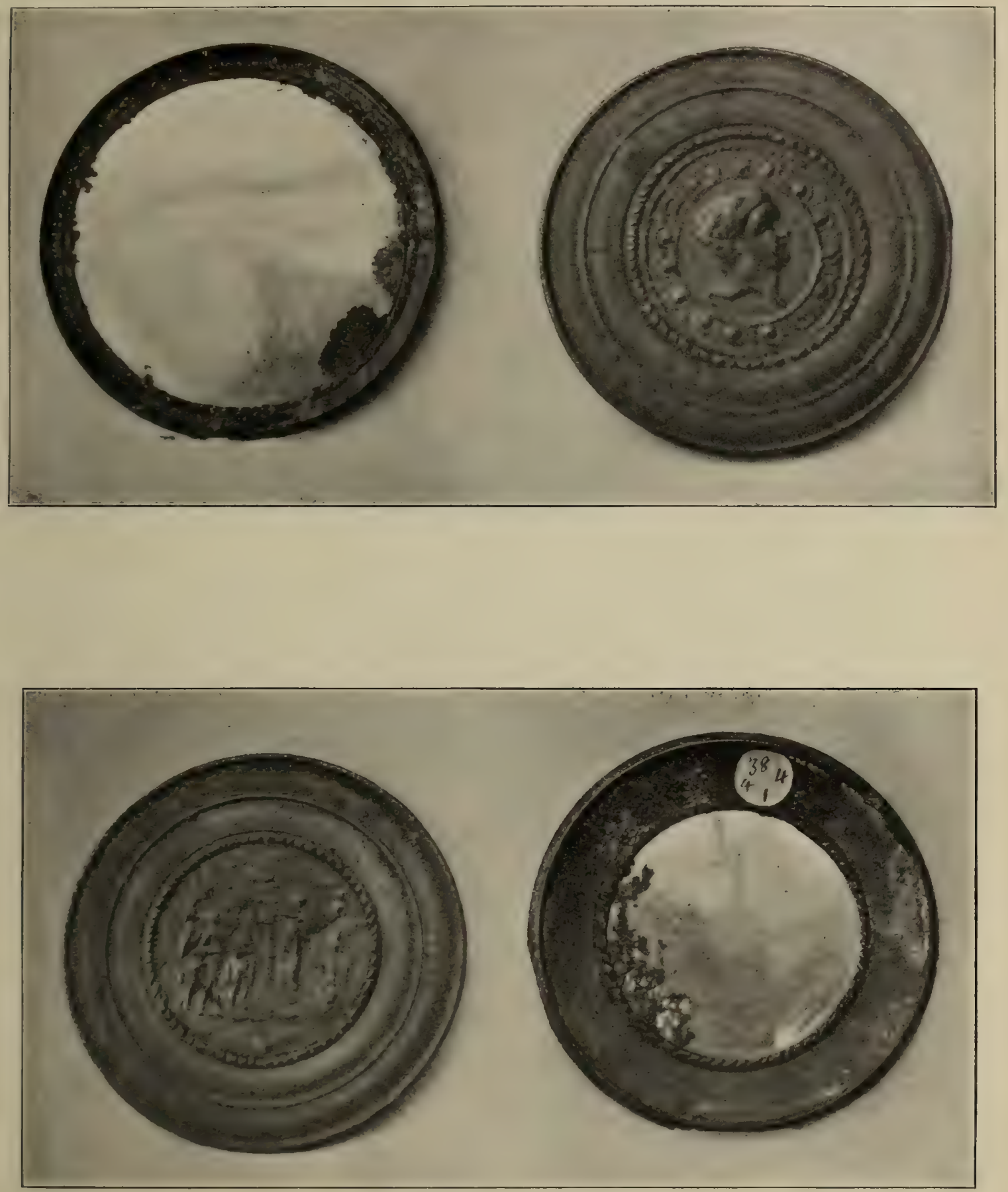

Mirror Casf found at Codpenham (2 $\frac{1}{2} \mathrm{in}$, diam.) 



\section{ROMANO-BRITISH SUFFOLK}

Cavendish.-A sepulchral urn was found here [East Angl. N. and Q. ii, 29].

CLARE.-About a mile from the town of Clare, in constructing a roadway in 1864 , on the glebe land where the railway leaves that land in the direction of Cavendish, the workmen came upon a quantity of Roman urns about I ft. 6 in. below the surface. Seven or eight were found within the space of a few yards. One only had any ornament on it ; they were of quite common material, and all full of bones and ashes. Near where they were discovered is a plot of broken ground called the 'Dane pits' [East Angl. N. and Q. i, 203; ii, 29]. This discovery is noted on O.S. 6-in. lxxi, NE., and described as having been made on the Suffolk bank of the Stour where the railway (Cambridge, Haverhill and Melford line) crosses the river. A small figure of a dancing boy or Mercury, in bronze, was found at Clare [ 7 ourn. Brit. Arch. Assoc. xxi, 343 et seq.].

Cockfield. - About a mile north-east of the church is Colchester Green, and near it a farm where in 1834 some mounds were to be seen. Perhaps on this site, but certainly only a quarter of a mile from Colchester Green, Roman tiles had been found about $2 \mathrm{ft}$. under the surface. A fragment of one of these, which was preserved, showed part of a turned-up edge and a scored surface, and was apparently part of a fue tile [Davy, Suff. Coll. B.M. MSS. i, 19077, fol. 243]. Within an encampment known as the Warbank was found a small bronze bust of a woman, the hair plaited in twelve twists and fastened on the top of the head with a bow; also the bronze handle of a knife or mirror with a crowned female head at the end [fourn. Brit. Arch. Assoc. xxxiii, 117 ].

Coddenham.- Traces of a Roman road were discovered in 1823 on the property of Sir William Middleton, bart., by labourers employed in draining to the west of the turnpike road from Ipswich to Scole (the Pye road), nearly 7 miles from Ipswich. This ancient road was traced in almost a straight course to a former ford over the River Gipping, through a field retaining the name of Sharnford and by a cottage called Sharnford Cottage, and across another field named Causeway Meadow, and so onwards in a southerly direction towards Great Blakenham Church. When this road was cut through, it was found to consist of a very solid stratum of stone and gravel about 6 or $7 \mathrm{yds}$. wide. In December 1823 , to the west of this road and near the River Gipping, were discovered at some $2 \mathrm{ft}$. from the surface a Roman urn of coarse slate-coloured ware containing human ashes, and close to it a smaller vase of fine light red ware. With the urns was turned up a small double bronze mirror $2 \frac{1}{2}$ in. in diameter, having on one side a head of Nero and on the other a general addressing his soldiers. This was presented by Sir W. Middleton to the British Museum in 1838 . The remains appear to have been deposited in the earth uninclosed in any cist. A further search showed that the ground was full of potsherds of different kinds to a depth of $3 \mathrm{ft}$. Amongst them were fragments of so-called Samian ware, and pieces of brick and tile were scattered through a great part of the field in which they were found, together with large oyster shells, ashes, and some slag. A wall was uncovered also, about 30 yards in length and $2 \mathrm{ft}$. in thickness, running in a direction nearly east and west. Probably the site was that of a villa. The coins found were : a supposed one of Claudius (A.D. 41-54), a middle brass of Nero (A.D. 54-68), one of Vespasian (A.D. 69-79) and one of Trajan (A.D. 98-II 7), a silver denarius of Crispina (A.D. 178-82), and three small brass, one of Magnentius (A.D. 350-3), one of Valentinian (A.D. 364-75), and one of Constantius I (A.D. 305-6) [Gent. Mag. 1824, pt. i, 261; ibid. 1825, pt. i, 291-3;Arch. xxvii, 359, 360; Chart, Watling Coll. in possession of Miss Nina Layard]. In 1843 a denarius of Postumus (A.D. 259-69) and some small brass coins of Constantius I (A.D. 29I-306), Constantine I (A.D. 306-37) and Constantius II (A.D. 337-6I) were found near the river, at a place called Sharnford, about a hundred yards from the previous discovery [Numis. Chron. vi, I04].

Combs.-A patera of so-called Samian ware was found in 1855 , with the potter's mark sIGINIVs. It is now in the Ipswich Museum.

Covenithe. - In the cliff between the Benacre road and the lane leading down to the beach from the village, between 1871 and 1876 , was exposed by a fall of the earth what looked like half a square well. One half of this well still remained in the cliff, the other had fallen and been washed away by the sea. It was not constructed with masonry, but with boards in the usual Roman fashion, the boards having ties crossing the angles, and it was filled with earth for some feet below the present ground level. In April I 890 another of these wells came to light, under the end of the road which terminates abruptly at the edge of the cliff. Very little of the woodwork was visible, but the beach was said to have been strewn with fragments of pottery which it had contained. Some few spikes or nails and the bones of some small animal were the only other contents of these wells. They were, however, never properly examined [Proc. Suff. Arch. Inst. vii, 303-4]. (See find of a similar well at Easton Bavents near Covehithe.)

Cowlinge. - A small bronze figure of Mercury, the eyes in white metal, found at Flempton Hall Farm, one of Hercules, and a mask of dark grey ware [Tymm. Coll.] are all in the Museum, 


\section{A HISTORY OF SUFFOLK}

Bury St. Edmunds. Three coins were found here, one brass of Maximin (A.D. 235-8), one brass of Magnentius (A.D. 350-3), one silver denarius of Antoninus Pius (A.D. I38-6I) [Proc. Suff. Arch. Inst. ii, 211 ], and some Roman flue tiles were found at Kirtlinge (? Cowlinge) [ibid. i, 232].

CReeting.-A black urn and red pot-shaped vase were found here [Chart, Watling Coll. in possession of Miss Nina Layard].

Debennam.-Here was found a silver coin of the Emperor Carausius (A.D. 286-93). On the reverse are two figures holding a standard, and circumscribed EXPECTATE veni [I Iswich fourn. 9 February 1828 ; Gent. Mag. 1828, pt. i, 164].

Dennington.-In a field south of Dennington Place Roman coins were found in 1843 [O.S. 6-in. xlviii, NE.].

Dunwich.- "The antiquity of this place is rendered very probable by this, that "Roman" coins are often found here...' [Lysons, Mag. Brit. (1730), v, I9I]. 'Mr. T. Martin exhibited some brass instruments, supposed to be a species of fbulae or bodkins, and a young Hercules in lead (?) which was found in a burying-ground near Dunwich' [MS. Min. Soc. Antiq. viii, 67]. In the collection of Mr. Frederick Barne of Dunwich, amongst other relics of Dunwich is a large brass coin of Nero (A.D. 54-68), well preserved [Suckling, Hist. of Suff. ii, 262]. The Rev. Greville Chester said that in June 1858 he observed

in various places in the face of the cliff, within $5 \mathrm{ft}$. of the top . . . numerous pieces of coarse blue, black, and brown pottery, some of which were manifestly of Roman manufacture, while other fragments were perhaps Saxon. Of one variety I found fragments lying together almost enough to form an entire urn. Animal bones, with teeth of the ox, sheep, and deer, were also numerous. In one place I discovered a rounded seam of black earth full of bones, ashes, charred wood, cockle, oyster, and whelk shelis, with broken fragments of Roman pottery. This apparently was an ancient rubbish pit. I saw an imperfect small brass coin of the Lower Empire, which was picked up near this spot.

Among the objects collected by Mr. Chester on this site were some keys, apparently Roman, especially one of bronze, and a bow-shaped fibula [Arch. Fourn. xv, 155]. It has been suggested that Dunwich was the site of the station Sitomagus in the gth Iter of Antoninus, as it answers to the distance, 32 miles, from Venta Icenorum (Norwich or Caister ?) [Wright, Celt. Rom. Sax. 135; Fourn. Brit. Arch. Assoc. xxxii, 216, 217]. Numerous fragments of Roman tiles and bricks are to be seen in all the ancient edifices of the place [ibid.]. The inclosure of the Grey Friars abounds in fragments of Roman tile and other débris [Arch. Fourn. xxxv, 82]. In the Museum at Ipswich are some objects of bronze, doubtfully Roman.

EAston.-Near Wickham Market. A Roman vault or grave was found in March 1850, at 'Rose's pit, by men digging for gravel. The vault was $4 \mathrm{ft}$. from the surface and about $2 \mathrm{ft}$. deep and $\mathrm{I} \mathrm{ft} .6 \mathrm{in}$. wide. In it were five urns, some bones and teeth; and a horn. Everything was destroyed. In March 1851 another urn was found in this pit, and in 1853 seven or eight more small Roman urns, one of which was full of bones and ashes. These fell to pieces on exposure to the air. From the same pit was picked up a bronze fibula of common type [Fourn. Brit. Arch. Assoc. viii, 159-60]. Some Roman coins with a fint arrow-head were turned up in a brickfield here; the coins were destroyed by the plough [Fourn. Brit. Arch. Assoc. $x, 3^{8} 3$ ].

EAston Bavents. - The remains of a boarded Roman well were observed in the cliff on the seashore in the autumn of 1888 , about 10 yards north of where some old farm-houses formerly stood. A considerable quantity of pottery is said to have come from this well [Proc. Suff. Arch. Inst. vii, 304].

Elveden.-Excavations were made in 1888 -9 on the site of an ancient burial ground near Elveden, and three large urns of brown ware were discovered. They had been deposited with their necks downwards, and covered with a circular situla, of which some of the metal mountings remained. Burnt bones were found outside the circle of the situla, but none were with the urns. Some ornamentation of Celtic style on the mountings led to a controversy as to the date of the remains, but it was concluded that they were Roman [Fourn. Brit. Arch. Assoc. xlv, 81 ; Arch. Rev. iv, 68 ; Antiq. xix, I81].

Exning.- 'Mr. Martin had some Roman coins and fibulae found here in 1720 ' [Camden, Brit. (ed. Gough), ii, 8I ]. Several coins of Trajan (A.D. 98-II7), one of Maximian (A.D. 286308), one of Faustina (A.D. I $38-4 \mathrm{I}$ ) were found on Newmarket Heath in the I 8 th century [Excursions in Suff. i, 19,91]; and a fibula and coin, now in possession of Lord Lowther, were found in levelling the course [MS. Min. Soc. Antiq. xxxvi, 42]. Several interments were found in a gravel pit in Exning parish in 1832 and the following years. In 1832 pieces of 


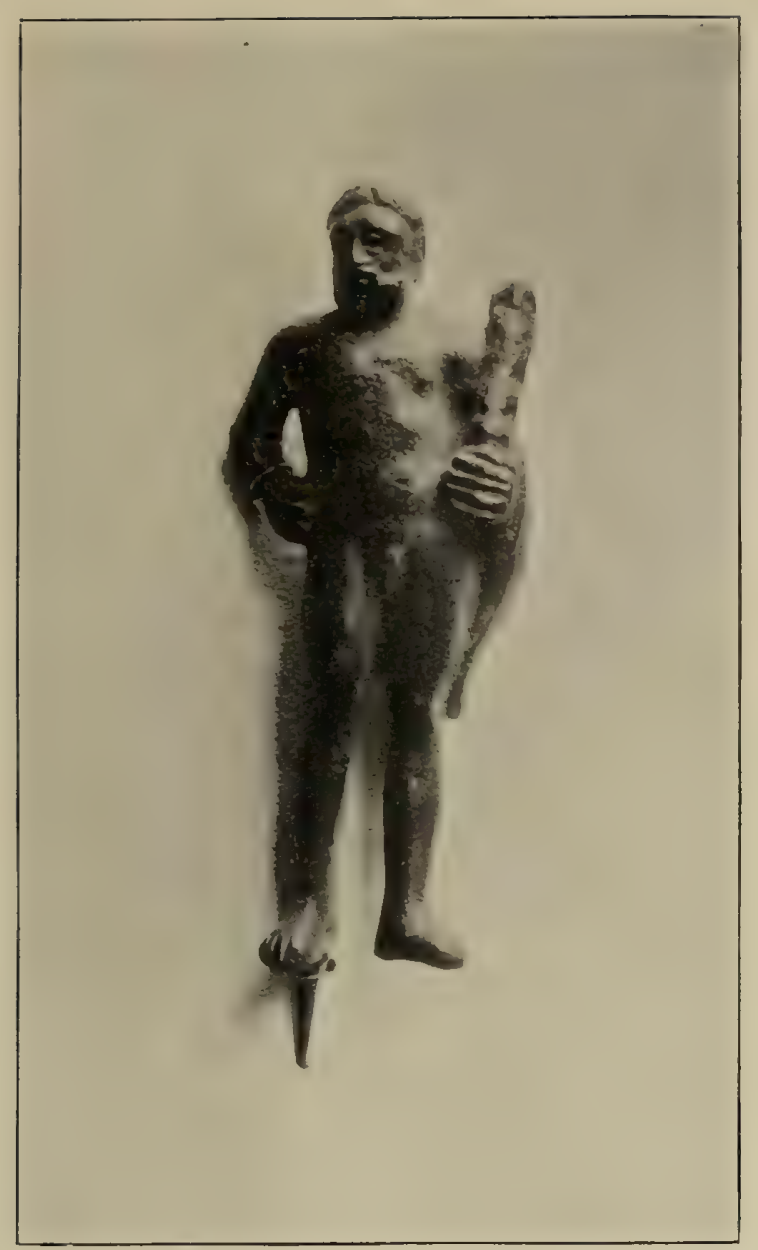

Bronze Lar or Household God (Hercules) yound at Cowlinge $\left(\begin{array}{l}1 \\ 1\end{array}\right)$

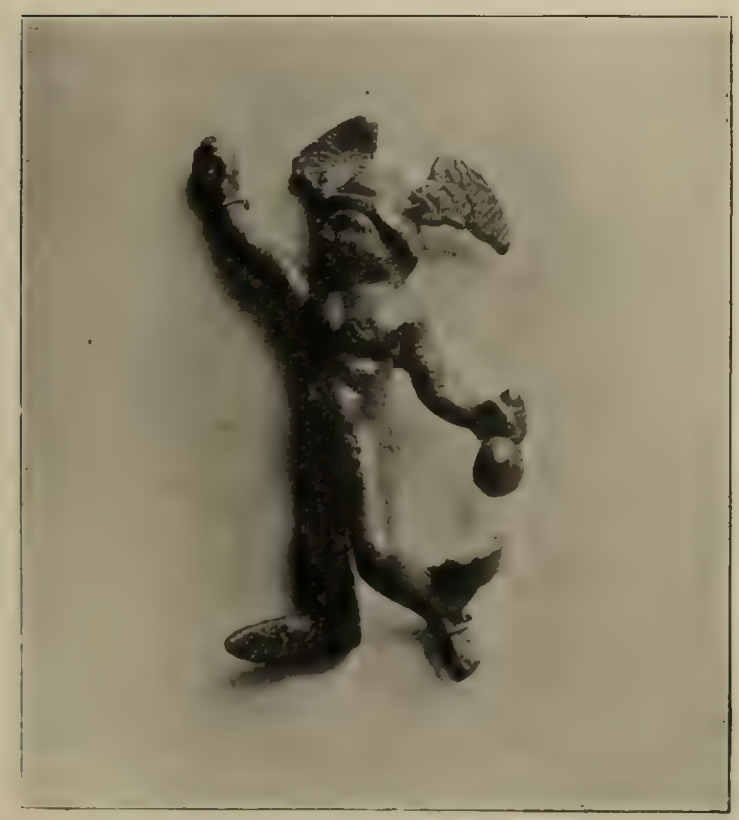

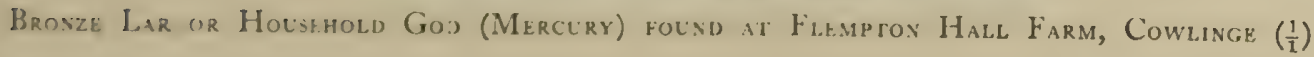





\section{ROMANO-BRITISH SUFFOLK}

coarse black ware mixed with large sandy grit, and two small vases filled with ashes and bones, were turned up, and at the same time appear to have been found five or six bronze objects resembling padlocks with a loop at the top for suspension, but with a circular hole through the centre. They were all of different sizes, the metal of which they were formed was very thin, and they were filled with a light-coloured earth. Besides these were found an object like a carpenter's gouge, spear-heads, an arrow-head, pieces of metal possibly parts of armour, and masses of metal apparently fused by fire. In February 1833, in the same spot, two more small earthen vessels were discovered, one 7 in., the other 9 in. high, filled with burnt bones, together with a 'small stone pot,' and three days later came to light a nearly perfect skeleton. It was found about $2 \mathrm{ft} .6 \mathrm{in}$. from the surface of the ground, lying upon its face, near the vessels just mentioned. Round the neck was a necklace of beads of ring-like form, of glass, the colours purple, yellow, and light green. One was veined and opaque, another opaque, formed in ridges and rough in texture. A small bronze tube was with these, probably the fastening of the necklace. The arm of the skeleton was encircled by 2 bronze bracelet. At a slightly later date and near the same place two more urns, one of which was $6 \frac{1}{2}$ in. high, filled with bones, were dug up together with a patera $6 \frac{1}{2}$ in. in diameter of so-called Samian ware, with leaves on the rim. Other articles from the same site, and from a long trench at a depth of $10 \mathrm{ft}$. (?) were discovered in 1834 . The list is as follows : a small glass bottle, very thin and opalized; a ring of wood, very black (probably Kimmeridge shale); a bronze pin and chain ; various rings of bronze differently ornamented, and one of twisted wire; many beads, some iron nails, and a fragment of a black pot. The greater number if not the whole of the objects described were purchased by Mr. Davy [Suff. Coll. B.M. MSS. iii, 19178, 216, 221; xix, 19095, 87, 116-18]. A vase of the shape called thumb-pot; a bracelet of bronze with three ring-like beads threaded on it; a vase of light brown earth and a small globular vase ornamented with rows of dots in slip, are all figured in Suff. Illus. (Fitch Coll.), xii. In the Museum, Bury St. Edmunds, are fragments of figured so-called Samian ware; three fragments of greyish ware with stamped ornament; a chain (Acton Coll.); a necklace of glass beads and amber; the top of a bottle; black ware; a fragment of grey ware with incised circles. In the Museum, Ipswich, is a large thumb-pot. In the British Museum are a pot of grey ware with lines of dots in slip; an upright pot of reddish drab ware; a jet spindle-whorl; a lead pin; a portion of a bone comb; a bronze pin; seven armlets; a neck-ring; and a necklace of jet and glass beads. The smaller objects were purchased in $1832-3$.

Eyr.-In 1733 a gold coin of Honorius (A.D. 395-423) was found at Hoxne near Eye [MS. Min. Soc. Antiq. ii, I 4]. A hoard of gold coins was discovered here, of which the following is the first account: "One day this week, as two labourers were digging in a sand-pit at Eye . . . they struck their spades against a case covered with lead, within $2 \mathrm{ft}$. of the surface, which gave way, and discovered upwards of 600 Roman gold medals ... They are of the purest virgin gold as fresh as if just coined ... We hear Mr. Pitt, the proprietor of the soil, has put in his claim' [Ipswich Fourn. 19 May 1781]. A further notice speaks of these coins as of the reigns of 'Valentinian (senior and junior) [A.D. 364-92], Gratian (A.D. 37583), Theodosius (A.D. 379-95), Arcadius (A.D. 383-408), and Honorius (A.D. 395-423)' [Camden, Brit. (ed. Gough), ii, 90]. A mention is made that human bones were found nea this treasure by Gillingwater [Hist. of Lowestoft, 1790, p. 38 note; MS. Min. Soc. Antiq. xviii, 2 (1781); Numis. Chron. (Ser. 3), xi, 10]. The hoard is said to have been turned up on Clint Farm [Proc. Suff. Inst. of Arch. v, 109], and the spot is thus noted on the O.S. maps: 'Roman coins and coffin found about A.D. 178I' [O.S. 6-in. xxxvi, NE.]. A small wingless Cupid in bronze $4 \mathrm{in}$. high was found at Eye (possibly Roman) [Suff. Illus. (Fitch Coll.), xi]. Remains of a Roman building were discovered in 1857 [East Angl. N. and Q. i, 249; O.S. 6-in. xxxvi, NE.].

Felixstowe.-Here was a Roman station known under the name of Walton Castle, formerly existing on land near the village of Felixstowe, which has long been washed away by the encroachments of the sea (see p. 287). The site of the cemetery attached to it still remains.

The following are the principal authorities for the former existence of the station :-A communication from Dr. Knight to the Society of Antiquaries of London, which has been inserted in the manuscript Minute Book of that society $[i, 71,2]$. The letter is dated 28 November 1722 [A Tour in the Whole Island of Britain, by a Gentleman (ed. 3), 39-40]. Mr. T. Martin, in his account of the remains, which is dated 16 September 1725 [Cburch Notes, i, 185], says, 'A bout half a mile from the town (of Felixstowe) are the ruins of a Roman fortification upon the brink of the clift (great part being already fallen down, a few years are likely to put a period to the whole), 'twas built very substantially with rock-stone and Roman brick.". . . . . . . . . . The portion of this wall of 


\section{A HISTORY OF SUFFOLK}

the station, still standing in 1740 , and the site generally, are described by J. Kirby [Suffolk Traveller (ed. 2), 89-9r]. Camden mentions Walton Castle, but not as a Roman station. Gough in his 'Additions' to his edition of Camden speaks of 'a castle (at Walton), the foundations $187 \mathrm{yds}$. long and $9 \mathrm{ft}$. thick . . plenty of Roman coins and other antiquities found there' [Camden, Brit. (ed. Gough), ii, 85]. The mention of the length of wall remaining is probably taken from Kirby. In Grose's account accompanying his text a view apparently taken in 1766 is given showing the remains of the wall lying upon the beach [Grose, Antiq. of Engl. and Wales; Suppl. ii]. Besides the view of the ruined wall in Grose's account others may be mentioned. There is a small sketch in Indian ink entitled 'Remains of Felixstow Castle I 780,' the drawing being by Isaac Johnson, in vol. ii of Suff. Illus. (Fitch Coll.). Another drawing in pen and ink, washed, was in the collection of the late Mr. Eyre of Ipswich. It purports to be a copy from a print in the possession of Mr. Oxburgh of Hartcliff in Kent, the print itself having been executed from a drawing made in I 700 by Thomas Bates of Ipswich. A second copy of this print is in the collection of Miss Nina Layard of Ipswich. Neither print nor original drawing is now traceable. These copies show the ruins of a circular bastion on the edge of the cliff, evidently that of the one at the south-west angle of the station, with a small portion of the south wall running seawards, and overhanging the precipice. Masses of the same wall lie upon the beach. Mr. Eyre also had a tracing from a pen-and-ink outline drawing washed with colour, of much earlier date than the last mentioned. Upon the original drawing there appears to have been this inscription in writing of the $17^{\text {th }}$ century : 'E Pros (?) Walton Castel,' and it was signed in one corner 'John Sheppard 1623.' The sea front of the station is represented entire, the edge of the cliff being in the foreground. A circular bastion is seen at each angle, and a wide break about the centre of the front marks a gateway. Beneath the view is a rough plan indicating that the walls of the station formed a parallelogram with a bastion at each angle. The drawing from which this tracing was made is not now to be found, and judging from the tracing it had the character of a sketch of the I 8 th rather than of the 17 th century, although the writing on it seemed to be of the latter period. Unless something more could be ascertained respecting the original drawing from which the tracing in question was made, its value as an authority for the condition of the remains early in the 17 th century must be considered doubtful. Many objects of the Roman period have been found about the site. Beginning with coins, it may be mentioned that Davy [Suff. Coll. B.M. MSS. I 9087, fol. 53-60] described a collection made at Felixstowe in the years $1742-3-4$, in full detail. The coins range from Pompey the Great (ob. 48 B.c.) of whom there was one example, to Honorius (A.D. 395-423), and their total number amounted to 420 . This collection was the property of the Rev. W. Brown of Saxmundham, and at the sale of his goods in 1827 it passed into the possession of the Rev. W. Layton of Ipswich. Coins were found at a later date, of Victorinus (A.D. 265-8), Tetricus (A.D. 268-73), Urbs Roma, Valens (2) (A.D. 364-78), and Gratian (A.D. 375-83) [Fourn. Brit. Arch. Assoc. xiv, $27 \mathrm{I}]$; also a gem of oval form, possibly a cornelian, engraved with a figure wearing a petasus, and with a panther skin hanging from one arm. In the right hand it held a poppy head and wheat ear, and in the left a pedum [ibid. 339]. A find is recorded in 1749 of very small Roman coins and some pieces of metal, as if melted in the fire, near Bawdsey Haven [MS. Min. Soc. Antiq. v, 241]. During the process of digging for coprolites in the field known as the Park near Felixstowe Church, many objects of the Roman period were turned up. Such as were noted were as follows:-Vase of so-called Samian ware, with hunting scenes and ornament of oak leaves and acorns (purchased ' $y$ ' the South Kensington Museum), flue tiles, amphorae, lagenae, a small glass phial, bronze pins, tweezers, a speculum, several fibulae and gold rings, silver rings, some set with stones, a gold chain of twisted wire, and a bronze bracelet, a bronze disk enamelled (a circular fibula?), a bronze enamelled tag or fibula, and other objects in the same metal; coins of gold, silver, and bronze, of Severus (A.D. 222-35), Gordian III (A.D. 238-44), Gallienus (A.D. 253-68), Victorinus (A.D. 265-8), Constantine (A.D. 306-37), and Arcadius (A.D. $383-408$ ). There was a great quantity also of mussel, periwinkle, and cockle shells, and of snail shells. Many sepulchral urns were dug up containing bones and ashes, closed in some instances with a cover, in others only with a stone [Proc. Soc. Antiq. (Ser. 2), xi, I2, I 4 : 'Communication from Mr. E. St. F. Moore of Woodbridge']. In 1843 Prof. George Henslow and his father found 'a sort of kitchen midden in the London clay cliff near Felixstowe.' Rough pottery, bones, cores of deer horns, a skull, rusty nails, and a so-called Samian vase, were among the objects discovered in it [Antiq. xlii, 283 (1906)]. The Roman objects of bronze in the collection of Lord Londesborough from this site are a bust of Mercury and several keys [Antiq. Etching Club Publ. iii, pl. 25]. In the Ipswich Museum there are three flue tiles, perfect, one of large size with reeded ornamentation; vessels of ordinary ware, some probably cinerary urns; a large thumb-pot of unusual size, and a harp- 


\section{ROMANO-BRITISH SUFFOLK}

shaped fibula $2 \frac{1}{2}$ in. long. Here are preserved an arm and a finger bone from one of the skeletons found by Prof. Henslow, together with bronze bracelets. The objects added to the museum in 1897 were fragments of vases of Durobrivian, Upchurch, and so-called Samian ware (all plain); pieces of a glass vessel, one fragment of window-glass, and small portions of roof and flue tiles. The animal remains consist of fragments of horns of red deer, \&rc, and there are some oyster shells.

In the Norwich Museum (Fitch Coll.) are preserved keys, tags of belts, tweezers, fibulaetwo perfect, two in fragments-nails, rings, a small bronze column 3 in. high, a figure of a goat, a head of an animal, two small busts, one perhaps of Mercury, a leaf, a portion of a vase, and fragments of ligulae. All these bronzes appear to be water-worn.

In the Bury Museum are a small vase with black glaze, presented by the late Lord John Hervey, 1853; needles and bone pins (Acton Coll.); implement in bone, probably a mesh gauge; jet pins; a double comb in bone, one button in shale and one in jet.

In the British Museum are bronze studs found here in a leaden coffin in 1853 ; the central band of an enamelled buckle; a bronze toilet implement; a brooch; a pin; beads; an armlet; a necklace of glass beads and shell found in a glass urn with bone bracelets in 1853 ; glass beads, one being engraved; a small rude flanged pan of dark drab ware, a pot of grey ware ornamented with groups of dots in slip, a small black vase with glazed bands; a small pot of rough reddish grey ware; and a reddish-grey vase with black bands. A vase of so-called Samian ware of oval form has the body ornamented with a wide band and simple marginal lines, this band having vine foliage, amongst which are interspersed figures of stags; the animals appear to be of slip, and resemble those seen on Durobrivian ware. This vase was given by Sir A. W. Franks in I88I [For site see O.S. 6-in. xc, NW. and SW.].

FrimTon.-Half a mile to the north of Fritton Broad, in a small hillock, pieces of pottery are occasionally found [Suckling, Hist. Suff. i, 353].

Glemsford.-A first brass coin of Antoninus Pius (A.D. 138-61) was found here [Proc. Bury and West Suff. Arch. Inst. i, 235].

Grundisburgh.- - Here were found a small pan of reddish cream-coloured ware, the top of the neck of a vase with oval mouthpiece, so-called Samian, and an ampulla of buff ware. A flat circular glass bead was discovered in 1848-50 [Davy, Suff. Coll. B.M. MSS. iii, 19178, 57]. Two terra-cotta lamps have also been found, and part of a third [Suff. Illus. (Fitch Coll.), ii].

HAVERHILL. - In the summer of $\mathbf{1 7 5 9}$, between Withersfield and Haverhill, a cemetery appears to have been discovered. The site of it was in a disused lane, beside the old Roman road from Cambridge to Colchester, near a rivulet under the wood by Haverhill Castle. In digging for gravel at this spot many cartloads of human bones were removed besides complete skeletons. In the same place the earth was black with the ashes of burnt bodies, and several large glass urns had been found. The following is a list of objects found on this spot in the possession of Mr. Barnard, then rector of Withersfield: A large white transparent glass vase, capable of holding 2 gallons, with a ribbed handle and short neck; a small bottle of transparent white glass, filled with an unctuous substance; another of the same character; a round squat vessel of transparent glass; a small patera of so-called Samian ware standing on a foot, the rim ornamented with sprigs and leaves (it had a potter's mark which was not recorded); another, without a foot, and a portion of a third, of the same ware; a large urn of whitish ware of coarse texture full of burnt bones; another of the same ware with handle and straight neck, and a small ordinary lamp of red ware. Besides these there were many pieces of urns and paterae with ashes and partly burnt bones [Coles MS. B.M. MSS. v, 3I, fol. 91 $b$, 92, 92b, 93 ; MS. Min. Soc. Antiq. xi, $3^{8}$ (1869)]. No coins were discovered.

HAWKEDON.-An amphora of globular form deprived of neck and handles, within which were two fragments of statuettes of pipeclay, both representing a nude type of the goddess Venus, was found in draining the Glebe Farm [Proc. Suff. Arch.Inst. vi, 2 pl]. A fragment of one of these statuettes and the amphora are in the Museum, Bury St. Edmunds.

HAzLEWOOD.-In May 1907 some excavations were made on 'Barber's Point,' a small sandy mound near the River Alde, about 3 miles from Aldeburgh. Finds of rough pottery, oyster shells, and other indications had led to the suggestion that a small settlement of some kind had existed on the spot. No foundations were discovered, but a quantity of fragments of so-called Samian and other ware, some bronze objects, iron nails, and hypocaust tiles were found, as well as one stone spindle-whorl, a horse-shoe, masses of oyster and other shells, bones of animals and birds, charcoal and burnt earth. It is thought possible that there may have been a villa on the common near this site. The so-called Samian ware has been identified by Mr. R. A. Smith, F.S.A., as follows: (I) A small patera, made at La Graufesenque in the is century. The potter's name on it is Quintrs in a lozenge. The dish is $5 \frac{1}{4} \mathrm{in}$. in diameter, 2 in. high. 


\section{A HISTORY OF SUFFOLK}

(2) The base of a flat bowl, with $T_{A s c}$ on it, made at Lezoux. The name appears at Aldborough (Isurium) in Yorkshire as TAscillI ; other specimens found at Colchester and in London have been read as T Ascilli. (3) A smaller fragment measured $\frac{3}{4}$ in. in lower section and $I$ in. in upper section. (4) Part of a two-inch vase; the potter's name on it was obliterated. (5) Portions of a flat dish, $\mathbf{I} \frac{1}{2}$ in. across. There were also a large portion of an urn of dark grey ware and a mortarium in two pieces, besides quantities of smaller fragments [Proc. Suff. Arch. Inst. xiii (1), 25 (1907); Antiq. xliii, 243-4]. The bronze objects were as follows : One small bronze bodkin with a knob head; one thick bronze ring with two nicks in it which may have been caused by articles suspended from the ring ; one pair of bronze tweezers, with a circular pattern on the sides and a little loop of bronze wire at the upper end. A more interesting find was a small diamond-shaped bronze locket, with a design of small circles on the cover, and traces of blue enamel on it. The hinge and catch worked well, the under side had four perforations in it, and a square notch on each of the sides showed where a chain may have been passed through it. These lockets were originally thought to be seal cases, but were probably either amulets or perfume cases. There are twenty-nine specimens from different parts of England in the British Museum. Of these one is from Suffolk, but from what precise locality is not known. Six specimens have been discovered in the county and are preserved in different places, two in the Cambridge Museum. Five of them were found at Wangford, Eriswell, Icklingham, Dunwich, and Hazlewood (Aldeburgh) [Proc. Suff. Arch. Inst. xiii, 25 et seq.; Antiq. xliii, 243-4; N. F. Hele, Notes or Fottings about Aldeburgh, I 870].

Helmingham.-Roman remains are said to have been found here, and were reported by the Rev. G. Carden. The account given is not very definite, but the remains of a cemetery seem to have been discovered in a little wood called 'The Wilderness,' adjoining the rectory garden [Fourn. Brit. Arch. Assoc. xxi, 267 et seq.]. A large number of skeletons, in very shallow cists, some only $18 \mathrm{in}$. deep, were found. The spaces between the cists were filled in with calcined earth and charcoal, the graves themselves being cut in the natural yellow clay and fint gravel. In the made earth above were many fragments of Roman pottery and querns, a bronze fibula, and a pair of bronze volsellae, but in the cists with the bodies only jaw-bones and teeth of animals, chiefly of bos longifrons and of the hog. No traces of clothing, ornaments, or coffins of any kind were discernible. Some of the skeletons showed signs of previous mutilation, such as a severed head, \&c. Two had children of five or six years old resting on their right arms. It is said that there were several hundred of these bodies, lying on their backs close together, with feet to the east, in a remarkable state of preservation. The cemetery extended for some distance under the rectory stable and garden to the churchyard [Illus. Lond. News, 2 July 1864; 31 March 1866]. A leaden ampulla and fragments of urns and scattered human bones were found in another place [Proc. Soc. Antiq. (Ser. 2), ii, 420], and in 1844 a gold coin of Vespasian (A.D. 69-79) was discovered [Numis. Chron. vii, 192].

A common red pan and a black olla from this site are shown on the chart in Watling Coll. in possession of Miss Nina Layard.

HerRingfleEt.-A Roman bronze vessel, with maker's name, QUattenvs F, engraved on the handle, was found in July I $74^{2}$ and presented to Norwich Castle Museum by Col. H. M. Leathes, of Herringfleet Hall [Gent. Mag. 1844, pt. i, 634 ; Suff. Illus. (Fitch Coll.), iii ; Arch. Fourn. xxxvii, I 5 I ; xxxviii, 301 ; Proc. Suff. Arch. Inst. iii, 406 et seq.; Ephemeris Epigraphica, vii, no. I167; Proc. Soc. Antiq. (Ser. 2), xvi, 237 et seq.].

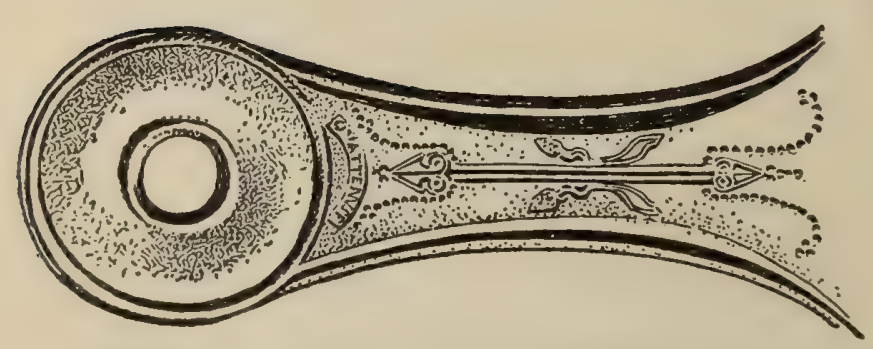

Handle of Bronze Vessel prom Herringfeet

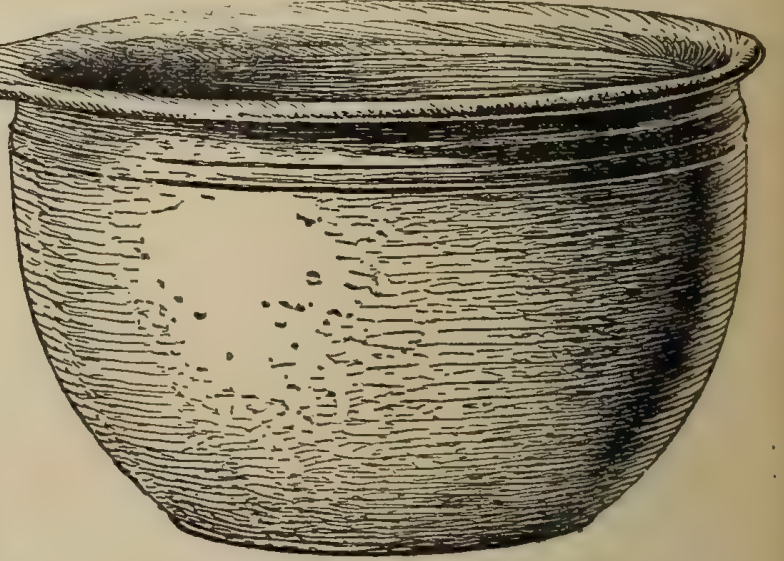

Bronze Vessel from Herringferet 


\section{ROMANO-BRITISH SUFFOLK}

HolBrook. - In I 841 a discovery of coins was made at Holbrook-second brass of Diocletian (A.D. 284-305), Maximian (A.D. 286-308), Constantius Chlorus (A.D. 305-6), Constantine I (A.D. 307-37), Constantius II (A.D. 337-61). They were in good preservation [Numis. Chron. iv, 64; Ipswich fourn. 20 March 1841]. In 1853 four third brass coins-(1) Maximin Daza (A.D. 308-I3), struck at Trèves; (2) Constantine the Great (A.D. 307-37), struck at Trèves ; (3) another struck in London; and (4) a different mintage of the same coin-were found on the banks of the Stour [Proc. Suff. Arch. Inst. i, I 5 I].

Hollesley. - A vase of grey ware with broad band of incised waved ornament, now in the British Museum, was found here.

ICKLINGHAM. - The following discovery is recorded by Salmon, who says: 'A bout three years ago a Leaden Cistern was found here by a ploughman, the share striking against the edge of it. The Treasure it had concealed was gone. The Cistern is in being; it contains about sixteen gallons, perforated on each side for Rings to lift it by. There is ornamental work on the Outside of it, imitating Hoops of Iron, but cast with the Thing itself. On one side is a Mark A, perhaps intending the Measure or the Use of it.' This cistern might possibly have been Roman [Salmon, $A$ New Surv. of Engl. (1730), i, 158 et seq.]. In I 720 Roman coins and fibulae were found, three coins of Marcus Aurelius (A.D. I6I-80), others of Victorinus (A.D. 265-8), Tetricus (A.D. 268-73), and Honorius (A.D. 395-423) [MS. Min. Soc. Antiq. i, 35, $173(1725)$ ]. A gold ring, exhibited at a meeting of the Society of Antiquaries of London, was picked up in a field between Mildenhall and Icklingham with a figure on it, perhaps of Mars, holding a Victory in his hand [MS. Min. Soc. Antiq. xxxv, 72]. Mr. Acton exhibited to the same society a service of pewter, which consisted of one large flat round dish, two very small dishes, two deeper round dishes, one square dish, one amphora, two standing dishes with octagonal borders, and one little pan, found in 1839 by labourers trenching heath land; these articles lay I ft. $6 \mathrm{in}$. beneath the surface, and seem to have been hastily buried. Two second brass coins, illegible, were turned up at the same place [Arch.xxix, App. 389 ; Proc. Soc. Antiq. (Ser. 2), iv, 430]. A funnel-shaped vessel of bronze, which belonged to Mr. E. Acton in 1850 [Antiq. Etching Club, ii, pl. 46] was found here, and an urn of large size was discovered in $185 \mathrm{I}$ in a sand-pit, from which pit many skeletons had been dug up at various times [Proc. Suff. Arch. Inst. i, 343]. There were exhibited from this site in a temporary museum at the Ipswich Congress of the British Archaeological Association two silver rings, one silver fibula, ten bronze fibulae, five bronze bracelets, one glass ring or bracelet (black), and one string of beads [Fourn. Brit. Arch. Assoc. xxi, 345; C. Roach Smith, Cioll. Antiq. iv, 95, 96]. There is mention of a coin of Honorius (A.D. 395-423) being found here [ibid. xxv, 82]. From the most southerly field of Dix's Charity land were turned up by a man ploughing in July 1877 fragments of a vase of Durobrivian pottery, and a hoard of coins, of which the full number may have been about 400. The coins were all silver, and generally in good condition. Shards of different kinds of pottery were scattered about the spot where they were found. The following is the list of those which were saved:-Constantius I (A.D. 305-6), I ; Julian (A.D. 360-3), 19; Jovian (A.D. $363-4$ ), I ; Valentinian (A.D. 364-75), 28 ; Valens (A.D. 364-78), 73 ; Gratian (A.D. 375-83), 4I ; Valentinian II (A.D. 375-92), 9 ; Theodosius (A.D. 379-95), 43; Magnus Maximus (A.D. $383^{8}$ ), 48 ; Victor (A.D. $3^{8} 3_{-8}$ ), 2 ; Eugenius (A.D. 392-4), 11; Arcadius (A.D. $3^{8} 3-408$ ), 51 ; Honorius (A.D. 395-423), 22; in all 349 [Proc. Suff. Arch. Inst. iv, 282 et seq.]. A vase of Durobrivian ware was also found [ibid. 367 et seq.]. The remains of a house discovered in a field called 'The Horselands' were partially excavated by Mr. H. Prigg [Fourn. Brit. Arch. Assac. xxxiv, 12 et seq.]. Objects observed during the excavations included fragments of different kinds of pottery, bones of animals, including those of the horse, ox, goat, pig,

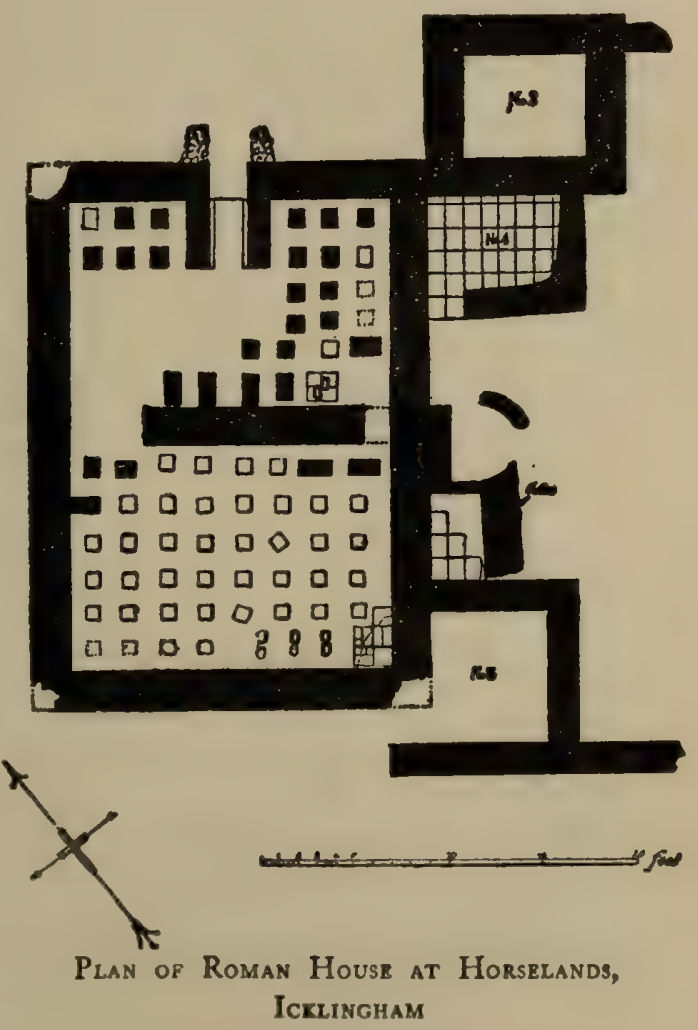




\section{A HISTORY OF SUFFOLK}

fox, and hare ; with these, many shells of a large kind of oyster and of the common snail, and part of a pearl mussel shell. Of metal there were three iron holdfasts, some nails, and an axe-head of Saxon type. The coins discovered were all small brass, and much oxidized, the most important being a Magnia Urbica (A.D. 282-5) and a Carausius (A.D. 286-93) of an ordinary type.

Mr. H. Prigg found a large cemetery near Icklingham, in which the remains were all of urn burial, the urns being of Roman manufacture. Such of the urns as he describes are, however, of Saxon form [fourn. Brit. Arch. Assoc. xxxvii, 154-5]. In the same cemetery was found in April I88r a silver ring set with an intaglio representing a genius holding in one hand a bunch of grapes and in the other two ears of corn [ibid. 214]. There is mention of a leaden Roman coffin with nails about it in a Roman burial-place (possibly the same cemetery) partly explored in $187 \mathrm{I}$, and of a Roman interment at Mitchell's Hill in Icklingham parish [Proc. Suff.Arch. Inst.vi, 56]. On Warren Hill, Icklingham, was found in 1877 a small head of Silenus in high relief, of red ware. It was probably part of horse-trappings or had been worn as an amulet [Antiq. vii, 32 ; Proc. Camb. Antiq. Soc. 1882]. Four tumuli in a row, with a single one some distance south-east of them, are to be seen in a field less than a quarter of a mile from Bernersfield Farm [O.S. 6 in. xxii, SE.], the site of a villa, and at a bend of the road a short distance farther south some coffins found in 1877 , which may be Roman, are noted in the Ordnance maps [O.S. $6 \mathrm{in}$. xxxii, NE.]. In the museum, Bury St. Edmunds, are a jar of bright red ware 6 in. high, $5 \frac{1}{2}$ in. in diameter, and another of the same ware, given in 1860; three vases of red ware, given in 1861 ; a vase of red ware and a black glazed globular urn, I ft. 6 in. high, presented by the Rev. - Gwilt ; a bronze fibula; bronze tweezers; a bronze knife-handle, from a Romano-British cemetery at Stone Pit Hill (Acton Coll.), a bow-shaped silver fibula, a gilt fibula, damascened with silver, found with glass vessels in same cemetery. Five different bronze armillae from the same cemetery (Acton Coll.), a roundel of white clear glass with a male bust in relief and $\mathrm{N} \mathrm{C}$ in raised letters, another with a galley having two rowers (Warren Coll.), a spindle-whorl in basalt $1 \frac{1}{4}$ in. in diameter (Tymm Coll.), a bronze knife and chain. In 1867 fragments of a casket of bronze with rosettes and bands of embossed silver were found and presented to the Society of Antiquaries by Mr. (afterwards Sir) John Evans, F.S.A. [Proc. Soc. Antiq.iv, I30]. In the British Museum are a large pan of black glazed ware; a small one-handled bottle of red ware ; a bowl or basin of coarse red ware; half a pair of bronze compasses; a flat-headed pin; a twisted bronze ring; a boss ; four small keys; two brooches; a weight; eight armillae; a pedestal; a bone pin ; an armilla of Kimmeridge shale ; a square pewter dish with circular sinking, and other plates and dishes, all purchased in 1844 , and a pewter vase of simple form without handles.

IckworTH.-A large pot of Roman coins found here is mentioned by Archdeacon Batteley [Camden, Brit. (ed. Gough), ii, 81].

Ilketshall St. John.-A billon denarius of Postumus, sen. (A.D. 259-69), was found on a farm in the occupation of Mr. J. O. Wayling [East Angl. N. and Q. iii, 90].

INGHAM.-A cemetery appears to have been found about the year I 823 or 1825 on land originally heath, close to the Culford boundary towards the south end of the parish. The land sloped upwards in a northerly direction from marshy meadows, through which flowed a stream running from Livermere through Culford to fall into the River Lark. In a field here, lying on the eastern side of a shallow depression bounded by a ditch, was the site of the cemetery. The report of a labourer of the name of Banham, who afterwards became parish clerk of Ingham, and who as a young man worked on the Hall Farm, on which this spot was situated, is to the following effect:- $-\mathrm{He}$, with other men, one harvest time about the year mentioned, was set, owing to an interruption of the harvest work by wet weather, to dig over the spot in question, and they turned over the surface for the space of 4 rods. A dozen pots were found, and various bottles and other things, which were all delivered to Mr. Worlledge, the then tenant of the farm. No metal seems to have been found with the pottery; only fragments of bone, and patches of dark soil. An urn of red pottery, presumably a cinerary urn, $9 \frac{1}{2}$ in. high, was discovered in $1825,2 \mathrm{ft}$. below the ground, together with a patera of so-called Samian ware, on this farm, which may have come from this cemetery. At a later date the upper stone of a quern of pudding stone was dug up; it was 18 in. in diameter, and showed traces of an iron rim and central point [Proc.Suff.Arch.Inst. i, 230; vi, 52]. The urn is in the museum, Bury St. Edmunds. Another cemetery was discovered in 1873, when the railway between Bury St. Edmunds and Thetford was in course of construction. The site is in a field called Cowpath Breck, west of the road to Thetford, and between it and the farm road to Bodney Barn. Nineteen interments at least were observed, and the bodies appear to have been buried in coffins, the nails of which were found. Interment no. I (close to the fifth milestone from Bury) was 


\section{ROMANO-BRITISH SUFFOLK}

$4 \mathrm{ft}$. $6 \mathrm{in}$. below surface, in a north and south direction with head to north. Iron nails were found with it and pieces of a globular urn of dark ware. The skull and long bones remained. Twenty yards to the north occurred interment no. 2, at a depth of $5 \mathrm{ft}$. in the same direction as no. I. There was a skeleton fairly entire, and only nails were found with it. Some yards farther in advance were fragments of a large vase of red ware covered with cream-coloured slip, which had contained calcined human bones. Some way from it lay an urn of red ware, but not of the same kind as the vase. A group of rubbish pits was found not far off. From these came some animal bones and pieces of pottery, some of coarse ware with a 'stellate pattern in relief.' Interment no. 3 was at the same depth as no. 2. It contained the skeleton of a woman buried in a coffin; the direction of the grave was east and west. At the head, to the west, was a cup of Durobrivian ware, $6 \frac{1}{2}$ in. high. Amongst the bones were more than a dozen horses' teeth. No. 4 was $44 \mathrm{ft}$. north of no. 3 ; the bones were much decayed, and had nothing with them. No. 5 was $34 \mathrm{ft}$. farther, on the west edge of the railway cutting. The bones lay in an east and west direction, and were much decayed. With them was a fragment of coarse red ware with two dogs and a boar upon it, perhaps part of a vase of Durobrivian ware. No. 6 was $17 \mathrm{ft}$. farther on the east side of the cutting, where at a depth of $3 \mathrm{ft} .6 \mathrm{in}$. in a long coffin lay the skeleton of a man well-preserved, the skull perfect, with the head to the north-east. Owing to untoward circumstances this was the last interment carefully observed, but there is a record of twelve more. Nails were seen in some of the graves; the bones were generally much decayed. The graves appeared to lie across the line of the railway cutting; that is, they would have been in an east and west direction. Many no doubt were not recorded. The site of the cemetery was not far from Icklingham [ibid. vi, 41 et seq.].

Ipswich.-A tall vessel of Castor ware with slip ornament, a globular urn inclosed in a larger urn which was broken, the head of a vase of white ware, $2 \frac{1}{2}$ in. across, with a fragment of handle and on the opposite side a female head, the details of head and a rude cross mark being in brown paint, were found on Bolton Farm, Ipswich, in September I 863 [Suff. Illus. (Fitch Coll.), ii]. A globular vessel with large circular incised ornament on it, a vessel with short neck and handle, an urn and another globular vessel with short neck and handle were found in digging the foundations of Paul's Brewery [ibid. iii]. A fibula in the form of a bee, and a bronze lamp in the shape of a dog, the head lost, were found near Ipswich in 1883 [Proc. Soc. Antiq. (Ser. 2), 98-9]. Fragments of Roman pottery were found in High Street, and a vase and other pottery from the site of the new Gas Offices in Carr Street [Proc. Suff. Arch. Inst. vii, 368]. A tetina of brown ware was found in 1862 when the new bank was built [Chart, Watling Coll, in possession of Miss Nina Layard]. In excavations on the site of the Carmelite Convent fragments of pottery at depths ranging from $10 \mathrm{ft}$. to $23 \mathrm{ft}$. have been brought up, but although some of these fragments have a certain resemblance to pottery of the Roman period, it is scarcely possible to identify any of them as of that age. Nothing definitely Roman appears to have been found [Arch. Fourn. lvi, 236]. At Gippeswyk Hall, near Ipswich, some fragments of so-called Samian and other Roman pottery were discovered in February 1897 [Antiq. xxii, I7]. In 1902 two large urns of brown ware, wheel-turned and sun-baked, were found in some sand-pits at 'The Dales.' They were standing upright, in a small cave, like a hollow roughly formed in the ground, and were both empty. One pot had a cover, and they were both ornamented, one with moulded bands in relief, the other with incised indentations. The larger, with cover, was 15 in. in height, II in. in diameter ; the smaller 7 in. in height, $4 \frac{1}{4}$ in. across the widest part. Pottery has been found in the brickfields on the Norwich road, and at Westerfield, where the railway line crosses the road, several more or less perfect examples have been discovered [Proc. Suff. Arch.Inst. xi, $33^{8}$ (1 $\left.90 \mathrm{I}-3\right)$ ]. In the Museum, Ipswich, is a pot-shaped vase, found in carrying out sewage works in Burlington Road. In the Museum, Bury St. Edmund's, are two bronze fibulae and a chain (Acton Coll.). There is also a bronze chain in the Castle Museum, Norwich (Fitch Coll.). In the British Museum is a bronze vessel found in the garden of Cardinal Wolsey's College, and purchased in 1857 .

IxWORTH.-A bronze fbula was found here in 1834. It was circular, convex, and set with concentric zigzag circles of enamel. With it at the same time was turned up a silver coin of Septimius Severus (A.D. 193-21 I), and from the same spot a few bronze coins. In 1838 some pieces of pottery were dug up in digging the foundations for the parsonage. In 1846 more pottery was found, part of a glass vessel, the tusk of a boar, and the skull of an ox with the horn cores remaining. In 1834 , near the road to Stowlangtoft, about half a mile south of the village, the remains of a chamber with an apsidal end, and with a pillared hypocaust, were discovered in the course of ploughing. Though attention was called to the discovery in the following spring (1835), no further investigation was made until 1849 , when the place was cleared for the inspection of members of the Suffolk Institute at a meeting at Ixworth. 


\section{A HISTORY OF SUFFOLK}

The main objects discovered included a grotesque mask, part of a vase, some black pottery, and 2 small bronze coin of Constantine I (A.D. 307-37). A silver coin, of which the inscription was illegible, had been picked up before the excavation of the site [Proc. Suff. Arch. Inst. i, 74 et seq.; O.S. 6 in., xxxiv, SW.]. In the churchyard was dug up a circular bronze fibula with eight semicircular projections. It was enamelled in blue, yellow, and perhaps red, and was $1 \frac{1}{8}$ in. in diameter [fourn. Brit. Arch. Assoc. viii, 364]. A bronze circular fibula, gilt, was hoed up in a field where other Roman remains have been found [Proc. Suff. Arch. Inst. ii, 275]. Other bronze fibulae were also discovered [ibid. iii, pl. pp. 296, 402]. From the churchyard have been obtained at different times the following coins :-I Antoninus Pius (A.D. 138-6I), first brass; 2 the same, middle brass; I Trajan (A.D. 98-117); I small brass of Licinius (A.D. 307-24); I small brass of Constantine I (A.D. 307-37) [East Angl. N. and Q. $i, 437]$. A bronze key found here was shown in the temporary museum at the Ipswich Congress of the British Archaeological Association [Fourn. xxi, 345], and a shield-shaped bronze enamelled fibula is recorded [ibid. xxviii, 282; xxix, 90]. Fragments of so-called Samian ware have also been found, and a vase of the same with hunting subjects (1840) [Suff. Illus. (Fitch Coll.), ixx]. Roman Key [Museum, Bury St. Edmund's]. A denarius of the Rubria family, restored by Trajan, was picked up at Ixworth in 1852 [Numis. Cbron. xv, 59]. The handle of a sword in bronze was also found here, and some enamelled fibulae [C. Roach Smith, Coll. Antiq. iv, 95-6].

KeLSALE. - About Kelsale Lodge many urns were found of ordinary black ware, and vessels of various shapes in red and buff ware [Chart, Watling Coll., in possession of Miss Nina Layard].

KesGRAVE. - A roundel in terra-cotta and a medallion in terra-cotta, Bestiarius and lion, from here are now in the Museum, Bury St. Edmund's [Acton Coll.].

Kettheburgh.-A small vase of grey ware was found here [Davy, Suff. Coll. B.M. MSS. iii, I 9178 , fol. 237].

KIRTON.-A large pot-shaped urn found here is now in the Ipswich Museum.

LAKENHEATH.- Not far from Feltwell (Norf.) was found a small pot containing brass Roman coins [Fourn. Brit. Arch. Assoc. xxxvi, 104]. Found here, and now in the British Museum, are a circular bronze brooch, four pewter plates, another circular brooch bought in 1871 , a number of iron fragments, hinges, an adze-head, bill-hooks, a padlock, the handle of a bucket, a knife, \&c., presented by Mr. Walter K. Foster, F.S.A., in I 882 ; a small blackish drab vase and a large vase of coarse blackish-brown hand-made ware, ornamented with a broad band of incised cross lines making a diamond pattern, the rim flat, with three ribs.

LAvenham. - Coins were found in 1823 near the site of the manor house, third brass of Domitian (A.D. 81-96), of Hadrian (A.D. I I 7-38), and of Faustina (A.D. 138-41). A silver coin, perhaps of Trajan (A.D. 98-117), was found in 1826 [Davy, Suff. Coll. B.M. MSS. i, I 9077 , fol. 37 I]. A fragment of a glass vessel was found inclosing a small quantity of liquid of a pinkish colour, with a white sediment; the glass was of pure white crystalline texture [Arch. Fourn. iii, 69]. A labourer, on 10 June 1874 , ploughing in a field near Lavenham Lodge [O.S. 6-in. lxiii, NE.] came upon a rude earthenware urn about a foot beneath the surface of the ground, containing 197 silver coins, of which 183 were saved and the rest dispersed. The following is the list of those saved :-M. Antonius (ob. B.C. 30), 3; Augustus (B.c. 27A.D. I 4), I; Tiberius (A.D. 14-37), I; Claudius (A.D. 4I-54), I; Nero (A.D. 54-68), 4; Galba (A.D. 68-9), 4; Otho (A.D. 69), I; Vitellius (A.D. 69), 4; Vespasian (A.D. 69-79), 65; Titus (A.D. 79-8I), 23 ; Domitian (A.D. 81-96), 42 ; Nerva (A.D. 96-8), 6; Trajan (A.D. 98-1 I 7), 28 ; in all 183 [Proc. Suff. Arch. Inst. iv, 414 et seq.].

Lowestort.-At a place called Bloodmore Hill, between Lowestoft and Pakefield, a barrow was excavated in 1758 and a skeleton was discovered, with a gold coin and an engraved onyx set in gold hung round its neck. The coin had the word AvrTus on it, and a copper coin with the same inscription was also found [MS. Min. Soc. Antiq. viii, 318 (1761)].

Martlesham. - The base of a bronze equestrian figure found here, with a dedication to Mars Corotiacus from Simplicia, made by Glaucus [Hubner, Corp. Inscr. Lat. no. 93], is now in the British Museum.

Melford, Long.- 'Many years since several Roman urns were dug up here in a gravel pit' [Excursions in Suff. i, 19,59]. In March 1823, at a distance of $300 \mathrm{yds}$. from the River Stour, near Mr. Almack's house, some workmen digging for gravel came upon a glass vessel at a depth of $6 \mathrm{ft}$. from the surface, together with two urns. The vessel and the urn stood upright at a distance of $2 \mathrm{ft}$. from each other, and the former was covered by a patera reversed, as a lid. It had contained calcined bones. The larger of the two urns had a coin in the mouth, too much corroded for identification. Both urns appear to have held ashes. Near where this discovery was made skeletons, with broken urns and coins of Hadrian (A.D. 117-38), 


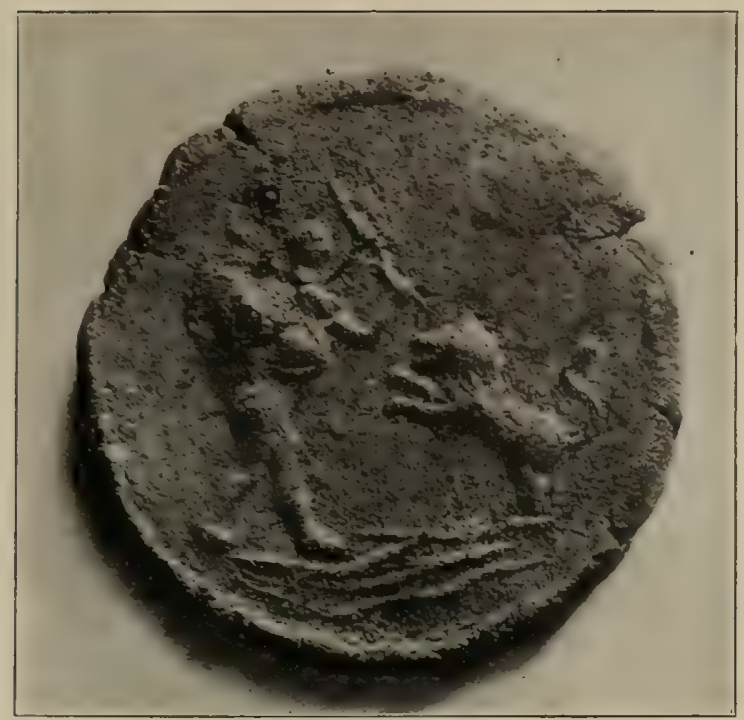

Medallion in Terra Cotta from Kesgrave $\left(\frac{1}{1}\right)$

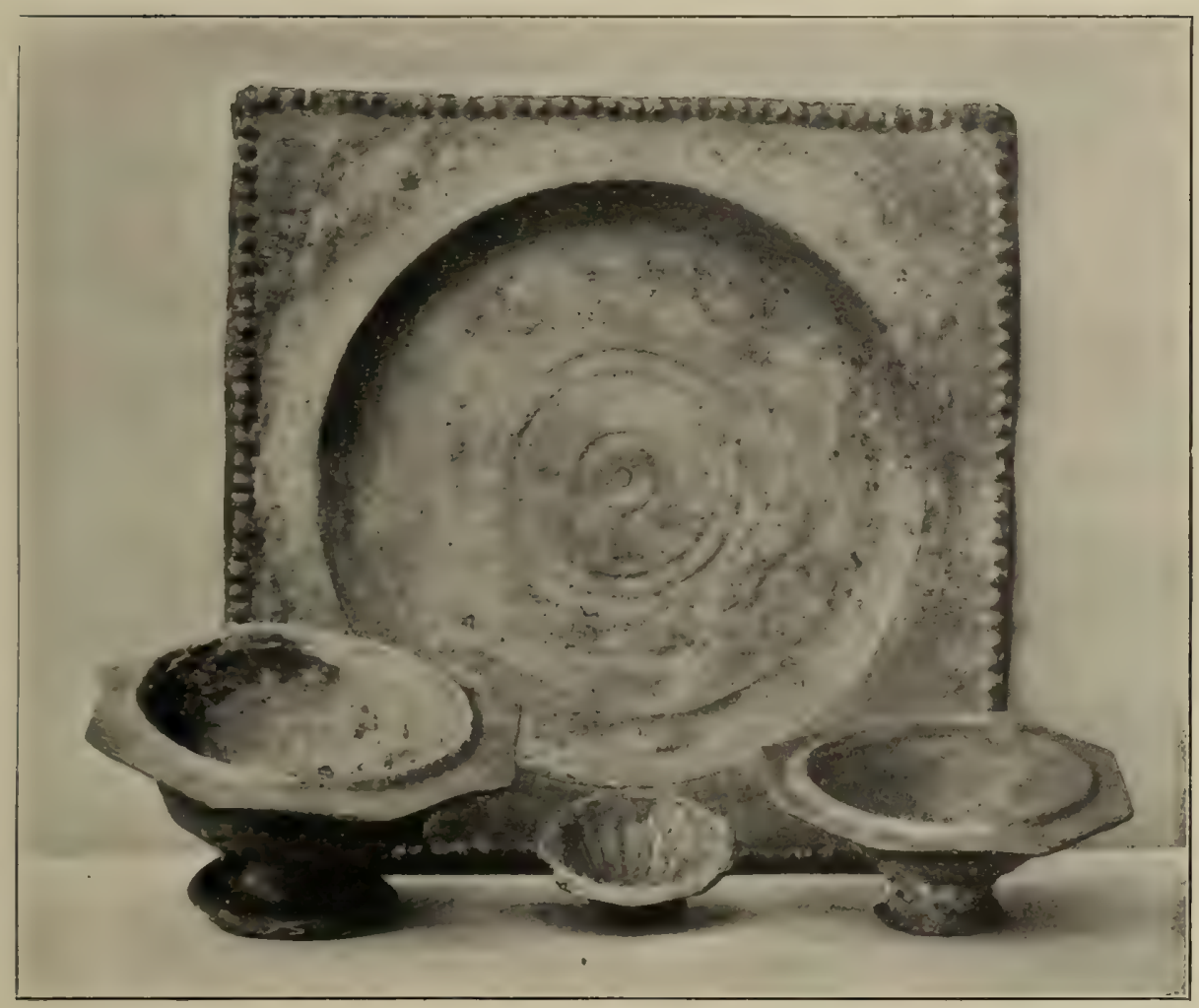

SQlare Pewter. Dish and other pieces from Icklingham (about $\frac{1}{4}$ )

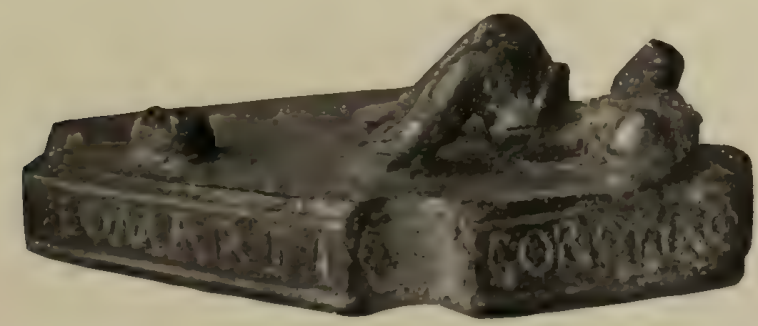

Base of Brontr. Figure from Martlesham (British Museum) ( $\left.1 \begin{array}{l}1 \\ 1\end{array}\right)$ 



\section{ROMANO-BRITISH SUFFOLK}

Vespasian (A.D. 69-79), \&c., had been dug up at different times [Arch. xxiii, App. 394-5; MS. Min. Soc. Antiq. xxxiv, 618; xxxv, 519]. Coins have been found on land called Stoney Land, and in a meadow, the property of Mr. Churchyard, a small vase, a patera of so-called Samian ware and more coins. The two fields are not far from each other [Proc. Suff. Arch. Inst. i, 223]. Some urns and a small cup of green glass found here were exhibited at a meeting of the Suffolk Archaeological Institute at Melford by Mr. Almack, at which meeting a second brass of Vespasian (A.D. 69-79) was also shown [Ibid. ii, 96-97]. Drawings of two vases of brown buff ware, wide mouthed and low, are amongst the Suffolk Illustrations $[($ Fitch Coll. $), x x v]$, and are also figured on a chart in the Watling Collection, now in possession of Miss Nina Layard. The glass vase found in 1823 was presented by Sir W. Parker to the British Museum in 1825 .

Meluss.-The lower stone of a quern was found here [Proc. Suff. Arch.Inst. ii, 277].

Melton.-The discovery of a Romano-British tile kiln was made here in December 1846, in a field occupied at the time by Mr. Isaac Churchyard. Mr. Churchyard's bailiff, having observed that the corn in a particular part of the field was much more luxurious than the rest, was induced to examine into the cause of it; he accordingly dug a hole on the spot. At the depth of about $4 \mathrm{ft}$. he came to a considerable number of large tiles, laid in regular order upon each other to the depth of $3 \mathrm{ft}$. or more; between each layer of tiles was a layer of loam of like thickness. Later Mr. Churchyard caused a more extensive opening to be made. At a depth of about $5 \mathrm{ft}$. a level floor was discovered, apparently of clay, but hardened by the action of fire. On the right-hand side of this floor, the tiles had been piled up in a regular way in courses, to the depth of about $4 \mathrm{ft}$., and for the length of $10 \mathrm{ft}$. or more; on the opposite side of this pile was another of the same kind, but it does not appear to have extended more than $3 \mathrm{ft}$. or $4 \mathrm{ft}$. from the east end ; the space between these two piles was not more than $3 \mathrm{ft}$. These piles were thoroughly burnt and fit for use. At the east end was a similar pile of tiles in the state in which they were when they came from the manufacturer's hands; these had also the layer of loam or clay between each course; the fire had never reached them, and they were as easily cut through with the spade as they would have been the moment they came out of the mould. Some hundreds, perhaps, of the tiles were extracted, and about forty or fifty uninjured ones were preserved ; the following are their dimensions : length, 14 in.; breadth, $10 \frac{3}{4} \mathrm{in}$.; thickness, $\mathrm{I}_{2}^{\frac{1}{2}}$ in. There were besides portions of roof and flue tiles, having the opposite edges turned up about 2 in. The dimensions are : length, $6 \frac{3}{4}$ in.; breadth between the turned up edges, 6 in.; and the thickness $\frac{3}{4}$ in.; on the upper side lines were scored, in a very rough manner, by way of ornament. The earth of which these tiles are made is of good quality, but the manufacture is very coarse. The only other object found was a small fragment of pipe, the diameter of which inside may have been about $2 \frac{1}{2} \mathrm{in}$, , and the thickness about $\frac{5}{8}$ in.; at one end there is a shoulder of about half the thickness of the pipe, which is left in order that the next piece of pipe might be fitted into it. At the west end of the excavation appeared a considerable quantity of wood ashes, and this was probably the mouth of the furnace. The land slopes to the west, and the opening of the kiln was, no doubt, at that point. The whole of the soil which has been removed is red, as if formed of powdered tiles, mixed, however, here and there, with pieces of a hard, coarse, white substance, which, upon being broken, have a disagreeable pyritic smell [Davy, Suff. Coll. B.M. MSS. xxxvii, 19113, fol. $194, a$ and $b]$.

MiCKFIELD.-A black urn of ordinary type, a smaller one of red ware, and a bottle-shaped onehandled vase of buff ware were found here [Chart, Watling Coll., in possession of Miss Nina Layard].

Mildenhall.-In 1833 a glass vase containing ashes was found with other remains in the parish; it was destroyed by the labourers who dug it up, and two clay vessels containing Roman coins were discovered not far from the same spot [Arch. xxv, App. 609: Proc. Suff. Arch. Inst. i, 24; MS. Min. Soc. Antiq. xxxvi, 312]. A bronze head was 


\section{A HISTORY OF SUFFOLK}

found at Kenny Hill about three miles north of Mildenhall [Proc. Soc. Antiq. (Ser. 2), xiv, 155). A cinerary urn with burnt bones; a portion of a quern of lava ; three bronze dishes, one within the other; a bronze winged figure holding flowers; a dagger with ivory (?) handle and some coins, silver and bronze, were all found in Mildenhall Fen [Proc. Suff. Arch. Inst. i, 312-13]. Lying on the clay under $6 \mathrm{ft}$. of vegetable mould in another fen near Mildenhall were found a portion of a concave mirror, the handle of bronze 3 in. long, and near it a bronze hand $2 \frac{1}{2} \mathrm{in}$. long, the fingers extended, evidently part of a figure which was not found ; two blue and white glass beads, and a button of transparent light green glass $\frac{3}{4} \mathrm{in}$. in diameter. At the same time and place were found coins of Hadrian (A.D. II 7-38), Vespasian (A.D. 69-79), and Constantine I (A.D. 307-37) [ibid. 310 et seq.], and a ring with a female figure at an altar, engraved on an amethyst set in silver [ibid. iii, 406]. A vase of Durobrivian ware was ploughed up at West Row in 1869 [ibid. iv, 374]. In 1897 a 'canister' of Roman coins weighing about $5 \mathrm{lb}$. was found in a field, but no particulars have been recorded [Antiq. xxxiii, I 7, Haverfield, 'Quarterly Notes']. In the Museum, Bury St. Edmunds, in one of the earthen pots containing coins, a glass vase having an inscription in relief, found near Holywell Row in 1833 , and a small black vase, exhibited, and the latter presented, by Sir Henry Bunbury ; also a steelyard hook, chain and loops in bronze (Acton Coll.).

Nowton.-A fragment of a quern of pudding stone was found here [Proc. Suff. Arch. Inst. i, 304 et seq.].

Pakenham.-A tessellated pavement was discovered in this parish on Redcastle Farm in grass-land near the farm-house. It was preserved for a time, but was finally destroyed by cattle getting into the inclosure which had been made for its protection [Camden, Brit. (ed. Gough), ii, 8 I ; Proc. Suff. Arch. Inst. i, 74]. A burial-place was opened early in the Igth century by a man digging for brick earth. This appears to have been at a spot near Pakenham Mill. The report of the man who made the discovery was to the effect that he found a square place full of pots set in rows. He could not tell the number, but there were a great many, and they were of a dark colour. Mr. Sharpe of Ixworth, who saw them, reports that several of them had covers. No care was taken to preserve them [ibid. 75]. One of these urns is figured on a chart in the Watling Coll. in the possession of Miss Nina Layard, where it looks like a Roman cinerary urn. In digging for gravel in 1844 , two perfect skeletons were discovered, also fragments of pottery, parts of two bronze plated spoons, hairpins in bone and bronze, a stylus, a piece of stag's horn, and an iron object. Besides these there was a bronze handle of good workmanship which, from fragments of wood adhering to it, may have belonged to the lid of a box holding some of the articles mentioned. At a somewhat later date, a coin of Constans (A.D. 337-50) was turned up. In 1845 a bronze bracelet and an enamelled fibula were found [Proc. Suff. Arch. Inst. iii, Figs. 5 and 6, pp. 296, 402-3; C. Roach Smith, Coll. Antiq. iv, 95-6], four or five urns of common ware, not cinerary, and some fragments of so-called Samian ware, together with pieces of thick buff ware and a large brass coin of Nerva (A.D. 96-8), were likewise found [Fourn. Brit. Arch. Assoc, i, 138 ; Proc. Suff. Arch. Inst. i, 74 et seq.]. A silver coin of Julia Domna (died A.D. 2I 7) with reverse of Geta (A.D. 211-12) was found in a village adjoining Ixworth (Pakenham?) [fourn. Brit. Arch. Assoc. vi, 445]. The traces of a Roman road occur in this parish on the Queach Farm, tenanted by Mr. Waites Matthew. When a ditch was cut through the line of the road in 1856 , the section showed gravel about $10 \mathrm{yds}$. wide and about $\mathrm{I} \mathrm{ft}$. thick at the crown. The road passed through fields formerly part of Pakenham Heath, and near it was a place called Puttocks Hill, where was once a tumulus. As far as it is possible to trace it, its course is roughly east and west. In a small field, where the line of it can be most clearly seen, was found a brass coin of Trajan (A.D. 98-1I7) and a harp-shaped enamelled fibula [Proc. Suff. Arch. Inst. i, 74 ; ii, 212, 221 ; O.S. 6-in. xxxiv, SW.]. A mortarium was found on Messrs. Burrell and King's land, on the south-west side of Ixworth Bridge [Proc. Suff. Arch. Inst. vii, 214]. A denarius of Tiberius (A.D. 14-37) was found in a field at a fork of the roads through Pakenham to Bury and Thurston station [Raven, Hist. of Suff. 26].

Peasenhall. - Close to the remains of Sibton Abbey, a quarter of a mile north-east of the village of Peasenhall, are traces of a 'supposed Roman road running north of east and some $600 \mathrm{ft}$. long' [O.S. 6-in. xxxviii, SE.].

Playford. - A vase 6 in. high, the same in diameter, found here in an old fosse is now in the Museum, Bury St. Edmunds.

Poslingford.-A Roman coin, a brass weight and a key were found at the Hall [Proc. Suff. Arib. Inst. $i, 87$ et seq.].

ReDGrave. - An urn was dug up here about $3 \mathrm{ft} .6$ in. in circumference [ibid. i, 148]. This may be the one of buff ware from Redgrave preserved in the Museum, Bury St. Edmunds. 


\section{ROMANO-BRITISH SUFFOLK}

Rougham. - Close to the highway at the junction of the roads to Hessett and Bradfield St. George, is a mound called Eastlow Hill, and not far from it two mounds between $50 \mathrm{ft}$. and $60 \mathrm{ft}$. in diameter. Various objects of the Roman period have been discovered in the neighbourhood from time to time. The land where these mounds stood had been common land until about 1813. A bout $250 \mathrm{yds}$. east of these tumuli were discovered remains of buildings, and in the middle of the field traces of a floor were uncovered, composed of a bed of pounded tile and mortar, and upon that a layer of white calcareous stucco [Gent. Mag. 1843, pt. ii, 190, 528]. The barrows mentioned (of which there were four, not three) were examined by Prof. Henslow in 1843 and 1844 . His long and elaborate accounts are here condensed. These barrows lay in a continuous line north-east and south-west, the one called Eastlow Hill being the largest. In July 1843 labourers were employed in taking earth from the most northerly of the smaller barrows, when they came upon a cist of tile which appears to have been a cube of $2 \mathrm{ft}$. Hollow flue tiles as well as the ordinary tiles were used in its construction, and the roof was of a single layer of large flat tiles. Within were found a large iron lamp with a short handle, and a square urn of green glass filled with burnt human bones. The urn was 8 in. square, 12 in. to the shoulder, and 16 in. full height, and the mouth $2 \frac{3}{4}$ in. in diameter. The cist, according to the workmen, contained nothing else. The next barrow, to the south-west, was opened 15 September of the same year, by cutting a trench $4 \mathrm{ft}$. wide across the middle of it, in a north-east and south-west direction. In diameter it was $54 \mathrm{ft}$. and in height from the ground about $6 \mathrm{ft}$. In the centre and beneath the surface of the soil lay a cist or chamber built of tiles, each 17 in. long, 12 in. broad, and 2 in. thick. The chamber measured slightly over $2 \mathrm{ft}$. square $\left(2 \mathrm{ft} .2 \frac{1}{2}\right.$ in. by $2 \mathrm{ft}$. I in.). It was $2 \mathrm{ft}$. 3 in. high from the floor to the crown of the straight-sided arch covering it, formed of five courses of tiles overlapping each other till they were covered by a row of single tiles at the top. Heaped above the cist was a mass of broken brick rubbish, then a layer of loam somewhat rounded above the natural ground level, and finally a coating of pounded brick and mortar. The cist contained the following objects : (I) An urn of bluish-green glass with broad reeded handles, the body nearly spherical, and about $9 \mathrm{in}$. in diameter, the neck 4 in. long and the opening of the mouth $3 \mathrm{in}$. wide. It had a foot 4 in. across. It had fallen in pieces and lay heaped up with the burnt bones it had contained. (2) A lachrymatory or perfume bottle of glass, in form a long neck with a small flattened body, had been placed on the bones within the urn and contained a brown matter. (3) A coin, apparently second brass, but illegible. $(4,5)$ Two small plain jars of coarse black ware, the one 3 in. high and 2 in. in diameter, the other $3 \frac{1}{2}$ in. high and 3 in. in diameter. They lay on their sides near the cinerary urn, and had perhaps been painted and gilt. (6) A spherical pitcher of coarse buff ware, $10 \mathrm{in.}$ high and 8 in. in diameter, with a narrow neck and one handle. (7) A similar vessel of smaller size. (8) A patera of so-called Samian ware, $7 \mathrm{in}$. in diameter with a potter's stamp badly impressed, the name might be BIFvsA. Near this were fragments of bone, perhaps the handle of a knife. (9) A very similar patera, of the same diameter, with potter's mark ALBvCI. (10) A third patera, a trifle smaller, potter's mark Micciof. This one had in it some chopped fragments of unburnt bone and pieces of the neck bone of an ox. (11) Another patera, potter's mark ILLIomRin. (12) An iron lamp hung from a twisted iron rod driven into the south-west wall of the chamber. The lamp was 5 in. long and open at the top. It had remains of a wick in the nozzle. (13) Two iron rods $3 \frac{1}{2}$ in. long, possibly handles of a small wooden chest or casket, traces of which lay in the east corner of the cist. Pieces of burnt bones were found lying near patera no. 10, which appeared to have been covered either with gold dust or gold leaf. The third and last of the small barrows was opened 22 September. It had been so much injured by the removal of earth, and by a road having been formed across it, that the exploration had but indifferent results. Two cinerary urns containing some bones, which appeared to have been placed upon the surface of the natural soil, were found and a few pieces of pottery, among them two fragments of so-called Samian ware. No signs of any cist were discovered. Prof. Henslow, in the following year (4 July I 844), opened the largest and last of this group of four barrows, called Eastlow Hill. A tunnel was driven into the mound towards its centre and at a distance of $50 \mathrm{ft}$. from the foot $2 \mathrm{tomb}$ was reached. This stood on the level of the natural soil upon a square platform of concrete, and was a diminutive model of a roofed building. It was constructed of flint rubble with rows of tile and tile quoins, and gabled at each end, the roof consisting of four rows of tiles on each side, with a ridge of Alue tiles. In the rectangular chamber formed by this masonry was found a skeleton of a man inclosed in a leaden shell, the body having been wrapped in the hide of some beast, as there was hair with the bones. Also, from the mass of carbonaceous matter at the bottom of the tomb, and from the nails from 2 in. to 12 in. long, lying with it, it was clear that the leaden shell had been inclosed in a wooden coffin. This shell measured $6 \mathrm{ft} .9 \mathrm{in}$. in length by $1 \mathrm{ft} .5$ in. in breadth, and had a 


\section{A HISTORY OF SUFFOLK}

depth of I ft. $4 \mathrm{in}$. The little rectangular chamber appears to have been just large enough to contain the coffin, and was covered by an arch turned with brick. At the head of the tomb was a small addition extending beyond the concrete platform. There was nothing about it to tell for what purpose it had been used. No objects appear to have been found with this interment [Henslow, Account of Roman Antiq. at Rougham near Bury St. Edmunds, 1843; Bury Post, 'The Roman Tumulus, Eastlow Hill, Rougham, opened 4 July 1844'; Proc. Suff. Arch. Inst. iv, 257 et seq.]. Reference is made by Prof. Babington in his introduction to the reprint of these papers [ibid.] as to the state of the barrows in June 1871 . Only two then remained, the large one, and one of the three smaller ones. The large barrow, Eastlow Hill, had an elliptical rather than a circular form and was four times larger than the other. It was $17 \mathrm{ft}$. high. The tunnel made in 1844 was still open and the tomb within the barrow could still be seen in situ. The roof was for the most part intact, and the bones of the skeleton yet lay within the chamber, although the skull had been removed to the Anatomical Museum at Cambridge, and the leaden coffin to the Fitzwilliam Museum at the same place. The barrow which had contained the cist with the glass urn and much pottery yet existed, showing the trench cut through it. It measured $56 \mathrm{ft}$. in diameter and was then something less than $5 \mathrm{ft}$. high. A bronze lamp found in one of the tumuli at Rougham was shown at a meeting of the Suffolk Institute at Thetford 29 September I 849 [Proc. Suff. Arch. Inst. i, I 50; Reliq. and Illus. Archit. viii, 127-30; O.S. 6 in. xlv, SW.]. A full-sized model of the small chamber found in the second barrow described is to be seen in the museum at Bury St. Edmunds, containing all the antiquities found in it. These were presented to the museum by the owner of the estate, Mr. P. Bennet of Rougham Hall. A number of fragments of plain and figured so-called Samian ware, dug up at Rougham, have lately been deposited in the same museum (1899).

Santon Downham.-A hoard of British coins was found near Brandon to the south of the Little Ouse, amongst them two second brass (dupondii) of the Emperor Claudius (A.D. 4I-54). The probable date of the deposit was from A.D. 50 to 55 [Arch. Fourn. xxvii, 92 et seq.; Num. Chron. (Ser. 2), ix, 319]. See Appendix.

SNAPE.-In the British Museum is a pot of pale buff ware ornamented with a chequer of slip dots, found in this parish. In 1862 , among Saxon and earlier relics a thumb ring of gold set with an undoubtedly Roman intaglio was found on the common [Proc. Soc. Antiq. (Ser. 2), ii, 181].

SotTERLEY.-Between Sotterley and Weston an olla of ordinary form was found [Chart, Watling Coll. in possession of Miss Nina Layard].

SourHwold. - A middle brass coin of Constantius I (A.D. 305-6) ploughed up here had on the reverse, MEMORIA FELIx, and there was a hole through it for suspension [Proc. Soc. Antig. ii, 184].

Stanton.-About a quarter of a mile from the village a good many fragments of Roman pottery and some coins were found [Fourn. Brit. Arch. Assoc, iv, 72].

Stoke Ash.- "Drawings were exhibited (at a meeting of the Brit. Arch. Assoc. 1 868) by Mr. H. Watling, of Roman remains consisting of ollae and other vessels of red and dust-coloured ware found at Stoke Ash. On the handle of an amphora was stamped ENN IVL (Ennius Julianus), and among the so-called Samian ware was a portion of a fine bowl with hunting subjects, bearing the stamp albvCI' [Fourn. Brit. Arch. Assoc. xxiv, 394]. A group of this pottery is figured on one of Mr. Watling's charts of Roman remains in Suffolk [Watling Coll. in possession of Miss Nina Layard] and shows, besides the bowl previously mentioned, a small fragment of figured so-called Samian ware with a rabbit upon it. The stamp on the handle of the amphora is thus given, ENNIY. There is also a plan of the site where the pottery was found, which shows spots in fields east and west of the main road, and south of an inn called the "White Horse' between it and the river. On the east side of the road, which runs due north, sepulchral urns were discovered, one reversed, the mouth covered by a tile. It is also noted on the chart referred to that the bed of the river contained a great quantity of animal bones and shards of pottery. Some coins were found, amongst them one of Crispus (A.D. 317-26). From Stoke Ash the road (presumably a Roman one) goes north by Scole, Dickleburgh, and Long Stratton, to Caister (Norf.), and it is said by the road-makers that there is a great difference in its character to the north and south of the White Horse Inn [Raven, Hist. of Suff. 25, 30].

Stonhams, The. - These parishes (Little Stonham, Earl Stonham, and Stonham Aspall) lie close together on the Roman road through the county from south to north. At Stonham Aspall was found an unguentarium containing traces of unguent [Proc. Suff. Arch. Inst. i, 24]. Discoveries are recorded at East (Earl?) Stonham, where some of the objects appeared to be British, but Roman cinerary urns were observed, also tiles, fragments of so-called Samian ware, \&c. These discoveries are said to have extended over several acres [fourn. Brit. Arch. Assoc. xxiii, 300]. 


\section{ROMANO-BRITISH SUFFOLK}

The following extract is from a communication to the British Archaeological Association, by Mr. Hamlet Watling of Stonham :-

A vast quantity of Roman and other remains have been found lately in the valley intersecting the two parishes of Earl Stonham and Little Stonham. This valley was apparently a village and that to the south a cemetery; a vast quantity of urns of a dark colour, covered with tiles and containing human bones, with long nails, \&c. have been found. To the north of the church is an extensive barrow, in the vicinity of which urns of a grey colour are found, and within the churchyard is a tumulus. Only fifteen rods have as yet been excavated, but from this small area vast quantities of pottery, iron, lead, glass, copper coins, querns, flue tiles, \&c., have been obtained, also flint implements and 2 quantity of oyster and other shells and horns and bones of deer, hog, horse, ox, wolf, goat, \&c.

The following objects were sent for exhibition :-Animal remains as noted, knives, a key and nail of iron, a leaden weight, a grotesque mask originally forming part of a vessel of brown ware, the bottom of a vase with the potter's stamp $\frac{G}{\mathrm{FAF}}$, the last two letters ligulated. The depth at which the Roman remains occurred appears to have been about $\mathbf{I} \mathrm{ft}$. $\mathbf{I} O$ in. beneath the present surface [ibid. xxiv, $184-5,286,397$ ]. The coins found, identified by the Rev. C. E. Searle, were mostly third brass of the Lower Empire. Those read with certainty were of Claudius Gothicus (A.D. 268-70), Diocletian (A.D. 284-305), Carausius (A.D. 286-93), Constantine I (A.D. 307-37), Constantine II (A.D. 337-40), Magnentius (A.D. 350-3), Valens (?) (A.D. 364-78). There was one plated denarius and a minimus. At a later date drawings of objects found at Stonham were sent for exhibition to the British Archaeological Association. These drawings showed various vessels ornamented with white slip, perhaps Durobrivian pottery, two mortaria, one of red, the other of grey ware, with loop handles. Near the former were found two flint pounders, also an object of lead resembling a key. These remains lay amongst ashes, together with coins of Constantine I (A.D. 307-37), bones, and cut horns of deer. Spindle-whorls, and upper and lower stones of querns of pudding stone, of Andernach lava, and of other stones, and flue tiles, were shown on the drawings [ibid. xxvii, 385-6]. In the restoration of Earl Stonham Church a conical muller of jasper was found, with fragments of Roman pottery, in the south transept [ibid. xxxi, 216]. The drawings mentioned, with others by Mr. Watling, representing objects from the same site, are in the collection of Miss Nina Layard. The pottery represented is of the character usually found on Roman sites, and includes specimens of red, black, and buff or stone-coloured ware, with a very small proportion of so-called Samian fragments. On one of these is a potter's mark, sEvERIM. One fragment is shown of New Forest ware. Portions of flue tiles are also figured. The objects of iron are of the usual character-keys, knives, shears, \&c. Amongst those in bronze may be noted three diminutive wide-mouthed pots, each with one handle, joined together in a group. Of lead there are two or three articles, and of Kimmeridge shale one, a simple ring bracelet. Some flat ovate jet beads were found in the gravel at Stonham, over an earlier deposit of bones, coarse pottery, \&c. [Fourn. Brit. Arch. Assoc. xxxvi, 357]. On a chart with these drawings is given a plan of the site of the discoveries. The remains appear to have been found for the most part in the glebe land south-west of the rectory of Earl Stonham, and in the fields west of this land, divided from it by a small stream. Other finds occurred in a field north of the rectory, and a line of them extended from the church of Earl Stonham to that of Stonham Aspall. There is a drawing of shears from this site, found in 1867 , in Suff. Illus. (Fitch Coll.) xiv [Arch. Fourn. xxvi, 401; Proc. Suff. Arch. Inst. v, 117; O.S. 6-in. lvii, NW.].

STOw, WEST.-Potters' kilns were found on a slight ridge on the heath, in the spring of 1879 . The first was circular in form, $3 \mathrm{ft}$. 6 in. in internal diameter, with a furnace chamber, also circular, attached to the east side. The walls were $\mathrm{Ift} 6 \mathrm{in}$. high and 4 in. thick, and were of puddled clay with a large admixture of chalk pebbles. Nothing of the upper floor of the kiln remained, but in one place half-way up the wall a triangular brick pierced in the centre remained. It was vitrified on the surface, and was the only indication left of the baking floor. Other perforated tiles, however, were found in the rubbish. A second kiln, $8 \mathrm{ft}$. south of the first, was only $3 \mathrm{ft}$. in diameter. The furnace was formed by walls with an outward splay. Bricks $1 \mathrm{ft}$. I in. long by 8 in. wide and 3 in. thick, each perforated with two holes $2 \frac{1}{2}$ in. in diameter, lay in the kiln, no doubt the remains of the baking floor; and a number of circular bricks $6 \frac{1}{2}$ in. in diameter and 3-4 in. thick were with them, evidently fragments of the pilae supporting this floor. The method of construction of the kilns was clear. The earth had been dug out in a circle to the depth of $4 \mathrm{ft}$., the bottom of the excavation filled with clay well trodden down, and then the walls to a height of some $18 \mathrm{in.}$ or $20 \mathrm{in}$. were formed against 


\section{A HISTORY OF SUFFOLK}

the side of the excavation, and the baking floor constructed. The pottery found about kiln no. I consisted principally of pieces of globular vessels with one handle, the vessels capable of holding from one pint to two quarts. They were rather fine ware, ruddy in hue. With them were some remains of little bowls of light red ware with machine-made markings, and some few other fragments. The pottery found about kiln no. 2, which had been used occasionally as a smother-kiln, was somewhat more varied. Fragments of urns resembling some kind of cinerary urns, some small jars of black ware ornamented with burnished lines as a diaper, a fragment of a jar with broad bands of dots in slip, and also pieces of a ware showing a micaceous glaze, lay about this kiln. On a spot about half a mile from the kilns to the east, and near the river (Lark), were a series of basin-shaped pits. It is possible that these pits were made by the potters in obtaining clay. Skeletons were discovered in digging for sand in an elevation of the land dividing the heath of West Stow from meadows by the river not far from the kilns described. By the right side of one of these, which lay north and south, was a patera of black ware placed edgeways. It had a potter's mark in a label, apparently an $\mathbf{N}$ between two dots, and from the disturbed soil near was turned up part of the rim of a mortarium with the stamp A BIC $\bigcirc \mathrm{F}$ with the lettering reversed. The potter's works were only half a mile from the supposed Roman station at Icklingham [Fourn. Brit. Arch. Assoc. xxxvii, 152 et seq.]. More kilns were discovered on the same site on West Stow Heath in and previous to I 890 . The fragments found about the fifth kiln consisted of portions of a shallow bowl in fine grey pottery, bowls of buff and brown ware, the rims ornamented with patterns in slip of various colours, parts of two smaller and deeper bowls of fine light red pottery with circles and lines in darker slip upon them. Also ampullae of large size in buff-coloured ware. In the kiln were found two coins, small brass of Constantius I (A.D. 305-6) [ibid. Ixvii, 94]. A vase of buff ware $5 \frac{1}{2}$ in. high, now in the Bury Museum, was found here, and also a bronze brooch now in the British Museum.

Stowlangtoft. - In a field half a mile below the church 'was found in 1764 a pot full of Roman coins of the Lower Empire' said to number I 2,420 [Camden, Brit. (ed. Gough), ii, 81 ; Royal Soc. Letters and Papers, Decade iii, 294]. Roman coins were found near 'Barber's Lane' [O.S. 6-in. xxxiv, SE.].

Stowmarket.-A coin of the Emperor Trajan (A.D. 98-117) was found here [Proc. Suff. Arch. Inst. ii, 214$]$.

Stratford St. AndRew. - A small urn was found here [Chart, Watling Coll., in possession of Miss Nina Layard].

Stratford St. Mary.-In this parish in 1877 was found a ridge of hard ground, apparently traces of a road, near which several cinerary urns were dug up. All were broken. Fragments of one are in the Colchester Museum [Arch. Fourn. xxxv, 82]. Between Stratford and Sproughton a wide-mouthed urn of brown ware was found [Chart, Watling Coll., in possession of Miss Nina Layard].

SUdBourne. - A small two-handled vase, between 2 in. and 3 in. high, of buff ware, now in the British Museum, was found here.

SUDBURY.-Three vases were found in 1848 ; one of red ware with a very small spout (a tetina), one globular with broad neck and one handle, of grey ware, and an olla of buff ware [Davy, Suff. Coll. B.M. MSS. i, I9176; Suff. Illus. (Fitch Coll.), xxvi]. They are stated to have formed part of the collection of Mr. E. Acton, Grundisburgh. Roman coins were found in the neighbourhood [Proc. Suff. Arch. Inst. i, 22 I et seq.].

Sutron.-Labourers in digging for coprolites (in 1870 ?) found a vessel which is said to have contained nearly a bushel of Roman coins, belonging to the period of Constantine I (A.D. 30737) and for the most part of ordinary types [Arch. Fourn. xxviii, 34 et seq.]. A further mention of this discovery states that a hoard of coins, third brass, in a hand-made dark brown pot, now in the Colchester Museum, was found here [Note on drawing in Chart, Watling Coll., in possession of Miss Nina Layard]. The following probably also refers to this find:-Close to Sutton Hall, 'Two urns containing Roman copper coins found 1870.' [O.S. 6-in. lxxvii, SW.].

TAtTingstone.-A globular urn of red ware covered with a buff slip and a smaller bottle-shaped vessel of buff ware, now in the Ipswich Museum, came from this place.

Thorington.- In digging the foundations for a cart-shed to a new farm-house on Colonel Bence's property in this parish in $1824-5$, six or seven Roman urns, much broken, were found [Davy Suff. Coll. B.M. MSS. vi, 19082, fol. 359].

Thurlow, Great.-In 1891 a Roman refuse pit was found, containing the usual pottery and household débris. The pit was only remarkable for the quantity and variety of so-called Samian ware found. It was not of the best class of paste, being somewhat soft and porous, but the exterior was good and the ornamentation elaborate. The only potter's mark that could be deciphered was OF ALBI. There were also many large rusty nails, oyster shells, bones, 


\section{ROMANO-BRITISH SUFFOLK}

pieces of Medermendig lava, a plain bronze fibula, bits of wire, a triangular embossed ornament in bronze, a small figure carved in chalk, without the head, about 3 in. high, probably of Mercury, and one small brass coin of Claudius Gothicus (A.D. 268-70) [Antiq. xxiii, 224. 'Proc. of Camb. Antiq. Soc. I891 ; ' ibid. xxiv, 20, 'Quarterly Notes,' Haverfield]. A strigil was found here later [Proc. Suff. Arch. Inst. viii, 218 ].

Trimley.-A large urn of greyish yellow ware, now in the Ipswich Museum, was found here.

WAINFORD. - Various fragments of Roman pottery, some pieces of so-called Samian ware, and calcined bones were found here in 1856 [Proc. Bury and West Suff. Arch. Inst. iii, $4^{\mathrm{I}} 3$ et seq.]. $\mathrm{N}$ aar the bridge over the Waveney were found in 1856 Roman coins and a flint arrow-head, and in 1893 a coin of Philip the Arabian (A.D. 244-9) and one of Antoninus Pius (A.D. 138-61) [Raven, Hist. of Suff. 30].

Walton Castle. See Felixstowe.

WANGForD.-(Near Brandon). A spindle-whorl of pottery and the 'head of a glass pin,' now in the British Museum, were found here.

Welnetham, Great.- 'A few years since were found, in digging, abundance of Platters and Potsherds of Roman earth, some of which had inscriptions upon them, as also Coals, Bones of Sheep and Oxen, with many Horns, a Sacrificing Knife, Ashes and Urns, Evidences that some Heathen Deity had an Altar here' [Lysons, Mag. Brit. 1730, v, 246]. This statement is repeated, with the omission of the last few words respecting the pagan worship, in Camden [Brit. (ed. Gough), ii, 81]. In the adjoining hamlet of Sicklesmere two Roman refuse pits were found, containing, among other miscellaneous traces of occupation, fragments of Roman pottery of various kinds, including so-called Samian ware; also building tiles, pieces of furnace slag, remains of bones, odd pieces of metal, bronze and iron, bone bodkins, a fibula, a knife and several coins, three in bronze of Faustina II (A.D. 147-76) and two silver denarii of Severus Alexander (A.D. 222-35). It was thought at the time of the discovery, from the scarcity of animal bones, that they were not the pits of a camp, but that, as they were evidently co-existent, they belonged to two distinct dwellings. The presence of oyster-shells and so-called Samian ware indicated prosperity and civilization. Three more refuse pits were found shortly afterwards in digging for gravel, not far from the others, so that a settlement probably existed near the spot. A quantity of pottery was found in a neighbouring field. The so-called Samian pottery was identified by Dr. C. H. Read of the British Museum, as the work of potters of Lezoux of the ist century, the marks being Belinnici . M. AELianus M. and Divixtus. It has been suggested that this was the site of 'Villa Faustini,' Colchester being 'Colonia' [Antiq. xl, 292 (1904); ibid. xlii, 248-50 (1 906)].

Westhall. - A space about 2 acres in extent of a field called Mill Post Field, bordered on the east by a water-course, showed in every part, at a depth of $\mathbf{I f t} 6 \mathrm{in}$., much burnt soil and a great quantity of broken pottery. One piece only of so-called Samian ware was dug up, part of a plain patera. Enamelled horse trappings of Celtic character were found about the centre of the space at a depth of $2 \mathrm{ft}$. from the surface. They appeared to have been contained in a bronze vessel of the same character, and with them were six hollow bronze cylinders $1 \frac{3}{4} \mathrm{in}$. long, a small blue glass bead, a bronze lamp with a crescent-shaped ornament over the handle, and a brass coin, said to be of Faustina (A.D. I38-4I) [Arch. xxxvi, 454 et seq.; Arch. Fourn. xii, 276].

Westleton.-In 1845 on Scotts Hall Farm was dug up a coarse earthen pot $\frac{1}{2}$ in. thick and from 8 to $10 \mathrm{in}$. high, containing eighteen or twenty pieces of Roman coins, some few silver and the rest brass. The coins were too much decayed to be identified. Near this pot was a smaller one, but empty [Davy, Suff. Coll. B.M. MSS. vii, 19083, fol. 132].

WhersTrad.-Roman coins were found in 1810 south of Wherstead Park, and south-west of Vicarage and Redgate lanes [O.S. 6-in. Ixxxii, NE.].

WhitTon.-In Castle Field, near Ipswich, in 1854 , when the present house and buildings on the site were erected, traces of a Roman villa were found. It was situated on the brow of a hill overlooking Ipswich, which is to the south, and it lies behind the modern house of Mr. Orford, which is between it and the high road. Nothing is to be seen but some fragments (in a newly planted orchard) of a floor of coarse buff sandstone and red tesserae, probably that of one of the corridors of the Roman house. No plan of the foundations that were found, or notes respecting it, appear to have been made when the new farm-house was built, but all the Roman building material dug up seems to have been used in the substructure of the modern building. Part of the pavement of one of the principal chambers of the villa was, however, fortunately preserved, and is now in the entrance hall of the museum at Ipswich. It is the only specimen of Roman mosaic existing in Suffolk. A drawing made shortly after its discovery shows a central square surrounded by seven concentric bands of varying widths ornamented for the most part with simple braids, or with straight or curved sided triangles, the bands being separated from each 


\section{A HISTORY OF SUFFOLK}

other by broad or narrow lines. Right and left on either hand, a band over $\mathbf{I} \mathrm{ft}$. wide containing a series of black scrolls on a white ground was added to the square composition, and the whole was set in a field of coarse red tile tesserae. In the hall of the residence on the spot are preserved three vases, one a small black cinerary urn, another a flower-pot-shaped vase ornamented with two rows of flutings divided by a fillet, and a globular amphora with its handles and neck removed. The cinerary urn when discovered was full of ashes and bones. The amphora was found in 1894, and all three vessels came from a gravel pit close to the site of the villa. The amphora was emptied by the labourers who found it, and it is supposed that it may have contained coins, but of this nothing certain could be ascertained. Three coins were preserved with these vases, one of Rome, with the wolf and twins on the reverse, one of Constantinople, and one of an emperor of the Constantine family [Gent. Mag. 1855, pt. i, 179; and from personal observation (G.E.F.)]. With the fragment of the mosaic pavement in the museum at Ipswich are photographs of the plain pavement mentioned, and a coloured print to an inch scale of the more elaborate one, published by H. Davy, Globe Street, Ipswich, May 1855. This was from a drawing made on the spot when the pavement was first uncovered. A tessellated pavement was found in 1870 , and from time to time coins have been turned up, some said to be of Vespasian (A.D. 69-79), others probably of the 4th century. In February 1897 another pavement was found, consisting of red and white tesserae of a less elaborate pattern than those formerly found [Antiq. xxxiii, 104 (1897), Haverfield, 'Quarterly Notes'].

Wickнambrook.-A fibula was ploughed up in a field called 'Four Acre Honeycomb' on the Lodge Farm, about I mile from the mediaeval entrenchments at Lidgate. The fibula was of bronze gilt, oval in shape, and set with a stone like an amethyst, rising nearly to a point. Some coins found with it were mostly of Constantine I. (A.D. 307-37), with some of Probus (A.D. 27681) and of Pertinax (A.D. 193). Also at the same time the bronze figure of a bird, an eagle or hawk, perhaps part of the handle of some vessel, was discovered [Gent. Mag. 1788, pt. ii, 702]. A small bowl of figured so-called Samian ware, diameter at top $9 \frac{1}{2}$ in., depth $5 \frac{1}{2}$ in., ornamented with medallions, in one of which is a Cupid, and surrounded by an egg and tassel band, was found in 1830 about $1 \frac{1}{2}$ miles from the church (of Lidgate?) towards Badmondisfield Hall [Davy, Suff. Coll. B.M. MSS. v, 19180, fol. 2]. A small bronze figure possibly of Hercules and a handle of some object ornamented with four faces, and some Roman coins (one of them of Constantine the Great [A.D. 307-37], third brass) were found before 1859 in draining the 'Honeycomb' Field before mentioned [Proc. Suff. Arch. Inst. i, $151 ; \mathrm{ii}, 98]$.

WingFieLD.-Silver coins and some objects of the same metal were found about 1836 , the find vouched for by Miss Heyman, sister of the then vicar of Fressingfield, Sir H. P. Heyman, who saw some of the coins. Attached to the find is a story of buried treasure [Davy, Suff. Coll. B.M. MSS. xv, 19092, fol. 379].

Wixoz.-In Ainsford, near the Stour, many coins have been found, two noted, one of Nero (A.D. 54-68), the other of Constans (A.D. 337-50) [Arch. xiv, 7I].

WoOdBridge. - A small bronze globular vessel with two handles was found near this town [Proc. Soc. Antig. (Ser. 2), xi, 174$]$.

WoolpIT.-The large entrenchments on Warren Farm are supposed to be Roman [Lysons, Mag. Brit. 1730, v, 249-50; Kirby, The Suff. Traveller, iv, 62 ; Camden, Brit. (ed. Gough), ii, 84]. Fragments of bronze horse furniture and two Roman coins were found within these entrenchments [Proc. Suff. Arch. Inst. ii, 207 et seq.]. A spoon and spatula of bronze, and two 'amulets' (?) of bronze, annular, with loops for suspension, filled with fine clay, diameter $1 \frac{3}{8}$ in., are in the museum, Bury St. Edmunds (Acton Coll.).

WORLINGWORTH.-Here were found in 1827 , in making a road in front of the parsonage, some bones, an urn, and four Roman coins, three of which were possibly of Allectus (A.D. 293-6) [Davy, Suff. Coll. B.M. MSS. xv, 19092, fol. 417].

Wratting, Great.-An ampbora and a patera were "found in a field called Nine Acres, upon Monks Land, belonging to Sotterly Green Farm.' A great quantity of Roman pottery, coins, urns, \&c., was also found in this field [Gent. Mag. 1804, pt. ii, 1006]. 


\section{ROMANO-BRITISH SUFFOLK}

\section{APPENDIX}

\section{Note on a Hoard of Bronze and Iron Objects found at Santon Downham}

A discovery at Santon Downham hitherto unpublished throws some light on the chronology of Early British antiquities, and by kind permission of Baron A. von Hügel is here included under Roman Remains, as the series must be dated by the latest specimen in it. It is a hoard of scrap bronze together with a few iron tools, all found in a large bronze cauldron by a labourer, who brought the whole to the Cambridge Museum of Archaeology in 1897, and was himself responsible for the damage to the containing vessel. There can be no question that the miscellaneous collection now placed on exhibition was made by a worker in metals for recasting; and as there are no objects obviously of another age, we may assume that the cauldron and its contents were practically contemporary. Some of the specimens had been worn out and subsequently repaired before being scrapped; others had been accidentally broken and were either unworthy or incapable of repair ; but we cannot credit the itinerant tinker with a taste for antiquities, and must assign the deposit of the hoard to the early years of Roman rule in Britain. It would be unwise to call this a period of transition from the late Celtic to the Roman style, as there are indications that British art survived the Roman occupation and started on a new lease of life in the Anglo-Saxon period. In south-east England, however, the native craftsmen could not hold out against Roman influence; and the Santon Downham hoard illustrates the Romanization of Britain at the expense of native traditions and craftsmanship.

Attention may first be directed to the large vessel, made up of thin bronze plates, that would generally be described as a cauldron, but cannot have been used for cooking, and may perhaps be added to the list of water-clocks found in Britain. It closely resembles one from Baschurch, Shropshire, ${ }^{1}$ now in the British Museum, that has a small round hole in the base; and comparison with other vessels so perforated suggests that they were used by the ancient Britons to measure time, as was done till quite recently in India and Ceylon. The vessel is comparatively light, and is placed on the surface of water, which gradually percolates through the bottom and causes the vessel to sink in a specified time. It is then raised and emptied by an attendant, who announces the hour or other division of the day and replaces it on the surface, to repeat the process. The present example has, however, no such perforation at the present time, as the centre of the base has been cut out and a large circular patch of bronze added, just like a large example from $W$ althamstow in the national collection. ${ }^{2}$ The extreme thinness of the bronze can only have been attained by continual hammering and firing, and suggests a delicate and important function for the vessel, which has a rim and two ring-handles of iron, and consists of an upright collar and swelling body with rounded base, the greatest diameter being $18 \frac{1}{2}$ in., the height $12 \frac{1}{4}$ in., and width of mouth 17 in. $^{3}$ At the junction of the collar with the body is a band of what might be taken for rivets, but the small bosses were produced by punching both thicknesses together from the inside at short intervals.

In this worn-out water-clock (if such it was) had been packed a curious collection of oddments that may be roughly classified as of British and Roman work. The former are specially interesting because of rarer occurrence, as well as of greater artistic value, and are for the most part well preserved. The best specimens are two open-work bronze plates, each with a pair of loops at the back for attachment to leather straps. They belong to a well-known type, and doubtless served to decorate chariot horses. The surface of both is adorned with sunk enamel (champlevé) that is now somewhat discoloured, but was originally of a uniform red, ${ }^{4}$ in graceful scrolls that are peculiar to late Celtic art. In one can be seen delicate engraved scrollwork on the bronze ground between the enamel patches, but the surface of the other is somewhat corroded. The edges are lobed, but both are roughly 3 in. square, and formed of stout metal. There is another example of late Celtic scrollwork on a thick bronze disk with tang, and there is a bronze joint for two straps with a sunk rosette. Part of a horse's bridle-bit belongs to a recognized British type well represented in the Polden Hill series at the British Museum; and there are several moulded terminals of bronze, some of which have had iron pins attached in the same way as the so-called linch-pins from Stanwick, Yorkshire.

1 Prec. Sec. Antig. xxi, 324, fig. 5, where details of British and foreign examples are given.

- Ibid. 329, where others similarly patched are cited.

Corresponding measurements of the Baschurch specimen are $17 \frac{9}{4}$ in., 12 in., and $17 \frac{3}{3}$ in.

- Some idea of the colour and design may be derived from the Guide to the Early Iron Age (Brit. Mus.), fig. 3 on plate opposite p. 90 ; fig. 1 has an outline more like those described above. 


\section{A HISTORY OF SUFFOLK}

Yorkshire also provides a parallel for the bronze nave-hoops included in the Santon Downham hoard. These were six in number, two of them being narrower but slightly larger in diameter and fitting on to the broader ones, which had an outside diameter of about $5 \frac{1}{2} \mathrm{in}$., and were $2 \frac{3}{4} \mathrm{in}$. deep, of fairly thick metal. Those found in a chariot-burial at Arras (British Museum) were over 5 in. in diameter and $\mathbf{I} \frac{3}{4} \mathrm{in}$. wide, with a raised rib round the middle, but the metal was too thin to give additional strength to the nave of the chariot wheel. The bronze band with incised lines found folded up and in pieces in the bronze vessel may have originally served the same purpose.

Other fragments definitely of late Celtic work are a thin bronze band $8 \frac{3}{4} \mathrm{in}$. by $I \frac{2}{5} \mathrm{in}$. embossed with a repeating pattern, rivet-holes separating the units of the design. Very similar bands are preserved in the national collection from Rodborough Common, near Stroud, Gloucester. There is also a bronze plate, forming the segment of a circle, with the curved edge moulded and the base measuring $6 \frac{3}{4} \mathrm{in}$. In the middle is a large patch or cover over an oblong opening, attached by two rivets with movable heads in the form of ducks, and engraved with a circular geometrical design on a hatched ground. Similar rosettes are engraved on the plate itself in the angles. The movable water-fowl may have had some religious significance.

There are several bronze ferrules, the use of which is uncertain, but one is in position at the end of a cylindrical bone $5 \frac{1}{5} \mathrm{in}$. in length, slightly tapering towards the ferrule. Also a thin bronze disk $1 \frac{1}{2}$ in. in diameter (perhaps the face of a brooch), embossed with a grotesque animal much resembling one from Westhall, Suffolk. ${ }^{6}$ A steelyard on the Roman principle $10 \frac{3}{4}$ in. long, with well-made scale-pan 4 in. in diameter, may be mentioned here as having an open-work weight with a triskele at the bottom, this being a favourite motive in the pre-Roman period. ${ }^{6}$

Late Celtic buckets of wood are not infrequently found, and the hoard included lengths of thin bronze heavily tinned that probably belonged to a vessel or vessels of that kind. One edge is cut straight to fit the top or bottom of the outside, while the other is deeply scalloped, ${ }^{6 a}$ the distance from point to point across each opening being about $3 \frac{1}{2}$ in. An arched handle, playing on two rivets with broad round heads, is bent in two planes, the middle section being flat for convenience in carrying; and the diameter, as calculated from the span of the handle and two flat bands that may also have belonged to it, is about 7 in. This agrees fairly well with the smaller of two from Aylesford, Kent, which was covered outside with thin bronze plate. ${ }^{7}$

Another group is unmistakably Roman, either as being imports from some richer part of the Empire or copies of Roman models more or less common on the Continent. The most striking specimen is a finely-made bronze jug (oenochoe') with trefoil lip and ornate handle with a lion's head at the point of junction with the lip. The lower end of the handle where it joins the body is in the form of a claw, and the whole is of elegant design, but the base was damaged and clumsily patched before being included in the hoard. The height of the jug itself is $5 \frac{1}{2}$ in., the handle rising 2 in. higher, and an approximate date is afforded by similar finds at Pompeii, which must date before the destruction of that town in A.D. 79 .

There are also several hinges and drop-handles of various sizes and patterns, the former being perhaps for use on armour, the latter for attachment to caskets or similar receptacles. Their staples are still attached, and in one case show that the wood or other material through which they passed was only $\frac{1}{8}$-in. thick.

Another bronze of artistic interest is the fluted handle, $4 \frac{1}{2}$ in. long, of a bowl or skillet that may have been used ceremonially with the jug already described. Only a fragment of the bowl remains on the handle, and the other end represents the head of a dog or other animal.

Further evidence of date is afforded by nine brooches of various recognized forms, and all of the Ist or early 2 nd century. Three ranging between $\mathbf{I} \frac{1}{2}$ and 2 in. consist of a rather massive bow with solid catch-plate for the pin, and across the head a curved cover for the spring, which is missing, but was originally caught in a hook or loop at the top of the bow. A fourth fragment, consisting of the head and half the bow, retains part of the spirally-wound wire that gave tension to the pin. Of the rest, two measuring $2 \frac{3}{4}$ in. are furnished with cylindrical covers for the spring and have a short broad bow connecting the head with a circular and lozenge plate respectively, which form the ornamental part of the brooch. The foot in both cases is grooved and slightly spreading, while the catch-plate at the back is pierced, with a step-pattern bar across the opening. Another brooch of kindred form has a pointed boss on the disk, and another somewhat smaller specimen may once have had a boss of the same kind. The first four described agree in the main with those included in the Polden Hill hoard, ${ }^{8}$ while the rest are assigned on independent grounds to the first half of the Ist century.

'Iron Age Guide (Brit. Mus.), 129 , fig. 110.

6. Compare Anderson, Scotland in Pagan Times: Iron Age, 129.

'Ibid. 102, with figs.

8 For the spring-cover, tension-hook, and catch-plate perforated with step-pattern, see the Polden Hill brooch figured in Iron Age Guide (Brit. Mus.), 128 , fig. 109.

'Koenen, Bonner Fabrbulcher, lxxxvi, pl. iv, figs. I 1, 18, p. 220 (Andernach). 


\section{ROMANO-BRITISH SUFFOLK}

Two small fragments of coloured glass were included: one with blue veins and white crosslines on a green ground probably formed part of a finger-ring; and the other, of bluish green colour, no doubt belonged to a bracelet. Examples of similarly coloured glass in these forms were found in the Celtic stronghold of Stradonitz, ${ }^{10}$ Bohemia, which was destroyed about 10 B.c.

It remains to mention several iron tools which were probably used by the artisan who collected the scrap-metal for recasting. Rust has damaged these specimens, but two large pairs of tongs or pincers survive, with a perforated pick-head, two tapering ferrules, and a broad-bladed knife of the same metal. The iron sockets, which may have belonged to spear-butts, resemble some recently found in Harborough Cave, Derbyshire, in association with remains of the same date as the Santon Downham hoard, but in the latter hoard there were no spear or lance-heads to support the hypothesis. As part of the working outfit may also be mentioned a lump of beeswax and a piece of thin leather very well preserved. One or two objects may have been lost after the discovery of the hoard, but there is reason to believe that the majority were recovered, in their present condition; and the importance of the series for purposes of chronology will be readily conceded. The brooches cannot well be earlier than the Claudian conquest, and native art as represented in metal and enamelling was at that time evidently in a fourishing condition. Further discoveries of the kind may some day show how long the British craftsman withstood the pressure of Roman civilization.

${ }^{10}$ Illustrated in colours by Piz, Le Hradischt de Stradonitz (trans. Déchelette), plates 5-7. 




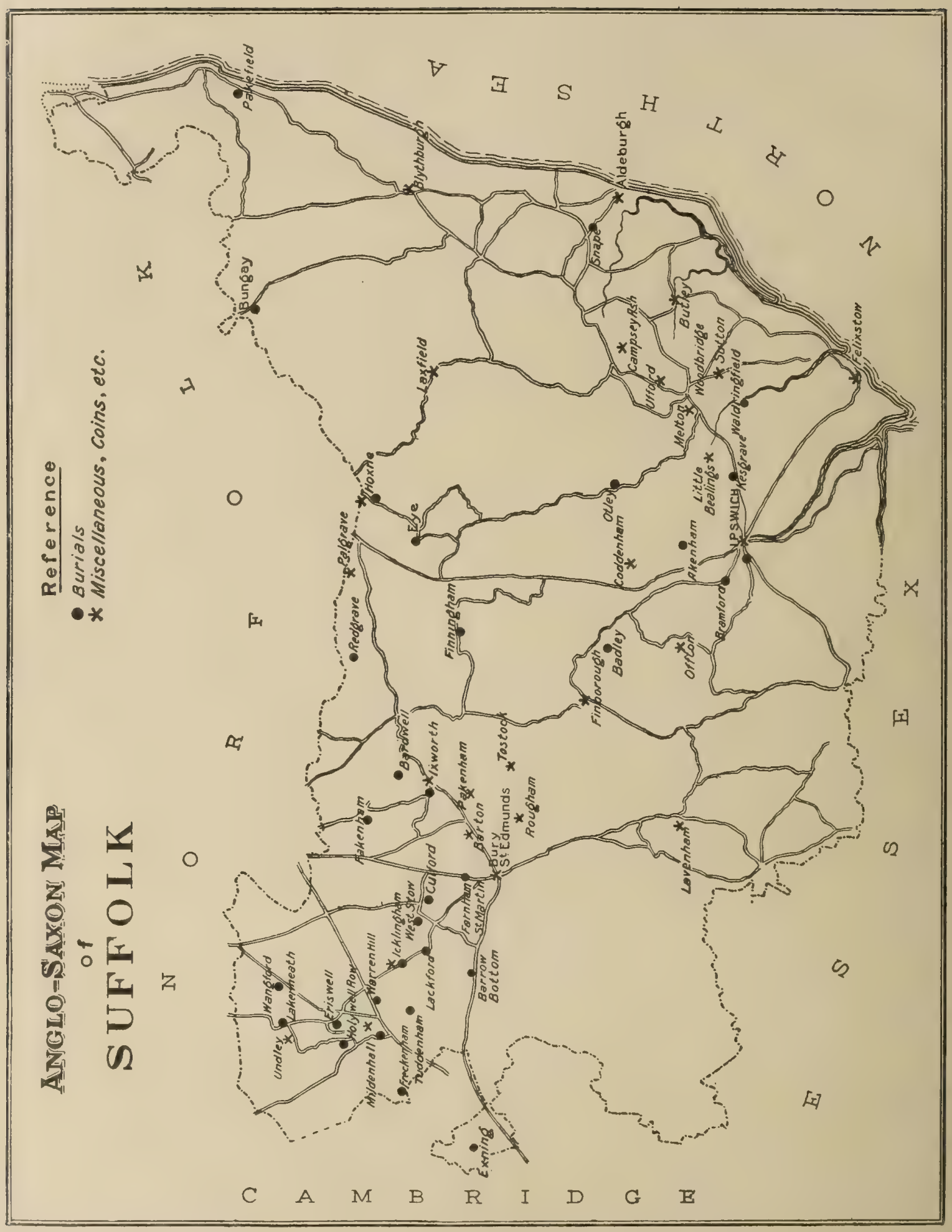




\section{ANGLO-SAXON}

\section{REMAINS}

7 HERE is abundant reason to expect more than a general resemblance between the Anglo-Saxon antiquities of Suffolk and those of its northern neighbour. Before the draining of the Fens, East Anglia was cut off from Lincolnshire and Cambridgeshire; and, to judge by the name of Essex, the Stour constituted an effective tribal frontier. That this isolation was not distasteful to the inhabitants, but rather desired as a matter of policy, is shown by the elaborate fortifications erected near Newmarket, against an advance from the interior. ${ }^{1}$ The principal of these is the Devil's Dyke across the famous Heath, barring the way between Reach in the Fens and the comparatively high ground near Wood Ditton, where primeval woodland no doubt continued the defensive line. It is the most easterly of the series, and consists of a rampart $18 \mathrm{ft}$. above the surface, the crest being $12 \mathrm{ft}$. wide and $30 \mathrm{ft}$. above the bottom of the ditch which lies on the west of it. Such a stupendous work over 7 miles in length will hardly be assigned to the Anglian settlers without further proof, but it must be remembered that the Bokerly Dyke was proved by the late General Pitt Rivers to be of Roman or later date, and the Wansdyke that runs from the Severn near Portishead to Andover is probably contemporary. ${ }^{2}$ Both these remarkable earthworks were evidently intended to withstand invasion from the Southern Midlands, as the ditch is on the northern side, and a limiting date may some day be found in the same way for these ramparts of East Anglia. Whether of post-Roman or prehistoric construction, they seem in any case to have constituted a tribal frontier in the Anglo-Saxon period, as relics on either side are for the most part quite distinct, though, as will be seen later, there is considerable variety in the Suffolk series. This is perhaps due rather to difference in date than to a conflict of races; but the evidence at present is insufficient to explain many of the discoveries now to be enumerated.

Of the accounts here summarized one was communicated by Rev. H. M. Scarth to the Archaeological Institute ${ }^{3}$ in 1863 , and was itself based on a report by Mr. Francis Francis to the Field newspaper; another was given to the Society of Antiquaries ${ }^{4}$ by Mr. Septimus Davidson, from which the

${ }^{2}$ Described in $188_{3}$ by Professor Babington, Ancient Cambs. 95 (2nd. edition, Cainb. Antiq. Soc. octavo publications, no. $\mathbf{x x}$ ).

V.C.H. Somers. i, 374; Pitt Rivers, Excovations in Bokerly Dyke and Wansdyke (1892), iii, 25 ; see also pp. xiii, 246.

- Arch. Josm. IX, 188 ; Field, 17 Jan. 1863, P. $61 ; 24$ Jan. p. 75.

- Prac. Sar. Antiq. (2nd. ser.), ii, 177 ; summary by G. H. Boehmer, Prehistoric Naval Architecture (Report of U.S. National Museum, Smithsonian Institution, 1891), p. 603, pl. Ixxvi, figs. 11 8, 119. 


\section{A HISTORY OF SUFFOLK}

illustrations are borrowed. The country traversed by the road from Snape to Aldeburgh, a distance of about 5 miles, is mostly covered with whin and bracken, and rises from the River Alde, which flows at the distance of half a mile or a mile from the road. About midway, or rather nearer to Snape, it passes between six large barrows, the highest being $5 \frac{1}{2} \mathrm{ft}$. from the ground level, and three standing on either side in lines parallel to the road. Other mounds are scattered irregularly over the common, and all seem to have been of conical form $4 \mathrm{ft}$. to $5 \mathrm{ft}$. high and of various sizes, some being as much as $72 \mathrm{ft}$. in diameter, but others $6 \mathrm{ft}$. to $7 \mathrm{ft}$. The chief group had been excavated about 1840 and again for the Ordnance Survey; but, the result being unknown except that a wagon-load of vases and other objects was removed on the first occasion, operations were resumed by Mr. Davidson in the autumn of 1862 on the north side of the road in a mound $4 \frac{1}{2} \mathrm{ft}$. high and $60 \mathrm{ft}$. to $70 \mathrm{ft}$. in diameter. They resulted in the discovery of a large

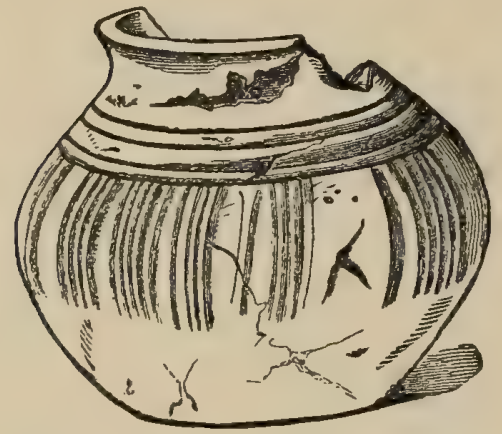

Fig. 1.-Cinerary Urn, SNape cinerary urn ${ }^{5}$ of the Anglo-Saxon period, containing charred bones in a compact mass. The ware was dark and lustrous, and the ornamentation consisted of incised triangles and rectangles alternately, which inclosed stamped patterns compared to ermine spots. A few days later the smallest of the group, at the east end, was opened; and as there were signs of previous excavation at the centre of all three, the work proceeded from the centre outwards.

On removing the surface soil of peaty sand, traces of large fires with layers of soft unctuous matter were noticed, while in some places the earth was black and caked, apparently where human bodies had been burnt. These hard brick-like patches sometimes adjoined a cinerary urn, but occurred irregularly in all parts of the mound. The larger barrow, towards the west, had been cut into for the road, but contained a fine Anglo-Saxon urn, in perfect condition, ornamented with incised lines, vertical bosses, and a device that may have been a swastika. ${ }^{\circ}$ It contained calcined bones and resembled specimens found by Lord Braybrooke at Linton and Wilbraham, in the adjoining county of Cambridge. Another vessel, entirely crushed, lay near it, and large quantities of broken flint were found in and around these barrows, though flint does not naturally occur in the locality. By driving a wide trench through the centre of the principal mound, Mr. Davidson found a cinerary urn of the Bronze Age (p. 267) empty and inverted, quite unlike the Anglo-Saxon specimens; and one or more iron spear-heads, found in association with this and numerous fragments of other urns, may have been contemporary, as a spear-head has been found within a Bronze-Age cinerary urn at Colchester. No cremated bones were noticed on this occasion, and so far there had been found only remains of different periods deposited in all parts of the mound at depths varying between one foot and three feet. The next proceeding was to reach the undisturbed soil on which the mound had been raised. Below the black strata already

Fig. 1 in the Field account.

- Fig. 3 in the Field account shows a swastika on this urn. Cf. Redgrave urn, pl. IV. 


\section{A HISTORY OF SUFFOLK}

distances small masses of iron encrusted with sand and entirely rusted. A few days later these iron bolts were traced throughout the length of the trench, and found to belong to a timber framing. On either side there were six rows exactly corresponding, and indicating the ribs of a clinker-built boat (fig. 3) that had fallen into decay, those at the side being horizontal, and four or five rows at the bottom vertical, the boat being of the section shown in the diagram (fig. 4). The two ends of the boat were distinctly traced, and its original length, estimated at $46 \mathrm{ft}$. or $48 \mathrm{ft}$., the width amidships being about $\mathrm{r} \circ \mathrm{ft}$. and

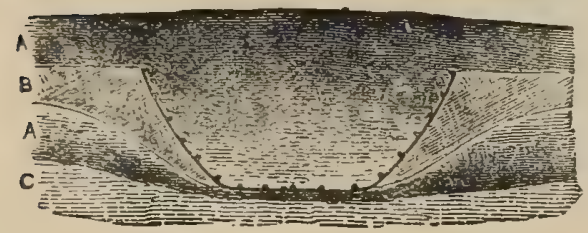

Fig. 4.-Ciross-section of Boat IN Grave-Mound, Smape height about $4 \mathrm{ft}$. The woodwork at the bottom, though quite rotten, showed clearly the method of construction, and the outline argued considerable skill and knowledge of ship-building. As the ring, hair, and glass were found precisely in the middle line of the boat (according to one account at the end), there can be little question as to the approximate period of its construction and burial, though parallel instances, at least in this country, are not easily found.

In July I 863 a further account of excavations on this site was furnished to the Archaeological Institute ${ }^{9}$ by Mr. F. Francis, who was indebted to an eye-witness for his facts and sketches. Stimulated by his success in 1862 , Mr. Davidson had directed his field adjoining the road to be trenched from east to west 12 yds. wide. By this means the whole circumference of the largest tumulus was included, and more than forty vases were exhumed, mostly in fragments. The majority of these were found in the level between the two large mounds, much outside the extreme base of either; and as this wide interval, singularly bare of furze, was rather depressed than otherwise, it is unlikely that earth had ever been heaped over them. No urn was discovered at a greater distance north or south than about royds., and most were within a short distance of the hedge on the south. All were found about I ft. below the surface, and in most instances were brought to light on the removal of the first sod. The mould was, as elsewhere, black and greasy, and in this many of the urns had altogether collapsed. An examination of some of the bones showed that the process of cremation was incomplete, and fragments were noticed that testified to more than ordinary stature. No arrangement could be traced in the deposit of the urns, some being at considerable intervals and others close together. They varied much in profile and decoration, as well as in the quality and thickness of the ware, but all contained incinerated bones. The only relics found were two small pieces of what was considered ivory in a serrated metal mount, with remains of a rivet in the centre; part of a convex copper plate having the appearance of part of a helmet; an oblong copper ring, evidently part of a buckle ; an iron spear-head 10 in. long, 'joined in the centre by a rivet'; a round bead of bone, and fragments of fused glass. All these items were from the smaller urns, the larger yielding nothing but bones. This then was doubtless the urn-field or cemetery of a community living on the bank of the Alde, who utilized a burying-place already a thousand years old, and raised a mound

- Arch. Fourn. xx, 373. 


\section{ANGLO-SAXON REMAINS}

over a boat, thus anticipating the Vikings of Norway. The scanty finds within the boat suggest that two persons were buried with it, the hair alone being preserved (as sometimes occurs), and the glass, if not the gold fingerring, fixes the interment within certain limits of date. Glasses of this peculiar form are fairly common in Kent (Reculver, Ashford, Gilton, Coombe, Sarre), and occur occasionally in other counties (Surrey, Hants, Gloucs., Bucks., Cambs., Northants, and Durham), as well as in the north of France, and on the Middle Rhine; but their place of origin is as yet undetermined. From associated objects it is, however, possible to assign them to the 6th century in general, though some may belong to the late $5^{\text {th }}$ or early $7^{\text {th }}$ century, and the ring seems, in the present instance, decisive for the earlier date.

In that part of the Deben Valley, which approaches the higher ground and runs parallel to the sea-shore at a distance of seven or eight miles, AngloSaxon finds have been plentiful. In this group may be included Kesgrave, where a fine cinerary urn has been found. It is now in Ipswich Museum, and is $8 \mathrm{in}$. high with a diameter of 9 in., the neck and shoulders being ornamented with stamps (cross in circle and triangle filled with dots) arranged in a Vandyke pattern. ${ }^{10}$ Another urn, now in the national collection, was found in Waldringfield churchyard, ${ }^{11}$ and is a typical specimen of Anglo-Saxon pottery. It is smaller than the average cinerary urn, being $5 \frac{1}{4}$ in. high, of dark brown ware, hand-made, with a row of bosses divided by triple vertical lines round the shoulder, and circular hollows round the neck between bands of lines.

Higher up the river at Ufford a good specimen of the long brooch was found in 1819 , and may have belonged to an unburnt burial, though no further details are given. ${ }^{12}$ It was 5 in. long, and about $\mathrm{I}$ in. was missing from the foot, which had a fan terminal and prominent 'nostrils' on either side of it. There were wings attached to the plate below the bow, and extensions to the knobs on the head, all these features pointing to the latter part of the 6th century or a little later.

In the British Museum is part of a jewelled buckle (frontispiece, fig. I) from Melton, that has all the appearance of Kentish work. ${ }^{13}$ It was found in I 833 , and is of triangular form, with a central plate of gold embossed with pure (not animal) interlacing and a border of garnets in cells of cheveron pattern. The hoop and tongue are missing, but the original appearance can be readily inferred from extant specimens, ${ }^{14}$ such as that found by Faussett at Gilton, Kent. ${ }^{15}$

Another relic, apparently of Kentish manufacture, was found in the same neighbourhood, at Sutton near Woodbridge. It is now in the Fitch Room at Norwich Museum, and has been well published, ${ }^{16}$ but is not by any means complete. Like the somewhat similar jewel from Ixworth, it is but the front of a circular brooch (fig. 5), and even if the back and pin were lost before interment, the finder cannot be pardoned for having thrown away all the settings

${ }^{10}$ Coll. Antiq. ii, 233, pl. liv, fig. 4 .

"East Anglian N. and Q. i, 347 .

18 Journ. Brit. Arch. Assoc. xviil, 225 , pl. xi, fig. 4 .

Arch. Foum. ix, i16 (fig.).

"Douglas, Nenia Britannica, 53 ; Arch. xxx, pl. i, fig. 21.

${ }^{2}$ Invensorium Sepulcbrale, pl. viii, fig. 8 ; cf. V.C.H. Kent, i, 373, pl. ii, fig. 7.

"Arch. Album, 206; Fairholt, Cossume in Engl. 465 ; Akerman, Arch. Index, pl. xvi, fig. 12. 


\section{A HISTORY OF SUFFOLK}

before selling the gold cell-work. It was found about $\mathrm{I} 835$ by a ploughman who stated that it had studs of precious stones or glass, red at the centre, and others blue, while the small spaces (cloisons) were filled with green and other colours. In the British Museum is a somewhat

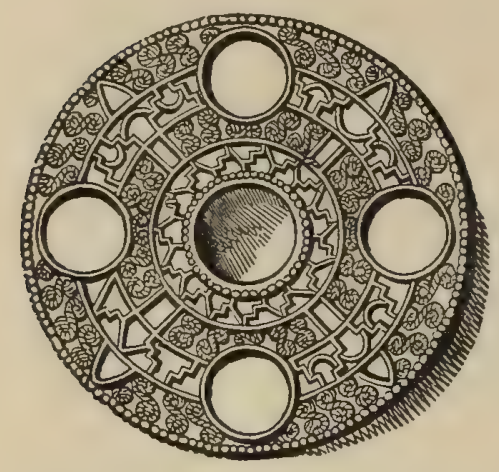

Fig. 5.- Gold Front OF JEWelled Brooch, Sutton, near WOODBRIDGE $\left(\frac{1}{1}\right)$ larger brooch of gold from Faversham, Kent, that has likewise lost all its settings; and both are good examples of an English (or perhaps Jutish) industry that flourished between $55^{\circ}$ and $65^{\circ}$ of our era and is best represented in the Kentish graves of that period.

Another link with Kent or indication of early foreign trade is a jewelled brooch, found in Suffolk (frontispiece, fig. 3). It belongs to the 'radiated' type more commonly found on the Continent and assigned, on adequate grounds, to the $5^{\text {th }}$ century. Derived ultimately from a Gothic model of the fourth century found in South Russia, ${ }^{16 a}$ it is a good specimen of the jeweller's art, and is engraved with linear patterns that are not definitely Teutonic, but survivals from classical art. The knots round the head are set with garnets, and along the bow and foot runs a strip of silver ornamented with niello in minute triangles. Of fifteen found in England six are from Kent and the Isle of Wight, while the rest have been found sporadically as far north as the East Riding, but mostly on the eastern side of England.

For Anglian immigrants arriving by sea the Orwell was doubtless one of the best approaches to the higher and drier ground of central Suffolk, and Ipswich has recently produced a splendid series of their remains. During the whole of 1906 burials were disturbed in the course of relief works for the unemployed on land belonging to the corporation in the triangle formed by the railway, Hadleigh Road, and London Road, on the western border of the county-town. The slope on the south side of Hadleigh Road was removed, and after four interments (possibly a larger number) had been destroyed by the workmen, the task of supervision was undertaken by Miss Nina Layard, who directed a gang of workmen a little in advance of the main body, and thus discovered and examined about 160 burials in one or other part of the ground. Full reports were prepared by Miss Layard for the Society of Antiquaries of London ${ }^{17}$ and the Suffolk Institute of Archaeology and Natural History ${ }^{18}$; and the finds handed over to the town. The rich and interesting collection, that might in other circumstances have been lost to science, is now admirably exhibited in Christchurch Mansion, and throws much light on the conditions prevailing in this part of the county in the 6th century, for it is to that period that most of the objects recovered belong.

In an area measuring roughly $400 \mathrm{ft}$. by I $50 \mathrm{ft}$. inhumations were frequent and only a few cinerary urns were found, but in the later stages of the work this area had to be abandoned for a smaller space a little to the

163 Arch. Fourn. 1xv, 76 .

17 Arch. 1x, 325-52, with map, illustrations, and three coloured plates; see also Proc. Soc. Antig. xxi, 241 , and further notes pp. $242-7$.

${ }^{18}$ Proceedings, xiii, 1-19, including the same coloured plates. 


\section{ANGLO-SAXON REMAINS}

south ${ }^{10}$ where cremations were numerous. Whether these areas were continuous cannot now be determined, but the larger cemetery (or portion if it) may be regarded as one of pure inhumation, the admixture of urns being hardly noticeable till its limits were passed. The mixed cemetery is not easy to explain, and there is nothing to prove whether the two rites were practised together or one was superseded by the other. The orientation is hardly conclusive, for nearly all the skeletons lay with their heads at the south-west end of the grave ; and though this and the grave-furniture suffice to show their pagan character, it is impossible in the present state of know. ledge to decide whether inhumation in this direction served as a transition from the essentially pagan practice of cremation to the Christian east-and-west interments without grave-furniture. The mixed cemetery shows that those who practised both rites were not debarred by religious or social laws from using the same burying-ground, but as their relation to each other is not yet clear, it will be advisable to draw conclusions mainly from the larger area where a certain uniformity is observable.

The skeletons lay generally between $2 \mathrm{ft}$. and $4 \mathrm{ft}$. from the surface in narrow graves, with the arms straight down the sides, the face upwards, and the legs extended. In one case a coffin may possibly have been used, but wood and nails are rarely found in Anglo-Saxon graves outside Kent, and the body is generally unprotected from the filling of the grave, though sometimes a heap of small stones is found or, in stone districts, slabs lining and covering the grave. Many of the men were buried with their spears point upwards on either side of the head indifferently, and their shields over their faces, the iron boss of which survived and was in this cemetery frequently found beside the head. The complete absence of swords was remarkable where so many warriors were interred and may be an ethnological feature. A few single beads were found in the graves of males, but the abundance and excellence of the women's necklaces may be appreciated from the coloured plates already referred to, the materials employed being coloured glass-pastes, crystal and, above all, amber. It was observed that most of the beads occurred in pairs, ${ }^{19 a}$ which were apparently divided on either side of a large central bead on the necklace, and one grave contained as many as 108 beads. Ring-brooches were found one above the other on the breast, not as the typical West Saxon brooches, one on each shoulder; and another point of interest is that at least one of the large square-headed brooches that enrich this collection was worn foot upwards, ${ }^{20}$ as were the Roman cross-bow

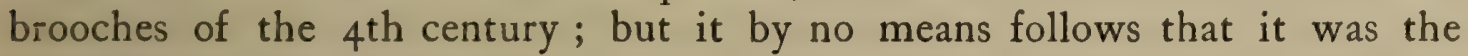
universal custom among the Anglo-Saxons to turn the square-head of their brooches downwards. Several of this type still retain the silver discs applied to the three extremities of the foot (pl. I, figs. I- -3 ), and the illustrations will render a minute description unnecessary. There are in all eight large squareheaded specimens, all decorated by water-gilding and showing minor variations, of which some deserve special mention. The disc attached to the bow of fig. 2 is a feature rarely found in England, ${ }^{21}$ but common in the following

"Far westward of the main area broken urns alone were found : Proc. Suff. Inst. Arch. xiii, 17.

12 Compare a necklace from Beeby, Leics. (V.C.H. Leics. i, 237).

* As at Bifrons, Canterbury ; and Brighthampton, Oxon.

n Proc. Soc. Antig. xxi, 35-7; outside Suffolk, at Tuxford (Notts.), and Brooke (Norf.). 


\section{A HISTORY OF SUFFOLK}

century in south Sweden. Besides pl. ii, fig. I, which retains a rivet on the bow probably for the purpose of attaching a disc, two other specimens have been found in the county, at Finningham and Mildenhall (fig. I3), and one just over the Norfolk border at Brooke, midway between Norwich and Bungay. A similar brooch from Bury St. Edmunds in Sir John Evans' collection has a rivet hole in the bow, apparently for attaching a disc, now lost.

Another variety of the square-headed brooch (pl. ii, fig. I) shows a curious blend of styles, which must be subsequent to the middle of the 6th century, for the wings below the bow do not seem to have been introduced earlier. In outline it is a 'long' brooch without the customary knobs, but with circular extensions at the angles of the head and a spreading foot of degenerate form; but instead of the severe decoration characteristic of the ' long or cruciform' brooch of Scandinavia, there appears on this specimen the animal-ornament of the Anglo-Saxon craftsmen that is seen more commonly on square-headed and saucer brooches.

The flat annular brooches of bronze had usually pins of iron (mostly perished), but the brooch-types at Ipswich are strangely limited. There were no long or cruciform specimens of the ordinary kind found in the cemetery, none of the smaller kind with square or trefoil heads, nor any bracelet-clasps ${ }^{22}$ so common in the west of the county. On the other hand, there are two remarkable circular brooches (pl. ii, figs. 2, 3) that must be of Kentish origin. They belong to what may be called the 'keystone' type ${ }^{23}$ but the garnet slabs do not exactly conform to the regulation pattern, that of the centre stone of an arch. They were found in separate graves, and both had central studs of some substance that is well preserved in one case and has the appearance of ivory, like one from Little Wilbraham, Cambridgeshire, published by the Hon. R. C. Neville. ${ }^{24}$

Another remarkable find in the Ipswich cemetery was a bronze buckle of Frankish manufacture (pl. ii, fig. 5), almost unexampled in this country, but common in certain parts of France, ${ }^{25}$ where they are attributed, at the earliest, to the 7 th century. A similar specimen was found at Bellevue near Lympne (Kent), ${ }^{26}$ and the three studs, now missing from the Ipswich specimen, are there seen in position. A collar of silver wire ${ }^{28 a}$ carrying a bead is a novelty for England, but one has since been found at Desborough, Northants.

Glass from this cemetery is particularly good, one vase much resembling that illustrated from Bungay, but having threads like stamens added to the petals round the base. Examples of pale green and amber-coloured cups are also given on the coloured plate (figs. 6,7 ), the types being usual and well represented in Kentish finds.

The peculiar iron adze, the strike-a-light, earrings, châtelaines or girdlehangers, and iron-hooped buckets from Ipswich all find parallels in the Little Wilbraham cemetery, which lies between Newmarket and Cambridge, about six miles from the Suffolk border, and other specimens common to the two

"These were closely connected with 'long' brooches at Little Wilbraham, Cambs.

${ }^{23}$ V.G.H. Kent, i, pl. i, fig. 4 (opp. p. 342); for other specimens see de Baye, Industrial Arts of the Anglo-Saxons, pl. x, figs. $3,6,7$.

${ }^{24}$ Saxon Obsequies, pl. 3, grave 172.

${ }^{25}$ B. Flavy, Arts industriels de la Gaule, album, plates xlviii, xlix; Boulanger, Mobilier funéraire, text of pl. 42.

${ }^{26}$ Roach Smith, Richborough, Reculver, and Lym:e, 264.

28a Suff. Inst. Arch. Proc. xiii, pl. iv, fig. 5, p. 6. 


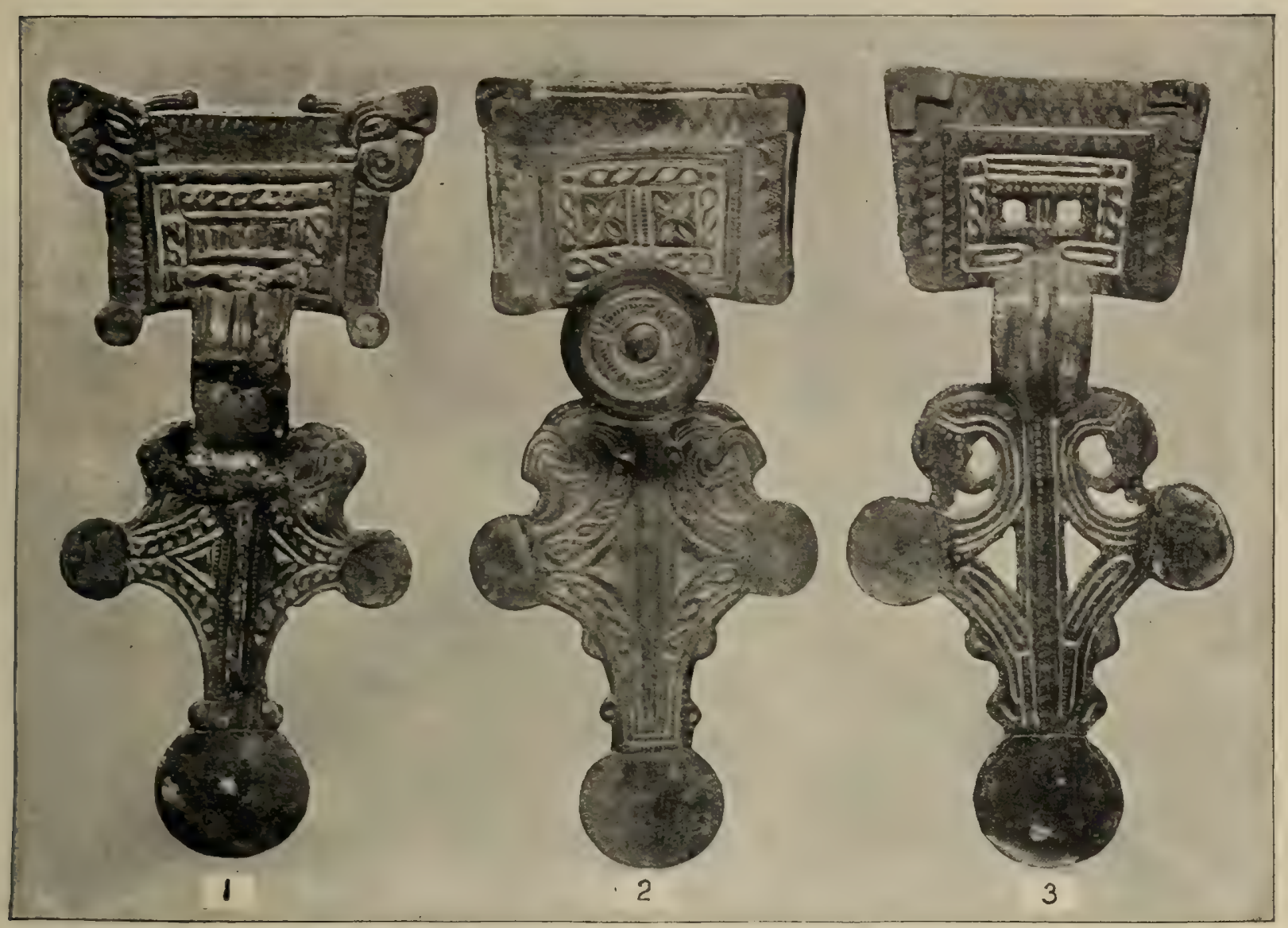

Bronze Square-headed Brooches from Ifswich $\left(\frac{2}{3}\right)$

PLATE I

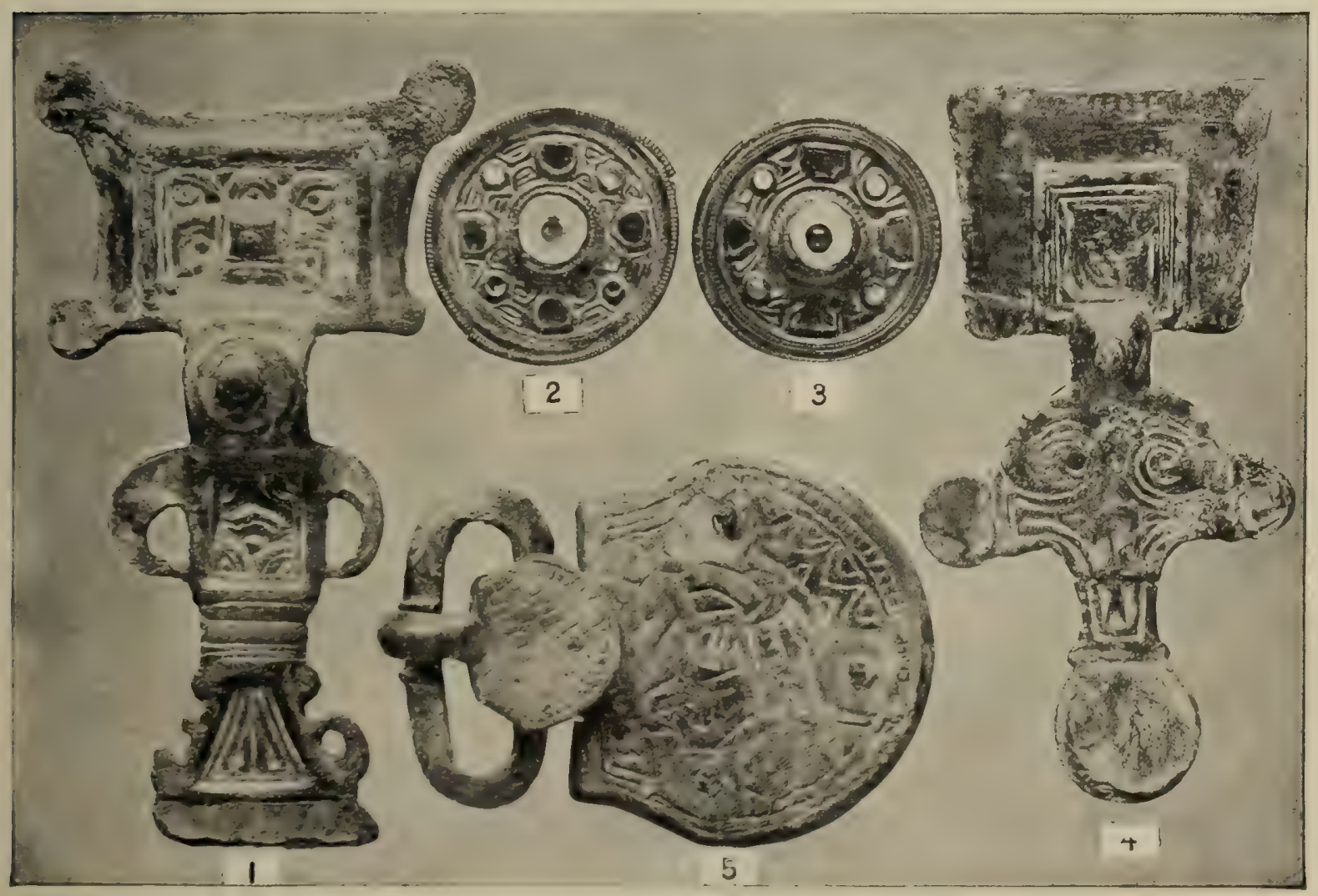

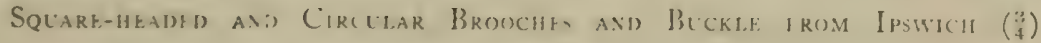





\section{ANGLO-SAXON REMAINS}

sites have already been mentioned, but there are essential points of difference between the Ipswich cemetery and others in East Anglia that have yet to be explained. The specimens present on one site and absent on another are, however, generally of native manufacture, and point rather to isolation in East Anglia than to immigration from different localities on the Continent. This is an important point, for the general uniformity of East Anglian burial grounds suggests a common origin for the population of the 6th century, different from that of the Saxon occupants of Essex and the Thames valley, though not far removed from that of the midland Angles.

The county town has also produced two jugs of blackish pottery that, like some other antiquities in the county, seem to be of Frankish origin. That found in Carr Street has a wide mouth with an insignificant spout and diminutive handle, and is $6 \frac{3}{4}$ in. high, while the Princes Street specimen is more like an ordinary jug with larger handle and spout. They are both in the museum at Christchurch Park, and may be compared with others from Kent ${ }^{87}$ in Maidstone and Liverpool Museums.

In the Gipping valley deposits showing occupation in the 6th century have been discovered. A cinerary urn from Bramford, similar to that on plate iii, fig. 3 , and of somewhat unusual form, with a cheveron pattern filled with stamps, is now in the Ipswich collection, as is also a fine pair of long brooches (pl. v), $5 \frac{1}{2}$ in. long, evidently from a burial at Akenham Hall ; while at Norwich is another brooch of the same variety from Coddenham, 3 miles farther up the valley.

At Badley, near Needham Market, during the construction of the railway, was found a bronze bowl that has unfortunately disappeared. According to a drawing published in the Reliquary ${ }^{28}$ it had two escutcheons of beaten form with rings for suspending chains and was furnished with a cover, while an enamelled disc ornamented the inside at the bottom. It was associated with another bronze bowl with open-work foot ${ }^{29}$ of a type common in Kent and sometimes found on the Continent, obviously dating from the 6 th or 7 th century. The Badley specimen in all probability served the same unknown purpose as those with three escutcheons attached to the outside below the moulded rim to hold the chains, and the type is well represented at Mildenhall (p. 346).

Interments in the valley of the Waveney show that there were early Anglo-Saxon settlements on what is now the boundary between Norfolk and Suffolk. North of that line burials are recorded at Stockton, Broom, and Earsham near Bungay, and on the Suffolk side urns (presumably cinerary) have been found at Stow Park, ${ }^{30}$ and a perfect cup of pale green glass, ${ }^{31}$ also in the neighbourhood of Bungay. The latter (frontispiece, fig. 5) is now in the British Museum and doubtless came from a burial, as it is difficult to conceive that so fragile a relic could have survived unless carefully deposited and protected in the earth. It is 5 in. in height, and has a spiral thread round the neck and applied threads springing from the base in the form of petals, just as on the specimen found at Ipswich and presented to the museum

\footnotetext{
7 One from Sarre is figured in V.C.H. Kent, i, 359.

* Reliquary and Illustrated Archaeologist (1900), vi, 243; Arch. Ivi, 48.

V.C.H. Kent, i, 372, fig. 19 .

"Figured in colour by Akerman, Pagan Saxondom, pl, xxv, fig. I.

${ }^{30}$ Norf. Arch. iv, 315 .
} 


\section{A HISTORY OF SUFFOLK}

there by Mr. H. G. Casley (p. 332). Such glasses are frequently found in south-east England beside the head of a skeleton as part of the grave furniture.

In the possession of Miss Betts, of Wortham Hall, ${ }^{31 a}$ were formerly some portions of an iron brooch (or brooches) of the long variety, inlaid with bronze and silver and with a panel of animal ornament in the centre of the heads, pointing to the latest pagan period. There were also beads, part of a clasp, and a diminutive bronze bell, all probably from a burial at Hoxne; and the iron brooch is of exceptional rarity. The next interment recorded was at Redgrave, ${ }^{32}$ on the watershed between the Waveney and Little Ouse or Brandon river. A fine cinerary urn, now in the Bury St. Edmunds Museum, has swastikas impressed on the shoulder (pl. iv), and a small vase from this locality is in Norwich Museum.

It is not easy to find an exact parallel for the gold pendant found at Palgrave near Diss, and published by Rev. C. R. Manning in $1852 .{ }^{33}$ It is formed of seven rings of corded gold wire soldered together and inclosing a centre globe of the same metal. Ornaments in the same style are not uncommon in the richer finds of the Anglo-Saxon period, and one found on Chartham Downs near Canterbury may be mentioned in particular, but here the centre is a cross, and the loop, as in other cases, is simply attached to the edge. The Palgrave example, however, has the strip that forms the loop prolonged across the back and turned to form a hook on the opposite edge, where it was broken off as if by accident. That the arrangement, as shown in the illustration, is not a mere accident, is proved by the fact that the narrow strip is soldered to the centre globe at the back; and it is just conceivable that it served for attachment to the ear. Its Anglo-Saxon origin is not perfectly established, but it is included here as a reputed county find of about the 7 th century, and its republication may lead to the discovery of closer parallels.

Both Finningham and Eye on the Dove, a tributary of the Waveney, have yielded relics that have been inaccurately described. At the latter place in 1818 were found in the space of 120 square yds. about 150 cinerary urns called British, but obviously of Anglo-Saxon date. Labourers working gravel came upon them at depths varying from 4 in. to $2 \mathrm{ft}$., under a covering of fine sand. They varied in size, shape, and ornamentation, and were from 5 in. to 9 in. in height, many being well preserved and containing calcined bones. Most, however, were destroyed in uncovering, and only a few survive. One was exhibited to the Bury anit W. Suffolk Archaeological Society ${ }^{34}$ in 1848 , and Sir Edward Kerrison in 855 exhibited to the Society of Antiquaries of London ${ }^{35}$ a set of bronze toiles implements (for the ears and teeth) strung on a smail bronze ring and found in one of the urns from Eye. Other relics mentioned are small shears of iron, a fragment possibly of gold 2 in. long, and two ivory buttons $\frac{1}{2}$ in. in diameter, which from the description appear to be draughtsmen with two holes in the fiat side for the prong-centre of the lathe.

s1a Information from Mr. C. W. Low, of Stowmarket.

ss Bury and W. Suff. Proc. ii, 89.

ss Arch Journ. ix, 107 ; for similar see Akerman, Pagan Saxondom, pl. xi, fig. 3 (Chartham); Inventorium Sepulebrale, pl. iv, fig. 23 (Gilton).

"Proceedings, ii, I 17 ; Gent.Mag. I 18 , ii, 131 ; the burial-ground found at Stoke Ash in 1851 evidently belonged to the late Bronze Age (Bury ana W. Suff. Proc. ii, 101).

${ }^{35}$ Proc. Soc. Antig. (1 st ser.), iii, 186, with fig.; for Kemble's opinion, see p. 215. 


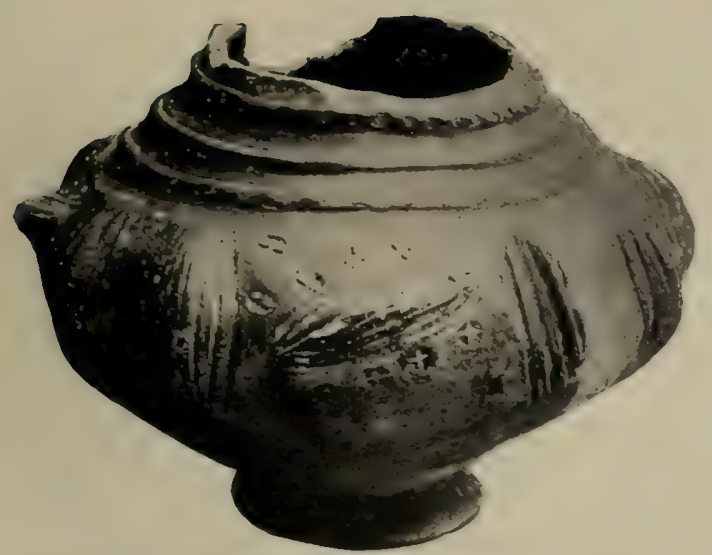

Fici. t. -. Cixerary Lri, Fakexham Heath (- IN. High) (IPSWICH MISELM)

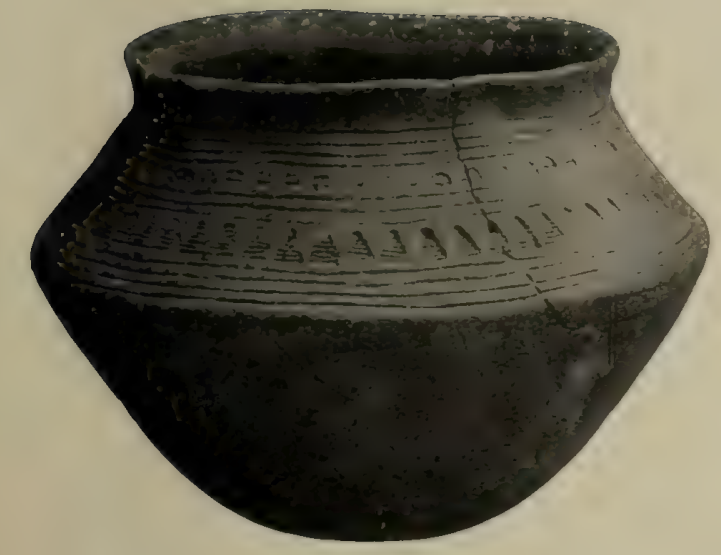

Fig. 3.-Cinerary Urn, Suffolk ( 6 In. high) (IPSWich ML'Sh:Li)

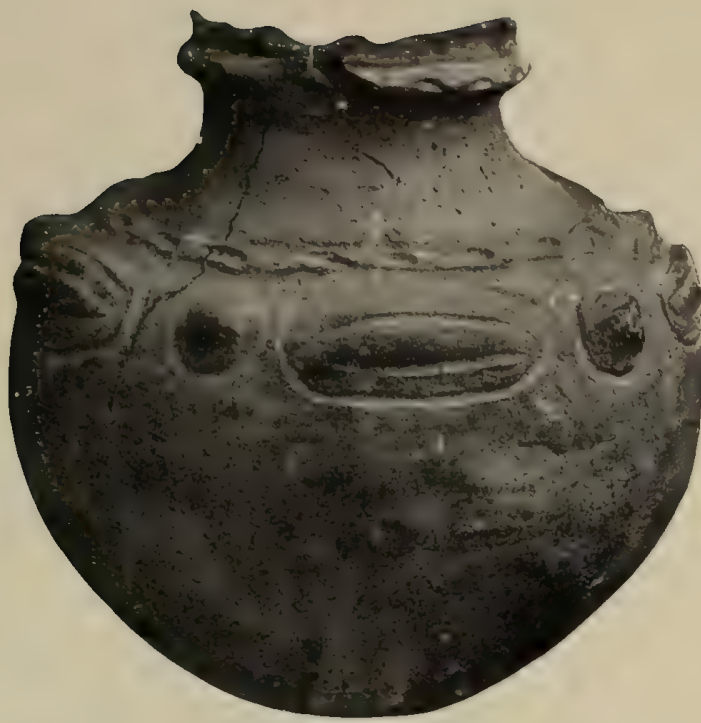

Fici. 2.-Cinfrary Urn, Culford (9 in. high) (I

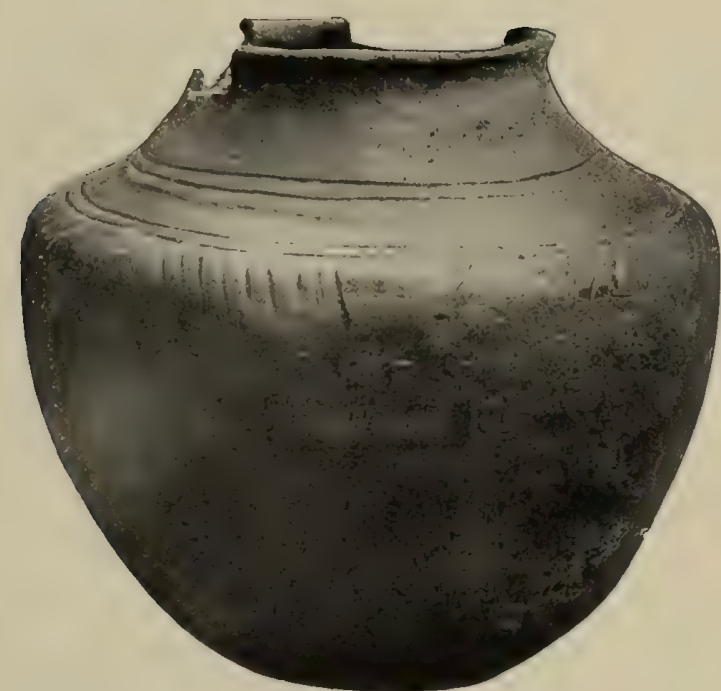

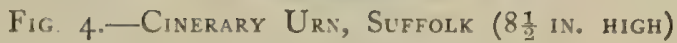
(Ірентсн Museum)

PLATE III-CINERARY URNS FOLNI) IN SUFFOLK 



\section{ANGLO-SAXON REMAINS}

Such have frequently been found in the Anglian district. ${ }^{36}$ The urn and contents now in the British Museum have been illustrated by Akerman, ${ }^{37}$ and are of more than ordinary interest. The cinerary vessel is a typical one about 9 in. high, with vertical ribs round the shoulder flanked by pairs of incised lines; and besides the calcined bones it contained a bone comb $3 \frac{1}{2} \mathrm{in}$. long with triangular handle ornamented with concentric circles; a pair of shears, measuring $2 \frac{3}{4} \mathrm{in}$., of an ordinary pattern, probably used by the housewife; a pair of tweezers 2 in. long, such as are frequent in cinerary urns; and a curved iron knife with looped handle, $3 \frac{1}{4}$ in. in total length, that cannot have been very serviceable.

Some specimens have actually been found with blunt edges ${ }^{38}$ that have obviously never been used for cutting, and it is permissible to see in these articles the make-believe furniture supplied by undertakers of all periods. They are smaller than those generally found with unburnt Anglo-Saxon burials, and different in form, ${ }^{39}$ while their inclusion in the cinerary urn seems to be exceptional. The comb and tweezers are, however, often found with the ashes both here and in Germany, and Kemble has drawn attention to the similarity of the funeral rites in the two areas. ${ }^{40}$

What is described as a Roman urn was found with many others in I 849 during the construction of the Eastern Union Railway at Finningham ;11 but as spear-heads of iron and 'ornaments of brass' (obviously bronze brooches) were found at the same time, it is fairly evident that a mixed Anglo-Saxon cemetery once existed here, the numerous urns pointing to cremation, and the weapons and ornaments to unburnt burials. In $185^{8}$ the Rev. Greville Chester exhibited in London ${ }^{42}$ portions of Anglo-Saxon brooches from this site : one was said to resemble that in the possession of Sir William Lawson found near Catterick Bridge, N.R. Yorks; ${ }^{43}$ and the other had a more elaborate ornament, but is not further described.

Another prolific area in Suffolk is that situated between the valleys of the Lark and Little Ouse, including a considerable proportion of fen. It was not on the sandy high ground that the Anglo-Saxons settled, but as usual in the river valleys, and there were evidently many settlements along the Upper Ouse River which flows into the Little Ouse near Euston Park.

In the Ipswich Museum is a fine specimen of the Anglian cinerary urn (pl. iii, fig. I), from Fakenham Heath. It is, as usual, made without the potter's wheel, and is black above the shoulder and a yellowish-grey below. The ware is of the ordinary quality, and the shoulder is ornamented with vertical and sloping ribs, the latter fringed with impressions from a stamp with a cross within a circle. It is $7 \mathrm{in}$. in height, and was evidently intended to contain the ashes of the dead, while its well-formed foot distinguishes it from the majority of Anglo-Saxon urns.

*V.C.H. Norf. i, 335 ; they are sometimes called 'pulley-beads.'

"Pagan Saxondom, pl. xxii ; Kemble and Franks, Horae Ferales, pl. xxx, fig. I4.

${ }^{39}$ Near Lewes and at Kempston, Beds. ; another from an urn at Long Wittenham, Berks. is figured in Arch. xxrviii, 342 .

fig. 124 .

${ }^{3}$ A large specimen of same type from Denmark; S. Muller, Ordning af Danmarks Olisager, ii (Jernålderen),

"Horae Ferales, 225, pl. xxx ; Arch. xxxvi, 275.

"Bury and IV. Suff. Proc. i, 60; ii, 118.

Arch. Journ. xv, 165.

${ }^{13}$ Arch. Gourn. vi, 216 , where two are figured, that from Thornbrough being the more likely parallel, as it closely resembles some found at Ipswich (pl. ii, fig. 4). 


\section{A HISTORY OF SUFFOLK}

A little distance up the river, at Bardwell, there was evidently an early cemetery, as Anglo-Saxon weapons, including the boss of a shield, were found there about I 846 , though no further details are available. ${ }^{*}$. Ixworth, that comes next in order, has yielded a large number of antiquities belonging to various periods, but the best of the series date from the early days of the English conquest. A rarity in England is a primitive long brooch, representing the evolution of the cruciform type in the 5th century. It was exhibited to the Bury and West Suffolk Archaeological Institute in $1859,{ }^{45}$ and its rarity is attested by the fact that only one other (probably from the Eastern counties) is known in this country. ${ }^{45 a}$ It has a comparatively high bow, and the square plate above it is still very unobtrusive, and can hardly have masked the spiral spring underneath, which originally had knobs at the end like that attached to the top of the plate. It is the parent of the long or cruciform brooches so often found in the Anglian districts of England and in Scandinavia.

A fine pair, representing a later stage in the development of this type, was found on the shoulders of a skeleton in a meadow near the Cross House at Ixworth in 1868 , and closely resemble another pair found in the county (pl. v, fig. I). They are peculiar in having circular grooves filled with red enamel (now much discoloured) in the centre of the panels above and below the bow. ${ }^{46}$ Brooches of this kind, at least till the last stages of their evolution, were not decorated by any additions to the bronze, the varied mouldings being held sufficient for the purpose, and it is all the more surprising to find enamel added at a date when the side-knobs of the head were still separate from the head-plate, and so particularly liable to be lost when the wire-spring perished. These specimens cannot well be later than the middle of the 6th century, and seem to point to a lingering use of the red enamel so

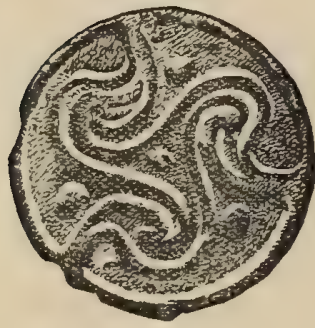

FIG. 6

BroNZE BROOCH, IXWORTH $\left(\frac{1}{1}\right)$ characteristic of the early British period. A bronze brooch from Ixworth (fig. 6) is difficult to date precisely, but may belong to the later Anglo-Saxon period, when round brooches were in fashion. The trigram is rather suggestive of late Celtic work, and should be compared with a specimen from London in the British Museum, likewise assigned to the pre-Norman period.

Two remarkable jewels ${ }^{47}$ from Ixworth have been published more than once, and were found about i 860 by labourers in what appeared to be a grave, together with iron clamps and staples that may have belonged to a coffin.

The first is a pendent cross of gold $I_{2} \frac{1}{2}$ in. square, of the same type as one from Wilton, near Methwold, Norfolk, and had cell-work of garnets and turquoise (probably blue glass) covering the front in a step pattern, the back being a plain gold plate repaired by means of a patch, and having $V$-shaped ridges below the barrel-loop.

The second jewel from this remarkable grave was a circular brooch, or rather the front of a brooch that had lost its bronze base and pin, perhaps

s4 Warren collection; drawings exhibited, Fourn. Brit. Arch. Assoc. ii, 345.

${ }^{45}$ Proc. iii, 402, fig. 1 on plate.

45a Arch. Foum. 1xv, 67.

48 Journ. Brit. Arch. Assoc. xxvii, pl. I 2, fig. 2 ; the 'green enamel' mentioned is explained by the contact of the bronze, and possibly by the oxidation of the copper in the enamel itself.

${ }^{47}$ Bury and W. Suff. Proc. iii, 296, figs. 1, 2 ; Coll. Antiq. iv, 162, pl. xxxviii. 

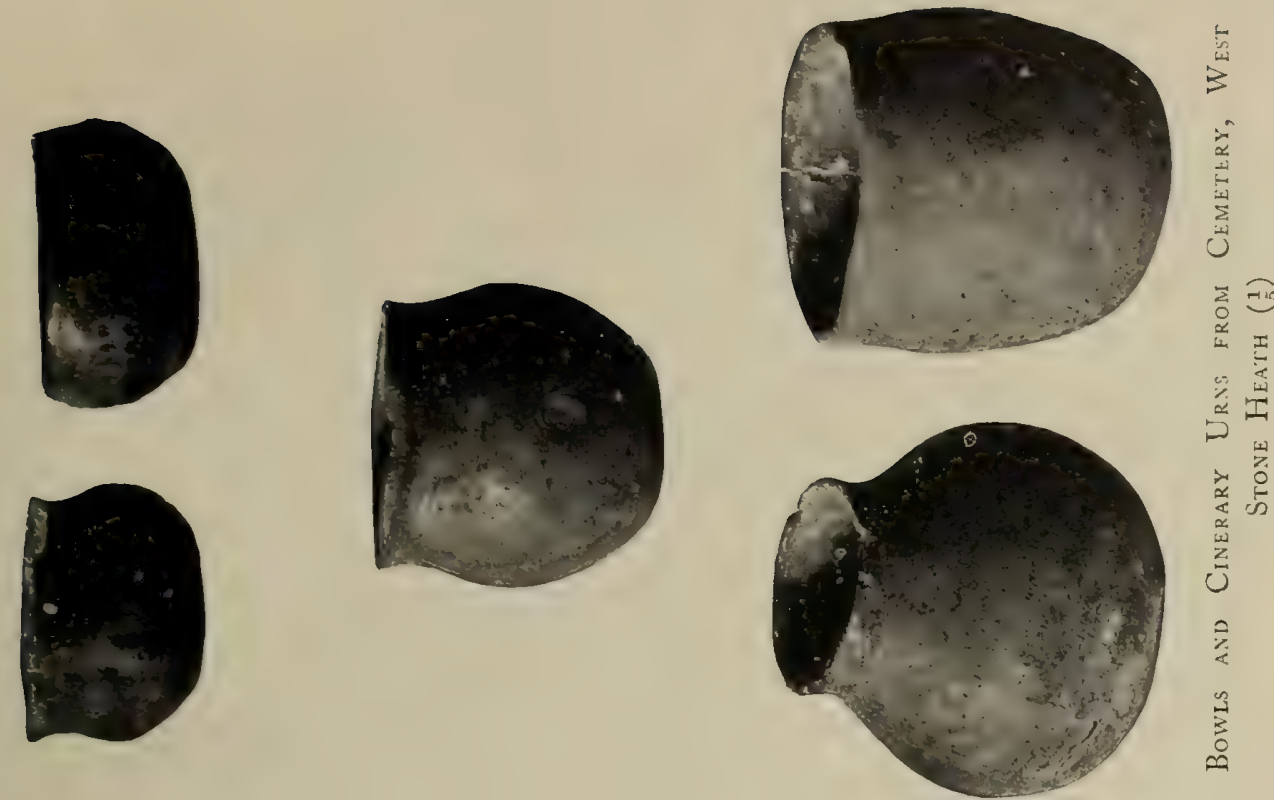

怎

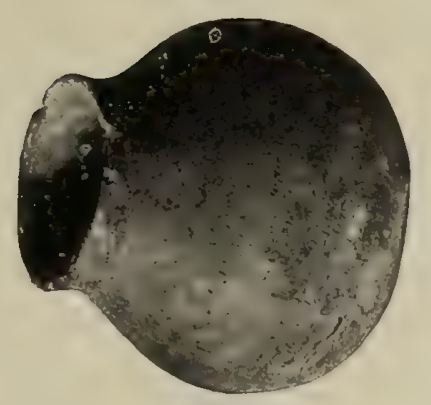

凅地

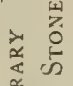

U

خ

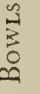
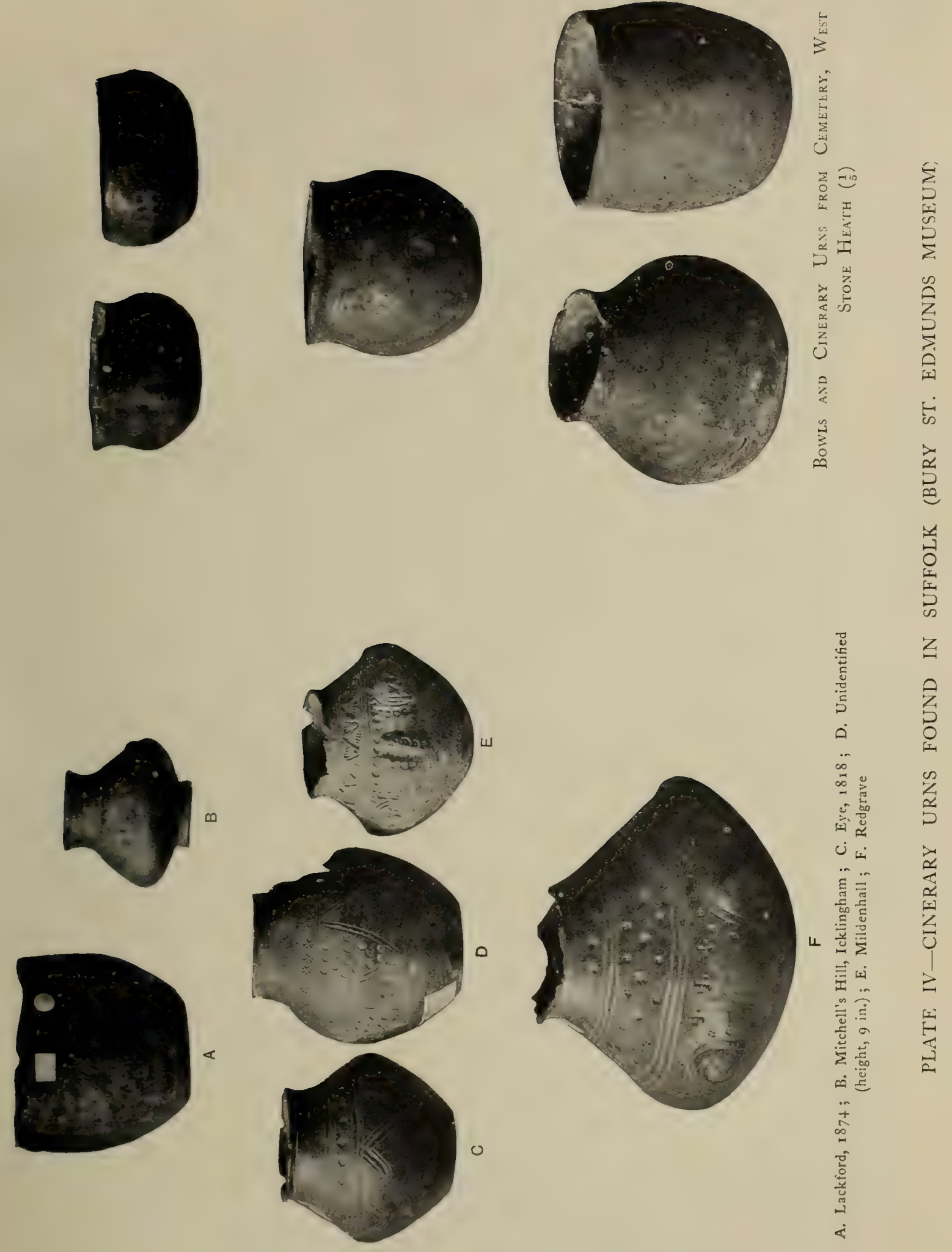



\section{ANGLO-SAXON REMAINS}

before interment. It consists of a gold disc $1 \frac{8}{4}$ in. across covered with bands of filigree in $\mathbf{S}$ and $\mathbf{C}$ scrolls and having four hollow settings round a larger setting, arranged in a manner characteristic of a Kentish type, ${ }^{47 a}$ and similar in all essentials to the brooch found near Woodbridge. The five bosses now missing were perhaps of ivory, though the material of existing specimens is generally described as pearl or shell.

Further discoveries made in 187 I showed that Mr. Rogers' meadow was the site of a cemetery, for among the relics was an iron sword in three pieces, which measured together about $2 \mathrm{ft}$. 2 in. (the normal length from tip to pommel being $3 \mathrm{ft}$.), and bore traces of the wooden scabbard; also a spear-head, knife, and three shield-bosses of the usual form, two still retaining their handles. These remains imply at least three unburnt burials on this site, possibly somewhat earlier than the richly furnished grave described above

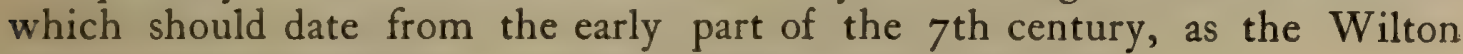
cross-pendant contained a gold coin of Heraclius I (6 I $3-64 \mathrm{I})$.

In the same meadow was found a pleasing example of later Anglo-Saxon art. It consists of a copper disc with slightly convex front, which is richly gilt and engraved in four quadrants leaving a plain cross between them. ${ }^{47 b}$ In each of the spaces is an animal form, suggestive of a horse, with interlacings in the field; and the rivetholes show that the disk was not the face of a brooch, but the head of a pin like one found in the Witham at Lincoln and now in the British Museum. ${ }^{48}$

At Pakenham, 2 miles south of Ixworth, was found in 1843 a curious bronze prick-spur that passed into the possession of Sir John Evans and has been published. ${ }^{49}$ It seems to have been an isolated find in a ploughed field, and, though no close parallels are known, probably

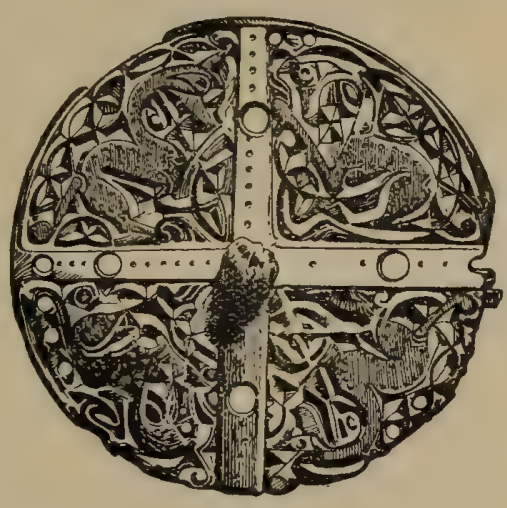

Fig. 7.-Bronze-Gilt Disc-head of

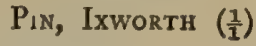
belongs to the late Anglo-Saxon period. The animal-heads that ornament the centre and the ends where the strap joined are evidently derived from models in use during the pagan period, but cannot be more precisely dated. The eyes of the three heads were filled with blue glass in a manner recalling the sealmatrix found at Eye (p. 352), and a bronze fragment inscribed with runes found in the Thames at Westminster. ${ }^{50}$ This is an obvious way of indicating the eye, and is not by any means confined to one period or country. The prick-spur was used by the Romans in Britain, but is seldom found, and Anglo-Saxon specimens are still rarer. Farther up the valley, on land called the Leys at Tostock, a discovery was made about i 843 that points to Kentish influence in the 6 th or early 7 th century. It consists of a bronze buckle ${ }^{50 a}$ with an oblong plate, the latter filled with one large slab of garnet. A smaller slab is shaped to fit the space at the base of the tongue, and the specimen is very

47. As Inventorium Sepulchrale, pl. ii, fig. 4 ; V.C.H. Kent, i, 354, pl. i, fig. 17.

470 Jours. Brit. Arch. Assoc. xxvii, 259, fig. 3 (Mr. S. Fenton's collection).

68 Reliquary, 1904, p. 52, frontispiece. The date is probably ninth century.

- Jourm. Brit. Arch. Assoc. iii, 119.

10 V.C.H. London, i, 167.

50a Figured in co'ours by Akerman, Pagan Saxondom, pl. i, fig. 9 ; Proc. Soc. Antig. xv, 268; for Giltun buckle, see Arch. xuo, pl. ii, fig. 5 ; Arch. Index, pl. xvii, fig. 10. 


\section{A HISTORY OF SUFFOLK}

like one in the British Museum that was found by Lord Londesborough at Gilton, near Sandwich. The latter can be approximately dated by associated finds, and it is possible that the Tostock buckle also came from a grave that was overlooked.

In Bury St. Edmunds Museum (Cat. III, 618, 619) are two oblong plates of bronze that probably belonged to a sword-scabbard (fig. 8). The exact site of their discovery is unknown, but special mention must be made of their elaborate ornamentation. The smaller piece has a doubled band
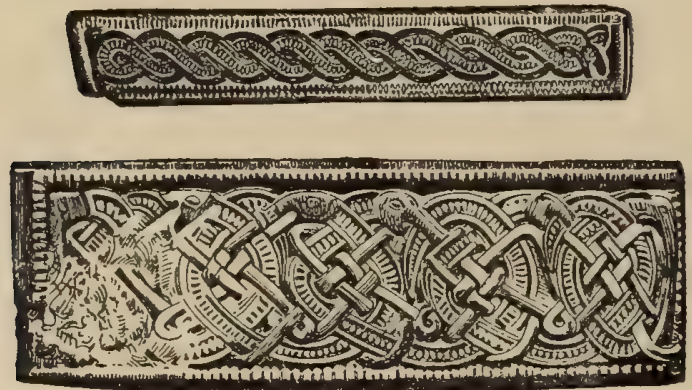

Fig. 8. - Two Bronze Mounts of Sword-

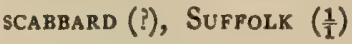
twisted on itself and ending in a serpentine head and tail, recalling a more intricate specimen on a beaker from Farthing-down, Surrey ${ }^{50 \mathrm{~b}}$; but closer parallels are published from Italy and Uppland, Sweden, and have been referred on stylistic grounds to the 7 th century. ${ }^{51}$ Uppland has also produced a plate ornamented in the same style as the larger figure, with ribbon-like bodies of animals covered with transverse lines, and long jaws clasping the body at intervals. ${ }^{62}$ The home of this kind of interlacing has not yet been determined, but the two plates here illustrated were more probably made in Sweden than in England, and were doubtless brought over by a Scandinavian settler.

At Moyses Hall is also preserved a series of iron spear and lance-heads, knives and strike-a-light, shield bosses of various patterns, glass beads, both variegated and plain dark blue, and the rim of a bronze bowl, from Fornham St. Martin, all having been deposited in graves with unburnt bodies about I 8 in. from the surface. The discovery was made in $1888-9$, and the antiquities presented to Bury by Mr. Walton Burrell. ${ }^{52 a}$ A short distance farther down the Lark valley, a cinerary urn, now at Ipswich (pl. iii, fig. 2), was found at Culford, and is peculiar as having a moulding below the lip, though the round and oval protuberances on the shoulder are common at the period.

Two series of Anglo-Saxon weapons and ornaments from West Stow Heath were exhibited by Mr. Gwilt and the Rev. S. Banks respectively, to the Bury and West Suffolk Archaeological Institute in $185 \mathrm{I}$, and were described by the secretary Mr. Samuel Tymms, who in the following year furnished the Institute with an illustrated report ${ }^{52 b}$ of excavations on the site. In the interval the Rev. E. R. Benyon, the proprietor of the heath, had presented specimens to the Institute, which are now in the museum at Bury St. Edmunds.

Stow Heath is a large tract of heath-land on the north side of the Lark valley in the parish of West Stow and on the borders of Lackford and Icklingham parishes. It consists of gravel or sand covered with a thin layer of vegetable mould; and the discoveries were made in removing the soil for

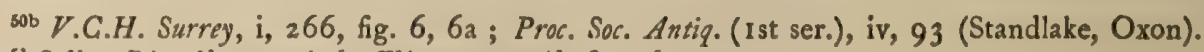

s1 Salin, Die Altgermanische Thierornamentik, figs. 690, 555.

Salin, op. cit. fig. 549 , also in style II ( 7 th cent.).

82a Earlier finds at Fornham St. Genevieve are mentioned; Bury and W. Suff. Proc. v1, 53.

${ }^{630}$ Proceedings, i, 304, 315 , with eight plates. 


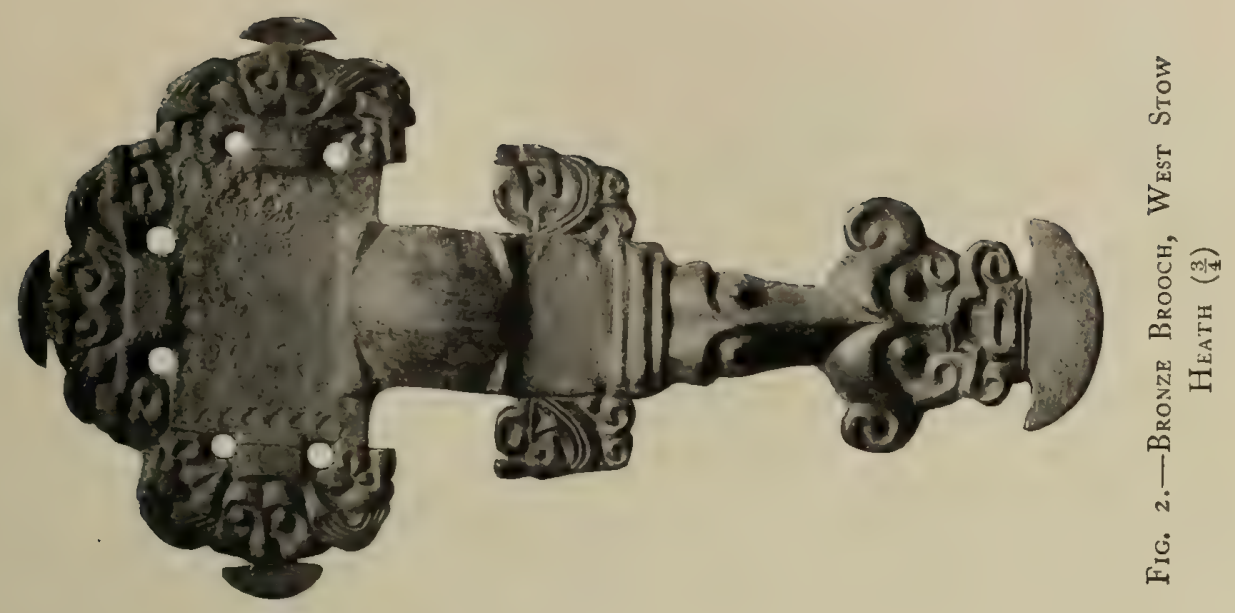

点

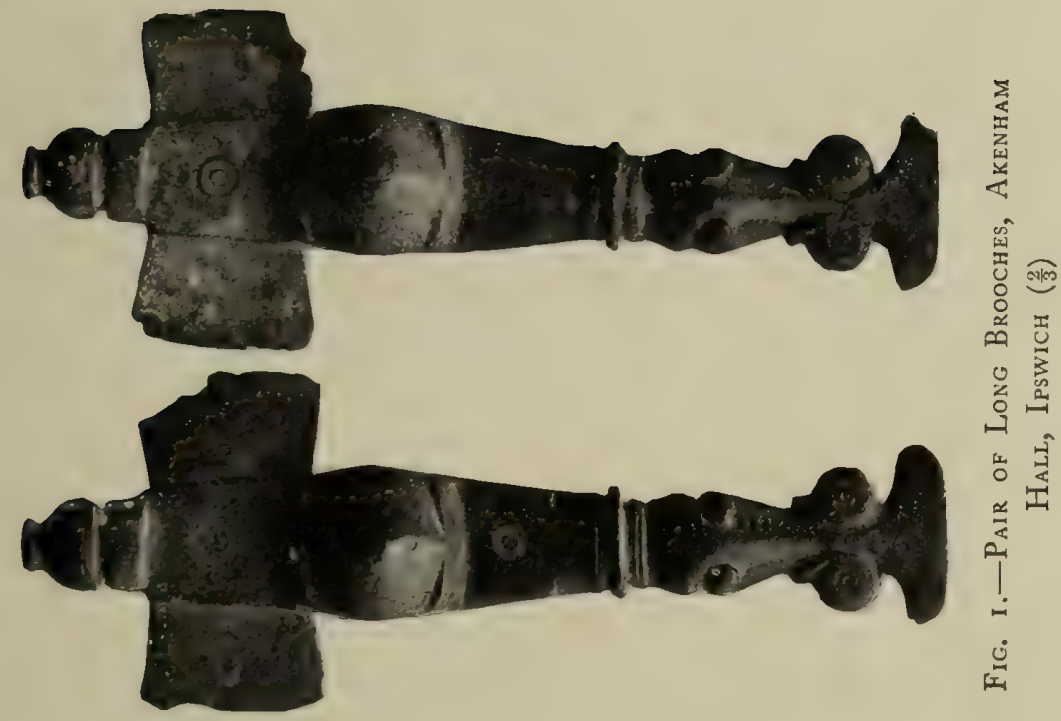





\section{ANGLO-SAXON REMAINS}

ballast. About two acres had been worked at that date, and a cemetery of the Anglo-Saxons revealed. ${ }^{53}$ The graves were at intervals of 2 or $3 \mathrm{ft}$. to as many yards, and were indicated by a dark streak in the gravel or sand. A north-and-south trench disclosed about 100 skeletons laid with the heads to the south-west and feet to the north-east, about i 8 in. below the surface and just within the gravel. Over an area of about $250 \mathrm{sq}$. ft. skeletons were lying in all directions, and nothing was found here but one small knife; but with the others were urns, beads, brooches, spear-heads, and other articles, and all were disinterred by the workmen without proper supervision, the association of objects not being generally determined. It was, however, clear that on the site bodies had been buried after cremation in cinerary urns and others unburnt, either with or without coffins, but in either case with the garments, weapons, or ornaments of the deceased. Cremation and simple inhumation seemed to have been contemporary on this site, but it was held that the small number of urns showed the former practice was on the decline; and the small accessory vessels of pottery found with skeletons were merely a survival from the days of incineration. This is, however, inconsistent with the view that both methods of disposing of the dead were adopted by contemporaries; and the presence of small vessels, not used as cineraries, was probably due to a radical change in the religious beliefs of the population, possibly to a new wave of immigration.

Descriptive notes on the various classes of objects accompany the numerous illustrations in $\mathrm{Mr}$. Tymms' paper, and the most interesting points may here be mentioned. Perhaps the greatest rarity is a coffin of Barnack stone, $5 \mathrm{ft}$. $8 \mathrm{in}$. long. It was without a lid, and lay about $\mathrm{I}_{5}$ in. below the surface, containing a few bones of a young person, accompanied by one half of a small bronze clasp and one or two pieces of iron. On the left side, but possibly belonging to an adjacent burial, were found a shield-boss and spear-head of iron. Besides the ordinary form of shield-boss with a stud on the point, one of conical form was discovered that may have been the earlier form, ${ }^{\text {sa }}$ and only one sword is known to have come from the heath. This was of the usual length ( 36 in.), retaining traces of a wooden scabbard, and with it in the grave were a shield-boss and spear-head, fragments of two buckets, two long brooches, two clasps (probably at the wrists), two flat rings (apparently annular brooches without their pins), and some beads (generally confined to female interments).

A mong the spear-heads may be noticed one with a long slender head and a socketed ferrule for the butt-end, while two arrow-heads of iron are recorded from this site. The bow does not appear to have formed part of the military equipment in England during the pagan period, but a few other arrowheads have been collected from cemeteries of that period, as at Marston St. Lawrence, Northants; North Luffenham, Rutland; Lowesby Hall, Leicestershire; and Chessel Down, Isle of Wight, where several together were

sany objects found in 1849 , in the collections of Messrs. Warren and Gwilt, were illustrated by Roach Smich, Coll. Antig. ii, 165, plates xxxix-xli, A and B. They include girdle-hangers, perforated coins and beads, bracelet-clasps, brooches of various types, and a bucket-mount, the last being figured in Pag. Sax. pl. xarv, fig. 3, with part of girdle-hanger (fig. 2). See also pl. xxxix, 1 (buckle), and 2 (girdle-hanger). The site is marked on the $I$-in. Ordnance Survey Map, sheet 189.

3ne of the early $5^{\text {th }}$ century from Vermand, Aisne, is figured by Eck, Deux Cimetitres gallo-romains, pl. ii, fig. 1. 


\section{A HISTORY OF SUFFOLK}

accompanied by a bow $5 \mathrm{ft}$. in length. Examples are fairly numerous in Kentish graves, but there are generally indications that the graves containing them were of children, and the weapon may have been regarded as a mere toy, though it was an important arm in some continental areas. Small iron knives appear to have been carried by old and young of both sexes for use at meals, and appear regularly in the graves, though their wooden handles and leather sheaths are seldom preserved. The two buckets found are of normal appearance, though rather smaller than usual, being only 4 in. high; and girdle-hangers or châtelaines, tweezers, and hairpins need only be mentioned as ordinary items of grave furniture. Beads were of amber, glass, pebble, and jet, those described as terra-cotta being in all probability opaque glass of various colours; but special mention should be made of what are called triplet beads, such as have been found also at Marston St. Lawrence, Northants ; Bassett Down, Wiltshire ; and Driffield, E.R. Yorks.

Perforated Roman coins for use as pendants were found here, as in several Anglo-Saxon cemeteries; though in themselves useless for dating the cemeteries, they are useful as showing that imperial coins had become scarce and were looked upon as curiosities. They are generally all of the Constantine period, ${ }^{54}$ and show signs of wear. Two silver disks were found, one with a boss in the centre and a stamped design round the edge (as at N. Luffenham, Rutland ; Sleaford, Lincs. ; and again at Warren Hill and Ipswich), and the other resembling a bracteate; these were normally of gold. Both bracteate and punched silver disk appeared in a woman's grave at Longbridge, Warwick. ${ }^{55}$ Pairs of bronze clasps are frequently found in graves of the Anglian district, and were probably for bracelets, as they have been noticed, sometimes with remains of leather, on the wrists of skeletons at Sleaford, Lincs. ; Barrington, Cambridgeshire ; Marston St. Lawrence, Northants; and again in Suffolk at Warren Hill. Buckles of iron and bronze occurred, and two retained traces of the cloth that they originally fastened, or on which they lay in the grave. Iron strike-a-lights for use with flint are by no means common, but one was found at West Stow, and others similar are known from Ipswich. It only remains to mention the brooches, which include broad annular specimens of a common type, some having lost their pins, small squareheaded and trefoil-headed with spreading foot, a typical long brooch of the late 6th century, and two remarkable specimens that must be described in more detail.

Though possibly made within a few years of each other, they represent two different stages in the evolution of the true cruciform brooch from the long brooch of Scandinavia. The illustration of the earlier (pl. v, fig. 2) shows that while the salient features of the long brooch were retained, the square head was furnished with a border of 'spectacle' and other patterns, with circular perforations at intervals round the head-plate. In the other specimen, from West Stow, ${ }^{55 a}$ the three knobs projecting from the edges of the head-plate are not only flattened out as before, but thrust outwards to form the arms and upper limb of the 'cruciform' type. The extravagant length

${ }^{54}$ Specimens of $V$ alens $(364-78)$ and Gratian $(367-83)$ are recorded from this site, both perforated ; Fourn. Brit. Arch. Assoc. v, 360 (excavations of $1849-50$ ).

${ }_{b 5}$ V.C.H. Warw. i, pp. 263-4, figs. 7,11 , on coloured plate.

${ }^{55 a}$ Bury and W. Suff. Arch. Soc. Proco i, pl. xli A. 


\section{ANGLO-SAXON REMAINS}

of this specimen ( 6 in.), and its debased ornament prepare us for the final extinction of this type in the 7 th century.

About two miles east of Mildenhall, and north of the high road to Bury, lies Warren Hill, an eminence formed by chalk outliers overlaid by deposits of sand, gravel, and clay. In I 866 one of several barrows on this link, measuring about $70 \mathrm{ft}$. in diameter, and 9 or $10 \mathrm{ft}$. in height, was being dug for gravel, and was found to contain a burial of the early Bronze Age, covered with eighteen antlers of the red deer. In the surface of the barrow were also found Saxon burials with the usual furniture, such as shield-bosses of iron, spear-heads, knives, and toilet articles, but no advantage was taken of the opportunity of examining these burials under proper supervision..$^{56}$ In I 88 I, however, an Anglo-Saxon cemetery, distant only a few yards from the site of the barrows, was explored and subsequently described by Mr. Henry Prigg, an account of previous discoveries west of the road-cutting being contributed by Mr. Simeon Fenton. ${ }^{57}$ The gravel pits had then been worked for many years, and the workmen had brought $\mathrm{Mr}$. Fenton a number of antiquities before he himself began to watch the site in 1875. In November of that year he excavated two graves, apparently of women, buried near a warrior, whose shield and spear-head had previously been found. Tweezers, 'long' brooches, and remains of cloth were recovered, and the teeth had been stained by contact with a bronze cruciform brooch $5^{\frac{1}{2}}$ in. long, which had evidently been worn at the shoulder. Next year a somewhat richer grave was found containing a cruciform brooch 6 in. long, part of a circular brooch, and remains of cloth as before, but there were also ten beads of rough amber, one of glass-paste, four silver-wire rings $\frac{1}{2}$ in. in diameter, and as many silver discs with a star pattern round a central boss and a border of dots punched from the back of the plate, closely resembling specimens from West Stow, Suffolk ; and Market Overton, Rutland.

In the following year a burial was found that seems to settle the use of the bronze clasps, so frequently found in this part of England. A pair sewn to cloth lay on either side of the body where the arms had been, and no doubt served to fasten the wristbands or bracelets. The grave contained three small brooches and the inevitable knife. Another woman had been buried near, two silver bracelets ${ }^{58}$ with overlapping ends and a pair of fingerrings being found at her left side. A few yards north of these, and close to the warrior mentioned above, was found the skeleton of a horse, as at Little Wilbraham, Cambridgeshire ; ${ }^{68}$ and a similar discovery was made on the outskirts of the well-known Anglo-Saxon cemetery at Marston St. Lawrence, Northants, ${ }^{80}$ though no human burial was there found in close association with it.

Mr. Prigg's own excavations on Warren Hill added a few points of interest. The first grave was that of an old man, laid with the feet eastsouth-east, and on his breast were found the remains of a shield, by his left hip a wooden drinking cup turned on the lathe, and (probably) an iron spearhead beside the skull. The shield had the handle still in position below the

Wury and W. Suff. Proc. iv, 298, figs. 4-8 on plate.

67 Ibid, vi, 57-72.

${ }^{3}$ Cf. specimens from Long Wittenham, Berks. (Arch. xxxviii, pl. xix, fig. 6); Malton, near Barrington, Cambs. (Brit. Mus.).

39 Neville, Saxon Obsequies, 9, grave 44.

- Plan in Arch. xxxiii, pl. xi, p. 330 (Barrow Furlong). 


\section{A HISTORY OF SUFFOLK}

boss, the latter being attached to the wooden framework by five circular studs. There was no trace of a leather facing, and the 'war-board' had apparently been constructed of seven or more narrow strips, about $\frac{2}{5}$ in. thick, held together by a dozen slight iron cramps $\frac{1}{2}$ in. long, six being found in position. Another grave in the same direction, $12 \mathrm{ft}$. to the north-east, contained a spear-head, and a third $2 \mathrm{I} \mathrm{ft}$. south-west proved to be that of a woman, buried in the east and west position. This was carefully excavated with interesting results. At the head was a large flint, and on the left of the waist an iron knife and iron 'girdle-hanger' in the form of a double hook, just above these being a bronze clasp with remains of woollen fabric adhering. On the breast a similar clasp, with more cloth and plentiful traces of wood, which suggested the busks of a bodice. At the neck was a gilt bronze cruciform brooch $5 \frac{3}{4}$ in. long, with remains of cloth of two qualities, and on either side a penannular brooch, while under the chin was a necklace of amber, glass-paste, and rock-crystal beads, arranged in threes separated by single beads of large size. Another large brooch had stained the left ulna, and the body had been protected by planks and coarse wheat straw. It was further noticed that the large brooch at the neck was without a pin at the back, and had been sewn on to a twill garment of open texture, the broken wings of the head being thus kept in position. Further, the wings of the head were not cast in one piece with the stem, but added, and kept in position by an iron rod passing through a shank behind each, and by a third behind the head of the brooch, much like a specimen found in Rutland. ${ }^{61}$

Farther east, on the other side of the road, the graves of two children were discovered, little remaining but two small urns of black hand-made pottery (like those found by Mr. Fenton), half a gilt clasp, a few amber beads, and three bronze ferrules (possibly worn on a necklace). There were

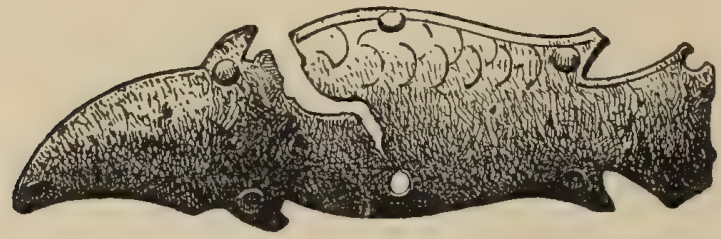

FIG. 9. --BroNze BadGe (?) OF FISH Form, WarReN Hill, Mildenhall $\left(\frac{1}{1}\right)$ no signs of cremation here, and the pottery consisted merely of accessory vessels placed in the grave possibly to contain offerings to the dead.

A tinned bronze badge in the form of a fish (fig. 9), the third specimen in England, was found at Warren Hill, and is now in Mr. Fenton's possession. One came from Kenninghall, just beyond the northern border of the county, ${ }^{62}$ and the other from Kempston, Bedford. ${ }^{63}$ All are from recognized AngloSaxon burying-places, the Suffolk specimen having been found with half a bracelet clasp, in what was doubtless an interment; and all agree so closely in shape and dimensions that there can be no question as to their common origin and purpose. What the latter was is, however, not quite certain, but the rivets point to their use as badges, perhaps on the front of the shield, and it is just possible that this form was chosen in allusion to the Early Christian use of the fish as a symbol of Christianity, the letters of the Greek word for fish being the initials of a Christian confession of faith. ${ }^{64}$

61 Pro. Soc. Antig. xix, 196 ; V.C.H. Rut. i, 102.

W.C.H.Beds. i, 183 (with fig.).

V.C.H. Norf. i, 340.

" O. M. Dalton, Guide to Early Christiast and Byzantine Antiq. (Brit. Mus.), 16. 


\section{ANGLO-SAXON REMAINS '}

There were evident traces of burials on Mitchell's Hill, Icklingham, and possibly another case of horse-interment, ${ }^{65}$ as at Warren Hill. The relics were mostly in Sir John Evans' collection, and comprised a square-headed brooch set with garnets in the Jutish style, two large and elaborate cruciform specimens, two clasps with woollen fabric attached, a buckle that may be of Frankish manufacture, a Roman spoon, girdle-hangers, tweezers, and among other brooches a pair of 'horned' specimens of local type, ${ }^{\circ}$ with curved projections from the upper angles of the square head-plate, and a circular brooch with an embossed plate applied to the front as at Kempston, Bedford.

In the Bury Museum a richly gilt buckle (fig. Io) from the site deserves special mention, as the pattern is of rare occurrence in England. The edges of the loop are bevelled, and the animal engraving executed not on the face of the loop, but on the sloping sides, suggesting a connexion with Sweden, ${ }^{67}$ where the same peculiarity occurs on buckles of the $5^{\text {th }}$ century. Another gilt buckle, from Icklingham, is illus-
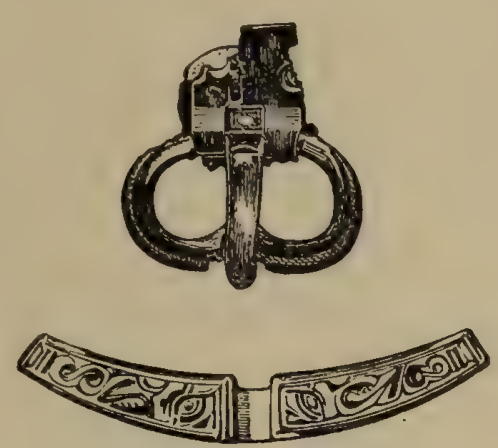

FIG. 10

Gilt Bronze Buckle, Mitchell's

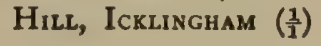
trated in colours (fig. 2 on frontispiece), and is now in the British Museum. The panel is filled with deeply engraved animal pattern in the style characteristic of the 6th century, when the principles of anatomy were disregarded in order to fill a given space.

A perforated axe-head of iron found at Undley and now in Mr. Fenton's possession has a Frankish appearance, and resembles one published from Icklingham. ${ }^{63}$ Two others, from Ipswich, are in the national collection, one

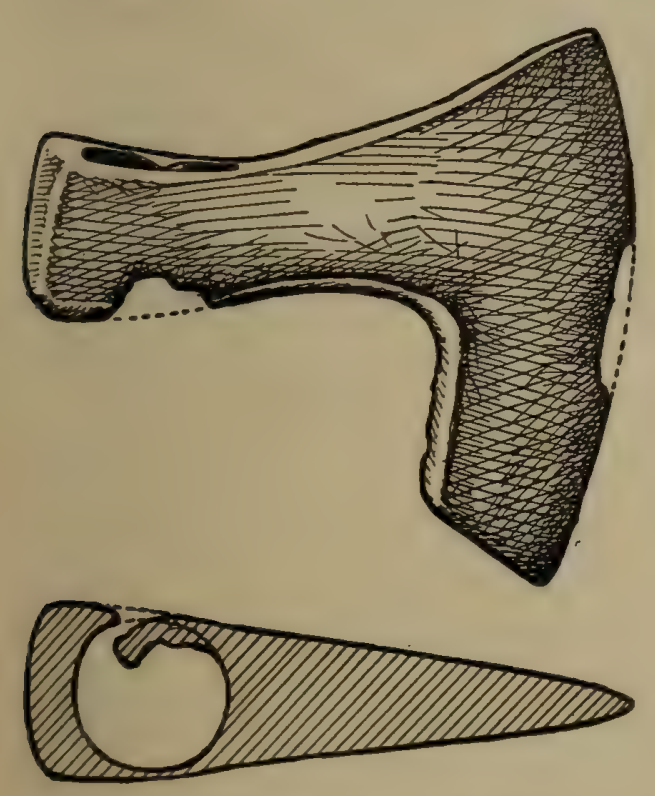

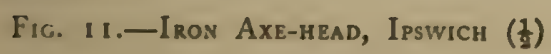

(fig. II) belongs to a type fairly common in France, but also found in the Thames, while the other is in poor condition, and has no expansion of the cutting edge. These weapons are rarely found in England, but are known from the Isle of Wight, London, and Croydon, ${ }^{68 a}$ and by comparison with continental specimens may be assigned to the sixth century.

Two iron spear-heads found in I 8 I 3 in a barrow at Barrow Bottom, ${ }^{89}$ about five miles due west of Bury, are sufficient evidence of one or two Anglo-Saxon burials here, whether the barrow was raised at that time or (as is more probable) had existed since the Bronze Age, a thousand or more years before. At

65 Bury and W. Suff. Proc. vi, 71.

One from Farndish, figured in V.C.H. Beds. i, 190 ; others from Soham and Barrington, Cambs., and Kenninghall, Norfulk.

${ }^{67}$ S.lin, Die alegermanische Thieromamentik, 164 , fig. 390.

V.C.H. Surr. i, 260.

* Akerman, Pagan Saxondom, pl. xxiii, fig. 3.

"Bury and W. Suff. Proc. ii, 207. 


\section{A HISTORY OF SUFFOLK}

Holywell Row, some eight or nine miles north-west, beyond Mildenhall, another Anglo-Saxon burial was indicated by the discovery of a string of clay (glass-paste) beads, a Saxon brooch, and a Roman coin ${ }^{69 a}$ the last being often found in graves of the post-Roman period, pierced for suspension on a necklace.

In the valley of the Lark, a little above Icklingham, has been found a cupshaped urn (pl. iv, fig. A), that points to a burial after cremation at Lackford. Farther west the finds at Tuddenham now in the Cambridge Museum include a large square-headed brooch with crenellated head, in the style of the 6th century, annular and other brooches of ordinary types; bracelet clasps, spearheads, knives, a pot-hook, ferrule, and small urn with $S$ stamps; a small axe-head of Frankish form, perhaps for the use of a child; and twelve bone draughtsmen (burnt and evidently from a cinerary urn), with two holes on the flat face where the prong-centre of the lathe was fixed..$^{70}$ Of special interest is a small hollow pyramid of bronze set with garnets in cell-work on the four faces and furnished with a cross-bar across the base. The use of these jewels is still uncertain, but a fair number have been found in this country, ${ }^{70 a}$ and a plain example of bronze, now in private hands, comes from Lackford.

The above relics must be mainly from graves, and Professor Ridgeway ${ }^{n}$ publishes a long brooch, without the two side knobs, found buried with a warrior in association with another of nearly the same size, an iron shieldboss, spear, sword, and knife, the ordinary grave-furniture of the period.

A pair of small square-headed brooches in the Cambridge Museum from Freckenham are not only evidence of an unburnt burial there, but also of intercourse with the Jutish area; for the type is practically confined to Kent and the Isle of Wight, ${ }^{71 a}$ where it occurs very frequently.

Exning, a village in the detached portion of Suffolk north of Newmarket, is also well represented by finds of the pagan period in the Cambridge Museum. Two silver finger-rings were found on a skeleton there in 1894 ; and among other finds, no doubt from a burial ground of the 6th century, are two pairs of 'horned' brooches as from Lakenheath; a long brooch with wings and three knobs that has lost its foot, but otherwise so closely resembles one from St. John's College in the same collection that they might have come from the same mould. A gilt cruciform brooch with large expanding foot illustrates the development of the long brooch, and resembles specimens from Sleaford, Lincolnshire, ${ }^{71 b}$ while another brooch, of unusual form, has circular projections from the upper angles of the head. A typical 'long' brooch also from Exning is in the Norwich Museum.

The numerous specimens from Lakenheath in the Cambridge Museum of Archaeology are sufficient evidence of Anglo-Saxon burials there, though a precise record is wanting. Besides glass and amber beads were found small bronze cylinders, probably worn as a necklace; a spear-head $\mathrm{I} 2 \mathrm{in}$. long of unusual form, with unsplit socket, and a vase of Frankish character with rows of stamped patterns round the shoulder. Among numerous brooches should be mentioned a large and elaborate cruciform specimen with enamel round

${ }^{603}$ Bury and W. Suff. Proc. i, 305. $\quad{ }^{70}$ Compare specimens from Norfolk (V.C.H. Norf. i, 336).

${ }^{70 a}$ Compare V.C.H. Essex, i, $32 \mathrm{I}$ (fig. $\mathrm{B}$ on coloured plate), where several references are given ; V.C.H. Kent, i, 357 (pl. i, fig. 7).

${ }^{71}$ Early Age of Greece, 587 , fig. 142.

71a V.C.H. Hants, i, 388 (fig. 2 on coloured plate).

${ }^{73 b}$ Arch. 50, pl. xxiv, fig. 2. 


\section{ANGLO-SAXON REMAINS}

the setting on the bow ; a pair of 'horned' examples of a type apparently confined to the neighbourhood of the Fens; and two ornate square-headed
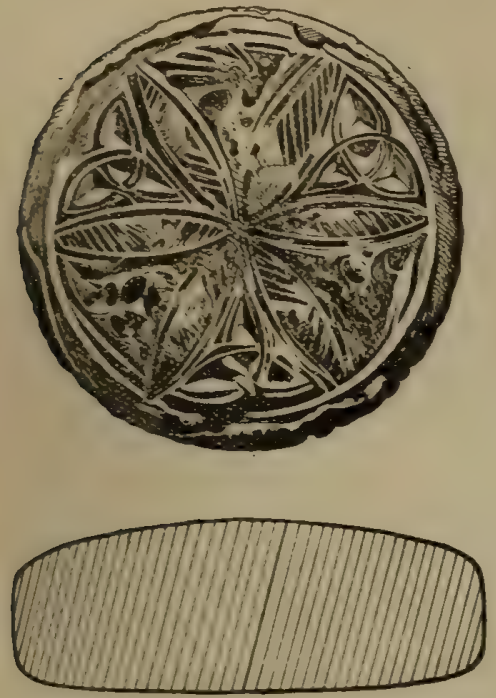

Fig. 12.-LEAD WEIGHT With Bronze-Gilt Top, wT. 3810 grains, Mildenhale $\left(\frac{x}{1}\right)$ brooches, one with silver disc attached to the foot, and the other with a garnet-setting in the middle of the head. A triangular bronze-gilt mount as fig. 14 belongs to a pair of clasps; and a small buckle with three rivets in a row and a garnet-setting on the plate may be compared with one from East Boldon, Durham, in Newcastle Museum.

Some beads of glass and amber and half a clasp in the British Museum are perhaps sufficient evidence of a pagan unburnt burial at Wangford; and a find at Eriswell, to the south of Lakenheath, is published by Professor Ridgeway, ${ }^{72}$ consisting of a small bronze brooch with cruciform head, and a larger and a finer specimen that belonged to an unburnt burial. These were generally interred with women in the 6 th century, and call for no further remark.

A leaden weight (fig. 12) of 38 I 0 grains (247.4 grammes), in the possession of Mr. Fenton, was found at Mildenhall, and is surmounted by a bronze-gilt disc engraved with a rosette, the spaces between the points being filled with looped triangles ${ }^{72 a}$ and (apparently) birds' wings. It probably dates from the 8 th or 9 th century, and is interesting as being 30 grains short of $8 \mathrm{oz}$. Troy, for which it was probably intended. It is in good preservation but slightly chipped, enough to account for the 30 grains; and though Troy weight is known to be of great antiquity, it is difficult to account for the present weight being 2 oz. over the half-pound Troy (6oz.).

In the same collection is a square-headed brooch (fig. I 3) of the 6 th century from Mildenhall, with debased animal ornament and a stout disc attached to the bow like several already mentioned from this and other counties (p. 332). Another interesting piece, now at Bury, is here illustrated (fig. I 4), from Mildenhall, the decoration showing the transition from the style of the 6 th to that of the
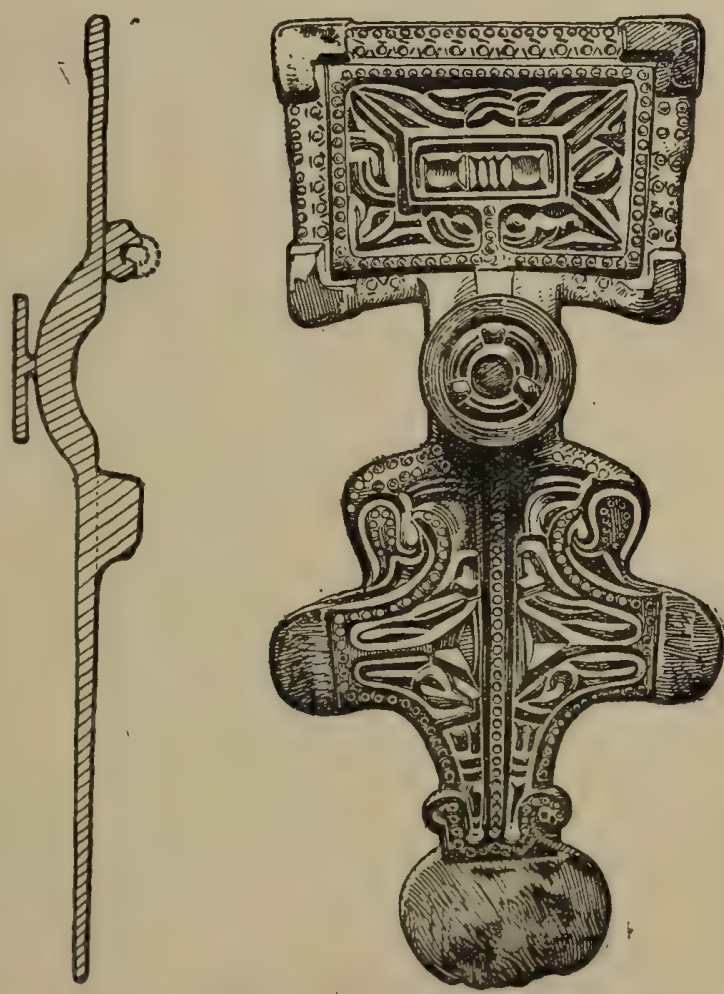

Fig. 13. - Bro: ze-gilt Brooch with Silver Mov. Ts, M.Ldenhall $\left(\frac{2}{5}\right)$

\footnotetext{
12 Early Age of Greece, i, 586, fig. 141.

72. C. for example the Canterbury cross, V.C.H. Kent, i, 382, fig. 26.
} 


\section{A HISTORY OF SUFFOLK}

7th century. It is of bronze gilt, and belongs to a bracelet-clasp now missing; a complete specimen from Barrington, in Cambridge Museum, shows the exact relation to the two limbs of the clasp,

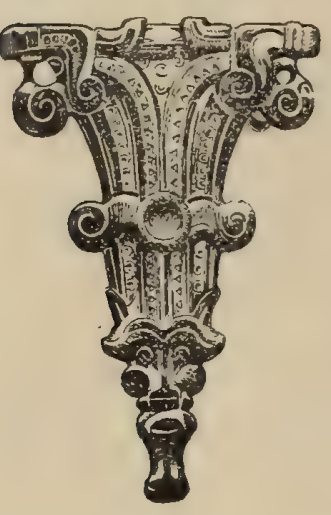

FIG. 14

Part of Bracelet-clasp, Mildenhall $\left(\frac{1}{1}\right)$ though the origin and utility of such an addition are not apparent.

Special notice must also be taken of a brooch (fig. I 5), in Mr. Fenton's collection, from Mildenhall. It is of bronze that has been in contact with iron and received a coating of iron rust, but is intact but for the pin and the square enamel setting at the centre. Traces of the red filling still remain, and birds' heads may still be traced at the end of the swastika, which forms the body of the brooch. Plain rectangular brooches of swastika or fylfot form are not uncommon in the Roman provinces, and one has been found in Brough, Westmorland, but the present specimen is a Teutonic version of the Roman pattern, and is allied to large and richly ornamented specimens of silver (or with applied silver plates) generally found in Denmark, but also occurring sporadically in Norway, South Sweden, and Mecklenburg, ${ }^{73}$ always in the graves of women. The springs on these to give tension to the pin are long spiral coils of wire, but this system had evidently been simplified before the Mildenhall brooch was made, as the two lugs for the hinge are quite close together. As the type lasted a comparatively short time and some specimens are known to belong to the latter part of the $3^{\text {rd }}$ century, the Suffolk example may belong to the $4^{\text {th }}$ or possibly the early $5^{\text {th }}$ century, and is in any case one of the earliest Teutonic antiquities in this country.

The most important find at Mildenhall is undoubtedly the set of enamelled mounts of a bowl in the Cambridge Archaeological Museum. They consist of four escutcheons, three having had hooks attached to their frames and the fourth belonging to the bottom of the bowl; a bronze ring showing traces

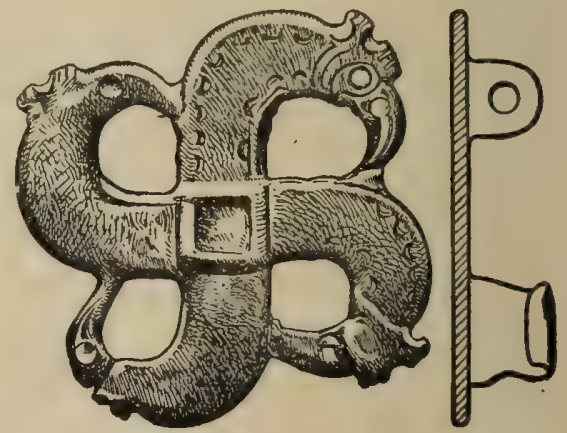

Fig. I j.-Bronze Brooch, once Enamelled, Mildenhall $\left(\frac{1}{1}\right)$ of wear inside and evidently belonging to one of the chain hooks of the bowl; narrow strips of bronze with sunk red enamel (mostly wanting) in a fret pattern ; and silver strips notched at their edges that apparently surrounded the escutcheons within the frame of bronze. The bowl to which all these enamelled mounts appertained is unfortunately wanting, but its size and character are evident from similar discoveries in other parts of England. The best parallel is the set from Barlaston, Staffordshire, found in a warrior's grave and republished in this series. ${ }^{74}$ The strips with their slanting ends are practically identical, and seem to have been fixed on the outside of a bowl (about 9 in. in diameter) in the three spaces between the hook-escutcheons and just below the

"S. Muller, Ordning of Danmarks Oldsager, fernalderen, no. 266 ; Almgren, Nordeurofaische Fibelformen, p. 104, figs. 232-5; Montelius, Den nordiske jernalderns Kronologi, p. 240 ; Mémoires de la Société des Antiquaires du Nord, 1878, pp. $22,29$. 


\section{ANGLO-SAXON REMAINS}

hollow moulding that is a constant feature of these bowls. Narrow bronze strips, forming a flat circle and decorated with sunk red enamel (champlevé), have also been found with enamelled escutcheons in association with a bowl of this kind at Old Park, Dover ; ${ }^{74 a}$ but no perfect specimen has yet come to light. They were evidently suspended by three chains and meant to be sometimes seen from below, as enamelled discs have been found in the 'kirk,' outside the base.

The body of the bowl is in nearly every case of extremely thin metal, beaten out in a manner that must have necessitated many firings; and the result is that they are found, if at all, in fragments. The designs on the escutcheons, which are generally decorated with red enamel, are for the most part varieties of the Celtic trumpet pattern, seen at its best in the early Irish illuminated MSS.; but the Mildenhall specimens seem to be a barbaric version of the classical inclosed palmette and, in this respect, stand quite alone. Though many bowls or their fragments have been found in England, their date is not definitely fixed : but the period $550-650$ suggested by some of the circumstances and associated objects may be provisionally accepted, though it leaves unexplained the occurrence of Celtic enamel and scrollpatterns which are generally supposed to have been abolished in Britain by the Roman occupation and to have survived only in Ireland where the Roman arms never penetrated. It may be added that one heart-shaped escutcheon of plain bronze, with the ring worn thin, has been found at Icklingham and probably belonged to a bowl of this kind, and a smaller lozenge-shaped specimen from Lakenheath, with a movable ring in the hook above it, may also be cited in illustration. Plain specimens like the former are known from Sarre, Kent ; and Barton, Cambridgeshire, while the latter somewhat resembles one from Faversham, Kent, in the British Museum.

The sites of discoveries on the coast were probably some distance inland during the early Saxon period, and a valuable find at Bacton, in Norfolk, was indirectly due to the encroachment of the sea. In Suffolk the fate of Dunwich is at once recalled to the memory, but finds there are almost exclusively mediaeval. At Pakefield, just south of Lowestoft, an interesting discovery was made in $175^{8}$ on Bloodmore Hill, and recorded by the worthy Douglas. ${ }^{75}$ In a barrow a skeleton was found buried with a coin pendant of gold, and another, set with an onyx intaglio, strung on a necklet of rough garnets. The coin mounted in a hoop was of Avitus, who was declared Emperor in Gaul in 455, but resigned and became Bishop of Placentia; on the reverse was CONOB, as in the Bacton pendant, ${ }^{76}$ but the legend has yet to be explained by numismatists. The onyx intaglio was of Roman workmanship and represented a warrior armed with a spear beside a horse to right. Coins of the Lower Empire are also mentioned, including one of Claudius II (268-70), evidently inscribed IMP. CLAvDIVs P F AVG (oriental crown on head to right) and victoria AVG (Victory flying to right with wreath and branch); and Douglas illustrates a crystal engraved with

7a This and other examples not included in the late Mr. Romilly Allen's list (Arch. lvi, 49) are publishcd in Proc. Sor. Antiq. xxii, with illustrations.

is Nenia Brisannica, $8 \mathrm{n}$. and 82 (crystal, pl. xx, fig. 11) ; MS. Min. Soc. Antiq. viii, 318 (sketches); Areb. xxiii, $65 \mathrm{n}$.

is V.C.H. Norf. i, 341, figs. 2, 20, on coloured plate. For conos see Wroth, Imperial Byzantine Coins (Brit. Mus.), p. xcix. 


\section{A HISTORY OF SUFFOLK}

a cross, found on the same occasion. It is of the size and shape sometimes mounted in metal sockets, and used in the I 2 th and I $3^{\text {th }}$ centuries for ornamenting the bindings of books, but quite distinct in character from the earlier crystal spheres frequently found in Kent, Isle of Wight, and Normandy, as part of the grave-furniture. ${ }^{77}$

At Aldeburgh, a Merovingian coin was found about 1846 , set in a finger-ring which had three pellets on either side of the bezel. ${ }^{78}$ This arrangement of pellets in triangles is common on Merovingian finger-rings, and was derived from a late Roman fashion, but the coin cannot be earlier than the first half of the $7^{\text {th }}$ century, as the cross standing on steps does not occur on coins before the time of Tiberius Constantine.

The bone disk from Felixstowe, illustrated on the frontispiece (fig. 4), is now in the British Museum with fragments of two bone combs and part of the case that protected the teeth when not in use. The combs are of ordinary patterns, ${ }^{78 a}$ but the disc is unusual and may have been part of a mirror-case, such as the Romans used. There are rivet-holes near the rim, and the design shows no trace of Anglo-Saxon influence, but rather a survival of Roman motives, such as occur on mosaic pavements in this country. Another Felixstowe find is a 'long' brooch of debased character with 'spectacle' ornament, now in Norwich Museum.

Another coastal find was a bronze brooch (fig. I6) from Felixstowe, ${ }^{79}$ of a type fairly common in later Anglo-Saxon times. It is $\frac{7}{8}$ in. in diameter, and rudely engraved with a lion passant to left, considerable

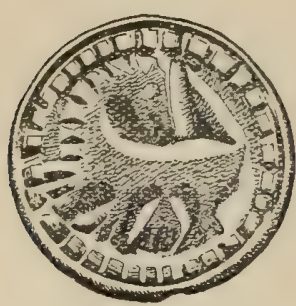

Fig. 16. -Lion Brooch of Bronze, FeLIX-

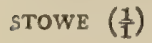
traces of red enamel remaining in the sunk field. Specimens practically identical come from Icklingham, and from Swaffham, Norfolk, while another of the same character was found at Butley, Suffolk. The last two are in the national collection and another is at Canterbury. It is remarkable that specimens ${ }^{80}$ with a lion and a horseman (somewhat like one next to be described) were found in the Gokstad ship-burial in Norway, and attributed to the gth century.

Another circular brooch, apparently of the IIth century, is published by Fairholt ${ }^{81}$ from Otley, a few miles north of Ipswich. It was found about $\mathrm{I} 834$ in a barrow by Mr. Fitch, whose collection is now at Norwich, but it is unlikely that it belonged to a burial, and had probably been dropped during a search for treasure. It is $I \frac{1}{8}$ in. in diameter, and on both sides is a horseman with a drawn sword in his right hand, and a cross and star in the field. The front bears the letters $s \bar{C} s$ (for Sanctus) and the back, which is provided with hinge and catch for the pin, has RO .... s, the intervening letters defaced, but probably for Robertus or Romanus. The shield and pointed helmet with nasal are both characteristic of early Norman work.

A few other brooches remain to be considered, and of these the most interesting is one in the form of a bee (fig. I 7 ) found somewhere in the county,

77 V.C.H. Kent. i, 342, 347, 359, 369 ; Hants. i, 388.

${ }^{78}$ Compare London specimens, V.C.H. Londor, i, 165, (with case).

${ }^{79}$ Proc. Soc. Antig. xi, 14; now in Bury Museum.

${ }^{50}$ Rygh, Norske Oldsager, figs. 603 (lion), 602 (horseman).

${ }^{81}$ Journ. Brit. Arch. Assoc. ii, 314 (figs.).

${ }_{78}$ Journ. Brit. Arch. Assoc. i, 257 (figs.). 


\section{ANGLO-SAXON REMAINS}

and acquired by Sir John Evans. ${ }^{82}$ The most famous examples of this type were found in the so-called tomb of Childeric, king of the Franks (d. $48 \mathrm{I}$ ), near Tournai; but several are known from localities extending from the Caucasus to France. Many of these have been published with the Suffolk specimen by Baron de Baye ${ }^{83}$ who connects them with the migrating Goths of the $5^{\text {th }}$ and 6 th centuries, but has no explaration of the pattern, which seems in some cases to represent a bee, but in most is strangely conventionalized. The type may have been derived from the Greek colonies, on the north coast of the Black Sea, and various forms of garnet settings show that it had a wide popularity among the barbarians. Such brooches are specially numerous in Hungary, and the bee is sometimes found applied to other
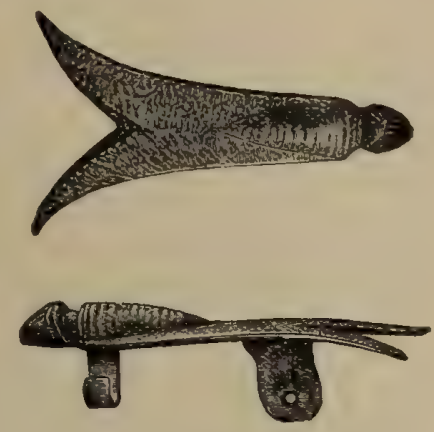

Fig. 17.-Bronze Brooch iN Form of BEE, SufFolk $\left(\frac{1}{1}\right)$ forms of jewellery, such as a circular filigree brooch supposed to have been found in Kent, but clearly of continental workmanship. ${ }^{84}$

Other Suffolk relics of which the precise locality is not recorded may be mentioned briefly. In $1878 \mathrm{Mr}$. Henry Prigg (later Trigg) exhibited to the British Archaeological Association ${ }^{85}$ a square-headed brooch 6 in. long with silver plates at the angles of the head and on the terminal of the foot, but the 'cable pattern' and absence of 'grotesque masks' are evidence of a comparatively early, and not late, date as he supposed. The exhibition included a richly gilt fragment of late Saxon work, "either a girdle-clasp or book-clasp, flowers of a simple form being prominent in the design'; and part of a girdle-hanger more ornate than usual. A ring-brooch with cruciform ring-and-dot pattern is also illustrated. ${ }^{86}$

Finger-rings figure conspicuously in the list of Anglo-Saxon remains from Suffolk, and the most interesting is doubtless one of silver now in the Moyses Hall Museum at Bury St. Edmunds. It is of plain silver, somewhat flat and broad like a modern wedding-ring, and is deeply engraved inside and out with a legend purporting to connect it with King Æthelstan, but the inscription does not inspire confidence.

Another specimen of silver, ${ }^{86 a}$ formerly in the collection of Sir John Evans, is engraved round the outside, SIGERIE HET MEA GEWIRCAN, or, in modern English, 'Sigerie ordered me to be made.' The formula is familiar from its occurrence on the Alfred jewel, ${ }^{87}$ and as there is no objection to connecting the latter with the great English king, this ring may be referred to the same period $(850-950)$.

Several finger-rings, apparently of late Saxon origin, were collected by Mr. Joseph Warren from Ixworth and published from time to time, but not fully illustrated. One of silver, ${ }^{88}$ found in a field there in 1852 , is evidently

- Proc. Sar. Antig. xi, 99.

Bulletin et Memoires de la Saciété nationale des Antiquaires de France, Ser. 6, vol. iv (1893), 137 (with coloured plate).

V.C.H. Kent, i, 380 , pl. i, fig. I (Canterbury Museum).

ss Joum. Brit. Arch. Assoc. xxxiv, 132 ; brooch compared to one from grave 158, at Little Wilbraham, Cambs. figared in Neville, Saxan Obsequies, pl. 10.

* Bury and W. Suff. Proc. i, 223 , fig. 2 on plate.

V.C.H. Som. i, 378, figs. A, B, c, D, on coloured plate.

${ }^{86 a}$ Bury and $W$. Suff. Proc. i, 223 , figs. $7,8$.

Gourn. Bris. Arch. Asso. xi, 80, pl. 6, fig. 2 ; gold ring, fig. 3 ; cf. viii, 159. 


\section{A HISTORY OF SUFFOLK}

a rough example of the type represented in the national collection by one from Garrick Street, London, ${ }^{89}$ and in the Ashmolean Museum by another from Bossington, Hampshire. ${ }^{90}$ The bezel expands into an oval with its longer axis at right angles to the hoop, and in the present case is rudely ornamented with punched annulets, while the tapering ends are fastened by a slip-knot. This feature is seen on a gold ring from Ixworth (1849), published at the same time, but the hoop is of a different form of circular section, thickest at the point opposite the slip-knot or twist of the terminals. A similar ring of silver was found in a barrow on Breach Down, Kent, ${ }^{, 1}$ and another of gold from Suffolk was exhibited by Mr. Whincopp in $1846 .^{92}$ This weighed I $2 \mathrm{dwt}$. I $4 \mathrm{gr}$. and was 'formed of silver round wires curiously twisted, like a rope tapering towards the extremities, which were united and formed a sort of loop to which a smaller ring or hook might be adjusted for suspension from the ear.'

In Ixworth churchyard were found 'a brass ring with the ends twisted in a facet,' and a 'finger-ring of bronze wire with pretty openwork pattern and the ends wound round the hoop,' both apparently of the Saxon period. ${ }^{93}$ Another, found in 18 ig near some coins of East Anglian kings in Laxfield churchyard, had a cruciform pattern of concentric circles ; ${ }^{94}$ and $\mathrm{Mr}$. Fenton has a bronze ring with overlapping ends and $\mathbf{S}$ scrolls in openwork between beaded borders, much like a gold specimen from Coggeshall in the neighbouring county of Essex. ${ }^{95}$ It was found either at Icklingham or Lakenheath.

Four examples of the sword-knife, generally known as the scramasax, and rare in this country, are known from Suffolk, but unfortunately there is no record of any associated finds from which their precise date might be deduced. The longest is now in the British Museum, and was found deep in alluvial soil near the old ford at Little Bealings, ${ }^{96}$ between Woodbridge and the county town. It measures 32 in. in length (including the tang), and is well preserved, with a strip of damascening (in the true sense) down both sides of the blade. Another was found at Hoxne, ${ }^{97}$ with a total length of I $4 \frac{1}{2}$ in., the hilt being 4 in. long, and as usual without its grip of bone or wood. The blade was $I$ in. wide, and two grooves ran parallel and near to the back edge. A third specimen, $\frac{1}{2}$ in. shorter, was found at Offton, ${ }^{98}$ with circular bands of bronze at the junction of the blade and hilt (no doubt to bind the grip). It is said to be in Ipswich Museum, but the only specimen there (now in Christchurch Mansion) is $\mathrm{II}^{\prime} 3$ in. long with a blade of $9 \mathrm{in}$. It has no history, but was probably found in the county, and has one groove at the back inlaid with silver and brass. London has yielded a fair number of these weapons, ${ }^{90}$ which seem to date from the later Anglo-Saxon period, as they are not found in pagan burials; but on the Continent they were commonly carried, at a somewhat earlier period, by the Burgundians, Alemanni, and Franks.

An exceptional relic of the later Anglo-Saxon period was found at Blythburgh on the property of Mr. Seymour Lucas, R.A., who presented it

\footnotetext{
${ }^{60}$ V.C.H. Lond. i, 157. $\quad{ }^{0}$ Gourn. Brit. Arch. Assoc. i, 341. $\quad$ "1 Akerman, Arch. Index, pl. xviii, fig. 27.

${ }^{92}$ Proc. Soc. Antig. (Ist ser.), i, 117 ; also a silver ear-ring found near Bury St. Edmunds.

${ }^{93}$ Bury and W. Suff. Proc. ii, $212 ; E$. Anglian N. and Q. i (1864), 437.

"Arch. Fourn. xiv, 177; E. Anglian N. and Q. i, 347 .

95 V.C.H Essex, i, 327 , fig. 15 on coloured plate. $\quad{ }^{96}$ Proc. Soc. Antig. x, 17.

${ }^{27}$ Ibid. viii, 80. $\quad{ }_{98}^{9}$ Coll. Antiq. ii, 243 , pl. lviii, fig. 4. ${ }_{99}$ V.C.H. Lond. i, 152.
} 


\section{ANGLO-SAXON REMAINS}

to the British Museum in 1902 . The site formerly belonged to the priory of Black Canons, a cell to the abbey of St. Osyth, Essex, founded in the reign of Henry $I,{ }^{100}$ but the writing-tablet here illustrated (fig. I 8 ) is certainly of earlier date. The two leaves (one now missing) were evidently fastened together by a cord or thong passed through both pairs of holes, and the sunk panel or panels filled with wax, which was written upon by means of a style, a pointed instrument of pen form made of bone or metal. The leaf itself is made of whale's bone, and though rubbed and broken still bears an
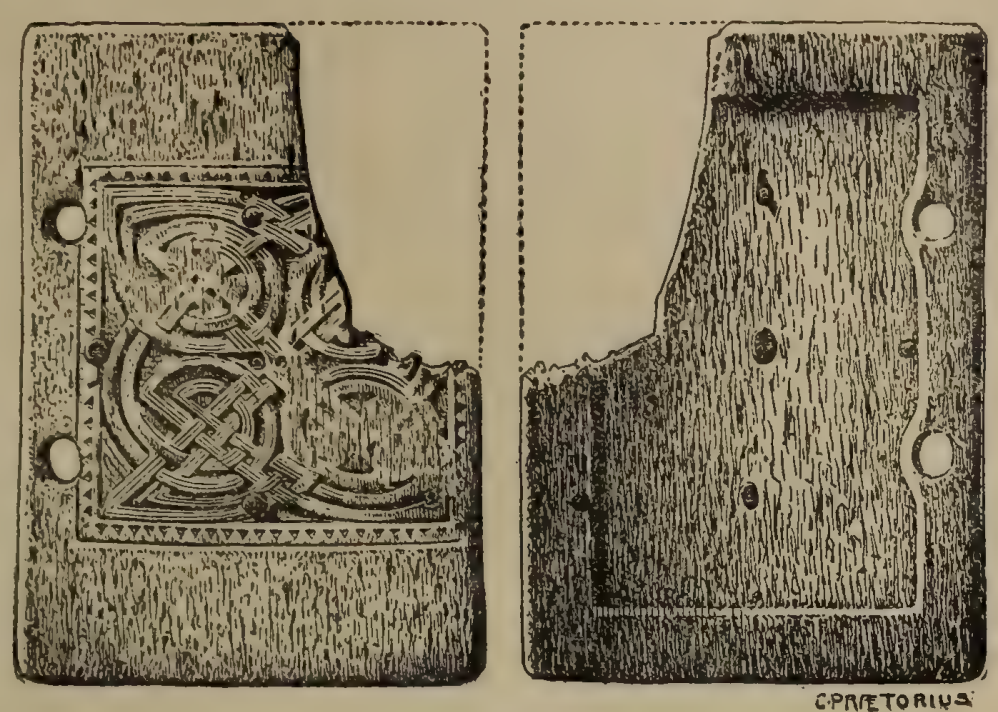

Fig. 18.-Whale's Bone Tablet for Writing, Blythburgh $\left(\frac{2}{3}\right)$ interlaced design that suffices to fix its date and origin. The use of such tabellae among the Romans is well known, but the material employed was generally wood, and only a few examples are preserved in this country, though styli are common; and the special interest of the Blythburgh tablet is that it was evidently made and used at a time when parchment was in common use, and such a primitive method of correspondence or note-taking might be supposed extinct. The system did, however, survive into the Middle Ages, but this is the only AngloSaxon specimen known; the resemblance of its ornamentation to that of the Book of Kells suggests an Irish origin, and throws light on its approximate date. Though hardly two authorities agree precisely as to the date of that famous Irish MS., most would assign this kind of interlacing to the 8th or

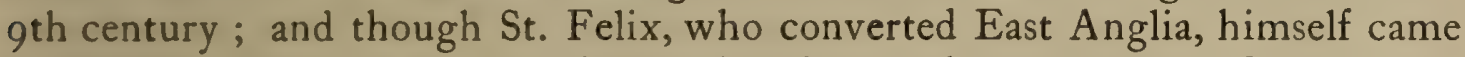
from Burgundy, it is quite probable, that during the supremacy of Northumbria, monks and missionaries introduced literary utensils from the north of England, where the Irish (or Scotic) influence was strong. St. Columba not only introduced the monastic rule into Scotland, but founded monasteries in Burgundy, the home of St. Felix himself; and the occupation of Lindisfarne in 635 by Aidan, who made it his see, was the signal for a great missionary movement in England. After the battle of the Winwaed in 655 East Anglia passed under the influence of the Northumbrian king Oswiu, and the relics of Irish monasticism might be expected in Suffolk after that date; but in spite of a large number of monuments displaying the interlaced patterns, it has not yet been found possible to assign exact dates to much work of this description. The bottom panel of the south face of the Bewcastle Cross has, however, a close resemblance to that on the tablet, and there are good reasons for assigning that well-known monument to the 7 th century ${ }^{101}$ which is indeed indicated by the inscription on it, and the interlacing motives are now generally held 


\section{A HISTORY OF SUFFOLK}

to be ultimately derived from Italy, but adapted and transformed by native artists.

That the Blythburgh tablet served another purpose when no longer used for writing on wax is deduced from the fact that the decorative panel was pierced by seven (now six) bronze rivets placed symmetrically, and apparently intended to hold a metal cross outside, as there are marks on the interlacing that would agree with the equal-armed cross then in use among the AngloSaxons. ${ }^{102}$ On this theory, however, there would be no use for the rivet at the angle and the corresponding one (if it ever existed) on the corner broken away.

A bone draughtsman now in the Bury Museum was found at Finborough; and may, like several found in London, ${ }^{102 a}$ date from the Viking period, but contemporary finds are scarce in the county; and special mention may be made of a trefoil brooch ornamented with conventional foliage in Carlovingian type found at Lakenheath Warren and now preserved at Cambridge. It resembles one in the British Museum from Roskilde, Zealand, though the latter is ornamented in a different style, and its locality explains the presence of this type in England during the Danish period.

Among Anglo-Saxon remains of the later period seals are perhaps the rarest, and at the same time the most interesting from the historical point of view. The series is very limited, but Suffolk is, as usual, represented. The seal-matrix is of bronze, $2 \frac{3}{4} \mathrm{in}$. in height, and in the form of a cone, with two tiers of pierced arches, each containing an animal head, and at the apex of the cone a terminal something like a fleur-de-lys. The eyes of the animal heads were originally represented by garnets, of which only one remains, and their loss is easily explained. After being dug up in a garden by a labourer, about $200 \mathrm{yds}$. from the site of the monastery at Eye, the seal was given as a plaything to a child, who threw it on the fire. The effect of this treatment may still be seen on the bronze, which was luckily rescued by the child's mother, and presented to the British Museum in 1822 by Mr. Hudson Gurney. ${ }^{103}$ The legend of the seal is : + SIG. EĐILWALDI EP.-, which shows that it belonged to Ethilwald, Bishop of Dunwich, in the middle of the 9 th century. This prelate addressed the Profession of Faith to Ceolnoth, Archbishop of Canterbury (830-70), and cannot have resided at Dunwich after 870 , when the see, created by St. Felix in the $7^{\text {th }}$ century, was ravaged by the Danes. The East Anglian bishopric had been divided about 673, and while Dunwich remained the see of Suffolk, that of Norfolk was removed to Elmham. The monks of Eye possessed the site of the bishopric at Dunwich till it was swallowed by the sea, and had a cell there till the Dissolution, hence the discovery of the seal near the monastery is easily explained. The lettering is an abbreviation of SIGILLVM ETHILWALDI EPISCOPI, and surrounds a star, of which four points have floral additions, much in the style of the coinage. ${ }^{108 a}$

In the abbey grounds at Bury an interesting relic was found more than sixty years ago by a labourer, and subsequently passed into the collection of

${ }^{102}$ Besides the jewelled crosses from Norfolk and Suffolk, compare the Gravesend and Canterbury examples (V.C.H.Kent, i, 381,382$)$ and that found in the coffin of St. Cuthbert, who died 687 (V.C.H. Dur. i, 254).

102a V.C.H. London, i, 166.

${ }^{103}$ This account is published with illustrations and the text of the Profession in Arch. xx, 479.

${ }^{103 a}$ Cat. Anglo-Saxon Coins (Brit. Mus.), ii, pl. viii, 16 (penny of Edward the Elder). 


\section{ANGLO-SAXON REMAINS}

Lord Londesborough. It consists of a leaden tablet bearing an Anglo-Saxon inscription with three holes along one edge, in one of which is a leaden loop as if for binding several such leaves together. The title is in runes which may represent 'The book of Alfred says,' and the remainder is in Anglo-Saxon minuscules, as follows: Ic Ælfric munc et mæsse-preost wearp asend on Æpılredes dæge cyninges fram Ælfeage biscope, Æpelwolde æfter-gengan, to sumum mynstre pe is Cernl'. pa bearn me on mode, ic treowege purh Godes gife, pet ic pas ... This represents in modern English: 'I, Æilfric, monk and mass-priest, was sent in King Æthelred's time from Alfeah the bishop, the successor of Æthelwold, to a certain minster (or monastery) which is called Cernel. Then it came into my mind I would this ...? These are the opening lines of ÆElfric's preface to his first collection of Anglo-Saxon homilies, and express his intention to translate the Latin text into English. Thomas Wright, from whose account ${ }^{104}$ the above is taken, considered it the front cover of a manuscript volume of the Homilies, the English introduction being continued on the first vellum page, as the back of this cover has no inscription. The runes were used at this date only exceptionally, as a piece of archaism, and from a comparison of the texts it is clear that this is an abbreviated version. Æthelwold and Alfeah were successive bishops of Winchester, and Ælfric (subsequently Archbishop of Canterbury) was sent as abbot to the newly-founded abbey of Cerne in 988 or 989 , where he translated his first volume of homilies in 990.

Discoveries of isolated coins add little to our knowledge of this later Saxon period, but may be noted as suggesting pre-Norman occupation of their sites. A silver penny of Cuthred, King of Kent (797-805), was found at Lavenham, ${ }^{105}$ bearing the name of the moneyer Sigeberht on the reverse ; and a number of pennies of Edward the Confessor are recorded from Campsey Ash. ${ }^{108}$ Sir John Evans has described coins of Ethelred II (978-IOI6) found at Ipswich, ${ }^{107}$ where at the depth of about $5 \mathrm{ft}$. from the modern surface is a continuous band of black earth about I ft. thick, in which Roman and Saxon antiquities are found. ${ }^{108}$ Three coins of Canute have also come to light in the churchyard at Rougham; ${ }^{109}$ and a number of Æthelred's coins, now at Bury, were found fused together in Sir Henry Bunbury's garden at Great Barton.

As might naturally be expected, a survey of the Anglo-Saxon remains of Suffolk suggests the same conclusions as in Norfolk. In both counties two distinct rites of burial were practised in what must be called the pagan period, that is from the end of the Roman occupation to the time when arms, ornaments, and utensils ceased to be buried with the dead. To explain this duality in a sphere most congenial to conservatism is one of the main problems of archaeology; and the advent of Christianity does not fully explain so radical a change as that from cremation to inhumation. The former may be considered frankly pagan, the latter perhaps as a step towards the Christian orientation of the grave, but unburnt burials in East Anglia and elsewhere are by no means uniformly east and west ; nor, indeed, if they

\footnotetext{
10s Arch. xoxiv, 438, pl. xxxvi ; Proc. Soc. Antig. (1st Ser.), ii, 105 ; Miscellanea Graphica, 12.

100 Bury and W. Suff. Proc. ii, 21 I. $\quad{ }^{100}$ Akerman, Pagan Saxondom, 43.

${ }^{107}$ Numis. Chron. iv, 1864, p. 28 ; one from St. Matthew's churchyard, Bury and W. Suff. Proc. ii, 214.

100 Antig. iv (1881), 272. 


\section{A HISTORY OF SUFFOLK}

were so orientated, would it be wise to conclude that all were Christian burials, for that direction was often adopted purely with reference to sunrise and sunset. Suffolk, on the whole, gives colour to the theory that cremation was the earlier practice, for while no relics of late character are associated with the cinerary urns, most of the grave-furniture in the other group indicates the 6th or early $7^{\text {th }}$ century, and it may reasonably be assumed that the Anglians arrived on our eastern coast in some number between $45^{\circ}$ and $550 .^{110}$ It is in Suffolk that some of the earliest Teutonic relics have been found; and a careful comparison of finds in East Anglia with those of counties that were presumably conquered by the Anglo-Saxons after their conversion to Christianity may eventually settle the stages of their advance and lead to a final classification of their remains.

Signs of intercourse with Kent were noticed in Norfolk, ${ }^{111}$ but are still more evident in Suffolk, and are an interesting confirmation of the historical records. When English history begins in the closing years of the 6th century, Kent is the dominant kingdom, and the Bretwalda Æthelbert is overlord of East Anglia. In the year 6I 6 this connexion was interrupted by the death of the Kentish king after a reign of nearly fifty years, and Redwald of East Anglia succeeded to the hegemony of Britain. His kingdom shortly afterwards passed into the hands of the redoubtable champion of the old faith, Penda of Mercia, whose fall at Winwaed in 655 inaugurated the period of Northumbrian supremacy and led to the final evangelization of East Anglia. The northern kingdom, however, was soon overshadowed by Mercia, and the eastern Angles were ruled from the midlands till the foundation of the English kingdom by Ecgberht in the second quarter of the $9^{\text {th }}$ century.

It is evident therefore that most of the burials that can be identified as Anglo-Saxon by their position or furniture must be referred to the period of Kentish supremacy, and these, for obvious reasons, are inhumations. Those who practised cremation in Early England did not, as a rule, place on the pyre objects of metal or other material that might resist the flames, for if combs survived (as at Eye), brooches and other such ornaments would also have been spared. A corollary from this is that the numerous bronzes found in the county without any notice of interments are probably from inhumations either perished or destroyed, and the probability becomes a practical certainty when such articles are found in pairs or in groups, for objects accidentally lost would be found, if at all, in isolation. On these grounds some of the sites have been marked on the map as burials even where there is no record of human remains either burnt or unburnt.

Though East Anglia was the first Danish kingdom in England, and belonged to the Danelagh after the partition under Alfred, it has been inferred from certain social indications that 'Guthrum's Danes did not, like their northern kindred, drive out a portion of the earlier population and establish themselves as a superior class above the remainder, but settled among the original East Anglians on a footing of comparative equality.' ${ }^{112}$

${ }^{110} \mathrm{Mr}$. Chadwick quotes Historia Brittonum, $\$ 59$, but thinks it unlikely that Wehha, the first King of East Anglia and great-grandfather of Redwald, lived at the time of the invasion. (Origin of the English Nation, 183.)

III V.C.H. Norf. i, 345 .

11 Robertson, Scotland under her Early Kings, ii, 435, 240. 


\section{ANGLO-SAXON REMAINS}

The scarcity of Suffolk place-names with the Danish termination -by is remarkable in view of their abundance beyond the Wash; and there is, moreover, physical evidence that the population is of English rather than of Danish descent. According to Dr. Beddoe, ${ }^{113}$ 'the southern part of Cambridgeshire is anthropologically more like Norfolk and Suffolk than the northern, and East Anglia is more Anglian than either Danish or British. The British element is perhaps stronger in Suffolk than in Norfolk. . . . The people of Brandon, a small town where flint-working is thought to have been carried on since prehistoric times, seem to be comparatively dark.' Danish remains, which are so numerous in York and other centres appropriated in the Viking period, are remarkably scarce in Suffolk and East Anglia generally; and a continuous coinage after the establishment of Guthrum's kingdom points to a measure of peace and prosperity that was not commonly enjoyed during the Danish wars. The whole question of the East Anglian mints has been discussed by Daniel Haigh, ${ }^{114}$ who arrived at some interesting ethnological results. The names of the moneyers (or persons responsible to the king for the weight and purity of the coinage) show that in the Danish hosts there must have been a large proportion not of pure Scandinavian descent. In the lists are two varieties of un-English names, some apparently Frankish and others certainly Scandinavian. Under Eadwig (955-9) the former diminish in number, and almost disappear by the time of Æthelred II (978-1016), while the Scandinavians naturally continue in large numbers. Three alternative explanations are offered, which may be given in the words of Messrs. Grueber and Keary ${ }^{116}$ : 'perhaps there were a great many Frankish soldiers in that portion of the great army which, under Guthrum, settled in East Anglia and Mercia; or the army brought over a certain number of Frankish thralls who, having some skill in metal work, were employed to engrave dies and were authorized to place their names upon them; or finally, the coins were issued by traders, and the majority of these in East Anglia at this time were men of Frankish descent.'

\footnotetext{
113 Races of Britain, 254. $\quad 114$ Numismatic Chronicle, iv (1841), 34, 195.

us Cat. of Engl. Coins (Brit. Mus.), ii, p. xliv; see also p. ciii.
} 




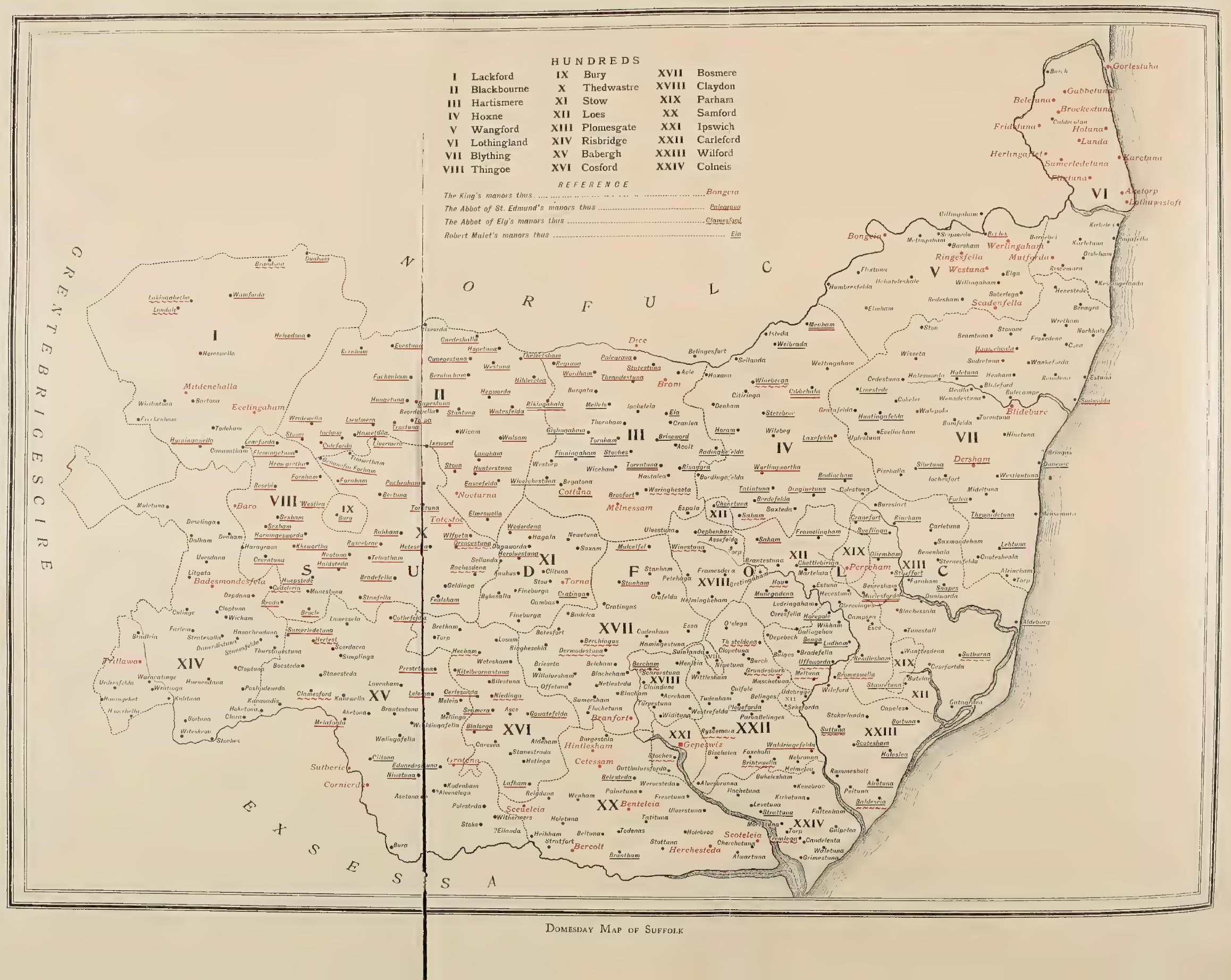




\section{DOMESDAY SURVEY}

7 HE Domesday Survey of Suffolk follows the Surveys of Essex and Norfolk in 'Little Domesday,' the volume which is supposed to have been compiled from the original returns of the jurors of the hundreds, at an earlier date and on a more elaborate scale than the less detailed and graphic, but also less bulky and cumbrous, 'Great Domesday.' At the end of the Suffolk Survey, which concludes the volume, stands in red capital letters the famous colophon:-

Anno millesimo octogesimo sexto ab Incarnatione Domini vigesimo uno regni Willelmi facta est ista descriptio. Non solum per hos tres comitatus sed etiam per alios.

As Mr. Round has pointed out, ${ }^{2}$ descriptio here probably refers to the Survey, or Inquest, not to Domesday Book, which did not take its final shape till much later. ${ }^{\text {A }}$ A valuable subsidiary source for the study of the Suffolk Survey is the Inquisitio Eliensis, which gives the lands held by the Abbot of Ely in six counties, including the three counties of Little Domesday. From the close correspondence between this document and the Ely returns in Domesday Book, Mr. Round has argued that the Inquisitio was copied, where Essex, Norfolk, and Suffolk are concerned, from the second volume of Domesday Book, or Little Domesday." As in Norfolk, so in Suffolk, a minute comparison of the two records makes it appear more likely that both were derived from the same original, ${ }^{6}$ and that in each case additions were made and gaps filled up from special knowledge.

Domesday Suffolk is divided into hundreds, leets, a territorial unit peculiar to East Anglia, vills (villae), terrae, and manors (maneria) with berewicks (berewitae). Superficial areas are measured by carucates, half-carucates, and acres; a virga or rood ${ }^{6}$ appears exceptionally, and perches (perticae) ${ }^{7}$ and arpents of vineyard ${ }^{8}$ are also mentioned. Lineal measurements are given in leagues and furlongs or quarentines (quarentenae, quarantenae, carantenae). That the normal carucate contained 120 acres might be assumed from the frequent

1 Round, Feud. Engl. 140-6; Maitland, Dom. Bk. and Beyond, i, et seq. ; V.C.H. Norf. ii, 2-4.

- Feud. Engl. 1 39-40.

V.C.H. Norf. ii, 2. Breve in the sense of a return is only once used in the Suffolk Survey; Dom. Bk. fol. 3796, 'Plas terrae pertinet sed inbreviata in Norfolc.'

Feud. Engl. 137-46.

V.C.H. Norf. ii, 4 .

- CE. Maitland, Dom. Bk. and Beyond, 384. It is, in the Suffolk instances, a rood or quarter acre, not a virgate or quarter carucate, Dom. Bk. fol. $285 ; 2$ acres of meadow, ' $i$ virgam minus,' 342 ; four freemen with 12 acres and 'i virga prati,' 389 ; four freemen I carucate and ' $i$ virg.' $423 ; 23$ acres and ' $i$ virga,' $433 b$; 4 acres worth $16 d$. ; 3 virgae worth 3 d. Here the worth of the 'virga' is just a quarter of the worth of the acre.

Dom. Bk. fol. $28 ; b, 287$.

' lbid. fol. 3826 (St. Aldreda), 'Berchingas, ii arpen ...... vinae.' Ibid. 418 (A. de Vere), 'Lavenham, i arpentum vineae.' Ellis, Introd. to Dom. i, 117. 


\section{A HISTORY OF SUFFOLK}

recurrence of units of $80,60,40$, and 30 acres, and is proved by the entry of Starlinc's estate in Glemham as ' 180 acres' in Domesday, and as ' I I $\frac{1}{2}$ carucates' in the Inquisitio Eliensis." There is direct evidence to show that 12 furlongs went to a league, for 16 quarentines in the Domesday Survey are referred to as I league and 4 quarentines in the corresponding passage of the Inquisitio Eliensis :-

Ratesdane ... habet xvi quarentenas in longo et $\mathrm{x}$ in lato $\left(D o m\right.$. $B k$. $\left.\mathrm{ii}, 3^{8} \mathbf{1} b\right)$.

Rattesdene ... habet $\mathrm{i}$ leugam et iiii quarentenas in longo et $\mathrm{x}$ quarentenas in lato (Inq. El. [Rec. Com.], 522b).

Another land division which is mentioned twice is the ferding or ferting. The Bishop of Thetford had soke and sac over the ferting of Elmham (super ferting de Almebam). ${ }^{10}$ This, as we learn from later records, ${ }^{11}$ was equivalent to a quarter of the hundred of Wangford, but when we read that 'St. Edmund held six freemen in Ferdinga de ealdham' (Aldbam), ${ }^{12}$ in Cosford Half-hundred, we can only guess at the meaning of the term.

In the modern county of Suffolk there are twenty-one hundreds. In the Domesday county there were twenty-four and a half hundreds, or twenty-four, if the small hundred of Luding (Lotbing) and the neighbouring half-hundred of Ludingaland (Lothingland) be counted as one. ${ }^{13}$ The hundreds of the I I th century correspond very closely to those of the present day, and, as a comparison with the Hundred Roll of I 274 shows, the few differences can be traced back to the I $3^{\text {th }}$ century. Thus the Domesday hundred of Claydon or Claindune was partly replaced by Thredling Hundred and partly coupled with Bosmere, while the hundred of Bradmere and the half-hundred of Parham, irregular and disconnected even in Domesday, ${ }^{14}$ were altogether lost by the reign of Edward I. Mutford, which forms one hundred with Lothingland, has taken the place of the older Lothing or Luding, and 'Bishop's ' Hundred has changed into the hundred of Hoxne, called after the episcopal manor, Hoxa Episcopi, ${ }^{15}$ in which, in the time of Edward the Confessor, there was "a church, the seat (sedes) of the bishopric of Suffolk.' hundred of Babergh was still double in 1274, and was represented by twenty-four instead of twelve jurors in the inquest of that year. Cosford still counted as a half-hundred, but the hundred and a half of Samford was reckoned as a single hundred. ${ }^{17}$ The half-hundred of Thredling and that of Exning, which appears as a half-hundred in the Hundred Roll, ${ }^{18}$ equalize the lists of 1086 and 1274 .

Of the twenty-four Domesday hundreds, seven, Lackford, Blackbourn, Bradmere, Hartismere, Bishop's, Wangford, and Lothing with Lothingland, lay along the northern or Norfolk border of the county. Seven-Risbridge, the double hundred of Babergh, the hundred and a half of Samford with the half-hundred of Cosford, Colneis, and Wilford-abutted on Essex to the

Dom. Bk. 430 ; Inq. El. 153.

${ }^{10}$ Dom. Bk. 379.

1 Rot. Hund. (Rec. Com.), ii, 191. 'Episcopus Norwic. tenet manerium de Suthelmham et quartam partem hundr. de Waynesford de dono Regum Anglorum antiquit.' Cf. Maitland, Dom. Bk. and Beyond, 93; Vinogradoff, Engl. Soc. in Eleventh Century, 151, note i.

${ }^{12}$ Dom. Bk. 369.

${ }^{13}$ Roy. Hist. Soc. Trans. (new ser.), xiv, 226.

"Cf. Map.

16 Ibid. 379.

16 Dom. Bk. 329, 4386 .

${ }^{18}$ Ibid. $197,199$.

${ }^{17}$ Rot. Hund. (Rec. Com.), ii, 142, $1516,176,1776$. 


\section{DOMESDAY SURVEY}

south, and the remaining ten were central. Their names, English rather than Danish in form, date in all probability from the early days of the Anglian occupation, and reflect the natural features of the country, the wide shining expanses of the 'broads' and 'meres,' the 'fords' over those riverways which have played so important a part in the history of tribal settlement. ${ }^{10}$

But, like the small Leicestershire hundreds, ${ }^{20}$ they often derive their names from one of their vills, ${ }^{21}$ or, as is the case with Lackford and Wangford, from a vill in another hundred. ${ }^{92}$ Thingoe and Stow, too, recall the primitive assembly and court of justice, the Scandinavian tbing, the Saxon moot-stow, ${ }^{29}$ and the existence of double and half-hundreds, with the artificial character of their grouping, suggests that the Suffolk hundreds were deliberately formed for administrative purposes, to supply the three chief needs of the infant state: military defence, justice and police, and taxation. The double hundred of Babergh in the south is balanced in the north by the closely connected and intermixed hundreds of Blackbourn and Bradmere, a double hundred in all but name." The southern hundred and a half of Samford is similarly matched by the intersected Plomesgate Hundred and Parham Half-hundred on the east, ${ }^{25}$ flanked on either side by the halfhundreds of Cosford and Ipswich. ${ }^{26}$

The area and population of the Suffolk hundreds at the time of the Domesday Survey cannot be precisely ascertained, since exact measurements are given for arable and meadow land alone, and even here the carucates are probably 'geld-carucates,' and do not represent the 'real' superficial area, while not only is the record of the tenants in a vill constantly followed by the phrases of uncertain interpretation, Alii ibi tenent: Plures ibi tenent, ${ }^{27}$ but it is often difficult to decide whether the returns represent the pre-Conquest or the post-Conquest population. Still, a careful analysis gives results which are useful for purposes of broad generalization, if they cannot be trusted for minute accuracy of detail. The following table shows the number of vills and the area of arable in each hundred, the relative proportions of free and unfree householders, and the average population per carucate of I 20 acres in the three groups, northern, central, and southern, of the Suffolk hundreds. In compiling these lists every individual freeman, sokeman, villein, bordar,

19 Round, The Commune of Lond. : 'The Settlement of the South Saxons and East Saxons.'

${ }^{20}$ Like the Leicestershire hundreds, also, the Suffolk hundreds were 'strangely intermingled among themselves'; Round, Feud. Engl. 80, 203.

"Loes, Parham, Wilford, Claydon.

" Lackford in Thingoe Hundred; Wangford in Lackford Hundred.

Stubbs, Const. Hist. i, 115 ; Maitland, Tounship and Boro. 39.

" Thus Blackbourn is assessed as a hundred and a half, Bradmere as a half hundred. In 1274 Blackbourn was counted as a double hundred; it had absorbed Bradmere altogether. Rot. Hund. (Rec. Com.), ii, I5 I6, 'Blakeburn respondet pro duobus hundr.'

${ }^{*}$ It is just these intersected divisions, Bradmere and Parham, which in modern times have lost their independent existence $2 s$ hundreds or half-hundreds.

"The economic unity of the hundred is seen in the hundred of Colneis, where there was a pasture common to all the men of the hundred; Dom. Bk. 3396. Its jurisdictional unity is seen in the 'witness' of the hundred. Cf. Vinogradoff, Growth of the Manor, 144-5, 249-50; Engl. Soc. in the Eleventh Century, 96-107.

$n$ They may mean either, 'There are others (living in the vill) holding here,' or 'Others (external to the vili) hola here.' Cf. Maitland, Dom. Bk. and Beyond, 20, n. I. "The words, "Alii ibi tenent" . . mcan, we lelieve, not that there are in this vill other unenumerated tillers of the soil, but that the vill is divided between several tenants in chief.' Ellis, Introd. ii, 491. 


\section{A HISTORY OF SUFFOLK}

and serf has been counted as a householder. Freemen, sokemen, and priests have been reckoned as free; villeins, bordars and serfs as unfree.

TABLE I-POPULATION AND AREA

\begin{tabular}{|c|c|c|c|c|c|c|c|}
\hline \multirow{2}{*}{ Hundred } & \multirow{2}{*}{$\begin{array}{l}\text { No. of } \\
\text { Vills, \&c. }\end{array}$} & \multirow{2}{*}{$\begin{array}{l}\text { Free and } \\
\text { Halff-free } \\
\text { House- } \\
\text { holders }\end{array}$} & \multirow{2}{*}{$\begin{array}{l}\text { Unfree } \\
\text { House- } \\
\text { holders }\end{array}$} & \multirow{2}{*}{ Totals } & \multicolumn{2}{|c|}{ Area of Arable } & \multirow{2}{*}{$\begin{array}{l}\text { Approximate } \\
\text { Average of } \\
\text { Households per } \\
\text { Carucate }\end{array}$} \\
\hline & & & & & Carucates & Acres & \\
\hline \multicolumn{8}{|l|}{ Northern Hundreds } \\
\hline Lackford . . . . . & 17 & 71 & 411 & 482 & 104 & 106 & 4 to 5 \\
\hline Blackbourn . & 25 & 498 c. & 230 & $728 \mathrm{c}$. & 80 & 74 & 9 \\
\hline Bradmere & 10 & 255 & 137 & 392 & 44 & $24 \frac{1}{2}$ & 9 \\
\hline Hartismer: & $4^{I}$ & $896 \mathrm{c}$. & $501 \mathrm{c}$ & I,397 c. & 122 & $4 \mathrm{I} \frac{1}{4}$ & II \\
\hline Bishop's . & 27 & $246 \mathrm{c}$ & $678 \mathrm{c}$ & $924 \mathrm{c}$. & 123 & II 2 & 7 \\
\hline Wangford . & 24 & $459 \mathrm{c}$. & 464 & $923 \mathrm{c}$. & 73 & $16 \frac{1}{2}$ & 12 \\
\hline Lothing . . . . . . . & 12 & 176 & 86 & 262 & 20 & $16^{2}$ & I 3 \\
\hline Lothingland (half-hundred) . & 17 & I 7 & $186 \mathrm{c}$ & $303 \mathrm{c}$ & 50 & 115 & 6 \\
\hline \multicolumn{8}{|l|}{ CEntral Hundreds } \\
\hline Thingoe. . . . & 19 & 283 & 360 & 643 & 86 & $91 \frac{7}{2}$ & 7 \\
\hline Thedwastre & $2 I$ & $694 \mathrm{c}$. & 434 & $\mathrm{I}, 128 \mathrm{c}$ & 113 & 18 & 9 to 10 \\
\hline Stow . . & 18 & 341 & 341 c. & $682 \mathrm{c}$. & 82 & 110 & 8 \\
\hline Bosmere . & 32 & $639 c$. & 453 & $1,092 \mathrm{c}$ & 94 & 92 & II \\
\hline Claydon & 25 & $429 \mathrm{c}$. & 316 & $745 \mathrm{c}$ & 64 & 48 & II \\
\hline Loes . . & 29 & $508 \mathrm{c}$ & $393 \mathrm{c.}$ & 901 c. & 78 & $56 \frac{1}{2}$ & II \\
\hline Carlford . . . . & 39 & $45 I$ & 379 & 830 & 94 & 118 & 8 to 9 \\
\hline Ipswich ${ }^{29}$ (half-hundred). & $2^{29}$ & 272 & 70 & 342 & 20 & 46 & 17 \\
\hline Parham (half-hundred) & 6 & 158 & 18 & 176 & 14 & 62 & II \\
\hline Plomsgate [or Plomesgate]. & 28 & $340 \mathrm{c}$ & $25^{8}$ & $598 \mathrm{c}$ & 60 & 62 & 9 to 10 \\
\hline Blything . . . . & 54 & $842 c^{30}$ & $1,28 \mathrm{Ic}$ & $2,123 \mathrm{c}$ & 201 & $96 \frac{1}{2}$ & $10 \frac{1}{2}$ \\
\hline Southern Hundreds & & & & & & & \\
\hline Risbridge.... & & 370 & 830 & 1,200 & 209 & $5 \mathrm{I}$ & 5 to 6 \\
\hline $\begin{array}{l}\text { Babenberg [or Babergh] (dou- } \\
\text { ble hundred) }\end{array}$ & 38 & 276 & 1,083 & 1,359 & 197 & $21 \frac{1}{2}$ & 6 to 7 \\
\hline Samford (hundred and a half) & 46 & 280 & 693 & 973 & 166 & 91 & 5 to 6 \\
\hline Cosford (half-hundred) . & 22 & 240 & 413 & 653 & 99 & $5 \mathrm{I}$ & $6 \frac{1}{2}$ \\
\hline Colneis . . . . & $3 \mathbf{I}$ & 340 & 173 & 513 & 29 & 67 & 17 \\
\hline Wilford . . . . . . & 33 & 749 & $126 \mathrm{c}$ & $875 \mathrm{c}$ & I 12 & 4 & 7 to 8 \\
\hline
\end{tabular}

Rough as these statistics are, they bring out clearly the strong element of freedom in the village population of Suffolk at the time of the Domesday Survey. This element is most apparent, if Ipswich Half-hundred be omitted, in the northern hundreds of Blackbourn, Bradmere, Hartismere, and Lothing; in the central hundreds of Thedwastre, Bosmere, Claydon, Loes and Carlford, Parham and Plomesgate; and in the southern hundreds of Colneis and Wilford. The unfree element is strikingly predominant in the hundreds of Blything, Risbridge, and Babergh, all 'manorialized' districts. In Babergh double hundred, where the proportion of free to unfree householders is about one to five, there are some thirty-eight manors to as many vills. In Colneis Hundred there are only nine small manors in thirty-one vills, and the proportion of free to unfree householders is about two to one.

In East Anglia, and in East Anglia alone, at the time of the Domesday Inquest, the hundreds were divided, for fiscal purposes, into smaller units called leets. Two passages in the Norfolk Domesday refer to these divisions, ${ }^{31}$

${ }^{28}$ Two hundred and sixty-three burgesses counted among the freemen.

${ }^{29}$ Ipswich 'burgus' and 'villa' and Stoke. ${ }^{30}$ Three hundred and sixteen burgesses in Dunwich.

s1 Dom. Bk. 119b. 'Hundredum de Grenehou de xiv. letis,' $212 b$; 'Hundredum et dimidium de Clakeinsa de x leitiso' V.C.H. Norf. i1, 5-6. 


\section{DOMESDAY SURVEY}

and an entry in a I 2th-century survey of the hundred of Thingoe, made for Abbot Sampson of St. Edmundsbury, ${ }^{32}$ gives the name of the twelve leets of Thingoe Hundred, with their constituent vills. The peculiar feature of the Norfolk and Suffolk Domesday Surveys is the existence of a system of supplementary assessment for the geld, based on these leet divisions. In many of the East Anglian entries a new term occurs, "the formula which prescribes how much geld the landholders of the vill must pay " when the hundred pays $20 s ., "$ "ss and, coupled always, or nearly always, ${ }^{34}$ with this formula, the measurements of the vill expressed in leagues and furlongs or quarentines (quarentenae). ${ }^{35} \quad$ By setting this Domesday assessment of the geld over against the vills of the Thingoe leets, as given in the I 2th-century survey, Mr. Round has shown that the hundred in this case was divided into twelve blocks of equal assessment, each paying $20 \mathrm{~d}$. when the hundred paid $\oint_{\mathrm{I}}$ sterling to the geld, and called leets. ${ }^{38}$ It is worth noting that $20 d$. is the Danish ora, at least in one of its forms, the twelfth part of a pound sterling, the eighth part of a mark. ${ }^{37}$ This may point to a Scandinavian origin for the leet system, which would be quite in keeping with the character of Suffolk, a carucated county, which had formed part of 'Guthrum's Kingdom,' and was settled as well as conquered by the Danes. ${ }^{38}$ Following the clue offered by the leet organization in Thingoe Hundred, it is possible to find much evidence which implies the existence of an ordered system of assessment of the same nature throughout the county. The total assessment of the twenty-four hundreds at $f_{0}$ i a hundred would be $\oint_{2} 24$. The actual assessment, as stated in Domesday Book, is $\oint_{2} 2$ I I s. $5 \frac{3}{4} d$., distributed among the hundreds in the following proportions :-

\begin{tabular}{|c|c|c|c|c|c|c|c|c|c|c|c|c|c|c|c|c|c|c|c|c|}
\hline & Nam & $e$ of & $\mathrm{Hu}$ & adre & & & & & 6 & s. & $d$ & & Name of Hundre & & & & & 6 & s. & d. \\
\hline Thingoe & . & - & - & - & . & - & - & - & I & 0 & $\mathrm{O} \frac{1}{2}$ & Bishop's & . . . . & & & & - & 0 & I 3 & $7 \frac{1}{2}$ \\
\hline vastre & & . & . & . & . & . & . & . & $\mathrm{I}$ & 0 & $\mathrm{I} \frac{1}{2}$ & Bradmere & . & & & & . & 0 & I I & $10 \frac{1}{2}$ \\
\hline Risbridge & - & . & . & . & . & . & - & . & $\mathbf{I}$ & 0 & I $\frac{3}{4}$ & Lothing & . & - & . & . & . & $\circ$ & 10 & 8 \\
\hline Lackford & . & - & - & . & . & . & . & . & I & 0 & $9 \frac{1}{2}$ & & Half 1 & Hun & & & & & & \\
\hline Blackbourn & & - & - & - & - & - & - & - & I & 7 & $9^{\frac{1}{4}}$ & & & & & & & & & \\
\hline Wilford & - & - & - & - & - & - & - & - & $0 \mathrm{I}$ & 19 & $8 \frac{1}{2}$ & $\begin{array}{l}\text { Lothinglan } \\
\text { Parham }\end{array}$ & • • & & & & & $\begin{array}{l}0 \\
0\end{array}$ & & \\
\hline arlford. & • & - & - & - & - & - & - & - & 0 I & 19 & $7 \frac{3}{4}$ & Cosford & . . . . & & & : & & 0 & 10 & \\
\hline ow & : & : & • & : & $\cdot$ & . & . & - & 0 I & $\begin{array}{l}19 \\
18\end{array}$ & $\begin{array}{l}6 \frac{1}{2} \\
8\end{array}$ & Ipswich [I & 00 'head-per & ennie & & & & & 0 & \\
\hline Coes & : & : & : & : & $\dot{0}$ & : & . & : & $\begin{array}{lll}0 & 1 \\
0 & 1\end{array}$ & $\begin{array}{l}10 \\
18\end{array}$ & 6 & & Hundred & and & 1 & Hal & & & & \\
\hline Claydon. & . & . & • & . & . & - & . & • & 0 I & 18 & 4 & Samford & & & & & & & & \\
\hline Plomesgate & & • & • & . & . & • & - & . & 0 I & 17 & & & $\cdot$ & & & • & - & $\mathbf{I}$ & 0 & \\
\hline Bosmere & - & - & . & . & - & . & - & . & 0 I & 17 & 3 & & Double & $H u$ & indr & & & & & \\
\hline Blything & . & - & . & - & . & . & • & . & 0 I & 171 & $11 \frac{1}{2}$ & Babergh & $\cdot \cdot \cdot$ & - & - & - & . & I & 13 & \\
\hline Wangford & - & - & - & - & - & - & • & - & 0 I & 141 & I I & & Total & & & & & & & \\
\hline Hartismere & & - & - & - & - & . & - & . & $0 \mathrm{I}$ & $I_{4}$ & 3 & & & • & & & & 21 & 11 & \\
\hline
\end{tabular}

st Gage, Suff. Hund. of Thingoe, Introd. xii ; Select Pleas in Manorial Courts (Selden Soc.), Introd. p. 1xxiii, n. A ; Round, Feud. Engl. 101 ; Chron. Foc. de Brakelonda (Camden Sóc.), 21.

${ }^{2}$ Maitland, Dom. Bk. and Beyond, 431, n. I ; Dom. Bk. $382 b$; 'Stoches,' assessed at ' $4 d$. in gelto de: 20 solidis,' 372 ; St. Edmund's Bury, 'et quando in hundreto solvitur ad geltum unam libram, tunc inde exeunt $60 d . a d$ victum monachorum.'

"In one case [Dom. Bk. 2b, 'Brumfort' (Bramford)] the lineal measurements are given without the geld.

ss Dom. Bk. 304, 'Edwardestuna. Habet hoc manerium sex quarentenas in longo et sex in lato et de gelto rod." ${ }^{38}$ Feud. Engl. 98 et seq.

It It appears to have been variously worth $16 d$. and 20d. Liebermann, Gesetze der Angelsachsen: Glossary 'ora ' ; cf. Chadwick, Anglo-Sax. Institucions; Index, 'ora'; Dom. Bk. 3 I 2 ; Dunwich, 'forisfacti sunt de ii oris'; cf. Round, 'The Domesday Ora' (Engl. Iiist. Rev. xxiii, 283). For the whole question of the Suffolk " ora" ef. below, p. 409 .

Round, Feud. Engl. $71-8 \%$.

It is interesting to note that Ipswich half-hundred was almost exempt from geld, and that Bradmere was practically assessed as a half-hundred. 'The 'head-pennies' are not here included in the geld. Cf. below, p. 416. 


\section{A HISTORY OF SUFFOLK}

The organization of the system is seen very clearly if the hundreds are arranged in groups, each with a separate unit of leet assessment, but all ultimately based on the $20 d$. ora. The first is the 'ora or $20 d$. unit group.' It includes the hundreds of Thingoe, Lackford, Claydon, Plomesgate, and Wangford, and the half-hundred of Parham certainly, and, with less certainty, Babergh double hundred, Cosford half-hundred, and the hundreds of Bosmere, Hartismere, Loes, and Colneis. To the second, 'ora and a half, or 3od. unit group,' belong the hundreds of Blything, Bishop's, Carlford, Stow, Risbridge, and the hundred and a half of Samford. The units of assessment are $30 \mathrm{~d} ., 60 d$., I $5 d$, and $7 \frac{1}{2} d$. In Blything Hundred no fewer than ten vills are assessed at $7 \frac{1}{2} d$., a quarter of $30 d$. The third group has $17 \frac{1}{4} d$. and $34 \frac{1}{2} d$. as units of assessment-a survival, possibly, of a double ora or $40 \mathrm{~d}$. unit. It contains only the hundreds of Blackbourn and Bradmere. The fourth group is based on a unit of $13 \frac{1}{2} d$. or $27 d$., which looks like a reduced ora and a half $(30 d$.); it is composed of the hundred of Wilford, while Thedwastre Hundred seems to have two units of assessment, $20 d$. and $27 d^{40}$ Lastly, the half-hundred of Lothingland is assessed as a whole at IOs., and in Lothing Hundred the unit is apparently $16 d$., possibly the ora of $16 d$. The reconstruction of this scheme of assessment is extremely complicated and difficult, since the geld was often distributed through the hundred in small fractions, and in combining these into 'leet' units it has to be remembered that, to judge from the Thingoe instance, neighbouring villages, as a rule, gelded together, and the leet, when it was made up of more than one vill, was a territorially compact district. Enough, however, may be done to show that the East Anglian leet system must at one time have been regularly and elaborately organized.1

In this system the vill appears as the gelding unit, but the tax falls on the vill through the hundred. This is proved by the entry relating to Lothingland, ${ }^{42}$ where the lineal measurements and geld are given for the whole half-hundred, without distinction of vills. This may help to explain the fact that only certain vills in each hundred were assessed to the geld. Thus in the hundred of Claydon, out of twenty-five vills mentioned in the Survey, the ' geld' falls on eleven ; in Wilford Hundred, out of thirty-three vills, eleven geld; in Blything twenty-nine of the fifty-six vills are assessed; in Risbridge twenty-one out of thirty-seven. Probably the hundred or half-hundred was assessed as a whole, and the geld was then partitioned among the smaller fiscal areas or leets, and through them again it would fall on the selected vills, which may have been tax-centres for a district. ${ }^{48}$

The problem of the relation between the geld assessment and the land measurements which usually accompany it in the East Anglian Domesday Inquest does not yet admit of a satisfactory solution. The normal entry in the Norfolk and Suffolk Surveys gives the number of carucates or acres held by the tenants, and the number of ploughs on the holding, but it omits the formula terra est $x$ carucis, the second term (B) of Professor Maitland's 'A B C of Domesday.' "4 That is to say, in the East Anglian Survey we have information about the 'geld carucates ' (A) and about the ' plough teams' (c), but not about the 'team-lands' (в), the 'potential arable' of the counties.

${ }^{10}$ Round, Feud. Engl. 102. $\quad$ See Table of Danegeld and Leet System.

13 C. Maitland, Dom. Bk. and Beyond, $120-1$; Round, Feud. Engl. 49 et seq.

"Dom. Bk. and Beyond, 399, 406, 413, 429 . 


\section{DOMESDAY SURVEY}

In this East Anglia is not singular. A similar omission is found in Gloucestershire, Worcestershire, and Herefordshire, and also in Essex, the third county in Little Domesday. ${ }^{45}$ What is really distinctively East Anglian is the occurrence in Norfolk and Suffolk of the new term placed at the end of the entry, which gives the lineal measurements of the vill or manor, and its assessment to the geld, e.g. 'King Edward held Barrow for a manor and for 7 carucates of land ... then the whole was worth (valuit) $f_{0}$ ro, now $£_{2} 0$ by weight (ad pensum). It has one league in length and 8 furlongs (quarentenas) in breadth and $7 d$. for the geld.' ${ }^{46}$ There are here two sets of measurements, and two valuations, and the connexion between the lineal measurements and the 'leet' system has long been a puzzle to students of Domesday. Three suggestions have been made : (I) The hypothesis, which Professor Maitland rejects, that these measurements represent geld carucates and that the carucates in the East Anglian formula represent the 'team-lands,' the 'potential arable.' (2) That the lineal measurements themselves represent the 'real' area or 'potential arable' and are the equivalent of the 'team-lands' of other counties.

(3) That they have no essential connexion with the geld, but are only one item in a cadastre of which the geld also forms a part, placed with it at the end of the 'villar' entry, and hence, when the cadastre was, so to speak, absorbed in a manorial terrier, clinging to the geld and repeated with it whenever it occurs. ${ }^{47}$ Professor Maitland inclines to think that the 'geld' represents the contribution fixed for the vill as a whole, while the statement of the number of carucates held by each tenant represents the apportionment of this sum among the various landholders in the vill, ${ }^{48}$ and the lineal measurements are a rough estimate of size, not intended for purposes of fiscal assessment. 'If the jurors had superficial measures in their heads,' he writes, ${ }^{49}$ ' and were stating this by reference to two straight lines, they would make the length of one of these lines a constant (e.g. one league or one furlong). This is not done.' And then he refers to Norfolk instances. The same argument applies to Suffolk, but here, as in Norfolk, ${ }^{50}$ there is a tendency to make I league a constant in the lineal measurements, and moreover, the same equation tends to recur, notably the equation of 6 carucates [ $I$ league $\times \frac{1}{9}$ league $=720$ acres] to a 20d. geld. Take for instance Lackford Hundred, a very perfect example in every respect. If its lineal measurements be reduced to superficial measurements, it contains 1262 carucates, and of the sixteen 'villar' measurements, thirteen have I 2 furlongs or I league as their line of length, one has 18 furlongs, or a league and a half, one has 6 furlongs or half a league, and one has Io furlongs. Of the lines of breadth, two are leagues, one is a league and a half, seven are half leagues, three are 8 furlongs, one is 5 furlongs, and two are 4 furlongs. The measurement $\mathrm{I}$ league $\times \frac{1}{2}$ league occurs seven times : six times in connexion with a $20 \mathrm{~d}$. geld, and once with a rod. geld. Possibly in the original scheme the leets, like the small 'Danish hundreds' of Lincolnshire, may have been 6-carucate or 12 -carucate units. ${ }^{51}$

"s Dom. Bk. and Beyond, 429, 431, n. I.

"Dom. Bk. and Beyond, 429-31.

${ }^{16}$ Dom. Bk. 2896.

"Ibid. 371.

${ }^{47}$ Cf. below p. 366 , Table II. ${ }^{s 0}$ Ibid. 432.

"Round, Feud. Engl. 72 et seq.; cf. 80,196 et seq. for the 'small local hundreds' of Leicestershire ; Roy. Hist. Sar. Trans. (new ser.), xiv, 213 ; Corbett, 'The Tribal Hidage.' Mr. Corbett suggests that the East Anglian leets may represent small ' early hundreds.' 'These 12 -carucate 'Danish hundreds' and the East Anglian leets may be based on the 'tenmanland' or 'tenmanlot' of 120 acres which occurs exceptionally in Norfolk; Vinogradoff, Engl. Sar. in the Eleventh Cent. 102-3, 280-1. 


\section{A HISTORY OF SUFFOLK}

In that case the lineal measurements may represent the 'communal' or 'villar' assessment of the geld, and the superficial measurement by carucates may be ' tenurial,' and may show the incidence of the geld on particular holdings and the share borne by the vills not directly included in the 'leet' assessment. ${ }^{52}$ But both systems are so confused and indeterminate that only a guess on the subject can be hazarded. A few instances, taken from different parts of the county, will illustrate the difficulty of fitting the Suffolk vills into neat groups of 5-hide or 6-carucate units, and of establishing an equation between the carucates and the geld pence, or between the superficial and lineal measurements :-

\section{HARTISMERE HUNDRED, NORTH}

(Total arable area, 91 carucates $12 \frac{3}{4}$ acres)

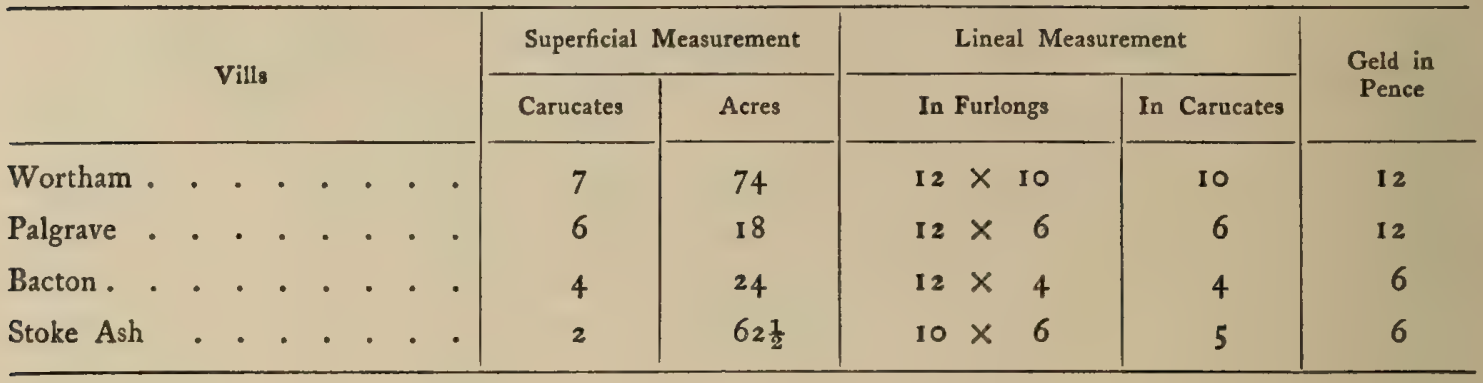

\section{LOES HUNDRED, CENTRE}

(Total arable area, 78 carucates $56 \frac{1}{2}$ acres)

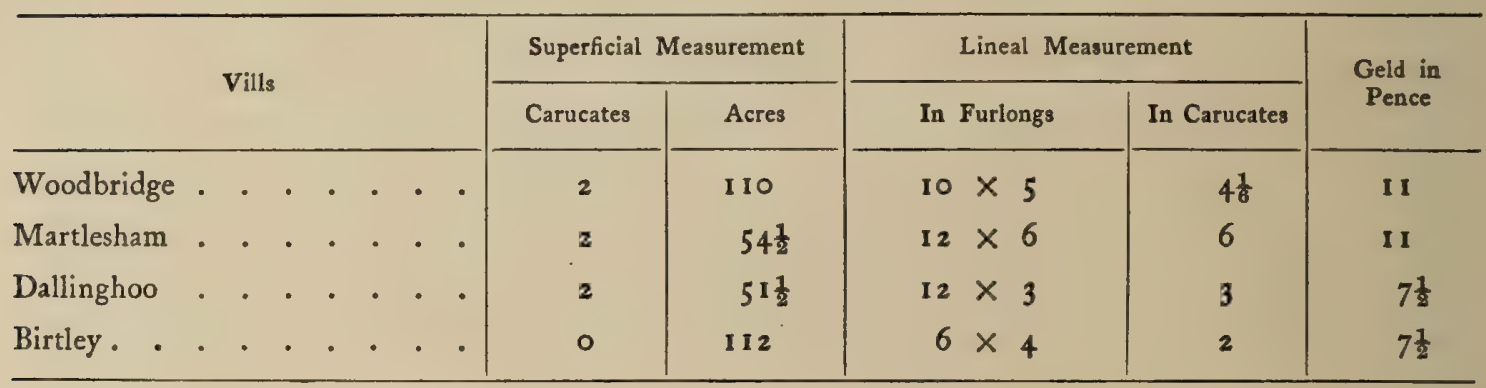

SAMFORD HUNDRED AND A HALF, SOUTH

(Total arable area, I66 carucates 9I acres)

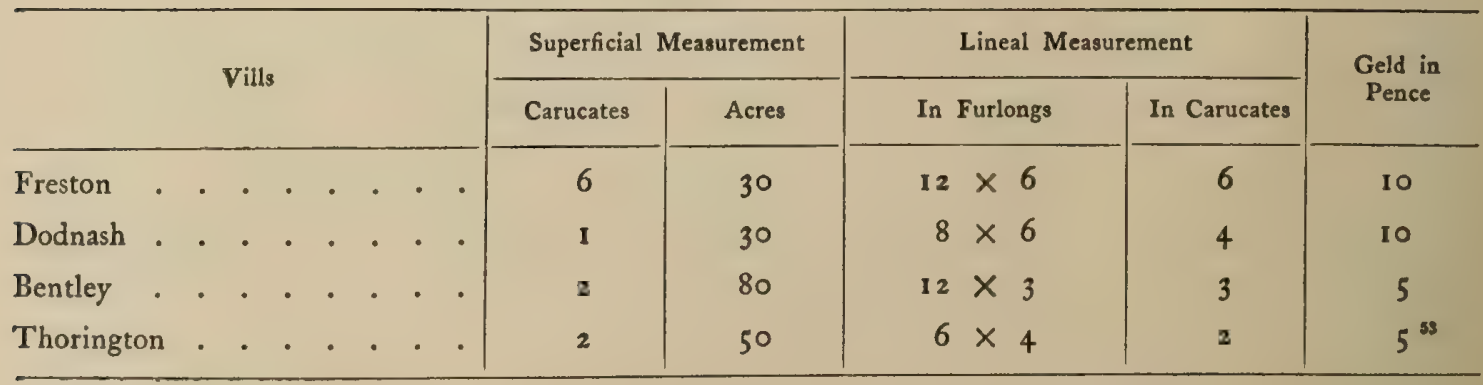

32 Professor Vinogradoff regards the measurements by carucates as ' remnants of older computations which had lost their value for some purposes,' and suggests that 'the carucate computation was kept up according to townships, while the estates were rated at so many pence in the pound ;' Engl. Soc. in the Eleventh Cent. 196-9, n. I ; cf. 145 .

${ }^{6}$ C. Table of Danegeld and Leet System for further instances ; cf. V.C.H. Norf. ii, 5-9, 204-I I. 


\section{DOMESDAY SURVEY}

Perhaps the very irregularity of these arrangements may be the result of a liberty that tended to licence. It is significant that in Suffolk the carucates break up, not into virgates or bovates, quarters and eighths, based on the plough-team, but into many small fractions, groups of acres, based on the individual freeholder. Suffolk does not know the virgatarius or the bovatarius, but it is the stronghold of the small liber bomo. ${ }^{54}$ The leet system was political and administrative rather than agrarian. The leets, as parts of the hundred, were concerned not only with taxation but with justice and police, and possibly also with military service. The $\mathrm{I} 2$ th-century survey of the abbey of St. Edmund, which gives the names of the Thingoe leets, ${ }^{55}$ connects them with 'suit (secta) of court,' and records of Sudbury that 'nullam sectam facit in hundreto, nec de aliquo reddet, nisi tamen coram justiciis errantibus, et tunc est coram illis pro quarta parte hundredi, scilicet pro tribus letis. Sunt enim in hundredo cum illa $\mathrm{I} 2$ lete. ${ }^{56}$ This jurisdictional function still survives in the court leet, which again connects with the police institution of frankpledge. ${ }^{57}$

One point, at least, seems to stand out clearly in the midst of much that is vague and uncertain. The vill or township, rather than the manor, appears as the original gelding unit. ${ }^{68}$ The 12 th-century survey notes that the leets are made up of vills : "In hundredo de Tinghowe sunt $\mathrm{xx}$ villae ex quibus constituuntur ix lete,' ${ }^{59}$ and the lineal measurements are frequently given for the whole vill, coupled with the geld. 'Canappetuna habet $\mathrm{v}$ quarentenas in longitudine et ii in latitudine et $6 \frac{1}{2} d$. de gelto.' 'Totum Brantham habet leugam in longo et dimidiam in lato $\&$ I $8 d$. de gelto.' ${ }^{60}$ In one case, even, the only mention of a vill, Chattisham (Cetessa), in Samford Hundred, is the entry of its lineal measurements and geld pence. No agrarian or 'tenurial' details are given. ${ }^{61}$ If the scattered fragments of the vills in the Domesday Survey be joined together, the geld assessment and the lineal measurements for the whole vill will be found attached sometimes to a manor, sometimes to a non-manorial estate, to the holding of a single tenant, or to the farm worked by a group of freemen. This diversity in the position of the geld entry, which is illustrated in the following table, may indicate that the vill was both measured and assessed as a whole, and that the responsibility for the geld lay on the township, not on individual landholders, or manorial lords, though the assessment is often connected with the largest holding in the vill. ${ }^{62}$

st Vinogradoff, Engl. Soc. in the Eleventh Cent. 36,196 et seq.

ss Above, p. 36 r. Gage, Suffolk, xii, et seq. From Liber de Consuetudinibus monasterii Sancti Edmundi.

${ }_{56}$ The curious position of Sudbury, as a quarter of the hundred, assessed at the heavy geld of $60 d$. will be discussed later. In connexion with the above passage from the Liber de Consuetudinibus cf. the famous jingle in the 'Becwoed,' or Saxon law formula, 'ne gyrne ic pines, ne labes ne landes, ne sace ne socne,' which seems to link the 'land or leet' with jurisdiction; Liebermann, Gez. der Angelsachsen; Glossary, 'lat' cf. Select Pleas in Manorial Courts (Selden Soc.), p. Ixxv. Prof. Maitland and Mr. Round quote Skeat to show that the Danish 'lregd' is a division for military conscription, and Mr. Round points out the analogy with the East Anglian leet, 'a division of the country for purposes of taxation'; Feud. Engl. I or.

${ }^{37}$ Vinogradoff, Engl. Soc. its the Eleventh Cent. 197, 214-17.

Gage, Suffolk, xii.

Dom. Bk. fol. 2876,303

s8 Ibid. 391 .

abid. $287^{\circ}$; 'Cetessa habet viii quarentenas in lon. et vi in lat. et $6 \frac{1}{3} d$. de $g$ (elto).'

* The substance of this and the preceding five paragraphs was originally read as a paper in Professor Vinogradoff's Seminar at Oxford. 


\section{A HISTORY OF SUFFOLK}

\section{TABLE II-VILLS AND MANORS}

BRAMFord. [Geld Assessment attached to Manor]

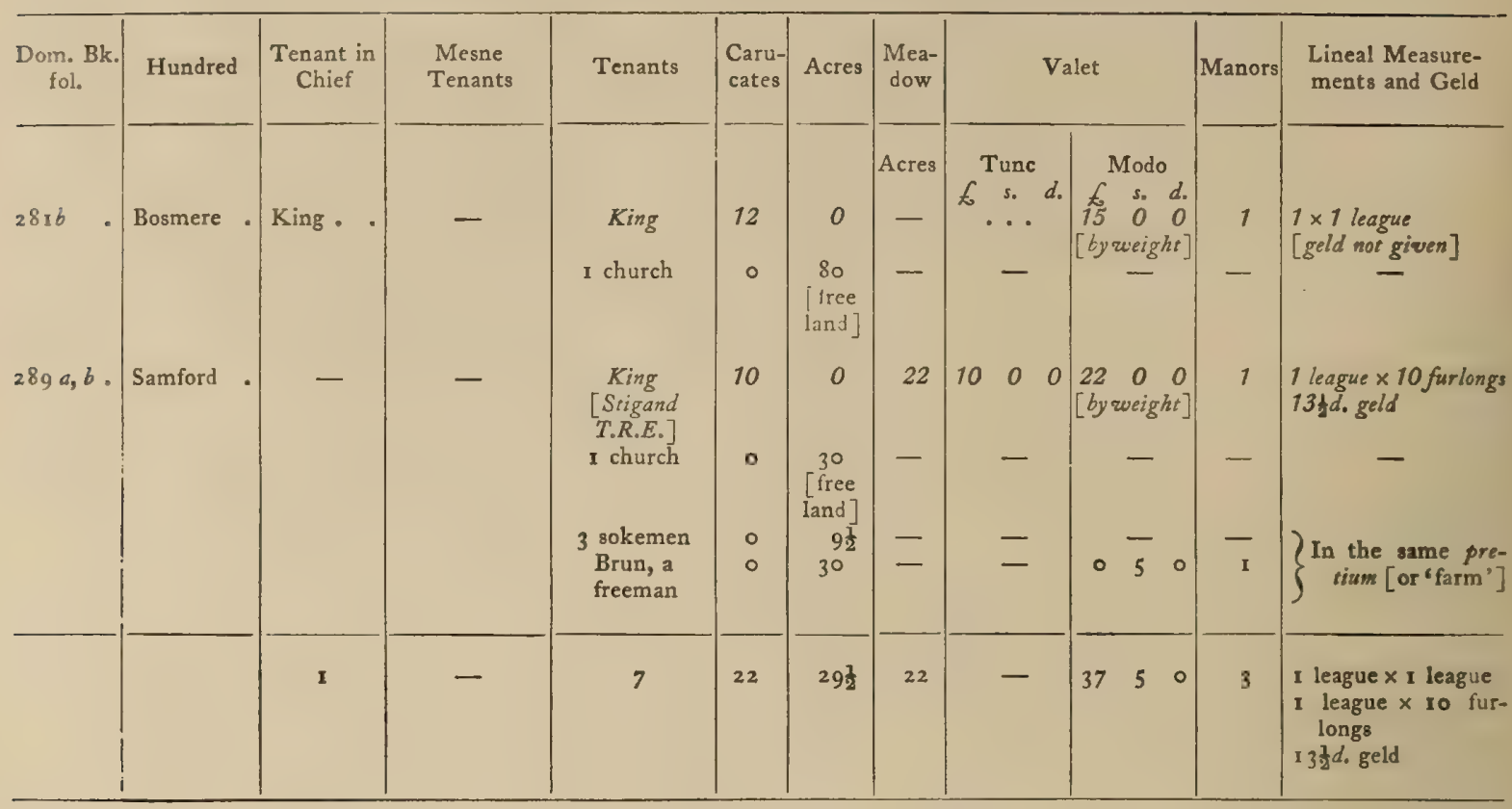

Benhall. [Geld Assessment attached to small non-manorial Holding]

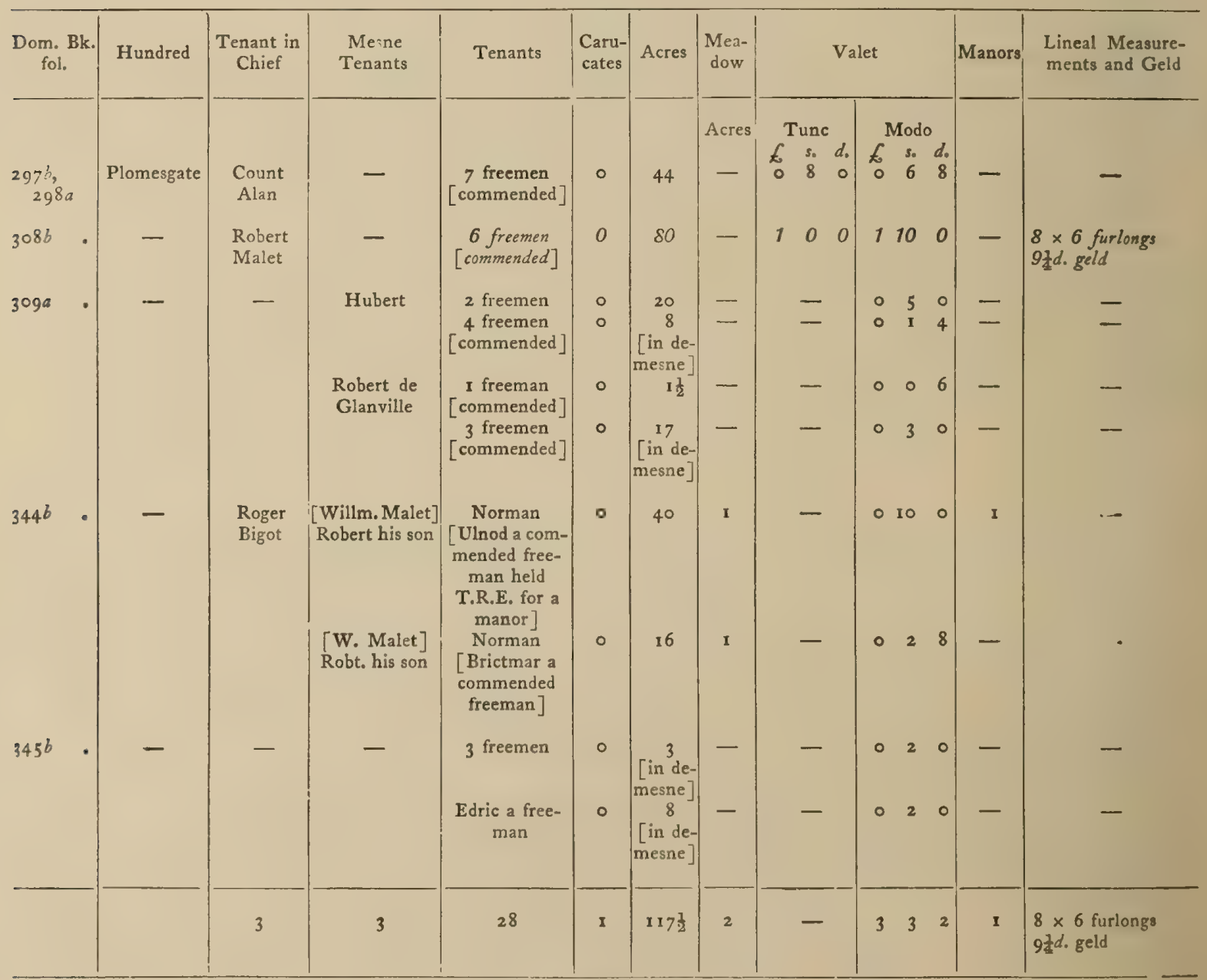




\section{DOMESDAY SURVEY}

\section{TABLE II-VILLS AND MANORS (continued)}

Ецмнам. [Vill containing many Manors]

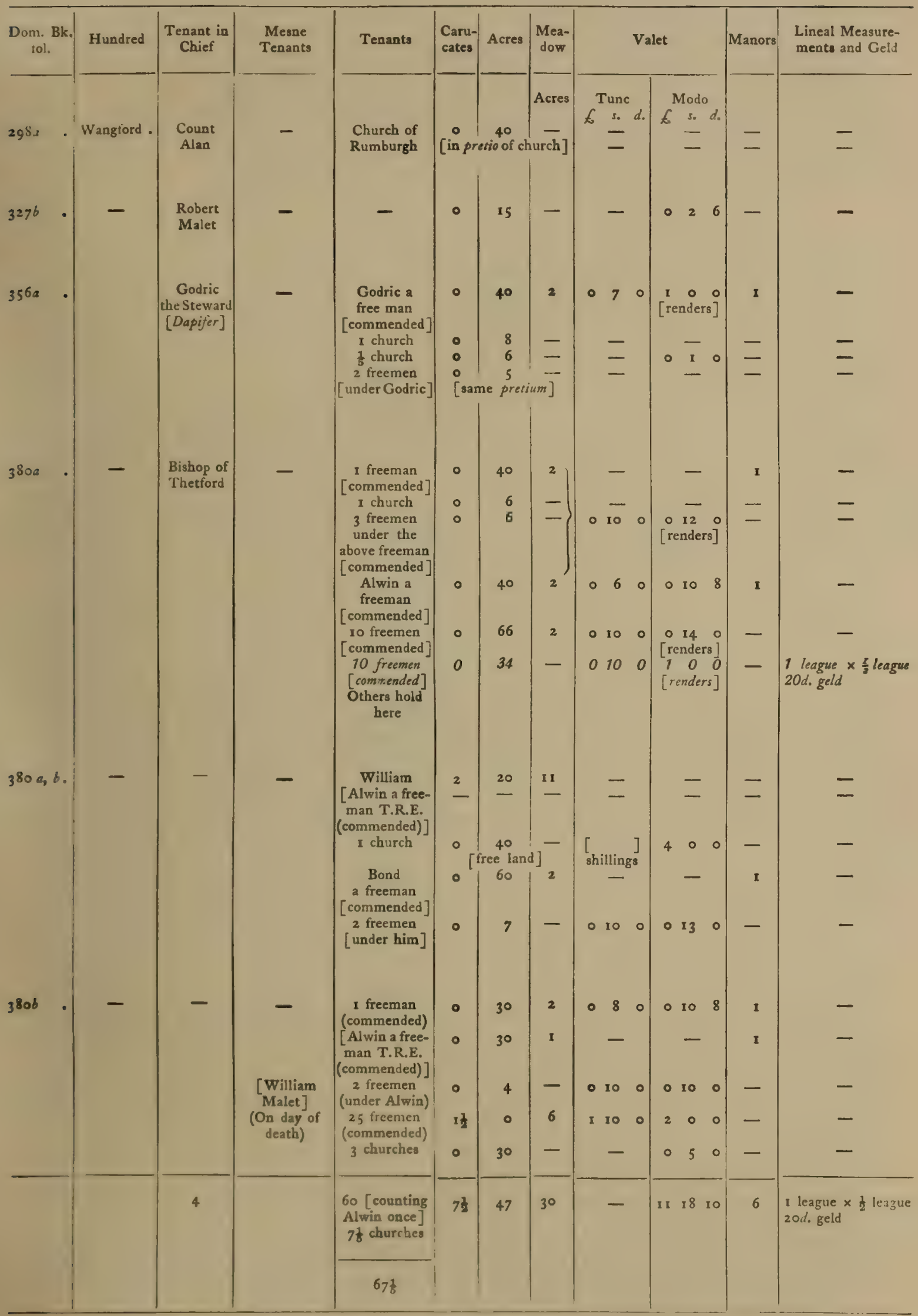




\section{A HISTORY OF SUFFOLK}

\section{TABLE II-VILLS AND MANORS (continued)}

WaDGate. [Vill containing no Manors]

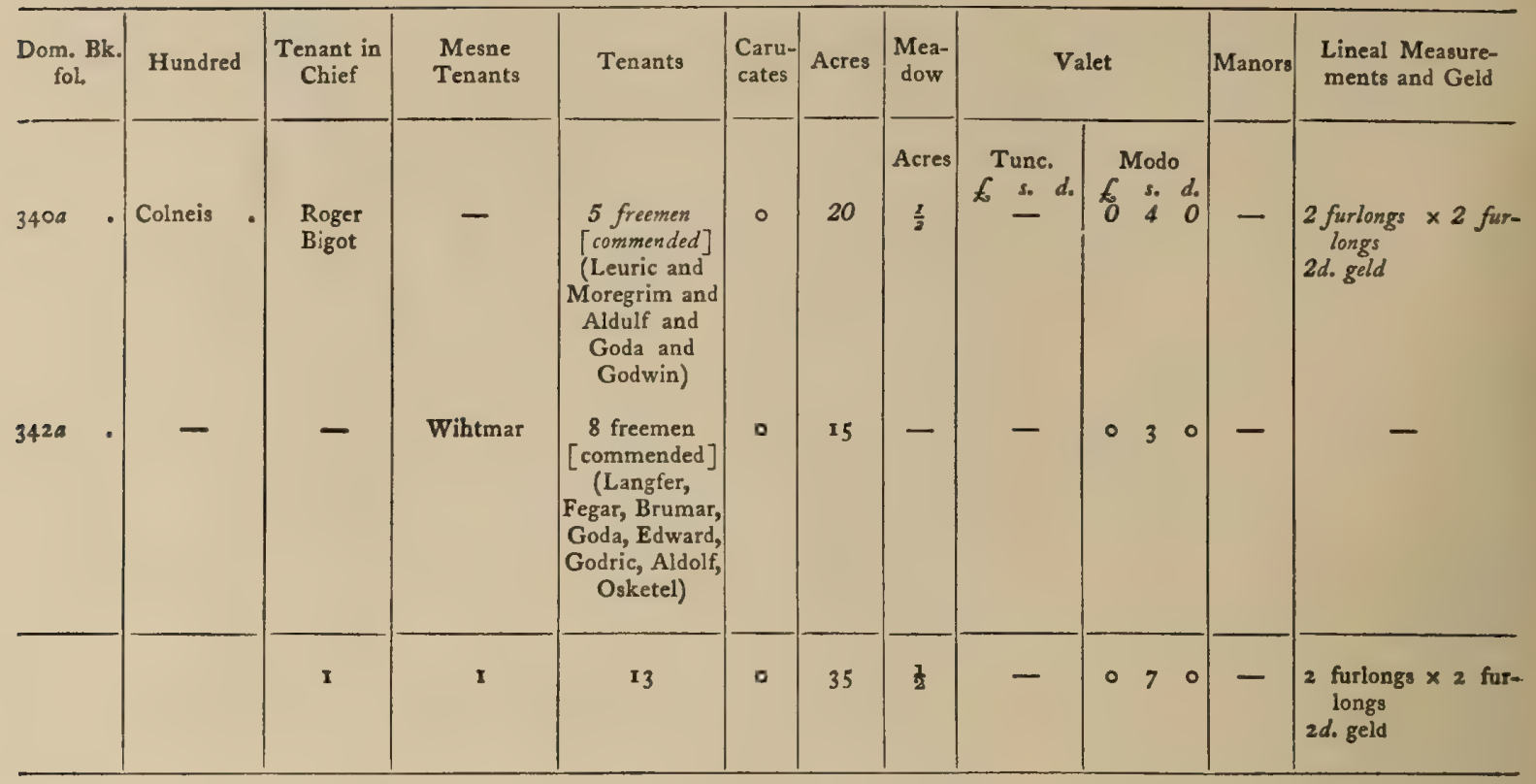

The phrase quicunque ibi teneat, which frequently follows the geld entry, seems to imply that the assessment is not regarded as 'tenurial' or manorial; it lies on the land as a public obligation, independent of accidents of changing tenure and special privileges. Still there was undoubtedly a tendency to shift public burdens on to the shoulders of the greater landholders, and possibly to make the lords of the manors responsible for the collection of the geld. Although in Suffolk, when the Domesday Survey was taken, the vill had by no means lost its importance as a fiscal unit, in a very large number of cases the geld and the manor were linked together. ${ }^{63}$ In one instance, where manor and vill coincide, the lineal measurements and geld are definitely related to the manor ${ }^{64}$ In another, at Thurlow, in Risbridge Hundred, both vill and manor are measured and assessed. ${ }^{65}$ It seems safe to conclude that in Suffolk, towards the close of the I Ith century, the manorial organization of the county was not fully consolidated, though it was fast consolidating, and that the political and administrative duties of the vill or township were being gradually transferred to the manor. Within the hundreds and leets two rival systems of local government were striving for the mastery, the 'communal' or 'villar' system, and the 'feudal' or 'manorial' system. The result was cross-division, inter-connexion, variety, and complexity, and final compromise. The 'manorial superstructure' rested on the foundation of the vill or township. ${ }^{66}$

Of the two systems, the older villar or 'communal' organization has left many traces. In the modern county of Suffolk there are 517 civil

${ }^{69}$ Vinogradoff, Engl. Soc, in the Eleventh Cent. 199-200, $211,218$.

${ }^{63}$ Dom. Bk. 304. 'Edwardestuna. Habet hoc manerium vi quarentenas in longo et vi in lato et de gelto Iod. quicunque ibi teneat.'

${ }^{65}$ Ibid. 286, 3716,397 . These entries show (1) the manor and 5 freemen valued separately, but measured and assessed as a whole; (2) 9 freemen valued separately; (3) 10 freemen and the church, valued together and foilowed by the measurements and assessment of the whole (tota); (4) 2 sokemen valued separately.

${ }^{66}$ Vinogradoff, op, cit. 390-402. 


\section{DOMESDAY SURVEY}

parishes, with parts of 7 others. In the Domesday Survey some 652 places, vills, hamlets, and small settlements are mentioned by names which are still, in the majority of cases, fairly easy to identify. Some point to early settlement. ${ }^{67}$ Hams, tuns, and balls are common; steads, wicks, worths, thorpes, tofts, and stows occur occasionally ; by only twice, at Wilby in the north and at Risby in the west of the county. Names derived from the natural features of the country are frequently found : fields, leys, dens, dons, and bolts, with the fords, meres, brooks, wells, and eys (islands), characteristic of a flat and marshy district. There are several instances of a cluster of two or more vills bearing the same name, which seem to indicate emigration, 'village colonization' and the throwing off of swarms from the parent stock. ${ }^{68}$

These vills varied greatly in size and character, from the single holding or the tiny group of two or three households to the large village numbering some hundreds of inhabitants. A good general idea of their relative importance and of the distribution of large and small settlements may be formed by classifying the free, sokeman, and villein holdings on the lines adopted by Professor Vinogradoff for the vills of Essex. ${ }^{69}$ Table III gives the summarized results of such a classification. It has seemed well to include freemen as well as sokemen and villeins in the enumeration, since in Suffolk the small freeholders played a most important part in the village economy. It will be seen that large settlements of over twelve households make up more than 50 per cent. of the whole number of households recorded; small settlements of from six to eleven households and hamlets of from two to five households are approximately equal in number, from i 6 to 19 per cent. of the whole, while the single holdings form about 7 per cent., and the vills without freemen, sokemen, or villeins, with those in which no population is recorded, about 3 per cent. of the total number tabulated. ${ }^{70}$ Suffolk, then, like Essex, appears as a land of large villages, and the areas of the largest settlements are in the north of the county, in Blackbourn, Bradmere, and Hartismere Hundreds, and in the central hundreds of Blything and Loes.

Side by side with the 'villar' system the ' manorial' or 'feudal' system was, even before the Norman Conquest, spreading through the county of Suffolk, and the manorial organization cut ruthlessly across the villar organization, as a Gothic arch might cut through a Norman arcade, obscuring but not altogether obliterating the original design. The mediaeval builders of fiefs and manors had as little regard for the work of their predecessors as the builders of churches and castles. Everywhere, in the Suffolk Survey, manors and their berewicks crowd the page, pre-Conquest manors and post-Conquest manors, tiny manors and enormous manors, humble peasant holdings and great aristocratic feudal estates. It is, however, the prevalence of small manors, maneriola, that specially characterizes Suffolk among English counties. Out of a total of 659 manors, 294, or nearly 45 per cent., are under I

- Cr. Round, Commune of Lond. : 'The Settlement of the South and East Saxons.'

* Thornham Magna and Thornham Parva in Hartismere Hundred. Whatfield and Other Whatfield (alia Watefelda) in Cosford Half-hundred. Fornham and Fornham St. Geneviève in Thingoe and Thedwastre Hundreds. Cf. 'Bura' (Bures St. Mary) in Suffolk and 'Bura' (Mount Bures) in Essex, on opposite sides of the River Stour, and the South Elmham and Ilketshall groups in Bishop's or Hoxne Hundred. South Elmham : All Saints, St. Nicholas, St. Michael, St. Peter, St. Margaret, St. Cross, St. James ; Ilketshall : St. Lawrence, St. Margaret, St. John, St. Andrew. Cf. Maitland, Dom. Bk. and Beyond, 14, 365, 367.

Vinogradoff, Engl. Sac. in Eleventh Cent. 264-73, App. v, vi.

Actually: $54^{\circ 7}$ per cent.; $19^{\circ} 1$ per cent. ; $16^{\circ} 1$ per cent. ; 6.9 per cent. ; 3 per cent. $=99^{\circ} 8$. 


\section{A HISTORY OF SUFFOLK}

carucate in size, and about the same proportion range from I to 5 carucates. Only 70 of the 659 manors are 5 carucates or more in area. The largest is an estate of 25 carucates 20 acres at Hundon, in Risbridge Hundred, held under King Edward by a certain Wisgar, afterwards forming part of the fief of Richard Fitz Gilbert. The smallest is a plot of I 2 acres at Sutton in Wilford Hundred, ${ }^{71}$ held, with a half freeman, half a bordar, half a ploughteam, and an acre of meadow, by Robert Malet, under the commendation of 'Saint Etheldreda.'

TABLE III-HOUSEHOLDS OF FREEMEN, SOKEMEN, AND VILLEINS

\begin{tabular}{|c|c|c|c|c|c|c|c|c|c|}
\hline \multicolumn{4}{|c|}{ Name of Hundred } & \multirow{3}{*}{$\begin{array}{c}\text { Over 12 } \\
\text { Households } \\
\text { II }\end{array}$} & \multirow{3}{*}{$\begin{array}{c}\begin{array}{c}6-11 \\
\text { Households }\end{array} \\
4\end{array}$} & \multirow{3}{*}{$\begin{array}{c}2-5 \\
\text { Households } \\
0\end{array}$} & \multirow{3}{*}{$\frac{\begin{array}{c}\text { Single } \\
\text { Households }\end{array}}{-1}$} & \multirow{3}{*}{$\left|\begin{array}{c}\text { Total Num- } \\
\text { ber of Vills }\end{array}\right|$} & \multirow{3}{*}{$\frac{-}{\left(\begin{array}{l}\text { (t without free, sokeman, or } \\
\text { villein housebolds) }\end{array}\right.}$} \\
\hline Northern & & IUNDR & REDS & & & & & & \\
\hline Lackford . & & $\cdot$ & · $\cdot$ & & & & & & \\
\hline $\left.\begin{array}{l}\text { Blackbourn } \\
\text { Bradmere }\end{array}\right\}$ & & $\cdot$ & $\cdot \cdot$ & 27 & 6 & I & I & 35 & \multirow{6}{*}{$\begin{array}{l}\text { (2 without recorded population) } \\
\text { (1 without recorded population) }\end{array}$} \\
\hline Hartismere & . & . & . & 29 & 4 & 2 & 4 & 41 & \\
\hline Bishop's . & & . & . & 16 & 6 & 4 & 0 & 27 & \\
\hline Wangford . & & . & . & 12 & 2 & 10 & $\circ$ & 24 & \\
\hline Lothing . & . & . & . . & 5 & 3 & 3 & I & I 2 & \\
\hline Lothingland & & . & · $\cdot$ & 4 & 6 & 4 & 3 & 17 & \\
\hline Central & & UNDRE & & & & & & & \multirow{9}{*}{ (I without recorded population) } \\
\hline Thingoe . & . & • & . . & 14 & 5 & o & $\circ$ & 19 & \\
\hline Thedwastre & . & - & . & 20 & 0 & $\circ$ & I & $2 I$ & \\
\hline Stow . & . & . & . . & 14 & o & $z$ & 1 & 18 & \\
\hline Bosmere & & . & . . & 16 & 5 & I I & $\circ$ & 32 & \\
\hline Claydon & . & . & . . & 15 & 2 & 4 & 4 & 25 & \\
\hline Loes : & & . & - . & 22 & 4 & I & I & 29 & \\
\hline Carlford & & . & . . & 18 & 8 & 8 & 2 & 39 & \\
\hline Ipswich . & & $\cdot$ & - . & $\begin{array}{c}\mathbf{I} \\
\text { (Ipswich) }\end{array}$ & $\begin{array}{c}\mathbf{I} \\
\text { (Stoke) }\end{array}$ & $\circ$ & $\circ$ & 2 & \\
\hline Parham . & & . & . . & 4 & 0 & I & I & 6 & \multirow{3}{*}{$\begin{array}{l}\text { (6 without free, sokeman, or } \\
\text { villein households) }\end{array}$} \\
\hline Plomesgate & & $\cdot$ & - . & 8 & 7 & 5 & 2 & 28 & \\
\hline Blything & 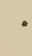 & . & - $\cdot$ & 27 & I 3 & 8 & 6 & 54 & \\
\hline Southern & & [UNDR & REDS & & & & & & \multirow{7}{*}{$\begin{array}{l}\text { (1 without free, sokeman, or } \\
\text { villein households) } \\
\text { (I without recorded population) } \\
\text { (3 without recorded population) }\end{array}$} \\
\hline Risbridge . & & $\cdot$ & $\cdot$. & 20 & 7 & 5 & 4 & 37 & \\
\hline Babergh & . & . & . & 19 & 7 & 8 & 3 & 38 & \\
\hline Samford & & . & . . & 15 & I I & I 2 & 4 & 45 & \\
\hline Cosford & & . & . . & 9 & 10 & I & 2 & 22 & \\
\hline Colneis. & & . & . . & I 3 & 9 & 8 & $\mathbf{I}$ & $3 I$ & \\
\hline Wilford & & $\cdot$ & . $\cdot$ & 18 & 5 & 7 & 3 & 33 & \\
\hline & & & & 357 & 125 & 105 & 45 & 652 & $\begin{array}{l}\text { (20 without free, sokeman, or } \\
\text { villein households, or with- } \\
\text { out recorded population) }\end{array}$ \\
\hline
\end{tabular}

As is seen by tabulating the results of a rough classification, manors of less than a carucate in extent are not found at all in the hundreds of Risbridge, Cosford, Thingoe, Thedwastre, Stow, Lackford, and Ipswich. They are rare in Babergh, Blackbourn, Bradmere, and Bishop's Hundreds, numerous in Claydon, Plomesgate, Hartismere, and Wangford Hundreds, and very

${ }^{71}$ Dom. Bk. 318, 387, entered under both R. Malet and St. Etheldreda. Inq. El. (Rec. Com.), 5266. But, as Professor Vinogradoff has reminded us, the acres in these cases are geld-acres, and probably correspond to larger areas; Engl. Soc. in Eleventh Cent. 337. 


\section{DOMESDAY SURVEY}

numerous in the hundreds of Samford, Bosmere, and Blything. Large manors of 5 carucates and more in area are also numerous in Babergh and Bishop's Hundreds, while in Risbridge Hundred they occur frequently, and are of exceptional size. Medium-sized manors, ranging from I to 5 carucates, are more evenly distributed throughout the county, but are specially common in the hundreds of Samford, Blything, and Babergh.

TABLE IV-DISTRIBUTION OF LARGE AND SMALL MANORS

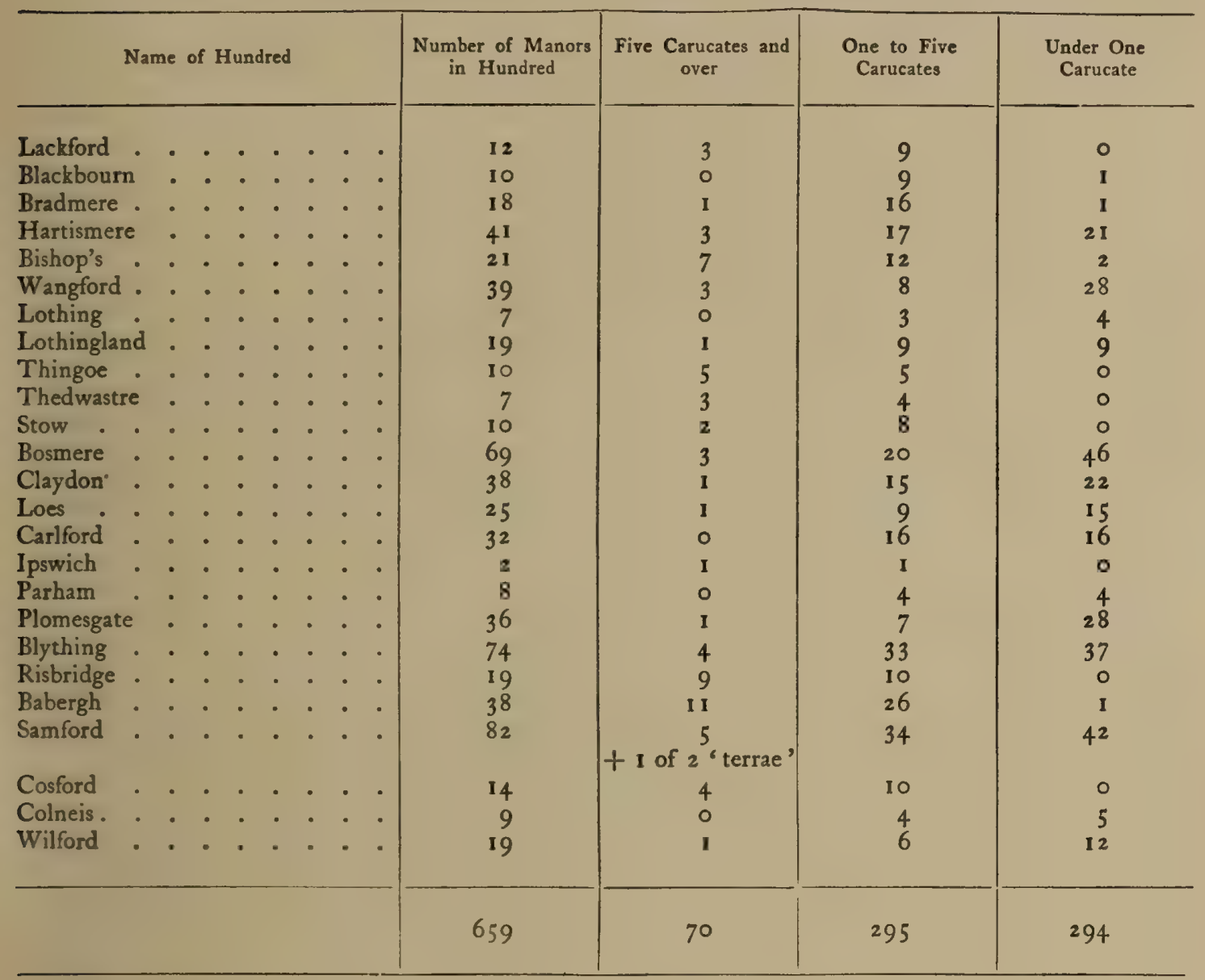

We would gladly know what was the precise territorial, economic, and administrative unit to which the compilers of Domesday Book applied the Norman term manerium, but the most patient investigation has hitherto failed to induce the Survey to yield up its secret. ${ }^{72}$ One thing, at least, is certain. Pre-Conquest England appeared to its Norman conquerors to be full of maneria, which could be distinguished from villae and terrae, and non-manorial holdings. In Suffolk, King Edward and his queen, the sons of Godwin, Archbishop Stigand, the great religious houses, the king's thegns, and many simple freemen, figure as lords of manors before the Conquest. In reality, these seem to have been rather ' manors in the making' than fully-developed manorial organizations, and we may conclude, with Professor Vinogradoff, ${ }^{73}$ that "the compilers of Domesday overstated their case when they currently

72 This paragraph and the next owe much to the suggestions and criticism of Prof. Vinogradoff.

$n$ Engl. Sor, in Eleoenth Cent. 339, 340. 


\section{A HISTORY OF SUFFOLK}

spoke of manors as they existed T.R.E.,' though it is probable that they did not use the term manerium at random, and that it carried with it some idea of lordship, of landlordship, and of political responsibility. The Suffolk manor of the Domesday Inquest is an economic unit, but an economic unit which forms a link in an administrative system, organized on an aristocratic basis. Sometimes, as Professor Vinogradoff has shown,${ }^{74}$ it is the economic unity on which stress is laid in the description of pre-Conquest estates, the manor appears primarily as an agrarian centre; or it is an administrative centre, or a jurisdictional and political centre, while at the two extremes of the manorial scale are the great royal manors, and the maneriola or small peasant holdings, which are called 'manors' in the returns. These small manors are sufficiently distinctive of East Anglia to be discussed somewhat more fully. Professor Maitland has asked what is the meaning of the "petty maneria' of Suffolk, and has answered that they are 'holdings which geld by themselves.' ${ }^{75}$ In that case, at Elmham, in Wangford Hundred, there would be six such holdings, six houses against which geld was charged, in a vill of about seventy free and fifty-three unfree ' recorded' inhabitants, with a 'recorded' area of 8 carucates I 5 acres, a valet of fio I $2 s$. Iod., and an assessment to the geld of $20 \mathrm{~d}$. in the pound. ${ }^{76}$ Or again, at Helmingham, in Claydon Hundred, where there were eight manors to a ' recorded' population of forty-one free and twenty-eight unfree persons in the days of King Edward, and a 'recorded' area of 6 carucates, I $3 \frac{I}{2}$ acres, there would be a tax-centre to every eight or nine householders. ${ }^{77}$ It seems more probable that the term manerium, when applied to these small holdings, is less narrowly technical than Professor Maitland would make it. ${ }^{78}$ The little manors of the Suffolk freemen and sokemen were often enough estates of 60 or 30 acres with no apparent division between demesne and tenant land, cultivated by one team or half a team, and by the labour of a bordar or two, or even, it may be, in some cases, by the 'lord of the manor' himself and his household. ${ }^{79}$ Thus at Raydon, on the land of the Bishop of Bayeux, in the south of the county, we have Edwi a freeman with a manor of I carucate in extent, one plough, 4 bordars, 5 acres of meadow and a mill, and in the same vill are two 30-acre manors, held by freemen, each with half a team, one bordar tenant, and 2 acres of meadow, and a 60-acre manor with one team and a bordar. ${ }^{80}$ At Tattingstone, in the same neighbourhood, no tenants at all are mentioned on the 60-acre manor of the freeman Turgot, which had been worked by a single plough before the Conquest, ${ }^{81}$ while at Thistleton, in Carlford Hundred, an instance occurs of a manor of 60 acres held by Ulmar, a freeman commended to the Abbot of Ely, with five freemen under him (sub se) and no servile or customary tenants. ${ }^{82}$ From the parallel passage in the Inquisitio

74. Cf. his classification of manors, op. cit. 311 et seq.

${ }^{75}$ Dom. Bk. and Beyond, 125.

${ }^{76}$ Dom. Bk. $3276,379,380$.

${ }^{77}$ Ibid. $352 b, 394 b, 423$.

${ }^{78}$ For a different theory of the meaning of the Suffolk 'maneria' cf. Ballard, The Dom. Ing. ;5, $135,136$.

79 Maitland, op. cit. I17-19; Vinogradoff, op. cit. 332-8.

${ }^{80}$ Dom. Bk. 378. 'Reindune ;' cf. 394b, 'Scoteleia' (Celeolt), 'Torp' (Osbern).

81 Ibid. $378 b$. 'Tatituna.'

${ }^{81}$ Ibid. 386 ; Maitland, op. cit. 119, n. 2 ; Ballard, op. cit. 136. Mr. Ballard explains this by interpreting 'sub se' as 'commended,' and concluding that the five freemen were not Ulmar's tenants. But the Survey specially records that two of them were commended to the 'antecessor' of Geoffrey de Mandeville. 


\section{DOMESDAY SURVEY}

Eliensis we learn that the five freemen held 20 acres. $^{83}$ In 1086 Ulmar with his estate and his freemen were held by Hervey of Bourges of the Abbot of Ely, while the small manors at Raydon and Tattingstone had passed into the hands of Roger Bigot, who held them of the Bishop of Bayeux. The process of the growth and development of manors from the days of King Edward to the days of King William can be traced with some minuteness in Little Domesday from the details of pre-Conquest society given in the returns for the three eastern counties. It is a process of aggregation, of the combination of many small units to form larger wholes, of absorption of insignificant holdings by important fiefs, of stir and movement, and varying fortunes and conditions. The changes effected in these conditions by the Norman Conquest, and, more particularly, the gradual absorption of the small estates by their larger neighbours, may be illustrated by the history of a few typical Suffolk manors, held by freemen in the days of King Edward. At Cransford, in Plomesgate Hundred, two freemen held small manors. One, Olf, had 30 acres and one plough-team ; the other, Cus, who was commended to Edric of Laxfield, had 90 acres, with nine bordars, two ploughs on the demesne and one plough belonging to the bordars, 4 acres of meadow and a few pigs, sheep, and goats. This manor came to Robert Malet, Edric of Laxfield's successor, who granted it to Walter his tenant, while Olf's little estate, with another small manor which he held at Chillesford (Cesefortda), passed into the demesne of Count Alan. ${ }^{84}$ A good example of a large manor held by a freeman before the Conquest is found at Bungay, in Wangford Hundred, ${ }^{85}$ where Aluric had a manor of 5 carucates with twenty-two villeins, twentytwo bordars, three serfs, two demesne ploughs, six villein ploughs, woodland, meadow, a mill, and stock. This manor was granted to Earl Hugh, and after the Conquest a certain William held it, and also two little 40-acre manors in the same vill, which two small freemen, Ulchetel and Somerlet, had held in the days of King Edward. Here three manors had been gathered up into one hand, and William had stepped into the shoes of three English or Danish pre-Conquest freemen.

Professor Vinogradoff has shown that in Norfolk there was, shortly before the Conquest, ' a policy tending to form estates called manors of the size of some 4 or 5 carucates.' 'A normal manor,' he tells us, 'in Norfolk, and perhaps in the east of England, ought,' according to this view, 'to consist of about 4 or 5 carucates, and to give roughly fio income.' 86 Although, in Suffolk and elsewhere, 'actual manors,' as Professor Vinogradoff notes, 'do not often conform to these averages,' there is certainly a tendency to combine many tiny manors in larger groups, and this is done in various ways, before and after the Conquest. In the first place, freemen could be ' added ' to manors, with their land. At Saxmundham, in Plomesgate Hundred, the king's thegn Algar held 2 carucates and 40 acres for a manor, and two berewicks in another hundred, one of 80 acres and one of 60 acres. Seven freemen with 48 acres, who had been commended to Algar, were afterwards added to this manor. This brought up the area of the manor

* Inq. El. (Rec. Com.), 527a. Dom. Bk. gives the stock on Ulmar's manor, and the value 'tunc' and

' modo.' 'The Inquisizio omits the stock, does not call the estate a manor, and only gives the present value.

* Dom. Bk. 2966, 297, 298. Olf, probably the same man, held a third manor at Bruisyard [Buresiart], which also fell to Count Alan.

Ibid. 300.

Engl. Sor, in the Eleventh Cent. 308-11. 


\section{A HISTORY OF SUFFOLK}

to 3 carucates and I08 acres, without counting 24 acres which were held by two churches. The value of the whole amounted to $£_{0} 7$ Ios., but the manor was farmed for $f_{0} 9$ ros. The aggregate, then, conforms very closely to what Professor Vinogradoff regards as the normal standard of the typical manor. Edric of Laxfield, again, held 40 acres as a manor in Parham Hundred at 'Brutge' valued at I 4s. $8 d$. Five freemen with 20 acres valued at $4 s$. were 'added by commendation' (additi commendatione), bringing the whole area up to half a carucate and the value to $18 s .8 d$. After the Conquest Waiter de Risboil held manor and freemen of Robert Malet. At Nettlestead, in Bosmere Hundred, Earl Ralph, before his forfeiture, added thirty-four freemen with $2 \frac{1}{2}$ carucates to a manor of 5 carucates. In this case the addition raised the value of the manor from $\oint_{0} 7$ Ios. to exactly $£_{0}{ }_{0} 0^{87}$

Sometimes the 'addition' of freemen seems to have been an act of pure aggression, as at Freckenham, where Earl Ralph added four freemen whom he appropriated, or 'invaded' (quos invasit), with 8 acres of land and half a plough team, to the large manor which had belonged to Orthi, Harold's thegn. ${ }^{88}$ Sometimes the processes of 'delivery' and 'addition' led to disputes, in which the hundred was called upon to decide the respective claims of rival land lords. ${ }^{89}$ Sometimes the men who had been 'commended' to the Norman lord's English antecessor appear to be 'added' to his manor as a matter of course. At Yoxford, in Blything Hundred, for instance, the thegn Norman had 100 acres for a manor and the commendation over five freemen with I 4 acres. His successor, Hugh de Corbun, who held under Roger Bigot, had the five freemen ' added' to his manor, and also two other freemen with 7 acres, possibly to bring the area of the manor up to a carucate. ${ }^{90}$ Once it is even stated that Roger Bigot received 40 acres of land and 5 acres of meadow at Buxhall, in Stow Hundred, ad perficiendum belham in alio bundreto. Turning to Beleham, or Baylham, in Bosmere Hundred, we find four small manors and thirty freemen holding $140 \frac{1}{2}$ acres, in all 4 carucates $20 \frac{1}{2}$ acres, worth I $37 \mathrm{~s}$. before the Conquest, I $42 \mathrm{~s}$. after it. The addition of the 40 acres at Buxhall, which after the Conquest were worth Ios., would just bring the arable area up to $4 \frac{1}{2}$ carucates (4 carucates $60 \frac{1}{2}$ acres), and raise the value to a little over $£ 7$ IOs. ( $£ 7$ I 2s.). Or, since one of the Baylham freemen 'lay' in Stonham, and was valued there, it may be that the Buxhall land was taken into the valuation of Baylham as compensation. Similarly, in Bures, in Babergh Hundred, before the Conquest Uluric son of Brictric held 2 carucates under King Edward, Tosti a freeman held I carucate under King Edward, and two freemen of Harold, who could sell their land, held 60 acres. After the Conquest the whole came into the hands of John Fitz Waleran, and Harold's two freemen were delivered ad perficiendum manerium. Their 60 acres would bring it up to exactly $3 \frac{1}{2}$ carucates, and would raise its value to $65^{\mathrm{s}} .^{91} \quad$ The king and the great Norman tenants in chief seem to have dealt very arbitrarily both with English 'manors' and English freemen,

${ }^{87}$ Dom. Bk. 338b, 306b, $294 b$.

${ }^{89} 38 \mathrm{r}$, cf. 449 ; Vinogradoff, op. cit. $425-8$; Below, p. 379 et seq.

90 Dom. Bk. 333 ; cf. 33 1, 33 I $b$. 'Blything. Hinetuna,' 50 acres added with freemen to a manor of 50 acres : value increased from 8 s. to $12 s$. ; 'Bringas,' 60 acres with freemen added to a manor of $\mathbf{I} \frac{1}{2}$ carucates ; 'Brantuna,' roo acres with freemen added to a manor of 2 carucates.

${ }^{81}$ Dom. Bk. $336 b, 337 b, 33^{8}, 435$ b. The hundred had seen 'neither writ nor livery' (' nec breve nec liberatorem '), conveying the 40 acres in Buxhall to Roger Bigot. On 'making up' ('perficiendum ') a manor, cf. Vinogradoff, op. cit. 309 et seq. 


\section{DOMESDAY SURVEY}

granting them out at will, moving freemen from one manorial jurisdiction to another, making new combinations or severing old connexions in wholesale fashion. 'Ralph the Staller,' Earl Ralph's father, joined Earl Gurth's estate in Bentley to the manor of Bergholt as a berewick. King William himself gave back three manors to Norman, their pre-Conquest lord, but granted away others; Phin, who held his honour under both King Edward and King William, added eight freemen and a sokeman to one of his small manors after the Conquest ; Geoffrey de Mandeville received 2 carucates as a manor ' by the King's gift' (ex dono Regis), which a freeman of the Abbot of Ely had held 'by mere commendation' (commendatione tantum) in the time of King Edward. At Buxhall twenty-five freemen who held $3 \frac{1}{2}$ carucates in the soke of the king (in soca regis) were 'delivered' (liberati) to Frodo, the brother of the Abbot, for a manor of $3 \frac{1}{2}$ carucates of land. At Brandeston, in Loes Hundred, William 'de Arcis' held one manor, where in King Edward's time there had been two, one of 60 acres, held by a married priest, the other of 80 acres, created by King Edward, and added to the smaller estate. ${ }^{92}$

It has seemed worth while to devote a considerable space to the manorial system in Suffolk, since the East Anglian manors are distinctive in character, and illustrate peculiarly well the social and economic changes which followed the Norman Conquest. ${ }^{93}$ The remaining divisions of the land, the terrae, berewicks, bonours, and sokes, may be more summarily dismissed. The term terra is used more vaguely and generally than manerium for a tract of land, which may or may not correspond to a manor. At Halesworth, in Blything Hundred, two manors and an estate of 60 acres held by four freemen are spoken of as tres terras; at Henstead, in the same district, a berewick of I carucate and 30 acres held by two freemen are called duas terras. In both these cases the freemen with their land had been 'added' to one of the manors.9. At Stutton, in Samford Hundred, where the king's thegn Fribern held two terrae for a manor before the Conquest, we are left to guess the size of the estates which were joined together to form a manor. At 'Wica,' in Bradmere Hundred, eight commended freemen with I carucate of land and eleven bordars were held de liberatione et pro terra. At Acton, in Babergh Hundred, Ralph Peverel received four freemen pro terra with 50 acres, and at Assington, also on the Peverel estates, a freeman was 'delivered' pro terra who did not belong to the manor. ${ }^{95}$ Of berewicks we hear more, and the term is used more definitely for an estate, often of considerable size, which, from the administrative point of view, is an outlying member of a manor. The berewick may lie in one hundred and the manor to which it belongs in another, as at Woolpit and at Fornham St. Genevieve, ${ }^{96}$ where two berewicks of St. Edmund's Abbey in Thedwastre Hundred 'belonged to halls' in another hundred. The most striking instance of a berewick lying far from its manor is Harold's holding of 5 carucates at Harkstead, near the estuary of the River Stour, which was a berewick (bervita) of his Io-hide manor of Brightlingsea (Brictesceseia), on the estuary of the River Colne, in Essex. Brightlingsea and Harkstead together rendered two nights' farm to the king, but

Dom. Bk. $287,338 b, 330 b, 331,393 b, 394,411,355 b, 431 b$.

" Cf. Vinogradoff, op. cit. 305-7 ; Dom. Bk. 299, 399b; cf. 400.

" Dom. Bk. 299, 3996.

Ibid. $411 b, 421,416 b$; 'Asetona, $i$ liber homo liberatus pro terra, sed non pertinet maneriu.'

Ibid. 362,3626 . 


\section{A HISTORY OF SUFFOLK}

Harkstead was separately assessed to the geld, on the East Anglian system. ${ }^{97}$ Similarly, 6o acres were held before the Conquest at Saxtead in Bishop's Hundred as a berewick of Framlingham in Loes Hundred, while Edric of Laxfield held 94 acres at Framlingham as a berewick of the neighbouring vill of Dennington (Dingivetuna). 'Kodenham,' or 'Kodeham' (Coddenham), a berewick of Cavendish, in Babergh Hundred, was, like Harkstead, assessed separately, while the berewick of Fenstead, in the same hundred, was included in the assessment of its manor, Houghton. ${ }^{98}$ A berewick might be larger and more populous than its manor, as at 'Coclesworda,' where a berewick of 8 carucates with a peasant population of thirty householders was attached to a manor of 6 carucates with twenty-six 'recorded' peasant occupiers. Berewicks had demesne and home farms, unfree tenants, meadow, woodland, and stock. They could be both valued and assessed independently of their manors, and sometimes their lineal measurements are given separately. ${ }^{99}$ They could even be held by separate lords, though of one manorial over-lord. Edric of Laxfield's manor of Hollesley, with the sokemen and freemen attached to it, came, after the Conquest, to Robert Malet; but its two berewicks, 'Culeslea' and Bawdsey, were held from Robert Malet, one by his mother and the other by Robert de Glanville. ${ }^{100}$ A berewick, like a manor, could be created out of another holding. Uthtret or Huhtradus, who held Houghton for a manor under Harold, and Fenstead 'for one carucate,' was succeeded by Ralph de Limesi, who held Fenstead 'for a berewick' (pro berewita) in Houghton. Ot Earl Gurth's two manors in Samford Hundred, Bentley was afterwards joined to the manor of Bergholt 'as a berewick' (pro bervita), and Shotley bore apparently much the same relation to the larger estate, a relation which in this case is primarily financial, for the two manors are said to be 'added to the farm' (que buic firme addita sunt) of Bergholt. They, in common with Shelley, the pre-Conquest berewick of Bergholt, are assessed separately to the geld. ${ }^{101}$

Of the honour, or great fief, the feudum, including many manors and smaller territorial units, several instances are found in the Suffolk Survey, notably the Saxon honour of Phin, the nucleus of the later honour of Clare. ${ }^{102}$ The early honours and 'fiefs' seem to have borne the personal names or titles of their original holders, the feudum Fedrici, the bonor fint (Phin), the feudum Pbin, the feudum Wisgari, the feudum Thederici or Tedrici (Theoderic, brotber of Walter the Deacon), the feudum Reginae, the feudum Episcopi de Tetfort, which seems to be distinguished from his terrae, though elsewhere terra and feudum appear as equivalent terms. Thus in Essex we hear of the feudum Baignardi, and in Suffolk of the Terrae Radulfi Baignardi; while the terrae of Frodo, the abbot's brother, and his feudum are apparently identical in the

${ }^{97}$ Dom. Bk. 2866 ; 6, (Essex) ; Maitland, Dom. Bk. and Beyond, 1 I 4, 333.

${ }^{88}$ Dom. Bk. 299, 325b, 428b; Vinogradoff, op. cit. 365-8.

99 Dom. Bk. $402 b, 403,288 b, 289$; Mildenhall, "Et supradicta berewita habet ii leu. et dim. in longo, et tantundem in lato, et de gelto xid. et $i$ ferdingum,' $317 b$.

${ }^{100}$ Ibid. $319 b$. Cf. ' Benga,' berewick of Staverton, $319 b$; Falkenham, berewick of Walton, $339 b$; Cavenham (Canavatham), 391 $b$; Farnham, $316 b$; Mendlesham, 285b; Lowestoft, Lund, Belton, Elga, $283 b$.

${ }^{101}$ Ibid. 428, 305, where Robert Malet's mother held a carucate of land at Debenham, in Claydon Hundred, which Britmar a freeman had held T.R.E. as a berewick of Kenton, in Loes Hundred; cf. 326 , 'Kenetuna'; $387 b$, Baldereseia berewita et enumerata.

${ }^{102}$ Vinogradoff op. cit. $34^{8}-50$. 


\section{DOMESDAY SURVEY}

record of his Suffolk estates. ${ }^{103}$ The honours with local names, Clare and Haughley and Eye, are of later growth. Lastly, the soke as a great territorial aggregate, comprising many scattered fragments, and uniting them all by the ties of jurisdiction and revenue, has a typical representative in Suffolk in the royal manor and soke of Bergholt. To this manor belonged the jurisdiction over the whole hundred and a half of Samford, and "with that which belonged to it, and with the soke of the hundred and a half, it rendered in the time of King Edward twenty-four pounds.' ${ }^{104}$

There were various forces working for the feudalization and manorialization of I Ith-century Suffolk. The three bonds, personal, tenurial, and jurisdictional, which held society together in feudal days, commendation, tenure, and soke, were all present in varying combinations. East Anglia, indeed, with its numerous commended freemen, offers a specially fruitful field for the study of commendation, the personal tie between lord and man. ${ }^{105}$ The Survey records of many, though by no means of all of the Suffolk freemen, half-freemen, and sokemen, that they are 'under' a lord 'by commendation,' or 'commended to' a lord, or that a lord 'has their commendation' (de quo or ex quo babet commendationem). Sometimes the lord had 'only the commendation,' or 'mere commendation,' and this was the slightest tie between lord and man. ${ }^{106}$ More frequently the same lord had soke as well as commendation, or customs (consuetudines) and service (servitium) were combined with commendation and soke. ${ }^{107} \mathrm{~A}$ man might be commended to more than one lord, ${ }^{108}$ or one lord might have the commendation and another the soke. ${ }^{109}$ Commendation over men came to be regarded as a kind of property, which could be inherited, alienated, and divided. Hence it was possible for Alwin the priest to be commended to one lord for a sixth of his commendation, and to another for the remaining five-sixths. ${ }^{110}$ At Wyverstone, in the hundred of Hartismere, three brothers and their mother held 30 acres for a manor. One brother, Aluric, was commended to the antecessor of Robert Malet for one-sixth of his holding, and to the antecessor of Robert Blund for five-sixths. ${ }^{111}$ Ulsin (Wlsin), the antecessor of Roger Bigot, had one-third of the commendation of the freeman Godric, and Ulsin's two brothers had the other two-thirds. ${ }^{112}$ In this last instance Professor Maitland sees a case of descent to three co-heirs. ${ }^{113}$ At Cotton, again, on the king's land, the Abbot of St. Edmunds had half the commendation, ${ }^{114}$ and at

100 Dom. Bk. 3986, 393b, 'de honore fint (Phin)' ; 394, 'ad feudum phin'; 393b, 'Wisgar'; 426b, 427, 'Thedericus,' 'Teodericus'; $310 b, 321$, 'Regina'; $379 b$, Bishop of Thetford; $55 b$, Essex, Baignard ; 41 $3 b$, R. Baignard ; 3546 , 'Terre Frodonis '; 355 , 'Frodo reclamat ad feudum suum '; 41 , ' feudum Ansgari'; 447 , Isteda.

${ }^{104}$ Ibid. 2876 et seq. ; Vinogradoff, op. cit. 379-80, 128 et seq., 320-3; Maitland, Dom. Bk. and Beyond, 90.

Ie Vinogradoff, op. cit. 348.

${ }^{106}$ Dom. Bk. 429; 'Qui fuit sub antecessore Roberti Malet commendatione tantum,' 432b, Cratinga.

107 Ibid. 356b, Risby, 'Super hos homines habuit Sanctus Edmundus sacam et socam et commendationem et omnem consuetudinem. Nec poterant dare et vendere terram sine concessu Abbatis' ; ibid. Huepestede [Whepstead], 'Hi poterant dare et vendere terram. Sed saca et soca commendatio remauebant sancto et servitium.'

${ }^{103}$ Ibid. $380 b, 381$, Barsham. Ten freemen : Aluric and Gurth had the commendation of eight and 2 half, Bishop Ethelmxer of the remainder ; cf. 3226 , Cotton.

in Ibid. 398, 'Helvedana' [Elveden]. A freeman, of whom St. Etheldreda has the commendation and St. Edmund the soke.

Inid. 3766 .

is Dom. Bk. and Beyond, 74.

"1) Ibid 309.

113 Ibid. 3336 .

11 Dom. Bk. 285 . 


\section{A HISTORY OF SUFFOLK}

Wyverstone he had three-quarters of the commendation of a freeman. ${ }^{115}$ There was sub-commendation, too, whereby a commended man could in turn have others commended to him, and a sort of feudal chain could be formed, with personal rather than tenurial links. Thus Edric held of Robert Malet two freemen who had been commended to Robert's antecessor, Edric of Laxfield, ${ }^{116}$ and a freeman was commended to one who was himself commended to Edric of Laxfield. ${ }^{117}$ But though the bond created by commendation was essentially personal, it constantly, perhaps usually, involved a tenurial relation. If the commended man were the lord's bomo ${ }^{118}$ he was also often his tenant. Here, too, the tie might be loose or close. It is carefully put on record that a man is or is not free to give or sell his land. The phrases, 'poterant dare et vendere terram,' ' non poterant dare et vendere terram sine licencia,' recur frequently, especially in connexion with the great religious houses. Sometimes freemen could give and sell their land, but the sac and soke and commendation remained to the former lord, with service and custom. There was a change of occupiers, but no change in the conditions of occupation. Of three freemen at Saxham, in Thingoe Hundred, two could give and sell, and the third had to obtain leave from the Abbot of St. Edmunds. Two of St. Edmund's sokemen at Long Melford could only give and sell with the full consent (pleno concessu) of the abbot. At Bradfield, in Thedwastre Hundred, there were freemen who could give and sell, but the soke and the service remained to the Saint, whoever should buy the land. ${ }^{119}$

At Whatfield, in Cosford Half-hundred, Roger Bigot had become the overlord of a freeman over whom in King Edward's day St. Edmund had commendation and the whole soke (totam socam). At Herringswell, in Lackford Hundred, a sokeman had half his land, with the soke, under Wisgar, and the other half, with the soke, under St. Edmund. In one case a man and his wife were free to give and sell their lands, but the sake and soke and commendation over the woman remained to St. Edmund; in another, the hundred was called on to bear witness that one of ten freemen could only give and sell his land with the full consent (pleno consensu) of the Abbot of St. Edmunds, while the other nine could give and sell at will. ${ }^{120}$

After the Norman Conquest all land in Suffolk was held by strict feudal tenure, by derivation from (de) a lord. The older, less stringent relation, the method of holding under $(s u b)$ a lord, and the old freedom in the choice of lords and the alienation of land, gradually became things of the past. ${ }^{121}$ Here,

115 Dom. Bk. $321 b$.

${ }^{116}$ Ibid. 3 I $3 b$; Dom. Bk. and Beyond, 74 ; cf. Dom. Bk. $305 b$, 'Winestuna : Duo liberi homines commendati cuidam commendato Edrici.'

${ }^{117}$ Ibid. $346 b$; cf. $309 b$, "Wivertestuna' : A man half commended to the abbot and half sub-commended to R. Malet's 'antecessor'; A free woman sub-commended ('sub-commendata') to R. Malet's 'antecessor'; 320b, Thornham Parva ; 376, Helmingham ; 377, Winston.

${ }^{118}$ Ibid. $342 b$; "In Kirketuna, i liber homo Godricus presbyter commendatus Edrici tempore regis Edwardi antequam se utlagavit et postquam se utlagavit fuit homo Normanni.' et seq.

${ }^{119}$ lbid. 3566 et seq. St. Edmund ; ibid. 359, 362; Maitland, Dom. Bk. and Beyond, 46 et seq., 66

${ }_{120}$ Dom. Bk. 330b, 392, 363b, Liuermera ; 368 , Bedingefelda.

121 Maitland, Dom. Bk. and Beyond, 46 ; Pollock and Maitland, Hist. of Engl. Law, i, 210 et seq ; Vinogradoff, op. cit. 219 et seq. ; cf. Dom. Bk. 333, 'Sub eo tenuit i libera femina '; 428,4286 , 'Hoketona ten[uit] Huthtradus sub Heroldo T.R.E. . . Kanavadisc ten[uit] Normannus cum soca et saca sub rege E.

Neuuetona ten[uit] idem Uthret sub Heroldo' But cf. $41 \mathbf{I} b$, W. de Boevilla holds sub G. de Mandeville. 


\section{DOMESDAY SURVEY}

as throughout England, the theory was that the land had, on one pretext or another, fallen into the Conqueror's hands, and had by him been granted out afresh, it might be to the previous holders, it might be to new tenants. An agreement is even dated from the time 'when the English redeemed their lands,' ${ }^{188}$ and King William is said to have 'restored ' (reddidit) three manors to their pre-Conquest lord. ${ }^{123}$ Royal grant was thus the chief title to land after I066, but the king's confirmation of possession might be conveyed in various ways, by gift, by 'writ and seal,' or by 'livery and seisin.' A dispute arose over an estate at 'Wineberga' in Bishop's Hundred, which Roger Bigot claimed by the king's gift (boc reclamat de dono regis), but the Abbot of Ely questioned his right, and apparently the affair was compromised by Roger consenting to hold of the abbot, 'by respite' (per respectum). ${ }^{124}$ The outward sign of the gift might be a royal writ (breve) under the king's seal, a charter, or the record of a formal act of 'livery and seisin.' The writ occurs less often in Suffolk than livery, but it is found sufficiently often to prove that by it rights could be given over land, men, and soke. Roger Bigot had received a freeman with a small estate, but the hundred had seen neither writ nor 'liberator,' and evidently doubted the validity of the transfer. The Abbot of St. Edmunds had sac and soke and commendation in the days of King Edward over a number of freemen in the hundred of Stow, as writs and seal (brevia et sigillum) showed. King William had recognized the gift (Postea concessit Willelmus Rex). But the king's reeve had received payment for the soke of one of these men, and the case came up before the hundred, which testified that it did not know if St. Edmund had been disseised after King Edward's grant. In this interesting case King Edward's writ had been confirmed by King William ; but elsewhere we find the hundred testifying that Abbot Baldwin of St. Edmunds had a writ of King Edward giving him sac and soke over the Saint's lands and men, and this right he apparently claimed as still valid in 1086, without further confirmation. At Poslingford, too, on Ralph Baynard's fee, St. Edmund had the commendation of a freeman in King Edward's time, and 'the king granted him the land,' and the hundred-jurors had seen the writ. At Clare, on the contrary, King William is seen disregarding the grants of his predecessors. Aluric son of Wisgar had given this important manor to St. John, and had committed it by charter (carta) to the guardianship of Levestan the abbot and of his own son Wisgar, with the provision that the clerks should not give or forfeit it away from St. John. But after King William came he took it into his own hands, and at the time of the Survey it was held by Richard Fitz Gilbert. ${ }^{125}$ A writ could be issued to the sheriff to order him

12 Dom. Bk. 360b, 'Hanc terram habuit Abbas in vadimonio... concessu Engelrici quando redimebant anglici terras suas.' The word 'redimere' in itself implies forfeiture; cf. Inquisitio Eliensis (Rec. Com.), 520 ; four freemen forfeited ('foris fecerunt') their land to the abbot ; later the hundred did not see that they redeemed it (' postea non vidit hundredus ut eam redimerent').

12 Dom. Bk. 3386, Saxmondeham. Cf. Vinogradoff, op. cit. $219-20$; Ballard, op. cit. 5 ; Freeman, Norman Conquest, iv, 723 ; Angl.-Sax. Chron. sub anno 1066 ; And menn guldon him [King William] gyld, and gislas sealdon, and syrran heora land bohtan.'

12 Inq. El. (Rec. Com.), 523b, 524, 'Et modo Rogerus bigot tenet per respectum de Abbate'; Dom. Bk. $3^{8} 5_{b}$; cf. ibid. Saham [Soham] : R. Malet held of the king a freeman with I carucate; the Abbot claimed and Robert now held of him ; ibid. 411 : G. de Mandeville holds a manor 'ex dono regis'; ibid. 447 : Juchel or Juichell the priest 'reclamat de dono regis.'

12. Dom. Bt. 376. $3606,379,4136$, 'Rex concessit ei terram : ex hoc vidimus brevem'; 3896 . 


\section{A HISTORY OF SUFFOLK}

to put a lord in seisin of lands and men, ${ }^{126}$ and such a writ, or a public act of ' delivery' or 'livery' would be accepted as evidence of title in a court of law. Roger de Candos held a carucate of land from Hugh de Montfort at Thorney, which in the time of King Edward had formed part of the royal manor (fuit de dominio manerio soca regis). The 'hundred' had 'heard tell ' that Ralph the Staller had held this plot in pledge or mortgage (in vadimonio) from the sheriff Toli, but they had not seen the writs or the 'liberator' (sed non viderunt breves neque liberatorem). Ralph the Staller, however, had held on the day of King Edward's death, and after him Ralph his son. This evidence does not appear to have been sufficient to invalidate Hugh de Montfort's title, as the carucate in question is entered among his lands in Domesday Book. ${ }^{127}$ The actual 'delivery' of lands or men, the liberatio or deliberatio, whereby seisin was given, was, of course, constantly appealed to as evidence of title, and the 'liberator' could be called upon to 'warrant' a transfer. A dispute arose in the borough of Ipswich over the church of St. Lawrence, which Turchil and Edric held, with I 2 acres, apparently as the successors of a freewoman of the days of King Edward. Count Alan claimed this church as belonging to the fee of Earl Ralph, and called in Ivo Tailebosc as his liberator (revocat Ivonem Tailebosc ad liberatorem). But Turchil and Edric vouched Roger the sheriff to warranty (revocant Rogerum vicecomitem ad garant'), saying that they had the church from him, and 'Roger was to them such a warrantor as any sheriff might justly be for the time of King Edward.' 128 Again, Roger de Ramis claimed the land and freemen of Wicolf, Roger Bigot's antecessor, at Coddenham and Hemingstone, in Bosmere Hundred, for he said that they had been delivered to him before Roger Bigot. The jurors of the hundred could not give a verdict, because the tenant, Warenger, held of both lords. But Warenger himself claimed to belong to Bigot's fee (revocat ad feudum Rogeri Bigot). Roger de Ramis denied this 'by all kinds of law' (boc contradicit omnibus legibus). ${ }^{129}$ Of the issue of this plea we are left in doubt; but in another case, where Roger de Ramis claimed 'by first livery' a freeman with his land whom Roger of Poitou held, the hundred gave judgement in his favour, because the livery had been made to him first (et bundretus testatur quod sibi prius liberatum fuit.) ${ }^{130}$ At Chilton and at 'Torstuna,' in Stow Hundred, Hugh de Montfort held in demesne, 'by livery, as he says,' sixteen sokemen with a carucate of land and seven bordars, but here the hundred testified that these men had belonged 'with all custom' to King Edward's manor of Thorney. ${ }^{131}$ Elsewhere the hundred was called on to witness that land was held without livery ; in these cases the tenant generally fell back on a second kind of title, the claim to succeed to all the rights of the previous holder, or antecessor, a claim which might even be pleaded against

${ }^{196}$ Dom. Bk. 377 ; 'Et Normannus dicit quod rex misit ei unum brevem ut saisiret Radulfum de Savigni ex omnibus liberis hominibus ex quibus Hubertus de portu saisierat episcopum ' (i.e. the Bishop of Bayeux) ; Vinogradoff, op. cit. 220-3, 427-8; Prof. Vinogradoff cites the cases of the Abbot of St. Edmunds, Dom. Bk. $360 b$, and of Norman and R. de Savigny.

${ }^{187}$ Dom. Bk. $409 b$. On the power of the Domesday Commissioners to settle questions of title, cf. Vinogradoff, op. cit. 228 and n. I ; Round, Dom. Studies, ii, 541 .

${ }^{198}$ Dom. Bk. 290b. ' Rogerus est illis talis guarant qualis aliquis vicecomes esset juste T.R.E.'

129 Ibid. 3386 ; Vinogradoff, op. cit. 233-4.

${ }^{130}$ Dom. Bk. 352 ; cf. ibid. $355^{6}$; 'Bakessalla': freemen and land 'liberati' to Frodo for a manor; 374 , 'Cratinga ': freemen liberati' with a manor ; $438 b$, 'Horan': 'quos reclamat de liberatione.'

${ }^{131}$ Ibid. 4096 . 


\section{DOMESDAY SURVEY}

a royal gift or grant. Hugh de Montfort, whose path of aggression seems to have been beset with difficulties, met the witness of the hundred by calling on his own men to prove his title. ${ }^{138}$ So, too, Walter the Deacon held land in Stow Hundred which his antecessor, his brother Theoderic, had ' without a liberator' (sine liberatore). ${ }^{138}$ Delivery to an antecessor is recorded in Thedwastre Hundred, where Robert of Mortain had succeeded to the estates of Count Brien of Brittany. ${ }^{154}$

At Combs (Cambas), in Stow Hundred, also in the Mortain fief, Hugh de Montfort claimed livery of half a mill, as belonging to his antecessor's fee, (reclamat liberatorem ad feudum antecessoris), but the hundred disallowed the claim. ${ }^{135}$ In a similar dispute over a freeman in the same vill, where Frodo had been in seisin and claimed by right of livery, the hundred knew nothing of the matter. In Blything Hundred, also, Robert Malet is found claiming land because the tenant Aluric had been the man (bomo) of Edric of Laxfield, the antecessor of Robert's father, William Malet. ${ }^{136}$ In cases of 'invasion' or encroachment upon rights of possession or property, the antecessor's seisin could be pleaded as conferring a legal title. In Babergh Hundred, where Roger de Orbec held land which he had 'invaded' or seized under (sub) Richard Fitz Gilbert, Richard's men 'vouched to the fee' (revocant ad feudum) of Richard's antecessor Wisgar, though apparently the land in question had never belonged to his estates. ${ }^{137}$

Recognition of a lord as a means of proving title ${ }^{188}$ is only twice mentioned in the Suffolk Survey. At Lakenheath and at Brandon, in Lackford Hundred, six sokemen had been 'delivered ' (liberati) to 'Lisia,' the antecessor of Eudo 'Dapifer,' for 2 carucates of land. Lisia afterwards ' recognized' St. Etheldreda. Although in 1086 these six men were held, with soke and sac, land and ploughs and bordars, by Eudo Dapifer, the Inquisitio Eliensis records the claim of the abbey, based on Lisia's 'recognition' (post recognovit Lysia de Sancta ßEdeldreda), and adds regretfully, for the estate had risen in value from 30s. to 70 s., 'but now Eudo the Steward holds.' 139 At Thorpe, too, in Bradmere Hundred, among the liberi bomines ' in the king's hand,' one freeman with 36 acres was held by Robert Blund, who supposed that he belonged to the fief of St. Edmund, as he himself asserted. The Abbot, however, would not be his 'warrantor' (ex boc non est sibi warant). Now at length Robert 'recognized' that he was not of the Abbot's fee, and gave him into the king's hand (dimisit eum in manu regis). ${ }^{140}$

Land might, further, be acquired by exchange or by purchase, and it could be held on lease, or under the terms of a specific agreement. In Suffolk, as in Norfolk, we hear of the 'Lewes Exchange,' by which William

132 Dom. Bk. 4076. The hundred witnessed that Walter de Doai (Douai) was seised on the day of his forfeiture, then Hugh the Earl, and that Hugh de Montfort now held, but not 'per liberationem.' The 'homines Hugonis de mut.' (Monteforti) say that W(alter) held of Hugh (de Montfort). The forfeiture, therefore, of Walter would not have affected de Montfort's seisin ; cf. Vinogradoff, op. cit. 220,223 , et seq.

130 Dom. Bk. 427 .

13 Ibid. 291, 2916. "Hoc totum fuit liberatum comiti Brieno antec. Rotberti com. pro ii. car. et xl. ac. terrae." Freeman, Norm. Conq. iv, 243, n. 3 .

is Dom. Bk. 291. 'Teste bundreto nunquam pertinuit.'

m Ibid. 29I. 'Sed hundredus nescit。'

is Vinugradoff, op. cit. $242-4$; Dom. Bk. ii, 1766 .

120 Dom. Bk. 403 ; Inq. El. (Rec. Com.), 5176 . 'Lisia' is Lisois de Moustiers; Round, Feud. Engl. 32.

163 Dom. Bk. 447 . 


\section{A HISTORY OF SUFFOLK}

de Warenne held estates in the hundreds of Thedwastre, Lackford, and Stow. ${ }^{141}$ These lands, poor and insignificant when compared with his extensive holdings de escangio Lewes or pro escangio Lewes in the county of Norfolk, ${ }^{149}$ had probably been granted to him as compensation for encroachments on his Lewes honour in Sussex. ${ }^{143}$ They consisted of small plots, one of 100 acres, one of 60 acres, and one of 80 acres, which had formerly been held under the abbeys of Ely and Bury St. Edmunds, and were now transferred, with the freemen holding them and their bordar tenants, to the Warenne fief. Ralph Baynard or Bainard (Baignard) also held a large part of his Suffolk fief pro escangio, with some portion of his estates in Norfolk and Essex. ${ }^{144}$ From the Norfolk record we learn that this exchange was effected during the lifetime of Archbishop Stigand, presumably before his deposition in 1070. ${ }^{146}$ Humphrey Fitz Aubrey (Humfridus Filius Alberici) seems to have obtained lands in Suffolk in exchange for estates in Normandy, de escangio normannie, ${ }^{146}$ and elsewhere Hugh de Montfort appears to have been making bargains with the King. At Dagworth a carucate and a half, which had belonged to a freeman who fell at the battle of Hastings, was 'delivered ' to Hugh for a half-carucate 'in exchange' (de escangio). At Newton he held a freeman and half a carucate 'by exchange' (pro escangio), and two freemen ' whose soke was in the hundred,' with 27 acres, 'by livery and by exchange' (ex liberatione et pro escangio), while on the royal manor of Thorney he held two freemen and their land in the same way (de escangio). ${ }^{147}$ At Battisford (Betesfort), in the hundred of Bosmere, land had been exchanged between Hugh de Montfort and his Kentish neighbour and fellow tenant-in-chief, the great Canterbury abbey of St. Augustine. ${ }^{148}$ Robert Grenon also claimed a manor in Samford Hundred by virtue of an exchange with Hugh de Montfort, ${ }^{149}$ and in Bishop's Hundred Roger Bigot had apparently received a small estate in exchange for land ceded to Isaac, the Suffolk tenant-in-chief. ${ }^{160}$ In one isolated instance we find Beorn, a pre-Conquest freeman, buying 50 acres for a manor from the Abbot of Ely on the understanding (conventio) that after his death his purchase should revert to the Abbey. ${ }^{151}$ In the Inquisitio Eliensis Beorn is entered as having held 50 acres from St. Etheldreda which he could not sell. But as the manor in question was held at the time of the Survey by Roger Bigot as a tenant of the Bishop of Bayeux, the Abbot of Ely seems to have failed to make good his claim, in spite of the witness of the hundred to its justice. ${ }^{152}$ Agreements of this nature are not uncommon. At Pakenham

${ }^{141}$ Dom. Bk. $39^{8}$.

${ }^{142}$ Ibid. 172; (Lewes); 163, 163b; (Laves, Lawes) ; 1576, 158, 159, 164, 165b, 169; (Laq's, Laquis).

${ }^{143}$ V.C.H. Norf. ii, $15,18$.

${ }_{14}$ Dom. Bk. 41 3b, 414, 415; 249, 251, 252b, 253b; (Norfolk), 70, 71b; (Essex).

${ }^{445}$ Ibid. $252 b$. 'Vivente Stigando liberatum est Baignardo pro escangio.'

146 Ibid. 436 ; cf. $262 b$ (Norfolk). Cf. Vinogradoff, op. cit. 226.

${ }^{247}$ Dom. Bk. 409b, 4106 . "Thedwastre. A freeman of Edith "dives" and his land held by Hugh de Montfort "pro escangio." "

148 Ibid. 4 10. 'Hoc est pro escangio de terra Sancti Augustini.'

140 Dom. Bk. 420. 'Hoc revocat Rob. pro escangio de terra Hugonis de Monteforti.'

${ }_{150}$ Ibid. 331. 'Pro escangio de terra Isac'; cf. 179. The king had enfeoffed Isaac with some of Earl Ralph's forfeited lands, and had given Roger Bigot lands in Norfolk by way of compensation; V.C.H. Norf. ii, 19. For Isaac cf. Dom. Bk. 4376, 438. The Suffolk estate mentioned in the text had belonged to Stigand and had been held by Bishop Ailmar or Ethelmaer of Thetford after the Conquest.

${ }^{161}$ Dom. Bk. 373. "Hanc emit ipse Beorn liber homo ab abbate, ec conventione quod post mortem suam rediret ad aecclesiam sanctae Eldredae testante hundredo.'

163 Ing. El. (Rec. Com.), $52 \mathrm{I}$. 


\section{DOMESDAY SURVEY}

in Thedwastre Hundred and at Gislingham in Hartismere Hundred the Abbot of St. Edmunds had made arrangements of the kind called on the Continent precaria remuneratoria, a lease of Church lands, with the reversion of the land granted and of additional estates from the property of the grantee. At Pakenham a freeman had procured a lease from the Abbot of half a carucate (impetravit ab abbate praestari sibi dimidiam carucatam terrae), 'by such an agreement (conventio) that all his land, wherever it might be, should remain to the Saint after his death.' St. Edmund's Abbey was in possession of this land in 1086, but at Gislingham a Norman tenant-in-chief of the Crown had encroached on the rights of the Church. Here Leofstan, or Levestan, Abbot of St. Edmunds in the lifetime of King Edward, had granted one of his demesne manors to a freeman called Alsi and his wife on condition that when they died the Abbot should have back his own manor and also Alsi's manor of Euston. If, as we may assume, this was 'Evestuna,' in Blackbourn Hundred, St. Edmund's Abbey held it at the date of the Survey, but the Gislingham manor had fallen into the hands of Gilbert 'Balastarius.' ${ }^{163}$ In other instances the agreement would seem to have been more one-sided. Edith, a freewoman, held a manor from the Abbot of St. Edmunds for her life. ${ }^{154}$ Edmund the Priest gave the land which he took with his wife, with her consent, to the church of St. Etheldreda, 'by such an agreement (conventio) that he could not sell or give away from the church.' ${ }^{165}$ From Topesfield, in Cosford Half-hundred, comes the record of an arrangement made with the Church before the Conquest, which was carried into effect in the time of King William. Leveva, a freewoman, undertook to give half a carucate to Holy Trinity, Canterbury, when she died, in return for another half-carucate which she held from the Archbishop during her life. This agreement was made under King Edward, but Leveva lived on into the reign of the Conqueror, and continued to hold the land. It then apparently passed to John, the nephew of Waleran, who claimed it in 1086 , but it is entered in the Survey among the estates which Archbishop Lanfranc had devoted to 'the feeding of the monks (ad victum monacborum. $)^{156}$ At Badley, too, in Bosmere Hundred, Richard Fitz Gilbert held certain freemen as belonging to his manor who had been added in the time of his antecessor Phin by agreement (accomodatio) with the sheriff, 'as the sheriff himself says.' ${ }^{167}$ 'The complexities of a system of divided commendation and the intricacies of tenurial relations could also sometimes be simplified by mutual arrangement. At Blaxhall, in Parham Half-hundred, a freeman who had been sub-commended, half to the antecessor of Robert Malet and half to the Abbot of St. Edmunds, came to an agreement with the Abbot concerning his claim, ${ }^{168}$ while at the neighbouring villages of 'Brutge' and Beversham Hervey of Bourges had

${ }^{133}$ Vinogradoff, op. cit. 229-32 ; Dom. Bk. 361b, 'Pachenham;' 444b, 'Gislincham.' Cf. 3676 , 'Evestuna.'

${ }_{149}$ Ibid. 286. In this case the land was in the hands of the moneyer, 'monetarius,' when King Edward died, and in $1086 \mathrm{King}$ William was in possession of it.

iss Ibid. 4316 . 'Cloptuna. Brantestuna. Terram quam cepit cum uxore ejus . . . misit in ecclesia concedente muliere.' Here, too, a Norman tenant-in-chief, William 'de Arcis' and his tenant are found in possession in 1086, but the fact of the priest's gift is recorded in the Inquisitio Eliensis; Inq. El. (Rec. Com.), 521 .

is Dom. Bk. $372 b$. Cf. ibid. $406 b$, 'Nachetuna.'

157 Ibid. 393. 'Et ipse Phin tenebat eos per accomodationem vicecomitis ut ipse vicecomes dicit'; Vinogradoff, op. cit. 393 .

is Dom. Bk. 307. 'Ex hac medietate est conciliatus Abbati.' 


\section{A HISTORY OF SUFFOLK}

taken over two estates which had similarly been held, as a whole or in part, by St. Edmund's Abbey. ${ }^{169}$ It was in cases of this kind, and in questions of disputed title, that the Domesday Commissioners were called on to adjudicate. The Suffolk Survey throws considerable light on these quasi-judicial decisions, and on the functions of the 'King's barons' who were sent into the counties to inquire and describe. ${ }^{160}$ Not only are the invasiones or encroachments on royal rights gathered together at the end of the record and followed by a group of 'claims' or calumniae. Other encroachments and claims which gave rise to interesting judicial disputes are found scattered through the text. We learn how Englishmen were not ashamed to turn their country's humiliation to their own profit; how, after the coming of King William, Wisgar ' invaded' or usurped two freemen with their land, who had formerly been bound by commendation alone. It is with some satisfaction that we read in the next entry how Wisgar himself 'made forfeiture' (se forisfecit), and how his land in turn was seized by the Norman Richard Fitz Gilbert. ${ }^{161}$ We see how the chances of battle and rebellion left vacant spaces in the ranks of the Saxon landholders, which their conquerors were not slow to fill. Edric the Deacon fell with Harold at Hastings (in bello), and the freeman whom he had held was 'delivered' to Bainard, then ' added' by Etgar to the manor of Cavendish, and finally held by Ralph de Limesi in the demesne of his hall. ${ }^{162}$

The forfeiture and disgrace of Earl Ralph were stepping-stones to fortune for many an ambitious adventurer. Robert de Curcun had seized (invasit) one of the earl's freemen at Wissett, but had been obliged to give security (vadem). ${ }^{163}$ At Somersham the king's reeve (praepositus) Ulmar had given security and had found a warrantor (fidejussor) for his appropriation (invasio) of another of Earl Ralph's freemen with his holding of 12 acres, but here the estate in question had been taken into the king's hand. ${ }^{164}$ The procedure in disputes of this nature is worthy of careful attention, and of comparison with the later proceedings before the itinerant justices, as recorded in the Eyre Rolls, the Assize Rolls, and the Hundred Rolls. The parties to a suit would bring either written evidence, charters, or royal writs (brevia), or personal witnesses to back their respective claims. As a rule, the jurors who had been chosen to swear for the whole hundred ${ }^{165}$ were appealed to by one of the claimants, and the witness of the 'hundred' was opposed by that of the bomines or feudal tenants of the plaintiff or defendant, or by the testimony of the 'vill' or township. ${ }^{166}$ 'There was 'vouching to warranty,' and in one

${ }^{159}$ Dom. Bk. 441. 'Brutge. De dimidio hujus terrae Herveus conciliatus Abbati ; et postea de Rege tenuit.' 'Beversham. Ipse est conciliatus Abbati et hoc supradicto modo.'

${ }_{160}$ Dugdale, Mon. i, 601 et seq.; Ellis, Introd. to Dom. i, 120. For the subject of the judicial powers of the Domesday Commissioners, cf. Round in Dom. Studies, ii, 539 et seq.; Vinogradoff, op. cit. 228.

${ }^{161}$ Dom. Bk. 448. Wisgar 'invaded' the two freemen and their land after the coming of King William, but 'ante conventionem Ricardi (R. Fitz Gilbert), qui modo tenet.'

162 Ibid. 449. 'Fuit liberata Bainardo pro terra. Etgarus addidit in Kanavadisc postquam Bainardus perdidit, modo tenet Radulfus de Limesi in dominio halle.'

163 Ibid. 449 .

164 Ibid. 4486 .

${ }^{165}$ Round, Feud. Engl. 118 et seq. For the different kinds of witness, written and verbal, cf. above, p. 379 et seq.

${ }_{166}$ Dom. Bk. 447b. 'Homines Ricardi (Fitz Gilbert) revocant ad feudum Wisgari antecessoris sui. Sed sicut hund. testatur nunquam pertinuit ;' ibid. 2856 . 'Hund. testatur quod vere rex et comes habuit socam et sacam T.R.E. sed homines illius ville (Melnessa) testantur quod Burchardus similiter habuit socam de liberis hominibus sicuti de suis villanis.' For writs cf. ibid. $336,379,409 b$.; cf. $360 b$. Anhus. 


\section{DOMESDAY SURVEY}

instance the warrantor is called by the somewhat unusual name of tutor. ${ }^{167}$ In the last resort there was an appeal to the customary methods of proof, battle, ordeal, or compurgation. The men of the vill of Mendlesham had no other witness than their own to the fact that Burchard had soke over both freemen and villeins, yet they were willing to prove their contention in any way. ${ }^{168}$ The hundred testified that Stanwin, a freeman, had been commended to Harold in the time of King Edward, but he himself asserted that he had been the 'man' of Edric, the antecessor of Robert Malet, and he 'offered proof' (juditium), probably by battle. ${ }^{169}$ A 'man' of Godric Dapifer was willing to prove his claim and the truth of his words 'against the whole hundred, by every kind of law.' ${ }^{170}$ In a dispute with Roger Bigot, Roger de Ramis contradicted the testimony against him 'by all kinds of law.' ${ }^{171}$ In the halfhundred of Ipswich Roger the Sheriff claimed roo acres, 5 villeins, and a mill which were in the possession of the church of St. Peter, as belonging to the king's manor of Bramford. A regular trial followed. Five villeins from the Bramford manor bore witness for Roger, and offered 'such law as should be adjudged to them' (legem qualem quis judicaverit). But the half-hundred of Ipswich witnessed that the property in dispute had belonged to the church (jacebat ad ecclesiam) in the time of King Edward, and that it was held by Wisgar, who held the church also, and this they offered to prove by process of law (offerunt derationare). ${ }^{178}$ Unfortunately, of the further proceedings we hear nothing, but enough has been recorded to show that formal 'pleading,' leading to legal 'proof' by ordeal or other customary methods, could take place before the Domesday Commissioners. This is borne out by the employment of technical judicial phrases, respondere, in misericordia regis, placitum, and by the use of essoins or excuses for non-appearance in court. Thus Hugh de Hosdenc could neither answer a charge against him, nor reply when he was vouched to warranty, because he was a prisoner in the king's hands (in captione regis), ${ }^{173}$ and Berenger could not 'come to the plea' because he was 'infirm.' ${ }^{174}$ Sometimes, no doubt, the Commissioners actually gave decisions, ${ }^{175}$ but in Suffolk they seem rather to have confirmed decisions already given. At Ashfield, on the lands of the Bishop of Bayeux, Suarinus, a priest and freeman, of whom Walter of Dol was seised when he forfeited his land, was afterwards held, as the hundred witnessed, by Earl Hugh. ${ }^{376}$ A certain cit. 224.

167 Dom. Bk. 388. 'Sed dominum suum G. de Magnavilla revocat ad tutorem ;' Vinogradoff, op.

${ }^{60}$ 'Dom. Bk. $285 b$. ' Non habent aliquid testimonium praeter se, et tamen volunt probare omni modo.'

16 Ibid. 332. 'I

170 Ibid. 371. 'Et hoc vult probare contra totum hundredum, omnibus legibus.'

${ }^{17}$ Ibid. 3386 . 'Hoc contradicit omnibus legibus ;' Vinogradoff, op. cit. 233. Cf. the striking case, Dom. Bk. 2876 , quoted by Professor Vinogradoff, op. cit. 379 , where the sheriff Aluric quarrels with his predecessor Roger Bigot over the 'farm' of Bergholt, and Roger wishes to make proof ('vult probare') by the men who had been present at his agreements ('conventiones'), while Aluric vouches the king to warranty.

i7s Dom. Bt. 3926, 393. The use of the present tense may be noted.

17 Ibid. 4ว5. 'Ideo non potuit dare responsum;' 4486. 'Revocat Hugonem de Hosdenc ad warant, sed ipse est in cap.ione regis, et non potest respondere.' Both passages refer to the same case. For Hugh de Hosdenc cf. Lom. Bk. 284,3376 ; V.C.H. Essex, i, 356 . For 'essoins,' cf. Pollock and Maitland, Hist. Engl. Law, ii, 560-66.

${ }_{174}$ Dom. Bk. 449 ; cf. 424 , where the men of the hundred give judgement, and one of the parties objects that he was not summoned to the plea ; $\mathrm{cf}$. Round in Dom. Studies, ii, 549.

${ }^{175} \mathrm{Cf}$. Vinogradoff, op. cit. 228. A case of disseisin 'per barones Regis' in Devonshire ; cf. Round in Dom. Studies, ii, $547-9$.

${ }_{176}$ Dom. Bk. 377. This case is quoted at length by Professor Vinogradoff, op. cit. 427-8. 


\section{A HISTORY OF SUFFOLK}

'Norman,' probably the sheriff of that name, ${ }^{177}$ stated that the king had sent him a writ bidding him put Ralph de Savigny in seisin of all the freemen of whom Hubert de Port had seised the Bishop of Bayeux. He accordingly put Ralph in seisin of the priest Suarinus, though he owned that he did not know whether the bishop had previously been seised of him by Hubert. When the king's barons came into the county they found this arrangement holding good as between Roger Bigot, who represented the bishop and the claim through Ralph de Savigny, and Earl Hugh, who represented the claim through Walter of Dol. 'And so,' the entry concludes, 'let it remain in peace until the case be decided' (donec sit derationatus). Here the 'king's barons' ratify the status quo ante, pending a final legal decision, while an appeal is made to two earlier acts of seisin, one by the king's sheriff and the other by Hubert de Port. Of Hubert we are told in a later entry ${ }^{178}$ that he adjudged (deracionavit) one of the Malet estates in Hartismere Hundred to be free land, and seised the Bishop of Bayeux of it 'because freemen held it.' But the mother of Robert Malet had been in possession (saisita), as the hundred testified, 'on the day when Ralph the Earl made forfeiture, and up to the plea (placitum) of Hodiham.' Now, the land was 'in the King's peace,' as the king decreed (precepit), between the bishop and Robert's mother. ${ }^{179}$ Are we here on the track of one of those special inquests which the 'king's barons' held from time to time even before the Great Survey? ${ }^{180}$ The Suffolk Domesday gives us welcome, if fitful, glimpses of several such inquests, and of the pleas which the royal judges heard. There is evidence that Hugh de Montfort, Roger Bigot, Richard Fitz Gilbert, Thorold the Sheriff of Lincolnshire, and others were 'holding pleas' at St. Edmundsbury in 1076-9, shortly after the revolt of the earls, Ralph of East Anglia and Roger of Hereford. ${ }^{181}$ Another eyre or commission of earlier date, which has left traces on the Suffolk Survey, is assigned by Professor Freeman to the year $1068,{ }^{182}$ and connected with the entry which refers to 'the redemption of the lands' of the English after the Conquest. We are told of a small estate on the lands of St. Edmund's Abbey that the abbot pledged (invadiavit) this land to (contra) the king's barons, namely, W. the bishop, Engelric, and Ralph the Staller (Stalra) for Ioos. ${ }^{183}$ Elsewhere, the Abbot of St. Edmunds held an estate in pledge or mortgage (in vadimonio) by the grant (concessu) of Engelric, 'when the English redeemed their lands.' ${ }^{184}$ The suit before Geoffrey of Coutances, when the abbey of Ely claimed its alienated lands, seems to be referred to in two other entries, where Roger Bigot is said to hold of the abbot 'by the decree (precepto) of the Bishop of St. Lô,' ${ }^{185}$ or ' because the abbot proved his right (derationavit)

177 Dom. Bk. 438 .

${ }^{178}$ Ibid. 450 . Hubert de Port was a tenant-in-chief of the Crown in Hampshire; Dom. Bk. i, 466. Hugh de Port, who held land in Hampshire, Berkshire, Dorset, and Cambridgeshire, was a tenant of the Bishop of Bayeux in Hampshire; ibid. i, 44b, 45, $51,656,83$. Ralph de Savigny is found in 1086 holding a number of freemen of Roger Bigot, who held of the Bishop of Bayeux; ibid. ii, 373-8.

${ }^{179}$ Odiham was a royal manor in Hampshire. There was also Odiham Hundred in Hampshire and Odeham in Essex; Dom. Bk. i, 38, 49b; ii, 73 .

${ }_{180}$ Round, Dom. Studies, ii, 547-9.

181 Round, Feud. Engl. 329.

${ }^{182}$ Freeman, Norm. Conq. iv, 25-6, 723-4; Round, Feud. Engl. 428-9; Com. of Lond. 28-36 ; Vinogradoff, op. cit. 220 , n. I ; V.C.H. Essex, i, 355 .

Dom. Bk. 3676 .

${ }^{184}$ Ibid. $360 b$; Professor Freeman sees here, apparently, a commission for the 'general redemption' of the lands of the English 'as a body.' For redemption after forfeiture cf. ibid. 4436 .

${ }^{185}$ Ibid. 383 ; St. Lô was the earlier seat of the bishopric of Coutances. The parallel passage in the Inquisitio Eliensis has 'coram episcopo Constantiensi'; Ing. El. (Rec. Com.), 5246. 


\section{DOMESDAY SURVEY}

against him before the Bishop of St. Lô.' ${ }^{186}$ The famous Suffolk plea in which Brungar, a freeman commended to Robert Wimarc's son, was tried for having stolen horses in his house, ${ }^{187}$ brings us to another thread in the 'labyrinthine web of legal relationships,' 188 the tie of 'sac and soke,' for while Brungar was 'commended' to Robert Wimarc's son, the Abbot of St. Edmunds had the sac and soke over him, and these conflicting claims led to litigation which was only ended by a compromise. The subject of sac and soke, too vast to be more than touched on here, is well illustrated by the Suffolk Domesday. Soke over persons and land was distinct from commendation, and could be held and granted separately. ${ }^{189}$ It could even be divided, as at Thornham, where the Abbot of St. Edmunds had three-quarters of the soke and the king had the fourth quarter. ${ }^{190}$ From Suffolk Professor Maitland takes two cases to prove that the lord had not always soke over his villeins. ${ }^{191}$ To these may be added the case at Mendlesham and Cotton, where the hundred bore witness that the king and the earl had soke and sac in King Edward's time over the freemen in Cotton, who had been added to the Mendlesham manor, and the men of the vill testified that Burchard, the lord of the manor, had soke alike over freemen and villeins. ${ }^{108}$ In Suffolk, too, are found admirable examples of territorial soke, and of private soke, and hundredal soke, annexed to a royal manor, or granted to an important religious house or to a great magnate. The soke of the hundred and a half of Samford belonged to the king's manor of Bergholt. ${ }^{193}$ The Confessor had granted the soke over eight and a half hundreds to St. Edmund's Abbey. ${ }^{194}$ St. Etheldreda of Ely had the soke over five and a half hundreds, ${ }^{195}$ and the Bishop of Thetford had soke and sac over the ferting of Elmham, or a quarter of the hundred of Wangford, with the exception of the men of Stigand and of the land and men of St. Edmund, whom Abbot Baldwin claimed. ${ }^{196}$ There are curious instances of local soke at Burstall, where the ' $s a c$ ' over the small manor of the freeman Godwin was in Bergholt, ' except for his house and for three acres' ${ }^{197}$ at Stoke, where St. Etheldreda had ' half the soke which is beyond the bridge '; ${ }^{198}$ at Buxhall, in Stow Hundred, where Lewin Croc had soke and sac over 'the hall and the bordars,' but the soke of the commended freemen was in the hundred ; ${ }^{199}$ and on Roger Bigot's land in Colneis Hundred, where the Abbey of Ely had the soke

20 Dom. Bk. $404^{b}$; the Ely suit probably belongs to the years $1072-5$; Round, Feud. Engl. 459 et seq.

10 Dom. Bk. 401b; Maitland, Dom. Bk. and Beyond, 104; Freeman, op. cit. iv, 735.

183 Maitland, op. cit. 104 .

10 Dom. Bk. $360 b$; 'A Abas revocat socam de dono regis,' 313 ; Vinogradoff, op. cit. 121, n. 5.

100 Dom. Bk. $437 b$; cf. 440 ; Vinogradoff, op. cit. 125.

$191 \mathrm{Dom} . \mathrm{Bk} .4086,425 b$; Dom. $B k_{\text {. }}$ and Beyond, 90,91 .

168 Dom. Bk. $285 b$; above, p. 385 .

1m Maitland, Dom. Bk. and Beyond, 90-2; Vinogradoff, op. cit. 128 et seq.; Dom. Bk. $287 b$.

in These were the hundreds of Risbridge, Lackford, Thingoe, Thedwastre, Blackbourn, and Bradmere, with the double hundred of Babergh and the half-hundred of Cosford; Rot. Hund. (Rec. Com.), ii, $151 b$, where the names of the hundreds are given; Chron. Foc. de Brakelonda (Camd. Soc.), 42, n. 132; Gage, Suff. i, Introd. ix.

${ }_{100}$ Dom. Bk. 3856 .; Rot. Hund. (Rec. Com.), ii, 1970, where they are named as Carlford, Colneis, Plomesgate, Loes, Wilford, and the half-hundred of Thredling. Thredling Half-hundred, however, is of later date. The abbot's Domesday half-hundred seems to have been Parham; cf. Maitland, op. cit. 93. For encroachments on these liberties cf. the Ely suit of 1072-5; Inquisitio Com. Camb. (ed. Hamilton), 194.

${ }^{200}$ Dom. Bk. 379. ${ }_{207}$ Ibid. $377 . \quad{ }^{198}$ Ibid. $382 b$.

100 Ibid. $350,350 b$; cf. 3496 ; Brockley. Two freemen who could only sell 'in the soke of St. Edmund '; Vinogradoff, op. cit. 131 . 


\section{A HISTORY OF SUFFOLK}

'except over the hall of Walton, and villeins.' ${ }^{200}$ At Haughley, Gutmund the brother of the Abbot of Ely held a manor under King Edward before the Conquest with soke and sac 'over the hall demesne only,' while the soke of the six sokemen on the demesne was in the hundred. ${ }^{201}$ In the borough of Sudbury the soke is said to be in villa. ${ }^{202}$ The freemen of those hundreds which had not been granted out to the great religious houses seem to have been normally under the soke of the public authorities, 'the King and the Earl' in the hundred court. ${ }^{203}$ A good illustration of this is found in Blything Hundred, in the case of those freemen of Roger Bigot who have a special heading of the Suffolk Survey to themselves. ${ }^{204}$ Even here, however, Bigot and Robert Malet were beginning to encroach on the royal jurisdiction, ${ }^{205}$ and the disputes over rights of sac and soke, which occur not infrequently in the Survey, show that in Suffolk, as in other parts of England, the Norman lords were 'assuming a soke which their antecessores did not enjoy.' ${ }^{206}$ At Combs and at Onehouse, on the fief of Robert of Mortain, ' no custom was rendered in the hundred after Count Brien, Robert's antecessor, had the land.' 207 Closely connected with these grants or assumptions of soke is the extension of seignorial jurisdiction, and in particular, in Suffolk, the surrender to St. Edmund's Abbey of the reserved pleas of the Crown, "the six forfeitures of St. Edmund.' ${ }^{208}$

If now we turn from franchises to those who exercised them, and look at the list of Suffolk tenants-in-chief of the Crown at the date of the Domesday Survey, we are at once struck by that 'unity of East Anglia, ${ }^{209}$ which was typified, both before and after the Conquest, not only by the common earldom and the common bishopric of Norfolk and Suffolk, but by the large number of territorial magnates, Norman feudatories and their antecessores, who held land in both counties. Suffolk, indeed, was a sort of half-way house, a meeting-place for the landholders of Norfolk on the one hand, and of Essex on the other. Out of 7 I Suffolk tenants-in-chief, 2 I held directly of the Crown in both Norfolk and Essex, I 7 held in Norfolk and not in Essex, and I 3 in Essex and not in Norfolk, while only 20 had a leading place in Little Domesday in Suffolk alone of the three eastern counties. ${ }^{210}$ It follows that much has already been written on these holders of land in the articles on Essex and Norfolk, though something still remains to be said of them, and one famous house at least, that of Richard Fitz Gilbert of Clare, among the lay feudatories, with one great ecclesiastical foundation, the abbey of St. Edmund, belong primarily to the history of Suffolk.

${ }^{200}$ Dom. Bk. 3436 .

${ }^{201}$ Ibid. $408 b$. For other instances of freemen and sokemen whose soke was 'in the hundred,' cf. 285 , 'Fineberga,' 'Staham,' 336, 350, 3506, 'Buckeshala.'

${ }^{202}$ Ibid. 2866 .

${ }^{203}$ Vinogradoff, op. cit. I 20 ; Maitland, op. cit. 95 ; V.C.H. Norf. ii, 32-4.

${ }^{204}$ Dom. Bk. $333 b$ et seq.

${ }^{205}$ Ibid. 333b, 334 ; Thorpe. R. Bigot soke, R. Malet soke over 2 acres. 'Cnotesheale.' R. Malet soke, cf. $291 b, 292 b, 295,305,309,313,313 b$, for the soke of the 'King and the Earl.'

${ }_{206}$ Maitland. op. cit. 94, n. 1 .

${ }^{207}$ Dom. Bk. 291 ; cf. $285 b, 319 b, 320$; 'Eiam.' $360 b$, 'Anhus'; here the king's reeve had 4 s. for the soke ('propter socam') of a freeman.

${ }^{208}$ Ibid. 349, 373, 384b, 391, 397, 397b, 413b, 414b ; 'Rex et Comes vi forisfacturas' ; Maitland, op. cit. 88 ; Vinogradoff, op. cit. 111 , et seq.

${ }^{209}$ V.C.H. Norf. ii, 5 .

${ }^{210}$ Of course many of these held also in Cambridgeshire and elsewhere. 


\section{DOMESDAY SURVEY}

First on the list of Suffolk landholders stands the name of King William himself, Will(elmus) Rex anglorum, a style which only occurs here and in the list of landholders prefixed to the Essex Survey. ${ }^{.11}$ The description of the Terra Regis fills a much smaller relative space of the Survey in Suffolk than in Norfolk, ${ }^{218}$ and is somewhat differently arranged. The first section treats of the king's demesne, de regione, ${ }^{, 13}$ then come the forfeited estates of ' Ralph the Earl,' then Harold's Harkstead estate, a berewick of Brightlingsea in Essex, then the borough of Sudbury with other lands of 'the mother of Morcar the Earl,' Harold's manor and 'soke' of Bergholt, and the forfeited estates of Archbishop Stigand. These are followed by two more demesne manors, under the heading of terrae regis de regno, and at the end of all stands the account of the borough of Ipswich. This borough, with the mass of the king's demesne lands, had been placed in the charge of Roger Bigot, and each of the other sections had its special keeper or custos. ${ }^{214}$ It seems probable that Roger Bigot was Sheriff of Norfolk and Suffolk at the time of the Survey, ${ }^{216}$ and even that he was in his second term of office. This may be gathered from a passage in the Suffolk Domesday, which distinctly implies that Robert Malet held the shrievalty after Roger Bigot, ${ }^{216}$ and from a number of references to 'Rogerus vicecomes,' which suggest that he was actually sheriff in $1086 .{ }^{217}$ The king's demesne lands (de regione), which Roger 'kept,' 218 were in the centre and north of the county, and included King Edward's manors of Thorney, Bramford, and Blythburgh, with Earl Gurth's manors and commended freemen in the hundred of Lothing and the half-hundred of Lothingland. The Confessor's Norfolk manor of Diss is for some reason surveyed here, under the hundred of Hartismere, with Gillingham, in Norfolk, where a small estate of 30 acres was appurtenant to Gurth's manor of Gorleston in the half-hundred of Lothingland, to which also belonged twenty-four Yarmouth fishermen. ${ }^{219}$ Some incidental light is thrown on the sheriffs and reeves and their doings by this section of the Survey. We see Roger Bigot removing the sokemen from Thorney Manor, and distributing them among the tenants-in-chief. We see Thorney rising in value, and Blythburgh deteriorating under his charge. ${ }^{220}$ We hear of villeins added to Blythburgh Manor 'in Robert Malet's time,' that is, probably, during his shrievalty, and we find 'Aluric

"x Dom. Bk. ii, I ; 'W. Rex anglorum,' cf. 109 , Norf. 'Willelmus Rex.'

nง V.C.H. Norf. ii, 9-14.

${ }^{213} \mathrm{Mr}$. Round, in Feud. Engl. I40, treats the use of the word 'regio' as a blunder, and would substitute 'regno.' But it occurs elsewhere; in Norfolk (Dom. Bk. 144) and in Suffolk (ibid. 4086), and Professor Maitland thinks that it may well stand for 'kingship'; Dom. Bk. and Beyond, 167, n. 2, cf. Ballard, The Dons. Ing. 88 ; Vinogradoff, op. cit. 326 et seq.; Maitland, op. cit. 213.

"' On the technical distinction between 'vicecomites' and 'custodes' cf. Round, Geoffrey de Mandeville, $107-8$, App. i, 297.

nis Dom. Bk. 179, 179b, 185b; V.C.H. Norf. ii, 19, 37.

n' Dom. Bk. 2876 . 'Quando Rogerus Bigot prius habuit vicecomitatum statuerunt ministri sui quod relderent $x$ lib. per annum. . . . Et quando Robertus Malet habuit vicecomitatum, sui ministri creverunt eos ad $\mathbf{x}$ lib. Et quando Rogerus Bigot eos rehabuit dederunt similiter $\mathbf{x x}$ lib.' Does 'rehabuit' refer to Roger's second tenure of the shrievalty? The freemen in question were under Aluric Wanz in 1086, but he is always called reeve, 'praepositus,' not sheriff; cf. Vinogradoff, op. cit. 379. 'Rogerus vicecomes' is mentioned in connexion with Suffolk in the Ely 'placitum' of 1072-5; Ing. Com. Camb. (ed. Hamilton), 194.

9.7 Dom. Bk. 179, 179b, 185b; (Norfolk), 282, $290 b$ (twice), 445b, "Vicecomes Rogerus habuit de patre suo herretum,' 446 (twice). The second case, 'Haminghelanda,' refers to the same incident as 282.

"s 'Servat.' Of Ipswich the phrase 'custodit . . . in manu regis' is used; Dorn. Bk. $2816,290$.

nom. Bk. $282,283,283 b$; V.C.H. Norf. ii, 5 .

nom. Bk. 2816,282 . 


\section{A HISTORY OF SUFFOLK}

the reeve' (praepositus), in whom we may, perhaps, recognize Aluric Wanz, appointing new customs for the freemen of the hundreds of Wangford and Lothing, and increasing the king's farm ' in the time of Roger Bigot,' and apparently under his direction, while we have a hint that Hugh de Hosdenc, who in 1086 was a prisoner in the king's hands, had at one time held office, either as sheriff or as reeve on the royal demesne. ${ }^{221}$ The demesne manors (de regno) of Barrow, which had belonged to King Edward and Badmondisfield, which had been held by Algar, were entrusted to the care of Picot, ${ }^{228}$ in all likelihood, if this be Picot the Sheriff of Cambridgeshire, ${ }^{223}$ because they are on the western side of the county.

The forfeiture of Earl Ralph of East Anglia overshadows Suffolk as well as Norfolk, and has set its mark deeply on the Suffolk Survey. The father of Earl Ralph, Ralph the Staller (Stalra), seems to have been earl in East Anglia, ${ }^{224}$ and to have acted with William, Bishop of London, and Engelric the priest as a royal commissioner in Suffolk shortly after the Conquest. ${ }^{225}$ As earl (comes) we find him apparently succeeding Gurth, and adding his estate of Bentley to the royal manor of Bergholt as a berewick, in the time of King William. ${ }^{226}$ We also come upon traces of him in the hundreds of Blything, Claydon, and Plomesgate, where his land, commended freemen, and rights of sac and soke passed to Count Alan and to Earl Hugh, and in the manor of Thorney, where he held a carucate of land in pledge from the sheriff Toli, on the day when King Edward was alive and dead, which his son Ralph held after him. ${ }^{27}$ To the 'Godwine, uncle (avunculus) of Earl Ralph,' who is mentioned in the Norfolk Domesday, may be added Hardwin, the brother of Earl Ralph and Alsi, Earl Ralph's nephew, whose names occur in the Suffolk Survey. ${ }^{228}$ The day when the younger Ralph 'made forfeiture' became an epoch to date from throughout East Anglia. ${ }^{229}$ After the unsuccessful revolt of Ralph Earl of East Anglia and Roger Earl of Hereford in I075, and the consequent flight and forfeiture of Ralph, ' Guader' or ' de Waer,' the king kept the bulk of his Suffolk estates in his own hands, and appointed the Englishman 'Godric Dapifer' his custos or bailiff. It would appear that Ralph had acquired some of these lands from Edith the 'Fair' or ' Rich,' who has been sometimes identified with 'Edith of the Swan Neck,' whose land at Great Sampford, Essex, passed in like manner to the East Anglian earl and then to the king, who entrusted it to the care of Godric Dapifer. ${ }^{230}$ Three of Ralph's manors, in Carlford Hundred, had been granted to Odo of Bayeux, who had taken an active share in the suppression of the revolt of $1075 .{ }^{231}$ The Harkstead Manor was, naturally enough, farmed by Peter of Valognes, the Sheriff of Essex, ${ }^{232}$ and the land of Alveva,

${ }^{221}$ Dom. Bk. 282, $2826,283,284$ : 'tempore H. de Hosdena'; cf. above, p. 385.

${ }_{929}$ Dom. Bk. $289 b$. ${ }^{928}$ Ibid. i, 193b; Round, Feud. Engl. Index, 'Picot.'

"23 V.C.H. Norf. ii, 10, II ; cf. Mr. Round's account of 'the two Ralfs'; ibid. 10-12 ; Freeman, Norm. Conq. vi, Index, 'Ralph the Staller; Ralph of Wader.' Cf. the writ addressed by the Conqueror to 'Raulf Eorl, 'Ethelmaer, Bishop of Thetford, and Nordman, Sheriff of Suffolk; Round, Feud. Engl. 427 et seq. ; V.C.H. Norf. ii, 11 .

${ }^{226}$ Dom. Bk. 287.

${ }^{928}$ Ibid. $322,324,338,350 b$; cf. V.C.H. Norf. ii, 11.

${ }^{289}$ Dom. Bk. 294, $294 b, 450$; cf. $301 b$.

930 Ibid. $7 b$; V.C.H. Essex, i, 350, n. 2 ; Freeman, Norm. Cong. iii, App. Note R. R. A freewoman called Edith also appears on 286.

${ }^{231}$ Dom. Bk. 373. One of these manors was claimed by the abbey of Ely. Above, p. 382 .

ss Dom. Bk. 2866 ; V.C.H. Essex, i, 349. 


\section{DOMESDAY SURVEY}

mother of Earl Morcar and widow of Earl Ælfgar, was 'kept' by William the Chamberlain, and by that Otto the Goldsmith who also farmed the Crown estates, which had belonged to Elfgar in Essex. ${ }^{233}$ The royal manor of Bergholt with its members was in the charge of Aluric 'Wanz,' an Englishman whose estates in Essex had come into the hands of 'Eudo Dapifer.' ${ }^{294}$ The lands which fell to the king when Archbishop Stigand was deposed in 1070 were, like his forfeited estates in Norfolk, farmed by William de Noyers. They were both extensive and important, and included three manors in Bungay, in Wangford Hundred, the Samford manor of Bramford, ${ }^{935}$ and the manor of Mildenhall, which King Edward had given to St. Edmund on his first visit to the abbey in $1044 .{ }^{236}$ Stigand held Mildenhall of St. Edmund's Abbey during the lifetime of King Edward, and it passed to the Crown in 1070, and was only recovered by Abbot Samson in 1189 , at the cost of 1,000 marks. ${ }^{237}$ Robert Malet, Roger Bigot, and Roger of Poitou had also profited by the archbishop's fall. ${ }^{288}$

The description of the fiefs of eleven lay tenants-in-chief intervenes between the account of the Terra Regis and that of the estates of the Church in Suffolk. 'The land of St. Edmund' heads the list of the fiefs of the ecclesiastical magnates, and occupies considerably more space in the Survey than the Crown lands. The great abbey, a tenant-in-chief in six counties, ${ }^{939}$ had vast possessions in Suffolk. Its estates extended into almost every hundred of the county, ${ }^{240}$ but the chief seat of its power was in the hundreds of Thingoe, Thedwastre, and Blackbourn. The abbot at the time of the Conquest was a Frenchman, Baldwin, ${ }^{241}$ and in spite of the loss of the manor of Mildenhall, and of occasional encroachments on its rights, ${ }^{248}$ the abbey seems to have flourished under the Conqueror. On his first visit to St. Edmundsbury King William had granted the Norfolk estate of Brooke to the monks, ${ }^{243}$ and in Suffolk he gave a freeman and his land at Preston, 'and soke and all customs' to St. Edmund and Abbot Baldwin, and also land at Somerton, while he confirmed King Edward's grant of sac and soke and commendation over the freemen of Wetherden, Harleston, and Onehouse, in the hundred of Stow. ${ }^{244}$ The abbot's jurisdictional privileges, the "six forfeitures of St. Edmund,' and the grant of soke over eight and a half hundreds, have already been mentioned, and the anxious insistence on these privileges in the Suffolk Domesday, especially in connexion with the rights of William, Bishop of Thetford, recalls the earlier rivalry between Abbot Baldwin and William's predecessor Herfast. ${ }^{245}$ The fiscal privileges of the abbey were

23 Dom. Bk. 2866 ; V.C.H. Essex, i, 350-1. For William the Chamberlain, cf. V.C.H. Beds. i, 197.

23 V.C.H. Essex, i, 355. Mr. Round sees in this 'a suggestive case of an Englishman whose lands had been taken from him actually employed by the Crown in a position of trust.'

2s. Dom. Br. 288,289 .

20 Ibid. 2886 ; Dugdale, Mon. iii, 100, $138 ;$ V.C.H. Suff. ii, 58.

w* Cbron. For. de Brakelonda (Camd. Soc.), 33, 34, $123,124$.

Dom. Bk. 313. 'Sibbetuna,' where a woman is called 'homo Stigandi episcopi'; 3216 , 'Soches'; $322 b, 323 b, 330 b$, 'Delham '; $349 b$, 'Resebi.'

saffolk, Norfolk, Essex, Cambridgeshire, Northamptonshire, Bedfordshire.

${ }^{20}$ The exceptions are Lothing and Lothingland in the north-east, Samford and Colneis in the south, and the half-hundreds of Parham and Ipswich.

"V.C.H.Suff. ii, 58.

" Dom. Bk. 284b. "Ex istis habuit sanctus E. commendationem cum omni consuetudine super iiii. integros et iiii. dimidios . . . sed comes R. tenuit eos quando se forisfecit ;' cf. 360b. 'Anhus.' 'Mulcefel'; V.C.H. Norf. ii, 16.

${ }^{24}$ Dom. Bk. $210 ;$ V.C.H. Norf. ii, 13.

us Ibid. 379 ; Freeman, Norm. Conq. iv (2nd ed.), 407, 408 ; (1st ed.), 411.

in Dom. Bk. 359b, 360, 3606 . 


\section{A HISTORY OF SUFFOLK}

also exceptional. When Danegeld was levied in the hundred, St. Edmundsbury paid 25 per cent., or $5^{5}$. in the pound, which was appropriated to the use of the monks, while a corresponding sum was apparently laid upon Sudbury, to make up the tax due to the king. ${ }^{246}$ Although in 1086 the later 'borough' of St. Edmund still only ranked as a 'vill' (villa) the description of it in the Domesday Survey is peculiarly interesting, as an illustration of the way in which a town might spring up round a great monastic centre. The 'mensal' land immediately surrounding the abbey, which was charged with the provision of the monks' food (ad victum monachorum), ${ }^{247}$ was occupied in the days of King Edward by I 8 tenants (bomines) who could give and sell their land, with fifty-two bordars under them, and by freemen and almsmen (elemosinarii), also with bordars dependent on them. At the date of the Survey the abbey precincts had extended over land which had been arable before the Conquest, and the terse entry in the Survey is yet full enough to bring up before us a picture of the community, a little world in itself, where the abbot and the brethren formed the nucleus round which gathered a population of clerks, nuns, and poor bedesmen, servants and artisans, bailiffs and soldiers (milites). ${ }^{248}$ The thirteen reeves or praepositi who had houses in the 'vill' and were set over the land, may have administered the outlying estates of the abbey as well as the demesne. ${ }^{249}$ We hear of Orger, the abbot's 'reeve,' who held two freemen at Wickham whom Aluric his predecessor had appropriated, ${ }^{250}$ of the freeman 'Goding the reeve,' who held 90 acres at Oakley and was commended to the Abbot of St. Edmunds, and of 'Bristric, St. Edmund's reeve.' 251 At Southwold, on the east coast, the abbey held a manor which, like St. Edmundsbury, had to provide food for the monks, in particular, apparently, for their fast-days, since it paid a rent of herrings, which had risen from 20,000 under King Edward to 25,000 in 1086. 258 In connexion with this manor occurs the solitary mention in Domesday Book of a beia maris or sea-weir.

The only estates held by Archbishop Lanfranc in Suffolk were also ' mensal' or 'board' lands for the Canterbury monks. Three out of his four manors had been granted to Stigand or to 'Holy Trinity,' Canterbury, before the Conquest, and the fourth had come to the archbishop through an agreement (conventio) with the freewoman Leveva. ${ }^{253}$

Four bishops held in chief of the Crown in Suffolk, the king's halfbrother, Odo of Bayeux, William Bishop of Thetford, Gundulf of Rochester, and Gilbert of Evreux.

The Suffolk fief of Odo, Bishop of Bayeux and Earl of Kent, ${ }^{254}$ is almost entirely composed of the lands of freemen who before the Conquest had been bound to their over-lords by sac and soke and commendation or by commendation alone. Part of these estates had been held by William

${ }^{246}$ Dom. Bk. 372 ; 'Quando in hundreto solvitur ad geltum i. libra tunc inde exeunt lx. denarii ad victum monachorum'; Maitland, Dom. Bk. and Beyond, 55, 240; Round, Feud. Engl. 101, n. I 87 ; Sudbury paid 5 s. in the pound and was assessed 2 s 3 leets, or a quarter of a hundred; above, p. 365 .

${ }_{347}$ Dom. Bk. 372 ; Ellis, Introd. to Dom. ii, 488 , seems to have misunderstood this passage.

${ }^{38}$ V.C.H. Suff. ii, $\mathbf{1} \mathbf{1}$.

${ }^{249}$ Cf. Chaucer's monk, who was an 'out-rydere.' Works of Geoffiey Cbaucer (ed. Skeat), iv, 6; v, 19, 20.

${ }^{350}$ Dom. Bk. 37 I.

${ }^{251}$ Ibid. $370 b, 437 b$; cf. $275^{b}$; a steward (dapifer) of the abbot in Norfolk. ${ }^{253}$ Ibid. 3716 .

${ }^{253}$ Ibid. $372 b, 373$; cf. above p. 383 .

as Cf. V.C.H. Essex, i, 342 ; V.C.H. Norf. ii, 17 ; Dom. Bk. 373 , et seq. 


\section{DOMESDAY SURVEY}

Malet and by his son Robert after him, ${ }^{255}$ and three manors had belonged to Earl Ralph, ${ }^{256}$ but most of them seem to have come straight to the bishop, and to have been granted out by him to Roger Bigot, ${ }^{867}$ who retained some of them in his own hands and enfeoffed Ralph de Savigny with others. ${ }^{258}$ Warenger, a tenant of Roger Bigot on his own fief, ${ }^{259}$ here also held some of the bishop's freemen under him, while Tehel de Herion, Ralph de Curbespine, and William de Boeville held directly of Odo himself. ${ }^{260}$ The whole process shows very clearly the sweeping up of the commended freemen of many lords into a compact tenurial group.

The lands of the Bishop of Thetford are divided, as is also the case in Norfolk, ${ }^{261}$ into the Terrae Episcopi, the ancient estates of the see in Bishop's Hundred and in the hundred of Wangford, and the Feudum Episcopi, the estates acquired since the Conquest, by Bishop Æthelmær or Aylmer, who shared his brother Stigand's disgrace in 1070, and was succeeded by Herfast or Arfast. William, who was bishop at the time of the Survey, was only consecrated in 1086. ${ }^{268}$ The manor of Hoxne, Hoxa Episcopi, where there was 'a church which was the seat (sedes) of the bishopric of Suffolk in the time of King Edward,' ${ }^{263}$ was kept by Aylmer in his own hands, and here he held a weekly market on Saturdays, until William Malet established a rival Saturday market in his new castle at Eye, and forced the bishop to change his market day to Friday. ${ }^{204}$ In Wangford Hundred the bishop held the manor of Homersfield, with soke and sac over the ferting of Elmham. ${ }^{265}$ The lands of the 'Fee' (Feudum) consisted of the estates of freemen who had been commended as a rule to Aylmer or to Stigand. Of one carucate in Mendham we are told that 'Ulf the thegn' held it in the days of King Edward, 'afterwards Aylmer and Arfast.' These lands, which, with the exception of 20 acres at Framlingham, were in the hundreds of Hartismere, Bishop's, and Wangford, were held from the bishop by William de Noyers, the 'farmer' of Archbishop Stigand's forfeited estates. ${ }^{266}$

The manor of Freckenham, which had been formerly held by one of Harold's thegns, had been awarded to the bishopric of Rochester by Lanfranc 'by the king's command' ( $j u s s u$ regis). Earl Ralph had 'added 'four freemen whom he had appropriated (quos invasit) to this manor, and though the bishop had the soke over the manor, the Abbot of St. Edmunds kept the soke over these freemen. ${ }^{967}$

The Bishop of Evreux, who here makes his only appearance as a tenantin-chief of the English Crown, held two manors and a few freemen in the

$2 s s$ Dom. Bk. $373 b$; 'Cerresfella,' $374 b$; 'Stanham,' $376 b$; 'Ulvestuna.'

${ }^{256}$ Ibid. 373.

Ibid. $373,373 b, 374,374 b, 375 b, 376 b, 377,377 b, 378,378 b$.

${ }^{230}$ Ibid. $377^{\prime}$; 'Asfelda.' Here we see the freemen of whom Hubert de Port had seised Bishop Odo, who were afterwards under Ralph de Savigny; above, p. 386.

${ }^{259}$ Ibid. 374, 374b, 375, 3776, 338, 3386. For the dispute between Roger Bigod and Roger 'de Ramis,' in which Warenger was involved, cf. Vinogradoff, op. cit. 233 ; above, p. 385.

Dom. Bk. 373, 373b, 374. Ralph de Curbespine held the freemen and manor of 'Brantestona,' which the mother of Earl Morcar had held T.R.E.

V.C.H. Norf. ii, 13,17 ; V.C.H. Essex, i, 339.

V.C.H. Norf. ii, 14, n. 8. Mr. Round points out that "the fact that William was bishop at the time of the Survey gives us an important note of date.'

Dom. Bk. 379 , above p. 358 . This statement is interesting, both on account of the controversy about the seat of the ancient bishopric of Elmham or of the East Angles (cf. V.C.H. Suff. ii, 4, n. 8) and from the peculiar territorial title given to the bishopric.

264 Dom. Bk. 379.

${ }^{200}$ Dom. Bk. 3806 . Stigand was bishop of the East Angles before Aylmer; cf. Dom Bk. 380 . 'Stigandi episcopi.'

sid Ibid. 381 . 


\section{A HISTORY OF SUFFOLK}

hundred of Wilford. Campsey, one of these manors, was claimed by the Abbot of Ely, and is entered in the Inquisitio Eliensis as demesne land. ${ }^{268}$ Next in importance to St. Edmund's Abbey, among the great ecclesiastical landholders in Suffolk, is St. Etheldreda's Abbey of Ely. The Domesday record of its estates can be compared both with the Inquisitio Eliensis and with the Ely placitum of $1072-5{ }^{.69}$ Some of the alienated estates which were claimed in the suit before Geoffrey of Coutances had apparently been recovered, ${ }^{270}$ but, as the Inquisitio shows, the bulk of them remained in the hands of the 'aggressors,' among whom the Bishop of Bayeux, Roger Bigot, Robert Malet, and Roger of Poitou seem to have been the chief offenders. ${ }^{271}$ The abbot, however, successfully asserted his right of soke over five and a half hundreds, which had been encroached upon by Earl Ralph, Roger Bigot, Robert Malet, Ralph Peverel, and many smaller men. ${ }^{272}$ The abbey had lands in every hundred of the county except Blackbourn, Bradmere, Wangford, Lothing, and Lothingland in the north, with Samford in the south. The abbot's chief under-tenants in Suffolk were Roger Bigot, Robert Malet, and Hervey of Bourges.

The Huntingdonshire Abbey of St. Benedict of Ramsey held a single manor in Suffolk, at Lawshall, in Babergh Hundred, and the account of the church fiefs is closed by the description of the small holdings of the Norman Abbey of Bernai and of the Cambridgeshire nunnery of Chatteris. ${ }^{273}$

The names of four great lay feudatories immediately follow the description of the king's land in Suffolk, Count Robert of Mortain, Count Alan of Brittany, Earl Hugh, and Count Eustace of Boulogne.

Robert of Mortain, the Conqueror's half-brother, succeeded Count Brien of Brittany ${ }^{274}$ in his Suffolk fief, which had been largely built up from the lands of the freemen of the Abbot of Ely, Bishop Aylmer, King Edward, and Harold. The depression of the free English tenantry by their Norman lords is seen in the manor of Combs (Cambas), where the rent had nearly doubled, and the freemen 'could not endure it without ruin (confusio).' We see, also, Count Brien assuming rights of private jurisdiction, ${ }^{275}$ and Nigel, a sergeant (serviens) of Count Robert, adding church lands to Stow Manor, and transferring the Stow parishioners to the church of Combs. But Robert could give as well as take. The next two entries tell of land which he had granted to the Norman Abbey of St. Mary of Grestein. ${ }^{276}$

Count Alan of Brittany or Penthièvre, the chief landowner in Norfolk, ${ }^{277}$ had considerable estates in Suffolk also. Much of his land had been held by Earl Ralph, or by Ralph the Staller, or by freemen under Ralph's commenda-

${ }^{968}$ Dom. Bk. $388 b$; Inq. El. (Rec. Com.), $519 a$.

${ }^{969}$ Dom. Bk. 38 I b et seq.; Inq. El. (Rec. Com.), 517, et seq.; Inq. Co. Camb. (ed. Hamilton), I92-5 ; Round, Feud. Engl. 459 ; V.C.H. Norf. ii, 16.

${ }_{270}$ Dom. Bk. 383, 'Dermodesduna,' 'Horswalda ;' 3836 , 'Bercham,' ' Escarletuna,' ‘Westrefelda ;' 385 ,

'Wineberga,' an undecided case, 'Staham ;' 3856 , Tremlega, Waletuna, 'Kenebroc ;' 388 , 'Hou ; ' cf. Ing.

Co. Camb. (ed. Hamilton), r93-5; above, p. 386 .

${ }^{271}$ Ing. El. (Rec. Com.), 51 7-22.

${ }^{873}$ Inq. Co. Camb. (ed. Hamilton), 194 ; Inq. El. (Rec. Com.), 517 et seq.; Dom. Bk. $385 b$; above, p. 387.

${ }^{273}$ Dom. Bk. 3786, 389. The Abbot of Bernai had, like the Abbot of Ely, profited by the forfeiture of

Hardwin ; cf. Dom. Bk. 383 , 'Berchingas;' Round, Feud. Engl. 23.

${ }^{77}$ Freeman, Norm. Conq. iii, 230, 231,315 ; iv, 243 ; Dom. Bk. 291.

${ }^{975}$ Ibid. 291, 2916; above, p. 388. For 'Cambas,' cf. Vinogradoff, op. cit. 298, 434.

${ }^{26}$ Dom. Bk. 3916 ; cf. ibid. i, 2226 ; V.C.H. Northants, i, 286.

${ }^{\prime 7}$ V.C.H. Norf. ii, 17 ; V.C.H. Essex, i, 350. 


\section{DOMESDAY SURVEY}

tion or soke, ${ }^{278}$ but much of it came from the thegns and freemen of Earl Gurth, from Edric Grim, Edric of Laxfield, and Edith the Fair, ${ }^{979}$ and from the abbeys of St. Edmund and Ely. In Ipswich, Alan seems to have acquired Gurth's comital rights, the third penny of the borough, and part of the profits arising from the pleas of the shire. ${ }^{880}$

The fief of Hugh of Chester was also composed of the estates of English or Danish thegns and freemen, ${ }^{281}$ and here, as in Norfolk, Roger Bigot seems to have held some of the forfeited lands of Walter of Dol of the earl. ${ }^{289}$

The antecessor of Count Eustace of Boulogne in the hundreds of Lackford and Stow was Ingelric or Engelric, the priest and 'commissioner of lands.' ${ }^{28 s}$ In Risbridge and Samford Hundreds he succeeded Leuric the thegn, two freemen, and a freewoman, while at Rattlesden, in the hundred of Thedwastre, he had encroached on the lands of the abbey of Ely. ${ }^{284}$

Although Robert Malet, whose fief is surveyed immediately after that of Count Eustace, was not of comital rank, he was one of the most powerful of the Suffolk magnates. His father, William Malet, is repeatedly mentioned in the Domesday Survey as a Suffolk landholder and the successor of the Saxon Edric of Laxfield. ${ }^{285}$ He held an important position in the county early in the reign of William the Conqueror, and was the founder of the great honour of Eye. ${ }^{286}$ In the manor of Eye, which had belonged to Edric of Laxfield under King Edward, he built a castle and established the market which brought him into competition with Bishop Aylmer. ${ }^{287}$ He was dead at the date of the Survey, but the manner of his death is uncertain. He may have fallen, as the Suffolk Domesday distinctly asserts, ' on the king's service,' ${ }^{288}$ or he may have found a more peaceful end as a monk of Bec, ${ }^{899}$ though this seems hardly compatible with the fact that he was seised of lands and men 'on the day of his death.' ${ }^{290}$ His widow survived him, and held estates in the hundreds of Bosmere, Claydon, Wilford, Hartismere, Loes, and Bishop's, including the lands of 'the queen's fee' in the hundreds of Bishop's and Hartismere, ${ }^{291}$ and 100 acres of Robert's demesne at Eye, the caput of his barony, in which we are tempted to see her dower farm. "The claims in dispute between the Bishop of Bayeux

"18 Dom. Bk. 292b, 293, 294b, 295, 297, 2976.

"n She was also his 'antecessor' in Herts. and Cambs.; V.C.H. Essex, i, 350 ; Dom. Bk. i, 193b, et seq.; 1366 , et seq.

's00 Ibid. 294, 294b, 'Cum tercio denario de duobus hundretis.'

283 Ibid. 1 52, 153,299b, 321 b, 322. Mr. Round thinks it probable that Walter of Dol was a Breton who lost his lands at the time of the revolt of the earls. V.C.H. Norf. ii, 10.

Dom. Bk. 303 ; above p. 386 ; V.C.H. Essex, i, 343, et seq.

${ }_{2 s}$ Dom. Bk. 303 ; Inq. El. (Rec. Com.), $517 a$.

Dom. Bk. $148 b, 305,312 b, 313,332 b, 373 b, 376 b, 379,440 b, 441,442 b, 443 b, 444$.

${ }^{200}$ Round, Feud. Engl. 429,430 . From the fact that a writ of William I relating to Suffolk is addressed to Bishop Ethelmær, Abbot Baldwin, and W. Malet, Mr. Round has argued that William 'held a position in Suffolk ... analogous to that of sheriff,' and has suggested that 'he may have succeeded Northman in that office.' Robert Malet was sheriff in Suffolk at a later date; above, p. $389 . \quad$ 2S7 Above, p. 393.

${ }^{255}$ Dom. Bk. 332b, 'Quando ivit in servitium regis, ubi mortuus est'; cf. $133 b, 189,276 b, 294,373 b$, $376 b, 380 b, 407,440 b, 442 b, 443 b, 444$.

V.C.H. Norf. ii, 17 ; Freeman, Norm. Cong. iii (2nd ed.), n. PP ; iv (2nd ed.), n. W ; v (1st. ed.), 39. Round, op. cit. 329, 331, 429,430; Academy, 26 Apr. 1884. The mention of the monk William Malet is in Lanfranc, OPp. (ed. Giles), i, 341.

Dom. Bk. $276 b, 440 b, 442 b, 443 b, 444$.

m Apparently land with which the queen had enfeoffed Robert ; cf. Dom. Bk. I 55, where Robert Malet's mother held land at Borston which Robert had received 'ex dono regine.' 


\section{A HISTORY OF SUFFOLK}

and Robert Malet's mother' have a section to themselves at the end of the Suffolk Survey. ${ }^{292}$ Robert Malet's fief was of great extent, though some of his father's possessions had passed into other hands, and he was not the sole successor of Edric of Laxfield. ${ }^{293}$ He had estates in seventeen and a half hundreds, and held the boroughs of Eye and Dunwich, ${ }^{294}$ with the lands of many an English thegn and freeman. Among the under-tenants to whom Robert had granted out these estates were Walter Fitz Aubrey, himself a tenant-in-chief of the Crown, Robert de Glanville, William Gulafra, and Walter of Caen. ${ }^{295}$

A Norman under-tenant might, like Robert de Glanville, hold lands in various parts of the county, as the representative of many free English landholders, ${ }^{296}$ or the lands of a wealthy Englishman might be divided up among several Normans, as with the estates of Godwin Alfer's son, a tenant of the king in Babergh Hundred and of the queen in Carlford Hundred, who was succeeded by Hubert, Walter Fitz Aubrey, and Humphrey son of Robert. ${ }^{297}$ Sometimes the change of lords made for simplification, as at Wyverstone, where Hubert took the place of a freeman commended to Edric of Laxfield, with a wife commended to the Abbot of St. Edmunds, and of a group of three freemen and their mother, also commended to two overlords. ${ }^{298}$ But in the majority of cases a fresh link was inserted in the feudal chain, and the English freeman, if he remained on his holding at all, remained as the tenant of a Norman under-tenant. Where Godwin 'Alsies sone,' Queen Edith's thegn, had held, presumably of the Crown, before the Conquest, Hubert now held of Robert Malet, who held of the king, and where Cus, a freeman commended to Edric of Laxfield, held 90 acres as a manor, Walter held of Malet and two freemen with 14 acres had been added to the estate. ${ }^{299}$ The succession to Edric of Laxfield, who had been outlawed by the Confessor and then pardoned and restored to his lands, led to disputes which are interesting from the light which they throw on the position of English freemen before the Conquest and on post-Conquest judicial procedure, ${ }^{300}$ and before leaving Robert Malet it may be noted that among his under-tenants was Walter son of 'Grip,' a name which recurs frequently in Domesday Book. ${ }^{301}$

The fief of Roger Bigot, the founder of the second house of East Anglian earls, is surveyed immediately after the lands of Robert Malet. ${ }^{30}$ Its distinctive characteristic in Suffolk, as in Norfolk, is the large number of freemen who held under the earl. They have a special section of the Survey to themselves, ${ }^{303}$ and it is possible that, as many of them had previously been under William and Robert Malet, or commended to the sheriffs Toli and

${ }^{299}$ Dom. Bk. 450.

${ }^{293}$ Ibid. $349 b, 432 b, 433,435,437 b, 438,439,440 b, 441,441 b, 442 b, 443,443 b, 444$.

294 Below, p. $410,411$.

${ }_{295}$ Dom. Bk. 304, 304b, 305, 306, 306b, 310, 311, 312b, 31 3, 31 3b, 314, 31 7, 318, 319, 319b, 320, $324 b, 325 b, 327,329 b$. William de Arcis, the Crown tenant-in-chief, was also a tenant of $\mathbf{R}$. Malet. For Walter of Caen and his connexion with the Stuarts and the Chesney's, cf. V.C.H. Norf. ii, 21, n. I1.

${ }^{296}$ Dom. Bk. 304, 304b, 308b, 309, 315b, 317b, 319, 327, 329.

297 Ibid. 304,3146 .

${ }^{299}$ Ibid. $306,3076,308$.

${ }^{300}$ Ibid. $310 b, 313,332,342 b$; cf. $179 b$. Freeman, Norm. Conq. v (Ist ed.), 799.

${ }^{201}$ Dom. Bk. 329, $329 b$; i, 78, 83b; cf. 'Wilgrip,' i, 249b, 254, $258 b$; ii, 404b, and 'Guillegrip' one of Henry I's 'Novi Homines'; Ord. Vit. Eccl. Hist. xi, chap. 2.

${ }^{202}$ Dom. Bk. $330 b$; V.C.H. Norj. ii, 19.

${ }^{\text {sos }}$ Dom. Bk. 3336,344 . 


\section{DOMESDAY SURVEY}

Norman, or held by a 'Norman,' who may be the ex-sheriff, have acquired the lordship over them in connexion with the East Anglian shrievalty.

Among Roger Bigot's predecessors by commendation or tenure are found Edric of Laxfield, the two Malets, Toli and Norman, the Englishmen Burchard and Lewin, and many other English or Danish freemen, among them one who had been reeve of Ipswich. ${ }^{305}$ His under-tenants included Stannard, probably the tenant-in-chief of that name, ${ }^{308}$ Hugh de Hosdenc, Robert and Hugh de Curcun, Godric Dapifer, Robert de Vallibus, Norman, Warenger, and Aitard. ${ }^{307}$ At Bulcamp he held a manor 'of the king's gift,' which had formed part of the forfeited estates of Earl Ralph. ${ }^{308}$

After Roger Bigot comes Roger of Poitou, ${ }^{309}$ with large and widelyscattered estates. He seems to have encroached considerably on the rights of the Abbot of Ely, and to have gathered many of St. Etheldreda's freemen into his fief. His freemen had been commended also to King Edward, to Harold, to Gurth, to Earl Algar (Elfgar), to Stigand, and to Edric of Laxfield. He held, too, woodland which had come to him from that 'Raymond Giralt' by whose aggressions he had benefited in Essex. ${ }^{.10}$

William de Scoies, Hermer de Ferrières, and Ralph de Bella Fago held in both the East Anglian counties. ${ }^{\text {s1 }}$ William's antecessores in Suffolk were Aluric a thegn, Aluric a freeman, and Wluric a freeman-possibly all the same person. Huard de Vernon and Robert de Vallibus held of William. Hermer de Ferrières had succeeded to the manor of Osmund a freeman at Barningham, in Blackbourn Hundred, and Ralph de Bella Fago held the lands of a number of commended freemen in the hundreds of Wilford and Hartismere. Frodo brother of Baldwin, Abbot of St. Edmunds, who held also in Essex, had a composite fief. Algar, a tenant of Siward or Seward of Maldon, a great Essex thegn, was among his antecessores, and his Lavenham manor came from St. Edmund, and could not be sold without the Abbot's leave. ${ }^{318}$ Godric Dapifer, who farmed the forfeited estates of Earl Ralph, held a small fief in his own right, composed of the lands of freemen, of whom one, Godric, had formerly held under Ralph the Staller. Perhaps the 'Edwin freeman' whom he succeeded at Blyford is Edwin, King Edward's thegn, who is also called Edwinus liber bomo, who was Godric's antecessor in Norfolk. ${ }^{313}$

After the description of the Church lands comes the account of the fief of one of the most noteworthy of Suffolk magnates, Richard Fitz Gilbert, or, as the Suffolk Domesday once calls him, 'Richard de Clare,' 114 the founder of the great family of De Clare. He was the son of Count Gilbert of Brionne, and came to England with the Conqueror. He received some hundred and seventy English lordships as his share of the spoils of conquest,

201 Dom. Bk. $333^{b}$ et seq. On 333 'Norman the thegn' is mentioned; cf. ibid. Ailward the king's reeve.

Ibid. 337b. Belham.

Ibid. 330 . Alwi or Ailwin of Thetford had held this land T.R.E.

207 Ibid. 331 et seq. Aitard had held of Stigand.

s03 Ibid. 333 .

Ibid. $345 b$ et seq.

n10 Ibid. 3506 ; V.C.H. Essex, i, 354 ; Round, The Ancestor, i, 127.

si Dom. Bk. 353 et seq. ; V.C.H. Norf. ii, 19, 20.

${ }^{123}$ Ibid. $355^{b}$; V.C.H. Norf. ii, 19 ; Dom. Bk. 175b, 202b, $203,203 b$.

12 Dom. Bk. $354^{6}$.

sis Ibid. 3896 et seq. $44^{8}$. Ricardus de Clara. 


\section{A HISTORY OF SUFFOLK}

of which ninety-five, with the castle of Clare, the caput of the later honour, were in Suffolk. ${ }^{815}$ He was chief justiciar in 1075, and was active in the suppression of the revolt of the earls, but he does not seem to have received any of Earl Ralph's estates. He held lands in the hundreds of Risbridge, Babergh, Cosford, and Samford, on the Essex border, and also in the hundreds of Thingoe, Thedwastre, Lackford, Blackbourn, Hartismere, Bosmere, Claydon, Stow, and Wilford, and in the borough of Ipswich. He had estates in Essex also, but the centre of his influence was in Risbridge Hundred, where, just on the Suffolk side of the line which divides the county from Essex, still lies the market town of Clare, with the moated mound of the castle. $^{316}$ Richard Fitz Gilbert's two chief antecessores were Wisgar or Withgar, son of Ælfric or Aluric, and 'Phin the Dane.' Ælfric, the father of Wisgar, and himself the son of an older Wisgar, was an Essex thegn and lord of the manor of Clare, which he gave to 'St. John,' placing a priest Ledmar over the religious house which he founded, and committing it by charter to the care of his son Wisgar and of Leustan or Leofstan, Abbot of St. Edmunds. ${ }^{317}$ When King William came he took the foundation into his own hands and granted the whole property to his favourite, Richard Fitz Gilbert. 'Phin the Dane' had held an 'honour' in Suffolk, and, like Wisgar, he continued in power after the Conquest, and, as Mr. Round has pointed out, ' even in 1086 his widow was holding in Essex 2 manors, of which one at least had previously been held by her husband.' ${ }^{18}$ In Suffolk he had 80 acres at Wattisham in Cosford Hundred and a small estate at Shelland in Stow Hundred, thirteen burgesses in Ipswich, who belonged to his 'honour,' and a manor at Badley in Bosmere Hundred, where he held twenty-six freemen, who had been added to the manor under King William 'by arrangement with the sheriff, as the sheriff himself says.' At Ringsett also, and at Ash (Bocking), in the same hundred, he had added freemen and a sokeman to his manors, and we hear of his 'fee' (feudum). At Helmingham in Claydon Hundred and at Erwarton in Samford Hundred, Turi, a thegn of King Edward, had held two manors 'of Phin's land' which in 1086 were held of Fitz Gilbert by Walter of Caen and Roger; at Boyton a commended freeman of Phin is mentioned, while at Higham and at Burstall Richard claimed freemen and lands as part of the 'honour' or 'terra' of Phin. ${ }^{319}$ Of Fitz Gilbert's under-tenants it is worth noting William Peche (Peccatum), who held also in Norfolk, ${ }^{320}$ Walter the Deacon, and Osbern de Wancy; while Roger 'de Ramis' and Ralph Peverel disputed Richard's title to his estate at Bricett in the hundred of Bosmere. ${ }^{321}$ The survey of his fief concludes with a list of the freemen in the hundreds of Risbridge and Cosford

${ }^{315}$ Dom. Bk. 3896 et seq. Dict. Nat. Biog. articles 'Clare, De, Family of,' 'Clare, Richard De'; Freeman, Norm. Cong. iv (Ist ed.), 580 ; v (Ist ed.), 430. He is often called Richard de Bienfaite.

${ }^{316}$ V.C.H. Essex, i, 348.

317 Dom. Bk. $389 b$; V.C.H. Essex, i, 348 ; Freeman, op. cit. v (Ist ed.), 753. The alternation of names in this family is worth noting. Grandfather and grandson bear the same name, as is also the case with the 'lawmen' of Lincoln, a Danish district ; Dom. Bk. i, 336.

${ }^{318}$ V.C.H. Essex, i, 348 ; Dom. Bk. 98, 98b, 'Terra Ulveve uxoris Phin.'

319 Dom. Bk. 391, 392b, 393, 393b, 394, 394b, 395, 395b, 'Hecham, Burghestala,' 'ad honorem phin ;' 'ad terram fin.'

${ }^{320}$ Ibid. $390 b$; V.C.H. Norf. ii, 2 1. He was 'the forefather of an East Anglian house.' The name occurs in Suffolk in the $13^{\text {th }}$ century; Rot. Hund. ii, $151 a, 173 a$.

${ }^{321}$ Dom. Bk. 391, 3936, 394. Esgar the Staller is also mentioned as the former lord of one of Richard's freemen; ibid. 395. 


\section{DOMESDAY SURVEY}

who had been under the commendation and soke of Wisgar in the time of King Edward. ${ }^{392}$

William de Warenne, a great landowner in Norfolk and in Sussex, ${ }^{323}$ takes a less prominent place in the Suffolk Domesday, where, however, the same distinction is made as in the Norfolk Survey between the land which he held of the fee of his brother Frederic and that which he had acquired by 'the Lewes exchange.' ${ }^{324}$ His Suffolk fief was composed of the lands of English thegns and freemen, of whom one, the thegn Toka, was Frederic's antecessor in both Norfolk and Suffolk. ${ }^{395}$ Among his under-tenants may be noted Robert de Glanville and Robert and Godfrey de Petro-ponte, whose name survives at Hurstpierpoint in Sussex. William de Warenne had also succeeded to some of the estates of Edric of Laxfield and William Malet, which were claimed by Robert Malet. ${ }^{326}$ Suane of Essex, his father Robert, and his grandmother Wimarc, belong to the history of Essex, where both Robert and Suane held the office of sheriff. Nearly all Suane's Suffolk estates had been held by his father. They were chiefly in the south of the county, but he held a few acres in Thingoe Hundred. Of his father's forty-one Ipswich burgesses fifteen were dead, and even over these Suane had lost the commendation, though he retained the soke and sac. ${ }^{327}$ Eudo the Steward (Dapifer), the son-in-law of Richard Fitz Gilbert, was a tenant-in-chief of the Crown in the three eastern counties, ${ }^{328}$ and in all three he succeeded Lisois de Moustiers, ${ }^{329}$ whom we find encroaching on the rights of Ely Abbey at Lakenheath and at Brandon. ${ }^{330}$ He succeeded also Godwin, a thegn of King Edward, Canut, Earl Algar's freeman, Edric of Laxfield and William Malet, and Aluric Campa, who was the antecessor of Eudo in Essex and Cambridgeshire as well as in Suffolk. ${ }^{331}$ The brothers Roger and William of Otburville, or Oburville, held composite fiefs built up from the estates of thegns, sokemen, and freemen..$^{338}$ One of Roger's predecessors, the thegn Gutmund, brother of Uluric or Wulfric, Abbot of Ely, was also the antecessor of a more important Suffolk landowner, Hugh de Montfort, who succeeded him at Nacton, Livermere, Occold, Dagworth, and in the manor of Haughley (Hagala), ${ }^{333}$ the caput of the later honour of Haganet or Haughley, the Honor Constabularie. This honour was connected with the constableship of Dover Castle, where in the attack of 1067 Hugh de Montfort was in command. The office passed to Robert de Vere, the son-in-law of Hugh de Montfort, and then to Henry of Essex, son of Suane of Essex and grandson of Robert Fitz Wimarc. ${ }^{334}$ Hugh de Montfort's chief under-tenant was Roger de Candos; Burchard, Gurth, 'Edith the rich,' Edric of Laxfield, and William Malet are mentioned among the former lords of the numerous freemen who

${ }^{m}$ Dom. Bk. 3956 et seq.

24 Dom. Bk. 398, 398b; above, pp. $381-2$.

m Dom. Bk. 3996 .

${ }^{2 m}$ Ibid. 401 et seq.; V.C.H. Essex, i, 345 ; Round, Feud. Engl. 168; Freeman, Norm. Conq. iv (1st ed.), 736.

${ }^{218}$ Dom. Bk. $402 b$ et seq.; V.C.H. Essex, i, 347-8; V.C.H. Norf. ii, 20.

${ }_{39}$ Round, Feud. Engl. 460 ; Freeman, Norm. Comp. iv (Ist ed.), $286 ; \mathrm{v}$ (1st ed.), 30. Lisois was 'the hero of the passage of the Aire.' He had lands in Cambridgeshire and Bedfordshire, where he was also succeeded by Eudo 'Dapifer.'

20 Dom. Bk. 403 ; Ing. El. (Rec. Com.), 5176 ; Round, op. cit. 32.

Dom. Bk. $402 b, 403,403 b ;$ V.C.H. Essex, i, 353.

220 Ibid. $405 \bar{b}$ et seq。; $\boldsymbol{V}$.C.H. Essex, i, $346 ; \boldsymbol{V}$.C.H. Norf. ii, 20.

324 Round, Commune of Lond. 278-82; Geofrey de Mandeville, 326-7, 388-96; Freeman, Norm. Conq. iv (2nd ed.), $73,114-16$; cf. Dom. Bk. 3016 , where 'W. Cunestabla' is mentioned.
${ }^{3 s}$ Dom. Bk. $403 b$ et seq. 


\section{A HISTORY OF SUFFOLK}

had been gathered into his fief, and he held much land in demesne. At Rushmere Walter of Douai, who 'made forfeiture,' seems to have been a tenant of Montfort; ${ }^{335}$ at Thorney there was a dispute over a small estate of crown land mortgaged by Toli the Sheriff to Ralph the Staller, which had come to Hugh after Earl Ralph's forfeiture, and had been granted by him to Roger de Candos. ${ }^{336}$ At Dagworth Hugh had received by exchange an estate which had belonged to Breme, a freeman who was killed at the battle of Hastings (in bello bastingensi). ${ }^{337}$

Geoffrey de Mandeville belongs specially to Essex, where his descendants ruled as earls. His antecessor in Suffolk, as in Essex, was Ansgar or Esgar the Staller, ${ }^{338}$ whom he succeeded at Holton and Raydon; he held also the lands of Witgar, Haldein, and other Englishmen, thegns and freemen of the Abbot of Ely, King Edward, Stigand, Ralph the Staller, and Edric of Laxfield. William son of Sahala de Bouville was his principal under-tenant.

Ralph Baignard or Baynard, Sheriff of Essex, succeeded Ailad or Ailith, a Saxon freewoman, in the important manors of Kedington and Shimpling. She was also his predecessor in Essex and Norfolk. His other antecessores in Suffolk were Godwin the Thegn and Toret or Tored, with the freeman Alwin and the freewoman Elflet. ${ }^{339}$ Ralph was connected with London through 'Baynard's Castle,' to which, under his I 3 th-century representatives, the Fitz Walters, his Suffolk manors of Shimpling and Poslingworth seem to have rendered castle-ward. ${ }^{340}$ The mention in the Ely placitum of Rotbertus bomo Bainardi in Ralph's holding of Reydon makes it probable that 'Bainard' was the Christian name of the father of the Domesday tenant in chief. ${ }^{341}$

Ranulf Peverel was the successor in Suffolk and in Essex of Siward or Seward of Maldon, a great thegn, and in Suffolk, Essex, and Norfolk of Ketel, a thegn of King Edward, while 'Saxo' is frequently referred to as his antecessor in Suffolk; Garin, or Warin, his under-tenant at Glemsford, held land from him in Norfolk, which in the I 4th century was still in the Peverel family. ${ }^{342}$

Of those tenants-in-chief who held estates in all the three eastern counties, we may also notice Robert Grenon, the successor of Harold's thegn and house-carl Scapi or Scalpi, Peter of Valognes, Sheriff of Essex and of Hertfordshire, who married the sister of Eudo Dapifer, ${ }^{343}$ and in Suffolk succeeded Alestan the thegn and Alti and Ketel, liberi bomines teigni, and Roger 'de Ramis' or 'de Raimes,' whose fief included lands held before the Conquest by freemen commended to Earl Algar, Edric of Laxfield, Gurth, Stigand, and Ranulf Peverel's predecessor Saxo. ${ }^{344}$ The story of the division of the lands of the Englishman 'Brictmar,' a thegn, as we learn from the Essex Survey, and the antecessor of Ranulf brother of Ilger and of Ralph

${ }^{335}$ Dom. Bk. $408 b$; Freeman, Norm. Cong. v (Ist ed.), 800 ; V.C.H. Essex, i, 350.

${ }^{336}$ Dom. Bk. $409 b$; cf. above, p. 382.

${ }^{338}$ Ibid. $4 \mathrm{I}$ I et seq.; $V$.C.H. Essex, $\mathrm{i}$, 343. 'The Honour of Ansgar' is mentioned in Dom. Bk. 4126.

${ }^{339}$ Dom. Bk. $413 b$ et seq.; V.C.H. Essex, i, 346, 347 ; V.C.H. Norf. ii, 20.

${ }_{340}$ Rot. Hund. (Rec. Com.), ii, 142-6 ; 'baronia Castelli Baynard,' 1506 , 1519 ; 'honor Castri Baynard,' 1716 , 173a, 174a ; 'feodum Bainnard.' Some of Ralph's Essex manors subsequently owed castle-ward to. Baynard's Castle ; V.C.H. Essex, i, 346, 347.

${ }_{341}$ Round, Feud. Engl. $46 \mathrm{I}$; Inq. Co. Camb. (ed. Hamilton), 195.

${ }^{42}$ Dom. Bk. $415 b$ et seq ; V.C.H. Norf. ii, 20 ; V.C.H. Essex, i, 346.

${ }^{34}$ Dom. Bk. $419^{b}$ et seq. ; V.C.H. Essex, i, $347,349,352$; V.C.H. Norf. ii, 21.

sm Round, Geofrey de Mandeville, 399 ; cf. Dom. Bk. 337b. 


\section{DOMESDAY SURVEY}

Pinel, has enabled Mr. Round to 'throw light on the devolution of an Essex thegn's estates,' to 'identify a thegn as a landowner in Essex and Suffolk,' and to 'obtain a good instance of an Englishman having not one but several aliens as his successors.' ${ }^{445}$ Brictmar's estates were divided into three portions, of which one, in Suffolk, fell to Ranulf Ilger's brother; one, in Suffolk and Essex, was granted to Ralph Pinel ; and the third, in Essex, was given by the king to Ingelric, and was in the possession of Ingelric's successor, Count Eustace, in 1086 . In 'Lewin of Bagatona' (Bacton), King Edward's thegn, the predecessor of Walter the Deacon in Suffolk, Mr. Round sees not only the 'Leofwine Cilt' whom Walter succeeded in Essex, but the Lewinus cilt liber bomo whose estates at Ulverston in Claydon Hundred were held by Roger Bigot of the Bishop of Bayeux. ${ }^{346}$ In Essex and Suffolk alike Walter the Deacon had succeeded his brother Thierri or Theoderic. ${ }^{347}$ Robert 'filius Corbutionis' and Tehel de Herion the Breton were of more importance in Essex than in Suffolk, and Ralph de Limesi, who held estates in ten counties, had only six manors and two berewicks in Suffolk, with the land of a few commended freemen. ${ }^{349}$ The Norfolk tenants-in-chief, Dreux de Beuvrières and Robert de Verli, held a single manor each in Suffolk, ${ }^{349}$ and Eudo son of Spiruic succeeded Henfrid of St. Omer in both Norfolk and Suffolk. ${ }^{350}$ Among. the remaining tenants-in-chief may be noticed Isaac, ${ }^{361}$ Juichell the Priest, and the king's two crossbowmen, Gilbert and Ralph, all of whom were Norfolk landholders, ${ }^{362}$ Norman the Sheriff, with his two burgesses in Ipswich ${ }^{353}$ and the small estate which he held of Robert Malet at Ash in Loes Hundred, the Breton Rainold, who held of the king 'in alms,' the Englishmen Gondwin the Chamberlain and Stannard son of Alwi, who also. held land in Essex, and Ulmar, possibly the 'Ulmar praepositus' of a later entry, from whose father Roger the Sheriff had received a heriot. ${ }^{354}$ The list closes with the land of the vavasours, of whom it may be noted that they all bear English or Danish names, the land of 'the freemen of Suffolk who remain in the king's hand,' the encroachments (invasiones) on the king' territorial rights and a record of the claims in dispute between the Bishop of Bayeux and the mother of Robert Malet. ${ }^{365}$

With the king's vavasours and freemen we pass from the tenants-in-chief to the lesser men, the mesne tenants, thegns and milites, clergy, burgesses, freemen, sokemen, and the unfree peasantry, villeins, bordars, and serfs. Of the smaller military tenants we hear but little. Some thirty-four thegns are mentioned by name in the Suffolk Domesday. They held before the Conquest of King Edward, of Queen Edith, and of Harold, and their lands had been absorbed by 1086 in the great Norman fiefs, but it is worth noting that the same man may be called teinus in one passage and simply liber bomo in another, and we even find the combination of liberi bomines teigni, ${ }^{356}$

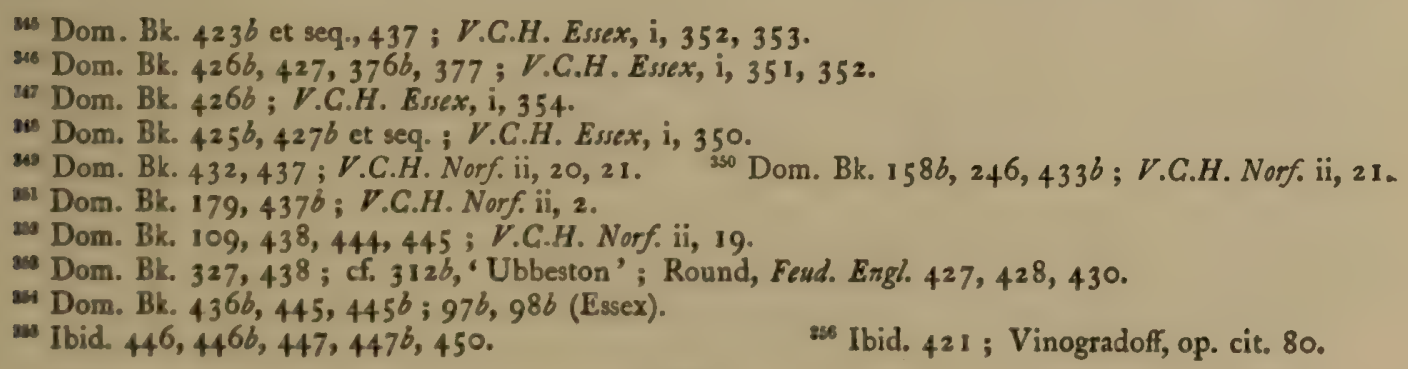




\section{A HISTORY OF SUFFOLK}

while we learn from the Essex Survey that Scalpi, Harold's thegn, was a 'house-carl.' ${ }^{357}$ The house-carls, Aschil and Ingulf, appear as the lords of commended freemen in Carlford Hundred, ${ }^{358}$ but the thegn and the house-carl were giving way before the knight, the miles, and the new Latin term is found in Suffolk applied to the thirty-four milites, French and English, of St. Edmund at St. Edmundsbury, ${ }^{359}$ who had twenty-two bordars under them, to the two milites who held freemen and their land at Ashfield, ${ }^{360}$ and to the miles with the Danish name of Ulfin who held Ingham as a manor under St. Edmund in the days of King Edward. ${ }^{361}$ The miles, like the teinus, is sometimes described by other terms: Humphrey son of Roderic, who is called the man (bomo) of William of Warenne in Domesday Book, is entered in the record of the Ely placitum as Humfridus miles de Will. de Warenna. ${ }^{362}$ We hear also of Nigel, a serviens of the Count of Mortain, ${ }^{363}$ of Berner the crossbowman of St. Etheldreda, and of Walter the crossbowman, as well as of the king's crossbowmen, Gilbert and Ralph. ${ }^{364}$

Of the Suffolk clergy, with their churches and glebe land, we learn a good deal from Domesday, but the passages relating to them are somewhat vague and fragmentary. The area of the glebe is usually given, and sometimes the tenants and plough-teams are added, but though the worth of the church and its land is frequently stated, it is also often included in the general valuation of the manor. ${ }^{365}$ There can be little doubt that the churches enumerated in the Survey fall short of the total number in the county, but the occurrence of such uncertain entries as pars ecclesiae, quedam aecclesia, quaedam pars trium ecclesiarum, ${ }^{366}$ with the subdivision of the ownership of churches, makes it impossible to reckon up precisely even those which are actually mentioned. ${ }^{367}$ A good example of the division of churches among several lords is seen at Debenham, in the hundred of Claydon, where Robert Malet had to 'defend' or answer for two parts of the church of St. Mary with its land and a quarter of the church of St. Andrew, while the remaining portions, held before the Conquest by the freeman Godwi, and Saxo, the lord to whom he was commended, had passed in 1086 into the hands of the Bishop of Bayeux and Ralph Peverel. ${ }^{368}$ At Ringsfield, in Wangford Hundred, the king had part of a church with 20 acres, and others shared it with him. ${ }^{369}$ The phrase, 'Several persons have shares therein' (plures ibi participantur; plures babent partem) occurs fairly often, ${ }^{370}$ and we read of a church which had 15 acres 'out of four demesnes' (dominationibus). ${ }^{371}$ The church may, however, be identified with the vill or with the parish. In Thedwastre Hundred Barton and Pakenham and Fornham and Rougham and Bradfield all had their 'village

${ }^{357}$ Dom. Bk. 4196,$420 ;$ V.C.H. Essex, i, 352.

${ }^{358}$ Dom. Bk. $44^{1} b, 44^{2}$. 850 Ibid. 372.

${ }_{360}$ Ibid. 439. Had these milites taken the place of Achi and Ketel, 'liberi homines teigni'? 'Achi' and 'Chetel,' 'liber homo,' had held manors in Ashfield T.R.E.

${ }^{361}$ Ibid. 364 ; Vinogradoff, op. cit. 74 et seq.; Maitland, Dom. Bk. and Beyond, 16 I et seq.

${ }^{362}$ Dom. Bk. 381 b, 'Ratesdane'; 398 , 'Ratesdana'; Inq. Co. Camb. (ed. Hamilton), 194, 'Ratlesdene.

${ }^{363}$ Dom. Bk. $291 b$.

${ }^{365}$ Ibid. ; $374^{b}$, 'Stanham '; 375 , 'Burgestala.' 'Codeham,' a church with 3 acres worth 6 d.; a church with 1 acre worth 2d.; $375 b$, 'Uledana.' 'Stanham,' cf. 339, 340, \&c.; 328, 'Totum valet xvi sol.'; cf. V.C.H. Norf. ii, 2 I.

${ }_{366}$ Dom. Bk. $3956,4 \times 7,4366$.

${ }^{367}$ Eillis makes 364 churches in Suffolk; Introd. to Dom. i, 286-7. Dr. Cox brings the total number up to 398 with two chapels; V.C.H. Suff. ii, 9, 10.

${ }_{368}$ Dom. Bk. $305 b, 376 b, 417 b$. R. Peverel had a share in St. Mary's only.

${ }^{969}$ Ibid. 2826 . ${ }^{370}$ Ibid. $326,388 b, 4006$. 371 Ibid. 4176. 


\section{DOMESDAY SURVEY}

churches' (ecclesiae villae), ${ }^{372}$ while at Combs the 'parishioners' (parrocbiani) of the church of Stow had been transferred to Combs Church. ${ }^{373}$ 'The rights of the parish church and the growth of daughter churches or chapels to meet the needs of increasing population are well illustrated on the royal manor of Thorney. Here four brothers, freemen, had built a chapel on their own land near the cemetery of the mother church (mater ecclesia), and had made an arrangement about fees, which is carefully recorded in the Survey. ${ }^{374}$ Another chapel, which had been built at Wissett, in Blything Hundred, was under the parish church, which was served by twelve monks (monacbi). ${ }^{375}$ Of the way in which the Church acquired land there are several interesting examples in the Suffolk Survey. At Stonham 20 acres had been given to the Church by nine freemen 'for their souls.' ${ }^{376}$ St. Edmund's Abbey held land which Gernon de Peiz gave back when he became a monk. ${ }^{377}$ The married priest Edmund gave the land which he received with his wife to the abbey of Ely. ${ }^{378}$ Most of the land held by the Church was 'free land' (libera terra), the 'freedom' probably here referring to exemption from the geld or from military services, ${ }^{379}$ and of a large number of Church estates it is expressly stated that they were held 'in alms' (pro elemosina, in elemosina). ${ }^{880}$ Occasionally, as at 'Lundale' in Lackford Hundred, a church without land (sine terra) is recorded. The clergy could, of course, hold of lay lords and by lay tenure. In Suffolk, in addition to the tenants-in-chief, Juichell the Priest and Walter the Deacon, we may note the freeman, Godric the Priest, commended first to the outlawed Edric, and then the ' man' (bomo) of Norman; Godwin the Priest, the 'man' of Harold; Warin (Guarinus), a priest of whom Walter of Dol was seised when he made forfeiture; Aluric the Deacon, a commended freeman ; Algar, priest and freeman ; Edwin, priest and sokeman; and the 'half-priest' who was 'added' to William of Warenne's manor of Middleton. Among the freemen of Roger Bigod we also find Liuric the Deacon, a ' half-freeman,' and Ansketil the Priest, Roger Bigot's chaplain (capellanus), who held a carucate of land which had belonged to seven freemen, one of them a deacon, and two other small estates. ${ }^{381}$

Something has already been said of what may be called the official class, but we may note in passing that a 'beadle' (bedel) with the English name of Brictmar held a freeman on the 'land of the vavasours,' for whom he had given pledge, ${ }^{, 8 z}$ while at Hemingstone, in Bosmere Hundred, Almar ' the king's reeve' (praepositus regis), also, presumably, an Englishman, had stepped into the shoes of the freeman Lewin. ${ }^{383}$

Into the difficult and technical question of the exact meaning of 'freedom' in the IIth century this is not the place to enter. ${ }^{384}$ It will be enough to notice the relatively large number of liberibomines in Suffolk, ${ }^{385}$ and to point

ns Dom. Bk. 361 $b, 362$.

37 Dom. Bk. 2816 .

37 Ibid. 3636 .
${ }_{379}$ Dom. Bk. 357, 3576, 3606, \&c. ; Vinogradoff, op. cit. 255, 413; cf. Dom. Bk. 316,12 acres of free land in lay hands.

${ }^{201}$ Ibid. $334,334 b, 342 b, 343,352 b, 353,377,400,423 b$. Cf. 283 , Weston : a church and 20 acres held by 'the King's freemen.'

Ibid. 446.

204 CF. 446.

2as Ellis, Introd, Dom. Bk. and Beyond; Vinogradoff, Growth of the Manor; Engl. Soc. in the Eleventh Cent. frequently, some of them may have been counted more than once, but there is great difficulty in identifying these small men.

I3 Ibid. 291b; Vinogradoff, op. cit. 434.

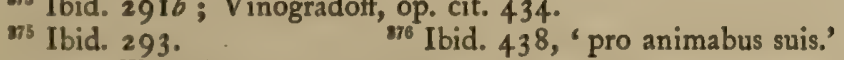
${ }^{78}$ Ibid. $431 b$; Ing. El. (Rec. Com.), $521 b, 522 a$

${ }^{380}$ Dom. Bk. $361 b, 362 b$, \&c.

in 


\section{A HISTORY OF SUFFOLK}

out that the same man may be styled teinus in one entry and liber bomo in another, or both liber homo and sochemannus in the same passage. ${ }^{886}$ Thus 'Alsi, a freeman,' who, as we learn from Domesday Book, was ' added ' with his 30-acre manor to the Abbot of Ely's manor of Winston, and who was in the abbot's 'soke and commendation,' is described in the corresponding entry of the Inquisitio Eliensis as 'freeman' and 'sokeman in the commendation of St. Etheldreda.' ${ }^{887}$ No doubt the Suffolk freemen varied greatly in wealth and social standing. Some were large landholders, others were mere peasant occupiers. ${ }^{388}$ There were degrees of freedom, too, even within the class of freemen. Some, like St. Edmund's free tenants at Downham, Groton, Rickinghall, and Hepworth, were at liberty to give and sell their land, though they were, as a rule, under the abbot's soke and commendation, and owed service sometimes in manors at some distance from their homes. ${ }^{359}$ Or again, they might be less free, in that they could not alienate their land without leave from their lord, as on St. Edmund's estates at Bradfield, Saxham, and Brockley, where some freemen could sell and some could not, and at Little Fakenham. ${ }^{390}$ At Brockley there were two freemen, commended to the king, who might only sell in St. Edmund's soke. At Barton, Fornham, and Rougham the free tenants were subjected, in addition to commendation and customary dues (consuetudines), to the peculiarly irksome duty of 'fold-soke,' or bringing their sheep to the abbot's fold, an obligation which is generally regarded as a distinct mark of inferiority. ${ }^{391}$ On the other hand, free tenants enjoyed a considerable amount of independence, especially before the Conquest. They were lords of manors and had tenants, free and unfree, under them, and we gather from a case which occurred in connexion with the outlawry of Edric of Laxfield that they might be at liberty to choose their own lords. When Edric of Laxfield was reconciled to King Fdivard, he restored to him his land, and 'gave him writ and seal that whosoever of his commended freemen- should wish to return to him they might return.' There was, however, evidently, no compulsion, and it was doubtful whether Edric the freeman had returned to his lord or remained 'in the king's hand.' ${ }^{392}$ Apparently the freemen who had no other lord were regarded as directly under the king, ${ }^{393}$ and both before and after the Conquest the king used his authority to make grants of freemen and the royal rights over them to private individuals. ${ }^{394}$ From these grants, from the definite oppression of sheriffs and reeves, and from the encroachments and greed of great men, it came about that the smaller freemen were gradually absorbed into the large fiefs, but the frequent

${ }^{386}$ Ante, p. 401 ; V.C.H. Norf. ii, $28-9$.

${ }^{387}$ Dom. Bk. $3^{8} 3 b$; Inq. El. (Rec. Com.), 525b. Cf. Dom. Bk. 353, 'Nordberia,' where a sokeman appears to be reckoned as a freeman.

${ }^{388}$ Vinogradoff, Engl. Soc. in the Eleventh Cent. 414 et seq. Cf. Dom. Bk. 344. Small freemen holding under Roger Bigot.

${ }^{389}$ Dom. Bk. 359, 359b, 362, 364b, 365, 365b, 395b. 'Isti sunt liberi homines qui T.R.E. poterant terras suas vendere et donare;' Vinogradoff, op. cit. 422 ; cf. Dom. Bk. 364 ; Stow ; Service in Lackford ; 3656 , Hepworth; Service in Stanton and Coney Weston; Hopton, Barningham ; Service in Coney Weston.

390 Ibid. $3576,358,362,3676,3706,371$.

${ }^{391}$ Ibid. $349 b, 361 b, 362$; Vinogradoff, op. cit. 424 ; cf. Dom. Bk. $310 b$, 'In Alrincham i. liber homo commendatione et soca falde et alia servitia xx. acras.'

${ }^{392}$ Ibid. 3 Iob. Here the freeman Edric, commended to Edric of Laxfield, himself had freemen commended to him. Cf. Stanwin's case, 3 I3, 3 I $8 b$; cf. 394, 'Assia,' 397b. A freeman of whom the hundred knew not if he could sell T.R.E., but witness that they saw him swear that he could not.

${ }^{393}$ Ibid. 447. Cf. 283 , Weston; 4466 , Thurlston.

${ }^{394}$ Ibid. $282 b$. On this subject cf. Vinogradoff, op. cit. 426 et seq. ; Dom. Bk. $420 b$; 'Torp,' $446 b$. 


\section{DOMESDAY SURVEY}

mention in the Suffolk Survey of the 'addition' or 'attachment' of freemen to manors, and the loose way in which this connexion was frequently effected, show that the process was far from being complete in $1086 .{ }^{395}$ The freemen and their land were often valued separately from the rest of the manor to which they had been joined, as at Kelsale, where the separate values of manor and freemen in the days of King Edward are followed by a statement of the present total value of the manor with the freemen; ${ }^{396}$ at Thorington, where the values of manor and freemen's land are given separately, but the whole is assessed to the geld as one estate (terra) $;{ }^{397}$ or at Freckenham, where the freemen added by Earl Ralph seem to stand even outside the geld assessment, as if they had been arbitrarily forced into an already matured organization. ${ }^{398}$ But the bond would soon become closer, the system would consolidate, and the general effect of the Conquest would be to depress the freemen and to force them down to the level of the unfree peasantry. ${ }^{399}$ Finally, we may call attention to the occasional mention in the Survey of women as landholders, ${ }^{400}$ and to the references to 'half free' men, and even to a 'quarter of a freeman,' phrases in which Professor Vinogradoff sees an allusion to the division of commendation, soke, and customary dues. ${ }^{401}$

The precise difference between the liberi bomines and the sochemanni, who are found in considerable numbers in Suffolk, has never been satisfactorily defined. The two terms are sometimes, as we have seen, interchangeable, ${ }^{402}$ and a sokeman might have freemen under him. ${ }^{403}$ Still, the sokeman is generally described as a less independent man than the liber bomo, more restricted in his power of giving and selling his land, more intimately associated in the manorial economy, and more heavily burdened with services and customary obligations. ${ }^{404}$ If we look through the list of St. Edmund's manors in the Suffolk Survey, we see that the men who could not alienate their land without licence, who 'belonged to the Saint's fold,' and who were subject to 'commendation and soke and all customs,' were more often sochemanni than liberi homines. ${ }^{405}$ Of one we are specially told that he was 'entirely' (omnino) the sokeman of the Abbot of Ely, while at Elmswell five sokemen were entirely (omnino) under the saint, and could not give or sell without the abbot's licence. Professor Vinogradoff is inclined to emphasize this inability to alienate land, and to regard the

${ }^{395}$ Dom. Bk. $282 b$, Ringsfield; 307b, Chilton; 308, Cransford ; 312 , Westleton. Vinogradoff, op. cit. 212 , et seq. $331,423,430$.

${ }^{396}$ Dom. Bk. 3306,331 ; cf. 350 , Boxted. Freemen set to farm. Now manor and freemen together worth 66 .

${ }^{107}$ Ibid. $412 b$; of. $384 b$, Wetheringsett.

${ }^{398}$ Ibid. 381 . That the relative positions of the entries concerning the 'added' freemen and the geld are significant appears in the passages referring to the Ely manor of Rattlesden in Domesday Book and in the Inquisitio Eliensis. In both the freeman is added after the geld entry, and this correspondence points to a careful copying of the exact order of the original return. Dom. Bk. $3^{81}$. Inq. El. (Rec. Com.), $522 b$.

Cf. Vinogradoff, op. cit. $210-18,410,424$, et seq. 472, 473. Maitland, Dom. Bk. and Beyond, 60, et seq. For cases of definite oppression of Suffolk freemen, cf. Dom. Bk. $282 b$, Ringsfield; $284 b$, Herringfleet ; 2876 , Bergholt ; of. 301 , Ilketshall.

${ }_{400}$ Dom. Bk. $347 b$, Kettleburgh ; $354 b$, Wortham; cf. $299 b$, Middleton. 'Esmoda tota femina Toli vicecomitis.'

${ }^{401}$ Ibid. 2886, 'Burghea '; 297, Glemham ; 2996, Middleton ; 387, Bredfield. Vinogradoff, op. cit. 423.

Ante, p. 404. A freeman in Dom. Bk. entered as a sokeman in the Ing. El.

4000 Dom. Bk. 371, Stoke Ash, Wickham.

- On this whole subject cf. Vinogradoff, up. cit. 431 et seq. ; Maitland, op. cit. ; Index, 'Sochemanni' ; Round, Foud. Engl. 18-19, 22, 24-26, 28-34; V.C.H. Herts. i, 265 et seq.

"3 Dom. Bk. 3;6b, 357 , Risby, Horringer, Whepstead, Nowton, \&c.; 364 , Ingham ; 3646 , Stanton ; 3636 , Mendham, \&c. 


\section{A HISTORY OF SUFFOLK}

sokeman as primarily a free peasant tied to the soil and unable to 'recede with his land,' though he also reminds us that 'ultimately the central notion in the socman's position is his subjection to soke.' ${ }^{206}$ Thus a man could be indifferently described as a 'sokeman' and as 'in the soke' of the Abbot of Ely. ${ }^{407}$ Reference is made to the services performed by Suffolk sokemen in the record of the famous Ely placitum. ${ }^{408}$ Here we read of the sokemen (socamans) of St. Etheldreda at Melton, in Carlford Hundred, that 'they belonged so fully (ita proprie) to the Abbot' that they had to go forth (ire) whenever the reeve of the monastery commanded, and pay fines for all offences (omnem rei emendationem persolvere), and if one of them wished to sell any of his possessions, he had first to get permission from the reeve. At Brandon, Lisois de Moustiers held six socamans, of whom we are told 'arabunt et c'terent (sic) messes ejusdem loci quotienscunque abbas precepit,' while others again ploughed, weeded (purgabunt), and reaped (colligent segetes), carried the monks' food to the monastery, provided horses for the abbot when he needed them, and paid fines to him for their own offences and those of their subordinates ('de omnibus illis qui in terris eorum deliquerint'). ${ }^{409}$

In conclusion, if we glance at the distribution of sokemen in Suffolk we see that they are most numerous in the hundreds of Blackbourn and Stow, where there are about $\mathrm{I}_{52}$ and 98 respectively; from 30 to 40 are found in each of the hundreds of Thingoe, Lackford, Risbridge, Babergh, Hartismere, Bishop's, Wangford, and Bradmere ; between 20 and 30 in Bosmere Hundred, under 20 but over 10 in the hundreds of Loes, Samford, and Wilford, and in Cosford Half-hundred, Io in Carlford Hundred, and under 10 in the hundreds of Blything, Plomesgate, Claydon, and Thedwastre, while they are altogether absent from Colneis Hundred, where there were many freemen, and from the half-hundreds of Parham, Lothingland, and Ipswich. The sokemen, like the freemen, were depressed by the Conquest, and we see Roger the Sheriff treating them in a very high-handed fashion on the king's manor of Thorney, removing them, and granting them out to new lords, while at Hintlesham, Suart, Stigand's sokeman, had been replaced by the Frenchman, Ralph; at Framlingham, Walter of Caen had succeeded the sokewoman Ieva; and on the manor of Bergholt the number of sokemen had fallen from 2 I 0 to I I $9 .{ }^{410}$ For the unfree peasantry in Suffolk a few words will suffice, as they present no specially distinctive features. They include villani and dimidii villani, who are closely bound up with the cultivation of the arable, and with the village economy ; bordarii, dimidii bordarii, and bomines bordarii, cottagers or crofters, often serving under freemen on the small Suffolk manors; and servi, who form less than a twentieth of the recorded population. ${ }^{411}$ Four bovarii are also mentioned, and four smiths, who, however, are counted as freemen, with

\footnotetext{
${ }^{106}$ Dom. Bk. 282, Stonham ; 'Iste socmaunus non poterat recedere'; 353, 'Nordberia' ; $364 b$, 'Elmeswella.' Vinogradoff, op. cit. 433-5, et sea. Cf. the Suffolk cases cited in the notes. Cf. Maitland, Dom. Bk. and Beyond; Index, 'Freizugigkeit'; cf. 'Round, Feud. Engl. 28 et seq.

${ }^{407}$ Ante, n. 387.

${ }^{109}$ Ing. Co. Camb. (ed. Hamilton), 193, 194. Round, op. cit. 32, 33 ; Maitland, op. cit. 77.

${ }^{109}$ Inq. Co. Camb. (ed. Hamilton), 193-5. Cf. 'Suthburna,' 'Kycestuna' (Kingston), 'Berham, 'Karsflet '; ' 4 homines qui tantum debent servire labbati cum propriis equis in omnibus necessitatibus suis.' Cf. Maitland, op. cit. 77. 'We observe that the slokemen of the east like the radmen of the west have horses.' Cf. 'Drincestune'; Ing. Co. Camb. 194, ' 15 soclamans . . . 6 homines de soca.'

$0^{10}$ Dom. Bk. $281 b, 287,295 b, 296,325 b, 425$, Boulge; where a villein's name is given; Vinogradoff, op. cit. 442 et seq.

"11 Ellis, Introd. to Domesday, ii, 488 et seq.
} 


\section{DOMESDAY SURVEY}

twenty-four fishermen (piscatores) at Yarmouth. ${ }^{412}$ Suffolk was mainly an agricultural county, and the peasants, free and unfree, were chiefly occupied in the cultivation of the arable. The manorial estates were usually divided into the lord's demesne and the land of the tenants, to which corresponded the demesne ploughs and the men's ploughs, though this distinction is not always apparent. The centre of the manor, the outward visible sign of the lord's authority, was the hall or manor-house, the aula, balla, mansio, or, as it is once called, the caput manerii. The Suffolk Survey has not very much to tell us about the manorial halls, but its occasional references to them are not without interest. We hear of horses ' in the hall' or ' in the demesne of the hall;' of berewicks 'belonging' (pertinens) to a hall in another hundred, and of soke which extended only over the demesne of the hall, or over the hall and the bordars; of a freeman and his land held 'in the hall demesne'; ${ }^{413}$ of a caput manerii worth 100 s. $^{414}$ and of two manors which are described as mansiones. ${ }^{415}$

In Suffolk, as in Norfolk and Essex, the stock on the manorial farms is recorded:- the ploughs and plough-oxen (boves), the 'beasts' (animalia) and animalia otiosa, or cattle used for other purposes than ploughing, the rounceys (runcini) and horses (equi), the sheep and goats, the pigs and the bees. ${ }^{416}$ Cows (vaccae) are only occasionally mentioned, but they may sometimes have been included in the animalia on a manor. ${ }^{417}$

Sheep-farming seems to have been more evenly distributed throughout the county in Suffolk than in Norfolk. ${ }^{418}$ Flocks of 100 sheep or more are found in every hundred except Loes and the half-hundreds of Parham and Ipswich. The largest flocks were in the northern hundreds of Lackford and Bradmere and the half-hundred of Lothing. On the royal manor of Mildenhall in Lackford Hundred there were 1,000 sheep, with 500 in the dependent berewick of Icklingham, while at Downham, in the same hundred, a manor which had passed from St. Edmund's Abbey to Frodo, the abbot's brother, there were 900 sheep ; at Eriswell, Godwin, King Edward's thegn, had kept a flock of 900 before the Conquest, which had been reduced to 800 in 1086.419 Goats are also entered in considerable numbers, especially in the hundreds of Blything and Bishop's, where as many as sixty are found in one herd. Of horses we hear frequently, but they are not very numerous and are more often rounceys or farm-horses than equi, which are generally connected with the hall, and may have been riding horses or horses used for breeding purposes, though the different terms were probably not applied with any great precision. ${ }^{420}$ 'Forest mares' (equae silvaticae), or mares turned

112 Dom. Bk. $283,314 b$, 'Edwinus faber'; $334^{b}$, 'Bunda faber'; $339 b$, 'Godricus faber'; $435^{b}$, 'Faber'; cf. $3 \mathbf{1} 4 b$, 'Aluricus filius fabri.' For the whole subject of the unfree peasantry cf. Vinogradoff, op. cit. sec. iii, chap. ii ; Maitland, op. cit.

als Dom. Bk. 286b, 304, 350b, 355, 355b, 362, 362b, 374, 381b, 382, 382b, 401 b, 402b, 403, 408b, $411,416,416 b, 418,449$; cf. $343 b$ : St. Etheldreda had soke over all the land except Walton Hall and villeins; Vinogradoff, op. cit. 353 et seq.

14 Dom. Bk. 2936. 118 Ibid. 415, Cratfield. et seq.

"16 For the meaning of the entries relating to the plough-teams and 'boves,' cf. Vinogradoff, op. cit. I 53

"19 Dom. Bk. 376b, 397b, 398b, 400, Middleton; cf. Thorington (animalia osiosa) ; cf. V.C.H. Norf. ii, 23. 6. V.H. Norf. ii, $23-4$. "10 Dom. Bk. 2886, 359, 4026 .

400 Where Domesday Book has 'equi' the Inquisitio Eliensis usually has 'runcini.' For horses in Domesday cf. Maitland, Dom. Bk. and Beyond; Index, 'Horses.' The horses which the Suffolk sokemen had to supply to the Abbot of Ely, which were presumably riding-horses, are called 'equi.' 


\section{A HISTORY OF SUFFOLK}

loose in the forest, occur twice, at Barnham and at Fakenham, in Bradmere Hundred, and two asses (asini) are entered at Brandon on the land of the Abbot of Ely. ${ }^{421}$ The meadows which provided hay for the winter feed of the farm-stock were appended to the manorial holdings and valued with them. Of pasture land little is said, but the Suffolk Survey contains one famous reference to the 'pasture common to all the men of the hundred ' of Colneis, which illustrates the practice of several vills 'intercommoning, or sharing pasture rights on the commons. ${ }^{422}$ Pigs, and the woodland in which they fed, play a prominent part in the Suffolk Domesday. The extent of the woodland is, indeed, usually estimated by the number of pigs for which it could provide pannage, and the pigs actually kept on an estate often fell far below this number. ${ }^{423}$ The most thickly wooded districts seem to have been in the hundreds of Blything, Bishop's, and Loes, ${ }^{424}$ where we find comparatively few sheep and a fair proportion of pigs and goats. It might happen, however, as in Lackford Hundred, that there were a good many pigs on the manors and yet no woodland is recorded. In connexion with the forest land may be noticed also the bays or hedges, which are twice mentioned, once in relation to the manor of Blythburgh, to which was paid 'the fourth penny of the rent of the hay (beia) of Riseburc,' and once under Southwold, where St. Edmund's Abbey held five-eighths of a sea-bay or weir (beia maris). ${ }^{425}$ 'Twice land is entered as ' waste' (guasta terra), and in one case the whole stock of a farm had perished or had been removed. ${ }^{426}$ Salt-pans (salinae) appear in the hundreds of Blything and Samford, and in the half-hundred of Lothingland. ${ }^{427}$ Fisheries and fish-ponds (piscariae, piscinae, vivariae) are of frequent occurrence, and we hear of four fisheries in Ely connected with Richard Fitz Gilbert's estate at Lakenheath, and of a fishing-boat. ${ }^{428}$ Rents were often paid in herrings, ${ }^{429}$ and the references to the Yarmouth fishermen, to the 'seaport' at Frostenden, and to the encroachments of the sea on the east coast, where a carucate of land had been washed away at Dunwich, ${ }^{430}$ remind us that we are in a maritime county. Of mills we also hear constantly, and, like the churches, they are divided up among many owners, so that we read of thirds, fourths, and sixths of mills. ${ }^{431}$ 'Winter mills' (molinum byemale) are entered at Edwardstone, at Pakenham, and at Rickinghall, ${ }^{432}$ and mill-dams or sluices (exclusae) at Creeting and at Barking. ${ }^{433}$ Parks are mentioned several times, ${ }^{434}$ and vineyards, measured by arpents, three times. ${ }^{455}$ Bee-keeping was carried on in most parts of the county, and a distinction is possibly made between

(21) Dom. Bk. $330 b, 420 b, 381 b$ (asses).

${ }^{423}$ Ibid. $339^{b}$; Vinogradoff, op. cit. 288-9; Maitland, op. cit. ; Index, 'Coleness' ; V.C.H. Essex, i, $336,369-74$.

${ }_{123}$ Dom. Bk. 287 (Bergholt), woodland for 1,000 swine and only twenty-nine on the farm; cf. 438 , 'Redles,' woodland measured by acres ; cf. 2946 , land 'inter silva et planum.'

${ }^{42}$ Cf. also Blackbourn Hundred.

${ }^{22}$ Dom. Bk. 282, $371 b$; Vinogradoff, op. cit. 289-304.

${ }_{126}$ Dom. Bk. 300 (Cretingham); 425 , 'Kingeslanda'; 444 , Easton.

${ }^{427}$ Ibid. $283,284 b, 289,295 b, 296,299 b, 313 b, 317,342,402,411 b, 414 b, 419 b, 425,444,445$.

"29 Ibid. $372,392,8$ c.

429 Ibid. $282,370,37 \mathrm{I} b, 406,407,4076$.

${ }_{430}$ Ibid. $283,311 b$, Dunwich ; $414 b$, 'Froxedena.' Professor Vinogradoff (op. cit. 201) cites the Dunwich instance to show the reality and actuality of hides and carucates in many cases.

${ }^{431}$ Dom. Bk. $336 b, 337,337 b$ ('quedam pars '); 4046 , 'Langhedana ; in tercio anno quarta pars mol,' \&c.

${ }^{43}$ Ibid. $304,3616,365$. ${ }_{433}$ Ibid. $304 b, 382 b$.

43 Ibid. 287, Bentley, half a park; 328 , Newton ; 4386 , Ixworth, \&c.

as Ibid. $382 b$, Barking; $389 b$, Clare ; $438 b$, Ixworth. 


\section{DOMESDAY SURVEY}

the vasa apum or beehives, and the ruscae, the ancestors of the straw 'skep' of modern days. ${ }^{436}$ The value set on honey is seen by the fact that the 'King's farm' was partly paid in it, as at Diss and at Blythburgh, while at Ipswich we see the old payment in kind in the process of commutation into a 'custom of honey.' 457 Payment in kind still lingered on in the form of herring rents, but as a rule the worth of estates was reckoned in cash, and the recurrence of the rate of $2 d$. an acre in the values of arable land is worth noting. ${ }^{438}$ Manors were often farmed out for a fixed sum, and the 'farmer' seems not infrequently to have been the loser by the contract. Thus St. Etheldreda's estate at Drinkstone, which had risen in value from 40s. to 60s. by 1086 , was let to farnı at Ioos., but 'could not render so much.' At Desning (Deselinga) Wisgar, the antecessor of Fitz Gilbert, had a manor of 20 carucates, which was worth $£_{3} 30$ in the time of King Edward, and afterwards rose in value to $£_{4}$. ' 'Yet he gave it to a steward to farm for $\oint_{65} 6$. But the manor could not bear it.' At Ringsett, Geoffrey de Mandeville only received 6os. for an estate which he had let to farm for $70 s$., while at Higham the manor was farmed for 30 s., its value before the Conquest, though in 1086 it was only worth 20s. At Pettaugh we hear of five commended freemen who were ruined (confusi) by their 18 acres of land, valued at $45^{s}$., having been farmed out at $75^{\mathrm{s} .},{ }^{439}$ and ruin seems also to have overtaken the farmers of William de Scoies' manor of Blakenham. ${ }^{400}$ On the other hand there are instances of a manor being farmed for what it was really worth, or even at less than its actual value. ${ }^{411}$ In one case the "men of the hundred 'appraised land at $48 \mathrm{~s}$, which had formerly rendered, and was rendering, as much as $f_{0} 6{ }^{442}$

The Suffolk Domesday has nothing new to tell of the currency in which these dues were paid, or of the system of weights and measures used in the county. Payments were made and values were estimated by weight (ad pensum) or by tale (ad numerum), in blanch money which had been assayed, or in unassayed coin, and an extra customary sum was occasionally exacted as gersuma (de gersuma).43 Marks of silver and of gold occur, nummos or pence, an 'ounce of gold,' "tw and oras, the Danish unit of account. As Mr. Round has shown, from a Suffclk case of later date than the Survey, and from other instances, the ora in customary use was probably equal to $16 d$. This, it may be pointed out, would, at Hacheston, where a church with i 6 acres was valued at 2 oras, agree well with the land value of $2 d$. an acre, and it may also be noted that $32 d$., or 2 oras of $16 d$, was very commonly the payment for mercbet, the marriage fine for the daughter of an unfree man. The ora of 2od. may, however, have been used, as has been already suggested, in royal taxation as

2Um. Bk. 328, Newton ('Vasa'); 385 , 'Wineberga'; 4436, Campsey ('Rusca').

Ibid. 282 , Diss, half a day's honey; Blythburgh, one day's honey; 2906 , six sextars of honey and 4 s. towards the custom of honey.

(25. Dom. Bk. 300, Cretingham : 8 acres of waste lar.d worth $16 d$; 366 , Bardwell : 30 acres and a. plough, 5s.; half a carucate and a plough, $10 s$. ; 425 , Boulge ; $425 b$, Wenham : 30 acres worth 5 s., \&c.

w Ibid. $381 b, 390,393 b, 436 b, 4406,441$; cf. $284 b$, Herringfleet ; 285 , 'Essa'; 303 , Ousden (farmed for double its value); $335 b$, Weston; 376 , Helmingham; $377 b$, Raydon.

Ibid. 353,3536 .

4 Ibid. 288,2886 , Bungay : land of the freemen; the manor had tripled in value ; Burghea,' cf. 3136 , Westleton.

"4 Ibid. $3+3$.

ss V.C.H. Norf. ii, 35 ; For gersuma cf. Vinogradoff, op. cit. 143, 390; Maitland, op. cit.; Dom. Bk. 281 , Thorney, Bramford; 282, Diss, Blythburgh; 285, Parham; 285b, 286, Mendlesham, Norton, Thurlow; 2866, Harkstead ; 287 , Groton; 2876 , Bergholt; 2886, 289 , Bramford, Barrow; 353, 353b, Blakenham.

ist Ibid. $287 b$, Bergholt ; $309 b$, Cotton; $353 b$, Blakenham ; $412 b$, Thorington. 


\section{A HISTORY OF SUFFOLK}

the unit of assessment for the geld. ${ }^{445}$ A similar use of two systems of reckoning side by side is found in the present day in the $16-o z$. pound avoirdupois and the 20-oz. pound Troy.

The primitive trade of the I I th century was carried on to a great extent at markets and fairs. In Suffolk there were markets at Thorney, Kelsale, Beccles, Hoxne, Eye, Clare, and Haverhill, and at Aspall, in Hartismere Hundred, there was ' the third part of a fair.' ${ }^{446}$ If we only see boroughs where we find burgesses, we cannot allow the title to more than six Suffolk towns, Ipswich, Dunwich, Eye, Beccles, Clare, and Sudbury, though St. Edmundsbury was rapidly qualifying for burghal rank. Of these, Ipswich, ${ }^{47}$ which gave its name to a half-hundred, was the most important, though it had apparently suffered greatly since the Conquest: where under King Edward there had been $53^{8}$ burgesses rendering customary dues, there were 110 in 1086, with 100 ' poor burgesses,' too impoverished to pay more than their ' headpennies ' to the king's geld. There were also 328 waste houses (mansiones) within the borough which were unable to contribute to the geld. It was doubtless owing to this depression that Roger the Sheriff was forced to remit $£_{3} 3$ of the $£_{4} 40$ farm of the town. The mint at Ipswich and the numerous churches and the comparatively dense population may have given it something of an urban character, but here and in the other Suffolk towns the rural element was still very strong, and there was a 'smack of the farmyard' even about the burgus. ${ }^{448}$ This is specially seen at Ipswich in the two 'granges' with their land and tenants, which had belonged to Queen Edith and to Earl Gurth before the Conquest, and were apparently connected with the firma burgi of which the queen had two-thirds and Gurth one-third, the 'Earl's third penny.' After the Conquest the queen's share came to King William, and Gurth's third penny, with the third penny of two hundreds, the grange and its farm, were granted to Count Alan. ${ }^{49}$ Without discussing the question of 'contributory' tenements and the garrison service of burgesses, we may indicate the connexion between the towns and the great country estates, and the claims made by the county magnates to burgesses, churches, land, and homesteads (mansuras) in the borough..$^{450}$ At Dunwich, which had been held by Edric of Laxfield before the Conquest, and had passed to his successor Robert Malet, the burgesses had increased from 120 to 236 , and there were 24 franci rendering customs, and 178 'poor men'; but it is spoken of as a manor, and the 'exchanger' (cambitor) seems to have been established at Blythburgh, where also corporal punishment was inflicted on the thief who had been caught and tried at Dunwich. The property of such thieves went to the lord of Dunwich, but the king had the fines, paid in oras, of the selected men who refused to attend the hundred court after due warning. ${ }^{451}$ At Eye, in like

${ }^{445}$ Dom. Bk. 2866, Hacheston ; 31 2, Dunwich; cf. 360 , Cornard ; 2906 , Ipswich (mint); V.C.H. Norf. ii, 35. Round in Engl. Hist. Rev. Apr. 1908; Vinogradoff, Vill. in Engl. 44 I (merchet); cf. ante, p. 36I.

${ }^{446}$ Dom. Bk. 281b, 330b, 369b, 370, 379, 389b, 418, 428, Haverhill; the third part of a market worth 13 s. 4 d.

${ }^{447}$ Ibid. 290, 2906.

${ }^{448}$ Cf. Maitland, Dom. Bk. and Beyond, 172 et seq.; Tosunship and Boro. 68-9, Index, 'Boroughs' : Vinogradoff, op. cit. 393, 398, 402 ; Ballard, Dom. Boro.

"19 Dom. Bk. 290, 290b, 294, 294b; Vinogradoff, op. cit. 364 et seq.

${ }_{430}$ Maitland, Dom. Bk. and Beyond, 179 et seq. ; Ballard, Dom. Boro.; Vinogradoff, op. cit. $40 \mathrm{r}$; Dom. Bk. 304b, Ipswich; 3146 , Playford; 392b, 393, Ipswich (burgesses dwelling on land of their own and rendering customs within the borough) ; $411 b, 4216,425,427,438$ (Ipswich).

${ }^{451}$ Dom. Bk. $311 b$, 312, 312b, Dunwich ; $313 b$, 'Bringas'; $333 b$, Thorpe ; $385 b$, 'Alnet'ne'; Maitland, Dom. Bk. and Beyond, Index, 'Dunwich.' 


\section{DOMESDAY SURVEY}

manner, Robert Malet had succeeded Edric of Laxfield. Here, though the manor is clearly seen, with its tenants and all its appurtenances, including a fishery, a mill, and a park, the urban element appears distinctly in the market with twenty-five burgesses living in or around it. ${ }^{452}$ Beccles was held by the Abbot of St. Edmunds before and after 1066, but the king had a fourth part of the market. It was a small place with twenty-six burgesses and a manor of 2 carucates. ${ }^{43}$ Clare, Richard Fitz Gilbert's manor, was much larger, with forty-three burgesses, five sokemen, and a considerable population of unfree peasants. Here, too, there was a market, but the urban element is somewhat obscured by the rural details entered in the Survey:- the woodland and mill, the vineyard, the farm-stock, and ploughs. ${ }^{454}$ At Sudbury, where King William had taken over the land of the mother of Earl Morcar, there were sixty-three burgesses attached to the hall, fifty-five burgesses on the demesne holding arable land and meadow, a market, and a mint (moneyers). ${ }^{450}$ Of Bury St. Edmunds we have already spoken. It had a great history before it, but in 1086 it was still merely the vill (villa) 'where rests enshrined Saint Edmund King and Martyr of glorious memory." ${ }^{466}$

We close the volume of 'Little Domesday' and leave the Suffolk Survey with the consciousness that its secrets are still unrevealed, and that years of labour must be spent if the text is to be fully analysed, and if the many problems which arise from it are to be solved. But in all investigations we shall be wise to treat Great and Little Domesday as one whole, and, in the words of the colophon which closes the description of Essex, Norfolk, and Suffolk, to extend our studies 'non solum per hos tres comitatus sed etiam per alios.'

45s Dom. Bk. 319b, 320, 321 ; Thrandeston, 445b. 4 Ibid. $389 b, 390$.
${ }^{455}$ Ibid. $286 b$.
${ }^{433}$ Ibid. $369 b, 370$.

${ }^{156}$ Ibid. 372. 


\section{THE DANEGELD AND THE LEET SYSTEM IN SUFFOLK ${ }^{1}$}

\section{PREFATORY NOTE}

IN the following Table an attempt has been made to 'reconstruct' the Suffolk leets in accordance with the theory suggested in the text. Although in many hundreds this 'reconstruction' can only be regarded as hypothetical, in several, notably in the hundreds of Lackford, Claydon, Plomesgate, Wangford, and Wilford and the half-hundred of Parham, the system can still be traced with an approach to certainty. In each case the model hundred, Thingoe, has been taken as a guide, and the fiscal groups have, as far as possible, been made to correspond with contiguous territorial areas.

Thingoe Hundred [12 'OrA' OR 2Od. LeEts]

Hartismere Hundred [8] 'Ora' Leets + Id.]

\begin{tabular}{|c|c|c|c|c|}
\hline I.eets & Vills & Geld in Pence & 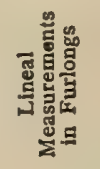 & 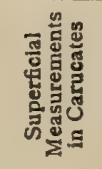 \\
\hline I & Barrow. & 7 & $12 \times 8$ & 8 \\
\hline & Flempton & $6\} 19$ & $6 \times 4$ & 2 \\
\hline 2 & Risby : & 20 & $\begin{array}{r}12 \times 10 \\
0 \times 8\end{array}$ & $\begin{array}{r}\text { I0 } \\
6\end{array}$ \\
\hline 3 & Westley & $\left.6 \frac{1}{2}\right)$ & $7 \times 5$ & $2+3$ \\
\hline & Saxham (I) & $7320 \frac{1}{2}$ & $12 \times 5$ & 5 \\
\hline & Saxham (2) & $7)$ & $8 \times 5$ & $3 \frac{1}{3}$ \\
\hline 4 & Hengrave? & 10 & $6 \times 6$ & 3 \\
\hline & Fornham . & $10\} 20$ & $8 \times 5$ & $3 \frac{1}{3}$ \\
\hline 5 & Ick worth . & $\left.7 \frac{1}{2}\right)$ & $8 \times 6$ & 4 \\
\hline & Chevington & $\left.6 \frac{1}{2}\right\} 21$ & $\begin{array}{r}10 \times 8 \\
8 \times\end{array}$ & $6 \frac{3}{3}$ \\
\hline & Hargrave. & & $8 \times 5$ & $3 \frac{1}{3}$ \\
\hline 6 & Brockley . & $7)$ & $8 \times 5$ & $3 \frac{1}{3}$ \\
\hline & $\begin{array}{l}\text { Rede : } \\
\text { Menston : }\end{array}$ & $\left.\begin{array}{l}7 \\
6\end{array}\right\} 20$ & $\begin{array}{l}8 \times 4 \\
3 \times 2 \frac{1}{2}\end{array}$ & $\begin{array}{l}2 \frac{2}{3} \\
2 \frac{2}{3}\end{array}$ \\
\hline 7 & & 20 & $9 \times 8$ & $\begin{array}{l}75 \text { acres } \\
6\end{array}$ \\
\hline 8 & Hawstead . & $\left.13 \frac{1}{2}\right\}_{20}$ & $8 \times 6$ & 4 \\
\hline & Nowton. & $\left.6 \frac{1}{2}\right\}^{20}$ & $10 \times 6$ & 5 \\
\hline 9 & Hornings- & 20 & $9 \times 8$ & 6 \\
\hline IO, II, I 2 & Sudbury . & 60 & $4 \times 3$ & I \\
\hline 12 & $\stackrel{20}{[\text { Saxham }=2]}$ & $£ I$ os. ot $d$. & & $\begin{array}{l}\text { Car. } 86 \\
\text { A. } 25\end{array}$ \\
\hline
\end{tabular}

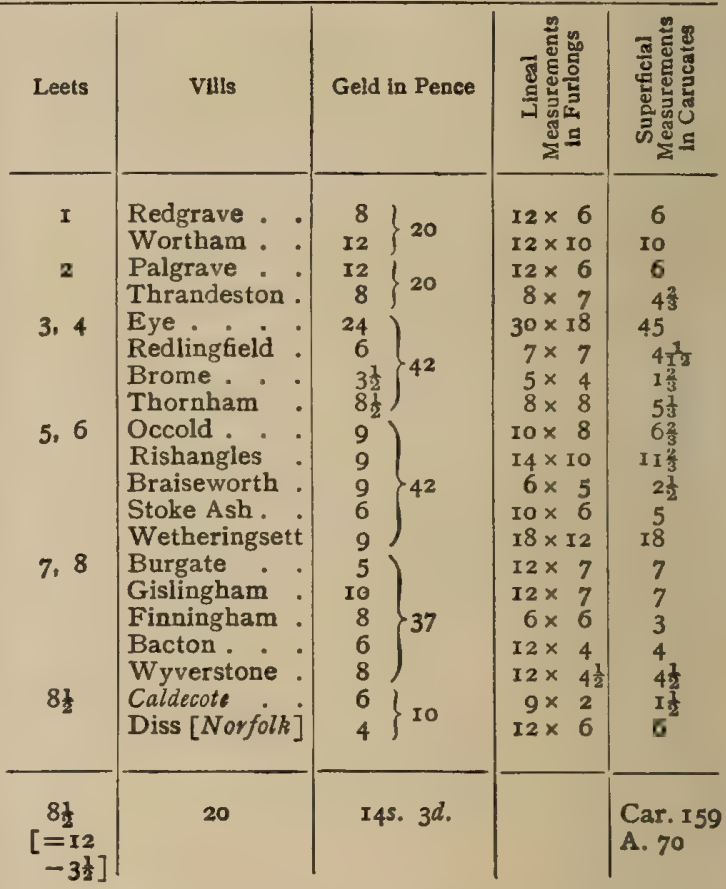

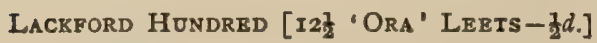

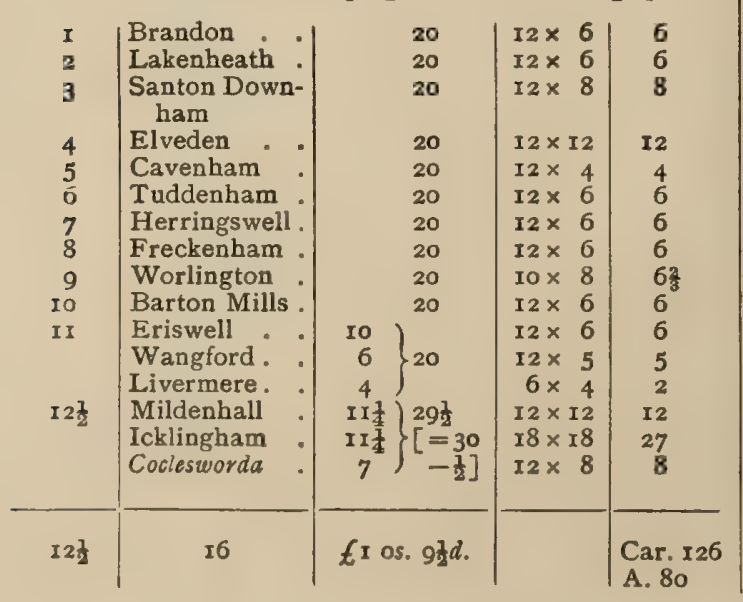

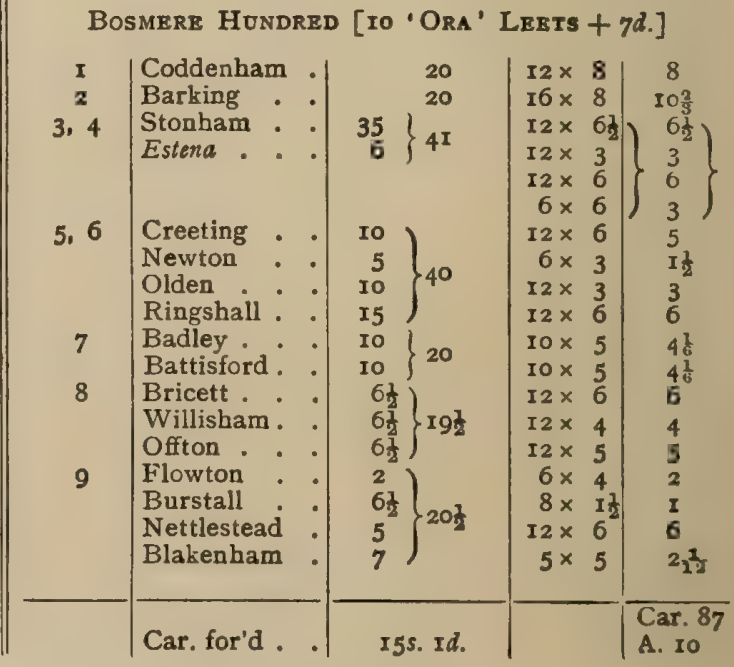

1 Names of places which have not been identified are printed in italics 


\section{THE DANEGELD IN SUFFOLK}

BOSMrRe HUNDRED [To 'ORA' LEETS $+7 d$.] - cont.

Wangtord Hundred [9 'Ora' Leets]

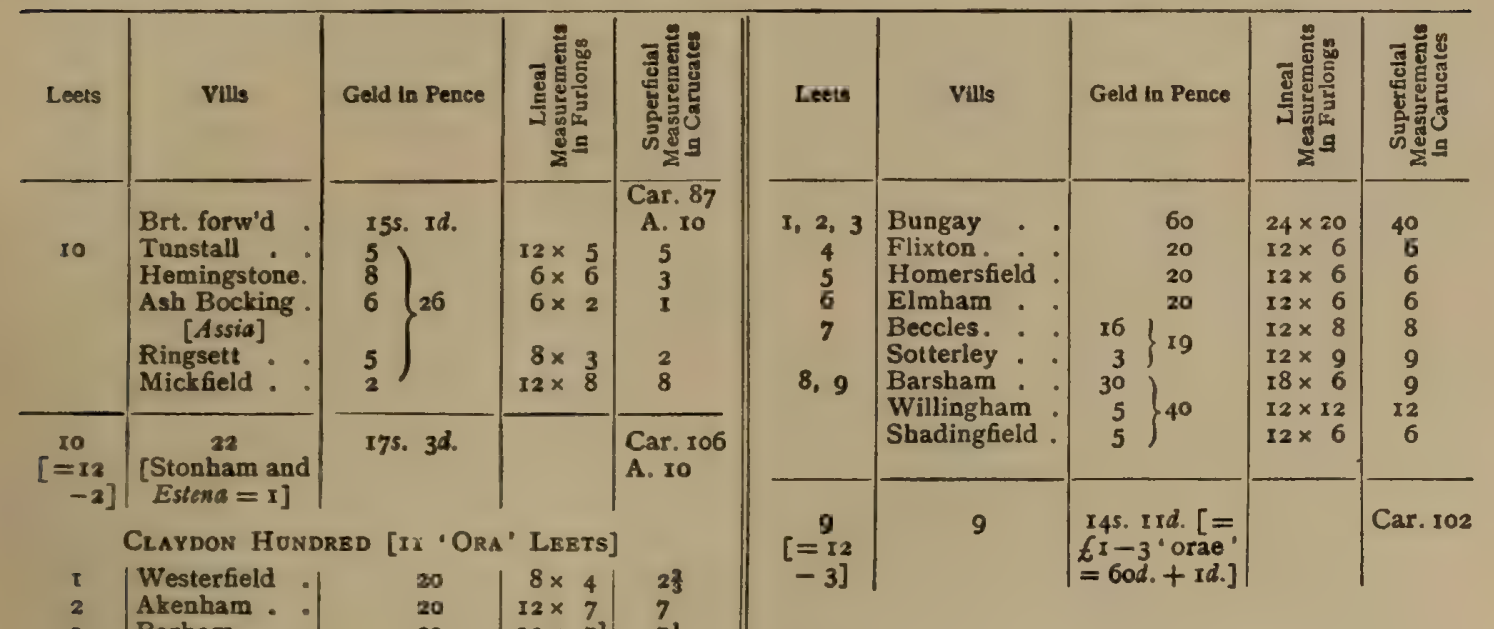

Parham Half-Hundred [6 'Ora' Legts]

\begin{tabular}{|c|c|c|c|c|}
\hline $\begin{array}{ll}\text { I, } & 2 \\
31 & 4 \\
5, & 6\end{array}$ & $\begin{array}{l}\text { Parham } \\
\text { Wantisden } \\
\text { Burgh } \\
\text { [Brucge] }\end{array}$ & $\begin{array}{l}40 \\
40 \\
40\end{array}$ & $\begin{array}{rr}\text { II } \times 6 \\
8 \times 6 \\
8 \times 6\end{array}$ & $\begin{array}{l}5 \frac{1}{2} \\
4 \\
4\end{array}$ \\
\hline 6 & 3 & Ios. & & $\begin{array}{l}\text { Car. } 13 \\
\text { A. } 60\end{array}$ \\
\hline
\end{tabular}

Colmeis Hundred [it 'Ora' Leets - 2d.]

LORS HUNDRRD [II 'ORA' LIETS + 4 d.]

I Framlingham | $20 \quad$ I4 $\times$ I2

2 Rendlesham. I4 3 2X $\mid$\begin{tabular}{r|r}
$12 \times 6$ & 14 \\
6
\end{tabular}

Campsey Ash 7$\} 21$

3 Charsfield II $\begin{aligned} & \text { Mrenden } \\ & \text { Monew }\end{aligned}$

Kettleburgh : II

Brandeston: : $\left.5 \frac{1}{2}\right\} 20$

$\left.5 \quad \begin{array}{l}\text { Cretingham : II } \\ \text { Soham . } 81\end{array}\right\}$ I9t

6,7

Martley : : $\left.8 \frac{1}{2}\right\}$

[Martele $]$

Glevering Hall 22$\} 40 \frac{7}{2}$

[Glerevinges]

Dallinghoo $\cdot 7 \frac{1}{2}$ )

8 Marlesford: 15 Butley $22 \frac{1}{2}$

\begin{tabular}{rr}
$6 \times$ & 4 \\
$8 \times$ & 6 \\
\hline & 2
\end{tabular}

$12 \times 48 \quad 18$

\begin{tabular}{r|r}
$12 \times$ & 4 \\
$6 \times$ & 4
\end{tabular}

9. 10 Woodbridge. II ) $10 \times 5$ (1)

Staverton - 22$\left.\} 291\} 40 \frac{1}{2} \mid \begin{array}{ll}18 \times 6 & 5 \\ 12 \times & 9\end{array}\right\}$

1 Kenton . . . $\left.\left.\begin{array}{l}7 \frac{1}{2} \\ 9\end{array}\right\} \begin{array}{lll}12 \times & 2 \\ 12 \times & 6\end{array}\right\} \begin{aligned} & 2 \\ & 6 \\ & 6\end{aligned}$

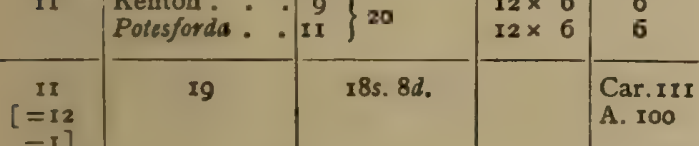

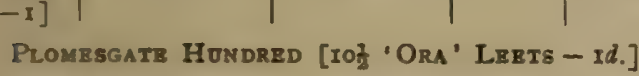

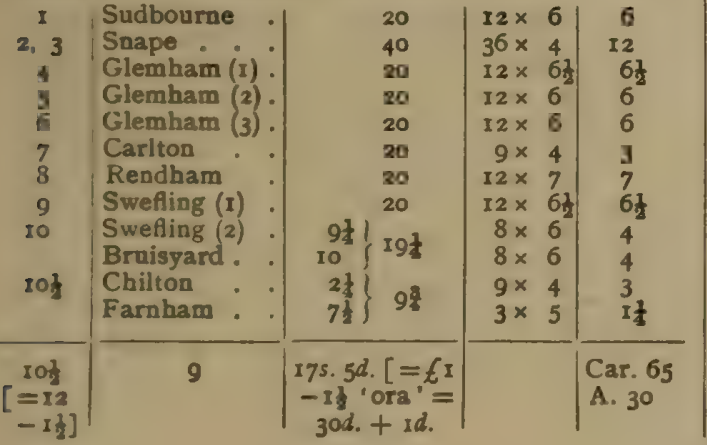

\begin{tabular}{|c|c|c|c|c|c|}
\hline \multirow{5}{*}{8,9} & Culvertestuna & \multicolumn{2}{|c|}{ 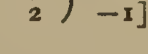 } & \multicolumn{2}{|l|}{$3 \times 2$} \\
\hline & Burch . . & & & $6 \times 2$ & $I_{\frac{2}{2}}$ \\
\hline & Struustura: & $6 \frac{1}{2}$ & & & o $\frac{5}{8}$ \\
\hline & Guthestuna. & 3 & $-40 \frac{1}{2}$ & $2 \times 2$ & $0^{6}$ \\
\hline & Alteston : & 7 & & $6 \times 2$ & I \\
\hline & Mycelgata. . & 2 & & $3 \times 2$ & o $\frac{1}{2}$ \\
\hline ro & Turstanestuna . & 4 & & $2 \times 2$ & $0 \frac{1}{3}$ \\
\hline & Nortuna & 12 & 20 & $6 \times 2$ & I \\
\hline & Langestuna & 4 & & $4 \times 2$ & o: $\frac{2}{3}$ \\
\hline II & Brihtolvestuna. & 10 & & $6 \times 2$ & I \\
\hline & Oxelanda . & 4 & 20 & $3 \times 2$ & $0 \frac{1}{2}$ \\
\hline & Plugeard . & 4 & & $2 \times 2$ & $0 \frac{1}{3}$ \\
\hline & Wadgate. & & & $2 \times 2$ & of \\
\hline$l_{[=12}^{I I}$ & & $18 \mathrm{~s}$. & $6 d$. & & Car \\
\hline & & & & & \\
\hline
\end{tabular}




\section{A HISTORY OF SUFFOLK}

Cosford Half-HondRed [6 'Ora' LeEts

$+4 \frac{a}{2}=\frac{1}{4}$ circ. $]$

\begin{tabular}{|c|c|c|c|c|}
\hline Leets & Vills & Geld in Pence & 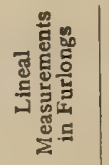 & 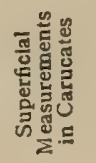 \\
\hline \multirow[t]{5}{*}{ I, 2} & $\begin{array}{l}\text { Thorpe Mori- } \\
\text { eux }\end{array}$ & & $12 \times 8$ & 8 \\
\hline & Brettenham . & $\begin{array}{l}10 \\
15\end{array}$ & $\begin{array}{l}12 \times 6 \\
16 \times 12\end{array}$ & $\begin{array}{r}6 \\
16\end{array}$ \\
\hline & Bildeston : & 5 & $12 \times 6$ & 6 \\
\hline & Nedging . . & $2 \frac{1}{2}$ & $12 \times 3$ & 3 \\
\hline & $\begin{array}{l}\text { Semer . } \\
\text { Chelsworth }\end{array}$ & $\begin{array}{l}2 \frac{1}{2} \\
3 \frac{3}{4}\end{array}$ & $\begin{array}{l}9 \times 7 \\
7 \times 6\end{array}$ & $\begin{array}{l}5 \frac{1}{1} \\
3 \frac{1}{2}\end{array}$ \\
\hline \multirow{4}{*}{3,4} & Lindsey . & 6 & $6 \times 5$ & $2 \frac{1}{2}$ \\
\hline & Kersey : . & $7 \frac{1}{2}$ & $8 \times 6$ & 4 \\
\hline & Hadleigh . & II & $12 \times 7$ & 7 \\
\hline & Whatfield . & I I & $\begin{array}{l}6 \times 5 \\
6 \times 3\end{array}$ & $\left\{\begin{array}{l}2 \frac{1}{2} \\
I\end{array}\right\}$ \\
\hline \multirow[t]{2}{*}{5} & Elmsett . & I5 $\}_{20}$ & $10 \times 7$ & $6 \frac{2}{\mathrm{~g}}$ \\
\hline & Aldham . & $5\}^{20}$ & $\begin{array}{l}\text { [Measur } \\
\text { What }\end{array}$ & $\begin{array}{l}\text { ed with } \\
\text { ield] }\end{array}$ \\
\hline 6 & Layham . & $20 \frac{1}{2}$ & $8 \times 6$ & $4)$ \\
\hline & & & $\begin{array}{ll}8 \times 7 \\
6 \times\end{array}$ & $\left.4 \frac{2}{3}\right\}$ \\
\hline & & & $\begin{array}{l}6 \times 4 \\
6 \times 6\end{array}$ & $\begin{array}{l}2 \\
3\end{array}$ \\
\hline 67 & Manton . & $3\}$ & $6 \times 4$ & 2 \\
\hline & Ash Street & $\left.I_{\frac{1}{2}}\right\}^{42}$ & $6 \times 3$ & $I_{\frac{1}{2}}$ \\
\hline 61 circ. & I6 & IOS. $4 \frac{8}{4} d$. & & $\begin{array}{l}\text { Car. } 88 \\
\text { A. Io }\end{array}$ \\
\hline
\end{tabular}

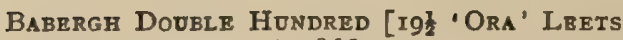
+7 ad. $d$.

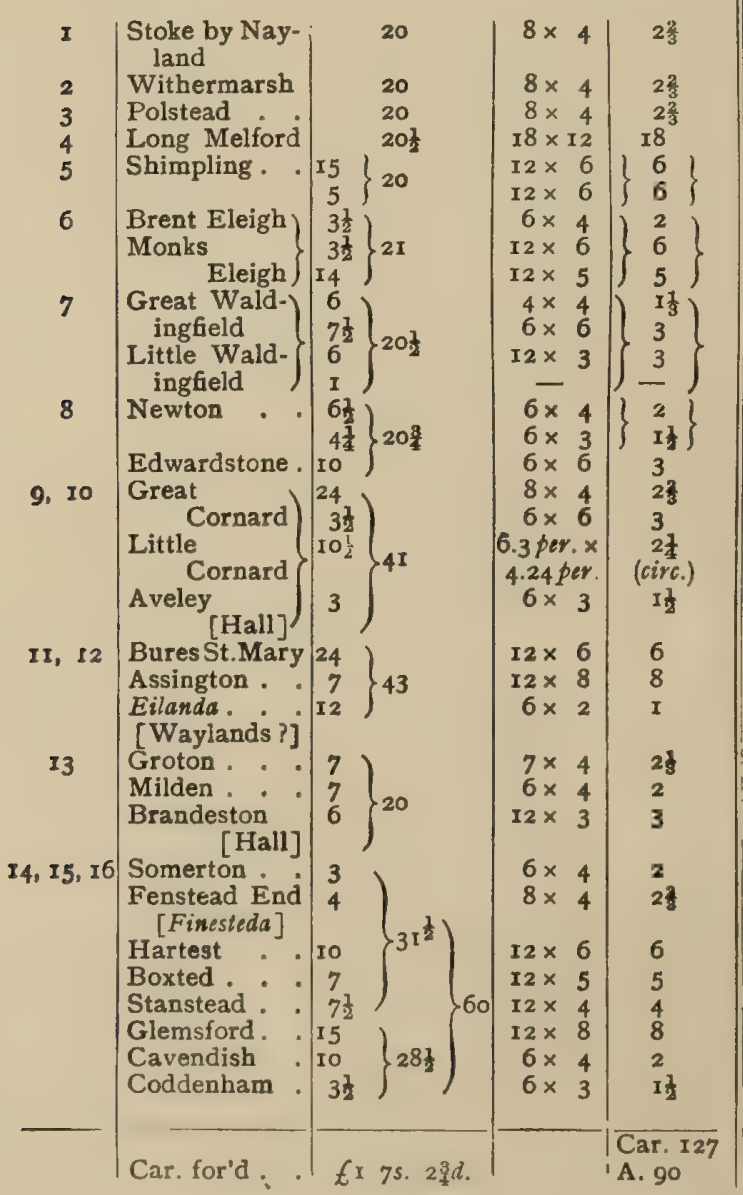

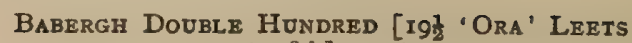
+7 章 $d$. ] cont.

\begin{tabular}{|c|c|c|c|c|c|}
\hline Leets & Vills & & Geld in Pence & 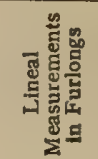 & 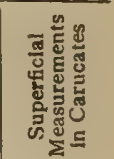 \\
\hline $17,18,19 \frac{7}{2}$ & $\begin{array}{l}\text { Brt. for'd . } \\
\text { Preston } \\
\text { Lavenham } \\
\text { Acton : } \\
\text { Chilton. : } \\
\text { Loose: } \\
\text { Chadacre . } \\
\text { Lawshall : } \\
\text { Cockfield . }\end{array}$ & : & 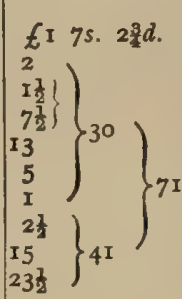 & $\begin{array}{rr}12 \times 6 \\
6 \times 4 \\
12 \times 6 \\
12 \times 12 \\
4 \times 3 \\
6 \times 4 \\
4 \times 2 \\
12 \times 6 \\
13 \times 12\end{array}$ & $\begin{array}{l}\text { Car. } 127 \\
\text { A. } 90 \\
6 \\
2 \\
6 \\
12 \\
1 \\
2 \\
03 \\
6 \\
13\end{array}$ \\
\hline $\begin{array}{c}19 \frac{1}{2}+7 \frac{8}{4} d . \\
=20 \\
\left.-2 \frac{1}{1}\right]\end{array}$ & 33 & & $t^{1}$ I3s. I $\frac{3}{4} d$. & & $\begin{array}{l}\text { Car. } 176 \\
\text { A. } 50\end{array}$ \\
\hline
\end{tabular}

Blything Hundred [6 'Ora and a Half'=3od. Leets + I LEET OF $22 \frac{1}{4} d .=6 \frac{2}{8}$ circ. $]$

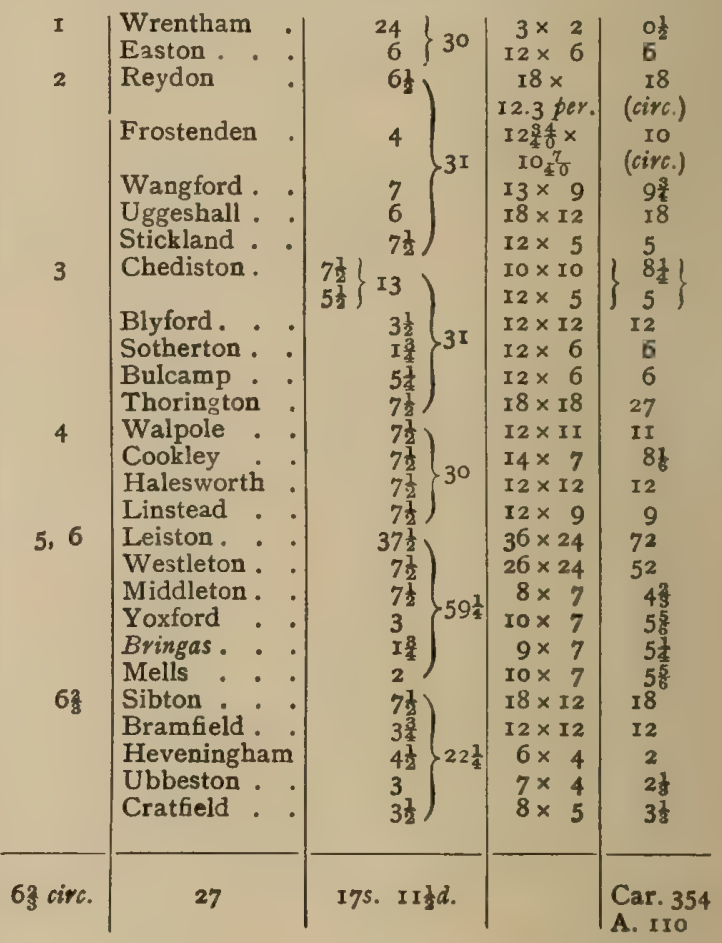

Bishop's Hundred [6 'Ora and a Half' LeEts
$\left.-\mathrm{I} \frac{1}{2} d.\right]$

\begin{tabular}{|c|c|c|c|c|}
\hline $\mathbf{I}$ & $\begin{array}{l}\text { Chepenhall } \\
\text { [Fressingfield] }\end{array}$ & $15\}_{30}$ & $18 \times 12$ & I8 \\
\hline & Mendham. & $15 \int^{0}$ & $2 I \times 12$ & $2 I$ \\
\hline 2 & Syleham . & $\left.7 \frac{1}{2}\right\} 30$ & $12 \times 8$ & 8 \\
\hline & Hoxne . . & $\left.22 \frac{1}{2}\right\} 30$ & $12 \times 8$ & 8 \\
\hline 3 & Denham . & $\left.7 \frac{\pi}{2}\right)$ & $6 \times 3$ & I \\
\hline & Southolt & $2 \frac{1}{2}$ & $9 \times 5$ & $3 \frac{3}{4}$ \\
\hline & Worlingworth & 10 & $12 \times 5$ & 5 \\
\hline & Tannington. & Io & $15 \times 12$ & I5 \\
\hline $4,4 \frac{1}{2}$ & Bedingfield . & 15 & $12 \times 6$ & 6 \\
\hline & Soham . . & $46 \frac{1}{2}$ & $7 \times 6$ & $3 \frac{1}{2}$ \\
\hline & Newton . & {$[45+$} & $\mathrm{r} 4 \times 6$ & 7 \\
\hline & Wineberga. & $\left.\left.I I \frac{1}{2}\right) \quad 1 \frac{1}{2}\right]$ & $14 \times 4$ & $4 ?$ \\
\hline $5 \frac{1}{2}, 6$ & Kelsale . & $42[45-3]$ & $18 \times 5$ & $7 \frac{1}{2}$ \\
\hline 6 & 13 & I $35.7 \frac{1}{2} d$. & & $\begin{array}{l}\text { Car. } 108 \\
\text { A. Iro }\end{array}$ \\
\hline
\end{tabular}




\section{THE DANEGELD IN SUFFOLK}

Carlford Hundred [8. Ora and a Hale' lebts $-4+d$.

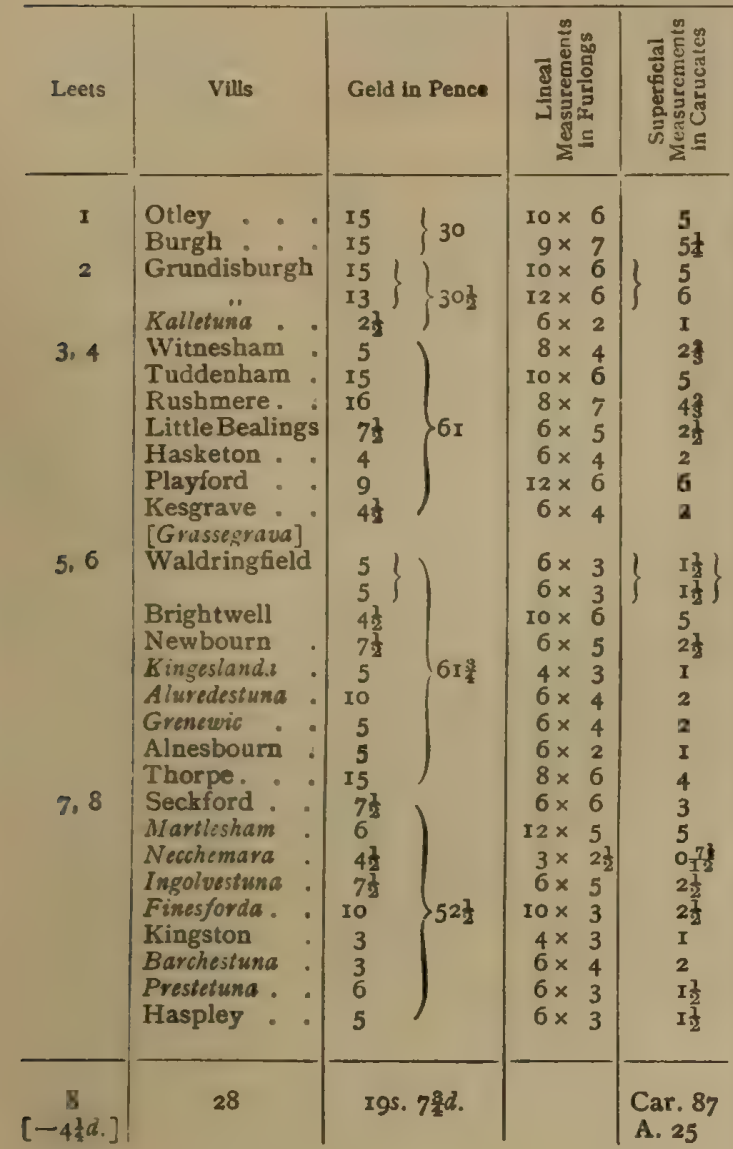

Stow Hundred [8 'ORA ANd a HalF' LeETS - $5 \frac{1}{2} d$.]

\begin{tabular}{|c|c|c|c|c|c|}
\hline I & $\begin{array}{l}\text { Creeting } \\
\text { Dagworth }\end{array}$ & \multicolumn{2}{|l|}{30} & $12 \times 6$ & 6 \\
\hline 3.4 & Combs. & $\begin{array}{l}30 \\
3713\end{array}$ & 60 & $\begin{array}{r}0 \times 18 \\
24 \times 12\end{array}$ & 24 \\
\hline & Finborough & $22 \frac{1}{2}$ & & $12 \times 8$ & 8 \\
\hline 5 & $\begin{array}{l}\text { Buxhall } \\
\text { Onehouse. }\end{array}$ & 25 & 3I娄 & $\begin{array}{r}12 \times 8 \\
5 \times 3\end{array}$ & 8 \\
\hline 6.7 & Wetherden & $25^{2}$ & & $12 \times 6$ & 6 \\
\hline & Haughley. & 17 & 60 & $12 \times 6$ & 6 \\
\hline & $\begin{array}{l}\text { Chilton } \\
\text { Ervestuna: }\end{array}$ & 10 & & $\begin{array}{r}4 \times 3 \\
10 \times 6\end{array}$ & I \\
\hline ब & Thorney . & 15 & & $12 \times 12$ & 12 \\
\hline$[-7 d]$. & Thorpe & 8 & 23 & $5 \times 3$ & I要 \\
\hline$\left[\begin{array}{c}8 \\
-5 \frac{1}{2} d\end{array}\right]$ & 12 & & $6 \frac{1}{2} d$. & & $\begin{array}{l}\text { Car. } 78 \\
\text { A. } 60\end{array}$ \\
\hline
\end{tabular}

\section{SAMTORd Hondred and a Haly [IOT 'ORA ANd a} Hale' Leets + ridd.]

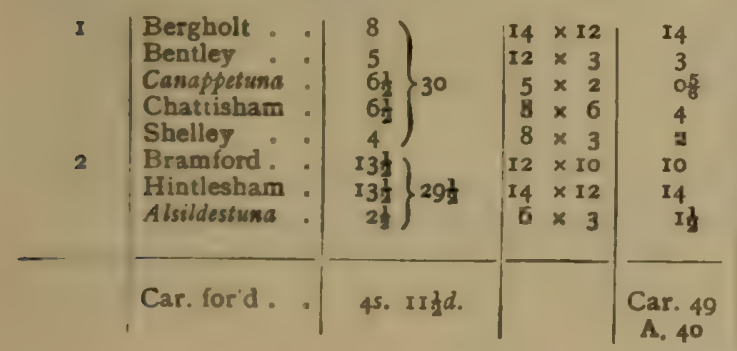

A. 40
SAMFORd HUNDREd AND a Half [IOL 'ORA ANd a HALF' LEETS + Itd.] - cont.

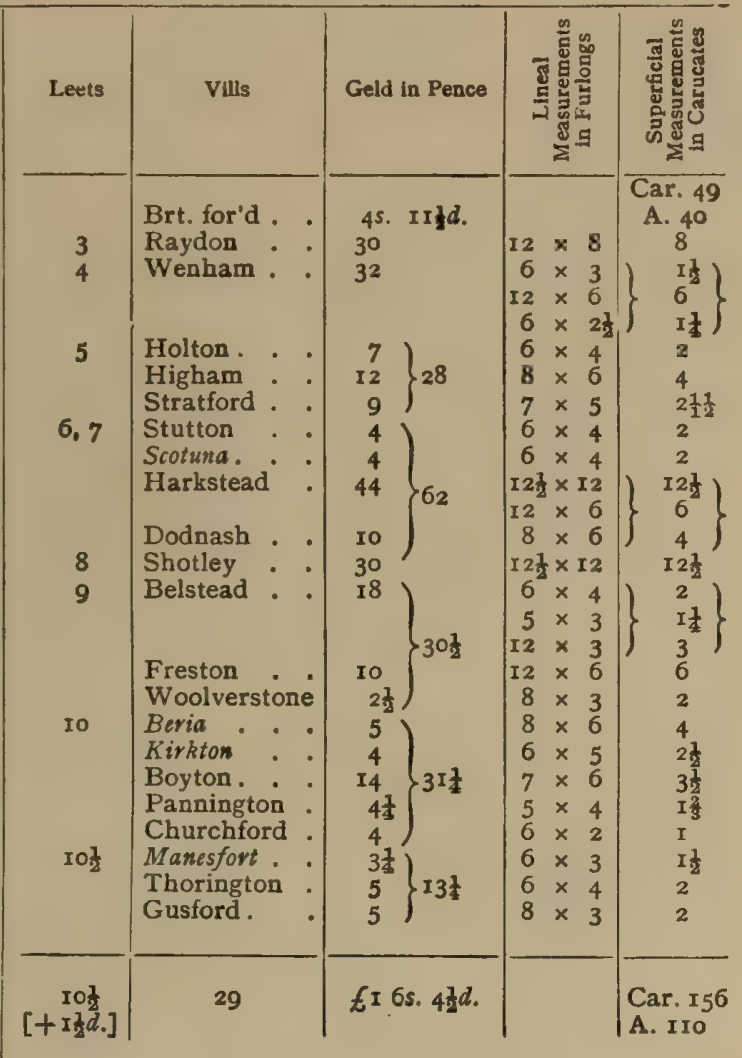

\section{Risbridge Hundred [8 'Ora aNd a Half} LEETS + I

1 Poslingford

2 Clare

Clare .. $\left.\begin{array}{r}15 \\ 15\end{array}\right\}$

Kedington: $\left.\begin{array}{r}3 \\ 12\end{array}\right\} 30$

3. 4 Haverhill.

Great Wratt-

ing \& Little

Wratting

Withersfield :

Great Thur-

low \& Little

Thurlow :

Great Brad-

ley \& Little

\begin{tabular}{c|c} 
Bradley : : & 6 \\
Cowlinge : & I $\frac{1}{2}$
\end{tabular}

5 Lidgate : I $13 \frac{1}{2}$

Badmondis-

field ... $13 \frac{1}{2}$

[Badmondis-

field Hall in

Wickham-

brook.]

Denston

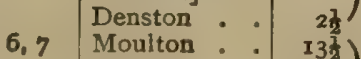

Deselinga

[Desning Hall

in Gazeley.]

Ousden

8

Chedburgh

Depden

Stansfield.

Hawkedon

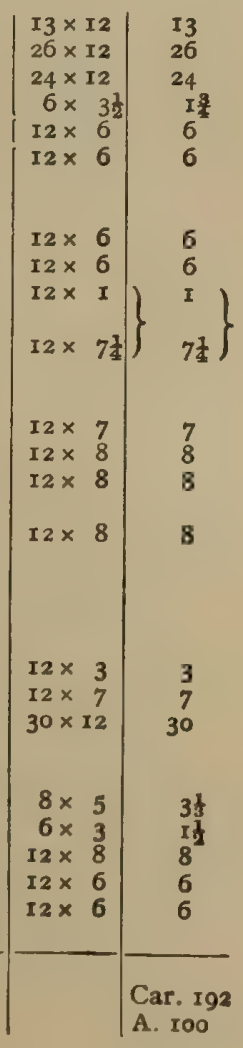




\section{A HISTORY OF SUFFOLK}

WiLford HUNDRED [9 LEets of 27d. $\left.-6 \frac{1}{2} d.\right]$

Blackbodr and Bradmere Hundred [13t Leets or $13 t d$. + IId.]-cont.

\begin{tabular}{|c|c|c|c|c|}
\hline Leets & Vills & Geld in Pence & 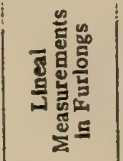 & 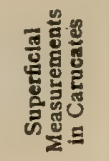 \\
\hline $\mathbf{I}$ & Sutton . & 27 & $12 \times 8$ & 8 \\
\hline 2 & $\begin{array}{c}\text { Capel St. An- } \\
\text { drew . }\end{array}$ & 27 & $12 \times 6$ & 6 \\
\hline 3 & Melton. . & 27 & $12 \times 9 \frac{1}{2}$ & $9 \frac{3}{2}$ \\
\hline 4 & Loudham . . & 27 & $12 \times 7$ & 7 \\
\hline 5 & Ch" & I $\left.3 \frac{1}{2}\right\}_{27}$ & $7 \times 4$ & 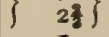 \\
\hline & Charsfield . & $13 \frac{1}{2} \int^{21}$ & $12 \times 5$ & 5 \\
\hline 6 & $\begin{array}{l}\text { Bredfield : . } \\
\text { Wilford : }\end{array}$ & $\left.\begin{array}{l}13 \frac{1}{2} \\
13 \frac{1}{2}\end{array}\right\} 27$ & $\begin{array}{l}18 \times 6 \\
12 \times 6\end{array}$ & $\begin{array}{l}9 \\
6\end{array}$ \\
\hline 7 & Bawdsey . . & 27 & $12 \times 5$ & 5 \\
\hline 8 & Culesiea. . & 27 & $12 \times 6$ & 6 \\
\hline 9 & $\begin{array}{l}\text { Hollesley } \\
\text { Peyton. } \\
\text { [Peyton Hall } \\
\text { in Ramsholt] }\end{array}$ & I $\left.3 \frac{7}{2}\right\} 20 \frac{1}{2}$ & $\begin{array}{l}12 \times 7 \\
12 \times 4\end{array}$ & $\begin{array}{l}7 \\
4\end{array}$ \\
\hline$\left[-6 \frac{9}{2} d.\right]$ & II & Igs. $8 \frac{1}{2} d$. & & $\begin{array}{l}\text { Car. } 74 \\
\text { A. } 100\end{array}$ \\
\hline \multicolumn{5}{|c|}{$\begin{array}{c}\text { TERDWASTRE 2 HUNDRED [I2 LEETS, IN } \\
\left.\text { AND } 2 \eta d .+ \text { I } \frac{1}{d} d .\right]\end{array}$} \\
\hline $\mathbf{I}$ & Rougham. & 20 & $16 \times 12$ & 16 \\
\hline 2 & Rattlesden . & 20 & $16 \times 10$ & $13 \frac{1}{3}$ \\
\hline 3 & $\begin{array}{l}\text { Gedding : } \\
\text { Felsham : }\end{array}$ & & $\begin{array}{l}3 \times 2 \\
8 \times 6\end{array}$ & $0 \frac{1}{2}$ \\
\hline & Bradfield . & $\begin{array}{r}5 \\
5 \\
-0\end{array}$ & $12 \times 4$ & 4 \\
\hline 4,5 & $\begin{array}{l}\text { Hessett : } \\
\text { Drinkstone : }\end{array}$ & 18 & $8 \times 7$ & $4 \frac{\overline{2}}{3}$ \\
\hline & Woolpit . & $\left.\begin{array}{l}\text { II } \\
\text { I I }\end{array}\right\}^{40}$ & $\begin{array}{l}8 \times 7 \\
9 \times 6\end{array}$ & $\begin{array}{l}43 \\
4 \frac{1}{2}\end{array}$ \\
\hline 6,7 & Great Barton & $27\} 40 \frac{1}{2}$ & $14 \times 12$ & $I_{4}$ \\
\hline 8 & $\begin{array}{l}\text { Pakenham } \\
\text { Great Liver- }\end{array}$ & $13 \frac{1}{2}$ & $16 \times 12$ & I6 \\
\hline & $\begin{array}{c}\text { mare } \\
\text { Ampton }\end{array}$ & $\left.\begin{array}{r}12 \\
7\end{array}\right\} 19$ & $\begin{array}{r}10 \times 8 \\
6 \times 4\end{array}$ & $\begin{array}{l}62 \\
2\end{array}$ \\
\hline 9,10, I I, & Timworth. & $14)$ & $8 \times 6$ & 4 \\
\hline [in urits & $\begin{array}{c}\text { Fornham St. } \\
\text { Genevieve }\end{array}$ & $8\}^{28 \frac{1}{2}}$ & $9 \times 4$ & 3 \\
\hline of $27 d]$. & Fornham . & $\left.6 \frac{1}{2}\right)$ & $9 \times 7$ & $5+$ \\
\hline & $\begin{array}{l}\text { Rushbrooke } \\
\text { Welnetham }\end{array}$ & $\left.\begin{array}{r}7 \\
10\end{array}\right\} 27$ & $\begin{array}{r}7 \times 4 \\
12 \times 6\end{array}$ & $\begin{array}{l}2 \frac{1}{3} \\
6\end{array}$ \\
\hline & Stanningfield & Io $\int$ & $8 \times 4$ & $2 \frac{2}{3}$ \\
\hline & $\begin{array}{l}\text { Thurston : } \\
\text { Tostock : }\end{array}$ & 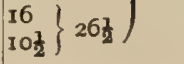 & $\begin{array}{r}10 \times 6 \\
7 \times 6\end{array}$ & $\begin{array}{l}5 \\
3 \frac{1}{2}\end{array}$ \\
\hline 12 & 20 & $t^{\mathrm{I}}$ os. I I $\frac{1}{2} d$. & & $\begin{array}{l}\text { Car. } 124 \\
\text { A. } 70\end{array}$ \\
\hline
\end{tabular}

BlackboURN AND BRADMERE HUNDRED [ $3 \frac{1}{2}$ LEETS OF $34 \frac{2}{2} d .+\mathrm{IId}$.]

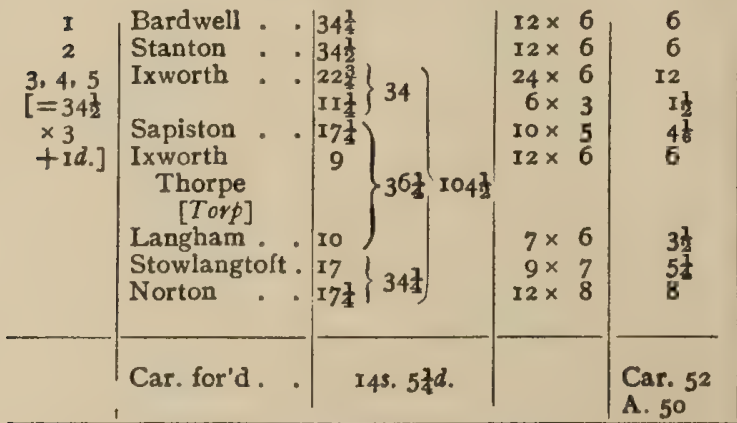

\begin{tabular}{|c|c|c|c|c|}
\hline Leets & Vills & Geld in Pence & 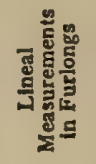 & 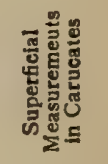 \\
\hline \multirow{4}{*}{6} & Brt. for'd . & \multirow{2}{*}{ I4s. $5 \frac{1 d}{4}$} & \multirow[b]{2}{*}{ II $\times$ II } & $\begin{array}{l}\text { Car. } 52 \\
\text { A. } 50\end{array}$ \\
\hline & Badwell Ash. & & & $10 \frac{1}{12}$ \\
\hline & $\begin{array}{l}\text { Great Ash- } \\
\text { field. }\end{array}$ & $\left.\operatorname{II}^{1 \frac{5}{2}}\right\}_{38}$ & $10 \times 5$ & $4 \frac{1}{6}$ \\
\hline & $\begin{array}{l}\text { Hunston : } \\
\text { Elmswell : }\end{array}$ & $\left(\begin{array}{r}98 \\
11 \frac{8}{4}\end{array}\right)$ & $\begin{array}{r}8 \times 7 \\
12 \times 10\end{array}$ & 12 \\
\hline \multirow[t]{2}{*}{7} & Walsham . & $17)$ & $24 \times 6$ & 12 \\
\hline & Rickinghall . & $1234 \frac{1}{2}$ & $12 \times 3$ & 3 \\
\hline \multirow[t]{2}{*}{8} & Wattisfield : & $\begin{array}{r}5 \frac{1}{2} \\
17 \frac{1}{7}\end{array}$ & $12 \times 6$ & 211 \\
\hline & Hepworth & $17 \frac{4}{4}$ & $7 \times 5$ & $2+\frac{12}{2}$ \\
\hline \multirow[t]{2}{*}{9} & $\begin{array}{l}\text { Thelnetham } \\
\text { Hopton } \\
\text { Market Wes- }\end{array}$ & $\begin{array}{r}97 \\
16\end{array}$ & $\begin{array}{r}10 \times 4 \\
6 \times 4\end{array}$ & $\begin{array}{l}3 \frac{5}{6} \\
2\end{array}$ \\
\hline & $\begin{array}{l}\text { ton } \\
{[\text { Westuna }]}\end{array}$ & 9 & $7 \times 5$ & $23 \frac{1}{2}$ \\
\hline \multirow[t]{2}{*}{ I0 } & Barningham . & I7. & $12 \times 6$ & 6 \\
\hline & $\begin{array}{l}\text { ConeyWeston } \\
\text { [Cunegestuna] }\end{array}$ & I7t 341 & $12 \times 6$ & 6 \\
\hline \multirow[t]{3}{*}{ I I } & Knettishall . & II & $12 \times 10$ & I0 \\
\hline & Euston . & $\left.x I \frac{1}{2}\right\} 34$ & $12 \times 5$ & 5 \\
\hline & Barnham . & $\left.\operatorname{II} \frac{1}{2}\right)$ & $8 \times 3$ & 2 \\
\hline \multirow[t]{2}{*}{12} & Fakenham & $24\}$ & $12 \times 8$ & 8 \\
\hline & Honington & $12 \frac{1}{2}$ & $6 \times 4$ & 2 \\
\hline \multirow[t]{3}{*}{13} & $\begin{array}{l}\text { Troston } \\
\text { Little Liver- }\end{array}$ & I I t & $10 \times 5$ & $4 \frac{1}{6}$ \\
\hline & $\begin{array}{c}\text { mere : } \\
\text { Ingham }\end{array}$ & $\left.\underset{16}{3 \frac{1}{4}}\right\}^{38}$ & $\begin{array}{l}12 \times 4 \\
16 \times 8\end{array}$ & $\begin{array}{c}4 \\
102\end{array}$ \\
\hline & Culford - & $7 \frac{1}{5}$ & $12 \times 5$ & 5 \\
\hline \multirow[t]{2}{*}{$13 \frac{1}{2}$} & Wordwell. . & $\left.7 \frac{1}{2}\right\} 17 \frac{1}{2}$ & $12 \times 4$ & 4 \\
\hline & West Stow & IO 1 - & $12 \times$ & 8 \\
\hline $13 \frac{1}{2}$ & 33 & tx Igs. $78 d$ & & $\begin{array}{l}\text { Car. } 193 \\
\text { A. } 20\end{array}$ \\
\hline
\end{tabular}

Lothing aNd Lothingland Half-hondred [8 LERTs OF $16 d .+6$ LEETS OF 20d.]

\begin{tabular}{|c|c|c|c|c|}
\hline $\begin{array}{c}1,2,3 \\
4,5,6 \\
7,8 \\
1,2,3,4 \\
5,6\end{array}$ & $\begin{array}{l}\text { Carlton } \\
\text { Mutford } \\
\text { Kessingland } \\
\text { Lothingland } \\
\text { half-hundred }\end{array}$ & $\begin{array}{r}48 \\
48 \\
32 \\
120\end{array}$ & $\begin{array}{r}8 \times 22 \\
24 \times 9 \\
12 \times 12 \\
72 \times 34\end{array}$ & $\begin{array}{l}143 \\
18 \\
12 \\
204\end{array}$ \\
\hline 14 & $\underset{\text { dred }}{+ \text { half }^{3} \text { hun- }}$ & $\sum \mathrm{I}$ os. $8 d$. & & $\begin{array}{l}\text { Car. } 24^{8} \\
\text { A. } 80\end{array}$ \\
\hline
\end{tabular}

IPSWICH HALF-HUNDRED

\begin{tabular}{|c|c|c|c|c|}
\hline $\begin{array}{l}\text { Stoke } \\
\text { Ipswich } \\
\text { rough }\end{array}$ & bo- & $\begin{array}{l}4 \text { [in a geld of } \\
20 s .] \\
\text { 100 [ head-pen- } \\
\text { nies] }\end{array}$ & $\begin{array}{l}6 \times 6 \\
4 \times 4 \\
8 \times 8\end{array}$ & $\left.\begin{array}{l}3 \\
1 \frac{1}{3} \\
5 \frac{1}{3}\end{array}\right\}$ \\
\hline 2 & & 8s. $8 d$. & & $\begin{array}{l}\text { Car. } 9 \\
\text { A. } 80^{\circ}\end{array}$ \\
\hline
\end{tabular}

${ }^{2}$ Cf. Round, Feud. Engl. p. roo et seq. The arrangement here adopted gives contiguous areas of assessment. 


\section{NOTE}

THE reader should bear in mind throughout that the date of the Domesday Survey is 1086; that 'the time of King Edward,' to which it refers, normally means the date of his death ( $5 \mathrm{Jan}$. I066), and that the intermediate date, which is sometimes spoken of as 'afterwards' and sometimes as 'when received,' is that at which the estate passed into the hands of the new holder. When the word 'semper' is used it means that the figures were the same in 1086 as 1066. The Domesday 'plough-land' or 'carucate' is not divided in Suffolk, as in other counties, into eight 'bovates,' but smaller holdings are expressed either in acres (of which 120 went to the 'carucate') or as fractions of the 'carucate.' 'Demesne,' in the Survey, is used in two senses: manors held 'in demesne' were those which the tenant-in-chief (who held directly of the Crown) retained in his own hands, instead of enfeoffing under-tenants therein; but when 'the demesne' of a manor is spoken of, the term denotes that portion which the holder (whether a tenant-in-chief or only an undertenant) worked as a home farm with the help of labour due from the peasants who held the rest from him. Of the peasantry the three classes are styled, in descending order, villeins, bordars, and serfs; above them were the 'freemen' and sokemen, survivals from before the Conquest, who are discussed in the Introduction. The essential element of the plough ('caruca') was its team of oxen, always reckoned in Domesday as eight in number. Apart from the plough-oxen the live stock on the lord's demesne is generally, though not regularly, entered in the Suffolk survey, a feature which adds greatly to its length, and is peculiar to the three eastern counties. It comprises horses (usually 'rounceys'), asses, and 'beasts' (i.e. cattle), sheep, swine, goats, and hives of bees.

It must be remembered that when Domesday speaks of a place as held by a certain tenant, it does not follow that the whole of it is meant. It may have comprised other manors, which form the subject of separate entries.

The assessment of geld in East Anglia is expressed in terms of pence per pound. For every pound of geld assessed on the hundred each 'vill' pays a definite number of pence, as is explained in the Introduction. It should be remembered that the measurements given are very rough, and that no calculation of acreage can safely be based upon them.

A translation of the portion of Domesday relating to Suffolk was published by the late Lord John Hervey in 1888-91. This, adapted to "Iniformity with the other Domesday translations in the Victoria County istories, formed the basis of the present translation. The latter has, "rever, been collated throughout with the photographic facsimile of the and the identifications have also been made independently of Lord rvey's work. The text of the Inquisitio Eliensis, quoted in the

T that printed by Mr. N. E. Hamilton in his edition of the tatus Cantabrigiensis. 


\section{SUDFOLC}

\section{[HOLDERS OF LANDS]}

I William, King of the English

II The Count of Mortain

III Count Alan

Iv Earl Hugh

v Count Eustace

vi Robert Malet

vir Roger Bigot

viII Roger of Poitou

Ix William de Scoies

$\mathrm{x}$ Hermer de Ferreris

xI Ralph de Bella fago

xII Frodo, the Abbot's Brother

xIII Godric the Steward (dapifer)

XIv Abbot of St. Edmunds

xv Lanfranc the Archbishop

XvI Bishop of Bayeux

xvil Abbot of Ramsey

xvin Bishop of Thetford

xIx The Fee of the same Bishop

xx Bishop of Rochester

xxi Abbot of Ely

xxir Bishop of Evreux

xxiII Abbot of Bernai

xxiv Abbot of Chatteris (Ceteritb)

xxv Richard, son of Count Gilbert

xxvi William de Warenne

xxvir Suen of Essex

xxviII Eudo Dapifer

xxix Roger de Otburvil

$\mathrm{xxx}$ William his brother

xxxi Hugh de Montfort

xxxII Geoffrey de Mandeville (magna villa)

xxxiII Ralph Baignard

xxxiv Ranulph Peverell (piperellus)

xxxv Aubrey de Vere

xxxvi Robert Grenon

xxxvir Peter de Valoines

rxxvirI Roger de Ramis xxxix Ralph, brother of Ilger

XL Robert, son of Corbutio

XLI Walter the Deacon

xLII Tihell de Herion

xLIII Ralph de Limesey

xLIV Robert de Toeni (Todeneio)

XLV Walter Gifart

xLvi Countess of Albemarle

xLvir William de Arcis

xLviII Drew de Beureria

xLIX Hugo de Grentemesnil

L Ralph de Felgeris

LI Walter de St. Valery

LII Humphrey the Chamberlain

LIII Eudo, son of Spiruic

LIV Walter de Watevil

LV John son of Waleram

LVI Humphrey son of Aubrey

Lvir Hubert de Monchensey (monte canesio)

LviII Gondwin

LIX Saisselin

Lx Robert de Verli

LXI Ralph Pinel

LXII Isaac

LXIII Norman

LXIv Juhichell the Priest

Lxv Gerald the Marshal

LXvi Robert Blund

Lxvir Hervey de Borcensis)

LxviII Gilbert th

LXIX Ralph *

Lxx Rain

LXXI Rc

LXXII $S$

LXXIII

LXX1"

LY

I 


\section{THE HOLDERS OF LANDS}

\section{LANDS OF THE KING IN THE ROYAL DEMESNE (de regione) WHICH ROGER BIGOT KEEPS IN SUFFOLK}

\section{HundRet of Stou [Stow]}

ToRnaI [Thorney ${ }^{1}$ ] King William holds, which King Edward held as a manor, and as 5 carucates of land. Then as now 36 villeins and 18 bordars. Then 6 serfs, afterwards 1 , now none. Then and afterwards $I$ plough on the demesne, now none; but T.R.E. there could have been 2 besides that $I$. Then and afterwards 45 ploughs belonging to the men, now 19. Then wood(land) for 30 swine, now for 6. Then 14 acres of meadow, afterwards and now 12. Then 2 mills, afterwards and now I. There is also 2 market. There was T.R.E. a church with I carucate of free land. But Hugh de Montford has 23 acres of that carucate and claims it as belonging to a certain chapel which 4 brothers, freemen under Hugh, built on land of their own hard by the cemetery of the mother church. And they were inhabitants (manentes) of the parish of the mother church (and built this chapel), because it could not take in the whole of the parish. The mother church had always a moiety of the burial fees, and had by purchase the fourth part of other alms which might be made. And whether or not this chapel were consecrated the Hundred doth not know. In this carucate of the church there were 5 bordars and I villein. Then as now 2 ploughs. In this manor T.R.E. 40 sokemen owing every kind of custom. After Roger received (his office) they were all removed but 7. These had then as now 58 acres, and half a plough. But T.R.E. there was a plough among four. And the reeve of this manor held 26 acres in the King's soke T.R.E. When this manor was undivided its annual value was 15 li. by tale, when Roger took it over 35 li., now 40 li. blanch. Tornei [Thorney] is $\mathrm{I}$ league long and I broad. And (pays) $15 d$. in geld whoso may be tenant there. Of this manor Hugh de Montfort has 20 sokemen, and Count Robert 6. Roger de Otburville 4. Frodo has 2. Roger of Poitou 3.

\section{HUNDRET OF Bosemera [Bosmere]}

King Edward held Brunfor: [Bramford] as 12 carucates of land and as a manor. Then as now 40 villeins, and 8 bordars, and I serf. Then and afterwards I plough on the demesne, now half. Then as now 18 ploughs belonging to the men. 30 acres of meadow. And then as now 1 mill. A church with 80 acres of free land and I plough. Then ro swine, now 12. Then as now 30 sheep. Then it was worth ... li., and now isli. by weight. It is I league long, and I league broad.

\footnotetext{
II Stowmarket.
}

In BLacham [Blakenham] (are) 9 sokemen with half a carucate of land in the King's soke. Then as now 3 ploughs. Then it was worth IOs., now 20 .

In Sumersham [Somersham] (are) 4 sokemen with 30 acres. Then as now I plough. Then it was worth 5s., now ros.

In UledanA [Olden ${ }^{2}$ ] (are) I $\frac{1}{2}$ sokemen with 10 acres and half a plough. Worth $20 d$.

fol. 282.

In Stanham [Stonham] (was) a sokeman with 12 acres T.R.E., (over) whom the Bishop of Bayeux now holds. And Roger Bigot holds of him. This sokeman could not withdraw from (his holdings).

\section{Hundret of Claindone [Claydon]}

In Haminghelanda [? Hemingstone] (vas) a free(man) under commendation to Gurth, with 30 acres. Then half a plough. Worth 5s. Ulmar the reeve joined this freeman on to the King's farm at Brunfort [Bramford], and Roger the sheriff is his warrantor. And (the freeman) renders each year 5s. The King and the Earl have the soke.

\section{Hundret of Hertismera [Hartismere]}

(At) Dice [Diss $\left.{ }^{22}\right]$ King Edward held T.R.E. 4 carucates of land as a manor T.R.E. (sic). Then as now 14 villeins, and 24 bordars, and 2 serfs. And 1 plough on the demesne. And 18 ploughs belonging to the men. And 10 acres of meadow. And a church with 24 acres and half a plough. Then as now 7 beasts. Then 5 swine. Then 9 sheep, now I I. Then as now 5 goats. Then worth $15 l i$. with the soke over one hundred and a half, and half a day's (provision) of honey with the customs, now (worth) 30 li. by weight. It is I league long and half (a league) broad. And (pays) $4 d$. in geld.

(At) Brom [Brome] Anand held T.R.E. 60 acres as a manor. Then as now 4 bordars. Then I serf. Then as now on the demesne half a plough. And half a plough belonging to the men. Four acres of meadow. Worth ros. And $3 \frac{1}{2}$ freemen under commendation to Anand (held) 14 acres and a plough; and were worth 2s. and $2 d$.

In Estuna [Easton Bavents (? ${ }^{3}$ ] 2 villeins, whom Earl Ralph held, (had) a carucate of land;

\footnotetext{
'In 1650 there was ' $a$ leet in Coddenham called Olden'; Parl. Surv. Suff. no. 3. The name is now apparently lost.

Now in Norfolk.

Saston Bavents is near Blythburgh, but is not in
} Hartismere Hundred. 


\section{A HISTORY OF SUFFOLK}

and afterwards Fulchred added them to the manor of Blideburo [Blythburgh] in Robert Malet's time.

In Gislingaham [Gislingham] Leverich a freeman (had) 3 acres, worth $6 d$.

In the same (vill) were 7 acres which $W$. de Burnoville holds at Dice [Diss].

\section{Hundret of Blidinga [Blything]}

Blideburc [Blythburgh] King Edward held as a manor 5 carucates and 15 acres of land. Then as now 8 villeins, and 39 bordars, and 1 serf. Then I plough on the demesne. Land (enough) for 5 ploughs on the demesne. But Roger received (only) 3 oxen, and now there are the like number. Then as now 2 I ploughs belonging to the men. Wood(land) for 40 swine. 6 acres of meadow. And 7 sokemen (subject to) all customs (held) 3 carucates and 84 acres of land. Then as now 16 bordars. And 9 ploughs. And a market. Wood(land) for 30 swine. And 2 acres of meadow. To this manor belongs the fourth penny of the rent (censu) of the haye (beia) of Riseburc [ ] between the King and the Earl. All this T.R.E. rendered 3oli. by tale and one day's (provision) of honey with all customs; when Roger received it 50li. by weight, now 23li. by weight. A church with 2 carucates of land. Then as now 9 villeins and 4 bordars. Then 1 plough on the demesne, now half a plough. Then 4 ploughs belonging to the men, now I plough. Wood(land) for 20 swine. And half an acre of meadow. Then it rendered ten thousand herrings, now 50s. and three thousand herrings. This Osbern Masculus holds in alms of the King; to this church belong two others without land.

\section{fol. $282 b$.}

In Dersham [Darsham] Alwin the priest held T.R.E. 30 acres of land as a manor, and I bordar, and I freeman with 2 acres, half a shurch with 6 acres worth $12 d$. Then as now I plough, I acre of meadow. Worth 10 s.

And in Stickingalanda [Stickingland ${ }^{4}$ ] the said Alwin held T.R.E. I carucate of land and 40 acres as a manor. Then as now 2 villeins. Then 4 bordars, now 1 I. Then as now on the demesne I plough. Then I plough belonging to the men, now $2 \frac{1}{2}$ ploughs. 3 acres of meadow. And I rouncey, 4 beasts, I swine, and I 6 sheep. Then it was worth 25s., now 30 . Over this the predecessor of Robert Malet had commendation T.R.E.

\section{Hundret of Carleford [Carlford]}

In Riscemara [Rushmere (St. Andrew)] (were) 9 freemen with $3 I$ acres of land. I plough,

' In Yoxford; see Cal. Chart. in B.M. now half a plough. Then it was worth 5s., now $3^{\text {s. }}$

\section{HUNDRET OF W ANNEFORDA [W ANGFORD]}

In Ringesfella [Ringsfield] a freeman under King Edward (held) $1 \frac{1}{2}$ carucates as a manor. Then as now I villein, and 5 bordars. On the demesne I plough, and belonging to the men I plough. 2 acres of meadow. Wood(land) for 20 swine. Half a mill. A church with 15 acres, worth 2s. and $8 d$. Then as now 2 ploughs. And 2 beasts, 5 swine, 30 sheep, and 16 goats. Then worth $20 s$, now 16 s.

In the same (vill) iI freemen under Ulsi's commendation T.R.E. (held) a carucate of land. Then 4 ploughs, now $1 \frac{1}{2}$ ploughs. 2 acres of meadow. 83 freemen out of this Hundred were added to Montford's manor in King William's time, among whom are the aforesaid 12 , who rendered no custom at all to this manor aforesaid T.R.E.; but now they render I 5 li.; and this custom Aluric the reeve appointed for them in Roger Bigot's time.

In Westuna [Weston] a freeman Hacun, a freeman under King Edward, (held) 40 acres as a manor. Then as now 1 villein, and 2 bordars. Half a plough on the demesne, and his men have half a plough. Wood(land) for ro swine.

In the same (vill) a freeman Ailric under Gurth's commendation (held) 40 acres as a manor. Then as now I bordar. Then as now half a plough. Wood(land) for 4 swine. I acre of meadow. All these T.R.E. rendered 6 s. and $8 d$.

In the same (vili) a freeman Sprottulf under the same (Gurth's) commendation (held) 30 acres as a manor. Then as now 2 bordars. Then I plough, now half a plough. And 2 oxen belonging to the men. Half an acre of meadow.

In WeRLINGAHAM [Worlingham] a freeman Vlf under Gurth's commendation (held) 40 acres as a manor. Then as now 2 bordars. And I plough. 2 acres of meadow.

In the same (vili) a freeman Adestan under Ulsi's commendation (held) 40 acres as a manor. Then as now I plough, 2 acres of meadow.

In the same (vill) a freeman Æthesi under Gurth's commendation (held) 30 acres as a manor. Then as now I plough. Half an acre of meadow.

In the same (vill) a freeman Godric under Ulsi's commendation (held) 30 acres and I bordar and I plough and I acre of meadow.

And 64 other freemen hold 5 carucates of land, and they always ploughed with 7 ploughs. 4 acres of meadow.

In Ringesfella [Ringsfield] the King has part of a church with 20 acres, and others have part therein, and it is worth $3^{\text {s. }}$ 


\section{THE HOLDERS OF LANDS}

fol. 283 .

In Westuna [Weston](is) I church which the King's freemen hold, with 20 acres; it is worth 3 s.

In WerLingaham [Worlingham] 2 churches with 40 acres, worth $6 s$. Others have part therein. Of one of these churches $R$. de Vallibus holds the half part with 30 acres and I bordar.

\section{HUNDRet OF LUdinga [now Mutford]}

MutForda [Mutford] Earl Gurth, and under him Ulsi, held T.R.E. $3 \frac{1}{2}$ carucates of land as a manor. Then as now 18 villeins, and 6 bordars. Then 16 serfs, now 10 . Then on the demesne 4 ploughs, now 3 . Then as now belonging to the men 3 ploughs. Wood(land) for 60 swine. 6 acres of meadow. Then 3 rounceys, now 2 . Then as now 7 beasts, 30 swine, 160 sheep, 50 goats, and 2 hives of bees. Then worth 6os., now the like. It is 2 leagues long, and 9 furlongs broad. And in geld (pays) 4 s.

In the same (vill) 12 freemen under Gurth's commendation (held) T.R.E. 3 carucates of land. Then as now 2 villeins, and 4 bordars. Then among them (were) 9 ploughs, now 7. 8 acres of meadow. Wood(land) for 16 swine. Two churches with 43 acres. Four of these 12 (freemen) dwell in Mutford and 2 in Riscemara [Rushmere] and in Gisleham [Gisleham] 2 and in Paggefella [Pakefield] 3 and in Kirkelea ‘Kirblosr?

A.

$30 \mathrm{acl}$

And 1.

men with

now 2.

And in $B_{A R_{\perp}}$

acres. Then 3

All these rende now they render 3 imposed (misit) upo time under Roger B.

In Kessingelanda Osfert under commend
[Laxfield] (held) 15 acres and I bordar. Half an acre of meadow. Worth $2 s$.

\section{Half Hundred of Ludingalanda [LOTHINGLAND]}

In Gorlestuna [Gorleston ${ }^{5}$ ] Guert held T.R.E. 5 carucates of land as a manor. Then 20 villeins, now 12 . Then as now 5 bordars. Then 5 serfs, now 4 . Then on the demesne 2 ploughs, now I. Then belonging to the men 5 ploughs, now 3 . Wood(land) for 5 swine. 10 acres of meadow. Three salt-pans. Then 2 rounceys, now none. Then 5 beasts, now none. Then as now 300 sheep.

In GrRnkmutha [Yarmouth] 24 fishermen belong to this manor.

fol. 2836 .

And in Lothuwistort [Lowestoft], a berewick, (are) 4 carucates of land less 30 acres. Then 5 villeins, now 3 . Then as now. ro bordars. Then 5 serfs, now 3. Then as now on the demesne 2 ploughs. Then belonging to the men 5 ploughs, now 3. Wood(land) for 8 swine. 5 acres of meadow. Then 14 beasts, now 8 . Then as now II swine. And 160 sheep.

Guert held a berewick, Lunda [Lound], as 2 carucates of land. Then as now 4 bordars. And 2 suis. Then as now 1 plough. Then belonging to the men ? plough, now half a plough. Wood(land) for 50 swine. And I rouncey.

freemen with I

Then as now 2

e (St. Michael)]

n I plough, now

] 6 freemen with

In Beletuna [Belton], a berewick, (was) I carucate of land. Then as now I villein, 4 bordars, and I serf. On the demesne I plough. Then I plough, now half a plough. Then I rouncey. Then as now 160 sheep.

In Gabbetuna [Gapton ${ }^{8}$ ] Ulsi held 2 carucates of land as a manor. Then 3 villeins, now 2. Then 3 bordars, now 2 . Then on the demesne 2 ploughs. Then belonging to the men 2 ploughs, now I. Two acres of meadow. Then as now worth 60 s.

In Wanneforda [Wangford] Hundred (is) ]5 freeThen 3 ploughs,

freemen with 80

35. and $6 d$., but Is custom Aluric King William's

and] a freeman dric of Laxestalla a berewick; in ElgA [Ellough ${ }^{7}$ ] and in WILLINGAHAM [Willingham] (there are) 60 acres. And 3 villeins. And I plough. Wood(land) for 40 swine.

And in Norfulc [Norfolk] in Gillingaham [Gillingham] are 30 acres and $I$ villein and half a plough.

${ }^{5}$ Now in Norfolk.

- Gapton Hall, a manor in Belton and Bradwell.

${ }^{7}$ In Willingham. 


\section{A HISTORY OF SUFFOLK}

And in Becles [Beccles] (are) 82 acres and 5 villeins and I plough.

And of BecLes [Beccles] market the King has the fourth part and (so) of all customs.

All this, except the 2 carucates, was worth T.R.E. roli., now it renders 27 li.

This (half hundred) is 6 leagues long and $2 \frac{1}{2}$ leagues and 2 furlongs broad. And in geld (pays) 1os.

Moreover in Sumerledetuna [Somerleyton] (are) 90 acres and these belong to Gorlestuna [Gorleston].

And there are 20 freemen in Gorlestuna [Gorleston] with 90 acres belonging as to all customs to the manor, and (included) in the value of the manor. Then 7 ploughs, now 5 .

And ABeCLEs [at BeCCLes] (are) 12 freemen with 48 acres and 1 plough. And these (belong) in like manner.

All this is within the valuation of the manor.

In Lunda [Lound] Alric a freeman under Gurth held $I \frac{1}{2}$ carucates of land as a manor. Then as now 2 villeins, and 3 bordars. Then and now I plough. And belonging to the men I plough. Wood(land) for 30 swine. 3 acres of meadow. 2 rounceys, 5 beasts, 12 swine, and 50 sheep. Then worth IOS., now 20 s. And under him were 4 freemen with I carucate of land. Then 2 ploughs, nc: $\mathbf{I}_{\frac{1}{2}}$ ploughs. Wood(land) for 10 swine. Then as now worth ros.

Moreover in Karetuna [Corton] the same freeman Alric under Gurth's commendation (held) 2 carucates of land. Then as now 5 bordars. On the demesne 2 ploughs, and belonging to the men I plough. Then 2 rounceys, 5 beasts, 12 swine, and 50 sheep. Then and now worth 20s. And under him I5 freemen (held) 80 acres. Then 4 ploughs, now 3. Wood(land) for 3 swine. Then and now worth ros.

In LuNDA [Lound] a freeman Ulsi under the same Gurth's commendation (held) I carucate of land as a manor and 3 bordars. Then as now on the demesne I plough, and belonging to the men I plough. Wood(land) for 12 swine. And 2 rounceys, 5 beasts, 15 swine, 60 sheep, and 2 hives of bees. Then worth ros., now the like. And under him 3 freemen (held) 40 acres of land. Then I plough, now half a plough. Worth 5 s.

In Flixtuna [Flixton] a freeman Hacun fol. 284 .

under Gurth's commendation (held) T.R.E. 3 carucates of land as a manor. Then and now 2 villeins, 14 bordars, and 4 serfs. Then on the demesne 3 ploughs, now 3. Then belonging to the men 3 ploughs, now 2. Wood(land) for ro swine. 3 acres of meadow. And 2 rounceys, 6 beasts, 15 swine, 160 sheep, and 20 goats. Then as now worth 30s. And under him 21 freemen (held) 3 carucates of land and 6 bordars. Then 10 ploughs, now 8 . Wood(land) for 10 swine. 4 acres of meadow. Then as now worth 40 s.

In Sumerledetuna [Somerleyton] a freeman Ulf under the said Gurth's commendation (held) 2 carucates of land as a manor. Then as now 4 villeins and 4 bordars. Then and now 2 ploughs. Then as now belonging to the men half a plough. Wood(land) for 15 swine. One acre of meadow. And 2 rounceys, 6 swine, and 80 sheep. Then as now worth 20s. And 5 freemen under him (held) 40 acres. Then as now I plough. Wood(land) for 4 swine. Worth $3^{\text {s. }}$

In Fridetuna [Fritton] a freeman Godwin under the said Gurth's commendation (held) 2 carucates of land as a manor. Then as now 2 villeins, 2 bordars, and 3 serfs. On the demesne 2 ploughs, and belonging to the men I plough. Wood(land) for 20 swine. And 2 rounceys, 8 beasts, 16 swine, 160 sheep, 3 goats, and 3 hives of bees. Then as now worth 20s. And under him 2 freemen (held) 60 acres. Then as now I plough. Then as now worth 5 s.

\section{In Flixtuni}

2 carucates of 2 villeins. $A r_{1}$ the demesne $2 \mathrm{~F}$ men 2 ploughs, for 6 swine. 2 and 40 sheep.

In the same ( with 5 acres, w

In the Horv under Gurth's a manor T.R Then as now o: (land) for $10 \mathrm{su}$ I rouncey, 5 b hives of bees.

In the same said Gurth's cor a manor and I Wood(land) for And I rouncey Then as now And under " 80 acres. TH Two acres of IOS.

In SUMERLE Wibtred the p
And and 3

Inder the vo acres as and I plough. ies of meadow. $1 e$, and 69 sheep.

ic 8 freemen (held) ns, now 2 ploughs. Then as now worth

somerleyton] a freeman, 1) 40 acres as a manor. 


\section{THE HOLDERS OF LANDS}

Then I bordar, now 2. Then as now I plough. : Wood(land) for ro swine, And I rouncey, 4 beasts, 5 swine, 33 sheep. Worth 5s. A church with 20 acres, worth 3 s.

In Brockestuna [Broceston ${ }^{8}$ ] a freeman Ulketel (held) 40 acres as a manor. Then as now half a plough. Wood(land) for ro swine. And I rouncey, 2 beasts, 7 swine, 30 sheep, and 3 goats. Worth 5s, And under him I freeman (held) 30 acres, worth 25.

In the same (vill) a freeman Broder (held) 60 acres as a manor. Then as now 2 bordars. Then as now on the demesne I plough. And belonging to the men half a plough. And $x$ rouncey, 2 beasts, 7 swine, and 40 sheep. Then as now worth 5 s.

Moreover in the same (vill) a freeman Godwin (held) 30 acres and a half a plough. Worth $3^{5}$.

In the same (vill) 2 freemen (held) 80 acres of land and $I$ bordar. Then as now $1 \frac{1}{2}$ fol. $284 b$.

ploughs. Then as now worth 6 s.

In Gorlestuna [Gorleston] 4 freemen (held) I carucate of land. Then $2 \frac{1}{2}$ ploughs, now 2. Then worth 20 s., now 16 s.

In Gabbatuna [Gapton] a freeman Ulf (held) 60 acres as a manor, and I bordar. Then as now I plough. Half an acre of meadow. And I rouncey, 3 beasts, 6 swine, and 80 sheep. Worth 5 s.

In the same (vill) a frecman Achestan (held) 60 acres as a manor. Then as now half a plough. One acre of meadow. And 4 beasts, 3 swine, and 30 sheep. Worth 4 s.

Moreover in the same (vill) a freeman Spottulf (held) 40 acres and I bordar. Then as now I plough. Wood(land) for 3 swine. One acre of meadow. Worth 4 s.

In the same (vill) a freeman Ulnoth (held) 30 acres. Worth 5 s.

In AKeTORP [Akethorp ${ }^{9}$ ] a freeman, Ailmar the priest, (held) 80 acres as a manor. Then as now 3 bordars. On the demesne I plough. And belonging to the men half a plough. Wood(lan 1) for 5 swine. One acre of meadow. And 3 swine, and 48 sheep. Worth ros.

In Neutuna [Newton ${ }^{10}$ ] a freeman (held) 30 acres and half a plough. Worth 3 s.

In Fridetuna [Fritton] 2 freemen (held) 80 acres. Then 2 villeins. Now 1 bordar. Then 2 ploughs, now I. Then I salt-pan. Then as now worth Ios.

- Broceston or Browston, a hamlet in Belton.

- In Lowestoft; Copinger, Suff. Rec.

in Newton formerly stood castward of Corton. It has been destroyed by sea.
In the same (vill) a freeman Leuric (held) 30 acres. Then half a plough, now none. Worth $3^{\text {s. }}$

In Beletuna [Belton] 3 freemen (held) 90 acres. Then 3 ploughs, now I. Then as now worth Ios.

In HerLingaflet [Herringfleet] a freeman Ulsi (held) I carucate of land as a manor. Then as now 2 villeins. And I bordar. And then on the demesne I plough, now none. Then belonging to the men half a plough, now none. Wood(land) for 12 swine. Then as now worth $4^{s .}$

All these men rendered T.R.E. 20s. to the farm (of the manor) and afterwards in Roger Bigot's time Aluric the reeve increased (crescebat) (the sum) to IOOs. and in the time of $\mathrm{H}[\mathrm{ugh}] \mathrm{de}$ Hosdena to $50 l i$, as the men say.

\section{LANDS OF EARL RALPH WHICH GODRIC THE STEWARD KEEPS IN SUFFOLK IN THE KING'S HAND}

\section{Hundret of Thewardestreu [Thedwastre]}

In Totestoc [Tostock] the King has 36 freemen, under commendation to Edith the Rich T.R.E., belonging to Nortuna [Norton]. Among the men I carucate of land. And then as now 5 ploughs. And 2 acres of meadow. Then as now worth 13 s. and $4 d$.

In Torstuna [Thurston] (are) $\mathbf{I}_{4}$ freemen. Out of them Saint Edmund had commendation with all customs over 4 full men (integros) and 4 half men belonging to Nortuna [Norton]. But Earl Ralph held them when he made forfeiture. Among them all half a carucate of land and under them 3 bordars. I acre of meadow. Then as now 2 ploughs. Then as now worth 6 s. and $8 d$.

fol. 285 .

\section{Hundret of Tingohou [Thingoe]}

In SAXAM [Saxham ${ }^{11}$ ] (were) 6 freemen under Edith the Rich by commendation T.R.E., and the soke was in Nortuna [Norton]. I carucate of land, and 2 bordars, and 2 ploughs. Wood(land) for 2 swine. Then as now worth Ios.

\section{HUNDRET OF STOU [STOW]}

In Fineburga [Finborough] 2 freemen under commendation to Edith held 25 acres. They are within the soke of the Hundred, and belong to Nortune [Norton]. Then as now half a plough. And the value is included in that of Nortune [Norton].

\section{"In Old Newton.}




\section{A HISTORY OF SUFFOLK}

In Mentessam [Mendlesham] a freeman with 3 acres belonging to Tornei [Thorney]. And (this) is worth $6 d$. The soke and sac are in the Hundred.

\section{Bosemera [Bosmere] Hundret}

In Staham [Stonham] (are) 5 sokemen with 18 acres-and the soke (is) in the hundred of Bosemera [Bosmere] belonging to Melnesham [Mendlesham]. Then as now I plough. Half an acre of meadow. It is worth $4 s$. To the same have been added 3 freemen (with) 12 acres who now belong to Melnesham [Mendlesham], I plough. Half an acre of meadow. It is worth $3^{\text {s. }}$

In Blacham [Blakenham] (were) 5 freemen in the soke and commendation of Edith the Fair (faire) with 60 acres. And they have been added (to the manor) in Norturna [Norton]. Then as now 2 ploughs. And 2 acres of meadow less 1 rood (virga). Then it was worth I2s. and $4 d$., now 16 s. and $4 d$.

In LANGHEDENa [

] (were)

3 freemen with 72 acres and $1 \frac{1}{2}$ ploughs and 3 acres of meadow. It was worth $12 s$, and $4 d$.

In Offetuna [Offton] (were) 2 freemen and 50 acres. Then as now I plough. And then it was worth 20 s., now IIs. and $4 d$. In the church, however, (there are) 16 acres.

In Badelea [Badley] (is) a freeman with 30 acres. Then as now 1 plough. And $2 \frac{1}{2}$ acres of meadow. Worth 7 s. and $8 d$. And I sokeman with 20 acres. Worth 4 s.

In DeRmodesduna [Darmsden] (is) a freeman with 60 acres as a manor. Then 1 plough. $3 \frac{1}{2}$ acres of meadow. Then 1 mill, and now. Then it was worth 16 s., now 9s. and $4 d$.

In SCarverstuna [? Sharpstone ${ }^{12}$ ] (is) a freeman with 2 acres. Worth $2 d$.

In Essa [Ashbocking] Alma, a freeman (held) 93 acres and 20 acres of pasture as a manor. Then 3 bordars, now 6 . Then as now 1 plough. 3 acres of meadow. And half a church with 16 acres. Then it was worth 305 ., now 20s. and $6 d$. A church with 3 acres, worth $6 d$. Over all these Edith the Fair had soke and commendation T.R.E. And they render $4 l i$. to the farm of Nortuna [Norton], and they were added in the time of Earl Ralph.

\section{Claindune [Claydon] Hundret}

In Codenham [Coddenham] Almar a freeman held 8 acres. Worth $16 d$. The soke is the King's and the Earl's.

$$
\text { 12 In Barham; see below, n. } 140 .
$$

\section{Perreham [Parham] Half Hundret}

(At) Perreham [Parham] Thurmot held 2 carucates of land as a manor. Then as now 4 bordars. Then 2 serfs, afterwards and now $x$. Then as now 2 ploughs on the demesne. And 1 plough belonging to the men. 8 acres of meadow. Then wood(land) for 20 swine, now for 10. And then 50 swine, now 30 . Then as now 5 beasts. Then 24 sheep, now 38 . Then 50 goats, now 58. Then it was worth Ioos., afterwards 7 li., now 10 (li.) blanch money fol. $285 b$.

and 20s. by tale as a fine (de gersumma).

In the same (vill) 6 freemen (held) 24 acres. Then as now half a plough. They are included in the above valuation. Over the manor Thurmot had soke and over 3 freemen, and the Abbot of Ely, over 3. It is II furlongs long and 6 broad. And (pays) 40d. in geld.

\section{Hertasmera [Hartismere] Hundret}

(At) Melnessam [Mendlesham] Burchart held 7 carucates and 42 acres of land as a manor. Then 33 villeins afterwards 27 , now 24 . Then as now 19 bordars. Then 3 ploughs on the demesne, afterwards and now 2. Then $15 \frac{1}{2}$ ploughs belonging to the men, afterwards and now 13. And 12 acres of meadow. Wood(land) for 1,000 swine, afterwards and now 800 . And 2 rounceys, II beasts, 90 swine, and 35 goats. And there was a berewick of 26 acres and I bordar and I plough. A church with 40 acres and I plough. Then worth 25li, when Godric took it over 20li., now it renders 25 li. blanch by tale (and) 40 s. as a fine (de gersumma). It is 1 league and 6 furlongs long, and I league broad. And (pays) $8 d$. in geld. Burchard (had) the soke.

In Cottuna [Cotton] i 8 freemen-over one, Alwin by name, with 10 acres the Abbot had half commendation;-(they were) added to this manor, (with) I carucate and 15 acres of land. Then as now 3 ploughs. And $\mathrm{I}$ acre of meadow. They were then worth ros., now $6 s$. and $8 d$., and they are included in the above valuation. The King and the Earl have the soke. It is 6 furlongs and 8 perches long, and 6 (furlongs) broad. And (pays) $12 d$. in geld.

And the Hundred bears witness that in truth the King and the Earl had soke and sac T.R.E.; but the men of that vill bear witness that Burchard had soke in like manner over the freemen as over his own villeins; and they have not any testimony except themselves; and yet they are willing to prove it by any means (volunt probare omni modo).

In Wiccham [Wickham (Skeith)] 8 bordars (have) 18 acres of the Melnessam [Mendlesham] demesne and 1 plough. And 2 half freemen 


\section{THE HOLDERS OF LANDS}

and 2 whole (freemen) (have) 8 acres. And this is included in the valuation of Melnessam [Mendlesham].

In the same (vill) 6 freemen (have) $37 \frac{1}{2}$ acres. Then as now $1 \frac{1}{2}$ ploughs. They were then worth 20s, now 12. And they are included in the above valuation. The King and the Earl have the soke.

In Cottuna [Cotton] a half freeman (has) 10 acres and half a plough. Wood(land) for 2 swine. And he is worth 20d., and is included in the valuation of Meldesham [Mendlesham].

In Weringheseta [Wetheringsett] 2 half freemen (held) 12 acres and half a plough, and are worth $2 s$. (included) in the same valuation.

In the same (vill) 4 freemen (held) 33 acres and I plough and 5 bordars, and render $40 \mathrm{~d}$. (included) in the same valuation.

In TORnhaM [Thornham] a freeman (holds) 2 acres, worth $4 d$.

In Acolt [Occold] a freeman (holds) 33 acres as a manor, and I plough and 2 bordars; and a freeman (holds) I acre. Wood(land) for 4 swine. Then worth IOS., now 15s.; and he renders 5 s., (included) in the above valuation.

In Wiuerthestuna [Wyverstone] a freeman under Burchard's commendation (held) 8 acres, worth $16 d$.

In Cottuna [Cotton] 2 freewomen under the same (Burchard's) commendation (held) 5 acres, worth $12 d$.

In the same (vill) a bordar under the same (Burchard's) commendation (held) $\mathrm{I} \frac{1}{2}$ acres, worth $3^{d}$.

In WIснам [Wickham (Skeith)], a berewick which belongs to the demesne of Mundlesham [Mendlesham], (are) 6I acres, and 1 acre of meadow.

In Stoches [Stoke (Ash)] 4 freemen under Burchard's commendation (held) 8 acres, (and) half an acre of meadow. Worth $2 s, 4 d$.

In Gislingham [Gislingham] a freeman (holds) an acre, worth $2 d$.

All this is included in the valuation of Munlesham [Mendlesham].

\section{Brackbruna [Blackbourn] Hundret}

At Nocturna [Norton] Edith a certain freewoman held T.R.E. as a manor 4 carucates of land. Then as now 9 villeins, and $2 \mathrm{I}$ bordars and serfs. And 2 ploughs on the demesne. And 5 ploughs belonging to the men. Wood(land) for 150 swine. 8 acres of meadow. Then as now 2 rounceys, 1o beasts, 50 swine, 100 sheep, and
30 goats. And 34 sokemen (held) 2 carucates of land. Then as now 10 ploughs. And 2 acres of meadow. Then worth roli., afterwards I5(li.) and ros., now I6li. blanch. A church with 30 acres. It is I league long and 8 furlongs broad. And (pays) $17 \frac{1}{4} d$. in geld.

This manor belonged to the demesne of the Abbot of Saint Edmund ; and Edith held it by an arrangement (accommodationem) with the Abbot, the agreement being such that after her death the Abbot was to have it back, and so (? she) held the manor on the day on which King Edward died.

(At) Hunterstuna [Hunston], 7 freemen-of these Edith had commendation T.R.E. (They held) half a carucate of land. Then as now I plough. Worth 6 s.

\section{Risebruge [Risbridge] Hundret}

In TRITLAwa [Thurlow ${ }^{13}$ ] the same (Edith) held T.R.E. 7 carucates of land. Then as now I6 villeins. Then 6 bordars, now 9. And 2 serfs. Then as now 3 ploughs on the demesne, and 7 ploughs belonging to the men. 18 acres of meadow. Wood(land) for 80 swine. Then as now 10 beasts, 36 swine, 46 sheep and 33 goats. A church with 32 acres of free land and half a plough. And 5 freemen (held) I carucate of land. And 2 bordars. And 3 ploughs. And 3 acres of meadow. Then the manor was worth gli., now I6li. And the freemen 20s. and 20s. as a fine (de gersuma) by tale. It is I league long, and 7 furlongs and Io perches broad. And (pays) $6 d$. in geld.

In Cileburna [Chilbourne ${ }^{14}$ ] a sokeman (held) 30 acres. And I bordar. And I plough. And 6 acres of meadow. Then worth 10s., now 20 s.

\section{BISSOPES [BISHOP'S] HUNDRET}

In WEIBRADA [Weybread] (are) $1 \frac{1}{2}$ bordars with $7 \frac{1}{2}$ acres of land and half an acre of meadow. Wood(land) for 6 swine. And half a plough. And this is included in the valuation of Radenhala [Redenhall $\left.{ }^{15}\right]$. The soke is in Hoxa [Hoxne].

\section{Losa [LoEs] Hundret}

In Marlesforda [Marlesford] 6 freemen under commendation to Turmod of Perham [Parham] (held) 25 acres of land. Then as now half a plough.

\section{fol. 2866 .}

And in Hecestuna [Hacheston] 3 freemen under the said Turmod's commendation (held)

$$
\begin{aligned}
& \text { 1s Formerly 'Thrillowe'; Feud. Aids, v, } 45 . \\
& \begin{array}{l}
\text { is In Barnardiston. } \\
\text { in Norfolk. }
\end{array}
\end{aligned}
$$




\section{A HISTORY OF SUFFOLK}

I $9 \frac{1}{2}$ acres and half a plough and $1 \frac{1}{2}$ acres of meadow; and they are included in the valuation of Perham [Parham]; and in Merlesforda [Marlesford] (there are) 35 acres on the demesne. A church with 16 acres, worth 2 ores. It is I league long, and 4 furlongs broad. And in geld (pays) $15 d$.

In Codetuna [Cotton] 3 freemen under Burchard's commendation T.R.E. (held) 8 acres. Then as now half a plough. Wood(land) for 2 swine. Half an acre of meadow. And they are worth 2s. The King and the Earl have the soke. A church (with) II acres, worth 2 s.

\section{LAND OF THE KING WHICH PETER DE VALOIGNES HAS IN CHARGE}

\section{Sanfort [Samford] Hundret and a Half}

(At) Herchesteda [Harkstead] Harold held T.R.E. 5 carucates of land, as a berewick of Brictesceseia [Brightlingsea], in the county of Essex. Then 21 villeins, afterwards and now 8. Then as now $\mathrm{I}_{3}$ bordars. Then 4 serfs, then as now 2 ploughs on the demesne. Then 8 ploughs of the men, afterwards 2, now I ; and 4 acres of meadow. A church. Then as now I rouncey, 3 beasts, 7 swine, and 12 sheep. Then and afterwards it was worth 6 li. by tale, now $6 \mathrm{li}$. by weight and $30 \mathrm{~s}$. by tale. It is $12 \frac{1}{2}$ furlongs in length and 12 in breadth, and (pays) $30 d$. in geld.

LAND OF THE MOTHER OF EARL MORCHAR WHICH WILLIAM THE CHAMBERLAIN AND OTHO THE GOLDSMITH KEEP IN THE KING'S HAND

\section{Tingohu [Thingoe] Hundret}

(At) Sutberie [Sudbury] Earl Morchar's mother held T.R.E., now King William holds in demesne, 3 carucates of land. Then I villein, now 2. And 63 burgesses attached to the hall (balle manentes). Then 6 serfs, now 2. Then as now 3 ploughs on the demesne, and 55 burgesses on the demesne, and 2 carucates of land. Among them all (were) 4 ploughs. (There is) a Church of St. Gregory with (de) 50 acres of free land, as the Hundred witnesses. And 25 acres of meadow. And I mill. And 2 horses on the demesne of the hall. And 17 beasts, 24 swine, and 100 sheep. And 9 acres of meadow belonging to the burgesses. And I market. And therein are moneyers. Then worth I8li, afterwards and now 28 (li.) by tale. It is 4 furlongs long, and 3 broad. And pays 5s. in geld. The soke is in the same vill.

\section{Babenberga [Babergh] Two Hundrets}

Cornierda [Cornard] the mother of Earl Morchar held T.R.E. as a manor, 3 carucates of land. Then 8 villeins, now ro. Then 9 bordars, now 25. Then 8 serfs, now 9. Then and afterwards 3 ploughs on the demesne, now I. Then 8 ploughs belonging to the men, afterwards and now ro. One mill and 14 acres of meadow. Wood(land) for 10 swine. A church without land. Then as now 4 horses at the hall, and 18 beasts, and 80 swine. Then as now 363 sheep.

fol. 287 .

In Grotena [Groton] 4 sokemen belonging to this manor (of Cornard held) 100 acres of land and 3 bordars. Among them all (was) I plough. The whole then was worth roli., afterwards and now $26 \mathrm{~s}$. and $8 d$. by tale. It is 6 furlongs and 3 perches long, and $4 \frac{1}{2}$ furlongs and 4 perches broad. And (pays) $10 \frac{1}{2} d$. in geld. The soke (is) in the same vill.

\section{LAND OF THE KING WHICH ALURIC WANZ HATH IN CHARGE}

\section{Sanfort [SAmford] Hundret and a Halt}

(At) Bercolt [Bergholt] Harold held T.R.E. I 3 carucates of land as a manor. Then 42 villeins, now 43. Then 5 bordars, now 22. Then 6 serfs, now 4. Then and afterwards 3 ploughs on the demesne, now 2. Then 20 ploughs of the men, afterwards and now 10. 12 acres of meadow. Wood(land) for 1,000 swine. Then as now I mill. Then as now I horse, 10 beasts, 29 swine, 85 sheep, and 26 goats. To this manor belongs I berewick, ScEueleia [Shelley] (having) 2 carucates of land T.R.E. Then ro villeins, afterwards and now 6 . Then 7 bordars. Then 4 serfs, now 2. Then 2 ploughs on the demesne, afterwards and now I. Then 8 ploughs of the men, afterwards and now 4; 16 acres of meadow, and I mill, then as now I rouncey, 4 beasts, 7 swine, and 23 sheep.

Benteleia [Bentley] Earl Guert held T.R.E. Afterwards Earl Ralph the Staller (Stalra) joined it to this manor in King William's time as a berewick with 2 carucates of land. Then 19 villeins, now 13. Then as now 3 bordars. Then 4 serfs. Then 2 ploughs on the demesne, afterwards and now I. Then 8 ploughs of the men, afterwards and now I; and 8 (more) ploughs might be furnished (restaurari), taking demesne and villeins together. 8 acres of meadow. Wood(land) for 12 swine. And 8 beasts, 7 swine, 42 sheep, and half a park (dimidius parcus). It is worth $6 d$. 


\section{THE HOLDERS OF LANDS}

(At) Scotreleia [Shotley] Earl Guert held $2 \frac{1}{2}$ carucates of land, and I acre, worth $2 d$. as a manor T.R.E. Then 12 villeins, now 6 ; and then as now 2 bordars; and then 4 serfs, now $\mathrm{x}$. Then 2 ploughs on the demesne, afterwards and now 1 . Then 4 ploughs of the men, afterwards and now $\mathrm{I}$; and 4 ploughs (more) might be furnished, and 4 acres of meadow, and 1 rouncey and 40 sheep.

To this manor belonged T.R.E. 210 sokemen. Now there are but II9, and they have $22 \frac{1}{2}$ carucates of land less 30 acres, and 42 bordars. Then 29 ploughs, now 27. And 24t acres of meadow. Two churches with 62 acres. Of the men who have remained upon this manor, Harold had not even commendation T.R.E. except of four-Ulnod, Estmunt, Aluric, Wistric -and Guert, Harold's brother, had commendation of two-Man and Alviet. All the others were in commendation to other barons T.R.E.

\section{fol. $287 b$.}

Of I Malet's predecessor had commendation, and Robert, son of Wimarc, of 4. But Harold always had soke over the aforesaid manor of Bercolt [Bergholt], to wit, with that which belonged to it, and with soke of the Hundred and a half (of Samford). It rendered T.R.E. 24li. And Guert's 2 manors aforesaid, which were added to this farm, then rendered gli. And when Robert Malet had it the whole together rendered 60 li. by weight, and 8 li. by tale as a fine (de gersumma) and the same amount the manor rendered to Roger Bigot as the reeve himself says. But Roger says that it rendered 40s. more by tale and one mark of gold. But Aluric the reeve contradicts (him) and Roger is willing to prove (his saying) by those men who were present at his agreements. The said Aluric now renders 60 li. by weight, and he so holds of the King by such agreement that he is bound to make the King (payment of) $60 l i$. out of the profit, and of this he vouches the King to warrant. So he says himself; and he says too that this does not hold good (non remanet) in that he does not make that profit.

Bercolt [Bergholt] in all is 1 league and 2 furlongs in length and $x$ league in breadth, and (pays) $8 d$. in geld. And Sceurleia [Shelley] 8 furlongs in length and 3 in breadth, and (pays) $t d$ in geld. And Benetrizia [Bentley] I league in length and 3 furlongs in breadth, and (pays) $5 d$. in geld. And Scotruera [Shotley] $12 \frac{1}{2}$ furlongs in length and 12 in breadth, and (pays) $30 d$. in geld.

Aubrey de Vere holds I sokeman of Bergholt, having 4 acres, and worth $12 d$; and he holds him as of ALDEHAM [Aldham].

Those freemen who T.R.E. belonged to the soke of Bercolt [Bergholt] each gave freely (gratis) to the reeve annually a gratuity of $4 d$. only, and rendered soke as the law required (fere$b a t)$, and when Roger Bigot first had the shrievalty his ministers ordered that they should render 15li. annually, which they did not do T.R.E. And when Robert Malet had the shrievalty his ministers increased them to 2oli. And when Roger Bigot had them again in like manner they gave 2oli., and now Aluric Wanz holds them by the like custom as T.R.E.

Canappetuna [

] is 5 furlongs in length and 2 in breadth and pays $6 \frac{1}{2} d$. in geld. And Cetessam [Chattisham] is $8 \frac{1}{2}$ furiongs in length and 6 in breadth, and (pays) $6 \frac{1}{2} d$. in geld.

\section{fol. 288.}

\section{LANDS OF STIGAND WHICH WIL- LIAM DE NOERS KEEPS IN THE KING'S HAND}

\section{BLIDINGa [Blything] HundRET}

In Bramtuna [Brampton] a freeman Thurs$\tan$ held T.R.E. 20 acres under commendation to Stigand. Then as now 2 bordars. Then I plough, now half a plough. And half an acre of meadow. Wood(land) for 3 swine and I rouncey, 2 swine, and 12 sheep. Then as now it was worth 4s. (There was) besides I freeman under him with 2 acres of land, worth $6 d$.

In Northals [North Hales] ${ }^{16}$ (were) 2 freemen under Stigand with 32 acres. Then as now I plough. It was worth 4 s.

This all belongs to Bongeia [Bungay]. The soke (belonged) to Stigand.

\section{(Half) Hundret of Cosforda [Cosford]}

In LafHaM [Layham] a sokeman (held) 4 acres. Worth I $2 d$.

\section{W ANNEForda [W ANGFord] Hundret}

At Bongria [Bungay] Stigand held T.R.E. 9 carucates of land as a manor. Then as now 20 villeins, and 16 bordars. Then 6 serfs, now 3. Then on the demesne 3 ploughs, now 2. Then as now belonging to the men $12 \frac{1}{2}$ ploughs.

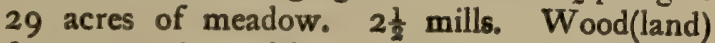
for 100 swine. Then as now 2 rounceys, 4 beasts, 3 swine, 9 sheep, and 60 goats. I church with 5 acres. Then worth IOOS., now it renders 12li.

In the same (vill) a freeman Ulmar under Stigand's commendation (held) I carucate of land as a manor. Then as now 3 villeins. And 6 bordars. Then as now on the demesne

${ }^{18}$ Covehithe. 


\section{A HISTORY OF SUFFOLK}

I plough. And belonging to the men I plough. Wood(land) for 20 swine. 2 acres of meadow. And 4 rounceys, 3 beasts, 6 swine, 20 sheep, and I 6 goats. And under him a freeman (held) I acre. Then as now worth 20s., but it renders I3s. as farm (ad firmam).

Moreover in the same (vill) a freeman Alwin under the same (Stigand's) commendation (held) I carucate of land as a manor T.R.E. ; 6 villeins, and 8 bordars. And I plough on the demesne. And 2 ploughs belonging to the men. Wood(land) for ro swine. 4 acres of meadow. 4 rounceys, I 5 swine, and 13 sheep. Then worth 20s. And 6 freemen (held) 14 acres and I plough. Then worth $4 s$. And since (postquam) King William came into this country 2 brothers have shared (babent partiti) (this land). One of them Ulsi is in hand under the King; Uluric is in the hands of Earl Hugh; and this Ulsi has 60 acres and 2 villeins and 4 bordars. And $4 \frac{1}{2}$ freemen (have) IO acres, I plough in demesne, and to the men belongs I plough. And (there are) 2 acres of meadow. And wood(land) for 6 swine. Now this, the King's part, is worth 18 s. and $8 d$., but it renders $14 s$. and $4 d$.

In Burghea [Bungay] Godric a freeman (held) 30 acres as a manor; and I bordar and I plough and 2 acres of meadow. Then worth 8 s., now IOS.; and it renders 8s. worth of farm.

\section{fol. $288 b$.}

In the same (vill) Pat a freeman held T.R.E. 60 acres as a manor. Now 2 freemen Houart and Ulsi hold it. Then as now 8 villeins. Then 8 bordars, now 4. Then 4 serfs, now 2 . Then as now 2 ploughs on the demesne. And 2 ploughs belonging to the men. Wood(land) for 12 swine. And 2 acres of meadow. Then as now 4 rounceys. Then 6 beasts, now 8 . And 12 swine. Then 30 sheep, now 100. Then worth 205. , now 305. ; and they render of farm I6s. A church with 12 acres, worth 2 s. To this manor belong 2 half freemen and one whole freeman with 16 acres. Then as now I plough. Worth 3 s.

In the same (vill) Alfger a freeman (held) 30 acres as a manor T.R.E., now Edric holds (it). Then as now 2 villeins, and 2 bordars, and 2 serfs. And I plough on the demesne. And I plough belonging to the men. And wood(land) for 16 swine. And 2 acres of meadow. Worth 8 s. and renders as much of farm.

Furthermore in the same (vill) 2 freemen held 7 acres worth $12 d$. A church with 8 acres worth I2d. In the same (vill) I5 freemen under Stigand's commendation (held) 80 acres, and 3 bordars. Then and now 4 ploughs. 3 acres of meadow. Then worth 13 s., now they render 20s. A church with 30 acres, worth $3^{\text {s. }}$ It is 2 leagues long, and I (league) and 8 furlongs broad. And (pays) 5s, in geld.
In Scadenafella [Shadingfield] a freeman under the same (Stigand's) commendation (held) 30 acres as a manor and 4 bordars, Then as now I plough. And the bordars (have) half a plough. Wood(land) for 6 swine. I acre of meadow. Then worth IOs., the like now.

In Westuna [Weston] $2 \frac{1}{2}$ freemen under Stigand's commendation (held) 12 acres and I plough. Worth 2s. A church with 20 acres worth $3^{\text {s. }}$

\section{Bissopes [Bishop's] Hundret}

In Deнam [ Denham] a freeman under commendation (held) 30 acres, and I bordar. Then as now I plough. And half an acre of meadow. Wood(land) for 3 swine. Worth 6 s. The soke is in Hoxa [Hoxne].

\section{LACFORdE [LACKFord] HUNDRET}

King Edward gave Mitdenehalla [Mildenhall] to Saint Edmund, and afterwards Stigand held under Saint Edmund in the lifetime of King Edward 12 carucates of land as a manor. Then and afterwards 30 villeins, now 33. Then 8 bordars, afterwards and now 15 . Then as now I 6 serfs. Then as now 6 ploughs on the demesne. And 8 ploughs belonging to the men. And 20 acres of meadow. A church with 40 acres. And I mill. And $3 \frac{1}{2}$ fisheries. 3 I forest mares (eque silvatice), 37 beasts, and 60 swine, and 1,000 sheep. And 8 sokemen with 30 acres. Then as now half a plough. To this (manor) belongs one berewick EccLINGAHAM [Icklingham] with 6 carucates of land. Then 6 villeins, now 4 . Then 7 bordars, now 5. Then as now 8 serfs. And then as now 3 ploughs on the demesne. Then 4 ploughs belonging to the men, afterfol. 289 .

wards and now 2. And I mill. A church with 24 acres. 2 rounceys, 3 beasts, 4 swine, 500 sheep. And therein was I sokeman with 30 acres. Then as now I plough. Then and afterwards the whole was worth $40 l i$, now $70 l i$. by tale. This vill is I league long, and I league broad. And (pays) I I $\frac{1}{4} d$. in geld. And several persons hold (land) therein. And the aforesaid berewick is $2 \frac{1}{2}$ leagues long, and as much broad. And in geld (pays) $11 \frac{1}{4} d$.

\section{Half Hundret of Gipeswid [Ipswich]}

In the borough of GIPEUUID [Ipswich] Stigand had 2 burgesses T.R.E. with soke and sac. And the King used to have the customs. Now they are dead. And the King has the customs and soke and sac.

\section{Claindune [Claydon] Hundret}

In ACReHam [Akenham] I sokeman under Stigand (held) 30 acres Then I plough, now 


\section{THE HOLDERS OF LANDS}

half a plough. And I bordar. And I acre of meadow. Worth 5 s.

\section{SAmfort [SAmford] Hundret}

Hintresham [Hintlesham] Stigand held T.R.E. as a manor, and for 10 carucates and 40 acres of land. Then as now 25 villeins and 17 bordars and 2 ploughs on the demesne. Then I 6 ploughs belonging to the men, afterwards and now 12. 10 acres of meadow. Wood(land) for 30 swine. Then as now $I$ mill and $1 \frac{1}{2}$ churches with 35 acres of free land. Then 2 rounceys, now 1,8 beasts, 30 swine, 200 sheep. Then worth roli., now 22(li.) by weight. It is I league and 2 furlongs in length, and I league in breadth, and (pays) $13 \frac{1}{2} d$. in geld.

In the same (vill are) 8 sokemen, with I carucate and 70 acres of land. Then as now I villein, and 3 bordars and 4 ploughs. 3 acres of meadow and I salt-pan. The whole is included in the above price. Stigand had soke and sac.

Stigand held Branfort [Bramford] T.R.E. as a manor and as 10 carucates of land. Then as now 28 villeins and 7 bordars. Then 4 serfs, now 2. Then as now 3 ploughs in demesne. fol. $28 g b$.

Then 13 ploughs belonging to the men. Afterwards and now 10. 22 acres of meadow. I mill. A church (having) 30 acres of free land. 6 rounceys, 24 beasts, 20 swine, 90 sheep. Then worth roli., now $22 k$. by weight. It is I league in length and 10 furlongs in breadth, and (pays) $13 \frac{1}{2} d$. in geld.

In the same (vill) 3 sokemen (hold) $9 \frac{1}{2}$ acres. Then I plough, now 2 oxen. This is included in the same valuation. Stigand (had) soke and sac.

In the same (vill) Brun a freeman (held) by commendation 30 acres for a manor, now 2 villeins and 2 bordars. Then I plough, now half a plough. And it is worth 5s. included in the same valuation. Harold had soke in Bergholt, and this was added in the time of Bishop Arfast.

\section{LANDS OF THE KING BELONGING TO THE KINGDOM OF WHICH PICOT HAS CHARGE}

\section{Tinchou [Thingor] Hundret}

King Edward held BARo [Barrow] as a manor and as 7 carucates of land. Then 6 villeins, now 15. Then 4 bordars, now 10. Then 2 serfs, now I. Then 2 ploughs on the demesne, now 3. Then 5 ploughs belonging to the men, now 14. Wood(land) for 8 swine. 3 acres of meadow, I mill. A church with 17 acres of free land. Then 16 swine, now 40. Now roo sheep, and 60 goats. And I sokeman with 30 acres. Then as now I plough. The whole was then worth Ioli., now 20 (li.) by weight. It is $\mathbf{I}$ league long, and 8 furlongs broad. And pays $7 d$. geld.

\section{Risebrugr [RISBRIDGe] HUNDRET}

Algar held Bademondesfelda [Badmondisfield in Wickhambrook] T.R.E. as a manor and as Io carucates of land. Then and afterwards I 8 villeins, now 14 . Then as now 14 bordars, and 4 serfs. And 5 ploughs on the demesne. And 10 ploughs belonging to the men. 7 acres of meadow. Wood(land) for 60 swine. 2 rounceys, 7 beasts, 88 swine, 24 sheep, and 25 goats. A church with $10 \frac{1}{2}$ acres of free land. And there were 12 freemen with $2 \frac{1}{2}$ carucates of land. Algar (had) the soke and commendation; and they did not render payment (censum) T.R.E. Then and afterwards $3 \frac{1}{2}$ ploughs, now $2 \frac{1}{2}$ ploughs. Nine acres of meadow. The manor was then worth 7 li, now ioli. And the freemen render 40s. It is 12 furlongs long, and 8 broad. And pays $13 \frac{1}{2} d$. in geld.

\section{fol. 290 .}

\section{OF THIS ROGER BIGOT HAS CHARGE IN THE KING'S HAND}

From the half hundred and from the borough of Gepeswiz [Ipswich] T.R.E. Queen Edith had two-thirds and Earl Gurth one-third. The Queen also had in her demesne a grange to which T.R.E. belonged 4 carucates of land, and the like now. Of this land 12 freemen dwelling upon other land of their own now as then hold 80 acres (bound) to (do) service and (render) custom to the King. And there are Io other men, bordars, who have not land of their own, but dwell upon 86 acres of the aforesaid land. Furthermore to the demesne of the aforesaid grange belong 2 burgesses who render to the King $6 d$. by way of custom. And (there were) then 2 ploughs on the demesne, and the like afterwards, now I. Then 3 beasts, now 8 . Then 2 rounceys, now 1 . Then 14 goats, now 7. Then 40 sheep, now 13. And the villeins now as then have 6 ploughs. This land is 8 furlongs in length, and the like in breadth. And it renders nothing to the King's geld.

In the borough there were T.R.E. 538 burgesses rendering custom to the King, and they had 40 acres of land. But now there are I IO burgesses who render-custom, and IOO poor burgesses who cannot render to the King's geld but one penny a head (de suis capitibus). And among the whole of them in like manner they have 40 acres of land. And 328 burgages (mansiones) within the borough lie waste, which 


\section{A HISTORY OF SUFFOLK}

T.R.E. used to pay scot towards the King's geld.

In the same borough Alnulf the priest has a church, Holy Trinity, to which belong 26 acres

fol. 2906 .

in alms. And one Culling a burgess has a church, St. Mary's, with 26 acres. Tumbi a church, St. Mary's, with 2 acres. Lestan the priest a church, St. Augustine's, with II acres. Ulwin the priest a church, St. Michael's, with 8 acres. In Turuestuna [Thurlston] in Claindune [Claydon] Hundred, Godric (has) a church, St. Botulf's, with I acre. Turchil and Edric have held (tenent) a church, St. Lawrence's, with I 2 acres, half a year last St. John's Day (ad festum Sci. Fobis. fuit dimidius annus). One Lefflett a freewoman held this church T.R.E., which Count Alan claims as having belonged to the fee of Earl Ralph, and vouches Ivo Taillebois as having made the livery. But Turchil and Edric vouch to warrant Roger the Sheriff saying that through him they had this church, and Roger stands to them as such warrant as any sheriff could rightfully be T.R.E. Ascer I church, St. Peter's, with I acre. Godric a church, St. Stephen's, with I acre.

All this rendered T.R.E. I 5 li. and 6 sextars of honey, and $4 s$. towards the custom of honey, and 8s. to the prebendaries. And Roger the Sheriff gave the whole to farm for 40 li. (payable) at the feast of St. Michael. Afterwards he could not have (this) rent, and of it he excused (condonavit) $60 s$. It now renders $37 \mathrm{li}$. And the moneyers used to render annually T.R.E. 4 li. for the mint. Now they ought to render 20li. But for four years they have rendered only $27 l i$. And the Earl now as then has the third part.

fol. 291.

\section{LANDS OF ROBERT COUNT OF MORTAIN IN SUFFOLK}

\section{Thewardestreu [Thedwastre] Hundret}

In Rengestuna ${ }^{16}$ [Drinkstone] a freeman under Saint Etheldreda by commendation, in Saint Edmund's soke (held) I carucate of land. And 8 bordars. Then 2 serfs, now I. Then as now $\mathrm{I} \frac{1}{2}$ ploughs. And 4 acres of meadow. Worth I6s.

In RACHESTDENA ${ }^{17}$ [Rattlesden] a freeman under commendation to and in the soke of Saint Etheldreda (held) I carucate of land. And I bordar. And then as now I plough. Worth ros.

In Bradefrlla [Bradfield] a freeman under commendation to Bishop Aylmer, in Saint Ed-

$$
\begin{aligned}
& 16 \text { 'Drincestona' ; Inq. El. } 142 . \\
& 17 \text { 'Ratesdena'; ibid. }
\end{aligned}
$$

mund's soke (held) 20 acres of land. Then half a plough, now I ox. Worth 2 s.

In Telueteham [Welnetham] a freeman under commendation to Bishop Aylmer in Saint Edmund's soke (held) 40 acres of land. Then I plough, now 2 oxen. Then worth ros., now 20 .

In Stanfella [Stanningfield] a freeman under commendation to Bishop Aylmer in Saint Edmund's soke (held) 60 acres of land. Then I plough, now half a plough. Then worth IOS., now 30s.; but it scarcely returns (so much). All this was delivered to Count Brien, predecessor of Count Robert as 2 carucates and 40 acres of land.

\section{STOU [STOW] HUNDRET}

Cambas [Combs] Ulnoth, a freeman, held under King Edward as 2 carucates of land. Then and afterwards as now 12 villeins 8 bordars. Then and afterwards 6 serfs, now 2 . Then as now 3 ploughs on the demesne. Then 5 , afterwards 3 ploughs belonging to the men, now I. Then and now 2 mills. Wood(land) for 16 swine. And 12 acres of meadow. Then as now 2 horses. Then as now 24 beasts and 16 swine. Then as now 121 sheep and 60 goats. Therein are 50 freemen of the same Ulnoth, and they have I mill, afterwards under Brien predecessor of Count Robert as to commendation only, (and) in the King's soke. And under them are 7 bordars, and they have among them all 8 carucates of land. Then I6 ploughs, and afterwards and now 8. But T.R.E. there were 62 freemen. Then and afterwards the manor of Cambas [Combs] was worth roli.; now it renders I6li., but can scarce yield that rent. And these 50 freemen were worth then and afterwards I 6 li., now 31 li. But they cannot endure it (sufferre) without ruin (confusione). After Count Brien the predecessor of Robert acquired this manor, it rendered no customary dues in the Hundred. Cambas [Combs] is 2 leagues long and I broad. And (pays) $37 \frac{1}{2} d$. in geld. Hugh de Montfort holds half a mill. And it belonged to a freeman (holding) of this manor in Brien's time. And he (Hugh) claims (it by) livery (liberatorem) as to the fee of his predecessor. But by the witness of the Hundred it never (so) belonged.

Anumus [Onehouse] Withmer held it under King Edward as I carucate of land. Then 3 bordars, afterwards and now 6 . Then and afterwards 2 serfs, now none. Then as now I plough on the demesne. And 4 acres of meadow. And 2 sokemen with 3 acres of land. But they could sell (their land) without licence. In the same (vill) a freeman held 9 acres, whom Nigel held under Count Robert, but Frodo was seised before him, and claims livery 


\section{THE HOLDERS OF LANDS}

(liberatorem), but the Hundred knows not (the rights of it). The entire holding was then and now worth 20s. And it was in the King's soke. After Brien acquired it, it rendered no customary dues in the Hundred.

\section{fol. $29 \mathrm{r} b$.}

One Nigel, a sergeant of Count Robert, seized (invasit) II acres of land belonging to Stou [Stow] Church and added them to the manor of Cambas [Combs]. But he is dead, and there is none to make answer thereupon. And the Hundred testifies that they were alms lands belonging to the Church. And 12 sokemen in Cambas [Combs] used to be parishioners in Stou [Stow] Church, but now they are in Cambas [Combs] Church. The same Nigel took them from Stow.

In Cratingh [Creeting (St. Peter ?)] Ulnoht a freeman under King Edward, Brien's predecessor, held I carucate of land. Then as now 2 villeins. Then as now I plough on the demesne, and half a plough belonging to the men. And 4 acres of meadow. And 7 beasts and 12 swine. Worth then as now 20s. This land St. Mary of Grestein holds of Count Robert with soke and sac.

\section{Bosemera [Bosmere] Hundret}

At Cratingas [Creeting (St. Olave)] Ulnod a freeman T.R.E. held 2 carucates of land as a manor T.R.E. and the Count gave them to Saint Mary (of Grestein). Then as now 6 villeins and 5 bordars and 4 serfs. And I plough on the demesne. Then 3 ploughs belonging to the men, now $1 \frac{1}{2}$ ploughs. 7 acres of meadow. Wood(land) for 24 swine. And 5 beasts, and 16 swine. Then as now it was worth 60 s. And $12 \frac{1}{2}$ freemen have been added in King William's time with 58 acres. Then 4 ploughs, now $2 \frac{1}{2}$. Worth IIs, and 4d. And (it is) I league long and half (a league) broad. And (pays) rod. in geld. Others have holdings therein. The King and the Earl have the soke. To this manor belongs half a mill which Hardwin the Count's brother took away from it in King William's time.

In Ringhesenla [Ringshall] the Count holds in demesne a manor of 30 acres which Ulmar 2 freeman held. Then 2 bordars. 2 acres of meadow. The 12th part of a church in Botresfort [Battisford]. Then I plough and the like now. Worth ros.

In the same (vill) a freeman Boti (held) 4 acres. Worth rlod. The King and the Earl (have) the soke.

\section{Clatndune [Claydon] Hundret}

In Hzlmingheram [Helmingham] the Count holds in demesne a manor of 30 acres. Anant (holds it). Worth I2s. In the same were 3 freemen, with 3 acres. To the church (belonged) I acre. Included in the above valuation. Anant, a freeman, held this manor. The King and the Earl (have) the soke.

\section{Half Hundret of Cosfort [Cosford]}

Bretham [Brettenham] the Count holds in demesne as a manor and as 4 carucates of land, and Ulnod held it T.R.E. Then as now 4 villeins and 9 bordars. Then 4 serfs, now 2. Then 2 ploughs on the demesne, and 2 ploughs belonging to the men, and 5 acres of meadow. Wood(land) for 4 swine. A church with 24 acres. Then as now I rouncey, and 3 beasts, and now 4 swine. Then it was worth 6os., now roos.

In the same (vill were) 5 freemen with 32 acres whom Brien added (to it). Then as now half a plough and half an acre of meadow. Worth 5 s. and $4 d$. It is 12 furlongs long, and 6 broad. And (pays) rod. in geld.

fol. 292.

Asce [Ash (Street) ${ }^{18}$ ] the Count holds in demesne as a manor and as $\mathrm{I} \frac{1}{2}$ carucates of land, and a freewoman held it T.R.E. And 5 bordars. Then 2 ploughs, and 6 acres of meadow, and I mill. Worth 40s. It is half a league long, and 3 furlongs broad. And (pays) $1 \frac{1}{2} d$. in geld.

In Gowatefreda [Whatfield] a freeman (held) 15 acres, worth 40d. Saint Edmund (has) the soke.

\section{Hundret of Colenesse [Colneis]}

In BUKELESHAM [Bucklesham] 30 freemen under commendation to Harold T.R.E. held 2 carucates of land. Then as now 2 bordars. And then among them 5 ploughs, now 4. 2 acres of meadow. A church with 8 acres and 2 bordars. (There were) moreover 2 freemen under commendation to Saint Etheldreda T.R.E., Edric and Uluric, with 18 acres ${ }^{19}$ and half a plough. Then it was worth 6os., now 4 li. And this Eudo son of Nigel holds of the Earl. It is 8 furlongs long, and 4 broad. And (pays) $12 d$. in geld. Others hold (lands) therein.

In Morestuna [Morston ${ }^{20}$ ] there were 5 freemen, Godwin the man of Aluric the priest, and Wlfere and Brihtric, the men of Roger Bigot's predecessor, and Ulwin the man of Robert Malet's predecessor, and Godric the man of Godeman the predecessor of Roger Bigot, with 50 acres. Then $I \frac{1}{2}$ ploughs. Now $I \frac{1}{2}$ acres of meadow. Then it was worth IOS, now 17 s.

$$
\begin{aligned}
& \text { 15 In Whatield. } 14 \text { " } 14 \text { acres'; Inq. El. I44. } \\
& { }^{20} \text { In Trimley. }
\end{aligned}
$$




\section{A HISTORY OF SUFFOLK}

In TORP [Thorpe ${ }^{200}$ ] a freeman Brumer, Robert Malet's predecessor, had by commendation Io acres. Then as now half a plough. Then it was worth $2 s$, and $8 d$., now $40 d$.

In Alteinestuna [Alteston ${ }^{21}$ ] were a freeman under commendation to Harold T.R.E. and moreover 2 freemen in the same (vill) Leveston and Goodwin under commendation to Norman T.R.E. with 48 acres of land. Then $\mathrm{I} \frac{1}{2}$ ploughs, now 1 . And then it was worth 8 s., now 15 s.

In Grimestuna [Grimston Hall ${ }^{203}$ ] were 2 freemen, Aluric under commendation to Harold and Brithnoth under commendation to Robert Malet's predecessor, with I4 acres of land. Then as now half a plough. Then it was worth $40 d$., now 5s. less $4 d$. Saint Etheldreda (has) the soke. The said Eudo holds all this.

\section{fol. $292 b$.}

\section{LANDS OF COUNT ALAN}

\section{Risebruge [RIsbridge] Hundret}

The thegn Manni the Swarthy (Mannius Suart) held Culinge [Cowlinge] T.R.E. as a manor, and as 9 carucates of land. The Count now holds it in demesne. Then as now 19 villeins and 16 bordars. Then 6 serfs, now 3 . Then $2 \frac{1}{2}$ ploughs on the demesne, now 3 . Then 9 ploughs belonging to the men, afterwards and now 6. 60 acres of meadow. Wood(land) for 60 swine. A church with 50 acres and half a plough. Then as now 7 beasts, and 40 swine, and 40 sheep, and 40 goats. Then worth gli., now 2oli. It is I league long, and 8 furlongs broad. And (pays) $12 \frac{1}{2} d$. in geld.

In the same (vill) a freeman under King Edward (held) I 40 acres and I bordar, and I plough. Worth Ios. All this Earl Ralph held.

In the same Hundred were 9 acres and I villein. Included in the valuation of WESTUNA (a manor) of Grentebruge [Weston in Cambridgeshire].

\section{Brademere [Bradmere] Hundret}

In Ston [Stone (Street) ${ }^{22}$ ] are 60 acres. And 3 bordars. Then I plough, now half a plough. And (this) is included in the valuation of $\mathrm{Ra}$ [m] burc [Rumburgh]. Saint Edmund (has) the soke.

\section{Blidinga [Blything] Hundret}

Manni the Swarthy held Bu[M]FELDA [Bramfield] T.R.E. as a manor and as 7 carucates

20a In Trimley.

"Alteston parish was united with Trimley in 1362 ; Copinger, Suff. Rec.

"In Rumburgh. of land-now the Count holds it in demesne. Then 24 villeins, afterwards and now 35 . Then 5 bordars, afterwards and now 7. Then 4 serfs, afterwards I, now none. Then 4 ploughs, afterwards 3, now 4. Then as now ro ploughs belonging to the men. Wood(land) for 300 swine. 7 acres of meadow. Then 1 rouncey. Then as now 8 beasts, and 24 swine, and 30 goats. Then it was worth 8 li. The King and the Earl (have) the soke. Afterwards (worth) r6li., now $15 l i$. and $13^{s}$ and $4 d$. It is I league long, and another broad. And (pays) $3 \frac{3}{4} d$. in geld. A church with 28 acres of free land and half a plough, worth $3^{\text {s. }}$

In Walepola [Walpole] (were) 7 freemen T.R.E. by commendation and soke and sac. Now 17. And they have 4 carucates of land and 90 acres. Then II villeins, afterwards and now 6 . Then 6 bordars, afterwards and now 5 . Then ro ploughs belonging to the men, afterwards and now 6 . And 6 acres of meadow. Wood(land) for 30 swine. (It is) 12 furlongs long, and II broad. And (pays) $7 \frac{1}{2} d$. in geld. Others have holdings therein. This is included in the valuation of Brunfelda [Bramfield]. The King and the Earl (have) the soke. A church with 16 acres, and half an acre of meadow, worth $12 d$.

In Torentuna [Thorington] and in WenaDESTUNA [Wenhaston] 6 freemen (hold) $2 \frac{1}{2}$ carucates of land. Then as now 3 villeins, and 16 bordars. And 5 ploughs. And 4 acres of meadow. Wood(land) for 16 swine. Then as now 1 mill. A church with IO acres of free land and half an acre of meadow.

In Mideltuna [Middleton] a freeman (holds) I 2 acres and 2 oxen.

In Dersam [Darsham] a freeman (holds) 8 acres and 2 oxen. Included in the above valuation. The King and the Earl (have) the soke.

In TORP [Thorpe ${ }^{23}$ ] livery was made of I freeman as an estate (pro terra) of 69 acres. And 3 bordars. And 2 acres of meadow. Wood(land) for 20 swine. Then it was worth 5s., now Io. The King and the Earl (have) the soke.

In Sibetuna [Sibton] a freeman Alwin (held) I carucate of land and 20 acres as a manor. Then as now 4 villeins. And 10 bordars. And 2 serfs. Then and afterwards I plough on the demesne, now 2. Then as now 2 ploughs befol. 293 .

longing to the men. 6 acres of meadow. Wood(land) for 60 swine. Then as now it was worth 40s. And 1 rouncey on the demesne. And 8 beasts. Then I swine, now 30. And then 2 sheep, now 30 . And 5 hives of bees. ${ }^{28}$ Near Heveningham. 


\section{THE HOLDERS OF LANDS}

Maynard (now) holds. The King and the Earl have the soke.

Ralph the Staller held Wisseta [Wissett] T.R.E. as a manor and as 4 carucates of land. Now the Count holds it in demesne. Then as now 10 villeins. And 10 bordars. Then 2 serfs. Then as now 2 ploughs on the demesne. And 5 ploughs belonging to the men. Wood(land) for 300 swine. And 4 acres of meadow. And 4 rounceys, 20 beasts, 60 swine, 63 sheep, and $5 \mathrm{I}$ goats. Then it was worth 8 li., afterwards I 5 li., now $20 l i$.

In the same (vill) 14 freemen under commendation (held) 4 carucates of land, and I 5 bordars. Then as now 8 ploughs. And 2 acres of meadow. Wood(land) then for 300 swine, now for 60 .

In HalesuUorda [Halesworth] 5 freemen (held) I carucate of land and 2 bordars. Then as now 3 ploughs. And I acre of meadow. Then wood(land) for 60 swine, now for 20 .

In Coua [Cove] 6 freemen (held) half a carucate of land and 4 bordars, and 2 ploughs.

In Sedestana [Chediston] (were) 2 freemen T.R.E., now 3. And they have 80 acres and 3 bordars. And $2 \frac{1}{2}$ ploughs. And 2 acres of meadow. Wood(land) for 60 swine. It is all included in the valuation of the manor. The Earl has sac and soke. It is Io furlongs long, and 10 broad. And (pays) $7 \frac{1}{2} d$. in geld.

In the same (vill of) WISSETA [Wissett] (is) a church with 2 carucates of free land. Then as now 12 villeins, and 16 bordars. And 6 ploughs. Wood(land) for 130 swine. And 3 acres of meadow. There belong (adjacent) to this church 5 villeins with 52 acres, and $4 \frac{1}{2}$ ploughs, and I acre of meadow. In this church are 12 monks, and under it a chapel. The whole is included in the above valuation of $20 l$.

In Wrabetuna [ $]^{24}$ which Ralph the Staller held T.R.E. (is) a villein with I 5 acres. It was worth I 5 d. This Hamo de Vellenis now holds.

In Norhrala [North Hales] ${ }^{25}$ (were) 4 freemen with 16 acres. Then as now half a plough. And they are included in the valuation of Uuitsede [Wissett], and on the Earl's demesne.

\section{Hundret of Carleforda [Carlford]}

In Bischerea [Bixley ${ }^{250}$ ] (was) I sokeman with 5 acres, and worth $12 d$. In the same (vill) I free-

"Occurs as 'Warabetona " in a charter of Henry II; Cel. Cbart. R. ii, 95 .

* Covehithe.

wh In Rushmere. man under commendation to Ralph the Staller T.R.E. (held) 20 acres and I plough; I acre of meadow. Then as now it was worth 45. Moreover the same freeman held 20 acres in RISCEMARA [Rushmere] and they are included in the same value.

In Tudenham [Tuddenham (St. Martin)] (was) I freeman (under) Ralph the Staller with 4 acres, worth $8 d$.

In Ryscemara [Rushmere (St. Andrew)] I I freemen under commendation to Gurth T.R.E. (held) 3 I acres. Then as now I plough. It was worth 5s. Moreover in the same (vill) were 6 acres, worth I2d. I church with 20 acres, worth 40 d.

In BuRC [Burgh] is one villein with I I acres; and he is included in the valuation of Saham [Soham].

\section{WILFORD HUNDRET}

In Capeles [Capel (St. Andrew) ] ${ }^{26} 6$ freemen under commendation of Edric Grim T.R.E. (held) $4 \mathrm{I}$ acres and I bordar. Then as now I plough.

In SutTuna [Sutton] 3 freemen under commendation of the same (Edric Grim held) 34 acres. Then as now 2 ploughs.

In BROMESWELLA [Bromeswell] I $\frac{1}{2}$ freemen under Edric Grim's commendation (held) 4 acres.

In Meltuna [Melton] 6 freemen under Edric's commendation (held) 43 acres. Then 2 ploughs, now 1. Two acres of meadow.

\section{fol. $293^{b}$.}

In LUDHAM ${ }^{27}$ [Loudham] a freeman under Edric (held) 9 acres. And in Ceresfella [Charsfield] (he held) 9 acres. Then as now half a plough. One acre of meadow.

In the same (vill) a freeman under Edric's commendation held 8 acres. Then as now half a plough. Half an acre of meadow.

In BRAdefrlla [Bredfield] (were) 5 freeman under Edric's commendation, except I (who) was under commendation to Saint Etheldreda, and (they had) 26 acres. Then as now half a plough.

In Parva Ceresfella [LittleCharsfield](were) 9 freemen under Edric Grim's commendation, except I who was under commendation to Robert Malet's predecessor, with I6 acres. Then half a plough.

\footnotetext{
${ }^{98}$ This is said to be 'In Campeseia [Campsey Ash]'; Ing. El. 147, 195.

"7 'Ludenham,' 'Ludeham'; ibid.
} 


\section{A HISTORY OF SUFFOLK}

In WIKHAM [Wickham (Market)] a freeman under Edric's commendation (held) 12 acres.

\section{In DePEBEK [Debach] were $7 \frac{1}{2}$ acres.}

(At) Bradefella [Bredfield] Athelwold the priest, under commendation to Saint Etheldreda, held as a manor T.R.E. 50 acres. Then I plough. And under him (were) 9 freemen with $4 \mathrm{I}$ acres. Then I plough, now half a plough.

All this is included in the valuation of KeTLEBERE [Kettleburgh].

And in Holapala ${ }^{28}$ [Harpole in Wickham Market] a freeman under Anand's commendation (held) I 2 acres.

And in Bulges [Boulge] ${ }^{29} 2$ freemen under the said (Anand's) commendation (held) 29 acres. Then as now half a plough.

And they are included in the valuation of SAHAM [Soham].

\section{HundRet of Losa [Loes]}

Edric Grim held Chettrebiriga [Kettleburgh] as a manor and as 4 carucates of land by commendation half to Saint Etheldreda T.R.E. and half to Edric of Laxafella [Laxfield]. Now the Count holds (this) in demesne. Then as now 10 villeins, and 5 bordars. Then 4 serfs, now 2. Then on the demesne 4 ploughs, now 3 , but (another) might be furnished. Then as now 5 ploughs belonging to the men. Wood(land) for 8 swine. Io acres of meadow. Then and now 2 rounceys, 6 beasts, 30 swine, and 32 sheep. The 'caput' of the manor was then worth Ioos. A church with 16 acres,

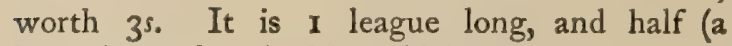
league) broad. And in geld (pays) I $\boldsymbol{d} d$.

In the same (vill) (were) 6 sokemen $^{30}$ with 36 acres. Then as now 2 ploughs.

And in the same (vill) 2 freemen under Saint Etheldreda's commendation (held) I carucate of land. Then as now I plough. Then 2 villeins, now $\mathbf{I}$.

And in Martelaia [Martley ${ }^{31}$ ] $12 \frac{1}{2}$ freemen under Edric Grim's commendation T.R.E. (held) $I$ carucate of land and 2 bordars. Then as now 4 ploughs.

28 'Horepol'; Inq. El. 147.

${ }^{29}$ 'This is said to be 'In Belinges [Bealings]'; ibid. Here the commendation in this and the preceding entry is ascribed to St. Etheldreda, these two estates being included under Kettleburgh instead of under Soham. 146.

80 'Under commendation to Edric Grim': ibid.

${ }^{81}$ In Easton.
And in Ceresfella [Charsfield] 16 freemen; I 2 of these were under commendation to Edric Grim, and I under the Saint (Etheldreda), and over three others (the Saint) had half commendation. (They held) I carucate of land. Then 5 ploughs, now 4. And I acre of meadow.

And in Hacestuna [Hacheston] Io freemen and 2 half freemen under commendation to Edric Grim (held) 80 acres of land. Then 3 ploughs, now 2. 3 acres of meadow.

In Campsea [Campsey (Ash)] 3 whole and 3 half freemen under commendation to Edric Grim (held) 32 acres of land. I $\frac{1}{2}$ acres of meadow. Then as now 1 plough.

In RendieshaM ${ }^{32}$ [Rendlesham] $5^{33}$ whole and 7 half freemen under commendation to Edric Grim (held) 50 acres and I bordar. Then 2 ploughs, now I. 2 acres of meadow.

In the same (vill) a freeman under commendation half to Edric of Laxfield-thereof was William Malet seised on the day on which he died fol. 294 .

-and half to Edric Grim. (He held) $34^{34}$ acres as a manor, and 2 bordars. I acre of meadow. Then as now I plough.

In Butelar [Butley] $7 \frac{1}{2}$ freemen under commendation to Edric Grim (held) 34 acres. $^{36}$ Then I plough, now half a plough. Of these was William Malet seised when he died; and Earl Ralph when he made forfeiture.

In Brodertuna [ ] 7 freemen by half commendation to Edric Grim and half commendation to Edric of Laxfield (held) 56 acres. Then 2 ploughs, now $1 \frac{1}{2}$. 2 acres of meadow. And of the moiety of this land was Robert Malet seised on the day on which Earl Ralph made forfeiture; but Count Alan has it by livery of seisin (liberationem).

In Dalingenou [Dallinghoo] a freeman by commendation to Edric Grim (held) $4 \frac{1}{2}$ acres. ${ }^{36}$

And in Merlesforda [Marlesford] a half freeman (held) I 3 acres and half a plough.

In Horepola [Harpole] (are) 8 acres on the demesne.

Now the whole of this manor (i.e., Kettleburgh) is worth 23 li. and IIs. with the whole soke.

In UDEBRYGE [Woodbridge] 3 freemen by commendation to Edric (held) II acres. And they are included in the above valuation.

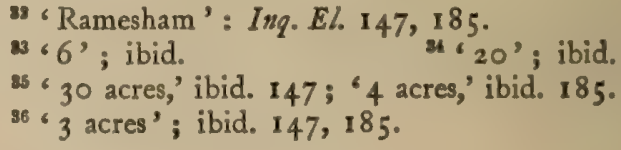




\section{THE HOLDERS OF LANDS}

At SaHam [Soham] Anand a freeman by commendation under Saint Edmund T.R.E. held 4 carucates of land as a manor; now the Count holds it in demesne. Then as now 15 villeins. Then 8 bordars, now 21. Then 2 serfs, now I. Then as now on the demesne 2 ploughs. Then 6 ploughs belonging to the men, now 5. Wood(land) for 100 swine. 12 acres of meadow. Then as now 2 rounceys, 4 beasts, 30 swine, 42 sheep, and 60 goats. Then it was worth roli. and afterwards I 6 li., now $18 l^{i}$. and $13^{\text {s. and }} 4 d$. It is I league long, and half (a league) broad. And in geld (pays) $8 \frac{1}{2} d$.

In Gretingaham [Cretingham] 5 freemen under commendation to Anand (held) 24 acres. Then as now I plough. 2 acres of meadow.

In Dallingahou [Dallinghoo] a half freeman under the said Anand's commendation (holds) I acre. All these are included in the valuation of Saham [Soham]. dow.

A church with 29 acres and 2 acres of mea-

In Gatagrava [Gedgrave] 2 villeins and 8 bordars $^{37}$ (held) 50 acres and $\mathrm{I} \frac{1}{2}$ ploughs. And they are included in the valuation of Carletuna [Carlton].

In Butrlea [Butley] 2 freemen under commendation of Edric Grim (held) 8 acres. And they are included in the said valuation.

In Gategrava [Gedgrave] 3 freemen under commendation of Edric Grim (held) 15 acres and half a plough.

In Mertlega [Martley] a church with 12 acres, worth 25.

In the same (vill) 2 freemen under commendation to Edric Grim (held) 2 acres.

Moreover 5 freemen under the same (Edric's) commendation (held) 45 acres. Then as now I plough.

All this is included in the valuation of Cetelbirig [Kettleburgh].

In Brumfrlla [? Bromeswell] a freeman under Uluric's commendation (held) 2 acres included in the same valuation.

\section{Hale Hundret of Ludingalanda [Loth- INGLAND]}

In Dunstuna [? Blundeston] a freeman Tored held 15 acres, worth $30 d$.

\section{Half Hundret of Gepeswiz [Ipswich]}

In the town of Gepeswiz [Ipswich] Earl Gurth (Guret) T.R.E. held a grange to which

"I 'Under commendation of Edric Grim'; Ing. El. 148. belong 2 carucates of land. (There were) then as now 7 bordars. Then and afterwards I fol. $294 b$.

plough, now none. Then as now 3 ploughs belonging to the men. 4 acres of meadow. The third part of a mill. This land is 4 furlongs long and 4 broad. Then it was worth IOOs. with the third penny of the borough, and it was delivered (liberatum) as (of the value of) $20 l i$. with the third penny of the borough, and with the third penny of the two hundreds; now, however, it renders but 15 li.

\section{Bosemera [Bosmere] Hundret}

At Netlesteda [Nettlestead] Gouti a freeman held T.R.E. 5 carucates of land as a manor. Now Halanalt holds of the Count. Then as now 7 villeins, and 6 bordars, and 4 serfs. Then 5 ploughs on the demesne, afterwards half a plough, now 1. Then as now 2 ploughs belonging to the men. 8 acres of meadow. And I mill. Now I rouncey, 27 swine, and 36 sheep. A church with 8 acres. And Earl Ralph added 34 freemen : over 26 only had his predecessor the commendation only T.R.E. and they have $2 \frac{1}{2}$ carucates of land. Then 8 ploughs, now 6 . And 3 acres of meadow. A church with $70 \frac{1}{2}$ acres. The manor was then as now worth 7 li. and IOs.; and the freemen 5os. It is I league long, and half a league broad. And pays $5 d$. in geld.

In the same (vill) a freeman (held) 60 acres as a manor, which Humphrey holds of the Count. Then as now I bordar. And I plough. And 5 acres of meadow. Then it was worth ros., now 20 .

In Dermodesduna [Darmsden] Kenric a freeman held 30 acres as a manor. Now Nardred holds of the Count. Then I bordar, now 3 . Then as now I plough. 3 acres of meadow. It was worth Ios. The Abbot of Ely has the soke. $^{38} \quad$ From this land Roger Bigot took 5 acres of demesne which William holds of him: he was, however, seised thereof when Ralph made forfeiture.

In Hamingestuna [Hemingstone] the Count has in demesne a sokeman with 15 acres. Then as now I plough. It was worth 2s. and $6 d$.

In Stanham [(? Earl) Stonham] Ulmar holds of the Count 5 freemen with 48 acres, and they hold 12 acres belonging to the Count's demesne. Then as now 2 ploughs. Wood(land) for 6 swine. An acre of meadow. It was worth $12 s$. To the aforesaid land which Humphrey holds belonged on the demesne 28 acres, part woodland and part clear land (inter silvam et planum), which

w 'Sac and soke and commendation'; ibid. 143. 


\section{A HISTORY OF SUFFOLK}

Godmar held T.R.E. : now Roger Bigot holds it, and Garenger of him ; and he held it in like manner when Ralph made forfeiture.

In the same (vill are) 2 acres of land, I freeman, and $1 \frac{1}{2}$ acres of wood(land). Worth $7 d$.

In CodehaM [Coddenham] 3 freemen with 4 acres. Worth $8 d$. The King and the Earl (have) the soke.

\section{Claindune [Claydon] Hundret}

(At) Westrefelda [Westerfield] Bar, a freeman under commendation to Ralph the Staller, held I carucate of land as a manor. Now Norman holds it of the Count. Then as now 2 villeins. Now 2 bordars. Then on the demesne I plough, now 2. Then as now I plough belonging to the men. 2 acres of meadow. Now 1 rouncey, 4 beasts, 20 swine, and 100 sheep. Then it was worth IOs., now 20s. The Earl (has) the soke.

fol. 295 .

In the same (vill) the same (Norman) holds 6 freemen with 24 acres (who were) under commendation to Ralph the Staller T.R.E. Then as now I plough. And it was worth 4s. The soke (is) the Earl's.

In the same (vill) Stanuin, a freeman, held 14 acres. Now Osbert (holds). And (this) is worth $2 s$. and $4 d$. It is 8 furlongs long, and 4 broad. And (pays) 20d. in geld. The soke (is) the Earl's.

In Scaruestuna [? Sharpstone ${ }^{39}$ ] 3 freemen under commendation to the Abbot of Ely (held) 12 acres. Then as now 2 oxen. Two of these men Harlenat holds. And this is included in the valuation of Nedesteda [Nettlestead; ] and the third is on the Earl's demesne, and included in the valuation of Hamigestun [Hemingstone]. The soke is the Abbot's.

In WestrefeldDa [Westerfield] 6 freemen T.R.E. (held) 20 acres. Then as now I plough. And they are included in the valuation of Gipeswiz [Ipswich]. The Count holds (this) in demesne. The King and the Earl (have) the soke.

En TuRuestuna [Thurlston] a freeman (held) 2 acres; and in Westrefelda [Westerfield] 2 freemen (held) 3 acres. Worth Iod. Aluric the priest holds of the Count.

In the same (vill) Uluric a freeman (held) 6 acres. Worth $12 d$. The $\mathrm{King}$ and the Earl (have) the soke.

In Assefelda [Ashfield] 4 freemen (held) 27 acres. Then 1 plough, now half a plough. Worth 3 s.

$$
{ }^{39} \text { See below, n. } 140 .
$$

In the same (vill) Brictmar a freeman (held) 24 acres as a manor T.R.E. Then I plough. Worth 5 s.

In Turoluestuna [Thurlston] Aluric a freeman held 16 acres of land T.R.E. And he was worth $32 d$.

In the same (vill) a freeman (held) 7 acres. Worth I $4 d$.

In the same (vill) (was) a freeman with 12 acres. Worth 2s. The King and the Earl have the soke.

\section{Sanfort [SAmFord] Hundret}

Ansgot held Wenham [Wenham] under commendation to Edith the Fair ; I carucate of land as a manor. Now Ermiot (?) holds it of the Count. Then as now 3 villeins and 3 bordars and 2 serfs. And 2 ploughs on the demesne, and 2 ploughs belonging to the men. And 4 acres of meadow. And part of a church. And 8 beasts, 35 swine, and $7 \mathrm{I}$ sheep. Then worth 6os., now 40s. Edith (had) the soke. It is 6 furlongs in length and 3 in breadth, and (pays) $4 d$. in geld.

Godman held Holebroc [Holbrook] under commendation to Edith ; I carucate of land as a manor. Now Oddo holds it of the Count. Then as now 2 villeins and 2 bordars. Then I plough on the demesne, afterwards none, and now I, and then as now I plough belonging to the men. Then worth 20s., now 15s. The soke (is) in Bercolt [Bergholt].

\section{Edith held BERIA [}

]$^{40}$ T.R.E. ; 2 carucates of land as a manor. Now Humfrid holds it of the Count. I bordar. Then 2 ploughs on the demesne, now $\mathbf{I}$ and $\mathbf{I}$ acre of meadow. Then I mill. Then 2 rounceys, now I, then 4 beasts, now I. Then 20 swine, now 40. Then as now 100 sheep and 12 goats. Worth 40 s. It is 8 furlongs in length and 6 in breadth, and (pays) $5 d$. in geld. Others have holdings there. Edith (had) the soke.

\section{fol. $295 b$.}

Edmund, a freeman of Robert son of Wimarc, held Wervesteda [Wherstead] T.R.E. as a manor and I carucate of land. Now Furic holds it of the Count. Then as now 2 villeins and 2 bordars. Then I plough on the demesne, after. wards none, now half a plough. Then I plough of the men and 3 acres of meadow. Worth 20s. The soke (is) in Bercolt [Bergholt].

In Benetleia [Bentley] the same Edmund held 40 acres for a manor T.R.E. and it was worth ros. Edith (had) soke. The same Furic holds of the Count.

${ }^{60}$ Copinger (Suff. Rec.) identifies 'Beria' with Bourne, i.e. Bournethall in Wherstead. 


\section{THE HOLDERS OF LANDS}

Edwin held Todenes [Dodnash ${ }^{41}$ ] in commendation to Edith, and in her soke; I carucate of land as a manor T.R.E. Then as now I villein and 6 bordars. Then 3 serfs. Then as now $1 \frac{1}{2}$ ploughs on the demesne, and I plough belonging to the men. 4 acres of meadow. Wood(land) for 30 swine, and I mill. A church (having) 30 acres of free land. Then worth I 5s., now 20s. It is 8 furlongs long, and 6 broad, and pays rod. in geld. Others have holdings there.

The same Edwin held Brantestuna [? Brantham] in Edith's soke, I carucate of land as a manor T.R.E. Then as now 4 villeins, and 5 bordars, and I plough on the demesne, and 2 ploughs belonging to the men, and I acre of meadow. Then worth 13 s, now $16 s$. Godinc holds these two (manors) of the Count.

Tostin held Uluerestuna [Woolverstone] in Edith's soke and commendation; I carucate of land as a manor. Then as now 5 villeins and 2 bordars. Then $\mathrm{I} \frac{1}{\mathrm{~g}}$ ploughs on the demesne, now 2 , and half a plough belonging to the men. 2 acres of meadow. Wood(land) for 15 swine. A church (having) Io acres. Then 5 rounceys, now 7. Then 8 beasts, now 12. Then 20 swine, now 30 . Then 60 sheep, now 100 , and 36 goats. Then worth 20 s., now 30 s. 8 furlongs long and 3 broad, and (pays) $2 \frac{1}{2} d$. in geld. Aluric the Priest holds (it) of the Count.

In BenetLeia [Bentley] the same Tostin held by the same tenure (eodem modo) 40 acres for a manor T.R.E. Then $I$ bordar, now 2. Then half a plough, now 1 , and then worth 5 s. and $4 d$., now 6s. The same Aluric holds of the same (Count).

The same Tostin held Painetuna [Pannington] T.R.E.; 60 acres for a manor. Then as now 2 villeins, and I plough, and 2 acres of meadow and worth 8s. Edith (had) the soke. The same Aluric (holds it).

In WERVESTEDA [Wherstead] the same (Tostin) held T.R.E. for a manor 40 acres. Then I plough, now half a plough, and I salt-pan. Worth 5s. Edith (had) the soke. The same Aluric (holds it).

The same Tostin held Calvwetuna [ ]$^{42}$ T.R.E. for a manor 40 acres. Then as now $I$ bordar and half a plough. Worth 5 s. and $4 d$. The soke (held) in the same way. Aluric holds it of the Count.

Suart, a sokeman of Stigand, held Hinclesham [Hintlesham], I carucate of land, for a manor T.R.E. Now Ralph holds it of the Count.

\footnotetext{
a In Bentley.

'3 'Kalewetun' in Kirton; Add. Chart. 10177.
}

fol. 296.

Then as now 3 villeins, and 3 bordars, and 2 ploughs on the demesne, and I plough belonging to the men, and 4 acres of meadow. Worth 40s. Stigand (had) the soke.

In Canapetuna [ ] the same Suwart, a freeman, held 30 acres for a manor T.R.E. (It is) in the soke of Bercolt [Bergholt]. This is included in the above valuation.

Ulestan, a freeman of Edith's, (held) BoITuna [Boyton ${ }^{43}$ ]; 50 acres for a manor T.R.E. The soke (is) in Bercolt [Bergholt]. Now Ulestan holds it of the Count. Then as now 2 bordars. Then half a plough, now 1 , and 2 acres of meadow. Worth 8 s.

In Brantham [Brantham] Godwin, a freeman, (held) 35 acres for a manor T.R.E. and Godwin holds of the Count. Then as now 2 bordars, and half a plough, and I acre of meadow, and worth $4 \mathrm{~s}$. In the same (vill) 8 freemen (held) I carucate and II acres of land. Then as now 2 ploughs, 4 acres of meadow, and I salt-pan, and worth 22s. and $8 d$. Now the Count holds it in demesne. The soke (is) in Bercolt [Bergholt].

Edwin, a freeman, held Stotruna [Stutton]; 60 acres for a manor. Then as now half a plough, and 3 bordars, and $\mathrm{I}$ acre of meadow. Included in the same valuation.

In Wenham [Wenham] Ansgot held I5 acres, and $\mathbf{I}$ acre of meadow. Worth 2s. and $6 d$. Edith (had) the soke.

Brantham [Brantham] altogether is I league long and half a league broad, and pays $18 d$. in geld.

\section{Perreham [Parham] Half Hundret}

In the Abbot of Ely's soke.

In Wanttesdena [Wantisden] 16 freemen, half under commendation to Malet's predecessor and half under commendation to the Abbot of Ely, and all in his (the Abbot's) soke, (held) 60 acres. Then as now 2 ploughs. Worth IOS. Now the Count holds in demesne.

In the same (vill) Edwin a freeman (held) $\mathrm{I}_{4}$ acres. Then as now half a plough. Worth $2 s$. and $8 d$. The Count holds in demesne.

In Blachessala [Blaxhall] a freeman (held) 2 acres, worth $4 d$. Hamo de Valenis (now holds).

(At) Perreham [Parham] Aluric the King's thegn held T.R.E. I carucate of land as a manor.

${ }^{63}$ In Bergholt and Bentley; Copinger, Suff. Rec. 


\section{A HISTORY OF SUFFOLK}

fol. 2966 .

Now Hamo holds of the Count. Then as now 8 bordars, and 1 serf. And 2 ploughs on the demesne. Then half a plough (belonging to the men). And 4 acres of meadow. Now 8 swine, and 20 sheep. Then it was worth 20s., now 40 s.

In Blachessala [Blaxhall] Brotho a freeman held I 2 acres. Worth 2s. The Count (holds) (this) in demesne. The soke (is) the Abbot's.

In the same (vill) Edric Grim a freeman half under commendation to Malet's predecessor and half to the Abbot of Ely (held) 20 acres. Worth 4od. Hamo holds of the Count.

In Prrreham [Parham] 3 freemen (held) 16 acres. Worth $32 d$.

In WANTESDEN [Wantisden] Oslac a freeman held 3 acres. Worth $6 d$.

In the same (vill) Edilt a freeman (held) 8 acres. Worth $16 d$. Now the Count holds in demesne.

In Blachessala [Blaxhall] Uluric a freeman (held) 4 acres. Worth $8 d$. (Now the Count holds) in demesne. The soke (is) the Abbot's.

\section{Plumesgate [Plomesgate] Hundret}

Cesefortda [Chillesford ${ }^{44}$ ] the Count holds in demesne. Olf a freeman under soke and commendation of the Abbot of Ely T.R.E. (held) as a manor 80 acres. Then as now I villein, and 4 bordars. Then and afterwards $1 \frac{1}{2}$ ploughs on the demesne, now $I$. Then and afterwards $I \frac{1}{2}$ ploughs belonging to the men, now 1. A church with 5 acres of free land. Worth 13 s, and $4 d$. And 3 freemen (held) 20 acres. Then as now I plough. Worth $40 d$.

(At) Carletuna [Carlton] Hamo holds of the Count I carucate of land as a manor. Edric Grim under commendation half to the Abbot of Ely and half to Robert Malet's predecessor (held it); and William Malet was seised thereof. Then as now $I$ villein, and 3 bordars, and I serf. And 2 ploughs on the demesne. And half a plough belonging to the men. And half a fishery. And 2 acres of meadow. Worth $60 s$. In demesne then as now 1 rouncey. And Ioo sheep, now I70. And a freeman under commendation (held) 2 acres. Included in the same valuation. It is 9 furlongs long, and 4 in breadth, and (pays) $20 d$. in geld. And on the demesne (were) 8 freemen with 60 acres. (Of them) Stain and Aluric (were) under sub-commendation to Malet's predecessor, ${ }^{45}$ and William

"Tormerly 'Chesilford'; Feud. Aids, v, 85.

1s 'Edric Grim'; Ing. El. 149. fol. 297.

Malet was seised thereof, and the others (were) under commendation to the Abbot of Ely. Then as now 2 ploughs. Worth I 2s. and $4 d$. The soke over the whole (belongs) to the Abbot of Ely.

At Gliemham ${ }^{46}$ [Glemham] the aforesaid Edric (held) in demesne 20 acres, and this belongs to Chetelberia [Kettleburgh] and it is worth $40 d$. The soke is the Abbot's.

In the same (vill) Sparhavoc a freeman held 60 acres as a manor under commendation to Edric Robert Malet's predecessor ; and William Malet was seised thereof. Then as now I bordar. And I plough. Half a church with IO acres and half a plough. Worth Ios.

In the same (vill were) 8 freemen with 60 acres. Leuric, Edric, Ulmar, Hunepot a half (freeman), Godric, Almar, Leuric, Ulmar. All these (were) under sub-commendation to Malet's predecessor. Then 4 ploughs, afterwards and now 3. Worth Ios.

In the same (vill) a freeman (held) 4 acres. Worth $8 d$. It (i.e. Glemham) is I league long, and half a league broad. And renders $20 d$. in geld.

In Thirue Gliemham [(? Little) Glemham] Ustred a freeman under commendation to Bishop Ailmar T.R.E. (held) 20 acres. Then half a plough, now I plough. And $1 \frac{1}{2}$ acres of meadow. And 2 freemen under commendation (held) 5 acres. Then it was worth 6 s., now 5 s.

In Sternesfelda [Sternfield] Osbern a freeman T.R.E. (held) 24 acres. Then as now half a plough. Worth 4 s. The Count now (holds) in demesne.

In the same (vill) 2 freemen (have been) added with $8 \frac{1}{2}$ acres. Worth $18 d$. (The Count now holds) in demesne. The soke is the Abbot's.

In BurEsiart ${ }^{47}$ [Bruisyard] Olf held 85 acres as a manor. Then as now 3 villeins, and 7 bordars. Then 2 ploughs on the demesne, afterwards and now I plough. Then as now 2 ploughs belonging to the men. And 2 acres of meadow. Wood(land) for 10 swine, 2 rounceys and 17 beasts. Then 9 swine, now 15 . Then 40 sheep, now 6, and 15 goats. In the same (vill) Edric a freeman held $9 \mathbf{I}$ acres as a manor. Then and afterwards 2 ploughs, now I. And I bordar. 2 acres of meadow. Wood(land) for 10 swine. Then and afterwards it was worth $60 s$., and now 6os. Hamo holds of the Count. Ralph the Staller (had) the soke T.R.E.

In the same (vill) Starling ${ }^{48}$ a freeman under commendation half to the predecessor of Malet,

\footnotetext{
46 ' Glamessam,' 'Gelemesham '; ibid. I 49, I 86.

47 'Burusgert,' 'Burchierth'; ibid.

48 'Sterdincg'; ibid.
} 


\section{THE HOLDERS OF LANDS}

whose father was seised thereof, and half under commendation to the Abbot, (held) 60 acres as a

fol. $297^{b}$.

manor. Then as now 7 bordars. Then and afterwards I plough on the demesne, now half a plough. Then as now I plough belonging to the men. And 3 acres of meadow. Worth ros. Hamo holds (this). It is 8 furlongs long, and 6 broad. And (pays) rod. in geld. The soke (is) the Abbot's.

In Rincham [Rendham] Ostula a freeman (held) 40 acres as a manor under commendation to the predecessor of Malet, whose father William was seised thereof. Then as now I villein, 2 bordars. And I plough on the demesne. And half a plough belonging to the men. Worth $7 \mathrm{~s}$. The soke (is) the Abbot's.

In the same (vill) Hune a freeman under commendation to Ralph the Staller (held) 30 acres as a manor. Then as now half a plough. And I acre of meadow. Worth 5 s.

In the same (viil) 9 freemen (held) 91 acres as a manor. Then as now 2 bordars. And $4 \frac{1}{2}$ ploughs. And 4 acres of meadow. Then it was worth 20s., now 275. These men were under commendation to the predecessor of Malet, and his father William was seised of them. The soke (is) the Abbot's.

In Surstringan [Swefling] Osmund a freeman under commendation to Malet's predecessor (held) 30 acres as a manor in the Abbot's soke. Then as now 3 bordars. And I plough. And 2 acres of meadow. Worth 5s. And William Malet was seised thereof. The soke (is) the Abbot's.

In the same (vill) 5 freemen held 54 acres. Two of these were under sub-commendation to Malet's predecessor with 10 acres, Aluric and Dot. And one, Buric by name, was under commendation and soke of Ralph the Staller with 24 acres. $^{49}$ Then as now 2 ploughs. And 4 acres of meadow. Worth ros. The soke (is) the Abbot's.

In the same (vill) I 4 freemen (held) 94 acres, and 3 bordars. Over $3 \frac{1}{2}$ Malet's predecessor had commendation and (over) a half the sub-commendation. And William Malet was seised thereof. Then as now 4 ploughs. And 6 acres of meadow. Then it was worth 30 s., now 25 s. and $4 d$. The soke (is) the Abbot's. It is I league long, and $6 \frac{1}{2}$ furlongs broad. And (pays) $20 d$. in geld. Others hold land therein.

In Benghalla [Benhall] 7 freeman held 44 acres. And 4 of these were under commendation to the predecessor of Malct, and

* The other two freemen, with 20 acres, were in the commendation of St. Etheldreda ; Inq. El. 149. fol. 298 .

his father was seised (thereof), Edric, Brictmar, Tutflet, Magna. Then I $\frac{1}{2}$ ploughs, now I plough. Then it was worth 8 s., now 6s. and $8 d$. The soke (is) the Abbot's.

In Gurmham [Glemham] 2 freemen, Wacra under sub-commendation to Malet's predecessor and Ulveva under commendation to Malet's predecessor, (held) 20 acres. Then as now I plough. Worth 7 s.

All this Hamo holds of the Count. The soke (is) the Abbot's.

In Craneforda [Cransford] Olf a freeman held 30 acres as a manor. Now the Count holds in demesne. Then as now I plough. Worth 5s. The soke (is) the Abbot's.

In the same (vill) 2 freemen (held) 4 acres, worth $8 d$.

In Surflinga [Swefling] 3 freemen (held) 4 I acres and I bordar and I plough and an acre of neadow. Then it was worth $6 s$. and $8 d$., now 5s. $10 d$.

\section{W AINEFORDA [W ANGFORU] HUNDRET}

In Almaham [Elmham] (are) 40 acres, and they belong to the church of Romburc [Rumburgh]. And 6 bordars. And 1 plough. And wood(land) for 6 swine. And they are included in the valuation of the same (church ?).

\section{fol. $298 b$.}

\section{IIII. LANDS OF EARL HUGH}

\section{Clatndune [Claydon] Hundret}

(At) Framesdena [Framsden] Adestan, the thegn, held T.R.E. 6 carucates and 40 acres of land as a manor. Then 25 villeins, now 29. And then as now 23 bordars. Then 4 ploughs on the demesne, now 3. Then 20 ploughs belonging to the men, now I6. 16 acres of meadow. Then wood(land) for 80 swine, now for 40 . Then as now 1 mill. Then 2 rounceys, now 3. Then 6 beasts, now 13. Then 20 swine, now 31. Then 50 sheep, now 100. Then 7 goats, now 31 . A church with 30 acres of free land T.R.E., with now I plough. Then it was worth I6li., now 20li.; and it was set to farm for $25 l i$. It is I league long, and 8 furlongs broad. It renders $10 d$. in geld. The soke (is) the Abbot's.

In Manuuic [

] Godric a freeman under commendation to the Earl's predecessor held 42 acres as a manor. Then as now I bordar. Then I plough, afterwards half a plough, now none. I acre of meadow. This was then worth 20 s., now 13 s. and $4 d$. 


\section{A HISTORY OF SUFFOLK}

In the same (vill) a freeman under the like commendation held 27 acres, ${ }^{80} 7$ bordars, I plough, and I acre of meadow. Worth IOs.

In Manuurc [

] Wailolf a freeman under commendation to the Abbot of Ely held 60 acres and 2 bordars. Then $1 \frac{1}{2}$ ploughs, now 2 ploughs. And a freeman (held) I acre. 2 acres of meadow. Wood(land) for 6 swine. Worth 20s: Half the soke (is) the Abbot's and half the Earl's.

In the same (vill) a freeman under commendation (held) $13 \frac{1}{2}$ acres. Then 2 oxen. Worth 4s. and $8 d$. The soke (belongs) in the same way.

In Winestuna [Winston] Iric a freeman under commendation (held) 30 acres. In the same (vill) Grimolf (and) Edward freemen (held) 30 acres. And (there were) 4 bordars. Then 2 ploughs, now I. 4 acres of meadow. They were then worth 20s, now 15s. Of two of them the Abbot has half the soke, and of the third the whole. And the Earl has the rest of the soke.

In Winestuna [Winstrnin half a freeman under commend action (holds) $7 \frac{1}{2}$ acres. Worth I $8 d$.

In TORP [Thorpe] and in Asfelda [Ashfield] $2 \mathrm{I}$ freemen (held) I carucate and $\mathrm{I} 4$ acres of land under commendation to his (Earl Hugh's) predecessor T.R.E. A church with 12 acres. Then 3 ploughs, now 2. And 3 acres of meadow. Wood(land) for 12 swine. They were then worth 40s., now 30 . The soke (is) fol. 299 .

half the Abbot's and half the Earl's. Assafelda [Ashfield] is I league long and 7 furlongs broad. And pays 20d. in geld. Others have holdings therein. All this Hugh, son of Norman, holds of the Earl.

In TORP [Thorpe] Oslac a freeman under commendation held IO acres. Worth 2s.

In HelmingheHam [Helmingham] a freeman (held) 8 acres. Worth $16 d$. The soke (belongs) in manner aforesaid.

\section{Perreham [Parham] Half Hundret}

In Perreham [Parham] 4 freemen under commendation to his (Earl Hugh's) predecessor (held) 20 acres. Worth 4s. Roger Bigot holds of the Earl.

\section{Brademera [Bradmere] Hundret}

Bernham [Barnham] Scula, King Edward's thegn, held as a manor, 2 carucates of land.

s0 'In Monauuic a freeman Wudebrunde with 27 acres': Inq. El. 145. 'In Munchewich'; ibid. 188. Cf. below, n. 54 .
Then as now I bordar, and 2 serfs. And 2 ploughs on the demesne. I acre of meadow. And 1 mill. Now 3 beasts. Then 25 swine, now 14. Then Io sheep, now 120 . Then as now it was worth 30 s. Saint Edmund (has) the soke.

WATESFELdA [Wattisfield] Aluric the thegn held as a manor T.R.E., I carucate of land. Then as now I villein. Then 2 ploughs. Then it was worth $25^{s}$, now 17 s.

\section{BISCOPES [BISHOP'S] HUNDRET}

SAXTEDA [Saxtead] T.R.E. Burchard held as a berewick of (in) FRAMincham [Framlingham], 60 acres. Then as now II villeins, and 5 bordars. Then as now 9 ploughs. And 4 acres of meadow. Wood(land) for 200 swine. This is included in the valuation of Framincham [Framlingham].

\section{Blidinga [Blything] Hundret}

HealesuUrda [Halesworth] Aluric held T.R.E. as a manor, 2 carucates of land. Then 4 villeins, now 5. Then 7 bordars, now 10 . Then as now 2 serfs. Then as now 2 ploughs on the demesne. Then 3 ploughs belonging to the men, now 2. Then wood(land) for 300 swine, now for 100 . Then as now 4 acres of meadow. A mill. I rouncey. Then as now 6 beasts. Now Io swine. I 8 sheep. Then it was worth 30 (shillings), now 40 s.

In the same (vill) Ulf the priest held 40 acres of land as a manor. 2 bordars. I plough on the demesne. Wood(land) for 6 swine. 4 acres of meadow. 14 sheep, and 2 goats. Worth 5s. And to this manor are conjoined 4 freemen with 60 acres of land. 2 bordars. 2 ploughs on the desmesne. Worth 10s. And Bigot de Loges holds these 3 estates under Earl Hugh. It fol. 2996.

is I league in length, and another in breadth. And it renders $7 \frac{1}{2} d$. in geld. And Count Alan claims the land of the aforesaid priest and these 4 men as of his predecessor's fee, and by seisin made to him. And the Hundred is his witness.

UGGICEHEALA [Uggeshall] Osketel a freeman held T.R.E. as a manor, 2 carucates of land. Then as now 5 bordars. I serf. Then 3 ploughs, now 2. And then as now I plo: gh belonging to the men. $2 \frac{1}{2}$ acres of meadow. Then I mill, now none. And I salt-pan. 24 swine. And I church. Then it was worth 40 s., now 3os. This R. de Curcun holds of Earl Hugh. Attached (jacet) to this manor is I man with (part of) the said land and included in the said valuation. It is $I \frac{1}{2}$ leagues long, and I (league) broad. And it renders $6 a$ in geld. Over this land, and over all the other l: ds which 


\section{THE HOLDERS OF LANDS}

Osketel the priest had, Ralph the Staller had soke and sac.

Mirdeltuna [Middleton] Munulf held T.R.E., now R. Bigot holds under Earl Hugh. Over this tenement (ex boc) Earl Hugh's predecessor had half commendation T.R.E. and Robert Malet's predecessor the other moiety of the commendation. And he had 80 acres as a manor. Then as now 2 villeins, and 2 bordars. And I plough on the demesne. And I plough belonging to the men. And 2 acres of meadow. Then it was worth IOs., now 20 s.

In the same (vill were) 6 freemen. Brunwin was wholly Munulf's man T.R.E. Alfac half. And Lefric half. Esmoda was wholly the woman of Toli the Sheriff. And Brihtmar her son was the man of Brihtmar Robert Malet's reeve, and (he was so) in respect of (cum) the sixth part of the land. Kenric was the man of Edric son of Ingold, and Grim of the same. And they have 50 acres of land, and $1 \frac{1}{2}$ ploughs. I acre of meadow. Worth 8s. The King and the Earl have the soke. Grim and Kenric were under commendation to Edric the predecessor of Robert Malet; and he (Robert) granted the profit of them to Walter de Caen after Walter de Dol made forfeiture. Now R. Bigot holds (them) as of Earl Hugh's fee.

fol. 300 .

\section{Hundret of Calleforda [Carlford]}

In GRUNDESBurh [Grundisburgh] a freeman of Harold's by commendation T.R.E., and his wife under commendation to Haldein, (held) 60 acres as a manor, now 4 freemen hold it. Then as now $I$ villein and 2 bordars, and I plough, and 2 acres of meadow. Then it was worth IOs., now the like.

In BURH [Burgh] I freeman under commendation to Countess Edgiva (neld) 5 acres. Half an acre of meadow. Worth $12 d$.

\section{HUNDRET OF LOSA [LOES]}

In Gretingaham [Cretingham] Edric a freeman by commendation half under Edric and half under Athestan held I carucate of land. Then as now 7 bordars, and $I$ serf. Then as now belonging to the men $\mathrm{x} \frac{1}{2}$ ploughs. And on the demesne the like. Wood(land) for 12 swine. 8 acres of meadow. And I rouncey, 4 beasts, 16 swine, 24 sheep, and 7 goats. A church with 18 acres, worth 3 s. Then it was worth 40 s., now a like amount.

In the same (vill) 3 freemen under the same (Edric's ?) commendation (held) $6 \frac{1}{2}$ acres. Half a plough. Included in the same valuation.

Moreover in the same (vill) 4 freemen under Athestan's commendation T.R.E. (held) 58 acres of land and 4 bordars. Then 1 plough, now 2. 4 acres of meadow. Then it was worth 15 s., now 20s. And (there are) 8 acres of waste land. Worth $16 d$.

\section{Wenefort [Wangrord] HUNDRET}

At Bunghea [Bungay] Aluric a freemen held T.R.E. 5 carucates of land as a manor. Now William holds (it) of the Earl. Then as now 22 villeins, and 22 bordars, and 3 serfs. And 2 ploughs on the demesne. Then 6 ploughs belonging to the men, afterwards 2 , now 3 ; and the others might be restocked. A church with 20 acres and 2 acres of meadow worth $40 d$. Wood(land) for 30 swine. And $1_{4}$ acres of meadow. Then as now 1 mill ; and three (fourth) fol. 3006 .

parts of another. Then as now 3 beasts. Then 22 swine, now 12. Then 32 sheep, now 100. Then worth 60s., now Ioos.

In the same (vill) a freeman Ulchetel (held) 40 acres as a manor T.R.E. Now the said William (holds it). Now 4 bordars. Then as now I plough on the demesne. And I plough belonging to the men. And I acre of meadow. And I mill. Then as now 2 rounceys, and 2 beasts. Now 5 swine. Then 20 sheep, now 80. Worth 13 s. and $4 d$.

In the same (vill) Sumerlet a freeman (held) 40 acres T.R.E., now the said William (holds it) as a manor. Then as now $I$ villein, and 3 bordars, and $I$ serf. Then as now on the demesne $x$ plough. And belonging to the men I plough. Wood(land) for 6 swine. $2 \frac{1}{2}$ acres of meadow. The fourth part of a mill. Then and now worth 13 s, and $4 d$.

In the same (vill) 27 freemen under Aluric's commendation T.R.E. (held) I carucate of land and 10 acres and $\mathrm{I}$ bordar. Then 3 ploughs, now 2. 4 acres of meadow. Wood(land) for 3 swine. Then as now worth 40 s,

In IlcheTELeshala [Ilketshall] Warin (now) holds. A freeman Ulsi under Gurth's commendation (held) 2 carucates of land as a manor. Then as now 5 villeins, and 13 bordars. Then 6 serfs. Then on the demesne 3 ploughs, now 1. Then 2 ploughs belonging to the men, now $I \frac{1}{2}$ ploughs. 4 acres of meadow. Wood(land) for ro swine. Half a mill. Now 5 swine. Then 30 sheep, now 40. Now 16 goats. Then as now worth 40s. This Warin son of Burn[win] (holds) of him.

In Metingaham [Mettingham] a freeman Aluric under Ulsi's commendation (held) 60 acres as a manor. Then as now 3 bordars. Then as now on the demesne I plough. Then belonging to the men I plough, now half a plough. Wood(land) for 2 swine. 3 acres of meadow. Then worth 8 s., now Ios. And under him 8 freemen 


\section{A HISTORY OF SUFFOLK}

under commendation to the same (Ulsi) (held) 20 acres. Then I plough, now half a plough, and worth 5s. A church with 20 acres, worth 3. The same Warin now holds.

In Ilcheteshala [Ilketshall] a freeman Alwin under Ulsi's commendation (held) 60 acres as a

fol. 301 .

manor. Then as now Io bordars. And I serf. And on the demesne $\mathrm{I}$ plough. And belonging to the men I plough. 2 acres of meadow. Wood(land) for Io swine. Then worth IOS., and now the like.

Furthermore in Ilchetrenala [Ilketshall] and in Metingaham [Mettingham] and in Scipmedu [Shipmeadow] dwell 7 freemen under the same (Ulsi's) commendation with 80 acres and I bordar. Then 3 ploughs, now 2. 2 acres of meadow. Then as now worth ros.

In Ilcheteshala [Ilketshall] a freeman Burchard held 2 carucates of land as a manor. Then as now 5 villeins, and 7 bordars. Then 5 serfs. Then on the demesne 3 ploughs, now 1 ; but there might be $(2$ more). Then 3 ploughs belonging to the men, now 2 ; but they might be restocked. Wood(land) for 30 swine. 4 acres of meadow. Then 2 rounceys; now I. Now 2 beasts, and 60 sheep. Then worth 30 s., now 40 s.

In Bongeia [Bungay] there are 60 acres, and they belong to a manor which the King holds. Worth IOS. To this land (belong) $\mathrm{I} \frac{1}{2}$ freemen with $5 \frac{1}{2}$ acres. Worth 2 s.

In Elcheteshala [Ilketshall] a freewoman under Burchard's commendation (held) 20 acres. Then as now 5 bordars. And on the demesne I plough. And belonging to the men I plough. Wood(land) for Io swine. $I \frac{1}{2}$ acres of meadow. Then as now worth 5s. A church with 20 acres, worth $2 s$.

In Scrpmedu [Shipmeadow] 3 freemen (held) I 5 acres. Then I plough, now half a plough. Worth $3^{\text {s. }}$

In Ilcheteshala [Ilketshall] 3 freemen under Burchard's commendation (held) 30 acres. Then as now I plough. Worth 5 s.

In RINGESFELDA [Ringsfield] 2 freemen under Burchard's commendation (held) I 2 acres and I bordar and half a plough. Wood(land) for 2 swine. Worth $3^{\text {s. and }} 6 d$. All this Warin son of Burnwin holds of him.

SoterRega [Sotterley] Mundret holds, and Burchard held it T.R.E. ; I $\frac{1}{2}$ carucates of land as a manor. Then 4 villeins, now 3. A church with 7 acres. Then 3 bordars now 16.
And 2 serfs. Then 2 ploughs on the demesne, fol. $30 \mathrm{r} b$.

now 3 and 3 oxen. Wood(land) for 100 swine. 4 acres of meadow. Then as now I rouncey, 14 beasts, 31 swine, 120 sheep, and 30 goats. Then as now worth $53^{\text {s. and }} 4 d$.

In Croscroft [ ] a freeman, Burchard, held $\mathrm{I} \frac{1}{2}$ carucates of land. Then as now 3 villeins, and 5 bordars. Then 2 ploughs, now none. But 2 could be made up. And 2 ploughs belonging to the men. Then I rouncey, and 5 beasts, now none. 3 acres of meadow. Wood(land) for ro swine. Worth 26s. and $5 d$. Soterlega [Sotterley] is I league long and 9 furlongs broad. And in geld (pays) $3 d$. This Mundret holds of Hugh.

In Ilchetrshala [Ilketshall] a freeman (held) 12 acres, whom Ralph, a man of W. the Constable (cunestabla), appropriated (invasit); and of him Earl Ralph was seised on the day on which he made forfeiture.

Furthermore in the same (vill) a freeman (held) 10 acres which Roger Bigot held; and Burnwin appropriated this holding against his right (super eum).

\section{In Hetheburgafella [} 3 freemen under Burchard's commendation (held) 22 acres and I plough, worth $4 \mathrm{~s}$.

In WeRLINGAHAM [Worlingham] a freeman under Gurth's commendation (held) 6 acres, worth $12 d$.

\section{HUNDRET OF LUdinga [LOTHINGLAND]}

At Kessingalanda [Kessingland] Burchard held T.R.E. 2 carucates of land as a manor; now Hugh son of Norman holds it. Then as now 2 villeins and 6 bordars, and 2 serfs. Then as now on the demesne 2 ploughs. And belonging to the men I plough. One acre of meadow. And I mill. Then as now I beast, 23 swine, and 40 sheep. Then worth 30 s., now 40 s. It is I league long, and I (league) broad. And (pays) $32 d$. in geld.

In the same (vill were) 40 freemen; of these I I were under Gurth's commendation and the others under Burchard's commendation; and among them (they held) 3 carucates of land. fol. 302 .

Then 8 ploughs, now 5. One acre of meadow. Then worth 4 li., now roos.

In Rodenhala [ ] a freeman under commendation to Tored, R. Bainard's predecessor, (held) 30 acres as a manor. 5 bordars. Then as now I plough. And belonging to the men half a plough. Wood(land) for 4 swine. $1 \frac{1}{2}$ acres of meadow. Then worth 8 s., now it renders $12 s$. 


\section{THE HOLDERS OF LANDS}

In Gislemam [Gisleham] a freeman under Gurth's commendation (held) 15 acres. Then I plough, now half a plough. And 2 villeins. And half an acre of meadow. Then worth 8s., now the like.

In Karletun [Carlton (Colville)] Burchard held T.R.E. 2 carucates of land as a manor. Then 8 villeins, now 4. Then 6 bordars, now 4. Then as now 4 serfs. And on the demesne 2 ploughs. Then belonging to the men 2 ploughs, now 1. Wood(land) for 30 swine. 4 acres of meadow. Then as now 1 rouncey, 8 beasts, 23 swine, and 100 sheep. Then worth 30s., now 40s. It is I league and 8 furlongs long, and 10 furlongs broad. And in geld (pays) 4 s.

In the same (vill) 30 freemen under Burchard's commendation (held) 2 carucates of land. Then 8 p'oug is, now 4 . 6 acres of meadow. Then worth 4 li., now 60 s.

In BARNEBY [Barnby] 5 freemen under Burchard's commendation (held) 44 acres. Then as now $I$ plough. Half an acre of meadow. Then and now worth 6s. The King and the Earl (have) the soke over the freemen. A church with 80 acres, worth $2 s$.

All this Hugh son of Norman holds of (Earl) Hugh.

At Ryscemara [Rushmere (St. Michael)] Aluric a freeman under Gurth held T.R.E. I carucate of land as a manor. Then as now 3 bordars. And on the demesne 1 plough. And belonging to the men half a plough. Wood(land) for 10 swine. Then worth 5s., now ros.

fol. $302 b$.

In PAgGefella [Pakefield] a freeman under the same (Gurth's) commendation (held) 16 acres. And half a plough. And half a church with $16 \frac{1}{2}$ acres. Worth 5 s.

\section{HUNDRET OF LOSA [LOEs]}

Framelingham [Framlingham] Ailmar the thegn held, now Roger Bigot holds (it); 9 carucates of land as a manor. Then 24 villeins, now 32. Then 16 bordars, now 28. Then 5 ploughs on the demesne, now 3. Then 20 ploughs belonging to the men, now 16 . Wood(land) for 100 swine. 16 acres of meadow. Then 2 rounceys, now 3 . Then 4 beasts, now 7. Then 40 swine, now 10. Then 20 sheep, now 40. Then as now 60 goats. Now 3 hives of bees. Then it was worth 16li, now 36 li.

In the same (vill) Monulf held by commendation half to Ailmar and half to Malet's predecessor I carucate and 40 acres of land as a manor. Then as now 4 villeins, and 12 bordars. And
2 ploughs on the demesne. And $2 \frac{1}{2}$ ploughs belonging to the men. Wood(land) for 100 swine. 6 acres of meadow. And 8 beasts, 20 swine, 60 sheep, 40 goats, and 4 hives of bees. Then as now worth 40 s. William Malet was seised.

And under him 6 whole freemen and 4 half (freemen) with 30 acres of land. Then as now I plough. An acre of meadow. And they are included in the 40 s. valuation.

In the same (vill) a freeman under commendation (held) 40 acres and a villein dwelling in ETHEREG [ ] and 3 bordars and 1 acre of meadow and I plough. Wood(land) for 4 swine. Worth 8 s.

In the same (vill) 3 freemen under commendation (held) 56 acres. Then as now 3 ploughs. And 2 acres of meadow. Wood(land) for 4 swine. Worth 17s. And a church with 60 acres and $I$ villein and 4 bordars and 2 ploughs. Worth 15s. It is 14 furlongs long, and 12 broad. And (pays) 20d. in geld. Saint Etheldreda has the soke; but Hugh's predecessor had it of her.

\section{fol. 303 .}

\section{LANDS OF COUNT EUSTACE}

\section{Risebruge [RISBRIDGE] Hundret}

At Uumsdana [Ousden] Leuric the thegn held 6 carucates as a manor T.R.E. Then 22 villeins, afterwards and now 15 . Then and afterwards 2 bordars, now 9. Then 8 serfs, now 2. Then and afterwards 4 ploughs on the demesne, now 2. Then 10 ploughs belonging to the men, afterwards 8 , now 6 . And $6 \frac{1}{2}$ acres of meadow. Wood(land) for 20 swine. Then 4 rounceys. Then 15 beasts, now 5 . Then 22 swine, now 30 . Then $\mathrm{I}_{4}$ sheep, now 88. A church with 30 acres of free land, and half a plough. Then worth $6 \mathrm{li}$., now $7 \mathrm{li}$. But it has been put (datum fuit) to farm for 14 li. It is 8 furlongs long, and 5 broad. And (pays) $6 \frac{1}{2} d$. in geld. Others hold (lands) therein.

\section{Thewardestree [Thedwastre] Hundret}

In RATESDANA [Rattlesden] a freeman under Saint Etheldreda by commendation and soke held T.R.E. 60 acres of land and this he could not sell. And now Heltret holds under Count Eustace, who appropriated (invasit) 7 acres of Saint Etheldreda's demesne in the same vill, (as belonging) to the fee of Count Eustace. Then as now I plough. And 4 acres of meadow. Worth ros.

\section{Lacforda [LAckford] Hundret}

In Heluedona [Elveden] Alsi held, and afterwards Ingelric, now Eustace (holds) two carucates 


\section{A HISTORY OF SUFFOLK}

of land as a manor. Then as now 3 villeins, and 3 bordars, and 2 serfs. Then and afterwards 2 ploughs on the demesne, now I. And I plough belonging to the men. And the fourth part of a fishery. A church with 15 acres of land. And 4 swine, and 150 sheep. Then it was worth 30 s., now 40 s.

\section{Stou (Stow) Hundret}

In Fineburga [(Little) Finborough ${ }^{\text {si }}$ ] Ingelric the predecessor of Count Eustace held T.R.E. $2 \frac{1}{2}$ carucates of land in the soke of the King and the Earl. 9 bordars then as now. Then and afterwards 6 serfs, now none. Then and afterwards 3 ploughs on the demesne, now 2. And 18 acres of meadow. Then I beast, now fol. $3 \circ 3^{b}$.

2 , and 8 swine. Then and afterwards (worth) 50 ., now roos.

In the same (vill) 7 freemen under the said Ingelric by commendation held 30 acres of land in the King's soke. Then and afterwards I plough. Their value is included in the roos. above.

In BuKesalla [Buxhall] Ingelric held $\mathrm{I} \frac{1}{2}$ carucates of land. Then as now 7 bordars. Then as now 2 ploughs on the demesne. And 2 sokemen with 4 acres. And 8 acres of meadow. And I beast. Then 30 sheep, now 40. Now II goats. Then and afterwards worth 40 s., now worth 4 li.

\section{SANFort [SAmFord] Hundret}

Heinham [Higham] Ledmar a freeman held I carucate of land for a manor T.R.E. Then as now 2 bordars and I plough on the demesne, and 6 acres of meadow. The fifth part of a church with 4 acres, and $24 \ldots$ Then worth IOs., now 20s. Ralph de Marci holds it of the Count. The soke is in Bercolt [Bergholt].

STANFELDA [

] Aluric a freeman

held I carucate and 15 acres of land for a manor. Now Hato holds it of the Count. Now 4 bordars, and I villein. Then as now I plough on the demesne, and I plough belonging to the men, and $1 \frac{1}{2}$ acres of meadow. Then worth 20s., now 4Os. The soke is in Bercolt [Bergholt].

In Reinduna [Raydon] Ulueru(n), a freewomen, held $\mathrm{I} 2$ acres T.R.E. Then half a plough. Included in the same valuation. The soke is in Bercolt [Bergholt].

${ }^{51}$ The Finborough which descended with Buxhall was Little Finborough, Feud. Aids, v, 64 . fol. 304 .

\section{LANDS OF ROBERT MALET IN SUFFOLK}

\section{Babenberga [Babergh] Hundret}

Eduardestuna [Edwardstone] Hubert holds of Robert Malet, and Godwin, Alfer's son, held it T.R.E. under the King with the soke as a manor ; 4 carucates of land. A church with 30 acres of free land. Then Io villeins, afterwards 9, now 6 . Then and afterwards 7 bordars, now 13. Then and afterwards 6 serfs, now 4. Then and afterwards 3 ploughs on the demesne, now 2. Then and afterwards 6 ploughs belonging to the men, now 3 . And 8 acres of meadow. Wood(land) for ro swine. A winter (byemale) mill. Then 2 horses at the hall, now I. Then 17 beasts, now 11 . Then 60 swine, now 37. Then 80 sheep, now 22. Then and afterwards it was worth 100s., now 7 li.

In the same (vill) 9 sokemen (held) half a carucate of land. Then and afterwards I plough, now half a plough. Valued above. This manor is 6 furlongs long, and 6 broad. And (pays) rod. in geld whoever be the tenant thereof.

Ciltona [Chilton] Walter son of Aubrey holds of the Earl (sic) and the said Godwin held it with the soke T.R.E.; 2 carucates of land as a manor. A church with 5 acres of free land. Then as now $I$ villein and 5 bordars. Then 4 serfs, now 1 . Then as now 2 ploughs on the demesne, and among the men. And 5 acres of meadow. Now 3 swine. Then 80 sheep, now 40.

And 3 freemen under the same Godwin, Robert's predecessor, by commendation and soke (held) 40 acres of land. Then as now I plough among them all. And $I$ acre of meadow. The freemen were then worth I2s., now 7s. The manor was then worth 20s., now 40s. It is 4 furlongs long, and 3 broad. And (pays) $5 d$. in geld, whoever be holder thereof.

\section{HUNDRET OF Stou [Stow]}

CRatinga [Creeting (St. Peter)] Robert de Glanville holds of Robert Malet, and Lewin a fol. $304 b$.

freeman under Edric the predecessor of Robert Malet held it by commendation only ; I carucate of land in the soke of the King and the Earl. Then as now 6 bordars. And then $1 \frac{1}{2}$ ploughs, afterwards half a plough, now 2 ploughs on the demesne. Then half a plough belonging to the men. 3 acres of meadow. And a fourth share of a mill. Then 2 horses, now none. Now 4 beasts. Now 14 swine. Now 43 sheep. And (there were) 6 freemen under the said Lewin by commendation only with $12 \frac{1}{2}$ acres. 


\section{THE HOLDERS OF LANDS}

Then as now half a plough among them all. And in the same (vill) was I sokeman under Edric with 20 acres. Then as now half a plough. Then and afterwards the entire holding was worth 20s., now worth 30 s.

\section{Half Hundred of Gepeswiz [Ipswich]}

In the borough Robert has I burgess whom his predecessor had by commendation T.R.E. The king has the customs.

\section{Bosemera [Bosmere] Hundret}

In Cratingrs [Creeting] a freeman under Edric by commendation (held) T.R.E. 20 acres and 2 bordars. And then half a plough, now 1 ox. And an acre of meadow. Worth 3 s. and 4d. Walter de Caen holds (it).

In the same (vill was) a freeman with $I \frac{1}{2}$ acres who was (by commendation) the man of one (himself) under commendation to Edric. Worth 2s. And Robert de Glanville (now) holds (it).

In the same (vill) a freeman under Edric (held) 8 acres. And (there was) one part of a weir (excluse). Worth 2s. Now Robert Malet holds (this) in demesne.

In Codenham [Coddenham] a freeman by commendation under Edric T.R.E. (held) Io acres. It was worth 20d. The said (Robert) (holds) in demesne.

In Ulebdana [Olden ${ }^{58}$ ] Walter de Caen (now) holds of Robert; a freeman under commendation (held) 6 acres. Worth $32 d$.

In the same (vill) a freeman under commendation (held) 5 acres. Worth rod. This Robert holds in demesne. The King and the Earl (have) the soke over the whole.

In Hamingestuna [Hemingstone] a freeman Etmar Leuric, predecessor of Robert Malet's fol. 305 .

mother, had by commendation T.R.E. 4 acres. Worth $8 d$. The King and the Earl (have) the soke. Robert's mother (now) holds.

In Stanham [Stonham] (was) a freeman Ailmar T.R.E. with 3 acres. Worth $6 d$.

\section{Hundret of Claindune [Claydon]}

In Bercham [Barham] Brictuold a freeman under commendation to Edric (held) 40 acres as a manor T.R.E. Worth $6 s$. and $8 d$. William Gulaffra now holds (this). The King and the Earl (have) soke.

In Depbenham [Debenham] Edric a freeman under commendation to Malet's predecessor held
I carucate of land as a manor in the Abbot's soke. Then as now I 6 bordars. And 2 ploughs on the demesne. Then 3 ploughs belonging to the men, now $I \frac{1}{2}$ loughs. 4 acres of meadow. Then wood(land) for sa swine, now 40. Then as now $I$ rouncey. Then 4 beasts, now 6 . Then 40 swine, now 20. Then 30 sheep, now 45. Then 40 goats, now 28. And there are 30 acres of demesne which are in another Hundred. Then it was worth 6os, now 50 . This William Gulafra holds. The soke is the Abbot's.

In the same (vill) 6 freemen under commendation to the aforesaid Edric (held) 36 acres. Then 2 ploughs, now I $\frac{1}{2}$ ploughs. And I acre of meadow. They were then worth IOs., now 6s. The soke is the Abbot's. The said William holds (them).

In the same (vill is) I carucate of land which Robert's mother holds of Robert Malet. Britmar a freeman held it as a berewick of (in) Chenetuna [Kenton] T.R.E. Then as now I villein. And 9 bordars. And 2 ploughs on the demesne. Then 3 ploughs belonging to the men, now 2 . And 4 acres of meadow. Then wood(land) for 100 swine, now for 40. This is included in the valuation of Chenetuna [Kenton].

In the same (vill) II $\frac{1}{2}$ freemen under commendation to Brictmar (held) 60 acres less one. Then 3 ploughs, now 2. And 2 acres of meadow. They were then worth 30s., now 20s. The soke is the Abbot's.

In the same (vill) Saxo the predecessor of Ranulph Peverel (piperellus) held 6 acres T.R.E. Now Robert's mother (holds them). And fol. $305^{b}$.

William Malet was seised thereof. And his predecessor in King William's time. Worth I $2 d$.

In the same (vill) are 2 acres. The whole (held) in the same manner. Worth $4 d$. The soke is the Abbot's.

In TORP [Thorpe ${ }^{53}$ ] Godwin a freeman under commendation held 16 acres T.R.E.; now Walter holds of Robert Malet. (This) was then worth $32 d$, now $3^{\text {s. }}$ This land is in Batingefelda [Bedingfield] Manor. The soke is the Abbot's.

In W ESTREFELDA [Westerfield] Ulviet a freeman under commendation to Gurth held 60 acres of land and they belong to (jacent in) Rissemera [Rushmere (St. Andrew)]. Now Humfrey holds of Robert Malet. Then I bordar. Worth Ios.

In the same (vill) 2 freemen under commendation to Ulviet (held) $6 \frac{1}{2}$ acres. Worth $2 s$. The same Humfrey (now holds). The soke is the Abbot's. 


\section{A HISTORY OF SUFFOLK}

In Winestuna [Winston] 2 freemen under commendation to one (who was himself) under commendation to Edric (held) 19 acres T.R.E. Then I plough, now half a plough. And an acre of meadow. And 2 bordars. Worth 4 s. William Gulafra (now holds). The soke is the Abbot's.

In Depbenham [Debenham] Ulviet a freeman under commendation to Edric held 10 acres. Then as now half a plough. Worth 2s. The same William (now holds). The soke is the Abbot's.

In Depbenhan [Debenham] half a freeman under commendation to one (himself) under commendation to Edric (held) 2 acres. Worth $4 d$.

In Henleia [Henley) a freeman under commendation to Stanwin held 3 acres under Harold. Worth $8 d$. Humfrey now holds. The soke is the Abbot's.

In Depbenham [Debenham] Robert has two parts of the church of St. Mary with 20 acres to answer for (ad defendendum), and the fourth part of the church of St. Andrew, and the fourth part of (its) land.

\section{In Manwic [}

] Sistric held 27 acres and could not sell his land. Then as now I plough. Worth 26s. and $8 d$. Goscelin ${ }^{54}$ now holds of Robert Malet. The Abbot (has) half the soke, and Earl Hugh the other moiety.

In the same (vill) a freeman under commendation (held) $13 \frac{1}{2}$ acres. Worth 5 s. Gilbert now (holds).

fol. 306 .

In Assefelda [Ashfield] 3 freemen under commendation (held) 15 acres. Then as now half a plough. It was worth 5s. The same Gilbert (now holds). The Abbot and Earl Hugh (have) the soke.

In TORp [Thorpe] a freeman under commendation (held) 3 acres. Worth rod. The soke (is held) in the same way. The same Gilbert (now holds).

In Assefenda [Ashfield] Turbern held 20 acres, and could not sell them. And this is included in the valuation of Saham [Soham]. The soke (is held) in the same way.

In TORP [Thorpe] a freeman under subcommendation (held) 5 acres. Then half a plough, now 2 oxen. Worth $16 d$. The Abbot of Ely has the soke. Tiger (now) holds.

"In 'Inaneuric tenet Gotselmus dominium abbatis;' Ing. El. 194. Cf. n. 50.
In Westrefelda [Westerfield] a freeman under commendation (holds) 10 acres. Worth 2s. The King and the Earl (have) the soke.

In ToRP [Thorpe] a freeman under subcommendation (held) 10 acres. Worth $20 d$. William Gulafra (now) holds. The Abbot (has) the soke.

\section{Sanfort [Samford] Hundret and a Half}

Godwin Alsies Sone, Queen Edith's thegn, held Belesteda [Belstead]; 2 carucates of land for a manor. Then as now 8 villeins, and 3 bordars. Then 2 ploughs on the demesne, now I. Then as now 4 ploughs belonging to the men. Io acres of meadow. Then I mill. Then 2 rounceys, now $\mathrm{I}$, and II swine. Then 100 sheep, now 30 . Then worth 4 li., now Ioos. The same Godwin (had) the soke. It is half a league long, and 4 furlongs broad, and pays $4 \frac{1}{2} d$. in geld.

The same Godwin held Brantham [Brantham]; I carucate and 20 acres of land for a manor, 3 bordars. Then 2 ploughs on the demesne, afterwards and now 1.2 acres of meadow. Worth 20s. The same Godwin (had) soke. Hubert holds it of Malet.

\section{Perreham [Parham] Half Hundret}

At BRUTGe [ ] Edric of Laxfield held 40 acres as a manor T.R.E. Then as now 1 plough. And 3 acres of meadow. The fourth part of a church with 6 acres. Now 6 beasts, 14 swine, 20 sheep, and 8 goats. Then worth I 4 s. and $8 d$. and the like now. Walter de Risboil holds of Robert. The soke (belongs) to the Abbot of Ely.

fol. $306 b$.

In the same (vill) 5 freemen (were) added (thereto) by commendation, in the Abbot's soke, (they held) 20 acres. The wife of one was under commendation to Norman. Worth 4 s. The same Walter (de Risboil) holds.

In Blachessala [Blaxhall] 6 freemen by commendation (held) 6r acres; (they are) in the Abbot's soke. Then as now 2 ploughs. Worth Ios. Gilbert holds.

In the same (vill) 3 freemen under commendation (held) 30 acres. Then I plough. 2 acres of meadow. Worth 5s. The soke (is) the Abbot's.

In Wantesdana [Wantisden] (are) 22 freemen under commendation; (they are) in the Abbot's soke. (There is) half a church with 20 acres of free land. (There are) 121 acres. Then and afterwards Io ploughs, now 5. And I serf. Then as now worth 30 s. Of them 


\section{THE HOLDERS OF LANDS}

Hubert holds $5 \frac{1}{2}$ and Gilbert $4 \frac{1}{2}$ and Gilbert de Wiscant 7 and William de Malavilla 5. It is 8 furlongs long and 6 broad. And (pays) $40 d$. in geld.

In the same (vill are) I 6 acres of the demesne of Staurrstuna [Staverton] and (included) in the same valuation.

In Perreham [Parham] (are) 40 acres of the demesne of Nuietuna [Newton ?] and they are worth $6 s$. and $8 d$.

In the same (vill) 2 freemen under commendation, in the Abbot's soke, (held) 12 acres. Worth 2s.

In the same (vill) Alnod a freeman under commendation to Edric (held) a carucate of land as a manor T.R.E. Then 4 villeins, now 2. Then and afterwards $I$ (plough) on the demesne, now none. Then and afterwards I plough belonging to the men, now half a plough. 3 acres of meadow. To the church (belong) 24 acres of free land. Then as now worth 30 . Walter son of Aubrey (holds) of Robert.

In the same (vill) Blacchesune a freeman under commendation (held) 40 acres as a manor T.R.E. Then as now half a plough. Then worth 6 s. and $8 d$., now 7 s. The same Walter holds.

In the same (vill) Ernulf a freeman under commendation held 40 (acres) as a manor. Then as now half a plough. An acre of meadow. Worth 7s.

In the same (vill) Alnot a freeman under commendation held 30 acres. Then as now half a plough. And I acre of meadow. Worth 5s.

In the same (vill) 2 freemen under commendation (held) 40 acres. Then as now I plough. And 1 acre of meadow. Worth 75. The said Walter (holds) of Robert. The soke is the Abbot of Ely's.

fol. 307 .

In Blaccheshala [Blaxhall] 2 freemen (held) 14 acres. One was entirely and one was half under sub-commendation (unus et dimidius fuit sub-commendatus) to the Abbot of Ely and half under sub-commendation to Malet's predecessor. Then as now half a plough. Worth $28 d$. William de Smalavilla holds of Robert.

In the same (vill) a freeman (held) 3 acres under sub-commendation to Edric. Worth $6 d$. The same William (holds). The soke is the Abbot's.

In Bracchrssala [Blaxhall] a freeman under sub-commendation to Edric (held) 10 acres. Worth $3^{\text {s. }}$ Gilbert (holds) of Malet. The soke is the Abbot's.

In the same (vill is) a freeman under subcommendation half to his (Malet's) predecessor and half to the Abbot, and as to (ex) this moiety he came to an agreement (est conciliatus) with the
Abbot; and he has 12 acres. Then as now half a plough. Worth 2s. The same Gilbert (holds).

In the same (vill) a freeman by commendation (holds) I acre. Worth $2 d$.

In the same (vill) 2 freemen one (wholly) and (the other) half under sub-commendation to Edric and half under the Abbot held 8 acres. Worth $16 d$. The same Gilbert (holds).

In Perreham [Parham] a freeman by commendation (held) 12 acres. Worth 2s. The same Gilbert (holds). The soke is the Abbot's.

In Tunestal [Tunstall] Godric a freeman held by commendation half to Edric and half to the Abbot 4 acres. Worth 8d. The same Gilbert (holds).

In Brachessala [Blaxhall] Gilbert holds of Robert Malet 3 freemen (formerly) under subcommendation to Edric (with) 6 acres. Worth 12d. The soke is the Abbot's.

In Wantesdana [Wantisden] 2 freemen, Alwin and Alflet, uncer sub-commendation to Malet's predecessor (held) 7 acres. Worth I $4 d$. The fourth part of a church with Io acres.

In Biachessala [Blaxhall] Hune a freeman (held) under sub-commendation to Malet's predecessor 12 acres. Worth 2s. Ranulf holds of Malet. The soke belongs to the Abbot of Ely.

In Wantesdana [Wantisden] Aluric a freeman held 4 acres. Worth $8 d$. Gilbert holds.

fol. 3076 .

In Blachessala [Blaxhall] (are) 16 acres of the demesne of Cheletuna [ ] ${ }^{55}$ Worth 25d. The soke is the Abbot's.

\section{Plusmesgata [Plomesgate] Hundret}

(At) Chiletuna [ $]^{56}$ Edric held T.R.E. 4 carucates of land and 20 acres as a manor. Then as now ro villeins, and 10 bordars. Then 3 serfs. Then and afterwards 3 ploughs on the demesne, now 2. Then and afterwards 5 ploughs belonging to the men, now 4. And ro acres of meadow. Then as now I mill. Then 12 beasts, now 2. Then 30 swine, now 14. Then 100 sheep, now 50. And I sokeman (with) 80 acres and 2 bordars. Then and afterwards 2 ploughs, now I $\frac{1}{2}$ ploughs. Then it was worth $8 l i$, now gli. and ros.

s5 This is presumably the same as the 'Chiletuna' of the next entry and the 'Keletuna' mentioned on fol. 327. Copinger (Suff. Rec.) gives a 'Kelton,' apparently near Harpole, as a member of the honour of Eye.

to See last note. 


\section{A HISTORY OF SUFFOLK}

In the same (vill were) $16 \frac{1}{2}$ freemen by commendation only, and these have been added to this manor with 153 acres. Then and afterwards 8 ploughs, now $3 \frac{1}{2}$ ploughs. Then it

"was worth 30s., now 20s. It is 9 furlongs long, and 4 broad. And pays $2 \frac{1}{4} d$. in geld. Robert (holds this) in demesne.

In Rimdham [Rendham] are I carucate and 69 acres of land as a berewick to this manor. Then as now 3 villeins, and 2 bordars. Then and afterwards 2 serfs, now $I$. Then as now 2 ploughs on the demesne. And then $1 \frac{1}{2}$ ploughs belonging to the men, now I plough. And 6 acres of meadow. Then wood(land) for 40 swine, now for 30 . And I rouncey, 24 swine, 18 sheep, and 30 goats. Worth 3 li, and Ios.

A church with 24 acres and I plough.

To this manor have been added I 3 freemen with 80 acres. Then 2 ploughs, now 1. And 3 acres of meadow. It is worth 20 s.

This Robert holds of Malet.

It is I league long, and 7 furlongs broad. And (pays) $20 d$. in a geld. The soke (is) the Abbot's.

In CRANefort [Cransford] Cus a freeman under commendation to Edric T.R.E. (held) 90 acres as a manor. Then as now 9 bordars. fol. 308 .

Then and afterwards 2 ploughs on the demesne, now I plough. Then as now I plough belonging to the men. And 4 acres of meadow. Now 16 swine. Then 13 sheep, now 30 . Then 16 goats. Then it was worth 20 s., now 25 s. Walter holds of Malet.

To this manor have been added 2 freemen with 14 acres and half a plough, worth $3^{\text {s. The }}$ same Walter holds. The soke (is) the Abbot's.

In Gliemham [Glemham] a freeman, Hune, half under sub-commendation to the Abbot of Ely and half to his (Malet's) predecessor (held) 30 acres as a manor. Then I plough, afterwards and now half a plough. Worth 75 . The said Walter holds. The soke (is) the Abbot's.

In the same (vill) Sparhavoc a freeman under commendation to Edric held 60 acres as a manor T.R.E. and 2 bordars. Then and afterwards $I \frac{1}{2}$ ploughs, now I plough. Worth ros. The said Walter holds. The soke (is) the Abbot's.

In the same (vill) 2 freemen (hold) 3 acres, worth $8 d$. The same Walter holds.

In Sueflinga [Swefling] a freeman, Osbern, under commendation to Edric (held) 60 acres as a manor T.R.E. Then 2 ploughs, afterwards and now $1 \frac{1}{2}$ ploughs. Then it was worth 20 s. and now 20 .

Robert de Claville holds of Robert.

In the same (vill) a freeman Brictnot by commendation held 5 acres, worth Iod. Robert son of Fulchered holds.
In the same (vill) Ailwi under commendation to (Robert's) predecessor (held) 60 acres as a manor T.R.E. Then I plough. And 4 acres of meadow. Then it was worth ros, now $5^{\text {s. }}$ The said Robert holds. The soke (is) the Abbot's.

In the same (vill) I I freemen (held) 90 acres, and they were under commendation to Malet's predecessor except one who was under commendation to Roger Bigot's predecessor, Harvin by fol. $308 b$.

name. Then and afterwards 3 ploughs, now $\mathrm{I} \frac{1}{2}$ ploughs. And 4 acres of meadow. A church with 15 acres. Then it was worth IOs., now 6s. The same Robert (holds). The soke (is) the Abbot's.

In Benenhala [Benhall] 6 freemen (held) 80 acres under commendation to Malet's predecessor. Then and afterwards 3 ploughs, now 2. The same Robert (holds). 'The soke (is) the Abbot's. Then it was worth 20s., now 30s. It is 8 furlongs long, and 6 broad. And (pays) $9 \frac{1}{4} d$. in geld.

In Straffort [Stratford (St. Andrew)] Hune a freeman under commendation to Edric held 80 acres as a manor. Then as now I plough. And 5 bordars. And half a plough belonging to the men. And 4 acres of meadow. Then I rouncey. Now 2 beasts. Then 12 swine, now 15. Then 16 sheep, now 30 , and 27 goats. Then it was worth 20s., now 25s. The same Robert (holds).

In the same (vill) $\mathrm{I} \frac{1}{2}$ freemen, Alwin (?), (held) 14 acres. Then as now half a plough. It was

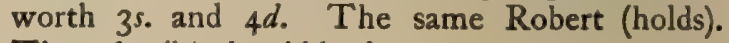
The soke (is) the Abbot's.

In Gliemham [Glemham] Ulmar a freeman under commendation to Malet's predecessor (held) 100 acres. And 5 bordars. Then as now I plough on the demesne. And I plough belonging to the men. A church with 10 acres, and $\mathrm{I}$ acre of meadow. Then I rouncey. Then it was worth 20s., and now (the same). The same Robert (holds) in like manner.

In the same (vill) 2 freemen under commendation to Leuric (held) $4 \mathrm{I}$ acres as a manor T.R.E. Then and afterwards I plough, now I ox. And I acre of meadow. Worth IOs. The same Robert (holds).

In the same (vill) 2 freemen (held) $I_{\frac{1}{2}}$ acres. Worth 26d. The soke (is) the Abbot's. The same Robert (holds).

In the same (vill) a freeman (held) 5 acres. Worth rod. The soke (is) the Abbot's. The same Robert (holds).

In Faraham [Farnham] 2 freemen under commendation (held) 40 acres, and in GliemhaN [Glemham] 2 freemen (held) 26 acres and 1 ? 


\section{THE HOLDERS OF LANDS}

ploughs. And 6 acres of meadow. And 2 bordars. Worth 21s, Robert holds of Malet.

In Gliemham [Glemham] Alwen a freeman (held) I 5 acres worth 2s. Robert de Glanville holds. The soke (is) the Abbot's.

fol. 309 .

In CRenefort [Cransford] a freeman by commendation (held) I 5 acres, and half a plough. It was worth 2s. Gilbert holds (this). The soke (is) the Abbot's.

In Benhalla [Benhall] 2 freemen (hold) 20 acres and I plough. Worth 5s. Hubert (holds) of Malet. 'The soke (is) the Abbot's.

In Benhala [Benhall] 4 freemen under commendation (held) 8 acres. Worth $16 d$. (This is) in demesne. The soke (is) the Abbot's.

In the same (vill) a freeman under commendation (held) $1 \frac{1}{2}$ acres. Worth $6 d$. Robert de Glanville (holds). The soke (is) the Abbot's.

In the same (vill) 3 freemen under commendation (held) 17 acres and half a plough. Worth 36d. (This is) in demesne.

In CRaneforda [Cransford] (are) 30 acres of the demesne land of HADINCHAM [? Badingham]. Worth 5s. Robert (holds) of Malet. The soke (is) the Abbot's.

In Gliemham [Glemham] a freeman under commendation (held) 6 acres, worth $12 d$. (This is) in demesne. The soke (is) the Abbot's.

\section{HuNdRET OF HeRtesmera [HARTISMERE]}

(At) WiUertestuna [Wyverstone] Alwin a freeman under commendation to Edric-and his wife was under commendation to the Abbot of St. Edmund's-held T.R.E. Ioo acres as a manor, now Hubert holds it of Robert. Then as now 2 bordars. Then I serf. Then 2 ploughs, afterwards 1 , now $1 \frac{1}{2}$. And 3 acres of meadow. Then as now wood(land) for 20 swine. Now I rouncey. Then 2 beasts, now 3. Then 15 swine, now IO. And 24 goats. Worth 20s, The King and the Earl have the soke.

In the same (vill certain) freemen, viz., three brothers and their mother, held 30 acres as a manor. One of them, Aluric, for the sixth part of his holding was under commendation to Malet's predecessor, and Achi, predecessor of Robert Blund, had five parts of the commendation over him. On this land was then and afterwards half a plough, now none. Worth 5s. The King and the Earl (have) the soke. Hubert (holds) of Malet.

fol. $3 \circ 9 b$.

I In the same (vill) a freeman half under com- mendation to the Abbot and half under sub-commendation to Malet's predecessor (held) 16 acres of land. Then as now half a plough. Worth 35. The same Hubert (holds). The King and the Earl (have) the soke.

In the same (vill) a freewoman Alflet under sub-commendation to Malet's predecessor (had) 3 acres. Worth $6 d$. The said Hubert holds.

In the same (vill) a freeman under sub-commendation (held) 3 acres. Worth $6 d$.

(At) WESTORP [Westhorpe]-Hubert holds of Robert Malet-a freeman Leuric under commendation to Edric of Laxafella [Laxfield] (held) 42 acres T.R.E. Then as now 3 bordars. And I plough. Wood(land) for 8 swine. I $\frac{1}{2}$ acres of meadow. Then worth IOs., now 30 s. And under him 4 freemen (held) 12 acres. Then as now half a plough. And they are included in the same valuation.

In Finningaham [Finningham] a freeman (held) 3 acres, and he could not sell his land; and (there was) another half freeman with 5 acres and $I$ bordar. And they are included in the same valuation. The King and the Earl have the soke.

Moreover in WEsToR [Westhorpe] 4 freemen under commendation to Edric (held) 28 acres. Then as now I plough. I acre of meadow. Then worth 4 s., now 5 s.

In the same (vill) a freeman under commendation to the same (Edric) (held) 7 acres. Worth 14d. He could not sell his land.

In Codetuna [Cotton] a freeman under commendation to Edric (held) 20 acres. Then as now I plough. Wood(land) for 4 swine. Half an acre of meadow. Then worth $40 d$., now 5s. And under him 3 freemen (held) 5 acres. Worth Iod. (nummos).

In the same (vill) a freeman under the said (Edric's) commendation (held) 7 acres and half a plough. Wood(land) for 2 swine. Worth I 4 .

All this is worth 21 s.

In Rikingahala [Rickinghall] Britfleda a freewoman under Edric of Laxafella [Laxfield] held a carucate of land and 30 acres T.R.E. Then as now I villein, and 4 bordars, and I serf. On the demesne 2 ploughs. And half a plough belonging to the men. Wood(land) for 8 swine. 2 acres of meadow. And 4 rounceys, 6 beasts, 20 swine, 60 sheep, and 16 goats. Then worth 20s., now 60s. The King and the Earl (have) the soke.

In the same (vill) 2 freemen under commendation to Saint Edmund (hold) $5 \frac{1}{2}$ acres, worth fol. 310 .

I2d. This Hubert holds of Robert Malet. 


\section{A HISTORY OF SUFFOLK}

In Brom [Brome] (are) 6 acres. Worth $\mathbf{I} 2 d$. In the same (vill) 3 half freemen (held) 7 acres. Worth $14 d$. This William Scutet holds of Robert Malet.

In BRoM [Brome] Warin (Guarinus) holds of Robert Malet 30 acres (which) a freeman Ulmar under commendation to Edric (held). Then as now $I$ plough. $\quad I \frac{1}{2}$ acres of meadow. Then as now worth 5s. And 5 freemen under Edric's commendation (held) 14 acres, and were worth 2s. This the same Warin holds of Robert.

In ACrE [Oakley] William Gulafra holds of Robert Malet 30 acres (which) a freeman Godman under the said Edric's commendation (held), and (there were) 2 freemen with half an acre. Then as now half a plough. $\quad \mathrm{I} \frac{1}{2}$ acres of meadow. I mill. Then as now worth IOS.

And in Thraudestuna [Thrandeston] the same Godman holds 16 acres, worth 2s. This William Gulafra holds of Robert Malet. A church with 6 acres worth I2d.

In Strandestuna [Thrandeston] William de Caen holds of Robert Malet 5 acres (which) a freeman under commendation to Edric T.R.E. (held), worth 12d. The King and the Earl (have) the soke.

In the same (vill) Hugh holds of Robert Malet 9 acres, worth $12 d$.

\section{Biscopes [Bishop's] Hundret}

In Badingafelda [Bedingfield] a freeman under Edric by commendation (had) 20 acres and 3 bordars and half a plough. Wood(land) for 10 swine. Worth 5 s.

In CARLETUNa [Carlton] Edric held 80 acres as a manor. One villein, and 5 bordars. And I plough. And I acre of meadow.

In the same (vill) 10 freemen (had) 160 acres of land less 2, and 3 ploughs. The whole is (included) in the valuation of Leistuna [Leiston]. The soke (is) in Keleshala [Kelsale] Roger Bigot's manor.

In Alrincham [Aldringham] (are) 7 villeins and $I$ bordar. (Included) in the valuation of Leestuna [Leiston]. And they have 90 acres. The soke (is) the Bishop's in Hoxa [Hoxne].

In Denham (Denham] (is) I sokeman with all customs with 50 acres of demesne land. (This is included) in the valuation of Heia [Eye]. Then as now I bordar. And I plough. And I acre of meadow.

\section{fol. 3 I 06 .}

In the same (vill are) 4 freemen under commendation (having) 30 acres and half a plough. Worth 5s. The soke (is) the Bishop's.
In Menham [Mendham] (is) I sokeman (having) ro acres and half an acre of meadow. Worth 24d. The soke (is) the Bishop's.

In Kereshalla [Kelsale] (is) I freeman under commendation, and he has 30 acres and I bordar. Then I plough, now half a plough. Worth 5 . Roger Bigot (has) the soke.

In Alrincham [Aldringham] I freeman by commendation and by fold-soke and other services (held) 20 acres and half a plough. Worth 4 od.

In Badingafelda [Bedingfield] 6 freemen under commendation (had) 80 acres. Then as now 2 ploughs. Then worth ros., now 15 s. The fourth part of a church with 6 acres.

\section{LAND OF ROBERT MALET'S MOTHER HELD OF THE QUEEN'S FEE}

In BADINGAFELDA [Bedingfield] (were) 3 freemen under commendation to Stigand (having) 44 acres and $\mathrm{I}$ bordar. Wood(land) for 20 swine. And I acre of meadow. Worth 5s. The Bishop (has) the soke.

In the same (vill) in BADINGAFELDA [Bedingfield] were 2 freemen under commendation to Stigand (having) 26 acres of land. Wood(land) for 6 swine. Then as now I plough. Worth 4 s. The soke (is) the Bishop's.

\section{Blidinga [Blything] Hundret}

In DERSAM [Darsham] Edric a freeman held T.R.E. 94 acres as a manor. Then as now 4 bordars. Then 2 ploughs, now $1 \frac{1}{2}$. And 2 acres of meadow. Worth $12 s$. and $8 d$. And under him 6 freemen under commendation (held) 36 acres. Then as now I plough. Worth 6 s.

In ForLeA [Fordley ${ }^{57}$ ] the said Edric held 60 acres and 3 bordars and $1 \frac{1}{2}$ ploughs and 4 acres of meadow and a mill. Worth ros. And under him 6 freemen under commendation (held) 26 acres and I plough. Worth $4^{5}$.

This Edric was under commendation to Edric of Laxfield, Robert Malet's predecessor, before King Edward died. Afterwards Edric became an outlaw (udlagavit); King Edward seized all his land; afterwards he was reconciled to King Edward ; and he granted him back his land. $\mathrm{He}$ gave him, too, a sealed charter (breve et sigillum) that whosoever of his freemen under commendation might choose to return to him, by his grant they might return; th s Edric King Edward seized into his hand; afterwards the Hundred saw no sign that he returned to Edric his lord;

$$
{ }^{87} \text { In Midaleton. }
$$




\section{THE HOLDERS OF LANDS}

but he himself says, and offers proof by ordeal (judicium) that he did return: and he holds the freemen whom he has by commendation under him, and as to them (ex eis) he vouches Robert to warrant.

Huntingafelda [Huntingfield] Edric of Laxfield T.R.E. held, and now Walter, son of Aubrey, holds, under Robert Malet. Then as now 6 carucates of land. And then and afterwards 18 villeins, now 12 . Then as now 28 bordars. Then I serf. Then as now 4 ploughs on the demesne. Then as now 18 ploughs belonging to the men. Then wood(land) for 150 swine, now for 100. And 15 acres of meadow. Then as now 2 rounceys. And 10 non-working (otiosa) beasts, 30 swine, roo sheep, 60 goats, and 6 hives of bees. Then it was worth 8li., and now 7 li. A church with 14 acres worth $2 s$.

In LINESTEDE [Linstead] as a manor Wluric a freeman T.R.E. held 60 acres of land (which) now Walter holds under Robert Malet. 6 bordars. 2 ploughs on the demesne. And $x$ plough belonging to the men. Then wood(land) for 30 swine, now for 20. 2 acres of meadow. And 1 rouncey, 4 beasts, 20 swine, 30 sheep, 20 goats. T.R.E. it was worth 20 s, now 30 s. And moreover to this manor of HUNTINGAFELDE [Huntingfield] are now attached 200 acres of land, which $2 \mathrm{I}$ freemen held T.R.E. Then as now ro ploughs. And under them 2 bordars. Wood(land) for 20 swine. 2 acres of meadow. Then as now it was worth 40s. And this land is I league long and 9 furlongs broad. And renders $7 \frac{1}{2} d$. in the King's geld. And moreover to this manor are attached in Huntingafelda [Huntingfield] 40 acres of land which 4 freemen held. Then 2 ploughs, now 1 . And they have I bordar. Worth 8s.

And over all this land of the freemen the sac and soke belongs to (jacet in) BLIDEBURH [Blythburgh] to the use of the King and the Earl. And over all these men Edric, Robert Malet's predecessor, had commendation.

Edric of Lessafelda [Laxfield] held Lehtuna [Leiston] as a manor and as 12 carucates of land. fol. $311 b$.

Then as now 25 villeins, and 27 bordars. Then 3 serfs, now 7. Then on the demesne II ploughs, and now 7. Then 6 ploughs belonging to the men, and now $3 \frac{1}{2}$. Then wood(land) for 500 (swine), afterwards (and) now for 200. Then as now a mill. 5 acres of meadow. And 4 rounceys, 5 beasts, 72 swine, 112 sheep, 7 hives of bees, and 1 pig. And 3 churches with 100 acres of free land. T.R.E. worth $16 \%$. and afterwards worth $28 \mathrm{li}$, and the like now. It is 3 leagues long, and 2 leagues and 1 furlong broad. And renders $3^{\text {s. and }} 3$ half-pence in the King's geld.
And in the same vill is a freeman with 40 acres, and he holds them as a manor. It is worth 6 s.; but they are part of the $28 \%$, aforesaid.

And moreover to this manor are attached (jacent) 47 freemen with 7 carucates of land. Then 8 ploughs, now $6 \frac{1}{2}$ ploughs. Then as now it was worth 4 li.

In the same vill Gilbert holds 7 score acres under Robert Malet, which Edric held as a manor. Then 4 bordars, and 2 villeins. Then as now 2 ploughs on the demesne. And half a plough belonging to the men. Now I rouncey, and 2 beasts. Then as now it was worth 20 s.

In the same vill (are) 8 freemen with $\mathrm{I} \frac{1}{2}$ carucates of land. Then 3 ploughs on the demesne, now 2. And I acre of meadow. Then as now it was worth 30 s. This land Fulchred holds of Robert Malet.

Edric of Laxfield held Duneuuic [Dunwich] T.R.E. as a manor, and now Robert Malet holds it. Then 2 carucates of land, now $\mathbf{I}$. The sea carried away the other. Then as now I plough on the demesne. Then 12 bordars, now 2. And 24 Frenchmen (franci) with 40 acres of land, and they render all customs to this manor. And then I 20 burgesses, and now 236. And 180 poor men less 2. Then I church, now 3 ; and they render $4 l i$. and IOs. And altogether it is worth $50 l i$, and 60,000 herrings fol. 312 .

by way of gift. And T.R.E. it rendered roli.

And moreover Robert de Vallibus holds I acre of land, worth $8 d$. And Norman holds I acre, worth 2s. and 8d. And Godric I acre, worth 8d. And this they hold of Robert Malet. And Gilbert Blund holds of the same Robert four score men, (who) render 4 li. and 8,000 herrings.

At Westlentuna [Westleton] Aki a freeman held as a manor 4 carucates of land. Then as now 13 villeins. Then as now $\mathrm{I}_{4}$ bordars. Then 4 serfs, now 2. Then 3 ploughs on the demesne, now none. Then ro ploughs belonging to the men, now 5. Wood(land) for 7 swine. 3 acres of meadow. 3 beasts, 20 swine, 60 sheep. Then as now 24 goats. 2 hives of bees. Then worth roos., now the like. And I church with 20 acres, worth $40 d$. To this manor are attached $14 \frac{1}{2}$ freemen with $103 \frac{1}{2}$ acres. Then 6 ploughs, now 3. Then as now worth 20 s. It is 2 leagues and 2 furlongs long, and 2 leagues broad. It (pays) $7 \frac{1}{2} d$. in geld. This Gilbert Blund holds of Robert Malet.

In Middeltuna [Middleton] 2 freemen held four score acres, now Gilbert Blund holds of Robert Malet. Then as now I bordar. Now half a plough, 2 acres of meadow. Then as now worth 16 s. 


\section{A HISTORY OF SUFFOLK}

In Stikingalande [Stickingland ${ }^{68}$ ] Edric a freeman held 40 acres. Then as now I bordar. Then I plough, now none. It was worth $6 s$. and $8 d$. This Gilbert Blund holds of Robert Malet.

In FORLE [Fordley] 2 freemen held 24 acres T.R.E. ; now the said Gilbert (holds) of Robert Malet. Then on the demesne half a plough, now none. Then worth IOS., now 4 s.

The King has in Duneuurc [Dunwich] the custom following, that two or three shall go to the Hundred (court) if they shall have been duly warned. And if they do not do this they shall make forfeiture of 2 ores. And if a thief be there caught, there he shall be brought to trial, and he shall suffer corporal punishment in Blieburc [Blythburgh], and his property (pecunia) shall remain to the lord of Duneuuic [Dunwich]. And fol. $312 b$.

T.R.E. there was no exchanger (cambitor) therein, but at Blideburh [Blythburgh].

In Sibbetuna [Sibton] a freeman held 25 acres T.R.E. as a manor. Now Walter de Caen holds of Robert Malet. Then as now I bordar. Then as now half a plough on the demesne. I acre of meadow. Then as now it was worth $4 \mathrm{~s}$. And I church.

In the same vill a freeman held I carucate and 20 acres of land as a manor. Then as now 4 villeins and Io bordars. Then as now 2 ploughs on the demesne. And 2 ploughs belonging to the men. Wood(land) for 60 swine. 4 acres of meadow. Then as now 2 rounceys, and 7 beasts. Then 30 swine, now 26. Then 50 goats. Now 50 sheep. Then it was worth 20 s., now 40s. This Walter de Caen holds of Robert Malet.

In the same vill a freeman held 25 acres T.R.E. as a manor. Then as now 3 bordars. Then as now half a plough. I acre of meadow. Then as now 1 rouncey. Then 6 swine, now none. Then as now it was worth $4 s$. And this Walter de Caen holds of Malet.

In the same vill Edric held 16 acres of land. Then as now I bordar. Wood(land) for 12 swine. 2 acres of meadow. Worthe 3 s.

In the same vill Aluric held 60 acres T.R.E. as a manor. Then as now 2 bordars. Then as now 2 ploughs on the demesne. I acre of meadow. Then I rouncey, now none. 3 score and 13 sheep. And 6 goats. Then it was worth Ios., now I6s. This Walter de Caen holds of Malet.

In the same vill $3 \frac{1}{2}$ freemen held 72 acres. I bordar. Then as now I plough on the demesne. I acre of meadow. Then as now worth IOS. It is $\mathrm{I} \frac{1}{2}$ leagues long, and I league broad.
And renders in geld $7 \frac{1}{2} d$. Two churches with 18 acres and 3 acres of meadow.

In UURABRETUNa [ ]$^{59}$ T.R.E. Amod a freewoman held 30 acres of land over which Norman the Sheriff had commendation. 2 bordars. 2 acres of meadow. Worth 4s. And now Robert Malet holds this. And Roger Bigot claims it.

In Pisemalla [Peasenhall] T.R.E. Leofsi a freeman held 40 acres of land as a manor. Now Fulchred holds of Malet. Then as now 4 bordars. Wood(land) for ro swine. And I plough.

fol. 313 .

And I acre of meadow. Worth 8s. The King and the Earl have the soke.

In the same (vill) a freeman Stanwin T.R.E. (held) I carucate of land as a manor. Now Fulchred holds. This Stanwin was under commendation to Edric Robert's predecessor before he became an outlaw ; afterwards he was Harold's man on the day on which King Edward was alive and dead ; so the Hundred says. Only Stanwin says that he was Edric's man by Harold's grant on the day on which King Edward died; and offers proof by ordeal (judicium). There are 2 bordars. Then as now I plough on the demesne. And I plough belonging to the men. And I acre of meadow. Wood(land) for 20 swine. And 2 beasts. And then 6 swine now 12. Now 26 sheep. Then it was worth 12s., now $22 \mathrm{~s}$. Harold had the soke, and Stanwin (had it) of him. And in King William's time Stanwin added 2 freemen under commendation with 8 acres, worth $16 d$. The same Stanwin had the soke of Harold.

In the same (vill was) a freeman Ailmar under commendation to Edric with 12 acres and half a plough. Worth 2s. The King and the Earl have the soke. Gilbert holds of Malet.

In Sibbetuna [Sibton] Blakeman, a freeman, held T.R.E. 50 acres as a manor. Then as now 2 bordars. Then as now I plough on the demesne. I acre of meadow. I rouncey. 16 sheep. Then as now it was worth IOs. And Blaceman was Edric's man: and he had commendation over him : and the King (had) the soke : but the wife of this man was Bishop Stigand's 'man' : and he had commendation over the woman: and William Malet held this land.

In the same vill 2 freemen held 32 acres of land. Then as now I bordar. Then as now I plough on the demesne. Half an acre of meadow. Worth 4s. This Walter de Caen holds of Robert Malet.

In Dersam [Darsham] a freeman, Blacheman, under commendation to Edric T.R.E. (held) 30

${ }^{58}$ In Yoxford; see Cal. of Chart. in B.M. 


\section{THE HOLDERS OF LANDS}

acres as a manor. Now Walter son of Richer (holds it). Then as now I bordar. Then I plough, now half a plough. And 2 acres of fol. $3^{1} 3^{b}$.

meadow. It was worth IOs. To this manor was added I freeman with 22 acres, over whom that same Blacheman had commendation T.R.E. Then as now half a plough. Worth 4 s. and $4 d$. The King and the Earl have the soke.

In DERsam [Darsham] Edric held 60 acres as a manor T.R.E. Now Fulchred (holds it). Then I plough. And 2 acres of meadow. Then it was worth 8 s., now 10 s. The King and the Earl have the soke.

In WESLETUNA [Westleton] a freeman under commendation (held) 30 acres as a manor. Now the same Fulchred (holds it). A church with 3 acres. Then and afterwards I plough, now none. And I acre of meadow. Then it was worth $8 s_{.}$, and when Robert received it it was at farm for 20s., now it renders 8s. The King and the Earl have the soke.

In Coua [Cove] Edric holds of Robert Malet 2 freemen under commendation to Edric, who was under commendation to Edric, Robert Malet's predecessor. And they have 16 acres. Then as now half a plough. Worth $3^{\text {s. }}$

(At) Stichinghrlanda [Stickingland] ${ }^{60}$ the same aforesaid Stanwin held 80 acres as a manor T.R.E. Now Walter de Caen (holds it). Then as now 2 bordars. Then I plough, now half a plough. And I acre of meadow. Then it was worth Ios., now 8s. The King and the Earl (have) the soke.

In the same (vill was) a half freeman under commendation with 8 acres. Worth $12 d$.

In the same (vill) Talcha a freeman under commendation T.R.E. (held) IO acres. Worth $20 d$.

In WARABETUNA [ $\quad]^{61} 2$ freemen under commendation (had) 9 acres, worth $18 d$. All this Walter de Caen (now) holds. The King and the Earl (have) the soke.

In Hoppetuna [ $]^{62}$ a freeman under commendation (? to) Alnot (held) 42 acres as a manor T.R.E. Now Gilbert holds it. Then as now 2 bordars. Then I plough, and now the like. And 2 acres of meadow. Then it was worth Ios., and (the same) now.

In the same (vill) 2 freeman under commendation (had) 18 acres. Worth 3 s. The King and the Earl (have) the soke.

$$
\begin{aligned}
& \text { "In Yoxford. "See n. 24. } \\
& \text { " Occurs below, fol. 333b, as 'Opituna.' }
\end{aligned}
$$

fol. 3 I 4 .

In DERSAM [Darsham] a freeman under commendation (had) 4 acres. Worth $8 d$. This is (now) in demesne.

In Holetuna [Holton] Edric held 20 acres as a manor. Now Robert (holds it) in demesne. Worth 3s. and 4d. The King and the Earl (have) the soke.

In Pesehala [Peasenhall] a freeman under commendation (had) 6 acres. Worth $8 d$. Walter de Caen (now holds).

In LINESTEDA [Linstead] are 8 acres, which are attached to WERESDEL [Withersdale] (in Bishop's Hundred) and (included) in its valuation.

In Westetuna [Westleton] (is) a villein (with) 6 acres. Gilbert Blund holds (this). (This) has been valued (above).

In Forlea [Fordley] (were) $3 \frac{1}{2}$ freemen. Swarting and Algar and Herewold, and Osfert the half, and they were under commendation to Edric. Osfert was wholly Toli's man. And they have 27 acres of land. Then as now I plough. 2 acres of meadow. Included in the valuation of Ledestuna [Leiston]. The King and the Earl (have) the soke.

In Mensemara [Minsmer] (are) 12 acres of free land. Worth I2d. The King and the Earl (have) the soke.

In the same (vill are) 2 freemen with 8 acres, worth $12 d$.

In the same (vill) moreover (are) 12 acres which Leuric Coc holds, worth $12 d$. Over all (these holdings) the King and the Earl (have) the soke.

In Wrabbatuna [ ] Godric son of Herebold holds 8 acres, worth I $2 d$. The King and the Earl (have) the soke.

In Thewardetuna [Theberton] a freeman Suarthoga held T.R.E. from Ulf son of Mannigsuart as a manor 60 acres. Then I plough, now none. 2 acres of meadow. It was worth T.R.E. 20s., now IOs. This Hubert holds of Robert Malet.

\section{Hundret of Colenesse [Colneis]}

In StRatTuna [Stratton ${ }^{63}$ ] Wlmar a freeman T.R.E. under Edric of Laxfield held a carucate of land as a manor. Then 4 villeins, now 2. Then as now 3 bordars. Then as now on the demesne I plough. Then belonging to the men I plough, now half a plough. Wood(land) for 6 swine. 10 acres of 


\section{A HISTORY OF SUFFOLK}

\section{fol. $3^{1} 4 b$.}

meadow. And 12 swine, and 8 sheep. Then it was worth $20 s$., now 30 s. To this manor have been added 12 freemen in King William's time. Leuric of Helmelea [Hemley] and Bruman of Burch [Burgh], and Goda of Struostuna [ and Leostan of Faltenham [Falkenham], and Gleman of Leuetuna [Levington], and Wihtric of Carlewuda [ ], and Edwin the smith in the same (vill), Aluric of Hopewella [ ], and Thuri of Kylvertestuna [ ], Aluric the smith's son in Carlewuda [ ], Orgar in Kylvertestuna [ ], and Modgeva of Colacar [Colcarr], all under commendation to the same (Edric) T.R.E. with $87 \frac{1}{2}$ acres and 2 bordars, and $2 \frac{1}{2}$ ploughs, 2 acres of meadow (and) a mill. Then it was worth 60s., it now renders 50s. All this Bernard of London (Lundonie) holds of Robert Malet.

In the said Strattuna [Stratton] a freeman Lewin son of Brun under commendation to Edric (held) 24 acres of land. Then as now half a plough. Half an acre of meadow. Worth 4s. And there was half a freeman Aluric under commendation to the said (Edric) with I acre. Worth $5 d$. This R. de Claville holds of Robert Malet.

\section{In Mycelegata [}

] a freeman

Levestan under commendation to Edric (held) 4 acres. Worth $12 d$.

\section{Hundret of Carleford [Carlford]}

Plegeforda [Playford] Humfrey son of Robert holds of Robert Malet, and Godwin son of Alfer held as under the Queen T.R.E.; 3 carucates of land as a manor. Then 8 villeins, now 4. Then 3 bordars, now 23 and $I$ burgess of Gipeswic [Ipswich]. Then 6 serfs, now 1 . Then on the demesne 3 ploughs, now 2. Then 8 ploughs belonging to the men, now 4 . Wood(land) for 20 swine, 20 acres of meadow, and I mill. Then 3 rounceys. Then 15 beasts, now I. Then 69 swine, now 25. Then 160 sheep, now 26. Then 6 hives of bees, now I. Then it was worth $87 i$, now IoOs. I church (having) Io acres; worth $20 d$.

And in the same (vill) I 2 freemen under commendation to the said Godwin,-except 2, fol. 3 I 5 .

- Etheric and Blacheman, whose commendation Halden the predecessor of Geoffrey de Magnaville had,-(held) 100 acres of land. Then 3 ploughs, now 2, and $2 \frac{1}{2}$ acres of meadow. Worth 20s. Robert has the sac and soke and custom. It is I league long and half a league broad, and (pays) $9 d$. in geld.

In Necchemara [ freemen under com win T.R.E. with 28 acres. Then 2 ploughs, now none, worth 2s. Robert Malet has the soke and sac as in the case of the aforesaid (holdings). It is 3 furlongs long and $2 \frac{1}{2}$ broad, and pays $4 \frac{1}{2} d$. in geld. Others have holdings there.

In Gressegrava [Kesgrave (?)] 3 freemen under commendation to Godwin (held) 20 acres of land and I plough. Worth 3 s. and $4 d$. Robert has soke and sac.

Moreover in the same (vill) a freeman, Oslac, under commendation to Edric of Laxfield T.R.E. held 10 acres. Then I plough, now none. Worth I $6 d$. Half a church with 2 acres. Soke and sac (belong to) Saint Etheldreda. It is half a league long, and 4 furlongs broad, and (pays) $4 \frac{1}{2} d$. in geld.

In Minima Waldringafelda [Lesser Waldringfield] a sokeman under Edric (held) 22 acres of land. I bordar and I plough. Worth $2 s$.

In Ryscemara [Rushmere (St. Andrew)] 2 sokemen under Godwin (held) 30 acres. Then I plough, now half a plough. I acre of meadow. Worth 5 s.

In the same (vill) 3 freemen, under commendation to Edric,-Leuric and Turchil and Aluric,held 44 acres. I bordar. Then 2 ploughs, now I plough, 2 acres of meadow. Worth IOs. Saint Etheldreda has soke and sac.

In Hopestuna [ ] a freeman under Edric held 25 acres of land. Then 1 plough, now none. I bordar. Then it was worth $2 s$. and $8 d$., now 4s. Saint Etheldreda has the soke.

In Haschetuna [Hasketon] a freeman, Lustwin by name, under commendation to Edric, and his wife under commendation to Halden, T.R.E. (held) 40 acres and half a plough. Worth 8s. Saint Etheldreda has the soke.

\section{fol. $315 b$.}

Moreover, in the same (vill) 2 freemen under commendation to Edric held I 7 acres, but their dwelling is in another hundred. Worth $3^{\text {s. }}$

In Burch [Burgh] 2 freemen under commendation to Edric (held) 16 acres and half a plough, and I acre of meadow. Then it was worth 4 s., now $3^{\text {s. }}$

In Tudenham [Tuddenham] a freeman under commendation to Edric T.R.E. (held) 12 acres. Then I plough, now none. Half an acre of meadow. Worth 2s. I church (with) 15 acres in this hundred. And another freeman under commendation to Godwin (held) 4 acres. Worth $8 d$.

In Belinges [Bealings] (is) a sokeman, Ulnot by name, with 14 acres. Then I plough, now 


\section{THE HOLDERS OF LANDS}

none, half an acre of meadow. Then it was worth $2 s$., now $28 d$.

In Grundessurh [Grundisburgh] 2 sokemen, under commendation to Edric (held) 5 acres and half a plough; worth I2d. All this Humfrey son of Robert holds of Robert Malet.

In BURCH [Burgh] a freeman Adelwold under commendation to Edric (held) 16 acres of land. Then half a plough, now 2 oxen. Worth 2 . Robert Malet holds it in demesne.

In BURCH [Burgh] R. de Glanville holds a freeman Ulwin the priest, (who was) under commendation to Edric T.R.E. with 6 acres worth $\mathbf{I} d$., and II acres of free land worth II $d$.

In Ryscemara [Rushmere] Ulviet a freeman under Gurth T.R.E. held 60 acres as a manor, and Humfrey holds (this) in demesne. Then I plough, now 5 acres of meadow. Worth 20 s.

In the same (vill) 2 freemen under him (held) 4 acres. Worth $16 d$. This Humfrey holds of Robert Malet.

In Hascetuna [Hasketon] a freeman under Edric held 5 acres. Worth $12 d$.

In Clopetuna [Clopton] 2 freemen under commendation to Edric (held) 40 acres of land and half a plough. Worth $7 s$. and $4 d$. Tiger holds one of them, and Gilbert de Colville the other of Robert Malet.

fol. 316.

\section{Hundret of Plusmesgata [Plomesgate]}

(At) Cranesforda [Cransford] Godric the priest under commendation of Edric of Laxfield held 40 acres. Then as now I plough. And $I$ acre of meadow. Then as now it was worth 10s. This Durand holds of Robert Malet.

SNAPES [Snape] Walter holds of Robert Malet, which Edric of Laxfield held as a manor, viz. 4 carucates of land T.R.E. Then as now 8 villeins, and 16 bordars. Then on the demesne 5 ploughs, now none; but there might be. Then 8 ploughs belonging to the men, now 4. Wood(land) for 6 swine, 6 acres of meadow. 1 mill. Then 2 rounceys. Then 6 beasts, now 2 . Then 24 swine. Then 160 sheep. Then as now it was worth $6 /$. It is 3 leagues long, and 4 furlongs broad. And (pays) in geld $40 d$. Robert Malet (has) the soke.

Moreover in the same vill (were) 25 freemen under commendation of Edric of Laxfield with I08 acres. Then among them (were) 6 ploughs, now 4. Then it was worth 235 , now 20 s.

In Aldeburc [Aldeburgh] Uluric a sokeman under Edric T.R.E. held 80 acres as a manor.
3 bordars. Then 2 ploughs, now 1. 2 acres of meadow. 5 swine. And 20 sheep. Then as now it was worth 20s. 2 churches with 60 acres, worth ros.

In the same (vill) are 12 acres of free land. Worth 2 s.

In the same (vill) a freeman Archil under commendation of Edric (held) 30 acres. Then as now I plough. I acre of meadow. Worth 5 s.

In STERnesfella [Sternfield] (is) a sokeman with 30 acres. And I acre of meadow. Worth 5 s.

In Bohtuna [Boyton ${ }^{64}$ ] was a freeman under commendation of Edric with 24 acres and I plough. Worth 5 s.

In the same vill (are) 30 acres of demesne land and half a plough, worth 5 s.

All this Walter son of Grip holds.

In SNAPES [Snape] Gilbert Blund holds of Robert Malet 21 freemen under Edric's commendation (with) I carucate of land (and) 30 acres. Then 6 ploughs, now 3. Then it was worth 20s., now 40 s. A church with 8 acres, worth $16 d$.

In Bohtuna [Boyton] (were) 8 freemen under Edric's commendation with 20 acres. Then 2 ploughs, now 1. Worth 5s. This Gilbert holds of Robert Malet.

fol. $316 b$.

Farnham [Farnham] Norman holds of Robert Malet, which Edric of Laxfield held as a berewick, viz. half a carucate of land. Io acres of meadow and 3 bordars. I plough on the demesne. And I mill. Then it was worth 20s., and now a like sum.

In the same (vill) (were) 9 freemen under Edric's commendation with 28 acres and I plough and $\mathbf{I}$ acre of meadow. Then it was worth 5s., and now a like sum. It is 8 furlongs long and 5 broad. And in geld pays $7 \frac{1}{2} d$. This Norman holds.

In Torp [Thorpe] (were) 4 freemen under Edric's commendation (with) 24 acres and I plough and 3 bordars and 6 acres. All these are (included) in the valuation of Ledestuna [Leiston].

In CRANesfod [Cransford] (were) 5 freemen under commendation of Edric with 35 acres. Then I plough, now half a plough. Their value is included in the valuation of Dinguiet[una] [Dennington].

This (Robert Malet) holds in demesne.

"Said to be in Kettleburgh and Parham ; Copinger, Suff. Rec. 


\section{A HISTORY OF SUFFOLK}

In Bohtuna [Boyton] William Gulafa holds of Robert Malet 12 freemen (formerly) under Edric's commendation with 60 acres. Then 4 ploughs, now 3. Half an acre of meadow. Worth 16s. 2 churches with 30 acres, worth 5 s.

In Riscemara [Rushmere (?)] 8 freemen under Edric's commmendation (held) 52 acres of land. Then 3 ploughs, now 2. Worth 75 ., but it renders 17 s. The same William holds it.

In Bohtuna [Boyton] a freeman under Edric's commendation (held) 24 acres, worth $4 s$. The same William (holds this).

In STERnEFella [Sternfield] 15 freemen under Edric's commendation (held) roo acres. I acre of meadow. Then 5 ploughs, now 4. I acre of meadow. Then it was worth 20 s., now 44 s. The same William (holds this).

\section{In Cle'pham [}

of demesne land, worth 2 s.

] (are) I0 acres

In Sutburna [Sudbourne] Gilbert de Wiscand [Wishant] holds of Robert Malet 12 treemen (formerly) under the said Edric's commendation with 60 acres. Then 3 ploughs, now 2. Worth 20s. To one of these freemen belonged (fuit) a manor with 20 acres. I beast, 30 swine, 40 sheep. I plough might be made up. I mill. Worth IOs. A church with 16 acres, worth 2 s.

fol. 317 .

In the same (vill) Walter de Caen holds of Robert Malet a freeman (formerly) under Edric's commendation with 30 acres and 1 bordar. Then as now I plough. I fish pond (piscina). I acre of meadow. I salt-pan. Worth I 2 s.

\section{In Burgesgata [ worth 3 d. \\ ] (is) I acre,}

In Burch [Burgh (?)] a freeman under Edric's commendation T.R.E. (held) 6 acres. Worth I $2 d$.

In Ingoluestuna [ acres, worth $\mathbf{I} 2 d$.

] (are) 6

In Prestetuna [ ] (is) I bordar with 3 acres of land and half (an acre) of meadow, worth $6 d$.

\section{HUNDRET OF WILEFORDA [WILFORD]}

In HolesLea [Hollesley] Edric of Laxfield T.R.E. held 6 carucates of land as a manor. Then 18 villeins, now 13 . Then 4 bordars, now 12. Then on the demesne 4 ploughs, now 2 ; and there could be 2 others. Then 8 ploughs belonging to the men, now 5. 30 acres of meadow. And I fishery. And 2 rounceys, 8 beasts, 30 swine, Ioo sheep. Robert (holds) the soke and sac of the King. To this manor belong 5 sokemen with 56 acres. Then 2 ploughs, now I. 4 acres of meadow. These 5 could not sell their land, nor give it to anyone. Then worth roos., now I 3 li. It is I league long, and half a league broad. And (pays) $7 d$. in geld. A church with 14 acres, worth 2s. Saint Etheldreda has soke throughout the entire Hundred.

In Suthtuna [Sutton] (were) 22 freemen, 20 under Edric's commendation and 2 under Saint Etheldreda, with 80 acres of land. Then 6 ploughs, now 5. 4 acres of meadow. And they are (included) in the valuation of HolesLea [Hollesley]. It is I league long, and 8 furlongs broad. And (pays) $27 d$. in geld.

In Capeles [Capel (St. Andrew)] (were) 2 freemen under Edric's commendation T.R.E. with 3 acres of land.

And in Laneburh [ ] a freeman under Edric's commendation with $\mathbf{I}$ acre of land.

In Aletuna [Alderton] a freeman under Edric with I acre of land.

\section{And in Turstanestuna [} 3 freemen under Edric's commendation with $4 \frac{1}{2}$ acres.

And in Baldeseia [Bawdsey] 2 freemen under Edric's commendation with I 3 acres.

And they are all included in the valuation of Holeslea [Hollesley].

fol. $317 b$.

In Sutruna [Sutton] Leofstan a freeman under Edric held T.R.E. 60 acres of land as a manor. Then I plough, now half a plough. 2 acres of meadow. Then as now worth $3^{\text {s. }}$ And 2 half freemen under him (held) 4 acres (included) in the said valuation.

(At) Culestea [ ], a berewick of HolesLea [Hollesley], Robert Malet's mother holds of him I carucate and 80 acres of land. Then as now 1 villein, and 13 bordars. Then on the demesne 4 ploughs, now 2. Then as now belonging to the men 3 ploughs. 6 acres of meadow. Then worth 6os., now the like. It is I league long, and 6 furlongs broad. And (pays) $27 d$. in geld.

In the same vill 2 freemen under Edric's commendation T.R.E. (held) 8 acres, worth $16 d$.

(At) Baldeseia [Bawdsey], a berewick of HolesLea [Hollesley] which Robert de Glanville holds of Robert Malet, (is) I carucate of land. 


\section{THE HOLDERS OF LANDS}

Then as now 3 bordars. Then $x \frac{1}{2}$ ploughs, now 2. Then it was worth $25 \mathrm{~s}$., now 40 s. And it is I league in length and 5 furlongs in breadth. And pays in geld $27 d$.

In the same (vill) I 7 freemen under Edric's commendation T.R.E. (held) 60 acres of land. Then 3 ploughs, now $1 \frac{1}{2}$ ploughs. 4 acres of meadow. Then worth IOs., now 125.

In Hov [? Hoo] (is) a freeman with the fourth part of an acre worth $2 d$.

In Alretuna [Alderton] were 31 freemen T.R.E., now there are 34 , (they were) under Edric's commendation. Over $2 \frac{1}{2}$ of these Godric the predecessor of Suene used to have commendation, but William Malet was seised of them. I carucate of land and 80 acres and $1 \frac{1}{2}$ bordars. Then 6 ploughs, now 5. 20 acres of meadow. Then worth 40s., now Ioos. One church with 24 acres and 1 acre of meadow. Worth $3^{\text {s. }}$

In Holessea [Hollesley] I mill worth I2s.

All this Robert de Glanville holds of Robert Malet.

In Baldeseia [Bawdsey] I $2 \frac{1}{2}$ freemen under commendation to Edric T.R.E. (held) 72 acres. Then as now 2 ploughs. One acre of meadow. Then worth 125., now 30s. A church with 20 acres, worth 3 s.

This Robert Malet's mother holds of him.

fol. 318 .

In Alretuna [Alderton] 2 freemen under commendation to Edric (held) 32 acres. Then as now 1 plough. Half an acre of meadow. Then worth 4s, now Ios. This W(alter) de Caen holds of Robert Malet.

In Litescros [ ] (are) 7 villeins with 40 acres. Then 2 ploughs, now r. 3 acres of meadow. Then worth 55., now IOS. Robert holds the soke of the King.

In Alretuna [Alderton] (was) a freeman with 12 acres $^{\text {es }}$ under commendation to Edric, worth 25 .

In Sutrusa [Sutton] W(alter) de Caen holds of Robert Malet half a freeman, Godwin by name, (who was formerly) under commendation to Edric with 12 acres as a manor. Half a bordar. Then half a plough, now the like. One acre of meadow. And 3 beasts, 60 sheep. Then worth 2s., now 5 s.

In the same (vill) 9 freemen under him (? Godwin) and I freeman under commendation to

4 ' 12 acres of the demesne (of St. Etheldreda)'; Ing. $B l .162$.

The other half of his commendation apparently belonged to Ely; ibid.
Halden T.R.E. (held) 40 acres of land. Then I plough, now I. Half an acre of meadow. Then worth $45 .$, now 7 s.

In Capeles [Capel (St. Andrew)] $3^{\otimes 8}$ freemen under commendation of Godwin (held) I 5 acres of land. Then I plough, now a half. Then it was worth 25. , now 45 . It is I league long, and half (a league) broad. And (pays) $27 d$. in geld. Others hold (land) therein.

In Scotrsham ${ }^{69}$ [Shottisham] I $\frac{1}{2}$ freemen under commendation to the same (Godwin) (held) 7 acres, worth $12 d$.

In Brameswella [Bromeswell] I $\frac{1}{2}$ freemen under commendation to the same (Godwin) (held) 8 acres. Half a plough. Worth $16 d$.

This the same Walter (de Caen) holds of Robert Malet.

In BREDEFELDA [Bredfield] the same W(alter de Caen) holds of Robert Malet 3 whole freemen and 3 half freemen and $I$ quarter freeman with 24 acres. Then 2 ploughs, now half a plough, and they are worth $6 s$. and $2 d_{0^{70}}$ And as to this Godwin of Sutton, Menard makes claim that Earl Ralph was seised of him one year before he made forfeiture ; and the Hundred bears witness that Robert Malet was seised thereof.

In Suttuna [Sutton] the same Walter (de Caen) holds of Robert Malet 2 freemen (formerly) under commendation to Edric (with) 6 I acres, and under one of them (were) 5 freemen. Then as now 2 ploughs. I $\frac{1}{2}$ acres of meadow. Then worth 75., now I5s. A church with 20 acres. (Included in) the valuation above.

fol. $3 r 8 b$.

In WILEFoRd [Wilford] Robert Malet holds in demesne I sokeman $\mathbb{E d i}$ (formerly) under Edric's commendation with 60 acres. Then as now 2 bordars. And then I plough, now none. 4 acres of meadow. Then worth 16s., now Ios. It is I league long, and half (a league) broad. And (pays) in geld $13 \frac{1}{2} d$.

Boituna [Boyton] Humfrey son of Robert holds of Robert Malet, which Stanwin under commendation to Edric held T.R.E., viz. 2 carucates of land as a manor. Then 3 villeins, now none. Then 18 bordars, now 15 . Then on the demesne 2 ploughs, now 1 . Then 4 ploughs belonging to the men, now I ; but there might be (3 more). Io acres of meadow. Then 2 rounceys, now none. Then 9 beasts, now I.

* All these ten freemen had been in the soke and commendation of St. Etheldreda; Inq. El. 162.

68 ' $3 \frac{1}{2}$ '; ibid.

' Eissestesham,' 'Escestesham' ; ibid. 162, 178.

70 'Worth 75. 2d.' ; ibid. 162. 


\section{A HISTORY OF SUFFOLK}

Then 24 swine, now 17 . Then 300 sheep, now 70. Then I mill. Then worth 60s., now 6os. A church with 8 acres, worth $12 d$.

In the same (vill) were 8 freemen under Stanwin's commendation with 63 acres. Then 2 ploughs, now $1 \frac{1}{2}$. Then worth $24 s$, now $22 s$.

In LANEBURC [

] Bricmar under commendation to Edric (held) 5 acres. Worth 12d. Walter holds.

In LANEBurC [

] 3 freemen under Edric's commendation (held) 30 acres and I bordar. Then $\mathrm{I} \frac{1}{2}$ ploughs, now half a plough, Then worth ros., now I 2 s.

In Meltuna [Melton] (were) 2 freemen under Edric's commendation with 64 acres, and I freeman under him with I acre. Then as now $1 \frac{1}{2}$ ploughs. Then worth I 5s., now IOs.

This Humfrey holds of Robert Malet.

Halgestou [ ] Malet's mother holds, which Godric, Edric's sokeman, held-he could not sell nor give it T.R.E.; I carucate of land and 20 acres and $I$ villein and I bordar. Then 2 ploughs, now I. And 2 acres of meadow. And I mill. Then as now worth I 7 s. and $4 d$.

Rammesholt [Ramsholt] Ralph holds of Robert Malet, and $3 \frac{1}{2}$ freemen under commendation to Godric. Suen's predecessor held it T.R.E.; 29 acres. Then 1 plough, now 2. Then worth IOs., now 5 s.

In the same (vill) 5 freemen under Edric's commendation - I was half under commendation fol. 319 .

to Roger Bigot's predecessor-held I 6 acres. Then I plough, now half a plough. Worth 2 s. Moreover in the same (vill are) 80 acres belonging to Malet's demesne. Then worth 5s., now 75 .

In SutTuna [Sutton] (was) a freeman under Edric's commendation T.R.E., now his 3 sons dwell there, (with) 25 acres ; and a freeman under him with 1 acre. Then as now half a plough. Worth then 45 , now 5 s.

In the same (vill was) a freeman under the same (Edric's) commendation with Io acres and I plough. One acre of meadow. Worth $2 s$. and $8 d$. This Ralph holds of Robert Malet.

In Caresfelda [Charsfield] Robert de Glanville holds of Robert Malet 24 freemen under Edric's commendation T.R.E. with 2 carucates of land and 5 bordars. Then 7 ploughs, now 4 . And 4 acres of meadow. Then worth 3 os., now 40s. It is I league long, and 5 furlongs broad. And in geld (pays) $13 \frac{1}{2} d$. To the church (belong) 36 acres, worth 3 s.

In Brammeswella [Bromeswell] Gilbert de Colville holds of Robert Malet $4 \frac{1}{2}$ freemen (for- merly) under Edric's commendation with 26 acres of land and $\mathbf{I} \frac{1}{2}$ acres of meadow. Then as now half a plough. Worth 4 s.

In Bulges [Boulge] Robert de Glanville holds of Robert Malet a priest Wlfwin, a church with 25 acres and 3 bordars and $I$ acre of meadow, worth 3 s. and $2 d$. And a church in BREDEFELD [Bredfield] with $3^{6}$ acres, worth $3^{\text {s. }}$

In Capeles [Capel (St. Andrew)] Walter son of Aubrey holds of Robert Malet 24 freemen (formerly) under commendation to Edric with I carucate and $6 \mathrm{I}$ acres of land and 4 acres of meadow. Then 6 ploughs, now 3. Then worth 6os., now a like amount. A church with 12 acres, worth 2 s.

In Suttuna [Sutton] a freeman under Edric's commendation (held) 80 acres as a manor. Then as now I plough. 3 acres of meadow. Then worth 20s., now a like amount.

In the same (vill) 8 freemen under Lustwin's commendation T.R.E. (held) 40 acres. 2 acres of meadow. Then 2 ploughs, now 1. Then worth 4s., now 75 .

In Brammeswella [Bromeswell] (are) 6 acres, worth $12 d$.

In Scotesham [Shottisham] a freeman Siric under King Edward's commendation (held) I 2 acres, and half an acre of meadow. Then worth $2 s$, now $4 s$.

In the same (vill) 4 freemen, 2 under Godric's commendation and the other 2 under Osmund's fol. $319 b$.

commendation T.R.E., (held) $32 \frac{1}{2}$ acres. Then 1 plough, now half a plough. Then worth 45 ., now 6 s.

In BengA [Byng ${ }^{71}$ ] a berewick of STAURETUNA [Staverton ${ }^{72}$ ] Edric held $I \frac{1}{2}$ carucates. Then $I$ villein and now (the same). Then I bordar, now 2. Then and now I serf. Then I plough, now 2. 2 acres of meadow. One rouncey, 4 beasts, 16 swine, and 80 sheep. Then worth 20s., now 40 s.

In the same (vill were) 20 freemen, and in LUDHAM [Loudham] 10 whole and 2 half (freemen) with I carucate of land under Edric's commendation T.R.E. Then 6 ploughs, now 3 . And 4 acres of meadow. Then worth 30 s., now 40 .

In Ludham [Loudham] (were) 2 freemen under the said Edric's commendation with 24 acres and $4 \frac{1}{2}$ acres of meadow. Then I plough. Now I mill. Now half a plough. Then worth 20s., now a like amount.

in In Pettistree.

In Butley. 


\section{THE HOLDERS OF LANDS}

Malet.

This Walter son of Aubrey holds of Rolert

In Brumeswella [Bromeswell] Hubert de Monchensey (Monte Canesitu) holds of Robert Malet 16 freemen (formerly) under Edric's commendation with 60 acres and I bordar. Then 2 ploughs, now $1 \frac{1}{2}$. 4 acres of meadow. Then worth 16 s., now 20 s.

\section{Hundret of Hertesmbra [Hartismere]}

(At) Ers [Eye] Edric held 12 carucates of land T.R.E. Now Robert holds them in demesne; and his mother holds 100 acres and I villein and 3 bordars and 9 sokemen with 16 acres, then 2 ploughs, now 1 , worth 20s. Then 39 villeins, now 20 . Then and afterwards 9 bordars, now 16 . Then 12 serfs, now none. Then and afterwards 8 ploughs on the demesne, now 5. Then and afterwards 15 ploughs belonging to the men, now 6 . And the other ploughs might be made up again (restaurari). And (there are) 50 acres of meadow. Then wood(land) for 120 swine, now for 60 . Then as now a mill. And a fishery. Then 7 rounceys, now I. Then 24 beasts, now none. Then 50 swine, now 17 . Then 80 sheep, now 90. And now I market. And a park. And in the market 25 burgesses have their dwellings (manent). To this manor belong 48 sokemen with 121 acres of land. Of these sokemen 37 (are) on the demesne; and Herbert holds 9 with 20 acres; and Walter $I$ with 5 acres; and fol. 320 .

Walter the crossbowman (arbalistarius) I with 16 acres. The whole is worth 9s. Then 4 ploughs, now 3. And I acre of meadow. Then worth 15 li., now 21 li. Edric had soke and sac of the bishopric which the Bishop ought to have. To this manor also belong 9 freemen with 110 acres of land (who were) in Edric's soke and commendation T.R.E. Then $4 \frac{1}{2}$ ploughs, now 4. And 3 acres of meadow. Then wood(land) for 16 swine, now for 6 . Worth 20s. These 9 were called Alestan, Uluric, Godwin, Lewin, Edric, Alfsi, Aluric, Godric, Dynechaie.

In the same (vill) a freeman Uluric under commendation to Edric (held) 30 acres as a manor T.R.E. Now Walter de Caen holds of Robert. Then as now 2 bordars. Then 1 plough, now half a plough. Worth 20 s.

In the same (vill is) a church, Saint Peter's, to which belong 2 carucates of free land and 7 bordars. Then I plough on the demesne, now 3. Then $x$ plough belonging to the men. And 3 acres of meadow. And a mill. Worth 40 s.

In the same (vill) a freeman Suartric under Harold's commendation and in his soke held 120 acres as a manor T.R.E. Now Robert holds in demesne. Then as now 4 bordars. And I plough on the demesne. And 4 acres of mea- dow. Wood(land) for 3 swine. Worth 20 s. It is $2 \frac{1}{2}$ leagues long, and $\mathrm{I} \frac{1}{2}$ leagues broad. And (pays) 2s, in geld.

In RAdingheFELDA [Redlingfield] a freeman Aluric under commendation to Edric (held) 3 carucates of land as a manor T.R.E. Then as now 11 villeins, and 4 bordars. Then 2 serfs. Then 2 ploughs on the demesne, now 3. Then as now 2 ploughs belonging to the men. Then wood(land) for 100 swine, now for 50. And 6 acres of meadow. And a church with 12 acres. Now 1 rouncey. Then as now 12 swine, and 24 sheep, and 34 goats. Then worth 60s., now roos. William de Archis holds of Robert Malet. The King and the Farl (have) the soke. (It is) 7 furlongs broad and 7 long. And (pays) $6 d$. in geld.

fol. $3^{20 b}$.

In Acolt [Occold] 5 freemen under commendation to Edric and in his soke (held) 46 acres, Smert, Raven, Pinstan, Godric, Lefsi, Alveva. Then 2 ploughs, now $1 \frac{1}{2}$. Wood(land) for 6 swine. And I acre of meadow. Worth 10 s. Robert's mother holds.

In Gissuincham [Gislingham] 2 freemen, Stannard and Stubbard, under commendation to Edric (held) 30 acres in the soke of the King and the Earl. Then as now 2 bordars. Then (and) afterwards I $\frac{1}{2}$ ploughs, now I plough. And $I \frac{1}{2}$ acres of meadow. Wood(land) for 5 swine. Then worth 4s, now 5s. Robert's mother holds.

In MelLets [Mellis] a free(man) Fulchard, half under commendation to Edric, (held) 27 acres and I bordar and I plough and I acre of meadow and half a church with 8 acres. Worth Ios. The King and the Earl (have) the soke. Robert's mother holds.

In Iacheleia [Yaxley] Alnod a freeman, half under commendation to Edric, (held) $8 \frac{1}{2}$ acres, worth $12 d$. The King and the Earl have the soke. Hubert holds.

In Wordham [Wortham] a freeman Algar under commendation to Edric (held) 4 acres, worth $8 d$. The King and the Earl (have) the soke.

In BRISEworde [Braiseworth] 4 freemen (held) $3^{8}$ acres of land under commendation to Edric. Then $x \frac{1}{2}$ ploughs, now 1 plough. Worth $7 \mathrm{~s}$. and $6 d$. The King and the Earl (have) the soke.

In little (parvo) Thornham [Thornham Parva] 2 freemen under Edric's sub-commendation (held) 7 acres, worth $16 d$. And Robert's mother holds. 


\section{A HISTORY OF SUFFOLK}

In MARTHORHAM [Thornham Magna] a freeman Stanhart under commendation to Edric (held) 4 acres, worth 12d. The King and the Earl have the soke. Robert's mother holds.

In Espala [Aspall] Brictmar a freeman under commendation to Edric (held) 30 acres as a manor T.R.E. Then as now I plough. And I acre of meadow. And 24 sheep. Worth Ios. The King and the Earl (have) the soke. Robert's mother (holds).

In Thrundestuna [Thrandeston] Awart (sic) a freeman under commendation to Edric (held) 36 acres as a manor T.R.E. Then and afterwards I plough, now 2 oxen. And I acre of fol. $32 \mathrm{I}$.

meadow. Worth 5s. The same Alwart holds of Malet. The King and the Earl (have) the soke.

In the same (vill) 2 freemen under commendation to Edric (held) 15 acres, in the soke of the King and the Earl, Godric and Lestan. Half a plough. Worth 26d. Walter holds of Robert.

In BRUM [Brome] 2 freemen under commendation to Edric (held) 4 acres in the King's soke, worth $8 d$. The same Walter (holds).

In Strandestuna [Thrandeston] the same Walter holds 2 villeins with 24 acres of the demesne of Eia [Eye]. Worth $4^{\text {s. }}$.

In BRISEWRDA [Braiseworth] 3 freemen under Edric's commendation (held) 17 acres and half a plough. Worth $3^{\text {s. }}$

In Espala [Aspall] a freeman under commendation (held) 3 acres, worth $6 d$. William Gulafra holds. The King and the Earl have the soke.

In the same (vill) Robert has 2 parts of a church.

In Fessefelda [Fressingfield (?)] Alwin a sokeman held 6 acres, worth $12 d$.

In Ghenetessala [Knettishall (?)] a freeman under commendation (held) 3 acres, worth $6 d$. The King and the Earl have the soke.

\section{Hundret of Hertesmara [Hartismere]}

In Finingaham [Finningham] Robert Malet's mother holds of Robert Malet and of the Queen's fief 18 freemen with $I \frac{1}{2}$ carucates of land. One of these had the name of Almar, over whose wife Saint Edmund had commendation, and 2 of them were under Lewin's commendation, Lewin and Brihtmar. The others were all under Leveric's commendation and Ulveva's T.R.E. ; and under them (were) 3 freemen with 5 acres and I bordar. Then $3 \frac{1}{2}$ ploughs, now the like num- ber. Wood(land) for 16 swine. 5 acres of meadow. They were then worth 305. now 50 s. It is half a league long, and half (a league) broad. And in geld (pays) $8 d$. The King and the Earl (have) the soke.

In WESTURP [Westhorpe] $3 \frac{1}{2}$ freemen (held) 30 acres. Then as now I plough. I acre of meadow. Then worth 50d., now 5s. The King and the Earl (have) the soke. Of these three the Abbot of Saint Edmund's claims I, Ordric, with Io acres; and the others were under commendation of Uluric the predecessor of Eudo son of Spiriuit.

\section{fol. $32 \mathrm{I} b$.}

In Wiverthrstuna [Wyverstone] (were) 4 freemen Ulmar, Alfeda and Ulwin, and Alwin and Alflet, and Alwin under commendation to Malet's predecessor. Over Ulwin the Abbot of Saint Edmund's had three parts of commendation. Altogether they have 67 acres. Then I plough, now half a plough. Wood(land) for 4 swine. They were then worth 6 s. and $8 d$., and now the like sum. The King and the Earl (have) the soke except over the one who was under the Abbot's commendation so far as relates to three parts of the commendation.

\section{In Caldecota}

] 6 freemen under commendation to Lewin of Bachetuna [Bacton] (held) 74 acres; and (there were) 7 freemen under them by commendation with $6 \frac{1}{2}$ acres. Then as now I bordar. And I $\frac{1}{2}$ ploughs. And I acre of meadow. Worth I Is. and IOd. The King and the Earl (have) the soke except over one, that is over Ulveva and her son. Walter de Dol was seised hereof on the day on which he made forfeiture.

At Soches [Stoke (Ash)] Ulveva under commendation to Stigand held $\mathbf{I}$ carucate of land and 40 acres as a manor. Then 4 bordars, now 8. Then as now 2 serfs. And 3 ploughs on the demesne. And 4 acres of meadow. Wood(land) for 8 swine. A church with 15 acres. Then 1 plough, now half a plough. And then 1 rouncey, now 2 . And 6 beasts. Then 12 swine, now 6. And 20 goats. Then as now worth roos. And 5 freemen under commendation (held) 32 acres. Then I plough, now half a plough. And I acre of meadow. Worth 5s. and $4 d$. It is 10 furlongs long and 6 broad. And (pays) $6 d$. in geld. Ulveva has soke, and over the freemen the King and the Earl (have) the soke.

In Martonham [Thornham Magna] 24 freemen (held) I carucate of land and 12 acres. Then and afterwards 6 ploughs, now 4 (ploughs) and 2 oxen. 4 acres of meadow. Then as now worth 23 s. Over all these Ulveva had commendation except over one who was half under commen- 


\section{THE HOLDERS OF LANDS}

dation to the Abbot of Saint Edmund's, Ulric by name. The King and the Earl (have) the soke.

fol. 322 .

In Thornham [Thornham] Brictmar under commendation to Ulveva held 26 acres and half a plough. Then worth 5s., now 7s. The King and the Earl (have) the soke.

In the same (vill are) 4 freemen, of one half freeman, Brungart by name, Walter de Dol was seised when he made forfeiture. 108 acres. Over $2 \frac{1}{2}$ Ulveva had commendation, and over the half (freeman) the Abbot of Saint Edmund had commendation, and over the fourth Burchard had commendation. Then 4 ploughs, now 2. And $\mathrm{I} \frac{1}{2}$ acres of meadow. And I rouncey, I beast, 25 swine, 16 sheep, and 27 goats. Then as now worth 20s. The King and the Earl (have) the soke.

In Gislingheham [Gislingham] 3 freemen. Over two Alveva had commendation. 7 acres and half a plough. Worth $16 d$.

In the same (vill) 2 freemen (held) 26 acres. One, Coleman by name, under commendation to Ulveva with 6 acres. Then half a plough, now none. Worth 4 s.

In the same (vill) Alviet a freeman under commendation to Alsi nephew of Earl Ralph (held) 30 acres as a manor T.R.E. Then I plough, now none. And $\mathbf{I}$ acre of meadow.

In the same (vill) 6 freemen under commendation to Alviet (held) 13 acres. Then as now half a plough. Then worth 20 s, now $12 s$.

In the same (vill) Ringulf a freeman (held) 30 acres as a manor under commendation to Alsi Earl Ralph's nephew. Then I plough, now none. Of this land Lewin son of Ringulf holds 3 acres and the fourth part of the wood(land).

In the same (vill) 4 freemen under commendation to Ringulf(held) ro acres. Half a plough. And 4 acres of meadow. Wood(land) for 10 swine. Then worth 20s, now Ios.

In the same (vill) Beso a freeman (held) 16 acres under commendation to Alsi. Then and afterwards I plough, now none. Worth $6 s$. and $8 d$. Of this land Aubrey de Vere's predecessor held 5 acres. The King and the Earl (have) the soke over all this.

In the same (vill) a freeman Sorches (held) 6 acres under commendation to Ulveva, worth $\mathbf{r} 2 d$.

fol. $322 b$.

In the same (vill) Chipinc a freeman under commendation to Ulwin, Aubrey de Vere's predecessor, and in his soke (held) 12 acres, and moreover he held an acre of land of Ulwin's demesne, and the fourth part of another (acre); and now Robert's mother holds all this. Worth 2s. The King and the Earl (have) the soke over all the rest (de toto alio).
In Cotetuna [Cotton] Ansger a freeman under commendation to Lewin of Bachetuna [Bacton] held 30 acres as a manor T.R.E. Then I plough, now half a plough. And I acre of meadow. Wood(land) for 6 swine. And 3 freemen under commendation (held) 60 acres and half a plough. Worth ros. The King and the Earl (have) the soke.

In the same (vill) Teit, half under commendation to Edric the King's reeve and half under commendation to Malet's predecessor, (held) 8 acres. Then as now half a plough. Worth 4s. The soke is the King's and the Earl's.

In Parvo Thornham [Thornham Parva] 8 freemen (held) 28 acres under commendation to Ulveva. Then 2 ploughs, now $1 \frac{1}{2}$. Worth 5 s.

In the same (vill) 2 freemen (held) 15 acres. One of them was under commendation to Ulveva, and the other half under sub-commendation to Malet's predecessor. Then as now I plough. Then worth $40 d$., now 5 s.

In the same (vill) a freeman Siric under commendation to Ulveva (held) 14 acres, and then I plough, now half a plough. Then worth 3 s., now 4 s.

In the same (vill) three parts of a church with 10 acres and half a plough.

The King and the Earl (have) the soke over all this.

In WorThaM [Wortham] Siric a freeman under commendation to Stigand (held) 20 acres. Then as now 2 bordars. And half a plough. And an acre of meadow. Wood(land) then for 6 swine, now for 2. And (there were) 3 freemen under him with 6 acres. Worth 5s. Stigand (had) the soke.

In Stoches [Stoke (Ash)] the same Siric held 20 acres and 2 bordars. Then I plough on the desmesne, now half a plough. And 2 acres of meadow. Worth $5^{\text {s. }}$ Stigand (had) the soke.

fol. 323 .

In Aspalle [Aspall] the same Siric held 30 acres as a manor. Then as now 3 bordars. And I plough. And 4 acres of meadow. Wood(land) for 60 swine. And I 3 beasts. Then worth ros., now 15 s. Stigand (had) the soke.

In Risangra [Rishangles] Ulveva under commendation to Stigand held 220 acres as a manor T.R.E. Then as now 3 villeins, and 7 bordars. Then 3 serfs, now 2. Then as now 3 ploughs on the demesne. And 2 ploughs belonging to the men. And 4 acres of meadow. Then wood(land) for 240 swine, now for 120. A church with 20 acres and I plough. Then as now 2 rounceys, and 7 beasts. And now 7 swine, and 30 goats. Then worth 50s., now 6os. Ulveva (had) the soke of Stigand. 


\section{A HISTORY OF SUFFOLK}

In the same (vill) 4 freemen (held) 40 acres under commendation to Ulveva. Then as now 2 ploughs. And I acre of meadow. Wood(land) for 6 swine. It was worth 6s. and $8 d$. The King and the Earl (have) the soke. It is 4 furlongs long and 10 broad. And (pays) $9 d$. in geld.

(At) Torentuna [Thorndon] Ulveva held under Stigand 3 carucates of land and 40 acres as a manor T.R.E. Then as now 4 villeins, and 16 bordars. Then 4 serfs, now 2. Then as now 4 ploughs on the demesne. And 3 ploughs belonging to the men. And 6 acres of meadow. Wood(land) for 200 swine, now for 120 . Now I mill. A church with 50 acres of free land and $I$ plough and I acre of meadow. Then as now 2 rounceys, and 15 beasts. Then 40 swine, now 31. Then 60 sheep, now 24. Then worth 5 li., now $8 l i$. Ulveva (had) the soke under Stigand.

In the same (vill) Turchetel a freeman under commendation to Ulveva (held) 30 acres as a manor. Then as now 2 bordars. And $1 \frac{1}{2}$ ploughs. I acre of meadow. Worth IOS. The King and the Earl (have) the soke.

In the same vill 7 freemen held 88 acres. Then as now 2 ploughs and 2 acres of meadow. Worth 20s. The King and the Earl (have) the soke.

In Acout [Occold] 7 freemen (held) 50 acres under commendation to Ulveva. Then 2 ploughs, fol. $323^{b}$.

now $I \frac{1}{2}$ ploughs. And I acre of meadow. Worth 9s. The soke is the King's and the Earl's.

(At) Brisevolda [Braiseworth] Ulveva held as a manor 60 acres and $I$ villein and I plough and 4 acres of meadow and 1 mill. Half a church with 17 acres and half a plough. And 4 beasts, and 8 swine. Worth 15 s. Ulveva (had) the soke under Stigand.

In the same (vill) a freeman (held) 3 acres, included in the same valuation.

In the same (vill) 15 freemen (held) 140 acres and $I$ bordar. Then 4 ploughs, now 3. And I acre of meadow. Half a church with 15 acres and half a plough. Worth 30 s. The King and the Earl (have) the soke. It is 6 furlongs long and 5 broad. And (pays) $9 d$. in geld.

In BRISEWRDA [Braiseworth] 8 freemen (held) 5 acres, worth $12 d$. The King and the Earl (have) the soke.

In the same (vill) Brichtmar Bubba a freeman under Harold held 20 acres. Then half a plough, now none. Worth 5s. The King and the Earl (have) the soke.

In Metres [Mellis] Lewric held 60 acres as a manor. Then and afterwards I plough, now none. And 3 freemen under commendation (held) 15 acres. Then and afterwards haif a plough, now 2 oxen. Then worth 20s, now IOs. Ulwin the predecessor of Aubrey de Vere (had) half the commendation and half the soke, and Ulveva (had) half the commendation, and the King (had) half the soke.

In BRISEWRDA [Braiseworth] Alestan a freeman under commendation to Ulveva (held) 30 acres as a manor. Then as now I plough. And I acre of meadow. Worth 5s. The King and the Earl (have) the soke.

In IAchelea [Yaxley] Hagris under commendation to Ulveva held 15 acres. Then as now half a plough. Worth 4s. The King and the Earl (have) the soke. All this Robert Malet's mother holds of him as of the Queen's fee.

In W Iснам [Wickham Skeith] 2 freemen under commendation to Ulveva (held) 16 acres and half a plough. Worth 3 s. The King and the Earl (have) the soke. Robert's mother holds as of the same fee.

In Felincham [Finningham (?) $]^{73}$ a freeman under commendation (held) 2 acres. Worth $4 d$.

In Badinghefelda [Bedingfield] a freeman by sub-commendation under Ulveva (held) half an fol. 324 .

acre. Worth 2d. Robert's mother holds (over him). The King and the Earl (have) the soke.

In Gildincham [Gislingham (?)] a freeman under commendation to Alsi nephew of Earl Ralph (held) 3 acres, worth 12d. The King and the Earl (have) the soke.

In WERINGHESETA [Wetheringsett] a freeman Godric (held) 7 acres. Worth 4 s.

\section{Wileforda [WILFORd] HUNDRET}

In Brumeswella [Bromeswell] Hubert holds of Robert Malet 44 acres of land and 6 acres of meadow. And this is in the demesne of Stauretuna [Staverton].

In Stokerlanda [Stokerland ${ }^{74}$ ] Gilbert de Colville holds of Robert Malet 2 freemen (formerly) under Edric's commendation with 30 acres. Then as now half a plough. Half an acre of meadow. Then worth $20 d$, now 5 s.

In the same (vill was) a sokeman with 30 acres, and he could not sell nor give. Then as now I plough. 2 acres of meadow. Then worth 5s., now 8s.

79 Copinger (Suff. Rec.) gives 'Felmingham' as an early form of Finningham.

"In Sutton. 


\section{THE HOLDERS OF LANDS}

In LUDHAM [Loudham] a freeman under the said Edric's commendation (held) 8 acres, worth $16 d$.

Scotesham [Shottisham] Walter the crossbowman (arbalastarius) holds of Robert Malet, which Osmund a freeman under Edric's commendation held T.R.E., viz. 44 acres as a manor, and I bordar. Then I plough, now half a plough. 2 acres of meadow. Then worth 20 s., now 10s. It is 7 furlongs long, and 4 broad. And in geld (pays) $13 \frac{1}{2} d$. A church with 13 acres, worth $32 d$.

In the same (vill) I 2 freemen under Edric's commendation and 3 under the commendation of Godric of Peyton (held) 80 acres. Then 3 ploughs, now $1 \frac{1}{2}$ ploughs. And 1 acre of meadow. Then worth I6s., now 20s. This Walter the crossbowman holds of Robert Malet.

UFFEWORDA [Ufford] Gilbert de Witsthant [Wishant] holds of Robert Malet, which Almar a freeman held as a manor T.R.E. under commendation half of Edric and half of Saint Etheldreda, viz. 60 acres. Then 4 bordars, now 2 . Then I $\frac{1}{2}$ ploughs, now half a plough. 4 acres of meadow. And I mill. Then as now worth ros.

In the same (vill) 9 freemen under the said (Edric's) commendation except 2 who were themselves under Saint Etheldreda's commendation (held) 25 acres and 2 acres of meadow. Then fol. $324 b$.

as now I plough. Then worth, as afterwards and now, 4 s.

In AlRetuna [Alderton] a freeman under Edric's commendation (held) 8 acres, worth $16 d$.

In WIKHAM [Wickham (Market)] 4 freemen under the said (Edric's) commendation T.R.E. (held) 16 acres, worth $12 d$.

In Suggenhou [Sigenhoe in Ufford] a freeman under Edric's commendation (held) 20 acres. Half an acre of meadow. Worth $16 d$.

In UFFEWORDA [Ufford] a freeman under Edric's commendation (held) 6 acres, worth $12 d$.

In Bulgrs [Boulge] i $\frac{1}{2}$ freemen under Edric's commendation (held) $3 \frac{1}{2}$ acres, worth $6 d$.

This Gilbert holds of Robert Malet.

In Benges [Byng] Walter de Caen holds of Robert Malet a freeman Godric (formerly) under commendation to Edric with 40 acres and I bordar. Then as now I plough. Then as now worth 75. And (there were) 2 freemen under him with 12 acres and half a plough, worth 2 s.

In BERDEFELDA [Bredfield] (were) 2 freemen under Edric's commendation with 27 acres. Then half a plough, now none. Worth 3 s. and $4 d$.
In Ludham [Loudham] a freeman Morewin held as a manor 40 acres, half under Saint Etheldreda's commendation, and half under Edric's, and I bordar. Then as now I plough. And under him (were) 14 freemen ${ }^{75}$ with 40 acres and 5 acres of meadow. Then 2 ploughs, now 1 . Then as now worth 20s. This Walter de Caen holds of Robert Malet. It is I league long, and 7 furlongs broad. And in geld (pays) $27 d$.

In Suttuna [Sutton] a freeman under Edric's commendation (held) 13 acres of land. Then half a plough, now 2 oxen. Worth $16 d$. This Hubert holds of Robert Malet.

In Bromeswella [Bromeswell] a freeman under Edric's commendation (held) 16 acres, worth I $6 d$. A church with 6 acres, worth $6 d$. This Hubert holds of Robert Malet.

In Hundesthost [ ] William holds of Robert Malet 2 freemen under commendation with 22 acres. Worth $2 s$. and $4 d$.

Horepola [Harpole] Robert Malet's mother holds, which Huna a freeman under Edric held T.R.E. as a manor, viz. 100 acres and 4 bordars. Then $1 \frac{1}{2}$ ploughs, now I plough. 5 acres of meadow. 8 swine, 30 sheep. Then and always worth 20 s.

In the same (vill were) ro freemen under Edric's commendation. And 4 in WIKHAM [Wickham (Market)]. Over 2 Saint Etheldreda had half the commendation and Robert fol. 325 .

Malet's predecessor half, 29 acres. Then I plough, now half a plough. Then as now worth $40 d$.

In Sutruna [Sutton] Robert Malet holds in demesne a freeman under Edric's commendation with 16 acres and half a plough. Worth 4 s.

In Horepola [Harpole] a freeman Bond under half commendation to Edric (held) 15 acres and half a plough (and) $1 \frac{1}{2}$ acres of meadow. Worth 5s. This Robert Malet's mother holds.

In Stituna [(?) Sutton] 3 freemen under Edric's commendation (held) 44 acres. Then 2 ploughs, now half a plough. One acre of meadow. Then worth 5s, now 4s. This Gilbert Blund holds of Robert Malet.

In UFFORDA [Ufford] a freeman under Edric's commendation (held) 8 acres and $I$ acre of meadow. This is included in the valuation of Dingifetuna [Dennington].

\footnotetext{
78 The freemen appear to have been divided between Edric and St. Etheldreda, as the notice of this holding in the $\operatorname{lng} . E$. (p. 163) runs, "And 7 freemen under him with 20 acres and 5 acres of meadow. Then I plough, now a half. Worth IOs.'
} 


\section{A HISTORY OF SUFFOLK}

In WILEFORDA [Wilford] a freeman under Edric's commendation (held) 2 acres, worth 4 d.

In the same (vill are) 30 acres, and they belong to Holeslea [Hollesley] and (are included) in its valuation.

In LudHaM [Loudham] a freeman under Edric (held) 8 acres. (This is included) in the valuation of Dingifetuna [Dennington].

In BREDEFrLla [Bredfield] a freeman under Saint Etheldreda's commendation (held) 6 acres, worth 12d. And Norman holds of Robert Malet.

In HoREPOLA [Harpole] a freeman holds 3 acres, worth $7 d$.

\section{HUNDRET OF LOSA [LOEs]}

StaURRTUNA [Staverton ${ }^{76}$ ] Hubert holds of Robert Malet, which Edric of Laxfield held as a manor, viz. 4 carucates T.R.E. Then 14 villeins, now 9. Then 6 bordars, now 15 . Then 4 serfs. Then on the demesne 4 ploughs, now 2 ; and 2 might be made up again. Then as now 2 ploughs belonging to the men. 8 acres of meadow. Wood(land) for 30 swine. I mill. And 2 beasts, 12 swine, 80 sheep, 20 goats, and 4 hives of bees. Then it was worth $6 \mathrm{li}$., now 4li. A church with Io acres, worth $20 d$. It is $1 \frac{1}{2}$ leagues long and half a league broad, and (pays) $22 d$. in geld.

In the same (vill) (were) 13 freemen under commendation of Edric of Laxfield with 57 acres, and 3 acres of meadow. Then 2 ploughs, now $1 \frac{1}{2}$. Then it was worth IOs., now a like sum. This Hubert de Monchensey (Monte Canesei) holds of Robert Malet.

In Ketelbiria [Kettleburgh] Humphrey holds of Robert Malet a freeman (formerly) under Edric's commendation T.R.E. with I 00 acres of land as a manor, and 3 bordars. Then and now I plough. $3 \frac{1}{2}$ acres of meadow. 4 beasts, 7 swine, and 30 sheep. Then it was worth I0s., now iss.

fol. $325 b$.

In Munegadena [Monewden] a freeman held as a manor 1 carucate of land T.R.E. under commendation of the same Edric. Then 2 bordars, now 3. Then 2 ploughs, now 1 . And belonging to the men half a plough. 3 acres of meadow. Then 3 beasts, now none. Now 6 goats. Then it was worth 40s., now 30s. The same Humphrey holds (this). And (there is) a freeman under him with 5 acres, worth Iod. It is I league long, and 4 (furlongs) broad. And (pays) $9 d$. in geld.

$$
{ }^{76} \text { In Butley. }
$$

In WUdEBRYGE [Woodbridge] a freeman under commendation to Robert Malet's predecessor (held) $20 \frac{1}{2}$ acres and half a plough. It was worth 5s. and $8 d$. This the same Humphrey holds.

(At) Framalingaham [Framlingham] Edric of Laxfield held T.R.E. 4 score and 14 acres as a berewick. Then as now 2 villeins, and 4 bordars. Then as now on the demesne 2 ploughs. And belonging to the men I (plough). Wood(land) for 4 swine. 2 acres of meadow. Then as now I rouncey, 4 beasts, 4 swine, and 5 hives of bees. And it is included in the valuation of Dingiuetuna [Dennington].

And a half freeman under Edric's commendation (held) 4 acres included in the valuation (of Dennington) above.

And in the same (vill was) a half freeman Brihtnoth under the same (Edric's) commendation with 2 acres; and (this) Robert Malet holds in demesne.

In the same (vill) Walter de Caen holds of Robert Malet (the land) which a sokewoman Ieva under Edric's commendation (held) T.R.E., viz. 80 acres as a manor. Then as now I villein, and 4 bordars. And I plough on the demesne. And belonging to the men $\mathbf{x}$ plough. Wood(land) for 4 swine. 4 acres of meadow. Then it was worth 13 s. and $4 d$, now a like sum.

And a freeman Turchetel under the said (Edric's) commendation (held) 4 acres, worth 2 s. This the same $W$ alter de Caen holds.

In Dalingahou [Dallinghoo] a freeman half under Edric's commendation and half under Saint Etheldreda's (held) 13 acres, and half a bordar, and half an acre of meadow. Worth 2s. and $8 d$. And the same William holds.

In Framelingaham [Framlingham] a freeman under Edric's commendation (held) 2 acres, worth $8 d$. It belongs to (in) Dingiuetuna [Dennington]; and (Robert Malet) holds (this) in demesne.

fol. 326 .

In Haetcetuna [Hacheston] 12 whole freemen and 9 half (freemen) under Edric's commendation T.R.E. (held) 60 acres and 28 (sic) and 6 bordars. Then 2 ploughs, now $1 \frac{1}{2}$ ploughs. 2 acres of meadow. And they are included in the valuation of Dingiuetona [Dennington]. And (this Robert Malet) holds in demesne.

In Rennesham [Rendlesham] 4 freemen under Edric's commendation (held) 33 acres, and I bordar. Then I plough, now half a plough. Half an acre of meadow. And 2 freemen under them with 2 acres; and they are included in the valuation of Dingiuetuna [Dennington]. 


\section{THE HOLDERS OF LANDS}

In KETDESBIRIG [Kettleburgh] a sokeman under Edric's commendation (held) 9 acres included in the valuation of Dingiuetuna [Dennington].

In Renlesham [Rendlesham] (was) a freeman, and in Estuna [Easton] another under Edric's commendation with 15 acres and they are (included) in the same valuation.

Kenetuna [Kenton] Malet's mother holds of Robert Malet, which Brihtmar held under Edric's commendation T.R.E. viz., 82 acres as a manor. Then as now $I$ villein, and 5 bordars, and I serf. Then as now 1 plough on the demesne. And belonging to the men 2 ploughs. Wood(land) for 12 swine. 2 acres of meadow. And I rouncey, I 6 beasts, 40 swine, and 3 hives of bees. Then as now worth 20s. And 2 freemen I under Brihtwold's commendation and the other under Brihtmar's commendation (held) 30 acres and 3 freemen with 4 acres under Edric's commendation. Then as now I plough. Worth $7\left(s_{0}\right)$. Robert Malet's mother (holds this) of him.

And in the same (vill) Huna.a freeman under Edric's commendation (held) 30 acres which Tiger (now) holds. Then as now half a plough. And I bordar. Worth 7 s.

In the same (vill) W(illiam) Gulafra holds a freeman Udebrun (formerly) under Edric's commendation having 30 acres as a manor. Then I plough. Half an acre of meadow. Worth Ios. It is I league long, and half (a league) broad. And in geld (pays) 9d. A church with 30 acres, worth 5s. Several persons have shares therein (participantur).

Remlesham [Rendlesham] Gilbert de Colville holds of Robert Malet, which Ulchetel held T.R.E. under commendation of Edric of Laxfield, viz. I carucate of land as a manor. Then as now 7 villeins, and 3 bordars. Then as now on the demesne 2 ploughs. Then I plough belonging to the men, now half a plough. 4 acres of meadow. I mill. Then 2 rounceys, now 1 . Now 2 beasts. Then 26 swine, now 8. Then 36 sheep, now 10. Then and now worth 40 s.

fol. 3266 .

In the same (vill) (were) 9 freemen under commendation of the said (Edric) with 30 acres of land. Then 2 ploughs, now 1.2 acres of meadow. Worth 5 s.

In Stauertuna [Staverton] a freeman under commendation of Edric of Laxfield (held) 30 acres. Then I bordar. Then as now I plough. I $\frac{1}{2}$ acres of meadow. Worth ros.

\section{In Clachestorp [}

] 6 whole freemen and 2 half (freemen) under commendation of Ulchetel (held) 42 acres. Then 2 ploughs, now I. Worth 75 .

In Gategraua [Gedgrave] (were) 5 bordars under the said Ulchetel's commendation with 30 acres. Then I plough. Worth 5s. It is a league long, and 2 furlongs broad. And (pays) $7 \frac{1}{2} d$. in geld.

In MerLesforda [Marlesford] a freeman under Edric's commendation (held) 36 acres as a manor. Then I plough, now half a plough. I acre of meadow. Then IOs., now 5s. And (there were) 6 freemen under the said Edric's commendation with 21 acres. Then half a plough. Worth 2 s. and $8 d$.

In Possefella [

] 2 freemen under Edric's commendation (held) 30 acres and 1 bordar. Then I plough, now half a plough. 3 acres of meadow. Then as now worth IOS.

In Brodertuna [

] a freewoman under the said (Edric's) commendation (held) 4 acres, worth $8 d$.; and in Campeseia [Campsey] 4 acres, worth $8 d$. This Gilbert holds of Robert Malet.

In Stauertuna [Staverton] Hubert holds of Robert Malet 2 freemen (formerly) under Edric's commendation with 14 acres. Then as now half a plough. Worth $2 s$, and $4 d$.

In REMLESHAM [Rendlesham] a freeman under Edric's commendation (held) 30 acres and I villein and I bordar and I plough. Worth 5 s. A church with 20 acres worth $40 d$. And (this) Gilbert de Wishant holds of Robert Malet.

In the same (vill) a freeman uncer the said (Edric's) commendation (held) I 2 acres and half a plough, worth $2 s$.

In EsCE [Ash] 12 freemen under Edric's commendation T.R.E. (held) a carucate of land. Then $2 \frac{1}{2}$ ploughs, now $1 \frac{1}{2}$ ploughs. Then as now it was worth 20 s.

In Hecetuna [Hacheston] (was) a sokeman with 30 acres under Edric's commendation and I bordar. Then, and now, I plough. 2 acres of meadow. Then it was worth 5s., now 8 s.

fol. 327 .

In the same (vill) a freeman under Edric's commendation (held) 6 acres, worth $12 d$.

In the same (vill) 4 freemen under Edric's commendation (held) 40 acres. Then I plough, now 1.2 acres of meadow. Then it was worth 7s., now $6 s$.

Moreover in the same (vill) 7 freemen under Edric's commendation (held) 24 acres. Then $\mathrm{I} \frac{1}{2}$ ploughs, now half a plough. I acre of meadow. Worth 4 s.

This Gilbert holds of Robert Malet.

In Clachestorp [ ] Walter de Risbou holds of Robert Malet $3 \frac{1}{2}$ freemen 65 


\section{A HISTORY OF SUFFOLK}

(formerly) under Edric's commendation with 22 acres. Then as now half a plough. Half an acre of meadow. Worth $3^{\text {s. }}$

And in SAHAM [Soham] a sokeman under Edric's commendation (held) 8 acres, worth 2 s. The said Walter de Risbou (holds this) of Robert Malet.

In Gategraua [Gedgrave] Gilbert de Wissand [Wishant] holds a freeman (formerly) under Edric's commendation with 30 acres and 4 bordars and I plough. Worth $5^{5}$.

In WUDEBRIGE [Woodbridge] (were) 2 freemen with 43 acres, and I sokeman with 8 acres. All were under Edric's commendation. Then as now I plough. And I acre of meadow. It was worth $8 s$. It is Io furlongs long and 5 broad. And in geld (pays) I I $d$. . A church with 19 acres, worth 2 s.

The said Gilbert holds (this).

In Campeseia [Campsey] a freeman under Edric's commendation (held) Io acres, and they are (included) in the valuation of Keletuna [ $]_{0}^{77}$

And in Framlingaham [Framlingham] a freeman Herewold under Edric's commendation (held) 2 acres, and they are (included) in the valuation of Dingiuetuna [Dennington].

In the same (vill) Fulchered holds of Robert Malet a freeman (formerly) under Edric's commendation with 10 acres, worth $2 s$.

In Esce [Ash] a freeman under Edric's commendation (held) 17 acres and 3 bordars and half

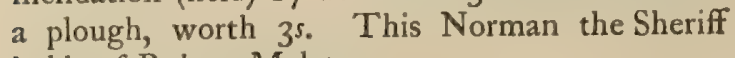
holds of Robert Malet.

In Dalingehou [Dallinghoo] Robert de Glanville holds of Robert Malet 4 freemen (formerly) under Edric's commendation with 80 acres and 17 (sic) and I bordar. Then as now fol. $327 b$.

2 ploughs. 2 acres of meadow. Wood(land) for 4 swine. Then as now it was worth 2 Is.

In ButElea [Butley] Walter son of Aubrey holds of Robert Malet $3 \frac{1}{2}$ freemen (formerly) under Edric's commendation with $3^{8}$ acres. Then $1 \frac{1}{2}$ ploughs, now I plough. Then as now it was worth 5 s. It is 6 furlongs long and 4 broad. And in geld (pays) $7 \frac{1}{2} d$.

In Mertlega [Martley] (was) a freeman under Edric's commendation with 20 acres and half an acre of meadow and 5 bordars and half a plough. Worth 8s. And William Gulafra holds (this) of Robert Malet.

$$
77 \text { See above, n. } 55 \text {. }
$$

In WiEBRIGE [Woodbridge] are 2 acres belonging to the demesne of Holeslea [Hollesley].

\section{HUNDRET OF WAINEFORdA [W ANGFORD]}

In Thicchebrom [

]$^{78}$ Humfrey holds of Robert Malet a freeman (formerly) under Edric of Laxfield's commendation, with 16 acres of land. Worth $2 s$.

In the same (vill) a freeman. under the said (Edric's) commendation (held) I6 acres and I bordar with half an acre. Valued in another Hundred.

In Barsham [Barsham] Warin son of Burnwin holds of Robert Malet a freeman, Alwin, formerly under Edric's commendation, with Io acres. Then as now half a plough. Worth $3^{\text {s. }}$

In Icheburna [

8 acres, worth $16 d$.

] a freeman (held)

In Eцmeнам [Elmham] (are) 15 acres, worth $30 d$.

\section{Hundret of Blacbrune [Blackbourn]}

In WaLSAM [Walsham] Hubert holds of Robert Malet a freeman with 60 acres over whom his (Malet's) predecessor had commendation T.R.E. Then as now I plough. And 2 acres of meadow. Wood(land) for 4 swine. Then as now worth ros. Saint Edmund (has) the soke and sac.

In Thelueteham [Thelnetham] (were) 2 men with all customs; but Saint Edmund had the soke; and they have 20 acres, and half a plough and an acre of meadow. Worth 5s. and 4d. And Robert Malet holds (them) in demesne.

In Stantuna [Stanton] Walter de Caen holds of Robert Malet a freeman over whom his (Malet's) predecessor had half commendation, and Saint Edmund (had) half commendation and soke fol. 328 .

and sac. And he has 90 acres, and 3 bordars, and 4 acres of meadow. Then as now I plough. And under him a freeman with 10 acres, whom the said Waiter holds. A church with 4 acres. The whole worth i6s.

In Rikinchala [Rickinghall] Hubert holds of Robert Malet a freeman with 30 acres. His (Malet's) predecessor had the commendation, and Saint Edmund the soke. Worth 5 s.

\section{Bissopes [Bishop's] Hundret}

In Binneuetuna [Dennington] ${ }^{79}$ Edric of Laxafella [Laxfield] held T.R.E. as a manor 6 carucates

78 ' Thickerbrone' subsequently occurs as one of the fees of the honour of Eye : Copinger, Suff. Rec. ii, 344.

${ }^{79}$ Formerly 'Dinnieueton'; see Cal. of Chart. in $B . M ., 225$. 


\section{THE HOLDERS OF LANDS}

of land and 20 acres. Then and afterwards 12 villeins, now 16 . Then and afterwards 16 bordars, now 15. Then as now 2 serfs. And 4 ploughs on the demesne. Then and afterwards 12 ploughs belonging to the men, now 9. Wood(land) for 160 swine. And I park. 20 acres of meadow. And then 2 rounceys, now I. And 20 beasts. Then 60 swine, now 40 . Then 40 goats, now 30. Now 30 sheep. Then as now 5 hives of bees. A church with 40 acres of free land and half a plough. Then worth 14 li. and now the like. It is I league and 2 furlongs long, and 6 (furlongs) broad. And (pays) rod. in geld.

(At) Tatintuna [Tannington] the said Edric held 8 carucates of land. Then and afterwards 13 villeins, now 15 . Then and afterwards 17 bordars, now 19 . Then as now 3 ploughs on the demesne. Then and afterwards I 2 ploughs belonging to the men, now 8 . Wood(land) for 200 swine. 20 acres of meadow. And 11 beasts. Then 16 swine, now 60. Then 16 sheep, now 20, and 20 goats, and 3 hives of bees. A church with 30 acres and half a plough, Then as now worth $14 l i$. It is I league and 3 furlongs long, and I league broad. And (pays) $10 d$. in geld. Richard holds of this manor 30 acres, worth ros., included in the same valuation. Garin (holds) 24 acres, worth 5 s, included in the same valuation.

fol. $328 b$.

(At) Laxefrida [Laxfield] Edric held 6 carucates of land and 80 acres. Then I 4 villeins, afterwards 8 , now 3 . Then and afterwards 14 bordars, now 37. Then 4 ploughs on the demesne, afterwards 3 , now 2 . Then and afterwards 14 ploughs belonging to the men, now II. Wood(land) for 260 swine. 27 acres of meadow. And 5 beasts. Then 40 swine, now 30, and 6 sheep, and 24 goats. A church with 43 acres and half a plough. Then worth $15 l i$. , now $8 l i$. It is $1 \frac{1}{3}$ leagues long, and I league broad. And (pays) $6 \frac{1}{2} d$. in geld. And Walter holds of this manor 3 villeins with 50 acres, worth 20 s, included in the samevaluation. Loernic (holds) 40 acres, worth ros., included in the same valuation.

(At) Badincham [Badingham] the same Edric held 9 carucates of land. Then 4 villeins, now 21. Then as now 26 bordars. Then and afterwards 10 ploughs on the demesne, now 5. Then 7 ploughs belonging to the men, now 5. Wood(land) for 100 swine, 20 acres of meadow. Then 1 rouncey. Then as now 15 beasts. Then 40 swine, now 32 , and 20 sheep, 60 goats, and I hive of bees. A church with 60 acres and I plough and I bordar and I acre of meadow. Then worth 15 li., now roli. It is 1 league and 6 furlongs long, and 1 league broad.
And (pays) rod. in geld. Walter holds of this manor 100 acres and 2 villeins and 6 bordars and 2 ploughs, worth 30 s., and included in the valuation of roli. Loernic holds 40 acres in the same valuation. Robert 40 acres in the same valuation of ros. (sic). And Edric has (sic) soke and sac.

(At) Berdefelda [Bedfield] Godwin held T.R.E. as a manor 4 carucates of land. Then 18 bordars, now 23. Then as now 2 ploughs on the demesne. Then 8 ploughs belonging to the men, now 9. Wood(land) for 200 swine. 9 acres of meadow. Then 2 rounceys, now 1 . Then 9 beasts, now 20. Then 40 swine, now 60 , and 83 sheep. Then worth 6li., now 7 li. It is 6 furlongs long, and 5 broad. And (pays) $3 \frac{1}{2} d$. in geld.

At SteTebroc [Stradbroke ${ }^{80}$ ] Edric held T.R.E. $5 \frac{1}{2}$ carucates of land. Then and afterwards 16 villeins, now II. Then II bordars, now 30. Then I I ploughs on the demesne, afterwards 6 , now 5. Then and afterwards 12 ploughs belonging to the men, now 5. And 12 ploughs might be restocked. And Wineberga [? Wingfield ${ }^{81}$ ] is a berewick included in the same account and valuation. All together 20 acres of

fol. 329 .

meadow. Wood(land) for 400 swine. Then 3 rounceys. Then 16 swine, now 30. And 30 sheep. Two churches with 40 acres and half a plough. And I 7 sokemen (with) I carucate of land and 3 ploughs. Wood(land) for 40 swine. 5 acres of meadow. Over these sokemen the sac and soke is in Hoxa [Hoxne] the Bishop's manor; and Edric held half of it of the Bishop. Then worth 14li., now 16li. And Walter holds of this manor 2 sokemen with 40 acres worth $8 \mathrm{~s}$. , included in the same valuation. Robert de Glanville 4 with 20 acres, (worth) 5s., in the same valuation. And Walter son of Gripp I with 15 acres, (worth) $30 d$, in the same valuation. Loernic I with 20 acres worth $3^{\text {s. }}$, in the same valuation. Edric (had) the soke and sac. It is 2 leagues long, and I league broad. And (pays) $14 \frac{1}{2} d$. in geld. Others have holdings. therein.

In HoR AM [Horham] a freeman, Aluric, (held) by commendation I carucate of land. Then as now 3 villeins, and 4 bordars. And 2 ploughs on the demesne. And I plough belonging to the men. And 4 acres of meadow. Wood(land) for 30 swine. And I rouncey, 9 beasts, 9 swine, 40 sheep, 30 goats, and 2 hives of bees. And 2 freemen (with) I 7 acres by commendation and half a plough. Then worth 40 s., and

* Afterwards held of the honour of Eye : Feud. Aids, v. 62 .

${ }^{81}$ Held with Stradbroke in 1316 : ibid. 37. 


\section{A HISTORY OF SUFFOLK}

now the like. And Robert de Glanville holds (this) of Robert Malet.

In WILEBEy [Wilby] Loernic holds 20 acres, which the said Aluric held. One bordar. And it is included in the above valuation. It (i.e. Horham) is 12 furlongs long, and 4 furlongs broad. And (pays) $10 \frac{1}{2} d$. in geld.

In Cibbehala [Chepenhall ${ }^{82}$ ] 9 freemen (held) by commendation $2 \frac{1}{2}$ carucates of land. Then as now I 7 bordars. And 9 ploughs. And 12 acres of meadow. Wood(land) for 300 swine. Then worth roos., now 6 i. Half a church with 20 acres and I plough. It is 2 leagues long, and I broad. And (pays) 15d. in geld. The soke is in Hoxa [Hoxne] the Bishop's (manor); but Edric used to hold half of it of Bishop Ailmar. Of this manor Walter holds 4 sokemen with I carucate of land, (worth) 30s., and included in the valuation of the 6li. Robert's mother (holds) 3 sokemen with 80 acres, (worth) $45^{5}$, included in the same valuation. Humfrey I (sokeman) with 20 acres,

fol. $329 b$.

worth 5s, in the same valuation. Walter son of Gripp I (sokeman) with 120 acres, worth 4 Os., in the same valuation.

In WeIBRADA [Weybread] I freeman under commendation held 2 carucates of land, which Humfrey holds as a manor. Io bordars. Then as now 2 ploughs on the demesne. Then 2 ploughs belonging to the men, now $1 \frac{1}{2}$. 10 acres of meadow. Wood(land) for 60 swine. And I mill. And I rouncey, 4 beasts, 30 swine, 30 sheep, and 4 hives of bees. And a freeman (with) 20 acres and half a plough. Then worth $30 s$, now 50s. This the said Humfrey holds. The soke is in Hoxa [Hoxne]. Half a church with 8 acres (and) half a plough, worth $16 d$.

In the same (vill) the said Humfrey holds 3 freemen under commendation (having) $9 \mathrm{I} \frac{1}{2}$ acres and 17 bordars. Then 3 ploughs, afterwards and now 2. And 6 acres of meadow. Then as now I mill. And three (fourth) parts of another. Worth 40s. The soke is in Hoxa [Hoxne].

In Menham [Mendham] a freeman under commendation (held) I carucate of land and 5 bordars. And I freeman under him (held) 3 acres. Then as now I plough on the demesne. Then 2 ploughs, now 2 oxen. 5 acres of meadow. Wood(land) for 100 swine. A church with 8 acres, and the eighth part of another with 5 acres.

In the same (vill) was a sokeman with 12 acres. Then worth 25s., now 30s. And the said Humfrey holds (this). The soke is in Oxa [Hoxne].

\section{${ }^{82}$ In Fressingfield.}

In WeIBrada [Weybread] (were) 6 freemen, and the said Humfrey holds 5, and Walter 1; worth IOs., 72 acres, and 5 bordars. Then 2

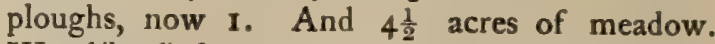
Wood(land) for 14 swine. Then as now I mill. Worth 17 s.

In Weibrada [Weybread] the said Humfrey holds 3 sokemen with 90 acres and 2 bordars. Then $2 \frac{1}{2}$ ploughs, and now I ox. 4 acres of meadow. Wood(land) for 20 swine. And I mill. Worth I5s, now 25s. and $6 d$.

In Horan [Horham] Walter de Caen holds of Robert Malet 3 freemen under commendation with 60 acres and 2 bordars. Then as now I plough. And 2 acres of meadow. Wood(land) for 6 swine. Worth $12 s$.

In Horam [Horham] Walter son of Grips holds of Robert Malet 2 freemen with I carucate fol. 330 .

of land and 30 acres and 5 bordars. Then as now $2 \frac{1}{2}$ ploughs. And 3 acres of meadow. Wood(land) for 28 swine. Then as now worth 25s. and $4 d$.

In Citriringa [Chickering in Wingfield] the same (Walter holds) 3 freemen under commendation with 36 acres. Then 1 plough, now half a plough. And $I \frac{1}{2}$ acres of meadow. Worth 6 s.

In the same (vill) the same (Walter holds) I freeman under commendation with 60 acres. Then I plough, now half a plough. And 2 acres of meadow. Wood(land) for 6 swine. Then worth IOs, and now (the same). Over him his (? Malet's) predecessor had commendation, and had the land in pledge (vadimonio) for 60 s.

In Badingefrelda [Bedingfield] the said Humfrey holds of Robert Malet a freeman under commendation with 84 acres and 8 bordars. And a priest by sub-commendation (with) 6 acres. And 2 ploughs. And I acre of meadow. Wood(land) for ro swine. And under him 6 freemen with 25 acres and I plough. Worth 22s. and $8 d$.

\section{fol. 3306 .}

\section{LANDS OF ROGER BIGOT}

\section{HUNDRET OF BRADAMERA [BRADMERE]}

At Bernham [Barnham] Stannard holds of Roger Bigot I carucate of land which Ailwin of Thetford (de Tedforte) held as a manor T.R.E. Then as now 6 bordars, and 1 serf. And 2 ploughs on the demesne. And half a plough belonging to the men. 2 acres of meadow. Then as now $x$ mill. Then 2 rounceys, now $I$. Then 3 beasts, now 6 . Then as now 14 swine. And 12 forest mares (eque silvatice). Then 160 


\section{THE HOLDERS OF LANDS}

sheep, now 300. And 5 freemen (with) 40 acres. Over these Roger's predecessor had commendation T.R.E. And this the said Stannard holds. Saint Edmund has soke and sac. The manor was then worth 30 s., now 40 s. ; and

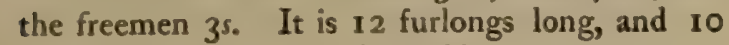
broad. And (pays) $11 \frac{3}{4} d$. geld.

\section{Half Hundret of Cosfort [Cosford]}

In Watesfelda [Whatfield] (is) a freeman, over whom Saint Edmund T.R.E. had (babet) commendation and soke complete. And he has 15 acres. Worth 2s. and 6d. This (Hugh) de Hosdene holds.

\section{Biscopes [Bishop's] Hundret}

CaRĀHalla [? Kelsale ${ }^{83}$ ] Roger Bigot holds in demesne, which Norman held T.R.E.; 4 carucates of land. Then and afterwards 10 villeins, now 15. Then and afterwards 7 bordars, now 17. Then as now 3 ploughs on the demesne. And ro ploughs belonging to the men. And 5 acres of meadow. Wood(land) for 60 swine. And now 3 rounceys, 2 beasts, and 30 swine. Then 25 sheep, now 100. A church with 30 acres and I plough. Then worth IOOs.

In the same (vill) Ulveva held 2 carucates of land as a manor, which Roger holds in demesne. Then 5 villeins, now 7 . Then 4 bordars, now 9. Then as now 2 ploughs on the demesne. And 5 ploughs belonging to the men. And 3 acres of meadow. Then worth 60 .

In this manor which Norman used to hold are 35 freemen having power to sell and give their lands, whom Roger holds in demesne by soke and sac and all customs. And they have 3 carucates of land. Then as now 12 ploughs. And I acre of meadow. And now a market of the King's gift. The freemen were then worth fol. 331 .

4li. The manor with the freemen is now worth $24 l i$, and the other manor $8 l i$. The whole is $1 \frac{1}{2}$ leagues long, and I league broad. And (pays) $42 d$. in geld. Roger Bigot (has) soke and sac.

Delham [Denham] Aitard holds of Roger Bigot, which Stigand held; I $\frac{1}{2}$ carucates of land. Then as now 3 villeins. And II bordars. And 2 ploughs on the demesne. And 2 ploughs belonging to the men. And 2 acres of meadow. Wood(land) for 30 swine. And 2 beasts, 10 swine, 30 sheep, and 20 goats. A church with 12 acres. And a sokeman belongs (pertinet) to this estate (terrae), which the said Ettard holds, and (his land) lies in Horam [Horham], with 40 acres and $I$ bordar and $I$ plough and 2 acres of meadow. Wood(land) for 6 swine. Then worth 40s., now 50 s.

Kelsale was one of the Bigot fees in 1316; Feud. Aids, v, 37. It occurs below (fol. 339) as "Cheressala."
In the same (vill is) I freeman of Stigand's whom (quam) the same Ettard holds, with 30 acres, and 2 bordars, and I plough, and I acre of meadow. Wood(land) for 4 swine. Worth 45. This is through the exchange with Isaac's land. In length it is half a league and 3 furlongs broad. And (pays) $7 \frac{1}{2} d$. in geld.

In the same (vill is) a freeman with ro acres. Stigand (had) commendation. Worth 2s. This is through the same exchange. And the said Ettard holds (it). The whole of this Bishop Ailmar had after the King came.

\section{In Blidigga [Blything] HUNdRet}

Hinetuna [Hinton] ${ }^{83 a}$ Egelward a freeman held as a manor T.R.E.; now Robert of Blideburh [Blythburgh] holds under Roger Bigot; 50 acres of land. 2 bordars. Then as now I plough on the demesne. And I rouncey, 4 beasts, 4 swine, 50 sheep. Worth $8 \mathrm{~s}$. And of that land Robert of Blythburgh holds 12 acres by way of alms from the King, to wit of the church of Blythburgh, and this the Hundred testifies. To this manor have been added 6 freemen over whom Roger's predecessor had commendation. And they have 50 acres of land. Then as now I plough. I acre of meadow. Worth 4 s.

(At) Bringas [? Bridge ${ }^{84}$ ] Ulsi held T.R.E. as a manor $1 \frac{1}{2}$ carucates of land. Then 2 vilfol. $33 \mathrm{I} b$.

leins. And 8 bordars, and now ro bordars. Then 4 serfs, now I. Then 4 ploughs on the demesne, and now 2. And a third could be made up. Then 2 ploughs belonging to the men, now $1 \frac{1}{2}$ ploughs. Wood(land) for 8 swine. I 8 acres of meadow. 2 mills. I salt-pan. I I swine, and 20 goats. Worth 3 os, now 40 s. And 3 acres of land in Duneuuic [Dunwich] belong to this manor. And the soke is Robert Malet's. Worth 22d. To this manor have been added 4 freemen with 60 acres of land. Then 2 ploughs, now 1. It was worth 8 s. And this Robert de Curcun holds of Roger Bigot. It is 9 furlongs long, and 7 broad. And renders $I \frac{3}{4} d$. in a King's geld. The soke is the King's and the Earl's.

Brantuna [Brampton] Padda held T.R.E. as a manor; now Robert de Curcun holds of $R$. Bigot; 2 carucates of land. Then 4 villeins, now 2. Then 4 bordars, now 6 . Then as now I serf. Then as now 2 ploughs on the demesne. And 2 ploughs belonging to the men. Wood(land) for 6 swine. I acre of meadow. I 4 swine. Four score sheep. Then as now it was worth 40s. And to this manor have been attached $9 \frac{1}{2}$ freemen with 100 acres. Then 5

As A hamlet of Blythburgh.

adjoining Dunwich. 


\section{A HISTORY OF SUFFOLK}

ploughs on the demesne, now 3. Worth I2s. The soke is the King's and the Earl's.

In UlKesala [Uggeshall] Godric (held) as a manor 2 carucates of land. Then as now 5 villeins. Then as now 5 bordars. 3 ploughs belonging to the men, I acre of meadow. Then as now it was worth 20s. And now R. de Curcun holds this under Roger Bigot. And of this land was William Malet seised.

In Holetuna [Holton] Godric a freeman held 30 acres and 2 bordars. Worth 4 s. This Godric the steward (dapifer) holds of Roger Bigot.

(At) Pesenhala [Peasenhall] Norman held as 2 manors 2 carucates of land T.R.E.; the same Norman now holds. Then as now 8 villeins, and 10 bordars, and 2 serfs. And 2 ploughs on fol. 332 .

the demesne. And 5 ploughs belonging to the men. And 4 acres of meadow. Wood(land) for 200 swine. Then it was worth 60 s., now 80 .

In the same (vill) 4 freemen under commendation (had) 40 acres. Then as now $\mathrm{I} \frac{1}{2}$ ploughs. Wood(land) for 8 swine. Worth 6s.

The said Norman (has) the soke of the manor and of 2 of the freemen and the King and the Earl of the other 2.

In Warabetuna [ $]^{85}$ (was) a freewoman T.R.E. over whom Norman had commendation, and she had 100 acres: of them Robert Malet holds 30 acres : and Norman holds the remainder of Roger Bigot as a manor. Then as now 2 villeins, and 2 bordars, and $\mathrm{I}$ serf. And 2 acres of meadow. Then it was worth 8s., now I2s. The King and the Earl (have) the soke.

In Nordhalla [North Hales] Norman now as then holds 6 acres. Valued in Pesehalla [Peasenhall].

In Evelincham [Heveningham] Stanwin a freeman under commendation T.R.E. to Harold, as the Hundred testifies, but he himself alone offers proof by ordeal (juditium), saying that he was the man of Robert Malet's predecessor Edric, held I carucate of land as a manor, now Anskettle holds of Roger. Then as now 6 villeins, and 4 bordars, and 2 serfs. Then 2 ploughs on the demesne, now 1 . Then as now $1 \frac{1}{2}$ ploughs belonging to the men. 3 acres of meadow. Wood(land) for 40 swine. I rouncey, 4 beasts, and 10 swine. Then 16 sheep, now 22. Then it was worth 40 s., now 20s. It is half a league long and 4 furlongs broad. And (pays) $4 \frac{1}{2} d$. in geld.

$$
\text { ssee n. 24. }
$$

In Cidestanes [Chediston] Godwin a freeman under the Queen held 55 acres T.R.E. as a manor. Now Robert de Vals (holds). Then as now 2 villeins, and 2 bordars. And I plough on the demesne. And I plough belonging to the men. And $\mathrm{I} \frac{1}{2}$ acres of meadow. Wood(land) for 30 swine. And 2 beasts, 12 swine, and 20 sheep. Worth IOs.

In Cidestan [Chediston] (was) a freeman Ulsi with 13 acres over whom one who was himself

fol. $33^{2 b}$.

under commendation to Robert Malet's predecessor had half commendation, and the Queen (had) the other half T.R.E.

In the same (vill was) a freeman, Anant by name, with 13 acres in like manner, and another freeman, Ulf, with 13 acres under commendation to the Queen T.R.E.; among them they had then I carucate, now (they have) half a carucate, (and) I acre of meadow. Worth 4s. The King and the Earl (have) the soke.

In the same (vill is) a freeman Edric, over whom Robert Malet's predecessor had half commendation, and the Abbot of Ely the other moiety, T.R.E.; and he has 100 acres as a manor. Then as now 2 villeins, and 5 bordars. Then as now I plough on the demesne. Then 2 ploughs belonging to the men, now I. And 3 acres of meadow. Wood(land) for 60 swine. And I beast, 4 swine, 22 sheep, and 7 goats. And five parts of a church with 16 acres. Then as now worth 30 s. Of this was William Malet seised when he went on the King's service (to the place) where he died.

In the same (vill were) 2 freemen, Ledman and Stavard. And they were under commendation to the King and Queen T.R.E., with 30 acres as a manor and I bordar. Then I plough. Wood(land) for 20 swine. I acre of meadow. Worth 5 s.

In the same (vill) a freeman Leuric (held) 26 acres as a manor T.R.E., over whom Baignard's predecessor had commendation. Then as now I villein, and 2 bordars. And I plough. And 3 acres of meadow. Wood(land) for 12 swine. And 2 beasts, 4 swine, and 20 sheep. Worth IOS.

In the same (vill was) a freeman Couta with I 5 acres, over whom Robert Malet's predecessor had commendation. Then half a plough. Worth 2s. William Malet was seised thereof.

In the same (vill was) a freeman, Lewin by name, with 14 acres, over whom Robert Malet's predecessor had commendation, and William (Malet) his father was seised. Then half a plough. Worth 2s. and $4 d$.

All this Robert de Vals holds. Over it all the King and the Earl (have) the soke. It is I league long, and 5 furlongs broad. And (pays). $5 \frac{1}{2} d$. in geld. 


\section{THE HOLDERS OF LANDS}

fol. 333 .

In TORP [Thorpe] (was) a freeman Ulmar under Robert Malet's predecessor with 20 acres as a manor. Then I plough. Wood(land) for 6 swine. Worth $40 d$. William Malet also his father was seised.

In HALEURDa [Halesworth] Gunner a freeman under commendation to the predecessor of Robert Malet, whose father was seised, (held) 15 acres as a manor, and 2 bordars. Then as now half a plough. And half an acre of meadow. Worth 3s. All this Robert de Vals holds. The King and the Earl (have) the soke.

(At) IoKesfort [Yoxford] Norman the thegn held T.R.E. as a manor 100 acres; now Hugh de Corbun holds. Then as now 4 villeins, and 7 bordars, and 1 serf. Then 3 ploughs on the demesne, now 2. Then 3 ploughs belonging to the men, now 2. And 5 acres of meadow. Then 3 rounceys, now 2. Now 7 beasts, 5 swine, and 12 sheep. Then as now worth 40 s.

In the same (vill) 5 freemen have been added over whom the said Norman had commendation T.R.E. with 14 acres and half a plough. Worth 2 s.

The said Norman had soke over it all.

There have also been added 2 freemen from the King's soke, to wit Algar and Edwin, under commendation to Ailward the King's reeve T.R.E., with 7 acres and 2 oxen. Worth $15 d$.

In Bulecampe [Bulcamp ${ }^{88}$ ] Ala a freeman under commendation to Manni, predecessor of Robert de Todeni, held T.R.E. 4 score and 10 acres as a manor. Then as now 2 villeins. $3 \frac{1}{2}$ bordars. And I plough on the demesne. And I plough belonging to the men. 3 acres of meadow. Wood(land) for 100 swine and 12 swine; 12 sheep, 40 goats. Worth 15 s. This Robert de Vals holds of Roger Bigot. It is I league long, and half a league broad. And in geld (pays) $1 \frac{1}{4} d$. And this land Earl Ralph held on the day on which he made forfeiture. Now Roger Bigot holds it of the King's gift as he says; and Robert de Vals holds of him.

And in Pesehealle [Peasenhall] Ranulf son fol. 3336 .

of $W_{\text {alter }}$ has 3 villeins and $x$ bordar with 60 acres of land. Then as now 2 ploughs belonging to the men. Wood(land) for 40 swine. And this land belongs to (jacet in) Sasmundeham [Saxmundham]. The King and the Earl (have) the soke.

In Cnotesheala [Knoddishall] Ranulf son of Walter holds of Roger Bigot 4 score acres of land, and it is a berewick of Sasmundesham [Sax- mundham]. Then as now 3 bordars, and 1 villein. And they have among them 2 ploughs. And Robert Malet (has) the soke.

In Stoune [Stoven] (were) 2 treemen, Langabein and Goda, under commendation to Godwin son of Tuka T.R.E. with 14 acres of land, and 2 bordars and half a plough. Worth 2 s. The King and the Earl (have) the soke.

\section{FREEMEN UNDER ROGER BIGOT}

\section{In Blidinga [Blything] Hundret}

In Holetuna [Holton] Alwin a freeman held I carucate of land, over whom Edric of Laxfield had commendation. Then as now I villein, and 3 bordars. And I plough. Wood(land) for 3 swine. Worth 12s. The King and the Earl (have) the soke. And this Robert de Curcun holds of Roger Bigot.

In Cokelei [Cookley] Godric a freeman held 30 acres; and Wlsin Roger Bigot's predecessor had the third part of the commendation, and Wlsin's two brothers had two parts of the commendation. Then as now 2 bordars. And I plough. 2 acres of meadow. Wood(land) for 7 swine. Worth 4s. The King and the Earl (have) the soke. And this Robert de Vals holds of Roger Bigot.

In Norhhala [North Hales] a freeman by name Harding held 20 acres under commendation to Ulketel, predecessor of William de Warenne. Then as now half a plough. And I bordar. Worth $3^{\text {s. }}$ The King and the Earl (have) the soke.

In THORPE [Thorpe] Wlmer a freeman held 50 acres as a manor, over whom William Malet's predecessor had commendation, and the said William was himself seised. Then as now I plough on the demesne. And 4 bordars. And half a plough belonging to the men. Wood(land) for 12 swine. Half an acre of meadow. It was worth I6s. Roger Bigot (has) the soke. And to this manor belong 2 acres in Duneuuic [Dunwich] to (complete) the said valuation. And Robert Malet has soke over these 2 acres.

In Hrueniggenam [Heveningham] Ulfketel a freeman held 24 acres, over whom Ulf had commendation. Then as now 2 bordars. And I plough. Wood(land) for 8 swine, Half an acre of meadow. And the fourth part of a church with $1 \frac{1}{2}$ acres. It was worth 8 s. The King and the Earl (have) the soke.

In Uurabetuna [ $\quad]^{87}$ Mansunu a freeman held 12 acres, over whom Norman had 


\section{A HISTORY OF SUFFOLK}

commendation. Then as now half a plough. And 1 bordar. And an acre of meadow. And a church with 6 acres. It was worth $40 d$. The King and the Earl (have) the soke.

In the same vill $4 \frac{1}{2}$ freemen held 40 acres. Then as now I plough. 2 acres of meadow. Wood(land) for 6 swine. Worth 12s. The King and the Earl (have) the soke.

In Opituna [

]$^{88}$ Bond a freeman held 60 acres as a manor, over whom Toli had commendation. Then 3 bordars, now none. Then I plough on the demesne. And half a plough belonging to the men, now I plough. And 2 acres of meadow. Wood(land) for 2 swine. Then as now it was worth 16 s. The King and the Earl (have) the soke. And half a church with 4 acres and half an acre (of meadow), worth 3 d.

In FORLEI [Fordley ${ }^{89}$ ] 15 freemen held 115 acres of land. And of these 15 Norman had commendation over 13. And over 2 the predecessor of Robert Malet had half commendation, and Norman half. Half a bordar. Then as now $4 \frac{1}{2}$ ploughs. 2 acres of meadow. Then as now it was worth 24s. The King and the Earl (have) the soke.

In Mideltuna [Middleton] $\mathrm{Li}_{\text {i }}$ ic the deacon, a half freeman, held 3 acres, over whom Toli the Sheriff had a moiety of the commendation. Worth I2d. The King and the Earl (have) the soke.

In Milsemere [Minsmer] (were) 4 freemen with 45 acres. But 3 were under commendation to Norman and the fourth under commendation to one himself under commendation to Norman. Then as now I plough. Worth I3s. and $4 d$. The King and the Earl (have) the soke.

In Cnotesheale [Knoddishall] (was) a freeman with 30 acres, Boti by name; he was King Edward's man; then as now I plough. Worth 8s. And Robert Malet has soke, and fol. $334 b$.

William Malet was seised on the day of his death.

In Forlex [Fordley] (are) 20 acres which belong to Chylesheala [Kelsale] and are included in the same valuation. And in STYkelande [Stickland] ${ }^{90}$ (are) 9 acres which belong to the same (vill).

In Diresham [Darsham] Ansketil the priest holds I carucate of land which did belong (fuit) to 7 freemen. Of these 7 men I was Toli's

88 See above, n. 62 .

${ }^{89}$ In Middleton.

${ }^{20}$ In Yoxford; see Cal. of Chart. in B.M. man. Then 2 bordars, now II. Then half a plough on the demesne, now I plough. And then as now 2 ploughs belonging to the men. Leuric Cobbe, over whom Agelward the King's reeve had a moiety of the commendation. And Turketel, over whom the said Agelward had half commendation. And Alnoth, Norman the Sheriff's man. And Brumanbeard, half Norman's and half Brimer's man. And Wluric the deacon, the man of Godwin son of Algar. And Hosmund, Edric of Laxfield's man.

And (there are) I 6 acres and 1 rood which Alviva a freewoman held T.R.E. over whom Norman had commendation. And 24 acres less I rood which Blakeman held T.R.E. and the said Blakeman was Edric of Laxfield's man; and William Malet was seised on the day of his death.

And all this Ansketil Roger Bigot's chaplain holds. Worth 25s. And of this land Robert Malet claims 6 acres, which a certain man of his gave with his daughter whom a man of Roger Bigot's married in King William's time. And Alnoth holds 24 acres in the manor of Kireshala [Kelsale]. Worth 5s., and they are included in the same valuation. The King and the Earl (have) the soke.

STIKRLANDE [Stickland ${ }^{90}$ ] Suartling a freeman held T.R.E., now Cus and Akile Sufreint 2 freemen hold of Roger Bigot; 80 acres as a manor. Then as now I plough on the demesne. And 6 bordars. And I plough belonging to the men. 2 acres of meadow. 4 beasts, 8 swine, 24 goats. Then as now it was worth 16 . And this land is I league long, and 5 furlongs broad, whoever holds the land there. And (it pays) $7 \frac{1}{2} d$. in geld. The King and the Earl have) the soke.

In the same vill (are) 5 freemen who were Ulf's men: Gode, Alfwin his brother, Aluric son of Bund, Osketel, Bunde the smith. Those 5 hold 60 acres. Then as now I bordar.

fol. 335 .

Then as now 2 ploughs. 2 acres of meadow. And (there was) I freewoman in the same vill over whom Norman had commendation, and she held 20 acres. Then as now I bordar. Then as now half a plough. One acre of meadow. And (there was) a half freeman with 8 acres of land. And a church with 24 acres, and I acre of meadow. And this was worth 19s. The King and the Earl (have) the soke. Hugh de Curbun holds it of Roger Bigot.

In ToRnintuna [Thorington] Norman holds 30 acres of Roger Bigot, and under him held Alveva a freewoman. A moiety of the commendation was Norman's and a moiety of the commendation was Edric's. Then as now I villein. And half a plough on the demesne. 


\section{THE HOLDERS OF LANDS}

Worth 4s. The King and the Earl (have) the soke.

In Middeltuna [Middleton] the same woman held of him 16 acres and it is under the same commendation. Then as now I plough. Worth 4 . The King and the Earl (have) the soke.

\section{W ANNEFORdA [WangFord] HUNDRET}

Bersham [Barsham] $R$. de Vals holds of Roger Bigot, which Leustan the priest held under Gurth's commendation T.R.E.; 35 acres as a manor. Then 2 bordars, now $x$. Then as now I plough. Wood(land) for 20 swine. 2 acres of meadow. Then worth 55., now 10 s. It is $I_{\frac{1}{2}}$ leagues long and half (a league) broad, And in geld (pays) $30 d$. Half a church with 20 acres, worth $3^{\text {s. }}$

In the same vill 12 freemen under the same Gurth's commendation-except 2, and of these I was under Haldein's commendation and the other was under Aluric's commendation-(held) 80 acres of land and 3 bordars. Then as now 2 ploughs. I acre of meadow. Wood(land) for 4 swine. Then worth ros., now 20 s.

In Ringesfella [Ringsfield] 8 freemen under Leustan's commendation, except 2, of whom one was under Ulchetil's commendation and the other under commendation of Ulsi of Mutford, held 76 acres. Then 2 ploughs, now 1 . Wood(land) for 6 swine. I acre of meadow. Then worth IOs., now 17 s.

At Willngaham [Willingham] Gunnulf held T.R.E. under commendation to Burchard 30 acres as a manor. Then 1 villein, and 3 bordars, now the like. Then I plough, and now. And I plough belonging to the men. Wood(land) for 10 swine. $1 \frac{1}{2}$ acres of meadow. Then as now 2 beasts, 8 swine, 20 sheep and fol. 335 .

20 goats. Then worth IOS., now 20s. It is I league long, and I (league) broad. And (pays) $5 d$. in geld.

In the same (vill) 5 freemen under the said Burchard's commendation (held) 80 acres of land. Then as now I villein. And I bordar. Then 25 now 2 ploughs. Wood(land) for ro swine. 1 acre of meadow. Then worth 10s., now 20s.

In Westuna [Weston] 5 freemen under Burchard's commendation T.R.E. (held) 18 acres of land. Then as now I plough. And they are in the valuation of the 20 s. above.

In ELGA [Ellough] 2 freemen under the said (Burchard's) commendation (held) 7 acres and half a plough. Worth $36 d$. Of all this Earl Ralph was seised when he made forfeiture; but Roger Bigot holds it of the King's gift; now $R$. de Vals holds it of him.
In Bersham [Barsham] 3 freemen under commendation to the King (held) $32 \frac{1}{2}$ acres. Then I plough, now $1 \frac{1}{2}$ ploughs. 4 acres of meadow. Half a mill. And I villein, and 5 bordars. And then as now a plough. Then worth 5s., now ros. And the said R. (de Vals) holds it.

In ELGA [Ellough] (is) I villein with 10 acres and he belongs to Mutford [Mutford].

(At) Scadenafella [Shadingfield] Godwin son of Tuka under Gurth's commendation T.R.E. held and holds $x$ carucate of land as a manor. Then as now 5 bordars, and 3 serfs. Then I plough on the demesne. Now $I \frac{1}{2}$ ploughs. And belonging to the men then and now I plough. Wood(land) for 12 swine. 1 acre of meadow. And 1 rouncey, and 20 sheep. Then worth Ios., now 20s. It is I league long and half a league broad. And in geld (pays) $5 d$.

In ScIPMETDUA [Shipmeadow] I freeman under Aluric's commendation T.R.E. (held) 10 acres and half a plough. I acre of meadow. Then worth $3^{\text {s., now }} 4$ s. This Godwin holds of Roger Bigot.

In Westuna [Weston] 3 freemen, of whom one, Ketel, was under Aluric's commendation, (held) 30 acres. And the other two (had) 6 acres under him. Then as now 1 villein, and 5 bordars. Then as now I plough. Wood(land) for 6 swine. I acre of meadow. Then worth Ios., and afterwards (this) was set to farm at 40s, now it renders 30 s. And R. de Vals holds.

fol. 336 .

In Dersham [Darsham] a freeman under Ulsi's commendation (held) 15 acres, worth 3 s.

In the same (vill) a freeman under Haldein's commendation (held) 5 acres, worth $12 d$. This R. de Vals holds of Roger Bigot.

In Redesham [Redisham] Robert de Curcun holds of Roger Bigot a freeman Godwin under Stigand's commendation with 60 acres as a manor. Then as now 2 villeins, and 2 bordars. Then as now on the demesne 1 plough. And belonging to the men half a plough. Wood(land) for 4 swine. Then worth IOs, and afterwards 40 s., now 30 s. And a freeman under him (had) 4 acres, worth $8 d$.

In Scadena [Shadingfield] a freeman under Ulsi's commendation (held) 8 acres, and they are valued with Briges [Bridge].91

\section{Ludinga [Lothingland] Hundret}

In Wimundahala [ ] are 24 acres and they belong to Westuna [Weston].

"Adjoining Dunwich. 


\section{A HISTORY OF SUFFOLK}

\section{Haif Hundret of Ludingaland [LOTHINGLAND]}

(At) Dunestuna [

] $\mathrm{Ala}$ under commendation to Mannis (?) (held) 45 acres as a manor, and half a bordar. Then as now half a plough. Wood(land) for 4 swine. Half an acre of meadow. Then worth ros., now $3^{\text {s. }}$ This R. de Vals holds of Roger Bigot.

\section{Stou [Stow] Hundret}

In Bukessalla [Buxhall] a freeman under Saint Etheldreda T.R.E. by commendation only, in the soke of the Hundred, held 40 acres of land. Then and afterwards I plough, now none. And 5 acres of meadow. Then and afterwards worth 20s, now Ios. This (land) Roger received to make up (ad perficiendum) (the value of) Belham [Baylham] in another Hundred. But the Hundred has seen neither writ nor feoffor (breve nec liberatorem).

\section{Bosemera [Bosmere] Hundret}

(At) Righeshala [Ringshall] Lewin a freeman under commendation to the Abbot of Ely held a carucate of land and 80 acres as a manor T.R.E. Then and afterwards 2 villeins. Now 4 bordars. Then and afterwards I serf. Then 2 ploughs on the demesne, afterwards I, now 2. Then I plough belonging to the men, afterwards and now half a plough. And 4 acres of meadow. Half a church with 15 acres. Then 3 rounceys, now 4 . Then 4 beasts, now 18 . Then 20 swine, now 40 . Then 40 sheep now 100. And now 30 goats. Then it was worth 30s., now 5os.

\section{fol. $336 b$.}

In the same (vill) Grim a freeman held 100 acres as a manor under commendation to the Abbot of Ely T.R.E. Then and afterwards $1 \frac{1}{2}$ ploughs, now none. And 4 acres of meadow. Then as now I rouncey, and 3 beasts. Then it was worth 20s., afterwards and now 30 s. These two manors William de Burnoville holds of Roger. The King and the Earl (have) the soke.

In the same (vill were) 4 freemen; Lewin Roger Bigot's predecessor had commendation over two who were called Frodo and Leuric, and the other two are called Lustuin and Edric, of them he had not the commendation. And they had 50 acres and I plough and I acre of meadow. It was worth 12s. The King and the Earl (have) the soke. The said William (de Burnoville) (now) holds. It is I league long, and half (a league) broad. And (pays) $15 d$. in geld. Others have holdings therein.

In BETEForda [Battisford] a freeman Godric under Harold's commendation held ro acres.
Then as now 2 oxen. And now I bordar. It was worth 20d., now $3^{\text {s. }}$ The same William (now) holds. The King and the Earl (have) the soke.

(At) Beleham [Baylham] Munding a freeman under commendation to the Abbot of Ely held a carucate of land as a manor T.R.E. Now the same William holds of Roger. Then as now I plough. And 2 acres of meadow. And the third part of a mill. And the third part of another mill. And half a church with 12 acres. Then I rouncey, now 2. Then 2 beasts, now 8. Then 20 swine, now 40. Then 20 sheep, now 105. Then it was worth 30 s., now 60s.

In the same (vill) Manstan a freeman under commendation to the Abbot of Ely held 60 acres of land as a manor T.R.E.; now the said William (holds). Then as now half a plough. And I acre of meadow. And the sixth part of a mill. Then and afterwards it was worth 20s, now IOs.

In the same (vill) Uluric a freeman under commendation to Robert Malet's predecessor, Edric to wit, held 60 acres as a manor T.R.E. Now the same William (holds). Then and afterwards half a plough, now none. And I acre of meadow. And the sixth part of a mill. Then and afterwards it was worth 20s., now IOs. The King and the Earl (have) the soke.

In the same (vill were) 20 freemen with 92 acres. None of these were under commendation to Roger's predecessor. Then and afterwards 4 ploughs, now 2. Then it was worth 40s., now 20s. It is I league long and 8 furlongs broad. And (pays) $15 d$. in geld. All this William de Burnolville holds. The King and the Earl (have) the soke.

fol. 337 .

In Sumersam [Somersham] a freeman, Lefsune, under commendation to Leuric Hobbesune, Bigot's predecessor, held 30 acres as a manor T.R.E. Now the said William (holds it) of Bigot as a manor. Then as now I villein. Then and afterwards half a plough, now 2 oxen. (There is) the fourth part of a church with $7 \frac{1}{2}$ acres. Worth 8s. The King and the Earl (have) the soke.

(At) Offetuna [Offton] Lefficilt, a freeman under commendation to Stigand, held 2 carucates of land as a manor; now Hugh de Hosdenc (holds) of Bigot. Then and afterwards 2 villeins, now 1 . Then as now 7 bordars, and 2 serfs. Then 2 ploughs, afterwards I, now none. I acre of meadow. Then half a plough, now I plough. Then I rouncey, 2 beasts, 12 swine, and 40 sheep, now none. Then as now it was worth 60 s. A church with 16 acres, worth $33 d$. Stigand (had) the soke.

In the same (vill) the said Hugh (holds) of Roger Bigot ro freemen. Of these one and a 


\section{THE HOLDERS OF LANDS}

half, Blacsun who'ly and Aldwin half, were under commendation to Bigot's predecessor; from the others he had nothing ; and they used to have $I \frac{1}{2}$ acres of land; and the others had I carucate of land and 4 acres. Then 3 ploughs, afterwards and now 2 ploughs. One of these, Blacuin by name, had 40 acres of the same land. Then it was worth 30 s., now 20s. The King and the Earl (have) the soke. It is I league long and 5 furlongs broad. And (pays) $6 \frac{1}{2} d$. in geld.

In Belham [Baylham] Wistric, a freeman under commendation to the Abbot of Ely, held 120 acres of land as a manor T.R.E. Now Ulmar (holds) of Bigot. Then as now 7 bordars. And I plough on the demesne. And I plough belonging to the men. 4 acres of meadow. Now I mill. Then as now I rouncey. Then 2 beasts, now 5. Then 7 sheep, now 30. Then it was worth 20s., now 35s. The King and the Earl (have) the soke.

In the same (vill were) 6 freemen with 20 acres less half an acre. Over them Wistric had fol. $337 b$.

only the commendation. Worth 5 s. The same Ulmar holds. The King and the Earl (have) the soke.

In Flochrtuna [Flowton] (was) a freeman Bruncart by name, (of whom) Lefcilt had the commendation T.R.E., with 10 acres. Worth 2s. Hugh de Hosdenc (now) holds.

In BeLham [Baylham] Warenger holds of Roger Bigot a freeman, by name Brun, (who was) reeve of Gypeswiz [Ipswich] and under commendation to the Queen, and he has I7 acres. This belongs to (jacet in) Stanham [Stonham] and is included in its valuation. The King and the Earl (have) the soke.

At Sтанам [Stonham] the said Brun held as a manor 60 acres T.R.E. Now Warengar holds of Roger. Then 2 ploughs, afterwards I, now 2. And 2 acres of meadow. Wood(land) for 80 swine, now for 40 . Now 8 beasts. Then 10 swine, now 35 , and 80 sheep, and 23 goats. A share (quedam pars) of a mill. Then it was worth 20s., now 40s.

In the same (vill) were 5 freemen with 16 acres, over whom the aforesaid Brun had commendation. Then 1 plough, now half a plough. Worth 3s. The King and the Earl (have) the soke.

In the same (vill) I 7 freemen have been added to this manor in King William's time, from whom Roger Bigot's predecessor had nothing. These freemen Roger de Ramis claims to have held as of his fee before Roger Bigot had received lands in Suffolk. But the Hundred witnesses that Roger Bigot received them first as of his fee. And to this Roger de Ramis offers denial by every kind of lawful procedure (contradicit omni $\log e$ ). And they have 69 acres. Of these 5 were under commendation to the predecessor of Ranulf Peverel (piperelli), that is to say to Saxo. Then and afterwards 6 ploughs, now 3 . And $1 \frac{1}{2}$ acres of meadow. Worth 16 s. The King and the Earl (have) the soke.

In Belham [Baylham] (were) 3 freemen. Over one who is called Ulbold Roger Bigot's predecessor, that is, Brun, had commendation, and over two, that is to say Lestan (sic) he had nothing; but the predecessor of Ranulf Peverel had the commendation. All together they had fol. $33^{8}$.

12 acres. Worth 2s. Garengar holds of Roger. The King and the Earl (have) the soke.

In LANGHEDENA [ ] (was) a freeman Aluric by name under commendation to Brun, Bigot's predecessor, having 10 acres, and 2 oxen. Worth 2s. The same (Garengar holds) of Roger. The King and the Earl (have) the soke.

Codenham [Coddenham] the said Garengar holds of Roger Bigot, which Wicolf a freeman held, viz. 76 acres as a manor, (Wicolf was) under commendation to Toli the Sheriff T.R.E. Then as now $I \frac{1}{2}$ villeins, and 3 bordars. Then 2 serfs. Then and afterwards 2 ploughs on the demesne, now I. Then and afterwards 2 oxen belonging to the men, now none. And 4 acres of meadow. Then wood(land) for 30 swine, now 10 . Then half a mill, but Hardwin, Earl Ralph's brother, took it away in King William's time. Half a church with $2 \frac{1}{2}$ acres of land. Then as now it was worth $36 \mathrm{~s}$. A church with I $2 \frac{1}{2}$ acres (worth) 25d. Another church with 8 acres, worth r6d. The King and the Earl (have) the soke.

In the same (vill was) a freeman Wailoff under commendation to the Abbot of Ely having 36 acres as a manor T.R.E. And the same Garengar holds (this). Then half a villein. Then and afterwards I plough, now none. And 4 acres of meadow. Then wood(land) for 30 swine, now for 10 . Then as now it was worth 15s. The King and the Earl (have) the soke.

In the same (vill are) 27 freemen with 75 acres. Of these 12 were under commendation to Wicolf, Roger Bigot's predecessor, T.R.E., and from the others he had nothing. And the same Garenger holds this. Then and afterwards 3 ploughs, now 2. I acre of meadow. Then it was worth 16 s, now 20s. and $6 d$.

In Hamingrstuna [Hemingstone] (was) a freeman with 5 acres, which the said Garenger holds, Farman by name, under commendation to Wicolf. Worth rod. The King and the Earl (have) the soke. All Wicolf's land and all these 


\section{A HISTORY}

freemen, whom Warenger holds of Roger Bigot, Roger de Ramis claims, and he said that fol. 3386 .

livery thereof was made to him before Roger Bigot; and the Hundred cannot say the truth of this; because that Garenger held of each of them : but however that $W$ arenger vouches (the holding to belong) to Roger Bigot's fee ; and Roger de Ramis offers to deny this by all kinds of lawful procedure (omnibus legibus).

Codeham [Coddenham] is I league long, and 8 furlongs broad. And (pays) 20d. in geld.

\section{Plumesgate [Plomesgate] Hundret}

At Saxmondeham [Saxmundham] T.R.E. Norman held 140 acres as a manor. Then as now 2 villeins, and 3 bordars. And 2 ploughs on the demesne. And 2 ploughs belonging to the men. And 3 acres of meadow. A church with 15 acres. Worth 30s. The said Norman has the soke, and holds this of Roger. This (is) one manor of three which the King gave back to Norman, and now he holds it of Roger.

At Samundeham [Saxmundham] Algar King Edward's thegn held as a manor T.R.E. 2 carucates of land and 40 acres. Then as now 5 villeins, and 10 bordars. Then 3 serfs, now 1 . Then as now 3 ploughs on the demesne. Then 3 ploughs belonging to the men, afterwards and now $2 \frac{1}{2}$ ploughs. 5 acres of meadow. 2 churches with 24 acres and half a plough. Then as now 2 rounceys. Then 3 beasts. Then 16 swine, now 30 . Then as now 80 sheep. And (there is) a berewick Chenotessala [Knoddishall] with 80 acres and it is in another hundred. And (there is) another berewick Pesenala [Peasenhall] with 60 acres in another hundred. The whole was then worth 7 li., and it was set to farm for gli. and IOs.; now it is valued at 7 li. Ranulf holds (it) of Roger. The soke (is) the Abbot's.

In the same (vill) 7 freemen (have been) added to this manor (who were formerly) under commendation to Algar, with 48 acres. One, Ulnod by name, was under commendation of Malet's predecessor. The same Ranulf now holds. Then and afterwards $3 \ldots$ now 2. And 4 acres of meadow. Then it was worth ros. and $4 d$, now 10s. The soke (is) the Abbot's.

In BeCcLinga [

] a sokeman (holds) 20 acres, and he belongs to CHeressala [Kelfol. 339 .

sale] and is worth 2s. And Ranulf holds this in demesne. 'The soke (is) the Abbot's.

At Burgsiart [Bruisyard] Uluric under commendation to Harold held 80 acres as a manor T.R.E., and 4 bordars. Then and afterwards $1 \frac{1}{2}$ ploughs on the demesne, now 1 plough. And half a plough belonging to the men. And 4 acres of meadow. Wood(land) for 40 swine. Then I rouncey. Then 3 beasts. Then 4 swine, now 20. And 24 sheep. Then 6 goats, now 12 . Then it was worth 20s., now 30 s. Ralph de Turlaville holds of Roger.

In Saxmondeham [Saxmundham] are 30 acres, and they belong to Cheresala [Kelsale] demesne.

\section{Hertesmera [Hartismere] Hundret}

(At) Brom [Brome] Goda a freewoman held T.R.E. under commendation toStigand 2 carucates of land as a manor, one in Brom [Brome] and the other in Acle [Oakley]. Then as now I villein, and $\eta$ bordars. Then I serf. Then as now on the demesne 2 ploughs. And half a plough belonging to the men. 8 acres of meadow. And I rouncey, 10 swine, and 40 sheep. Then worth 30 s., now 6 Is. And half a church with $I_{4}$ acres worth $2 s$.

In the same (vill) 25 freemen and 3 half freemen under commendation of the said (Stigand) (held) 4 score and 16 acres. And 2 acres of meadow. Then 3 ploughs, now $1 \frac{1}{2}$ ploughs. Then it was worth 30 s, now 20s. This William Scutet holds of Roger Bigot. And it is 5 furlongs long and 4 broad. And in geld (pays) $3 \frac{1}{2} d$.

In the same (vill) Hugh holds of Roger Bigot I freeman Aluric under Gurth's commendation T.R.E. with 60 acres as a manor. Then as now 3 bordars. Then as now on the demesne I plough. Then and now half a plough belonging to the men. 3 acres of meadow. Then as now it was worth IOs. And a freeman under commendation to Aluric (held) 8 acres, worth $16 d$. The wife of this freeman was under commendation to Robert Malet's predecessor. This Hugh de Corbun holds of Roger Bigot.

\section{fol. $339 b$.}

\section{Hundret of Colenese [Colneis]}

At W aletuna [Walton] Norman held T.R.E. and now he holds under Roger 2 carucates of land as a manor. Then 14 villeins, now 6 . Then 6 bordars, and now the like. Then on the demesne 2 ploughs, and now $2 \frac{1}{2}$. Then as now 2 ploughs belonging to the men. 4 acres of meadow. And now I mill. A church with 8 acres, worth $16 d$. Then a fishery, now none. And 6 rounceys, 26 swine, and 140 sheep.

To this manor (belongs) Faltenham [Falkenham] as a berewick, 1 carucate of land. Then as now 3 bordars. And I plough on the demesne. And half a plough belonging to the men. 2 acres of meadow. And I rouncey, and 


\section{THE HOLDERS OF LANDS}

80 sheep. The whole together was then as now worth $6 \%$. It is half a league long, and 4 furlongs broad. And (pays) I 2d. in geld.

In the same (vill) were 15 freemen under commendation, Godric the smith, and Edric, and Ulnot, and Osulf, and Uluric, and Stanmar, and Leviet, and Wihtric, and Blacheman, and Mansuna, and Lewin, and Ulmar, and Ulfah and another Ulfah, and Leofstan with 40 acres; and they have 2 ploughs. Worth 10 .

\section{Freemen. In Buregata [} same Norman held T.R.E. I 3 freemen. They are freemen under Roger Bigot. Godric, and Sereman, and Suan, and Leofric, and Morcar, and Swetman, and Sprot, and Godric, and another Godric, and Ulmar, and Aluric Stikestac, and Coleman, and Godric the tall (longus), and Siwert, with 80 acres of land; and under them 6 bordars. Then as now among them 3 ploughs. One acre of meadow. Worth 30 . It is half a league long, and 4 furlongs broad. And in geld (pays) 20d. Of these I was half a freeman under Edric, and he was called Aluric Stikestac.

In Colanss [Colneis] Hundred there is a certain pasture common to all the men of the Hundred.

In Maistana [

] the same Norman held T.R.E. 6 freemen under commendation with 100 acres of land. Edric, Burchric, and Wlbald, and Aluric, and Almar, and Wluric. fol. 340 .

And 1 villein with 4 acres. And 4 bordars. Then as now among them 3 ploughs. 2 acres of meadow. Worth 20s. And of these Alfah father of Wlbald was a man half under Edric, Robert Malet's predecessor. It is half a league long, and 2 furlongs broad. And (pays) $4 d$. in geld.

In Burch [ ] the same Norman held T.R.E. 16 freemen under commendation Leveric, and Swetman, Godric, and Brihtric, and Almar, and another Almar, and Brihtnoth, and Leveric, and Thoka, and Godric, and another Godrich, and Norman, and Goda, and Lunden, and Aldolf, and Coleman, with I carucate of land, and 6 bordars. They belong to Waletuna [Walton]. And 4 ploughs among them. 2 acres of meadow. Worth 4Os. It is half a league long, and 2 furlongs broad. And (pays) in geld 22d. A church with 12 acres. Worth $2 s$.

In Gulpelza [Gulper " ${ }^{2}$ (were) 5 freemen under commendation to Norman T.R.E. with 40 acres of land, and 2 ploughs, I acre of meadow. Worth 5s. It is 2 furlongs long, and 2 broad. And in geld (pays) $3 d$.

$$
\text { n Gulper Hall in Walton. }
$$

And in Wadgata [Wadgate ${ }^{93}$ ] (were) 5 freemen under commendation to Norman; Leuric, and Moregrim, and Aldulf, and Goda, and Godwin with 20 acres. Then as now I plough. Half an acre of meadow. Worth $4^{\text {s. }}$. It is 2 furlongs long, and 2 broad. And (pays) $2 d$. in geld.

In TuRstanestuna [ ] (were) 3 freemen under commendation to Norman; Ernet, and Wihtric and Almar with 15 acres and I plough, half an acre of meadow. Worth

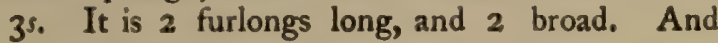
in geld (pays) $4 d$.

In Nortuna [

] were 4 freemen under commendation to Norman; Mansura, and Wihtmar, and Durand, and Otti with $3 \mathbf{r}$ acres, and I bordar, and I plough, and I acre of meadow. Worth Ios. It is 6 furlongs long, and 2 broad. And (pays) $12 d$. in geld.

In Plugtard [ $\quad]^{94}$ (were) 6 freemen under commendation to Norman with 30 acres; Osfert, and Alwin, and Ulmar, and Ednoth and Godric, and Hardecnot, and under them fol. $340 b$.

(were) 4 bordars. T.R.E. 2 ploughs, now I. Half an acre of meadow. Worth 4 s. It is 2 furlongs long and 2 broad. And in geld (pays) $4 d$.

In Faltenham [Falkenham] (were) 4 freemen, Leuric, Suneman, Manesuna, Leofstan, under Norman by half their commendation, and the other moiety belongs to Ralph de Turlaville, (with) 30 acres, and I bordar and 2 ploughs, (and) I acre of meadow. Worth 5s. It is half a league long, and 4 furlongs broad. And in geld (pays) $22 \frac{1}{2} d$.

In KIRKETUNA [Kirton] (were) 3 freemen under commendation to Norman; Grim, and Brihtric, and Stanmar (with) 20 acres, and a bordar and a plough. Worth $3^{\text {s. It }}$ is 2 furlongs long, and 2 broad. And in geld (pays) $2 d$.

In Struustuna [ ] (was) a freeman under Norman, called Uluric, with 16 acres and I bordar, and half a plough, (and) half an acre of meadow. Worth 2s. It is 5 furlongs long, and 2 broad. And in geld (pays) $6 \frac{1}{2} d$.

In Guthestuna [ ] were 6 freemen under commendation to Norman; Grim, Moregrim, Goding, and Leofstan, Ulmar, Goding, and 7 bordars, with 40 acres, 2 ploughs (and) 1 acre of meadow. Worth 5s. It is 2 furlongs long, and 2 broad. And (pays) $3 d$. in geld.

In Felixstowe.

" Called 'Plumgeard' below (fol. $385 b$ ), and 'Plumgar' in Ing. El. 158. Occurs at a later date as 'Plomesyard'; Copinger, Suff. Rec. 


\section{A HISTORY OF SUFFOLK}

In Mothestuna [Moston] ${ }^{95}$ (were) 3 freemen under commendation to Norman; Godman, Leofsuna, Goddua, (with) 50 acres, I villein and 3 borders and $I \frac{1}{2}$ ploughs, $I$ acre of meadow. Worth $8 \mathrm{~s}$. It is 5 furlongs long, and 2 broad. And (pays) $4 d$. in geld. Two were men half under Edric.

In Helmelea [Hemley] (were) 2 freemen under commendation, Osfert and Godric, (with) 20 acres, and 2 bordars, and half a plough, (and) I acre of meadow. Worth $3^{5}$. and $4 d$. It is 4 furlongs in length and 3 in breadth. And (pays) $4 d$. in geld.

In Kenebroc [Kembrook] (were) 5 freemen under Norman ; Siwold, and Wlwin, and Ordric, and Godwin, and Spretman, with 30 acres, and 4 bordars and I $\frac{1}{2}$ ploughs (and) I acre of meadow. fol. $34 \mathrm{I}$.

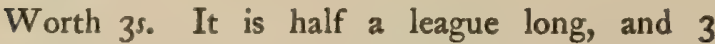
furlongs broad. And (pays) $10 d$. in geld. Others hold land therein.

In Leofstanestuna [ ]$^{86}$ (were) 2 freemen under Norman, Leofstan, and Stanfled, with 6 acres. Worth $12 d$. It is 3 furlongs long, and 3 broad. And (pays) $6 d$. in geld.

In Leuetuna [Levington] (was) a freeman under Norman, Leuric, with 4 acres. Worth $8 d$. It is 4 furlongs long, and 2 broad. And (pays) $4 d$. in geld.

In Candelenta [Candelent ${ }^{97}$ ] (was) a freeman Brihtric with 3 acres. Worth $6 d$. It is I furlong long, and I furlong broad. And (pays) $2 d$. in geld.

In Alteinestuna [Alteston ${ }^{98}$ ] (were) 2 freemen with II acres, Turbin and Ulwin. Worth 22d. A church with 5 acres of free land; worth $16 d$. It is 6 furlongs long and 2 broad. And (pays) $7 d$. in geld. Others hold (land) in these manors. These are all freemen under Roger Bigot, and Norman holds them of him.

(At) Tremlega [Trimley] Godric under commendation to Norman T.R.E. held 50 acres of land as a manor. Now Thorold (holds) of Roger Bigot. 3 bordars. And I plough. 2 acres of meadow. And a freeman Leuric under him holds 4 acres. And (the manor) renders 35 s. A church with 20 acres worth $40 d$. It is 4 furlongs long and 3 broad. And (pays) $4 d$. in geld. A church with 8 acres, worth $8 d$. Others hold (land) therein.

${ }^{95}$ In Trimley St. Martin.

"Occurs later as 'Lestaneston': Cal. Chart. $R$., ii, 331 .

${ }_{97}$ Candlets Farm in Trimley St. Mary.

${ }^{93}$ See n. 21.
In Faltenham [Falkenham] Edric under commendation to Norman T.R.E. held I carucate of land as a manor, now Ralph de Turlaville (holds) of Roger Bigot. Then as now 6 bordars, and $I$ serf. Then as now on the demesne 2 ploughs. 2 acres of meadow. Then 4 rounceys, now 3, 10 swine, and 60 sheep. Worth 30 s. And (there were) $7 \frac{1}{2}$ freemen with 57 acres under commendation to Norman. Then as now 3 ploughs. Brihtmar, and Wlmar, and Godwin, and Ulward, and Godric, and Sweting, and of this Sweting was R. seised, and Leuric Levesun. And they have half an acre of meadow. Worth IOS.

fol. $34 \mathrm{I} b$.

In Grimestuna [Grimston ${ }^{99}$ ] the same Ralph (de Turlaville) holds a freeman (formerly) under Norman with 40 acres, called Blakeman. And under him (are) 7 bordars. One plough. 2 acres of meadow. Worth ros. And (there are) 3 men in the same vill under commendation to Ralph, with 30 acres, Herman, and Kenric and Wlfah. And they have $\mathrm{I} \frac{1}{2}$ ploughs (and) half an acre of meadow. Worth 5s. It is 3 furlongs long, and 3 broad. And in geld (pays) $7 d$. Others hold land therein.

In Langestuna [? Langer ${ }^{80}$ ] (were) $2 \frac{1}{2}$ freemen Wlfah and Turbern and Raven under half commendation to Norman T.R.E. with 30 acres, and I $\frac{1}{2}$ ploughs, (and) half an acre of meadow. Worth IOs. It is 4 furlongs long and 2 broad. And (pays) $4 d$. in geld. And the same Ralph (de Turlaville) holds.

In Alteinestuna [Alteston] the same Ralph holds 3 freemen, Leuric and Almar and Raven, with 30 acres, (formerly) under commendation to Norman. And I bordar. And I plough. Half an acre of meadow. Worth 5 s.

In LANGestuna [ ] (was) a freeman Alnoth the man of Harold T.R.E., now (held by) Bernard of Roger Bigot, (with) 40 acres. I villein and 3 bordars. Then I plough, and now (the same). I acre of meadow. Worth 10s. And a freeman under commendation to Alnot, called Sewin, (with) 4 acres, worth $8 d$.

In Struestuna [ ] (was) a freewoman Durilda under commendation to Norman T.R.E., with 55 acres of land. Now Hugh de Hosden holds of Roger Bigot. 7 bordars. And 1 plough. 2 acres of meadow. Worth 40 s.

In Torpa [Thorpe ${ }^{100}$ ] the said Hugh holds 5 freemen, Ulric, Almar, and another Ulric, Alric, Ketelwa (formerly) under commendation to

${ }^{99}$ In Trimley St. Martin.

92a There is a Langer Common near Felixstowe; ex inf. Mr. C. D. Pridden.

100 In Trimley St. Martin. 


\section{THE HOLDERS OF LANDS}

Norman with 72 acres, and 2 ploughs, (and) 1 acre of meadow. Worth 20s. It is 4 furlongs long, and 2 broad. And (pays) $5 d$. in geld.

In Struestuna [ ] the said Hugh holds 3 freemen (formerly) under Norman, Husteman, Edric, and Goda, with 6 acres, worth $12 d$.

In Leofstanestuna [

]$^{101}$ (were)

2 freemen, Burric and Brihtric, under Norman's commendation, with 20 acres, and I bordar, and I plough, 2 acres of meadow, a mill, and a salt pan. Worth ros. This Wihtmar holds of Roger Bigot.

In Nortuns [ ] the said Wihtmar holds a freeman Aldolf, under Norman's commendation, with 20 acres, and 3 bordars, and I plough, (and) 2 acres of meadow. Worth 5 s.

In Buregata [ ] (was) a freeman Wihtmar under commendation to Godric, with 20 acres, and 4 bordars, (and) I acre of meadow. Worth 5s. The same Wihtmar (now holds).

In the same (vill were) 9 freemen, Aldulf, Aluric, Brihtric, Osgot, Goda, Wihtmar, Bruman, Wiking, Leuric, under Norman's commendation, with 15 acres, and I plough. Worth 3s.

In WADGATA [Wadgate] the said Wihtmar holds 8 freemen, Langfer, Fegar, Brumar, Goda, Edward, Godric, Aldolf, Osketel, under commendation to Wihtman, and Langfer and Aldolf, under commendation to Norman T.R.E., with 15 acres. Then as now I plough. Worth $3^{\text {s. }}$

\section{In Mycelegata [}

] (were) 4 freemen T.R.E., Regifer and Goda under commendation to Norman with 12 acres, and Leovestan and another Goda under commendation to Wihtmar with 4 acres. Then as now among them I plough. One rood (virga) of meadow.

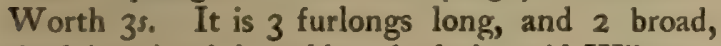
And (pays) 2d. in geld. And the said Wihtmar holds.

\section{In Leofstantestuna [}

] (were) 4 freemen under Norman's commendation T.R.E., Blacheman, and Durand, and Sewin, and Wluric, with 14 acres. Then as now half a plough. Worth $2 s$.

In the same (vill) were 8 freemen under commendation to a certain man of Norman's, Blache-

fol. 3426 .

man, and Brumar, Edric, Leofric, and Alwin, and Wlbald, and Theodric, (and) Leofleda, with 12 acres. Half a plough. Worth 2 s.

In Tremlega [Trimley] (were) 3 freemen, Goda, Hildeuert, Derstan under commendation

$$
{ }^{101} \text { See n. } 96 .
$$

to Norman, and Derstan under commendation to Wihtmar with 6 acres, and half a plough. Worth I2d. The said Wihtmar holds.

In Alteinestuna [Alteston] ${ }^{102}$ the said Wihtman holds I freeman (formerly) under Norman, named Wluric, with 12 acres. Worth $2 s$.

In Kirketuna [Kirton] a freeman, Godric the priest, under commendation T.R.E. to Edric before he made himself an outlaw, and after he made himself an outlaw (Godric) was Norman's man, with 7 acres and $I$ plough and 1 acre of meadow. Worth 3 s.

In the same (vill) is a church with 6 acres, worth 12d. All this Wihtmar holds of Roger Bigot.

In Mothestuna [Moston] (was) a freeman Brihtmar under commendation to Norman T.R.E. with 20 acres, and I bordar, and I plough, and half an acre of meadow. Worth $6 s$. This William de Silva holds of Roger Bigot.

In TORP [Thorpe] the same William holds a bordar with 8 acres. Worth 2 s.

In Leuetuna [Levington] William de Burnoville holds of Roger Bigot Io freemen under commendation to Norman, Godeman, and Leuric, and Brihtric, Gunnere, Wluric, Siwold, Huna, Whita, Godric, with 32 acres. Then as now 2 ploughs. 2 acres of meadow. Worth IOs. A church with 8 acres, worth I2d.

In Kuluertestuna [ ] (were) 7 freemen under commendation to Norman T.R.E., Dering, Godric, Leuric, Algar, Wlvar, Durand, Aluric, with 25 acres. Then as now I plough. One acre of meadow. Two mills, worth 5s. It is 2 furlongs long, and 2 broad. And (pays) $4 d$. in geld.

In Strattuna [Stratton] was a freeman Wihtric, Harold's man T.R.E., with 32 acres as fol. 343 .

a manor. And 3 bordars. And I plough. One acre of meadow. Worth 5 s.

Moreover in the same (vill) were 2 freemen under commendation to Norman, Ulketel and ...., with $3^{8}$ acres as a manor. 2 bordars. Then as now I plough. One acre of meadow. Worth 6s.

In the same (vill was) a freeman under commendation to Norman, Godeman, with 10 acres, and I bordar, and half a plough. Worth 2s. A church with 10 acres, worth $2 s$. It is 6 furlongs long, and 4 furlongs broad. And (pays) in geld $7 d$. Others hold (land) therein.

All this William de Burnoville holds. 


\section{A HISTORY OF SUFFOLK}

In Oxelanda [ ] (were) 5 freemen under commendation to Norman, Blacheman, Osbert, Wihtric, Godric, Brihnoth with 42 acres, and 4 bordars, and 2 ploughs, and half an acre of meadow. Worth 5s. It is 3 furlongs long, and 2 broad. And (pays) in geld $4 d$.

In Kinebroh [Kembrook] (were) 14 freemen (over whom) Norman had commendation, Wihtgar, and Osbert, and Leofstan, Edric, Freowin, Brihtmar, Blacheman, Wlward, Durand, Godric, Siric, Wlvi, Aluric, Almar, Bond, with 73 acres, and 3 ploughs, (and) 3 acres of meadow, and $\mathrm{I} \frac{1}{2}$ mills. Worth I5s. All this William de Burnoville holds under R. Bigot.

The men of the Hundred hold this land to be worth (babent hanc terram pretiata) $48 \mathrm{~s}$. ; but it formerly rendered, and they now render $6 l i$.

In Nortuna [ - ] a freeman, Godwin the priest, Harold's man T.R.E. (held) 50 acres as a manor. Then as now 3 bordars. Then as now on the demesne I plough. And half a plough belonging to the men. Half an acre of meadow. Worth 34s. And 3 freemen under him with 3 acres, and half a plough. Worth fol. $343^{b}$.

12d. This Thurstan son of Wido holds of Roger Bigot.

Over all this land Saint Etheldreda has soke, except over the hall (ballam) of Waletuna [Walton] and the vill(eins).

\section{HUNDRET OF WILEForda [WiLford]}

In Ludham [Loudham] a freeman, Turnold, under Edric's commendation (held) 7 acres and I acre of meadow. Worth $16 d$.

In Horpola [Harpole] a freeman Algar (?) under Stigand's commendation (liber bomo comd" Algari. Stigandi) (held) 10 acres, worth 2 s.

And (them) Ranulf son of Walter holds.

In Debenbeis [Debach] Sturstan son of Widdo holds $I \frac{1}{2}$ freemen (formerly) under Edric's commendation with 8 acres, worth $\mathrm{r} 6 d$.

In Capeles [Capel (St. Andrew)] a freeman under Norman's commendation (held) 20 acres. Then I plough, now half a plough. Half an acre of meadow. Worth 4s. And Norman holds.

In OFFEWORDA [Ufford] a freeman under the said Norman's commendation (held) 3 acres, and in LUDHam [Loudham] 2 acres, worth $12 d$.

In Wileforda [Wilford] a freeman under Norman's commendation (held) 7 acres, and half an acre of meadow. Worth $14 d$. This Norman holds from Roger Bigot.
In BREDEFELLA [Bredfield] a freeman under Norman's commendation (held) $4 \frac{1}{2}$ acres, worth $12 d$.

In WIKHAM [Wickham (Market)] a freeman (held) $2 \frac{1}{2}$ acres, worth $4 d$. This the same Norman holds.

\section{HUNDRET OF LOSA [LOES]}

In Renlesham [Rendlesham] (was) a freeman under Edric's commendation with 18 acres of land and I bordar, worth 2s. and $8 d$. William Malet was seised on the day on which he died.

In Gategraua [Gedgrave] a freeman under Norman's commendation (held) ro acres; and this is included in the valuation of Keleshala [Kelsale].

In Cerfella [Charsfield] Turstan son of Witdo holds a freeman Brihtmar (who was) under Saint Etheldreda's commendation T.R.E. with 30 acres. Then as now I plough. I acre of meadow. Then (this) rendered 3os. And (there were) 5 freemen under the same commendation, except that I was under commendafol. 344 .

tion to Earl Ralph, and he was seised thereof, with 16 acres: and they are included in the same valuation; but they could not render (their share). One of them was under Edric's commendation, and William Malet was seised thereof. Now it is worth 20s. This Thurstan holds of Roger Bigot.

In UDEBRIGA [Woodbridge] a freeman under Aluric's commendation (held) 4 acres, worth $8 d$. And (this) William de Nemore holds.

\section{Plumesgata [Plomesgate] Hundret}

In RINDHAM [Rendham] (is) I bordar with IO acres, worth $20 d$.

\section{FREEMEN UNDER ROGER BIGOT}

\section{Perreham [Parham] Half Hundret}

In Blactheshala [Blaxhall] 8 freemen held 66 acres. Of them 5 were under commendation to Norman and 2 to the Abbot of Ely, and I, Alwin by name, to Malet's predecessor. Then as now $2 \frac{1}{2}$ ploughs. And 4 acres of meadow. Then worth 20 s., now 25 s.

In the same (vill) a half freeman (held) 3 acres, worth $6 d$. The soke is the Abbot of Ely's.

In the same (vill are) 2 acres. And I serf. Worth $8 d$. Norman holds.

In the same (vill) a freeman Ulf under commendation to Norman (held) 10 acres and half 


\section{THE HOLDERS OF LANDS}

a plough. Worth 2s. Norman holds of Roger. The soke is the Abbot's.

In Wantesdana [Wantisden] Aluric Brictric Edilt, freeman under sub-commendation to the predecessor of Bigot, (held) II acres. Worth 2 . The same Norman holds. The soke is the Abbot's.

In the same (vill) the said Norman holds the fourth part of a church with IO acres, which some one under his commendation held T.R.E.

\section{Plumesgata [Plomesgate] Hundret}

(At) Sternesfelda [Sternfield] Leuric under commendation to Norman T.R.E. held 50 acres as a manor. Then as now 3 bordars. And $1 \frac{1}{2}$ ploughs. And I acre of meadow.

And in the same (vill were) 2 freemen under sub-commendation to Norman with 3 acres, worth 20s. Norman holds of Roger. The soke (is) the Abbot's.

fol. $344^{b}$.

This manor William Malet held on the day of his death, and Robert his son (after him).

In Ferneham [Farnham] the same Leuric T.R.E. (held) 20 acres and 3 bordars and half a plough and 4 acres of meadow and I mill. Worth 5s. This also William Malet held and Robert Malet (after him). Now Norman holds of Roger. The soke (is) the Abbot's.

At Benhala [Benhall] Ulnod a freeman under commendation to Malet's predecessor held 40 acres as a manor T.R.E. Then as now 2 bordars. And I plough. And I acre of meadow. Worth 10s. The same Norman (holds). William Malet held and was seised (of this), and Robert his son (after him). The soke is the Abbot's.

In the same (vill was) a freeman Brictmar under commendation to Malet's predecessor, and William was seised thereof, and Robert in like manner. 16 acres and 1 bordar. I acre of meadow. Worth 22d. And (this) Norman holds.

In RINDEHAM [Rendham] Olf a freeman under commendation to Norman (held) 30 acres as a manor. I bordar and half a plough and I acre of meadow. Worth 5s. Norman holds this of Roger. 'The soke (is) the Abbot's.

In CRanefort [Cransford] Edric a freeman under commendation to Edric held 14 acres T.R.E. Then as now half a plough. Worth 26d. The said Norman (holds this). The soke (is) the Abbot's.

In Sternesfelda [Sternfield] Edric a freeman under Norman's commendation (held) 34 acres. And William Malet was seised thereof, and
Robert in like manner. Then as now half a plough. And 2 acres of meadow. Worth 10 . and 8d. The soke (is) the Abbot's. Roger (holds this) in demesne.

In the same (vill were) $16 \frac{1}{2}$ freemen with 130 acres. Then as now 5 ploughs. Worth 30s. Norman had commendation over $7 \frac{1}{2}$ T.R.E., the same Roger holds over these in fol. 345 .

demesne, and Robert Malet's predecessor (had commendation) over $3 \frac{1}{2}$, Oschetel, Leuric, Osiet, and Leuric Snipe the half (freeman). Of these William Malet was seised, and Robert in like manner. The soke (is) the Abbot's.

In Gliemham [Glemham] (were) 5 freemen with 54 acres. Then as now $1 \frac{1}{2}$ ploughs. Worth ros. And 4 of these were under commendation to Malet's predecessor, and thereof was Malet seised, and William his father (before him). This same Roger (holds this) in demesne. The soke (is) the Abbot's.

In Buresiart [Bruisyard] Brictmar a freeman under commendation to Edric Malet's predecessor (held) 30 acres as a manor T.R.E. Then I plough, afterwards and now half a plough. And $1 \frac{1}{2}$ acres of meadow. And $1 \frac{1}{2}$ freemen under commendation (held) 2 acres, worth $5 \frac{1}{2} \mathrm{~s}$. Ralph holds this of Roger. The soke (is) the Abbot's.

In Rinham [Rendham] Blacsune a freeman under commendation to Edric, Malet's predecessor, and William was seised thereof, held 66 acres as a manor T.R.E. Then as now I villein, and 3 bordars. And $1 \frac{1}{2}$ ploughs. And 2 acres of meadow. Wood(land) for 4 swine. Worth I2s. The said Ralph (now holds). The soke (is) the Abbot's.

In Suestlingua [Swefling] Uluric a freeman under Harold (held) 60 acres as a manor T.R.E. Then as now 3 bordars. And I plough on the demesne. And 3 freemen under commendation (have been) added with 9 acres and I plough and 2 acres of meadow. Then $I$ rouncey. Now 2 beasts, and 10 swine, and 15 sheep. Worth I 5s. The same Ralph (holds).

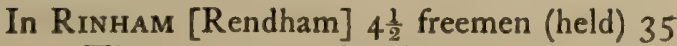
acres. Then as now I plough. Worth 5s. and rod. Of these 3 were under commendation to Malet's predecessor, Gadric and Godric and Tulf; and William Malet was seised thereof. The said Ralph (holds). The soke (is) the Abbot's.

\section{fol. $345^{b}$.}

In DunrwordA [Dunningworth] ${ }^{103}$ (was) a freeman with 8 acres, and in Benenhala [Benhall] 3 freemen with 3 acres, worth $24 d$. Roger (holds) in demesne.

$$
{ }^{103} \text { In Blaxhall. }
$$




\section{A HISTORY OF SUFFOLK}

In Benehala [Benhall] Edric a freeman held 8 acres worth 2s. This is in demesne.

In Gliemham [Glemham] a freeman under commendation (held) 5 acres, worth 12 pence. And (this) Norman holds of Roger. The soke (is) the Abbot's.

fol. 346 .

\section{LANDS OF ROGER OF POICTOU}

\section{Hundret of Carleforda [Carlford]}

In Culfole [Culpho] Brihtric, a freeman under St. Etheldreda, T.R.E. held 80 acres of land as a manor. Then as now 10 bordars, and then 4 serfs. Then on the demesne 2 ploughs, now 3. Then 2 ploughs belonging to the men, now I. 4 acres of meadow. Then 2 rounceys, now 1. Then 7 beasts, now 2. Then 36 swine, now 15. Then roo sheep, now 60. Then it was worth 20s, now 30 s.

In GRundesburc [Grundisburgh] a freeman under Saint Etheldreda Brihtnoth (held) 60 acres as a manor. Then as now 3 bordars. Then I plough, now none, and half a plough belonging to the men. I acre of meadow. Then as now it was worth 15 s.

In CULFol [Culpho] moreover Godric, a freeman under Harold, T.R.E. held 40 acres of land as a manor, and 3 bordars. Then I plough, now none. 2 acres of meadow. Then as now it was worth IOs.

In Tedenham [Tuddenham] Lihtwin, a freeman under Halden, the predecessor of Geoffrey de Magnavilla, held 30 acres and 2 bordars. Then I plough, now none, 3 acres of meadow, worth Ios.

In the same (vill) Godere, a freeman under Saint Etheldreda, T.R.E. held 68 acres ${ }^{104}$ of land as a manor. Then 3 bordars, now none. Then 2 ploughs, now half a plough. 4 acres of meadow. Then as now it was worth 25 s.

Moreover in the same (vill) 12 freemen under commendation to Saint Etheldreda T.R.E. held 50 acres of land and 2 bordars. Then 3 ploughs, now 2. 4 acres of meadow. Then it was worth 20s., now I 5 s.

In Culfola [Culpho] 5 freemen ${ }^{105}$ under commendation to St. Etheldreda T.R.E. (held) 21 acres. Then I plough, now half a plough. Half an acre of meadow. Then it was worth 75., now 5s. I church (having) Io acres, worth $20 d$.

In Grundesburch [Grundisburgh] 7 freemen under commendation to Saint Etheldreda

$$
\begin{aligned}
& 104 \text { ' } 80 \text { acres'; Inq. El. I } 49 . \\
& 105 \text { ' } 4 \text { freemen'; ibid. }
\end{aligned}
$$

T.R.E. (held) 20 acres ${ }^{108}$ of land. Then I plough, now half a plough. Then it was worth 45., now 5s.

In the same (vill) a freeman Siric, King Edward's man, (held) $I \frac{1}{2}$ acres, and a freeman fol. $346 b$.

under commendation to Brihtric (held) 4 acres of land; and 2 freemen, Aluric and Brihtman, under commendation to Ailric de Burch, (held) 14 acres, and then among them I plough, now none. Worth Ios.

In the same (vill) 2 freemen, I under commendation to Saint Etheldreda, and the other under commendation to Halden, (held) 60 acres and 6 bordars. Then as now 2 ploughs. 2 acres of meadow. Then it was worth 12 s., now IOs.

In the same (vill) Roger holds of Roger of Poictou a freeman ${ }^{107}$ (who was) under Saint Etheldreda T.R.E. (with) 40 acres and I bordar. Then I plough, 2 acres of meadow. Then it was worth IOs., now 8 s.

In Cloptuna [Clopton] a freeman Uluric, under commendation to Harold, T.R.E. held I carucate and 22 acres of land as a manor. Then as now I villein, 6 bordars, and I serf, and on the demesne 2 ploughs. 4 acres of meadow. Then I plough, belonging to the men, now none. Then I rouncey, and now 4 beasts and 80 sheep. Then it was worth 40 s., now 2 Is. It is I league long and half a league broad, and (pays) $13 d$. in geld. And this Roger holds in demesne.

In the same (vill) a freeman under commendation to the above Uluric T.R.E. held I $\frac{1}{2}$ acres, worth $3^{d}$. Roger son of Ernald holds this.

In Haschetuna [Hasketon] Alwin, a free$\operatorname{man}^{108}$ under Saint Etheldreda, T.R.E. held 40 acres as a manor. Then and now I plough, I acre of meadow. Then it was worth IOs., now 6s. This Alwin could not sell or give his land away from the Church of Ely.

In the same (vill) 7 freemen under commendation to Saint Etheldreda (held) I6 acres. Then as now half a plough. Worth 3 s.

Moreover in the same (vill were) 2 freemen under half commendation to Edric, the predecessor of Robert Malet, and I freeman under commendation to one who was himself under commendation to Edric, and I under commendation to Brun, with 12 acres, worth $2 s_{0}{ }^{100}$

In the same (vill) a freeman ${ }^{110}$ under com-

108 ' 30 acres'; Inq. El. 149.

107 'A freeman Brixnod'; ibid.

100 'A sokeman'; ibid. 150.

${ }^{109}$ Inq. El. (p. 150) enters: 'A freeman, Brun, under commendation to St. Etheldreda with 6 acres, worth I 2 d.'

110 'A freeman Grimold'; ibid. 


\section{THE HOLDERS OF LANDS}

mendation (datus) to Saint Etheldreda (held) T.R.E. $9 \frac{1}{2}$ acres. Half an acre of meadow. Worth 2s. It is 6 furlongs long and 4 broad, and (pays) $4 d$. in geld. This Roger son of Ernolf holds.

\section{fol. 347 .}

In Thisteldena [Thistleton] ${ }^{111} 8 \frac{1}{2}$ freemen under commendation to Saint Etheldreda T.R.E. (were tenants) of 30 acres. Then 2 ploughs, now I. Then it was worth 20s., now 8 s.

In the same (vill) $I \frac{1}{2}$ freemen under commendation to झldric of Burgh (held) Io acres, and half a plough, worth $2 s$.

Moreover in the same (vill) Ærnold holds of Roger of Poictou a freeman ${ }^{112}$ under commendation to Saint Etheldreda T.R.E. (having) 50 acres as a manor and 2 bordars. Then I plough. I acre of meadow. Then it was worth 20 s, now II

And in BURc [Burgh] a freeman under Saint Etheldreda (held) 16 acres and 2 bordars. I acre of meadow. Then half a plough, now none. Then it was worth 5s., now 7s. This Ernolf holds of Roger.

In Otelega [Otley] Andrew holds of Roger de Poictou (the land) which Ædwold, a freeman under Harold, and his wife under commendation to Edric, held T.R.E. ; 2 carucates of land as a manor. Then as now 3 villeins and ro bordars. Then 3 serfs, now I. Then on the demesne 3 ploughs, now I, but more might be made. Then 5 ploughs belonging to the men, now 3 . Wood(land) for 4 swine. 3 acres of meadow. Then 3 rounceys, now none. Then 12 beasts, now 1. Then 30 swine, now 10. Then 60 sheep, now none. Then it was worth roos., now 40 s. It is 10 furlongs long and 6 broad, and (pays) $15 d$. in geld.

In Haschetuna [Hasketon] 2 freemen, I under commendation to Saint Etheldreda ${ }^{113}$ and the other under commendation to Lustwin, T.R.E. (held) 13 acres, worth $2 s$.

In the same (vill) $7 \frac{1}{2}$ freemen under commendation to Ædwold T.R.E.; I t of these were under commendation to Grimolf. 25 acres and I bordar. Then as now I plough. Half an acre of meadow. Then it was worth 5s., now 4 .

In Alugsbrunna [Alnesbourn] Albert holds of Roger of Poictou (the land) which Saint Andrew held T.R.E. I carucate of land as a manor. Then as now 4 bordars. Then as now I plough on the demesne. 6 acres of meadow and 60 sheep. Then it was worth 30s, now

in In Burgh.

in 'A freeman Ædwi'; Inq. El. 150.

In 'A freeman, Alfuric, under commendation to St. Etheldreda with 8 acres, worth $8 d 0^{\prime}$; ibid. 10s. It is 6 furlongs long and 2 broad, and (pays) $5 d$. in geld.

In Grenewic [ ] 2 freemen, $I$ under commendation to King Edward, and the other to Gurth, (held) 2 carucates of land as 2 manors. Then as now 3 villeins, and 7 bordars. Then 4 ploughs on the demesne, now none. Then fol. 3476 .

6 ploughs belonging to the men, now none. 3 acres of meadow. Then it was worth 40 s., now ros. It is 6 furlongs long and 4 broad, and (pays) $5 d$. in geld.

In Nebrunna [Newbourn] a freeman under Gurth (held) 15 acres. Worth $16 d$. This Albert 'Crematus' holds of Roger of Poictou.

In Riscemara [Rushmere (St. Andrew)] are 6 acres, worth $12 d$., and Hunebot holds them of Roger of Poictou.

\section{HUNDRET OF WILEFORDA [WILFORd]}

In Meltuna [Melton] $R$. son of Arnold (Erloldi) holds of Roger de Poictou 7 freemen (formerly) under commendation to Saint Etheldreda, with 60 acres. Then as now I plough. Then worth 8 s., 114 now a like amount.

In the same (vill was) a freeman ${ }^{115}$ under Saint Etheldreda with 26 acres, worth 50d.

In Bulges [Boulge] are 6 acres, worth $12 d$.

In Depebes [Debach] (were) $2 \frac{1}{2}$ freemen under Uluric's commendation with 15 acres and I acre of meadow. Worth $3^{\text {s. }}$

\section{HUNDRET OF LOSA [LOES]}

At Mangedena [Monewden] Ulmar a freeman under Saint Etheldreda held T.R.E. as a manor I carucate of land and 40 acres. Then 2 villeins, now none. Now 9 bordars. Then 2 ploughs on the demesne, now I. And belonging to the men then as now I plough. 3 acres of meadow, and 2 beasts. Then it was worth 40s., now 30 .

At Kettrlaberga [Kettleburgh] the same Ulmar held 80 acres of land as a manor. Then as now 2 villeins, and 2 bordars. Then as now on the demesne I plough. And belonging to the men I plough. 3 acres of meadow. Then as now it was worth 20s. To this manor a freewoman under the same (Saint's) commendation ${ }^{116}$ held 14 acres. I $\frac{1}{2}$ acres of meadow.

Worth $2 s .4 d$.

I14 'Worth Ios.' ; Ing. El. I 51 .

1115 'A freeman Godric'; ibid.

116 'A freewoman under him in commendation to Saint Etheldreda'; ibid. 152. 


\section{A HISTORY OF SUFFOLK}

In Mungedena ${ }^{117}$ [Monewden] T.R.E. (were) $14 \frac{1}{2}$ freemen, now (there are) 10, under the said (Ulmar's) commendation with 4 score and 4 acres. Then 4 ploughs, now 2. Then it was worth 20s, now I6s. The moiety of one of these Humfrey the Chamberlain (cahararius) held; but Ertald took it away from him. A church with 30 acres and $I \frac{1}{2}$ acres of meadow, worth 5 .

In Estuna [Easton] a freeman held 10 acres under Wulmar's commendation, worth $2 s$.

fol. 348 .

And in LeDringaham [Letheringham] a freeman under the same (Wulmar's) commendation (held) $1 \frac{1}{2}$ acres, worth $4 d$.

In Butrlea [Butley] (were) $5 \frac{1}{2}$ freemenSaint Etheldreda had commendation over $4,{ }^{118}$ and Edric over 2. 32 acres. Then $1 \frac{1}{2}$ ploughs, now I plough. And they are valued with Sutburna [Sudbourne].

In Dallingahou [Dallinghoo] a half freeman under commendation of Edric Grim (held) 6 acres of land, worth 3 od.

In WDEBRIDE [Woodbridge] I6 freemen under Saint Etheldreda's commendation (held) $I$ carucate of land and 2 acres, and 2 bordars. Then 3 ploughs, now 2. Half an acre of meadow. Then it was worth 245 , now 20 s. In the same (vill) are 10 acres in demesne.

In Mungadena [Monewden] (was) a freeman with half an acre; and one with half an acre in Mertiega [Martley], worth 2d.

\section{HuNDRET OF W ANNEForda [WANGFord]}

In Catesfella [ ] 5 freemen, 2 were under commendation to Edric of Laxfield and 3 under Uluric's commendation, (held) 30 acres. Then 2 ploughs, now 1 . Worth 5 s.

In Thrandestuna [Thrandeston] 3 half freemen under Edric's commendation (held) 20 acres, worth $40 d$.

\section{Hertesmara [Hartismere] Hundret}

At W Iкнам [Wickham (Skeith)] Alfleda a freewoman under commendation to Harold held 2 carucates of land as a manor. Then as now 21 bordars. Then 6 serfs. Then on the

${ }^{117}$ In Inq. El. (p. 152) the 14 (sic) freemen are said to be 'in hoc manerio,' i.e. Kettleburgh. At the end of the entry is added: 'And Brixtwolt with 10 acres, worth 2s. (i.e. the 'Estuna' entry of Dom. Bk.). And Hedric with 15 acres, worth 3od.' (omitted by Dom. Bk.).

${ }^{118}$ 'These 4 held 8 acres; ibid. demesne 3 ploughs, now I. Then 6 ploughs belonging to the men, now 2. Wood(land) for 40 swine. 4 acres of meadow. Then 2 rounceys. Then 18 beasts, now 1 . Then 40 swine, now 14. Then 260 sheep, now 33. Then 60 goats. Then worth 100s, now 40 s.

In the same WIKAM [Wickham] a freeman and 3 half (freemen) under commendation to the same (Harold) (held) 16 acres and half a plough and I bordar (and) half an acre of meadow. Worth $3^{\text {s. }}$ A church with 12 acres worth $2 s$.

\section{Bradesmera [Bradmere] Hundret}

(At) Inсham [Ingham] Lewin, King Edward's thegn, held I carucate of land as a manor. Then as now 2 bordars. Then 2 ploughs on the demesne, afterwards (and) now half a plough. 4 acres of meadow. Then 1 rouncey. Then it was worth $4 i i$., now 20 .

fol. $348 b$.

In the same (vill) were 10 freemen, over whom his (Roger's) predecessor had commendation T.R.E. ; and they have 40 acres. Then I plough, now half a plough. Then it was worth 5s., now $3^{\text {s. }}$. Saint Edmund (has) the soke.

\section{Risebruge [Risbridge] Hundret}

(At) Thurstanestuna [Thurston ${ }^{118 \pi}$ ] Etmar, Earl Algar's thegn, held as a manor T.R.E. 2 carucates of land. Then as now 2 villeins. And 6 bordars. And 2 ploughs on the demesne. Then half a plough belonging to the men, 3 acres of meadow. Wood(land) for 6 swine. Then 2 beasts, now 5. Then 13 swine, now 20. Then 40 sheep, now 50. And 6 hives of bees. Half a church with 15 acres of free land. Then as now worth 40 s.

(At) Hauochenduna [Hawkedon] Olf held as a manor T.R.E. 2 carucates of land. Then as now 2 bordars, and 3 serfs. And 2 ploughs on the demesne. And 3 acres of meadow. Wood(land) for 4 swine. Then as now 1 rouncey, 2 beasts, 16 swine, 40 sheep, and 12 goats. Half a church with 15 acres of free land. Then worth 30s., now 40s. It is I league long, and half a league broad. And pays $13 \frac{1}{2} d_{0}$ in geld. Others have land therein.

\section{Half Hundret of Cosfort [Cosford]}

In TORP [Thorpe (Morieux)] a freeman (held) 4 carucates of land as a manor. Then 7 villeins, now 3. Then as now $\mathbf{I}$ bordar and 2 serfs. Then 3 ploughs, now 2. Then I plough belonging to the men, now 2 oxen. 7 acres of meadow.

\footnotetext{
118s Thurston in Hawkedon.
} 


\section{THE HOLDERS OF LANDS}

Then 2 horses. Then 7 beasts, now 1 . Then 60 swine, now 9. Then 140 sheep. Then it was worth $6 l i$, afterwards (and) now $4 l i$. To this manor Norman son of Tan(c)red (Taured) added 7 freemen with 25 acres. Thereof Saint Edmund had soke and commendation. Then 1 plough. Worth 3 s. A church (with) 50 acres, and 2 acres of meadow. Then I plough, now 2 oxen, and 2 villeins. Worth $6 s$. It is I league long, and 8 furlongs broad, and (pays) $5 d$. in geld.

In the same (vill) a freeman (held) $1 \frac{1}{2}$ carucates of land as a manor. Then 6 villeins, now fol. 349 .

7 , and 2 bordars. Then 2 serfs, now 1 . Then 2 ploughs on the demesne, now 1 . Then 1 plough belonging to the men, now half a plough. 5 acres of meadow. Wood(land) for 4 swine, and 2 beasts. Then 26 swine, now 14. Then 30 sheep, now 13 , and 13 goats. Then it was worth 60s., now 40 s. Thereof Richard's predecessor, Wisgar to wit, had commendation and soke. Saint Edmund had the six forfeitures.

\section{Biscopes [Bishop's] HUNDRET}

(At) Wettingaham [Whittingham] Uluric the thegn held T.R.E. $\mathrm{I} \frac{1}{2}$ carucates of land as a manor. Then 9 bordars, afterwards and now 14. Then as now 2 ploughs on the demesne. Then 2 ploughs belonging to the men, afterwards and now I. Wood(land) for roo swine. 16 acres of meadow. And 4 acres of free land. Then as now 5 beasts. Then 20 swine, now 18. Then 30 goats, now 40. And $\mathrm{I}$ hive of bees. Then as now worth 6os. The soke (is) in Hoxa [Hoxne].

(At) Mrnham [Mendham] the same (Uluric) held T.R.E. as a manor I carucate of land and 40 acres. Then as now I villein. Then 6 bordars, afterwards and now ro. Then as now I plough on the demesne. Then 3 ploughs belonging to the men, afterwards and now $I \frac{1}{2}$. Wood(land) for 100 swine. Io acres of meadow. Then as now I mill. And 3 men with 20 acres of land. Then I plough, now half a plough. And the fourth part of a church with 10 acres. Those men could not give and sell their land. But yet the soke is in Hoxa [Hoxne]. Thereto belong 60 acres and they are part of (jacent in) Weibrada [Weybread]. Then as now 2 villeins, and 2 bordars. Wood(land) for 6 swine. 3 acres of meadow. Then as now worth $4 l i$.

In WeIBRADA [Weybread] $4 \frac{1}{2}$ freemen under commendation (held) $35 \frac{1}{2}$ acres. Then 2 ploughs, afterwards $\mathrm{I}$, and now half a plough. Worth 10s.

In Statrbroc [Stradbroke] 2 freemen under commendation (held) 30 acres. Wood(land) for
8 swine. Then I plough, afterwards and now half a plough. Worth Ios.

In Cikelinga [Chickering] a freeman under commendation (held) 24 acres. Wood(land) for 4 swine. And half an acre of meadow. Then and (afterwards?) half a plough, now none. Worth 4s.

In WeIBrada [Weybread] (are) 4 acres of demesne land.

fol. 3496 .

In Menham [Mendham] 3 freemen with $\mathrm{I}$ carucate of land. Of these William Malet was seised. Two were under the commendation of Robert Malet's predecessor and the third of Bishop Ailmar with the fourth part of the land. Then as now I villein. Then 6 bordars, now 9. Wood(land) for 60 swine. 5 acres of meadow.

In the same (vill were) 2 men with 3 acres. And then half a plough, now 2 oxen.

In the same (vill was) a freeman with 15 acres. Ulf his (Roger de Poictou's) predecessor had the commendation T.R.E. Then half a plough. The whole is worth 56s. Over the whole the soke is in Hoxa [Hoxne], the Bishop's (manor).

\section{Colenesse [Colneis] Hundret}

In Halmeleia [Hemley] (are) IO acres which belong to Cleopetona [Clopton]. 2 bordars have 2 oxen. (This) is included in the valuation of Clopton.

\section{Tingohou [Thingoe] Hundret}

At Resebi [Risby] Ulmar the thegn held 2 carucates of land under Stigand. Then 6 bordars, now 3. Then 4 serfs, now none. Then 2 ploughs, now I. And 2 acres of meadow. And half a mill. Then worth 6os., now 20 s.

In Brocle [Brockley] (were) 3 freemen. Saint Edmund had commendation and soke over one ot these, and he could not sell; over the other 2 the King had commendation, but they could sell in Saint Edmund's soke. Among them all 60 acres of land. And I villein, and I serf. Then as now I plough. And $1 \frac{1}{2}$ acres of meadow. Then as now worth IOS.

\section{BABENBERga [BABERgh] TWO Hundrets}

Ulric, King Edward's thegn, held BoEsteda [Boxted] as 2 carucates of land. Then and afterwards 2 villeins, now $x$. Then and now II bordars. Then 4 serfs, afterwards and now 3. Then 3 ploughs on the demesne, afterwards and now 2. And half a plough belonging to the men. And 15 acres of meadow. Wood(land) for 5 swine. Then 3 horses, when R[alph] 


\section{A HISTORY OF SUFFOLK}

left (reliquit) 2, now none. Then 5 beasts, now 4. Then 24 swine, now 15. Then 30 sheep, now 71 .

In the same (vill were) 5 freemen under Wisgar by commendation and soke with 2 carucates of land; and they could sell. But the King gave them to Norman son of Tancred (Tunri).

And in the same (vill was) a freeman under commendation to the said Ulric with 45 acres. Of that land 30 acres are in the soke of Saint Etheldreda and 15 in the soke of Norman, the fol. 350 .

predecessor of Ralph de Limesey, in Kanauadis [Cavendish]. And under them were 3 bordars. Then among them all 4 ploughs, afterwards and now 2.

And in the same manor (was) half a carucate of land under Saint Edmund, which (the tenants) could not sell without licence of the Abbot. But the King gave it to Norman, son of Tancred (Tanre). And (thereon) I serf. Then I plough, now none.

BoestedA [Boxted] was then worth $8 \%$., afterwards $7 \mathrm{li}$, now Ioos. And the freemen were set to farm at 525. Now manor and freemen together are worth $6 l_{i}$. It is I league long, and 5 furlongs broad. And pays $7 d$. in geld.

(At) Prestetona [Preston] Ulwar, a freeman under Stigand T.R.E., held as a manor 2 carucates of land with soke. Then as now 4 villeins, and 4 bordars, and I serf. Then 3 ploughs on the demesne, afterwards and now 2. Then and now I plough belonging to the men. And 9 acres of meadow. Then 5 beasts, now 4. Then 24 swine, now 3 . Then 40 sheep, now 36 .

In the same (vill) were 3 freemen under commendation to Wluard. Over 2 Saint Edmund had soke and sac; and over the third Wisgar the predecessor of Richard (had them); but earlier Norman son of Tancred; now Roger of Poitou has (soke and sac). And they had 23 acres among them all, and half a plough. Then and afterwards the whole was worth 4 li., now 3 li.

In WaLINGafella [Waldingfield] Ulmer the thegn held under Harold T.R.E. I carucate of land with soke. Then as now I villein, and 5 bordars. Then I serf, now none. Then as now 2 ploughs on the demesne. Wood(land) for 3 swine. And 4 acres of meadow. Then as now I horse. Then as now 2 beasts. Then 12 swine, now none. Then it was worth 30 s., afterwards and now it renders 40 s. It is half a league long, and half broad. And (pays) $7 \frac{1}{2} d$. in geld, whoever may be holders thereof. A church with 30 acres.

\section{Stou [STOW] Hundret}

Buckeshala [Buxhall] Lewin Croc held T.R.E. 2 carucates of land. Then as now 4 bordars. Then 3 serfs, afterwards and now none. Then as now 2 ploughs on the demesne. And fol. $350 b$.

I 6 acres of meadow. Then half a mill. Then 2 rounceys. I beast. Then 53 swine, now 16. Then 28 sheep, now 30. A church with 30 acres, and half an acre of meadow. Then as now worth 6os. He (Lewin Croc) had soke and sac over the hall and the bordars. And there were $7 \frac{1}{2}$ freemen under the same (Lewin) by commendation only T.R.E. The soke was in the Hundred. And they have 37 acres. Then 2 ploughs, afterwards and now half. And I acre of meadow. Then as now worth Ios. And to this manor Norman son of Tan(c)red added 3 freemen under the King by commendation and soke with 24 acres. Then and afterwards I plough, now 2 oxen. Worth $40 d$.

In Newetuna [(Old) Newton] T.R.E. 2 freemen under Alsi nephew of Earl Ralph by commendation only (held) 70 acres of land within the soke and sac of the King and the Earl, and 2 bordars. Then $1 \frac{1}{2}$ ploughs, afterwards and now none. Then worth 30 s., afterwards and now 20 .

In TORNEI [Thorney] a freeman under King Edward with soke and sac. And after King William came he was in like manner, and Norman received (the freeman) from this manor without livery of seisin, and afterwards Gerald held him, after Gerald Roger of Poictou. He has 60 acres. Then I plough, and afterwards half (a plough), now I ox. Then worth IOs., now it scarce renders 5 s.

In Stanaham [Stonham] are 50 acres of demesne land of the hall in Cratinga [Creeting].

In Gratinga [Creeting] (were) 7 freemen, 5 were under Alfleta T.R.E. by commendation only, and 2 were under commendation to the King, with soke and sac over all them in the Hundred. 30 acres. Then as now 2 ploughs, Worth 20s. In the same (vill) I sokeman (holds) 3 acres of forfeited land.

In TornIE [Thorney] are 24 acres and I bordar, and they belong to the hall of Stanham [Stonham].

\section{Bosemera [Bosmere] Hundret}

(At) Stanham [Stonham] Uluric the thegn held as a manor T.R.E. 2 carucates of land. Now Roger holds in demesne. Then as now 8 villeins, and 3 bordars, and 4 serfs. And 2 ploughs on the demesne. Then and after- 


\section{THE HOLDERS OF LANDS}

wards 3 ploughs belonging to the men, now $2 \frac{1}{2}$ ploughs. 5 acres of meadow. Wood(land) for 60 swine. The third part of this wood(land) belonged to (jacebat in) Tonestala [ ], William de Warenne's manor T.R.E. Now Roger de Poictou holds. And Raymond Giralt formerly held it. The third part of a fol. $35 \mathrm{I}$.

church with 5 acres. Then as now 2 rounceys. And 30 swine. Then 5 beasts, now 9. Now 60 sheep. Then 30 goats, now 50 . Then it was worth roos., now $6 \mathrm{li}$. The King and the Earl (have) the soke.

In the same (vill) Ulmar the thegn held 2 carucates of land as a manor T.R.E. under commendation to Harold. Then as now 8 villeins, and 3 bordars, and 4 serfs. And 2 ploughs on the demesne. And a mill in Clainduna [Claydon]. Then and afterwards 3 ploughs belonging to the men, now $2 \frac{1}{2}$ ploughs. 5 acres of meadow. Wood(land) for 60 swine. The third part of a church with 4 acres. Then as now 2 rounceys. Now 60 sheep. Then it was worth roos., now 6 li. The King and the Earl (have) the soke.

In the same (vill) Alflet under commendation to Harold held 2 carucates of land as a manor T.R.E. Then as now 8 villeins, and 3 bordars, and 4 serfs. And 2 ploughs on the demesne. Then as afterwards 3 ploughs belonging to the men, now $2 \frac{1}{2}$ ploughs. 5 acres of meadow. Wood(land) for 60 swine. The third part of a church with 5 acres. Then as now I rouncey. Now 60 sheep. Then it was worth IOOs., now $6 \mathrm{i}$. The King and the Earl (have) soke over the whole.

In the same (vill) Ulwin a freeman under commendation to Ulmar the predecessor of Roger de Poictou held 40 acres as a manor. Now Roger holds in demesne. Then as now 3 bordars. Then I plough, now half a plough. 2 acres of meadow. (Included) in the above valuation of Stalham [Stonham].

In the same (vill) a freeman Uluret under commendation to Alflet Roger's predecessor held 20 acres, and they are included in the said valuation. It is I league long, and half (a league) broad. And (pays) $7 \frac{1}{2} d$. in geld.

In the same (vill) a freeman Aluric held 12 acres; over whom the Abbot of Saint Edmund's had half the commendation; and the other moiety of the commendation (is attached) to the King's manor of Meldeham [Mendlesham]. The Abbot held this moiety of the commendation and of the land until Artald seized it (eum saisivit). And it is included in the above valuation.

At Willaluesham [Willisham] Alflet a freewoman under commendation to Harold fol. $351 b$.

T.R.E. held 2 carucates of land as a manor.
Now Albert holds of Roger. Then as now 3 villeins, and to bordars. Then 3 serfs, now I. And 2 ploughs on the demesne. Then 5 ploughs belonging to the men, now 3 . 5 acres of meadow. A church with 32 acres. Then it was worth 4 li., now 3 li.

In the same (vill was) a freeman by name Leuric with 20 acres. Worth 4s.

In the same (vill) a freeman Guiolf (held) 40 acres as a manor T.R.E. Now the same Albert (holds). Then half a plough. Worth 8s. The King and the Earl (have) the soke.

In the same (vill) a freeman Tedric held 80 acres as a manor T.R.E. Then as now 2 bordars. I plough on the demesne and half a plough belonging to the men. 2 acres of meadow. Worth 16s. The King and the Earl have the soke.

And (there were) 2 freemen with 9 acres, Leuric and Godman. This Godman was under commendation to the Abbot of Ely. And he had the soke T.R.E. Worth $3^{\text {s. }}$ All this Albert (now) holds. It is I league long, and 4 furlongs and 20 perches broad. And (pays) $6 \frac{1}{2} d$. in geld.

(At) Blacheham [Blakenham] Lestan under commendation to the Abbot of Ely held $1 \frac{1}{2}$ carucates as a manor. Now the same Albert (holds). Then as now 4 bordars. Then $1 \frac{1}{2}$ ploughs on the demesne, now none. 5 acres of meadow. Then it was worth 405 , now 30 s. The King and the Earl (have) the soke.

In the same (vill) (were) 3 freemen with $6 \frac{1}{2}$ acres. Worth $12 d$. The King and the Earl (have) the soke.

(At) Tonestala [Tunstall] Edred a freeman under commendation to Wisgar held 60 acres, and 2 acres of meadow. Then as now 2 bordars. And (there was) a freeman Edwi with 3 acres. And they were worth IOs. The same Albert (now) holds. It is I league long, and 5 furlongs broad. And (pays) $5 d$. in geld.

In Hamingestuna [Hemingstone] (were) 20 freemen with 142 acres. One of these with 13 acres was under commendation to the Abbot of Ely. And he had the soke. And 6 bordars. Then as now 5 ploughs. And 2 acres of meadow. And half a church with 15 acres, worth fol. 352 .

3od. 8 acres used to belong (thereto) which Hervey de Bourges (Bituricensis) took away. To the aforesaid church belong moreover 6 acres which Phim, Richard's predecessor, took away. Then it was worth 40 s., now 30 s. These (freemen) Roger (holds) on the demesne. The King and the Earl (have) the soke. It is 6 furlongs long, and 6 broad. And (pays) 8d. in geld. A church with 3 acres, worth $6 d$. 


\section{A HISTORY OF SUFFOLK}

In Hamingestuna [Hemingstone] a freeman Lewin held an acre of land and 1 bordar T.R.E. Now Almar the King's reeve holds it. Worth 2d. The King and the Earl (have) the soke.

In UleDANA [Olden ${ }^{110}$ ] a freeman Almar (held) 4 acres, and half a plough, and I bordar. Worth $8 d$. The King and the Earl (have) the soke.

In Langhedena [ freeman (held) 3 acres. Worth $6 d$.

In Stanham [Stonham] a freeman Leuric under commendation to the Abbot of Ely (held) 6 acres, and in Codenham [Coddenham] 3 acres. Worth $18 d$.

In the same (vill) Godwin a freeman (held) IO acres and 2 oxen under commendation to Wisgar the predecessor of Richard son of Earl Gilbert. Worth 4s. Of this (freeman) Raymond Giralt was seised. And Roger de Poictou holds him. And Roger de Ramis (held) by right of the first livery (de prima liberatione). And the Hundred witnesses that to him livery was first made (prius liberatum fuit).

In Langedana [

] Ghim a freeman (held) $1 \frac{1}{2}$ acres. Worth $3 d$. The King and the Earl (have) the soke.

In Hamingestuna [Hemingstone] a freeman Adelwin held $\mathrm{I} \frac{1}{2}$ acres. Worth $3 d$.

In the same (vill) a freeman Brictmar (held) $I_{\frac{1}{2}}$ acres. Worth $4 d$.

\section{Claindune [Claydon] Hundret}

In Bercham [Barham] Lustwin held 60 acres as a manor. Wisgar had half the commendation and soke, and the Abbot of Ely the other moiety and soke. ${ }^{120}$ Then I plough. Then as now 5 bordars. 3 acres of meadow. Worth 10s. The same Gosbert holds of Roger.

fol. $352 b$.

In the same (vill) were 7 freemen with 47 acres. Then 2 ploughs, now I. And 2 bordars. Worth IOs. The same Gosbert (holds).

In the same (vill) 4 freemen (held) 40 acres. Then as now I plough. Then it was worth 8s., now 6s. 8d. Of three of them the Abbot had half the soke and the whole of the commendation. And of the fourth the King (had) soke and commendation.

In Hamingestuna [Hemingstone] a freeman (held) $1 \frac{1}{2}$ acres. Then it was worth $4 d$, now

119 See n. 2.

190 Inq. El. (p. 145) reads: 'In Bercheham tenuit S. Edeldreda T.R.E. dimidiam commendationem, et dimidium sochemannum de Lustuuino, lx acras.' 3d. Isaac (holds) of Roger. The King and the Earl (have) the soke.

In ACHream [Akenham] Leuolt a freeman (held) 20 acres in the King's soke and commendation. Worth 4s.

In the same (vill) (was) a freeman Aluolt with 6 acres in the Abbot's soke and commendation. Worth I2d.

In TuRlestuna [Thurlston] 5 freemen (held) 26 acres in the King's soke. Then half a plough. Worth 4s. Gosbert holds (this). The soke (is) the King's and the Earl's.

In Turlestuna [Thurlston] the same Gosbert holds 18 freemen (with) 80 acres less 2. Then 3 ploughs, now 2. And 1 acre of meadow. Half a church with 5 acres. Then it was worth 20s., now 13 s. and $4 d$. The soke (is) the King's and the Earl's.

In ACreham [Akenham] 3 freemen (held) I6 acres and half a plough. And half a church with 5 acres. Worth $32 d$. The soke (is) the King's and the Earl's.

In Henleia [Henley] a freeman (held) 6 acres. Worth $12 d$. The soke (is) the King's.

In Westrefelda [Westerfield] (is) half a church with $7 \frac{1}{2}$ acres.

In Helmingham [Helmingham] 3 freemen (held) 9 acres. Worth 2s. The King and the Earl (have) the soke.

In Turduestuna [Thurlston] Almar the priest a freeman (held) 3 acres. Worth $6 d$.

In Westrefelda [Westerfield) 2 freemen held 2 acres. Worth $18 d$. The soke (is) the King's and the Earl's.

In CoDeham [Coddenham] 2 freemen (held) 18 acres. T.R.E. I plough, now none. Worth 4 s.

In Bercham [Barham] a freeman (held) I acre. Worth 3 d.

fol. 353 .

In Henleia [Henley] a freewoman (held) half an acre. Worth Id. The soke (is) the King's and the Earl's.

\section{Half Hundret of Perreham [Parham]}

In the soke of the Abbot of Ely.

In Wantesdena [Wantisden] 14 freemen (held) 40 acres in the soke and commendation of the Abbot of Ely ; and in Bracheshala [Blaxhall] I freeman (held) 10 acres in the soke and 


\section{THE HOLDERS OF LANDS}

commendation of the Abbot of Ely. Then and afterwards 2 ploughs, now $1 \frac{1}{2}$ ploughs. And 2 acres of meadow. Worth 8s. Roger holds in demesne.

\section{Plumesgate [Plomesgate] Hundret}

(At) Nordberia [ ] $]^{191}$ Edwin the priest, a sokeman under the Abbot, held 30 acres as a manor T.R.E. Then as now I plough. And 4 beasts, and 8 swine. Then 60 sheep, now 40. Then and afterwards it was worth $20 s$., and now a like sum.

In the same (vill) 49 freemen (have been) added to this manor with $260 \frac{1}{2}$ acres. Then as now Io ploughs. And 2 acres of meadow. Wood(land) for 8 swine. Then and afterwards it was worth roli., now I $l i$. All these men were in the Abbot's soke and commendation, and one (was) wholly a sokeman, by name Godric.

In Gliemham [Glemham] (is) a freeman with 5 acres, worth $12 d$. (This is) in demesne. The soke (is) the Abbot's.

\section{LAND OF WILLIAM DE SCOIES}

\section{Bosemera [Bosmere] Hundret}

(At) Blacham [Blakenham] Aluric the thegn held T.R.E. I carucate of land as a manor. Then as now 6 bordars. And then I plough on the demesne, now 2. And half a plough belonging to the men. 5 acres of meadow. Then fol. 3536 .

as now 2 mills. And 1 rouncey. Then 2 beasts, now 4. Then 7 swine, now 11 . Then 12 sheep, now I4. A church with I acre, (worth) $2 d$. To this manor Hardwin added 28 freemen with I 7 acres and I bordar. Brunard holds 60 acres of this land and I plough. Worth I5s. Then 6 ploughs, afterwards and now 2. Then 10 acres of meadow. And 2 (third) parts of a mill. The manor was then as now worth 3 li.; and the freemen 45s. The King and the Earl (have) soke over the whole. It is 5 furlongs long, and 5 broad. And (pays) $7 d$. in geld. This manor (was set) to farm for three years at 12li. each year, and an ounce of gold for (in) the three years together by way of fine (gersuma); but the men who thus received it to farm have all been ruined (confusi).

191 Ing. El. (p. $14^{8}$ ) reads: 'In Norberia (are) 50 freemen belonging to Sudburne with 2901 acres, whereof the abbot had sac and soke and commendation T.R.E. and two of these, Alfuric and Edwin, could not give or sell their land." In the summary of the lands taken from the abbey by Roger (p. 187) these freemen are said to have belonged to 'Bercham.'

\section{Blachebruna [Blackbourn] Hundret}

Westuna [(Market) Weston] Huard de Vernon holds of William, which Aluric, a freeman, held T'R.E. as a manor; $I$ carucate of land, and 8 acres in TORP [Thorpe]. Then 4 villeins, now 2. Then as now 1 plough on the demesne. And I plough belonging to the men. 2 acres of meadow. Wood(land) for 10 swine. Now 2 rounceys. Then as now 10 swine. Then 15 sheep, now 80. A church with 4 acres. Worth 20s. And 3 freemen (hold) I carucate with 20 acres. Then 3 ploughs. 3 acres of meadow. Worth 20s. Of this land Hugh, William's man, appropriated (invasit) 25 acres against the Abbot. They could give and sell their land T.R.E., but commendation and soke and sac remained in Saint Edmund's possession.

And in the same (vill were) rosokemen under Saint Edmund with all customs T.R.E., but Hardwin held them in King William's time : and they have 60 acres of land. Then 2 ploughs, now half. Worth 4 s. It is 7 furlongs long, and 5 broad. And pays $9 d$. in geld. Others hold (land) therein.

In the Hundret of Blidinga [Blything] William de Scoies has the manor of CoKelI [Cookley]. T.R.E. Wluric a freeman held it. fol. 354 .

Then as now 6 carucates of land. Then 6 villeins, and now 2. Then 6 bordars, now I1. Then as now I serf. Then as now 2 ploughs on the demesne. Then as now 2 ploughs belonging to the men. Then as now wood(land) for 4 score swine. And 6 acres of meadow. And 1 mill. Then 2 rounceys. And then as now I cow, 8 swine, 7 sheep, 30 goats, and 2 hives of bees. And half a church with I acre. And upon this manor Huard de Vernun and Robert de Vals are enfeoffed (casati); and Huard's share is worth 50s. and Robert's share 8 s. It is 14 furlongs long, and 7 broad. And it renders in the King's geld $7 \frac{1}{2} d$.

\section{Claindune [Claydon] Hundret}

In Turoluestuna [Thurlston] (were) 2 freemen (with) 5 (acres?), and I bordar. Then half a plough. Worth $15 d$.

\section{$X$. LANDS OF HERMER DE FERRIERES}

\section{Blachrune [Blackbourn] Hundret}

Osmund, a freeman, over whom Saint Edmund had commendation T.R.E. and soke and sac, held Bernincham [Barningham] as a manor. Half a carucate of land. Then as now I villein, and 2 bordars. And I plough on the demesne. And half a plough (belonging to the men). And 2 acres of meadow. Worth IOS. Saint Edmund (has) the soke. 


\section{A HISTORY OF SUFFOLK}

\section{LANDS OF RALPH DE BELLA FAGO}

\section{HundRet OF WILESForda [WILFord]}

In Baldeseia [Bawdsey] I 4 freemen under Godric's commendation T.R.E. (held) 62 acres as a manor. I bordar. Then 3 ploughs, now 2. 2 acres of meadow. Worth 3 os.

In Thurstanestuna [

6 freemen under the said Godric's commendation fol. $354 b$.

(held) 40 acres as a manor. Then 2 ploughs, now I. Worth 20 s.

In RAMESHOLT [Ramsholt] 6 freemen under the said Godric's commendation (held) 20 acres. Then I plough, now half a plough. Worth IOs.

\section{Hertesmara [Hartismere] Hundret}

Wortham [Wortham] Richard de St. Clair (Sencler) holds of Ralph, which Modgeva a freewoman under commendation to Saint Edmund T.R.E. held; $I \frac{1}{2}$ carucates of land as a manor. Then as now 18 bordars, and 2 serfs. And on the demesne 2 ploughs. And belonging to the men 2 ploughs. Wood(land) for ro swine. 2 acres of meadow. And I rouncey, 3 beasts, 20 swine. Now 20 goats. Then worth 40 s, now roos. This land (Modgeva) could not sell or give away from the church. Saint Edmund has the soke.

In the same (vill) a freewoman Godgeva under the commendation and soke and sac of Saint Edmund T.R.E. (held) 80 (acres) as a manor. Then as now 6 bordars. Then 1 plough, now none. Then and now belonging to the men I plough. 4 acres of meadow. Then worth 20 s., now a like sum. 2 churches with 40 acres, worth $7 \mathrm{~s}$.

And in the same (vill) I4 freemen under commendation to the same (Saint Edmund) (held) 90 acres. Then as now 3 ploughs, I acre of meadow. Then as now worth $13^{\text {s. }}$ This Richard holds of Ralph.

In Brom [Brome] (is) I bordar with 8 acres, and he belongs to Wortham [Wortham], and is worth $12 d$.

\section{LANDS OF FRODO, THE ABBOT'S BROTHER}

\section{Blachrune [Blackbourn] Hundret}

(At) Teluettrham [Thelnetham] Acolf the thegn held 2 carucates of land as a manor T.R.E. Then as now 8 bordars. Then 6 serfs, now 2 . Then as now 3 ploughs on the demesne. And I plough belonging to the men. 4 acres of meadow. Wood(land) for 30 swine. And then as now I mill. Then I rouncey. Then as now 3 beasts. Then 50 swine, now 25. Then 2 sheep, now 35. And now 3 hives of bees. fol. 355 .

And 15 freemen under commendation (held) 40 acres. Then as now 2 ploughs. (The manor) was then worth $3 l_{i \text {., }}$ and now 50s. and the freemen 60s. A church with 20 acres, Saint Edmund has soke and sac. It is I o furlongs long and 4 broad. And pays $9 \frac{1}{4} d$. in geld.

\section{Thewardestreu [Thedwastre] Hundret}

In Heteseta [Hessett] 6 freemen under commendation to Saint Etheldreda in Saint Edmund's soke (held) I carucate of land. And I bordar. Then and afterwards 3 ploughs, now 1. And I acre of meadow. They were then worth 60s., now 20 s.

\section{LACHEFORdA [LACKFord] HUNDRET}

At Wirilintona [Worlington] Ormer held T.R.E. 6 carucates of land. Then as now 16 villeins, and 6 bordars, and 2 serfs. And 2 ploughs on the demesne. And 4 ploughs belonging to the men. 12 acres of meadow. 2 fisheries. And I mill. A church without land. Then as now I horse. Then 20 beasts, now 8 . Then 80 sheep, now 100. Then and afterwards it was worth 6 li., now 8 li. It is 10 furlongs long, and 8 broad. And in geld (pays) $20 d$.

In Todeham [Tuddenham] Leuric a freeman under Earl Algar held I $\frac{1}{2}$ carucates of land. Then as now 2 villeins, and 2 bordars, and 2 serfs. Then as now I plough on the demesne. And half a plough belonging to the men. $1 \frac{1}{2}$ acres of meadow. I mill. Now 6 swine. Then 160 sheep, now 80 sheep. Then it was worth 40s., now 6os. The soke and sac are Saint Edmund's.

\section{Babenberga [Babergh] two Hundrets}

(At) Kanewella [Kentwell] Algar held freely under Seward of Meldona [Maldon] T.R.E. as a manor 2 carucates of land with soke. Then 7 villeins, afterwards and now 4. Then and afterwards 1 bordar, now 3. Then and now 2 ploughs on the demesne. Then and afterwards 2 ploughs belonging to the men, now 1. And 8 acres of meadow. Then and now 1 horse at the hall. Then 5 beasts, now 8 . Then 30 swine, now 40. Then 80 sheep, now 50. Then and afterwards it was worth 4 Os., now 4 li.

(At) Lauenham [Lavenham] Alwi held under Saint Edmund with soke T.R.E. 2 carucates of land as a manor. And this he could not sell without licence of the Abbot. Now Frodo holds 


\section{THE HOLDERS OF LANDS}

(it) of King William, and claims it (as appertaining) to his fee, saying that it was delivered to fol. 355 .

him. Then as now 5 bordars, and I serf. Then as now 2 ploughs on the demesne. And 2 ploughs belonging to the men. And 3 acres of meadow. Now 2 horses at the hall. Now 12 beasts. Then 12 swine, now 4. Then 40 sheep, now 102. Then it was worth 40 ., now 4 li. It is half a league long, and 4 furlongs broad. And pays $1 \frac{1}{2} d$. in geld.

\section{STOU [STOW] HundRet}

In Bukessalla [Buxhall] 25 freemen held $3 \frac{1}{2}$ carucates of land in the King's soke, who (with their lands) were delivered to Frodo as a manor (containing) $3 \frac{1}{2}$ carucates of land. Then as now

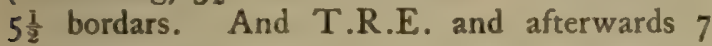
ploughs among them all, now 2 on the demesne, and 3 belonging to the men. And 10 acres of meadow. Then 2 rounceys, now 1 . Then as now 6 beasts. Now 22 swine. Now 36 sheep. Then and afterwards worth 6os., now Ioos. It is 1 league long and 8 furlongs broad. And pays $25 d$. in geld whoever be tenant there. The King and the Earl (have) the soke.

\section{LAND OF GODRIC THE STEWARD (Dapifer)}

BISCOPES [BISHOP's] HUNDRET

In Mendham [Mendham] (is) I bordar with 4 acres. Worth $12 d$.

\section{Blidinga [Blything] Hundret}

(At) Blideforda [Blyford] Edwin a freeman held T.R.E. 2 carucates of land as a manor. Now Godric holds it in demesne. Then as now 5 villeins, and 3 bordars, and 2 serfs. And 2 ploughs on the demesne. And 3 ploughs belonging to the men. And I acre of meadow. Wood(land) for 160 swine. Now I mill. And then as now I rouncey. Then 4 beasts, now 9, and 17 swine, and 3 sheep. A church with 12 acres. Then as now it was worth 40s. It is I league long and I league broad. And (pays) $3 \frac{1}{2} d$. in geld. The same Godric (has) the soke.

fol. 356 .

In Holetuna [Holton] 3 freemen, Ulmar, Ailmar, Odulf, (held) 33 acres (and) half an acre of meadow. Then as now I plough on the demesne. Worth 5s. Over all Holetuna [Holton] Count Alan has the soke except over Osbert's land.

In the same (vill) are 6 freemen with 27 acres and I plough. Worth IOS.
In WARLE [

] ${ }^{122}$ a freeman held 50 acres as a manor. 4 bordars. Then as now I plough. 4 acres of meadow. Wood(land) for 12 swine. Worth 7 s. The soke (is) in the Hundred.

In Bulecampa [Bulcamp] Thored a freeman held 30 acres of land as a manor. Then as now 2 villeins, and half a bordar. And I plough. I acre of meadow. Wood(land) for 40 swine. Worth 5 s.

\section{WAINEForda [WangFord] Hundret}

(At) Almaham [Elmham] Godric a freeman under Ralph the Staller (Stalra) held 40 acres as a manor. Then as now 2 villeins, and I bordar, and I serf. And I plough on the demesne. And belonging to the men half a plough. Wood(land) for 4 swine. 2 acres of meadow. The fifth part of a mill. A church with 8 acres, and the fifth part of a church with 6 acres, worth $12 d$. Then worth 75 ., now it renders 20s. And under him 2 freemen (had) 5 acres and half a plough, and are included in the said valuation.

In Ilcheteshala [Ilketshall] a freeman Anand under Ædwin's commendation (held) 30 acres, and 5 bordars. Then as now I plough on the demesne. And belonging to the men half a plough. I acre of meadow. Then worth 8s. and $4 d$., now Ios.

fol. $356 b$

\section{XIIII. SUFFOLK, SAINT EDMUND'S I,AND}

\section{Chinhoge [Thingoe] Hundret}

(At) Risebi [Risby] T.R.E. Saint Edmund held as a manor 2 carucates of land. Then as now 4 villeins, and 2 bordars. And then 2 ploughs on the demesne, now 4. Then as now I plough belonging to the men. And then 3 serfs, now I. And I acre of meadow. And now 3 rounceys, 12 beasts, 30 swine, 90 sheep, and 32 goats. And 7 sokemen with $1 \frac{1}{2}$ carucates of land, I bordar and I serf. Then as now 3 ploughs. Over these men Saint Edmund had sac and soke and commendation and all customs. And they could not give or sell this land without leave of the Abbot; all (had to bring their sheep) also to (the Abbot's) fold except one who had a fold for himself.

In the same (vill) I freeman with half a carucate of land which Norman holds of the Abbot. And 4 bordars. And 1 serf. Then 1 plough, and now (the like). And I acre of meadow. He could give and sell his land. But sac and

19 In 1275 W. de Monchensey held at 'Warsle' in this hundred: Hund. R. (Rec. Com ), ii, 147. 


\section{A HISTORY OF SUFFOLK}

soke and commendation would remain in the Saint's (possession). Then as now worth ros. A church with 24 acres of free land. This manor-the freeman not included-(was) then worth 4 li., now 6li. It is 9 furlongs long, and 8 broad. And pays $20 d$. in geld. Others have holdings therein.

(At) Horningesworda [Horringer] Saint Edmund held T.R.E. 4 carucates of land as a manor. Then as now 3 villeins, and 15 bordars. Then as now 4 ploughs on the demesne and 5 ploughs belonging to the men. Then as now 7 serfs. And 3 acres of meadow. Wood(land) for 5 swine. And now 5 rounceys. And now 14 beasts, and 30 swine, and 45 sheep. And 15 sokemen with I carucate of land, and I bordar. Then as now 4 ploughs. These men are under the Saint by sac and soke and all customs; and they could not give or sell the land without the Abbot's licence. A church with 6 acres of free land. Then (was) this manor worth $6 l_{i}$, now 8li. It is 9 furlongs long, and 8 broad. And (pays) 20d. in geld. Others have holdings therein.

(At) Huepestede [Whepstead] T.R.E. Saint Edmund held 5 carucates of land as a manor. Then as now 10 villeins, and 18 bordars. Then as now 4 ploughs on the demesne. Then as now 6 ploughs belonging to the men. Then as now 9 serfs. And 10 acres of meadow. Wood(land) for 40 swine. Now 5 rounceys, I 8 beasts, 30 swine, and 100 sheep. And I sokeman with 30 acres of land, 4 bordars and I serf. Then as now I plough. And 2 acres of meadow. Wood(land) for 5 swine. Over the man the Saint has sac and soke and commendation and all customs. And without licence of the Abbot he could not give and sell the land.

In the same (vill were) 6 freemen with $1 \frac{1}{2}$ carucates of land, which Ralph holds except 30 acres, and 4 bordars. Then as now 3 ploughs. And 3 acres of meadow. Wood(land) for 3 swine. Worth 50s. These men could give and sell the land. But sac and soke and commenda-

fol. 357 .

tion and service would remain to the Saint. Then as now worth 60 s. A church with 30 acres of free land. This manor, the freemen not included, was then worth 7 li., now roli. It is 9 furlongs long, and 8 broad. And (pays) $20 d$. in geld.

(At) Neotuna [Nowton] T.R.E. Saint Edmund held 4 carucates of land as a manor. Then as now $\mathrm{I} O$ villeins and $\mathrm{I} O$ bordars. Then as now 4 ploughs on the demesne. And then as now 4 ploughs belonging to the men. And then as now 4 serfs. And 4 acres of meadow. Wood(land) for 5 swine. And 1 mill. And now 4 rounceys, 18 beasts, 23 swine, 80 sheep, and 3 hives of bees. And 10 sokemen with half a carucate of land, Then as now 2 ploughs. And 4 acres of meadow. Over these men (the Saint) then as now had sac and soke and commendation and all customs. And they could not give or sell the land without the Abbot's licence. A church with 8 acres of free land. Then this manor was worth 5 li., now Ioli. It is ro furlongs long, and 6 broad. And (pays) $6 \frac{1}{2} d$. in geld.

(At) Ceuentuna [Chevington] Saint Edmund held 6 carucates of land as a manor. Then as now 13 villeins and 9 bordars. Then as now 4 ploughs on the demesne. And then as now 4 ploughs belonging to the men. Then 6 serfs, now 7. And 10 acres of meadow. Woot(land) for 100 swine. Now 7 rounceys, 22 beasts, and 30 swine. And now 140 sheep, and 40 goats, and 3 hives of bees. And I sokeman with 30 acres of land. 2 bordars. Then as now I plough. And I acre of meadow. Wood(land) for 4 swine. Over him the Saint has sac and soke and commendation and all customs. And he could not give or sell the land without licence. A church with 30 acres of free land. This manor was then worth $6 \mathrm{li.g}$ now $10 \mathrm{li}$. It is 10 furlongs long, and 8 broad. And (pays) $6 \frac{1}{2} d$. in geld.

(At) Sexham [Saxham ${ }^{123}$ Saint Edmund held 5 carucates of land as a manor. Then as now I 2 villeins, and 6 bordars. Then as now 3 ploughs on the demesne. And then as now 6 ploughs belonging to the men. Then as now 4 serfs. And 5 acres of meadow. Wood(land) for 80 swine. Now 4 rounceys, 15 beasts, 36 swine, and roo sheep. Then worth $6 l i$, now 1oli. It is I league long, and 5 furlongs broad. And (pays) $7 d$. in geld.

(At) LEAcForda [Lackford] T.R.E. Saint Edmund held 5 carucates of land as a manor. Then as now 14 villeins and 7 bordars. Then as now 3 ploughs on the demesne. And then as now 4 ploughs belonging to the men. And then as now 4 serfs. And 30 acres of meadow. And 2 mills. Now 2 rounceys, 9 beasts, 13 swine, and 160 sheep. And I sokeman with 8 acres of land. Then as now 2 oxen. Over him the Saint has sac and soke and commendation. And he could not give or sell the land without licence. A church with 20 acres of free land. Then this manor was worth $6 l_{i}$, now 8 li. It is I league long, and 10 furlongs broad. And (pays) $6 d$. in geld.

\section{fol. 3576 .}

(At) Hemegretha [Hengrave] 12 T.R.E. Saint Edmund held 3 carcucates of land as a

${ }^{123}$ Great and Little Saxham were both held by the abbey : Feud. Aids, v, 44.

124 Formerly 'Hemegrave' : ibid. 


\section{THE HOLDERS OF LANDS}

manor. Then as now 2 villeins. And then 2 bordars, now 6 . Then as now 2 ploughs on the demesne. And then as now 3 ploughs belonging to the men. Then as now 3 serfs. And I acre of meadow. And I mill. Now 2 rounceys, 12 beasts, 20 swine, and 60 sheep. And 8 sokemen with 60 acres of land. Then as now I plough. Over them (the Saint) has sac and soke and commendation as to all customs. And they could not give or sell the land without licence of the Abbot. A church with 30 acres of free land. Then this manor was worth 50s., now 60 s. It is 6 furlongs long, and the like 6 broad. And (pays) rod. in geld.

(At) Fornham [Fornham (All Saints)] T.R.E. Saint Edmund held I carucate of land as a manor. Then as now 4 bordars. Then as now I plough on the demesne. And then as now I plough belonging to the men. Then as now I serf. And 4 acres of meadow. And 1 mill. And then as now 2 rounceys, 14 beasts, 30 swine, and 60 sheep. And 3 sokemen with 30 acres of land. Then as now half a plough. These men hold under the Saint with sac and soke and commendation and all customs. And then could not give or sell the land without licence.

In the same (vill were) 2 freemen with I $\frac{1}{2}$ carucates of land. I villein. 3 bordars. Then as now 2 ploughs. These men could give and sell the land. But the sac and soke and commendation would remain under the Saint. They were then as now worth 40s. A church with 12 acres of free land. This manor, the freemen not included, was then as now worth 40s. It is 8 furlongs long, and 5 broad. And (pays) rod. in geld.

Saint Edmund held KKEworths [Ickworth] T.R.E. as 3 carucates of land. Then as now 9 villeins, and 3 bordars. Then as now 2 ploughs on the demesne. Then as now 4 ploughs belonging to the men. Then as now 4 serfs. And 6 acres of meadow. Wood(land) for 24 swine. I mill. And 2 rounceys, 16 beasts, 30 swine, and 80 sheep. A church with half an acre of land. Then this manor was worth 3 li., now 4 li. It is 8 furlongs long, and 5 broad. And (pays) $7 \frac{1}{2} d$. in geld.

In Sexнam [Saxham] Albert and Fulcher hold of the Abbot 3 freemen with $2 \frac{1}{2}$ carucates of land. 8 bordars. Then as now 4 ploughs. And 3 acres of meadow. Wood(land) for 5 swine. And half a mill. Two of these men could give and sell the land. But the sac and soke and commendation would remain under the Saint. And the third could not (sell) without the Abbot's (licence). They were then as now worth 8os. Two (third) parts of a church with 6 acres of land. It is 8 furlongs long, and 5 broad. And pays $7 d$. in geld. Others have holdings therein.
In Fiemingtuna [Flempton] Ulward holds of the Abbot IO sokemen with I carucate of fol. 358 .

land. 6 bordars. Among them all then as now 3 ploughs. And I acre of meadow. And I mill. These men are under the Saint by sac and soke and commendation. And they owe service at Riseby [Risby], and at Leacforda [Lackford], and at Hemegretha [Hengrave]. And they could not give or sell the land without the Abbot's licence. They were then as now worth 40s. A church with 8 acres of free land. It is 6 furlongs long, and 4 broad. And (pays) $6 d$. in geld.

In Haldsteda [Hawstead] (are) 28 freemen with 4 carucates of land. And Odo holds I carucate. And 2 clerics Albold and Peter 2 carucates. And Agenetus 20 acres. Then as now 3 villeins and $2 \mathrm{I}$ bordars. Then as now 13 ploughs. And 2 serfs. And 16 acres of meadow. Wood(land) for 3 swine. These men could give and sell the land. But the sac and soke and commendation would remain under the Saint. They were then as now worth 4 li. A church with 30 acres of free land. It is 8 furlongs long, and 6 broad. And (pays) $13 \frac{1}{2} d$. in geld.

In Broclega [Brockley] 'Tebald and Robert hold of the Abbot 3 freemen with 2 carucates of land. 3 villeins, and 6 bordars, and 6 serfs. Then as now among them 4 ploughs. And 5 acres of meadow. Wood(land) for 24 swine. Two of these men could give and sell the land. But the sac and soke and commendation would remain under the Saint. The third cannot give or sell land without the Abbot's licence. 'They were then as now worth 4 li. A church with 6 acres of free land. It is 8 furlongs long, and 5 broad. And pays $7 d$. in geld. Others have holdings therein.

In Manestuna [Menston] Garin has of the Abbot I sokeman with 20 acres of land. I bordar. Then as now half a plough. And I acre of meadow. Wood(land) for 2 swine. Over him the Saint has sac and soke and commendation; and he owes him (the Saint) service. And he could not give or sell the lands without the Abbot's licence. Then as now worth 4 s. It is 3 furlongs long, and $2 \frac{1}{2}$ furlongs broad. And (pays) $6 d$. in geld. Others have holdings therein.

In REODA [Rede] Henry has of the Abbot I sokeman with lialf a carucate of land. 4 bordars. And I serf. And then as now I plough. And 3 acres of meadow. Wood(land) for 3 swine. Over him the Saint has sac and soke and commendation. And he could not give or sell the land without the Abbot's licence. Then worth 20 s., now 40 s. 


\section{A HISTORY OF SUFFOLK}

In the same (vill) Berard holds of the Abbot 7 freemen with half a carucate and 50 acres of land. Then as now 2 ploughs. And 3 acres of meadow. Wood(land) for 6 swine. These men could give and sell lands. But the sac and commendation and service would remain under fol. $358 b$.

the Saint. They were then as now worth 30 s. It is 8 furlongs long, and 4 broad. And (pays) $7 d$ in geld. Others have holdings therein.

In Westiefa [Westley] (are) II freemen with 2 carucates of land. Peter holds I of the Abbot. 5 bordars. Then as now 3 ploughs. And $1 \frac{1}{2}$ acres of meadow. Wood(land) for 3 swine. These men could give and sell the lands. But the sac and soke and commendation and service would remain to the Saint. Then they were worth 30s., now 40s. One third share in a church, with 4 acres of land. It is 7 furlongs long, and 5 broad. And pays $6 \frac{1}{2} d$. in geld. Others have holdings therein.

\section{LeacForde [LAckford] Hundret}

(At) Hyrningwella [Herringswell] T.R.E. Saint Edmund held as a manor 4 carucates of land. Then as now 7 villeins, and 6 bordars, and $I$ serf. Then as now 3 ploughs on the demesne. Then as now 3 ploughs belonging to the men. And 4 acres of meadow. Then I mill, now 2. And I rouncey, 5 beasts, 12 swine, and 80 sheep. And 2 sokemen with 54 acres of land. Then as now $1 \frac{1}{2}$ ploughs. And I acre of meadow. Over them the Saint then as now had sac and soke and commendation with all customs. But they could give and sell their lands without the Abbot's licence. A church with 30 acres of free land. This manor was then worth $6 l i$, now 7 li. It is I league long, and 6 furlongs broad. And in geld (pays) 20d. Several persons hold (land) therein.

(At) WAMForda [Wangford] Saint Edmund held as a manor 2 carucates of land. Now Ulwart holds of the Abbot. Then as now 4 villeins, and 4 bordars, and 5 serfs. Then as now 2 ploughs on the demesne. And then as now I plough belonging to the men. And 8 acres of meadow. And now 5 rounceys, 18 beasts, 26 swine, 413 sheep, and now 2 hives of bees. A church with 15 acres of free land. Then it was worth 40 s, now 60s. It is I league long, and 5 furlongs broad. And in geld (pays) 6d. Others hold (land) therein.

(At) Eluedena [Elveden] Saint Edmund held T.R.E. as a manor 2 carucates of land. Then as now 4 villeins, and 4 bordars, and I serf. Then 2 ploughs on the demesne, now 1. Then as now $1 \frac{1}{2}$ ploughs belonging to the men. And now 2 rounceys, 4 beasts, 12 swine, 260 sheep, and 13 goats. And the fourth part of a fishery. A church with 15 acres of free land. And $4 \frac{1}{2}$ freemen with I carucate of land, (and) 3 bordars. Then 3 ploughs, now 2. They could give and sell their lands. But sac and soke and commendation and the service remained in the Saint's possession. They were then worth IOs., now I5s. This manor, the freemen excepted, was then worth 30 s., now 40 . It is I league long, and likewise I league broad. And in geld (pays) 20d. Several persons hold (land) therein.

fol. 359 .

(At) Dunham [Downham] Saint Edmund held 3 carucates of land as a manor. Frodo ${ }^{125}$ now holds it. Then as now I bordar. Then 5 serfs, now 3. Then as now 3 ploughs on the demesne. And 5 acres of meadow. And I fishery. And I ox, 2 I swine, and 900 sheep. And 9 free men with $2 \frac{1}{2}$ carucates and 60 acres of land and 3 bordars. Then 8 ploughs, now $4 \frac{1}{2}$ among them all. And 4 acres of meadow. These men could give and sell. But sac and soke and commendation and all customs remained in the Saint's possession. They were then worth 35s., and now the like. A church with 20 acres of land. This manor, the freemen excepted, (was) then (worth) 8 li., now I I li. It is I league long, and 8 furlongs broad. And (pays) in geld 20d. Others hold (land) therein.

In Liuelmera [Livermere] Fulcher holds of the Abbot 2 freemen with 20 acres of land (and) I bordar. Then as now half a plough. And half an acre of meadow. These men could give and sell their lands. But sac and soke and commendation remained in the Saint's possession. They were then as now worth $3^{\text {s. }}$

\section{Babenberga [Babergh] Two Hundrets}

(At) Melaforda [Melford] T.R.E. Saint Edmund held 12 carucates of land as a manor. Forty acres of this land Walter holds of the Abbot. Then as now 37 villeins. And then 25 bordars, and now 10. Then 8 ploughs on the demesne, now 6 . Then 20 ploughs belonging to the men, now 13 . Then as now 16 serfs. And 50 acres of meadow. Wood(land) for 60 swine. And 2 mills. Now 3 rounceys. Then as now 30 beasts. Now 300 sheep. Then as now 140 swine. Now I 2 hives (of bees). And 40 forest mares (equae silvaticae) now. And 2 sokemen (there were) with 80 acres of land. The same Walter held of the Abbot one with

125 Abbot Baldwin obtained from the Conqueror ' ad opus ecclesie et fratris sui' the whole fee of Brithus son of Leomar, namely the manors of Chenentone, Saham, Dunham, Tostok, and Somerledeston, and of them Frodo, the abbot's brother, was enfeoffed: Add. MS. 14847 , fol. 23 d. 


\section{THE HOLDERS OF LANDS}

40 acres. Then as now 2 ploughs. Over them the Saint had commendation and sac and soke and all customs, nor could they ever give or sell their lands without full consent of the Abbot. A church with 2 carucates of land, 4 villeins, 9 bordars. Then as now 2 ploughs belonging to the church. Then as now 2 ploughs belonging to the men. Then this manor was worth 20li., now 3oli. It is 18 furlongs long, and 1 league broad. And (pays) $20 \frac{1}{2} d$. in geld, whoever may be holder thereof.

(At) Cothefrlda [Cockfield] Saint Edmund held T.R.E. $4 \frac{1}{2}$ carucates of land as a manor. Then as now 14 villeins. And then 16 bordars, now 22. Then 2 ploughs on the demesne, now 3. And then 12 ploughs belonging to the men, now 6. Then as now 4 serfs. 8 acres of meadow. A winter mill. Now 3 rounceys, 12 beasts, 37 swine, and 98 sheep. Now 12 hives of bees. This manor was then worth 6 li., now $8 l i$.

In the same (vill are) 21 freemen with 5 carucates of land, which (quos) 4 men hold of

fol. 3596 .

the Abbot-Berard 3 carucates, and James I, and Coleman 1. (There are) 13 bordars, and 3 serfs. Then among them all 8 ploughs, now 7 . And 16 acres of meadow. Wood(iand) for 6 swine. These (men) could all give and sell their land. But by soke and commendation they were under the same Saint, except I man over whom (the Saint) had soke only. Then they were worth 3 li., now 4 li. This vill is 13 furlongs long, and 1 league broad. And (pays) $23 \frac{1}{2} d$. in geld. But others have holdings therein.

(At) Grotena [Groton] T.R.E. Saint Edmund held $I \frac{1}{2}$ carucates of land as a manor. Then as now 8 villeins, and 5 bordars. Then as now I plough on the demesne. Then as now 2 ploughs belonging to the men. And I acre of meadow. Wood(land) for 10 swine. A winter mill. Then as now I rouncey, 6 beasts, I6 swine, and 30 sheep. And (there were) 2 freemen with half a carucate of land. And they could give and sell their land. 6 bordars. Then as now I plough. And I acre of meadow. Then they were worth 30 s., and now 40s. It is 7 furlongs long, and 4 broad.

In the same (vill are) 12 freemen, and they have I carucate. And this is worth 20s. All these men could give and sell their land T.R.E. Saint Edmund has soke, commendation, and service. (This pays) $7 d$. in geld. But others have holdings therein.

In Prestetune [Preston] T.R.E. Saint Edmund held a freeman. Ernulf (now holds him). And he could give and sell his land. And he had 3 carucates of land on the demesne. And then he used to plough with 3 ploughs, now with 2. Then and now 2 villeins, 4 bordars. And they used to plough (with) half a plough. I serf. 3 acres of meadow. (There were) 3 sokemen, and they had $26 \frac{1}{2}$ acres of land, and half an acre of meadow. And they could give and sell their land. And they then were worth 4 li., now 3 li. It is $\mathbf{1} 2$ furlongs long, and 6 broad. A church with 7 acres. This man and his land King William gave to Saint Edmund and to $B$ [aldwin] the Abbot, and soke and all customs. (This pays) $2 d$. in geld. But others have holdings therein.

In Lrlega [(Brent) Eleigh] ${ }^{128}$ Saint Edmund held 5 freemen whom the said Arnulf holds of the Abbot. They then as now had $3 \frac{1}{2}$ carucates (of land). 5 bordars. 3 acres of meadow. Wood(land) for 2 swine. I serf. Then they used to plough with 4 ploughs, and do now. And they could give and sell their land. But soke and sac and commendation were St. Edmund's, and custom. Then they were worth 3 li., now 4 li. It is 12 furlongs long, and 6 broad. (This pays) $3 \frac{1}{2} d$. in geld. But others have holdings therein.

At Sumerledetuna [Somerton] Saint Edmund held in the same hundred I carucate of land, Frodo (now holds) I villein, 5 tordars. Then they used to plough with 3 ploughs, now the like. And then it was worth $43^{s}$. less $4 d$., and now (the same). And King William gave fol. 360 .

the land to Saint Edmund with soke and commendation and all customs. It is 6 furlongs long, and 4 broad. (And pays) $3 d$. in geld. But others have holdings therein.

At Cornerda [(Great) Cornard $]^{127}$ Saint Edmund held 2 freemen, and they had 50 acres of land. I acre of meadow. T.R.E. . . (reg' val' vi bor), and now (the same). And they could give and sell their land. But to Saint Edmund belonged soke and all customs.

At Bura [Bures] Saint Edmund held 3 sokemen, and they had 8 acres of land, and $I$ of meadow. And those 8 acres were worth $16 d$. And these men could give (and) sell their land. And by soke and all customs they were and are under the Saint.

(At) Waldingefelda [Waldingfield) Saint Edmund held I I freemen; and under them were half a carucate of land, 3 bordars, 2 acres of meadow. And they could give and sell their land. But the soke was the Saint's and the commendation and the service. They were then worth IOs., and now (the same). (They pay) $1 d$. in geld.

${ }^{198}$ The abbey held 3 carucates at Brent Eleigh at the time of the Conquest, according to the list of possessions in Harl. MS. 743.

18 'Cornherthe magna'; ibid. 


\section{A HISTORY OF SUFFOLK}

Saint Edmund held Niwetuna [Newton] as a manor T.R.E., and now Aelons holds it of the Abbot. Therein were then as now 2 carucates of land. Then as now 2 ploughs on the demesne. And $1 \frac{1}{2}$ ploughs belonging to the men. Then 2 serfs, now none. Then 3 beasts, now 7. Then 40 swine, now 29. Then 97 sheep, now 102. Then as now 3 villeins. Then 4 bordars, now 10 . Now 14 goats, then none. Then 16 hives of bees, now 9. Wood(land) then for 8 swine, now 6 . Then as now 2 acres of meadow. This manor is 6 furlongs long, and 3 broad. Then it was worth $2 l i$, now $2 \frac{1}{2} l i$. And (pays) $4 d$. less I farthing in geld.

In Somerledetona [Somerton] a freeman under Saint Edmund (heid) $30 \frac{1}{2}$ acres of land. Now Frodo holds him of the Abbot. Worth 2 s.

In Mellinga [Milden ${ }^{128}$ ] a freeman (with) 15 acres of land, and 3 oxen. Worth 2s.

\section{STOHU [STOW] HundRET}

In WEDERDENA [Wetherden] 20 freemen under Saint Edmund T.R.E. (held) 2 carucates of land. Ralph holds half a carucate, and Ernulf 40 acres. And (there are) 13 bordars. Then 5 ploughs, now 7. And 8 acres of meadow. And half a church with 15 acres and I acre of meadow. Then worth 30 s., now 40 s.

In Heroluestuna [Harleston] were 2 freemen under Saint Edmund T.R.E. with I carucate and 20 acres of land. Now Aelons holds of the Abbot, Peter holds 20 acres. Then as now 2 villeins, and II bordars and 2 serfs. Then and now among them $I \frac{1}{2}$ ploughs. And $8 \frac{1}{2}$ acres of meadow. And under them are II freemen with 23 acres. Then 2 ploughs among them, now half a plough. A church with 25 fol. $360 b$.

acres of free land. The entire holding then as now was worth 26 s.

In ANhus [Onehouse] a freeman under Saint Edmund held half a carucate of land and 3 bordars. Then as now 1 plough and 4 acres of meadow. And then and now worth 20 s. T.R.E. sac and soke and commendation over all these men belonged to Saint Edmund of the gift of King Edward as his writs and seals show, which the Abbot has. Afterwards King William allowed the gift (concessit). But the King's reeve had 4s. on account of the soke of one of them, whether it was rightly or wrongly, neither the Abbot nor his ministers knowing. And the Hundred testifies that they did not know Saint Edmund to have been at a later time disseised (of the soke) after King Edward gave it.

$$
{ }^{198} \text { Formerly 'Mildinges'; Feud. Aids, v, } 43 .
$$

\section{Bosemrra [Bosmere] Hundret}

(At) Mulcelfel [Mickfield] Saint Edmund held T.R.E. 60 acres as a manor. Then as now 2 villeins, and 3 bordars, and 1 serf. And I plough on the demesne. And I plough belonging to the men. And 3 acres of meadow. And 5 beasts, 10 swine, 27 sheep, and 21 goats. Then it was worth Ios., now 15 s. The King and the Earl (have) the soke.

In the same (vill) Ailric a freeman held 60 acres of land. Saint Edmund (had) commendation. And I villein, and I bordar. And I plough. And 2 acres of meadow. A church with 8 acres, and half a plough. Then it was worth 10s., now 15s. This land the Abbot so holds, bccause this Ailric T.R.E. took a wife who held this land freely in the King's soke; but the Abbot claims (revocat) the soke of the King's gift. Berengar holds it of the Abbot. It is I league long, and 8 furlongs broad. And (pays) $2 d$. in geld.

(At) Stanham [Stonham] Ulwar a freeman in the soke of the King and the Earl held 60 acres as a manor. And then as now 4 bordars. And I plough on the demesne. And I acre of meadow. Wood(land) for 5 swine. And I rouncey, 2 beasts, and 16 sheep. Worth IOs. Ailbold the priest holds this land. The Abbot has it in pledge for the sum of two marks of gold by the grant of Engelric when the Englishmen redeemed (their lands).

\section{Claindune [Claydon] Hundret}

In TORP [Thorpe] 2 freemen under commendation held 6 acres of land. Worth $16 d$. Saint Edmund (has) the soke over one, and Saint Etheldreda over the other.

\section{Plumesgate [Plomesgate] Hundret}

In Gliemham [Glemham] (was) a freeman, Aluric, and $6 \frac{1}{2}$ freemen under commendation, with $2 x$ acres and 2 acres of meadow. Then as now 1 plough. Worth $5^{\text {s. The }}$ soke (is) the Abbot's. Norman holds of the Abbot.

\section{Hertesmera [Hartismere] Hundret}

(At) REG[R]AUA [Redgrave] Saint Edmund held T.R.E. 6 carucates of land as a manor. Then as now ro villeins, and 19 bordars. Then 8 serfs, now 6 . Then as now 4 ploughs on the demesne. And 6 ploughs belonging to the men. 8 acres of meadow. Wood(land) for 120 swine. A church with 30 acres of free fol. 361 .

land and half a plough. And 2 rounceys, 12 beasts, 30 swine, 60 sheep, and 30 goats. Then as now worth roli. 


\section{THE HOLDERS OF LANDS}

In the same (vill) 24 freemen (held) 80 acres under soke and commendation of the Abbot. Then as now 8 ploughs. Then as now worth 3os. It is I league long, and half (a league) broad. And (pays) $8 d$. in geld. The Abbot holds in demesne.

In WORDHAM [Wortham] 2 sokemen (held) 60 acres as 2 manors T.R.E. Then as now 8 bordars. And $2 \frac{1}{2}$ ploughs. And 4 acres of meadow. Wood(land) for 14 swine. Worth 20 s.

In the same (vill) I sokeman (with) I4 acres. Half a plough. Worth $32 d$.

In the same (vill) Alfahc a freeman under the Abbot's soke and commendation (held) 30 acres as a manor T.R.E., and 4 bordars and I plough, and I acre of meadow. Worth 10 s.

In the same (vill) Uluric a freeman held 30 acres under the Abbot's soke and commendation. And $6 \frac{1}{2}$ bordars. And I plough on the demesne, and half a plough belonging to the men. I acre of meadow. Worth IOs.

In the same (vill) 25 freemen (held) 3 carucates of land. Then as now 6 ploughs. Worth 30s. The soke and commendation (are) the Abbot's. It is 1 league long, and 1o furlongs broad. And (pays) $12 d$. in geld.

In Gisinghenam [Gislingham] a sokeman Aluric (held) 30 acres. Then as now I plough. And I bordar. And I acre of meadow. Worth Ios.

In the same (vill) 12 freemen and I sokeman (held) 8 acres out of the 30 acres in the same soke, land and commendation belonging to the Abbot. Then 3 ploughs, now 2. And I acre of meadow. Worth Ios.

(At) Palegrava [Palgrave] Saint Edmund held T.R.E. 4 carucates of land as a manor. Then as now II villeins and 17 bordars. Then 3 serfs, now I. Then as now I plough on the demesne. And 4 ploughs belonging to the men. And 6 acres of meadow. And 2 churches with 30 acres and half a plough. And 2 rounceys, 12 beasts, 6 swine, and 8 sheep. Then worth $6 / i$, now 8 li. The soke is the Abbot's.

In the same (vill) 29 freemen (held) 2 carucates of land less 12 acres. Then as now 8 ploughs. And 2 acres of meadow. Worth 40s. The soke and commendation (are) the Abbot's. It is $I$ league long, and half a (league) broad. And (pays) 12d. in geld.

In Richingehala [Rickinghall] 14 freemen under the Abbot's soke and commendation (held) 80 acres. Then as now 3 ploughs. And 2 acres of meadow. The fifth part of a church with 5 acres. Worth 20 s.

(At) BrocFort [Brockford] Saint Edmund held T.R.E. 3 carucates of land and 43 acres.
Then as now 14 bordars, and 3 serfs. And 2 ploughs on the demesne. And 2 ploughs belonging to the men. And 4 acres of meadow. Wood(land) for 40 swine. And 8 beasts, 6 swine, 20 sheep, and 20 goats. Then as now worth Ioos.

fol. 3616 .

\section{Theodwardestreo [Thedwastre] Hundret}

(At) Bertuna [(Great) Barton] Saint Edmund held T.R.E. as a manor 5 carucates of land. Then as now 22 villeins, and 5 bordars. Then 4 ploughs on the demesne, now 3. Then as now 6 ploughs belonging to the men. Then II serfs, now 4. And 3 acres of meadow. Wood(land) for 4 swine. 4 rounceys, 18 beasts, 44 swine, and 402 sheep. And now 2 hives of bees. And 70 freemen (held) 5 carucates of land. And then as now among them all 18 ploughs. And 2 bordars. And 1 acre of meadow. Over these men (the Saint) has and always had sac and soke and all customs. And they all belong to the (Saint's) fold except 3 . To the church of this vill 50 acres of free land belong as alms. Then worth $16 \mathrm{li}$, now $20 \mathrm{li}$. It is $I$ league and 2 furlongs long, and $I$ league broad. And (pays) $27 d$. to a geld.

(At) Pachenham [Pakenham] T.R.E. Saint Edmund held as a manor 7 carucates (of land). Then as now 44 villeins, and 23 bordars. Then 3 ploughs on the demesne, now 4. Then as now 23 ploughs belonging to the men. Then 6 serfs, now 9. And 26 acres of meadow. Wood(land) for 100 swine. Then 2 mills, now 1. And 3 rounceys, 48 beasts, 65 swine, and 190 sheep. And now 8 hives of bees. And 31 freemen and I bordar (held) 2 carucates of land. Then as now among them were II ploughs. And 3 acres of meadow. These all have always belonged to the Saint with sac and soke and all customs, and to the (Saint's) fold.

In the same (vill were) 3 freemen with 30 acres of land. Then as now I plough. Wood(land) for 4 swine. They could give and sell the land, but soke and sac and commendation would remain in the Saint's possession.

In the same (vill) T.R.E. I freeman with I carucate of land got the Abbot's consent to lease him (impetiavit ab abbati prestari sibi) half a carucate of land on condition that the whole of his land, wheresoever it should be, should remain in the Saint's possession after his death. And now out of this (freeman's) land I carucate lies in Pachenham [Pakenham] in demesne. And I plough. And 5 bordars, and 2 serfs. And a winter mill. And the Saint had always commendation and sac and soke over him. To the church of this township belong (jacent) 30 acres of free land as alms. Then Pachenham [Paken- 


\section{A HISTORY OF SUFFOLK}

ham] was worth Ioli., now 25li. It is 16 furlongs long, and I league broad. And (pays) I $3 \frac{1}{2} d$. to a geld.

(At) Fornham [Fornham (St. Martin) ${ }^{129}$ ] T.R.E. Saint Edmund held as a manor I carucate of land. Then as now 3 villeins, and 4 bordars. Then I plough on the demesne, now 2. fol. 362 .

And then as now 2 ploughs belonging to the men. Then 4 serfs, now 3. And 2 rounceys. And then as now 4 beasts. And now 12 swine, and 80 sheep. And 10 freemen and 6 bordars (held) 30 acres of land. Then as now I plough. They were (and) are wholly under the Saint as to all customs, and as to the fold.

In the same (vill was) a freeman with 12 acres of land. He could give and sell the land, so however that sac and soke and commendation would remain in the Saint's possession. To the church of this vill belong 16 acres of free land in alms. This manor T.R.E. was worth 3 li., now 4 li. It is 9 furlongs long, 7 broad. And (pays) $6 \frac{1}{2} d$. to a geld.

At Ruнham [Rougham] T.R.E. Saint Edmund held as a manor 5 carucates of land. Then as now 15 villeins, and 4 bordars. Then as now 3 ploughs on the demesne. And 2 ploughs belonging to the men. Then as now 6 serfs. And 4 acres of meadow. And 3 rounceys, 22 beasts, 25 swine, and 55 sheep. And (there are) 90 freemen, and II bordars, and I serf. And 5 carucates of land. Then as now I 8 ploughs. And 3 acres of meadow. These also always were and are under the Saint by commendation and all customs, and as to the fold. To the church of this vill belong 40 acres of free land in alms. Then worth 14 li., now 16 li. It is I 6 furlongs long, and I league broad. And (pays) 20d. in geld.

(At) Bradefelda [Bradfield] T.R.E. Saint Edmund held as a manor 3 carucates of land. Then as now 15 villeins, and 18 bordars. Then 2 ploughs on the demesne, now 3. Then as now 4 ploughs belonging to the men. Then I serf, now 6. And 7 acres of meadow. And 3 rounceys, Io beasts, 28 swine, and 99 sheep. And now 80 goats. And (there were) 3 freemen with 24 acres of land. And then as now I plough. And I acre of meadow. Over them the Saint had commendation, and sac and soke as to all customs. And they could not give or sell their land without the Abbot's licence.

In the same (vill were) 9 freemen with 1 carucate of land. 2 bordars. Then as now among them 3 ploughs. And 2 acres of meadow. Worth 6s. They had power to give and sell their lands. But the soke would remain in the

13* See list in Harl. MS. 743.
Saint's possession, and the service (also), whoever might buy the land. To the church of this vill belong $10 \frac{1}{2}$ acres of free land as alms. This manor T.R.E. was worth 6 li., now $8 l i$. It is 1 league long, and 4 furlongs broad. And (pays) $5 d$. to a geld.

(At) Genonefae Forham [Fornham St. Genevieve] T.R.E. St. Edmund held as a berewick 2 carucates of land. Peter has of these 2 carucates 40 acres. He holds of the Abbot. 2 villeins (and) 2 bordars have I carucate of them. And the hall to which they belong is in another Hundred. Ralph holds from the Abbot 12 acres of the 2 carucates. Then as now 8 villeins, and 3 bordars. Then as now 2 ploughs on the demesne. And 3 ploughs belonging to the men. Then as now 3 serfs. And 4 acres of meadow. And then as now 3 mills. And I rouncey, and 100 sheep. And 6 freemen and 1 villein and 5 fol. $362 b$.

bordars have I carucate of land. And then as now 3 ploughs. These men had power to give or sell their lands; but the soke would remain in the Saint's possession over the land, and the service. They are worth Ios. There is a church with 14 acres of free land for alms. This berewick was then as now worth 4 li. It is 9 furlongs long, and 4 broad. And (pays) $8 d$. to a geld.

(At) Thurstuna [Thurston] T.R.E. Saint Edmund held as a manor $I \frac{1}{2}$ carucates of land. Then 6 bordars, now 8 . Then as now 2 ploughs. And I plough belonging to the men. And now I serf. And 5 acres of meadow. Wood(land) for 8 swine. And now I rouncey. Then as now 5 beasts, and 32 swine, and 52 sheep. And (there were) 28 freemen with $2 \frac{1}{2}$ carucates of land. Richard holds of the Abbot I carucate of land. And he has 8 freemen and 12 bordars. Then as now 8 ploughs. And 5 acres of meadow. Wood(land) for 3 swine. And ... (medietal? ome). Worth 40s. And the Abbot's other men 125. They could give and sell their lands; but the soke over the land would remain in the Saint's possession, and the service. Worth 2li. A church with 30 acres of free land in alms. This manor, these freemen excepted, was then and now worth $1 \frac{1}{2} l i$. It is 10 furlongs long, and 6 broad. And (pays) I $6 d$. to a geld. But several persons have holdings therein.

(At) WlfpPETA [Woolpit] Saint Edmund held T.R.E. as a berewick 3 carucates of land. And the hall to which it belongs is in another Hundred. Then as now 17 villeins, and 3 bordars. Then as now 3 ploughs belonging to the men. In demesne 4 acres of meadow. Wood(land) for 20 swine. And (there were) 40 freemen with I carucate of land. Then as now 6 ploughs. 3 acres of meadow. And they all had power 


\section{THE HOLDERS OF LANDS}

T.R.E. to give and sell their lands, but the soke over the land would always remain in the Saint's possession, and all services. To the (Saint's) fold too they all belong. Worth IOs. and $8 d$. To the church (belong) 15 acres in alms. This berewick was then and is now worth $3 l i$. It is 9 furlongs long and 6 (broad). And (pays) I Id. in geld. But several persons have holdings therein.

In Drencestuna [Drinkstone] (were) I I freemen with 1 carucate of land. And they had 6 bordars, and 3 ploughs, and 8 acres of meadow. T.R.E. they could give and sell their lands. But so that the soke over the land remained in the Saint's possession. They were worth 10 s. and $8 d$.

In Etrseta [Hessett] (were) 60 freemen with $5 \frac{1}{2}$ carucates of land. And 6 bordars. Berard holds half a carucate of land, and 2 bordars, and 1 plough. He is charged (super eum) 20s. Among them all then as now 6 ploughs. 5 acres of meadow. They could sell and give their lands T.R.E. But the soke remained in the Saint's possession, and they owe all services in Ruhham [Rougham]. To the (Saint's) fold too they all belong except 6 . Worth 40 s. To the church (belong) 12 acres. It is 8 furlongs long and 7 broad. And (pays) $18 d$. in geld whoever have lands there.

In Fealsham [Felsham] (were) 25 freemen with 3 carucates of land. I villein, and 5 bordars. Adelelund (holds) $I_{2} \frac{1}{2}$ carucates of land. And 8 freemen hold 4 carucates, and are worth 50s. Then as now among them 8 ploughs, and 5 acres of meadow. They (could) give and sell their lands.... (The soke) would remain in the Saint's possession. Then worth 30 s, now 6os. A church with 10 acres of free land in alms. It is 8 furlongs long and 6 broad. (And pays) $5 d$. to a geld.

In BRADEFrLda [Bradfield] (were) Io freemen with $2 \frac{1}{2}$ carucates of land. Roric holds of the fol. 363 .

Abbot $1 \frac{1}{2}$ carucates of land. And Falc half a carucate. $4 \frac{1}{2}$ ploughs. Under them 54 sokemen (sol). And they have 12 bordars. Then as now 6 ploughs. And 8 acres of meadow. They could give and sell their lands, so however that the soke would remain in the Saint's possession. Worth T.R.E. 2li., now 3li. This vill is 10 furlongs long, 3 broad. And (pays) $5 d$. in geld.

In Geldinga [Gedding] (were) 13 freemen with 55 acres of land. Among them all half a plough. They also could give and sell their land. But the soke would remain in the Saint's possession. Then worth $16 d$, , now 2s. A church with 6 acres of free land in alms. It is 3 fur- longs long and 2 broad. And (pays) $5 d$. in geld. Others have holdings therein.

In RATLesdena [Rattlesden] (was) a freeman with half a carucate of land. And 4 bordars then and now have $x$ plough, and 2 acres of meadow. And wood(land) for 4 swine. Then worth IOs., now 20s. Peter holds of the Abbot. He (the freeman) had power to give or sell his lands, so however that the soke would remain in the Saint's possession.

In Huelfiham [Welnetham] were 41 freemen with 6 carucates of land. Of these 6 carucates Ernulf holds I carucate of land from the Abbot. He is charged (super eum) 20s. And Robert (holds) 20 acres. 12 bordars. Then as now 16 ploughs among them all. And 13 acres of meadow. And wood(land) for ro swine. They could all sell and give their land, so however that the soke would remain in the Saint's possession. (Worth) T.R.E. 2li., now 3 li. and ros. Two churches with 40 acres of free land for alms. This vill is I league long, 6 furlongs broad. And (pays) to a geld rod.

In Timwrtha [Timworth] (were) 29 freemen with $3 \frac{1}{2}$ carucates of land. John holds of the Abbot 6 freemen with I carucate of land and 2 ploughs. Worth 20s. On the Abbot's demesne (were) 8 bordars and 5 ploughs, and 6 acres of meadow. They could all give or sell their land; su however that the soke would remain in the Saint's possession, and the service. Then worth 1 li. and IOs., now 20s. A church with 30 acres of free land in alms. It is 8 furlongs long and 6 broad. (Pays) 14d. in geld.

In Hametuna [Ampton] (were) 22 freemen with 2 carucates of land. Robert (holds) of the Abbot half a carucate of land and $\mathbf{Y}$ plough. Worth 20s. On the Abbot's demesne (were) then as now 5 ploughs. And 2 acres of meadow. And these men could give and sell their land, so however that the soke would remain in the Saint's possession, and the service at Ingham.

fol. $363^{b}$.

Then worth 20s., now 30s. A church with 8 acres of free land as alms. It is 6 furlongs long, 4 broad. And (pays) $7 d$. to a geld.

In Totstocha [Tostock] T.R.E. the Saint held as a manor I carucate of land, now Frodo ${ }^{130}$ holds of the Saint. Then 2 bordars, now I. Then as now I plough on the demesne. And 4 acres of meadow. Wood(land) for 8 swine. And I rouncey. Worth 20s. $17 \frac{1}{2}$ freemen with 1 carucate of land. And they have 3 bordars. Then 3 ploughs among them, now 2 . And 2 acres of meadow. And they could give

$$
{ }^{180} \text { See n. } 125 .
$$




\section{A HISTORY OF SUFFOLK}

and sell their lands, so however that the soke would remain in the Saint's possession, and the service. And they were then worth IOS., now Ios. and $8 d$. A church with 12 acres of free land in alms. It is 7 furlongs long, 6 broad. And (pays) $10 \frac{1}{2} d$. to a geld. Others have holdings thereon.

In Stanesfelda [Stanningfield] (were) I I freemen with $I \frac{1}{2}$ carucates and $I 2$ acres of land. Gaurinc holds of the Abbot 80 acres, and $1 \frac{1}{2}$ ploughs. Worth 20s. On the Abbot's demesne (were) 5 bordars. Then as now 4 ploughs among them. And 9 acres of meadow. They could give and sell their land; so however that the soke would remain in the Saint's possession, and the service. Then as now worth $125 . A$ church with 16 acres of free land in alms. It is 8 furlongs long, and 4 broad. And (pays) $10 d$. to a geld. But others have holdings therein.

In RYSCEBROC [Rushbrooke] (were) 22 freemen with 2 carucates of land, 4 bordars. Then as now 4 ploughs among the men. And 2 acres of meadow. They could give and sell their land; so however that the soke would remain in the Saint's possession, and the service in Ruhham [Rougham]. 'To the (Saint's) fold too all (belong) except 3. Then worth I6s, now 20 s. and $23 \mathrm{~d}$. It is 7 furlongs long and 4 broad. And (pays) $7 d$. to a geld.

In LIVERMERA [Livermere] (were) Io freemen with I carucate of land. And then as now 3 ploughs among them. And 2 acres of meadow. They could give and sell the land, so however that the soke would remain in the Saint's possession. Then as now worth ros. and $8 d$.

In the same (vill) Frodo holds 12 freemen with 2 carucates of land. And 5 ploughs. Worth 6os.

In the same (vill) the said Frodo holds a freeman (formerly) under Edric of Laxfield with 2 carucates of land, and his wife (was) under Saint Edmund. 2 villeins, 8 bordars, and 2 serfs. Then as now 2 ploughs on the demesne. And 2 ploughs belonging to the men. And 4 acres of meadow. They could give and sell the lands. But sac and soke and commendation over the woman only would remain in the Saint's possession. This man's lands the King received from the Abbot, and gave to Gernon de Peiz. Afterwards by the King's licence, becoming a monk (deveniens monac'), he gave back the land. Then as now worth 40 s. A church with 12 acres of land. It is Io furlongs long, and 8 broad. And (pays) $12 d$. in geld.

fol. 364 .

\section{Brademera [Bradmere] Hundret}

INGHAM [Ingham] T.R.E. one Wlfin, a knight (miles) under Saint Edmund held of him as a manor, now the Saint himself holds; 3 carucates of land; and a fourth carucate of land lies in another Hundred. Then as now I villein, and 2 bordars. Then 3 ploughs on the demesne, now 4. And then as now I plough belonging to the men. Then 3 serfs, now 9. And 27 acres of meadow. And I mill. And now 4 rounceys. And now 19 beasts. And now $3^{\circ}$ swine. And 520 sheep. And (there were) 21 sokemen with I carucate of land. Then as now 7 ploughs. And 2 acres of meadow. And these are all under the Saint by sac and soke and all customs : to the (Saint's) fold too (they belong). Nor could they ever give or sell without the Abbot's consent. A church with 24 acres of free land in alms. This manor was then worth 4 li., now 8li. It is 16 furlongs long, and 8 broad. And (pays) $16 d$, in geld. But the King holds there.

(At) Culeforda [Culford] Saint Edmund T.R.E. held as a manor I carucate of land. Then as now 2 villeins, and 2 bordars. Then as now I plough on the demesne. Then I plough belonging to the men, now half a plough. And 8 acres of meadow. And I beast, 2 swine, and 85 sheep. And (there are) 18 sokemen with half a carucate of land. Then as now 2 ploughs. These also belong to the Saint by sac and soke and all customs: nor could they ever give or sell without the Abbot's leave. Then it was worth 4 li., now 3 li.

In the same (vill was) a freeman with 1 carucate of land which Peter holds of the Abbot. 7 bordars, and 2 serfs. Then as now 2 ploughs. And 2 oxen belonging to the men. 6 acres of meadow. Then it was worth Ios., now 30 s. It is 1 league long and 5 furlongs broad. And (pays) in geld $7 \frac{1}{4} d$.

In STow A [(West) Stow] (are) 2 I freemen with 2 carucates of land. Then as now 6 ploughs among them all. And 2 acres of meadow. These are under the Saint by sac and soke and all customs and do their service in Lecforda [Lackford]. Then as now it was worth 20 s.

In the same (vill is) a freeman with half a carucate of land. Then as now I plough. Then as now it was worth 4 s. A church with 12 acres of free land in alms, and it lies in another hundred. It is 9 furlongs long, and 7 broad. And in geld (pays) $17 d$.

\section{Blachebrune [Blackbourn] Hundret}

(At) Statuna [Stanton] Saint Edmund held T.R.E. I carucate of land as a manor. Then fol. $364 b$.

I plough on the demesne, now 2. Then 4 serfs, now 3. And 2 acres of meadow. Wood(land) for 8 swine. And now 2 rounceys, 3 beasts, 28 swine, 52 sheep, and 30 goats. And (there were) 60 sokemcn with 2 carucates of land. 


\section{THE HOLDERS OF LANDS}

Then as now 5 ploughs. And 4 acres of meadow. These men are and were under the Saint by commendation and sac and soke and all customs; and they could never give or sell their land without licence of the Abbot; and (they belong) to (the Saint's) fold. This manor was then worth $6 l i$, and now $6 l i$.

In the same (vill were) 7 freemen with I carucate and 30 acres of land. Then as now 4 ploughs. And 4 acres of meadow. Wood(land) for 10 swine. They could give and sell their land. But commendation and soke remained in the Saint's possession, and the service. A chirch with 28 acres, and the fourth part of a church with 7 acres of land. Then worth Ios.,

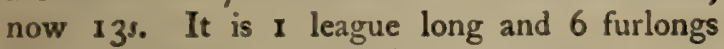
broad. And (pays) in geld 2s. and $10 \frac{1}{2} d$.

(At) Elmeswelux [Elmswell] Saint Edmund held T.R.E. 2 carucates of land as a manor. Then as now 16 villeins, and 14 bordars. Then and now 2 ploughs on the demesne. Then as now 4 ploughs belonging to the men. Then 4 serfs, now 5. And 8 acres of meadow. Wood(land) for 80 swine. Now 3 rounceys, 5 beasts, I 5 swine, 18 sheep, and 48 goats. And 5 sokemen with 40 acres of land. And then as now 2 ploughs. And 1 acre of meadow. These men are entirely under the Saint; nor could they give or sell without the Abbot's licence. A church with 20 acres of free land in alms. This manor was then worth 5 ki., now $6 l i$. It is I league long, and io furlongs broad. It (pays) to a geld $I I \frac{1}{4} d$. Others hold (land) therein.

(At) Hilderclas [Hinderclay] T.R.E. Saint Edmund held 4 carucates of land as a manor. Then 6 villeins, now 8 . And then 8 bordars, now 12. Then 6 ploughs on the demesne, now 5. Then Io serfs, now 8. Then as now 2 ploughs belonging to the men. And 8 acres of meadow. Wood(land) for 60 swine. Now 3 rounceys, 8 beasts, 20 swine, and 60 sheep. And (there were) 7 sokemen with 40 acres of land. Then as now 2 ploughs. A church with 1 acre of free land in alms. This manor was then as now worth $8 l i$. It is I league long, and 6 furlongs broad. And pays in geld $5 \frac{1}{2} d$. Others hold (land) there.

At Richingeralla [Rickinghall] T.R.E. Saint Edmund held 2 carucates of land as a manor. Then 4 villeins, now 2. And then as now 6 bordars. Then as now 2 ploughs on the demesne. And then I plough belonging to the fol. 365 .

men, now half. A winter mill. Then 4 serfs, now 2. And 8 acres of meadow. Wood(land) for 60 swine. And now 2 rounceys, 8 beasts, 16 swine, 24 sheep, and 30 goats. And (there were) 22 sokemen with half a carucate of land. Then as now among them 6 ploughs, and 6 acres of meadow. These men hold under the Saint by commendation and sac and all customs; and they could not ever give or sell their land without licence. To the (Saint's) fold all (belong). This manor was then worth with its appurtenances 5 li., now $7 l i$.

In the same (vill) were 2 freemen with half a carucate of land. I bordar. Then as now 2 ploughs. And 2 acres of meadow. Wood(land) for 8 swine. These men could give and sell their land. But sac and commendation remained in the Saint's possession, and the service. And they were then as now worth ros. A church with 24 acres of free land in alms. It is I league long, and 3 furlongs broad. And (pays) in geld I 2d. Others hold (land) there.

(At) Cunegestuna [Coney Weston] T.R.E. Saint Edmund held 2 carucates as a manor. Then 2 villeins. Now and always 3 bordars. Then as now 2 ploughs on the demesne. Then as now half a plough belonging to the men. Then as now 1 serf. And 2 acres of meadow. Wood(land) for 4 swine. And now I rouncey, 10 beasts, 12 swine, 80 sheep, and 24 goats. And (there were) 12 sokemen with half a carucate and 30 acres of land. Then 6 ploughs, now 4. And 2 acres of meadow. A church with 8 acres of free land in alms. This manor was then worth 5 li., now 6 li. It is I league long, and 6 furlongs broad. And (pays) in geld $17 \frac{1}{4} d$.

In Stoua [Stow] Durand holds of the Abbot 4 carucates of land which 2 freemen held T.R.E. Then as now 8 bordars. Then 4 ploughs on the demesne, now 2. And a mill. Wood(land) for 20 swine. And 30 sheep. And 8 acres of meadow. Then it was worth 6 li., now 6 li.

In the same (vill were) 14 freemen with half a carucate of land. Then as now 4 ploughs. And 2 acres of meadow. These men could give and sell their land. So however that the soke and commendation would remain in the Saint's possession and the service. To the (Saint's) fold also all except one (belong). Then as now it was worth 6 s. and $8 d$. A church with 40 acres of free land. This vill is I league long, and 8 furlongs broad. And (pays) in geld rod. Several persons hold (land) there.

\section{fol. $365 b$.}

In HePworda [Hepworth] (are) 20 freemen with $2 \frac{1}{2}$ carucates of land. And they have 3 villeins, and 4 serfs. Then as now 8 ploughs. And 4 acres of meadow. Wood(land) for 6 swine. A church with 15 acres of free land in alms. These men could all give and sell their land. But by sac and soke and commendation and all customs they would remain under the Saint, and (would do) service in Stantuna [Stanton] and Cunegestuna [Coney Weston]. They were then worth 20s., now 40s. Of this 


\section{A HISTORY OF SUFFOLK}

land Fulcher holds of the Abbot I carucate. ... (de omne medietat'). And Peter de Valoignes (waleniis) 30 acres and 3 bordars. It is worth 32s. (and is included) in the same valuation. It is 7 furlongs long, and 5 broad. And (pays) $17 \frac{1}{4} d$. in geld. Others hold (land) there.

In W ATLesfeida [Wattisfield] (were) 20 freemen with $\mathbf{I} \frac{1}{2}$ carucates of land. I bordar, and I serf. Then 8 ploughs, now 6. And I acre of meadow. Wood(land) for 12 swine. A church with 12 acres of free land in alms. These men could give and sell their land. But the sac and soke and commendation remained in the Saint's possession, and the service at Richingehalla [Rickinghall]. Then it was worth 30s, now 40s. Of this land Roric holds I carucate, and 3 ploughs. It is worth 30 s. (and is included) in the above valuation. It is 7 furlongs long, and 5 broad. And (pays) $17 \frac{1}{4} d$. in geld. Others hold (land) there.

In Hopetuna [Hopton] (are) 23 freemen with 2 carucates of land. 4 bordars. Then as now 6 ploughs. And 4 acres of meadow. Wood(land) for 2 swine. And I mill. A church with 13 acres of free land in alms. These men could give and sell their land. But sac and soke and commendation remained in the Saint's possession, and the service at Cunegestuna [Coney Weston]. They were then worth 20s., now 30s. Of this land Fulcher holds half a carucate. Worth 20s. (and included) in the above valuation. It is 6 furlongs long, and 4 broad. And (pays) $16 d$. in geld. Others hold (land) there.

In Barningham [Barningham] ig freemen (held) 2 carucates of land. 2 villeins and 2 bordars. Then 9 ploughs, now 6 . And 4 acres of meadow. A church with 15 acres of free land

fol. 366 .

in alms. These men could give and sell their land. But sac and soke and commendation remained in the Saint's possession, and the service at Cunegestuna [Coney Weston]. They were then worth 20s., now 40s. Of these freemen Bucard holds 3 freemen with I carucate of land, and 2 ploughs. Worth 15 s. (and included) in the above valuation. And Peter de Valoignes $\left(w a l^{\prime}\right)$ (holds) 6 freemen with 3 carucates. Worth 20s. (and included) in the above valuation. It is I league long, and 6 furlongs broad. And (pays) $\mathbf{r} \mathbf{d}$. in geld. Others hold (land) there.

In BeoRdewella [Bardwell] (were) 8 freemen with 2 carucates and 30 acres of land; which men Bucard holds. 4 bordars, and 2 serfs. Then as now 4 ploughs. And 2 parts of a mill. And II acres of meadow. Wood(land) for 8 swine. A church with 8 acres of free land. These men could give and sell their land. But $\mathrm{sac}$ and soke and commendation remained in the Saint's possession. Then it was worth 20s., now 60s. And under them (were) 20 sokemen, of whom the Abbot holds 10 with 30 acres and I plough; and they are worth 5s.; and Peter de Valoignes holds Io with half a carucate of land and I plough. Worth ros. It is a league long, and 6 furlongs broad. And in geld (pays) $34 \frac{1}{4} d$. But several persons hold (land) there.

In Sapestuna [Sapiston] were II freemen with $1 \frac{1}{2}$ carucates of land. Then as now 2 ploughs. And 2 mills. And 6 acres of meadow. These men could give and sell their land. So however that by soke and sac and commendation (the land) would remain in the Saint's possession. Two thirds (partes) of a church with 6 acres of free land in alms. They were then as now worth 25s. Of these freemen Peter de $\mathrm{Va}$ loignes holds 4 freemen with 80 acres and I serf and I plough. Worth I 3 s. It is ro furlongs long, and 5 broad. And pays $17 \frac{1}{4} d$. in geld. Several persons hold (land) there.

In Westuna [Weston] (were) $3 \frac{1}{2}$ freemen with 1 carucate of land, and 6 bordars. Then as now 2 ploughs. And I acre of meadow. Wood(land) for 4 swine. These men could all, except I with 40 acres, sell and give their land. But the soke and sac and commendation remained in the Saint's possession, and the service at Cunegestuna [Coney Weston]. They were then as now worth ros.

In Hungetuna [Honington] (were) 16 freemen with 2 carucates of land. 2 bordars. Then fol. $366 b$.

as now 5 ploughs. And 8 acres of meadow. Wood(land) for 2 swine. These men could give and sell their land. But the soke and sac and commendation would remain under the Saint. Then as now it was worth 20s. A church with 20 acres of free(land). Of this land Peter holds I carucate. It is 6 furlongs long, and 4 broad. And (pays) $12 \frac{1}{2} d$. in geld. Others hold (land) there.

In Trostuna [Troston] (were) 24 freemen with $2 \frac{1}{2}$ carucates of land. Then as now 5 ploughs. These men could give and sell their land. But by sac and soke and commendation they would remain under the Saint. Then it was worth 20s, now 30s. Of them Frodo holds I 2 freemen with I carucate of land, and 2 ploughs. Worth 20s. (included) in the above valuation. It is 10 furlongs long, and 5 broad. And (pays) I I $\frac{1}{2} d_{0}$ in geld. Others hold (land) there.

In Litla Livermera [Little Livermere] (were) 7 freemen with 2 carucates of land. 3 bordars. Then as now 4 ploughs. And half an acre of meadow. These men could give and 


\section{THE HOLDERS OF LANDS}

sell their land. But the sac and soke and commendation remained in the Saint's possession. A church with 12 acres of free land. They were then as now worth 30 s. Of them Walter holds 3 freemen with 1 carucate of land and I plough. And they are worth 15s. (included) in the above valuation. It is I league long, and 4 (furlongs) broad. And (pays) $3 \frac{1}{4} d$. in geld.

In WRIDEWelia [Wordwell] (were) II freemen with 2 carucates of land. 4 bordars, and 2 serfs. Then as now 5 ploughs. And 3 acres of meadow. Now I mill. These men could give and sell their land. But sac and soke and commendation remained in the Saint's possession, and the service at Culeforda [Culford]. They were then as now worth 30 s. A church with I acre of free land. It is I league long and 4 furlongs broad. And pays $7 \frac{1}{2} d$. in geld.

In Bernham [Barnham] (were) 3 freemen with I carucate of land. Then as now 2 ploughs. And 1 mill. These men could give and sell their land. But sac and soke and commendation remained in the Saint's possession. Half a church with 8 acres of land. They were then as now worth 25s. Of this land Fulcher holds 80 acres, and I plough. Worth 20 s.

In Trolftham [Thelnetham] Fulcher holds of the Abbot 8 freemen with I carucate of land. 6 bordars, and 1 serf. Then as now $2 \frac{1}{2}$ ploughs. And 3 acres of meadow. Wood(land) for fol. 367 .

30 swine. These men could give or sell their land. But sac and soke and commendation would remain in the Saint's possession. They were then worth 20s., now 30 .

In TORPA [Thorpe by Ixworth] (were) 2 freemen with 16 acres of land. Then as now half a plough. And half an acre of meadow. These men could give and sell their land. But sac and soke and commendation remained in the Saint's possession. They were then as now worth $12 d$.

In W asham [Walsham] (were) 30 freemen with 3 carucates of land. 2 bordars. Then 9 ploughs, now 6. And 8 acres of meadow. Wood(land) for 30 swine. These men could give and sell their land. But sac and soke and commendation would remain in the Saint's possession. They were then worth 30 s., now 45 s. Of these freemen and of this land Robert Blund holds 10 freemen with 2 carucates of land. And 2 ploughs. And they are worth 40 s, as part of the above sum.

In Eascefrelda [(Great) Ashfield $\left.{ }^{131}\right)$ ] (were) 21 freemen with $1 \frac{1}{2}$ carucates of land. And

12 'Aisechfelde Magna' in the list of abbey lands : Harl. MS. 743.
I villein, and 4 bordars. Then as now 5 ploughs. And 12 acres of meadow. Wood(land) for 20 swine. These men could give and sell their land. But sac and soke and commendation would remain in the Saint's possession. They were then as now worth $33^{\text {s. }}$ Of these freemen and of this land Odar holds 17 freemen with I carucate and 30 acres of land and 4 ploughs. And they were worth 30 s. as part of the above sum.

In the same (vill was) I sokeman with half a carucate of land and 2 bordars. Then as now I plough. And 4 acres of meadow. Wood(land) for 4 swine. Over this man the Saint then as now had sac and soke and commendation, and without licence he could not give or sell his land. He was then as now worth 10 s. A church with 12 acres of free land. It is 10 furlongs long, and 5 broad. And (pays) $11 \frac{3}{4} d$. in geld. Others hold (land) there.

In Langham [Langham] (were) 7 freemen with I carucate of land and $\mathbf{I}$ bordar. Then as now 3 ploughs. And 6 acres of meadow. Wood(land) for 6 swine. These men could give and sell their land. Sac and soke and commendation, however, would remain in the Saint's possession. They were then as now worth IOS. A church with 20 acres of free land.

In Hunterstuna [Hunston] were 9 freemen with 2 carucates of land. 4 bordars. Then as now 4 ploughs. And 10 acres of meadow. Wood(land) for 12 swine. These men could give and sell their land. But sac and soke and commendation remained in the Saint's possession. Half a church with 15 acres of free land. Then and now worth 40 s. Of this land and of those freemen Bucard holds 6 freemen with $1 \frac{1}{2}$ carucates of land and 3 ploughs. And they are worth 35. as part of the above sum. It is 8 furlongs long, and 7 broad. And (pays) $9 \frac{3}{4} d$. in geld.

fol. 3676 .

In Fachenham [Fakenham] Peter holds of the Abbot 2 freemen with 1 carucate of land. 3 villeins, and 4 bordars. Then as now I plough on the demesne. And half a plough belonging to the men. And 4 acres of meadow. Wood(land) for 4 swine. These men could give and sell their land. But sac and soke and commendation remained in the Saint's possession. Then as now it was worth 20 s.

In Litra Fachenham [Little Fakenham] the same Peter holds of the Abbot a freeman with 60 acres of land. Then as now I plough. This man is under the Saint with sac and soke and commendation. And he could not give or sell the land without the Abbot's licence. Then as now worth 5 s. 


\section{A HISTORY OF SUFFOLK}

In Euestuna [Euston] Adelund holds 2 freemen of the Abbot with I carucate of land. 4 villeins. Then as now 2 ploughs on the demesne. And half a plough belonging to the men. And 3 acres of meadow. And 2 mills. These men could give and sell their land. But sac and soke and commendation remained in the Saint's possession. Then as now (it was worth) 30s. It is I league long, and 5 furlongs broad. And (pays) $11 \frac{1}{2} d$. in geld. Others hold land there.

In Gnedeshalla [Knettishall] Fulcher holds of the Abbot 4 freemen with I carucate and 30 acres of land and 6 bordars. Then as now 3 ploughs among them. And I mill. And 2 acres of meadow. These men could give and sell their land. But sac and soke and commendation would remain in the Saint's possession. Then as now they were worth 20s. A church with 12 acres of land. It is 8 furlongs long, and 3 broad. And (pays) $11 \frac{1}{2} d$. in geld. Others hold (land) there.

At Ixeword [Ixworth] Robert Blund (Blon) holds of the Abbot I carucate of land, and 5 men. 3 acres of meadow. Then as now 2 ploughs. And they were then as now worth Ios. These men could all give their land T.R.E. Saint Edmund has sac and soke and commendation.

In Torp [(Ixworth) Thorpe] the same Robert Blund (Blon) holds 9 freemen of the Abbot with I carucate of land. Then as now 2 bordars. And 2 ploughs. And I acre of meadow. And I mill. Worth 20s. These men could give and sell their land. But sac and soke remained in the Saint's pussession. And it is I league long, and half a league broad. And (pays) $9 d$. in geld.

In the same (vill) the same Robert holds of the Abbot I freeman with 60 acres, and I bordar. Then as now I plough. And 4 acres of meadow. It was worth IOs. This land the Abbot put in pledge to (invadiavit contra) the King's Barons, viz. William the Bishop, Engelric and Ralph the Staller for roos. This man could sell and give his land. But soke and sac would remain in the Saint's possession.

fol. 368 .

\section{Biscopes [Bishop's] Hundret}

(At) SAHAM [Soham] Saint Edmund held T.R.E. as a manor 4 carucates of land with its soke. Then as now 8 villeins, and I I bordars. Then 2 serfs, now 1 . Then as now 2 ploughs on the demesne. Then as now 6 ploughs belonging to the men. And 6 acres of meadow. Wood(land) for 40 swine. Now I horse, 5 beasts, 3 I swine, 3 I sheep, and $2 I$ goats. A church with 50 acres of land. This manor was then worth 4 li., now 5li. (It is) 7 furlongs long, and
6 broad. In geld (it pays) rod. Others have holdings therein.

(At) WYRLINGWORTHA [Worlingworth] T.R.E. Saint Edmund held as a manor 6 carucates of land with its soke. Then as now 16 villeins, and $\mathrm{I} 4$ bordars, and $\mathrm{I}$ serf. Then as now 2 ploughs on the demesne. Then as now 12 ploughs belonging to the men. And 16 acres of meadow. Wood(land) for roo swine. Then as now 2 horses, 8 beasts, 24 swine, 25 sheep, and 33 goats. And now 6 hives of bees. And (there was) a sokeman with 20 acres. A church with 10 acres of free land. This manor was then worth $6 l i$., now $8 l i$. It is I league long, and 5 furlongs broad. And in geld (pays) Iod.

In Bedingefelda [Bedingfield] (were) io freemen with half a carucate of land. Then as now 2 bordars. Then as now 2 ploughs among them all. Wood(land) for 8 swine. One of these with 30 acres of land never could give or sell the land without the full consent of the Abbot : and to this the Hundred bears witness : and the 9 could give and sell their lands. The whole was then worth 5 s, now $8 s$. It is I league long, and 6 furlongs broad. And in geld (pays) $15 d$. Others have holdings therein.

(At) Cybenhalla [Chepenhall] T.R.E. Saint Edmund held as a manor $1 \frac{1}{2}$ carucates of land with the soke. Then as now 6 villeins, and 12 bordars. Then $1 \frac{1}{2}$ ploughs on the demesne, now 2 ploughs. Then 3 ploughs belonging to the men, now 5. And Io acres of meadow. Wood(land) then for 160 swine, now for $100 .^{133}$ Then as now I rouncey. Now 16 beasts, I 6 swine, and 30 goats. Half a church with 20 acres. This manor was then worth 40s., now 6os. It is $I \frac{1}{2}$ leagues long, and I league broad. And in geld (pays) $15 d$. Others have holdings therein.

(At) Mendham [Mendham] Frodo holds of the Abbot what Saint Edmund held as a manor, 2 carucates and $I 9$ acres of land. Then as now 2 villeins. Then 18 bordars, and now 26. And fol. $368 b$.

I serf. Then as now 2 ploughs on the demesne. Then 6 ploughs belonging to the men, now 8 . And 18 acres of meadow. And I mill. Wood(land) then for 360 swine, now for 300 . Then as now I rouncey. And now Io beasts, 41 swine, 40 sheep, and 36 goats. And (there were) 6 sokemen with half a carucate of land and then as

${ }^{138}$ Mannig Sparcingesone gave Chepenhall to the abbey; his son Ulf revoked the gift, but, being bitten by a snake, offered the monks the choice of this manor or Silham; they chose Chepenhall, 'because it abounded in woods': Add MS. 14847 , fol. 24. 


\section{THE HOLDERS OF LANDS}

now 3 ploughs and 2 acres of meadow. Wood(land) for 3 swine. And a freeman holds 3 acres, worth $6 d$. These belong to the Saint with sac and soke and commendation; nor could they ever give or sell their lands without the Abbot's licence. A church with 20 acres. This manor was then worth $4 l i$. and Ios, and now $12 l i$. and 4s. It is I league and 9 furlongs long, and $I$ league broad. And (pays) in geld $15 d$. Others hold land therein.

In WEIBRADE [Weybread] Saint Edmund has 30 acres. And 2 villeins. And 1 plough. And 3 acres of meadow. Wood(land) for 10 swine. Worth Ios.

\section{Corsforde [Cosford] Half Hundret}

T.R.E. Saint Edmund held Seamera [Semer] as a manor. Therein are $3 \frac{1}{2}$ carucates of land, and II acres of meadow. 6 villeins, I 3 bordars, I serf. Then as now 3 ploughs on the demesne. And 2 ploughs belonging to the men. 1 mill. 2 rounceys, 16 beasts, 24 swine, 97 sheep. Then it was worth 5li., now 6 li. In the same (vill) is a church with 30 acres of land, and I acre of meadow. Then as now I plough belonging to the church. This vill is 9 furlongs long, and 7 broad. And pays $2 \frac{1}{2} d$. in geld. But others have holdings there.

Cerleswrda [Chelsworth] T.R.E. Saint Edmund held as a manor, then as now $3 \frac{1}{2}$ carucates of land. 8 villeins, Io bordars, and 4 serfs. Then 2 ploughs on the demesne, and 4 (ploughs) belonging to the men, and now the like. 12 acres of meadow. Then and now (and) then as now I mill. Then as now 2 rounceys. Then Io beasts, now 9. Then 16 swine, now 20. Then 30 sheep, now 6o. This manor was then worth 4 i., now 5 li. It is 7 furlongs long, 6 broad. A church with 30 acres of land and $\mathbf{I}$ acre of meadow. And it pays $3 \frac{3}{4} d$. in geld.

In LafHaM [Layham] Saint Edmund T.R.E. held 26 freemen, and they had 2 carucates of land, and 6 acres of meadow. 2 bordars. And then they ploughed with 6 ploughs, now with 4. And they might give or sell their land. But Saint Edmund had soke and sac and commendation and all customs except in one case. Then their land was worth 30s., now 40s. And Berard holds half a carucate of land, and $x$ plough. Worth 22s. (included) in the same value. It is 6 furlongs long, 4 broad. And pays $3 \frac{1}{2} d$. in geld. But others have holdings there.

fol. 369 .

In WAtefredA [Whatfield] T.R.E. Saint Edmund held 18 freemen and they had $2 \frac{1}{2}$ carucates of land, 7 acres of meadow. 6 bordars. Then they ploughed with 4 ploughs, and now (likewise). Then it was worth 40 s., now 5os. And of this land the said Berard holds I carucate of land, and 3 freemen, and I plough. Worth 20 s. (included) in the same value. Saint Edmund had commendation and soke and sac. It was then 6 furlongs long, and 5 broad. And (paid) $5 d$. in geld. But others have holdings there.

In the ferding of EALDHAM [Aldham] T.R.E. Saint Edmund held 6 freemen and in the other W Atefelda [Whatfield] 10. And they had $1 \frac{1}{2}$ carucates of land. They then as now ploughed with 6 ploughs. 4 bordars. And 6 acres of meadow. And they could give and sell their land. But both soke and commendation and all customs belonged to the Saint (Edmund). Their land was worth 30s. then, now 40s. And (pays) $5 d$. in geld. And of this land Berard holds 40 acres, And I plough. Worth Ios. (included) in the same value. These two vills are 6 furlongs long, and 3 broad, and pay $6 d$. in geld. But others have holdings there. In the same (vill) is a church with 2 acres of land.

In Blalsega [Lindsey ${ }^{133}$ ] T.R.E. Saint Edmund held 20 freemen, and they had $1 \frac{1}{2}$ carucates of land, 16 bordars, and 2 serfs. They then as now ploughed with 5 ploughs, and T.R.E. they could give or sell their land, but Saint Edmund had soke and commendation and all customs. Then it was worth 20s., now 30 s. It is 6 furlongs long, and 5 broad, whoever may be the tenant there. A church with Io acres of land. And (it pays] $6 d$. in geld.

In Manetuna [Manton ${ }^{134}$ ] and in KrTelBeornastuna [Kettlebaston] T.R.E. Saint Edmund held 4 freemen and they had 2 carucates of land, and 6 acres of meadow, and 8 bordars, (and) 3 serfs. They then as now ploughed with 3 ploughs, and could give and sell their land. Saint Edmund had soke and commendation and all customs. Then as now it was worth 60 s. Of this land Gamas (holds) I carucate of land, 2 ploughs on the demesne, and Humphrey I carucate. Worth 40s. (included) in the same value. Their land is 6 furlongs long, and 4 broad. And (pays) $3 d$. in geld. But others have holdings there.

In Bretenhama [Brettenham] and Rescebroc [ ] and in TORPA [Thorp (Morieux)] T.R.E. Saint Edmund held I 4 freemen, and they had then as now $2 \frac{1}{2}$ carucates (of land). 8 acres of meadow, 7 bordars. They then ploughed with 5 ploughs, now with 2. Over them Saint Edmund has soke and sac and commendation, fol. $369 b$.

and all customs. Then it was worth 50s., now 3 os.

us Formerly 'Lelleseye'; see Cal. Chart. B.M.

13. Manton in Hitcham; Copinger, Suff. Rec. 


\section{A HISTORY OF SUFFOLK}

Of this estate (terra) Arnulf holds 7 freemen, and 1 carucate, and 30 acres of land. Worth I5s. (included) in the above value.

In TORP [Thorp (Morieux)] (Saint Edmund held) 20 acres (and) I freeman. Worth $3^{\text {s. }}$ and $4 d$. Saint Edmund (has) commendation and soke.

\section{Hundret of Carleforda [Carlford]}

In W.ALDRINGAFELDA [Waldringfield] T.R.E. Quengeva held under Saint Edmund $I \frac{1}{2}$ carucates of land. Now 8 bordars. Then as now on the demesne 2 ploughs and I plough belonging to the men. 2 acres of meadow. And 1 rouncey, Io swine and 100 sheep. Then as now it was worth 20 s. It is 3 furlongs broad and 6 long, and (pays) $5 d$. in geld.

In Neubrunna [Newbourn] (are) 3 freemen and in Hespelea [Haspley ${ }^{135}$ ] I under commendation to the said Quengeva with 6 acres, worth r 2d. This Roger Bigot holds of the Abbot.

\section{Hundret of Losa [Loes]}

(At) MERLesforda [Marlesford] Saint Edmund held T.R.E. I carucate and $I 2$ acres of land as a manor. Then as now 5 bordars. And 2 ploughs on the demesne. And half a plough belonging to the men. 5 acres of meadow. I mill. And 2 rounceys, 4 beasts, 14 swine, 50 sheep, and 3 hives of bees. Then it was worth $30 s_{\text {., now }} 40$ s. And (there were) 9 whole (free)men and 2 half freemen with 83 acres. Then 3 ploughs, now 2. I acre of meadow.

In Hecetuna [Hacheston] 4 freemen, half under the Saint's (?) commendation and half under... (held) 2 I acres. Then as now half a plough. Worth 8 s.

In Chenetuna [Kenton] Durand holds from the Abbot 2 freemen with 80 acres. Then 2 villeins, now 1. Now 3 bordars. Then as now 2 ploughs on the demesne. And belonging to the men half a plough. Wood(land) for Io swine. And I acre of meadow. And I rouncey. And 3 beasts. And 16 swine. And 80 sheep. And 25 goats. And 3 hives of bees. Then it was worth 20s., now 30s. This Durand holds of the Abbot. Saint Etheldreda (has) soke and sac.

\section{W anneforda [W angford] Hundret}

(At) Becles [Beccles] Saint Edmund held T.R.E. 2 carucates of land as a manor. Then as now 2 villeins, and 26 bordars. Then 2 serfs. Then as now on the demesne $I$ plough. And fol. 370 .

belonging to the men ... And 10 acres of mea-

$$
195 \text { In Hemley. }
$$

dow. Wood(land) for 8 swine. And I market. And 26 burgesses. And the Abbot has three parts of the market, and the King the fourth part. And (there are) 2 rounceys.

In the same (vill) 30 sokemen owing all kinds of custom (held) $1 \frac{1}{2}$ carucates of land. And under them (were) 20 bordars. Then 7 ploughs, now 8. But they could sell their lands T.R.E. A church with 24 acres. This manor then rendered 30,000 herrings, now 60,000 . It is I league long and 8 furlongs broad. And in geld (pays) $16 d$.

In Linburna [Linburne ${ }^{136}$ ] Saint Edmund held 30 acres of land. Then as now 5 bordars. Then as now I plough. 2 acres of meadow. The fifth part of a mill. Then and always worth IOs. Bishop William (has) soke and sake.

In WeRLINGAHAM [Worlingham] half a church, with 5 acres, worth $12 d$.

\section{Hertesmara [Hartismere] Hundret}

In Stotas [Stoke (Ash)] 7 freemen under the Abbot's soke and commendation held 10 acres and half a plough. Wood(land) for 2 swine. Half an acre of meadow. Worth 3 s.

In WiUkrthesstuna [Wyverstone] Robert Blond holds 19 acres of the Abbot, which Grim a freeman held under the commendation and soke of the Abbot. Wood(land) for 2 swine. Half an acre of meadow. Worth $40 d$.

\section{Saint Edmund's (FeE)}

In WEDERINGASETA [Wetheringsett] Io freemen (held) 40 acres, and 2 borders. 2 ploughs. And I acre of meadow. Wood(land) for 3 swine. Worth $6 s$. and $8 d$.

In StgTa [Stoke (Ash)] (were) I 4 freemen with $33 \frac{1}{2}$ acres. Then as now 2 ploughs. And I acre of meadow. Worth 6s. The soke and commendation (were) the Abbot's except over one.

In W Iснам [Wickham (Skeith)] 14 freemen (held) 60 acres under the Abbot's soke and commendation. Then as now 2 ploughs. And I acre of meadow. Wood(land) for 4 swine. Worth ros.

In Tornham ['Thornham] (were) 9 freemen with 35 acres under the Abbot's soke and commendation. And $1 \frac{1}{2}$ ploughs. And half an acre of meadow. Worth 6s.

In TORnduna [Thorndon] Leuric a freeman under commendation to the Abbot held I carucate of land and 6 bordars. And 2 ploughs on 


\section{THE HOLDERS OF LANDS}

the demesne, and half a plough belonging to the men. And I acre of meadow. Wood(land) for 8 swine. Worth 20 s.

fol. $370 b$.

In Acre [Oakley] (Part) of Hartismere Hundred. In ACLE [Oakley] a freeman, Goding the reeve, under commendation to Saint Edmund T.R.E. (held) 90 acres of land. And he could not sell nor give (the land). Then as now 5 bordars. And I plough on the alemesne. And half a plough belonging to the men. Wood(land) for 5 swine. 2 acres of meadow. And I mill. And 1 rouncey, 2 beasts, and 5 sheep. Then as now it was worth 20s. And under him 10 freemen (held) 30 acres. Then as now $1 \frac{1}{2}$ ploughs. And 2 acres of meadow. Worth IOs. Saint Edmund (had) soke and sac and commendation. Two (third) parts of a church with 12 acres, worth $16 d$.

In Tornham [Thornham] 5 freemen under the Abbot's soke and commendation held $44 \frac{1}{2}$ acres. Then as now $1 \frac{1}{2}$ ploughs. 2 acres of meadow. Wood(land) for 4 swine. Then as now worth $8 s$.

In Finingaham [Finningham] II freemen under Saint Edmund's soke and commendation (held) 68 acres. Then as now $I \frac{1}{2}$ ploughs. And 2 bordars. 4 acres of meadow. Wood(land) for 8 swine. Then as now worth I2s. A church with 26 acres, worth 4 s.

In WEST TORP [Westhorpe] 8 freemen under the Abbot's soke and commendation (held) 60 acres. Then as now $1 \frac{1}{2}$ ploughs. 2 acres of meadow. Wood(land) for 4 swine. Then as now worth ros.

In the same (vill) a man (held) 7 acres, worth 14d. And he could not sell.

And in Finingaham [Finningham] a (freeman) in like manner held 8 acres worth $16 d$.

In WiUERTHESTUNa [Wyverstone] 6 freemen under the Abbot's soke and commendation (held) 75 acres. I villein and 2 bordars. Then as now I 1 ploughs. Wood(land) for 4 swine. I acre of meadow. Then as now worth 13 s.

In Kodetun [Cotton] I villein (held) 8 acres, worth $16 d$. And (this) belongs to Escefella [Ashfield].

In KaLDeCOTES [ ] a freeman (held) 6 acres under the Abbot's soke and commendation, worth $12 d$.

All these perform their customary duties (faciunt consuetudines) at Rikingahala [Rickinghall].

Moreover the Abbot has in AcLE [Oakley] and in Stutrstuna [Stuston] 15 freemen under soke and commendation with I carucate and 10 acres of land. Then as now II bordars. And 3 ploughs. Wood('and) for 2 swine. 6 acres of meadow. A church with 24 acres, worth 45 . And with half an acre of meadow. Then as now worth 20 s.

In ACLE [Oakley] Gotselin holds a freewoman by name Leuseda (with) 30 acres, but (? she) fol. 371 .

could neither sell nor give (the land). And 3 bordars. Then as now half a plough. Wood(land) for 4 swine. 2 acres of meadow. Worth $32 d$.

In Frandestuna [Thrandeston] Anselm holds of the Abbot 2 carucates of land as a manor. Then as now 6 bordars. And on the demesne 2 ploughs. And belonging to the men I plough. 8 acres of meadow. And 2 rounceys, 2 beasts, 12 swine, and 55 sheep. And $12 \frac{1}{2}$ freemen (held) 42 acres. But they could sell. A church with 8 acres, worth $16 d$. Then as now 3 ploughs. Wood(land) for 4 swine. I acre of meadow. Then worth 40s, now 60s. The Saint had soke and commendation. It is 8 furlongs long, and 7 broad. And in geld (pays) $8 d$.

In Melles [Mellis] a freeman under Saint Edmund's commendation and soke (held) $I_{\frac{1}{2}}$ acres, worth $6 d$.

In Brom [Brome] a freeman under (Saint) Edmund (held) I acre, worth $4 d$.

In WEST TORP [Westhorpe] a freeman under Saint Edmund held I acre, worth $2 d$.

In Torneduna [Thorndon] 6 freemen under the Abbot's soke and commendation (held) 16 acres, worth 3 s.

In Acout [Occold] (are) 3 acres on the demesne.

In Cebbenhala [Chepenhall] (are) 12 acres, worth $2 s$.

In Stoches [Stoke (Ash)] T.R.E. Buchard the Abbot's sokeman held 14 acres, worth $3^{\text {s. This }}$ land Robert Fardenc, the man of Godric the steward, claims as belonging to the King's manor of Melinessam [Mendlesham]: and he says that Walter de Dol held it when he made forfeiture; and this he will prove against the whole hundred by all kinds of lawful procedure (omnibus legibus).

In the same (vill) 8 freemen under commendation and soke (held) 24 acres. Then as now I plough. And 2 acres of meadow. Worth 5 s.

In THORNHAM [Thornham] a freeman by soke and commendation (held) 2 acres, worth $4 d$. 


\section{A HISTORY OF SUFFOLK}

In Cotituna [Cotton] 3 freemen in the Abbot's soke and under his commendation (held) 3 acres.

\section{In Caldecota [}

] Aluric a freeman under sub-commendation (held) $4 \frac{1}{2}$ acres, worth $12 d$.

In Thrandestuna [Thrandeston] Uluric by commendation (held) 3 acres, worth $6 d$.

In WiUkrdestuna [Wyverstone] 4 free(men) under commendation (held) $16 \frac{1}{2}$ acres, worth $3^{\text {s. }}$ Richard holds (them).

In Wiснам [Wickham] 2 freemen under commendation to Burcard of Melnessam [Mendlesham], Brunloc and Heruart, (held) $5 \frac{1}{2}$ acres, worth Iod. The King and the Earl (have) the soke. These (freemen) Orger the Abbot's reeve holds. And Aluric, who was reeve before him, appropriated (invasit) them.

In WeRINGheseta [Wetheringsett] (are) 3 acres on the Abbot's demesne, worth $6 d$. Godwin l.olds (them).

\section{fol. $371 b$.}

\section{Risebruge [Risbridge] Hundret}

In Poslindewrda [Poslingford] (were) 12 freemen under Saint Edmund by commendation and soke and sac T.R.E. And they had 60 acres and $I$ bordar and 2 ploughs. Worth IOs.

In STANESFELda [Stansfield] 7 freemen (held) 75 acres. Then as now 2 ploughs. Saint Edmund (has) commendation and soke. Worth I I $s$. and $3 d$.

In Thrillauura [Thurlow] 9 freemen held 95 acres. 5 bordars. And 4 ploughs. And 4 acres of meadow. Wood(land) for 6 swine. Worth 15 s. Saint Edmund (has) soke and commendation.

In Bradleia [Bradley] 8 freemen (held) 80 acres and I bordar. And 2 ploughs. And I acre of meadow. And they were worth IIs. and $3 d$.

In the same (vill) 4 freemen (held) 60 acres and $I$ bordar and 2 ploughs, and $I$ acre of meadow. Worth ros. Saint Edmund (has) commendation and soke and sac.

In Kidrtuna [Kedington] a freeman (held) 5 acres. Worth I $2 d$. Saint Edmund (has) commendation and soke and sac.

In W ARACatinge [Wratting] a freeman (held) 7 acres. Worth $12 d$.

In Haverhol [Haverhill] 2 freemen (held) 5 acres. Worth $7 d$. Saint Edmund (has) soke and commendation.

\section{Biscopes [Bishop's] Hundret}

In HoRAnT [Horham] 4 freemen had 30 acres and 1 plough. Worth 5s. Saint Edmund (has) commendation. The soke (is) in Hoxa [Hoxne].

SudHoLda [Southwold] ${ }^{136}$ is 9 furlongs long and 5 broad. This division (extends) from the sea as far as Iersnesmua [Yarmouth]. And (it pays) $2 \frac{1}{2} d$. in geld.

\section{Blidinga [Blything] Hundret}

(At) Sudwolda [Southwold] Saint Edmund held for the provision of (advictum) the monks I carucate of land as a manor. And 5 villeins, and 4 bordars. And I plough on the demesne. And 4 belonging to the men. And 4 acres of meadow. And I rouncey, 4 beasts, 3 swine, and 30 sheep. The moiety of a sea-weir (beia maris). And the fourth part of the other moiety. Then it rendered 20,000 herrings, now 25,000. Saint Edmund (has) soke and sac.

Ugghecat,A [Uggeshall] Godwin held. The soke (socam) (was) Saint Edmund's. I carucate of land. Then as now 3 villeins, and 12 bordars. And I plough on the demesne. And 3 ploughs belonging to the men. Wood(land) for 3 swine. And 2 acres of meadow. And 4 beasts, I pig, and 80 sheep. And $1 \frac{1}{2}$ freemen (held) $22 \frac{1}{2}$ acres of land by commendation. Then as now I bordar. And I plough. And half an acre of meadow. Saint Edmund (has) the soke. The manor was then as now worth 60s., and the freemen 4 s. and $8 d$.

In BENAGRA [Benacre] a sokemen (held) 10 acres, worth $16 d$.

\section{HUNDRET OF WILDEFORDA [WILFORD]}

In UFFEFORDA [Ufford] a freeman under Saint Edmund's commendation T.R.E. (held) 24 acres, and 2 acres of meadow. Then as now I plough. Then and now worth 5 s.

\section{fol. 372 .}

\section{(BURY SAINT EDMUNDS)}

In the town where rests enshrined Saint Edmund King and Martyr of glorious memory Abbot B[aldwin] held, T.R.E., towards the provision of ( $a d$ victum) the monks i 8 men; and they could give and sell their land; and under them 52 bordars from whom the Abbot can have some little aid (aliquid adjutorii), 54 freemen poor enough (satis inopes), 43 almsmen; each of them has I bordar. Now (there are) 2 mills. And 2 stews or fish ponds (vivaria vel piscinae).

138 This should come with the next entry, under Blything Hundret. 


\section{THE HOLDERS OF LANDS}

This town was then worth 10li., now 20li. It is $1 \frac{1}{2}$ leagues in length, and as much in breadth. And when a pound is levied on the hin lred for geld (quando in bundreto solvitur ad geltum $j$ libram), then there go from the town $60 d$. towards the sustenance of the monks. But this refers to (est de) the town as (it was) T.R.E. as if (it was still) so ; for now the town is contained in a greater circle, including $(d e)$ land which then used to be ploughed and sown; whereon there are 30 priests, deacons, and clerks together (inter); 28 nuns and poor persons who daily utter prayers for the King and for all Christian people : 80 less 5 bakers, ale brewers, tailors, washerwomen, shoemakers, robe makers (parmentarii), cooks, porters, agents (dispensatores) together. And all these daily wait upon the Saint, and the Abbot, and the Brethren. Besides whom there are 13 reeves over the land who have their houses in the said town, and under them 5 bordars. Now 34 knights, French and English together, and under them 22 bordars. Now altogether (there are) 342 houses on the demesne on land of Saint E Imund's which was under the plough T.R.E.

\section{fol. $372 b$.}

\section{LANDS OF ARCHBISHOP LAN- FRANC FOR THE MONKS' FOOD}

\section{Risebruge [Risbridge] Hundret}

(At) Muletuna [Moulton] Stigand held as a manor T.R.E. 7 carucates of land. Then 32 villeins, now 22. Then 7 bordars, now 16 . Then 6 serfs, now 2. Then as now 3 ploughs on the demesne. And 6 ploughs belonging to the men. And 8 acres of meadow. Wood(land) for 20 swine. And 2 rounceys, 2 beasts, 40 swine, 270 sheep, and 4 hives of bees. And then worth 15 li, now 12 li. It is I league long, and 7 furlongs broad. And (pays) $13 \frac{1}{2} d$. in geld. Stigand had soke and sac and all customs.

\section{Half Hundret of Cosforda [Cosford]}

(At) Hetlega [Hadleigh] Holy Trinity T.R.E. held 5 carucates of land as a manor. Then as now 22 villeins. Then 26 bordars, now 19. Then as now 2 serfs, and 2 ploughs on the demesne. Then 15 ploughs belonging to the men, now 10. Then as now 2 mills, and 16 acres of meadow. Now 2 rounceys, 12 beasts, 120 sheep, and 20 swine. Then it was worth 12lis, now 15li. A church with I carucate of free land, and I plough, and I mill, worth 12s. And (there was) a sokeman with 60 acres T.R.E. Now on the same land dwell 3 sokemen. Then as now they had I plough, and 1 acre of meadow. And $I$ freeman T.R.E. (held) 60 acres under commendation and soke. On the same land now dwell 3 freemen, and they have 1 plough, and $2 \frac{1}{2}$ acres of meadow. Then it was worth 8s., now ros. The whole (vill) is I league long, and 7 furlongs broad. And pays $1 \mathbf{1} \frac{1}{2} d$. in geld.

In Topesfelda [Topesfield] a certain freewoman, Leveva by name, held 2 carucates of land as a manor. Then 2 bordars, now 5, and I serf. And 2 ploughs. And 5 acres of meadow. And I mill. Then 7 sheep, now 34, and 3 beasts and I rouncey. Then it was worth 40 s., now 60s. Of this land this Leveva gave half a carucate to Holy Trinity after her death in return for another half carucate which she had of the Archbishop in her lifetime. This agreement was made T.R.E. and Leveva was living in King William's time, and was seised thereof. This land, John, nephew of Waleran, claims. And of all this land Saint Edmund held soke and sac.

In Topesfelda ['Topesfield] (was) a freeman with 20 acres, over which Uluric, the predecessor of the Abbot of Saint Edmund, had commendation T.R.E. and soke. Then as now half a plough. Worth 3 s. and $4 d$.

fol. 373 .

B'binberga [Babergh] Two Hundrets

(At) Illebeia [(Monks) Eleigh] Holy Trinity held T.R.E. 5 carucates of land as a manor with soke and sac. Then 2 I villeins, now I3. Then 13 bordars, now 12 . Then 4 serfs, now 3 . Then as now 2 ploughs on the demesne. Then 21 ploughs belonging to the men, now 13. Then 12 acres of meadow. Then as now 1 mill. Now 2 horses. Now 19 beasts. Now 20 swine. Now 160 sheep. A church with $22 \frac{1}{2}$ acres. Then it was worth $15 / i$, now 20li. It is I league long, and 5 furlongs broad. And pays I $4 d$. in geld.

\section{LANDS OF THE BISHOP OF BAYEUX}

\section{Risebruge [Risbridge] Hundret}

In HaVerhella [Haverhill] a freeman (holds) 24 acres and half a plough. And he is worth 3s. Him Tihell holds of the Bishop. His (the Bishop's) predecessor T.R.E. (had) commendation. Saint Edmund (had) the six forfeitures.

\section{Hundret of Carleford [Carlford]}

In Sekeforda [Seckford] Aluric son of Ulviet, under commendation to Harold, held T.R.E. 2 carucates of land as a manor. Then as now 4 villeins. Then 13 bordars, now 15. Then as now on the demesne 2 ploughs, a third might be made up; and 3 ploughs belonging to the men. 10 acres of meadow. I mill. Then I rouncey, now none, and 4 beasts. Then 30 


\section{A HISTORY OF SUFFOLK}

swine, now none. Then 100 sheep, now 36. Then it was worth $4 l i$., now $40 s$. It is 6 furlongs long and 6 broad, and (pays) $7 \frac{1}{2} d$. in geld.

In the same (vill are) 4 freemen under commendation to the said Aluric with 8 acres. I acre of meadow. And half a plough. Worth 16d. This Roger Bigot holds of the Bishop.

In Parvo Belinges [Little Bealings] the same Aluric held T.R.E. $5^{\circ}$ acres as a manor. 2 bordars. Then I plough, now half a plough. 3 acres of meadow. Then I mill, now none. Then it was worth 20s., now IOs.

In the same (vill) Beorn, a freeman, T.R.E. held 50 acres as a manor, and 3 acres of meadow. Then it was worth, as afterwards and now, $8 j$. This land the freeman Beorn himself bought of the Abbot with an agreement that after his death it should revert to the Church of St. Etheldreda, as the Hundred witnesses. This Roger Bigot holds of the Bishop, and W. de More of him. These three manors Earl Ralph held on the day of his forfeiture; and Hilary of him.

\section{fol. $373^{b}$.}

\section{HUNDRET OF WILEFORDA [WILFORD]}

In WIKHAM [Wickham (Market)] Roger Bigot held a freeman (formerly) under commendation to Saint Etheldreda with 25 acres. And under him (were) 4 freemen with 7 acres. Then I plough, now half a plough. 2 acres of meadow. Worth $5^{5}$.

This Ralph de Savigny (Sauenie) holds of Roger Bigot as of the Bishop's fee.

In Debeis [Debach] (are) I 5 acres, and they belong to Cerfella [Charsfield].

In the same (vill is) a freeman with half an acre.

\section{HUNDRET OF LOSA [LOES]}

In CerResfella [Charsfield] I 4 freemen (held) I carucate of land, Roger Bigot holds this and Ralph de Savigny (Sau'gno) (holds it) of him; and 13 acres. Then 5 ploughs, now 3. 1 acre of meadow. $3 \frac{1}{2}$ of those (freemen) were under commendation of Saint Etheldreda and of Edric of Lessefella [Laxfield]. William Malet was seised (thereof) on the day of his death. And the others were under commendation of the Abbot only. Then it was worth 60 s, now a like sum.

In the same (vill were) 2 sokemen under Saint Etheldreda with 7 acres. They are included in the said valuation.

In the same (vill was) a freeman, Marculf, under commendation of Edric of Laxfield. William Malet was seised (thereof) on the day on which he died. I bordar. Then I plough. I acre of meadow. And under him (were) 4 freemen with 4 acres. Then it was worth IOs., now 5s. It is 8 furlongs long and 6 broad. And (pays) $\mathbf{I} \mathbf{I}$. in geld. Others have holdings therein.

In Gretingeham [Cretingham] (was) a freeman Balchi, (whom) the same Ralph (de Savigny) holds under commendation of Adestan, with 24 acres of land, (and) I acre of meadow. Then half a plough, now the like. Worth $4^{5}$.

In the same (vill was) a freeman under the same (Adestan's) commendation with $38 \frac{1}{2}$ acres. I bordar. 2 acres of meadow. I plough. Then it was worth I2s., now a like sum.

In Kenetona [Kenton] (were) 5 freemen, 4 were under commendation to Saint Etheldreda, and Sacxe the predecessor of Ralph de Savigny (Savigno) (had commendation) over one. 30 acres of land. Then as now I plough. Then it was worth Ios., now 6s. Now Ralph de Savigny holds of Roger Bigot.

\section{Banberga [Babergh] Two Hundrets}

In IleLega [Eleigh] (were) 3 freemen under soke and commendation of Earl Algar, now Tehel de Herion holds them of the Bishop. And they had 30 acres. Then I plough, now half a plough, and half an acre of meadow. Worth 5 s.

At Brantestona [Brandeston] ${ }^{137}$ Alveva, mother of Earl Morchar, held T.R.E. 3 carucates

fol. 374 .

of land as a manor. And 5 villeins, 6 bordars, and 5 serfs. Then as now 2 ploughs on the demesne. Then and afterwards 2 ploughs belonging to the men, now 1. And 4 acres of meadow. Wood(land) for ro swine. Then as now 2 horses at the hall. Then 5 beasts, now 3. Then 20 swine, now 23. Then 100 sheep, now 120.

In the same (vill) 3 freemen under Alveva by commendation and soke and sac, who could sell without licence, (held) 24 acres of land. They were then as now worth $5 \mathrm{li}$. It is I league long, and 3 furlongs broad. And (pays) 6d. in geld. Ralph de Curbespine holds this manor of the Bishop.

\section{Stou [STOW] HundRet}

In Cratinga [Creeting (St. Peter)] Aluric son of Brune, a freeman under Wisgar by commendation only, T.R.E. held I carucate of land in the King's soke. Now William de Boeville holds it of the Bishop. Then as now 5 bordars and I serf. Then as now I plough on the demesne, and half a plough belonging to the men. And a third share of a mill. And 4 acres of meadow. And 4 beasts, and 8 swine. Then 8 sheep, now

$$
{ }^{137} \text { In Waldingfield. }
$$




\section{THE HOLDERS OF LANDS}

20. Then as now worth 20s. It is I league long, and half a league broad. And pays $30 d$. in geld. But several persons have holdings therein. And therein were 5 freemen under the said Aluric by commendation only with 18 acres and half a plough. And they were delivered with the manor, and were worth 2 s. The King and the Earl have soke and sac.

In NEWETONA [(Old) Newton] 2 freemen under Alsi by commendation only held 80 acres of land in the soke of the King and the Earl. Now Roger Bigot holds of the Bishop (and) under Roger Wareng[er] (holds). Then 2 bordars, afterwards and now $\mathbf{I}$. Then $\mathbf{I}_{\frac{1}{2}}$ ploughs on the demesne, afterwards none, now I plough. And 3 acres of meadow. And now 2 beasts, 6 swine, and 40 sheep. A sixth share of a church (having) Io acres of free land. Then worth 30 s., afterwards 20s., now 40 s.

In RODEHAM [

] a freeman under Saxo (held) by commendation under St. Etheldreda T.R.E. Io acres within the soke of the Hundred. Then as now half a plough. Roger Bigot holds of the Bishop, and Ralph de Savigny (Saviniaco) under him. Worth $2 s$.

\section{Bosemera [Bosmere] Hundret}

In Crofelda [Crowfield] Wdebrun a freeman under commendation to Edric, Robert Malet's predecessor, held 20 acres as a manor. Then and afterwards I plough, now none. And I acre of meadow. Then and afterwards it was worth 5s., now $3^{\text {s. }}$ Roger Bigot holds of the Bishop.

fol. $374 b$.

In the same (vill) 5 freemen (held) 40 acres. Then and afterwards 2 ploughs, now none. I acre of meadow. This Roger Bigot holds. Then it was worth 16 s., now 20 s.

In Stanham [Stonham] a freeman Lewin, under commendation to Edric of Laxfield, (held) 20 acres as a manor T.R.E. and 2 bordars. Then as now I plough. And 2 acres of meadow. And 2 churches with 3 acres. Then it was worth 5s. and 4d., now 10 s. and 8d. And Roger Bigot holds (this) of the Bishop. The King and the Earl (have) the soke. Of this was Robert Malet seised, and (so was) his father on the day of his death.

In the same (vill) a freeman, Aluric, (held) 20 acres and 2 bordars and $I$ acre of meadow. Then it was worth 4s, now 8s. He was under commendation to the predecessor of Richard son of Earl Gilbert. The King and (the Earl) have the soke.

In the same (vill) 2 freemen (held) 2 acres, worth $6 d$.

In the same (vill) Lewric, a freeman under commendation to Lewin, (held) Io acres. Then half a plough. Then it was worth $3^{s,}$, now $2 s$.

In the same (vill were) II freemen with 52 acres. And 10 of these were under commendation to Lewin, himself under commendation to Robert Malet's predecessor, and the eleventh, Sperun by name, was under commendation to Burchard T.R.E. and had 8 acres of the said land. Then 4 ploughs, afterwards and now 2. And 2 acres of meadow. Then it was worth 20s., now 30s. It is I league long, and $6 \frac{1}{2}$ furlongs broad. And (pays) 20d. in geld. Others hold (land) therein. The King and the Earl (have) the soke.

In Uledana [Olden ${ }^{138}$ ] a freeman Aluric under commendation to Saxo (held) 16 acres. Then as now I plough. Then I bordar, now none. Roger de Ramis claims that he held this Aluric in his fee before (the men) were delivered to the Bishop. Then wood(land) for 24 swine, 8 swine, 22 sheep, and 3 goats. Then it was worth IOs., now $8 \mathrm{~s}$.

In the same (vill were) 6 freemen with 52 acres. Over one and a half of these, to wit over Lewin and Thurmer, the Abbot of Saint Edmund's had commendation T.R.E. And one Brictwolt by name was under commendation to Edric, Malet's predecessor. Then among the whole of them (were) $2 \frac{1}{2}$ ploughs, now 2. Then and now it was worth 20s. Roger Bigot holds of the Bishop. And Gar[enger] of him.

In Cratingis [Creetings] Osgot a freeman held 30 acres T.R.E. as a manor. Then as now I bordar. And I plough. 8 swine, and 9 sheep. And I acre of meadow. Then as now it was worth 12s. And Roger Bigot holds

fol. 375 .

of the Bishop. And Gar[enger] of him. The King and the Earl (have) the soke.

In Burgestala [Burstall] a freeman T.R.E., Ailbern, held 14 acres. A church with 26 acres. Then as now I plough. And I acre of meadow. Then it was worth Ios, now 8 s. and $4 d$.

In the same (vill) Ailric, a freeman under King Edward, (held) 14 acres and half a plough and $I$ acre of meadow. Then it was worth 5 s. and $4 d$., now 4 s.

In the same (vill) Ulin a freeman under the King (held) 2 acres. Then it was worth $5 d$., now $6 d$. It is 8 furlongs long and $1 \frac{1}{2}$ furlongs broad. And (pays) $6 \frac{1}{2} d$. in geld. The King and the Earl (have) the soke.

In Pachetuna [ under King Edward (held) 24 acres 3 freemen 138 See n. 2. 


\section{A HISTORY OF SUFFOLK}

now I plough. And I acre of meadow. Then it was worth $8 \mathrm{~s}$., and the like sum now.

In the same (vill) a freeman under King Edward and a half (freeman) (held) $5 \frac{1}{2}$ acres. Worth I 2 d.

In Codeham [Coddenham] a freeman Almar by name, under commendation to the Abbot of Ely, (held) 60 acres of land as a manor. Then 2 ploughs, now $1 \frac{1}{2}$ ploughs. And I bordar. Then wood(land) for Io swine, now 2. Then as now it was worth 30 . A church with 3 acres, worth $6 d$.

In the same (vill) 2 freemen, Aluric and Uluric, (held) 60 acres as 2 manors. And I villein, and 2 bordars. And 2 ploughs. And 40 sheep, and 2 beasts. And 4 acres of meadow. Then wood(land) for 30 swine, now II. Then it was worth 30 s., now 40 s. The Abbot of Ely had the commendation.

In the same (vill) 2 freemen Aluric and Wistric (held) 2 acres, worth I $2 d$. A church with I acre, worth $2 d$. The King and the Earl (have) the soke over the whole.

In the same (vill) Harold, a freeman in the Abbot of Ely's soke and commendation, (held) 30 acres as a manor T.R.E. Then as now 2 bordars. And I plough. And 2 acres of meadow. Wood(land) for 10 swine. Worth 10 . 'To the church (belong) 2 acres, worth $4 d$.

In the same (vill) 3 freemen (held) $7 \frac{1}{2}$ acres. Half a plough. Worth 2s. The King and the Earl (have) the soke.

In the same (vill) a freewoman, Leveva, (held) T.R.E. 10 acres. Half a plough. And 3 bordars. And I acre of meadow. Worth 4 s.

In the same (vill) is freemen (held) 80 acres less 1. Of these 6 were under commendation to Saxo, the predecessor of Ranulph Peverel (piperelli). Then and afterwards 5 ploughs, now 1. Wood(land) for 10 swine. 2 acres of meadow. Then and afterwards it was worth 30s., now 20s. The King and the Earl (have) the soke.

\section{fol. $375^{b}$.}

In Uledana [OIden] 8 freemen (held) 40 acres. Of these 4 were under commendation to Saxo, the predecessor of Ranulph Peverel, having 25 acres. Then among the whole of them (were) 2 ploughs, now I. And $1 \frac{1}{2}$ acres of meadow. And I rouncey. Then 6 beasts, now 7. Then 28 sheep, now I7 sheep. Now 20 goats. Then 5 swine, now I9. A church with $7 \frac{1}{2}$ acres, worth $15 d$. They were then worth 20s., now 21s. The King and the Earl (have) the soke.

In STANHAM [Stonham] Uluric a freeman held 60 acres as a manor in the Abbot of Ely's commendation. 'Then 4 bordars, now 3. Then 2 ploughs on the demesne, now I. Then I plough belonging to the men, now half a plough. And 3 acres of meadow. A church with $7 \frac{1}{2}$ acres, worth $15 d$. Then it was worth 40 s., now 20 s.

In the same (vill) Aluol the priest and Godwi, freemen under commendation to Saxo the predecessor of Ralph Peverel, (held) 40 acres as 2 manors T.R.E. Then as now 3 bordais. Then and afterwards 2 ploughs on the demesne. Then as now half a ploigh belonging to the men. And $I_{2} \frac{1}{2}$ acres of meadow. A church with 2 acres, worth $4 d$. Then it was worth 30 s, now I 25 .

In the same (vill were) 26 freemen under commendation to Saxo, except one Wiching by name, (with) 142 acres. Then 7 ploughs, now 5. And $1 \frac{1}{2}$ acres of meadow. Then it was worth $4 l i$, now 40 s. and $4 d$.

In the same (vill was) a freeman with 3 acres, w $\therefore$ rth Iod.

In Hamingestuna [Hemingstone] 2 freemen under commendation to Saxo the predecessor of Peverel (held) Io acres. Worth $28 d$. All this Ralph de Savigny holds from Roger Bigot, and Roger from the Bishop. The King and the Earl (have) the soke over it all.

In the same (vill) 2 freemen Brunwin and Godric (held) 3 acres, worth 6d. The same Roger holds (this). The King and the Earl (have) the soke.

In Scaruestuna [? Sharpstone ${ }^{139}$ ] 3 freemen Lewin, Lewric, (and) Edric (held) 4 acres and 2 oxen, worth Iod. Ralf de Savigny holds from Roger.

\section{Claindune [Claydon] Hundret}

In Helmingheham [Helmingham] Burrant a freeman under commendation to Edric of Laxfield, Malet's predecessor, held 80 acres as a manor T.R.E. Then as now I villein, and 2 bordars. Then 2 ploughs on the demesne, afterwards 1 , now none. Then as now I plough belonging to the men. And 2 acres of meadow. Then fol. 376 .

it was worth 30 s., now 20 s.

In HMrngheham [Helmingham] Balchi under commendation to Aistan held 40 acres as a manor. Then as now 4 bordars. And I plough on the demesne. And I acre of meadow. And I rouncey. Then 4 beasts, now 2. Then 30 swine, now 27. Then 40 sheep, now 24. Worth ros.

In the same (vill) a freeman Wichinc under commendation to Burchard (held) 30 acres as a manor T.R.E. Then as now I plough. And 1 acre of meadow. Wood(land) for 4 swine. Then it was worth 6s., now 13 s. and $4 d$.

\footnotetext{
${ }^{139}$ See next note.
} 


\section{THE HOLDERS OF LANDS}

In the same (vill) a freeman Ailric under King Edward (held) 25 acres and 1 bordar. 'Then and afterwards I plough, now half a plough. Then it was worth $50 d$., and it was set to farm for IOs., now it is worth 4 s.

In the same (vill) a freeman Blacheman, half under commendation to one himself under commendation to Edric, Malet's predecessor, and half under commendation to Saxo, (held) 24 acres as a manor. Then as now I plough. Then it was worth 55., and it was set to farm for $155^{\circ}$, now it is worth 8 s.

In the same (vill) Godric, a freeman half under commendation to one himself under commendation to Edric, Malet's predecessor, and half under commendation to Saxo, (held) 20 acres as a manor. And I bordar. And I plough. And the fourth part of a church with I $\frac{1}{2}$ acres of free land. Then it was worth $6 s$. and $4 d$., and it was set to farm for 145., now it is worth ros.

In the same (vill) Levestan, a freeman under commendation to one himself under commendation to Edric, (held) 20 acres as a manor. Then as now 1 plough. And the fourth part of a church (? with $1 \frac{1}{2}$ acres) of free land. Then it was worth 6s., and it was set to farm for $14 s$., now worth Ios.

In the same (vill) I I freemen (held) 7 I acres. Over $2 \frac{1}{2}$ of them the aforesaid Saxo predecessor of Ranulph Peverel had commendation, and a half (freeman) was under commendation to one himself under commendation to Edric, Robert Malet's predecessor. Among them they had then 2 ploughs, now 3 ; and 2 acres of meadow. And half a church with 3 acres. Then it was worth 20s., now 20s. The King and the Earl (have) soke over the whole.

In Escaruestuna [? Sharpstone ${ }^{140}$ ] 27 freemen under soke and commendation of the Abbot of Ely (held) I carucate of land. ${ }^{141}$ Then and afterwards 4 ploughs and now 3. And 2 acres of meadow. Then as now it was worth 40 s.

fol. $376 b$.

In Depвeham [Debenham] Godwi a freeman under commendation to Saxo (held) 40 acres as a manor. Then as now 2 bordars. And I plough. And I acre of meadow. And the fourth part of a church, Saint Mary's, with ro acres. Worth 20s. Saint Etheldreda (has) the

16. 'Scarvastona,' which occurs under Bosmere and Claydon Hundreds (fol. $285,295,3756$ ), is appareatly found at a later date as "Scarfeston" (Copinger, Suff. Rec.); Sharpstone in Barham seems to be the modern equivalent. CF. $n$. 186.

101 Ing. El. enters these freemen as held of the Bishop by Roger Bigot (p. 145). It also records them amongst the "invasiones" in the list headed "senure Haimoris de S. Claro' (p. I82), which is repeated in the list of Roger Bigot's 'invasiones' (p. 188). soke. And three fourth parts of a church, Saint Andrew's, with $1 \frac{1}{2}$ acres: and the fourth part of a church, Saint Mary's, with Io acres.

In Uluestuna [Ulverston ${ }^{142}$ ] T.R.E. the same Godwi (held) I5 acres, and in AsFeldA [Ashfield] 8 acres. Then as now 3 bordars. And I plough.

In the same (vill) a freeman Goda, under commendation to one himself under commendation to Edric, Robert Malet's predecessor, (held) I 5 acres. Then I plough, now half a plough. And I acre of meadow. These three (tenements) make (sunt pro) one manor. Now 4 beasts on the demesne, and 10 swine, 30 sheep, and 12 goats. Then as now it was worth 22s. The soke (is) the Abbot's.

In Uluestuna [Ulverston] Alwin the priest, a freeman a sixth part of whose commendation belonged to one himself under commendation to Malet's predecessor and five sixths to Saxo predecessor of Peverel, (held) 40 acres as a manor. Then as now I villein, and I priest, and 2 bordars. And 2 acres of meadow. And I plough on the demesne. Then and afterwards it was worth 20s., now ros. The soke (is) the Abbot's. Of the fourth part of this land was William Malet seised, and of the priest who was settled upon it, on the day of his death.

In the same (vill) Aluric the priest, a freeman, held 30 acres as a manor in the Abbot's soke and commendation. Then 1 plough. Then it was worth Ios., now 5 s.

In the same (vill) 2 freemen under commendation to Saxo, Edric and Alnod, (held) 40 acres and I bordar. Then as now I plough. Now 2 cows, 12 swine, and 20 sheep. Worth 20 s.

In the same (vill) Thure a freeman (held) 40 acres as a manor. And 2 bordars. And I plough. Then wood(land) for 8 swine, now for 4. Worth 20s. The soke and commendation (are) the Abbot's.

In the same (vill) Lewin Cilt a freeman (held) T.R.E. in the Abbot's soke and commendation 40 acres as a manor, and 2 villeins in another hundred. Then I plough. And I acre of meadow. Wood(land) for I2. swine. Then it was worth 20s., now I5s. The whole of this Roger Bigot holds of the Bishop, and Ralph de Savigny of him.

In DEPHAM [Debenham] a freeman Ailric under commendation to Saxo in the Abbot's soke (held) half an acre. Worth $4 d$.

\section{fol. 377 .}

In Manewic [ ] Wdebrun a freeman in the Abbot's soke and commendation (held) 27 acres. Then as now I plough. And 3 bordars. And half an acre of meadow. Then it was worth ros., now 6 s.

$$
\text { "In Debenham. }
$$




\section{A HISTORY OF SUFFOLK}

In Winestuna [Winston] $2 \mathrm{I}$ freemen (held) 1 carucate of land. And 2 acres of this land were T.R.E. on the demesne of Saxo, the predecessor of Ranulph Peverel, in Depbenham [Debenham]. One of them was under commendatior. to Saint Edmund with 13 acres; and (the Saint) was seised thereof until Ralph made forfeiture. Then as now 5 ploughs. And $4 \frac{1}{2}$ acres of meadow. Then it was worth 40 s., now 45s. Of 8 Saxo had commendation, and the Abbot of Ely had both soke and commendation over the others, except two, namely Alwin and Lewin, who were under commendation to one himself under commendation to Edric, Malet's predecessor.

In Asfredd [Ashfield] Saurin the priest, a freeman in the Abbot's soke and commendation, (held) 30 acres. Then as now 2 bordars. And I plough. Worth IOs. Of this priest Walter de Dol was seised when he forfeited his land, and Earl Hugh was seised afterwards as the Hundred bears witness. And Norman says that the King sent him a writ that he should deliver seisin to Ralph de Savigny of all the freemen over whom Hubert de Port had delivered seisin to the Bishop ; and so Norman delivered seisin of this priest to Ralph ; but still he does not know if Hubert had formerly delivered seisin of him to the Bishop. And the King's Barons when they came into the county found him (held) peaceably (in pace) between Roger Bigot and Earl Hugh, and so he shall remain undisturbed (in pace), until his case be decided (donec sit derationatus).

\section{Sanfort [Samford] Hundret and a Half}

In Burghestala [Burstall] three freemen, Godinc, Ulmar, Alviet, one in commendation to Guert, another to Aluric, and the third to Scalpo, (held) 37 acres. Then I plough, now half a plough. And 4 acres of meadow. Worth 8 s. The soke is in Bercolt [Bergholt].

In the same (vill) Godwin, a freeman of Stigand, (held) 30 acres for a manor. Then and afterwards I plough and I mill, now half a mill. Worth 7s. The sac, except for his house and for 3 acres, is in Bercolt [Bergholt]. In the same (vill) 3 freemen, Ulviet, Brungar, Blacsune, held 18 acres. Then as now half a plough. Worth 4s. This Roger Bigot holds of the Bishop, and Ralph de Savigny of him.

\section{fol. $377 b$.}

\section{Sanfort [Samford] Hundret and a Halp}

In WenhaM [Wenham] Algar a freeman (held) 24 acres as a manor T.R.E. Worth 4 s. The soke was in Bercolt [Bergholt].

In the same (vill were) 4 freemen Brictuolt, Osgot, Ledmer, Godric, having 50 acres and
6 bordars. Worth ros. The soke (was) in Bercolt [Bergholt].

In Reinduna [Raydon] Ednod, a freeman, held I carucate and 100 acres of land as a manor. Then as now 3 villeins and 6 bordars, and $1 \frac{1}{2}$ ploughs on the demesne. Then as now I plough belonging to the men and 4 acres of meadow. Wood(land) for 8 swine. The fifth part of a church with 5 acres. Then worth 3 li., now 4li. But it was (let) to farm for $6 l i$. The soke (is) in Bercolt [Bergholt]. This Roger Bigot holds of the Bishop.

\section{Claindune [Claydon] Hundret}

In Uluestuna [Ulverston] 2 freemen Aluric and Lewin, (of whom) the latter was under commendation to one himself under commendation to Edric, Malet's predecessor, and Aluric was under commendation to Wisgar, (held) 30 acres, and 2 bordars. Then 2 ploughs, afterwards none, now half a plough. And 2 acres of meadow. Then it was worth 10s, now $8 s$. Roger holds of the Bishop, and Garenger of him. The soke (is) the Abbot's.

In the same (vill) a half freeman (held) 2 acres; and they are included in the above valuation.

In Petrhaga [Pettaugh] Siward a freeman T.R.E. (held) 5 acres. Worth 2s. The soke (is) the Abbot's. The said Garenger holds (the land).

\section{SAnfort [SAmford] Hundret and a Half}

Tuneman King Edward's (thegn), Harold's man by commendation, held WENHAM [Wenham] T.R.E., I carucate of land as a manor. Then and (? afterwards) 7 villeins, now 2 . Then 3 bordars, now 17. Then 2 serfs, now 1 . And the fourth part of a church. Then as now 2 ploughs on the demesne. Then 5 ploughs belonging to the men, afterwards and now 2 . 6 acres of meadow. Wood(land) for 8 swine. 6 acres of church(land). Then I rouncey, now 2. Then 4 beasts. Then 24 swine, now 40. Then 60 sheep, now 70. Then worth 60s, and the like now. Roger Bigot holds it of the Bishop. It is 6 furlongs long and $2 \frac{1}{2}$ furlongs broad and (pays) $4 d$.

In the same (vill) Uluric, a freeman, held 40 fol. 378 .

acres as a manor T.R.E. Then I plough, then worth 5s., now 6s. Harold (had) the soke. The same Roger holds of the Bishop.

(At) Reindune [Raydon] Edwi a freeman T.R.E. held I carucate of land as a manor. Then as now 4 bordars and 1 plough. 5 acres of meadow and I mill. The fifth part of a church, with 5 acres. Then worth 30 s., and the like now, 


\section{THE HOLDERS OF LANDS}

but it was (let) to farm for 6os. It is I league in length and 8 furlongs in breadth, and (pays) $30 d$. in geld. Others have holdings there. In the same (vill) Alwin a freeman (held) 60 acres as a manor. Then I bordar. Then as now I plough, and 4 acres of meadow. The fifth part of a church with 5 acres. Now 4 beasts, 13 swine, and 36 sheep. Then worth 20s., now 15 s.

In the same (vill) Smeri a freeman (held) 30 acres as a manor T.R.E. by commendation to Aluric Capin, the predecessor of Eudo Dapifer. Then as now 1 bordar. Then half a plough. 2 acres of meadow. Worth 5 s. In the same (vill) I freeman Ulwin (held) 30 acres. Then as now I bordar. Then half a plough, now 2 oxen. And 2 acres of meadow. Worth 55. In the same (vill) Aluric a freeman (held) 30 acres as a manor. Then as now half a plough, and 2 acres of meadow. Then worth 5 s., now 10s. The soke (is) in Bercolt [Bergholt].

In Reindune [Raydon] I freeman Aluric (holds) 5 acres; and (this) is (included) in the valuation of Raydon.

In Belesteda [Belstead] Aluric a freeman held 30 acres as a manor and 2 bordars. Then I plough. Worth 5 s.

In BRAnthaM [Brantham] (were) 3 freemen, Brun, Siric, Godestan; and in BeleneI [ ] I freeman, Burcheric; and in Heснам [Higham] I freeman, Edric; holding (babentes) 60 acres and I bordar. Then 2 ploughs, now I. Then worth IOS., now 14 s.

In Bortuna [Boyton] Godwin a freeman held T.R.E. 60 acres as a manor. 3 villeins. And I plough on the demesne, and I plough belonging to the men. Wood(land) for ro swine. The fourth part of a church (having) 6 acres. Worth 20 s.

(At) Alstldestuna [ ] Alnold, a freeman, held T.R.E. 2 carucates of land as a manor. Then I bordar, now 5. Then 2 ploughs on the demesne, now 1 , and $1 \frac{1}{2}$ acres of fol. 3786 .

meadow. Then as now I mill. Worth 25 s. It is 6 furlongs long and 3 broad, and pays $2 \frac{1}{2} d$. in geld.

In Tatrtuna [Tattingstone] Turgot, a freeman, held 60 acres as a manor. Then I plough, and $1 \frac{1}{2}$ acres of meadow. Then worth IOs., now 4. All this Roger Bigot holds of the Bishop, and of all the soke (is) in Bercolt [Bergholt].

In Grpeswiz [Ipswich] I house with half an acre, and in ToFr [Toft] Edwi a freeman, (with)
$2 \frac{1}{2}$ acres. Worth $6 d$. Roger Bigot (holds). The soke (is) in Bercolt [Bergholt].

\section{Hertesmara [Hartismere] Hundret}

In Espala [Aspall] Leveva, under commendation to the Abbot of Ely and in his soke, held 20 acres, worth 4s. 'This Roger Bigot holds, and Ralph de Savigny under Roger.

In the same (vill) are 12 acres of the demesne of Dephenham [Debenham] and 5 bordars. (Included) in the same valuation.

\section{LAND OF SAINT BENEDICT OF RAMSEY}

\section{Two Hundrets of Babenberga [Babergh]}

(At) Lawessela [Lawshall] T.R.E. Saint Benedict held 8 carucates of land as a manor with soke. Then 14 villeins, now $\mathrm{r} 6$. Then 12 bordars, now 10. Then 4 serfs, now 5 . Then 2 ploughs on the demesne, now 3 . Then as now Io ploughs belonging to the men. 8 acres of meadow. Then as now I rouncey. Now 10 beasts and 30 swine, 100 sheep, and 12 goats. A church with 30 acres of free land. Then it was worth 8 li. now 12li. It is I league long, and half a league broad. And pays $15 d$. in geld.

fol. 379 .

\section{LANDS OF WILLIAM BISHOP OF THETFORD}

\section{Biscopes [Bishop's] Hundret}

(At) Hoxana [Hoxne] Bishop Ailmar held T.R.E. as a manor 9 carucates of land. Then 40 villeins, now 20 . Then 15 bordars, now 51 . Then 4 serfs. Then as now 3 ploughs on the demesne. Then 40 ploughs belonging to the

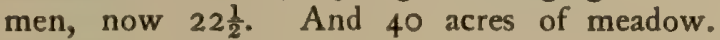
Wood(land) for 250 swine. Then as now 2 mills. And 2 rounceys, 12 beasts, 80 swine, I 7 sheep, and 40 goats. In this manor there used to be a market T.R.E. and (it went on) after King William came hither ; and it was set up (sedebat) on Saturdays. And William Malet made his castle at Eia [Eye], and on the same day as the market used to be held on the Bishop's manor William Malet made another market in his castle and thereby the Bishop's market has been so far spoilt that it is of little worth; and now it is set up on Fridays. But the market at Heia [Eye] is set up on the Saturday. Now Robert holds it by the King's gift. In this manor there is a church, (which was) the seat of the Bishopric of Suffolk T.R.E. This manor was then worth $28 \mathrm{li}$, now $20 \mathrm{li}$.; but to Arfast it rendered 30 i. It is I league long, and 8 furlongs broad. And (pays) $22 \frac{1}{2} d$. in geld. 


\section{A HISTORY OF SUFFOLK}

In WEIBRADA [Weybread] (is) a sokeman with 2 acres, worth $10 d$.

In WILeBI [Wilby] (is) a sokeman with 40 acres and $I$ bordar and I plough. 2 acres of meadow. Wood(land) for 20 swine. Then worth IOS., now 8 s.

\section{W ANEFORDA [W ANGFord] HundRet}

(At) Humbresfelda [Homersfield] Elmer the Bishop T.R.E. held a manor of 5 carucates of land; now Bishop William holds it. Then as now 16 villeins. Then as now 12 bordars. Then as now 4 serfs. Then 2 ploughs on the demesne, now 3. Then Io ploughs belonging to the men, now 5 ; and 5 might be restocked there. 12 acres of meadow. Then wood(land) for 600 swine, now for 200. I mill. A church with 12 acres. And (there were) 3 horses when he took it over, and (are) now. Then as now 6 beasts. Then as now 26 swine. 200 sheep. Then with the soke worth 12li., now it renders (reddidit) i6li. Over the ferting of Almeham [Elmham] Bishop William has soke and sac except over Bishop Stigand's men ; and B[aldwin] the Abbot according to the testimony of the Hundred had a writ of King Edward (testifying) that he ought himself to have soke and sac over Saint Edmund's land and over his men.

In BARSHAM [Barsham] (are) I6 acres and 2 bordars and half a plough. Worth 2 s.

\section{fol. 3796 .}

\section{XVIIII. FEE OF THE BISHOP OF THETFORD}

\section{Hertesmara [Hartismere] Hundret}

In Iacheslea [Yaxley] and in Thrandestuna [Thrandeston] Bishop Aylmar held T.R.E. I carucate of land as a manor. Then as now 5 bordars. And I plough. 2 acres of meadow. Worth 20s. And (the manor) belongs to the church of Hoxna [Hoxne].

In SeILANDa [Syleham] a freeman under Stigand (held) 2 carucates of land and 12 bordars and 2 ploughs on the demesne. Then 4 ploughs belonging to the men, now 2. And 5 acres of meadow. Wood(land) for 60 swine. And I mill. Then as now worth 6os. This Ailmar (and) Arfast held.

In Menneham [Mendham] Ulf the thegn held T.R.E. I carucate of land, afterwards Ailmar and Arfast (had it). Then as now I villein. And 10 bordars. And I plough on the demesne. Then 3 ploughs, now $1 \frac{1}{2}$. And 6 acres of meadow. Wood(land) for 60 swine.
And I mill. And 2 freemen (having) II acres by commendation and half a plough. The eighth part of a church with 40 acres and half a plough. More land belongs to it but is accounted for (in breviata) in Norfolc [Norfolk]. ${ }^{143}$ Then worth 30s., now 60 s.

In Denham [Denham] 5 freemen under Almer (held) 60 acres and I plough. Worth Ios.

In Horam [Horham] 7 freemen by commendation (held) 42 acres. And then as now $1 \frac{1}{2}$ ploughs. Wood(land) for 16 swine.

In WILEBi [Wilby] a freeman (held) ro acres. In Ciccheliga [Chickering] a freeman (held) if 6 acres and 2 bordars. Then as now half a plough. A church with 8 acres. The whole is worth 20 s.

In HoRAM [Horham] 2 freemen by commendation and soke (held) 19 acres and half a plough. Worth $3^{\text {s. and }}$ rod.

In WILEBEY [Wilby] a freeman (held) 40 acres by commendation and soke. Then as now 1 bordar. And I plough. And 2 acres of meadow. Wood(land) for 20 swine. Then worth IOs., now 8 s.

In WigheFELDA [Wingfield] a freeman by commendation and soke (held) 10 acres, worth $20 d$.

In Cicchelinga [Chickering] a freeman by commendation held 28 acres and 3 bordars. Then as now half a plough. Worth 55.

In the same (vill) a freeman (held) 40 acres and half a plough. Wood(land) for 12 swine. Half an acre of meadow. Worth $6 \mathrm{~s}$. and $8 d$.

In the same (vill) a freewoman (held) 8 acres. Robert Malet's predecessor had commendation T.R.E. Worth $16 d$. Ailmar had soke and sac.

In Badingelelda [Bedingfield] 2 freemen held 30 acres by commendation and I plough. Then worth 6s., now 10 .

fol. 380 .

\section{HUNDRET OF LOSA [LOES]}

In Framalingaham [Framlingham] a freeman under commendation of Bishop Almar (held) 20 acres of land and half a plough. Worth 4 s.

\section{Hertesmara [Hartismere] Hundret}

In ACLE [Oakley] a freeman Algar by commendation to Saint Edmund T.R.E. (held) 14 acres and half a plough, and half an acre of meadow. Worth 2s. Drogo holds from the Bishop.

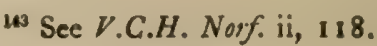




\section{THE HOLDERS OF LANDS}

\section{W ANEFORdA [W ANGFord] HundRet}

(At) Humbresfelda [Homersfield] a freeman under Elmar's commendation (held) 40 acres as a manor. Then as now 2 bordars. Then 2 ploughs, now 1. 2 acres of meadow. A church with 30 acres. Then worth 6 s. and $8 d$., now 9s. and $4 d$.

Furthermore in the same vill 23 freemen (held) 80 acres. Then 6 ploughs, now 5. Then worth 40 s., now 30s. It is I league long and half (a league) broad. And in geld (pays) $20 d$.

In Halmeham [Elmham] a freeman by commendation and soke under Bishop Elmar (held) as a manor 40 acres and 4 bordars. Then as now 1 plough. And 2 acres of meadow. Wood(land) for 8 swine. A church with 6 acres. And under him 3 free(men) under the same (Bishop Elmar's) commendation (held) 6 acres and half a plough. Then worth ros., now it renders 125 .

In the same vill a freeman Alwin by commendation and soke under Elmar (held) 40 acres as a manor and 2 bordars. Then I plough, now half a plough. 2 acres of meadow. Then worth $6 s$. now worth Ios. and $8 d$.

Furthermore in the same (vill) Io freemen by commendation and soke under the same (Elmar) (held) 66 acres. Then as now 1 plough. 2 acres of meadow. Then worth Ios., they now render 14 s.

In the same (vill) 10 freemen by commendation and soke under the same (Elmar) (held) 34 acres. Then 3 ploughs, now 2. Then worth IOs., they now render 20s. It is I league long and half (a league) broad. And in geld (pays) 20d. Others hold (land) there.

In Fuixtuna [Flixton] a freeman Osketel by commendation and soke under Bishop Stigand (held) as a manor 30 acres and $x$ bordar. Then as now I plough. 2 acres of meadow. The fifth part of a mill. Then worth $8 s$., he now renders Ios. and $8 d$.

In the same (vill) 8 freemen by commendation and soke and sac under Bishop Almar (held) 107 acres. Then 2 ploughs, now $1 \frac{1}{2}$ ploughs. Half a church with 12 acres. Then worth 10 s., they now render 31 s, and $4 d$.

Azmeham [Elmham] William holds of the Bishop, which Alwin a freeman by commendafol. $3^{80 b}$.

tion under Inwar the thegn held T.R.E. ; (viz.) 2 carucates of land and 20 acres. Then 10 villeins, now 4. Then II bordars, now 20. Then 4 serfs. Then on the demesne 3 ploughs, now half a plough. I rouncey, 7 beasts, 30 swine, 13 sheep, and 30 goats. Then belonging to the men 6 ploughs, now $3 \frac{1}{2}$ ploughs. And 11 acres of meadow. Wood(land) for 30 swine. A church with 40 acres of free land and half a plough. Then worth [ ] shillings, now 4 li.

In the same (vill) a freeman Bond by commendation under Bishop Ailmar (held) 60 acres as a manor. And 2 villeins, and 2 bordars. And I plough on the demesne. Then belonging to the men I plough, now half a plough. 2 acres of meadow. And under him were 2 freemen with 7 acres. Then I plough, now half a plough. Then worth IOs,, now worth $13^{\text {s. }}$

Furthermore in the same (vill) a freeman by commendation and soke and sac under Stigand (held) 30 acres as a manor. Then as now 2 villeins. And I plough. And belonging to the men I plough. 2 acres of meadow. Wood(land) for 8 swine. Then worth 8 s., now worth IOs. and $8 d$.

In the same (vill) a freeman Alwin by commendation under Edric of Laxfield T.R.E. (held) 30 acres as a manor. Then 2 bordars, now 3 . Then as now half a plough. I acre of meadow. Wood(land) for 8 swine. And under him 2 freemen (held) 4 acres and half a plough. Then worth Ios., now the like. William Malet was seised the day on which he died.

In the same (vill) 25 freemen under commendation to Bishop Almar (held) $1 \frac{1}{2}$ carucates of land. Then 8 ploughs, now 6 . And 6 acres of meadow. Wood(land) for 16 swine. Then worth 30 s, now 40s. 3 churches with 30 acres worth 5 s.

In Flixtuna [Flixton] a freeman Brihtnoth under commendation to Almar (held) 30 acres as a manor, and 4 bordars. Then as now I plough. And belonging to the men half a plough, and 2 acres of meadow. Wood(land) for 4 swine. Then worth 5s. and $4 d$., now 20 s.

Furthermore 3 freemen under commendation and soke and sac to Almar (held) 38 acres. Then as now $I \frac{1}{2}$ ploughs. Wood(land) for 4 swine. 3 acres of meadow. Then worth 6s., now IIs. and $8 d$.

All this William de Noers holds of the Bishop.

Moreover in the same vill a freeman by commendation and soke under Stigand (held) 30 acres as a manor. Then 2 bordars, now 8 . Then I plough, now 2. 2 acres of meadow. Wood(land) for 4 swine. And under him a freeman (held) I6 acres. Then half a plough, now 2 oxen. Then worth $10 s$, and now the like. The said William (de Noers) holds it.

In BARsHaM [Barsham] 10 freemen, of whom Aluric and Gurth had commendation over $8 \frac{1}{2}$ fol. $3^{81}$.

and Bishop Almar over the others, (held) 60 acres. Then 2 ploughs, now $1 \frac{1}{2} .2$ acres of meadow. Then worth 8 s., now 10 s.

Hertesmara [Hartismere] Hundret

In Iachlesea [Yaxley] and in Thrandestuna [Thrandeston] 40 freemen (held) I carucate and 


\section{A HISTORY OF SUFFOLK}

I9 acres of land. Then 3 ploughs, now $3 \frac{1}{2}$ ploughs. 2 acres of meadow. Then as now worth 40s. The Bishop (had) soke and sac. This Othem holds of the Bishop.

In Brom [Brome] a freeman under commendation to one himself under commendation to Bishop Aylmar (held) 6 acres worth $12 d$.

\section{Half Hundret}

In Furxtuna [Flixton] Saint Michael held in alms T.R.E. I carucate of land. Then 13 bordars, now 8. Then and now on the demesne I plough. Then belonging to the men 3 ploughs, now 1. Wood(land) for 8 swine. 4 acres of meadow. Half a mill. Then as now worth 20s. The soke (belonged to) Stigand.

\section{LANDS OF THE BISHOP OF ROCHESTER}

\section{LACFORDA [LACKFORD] HUNDRET}

(At) Frakenaham [Freckenham] Orth, Harold's thegn, held T.R.E. Io carucates of land as a manor, and afterwards Lanfranc by the King's command decided (derationatus est) that they should belong to the bishopric of Rochester. Then as now 16 villeins, and 8 bordars, and 6 serfs. And then as now 5 ploughs on the demesne. And 6 ploughs belonging to the men, but 8 might be stocked. And 20 acres of meadow. And I mill. And 2 fisheries. A church with 20 acres. And 3 horses, 13 beasts, 40 swine, 230 sheep, and 6 hives of bees. Then it was worth $12 l i$, now $14 l i$. It is I league long, and half a league broad. And in geld (pays) $20 d$. To this manor Earl Ralph added 4 freemen, whom he appropriated (invasit), with 8 acres of land. Then as now half a plough. Worth $8 d$. The said Bishop had the soke of this manor, and Saint Edmund has the soke of the freemen.

\section{fol. $38 \mathrm{I} b$.}

\section{LANDS OF SAINT ETHELDREDA}

\section{Thewardestreu [Thedwastre] Hundret}

Saint Etheldreda held Ratesdane [Rattlesden] T.R.E. as 6 carucates of land. Then as now 18 villeins. Then 20 bordars, now 27. Then 6 serfs, now 4. Then as now 3 ploughs on the demesne. Then 12 ploughs belonging to the men, now $3 .^{144}$ Wood(land) for 24 swine. And 16 acres of meadow. Then as now 5 rounceys. Then and now 12 beasts, 90 sheep, 40 swine. Now II goats. ${ }^{145}$ Then as now worth roli. ${ }^{146}$ I church (with) 24 acres. And 15 acres Hun-

\footnotetext{
44 ' now 6'; Inq. El. I53.

105 ' 2 hives of bees'; ibid.

16 "Then it was worth 8ii., now Ioli." ; ibid.
}

frid, William de Warenne's man, holds, and Goscelin, the Count of Moretaine's man, (holds) 2. It is 16 furlongs ${ }^{147}$ long, and 10 broad. And (pays) 20d. in geld. The soke is Saint Etheldreda's.

In the same (vill) a freeman under Saint Etheldreda by commendation and soke T.R.E. held 3 acres. Worth $6 d$.

In Ratesdana [Rattlesden] a freeman under Saint Etheldreda by soke and sac (held) 8 acres. Worth 2s. Falco, Saint Edmund's man, had these 8 acres while the Abbey of Saint Etheldreda was in the King's hand, and has held them up to this time; but he denies that he withheld the service.

At Drincestona [Drinkstone] Saint Etheldreda held T.R.E. 2 carucates of land. A church (with) 12 acres. Then 15 bordars, now 7. ${ }^{148}$ Then 6 serfs, now 4. Then as now 2 ploughs on the demesne. Then 3 ploughs belonging to the men, now I. Wood(land) for 100 swine. And 6 acres of meadow. Then as now 2 horses at the hall, ${ }^{149}$ Io beasts, 32 swine, 30 sheep, 8 goats. Then worth 40 s, now 60 . ; but it was (let) to farm at $100 s_{\circ}$, and could not render (so much). It is 8 furlongs long, and 7 broad. And (pays) $11 d$. in geld.

\section{Thingohou [Thingoe] HUNDReT}

In REDA [Rede] (are) 20 acres in demesne. And 4 bordars. 2 acres of meadow. And half a plough. The soke and sac (are) Saint Etheldreda's. Worth 4 s.

\section{LacForde [LackFord] Hundret}

(At) Brandona [Brandon] Saint Etheldreda held T.R.E., and now (holds) as a manor 5 carucates of land. Then as now 8 villeins, and 4 bordars, ${ }^{150} 7$ serfs. Then as now 3 ploughs on the demesne. Then 4 ploughs belonging to the men, now 3. And 3 acres of meadow. ${ }^{151}$ And I fishery. ${ }^{188}$ And 2 asses, II beasts, 200 sheep, fol. $3^{82}$.

and 20 swine. A church with 30 acres. Then it was worth $6 l_{i}$, now $8 l i$. It is I league long, and half a league broad. And in geld (pays) $20 d$.

(At) LaRingahetha [Lakenheath] Saint Etheldreda held T.R.E. as a manor 3 carucates of land. Then as now 6 villeins, and 5 bordars, ${ }^{163}$ and 4 serfs. Then 3 ploughs on the demesne,

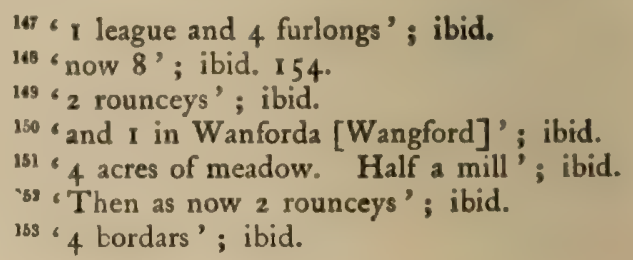




\section{THE HOLDERS OF LANDS}

now 2. Then as now 2 ploughs belonging to the men. And 5 acres of meadow. And half a mill. ${ }^{164}$ And 2 fisheries. And 2 l.orses at the hall, ${ }^{163}$ and 5 beasts, 100 sheep, and 17 swine. A church with 60 acres. Then it was worth $4 l i$., now $6 \%$. It is 1 league long, and half a league broad. And in geld (pays) $20 d^{156}$

(At) Lundale ${ }^{157}$ [Undley] Saint Etheldreda held I carucate of land. And 3 bordars, ${ }^{158}$ and 4 serfs. Then as now 2 ploughs ${ }^{159}$ on the demesne. And 13 acres of meadow. And 2 fisheries. And 1 horse, 24 beasts, ${ }^{160}$ and 62 sheep. Then as now it was worth 20s. A church without land. It is 2 furlongs long, and 2 broad. Its geld is included in that of Laringeheta [Lakenheath].

In Dunham [Downham] a half freeman with his soke under Saint Etheldreda (held) half a carucate of land, and 3 bordars, and 1 acre of meadow. Then as now half a plough. Worth 5s.

In LIURRmera [Livermere] ${ }^{101} 3$ freeman under Saint Etheldreda ${ }^{168}$ by commendation only, in Saint Edmund's soke, (held) 29 acres of land. Then as now half a plough. Worth 5 s.

\section{Baberga [Babergh] Two Hundrets}

(At) Clamesford ${ }^{163}$ [Glemsford] Saint Etheldreda held 8 carucates of land T.R.E. as now as a manor. Then as now 16 villeins, and $18^{164}$ bordars, and 5 serfs. Then as now 3 ploughs on the demesne, and $7^{105}$ ploughs belonging to the men. And 12 acres of meadow. Wood(land) for 5 swine. And 1 mill. Then as now 3 horses at the hall, ${ }^{168} 8$ beasts, ${ }^{167}$ and now 200 sheep, and 32 swine. A church with 30 acres of free land. And I sokeman with 8 acres. ${ }^{168}$ Then it was worth roli., now 16 li. It is I league long, and 8 furlongs broad. And (pays) $15 d$. in geld.

(At) Hertest [Hartest] T.R.E. Saint Etheldreda held 5 carucates of land as a manor. Then as now 12 villeins, and 14 bordars, and 4 serfs. Then as now 2 ploughs on the demesne. Then 5 ploughs belonging to the men, now 6 . And 10 acres of meadow. Wood(land) for 6

\footnotetext{
is Omitted; Ing. El. 154.

iss ' rounceys'; ibid. 100 ' rod.' ; ibid.

187 'Undelai [Úndley in Lakenheath]'; ibid.

1us 'Then as now 5 bordars'; ibid.

139 'I plough'; ibid.

160 'Then as now I rouncey, 23 beasts'; ibid.

ve. 'and in Wanforda [Wangford]'; ibid.

163 'T.R.E. and now'; ibid.

100 'Glammesforda'; ibid. I55.

in ' 16 '; ibid.

165 ' 8'; ibid.

16 'rounceys'; ibid.

107 ' 18 beasts"; ibid.

'Worth $12 d$.' ; ibid.
}

fol. $3^{82 b}$.

swine. Then as now 4 horses at the hall, ${ }^{169} 20$ beasts, 25 swine, and 60 sheep. A church with 80 acres of free land. Then it was worth $6 / i$, now I I li. It is I league long, and half a league broad. And (pays) rod. in geld.

In the same (vill were) 4 sokemen with 30 acres of land, and half a plough. Worth 5 s.

Moreover there is a sokeman with 1 carucate of land. Then as now I plough. Worth 20 s. This Berner the crossbowman (balistarius) holds of Saint Etheldreda.

\section{STOHU [Stow] Hundret}

In Ciltuna [Chilton] Saint Etheldreda held 2 sokemen with 36 acres, but they had no power to sell without licence of the Abbot. And I bordar. Then I plough, now none. Half an acre of meadow. Worth $5^{\text {s. }}$

In Bukessalla [Buxhall] (are) I sokeman with 10 acres of forfeited (forefacte) land, ${ }^{170}$ and I bordar with 5 acres. Worth Iod.

In Fineberga [Finborough] Roger de Oburville holds of Saint Etheldreda 3 sokemen with 34 acres of land. ${ }^{171}$ Worth 4 s. In the same (vill) are 7 acres of the demesne in Berkinges [Barking]. The sac and soke (are) Saint Etheldreda's.

\section{Half Hundred of Gepeswiz [IPSwich]}

(At) Stoches [Stoke] Saint Etheldreda held 3 carucates of land as a manor T.R.E. (There were) then as now 9 villeins. And then 5 bordars, now I 5. Then I serf. ${ }^{172}$ Then as now 2 ploughs on the demesne. And 6 ploughs belonging to the men. And I church with 40 acres of free land. And I mill. And 20 acres of meadow. And 12 beasts, 20 swine, 24 sheep, and 14 goats. Furthermore Saint Etheldreda has a moiety of the soke which lies beyond the bridge. Then it was worth 4 li., now 100 . It is 6 furlongs long, and 6 broad. And (pays) $4 d$. in a geld of 20 s.

\section{Bosemera [Bosmere] Hundret}

(At) Berchingas [Barking] Saint Etheldreda held T.R.E. with soke and sac 7 carucates of land as a manor. Then 27 villeins, now 25 . Then 24 bordars, now 30. Then 5 serfs, now 4. Then as now 3 ploughs on the demesne. Then 24 ploughs belonging to the men, now 15 . A church with 83 acres of free land and 2 ploughs and 52 acres of meadow. Wood(land)

$$
\begin{aligned}
& 169 \text { ' } 4 \text { rounceys'; ibid. } \\
& 170 \text { 'a sokeman with } 10 \text { acres who could not sell } \\
& \text { his land'; ibid. } 157 \text {. } \\
& 171 \text { 'which they could not sell. Half a plough'; } \\
& \text { ibid. }
\end{aligned}
$$$$
\text { ibid. }
$$ 


\section{A HISTORY OF SUFFOLK}

for 50 swine. Then as now 1 mill. And a weir (exclusam) of another mill; and in the weir of the other mill Robert Malet has a share. And 2 arpents of vineyard. ${ }^{173}$ On the demesne (are) I I rounceys, 23 beasts, 30 swine, roo sheep, fol. $3^{8} 3$.

and 48 goats. And (there are) 4 freemen with 6 acres, and they have I plough. These men were added to this manor in King William's time. Worth 2 shillings. The King and the Earl (have) soke. Hardwin had one and a half of these when he made forfeiture; now the Abbot holds (them). The manor was then worth 16 li., and the Abbot gave it to farm for 20li. It is I league and 4 furlongs long, and 8 furlongs broad. And (pays) 20d. in geld.

In Dermodesduna [Darmsden] 25 freemen held I carucate of land, over whom Saint Etheldreda had commendation and soke T.R.E. Then 6 ploughs, now 2. And 3 acres of meadow. Worth 20s. Roger Bigot holds of the Abbot because the Abbot proved his right to it (derationavit) against him before the Bishop of St. Lo (de Sancto Laudo) ; ${ }^{174}$ but before that however he held of the King.

In Berchingas [Barking] Roger holds i i 8 acres of the Abbot of his demesne. And a church with 6 acres. Worth 10 .

In Horswalda [Horswold] ${ }^{175}$ (was) a freeman by commendation and soke T.R.E. with $22 \frac{1}{2}$ acres. And half a p'ough. And half an acre of meadow. Worth $3^{\text {s. }}$ Roger de Otburville held him of the King. And the Abbot proved his right against him. Now he holds of the Abbot.

In Badeleia [Badley] Saint Etheldreda held 30 acres in demesne T.R.E. This is included in the valuation of Berchingis [Barking].

In Hamingrstuna [Hemingstone] (was) a sokeman under Saint Etheldreda, with 12 acres. ${ }^{176}$ William de Scoies holds of the Abbot and this is included in the valuation of Blacham [Blakenham].

In Hamingestuna [Hemingstone] Iric a freeman under commendation to the Abbot and in his soke (held) 15 acres and 2 bordars. Worth 2s. and $6 d^{177}$

${ }^{13}$ Imq. El. adds, 'et una pars bosemaris,' and omits 'on the demesne'; ibid. 157.

174 'before the Bishop of Coutances (Constantiense)' ; ibid.

${ }^{175}$ In Crowfield.

176 'Worth 8 s.'; ibid. 158

177 'This belongs to (jacet in) Bercham [Barham]';
In Uledana [Olden] ${ }^{178}$ Aluric, a freeman by commendation only, (held) $\mathrm{I} \frac{1}{2}$ acres. Worth $3^{d}$. The King and the Earl (have) the soke. ${ }^{179}$ This is (held) in demesne.

In Codenham [Coddenham] are 16 acres of demesne land: and they are included in the valuation of Bercham [Barham].

In HAsSA ${ }^{180}$ [Ash (Bocking)] a freewoman, Listeva, under the Abbot's commendation (held) fol. $3^{8} 3^{b}$.

I acre. Worth $2 d$. The King and the Earl (have) the soke.

In the same (vill) a freeman by commendation only (held) half an acre. Worth $I d$. The King and Earl (have) the soke.

\section{Claindune [Claydon] Hundret}

(At) Bercham [Barham] Saint Etheldreda held T.R.E. 4 carucates of land as a manor. ${ }^{181}$ Then as now 24 villeins. Now 9 bordars. Then 6 serfs, now 2. Then 3 ploughs on the demesne, now 1 . Then 8 ploughs belonging to the men, now 6 . A church with 16 acres. ${ }^{182}$ Then as now I mill. And 12 acres of meadow. Then wood(land) for 100 swine, now for 16 . Now 9 swine, and 17 sheep. ${ }^{183}$ And (there was) a sokeman with 30 acres. Then as now I plough. ${ }^{184}$ Then it was worth 12 li, now Ioos. It is I league long, and $7 \frac{1}{2}$ furlongs broad. And (pays) 20d. in geld.

In the same (vill) a freeman (held) 35 acres in the Abbot's soke and commendation. Then I plough, now half a plough. Then I bordar now 2. ${ }^{185}$ And 3 acres of meadow. And I mill. Then it was worth ros., now 20s. Roger de Otburville used to hold of the King, now (he holds) of the Abbot.

In EsCarlestuna ${ }^{186}$ [? Sharpstone ${ }^{187}$ ] 3 freemen in the Abbot's soke and commendation (held) 8 acres, and 2 oxen. Then it was worth 20d., now 2s. This William de Scoies held of the King, now (he holds) of the Abbot.

At Winestuna [Winston] Saint Etheldreda held T.R.E. in demesne I carucate of land and 40 acres as a manor. Then as now 6 villeins, and 4 bordars. Then 2 ploughs on the demesne, now 1 . Then as now 3 ploughs belonging to the men. 6 acres of meadow. Then wood(land)

${ }^{178}$ In Coddenham, see n. 2.

179 'In the King's soke'; Inq. El. I 59.

180 'Ai sia'; ibid. 181 ' in demesne' ; ibid.

182 ' of free land'; ibid.

163 ' 27 sheep'; ibid.

184 'and 2 acres of meadow'; ibid.

185 ' 3 bordars. Then as now 1 plough'; ibid.

186 'In the same vill' [i.e. Barham]; ibid.

${ }^{187}$ In Barham; cf. n. 140. 


\section{THE HOLDERS OF LANDS}

for 100 swine, now for 60 . A church with 8 acres. 2 rounceys, 4 beasts, 20 swine, and 50 sheep. Ther it was worth $4 l i .$, now $4 l i$. and ros. And Alsi, a freeman added to this manor, (has) 30 acres as a manor in the Abbot's soke and commendation. Then as now 2 bordars. And $I$ plough. Worth IOs. It is I league long and 3 furlongs broad. And (pays) $13 \frac{1}{2} d$. in geld.

In Westrefielda [Westerfield] Aseret a sokeman under the Abbot held 25 acres. ${ }^{188}$ Then as now I plough. And I acre of meadow. Worth 55. Hervey holds of the Abbot by the King's command.

In the same (vill) Turchil a freeman under commendation (held) 8 acres. Worth $16 d$. Hervey held of the King, and now (he holds) of the Abbot, by the King's command as he says. The soke is the King's.

fol. 384 .

In Petenaga [Pettaugh] the said Turchil under commendation, half to the Abbot T.R.E. and half to Gurth, (held) 20 acres and I acre of meadow and $I$ villein and half a plough. Worth 5s. This also Hervey held of the King, and now of the Abbot, by the King's command, as he says. Half the soke was the Abbot's and (half belonged) to Hugh's predecessor. ${ }^{189}$

In Depleham ${ }^{100}$ [Debenham] a half freeman by soke and commendation held 4 acres. Worth 8d. Him Robert Malet held of the King, now (he holds) of the Abbot.

In Assefrida [Ashfield] a freeman by soke and commendation (held) 3 acres. Worth $8 d$.

In Henlea [Henley] a freeman by commendation and soke (held) half an acre. Worth $I d$.

In TORP [Thorpe] Alsi a freeman by soke and commendation (held) 10 acres. Worth $20 d$.

In Scaruetuna [? Sharpstone ${ }^{191}$ ] a freeman by soke and commendation (held) 2 acres. Worth 4d. Walter ${ }^{191 *}$ holds.

\section{Pereham [Parham] Half Hundret}

In Blachessata [Blaxhall] 5 freemen in the soke and commendation of the Abbot (held) 26 acres. Then as now half a plough. ${ }^{122}$ Worth 4 s.

In WANTESDENA [Wantisden] (are) 12 acres belonging to the demesne of Sutburne [Sudbourne], worth $24 d$.

is 'and he could not sell his land'; Ing. El. 160.

100 'Half the soke (is) the Abbot's and half the Earl's? ; ibid.

19. "Debenham"; ibid. 10 See n. 140.

1014 'Walter the Deacon'; Inq. El. 161.

193 '1 plough'; ibid. 165.
In the same (vill) Morwin a freeman held 2 acres, worth $4 d$. The said Morwin holds of the Abbot.

\section{Plumesgata [Plomesgate] Hundret}

(At) Sudburna [Sudbourne] Saint Etheldreda held T.R.E. as a manor 6 carucates of land. Then as now I 4 villeins. Then 15 bordars, now 21. ${ }^{193}$ Then 2 serfs. ${ }^{194}$ Then 3 ploughs on the demesne, now 1 . Then 12 ploughs belonging to the men, now 6 ; $^{195}$ and 6 might be re-stocked. 4 acres of meadow. Wood(land) for 12 swine. Then I rouncey, now 2. Then as now 7 beasts, 17 swine, and 120 sheep. Then as now it was worth 7 li. ${ }^{196}$ A church with 8 acres. It is I league long, and half (a league) broad. And

fol. $3^{8} 4 b$.

\section{Hertesmara [Hartismere] Hundret}

At Weringheseta [Wetheringsett] Saint Etheldreda held T.R.E. 4 carucates of land as a manor, now Ralph de Savigny holds the fourth 197 of Ranulph Peverell. Then as now 10 villeins. And 9 bordars. Then 4 serfs, now 2. Then as now 2 ploughs on the demesne. And 3 ploughs belonging to the men. And 4 acres of meadow. Then wood(land) for 500 swine, now for 400 . A church with 16 acres and half a plough. And 2 rounceys, ${ }^{198} 8$ beasts, 30 swine, 107 sheep, and 18 goats. Then worth roli., and the like now.

In the same (vill) 4 freemen under commendation, Gotwin, Brictmar, Osulf, Derolf, (held) 40 acres. Then as now 2 ploughs. Worth I Os. Saint Etheldreda (had) the soke. It is $1 \frac{1}{2}$ leagues long, and I league broad. And (pays) $9 d$. in geld. Others have holdings therein.

\section{RISebruge [RIsbridge] Hundret}

(At) Ceneberia [Chedburgh] 2 freemen T.R.E. held 2 carucates of land as 2 manors. Then 2 bordars, now 5. Then as now 4 serfs. Then 2 ploughs on the demesne, now 4. And half a plough belonging to the men. 8 acres of meadow. Wood(land) for 12 swine. This Frodo holds of the Abbot. When he took it over (there were) 4 rounceys, now none. Then 8 beasts, now 14. Then 20 sheep. ${ }^{199}$ All this land belonged to (jacebat in) the demesne of the

19 ' now 22' ; ibid. 19 'now none'; ibid. 198 "now $5^{\text {' }}$; ibid. Here Dom. Bk. is evidently the more accurate, as the loss of the 6 ploughs which 'might be restocked' would leave 6 .

106 'Then worth 6li., now 7 li.' i ibid. Here the advantage of accuracy would seem to lie with the Inq.

197 'one of them'; ibid. 166

198 ' 2 rounceys at the hall'; ibid.

19 "now none"; ibid. 155. (pays) $20 d$. in geld. 


\section{A HISTORY OF SUFFOLK}

abbey T.R.E. with every kind of custom except Saint Edmund's six forfeitures. Then worth 40 s., now 6os. It is half a league long, and 3 furlongs broad. And (pays) $1 \frac{1}{4} d$. in geld. Others hold land therein.

In Copletuna ${ }^{200}$ [Clopton] 3 freemen (held) 20 acres. Saint Etheldreda had soke and sac and commendation. And they were worth 25. Saint Edmund (held) the 6 forfeitures.

\section{Half Hundret of Cosforda [Cosford]}

(At) Hecham [Hitcham] Saint Etheldreda held T.R.E. I I carucates of land. Then 30 villeins, now 36. Then 18 bordars, now 26. Then as now 8 serfs. Then 4 ploughs on the demesne, now 3. Then 20 ploughs belonging to the men, now 16 , and 16 acres of meadow. Wood(land)

fol. $3^{85}$.

for 20 swine. Then as now II rounceys, 30 beasts, 175 sheep, 60 swine, 42 goats, and 2 hives of bees. A church with 2 acres. Then it was worth 20 li., ${ }^{201}$ now 40 li. It is I league and 4 furlongs long, and I league broad. And (pays) $15 \mathrm{~d}$. in geld. Others have holdings there.

(At) Niedrnga [Nedging] T.R.E. Saint Etheldreda held 3 carucates of land. Then 8 villeins, now 6. Then 6 bordars, now 9. Then 3 serfs, now 1 . Then as now 3 ploughs on the demesne. Then 2 ploughs belonging to the men, now I. 8 acres of meadow. Wood(land) for 6 swine. And 1 mill. And 2 rounceys, 14 beasts, 100 sheep, and 20 swine. A church with $7^{202}$ acres. And 2 sokemen with 14 acres. Then 1 plough, now 2 oxen. Then it was worth 4 li., now 8 li. It is I league long, and 3 furlongs broad. And (pays) $2 \frac{1}{2} d$. in geld.

In HECHAM [Hitcham] 5 sokemen (held) 60 acres. Then $2 \frac{1}{2}$ ploughs now 1 , and 3 acres of meadow. Worth I os. Roger Bigot holds(this).

In the same (vill are) 123 acres of demesne land, and 3 bordars, and I plough, and $I \frac{1}{2}$ acres of meadow. Worth Ios. In the same (vill) I sokeman (held) 40 acres. Worth 5 s. This Richard, son of Count Gilbert, holds.

\section{BissCopes [Bishop's] Hundret}

(At) Wineberga [? Wingfield ${ }^{203}$ a freeman over whom Saint Etheldreda had commendation T.R.E. held 2 carucates of land, and 7 bordars. ${ }^{204}$ Then 2 ploughs on the demesne, now I. Then as now 2 ploughs belonging to the men. II acres of meadow. Wood(land) for 140 swine.

$$
\begin{aligned}
& 200 \text { 'Cloptuna'; Inq. El. } 155 . \\
& 208 \text { 'Then worth I6li.' ; ibid. } 156 . \\
& 202 \text { ' } 8 \text { acres'; ibid. }{ }^{003} \text { See n. } 8 \text { I. } \\
& 504 \text { ' } 8 \text { bordars"; Inq. El. } 156 .
\end{aligned}
$$

Then 2 rounceys, now I. And I beast. Then 60 swine, now 20. And 20 sheep. And 2 hives (of bees). A church with 24 acres. Worth 4 s. And 13 freemen with 80 acres. Over one Robert Malet's predecessor had commendation. Then 4 ploughs, now 3. Then worth $4 l i$. and 135. and $4 d$, now $4 l i$. This Roger Bigot claims as of the King's gift: but the Abbot of Ely proved his right against him: now Roger holds ${ }^{205}$ on account of the respite of plea (per respectum). The soke (is) in Hoxa [Hoxne]. It is I league and 2 furlongs long, and 4 furlongs broad. And (pays) $11 \frac{1}{2} d$. in geld. Others hold land therein.

In SAHAM [Soham] a freeman by commendation (held) I carucate of land and 2 villeins and 3 bordars. Then as now 2 ploughs. And 5 acres of meadow. Wood(land) for Io swine. Then fol. $3^{8} 5^{b}$.

worth 20s., now 25s. The soke is in Oxa [Hoxne]. This Robert Malet held of the King: the Abbot proved his right, and Robert holds it of him.

\section{In Blidinga [Blything] Hundret}

Saint Etheldreda held at ALNET'NE ${ }^{206}$ [ as a manor T.R.E. 2 carucates of land. Then 9 villeins, now 7 . Then as now I 3 bordars. Then as now I serf. Then as now 2 ploughs on the demesne. And 3 ploughs belonging to the men. And half a church with 2 acres. Wood(land) for 6 swine. 2 acres of meadow. And I rouncey, 8 beasts, 28 sheep, 8 swine, I 6 goats. To this manor belong 80 burgesses in Dunewic [Dunwich], and they dwell upon 14 acres. Then as now it was worth roos.

In the same (vill) ${ }^{207}$ belong 3 freemen dwelling in Besemera [ ] ${ }^{208}$ with 14 acres and

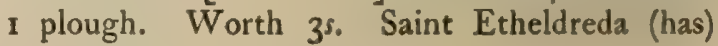
soke and sac.

\section{Hundret of Colenesse [Colneis]}

In Morestuna [Moston ${ }^{209}$ ] (was) a freeman Ulviet ${ }^{210}$ with 5 acres under commendation to Saint Etheldreda T.R.E. Worth I6d. Robert Malet holds him of the Saint.

In TRemlega [Trimley] (was) a freeman Lewric with 40 acres as a manor under the Abbot's commendation T.R.E. Roger Bigot holds him of the king. The Abbot proved his right, and Roger (now) holds of him. And I plough. And 3 bordars. One acre of meadow. And a freeman under him with 4 acres. Worth 20 s.

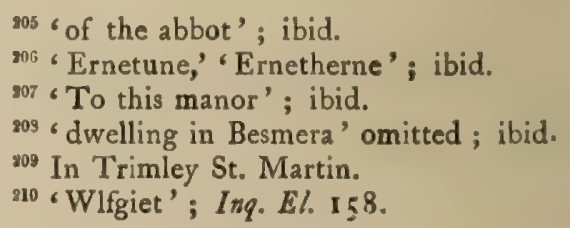




\section{THE HOLDERS OF LANDS}

In Waletuna [Walton] (was) a freewoman Alveva ${ }^{211}$ with 16 acres under the Abbot's commendation. And 2 bordars. And half a plough. Worth $3^{s}$. H[ervey] Beruarius ${ }^{212}$ holds of the Abbot; and he held of the king, but the Abbot proved his right.

And in Plügeard [ $]^{213}$ (was) a freeman (under Saint) Etheldreda, Edwin, with 2 acres. Worth $4 d$. And now the same $\mathrm{H}$ [ervey] holds of the Abbot.

In KENEBROC [Kembrook] (was) a freeman (under Saint) Etheldreda, Godric, with 7 acres. And 2 oxen. Worth 20d. Roger Bigot held him of the king, but the Abbot proved his right ; and Roger Bigot holds of him.

Saint Etheldreda has the soke of the $5 \frac{1}{2}$ Hundreds. And it renders to her 1 I $l i{ }^{214}$

fol. 386.

\section{Hundret of Carleforda [Carlford]}

(At) Krngestuna [Kingston] ${ }^{215}$ Saint Etheldreda T.R.E. held I carucate of land as a manor. Then 8 villeins, now 5, now 8 bordars. ${ }^{216}$ Then 2 serfs, now I. Then as now on the demesne 2 ploughs, and 3 ploughs of the men, and $8 \frac{1}{2}$ acres of meadow. Wood(land) for 5 swine. Then as now I rouncey, 4 beasts, 30 sheep, and 12 swine. Then as now it was worth 40s. It is 4 furlongs long and 3 broad, and (pays) $3 d$. in geld. Others have holdings there.

(At) Brihtewella [Brightwell] the Saint T.R.E. held as a manor 2 carucates of land. Then 6 villeins, now 5. Then as now 3 bordars. Then 5 serfs, now 2. Then as now on the demesne 2 ploughs. Then 4 ploughs belonging to the men, now 3. And I church without land. And 6 acres of meadow. And 2 mills. Then as now I rouncey, 40 sheep, and 8 swine. And there is 1 sokeman with 12 acres, and he dwells in Neubrumna [Newbourn] Then as now it was worth 40s. It is Io furlongs long and 6 broad. And (pays) $4 \frac{1}{2} d$. in geld. Others have holdings there.

In Grundesburc [Grundisburgh] Algar, a freeman under Saint Etheldreda T.R.E. held 1 carucate and 30 acres of land as a manor. Then as now 2 villeins and 5 bordars. Then as now on the demesne 2 ploughs and 1 plough belonging to the men. 4 acres of meadow. Then as

us 'Alfgeve'; Inq. El. 158.

мa 'Bebruel'; ibid. 12 See n. 94.

ns Inq. El. (p. 159) substitutes for this: 'Over the whole hundred of Colneis St. Etheldreda has sac and soke, and it is worth 40 s.' $^{\prime}$

"In Woodbridge.

ns 'now 7 bordars'; Ing. El. 160. now 3 rounceys, 6 beasts, 16 swine, and 70 sheep, and 3 hives of bees. Then it was worth 20s., now 40s. 'This Hervey de Beruari' holds of Saint Etheldreda. It is 10 furlongs long and 6 broad, and (pays) $15 d$. in geld.

In Grundesburgh [Grundisburgh] 3 men under half commendation to Algar T.R.E. (held) 7 acres, worth $\mathbf{2} 2 d^{217}$

In Haschetuna [Hasketon] are 22 acres, worth $4 s^{218}$

In Thisteldena [Thistleton] Ulmar, a freeman under commendation to Saint Etheldreda, held 60 acres as a manor, and 5 freemen ${ }^{219}$ under him. Of them 2 were under commendation to the predecessor of Geoffrey de Magnaville. fol. $386 b$.

Then $1 \frac{1}{2}$ ploughs, now $\mathbf{I}$, and 3 acres of meadow. Then it was worth IOs., now I 2s. When he 220 received it there was $I$ rouncey, and there is now. Then 5 beasts, and now 15 swine, and 50 sheep, and 12 goats, and 5 hives of bees.

In Parva Belinges [Little Bealings] are 2 freemen with 20 acres under commendation to Saint Etheldreda, and half a plough, worth 3 .

In Foxehola [Foxhall] are 15 acres, ${ }^{221}$ worth $2 s$. $8 d^{222}$

In Buclesham [Bucklesham] 5 acres, worth

In Rishemara [Rushmere (St. Andrew)] Turchil, a freeman T.R.F.. under commendation half to Saint Etheldreda and half to Gurth, held 80 acres of land as a manor. Then 1 plough, now half a plough. 5 acres of meadow. Then it was worth 20 s., now IOS.

In the same (vill was) Edric, a freeman under the same commendation as the other, with 20 acres. ${ }^{223}$ Then I plough, now half a plough, and half an acre of meadow. Then it was worth IOs., now 6s, ${ }^{224}$

Moreover in the same (vill) 5 freemen under commendation to Turchil (held) I 5 acres. Then half a plough, now none. Then it was worth $30 d$., now $3^{\text {s. }}$

ข' 'In Grundesburch Hervey Breduel holds 3 halffreemen under commendation to St. Etheldreda. Worth 3s.' ; Inq. El. 163. This appears to be duplicated below under the lands of Hervey de Bourges; see n. 361 .

210. 'worth 25.' Inq. El. 163.

218 "with 20 acres"; ibid.

${ }^{n}$ Inq. El. makes Hervey the tenant; ibid.

m ' 20 acres'; ibid.

m 'In Bucheshala 5 acres, worth rod.' ; ibid.

m ' 25 acres'; ibid. 234 'worth 5s.'; ibid. 


\section{A HISTORY OF SUFFOLK}

In Todenham [Tuddenham] Aluric, a freeman ${ }^{295}$ under commendation to one under commendation to Saint Etheldreda, worth 8d. All this Hervey de Berruariū holds of Saint Etheldreda.

In KaLletuna ${ }^{226}$ [

] Isaac holds 8 freemen ${ }^{227}$ under commendation to Saint Etheldreda (with) I carucate of land, and 2 bordars. Then 3 ploughs, now I. 4 acres of meadow. Worth $16 s$. It is 6 furlongs long and 2 broad, and (pays) $2 \frac{1}{2} d$. in geld, Isaac holds of the Abbot.

\section{In Ingoluestuna [}

] (is) a freeman with 16 acres, and half an acre of meadow, and half a plough. Worth $3^{\text {s. }}$ This Robert Malet holds of the Abbot.

In Isleuestuna ${ }^{228}$ [? Isleton ${ }^{229}$ a freewoman under commendation to Saint Etheldreda holds 30 acres. $^{230}$ Then I plough now half a plough. 2 bordars, 4 acres of meadow, and a freeman with Io acres. Worth 4 s.

In BuRH [Burgh] (are) 6 acres, worth I $2 d$.

In BischeleA ${ }^{231}$ [Bixley] 4 acres, worth $8 d$.

In Risemara [Rushmere] Leuric a freeman ounder commendation to Saint Etheldreda, held fol. 387 .

40 acres, and 7 bordars, and $1 \frac{1}{2}$ ploughs. I acre of meadow. Worth IOs. ${ }^{232}$

In Finesford [ ] $]^{233}$ Leveva a freewoman under commendation to Saint Etheldreda (held) 40 acres and I plough, and 4 bordars. Worth 6s.

\section{HUNDRET OF WILEFORDA [WILFORD]}

In Sutruna [Sutton] Robert Malet (now) holds a half freeman Godwin under Saint Etheldreda's commendation with 12 acres as a manor. Half a bordar. Then half a plough. And now I acre of meadow. Then worth 25., now 5 s.

In the same (vill) were 9 freemen under him (Godwin) and a freeman under Saint Etheldreda's commendation with 40 acres. Then I plough, now the like. Half an acre of meadow. Then worth 4s., now 7 s.

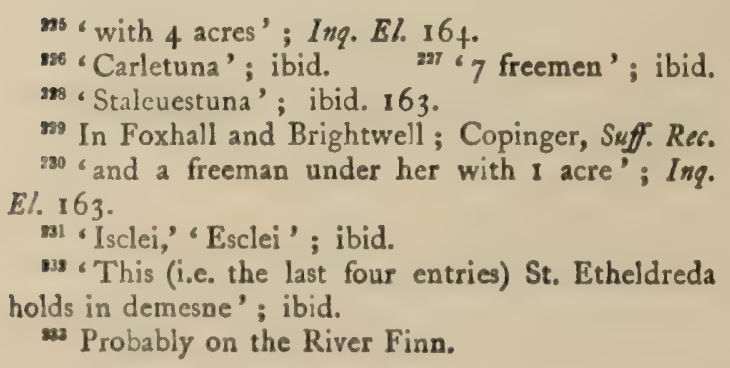

ws Probably on the River Finn.

In CAPeles [Capel (St. Andrew)] (were) $3 \frac{1}{2}$ freemen under Saint Etheldreda's commendation with 15 acres of land. Then I plough, now half a plough. Then worth 2 s, now 4 s.

And in Scotesham ${ }^{234}$ [Shottisham] $\mathbf{x} \frac{1}{8}$ freemen under the said Saint Etheldreda's commendation with 7 acres, worth $\mathbf{1} 2 d$.

In Brameswella [Bromeswell] (were) I $\frac{1}{2}$ freemen under Saint Etheldreda's commendation with 8 acres. Half a plough. Worth $\mathbf{1} 6 d$.

This Robert Malet holds of Saint Etheldreda.

In Bredefelda [Bredfield] (were) 3 whole freemen and 3 half (freemen) and a quarter of $a$ freeman with 24 acres (?). Then 2 ploughs, now half a plough. Worth $6 s$. and $2 d_{0}{ }^{235}$ Robert Malet (holds) of Saint Etheldreda.

And a freeman Farman (had) 12 acres in the Abbot's soke and commendation, worth $2 s$.

In Baldeseia [Bawdsey] 2 freemen under Saint Etheldreda's commendation (held) 7 acres, worth $12 d$.

In Alretuna [Alderton] are 12 acres, ${ }^{236}$ worth $2 s$.

In CARSFELda [Charsfield] 2 freemen under Saint Etheldreda's commendation (held) 33 acres ${ }^{237}$ and I plough and I acre of meadow. Worth 5 s.

In CAPEles [Capel (St, Andrew)] (was) a freeman. And in BradeFELDA [Bredfield] ${ }^{238}$ another with 32 acres of land; and the Abbot of Ely (had) commendation. Then 1 plough, now half a plough. Then as now worth 5 s. This Robert Malet holds of the Abbot of Ely.

(At) Meltuna [Melton] belonging to the Abbot of Ely (were) 2 carucates of land as a manor. Then 18 villeins, now 9. Then 6 bordars, now 13. Then 2 serfs, now none. Then as now 2 ploughs on the demesne. Then 5 ploughs belonging to the men, now $3 \frac{1}{2}$. 17 acres of meadow. One rouncey. ${ }^{230}$ And I mill. fol. $3^{8} 7 b$.

II swine, 37 sheep. And to this manor belongs a berewick, BaLDEREseia [Bawdsey], and it is so reckoned (enumerata). ${ }^{240}$ And 4 sokemen with 32 acres of land. They could not give nor sell the land. Then 2 ploughs, now $1 \frac{1}{2}$. 2 acres of meadow. Then as now worth 40 s. It is

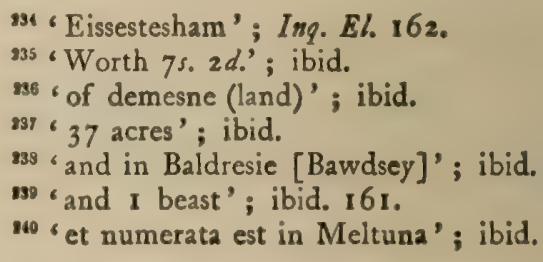




\section{THE HOLDERS OF LANDS}

1 league long, and 9 furlongs 211 broad. And (pays) $27 d$. in geld.

In the same Baldereseia [Bawdsey] 5 freemen $^{249}$ (held) 19 acres of land. Then the Abbot of Ely (had) commendation. Then as now worth $40 d$.

In $\mathrm{HoI}^{243}$ [Hoo] (was) a freeman with 19 acres of land. Then as now half a plough. One acre of meadow. Then as now worth 5 s.

In HuNdestuF ${ }^{24}$ [ ] (was) a freeman with 6 acres of land. The Abbot of Ely (had) commendation. Worth I $2 d$.

In Brumesuelle [Bromeswell] (were) 2 freemen with 10 acres of land. And the Abbot of Ely (had) commendation. Worth $12 d$. In the same (vill) a church with 16 acres, worth 2 s. And this is (upon) the Abbot's demesne.

And in the same vill Hervey holds 70 freemen from whom the Abbot had commendation soke and sac and all customs; of these the predecessor of Roger Bigot had commendation over I with 6 acres; and now (there are) 45 (with) 2 carucates of land and 16 acres. Then 12 ploughs, now 6 . And 3 acres of meadow. They were then worth 40 s., and now 60 s.

In the same (vill) 4 freemen under commendation to the Abbot (held) 76 acres of land. Then 4 ploughs, now 3. And 4 acres of meadow. And 2 rounceys, 6 swine, 57 sheep. Then worth 20s., and now a like amount.

In Berdesfella 245 [Bredfield] (were) 3 freemen under commendation to the Abbot with 76 acres ${ }^{216}$ of land. Then 3 ploughs, now 2. And under them (were) 3 freemen with 5 acres. ${ }^{247}$ Half an acre of meadow. Then worth I5s., now 20 s.

In BerdefeldA [Bredfield] (are) 6 acres, which Robert Malet's predecessor held; now Hervey de Berruarius (holds) of the Abbot.

All this Hervey holds of the Abbot.

Moreover in the same (vill is) a church with $3 I$ acres of free land and 2 acres of meadow, worth 5 .

In Bromeswella [Bromeswell] Hervey (now holds) 2 freemen under Saint Etheldreda's commendation with 22 acres. Then 2 ploughs, now half a plough. $1 \frac{1}{2}$ acres of meadow. Then worth 4 s., now 5 s.

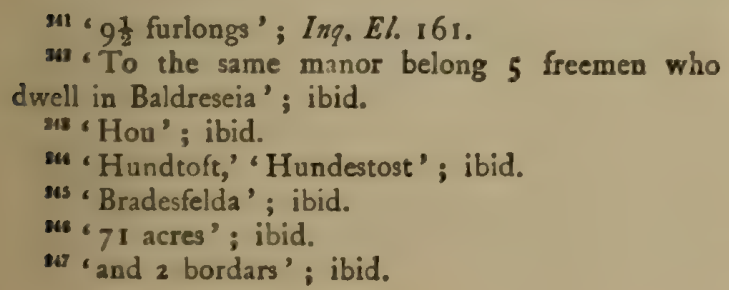

fol. 388 .

In BRADEFelda [Bredfield] Hervey holds 2 freemen under Saint Etheldreda's commendation with 4 acres, worth $12 d$.

In Brumeswella [Bromeswell] Robert Malet (now) holds 3 freemen under Saint Etheldreda's commendation with 4 acres, worth 2 s.

In Scotesham [Shottisham] (is) I acre, ${ }^{248}$ worth $2 d$.

In UFFORDA [Ufford] Almar a freeman T.R.E. under commendation half of Edric and half of Saint Etheldreda held as a manor 60 acres. Then 4 bordars, now 2. Then $1 \frac{1}{2}$ ploughs, now half a plough. 4 acres of meadow. And I mill. Then as now worth IOS.

In the same (vill were) 9 freemen ${ }^{240}$ under commendation of the same (Almar) except 2, who (ipsi) were under Saint Etheldreda's commendation, with 25 (acres of land) and 2 acres of meadow. Then as now I plough. Then as now worth 4 s.

In LudHam [Loudham] a half freeman Morewin under Saint Etheldreda's commendation (held) 20 acres, half a bordar. Half a plough. ${ }^{250}$ And 7 freemen under him with 20 acres. $2 \frac{1}{2}$ acres $^{201}$ of meadow. Then I plough, now half a plough. Then as now worth ros.

In Horapola [Harpole] (were) 2 half freemen with $13 \frac{1}{2}$ acres, ${ }^{202}$ worth $20 d$.

In Meltuna [Melton] (was) a freeman under Saint Etheldreda (with) 2 acres, worth $4 d$.

In Horepolo [Harpole] (was) a half freeman under Saint Etheldreda (with) I 5 acres. Then half a plough, now none. Worth $3^{\text {s. }}$

\section{Hundret of LOSA [LoEs]}

(At) Hou [Hoo] Saint Etheldreda held T.R.E. as a manor 3 carucates of land. Then 18 villeins, now Io. Then I bordar, now 16 . Then 6 serfs, now 2. Then on the demesne 3 ploughs, now 2. Then 6 ploughs belonging to the men, now 5. Wood(land) for 20 swine. 7 acres of meadow. I mill. And 7 beasts, 24 swine, 30 sheep, and 40 goats. Then it was worth Ioos., now 4 li. And W. de Buville took one of these carucates before its possession was decided (derationata est) by the King's precept and seisin given to the church: but he vouches his lord (dominum suum) Geoffrey de Magnaville as guarantor (ad tutorem); and he

$$
\begin{aligned}
& \text { "so ' of demesne (land)'; ibid. } 162 . \\
& \text { " ' } 11 \text { freemen'; ibid. } \\
& \text { 950 ' } 60 \text { acres, } 1 \text { bordar. Then as now I plough'; } \\
& \text { ibid. } 163 \text {. } \\
& \text { "si ' } 5 \text { acres'; ibid. } 242 \text { acres'; ibid. }
\end{aligned}
$$




\section{A HISTORY OF SUFFOLK}

has given security thereupon; now the land is in the King's hand. To this manor belong 4 freemen under commendation to Saint Etheldreda with 6 acres of land, worth 12d. A church

\section{fol. 3886 .}

with $8 \frac{1}{2}$ acres, worth $16 d_{0}{ }^{253}$ It is 8 furlongs long and 4 broad. And in geld (pays) $3 \frac{1}{2} d$.

In Brandestuna [Brandeston] Hervey de Bituricensis (now) holds a freeman under Saint Etheldreda with 8 acres, worth 4 s.

In L_ETHERINGAHAM [Letheringham] (are) $3 \frac{1}{2}$ acres on the demesne, worth $6 d$.

In Gretingaham [Cretingham] (is) a villein with 16 acres and half a plough, worth $3^{s}$.

In Dalingahou [Dallinghoo] 4 freemen under commendation of Saint Etheldreda (held) half a carucate of land. Then 2 ploughs. Now I acre of meadow. Then it was worth 8 s., now a like sum.

In Udebriga [Woodbridge] (were) 7 freemen T.R.E. now (there are) $2^{284}$ under commendation to Saint Etheldreda with 40 acres. Then I plough. ${ }^{255}$ Then it was worth 6s., now $5 s^{256}$

In the same (vill) Robert Malet (now holds) a freeman with $16 \frac{1}{2}$ acres ${ }^{267}$ and half a plough, worth 5 s.

In Dalingahou [Dallinghoo] (was) a half freeman with 16 acres, worth $2 s$. and $8 d$.

In RensLesham ${ }^{268}$ [Rendlesham] (was) a half freeman with 6 acres, worth $12 d$.

In UDEBRIGE ${ }^{259}$ [Woodbridge] (were) 2 bordars with 10 acres, worth $2 s$.

In Mungedena ${ }^{200}$ [Monewden] (was) a freeman and in Ceresfelda [Charsfield] another with I 8 acres, worth 3 s.

\section{Plumgata [Plomesgate] Hundret}

In Aldeburc [Aldeburgh] (are) 5 acres; and (this) is in demesne; worth $10 d$. Norman (holds it).

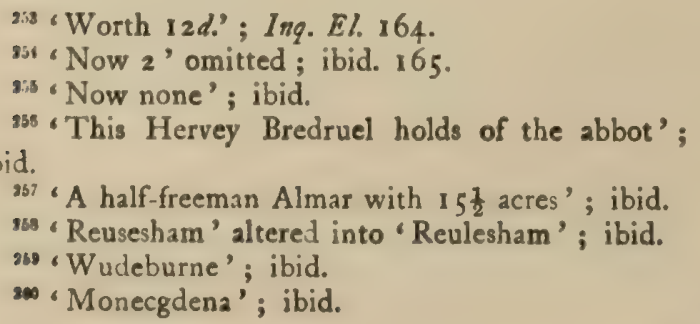

\section{LAND OF GILBERT, BISHOP OF EVREUX}

\section{WILEFORT [WILFORD] HUNDRET}

Turmod held UDEHAM [ ] as a manor with 2 carucates of land. Then 2 villeins, now 7. Then as now 2 ploughs on the demesne. And I plough belonging to the men. And 10 acres of meadow. One mill. One rouncey, 7 beasts, 56 swine. Then worth 40 s., now I $2 l i$.

(At) Capesia [Campsey] Brictmar a sokeman under Saint Etheldreda held 50 acres as a manor, and he could not sell or give his land. Then as now I villein, and 3 bordars. Then I plough. 2 acres of meadow. Then 1 mill. And he renders 35 s. (which are included) in the above valuation.

In LUDHAM [Loudham] (were) 34 freemen under commendation to Turmod; of these 15 were under Edric's commendation and one was in St. Etheldreda's commendation with 20 acres. Altogether they have $I \frac{1}{2}$ carucates of land. Then 6 ploughs, now 3. 6 acres of meadow. Worth 8 ii. And a church with 60 acres worth 5 s. Several persons have shares therein (ibi parciuntur).

fol. $3^{8 \mathrm{~g}}$.

\section{LAND OF THE ABBOT OF BERNAI}

\section{STOU [STOW] HundReT}

In CRatinga [Creeting (St. Peter)] (there is) a freeman with 20 acres. Half a church with 10 acres. And $x$ villein and 2 bordars. Then as now I plough among them all. And 2 acres of meadow. Valued in Cratinga [Creeting (St. Mary)] in another Hundred. In the same (vill) is a freeman with 5 acres. He is valued (in like manner). The King gave (this holding) out of Hardwin's fee.

\section{Bosemara [Bosmere] Hundret}

At CRatingas [Creeting (St. Mary)] Aluric a freeman held $\mathrm{I} \frac{1}{2}$ carucates of land as a manor. Then as now 4 villeins, and 12 bordars, and 2 serfs. Then 2 ploughs on the demesne, now $\mathbf{x}$. Then 2 ploughs belonging to the men, now $\mathbf{I}$. And 4 acres of meadow. And 6 beasts, and 15 swine. Then 100 sheep, now 36 . Then it was worth 100s, now 6 li.

(At) Nrwetuna [(Old) Newton] Aluric held I carucate of land as a manor T.R.E. Then as now 3 villeins, and 12 bordars and 1 serf. And I plough on the demesne. Then 2 ploughs belonging to the men, now 1. 5 acres of meadow. Wood(land) for 6 swine. And 2 mills. Worth 6os. 


\section{THE HOLDERS OF LANDS}

In Cratingas [Creeting] 24 freemen (held) I carucate of land and I virgate. Then 3 ploughs, now $1 \frac{1}{2}$ ploughs. Worth 20s. A church with 12 acres. Nieutuna [Newton] is 6 furlongs long, and 3 broad. And (pays) $5 d$. in geld. The King and the Earl (have) soke over the whole.

In Uledana [Olden ${ }^{201}$ ] Alwin (holds) 2 freemen with 11 acres. Then half a plough, now none; (included) in the same valuation.

\section{XXIIII. LANDS OF THE ABBEY OF CHATERIS}

Half Hundret of Cosfort [Cosford]

(At) Caresea [Kersey] Saint Mary T.R.E. held $3 \frac{1}{2}$ carucates of land. Then as now 6 villeins, and 18 bordars, and 1 serf. And 2 ploughs on the demesne, and 4 ploughs belonging to the men. And 4 acres of meadow. Wood(land) for 60 swine. And I mill. And I rouncey, 10 beasts, 36 swine, 140 sheep, and 3 hives of bees. A church with 3 acres. And 1 sokeman with 2 acres, and I freeman with 20 acres, and I plough, and I acre of meadow. Then this manor was worth 4 li., now roos., and the freemen 4 s. less $4 d$. It is 8 furlongs long and 6 broad, and (pays) $7 \frac{1}{2} d$. in geld.

fol. $3^{89 b}$.

\section{LAND OF RICHARD SON OF COUNT GILBERT}

\section{Risebruge [RIsbridge] Hundret}

(At) Clara [Clare] Aluric held as a manor 24 carucates of land T.R.E. Then 40 villeins, afterwards 35 , now 30 . Then and afterwards 10 bordars, now 30. Then as now 20 serfs. Then 12 ploughs on the demesne, afterwards 6, now 7. Then 36 ploughs belonging to the men, afterwards 30 , now 24. 37 acres of meadow. Wood(land) for 12 swine. Then as now I mill. Now 5 arpents of vineyard. Then as now 6 rounceys. Then Io beasts, now 14 . Then 12 swine, now 6o. Then 60 sheep, now 480. And 12 hives of bees. Then as now a market. Now 43 burgesses. Aluric son of Wisgar gave this manor to Saint John T.R.E., his son consenting thereto, and put in (imposuit) Ledmar the priest and others with him. Having also made a charter he committed the church and the whole place into the hands of Leustan the Abbot to keep, and into the keeping of Wisgar his own son. ${ }^{20}$ But the clerks could neither give nor alien-

261 See n. 2

12 "The celebrated Earl Elfric son of Wlgar gave Melford to St. Edmund and built the church of St. John the Baptist at Clare and appointed (collocavit) clerks there and gave that manor to the church : and ate (foris facere) this land away from Saint John. However, after King William came he seized it into his own hand. To this manor then as now belonged 5 sokemen with all customs, (having) I $\frac{1}{2}$ carucates of land. Then as now $1 \frac{1}{2}$ ploughs. 6 acres of meadow. Then worth 40 li, and now the like. It is 2 leagues long, and I broad. And (pays) $15 d$. in geld.

(At) Huenendana [Hundon] T.R.E. Wisgar (held) as a manor 25 carucates and 20 acres of land. Then as afterwards 54 villeins, now $4 \mathrm{I}$. Then as now 30 bordars, and 14 serfs. Then 9 ploughs on the demesne, afterwards 4 , now 7 . Then $3^{1}$ ploughs belonging to the men, afterwards and now 23. And 45 acres of meadow. Wood(land) for 160 swine. Then as now I mill. A church with half a carucate of free land, and another church with $4 \frac{1}{2}$ acres; then as now I plough and 3 acres of meadow. Then 2 rounceys, now 6 . Then 14 beasts, now 31 . Then 130 swine, now 160 . Then 80 sheep, now 480. Now 17 hives of bees. Then worth 30 li., afterwards and now $40 l i$. and $4 s$. It is 2 leagues and fol. 390 .

2 furlongs long, and I league broad. And (pays) $15 d$. in geld. Others hold (land) there.

(At) Deselinga [Desning] ${ }^{263}$ Wisgar held as a manor T.R.E. 20 carucates of land. Then as now 28 villeins, and 91 bordars, and 20 serfs. And ro plor $g$ 's on the demesne. And 32 ploughs belonging to the men. And 15 acres of meadow. Wood(land) for 80 swine. Then 5 mills, now 4. Two churches with $\mathrm{I} \frac{1}{8}$ carucates of land, and $I_{\frac{1}{2}}$ ploughs. Then 8 rounceys, now 5. Then 18 beasts, now 40. Then 100 swine, now 80 . Then 840 sheep, now 960 . And 9 hives of bees. Then worth $30 l i$, afterwards and now 40 li. But yet he gave it to a certain steward to farm for $65 l i$. But the manor could not bear it. It is $2 \frac{1}{2}$ leagues long, and $I$ league broad. And (pays) $37 d$. in geld in two hundreds. ${ }^{264}$

In Danerdestuna [Denston] (was) a sokeman (Robert holds him) with 2 carucates of land and IO acres as a manor. And 3 bordars, and 2 serfs. Then 3 ploughs, now 2. And 2 acres of meadow. Wood(land) for 10 swine. Now 2 rounceys, 13 beasts, 28 swine, 32 sheep, and 4 goats. Then and afterwards worth 40 s., now 50 .

In Cleptuna [Clopton] (were) 2 sokemen (with) I carucate and $8 I \frac{1}{2}$ acres of land. And 9 bordars, and 2 serfs. Then 2 ploughs on the

the son of Elfric dwelt in a certain tower (turrim ?'), where the hospital now is, by leave of Abbot Leofstan, and gave the said Melford to the use of the sick.' Add. MS. 14847 , fol. 24.

${ }^{23}$ In Gazeley.

m Presumably Risbridge and Lackford, see below. 


\section{A HISTORY OF SUFFOLK}

demesne, now 3. And half a plough belonging to the men. And 3 acres of meadow. Wood(land) for 4 swine. Then as now 2 rounceys. Then 6 beasts, now 12. Now 30 swine. Then 40 sheep, now 80 . And 3 hives of bees. They were then worth 20 s., now 40 s.

Danardestuna [Denston] is I league long, and 3 furlongs broad. And (pays) $6 \frac{1}{2} d$. in geld.

And Croptuna [Clopton] is I league long, and 3 furlongs broad. And (pays) $6 \frac{1}{2} d$. in geld.

In Dalmam [Dalham] (was) I sokeman with 2 carucates of land. And I villein, and 5 bordars, and 2 serfs. And 2 ploughs on the demesne. Then 2 ploughs belonging to the men, now $1 \frac{1}{2}$. And 2 acres of meadow. Wood(land) for 60 swine. Then as now 2 rounceys. And 10 beasts, now 16. Then 24 swine, now 30. Then 100 sheep, now I 50 . And 50 goats. Then worth 40 s. now 6os. A church with 40 acres fol. $390 b$.

of free land and half a plough, worth 5 s. William Pecche (pecratum) holds this.

In Denham [Denham] (were) 2 sokemen with 3 carucates of land. Then as now 5 villeins, and 13 bordars, and $I$ serf. Then 4 ploughs on the demesne, now 3. Then as now 4 ploughs belonging to the men. 6 acres of meadow. Wood(land) for 20 swine. A church without land. W. Hurrant holds this. Then I horse, now 2. Now 4 beasts. Then 15 swine, now 33 , and 72 sheep, and $3^{8}$ goats. They were then worth $3 l i$, now $4 l i$. and 10 .

In Auokeduna [Hawkedon] (was) I sokeman with I carucate of land then as now. And 2 villeins, and I serf. And I plough on the demesne. And half a plough belonging to the men. Worth 20s. This Gislebert holds.

In AUoKeduna [Hawkedon] (was) I sokeman with I carucate of land. Now 3 bordars. And I serf. Then as now I plough on the demesne. And 4 acres of meadow. Then as now worth 20s. This Fulkered holds.

In Wratinga [(Little) Wratting] (was) I sokeman with I carucate of land. Then as now I villein, and 3 bordars, and I serf. And I plough on the demesne. Then half a plough belonging to the men, now 2 oxen. And 4 acres of meadow. A church with 32 acres of free land. Then as now worth 20s. Ulmar then as now holds.

In StANESFrLda [Stansfield] (was) I sokeman with I carucate of land. And 2 bordars. And then as now I plough. And 3 acres of meadow. Roger holds. When he received this (there were) 3 rounceys and now the like. Then
4 beasts, now 6 . Then 7 swine, now 30 . Then 40 sheep, now 80 . Then worth 20s., now 30 s.

In Hunedana [Hundon] (was) I sokeman with I carucate of land. Then as now 2 bordars. And 1 plough. Hamo holds (over him). Then 30 sheep, now 50. Worth 20 .

In the same (vill were) ro sokemen with I carucate of land. Then as now I plough. And 2 acres of meadow. Worth 20 s.

In FarLeia [Farley] (was) I sokeman with 7 acres, worth I $4 d$.

In Brochola [Brockley] was I sokeman with half a carucate of land. Then as now I plough. And 2 acres of meadow. Then worth 8 s., now 16 s.

In Kidituna [Kedington] (was) I sokeman with 30 acres and half a plough. Worth 5 s.

In BoItuna [Boyton] (was) I sokeman with 60 acres. And 3 bordars. Then as now 1 plough. And 2 acres of meadow. Worth ros. fol. 391 .

In Stoches [Stoke-by-Clare] (was) I sokeman with 37 acres. Then half a plough, now 2 oxen. And 3 acres of meadow. Worth $6 s$. and $2 d$. T.R.E. Wisgar held these sokemen with all customs except the six forfeitures of Saint Edmund.

\section{Risebruge [Risbridge] Hundret}

In Wimundestuna [ ] (were) 3 sokemen with 65 acres and half a plough. Worth IOs. From them his (Richard's) predecessor had all customs.

\section{Half Hundret of Cosfort [Cosford]}

In Wetesham [Wattisham] Uluric a freeman T.R.E. held 80 acres. This (holding) belongs to the fee of Phinc. Then as now 3 bordars, and I serf, and I plough on the demesne, and $I \frac{1}{2}$ acres of meadow. Then 3 rounceys, now 5. Then 8 beasts, now $1 \mathrm{r}$. Then 3 swine, now 25. Now 80 sheep. Worth 25s. Saint Edmund (has) the soke.

In the same (vill) I freeman held 15 acres. Worth $2 s$, and $6 d$. Wisgar (had) the soke. Saint Edmund (has) the six forfeitures.

In Hетснам [Hitcham] 2 freemen held I carucate of land, 4 bordars, and 2 serfs. Then 2 ploughs, now I, and 4 acres of meadow. Worth 20s. This Ailward son of Bell holds.

\section{Brakebrune [BLACKBOURN] Hundret}

In BARDEWELLA [Bardwell] (was) a freeman under commendation with 30 acres and I bordar. Then half a plough. Worth 5 s. 


\section{THE HOLDERS OF LANDS}

In Stou [Stow] (was) a sokeman with 28 acres. Then half a plough. Worth $3^{\text {s. }}$. This Robert Blund holds. Saint Edmund (has) the soke.

\section{Wileford [WILFORd] HUNDRET}

In BREDEFElla [Bredfield] (are) 12 acres of land. And I villein. Worth 2s. This Norman holds of Richard.

\section{Hertesmera [Hartismere] Hundret}

In Cotetuna [Cotton] Fader held 7 acres, worth I4d. Walter the Deacon (now) holds.

\section{Thewardestre [Thedwastre] Hundret}

In TIMEWORda [Timworth] a freeman T.R.E. under Wisgar, Richard's predecessor, by commendation only (held) 60 acres. Then I plough. Worth 10s. The soke was Saint Edmund's.

In RAsTEDena [Rattlesden] 2 sokemen (had) 7 acres. Worth $12 d$.

\section{Thingehou [Thingoe] Hundret}

In Westuea [Westley] 3 freemen under Wisgar by commendation and soke, except Saint Edmund's six forfeitures, (held) 80 acres. And I bordar. Then as now 2 ploughs. And 2 acres of meadow. A church with 8 acres. Wood(land) for 9 swine. And two thirds (partes) of a mill. Worth ros.

In the same (vill) a freeman under Saint Edmund by commendation and soke (held) half a carucate of land. 3 acres of meadow. Then as now I plough. Then as now worth Ios.

In SAXHAM [Saxham] (was) a sokeman under Wisgar with 15 acres. Then as now half a plough. Worth $3^{\text {s. }}$

In HoRnINGeserda [Horringer] a sokeman under the same with 20 acres and 2 bordars. Then as now I plough. Worth 4s.

In Hersteda [Hawstead] 2 freemen under Wisgar and in his soke, but they could sell without licence, (held) 15 acres. Then as now half a plough. Worth $3^{s}$.

In Manestuna [Manston] a freeman under Wisgar and in his soke (held) half a carucate of land T.R.E. Then 3 bordars, now 1 . Then and afterwards I plough, now half a plough. And 2 acres of meadow. Then as now worth Ios.

In REDA [Rede] 7 freemen under Wisgar with soke and sac (held) 1 carucate of land. And 6 bordars. Then and afterwards 3 ploughs, now I $\frac{1}{2}$ ploughs. And 4 acres of meadow. Wood(land) for 3 swine. Then and afterwards they were worth 30 s., now 40 s. A church with 12 acres of free land.

\section{LACFORda [LACKFord] Hundret}

In BARTona [Barton (Mills)] Godeva, a freewoman under Wisgar, by commendation only, in Saint Edmund's soke, held T.R.E. 60 acres of land and 4 bordars, and $\mathrm{I}$ serf. Then as now half a plough on the demesne. And I acre of meadow. Worth 5 s.

In the same (vill) a sokeman under Wisgar (held) 60 acres and 4 bordars. Then as now half a plough. And I acre of meadow. Worth 5 s. Wisgar (had) the soke.

(At) Haluedona [Elveden] Levett, a freeman under Wisgar, by commendation only, in Saint Edmund's soke, held T.R.E. 2 carucates of land as a manor. Then 4 villeins, now 2. And then as now 3 bordars. And 1 serf. Then 2 ploughs belonging to the men. And a fourth part of a fishery. Then as now 1 horse, and 12 swine, and 150 sheep. Then it was worth 30 s., and afterwards and now the like. A church with i5 acres of free land.

Wisgar, Richard's predecessor, held CanauaTHAM [Cavenham] as 5 carucates of land with the soke as a berewick to Deselinga [Desning]. ${ }^{266}$ Then as now 25 villeins. And 5 ploughs. A fol. 392 .

church with 60 acres of free land. And then 5 mills, now 4. And 3 acres of meadow. It is I league long, and 4 furlongs broad. And in geld (pays) $20 d$.

In LAKINGAHETHE [Lakenheath] (is) I carucate of land. And 8 villeins. Then I plough on the demesne, now $1 \frac{1}{2}$ ploughs. And 4 fisheries in Eli [Ely]. And I fishing boat. And I acre of meadow. These 2 estates (terrae) are included in the valuation of Desilinges [Desning]. ${ }^{268}$

At Totenham [Tuddenham] the said predecessor of Richard (held) $\mathbf{1} \frac{1}{2}$ carucates of land and 9 villeins. Then as now 2 ploughs. And $\mathrm{I} \frac{1}{2}$ acres of meadow. And (this) renders $50 \mathrm{~s}$.

In BARTONa [Barton] (were) 30 acres of land in Wisgar's demesne. And 2 oxen. Worth $3^{\text {s. }}$

In Mudene Halla [Mildenhall (?)] (were) 2 sokemen with 60 acres and I bordar. And then as now 2 ploughs. Worth 5s. And they belong to Deselinga [Desning]. And they might not sell (their land).

$$
{ }^{265} \text { In Gazeley. }
$$

${ }^{266}$ In Risbridge Hundred, see n. 264. 


\section{A HISTORY OF SUFFOLK}

In Hernigawella [Herringswell] (were) 3 sokemen under Wisgar with 60 acres. Then as now half a plough. The holding is valued at Deselinga [Desning].

In the same (vill) (was) I sokeman with half his land with the soke under Wisgar, as the Hundred witnesses, and half his land with the soke under Saint Edmund. And he has a carucate of land and 5 bordars. Then as now 1 plough among them all. Worth 15 s.

In WAMFORDA [Wangford] (were) 4 sokemen with the soke under the same (Wisgar) with I carucate of land and I bordar. Then as now 2 ploughs among them all. And 3 acres of meadow. Worth ros. And they belong to Desilinges [Desning].

\section{Baberga [Babergh] two Hundrets}

In BURE [Bures] Wisgar held (tenet) i 8 freemen by commendation and soke and sac T.R.E. and they could sell their land T.R.E. without his licence. And (there were) 4 sokemen who could not sell. And the 18 (freemen) had $1 \frac{1}{2}$ carucates of land. And the 3 sokemen (had) $\mathrm{I} \frac{1}{2}$ carucates of land; and these three had under them 1 villein and 7 bordars, and 3 ploughs and 4 acres of meadow; worth 30s. And these I 8 freemen had under them ro bordars. Then as now 2 ploughs and 4 acres of meadow. Wood(land) for 6 swine. And I mill. Worth 30 s.

BURA [Bures] is I league long, and half a league broad. And (pays) 24d. in geld. But others hold (land) therein. A church with 18 acres of free land.

In Cornierda [Cornard] 7 freemen under Wisgar by commendation and soke and sac fol. $392 b$.

(held) 2 carucates of land T.R.E. and I bordar. Then 3 ploughs, afterwards and now 2. And 5 acres of meadow. Worth 26s. and $8 d$.

\section{In Coresfella}

] 7 freemen under the same (Wisgar) by commendation and soke and sac (held) $3 \frac{1}{2}$ carucates of land, 25 acres, and 10 bordars. Then as now 3 ploughs among them all. And 13 acres of meadow. Worth 3 li.

In Ilelega [Eleigh] 7 freemen under the same by commendation and soke and sac held 60 acres of land. Then as now I plough among them all, and I mill. Worth ros.

In Waldingafelia [(Little) Waldingfield ${ }^{2063}$ ] 3 freemen under the same by commendation and

ree 'Waldyngfeld Parva' was held by the Earl of Gloucester in 1302 : Feud. Aids, v, 28. soke and sac (held) I carucate and 45 acres of land, and 9 bordars. Then 3 ploughs, afterwards 2, now 1. And 3 acres of meadow. And I rouncey, 2 beasts, and 93 sheep. Wood(land) for 3 swine. It was worth 50s. Now Elinant holds them. The third part of a church with Io acres of free land.

In RanaUadisc [Cavendish] 9 freemen under the same by commendation and soke and sac (held) 3 carucates of land, and 5 bordars, and 1 serf. And 3 ploughs. And 14 acres of meadow. And 4 beasts, I horse, now 15 swine, and 46 sheep. Worth 3 li. Roger de St. Germains holds them.

In Herterst [Hartest] (were) 2 freemen under the same by commendation and soke and sac with 2 carucates of land, and 3 bordars. Then as now 2 ploughs and 8 acres of meadow. Worth 2li.

In W Alingafella [(Little) Waldingfield] 2 freemen, and I was under Robert son of Wimarc by commendation, both under Wisgar by soke and sac, and 2 carucates of land, and 9 acres of meadow. And 2 ploughs. And 9 beasts, 37 swine, 69 sheep, and II goats. Worth 50s. It is 4 furlongs long, and 4 broad. And (pays) $6 d$. in geld whoever be the holders thereof.

In Grotena [Groton] (was) a freeman by commendation and sac and soke, and he had ro acres of land. Worth $20 d$.

\section{STOHU [STOW] HUNDRET}

In Sellanda [Shelland] Find, the predecessor of Richard, held 23 acres and 4 bordars. Then as now half a plough and 2 oxen. Worth 5 .

\section{Half Hundred of Gepeswiz [Ipswich]}

In the borough of GePEswrz [Ipswich] Wisgar held T.R.E. a church, St. Peter's, to which belonged then as now 6 carucates of land as a manor. (There were) then and afterwards 6 villeins, now 8 . Then and afterwards 5 bordars, now 15. Then 4 serfs. Then as fol. 393 .

now 2 ploughs on the demesne. Then 3 ploughs (belonging to the men), now 4. Then wood(land) for 8 swine, now for 4 . Then as now a mill. And 3 acres of meadow. Now I rouncey, I beast, 9 swine, and 80 sheep. Furthermore to this church belong 5 burgesses, and 15 acres of free land within the borough, and 6 vacant burgages (mansure). Out of the aforesaid 6 carucates of land Roger the Sheriff claims 100 acres and 5 villeins, and a mill (as belonging to) the King's manor of Branfort [Bramford]. And 5 villeins of the said manor 


\section{THE HOLDERS OF LANDS}

bear witness for him. And they offer trial of law by any mode by which anyone may adjudicate. But the Half Hundred of Ipswich bears witness that this belonged to the church T.R.F., and Wisgar held it, and they offer to prove it. Then it was worth $100 s .$, now $15 k$. with other lands which belong to this church.

In the said borough Richard has 13 burgesses, whom Phin held T.R.E. Over 4 of them he had soke and sac and commendation. One of them is a serf. And over 12 he had commendation only. But they dwelt on land of their own, and rendered within the borough the whole customs. And this is (part) of the honour of Phin.

\section{Bosemara [Bosmere] Hundret}

Aschil held T.R.E., and now Richard holds in demesne, Badelera [Badley] as 2 carucates and 20 acres of land as a manor. Then as now 4 villeins, and 4 bordars, and 5 serfs. And 2 ploughs on the demesne. And 2 ploughs belonging to the men. 8 acres of meadow. And half a mill. And 2 rounceys, 26 beasts, 32 swine. Then 60 sheep, now 100. A church with 14 acres. Then it was worth 6os., now 4li. Of this land the Abbot claims half a carucate, as witnesses the Hundred. The King and the Earl (have) the soke. To this manor have been added in King William's time 26 freemen with I carucate and 45 acres of land. All these Richard holds as belonging to this manor which Phin (Fint) held. And Phin himself held them by arrangement with the Sheriff, as the Sheriff himself says. Then and afterwards 5 ploughs, now 2. Then it was worth 40s., now 47 s. The King and the Earl (have) the soke and sac. It is 10 furlongs long, and 5 broad. And (pays) $10 d$. in geld.

In Stanham [Stonham] (are) 5 acres of land. And wood(land) for 4 swine. This is included in the valuation of the 15 li.

\section{fol. $393^{b}$.}

Godman held Frochetuna [Flowton] T.R.E. Wisgar had the commendation, and the King and the Earl (had) the soke. This Germund holds of Richard as a manor and as 2 carucates of land. Then as now 4 bordars. And 1 serf. And 2 ploughs on the demesne. And 9 acres of meadow. Then $\mathrm{I}$ rouncey. Then 4 beasts, now 8. Then 4 swine. Then 15 sheep, now 6o. Then it was worth 4 li., now 6os. It is half a league long, and 4 furlongs broad. And (pays) $2 d$. in geld. To this manor Germund added 15 acres in King William's time; which a certain priest held freely T.R.E. in the soke of the King and the Earl. Worth 2s, and 6d.

Bondo a freeman held Brieseta [Bricett] T.R.E. And Queen Edith had commendation only; but Richard claims it as belonging to Wisgar's fee; and the King and the Earl (have) the soke. Now Roger (holds it) as I carucate of land and as a manor. Then as now I villein, and I bordar. And I plough on the demesne. And then I plough belonging to the men. Then it was worth 20s, now 30 s. This land Roger de Ramis claims as of the King's gift and he was seised thereof.

In the same (vill) the same Roger de Orbec holds 2 freemen with 15 acres. Worth $30 d$. This also Roger de Ramis claims as above; but Richard claims it as belonging to Wisgar's fee.

In the same (vill) Ranulf Peverel holds 4 acres which were attached to the aforesaid manor T.R.E. This he claims as belonging to Phin's fee.

In Rigneseta [Ringsett] Hardechin a freeman held 100 acres as a manor T.R.E.; now Geoffrey holds. Then as now 2 villeins, and 4 bordars. And I plough on the demesne. Then half a plough belonging to the men. 7 acres of meadow. Wood(land) then for 30 swine, now for 16 . Then it was worth 20 s., now 35 s.

In the same (vill) Godric a freeman held T.R.E. 60 acres as a manor. Then as now $I$ plough. Then it was worth IOS., now 20 s.

In the same (vill) Codwi a freeman held 60 acres as a manor. Then I plough. Then it was worth 10 s., now 155 .

All this Geoffrey holds, and he gave it to farm for 70s. But he could have only 6os. To this manor Phin added in King William's time 3 freemen with 20 acres. Then fol. 394 .

I plough. This is included in the same valuation. It is 8 furlongs long and 3 broad. And (pays) $5 d$. in geld. The King and the Earl (have) the soke.

In Facheduna [ ] a freeman under Earl Algar held 30 acres T.R.E.; now Ulmar (holds) of Richard. Then as now I plough. Worth 5s. And the King and the Earl (have) the soke.

(At) Assia [Ash (Bocking)] Uluric a freeman held 60 acres as a manor. Then as now 2 villeins. And 2 sokemen with 7 acres. And 2 bordars. And I plough on the demesne. And half a plough belonging to the men. And 2 acres of meadow. Then it was worth 20s, now 30 . And the King and the Earl (have) the soke.

In the same (vill) Iric a freeman held 60 acres as a manor and 2 bordars. And then as now I plough. And I acre of meadow. Worth 30 s. The King and the Earl (have) the soke.

In the same (vill) Edric a frecman held T.R.E. 40 acres as a manor. Then I plough. And $I$ acre of meadow. The King and the Earl (have) the soke. Worth 20 s. 


\section{A HISTORY OF SUFFOLK}

To this manor Phin added in King William's time 8 freemen with 35 acres and a sokeman with 12 acres, who could not take himself ${ }^{207}$ out of the lordship of Saint Etheldreda, and among them they had then 3 ploughs, now 2. Then it was worth I5s., now 20s. Osbern de Wancey holds the whole; and Richard claims it as belonging to Phin's fee. The King and the Earl (have) the soke. Two of these freemen Roger de Ramis claims as of his fee, and he was seised thereof. The whole is 6 furlongs in length, and 2 broad. And (pays) $6 d$. in geld. Of all this Phin had nothing T.R.E.

\section{Claindune [Claydon] Hundret}

In Toroluestuna [Thurlston] on the demesne were 18 freemen. Of these $12 \frac{1}{2}$ were under commendation to Aluric the priest, who was himself under commendation to Wisgar. Among them all they had 64 acres. And of the others, that is to say of $5 \frac{1}{2}$, Richard's predecessor had not commendation over Aluric, Waldwin, Harold, Godwin, Ulmar, Aluric. These latter had 24 acres T.R.E. These men

\section{fol. 3946 .}

Richard so holds, because Bishop trfast held them when Richard made good his claim to the church of St. Peter at Ipswich against him; but now he did not know that they did not belong to his fee. Among them all they had always 3 ploughs, and I acre of meadow. The above 12 were then worth $6 s$. and $8 d$., and the others 4s. and $I d$. The King and the Earl have soke over the whole of them.

In Hrlmingheam [Helmingham], of Fin's land, Turi King Edward's thegn held I carucate of land as a manor. Then as now I plough. And 2 ploughs belonging to the men. And 3 villeins, and 5 bordars. And 3 acres of meadow. Then wood(land) for 20 swine, now for 10. And 2 rounceys. And 4 beasts, 24 swine, 40 sheep, and 2 hives of bees. Then it was worth 16 s., now 20s. It is I league long, and 7 furlongs broad. And (pays) 20d. in geld. Others hold (land) therein. The King and the Earl have the soke. Walter de Caen (holds under Richard).

In Turoluestuna [Thurlston] (were) 9I acres belonging to the church of St. Peter at Ipswich. Worth 15s. And this is included in the valuation of the aforesaid I 5 li. It is 10 furlongs long, and 6 broad. And (pays) 20d. in geld. Others (hold) land therein.

\footnotetext{
268 'qui non potuit recedere' : the last three letters of 'potuit' deleted in the MS. by a corrector who supposed the phrase applied to all the men; but it was the sokeman and not the freemen who had been taken away from St. Etheldreda; Ing. El. 143.
}

SANFort [SAmFord] Hundret and a Half

(At) Alwartuna [Erwarton], of Phin's land, 'Turi the king's thegn held $\mathbf{I} \frac{1}{2}$ carucates of land as a manor. Then 8 villeins, now 3 . Then 4 bordars, now 7 . Then as now $1 \frac{1}{2}$ ploughs on the demesne. Then 4 ploughs on the demesne (sic), now I. And 3 acres of meadow. The third part of a fishery. Then I rouncey, now 2. Then 6 beasts, now 8 . Then 20 swine, now 26. Then as now 80 sheep. Now 4 goats. Then worth 40 s, now 30s. Roger holds (it) of Richard. The same Turi (had) the soke.

In Scotrleia [Shotley] Celeolt held T.R.k. by commendation to Aluric 60 acres as a manor. Then as now I villein and $\mathbf{I}$ bordar, and half a plough. Worth ros. The same Roger (holds it). The soke is in Bercolt [Bergholt].

In TORP [ ] Osbern Aluric's freeman held 100 acres as a manor T.R.E. Then as now 3 bordars, and I plough, and 3 acres of meadow. Worth 20s. The soke (is) in Bergholt. The same Osbern (holds) of Richard.

(At) Purte Pyt [

] the same Osbern T.R.E. held 60 acres as a manor. Then as now 3 villeins, and 2 bordars, and 2 serfs. Half a plough on the demesne, and 2 ploughs fol. 395 .

belonging to the men. Worth IOs. The same Osbern (holds it). The soke (is) in Bercolt [Bergholt].

In Cherchetuna [Kirkton ${ }^{38}$ ] Edmund a freeman held 60 acres as a manor T.R.E. Then as now half a plough and I acre of meadow. Then worth $20 s$, now $23^{s}$. and $2 d$. In the same (vill) Strangulf a freeman held 60 acres as a manor T.R.E. Then as now half a plough. Worth 4s. In the same (vill) Turi, a freeman of Guert's, (held) 60 acres as a manor T.R.E. Then as now 4 bordars and half a plough. Then worth IOs., now IIs. and $5 d$. In the same (vill) 2 freemen, Huna and Godric, (held) 15 acres T.R.E. and 2 oxen. Then worth 5 s., now 8s. The soke (is) in Bercolt [Bergholt]. It is 6 furlongs long and 5 broad, and (pays) $4^{d}$. in geld.

In Eurewardrstuna [Erwarton], Ailbern, a freeman, held 60 acres as a manor. Then as now half a plough. Worth 8 s.

In Eduinestuna [

] Gosric, a freeman, held 30 acres as a manor. Then as now half a plough. Then worth 5 s., now $3^{\text {s. }}$ The soke (is) in Bercolt [Bergholt].

And in the Hundred Richard has 3 freemen, Godric, Edwin, Leuric, (holding) 33 acres. In Shotley. 


\section{THE HOLDERS OF LANDS}

Then as now half a plough. Then worth 5s., now $6 s$. and $6 d$. The soke (is) in Bercolt [Bergholt].

In Burghestala [Burstall], Aluric Stari, Guert's man by commendation, held 40 acres as a manor 'T.R.E. Then as now 2 bordars. Then I plough, now half a plough, 2 acres of meadow. Worth 8 s.

In Bortuna [Boyton ${ }^{269}$ ] Leuestan, Fin's freeman by commendation, held T.R.E. 50 acres. 'Then as now 3 bordars. Then $\mathbf{r}$ plough, now half a plough, and 3 acres of meadow. Then worth IOs., now IIs. and $5 d$. The soke (is) in Bercolt [Bergholt].

In ToFT [ ] Alwin, freeman under commendation to Fsgar Stalre, (held) 20 acres. In the same (vill) Aluiet a freeman (held) 8 acres. 'Then as now half a plough. Then worth 55., now 95. and $4 d$. The soke (is) in Bercolt [Bergholt].

In Reindune [Raydon] Leuric, a freeman, held 30 acres as a manor. Then as now half a plough, and 2 acres of meadow. Then worth 5s., now IIs. and $5 d$. All this Richard holds in demesne.

\section{fol. $395^{b}$.}

And in Hвснам [Higham ${ }^{270}$ ] Godric, a freeman, held I carucate of land as a manor T.R.E. Then as now I villein, and 2 bordars, and I plough on the demesne, and 6 acres of meadow. A church (with) 4 acres. Then worth $205 .$, now 25s. Osbern holds (it). Of all these freemen Phin, the predecessor of Richard, had nothing T.R.E. except of one alone by commendation only. The soke of the whole is in Bercolt [Bergholt], and Richard holds them (as belonging) to the Honour of Phin.

(At) Fresetuna [Freston] Robert son of Wimarc held T.R.E., and Roger de Arbernum holds, 6 carucates of land as a manor. Then as now 24 villeins, and 4 bordars. And 2 ploughs on the demesne. Then 8 ploughs belonging to the men, now 6.8 acres of meadow, and I mill. A (quedam) church. Then II beasts, now 3. Then 40 swine, now 3. Then 140 sheep, now ror. Then worth $8 \mathrm{li}$, now I I $l i$. and I Os. I league long, and half a league broad, and it pays $10 d$. in geld. The same Robert (had) the soke.

In Burghestala [Burstall] Leuric, by commendation to Earl Algar, T.R.E. (held) 17 acres. Worth 35. This Richard claims (as

w In Bergholt and Bentley; Copinger, Suff. Rec.

m Formerly 'Hegham,' he'd of the Earl of Gloucester in 1346 ; Feud. Aids. v, 50. belonging) to Fin's land. Ulmar holds it of Richard. The soke (is) in Bercolt [Bergholt].

\section{RISEBRUGE [RISBRIDGE] HUNDRET}

These are the freemen who T.R.E. could sell and give their land. Wisgar, Richard's predecessor, had (over them) commendation and soke and sac, except the 6 forfeitures of Saint Edmund.

In Stanesfelda [Stansfield] Edric Spucla, a freeman, held 2 carucates of land. And 2 bordars, and 3 serfs. Then as now 2 ploughs. And 2 acres of meadow. Now 14 beasts. Then 4 sheep, now 80 . And 25 swine. Then worth 40s., now 60s. This Gilbert holds.

In the same (vill) Ulflet, a freeman, held I carcuate of land. Then as now I plough. And 4 acres of meadow. Then worth 20 s., now 30 . Robert holds.

In the same (vill) Crawa, a freeman, (held) 60 acres of land. And 1 serf. Then as now I plough. And $3 \frac{1}{2}$ acres of meadow. Then as now I mill. Then worth I Os., now 15 s. This fol. 396.

Roger holds. A church with I5 acres of free land. Stenesfelda [Stansfield] as a whole is 12 furlongs long, and 6 broad. And (pays) $13 \frac{1}{2} d$. in geld.

In Depdana [Depden] Brictric Blac, a freeman, held 2 carucates of land. Then as now 7 bordars, and 1 serf. And 2 ploughs on the demesne. Then half a plough belonging to the men. And 3 acres of meadow. Now 1 rouncey. Then 7 beasts, now 14. Then 15 swine, now. 30. Then 37 sheep, now 80 . Now 10 goats. And 3 hives of bees. Then as now worth 6os. Frodo the Abbot's brother holds.

In the same (vill) 2 freemen, Blacwin and Godwin, (held) 2 carucates of land, and 3 bordars. Then $1 \frac{1}{2}$ ploughs, now 2. And 3 acres of meadow. Then I rouncey. Then as now 6 beasts. Then 16 swine, now 26. Then 40 shcep. Then worth 30s., now 50s. Osbern holds.

In Cloptuna [Clopton ${ }^{271}$ ] Leviet, a freeman, holds $1 \frac{1}{2}$ carucates of land, and $I$ villein, and I bordar, and 3 serfs. Then I plough, now 2 ploughs. And 4 acres of meadow. Then as now I rouncey, and Io beasts. Now 34 swine, and 83 sheep. Then worth 20 s., now 30 s. Roger holds (over him).

In VRATINGA [Wratting] Goda, a freewoman, held 2 carucates and 30 acres of land. Then as now 9 bordars. And 2 ploughs on the demesne. And half a plough belonging to the ${ }^{m}$ In Wickhambrook. 


\section{A HISTORY OF SUFFOLK}

men. 7 acres of meadow. And 1 mill. Then I rouncey, now 2. Then 4 beasts, now 10 . Then I swine, now 52. Then 80 sheep, now 100. Then 4 goats, now 40. Then worth 30s., now 40s. Pagan holds. The whole (vill) is I league long, and half a league broad. And (pays) $12 d$. in geld.

In Hauerhella [Haverhill] Fredebern a freeman held 5 bordars. And they had 80 acres. And I plough on the demesne. And 2 oxen belonging to the men. And 2 acres of meadow. Then worth $13^{s}$. and $4 d$., now $15^{s}$. The said Pagan holds.

In HANINGEHET [Hanchett ${ }^{272}$ ] Alwine a freeman held 100 acres and I bordar, and I plough, and 2 acres of meadow. Then worth IOs., now 15 s.

fol. 3966 .

In URDRESFELDA [Withersfield] Woolmar a freeman held 51 acres and I bordar and half a plough and an acre of meadow. Worth 8 s. The said Pagan holds.

In the same (vill) a freeman Leuiara (held) I 00 acres and I bordar and I plough. Worth 20 s. Goddard holds.

In the same (vill) a freeman Alwin (held) 3 carucates of land, and 2 villeins and I 1 bordars and 3 serfs. And 3 ploughs on the demesne. Then I plough belonging to the men, now half a plough. And 2 acres of meadow. Wood(land) for 20 swine. Then 2 rounceys, now 3. Then 22 beasts, now 20. Then 60 swine, now 45. Then 60 sheep, now 123. Then 60 goats, now 57. Then as now worth 60 s. Wilard holds. The whole (vill) is I league long, and half a league broad. And (pays) $6 d$. in geld.

In WratiNGA [Wratting] a freeman Albern (held) 3 carucates of land. And 5 villeins, and io bordars. Then 3 ploughs on the demesne, now 2. Then as now I plough belonging to the men. And 12 acres of meadow. Wood(land) for 8 swine. And I mill. Then 2 rounceys, now 3. Then 9 beasts, now 13. Then 24 swine, now 48. Then 60 sheep, now 700. And 6 hives of bees. And under him (were) 9 freemen with half a carucate of land. Then half a plough. And I acre of meadow. A church with 13 acres. Then worth 50s., now 6os.

In Cileburna [Chilbourne ${ }^{978}$ ] Godwin a freeman held 2 carucates of land. I villein, and 4 bordars. Then 2 ploughs, now 1. And 6 acres of meadow. And 1 mill. Then as now I rouncey. Then worth 40sa, now 50 s. Geoffrey son of Hamon holds.

$$
{ }^{n 3} \text { In Withersfield. } \text { "Is In Barnardiston. }
$$

In Poslingerorda [Poslingford] a freeman Edric (held) 35 acres. And half a plough. And 2 acres of meadow. Worth 8s. Loher holds.

In Bortuna [Boyton ${ }^{2 / 4}$ ] a freeman Ulgar (held) 8 acres. Worth $16 d$. Ralph holds.

In the other Bortuna [Boyton] Almar a freeman held 24 acres. Worth 4s. W. Peret holds.

In Hauokeduna [Hawkedon] Alwin a freeman (held) 40 acres. And half a plough. And 2 acres of meadow. Worth 6s, and 8d. Folkered holds.

In Cloptuna [Clopton] (was) a freeman Roc with 13 acres. Worth 2s. William Pecche (Peccatum) holds.

In Bradeleia [Bradley] were then as now 2 freemen with 69 acres. And 1 acre of meadow. Then as now I plough. Worth 17 s. and $6 d$.

fol. 397 .

In TridlauUa [Thurlow] io freemen then as now (held) I carucate of land. And I plough. And I acre of meadow. A church with 29 acres. Worth 1 Os. The whole (vill) is I league long and I furlong broad. And (pays) $12 d$. in geld.

In Kidrtuna [Kedington] 10 freemen then as now (held) I carucate of land. And 2 ploughs. Worth 20 s.

In Hauerhella [Haverhill] 13 freemen then as now (held) I carucate and 60 acres of land. And $1 \frac{1}{2}$ ploughs. Wood(land) for 7 swine. And they were worth 30 s.

In WEDRESFELDA [Withersfield] 9 freemen (held) $1 \frac{1}{2}$ carucates of land. Then as now $2 \frac{1}{2}$ ploughs. They were then worth 20 s, now 30 .

In Stoches [Stoke-by-Clare] 21 freemen then as now (held) I carucate (and) 68 acres of land. Then $1 \frac{1}{2}$ ploughs, now 2 ploughs. And 10 acres of meadow. They were then worth 20s., now 31 s. and $4 d$. A church with 60 acres, worth 10 .

In Poslingewrda [Poslingford] 6 freemen then as now (held) 85 acres. And 3 bordars. And 4 ploughs. Worth $14 s$. and $3 d$.

In Wiснам [Wickhambrook] a freeman then as now (held) 60 acres. And 2 bordars. And I plough. And 4 acres of meadow. Worth ros.

In Stratesella [Stradishall] 16 freemen then as now (held) I carucate of land. Then as 


\section{THE HOLDERS OF LANDS}

now 3 ploughs. And 2 acres of meadow. Worth 20 . A church with 30 acres, worth 5 s.

In HaUoKeduna [Hawkedon] 8 freemen then as now (held) 30 acres. And 2 bordars. And 1 plough. Worth 13 s. and $4 d$.

In Haverha [Haverhill] 2 freemen (held) 26 acres. Worth $4 \frac{1}{2} s$.

These could all sell and give their lands. But Wisgar had T.R.E. both soke and sac, except the 6 forfeitures of Saint Edmund, as we have said above.

In BRADELEIA [Bradley] (are) 4 freemen, Ulwin, Leuric and Lewin, and they have I 5 acres. The fourth is Bundo and he has I carucate of land. Then as now 2 ploughs. And 2 acres of meadow. Worth 22s. and 6d. Of these Richard's predecessor had not commendation T.R.E. Saint Edmund had the entire soke.

In Tridlauva ['Thurlow] (were) 2 sokemen under Edith with all customs, whom Ralph held when he forfeited, and they have 25 acres. And then as now half a plough. And they were worth 4s. and $4 d$. This Widard holds.

fol. 3976 .

In Wimundestuna [

] (were) 6 freemen. Of the sixth, who is called Brictric, the Hundred know not if he could sell his land or not T.R.E.; but bear witness that they saw him swear that he could not give (or) sell his land away from Richard's predecessor. And they have 2 carucates and $I I$ acres of land. Then as now 2 ploughs. 7 acres of meadow. Now 2 rounceys. Then 2 cows, now 3. Then 6 swine, now 30. Then 16 sheep, now 62 . The whole is worth 40s. This Gerold holds.

\section{Half Hundret of Cosfort [Cosford]}

In Hеснам [Hitcham] 14 freemen (held) 60 acres. Then 2 ploughs, now I, and 2 acres of meadow. Worth IOs.

In Balesheia [Lindsey] ${ }^{273} 6$ freemen (held) I carucate of land, and 6 bordars. And 2 ploughs. And 2 acres of meadow. Worth 20 s.

In Careseia [Kersey] I freeman (held) 5 acres. Worth rod. His (Richard's) predecessor had soke and commendation

In Brettham [Brettenham] 8 freemen (held) 30 acres and I plough. Worth 5 s.

In Risebroc [Rushbrooke] 2 freemen (held) 10 acres. Worth $20 d$.

"Is Cf. above, n. 133.
In Watefredd [Whatfield] 3 freemen (held) 60 acres, and 3 bordars. Then $1 \frac{1}{2}$ ploughs, now 2 ploughs. Worth 10s. Over these his (Richard's) predecessor had commendation T.R.E. and soke and sac. Saint Edmund (has) the six forfeitures.

In Stanestrada [Stone Street] a freeman held 24 acres. Worth 4s. (Richard's) predecessor (had) half commendation, and the Abbot of Ely the other (half). Half this land R. Pevrel claims, and livery was made of it to him in Losa [Loes]. Saint Edmund (had) the soke.

fol. 398.

\section{LANDS OF WILLIAM DE WARENNE}

\section{Thewardestreu [Thedwastre] Hundret}

In Ratesdana [Rattlesden] 2 freemen held under Saint Etheldreda with soke and sac. One of them could sell (his) land, and the other could not. He who could sell had 40 acres and 5 bordars. And the other, who could not, had 60 (acres). Then as now 2 bordars. Then as now among them 2 ploughs; and 2 acres of meadow. Worth 20s. And this is of the Lewes exchange. ${ }^{276}$ This Humfrey son of Rodric holds.

In Gedinga [Gedding] 2 freemen under Saint Edmund by commendation and soke (held) 60 acres of land and 3 bordars. Then I plough, now none. And 5 acres of meadow. Worth 5s. By the Lewes exchange.

\section{LACFORdA [LACKFORD] HUNDRET}

In Heluedana [Elveden] a freeman under Saint Etheldreda by commendation only, in Saint Edmund's soke, held 2 carucates of land (which William obtained) by virtue of the Lewes exchange, which Nicholas holds of William. Then and afterwards 4 villeins, now 3 . Then as now 2 bordars, and I serf. Then and afterwards 2 ploughs on the demesne, now 1 . Then as now I plough belonging to the men. And the fourth part of a fishery. And a church with 15 acres of land. Then 4 swine, now 2. Then 200 sheep, now 300. Then 50 goats, now 100 less 6. 'Then and afterwards it was worth 305 , now 50 s.

In Herningawella [Herringswell] Roger holds, - the reeve holds, - and it belonged to Tohe a freeman, but he could not sell it; I carucate of land and 2 bordars. Then as now 1 plough. And 60 sheep. Worth I6s. It belongs to Frederic's fee in Saint Edmund's soke. 


\section{A HISTORY OF SUFFOLK}

In the same (vill) a freeman under Frederic's predecessor in Saint Edmund's soke held 40 acres, which Nicholas holds of William. Then half a plough, now none. Worth $40 d$.

\section{STOU [STOW] HundRet}

In Buressalla [Buxhall] Humfrey (holds); Monulf the priest, a man by commendation under Saint Etheldreda, in the King's soke, held half a carucate of land and 30 acres. Now William holds by reason of the Lewes exchange. Then and afterwards 2 bordars, now 7 . Then and always 1 plough on the demesne. Then as now 2 oxen belonging to the men. And 2 acres of meadow. In the same vill 4 freemen under the said Monulf by commendation held 2 acres. Worth $12 s$.

fol. 3986 .

\section{Bosemara [Bosmere] Hundret}

Tonestala [Tunstall ${ }^{277}$ ] Nicholas holds; Leofwin a freeman held I carucate of land and 20 acres as a manor T.R.E. Then as now I villein. Then 2 ploughs on the demesne, afterwards and now I. And 2 acres of meadow. Now I rouncey, and I cow. Then 30 sheep, now 60. Then it was worth 24s., now 25 s. The King and the Earl (have) the soke.

In Gratingrs [Creeting (All Saints)] Humfrid holds of William a freeman with $3^{8}$ acres. Then as now I plough. Then it was worth 8 s., now IOS.

\section{Brademara [Bradmere] Hundret}

BERHAM [Barnham] Hugh son of Gold ${ }^{278}$ holds, which Bos the thegn held T.R.E. ; half a carucate of land as a manor. Then as now 3 bordars, and 2 serfs. And I plough on the demesne. Then half a plough belonging to the men, now 2 oxen. Then 2 rounceys, now 1 . Then 13 swine. Then 85 sheep, now 9o. And (there were) 3 freemen with 4 acres and half a plough. Over them his (William's) predecessor had commendation. Then it was worth 16 s, now 20 s.

\section{Risebruge [Risbridge] Hundret OF Frederic's FEE}

Depdana [Depden] Hugh de Wancey holds, which Toka the thegn held T.R.E. as a manor; 3 carucates of land. Then as now 16 villeins, and 7 bordars. Then 4 serfs. Then and afterwards 2 ploughs on the demesne, now 4. Then as now 4 ploughs belonging to the men. I 2

277 Near Nettlestead; Copinger, Suff. Rec.

${ }^{273}$ Hugh son of Gold, who also held under William in Sussex (V.C.H. Suss. i, 435 , n. 9), appears to have been ancestor of the 'Plaiz' or 'Plays' family. Richard de Plays held Barnham in 1346 ; Feud. Aids, v, 73. acres of meadow. Wood(land) for 100 swine. Then as now 2 rounceys. Then 22 beasts, now 17. Then 40 swine, now 72 . Then 24 sheep, now 112 . Now 13 hives of bees. A church with 24 acres of free land. Then worth 4 li., now $6 \mathrm{li}$. It is I league long, and 8 furlongs broad. And (pays) $5 \frac{1}{2} d$. in geld.

WEDRESFELDA [Withersfield] Wimer holds, which he himself held T.R.E. as a manor; 2 carucates of land. Then as now 5 villeins, and 5 bordars. Then 3 serfs. Then 2 ploughs on the demesne, now 3. Then as now I plough belonging to the men. 2 acres of meadow. Wood(land) for 20 swine. Then 2 rounceys, now 3. Then 4 beasts, now 12 . Then 20 swine, now 30 . Then 80 sheep, now 100 . fol. 399.

Then as now 16 goats. And 6 hives of bees. Then worth 70 s., now 4 li.

In the same (vill) a freeman (held) 24 acres. Then as now half a plough. Worth 4 s.

In Cloptuna [Clopton ${ }^{279}$ ] Hugh holds (the land) which the said Toka held, viz. I carucate of land. Then as now I plough. And 2 acres of meadow. Then as now worth 20 .

\section{Hundret of Bledinga [Blything]}

(At) Wretham [Wrentham] Edric a freeman held T.R.E. 2 carucates of land as a manor. Then as now 5 villeins. Then as now II bordars. Then 6 serfs, now 3 . Then $1 \frac{1}{2}$ ploughs on the demesne, now 2 ploughs. Then 3 ploughs belonging to the men, now 2 ploughs. Then as now wood(land) for 20 swine. Then as now 2 acres of meadow. Now 2 rounceys, 13 beasts, I 2 swine, II 3 sheep, 20 goats, and 5 hives of bees. And a church with 40 acres. Then 25 now it was worth $40 s$. And that manor Robert de Petro-ponte holds of him.

In the same vill Turchil a freeman, T.R.E. (and) then as now, held 2 carucates of land as a manor. And then as now 5 villeins. And then as now II bordars. 2 ploughs might be made up (fieri) on the demesne. And (there was) I when he (William) received it. 2 acres of meadow. Wood(land) for 20 swine. Then as now it was worth 40 s. And this land $\mathrm{R}$ (obert de Petro-ponte) himself holds.

In the same vill Wluric a freeman held 2 carucates of land as a manor. Then as now 5 villeins, and I I bordars. I plough on the demesne. And another might be made up. And 2 ploughs belonging to the men, 2 acres of meadow. Wood(land) for 20 swine. Then as now it was worth 40 s. And a church with 8 acres. And this the same Robert holds.

In the same vill dwelt 20 freemen with 360 acres and 2 bordars. And then as now 6 ploughs

970 In Wickhambrook. 


\section{THE HOLDERS OF LANDS}

on the demesne. Then as now worth 6os. Of I of those men Count Alan has half commendation and half the land and soke and sac. And all this Robert has of William de Warenne. Over all this land the soke and sac belong to Blideburg [Bythburgh] Hundred.

\section{fol. 3996 .}

Moreover William has in the same vill a manor of 3 carucates of land which Halden a freeman held. Then 6 villeins, and now 4. Then I I bordars, now 13. Then 3 serfs, now I. 'Then as now 3 ploughs on the demesne. Then and now 2 ploughs belonging to the men. 2 acres of meadow. Wood(land) for 40 swine. Now 7 beasts, 24 swine, 80 sheep, 30 goats. It was worth T.R.E. 4 li., and now 3 li. And this William son of Rainald ${ }^{280}$ holds of William de Warenne.

In the same vill dweit a freeman, and he held half a carucate of land as a manor, which the same (William) holds, and under him he had 2 freemen with $\mathrm{r} O \mathrm{acres}$, and I bordar. Then as now I plough on the demesne. And half a plough belonging to the men. Wood(land) for 4 swine. And half an acre of meadow. 2 rounceys, 6 beasts, 10 swine, 30 sheep, 20 goats. Then it was worth ros., and the like now.

In the same vill Aluric of Sanford held 50 acres as a manor. Then as now 2 bordars. Then as now I plough on the demesne. I acre of meadow. And I rouncey, 4 beasts, 8 swine, 60 sheep, 7 goats. Then as now it was worth 10 .

In the same (vill) dwell 8 freemen, and they hold $1 \frac{1}{2}$ carucates and 10 acres of land, and they hold I bordar. Then as now 2 ploughs on the demesne. Then as now it was worth I2s. And all this William son of Rainald holds under William de Warenne.

Henestede [Henstead], a berewick of WerETEHAM [Wrentham], I carucate of land. Then as now 4 villeins. And then as now 9 bordars. And then as now I plough on the demesne. And then as now 2 ploughs belonging to the men. And 6 beasts, 40 sheep, 12 swine, 20 goats. Then as now it was worth 20s. And now 2 freemen have been added with 30 acres of land, and they have $I$ plough on the demesne and are worth 3s. And these two lands Godfrey de Petro-ponte holds under William de Warenne. And all these estates (terrae) are 3 leagues long, and 2 broad. And it renders 2s, in the King's fol. 400 .

geld. Throughout the whole of this land the King has soke and sac except over the demesne of Aldan [Halden]. And of this estate 6 acres of land have been taken from Earl Alan, which

35 Ancestor of the Poynings family, who afterwards (Fend. Aids, v, 59) held land in Wrentham and North Hales; cf. V.C.H. Sussex, i, 440.

William's men took from him, as witnesses the Hundred. And Thurkil of Wereteham [Wrentham] was the man of Edric, Robert Malet's predecessor.

Mideltuna [Middleton] Ranulf the nephew (nepos) holds, which Aluric a freeman held as a manor; now William de Warenne holds in demesne; 2 carucates of land. Then as now 2 villeins. Then as now 8 bordars. Then 4 serfs, and now I. Then 2 ploughs on the demesne. And now half a plough belonging to the men. 6 acres of meadow. Then 1 rouncey, and now 2. And now 2 cows, 20 swine, and 50 sheep. Then it was worth $40 \mathrm{~s}$, and (the like) now. And a church with 15 acres, worth 2s. And to this manor have been added 5 free- 1 men and half a priest, and they hold $55 \frac{1}{2}$ acres and $1 \frac{1}{2}$ ploughs on the demesne, and 2 acres of meadow. It was worth ros. It is 8 furlongs long and 7 broad, whoever have the land there. And it renders $7 \frac{1}{2} d$. (in geld). And over these 6 men the King and the Earl have soke and sac. And Aluric who held this manor was the man of Edric, Robert's predecessor, and William Malet and Robert were seised of this land.

Torintuna [Thorington] Aluric a freeman held as a manor T.R.E., now Godfrey de Petroponte holds of William de Warenne; then as now 2 carucates of land. Then as now 5 villeins, I I bordars. Then 3 serfs, now 2. Then 2 ploughs, and now 3 on the demesne. And then as now 4 ploughs belonging to the men. Wood(land) for 6 swine. 2 acres of meadow. And 6 non-working (otiosa) beasts, 40 swine, 120 sheep, and 4 hives of bees. It was worth 6os. And this land Robert Malet claims like the other. This witnesses the Hundred. And the King and the Earl (have) soke and sac.

(At) Norhals [North Hales] T.R.E. Edric a freeman held as a manor 2 carucates of land. fol. 400 .

Then 5 bordars, now 6 . Then I serf. Then 2 ploughs on the demesne, now $1 \frac{1}{2}$ ploughs. And half a plough belonging to the men. An acre of meadow. Then I rouncey, and now I. And 8 swine, and 105 sheep. Then it was worth 40 s., and now 20s. To this manor have been added 100 acres of land which $\mathrm{I}_{4}$ freemen held. Then 2 ploughs, now I. And I acre of meadow. Worth ros. And all this land William son of Rainald held of William de Warenne. And 2 half (freemen) of those I 4 men William's men have seized against Earl Alan.

\section{Hundret of Carlaforda [Carlford]}

In Burhc [Burgh] Ailric, a freeman, T.R.E. held I carucate and 20 acres of land as a manor. Then 2 bordars, now 7 . Then I plough, now 2. 


\section{A HISTORY OF SUFFOLK}

Then half a plough belonging to the men, now I plough. 4 acres of meadow, and I rouncey, and 7 beasts. Then 16 swine, now 12, and 17 sheep. Then it was worth 20 s., now 30 s.

In the same (vill) (were) I I full freemen, and 3 half freemen under commendation to the said Ailric, with 50 acres, and 2 bordars. Then 2 ploughs, now I. Half an acre of meadow. Then it was worth Ios., now 8s. All this William received as I carucate of land, and $R$. de Glanville (holds it) of him. And (there is) one church with 8 acres, and several persons have part (in it).

\section{HUNDRET OF WILEFORDA [WILFORD]}

In Bulges [Boulge] Robert (now) holds; a freeman under Ailric's commendation T.R.E. (held) $13 \frac{1}{2}$ acres, and half a plough. Worth 2 s.

In Depebecs [Debach] a freeman under the said Ailric's commendation (held) 4 acres, worth $8 d$.

In Torstanestuna [ ] (are) 6 acres, worth $12 d$. This R(obert) de Glanville holds of William de Warenne.

In Berdefelda [Bredfield] Ailric a freeman held 3 acres, worth $6 d$. The same Robert (de Glanville now holds).

fol. 401 .

XXVII. LANDS OF SUANE OF ESSEX IN SUFFOLK

\section{Tingoou [Thingok] Hundret}

In RIETE [Rede] a sokeman with 20 acres and I bordar. And half a plough. And I acre of meadow. Worth 5s. Saint Edmund (has) the soke.

In Manestuna [Manston ${ }^{281}$ ] a sokeman with 20 acres, and I bordar. And half a plough. And $I$ acre of meadow. Worth 5 .

\section{Baberga [Babergh] Two Hundrets}

At STOKes [Stoke(-by-Nayland)] Robert held T.R.E. 4 carucates of land as a manor with soke. Then 25 villeins, now 15 . Then 32 bordars, now 23. Then 8 serfs, now 6 . Then 2 ploughs on the demesne, now 3 . Then 12 ploughs belonging to the men, now 7 . Now 2 mills. And 25 acres of meadow. Wood(land) for 60 swine. Now 3 horses, 8 beasts, 20 swine, 70 sheep, 4 goats. Then it was worth Ioli., now I 2 li. A church with 60 acres of free land.

In the same (vill were) in freemen under Robert by commendation and soke. Among them all I carucate of land; but these could

*1 In Whepstead. sell ; and I freeman with 12 acres under Robert by commendation ; but sac and soke were Saint Edmund's. Among them all $I_{\frac{1}{2}}$ ploughs then, now I plough. Worth 30 s. It is 8 furlongs long, and 4 broad. And (pays) 20d. in geld.

(At) Withermers [Withermarsh] ${ }^{282}$ Robert, Suane's father, held T.R.E. 4 carucates of land as a manor with soke. Then 27 villeins, now 24. Then 32 bordars, now 27. Then 2 serfs, now 1 . Then 3 ploughs on the demesne, now 2. Then 13 ploughs belonging to the men, now 8. Then as now 1 mill. And 30 acres of meadow. Now 2 horses, 20 beasts, 24 swine, and 15 forest mares. Now 80 sheep. Then it was worth roli., now 1 $2 / i$. It is 8 furlongs long, and 4 broad. And (pays) 20d. in geld.

(At) Polesteda [Polstead] the same Robert, father of Suane, held T.R.E. 4 carucates of land fol. $40 \mathrm{I} b$.

as a manor with soke. Then 26 villeins, now 21. Then 36 bordars, now 30 . Then as now I serf. Then and always 2 ploughs on the demesne. Then 15 ploughs belonging to the men, now 9. Then as now I mill. Wood(land) for 80 swine. And 31 acres of meadow. Now 8 horses at the hall, 28 beasts, 40 swine, I 50 sheep. Then it was worth roli., now 12 li. It is 8 furlongs long, and 4 broad. And (pays) $20 d$. in geld whoever be the landholder therein.

(At) Erlanda [? Waylands $\left.{ }^{283}\right]$ the same Robert, father of Suane, held T.R.E. 2 carucates of land as a manor with soke. Then as now 6 villeins. Then 20 bordars, now 17 . Then 6 serfs, now 2. Then as now I plough on the demesne. Then 4 ploughs belonging to the men, now 3. Then as now I mill. And 10 acres of meadow. Now 3 horses at the hall, 31 beasts, 45 swine, 80 sheep, 35 goats. Then it was worth $6 l i$, now $8 l i$. It is half a league long and 2 furlongs broad. And pays 12d. in geld.

At Aluenelega [? Aveley ${ }^{284}$ ] Brungar a freeman under Robert by commendation only T.R.E. held I carucate of land as a manor with soke. Then as now I villein, and Io bordars. Then as now 2 ploughs on the demesne. And half a plough belonging to the men. Wood(land) for 6 swine. And 4 acres of meadow. And I mill. And I horse at the hall. And now I 4 beasts, 49 swine, and 87 sheep. Then it was worth 20 s., afterwards and now 30 . It is 6 furlongs long, and 3 broad. And (pays) $3^{d}$. in geld. Over him Saint Edmund had soke and sac T.R.E. and Robert, son of Wimarc and father of Suane, had commendation only. In the same (King's) time were stolen horses found in the house of this Brungar, so that the Abbot

In: In Stoke-by-Nayland.

In Stoke-by-Nayland. 


\section{THE HOLDERS OF LANDS}

whose was the soke and sac, and Robert, who had commendation over this man, came to the fol. 402 .

plea about this theft. And thus the Hundred testifies. They went away on terms of friendship without a verdict so far as the Hundred could see.

\section{Half Hundret of Gepeswiz [Ipswich]}

In the borough Robert had T.R.E. 4 I burgesses with soke and sac and commendation; and the King had the other customs. Of them I5 are dead. (Suane) lost the commendation, but has the soke and sac. And of the others in like manner. And the $\mathrm{King}$ has the other customs.

\section{SANFORT [SAMFORD] HUNDRET}

(At) Stratfort [Stratford (St. Mary)] T.R.E. Robert held as a manor 3 carucates of land. Then as now 20 villeins. Then 8 bordars, now 10. Then 4 serfs. Then 2 ploughs on the demesne, now 1 . Then ro ploughs belonging to the men, now 5 , and 5 could be restored. And 16 acres of meadow. Wood(land) for 16 swine. Then as now 1 mill. A church (having) 20 acres of free land, and half a plough. I rouncey. And 6 beasts, 36 swine, and 50 sheep. Then as now worth 6 li. Robert (holds) of him. Suane (has) the soke. It is 7 furlongs long, and 5 broad, and pays $9 d$. in geld.

(At) Painetuna [Pannington] ${ }^{986}$ Robert held T.R.E. 2 carucates of land as a manor. Then 3 villeins. Then as now 3 bordars. Then 2 ploughs on the demesne, now I. Then 3 ploughs belonging to the men. And 10 acres of meadow. 3 acres of free land (belonging) to the church. Now I salt-pan. And 8 beasts, 20 swine, 80 sheep, and 28 goats. Then worth

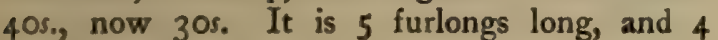
broad, and (pays) $4 \frac{1}{4} d$. in geld. Robert (has) the soke. Algar (holds) of Suane.

(At) Wervesta [Wherstead] Toli, a freeman under commendation to Robert, held I carucate of land. And $\mathrm{I}$ bordar. And $\mathrm{I}$ plough. And 3 acres of meadow. And 5 swine, 30 sheep, and 14 goats. Then worth IOs, and now the like. Suane (holds it) in demesne.

In FRIsetuna [Freston] T.R.E. Robert held 30 acres on the demesne. Then as now I plough and I acre of meadow, and worth Ios. Ernulf (holds) of Suane. The same Robert (had) the soke.

26b In Wherstead. fol. $402 b$.

\section{HUNDRET OF WILEFORDA [WILFORD]}

At Peituna [Peyton ${ }^{288}$ ] Godric under Harold's commendation held T.R.E. as a manor 3 carucates of land. Then 10 villeins, now 8. Then 4 bordars, and now. Then $I$ serf. Then as now on the demesne 2 ploughs. And 3 ploughs belonging to the men. 3 acres of meadow. And I mill. Then 2 rounceys. Then 4 beasts, now 2. Then I swine, now 6 . And 27 sheep. Then worth 6os,, now 40 s. It is $I$ league long, and 4 furlongs broad. And in geld (pays) $13 \frac{1}{2} d$.

In the same (vill) belong 20 freemen under the same (Godric's) commendation with 80 acres of land and 2 acres of meadow. Then as now 2 ploughs. Then worth 13 s., now 15 s.

\section{LANDS OF EUDO THE STEWARD (Dapifer) IN SUFFOLK \\ LacForda [Lackford] Hundret}

(At) Hereswella [Eriswell] Godwin, King Edward's thegn, held as a manor 6 carucates of land. Then I I villeins, afterwards Io, now II. And then as now 4 bordars. Then as now II serfs. Then and afterwards 5 ploughs on the demesne, now 3. Then as now 5 ploughs belonging to the men. And 14 acres of meadow. And $2 \frac{1}{2}$ mills. A church with 60 acres of land. 2 fisheries. Then as now 2 horses at the hall. Then 20 beasts, now I 3 . Then 40 swine, now 20. Then 900 sheep, now 800 . Then and afterwards it was worth roli., now 16li. It is a league long, and 6 furlongs broad. And in geld (pays) rod.

To this (manor) belongs one berewick CoclesWORDA [ ] with 8 carucates of land. A church with 60 acres. Then and afterwards 15 villeins, now II. Then and afterwards 4 bordars. Then and afterwards II serfs, now 8 . And 22 acres of meadow. Then and

fol. 403 .

afterwards 5 ploughs on the demesne, now 4. Then and afterwards 6 ploughs belonging to the men, now 5. And 2 horses at the hall. Then 1200 sheep, now 900 less 20 . Then and afterwards it was worth $12 l i$, now $24 l i$. It is 1 league long, and 8 furlongs broad. And in geld (pays) $7 d$. Saint Edmund (has) soke and sac.

In LAKINGAHEDA [Lakenheath] and in BRANTONA [Brandon] 6 sokemen under (Saint) Etheldreda and in her soke so that they could not sell. They were delivered to Lisia ${ }^{287}$ the predecessor

${ }^{296}$ In Ramsholt.

${ }^{207}$ Lisois de Moustiers; see above, p. $38 \mathrm{I}$. 


\section{A HISTORY OF SUFFOLK}

of Eudo as (having) 2 carucates of land ; but yet he (Lisia ${ }^{288}$ ) afterwards made recognizance (that he held) under Saint Etheldreda (recognov' de Sca. Aldreda) ; and Eudo held ${ }^{289}$ them with soke and sac. And 4 bordars. Then as now 3 ploughs. And 3 acres of meadow. And 2 fisheries. Then and afterwards they were worth 30 s., now (this) renders 70 s.

(At) Todenham [Tuddenham] Canut a freeman under Earl Algar held as a manor 3 carucates of land. Then 6 villeins, afterwards 4, now 6 . And then 4 serfs, now 1. Then 3 ploughs on the demesne, afterwards half a plough, now 2 ploughs. And $1 \frac{1}{2}$ ploughs belonging to the men. And 3 acres of meadow. And 1 mill. There was I fishery, but now there is none. A church with 30 acres. Now 10 horses at the hall. And now 40 swine, and I I beasts. Then 200 sheep, now 60. Then and afterwards it was worth 4 li., now roos. And it is I league long, and 6 furlongs broad. And in geld (pays) $20 d$.

In Kanauaham [Cavenham] there was a freeman under Canute by commendation only in Saint Edmund's soke with 60 acres, and I bordar. Then as now I plough. Then as now it was worth 5 s.

\section{Sanfort [SAmFord] Hundret and a HalF}

In Rienduna [Raydon] Suerting a freeman

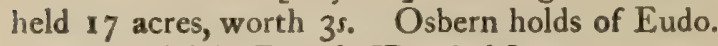
The soke (is) in Bercolt [Bergholt].

\section{Plumestgata [Plomesgate] Hundret}

(At) Glemham ${ }^{290}$ [(Great) Glemham] Uluric, under commendation half to the Abbot of Ely and half to Malet's predecessor, held 2 carucates of land as a manor T.R.E. And William Malet was seised thereof. Then as now 7 bordars. And 2 ploughs on the demesne. And half a plough belonging to the men. And 8 acres of meadow. fol. $403^{b}$.

And I mill. And half a church with 10 acres. Then 9 swine, now 16. Then 5 sheep, now 40. Then it was worth 40 s, now 50 s.

In the same (vill) have been added 10 freemen (formerly) under commendation to Uluric with 53 acres and I plough. It was worth IOs. and I od. Pirot holds this of Eudo. The soke (belongs) to the Abbot of Ely. William Malet was seised of the whole. It is 12 furlongs long, and $6 \frac{1}{2}$ broad. And renders $20 d$. in geld.

${ }^{298}$ Cf. Inq. El. $142 . \quad 299$ 'and holds'; ibid.

200 'In Nordglemmeham a freeman Wlfuric Hugo sune under commendation to St. Etheldreda (held) It carucates of land. This Eudo Dapifer holds'; ibid. 153.

\section{HALF HUNDRET OF COSFORT [COSFORd]}

(At) Leinam [Layham] Aluric Campa T.R.E. held 4 carucates of land as a manor. Then as now I 5 villeins, and 3 bordars, and I serf. Then as now 2 ploughs on the demesne. Then 6 ploughs belonging to the men, afterwards and now 3. 12 acres of meadow. Wood(land) for Io swine. And I mill. A church with 40 acres, and I acre of meadow, and I plough. Then as now I rouncey, 20 beasts, 36 swine, 180 sheep, and 23 goats. Then as now it was worth 6 i. It is 8 furlongs long, and 6 broad. And pays $7 \frac{1}{2} d$. in geld.

\section{LAND OF ROGER DE OBURVILLE}

\section{STO [STOW] HuNDRET}

In Fineberga [Finborough] Leuesuna a freeman under Gutmund, the predecessor of Hugh de Montfort, by commendation only held 2 carucates of land. Then 4 bordars, afterwards and now 3. Then as now 2 ploughs on the demesne. Wood(land) for 12 swine. And 16 acres of meadow. And I mill. A church with 30 acres of free land and I acre of meadow. Then I fol. 404 .

rouncey, now none. Then as now 8 beasts. Then 20 swine, now 6 . Then 30 sheep, now 100. Then worth $4 l i$, afterwards $2 l i$, now 60 s. It is I league long and 8 furlongs broad. And (pays) $22 \frac{1}{2} d$. in geld.

In the same manor 18 freemen under the said Leuesune by commendation only held I carucate of land within the soke of the King and the Earl. Then and afterwards 3 ploughs, now I. And $3 \frac{1}{2}$ acres of meadow. These (freemen) Roger holds by exchange.

In the same (vill are) 6 sokemen belonging to ToRNeI ['Thorney ${ }^{291}$ ], King Edward's manor, with commendation and soke and sac and summage, and they have $65 \frac{1}{2}$ acres of land, and I bordar. Then and afterwards 3 ploughs among them all, now 1 . And 3 acres of meadow. And these men Roger holds by exchange.

In the same (vill) 2 freemen under Gutmund, the predecessor of Hugh, by commendation only held 80 acres within the soke of the King and Earl. Then $1 \frac{1}{2}$ ploughs, afterwards and now none. And these men (Roger) holds in like manner.

Furthermore in the same (vill) a freeman by commendation under the predecessur of Eustace held 4 acres.

In the same (vill) a freeman under Leuestan de Losa by commendation (held) 4 acres.

$m$ In Stowmarket. 


\section{THE HOLDERS OF LANDS}

Yet again in the same (vill) a freeman under the King by commendation, the soke and sac (being) in the Hundred, held 20 acres. Then half a plough and I acre of meadow.

In the same (vill) a freeman under $W$ isgar, the predecessor of Richard, by commendation, but the soke (was) in the Hundred, (held) 30 acres and I villein. Then I plough, afterwards and now none. And 2 acres of meadow.

In the same (vill) 4 freemen, (whose) soke (was) in the Hundred, held 16 acres. Then $1 \frac{1}{2}$ ploughs, afterwards and now none. These men (Roger) holds by exchange.

Then and afterwards all these freemen were worth $4 k i$, now 40 s.

\section{Bosemara [Bosmere] Hundret}

(At) Sumersham [Somersham] on the demesne Leffchilt held I carucate of land as a manor in (King) Edward's time. Then as now I plough. And I acre of meadow. Worth 30 s.

\section{At Pileberga [}

] Dot a freeman held 60 acres as a manor T.R.E., now Roger (holds) in demesne. I bordar. Then as now I plough. And I acre of meadow. Worth 20 s. The King and the Earl (have) the soke.

In the same (vill) 5 freemen (held) 30 acres. Included in the above valuation. The King and the Earl (have) the soke.

In Flochetuna [Flowton] on the demesne 2 freeman Godman held 20 acres T.R.E., and fol. $404 b$.

still holds them under Roger. Worth $40 d$.

In the same (vill) on the demesne (were) 2 freemen Wilgrip and Edric, one with 40 acres and the other with 10 acres. Then as now I plough. And I acre of meadow. It was worth 16s. The King and the Earl (have) the soke.

In BLACHAM [Blakenham] on the demesne Ulwart, a freeman, held 30 acres. Then as now half a plough. And I acre of meadow. Worth $14^{s}$.

In Elia [ ] on the demesne a freeman, Aluiet, held 12 acres and 2 oxen. Worth 7 s.

In the same (vill) a freeman (held) 3 acres and this is included in the valuation of Sumersham [Somersham].

In Offetuna [Offton] (was) a freeman Waldwin under commendation to Leuric Hobbeson, and he had 20 acres and I bordar. Then half a plough. Then it was worth $40 d$, now 4 s. William holds of Roger.

In BRIRSETA [Bricett] (was) a freeman, Leuric, under commendation to Godric of Ringeshala [Ringshall] the predecessor of William de Otbur- ville, and he had 10 acres. Then 2 oxen. Worth 2od. Gilbert holds of Roger. The King and the Earl (have) the soke.

In Horswalda [Horswold] 2 freemen Hardinc and Tovi under the commendation of the King held $22 \frac{1}{2}$ acres. Now William holds of Roger. Then as now half a plough. And half an acre of meadow. Worth 5s, and Iod. The King and the Earl (have) the soke. This land Roger holds of the Abbot of Ely by the precept of the Bishop of St. Lo as Roger himself says.

In Langhedana [ ] a freeman Wlbolt (held) 24 acres as a manor. And $1 \frac{1}{2}$ acres of meadow. And in every third year the fourth part (of the profits) of a mill. And it is and was worth 5 s. and $8 d$.

\section{Claindune [Claydon] Hundret}

At Henleia [Henley] Tepechin a freeman under commendation to Harold held T.R.E. 2 carucates of land as a manor, and 16 bordars. Then 4 serfs. Then 3 ploughs on the demesne, now 2. Then 4 ploughs belonging to the men, now 3. 8 acres of meadow. Wood(land) for 6 swine. And 7 beasts, 14 swine, and 30 sheep. To the church (belong) 2 acres. Then it was worth $4 l i$, now $3 l i$. Eudo the Steward holds (under Roger) on his demesne.

In the same (vill) 4 freemen added (to the manor hold) 8 acres and 2 oxen. Worth 2s. The King and the Earl (have) the soke.

fol. 405 .

\section{Half Hundret of Cosfort [Cosford]}

(At) Elmrseta [Elmsett] Thou the thegn T.R.E. held 6 carucates and 40 acres of land as a manor. Then and afterwards I I villeins, now 2. Then as now 12 bordars. Then 4 serfs. Then as now 2 ploughs on the demesne. Then and afterwards 12 ploughs belong $n g$ to the men, now 4. A church with 15 acres, and half a plough. Then 2 rounceys. Then 16 beasts, now 4. Then 30 swine, now 20. Then 240 sheep, now 200. Then it was worth roli., now 7 li. It is 10 furlongs long, and 7 broad, and (pays) 15 . in geld. Saint Edmund (has) half the soke.

In W ATEFELDA [Wattisfield] a freeman (held) 60 acres and 2 bordars. Then and afterwards 1 plough, now half a plough and $I$ acre of meadow. Worth Ios. Saint Edmund (has) the commendation and soke.

\section{Hundret of Carleford [Carlford]}

In FinzsFord [ ] ${ }^{298}$ Tepekin (held) 24 acres and $I$ acre of meadow. Then half m Cf. n. 233. 


\section{A HISTORY OF SUFFOLK}

a plough, and (there was) a freewoman with half an acre. Then as now it was worth 45.

\section{LAND OF WILLIAM THE BROTHER OF ROGER DE OTBUR- VILLE}

\section{Bosemara [Bosmere] Hundret}

At Ringeshala [Ringshall] Godwi a freeman held I carucate of land and 40 acres as a manor. Then I villein. Then 2 ploughs, now half a plough. And 4 bordars. And 6 acres of meadow. Wood(land) for 8 swine. Half a church with 12 acres. Then 4 rounceys, now 1 , and 13 swine, 60 sheep, and 32 goats. Worth $47 s$. Of this estate one under commendation to the Abbot of St. Edmund's held II acres T.R.E. Of this manor Hugh holds 40 acres. And they were worth 5s., (which sum is included) in the above valuation.

In the same (vill) a freeman Uluric held 80 acres as a manor. Then 1 plough. And 4 acres of meadow. Then it was worth 20s., now 8s. Fulcho holds of William. The King and the Earl (have) the soke.

fol. $405 b$.

In the same (vill) Trumwin a freeman under the King held 18 acres T.R.E. Now William holds on the demesne. Then half a plough. It was worth $3^{s}$.

In Ringeshala [Ringshall] Edric a freeman under commendation to William's predecessor held 5 acres. Now William (holds) on the demesne. Worth I2d.

In BRIEsETA [Bricett] Fulcho holds of William; Anschill a freeman under commendation to Leuric Hobbeson held 60 acres, T.R.E., as a manor. Of these William has 40 acres, but it was all delivered to him together. On this estate (terra) is I bordar. And then as now I plough. Worth IOs. The King and the Earl (have) the soke. Of the above 60 acres Hugh de Hosdenc took away 20 acres as William says, and as the Hundred (says); but Hugh is himself a prisoner in the King's hands (est in captione regis) and so he could not give an answer.

\section{LANDS OF HUGH DE MONT. FORT}

\section{Brademara [Bradmere] Hundret}

In Berham [Barnham] on the demesne (are) 9 freemen with 16 acres and half a plough.

In WATRFELDA [Wattisfield] on the demesne (are) 9 freemen with 16 acres and half a plough.
Worth 15s. Saint Edmund (has) the soke. Two of these were under Saint Edmund as to their commendation T.R.E. and 7 under Earl Hugh's predecessor.

\section{BISSCOPES [BISHOP'S] HUNDRET}

At Saham [Soham] Oslac the thegn held T.R.E. as a manor I carucate of land. Roger de Candos holds it. Then as now I villein, and 3 bordars, and I serf. And I plough on the demesne. And half a plough belonging to the men. And 4 acres of meadow. Wood(land) for 10 swine. Then 10 swine, now 12. And fol. 406 .

5 beasts. Then 4 sheep, now 12. Then as now worth 20s. The soke (is) the Bishop's.

In Horant [Horham] the same (Roger de Candos) holds a freeman by commendation (with) 14 acres and half a plough, worth 3 s.

In BADINGAFELDA [Bedingfield] the same(holds) 5 freemen by commendation (with) 60 acres and 2 bordars and $\mathrm{I} \frac{1}{2}$ ploughs and 2 acres of meadow, worth IOs. The Bishop (has) the soke.

In Badingafelda [Bedingfield] the same (holds) 7 villeins (with) 60 acres and $I \frac{1}{2}$ ploughs. Wood(land) for 40 swine. This lies in Acolt [Occold] and is included in its valuation. The soke (is) the Bishop's.

\section{In Blidinga [Blything] Hundret}

In Stouone [Stoven] Hugh de Montfort holds in demesne 50 acres of land which 4 freemen held T.R.E., and now 3. Half an acre of meadow. And I plough on the demesne. It was worth then as now $7 \frac{1}{2} \mathrm{~s}$, and 100 herrings. And the King and the Earl had soke and sac over these 4 men.

\section{Hundret of Colonesse [Colneis]}

In Nachetuna [Nacton] Gutmund held in demesne T.R.E. 2 carucates of land as a manor. Then as now 6 villeins. Then as now on the demesne 2 ploughs. Then 3 ploughs belonging to the men, now 2. Wood(land) for 8 swine. 2 acres of meadow. Then I mill, now none. Then 4 rounceys, now I, and $I$ beast. Then 8 swine, now none. Then 23 sheep, now 123. Then 30 goats, now none. Then as now it was worth and is worth 70 s. $^{273}$ It is $I \frac{1}{2}$ leagues long, and I league broad. And in geld (pays) $2 d$.

In Brihtoluestuna [ ] (were) 18 freemen under commendation to Guthmund with I carucate of land and 20 acres. 4 bordars.

$$
\text { n3 ' 'it is worth } 4 \text { h' ; Inq. El. } 143 .
$$$$
294 \text { ' } 3 \text { bordars'; ibid. }
$$ 


\section{THE HOLDERS OF LANDS}

Then 10 ploughs, now 5. 2 acres of meadow. Wood(land) for 2 swine. A church with 6 acres. It is half a league long and 2 furlongs broad. And (pays) rod. in geld.

In Leukntona [Levington] (were) 3 freemen with 20 acres under commendation to the said (Guthmund). Then 2 ploughs, now 1.

\section{In Culuerdestuna [}

] (were) 5 freemen under commendation to the same with $21 \frac{1}{2}$ acres. Then 2 ploughs, now $I$. It is 3 furlongs long, and 2 broad. (Pays) 2d. in geld.

\section{In IsteuERTONA ${ }^{298}$ [ ] were 4 freemen} under commendation to the same with 18 acres. Then 2 ploughs, now I. And I acre of meadow. Worth 4 li. and Ios. ${ }^{2 m}$ Over all this land Saint Etheldreda (has) the soke.

fol. 4066 .

In W ALETUNa [Walton] was a freeman Lurc by name under commendation to the said Norman with 24 acres. Worth 4s. Norman holds of Hugh. Saint Etheldreda (has) the soke.

And the aforesaid manor of Nachetuna [Nacton] Gutmund held, on the day on which King Edward died, of Saint Etheldreda so that he could not sell or give it from the church by the agreement that after his death it ought to return to the church in demesne. And this the Hundred ${ }^{283}$ testifies.

\section{Hundret of Carleforda [Carlford]}

In Bischelea [Bixley] on the demesne 3 freemen under commendation to Gudmund T.R.E. (held) 29 acres, and I plough and I acre of meadow, and they are (included) in the valuation of Brithtoluestuna [ ].

In Burg [Burgh] (was) a freeman under commendation T.R.E. half to Saint Etheldreda, and half to the predecessor of Robert Malet. Now (there are) 3 men (with) 20 acres of land. ${ }^{999}$ Then I plough, now half a plough. 2 acres of meadow. Then it was worth IOs., now 5s.

In the same (vill was) a freeman under commendation half to Saint Etheldreda, and half to Edric Grim with 19 acres ${ }^{300}$ of land and 1

as Measures and geld omitted; ibid. See n. 297.

m 'Misdeuetona,' 'Isdeunetnna' ; ibid. 'Isdeuetune'; ibid. 186.

$\$$ 'All these freemen are worth 4 il. Ios.' Then are entered the measures and geld of 'Brixtewoldestona'; ibid. 143. 'Sdeuetona (Isdeuetona) is 3 furlongs long and 2 broad. And (pays) 2d. in geld '; ibid. 144 .

'and the shire'; Inq. El. 144.

2. 'a half-freeman Stanhard under commendation to St. Etheldreda (with) 20 acres $^{3}$; ibid. 150. 500 ' 16 acres"; ibid. bordar. Then I plough, now half a plough. I acre of meadow. Worth 4 s. and $9 d^{301}$

In Parva Brlinges [Little Bealings] a freeman under commendation half to Saint Etheldreda and half to Edric (held) $4 \frac{1}{2}$ acres. Worth $8 d^{302}$

In Clopetuna [Clopton] $2 \frac{1}{2}$ freemen ${ }^{203}$ under commendation like the others as above (held) 14 acres. Then half a plough, now none. Worth 2s. and $7 d^{304}$

\section{HUNDRET OF Wileford [WiLFord]}

In KRRESFELDA [Charsfield] on the demesne Io freemen, half under Edric's commendation and half under Saint Etheldreda's, ${ }^{306}$ (held) 60 acres and $I$ acre of meadow. Then 2 ploughs, now 1. Then worth 245 , now $22 s$. and $8 d^{306}$

\section{HUNDRET OF LOSA [LOES]}

In CER ESFELda [Charsfield] 2 freemen ${ }^{307}$ under commendation of Saint Etheldreda, and over I Hugh de Montfort's predecessor had half commendation, (held) 7 acres, worth $16 d$.

In Gretingaham [Cretingham] Roger de Candorso (now) holds; Aluric a freeman under Harold held T.R.E. $2 \frac{1}{2}$ carucates of land and I 5 acres. Then as now 6 villeins, and 2 I bordars. Then 2 serfs. And on the demesne 2 ploughs. And 6 ploughs belonging to the men. And 8 acres of meadow. Wood(land) for 8 swine. I

fol. 407 .

mill. Then I rouncey, 2 beasts, 20 sheep, and 20 swine. Then it was worth roos, now $8 \mathrm{li}$. and an ounce of gold. It is I league long, and 3 furlongs broad. And in geld (pays) IId. Others have holdings therein.

In the same (vill were) Io freemen under commendation of the same (Harold) with 46 acres. $9 \frac{1}{2}$ acres William de Arcis claims and 2 half (free)men. Then as now I plough. Worth 20s. One of these was under commendation of Edric of Laxfield, and William Malet was seised thereof on the day on which he died.

This R[oger de Candos] holds of Hugh.

\section{WANNEForda [W ANGFord] Hundret}

In Willingaham [Willingham] on the demesne 15 freemen T.R.E. under Burcard's

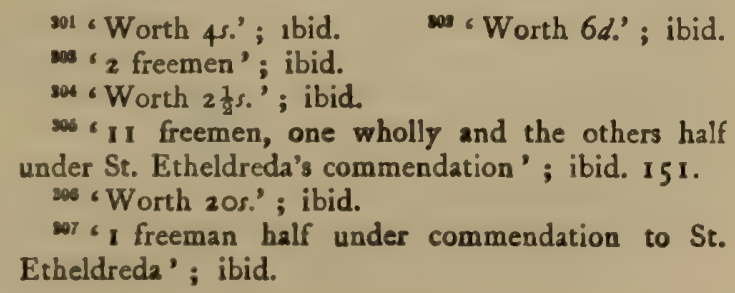




\section{A HISTORY OF SUFFOLK}

commendation (held) I $\frac{1}{2}$ carucates of land and I 8 acres. Then as now 2 villeins. Then 7 ploughs, now 6. Wood(land) for ro swine. I acre of meadow. A church with 40 acres, worth 7s. Several persons have part thereof. Then worth 60 s., now 30 s. and $30 \mathrm{~d}$. and 3,000 herrings. The King and the Earl (have) the soke.

In WESTUNA [Weston] a freeman under the same (Burckard's) commendation, held 16 acres and half a plough. Worth 5 s. and 400 herrings.

In Wellingaham [Willingham] a freeman under Burckard's commendation, who could not sell nor give his land, (held) 3 acres of free land. Worth $18 d$. and 100 herrings.

\section{In Hatheburgfelda [}

freemen under commendation to Burcard (held) 60 acres. Then 2 ploughs, now $1 \frac{1}{2}$. Then worth I Os., now I Is. and $8 d$., and 900 herrings.

In W ARLINGAHAM [Worlingham] $5 \frac{1}{2}$ freemen under commendation to Gurth (held) 60 acres. Then as now 2 ploughs. And 1 bordar. 2 acres of meadow. Then as now worth 10 . and $6 d$. and 1,000 herrings.

\section{Ludinga [Lothingland] Hundret}

In Beketuna [ ] on the demesne 6 freemen under Burchard's commendation (held) 50 acres of land. Then I plough, now half a plough. Then worth 4s., now 2 Is, and 4d. and 1,500 herrings.

In Kessingelanda [Kessingland] a freeman under commendation to Edric of Laxfield (held) 30 acres of land as a manor. Then as now I plough. And I acre of meadow. Then worth $5 s$, now 8s.

\section{fol. $407 b$.}

In the same (vill) 4 freemen, I under Edric's commendation and 3 under Burckard's commendation, (held) T.R.E. 90 acres, and 2 bordars. Then as now 2 ploughs. And 1 acre of meadow. Then worth IOs., now 22s, and I,, 00 herrings.

In RodenhalA [? Rotherhall ${ }^{208}$ ] a freeman Aslac under Burcard's commendation (held) 40 acres as a manor. Then as now 4 bordars. Then as now on the demesne I plough. And belonging to the men half a plough. Wood(land) for 3 swine. And $1 \frac{1}{2}$ acres of meadow. Then worth 5s., now 9s. and 600 herrings.

The whole (is held) in demesne.

In Wimundahala [ ] 2 freemen under Burckard's commendation (held) 12

$$
\text { as In Pakefield. }
$$

acres. Then as now half a plough. Then

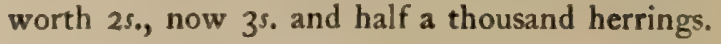

In Gisleham [Gisleham] 2 freemen under the same (Burckard's) commendation (held) $1 \frac{1}{2}$ acres. Worth $2 s$. and $6 d$. and 200 herrings.

In the same (vill) a freeman under the same (Burckard's) commendation (held) 16 acres and half a plough. Worth 5 s. and 300 herrings.

In Hornes [ ] a freeman under Gurth's commendation T.R.E. (held) 5 acres. Worth $3^{5}$. and 160 herrings.

In Carletuna [Carlton (Colville)] 2 freemen under Burchard's commendation (held) 30 acres. Then as now 1 plough. Worth 3s. and 400 herrings.

In the same (vill) a freeman under the same (Burchard's) commendation held 30 acres. Then I plough, now none. Half an acre of meadow. Then and now worth 5s. and 300 herrings.

In KirkrLeA [Kirkley] a freeman half under Burchard's and half under Ulsi's commendation (held) 12 acres. Then half a plough, now none. Then worth 25 ., now 3 s. and 200 herrings.

In Riscemara [Rushmere (St. Michael)] a freeman under Gurth's commendation (held) 16 acres. Then I plough, now half a plough. Worth 5 s. and 300 herrings.

All this Hugh holds in his demesne.

And (there is) the fourth part of a church with I acres, worth $16 d$. The King and the Earl (have) the soke. (Of) four of the men aforesaid the Hundred witnesses that Walter de Douai was seised on the day on which he made forfeiture, and later Earl Hugh (was seised), now Hugh de Montfort. But he does not hold by livery of seisin (per liberationem), as witness the Hundred. And Hugh de Montfort's men say that W(alter) himself held of him.

fol. 408.

\section{Hertesmara [Hartismere] Hundret}

In Cotintuna [Cotton] a freeman Saxwin under Burchard's commendation (held) 20 acres T.R.E. Then 1 plough, now half a plough. Half an acre of meadow. Wood(land) for 2 swine. And it is included in the valuation of the demesne of Neutuna [(Old) Newton].

In Wluerthestuna [Wyverstone] Hervey holds 2 freemen (formerly) under commendation to Burchard with 18 acres. Wood(land) for 2 swine. Worth 4 s. and 5 (pence).

In Caldecoten [ ] (Hugh) holds in demesne a freeman (with) $2 \frac{1}{2}$ acres, worth $6 d$.

In Gislingaham [Gislingham] Gilbert holds a freewoman (formerly) under commendation to 


\section{THE HOLDERS OF LANDS}

Gutmund with 15 acres and 1 acre of meadow. Worth 2 s.

In Caldrcotan [ (are) $3 \frac{1}{2}$ acres worth $6 d$.

] in demesne

\section{LAcForda [Lackford] HUndret}

Liuermera [Livermere] Hugh de Beuerda holds of Hugh, which Gutmund held T.R.E. under Saint Etheldreda, and he could not sell it; 2 carucates of land as a manor. Then as now 4 villeins, and 3 bordars. Then 3 serfs, now $\mathbf{I}$. Then as now 2 ploughs on the demesne. Then and afterwards 2 ploughs belonging to the men, now 1. And 4 acres of meadow. And I fishery. Then as now 1 horse. And 3 beasts. Then ro swine, now 3. 160 sheep, now 100. Saint Etheldreda has soke and sac. And the same (Hugh) holds 3 freemen under Gutmund by commendation and by soke and sac under Saint Edmund (with) 80 acres of land, and half the commendation of one (freeman) with the land Saint Edmund had T.R.E. Among them all were then as now 2 ploughs. And I acre of meadow. The manor was worth 40 s., and the

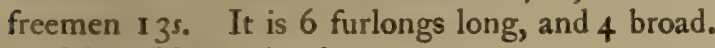
And in geld (pays) $4 d$.

\section{Baberga [Babergh] Two Hundrets}

Stanksted a [Stanstead] Gutmund the thegn held T.R.E., Hugh holds it in demesne; 5 carucates of land as a manor with soke. Then 4 villeins, afterwards and now 3 . And 10 bordars. Then and afterwards 10 serfs, now 6 . Then 4 ploughs on the demesne, afterwards and now 3 . Then as now 2 ploughs belonging to the men. And 16 acres of meadow. And 1 mill. Wood(land) for 20 swine. Then 3 horses, now 4. fol. 4086 .

Then as now 16 beasts, 60 swine, and 100 sheep. Then and later it was worth $6 / i$, now it renders $12 l i$. It is 1 league long, and 4 furlongs broad. And (pays) $7 \frac{1}{2} d$. in geld whoever be the holier thereof. A church with 25 actes of free land.

\section{Stou [Stow] Hundret}

Hagala [Haughley] Gutmund held under King Edward as a manor 8 carucates of land with soke and sac over the hall demesne only. Then 32 villeins, afterwards and now 30 . And 8 bordars. And then 10 serfs, afterwards 6, now 3 . Then as now 4 ploughs on the demesne. Then and afterwards 24 ploughs belonging to the men, now 8 ploughs. Wood(land) for 200 swine. And 42 acres of meadow. A church with $3^{1}$ acres of free land and half an acre of meadow. Then as now 6 horses at the hall, 18 beasts, 80 swine, 146 sheep, and 80 goats.
And on the demesne 6 sokemen under the said Gutmund, whose soke is in the Hundred, and they had not power to sell their land, (held) then and always half a carucate and 20 acres of land. Then and afterwards 2 ploughs, now none. Then the whole was worth $16 \%$, afterwards 12li, now 20.i. Of this manor Hervey holds I carucate and 30 acres worth 63s., and Ralph (holds) I carucate worth 20s. Turold I carucate worth 30 . Pesserera half a carucate worth I0s. Robert 20 acres worth 5s. Richard 30 acres at 5s. All this is (included) in the valuation (pretio) of the manor. It is I league long, and half a league broad. And (pays) $17 d$. in geld.

In DaGaworda [Dagworth ${ }^{309}$ ] Hugh holds in demesne 7 freemen whom Gutmund, predecessor of Hugh, held by commendation only (having) 2 carucates of land within the soke of the King and the Earl. And under them are 17 bordars. Then and afterwards 5 ploughs among them all, now 4. Wood(land) for 12 swine. And 8 acres of meadow. Then and afterwards worth $45^{\text {s., }}$ and now 45 s.

In the same DAGAWARDA [Dagworth] (Roger) holds in demesne 6 sokemen belonging to Tornei [Thorney ${ }^{310}$ ] the King's crown manor (manerium regis de regione) with all customs. And they have among them all I carucate of land and 4 bordars. Then and afterwards 3 ploughs, now 2. And 5 acres of meadow. Then and afterwards worth 30 s, now 20 s. Half a church with 25 acres of free land. And these 6 sokemen Hugh claims by livery of seisin (ex liberatione). Dagaworda [Dagworth] is I league (long), and

fol. 409 .

half a league broad. And (pays) 30d. in geld, whoever may be tenant therein.

In WatDena [Wetherden], (now held) in demesne, were 17 freemen under Gutmund, the predecessor of Hugh, by commendation only ; and they had 2 carucates of land within the soke of the King and the Earl. Then 10 bordars and always. Then 5 ploughs, afterwards 4 , now 5 among them all. Wood(land) for 4 swine. And 6 acres of meadow. Half a church with 15 acres of free land and $I$ acre of meadow. Then and afterwards worth 50 s., now 40 s. It is I league long and half a league broad. And (pays) $25 d$. in geld, whoever may be the tenant therein.

In ERUestuna [ ] Io freemen under Gutmund, the predecessor of Hugh, by commendation only (held) half a carucate of land within the soke of the King and the Earl; and 2 bordars. Then and afterwards 3 ploughs among them all, now they have scarcely 1 plough. And 4 acres of meadow. Then and afterwards

${ }^{200}$ In Haughley.

${ }^{30}$ In Stowmarket. 


\section{A HISTORY OF SUFFOLK}

worth 20s., now IOS. A church with 10 acres of free land. It is 10 furlongs long, and 6 broad. And (pays) $10 d$. in geld whoever may be the tenant therein.

In TORPE [Thorpe] 16 freemen under (Hugh's) predecessor by commendation only (held) I carucate of land within the soke of the King and the Earl; and 2 bordars under them. Then and afterwards 3 ploughs among them all, now I. And 3 acres of meadow. Then and afterwards worth 30 s. Now worth scarcely Ios. It is 5 furlongs long and 3 broad. And (pays) $8 d$. in geld whoever may be the tenant there.

In UltuNa [ ], (now held) in demesne, 3 freemen under the said Gutmund by commendation only (held) half a carucate of land within the soke of the King and Earl and I3 acres. Then and afterwards 3 bordars, now I. Then as now I plough. And 4 acres of meadow. And I mill. But the Count of Moretaine claims half. And the Hundred testifies (in his favour). Then and afterwards worth 125 , and now a like amount.

In Ciltuna [Chilton ${ }^{311}$ ] and in Torstuna [ ] Hugh holds in demesne, by livery of seisin as he says, 16 sokemen who used to belong to Tornei [Thorney] King Edward's manor with every (sort of) custom, as the Hundred testifies, and they have I carucate of land, and 7 bordars. Then and afterwards 4 ploughs among them all, now 3 ploughs, and 6 acres of meadow. Then and afterwards worth 50 s., now 30s. The whole is 4 furlongs long and 3 broad. And (pays) 8d. in geld. And all fol. $409 b$.

these freemen with commendation and soke were delivered, so all Hugh's men say, as 2 manors of 5 carucates of land.

In Dagaworda [Dagworth] Breme a freeman under King Edward, who was killed at the battle of Hastings, held, and he had $1 \frac{1}{2}$ carucates of land, but (this land) was delivered to Hugh as half a carucate by exchange. And the soke (belonged) to the King and the Earl. Then as now I I bordars, and 3 serfs. Then and always 2 ploughs on the demesne. Then and afterwards 2 ploughs belonging to the men, now I plough. Wood(land) for 60 swine. And 9 acres of meadow. And I mill. I church without land, and half a church with 30 acres of land and $x \frac{1}{2}$ acres of meadow. Then 13 beasts, now I0, and 12 swine, 16 sheep, and 40 goats. Then as now worth 60 s. In the same manor (was) Bremere a freeman by commendation only, and he had $11 \frac{1}{2}$ acres, and $I$ bordar. Then and afterwards half a plough, now none. Worth $3^{\text {s. }}$

su In Stowmarket.
William son of Gross holds this manor of Hugh de Montfort.

In Newetuna [(Old) Newton], (now held) in demesne, Alwin de Mellesam [Mendlesham] held I freeman with half a carucate of land, now Hugh holds by exchange; under him were 2 bordars. Then as now I plough. And $I_{\frac{1}{2}}$ acres of meadow. And now 40 sheep, and 3 swine. Then as now worth 40 s.

In the same (vill) Hugh holds in demesne by exchange by livery (ex liberatione) 2 freemen, of whom the soke was in the Hundred, and they have 27 acres. Then as now half a plough. Worth 5 s.

In DaGaworda [Dagworth] Hugh holds half a freeman having 20 acres. Worth $3^{\text {s. }}$

In Torneia [Thorney] Roger de Candos holds I carucate of land of Hugh, which was demesne land in the King's manor and soke T.R.E., but it was delivered (to Hugh) as I carucate of land. This land Ralph the Staller had in pawn (in vadimonio) from Toli the Sheriff, as the Hundred heard say; but (the Court) neither saw the writs nor the feoffor (liberatorem); and Ralph (held) on the day of King Edward's death ; and afterwards Ralph his son. And he (Roger) had 4 villeins, and 3 bordars, and 2 serfs. Then 2 ploughs on the demesne, now I. Then as now 2 ploughs belonging to the men. And 4 acres of meadow. fol. $4 \mathrm{IO}$.

And I mill. Wood(land) for 4 swine. Now Io swine, and 30 sheep. Then as now worth 60 s.

And in the same (vill) the same (Roger) holds 2 freemen having 20 acres. Then and afterwards I plough, now half (a plough). Worth 4od. This is by exchange.

\section{Thewardestreu [ThedWastre] Hundret}

In Begatona [Bacton] a freeman under Edith the Rich held 40 acres of land T.R.E. Now Hugh de Montfort holds (them) through exchange. Then as now half a plough. Worth 5 s.

\section{Half Hundred of Gepeswiz [Ipswich]}

In the borough Hugh has in demesne I burgage (mansura), and it belongs to Nechetuna [Nacton]. The King has all the customs.

\section{Bosemara [Bosmere] Hundret}

At Betesfort [Battisford] Roger de Candos holds of Hugh the land which Aluric a freeman held T.R.E. as a manor, viz. I carucate of land. Then as now 8 bordars. Then 2 ploughs on the demesne, now I. And half a plough belonging to the men. 6 acres of meadow. Wood- 


\section{THE HOLDERS OF LANDS}

(land) for 20 swine. Half a church with 20 acres. Now I rouncey, 4 beasts, 12 swine, 2 I sheep, and 4 goats. Worth 30 s. To this manor Hugh added 5 freemen with I carucate and 10 acres of land. 3 bordars. Then 3 ploughs, now $1 \frac{1}{2}$ ploughs. 6 acres of meadow. Wood(land) for 5 swine. Worth 20s. This is on account of the exchange with St. Augustine's land. Roger de Candos now holds. The King and the Earl (have) the soke. It is Io furlongs long, and 5 broad. Others hold land therein. And it (pays) Iod. in geld.

In DeRmodesduna [Darmsden] Uluric a freeman under commendation (held) T.R.E. 18 acres and half a plough. Worth 2 s. and $7 d$.

\section{Ciaindune [Claydon] Hundret}

In Westrefelda [Westerfield] Hugh holds on the demesne a freeman with 8 acres whom Ordric held. Worth $16 d$.

In SAHAM [Soham] (are) 2 acres of land on the demesne. Worth $4 d$.

fol. 4 I $0 b$.

\section{Hertesmere [Hartismere] Hundret}

At Acolt [Occold] Gutmund held from Uluric his brother, Abbot of Ely, I carucate of land and 40 acres as a manor. Now Roger de Candos holds this of Hugh. Then as now 5 villeins, and 8 bordars. Then 2 serfs. Then and afterwards 2 ploughs on the demesne, now I. Then 2 ploughs belonging to the men, afterwards and now $1 \frac{1}{2}$ ploughs. And 3 acres of meadow. Wood(land) for 40 swine. A church with 8 acres and half a plough. Then as now I rouncey. Then 8 beasts. Then 60 swine, now I3. Then 40 sheep, now 28. And 21 goats. Then worth 6os,, afterwards 4 li., now Ioos. And to this manor have been added 8 freemen with 40 acres. Then and afterwards 2 ploughs, now $1 \frac{1}{2}$ ploughs. A church with 12 acres. Worth Ios. Gudmund (had) soke over the whole. ${ }^{312}$ It is ro furlongs long, and 8 broad. And (pays) $9 d$. in geld.

fol. 411 .

\section{LAND OF GEOFFREY DE MAGNAVILLE}

\section{STOHU [STOW] HUNDRET}

In Cratinga [Creeting] Witgar, a freeman under the Abbot of Ely by commendation only, held T.R.E. 2 carucates of land within the soke of the King and the Earl. Geoffrey has (it) as a

$$
\text { ne 'under the Abbot'; Ing. El. } 153 .
$$

manor by the King's gift. And under him (holds) William de Boeville, but (this land) did not belong to the fee of Ansgar the predecessor of Geoffrey. Then as now 6 bordars. Then as now 2 ploughs on the demesne. Then and afterwards half a plough belonging to the men, now none at all. And 5 acres of meadow. And a fourth share of a mill. And a half share of another mill. Then as now 2 horses at the hall, and 5 beasts, and 8 swine. Then 20 sheep, now 30 . Then as now worth 40 .

And in the same (vill) 5 freemen under the said Witgar by commendation only held 9 acres of land within the soke of the King and the Earl. And half a plough. Worth $2 s$.

In the same manor (was) a freeman under Edric the predecessor of Robert Malet by commendation only; now William de Boeville holds under Geoffrey, and he has 16 acres and 1 bordar, and half a plough; and I acre of meadow. Worth $36 d$.

\section{Claindune [Claydon] Hundret}

In Westrefelda [Westerfield] Langfere a freeman under commendation to Haldein held 14 acres. Worth 2s. The said William holds (under Geoffrey). The King and the Earl (have) the soke.

\section{Sanfort [SAmford] Hundret and a Half}

(At) Holetuna [Holton (St. Mary] Ansgar T.R.E. held 2 carucates of land as a manor. Then as now 13 villeins and 2 bordars. Then 4 serfs, now 3. Then as now 2 ploughs on the demesne. Then 5 ploughs belonging to the men, now 3 , and 24 acres of meadow. A church. Then 2 rounceys, now I, and 2 beasts. Then 12 swine, now 6. Then 60 sheep, now 74. Then worth 60 s., now 40 s. It is 6 furlongs long and 4 broad, and pays $7 d$. in geld. The same Ansgar (had) the soke.

(At) Reinduna [Raydon] Angar held 2 carucates of land as a manor T.R.E. Then as now 8 villeins and 3 bordars and 3 serfs, and 2 ploughs on the demesne. Then 7 ploughs belonging to the men, now 4. 6 acres of meadow. Wood(land) fol. 411 b.

for 16 swine. Then 2 rounceys, now 1 . Then as now 5 beasts and 12 swine. Then 30 sheep, now 50. Then as now worth 8\%. (It is held) in demesne. Of the same land Alured holds I villein with 30 acres, worth 5s. Angar (had) the soke. Of the same land Gilbert, the priest, holds I villein with 30 acres, and half a plough, worth 5 s.

In Belesteda [Belstead] Olf, a freeman under commendation to Ansgar, held T.R.E. and still holds 80 acres. Then as now I villein and 2 


\section{A HISTORY OF SUFFOLK}

bordars. Then I plough, now half a plough, and 2 acres of meadow. Then 1 mill. The fourth part of a church. Then worth ros., now 75. The soke (is) in Bercolt [Bergholt].

Scottuna [Stutton] Rainelm holds of Geoffrey, which Fribern, the King's thegn, held T.R.E. ; 2 (? carucates) of land as a manor. Then as now 2 villeins, and 10 bordars. Then 2 serfs, and now. Then as now 1 plough on the demesne, and I plough belonging to the men, and 4 acres of meadow. The third part of a church with 15 acres. Now 7 beasts. Then 2 swine, now 13 , and 60 sheep, and I salt-pan, and 2 hives of bees. Worth 40s. It is 6 furlongs long and 4 broad, and pays $4 d$. in geld. The same Friebern (had) the soke.

In Gipewiz [Ipswich] I burgage (mansura) and it belongs to (in) Mosa [ ].

In Reinduna [Raydon] Edwin and Brictmar, freemen under commendation to Ansgar, T.R.E. (held) I 5 acres and half a plough, worth 5s. The soke is in Bercolt [Bergholt].

\section{HUNDRET OF WILEFORdA [WILFORd]}

In Cerefelda [Charsfield] a freewoman Leveva under Haldein's commendation T.R.E. (held) 30 acres and 2 bordars. Then as now I plough. 2 acres of meadow. Then and always worth ros.

In the same (vill) a freeman under the said (Haldein's) commendation (held) I I acres, worth $2 s$.

In DEPEBEK [Debach] a freeman under commendation of one himself under commendation of Ralph the Staller held 6 acres, worth $12 d$.

In Bulges [Boulge] a freeman under Haldein's commendation (held) 16 acres. Then I plough, now 2 oxen. Worth 2 s.

fol. 412 .

In the same (vill) a freeman under Haldein's commendation and Uluric's (held) 6 acres, worth I 2 .

In WIKAM [Wickham (Market)] a freeman under Haldein's commendation (held) 3 acres, worth $6 d$.

In Meltuna [Melton] 2 freemen under Haldein's commendation (held) 4 acres, worth $8 d$.

This W[illiam] son of Sahuala holds of Geoffrey de Magnaville.

\section{HUNDRET OF LOSA [LOES]}

At Ledringaham [Letheringham] Haldein held T.R.E. under commendation of Harold 80 acres as a manor. Then 5 bordars, now 10. Then I serf, now 2. Then as now on the demesne 2 ploughs, and belonging to the men 2 ploughs. Wood(land) for 4 swine. 6 acres of meadow. I mill. Then as now 2 rounceys, 6 beasts, 30 swine, 80 goats, and 5 hives of bees. A church with 20 acres, worth $40 d$. Then it was worth 20 s., now a like sum.

In the same (vill) 13 freemen and 2 half freemen under commendation of the same (Haldein), except 6 (who) were under commendation of Saint Etheldreda, (held) 60 acres. Then as now 4 ploughs. 2 acres of meadow. Then it was worth I 7 s., now a like sum.

Moreover in the same (vill) a freeman ${ }^{313}$ under commendation half of Saint Etheldreda and half of Haldein (held) 60 acres as a manor; and 2 bordars. And I plough. ${ }^{314} 4$ acres of meadow. Then as now worth 20 .

In UDEBRIGE [Woodbridge] (were) 2 freemen under commendation of the said Haldein with 33 acres and half a plough and I bordar. Worth 3 s.

This the same William [son of Sahala] holds of Geoffrey de Magnaville.

\section{Waineforda [W AngFord] Hundret}

(At) Scadenafella [Shadingfield] Haldein a freeman under Harold's commendation held I carucate of land as a manor. Then as now I villein, and 10 bordars. Then on the demesne 2 ploughs, now 2. Then as now belonging to the men I plough. 4 acres of meadow. Woodland for 20 swine. And I rouncey, II swine, 80 sheep, and 2 hives of bees. Then worth ros., now 20 s.

In the same (vill) a freeman under Bishop Stigand's commendation (held) I carucate of land as a manor. Then I villein, now the like. Then 5 bordars, now 4. Then on the demesne I plough. Then belonging to the men 2 ploughs, now I. Then worth 20s., now the like. This man was adjudged (derationatus) and seized to the use of the King; and later Waleram seized him ; and gave security thereupon.

Moreover in the said (vill) 2 freemen under commendation to Haldein (held) $32 \frac{1}{2}$ acres as a fol. $412 b$.

manor. Then as now half a plough. Worth 5s. and $8 d$.

In Westuna [Weston] a freeman (held) 5 acres, worth $16 d$.

\footnotetext{
In Wichedis [ ] a freeman (held) I acre, worth $4 d$.
} 313 'Gelric'; Inq. El. 151.
311 ' $1 \frac{1}{2}$ ploughs'; ibid. 


\section{THE HOLDERS OF LANDS}

\section{Hundret of Blidigga [Blything]}

At Turintuna [Thorington] Haldein (Aldenus) held T.R.E. 3 carucates of land as a manor: Then 8 bordars, now 13. Then as now 2 serfs. Then 2 ploughs on the demesne, now 3. Then as now 3 ploughs belonging to the men. Wood(land) for 20 swine. 7 acres of meadow. Then 1 rouncey, now 2. And now 14 swine. Then 72 sheep, now 92. And now 4 hives of bees. And 15 goats. And a mill. And a church with 8 acres. Then it was worth 40 s, now 60s. William de Boeville holds of Geoffrey de Magnaville; and (this estate) does not belong to the Honour of Ansgar.

To this manor are attached 2 freemen with I 20 acres of land. 2 bordars. 4 acres of meadow. Then 2 ploughs on the demesne, now none. Then it was worth I mark of silver, now 8s. This estate (terra) is $\mathrm{I} \frac{1}{2}$ leagues in length, and $1 \frac{1}{2}$ leagues in breadth. And renders $7 \frac{1}{2} d$. in geld.

In NorHais [North Hales] (are) 20 acres of land which a freeman held T.R.E. under Stigand. Now $W$. de Boeville holds them of Geoffrey de Magnaville. Then as now half a plough. Worth 4s.

\section{Hundret of Carleforda [Carlford]}

In TORP [Thorpe (?)] ${ }^{315}$ Halden a freeman T.R.E. held 3 carucates of land as a manor. Then as now 4 villeins and 11 bordars. Then 2 serfs, now 1. Then as now on the demesne 2 ploughs. Then 2 ploughs belonging to the men, now 1. 7 acres of meadow. And 2 rounceys, 7 beasts, 12 swine, and 100 sheep. Then it was worth 20s., now 40s. It is 8 furlongs long, and 6 broad, and (pays) $15 d$. in geld. Others have holdings there.

In Burcg [Burgh] 8 freemen under commendation to the said Halden (held) 54 acres. Then as now 2 ploughs. 2 acres of meadow. Worth 10 .

In GRundesburg [Grundisburgh] (were) 4 freemen under commendation to Halden T.R.E. fol. 413 .

with 26 acres of land, and I plough. Half an acre of meadow. Worth 4 s.

In the same (vill was) Almar, a freeman under commendation to Eilric de Burgh with 8 acres, and half an acre of meadow. Worth $16 d$.

In Hashetuna [Hasketon] (were) 3 half (free)men and I full (freeman) under commendation to Halden T.R.E. with 22 acres of land, and I plough and half an acre of meadow. Worth $3^{\text {s. }}$

In Neckemara [ ] (were) 2 freemen under commendation to Halden with 20 ${ }^{315}$ In Dallinghoo. acres and half a plough. Half an acre of meadow. Worth $2 s$.

In Ingoluestuna [ ] Godric, a freeman, under commendation half to Halden and half to Saint Etheldreda, (held) 20 acres of land. 2 acres of meadow. Worth 2 s.

\section{In Isleuestuna [}

] Halden a soke man held 15 acres, and I bordar. Then I plough, now $\mathbf{I}$ ox. $\quad 1$ acre of meadow. Worth 25.

In BURG [Burgh] 3 freeman T.R.E. under commendation to Halden (held) 50 acres of land. Then 2 ploughs, now I. I $\frac{1}{2}$ acres of meadow. Worth IOS.

In the same (vill) Brichtric, a freeman under commendation to Alric de Burgh, (held) Io acres. Worth 20d.

Moreover in the same (vill) Brihtwold Mufle, under commendation half to the predecessor of Hervey de Beru' and half to the predecessor of Robert Malet, (held) 24 acres. ${ }^{316}$ Then I plough, now none. I acre of meadow. Worth 5s. It is 9 furlongs long and 7 broad, and pays $15 d$. in geld. Others have holdings there.

In Culfola [Culpho] 3 freemen, 2 under commendation to Halden and the third under commendation to Saint Etheldreda, ${ }^{317}$ (held) 30 acres of land, and I bordar. Then 2 ploughs, now none. 2 acres of meadow. Worth 5 s.

In Hobbestuna ${ }^{318}$ [ ] a freeman under commendation to (Saint) $\mathrm{E}$ [theldreda (?)] and his wife under commendation to Halden T.R.E. (held) 30 acres. Then I plough, now none. I acre of meadow. Then as now it was worth 5 s.

In the same (vill) Topi, a sokeman under commendation to Saint Etheldreda, ${ }^{319}$ (held) 15 acres. Worth $3^{\text {s. }}$

In Finlesforda [ ]$^{320}$ Halden (held) 2 acres T.R.E. worth $4 d$. All this William, son of Sahala de Bouville, holds of Geoffrey de Magnaville. Saint Etheldreda owns the whole soke of this hundred.

316 ' In Burch Brixtewold a freeman half under commendation and soke of St. Etheldreda with 40 acres "; Inq. El. 145. This is preceded by the entry of another holding in the same Hundred appropriated by Geoffrey: 'In Guluesteham (Culuesteham, ibid. p. I 86) a half freewoman Mawa in the soke and commendation of St. Etheldreda with 20 acres.'

317 ' a freeman Brixnodde in the soke and commendation of St. Etheldreda (with) I 6 acres'; ibid. 145 .

s18 'Hopestuna'; ibid.

319 'who could not sell his land'; ibid.

${ }^{300}$ Cf. n. 233. 


\section{A HISTORY OF SUFFOLK}

fol. $4^{1} 3^{b}$.

\section{LANDS OF RALPH BAIGNARD}

\section{Risebruge [RIsbridge] Hundret}

(At) Kidituna [Kedington] Ailad held T.R.E. as a manor 5 carucates of land. Then and afterwards 13 villeins, now II. Then and afterwards I bordar, now 2. Then and afterwards 9 serfs, now none. Then and afterwards 3 ploughs on the demesne, now 2. Then and afterwards 8 ploughs belonging to the men, now $2 \frac{1}{2}$ ploughs. 20 acres of meadow. Then I mill. Then 4 rounceys, now 3 . Then 15 beasts, now 4. Then 27 swine, now 18 . Then 52 sheep, now 150 . Now 6 hives of bees. Then worth 6li., now 7 li. and 5 s.

In the same (vill) 25 freemen (held) 2 carucates of land. And 5 bordars, and 2 serfs. Then as now II ploughs. And 6 acres of rrea low. Worth 40s. His (Ralph Baignard's) predecessor had commendation and soke and sac except as to the six forfeitures of Saint Edmund. And of one the predecessor of Richard son of Count Gilbert had commendation. But Baignard claims the whole by exchange. A church with 40 acres of free land and $I \frac{1}{2}$ acres of meadow worth 6 s. It is 12 furlongs long, and 6 broad. And (pays) I $2 d$. in geld, Others hold (land) therein.

In Poslingewrda [Poslingford] (were) 3 freemen. Of two of these his (Baignard's) predecessor had commendation T.R.E., and soke and sac, except the six forfeitures belonging to Saint Edmund, and the same Saint Edmund (had) commendation over the third T.R.E. And the King granted him the land. About this we have seen the writ. And they have I carucate and 20 acres of land. And 7 bordars. And $1 \frac{1}{2}$ ploughs. Wood(land) for 5 swine. Then as now worth 3 Is.

In the same (vill) a freeman (held) $I \frac{1}{2}$ carucates of land. Then as now 6 bordars. And $\mathbf{r}$ plough on the demesne. This Noriolt holds. Then 2 rounceys, and now the like, and 6 beasts, 16 swine, and 20 sheep. Then worth 20 s, now 25 s.

In the same (vill) a freeman (held) $1 \frac{1}{2}$ carucates of land. And 3 bordars. And $1 \frac{1}{2}$ ploughs. And 4 acres of meadow. Now 2 rounceys, 4 beasts, 20 swine, and 29 sheep. This Walter holds. Worth 30 s.

In the same (vill) 2 freemen held $\times 60$ acres. And 8 bordars. And I plough. Worth 26s. fol. 414 .

and $8 d$. This Richer holds. A church with 40 acres of free land, wort' 6 s. Saint Edmund (has) the six forfeitures. Baignard (has) the soke. It is 13 furlongs long, and 12 broad. And (pays) 15d. in geld. Others hold (land) therein. This is on account of the exchange.
(At) Witeskeou [Wixoe] Godwin the thegn held as a manor 3 carucates and 15 acres of land T.R.E. Then as now 6 villeins. Then 4 bordars, now 5. Then 6 serfs, now 4. Then as afterwards 3 ploughs on the demesne, now 2. Then as now $2 \frac{1}{2}$ ploughs belonging to the men. Wood(land) for 10 swine. 12 acres of meadow. Then as now I mill. Now 2 rounceys. Then 24 beasts, now 12 . Then 40 swine, now 12. Then 60 sheep, now 40. And 5 hives of bees. A church with 5 acres. And 2 freemen (held) 25 acres, I plough and I acre of meadow. His (Baignard's) predecessor (had) commendation and soke. Saint Edmund (had) the six forfeitures. Then and afterwards worth 83 s., and the like now. It is half a league long, and $3 \frac{1}{2}$ furlongs broad. And pays $3 d$. in geld. Others hold (land) there.

\section{Bidinga [Blything] Hundret}

(At) Rernduna [Reydon] Toret held 5 carucates of land. Then and afterwards 14 villeins, now 5. Then and afterwards 16 bordars, now 20. Then 2 serfs, now I. Then and afterwards 3 ploughs on the demesne, now 2. Then and afterwards II ploughs belonging to the men, now 7 . Wood(land) for 60 swine. Then 3 rounceys, now 1. Then 12 beasts, now 5. Then 40 swine, now 30. Then as now II sheep. Now 15 goats. Then it was worth roos, now 7 li. and Ios.

In the same (vill) 30 freemen held 2 carucates of land and 5 acres and 2 bordars. Then and afterwards 8 ploughs, now 6 . It was worth 12li. and ros. Over these his predecessor (had) commendation and soke and sac T.R.E.

In the same (vill) 2 freemen by commendation (held) 16 acres and half a plough. It was worth 10s. The King and the Earl (have) the soke. This is by way of exchange. It is I league and 6 furlongs long, and I league and 3 perches broad. And pays $6 \frac{1}{2} d$. in geld. 2 churches with I carucate of land are worth Ios.

In Brantuna [Brampton] II freemen by commendation T.R.E., now IO, (held) 2 carufol. $414^{b}$.

cates of land and 60 acres. Then 2 villeins, now 1. Then 8 bordars, now 17. Then 9 ploughs, now 7 . Wood(land) for 20 swine. And 2 acres of meadow. Then it was worth 30s., now 40 s. The King and the Earl (have) the soke. (This he holds) by way of exchange.

In the same (vill) a sokeman holds 2 carucates of land. And 2 villeins, and 8 bordars. And 3 ploughs. Wood(land) for 3 swine. And 2 acres of meadow. Worth 30 s. A church with 16 acres, worth $16 d$. The King and the Earl (have) the soke.

At Froxedena [Frostenden] Toret held as a manor 3 carucates of land T.R.E. Then as 


\section{THE HOLDERS OF LANDS}

now 10 villeins. Then 14 bordars, now 20 . Then 2 serfs. Then as now 2 ploughs on the demesne. Then as now I seaport. Then and afterwards 9 ploughs belonging to the men, now 7 . Wood(land) for 40 swine. Then I salt-pan, now none. And 3 acres of meadow. Then 2 rounceys, now 1. Then ro beasts, now 6 . 'Then 60 swine, now 13 , and 60 sheep, 24 goats, and 2 hives of bees. Then as now it was worth 4 li. The King and the Earl have the six forfeitures.

In the same (vill) 8 freemen T.R.E., now 3, (held) 113 acres. Then 3 ploughs, now I. And half an acre of meadow. Then it was worth 10s., now 14s. (This he holds) by reason of the exchange. The King and the Earl (have) the soke.

(It is) $x$ league and 24 perches long and 10 furlongs and 7 perches broad. And pays $4 d$. in geld. Ranulf holds it. 2 churches with 28 acres (and) I plough, worth 3 s.

(At) W ANKEFordA [Wangford] Toret held as a manor T.R.E. 2 carucates of land. Then as now 8 villeins. Then and afterwards 13 bordars, now 21. Then 2 serfs. Then as now 2 ploughs on the demesne. Then 8 ploughs belonging to the men, now 7. Wood(land) for 60 swine. And 2 acres of meadow. Then as now I mill. Then I salt-pan. Then 2 rounceys. Then 24 beasts, now 17. Then 35 swine, now 17. Then roo sheep, now 80. And 8 goats. And 5 hives of bees. Albold holds it. Then as now it was worth 4 li. It is I league and I furlong long, and 9 furlongs broad. And pays $7 d$. in geld. Others have holdings therein. The King and the Earl (have) the six forfeitures.

In Henнam [Henham] a freeman Alwin held by commendation I carucate of land as a manor. Then as now 4 villeins. Then $1 \mathrm{I}$ bordars, now 14. Then 2 ploughs on the demesne, afterwards 1 , now 2. Then and afterwards 5 ploughs belonging to the men, now 3. Wood(land) for 40 swine. And half an acre of meadow. Then fol. 415 .

as now I mill. Now I rouncey, and 8 beasts. Then 4 swine, now 14 . Then 20 sheep, now 40. Then as now 16 goats. Now 4 hives of bees. Then as now it was worth 40 s. The King and the Earl (have) the soke. This Robert of Blideburc [Blythburgh] holds. This is by reason of the exchange.

\section{Blidinga [Blything] Hundret}

(At) Upbestuna [Ubbeston] Tored held T.R.E. as a manor 3 carucates of land. Then 15 villeins, afterwards 7 , now 3 . Then 4 bordars, afterwards 5, now 20. Then 2 serfs, now 1. Then and afterwards 2 ploughs on the de- mesne, now 3. Then and afterwards 9 ploughs belonging to the men, now ro. Wood(land) for I 60 swine. And 7 acres of meadow. Then I rouncey, now 2. Then 16 beasts, now 19. Then as now 30 swine. Then 12 sheep, now 92. Then as now it was worth Ioos.

To this manor belong (jacent) 3 freemen with 42 acres and $I$ bordar and I plough and wood(land) for 16 swine and $I$ acre of meadow. T.R.E. they were worth $6 s$. and $8 d$., now 8s. And a church with 3 acres, worth $3 d$. And all this land is 7 furlongs long and 4 broad. And in a King's geld renders $3 d$.

In Cratafelda [Cratfield] Tored held $3 \frac{1}{2}$ carucates of land as a manor. Then as now 5 villeins. Then and afterwards 9 bordars, and now 31 . Then as now 1 serf. Then as now on the demesne 2 ploughs. Then 7 ploughs belonging to the men, now 10. Wood(land) for 250 swine. $3 \frac{1}{2}$ acres of meadow. Then and now I rouncey. Then 8 beasts, now 14. Then 40 swine, now 47 . Then 26 goats, now 32 . And a church with 6 acres, worth $6 d$. Then as now (it was worth) 4 li. And to this manor are attached 5 free (franci) men with 26 acres. And then as now 2 ploughs. And wood(land) for 6 swine. It was worth 6s. and 8d. And those men render soke to this manor.

(There were) besides 2 men with 40 acres and I plough. Worth 5s. And the soke of those two was in Bledeburc [Blythburgh]. And William Bainard holds these two manors (mansiones) of Ralph his uncle.

In the same vill a certain freeman (francus) holds a manor of 40 acres, and 3 bordars. Then as now I plough. Wood(land) for 6 swine. I $\frac{1}{2}$ acres of meadow. T.R.E. it was worth IOS, now 20s. And this manor is in Ralph's demesne.

And all this land is 8 furlongs long and 5 broad. And renders towards the King's geld $3 \frac{1}{2} d$.

\section{fol. 4156 .}

\section{HUNDRET OF W ANNEFORD [W ANGFORD]}

In Scadenafella [Shadingfield] a freeman Toredi (held) 20 acres of land. Then I plough, now none. Worth 3 s.

\section{Thewardastreu [Thedwastre] Hundret}

In Stanfella [Stanningfield] Elflet a freewoman held under Saint Edmund T.R.E. I carucate of land. Now Bainard holds it through exchange. Then I bordar, now 3. Then 2 serfs, now I. Then 2 ploughs on the demesne, afterwards half a plough, now I plough. And 5 acres of meadow. Now 1 mill, Then worth 30s., now 40s. In the same (vill) 3 freemen under the said Elflet by commendation (held) 30 acres of land within Saint Edmund's soke. Then as now I plough. And 1 acre of meadow. Then as now worth 5 s. 


\section{A HISTORY OF SUFFOLK}

\section{Babenberga [Babergh] Two Hundrets}

At Simplinga [Shimpling] Ailith a freewoman under King Edward of glorious memory held $6 \frac{1}{2}$ carucates of land as a manor. Then 9 villeins, now 12. Then 12 bordars, now 16 . Then 3 serfs, now none. Then and afterwards 4 ploughs on the demesne, now 3. Then 7 ploughs belonging to the men, now 6. Wood(land) for 100 swine. And 17 acres of meadow. Then 4 horses, now 5. Then 7 beasts, now 5. Then 60 swine, now 33. Then 80 sheep, now 100. Then I6 goats, now 24. A church with 60 acres of free land, and I bordar, and I plough, and half an acre of meadow. Then it was worth 1oli., afterwards and now $12 \%$. It is I league long, and half a league broad. And (pays) $15 d$. in geld.

In the same (vill) a freeman under Ailith by commendation in Saint Edmund's soke (held) 30 acres and I bordar. Then as now I plough and $\mathrm{I} \frac{1}{2}$ acres of meadow. Then as now it was worth ros. And this Bainard holds by reason of the exchange.

fol. 416 .

\section{XXXIIII. LANDS OF RANULF PEVERELL}

\section{LACFORda [LACKFord] HUNdRet}

In Ecclingaham [Icklingham] Seward of Melduna [Maldon] held under King Edward, but in Saint Edmund's soke and sac, 3 carucates of land as a manor. Then as now 6 villeins. Then 2 bordars, now 1 . Then and afterwards 4 serfs, now 3. Then as now 3 ploughs on the demesne. And 2 ploughs belonging to the men. And I mill. Then 1 horse, now none. And then 3 beasts, now 2. Then 30 swine, now 21 . Then 250 sheep, now 350 . Then and afterwards it was worth 4 li., now roos. Saint Edmund (has) the soke.

\section{Baberga [Babergh] Hundret}

At Aketona [Acton] Seward of Meldona [Maldon], the thegn, T.R.E. held 12 carucates of land as a manor with soke and sac. Then as now 23 villeins. Then as now $3^{8}$ bordars. Then as now 17 serfs. Then 8 ploughs on the demesne, afterwards and now 6 . Then 20 ploughs belonging to the men, afterwards and now I 4 . And 50 acres of meadow. Wood(land) for 40 swine. Then and afterwards 2 mills, now 1 . Then 8 horses at the hall, now II. Then 34 beasts, now 3r. Then 200 swine, now 160. Then 300 sheep, now 423 sheep. Then 9 hives of bees, now 7. A church to which are attached 30 acres of free land. Then and afterwards it was worth 20li, now 30 li.
In Aratona [Acton] (were) 4 freemen whom Ranulf received as an estate (terra) of 50 acres. In Walingafella [Waldingfield] 5 freemen (with) 72 acres. In the other Walingafella [Waldingfield] 3 with 50 acres. In Honilega [ ] I with 50 acres. In Manetuna [Manton] ${ }^{321}$ I freeman with 50 acres. Among them all they had 7 bordars. Then and afterwards 5 ploughs, now 4. These freemen then and afterwards were worth 4 li., now 6os. Of them all II could and 4 could not sell their lands; but of all of them Ranulf's predecessor in title had commendation and soke, except of one who is in Saint Edmund's soke. Ranulf received them all as (one) estate (terra).

Achetuna [Acton] is one league long, and I league broad. And (pays) 13 d. in geld.

At Asetona [Assington] the same Seward, fol. $416 b$.

Ranulf's predecessor, held 8 carucates of land as amanor with soke and sac T.R.E. Then and afterwards 14 villeins, now 5 . Then and afterwards $2 \mathrm{I}$ bordars, now 55 . Then and afterwards 14 serfs, now 12 . Then and afterwards 7 ploughs on the demesne, now 6. Then and afterwards 13 ploughs belonging to the men, now 12 . Wood(land) for 30 swine. And 15 acres of meadow. And 1 mill. Then 6 horses at the hall, now 5. Then 24 beasts, now 23 . Then 100 swine, now 60. Then 210 sheep, now 90. Then 14 hives of bees, now 6. Now 12 goats. A church with 30 acres of free land.

In the same (vill were) 5 freemen under the same Seward by commendation and soke. But they could not sell their lands, still remaining however within the soke. And they had among them all 30 acres of land and $I$ acre of meadow. Then as now I plough. Moreover in the same (vill was) a freeman made over as an estate (liberatus pro terra), but he does not belong to the manor of which Ranulf's predecessor had commendation and soke. And he had 30 acres. Then as now I plough. Then it was worth roli., and afterwards 1 2 li., now 20li. But it could not render within IOOs. (of that amount). Of these 20li., 20s. are (assessed) upon these freemen. It is I league long, 8 furlongs broad. And (pays) $7 d$. in geld.

In Clamesforda [Glemsford] Blacuin under Siward's commendation held 30 acres as a manor T.R.E. Worth 6s. Garin holds it. Saint Etheldreda has the soke.

In LosAM [Loose ${ }^{322}$ ] Leustan holds (and) held under King Edward of glorious memory $1 \frac{1}{2}$ carucates of land. Of I carucate the soke belonged

${ }^{3 n}$ In Hitcham; Copinger, Suff. Rec.

"In Hitcham; ibid. 


\section{THE HOLDERS OF LANDS}

to Holy Trinity in Canterbury. Then as now 6 bordars. Then 2 serfs. Then as now 2 ploughs on the demesne, and none belonging to the men. And 6 acres of meadow. Then 2 horses, now none. Then 10 beasts, now none. Then 30 swine, now none. Then 74 sheep, now none. Then and afterwards it was worth 40 s., and (the like) now. It is half a league long, and 4 furlongs broad. And (pays) I $d$. in geld.

\section{STOHU [STOW] HundReT}

Anuhus [Onehouse] Ketel King Edward's thegn held as $1 \frac{1}{2}$ carucates and 20 acres with the soke. Then as now 8 bordars and 4 serfs. Then and afterwards 3 ploughs on the demesne, now 2. fol. 417 .

And then as now $x$ plough belonging to the men. And 12 acres of meadow. Woodland for 6 swine. And 1 rouncey, and 6 beasts. Then 16 swine, now 30. Then 40 sheep, now 87 , and 22 goats. A church with 3 acres of free land. Then and afterwards worth 4 Oos, now 5 os. It is 5 furlongs long and 3 broad. And pays $6 \frac{1}{2} d$. in geld.

To (in) ANEus [Onehouse] belonged T.R.E. 26 acres, and now Osbert Masculus holds (them as belonging) to the church of Stou [Stow]; and he held them before Ranulf had the manor of Anuhus [Onehouse].

\section{Bosemara [Bosmere] Hundret}

Burghestala [Burstall] Ralph de Savigny holds of Ranulph, which Turchill the thegn held T.R.E. as a manor, viz. 28 acres. Now 2 bordars. Then as now 1 plough on the demesne. And 2 acres of meadow. Then as now $\mathbf{I}$ rouncey, and I beast. Now 9 swine. Then 14 sheep, now 30 . Then it was worth 5s. and $4 d$., now 8s.

In BRIrsetA [Bricett] Ralph son of Brien holds what Lefstan held T.R.E., viz. 2 carucates of land and 4 acres as a meadow. Then as now $I$ villein, and ro bordars, and 2 serfs. And 3 ploughs on the demesne. And 6 acres of meadow. Wood(land) for 10 swine. Then 2 ploughs belonging to the men, now I. Of this land 54 acres which Ralph son of Brien now holds on his demesne were attached to a certain church. Then 2 rounceys, now 5. Then I0 beasts, now 15. Then 30 swine, now 50. Then 80 sheep, now 140.

In the same (vill were) 4 sokemen with $4 \mathrm{I}$ acres. Then $\mathrm{I}_{2} \frac{1}{2}$ ploughs, now 2 oxen. The King and the Earl (have) the soke. Then it was worth 6os., now roos.

Codeham [Coddenham] Humphrey son of Aubrey holds, he holds of Ranulf, which Leuric a freeman held T.R.E., viz. 60 acres as a manor. Then as now 3 bordars. And 2 ploughs. And 4 acres of meadow. Wood(land) for 60 swine. Some part of three churches. And I rouncey. Then 8 beasts, now 6 . And 14 swine, and 12 sheep. Then it was worth 20s., now 40s. A church with 3 acres, worth $6 d$.

In Mucelfelda [Mickfield] Ralph de Savigny holds 12 acres, and 3 bordars. Half a church. And $2 \frac{1}{2}$ acres (of meadow). And they are included in the valuation of Oluestuna [Ulverston]. The King and the Earl (have) soke over the whole.

In Stanham [Stonham] the fourth part of a church with $7 \frac{1}{2}$ acres. Worth $15 d$.

fol. $417 b$.

\section{Claindune [Claydon] Hundret}

(At) Depheam [Debenham] Saxo held I carucate of land as a manor ${ }^{323}$ and 22 acres. Of these 22 acres Robert Malet's predecessor T.R.E. had 8 acres in the Abbot's soke and commendation. Then 4 villeins, now 2. Then as now 19 bordars. Then I serf. Then as now 2 ploughs on the demesne. The third part of St. Mary's Church with 10 acres. Then as now 2 ploughs on the demesne. Then and afterwards 3 ploughs belonging to the men, now 2. And 4 acres of meadow. Then wood(land) for 100 swine, now for 40. Then I rouncey, and 4 beasts. 40 swine, now 28. And 27 goats. Then 40 sheep, now 30. And 30 acres of demesne land in the Hundred of Losa [Loes]. Then it was worth 60s, now 50s. Ralph de Savigny holds (under Ranulf).

At Uluestune [Ulverston] the same Saxo held in like manner 1 carucate of land as a manor T.R.E. Then and afterwards 3 villeins, now $I$. Then and afterwards 9 bordars, now 14. Then and afterwards 2 ploughs on the demesne, now I. Then and afterwards 3 ploughs belonging to the men, now 2. Then 1 rouncey. Then 14 beasts. Then 60 swine, now 22. Then 22 sheep, now 30. Then and afterwards it was worth 40 s., $^{2}$ now 30 . To this manor belonged T.R.E. 8 acres on the demesne, which Robert Malet's mother now holds. It is I league long, and 7 furlongs broad. And (pays) $26 \frac{1}{2} d$. in geld. Others hold (land) therein.

\section{Halt Hundret of Cosfort [Cosford]}

In W ATEFELDA [Wattisfield] Lestan held 20 acres, worth 20d. Saint Edmund had the soke.

ss 'In Debenham Saxo a freeman held T.R.E. I carucate of land as a manor in the soke and commendation of St. Etheldredra '; Inq. El. 145. 


\section{A HISTORY OF SUFFOLK}

\section{Hundret of Carleford [Carlford]}

In Clopetuna [Clopton] T.R.E. Edric Grim, under commendation half to Saint Etheldreda and half to the predecessor of Robert Malet, held I carucate and 42 acres of land. ${ }^{324}$ Then as now 2 villeins, and 13 bordars. Then on the demesne 3 ploughs, now 2, but (the other) could be made up (sed potest fieri). Then 2 ploughs belonging to the men, now I. 5 acres of meadow. Wood(land) for Io swine, and I rouncey. Then 8 beasts, now 3 , now 30 swine. Then 80 sheep, now 20. Then it was worth 60s., now 50 . This Thorold holds of Ralph. I church with I5 acres out of 4 demesnes (dominationibus) worth $2 s$.

\section{HUNDRET OF WILEFORDA [WILFORD]}

In Depebes [Debach] (are) I 5 acres and they belong to Clopetuna [Clopton], and are worth $3^{\text {s. }}$

fol. 418 .

\section{Hertesmara [Hartismere] Hundret}

In Tusemera [ ] (there is) I carucate of land of the Abbot of Ely's demesne, which Saxo held T.R.E. for his pension (?) (solidatis). Then and afterwards I plough, now none. Then it was worth 20s, now I0s. Ralph de Savigny holds it.

In Aspella [Aspall] (are) 16 acres of the demesne and (they are included) in the valuation of Uluestuna [Ulverston]. And 4 bordars. And half a plough.

In the same (vill) is the third part of a church and the third part of a fair.

\section{LANDS OF AUBREY DE VERE}

\section{Babenberga [Babergh] Two Hundrets}

(At) Lauenham [Lavenham] Ulwin King Edward's thegn held 6 carucates of land as a manor with sac and soke. Then and afterwards II villeins, now 7 . Then and afterwards 24 bordars, now 38. Then as now 6 serfs. Then as now 4 ploughs on the demesne. Then and afterwards 9 ploughs belonging to the men, now 7. And ro acres of meadow. Wood(land) for I oo swine. Then 5 horses at the hall, now I. Then 24 beasts, now 25. Then 160 swine, now 65. Then and always 200 sheep. Then 60 goats, now 8o. Then 5 hives of bees, now 6. One arpent of vineyard. And I sokeman, who could not give nor sell, with I carucate of

$2 x$ ' $R$. Peverel holds a half freeman under commendation to St. Etheldreda (with) 1 carucate and 30 acres, and 12 acres in Caisneid [ Inq. El. 150. land, and 5 bordars. Then as now 2 ploughs. Now I mill. And 3 acres of meadow. Then and afterwards the whole was worth roli., now I 5 li. It is I league long, and half a league broad. And (pays) $7 \frac{1}{2} d$. in geld.

fol. 4 I $8 b$.

At Walingafella [Waldingfield] the same Ulwin, Aubrey's predecessor, held under King Edward 2 carucates of land as a manor with soke and sac. Then as now 4 villeins, and 10 bordars, and 4 serfs. Then as now 2 ploughs on the demesne, and 2 ploughs belonging to the men. And 4 acres of meadow. Wood(land) for 4 swine. Then as now 1 horse at the hall and 3 beasts and 16 swine. Then as now roo sheep. Then as now it was worth 5 li. It is 12 furlongs long, and 3 broad. And (pays) $6 d$. in geld.

\section{Sanfort [SAMFord] HUNDReT}

(At) Belesteda [Belstead] Tocha, a freeman, held by commendation only 80 acres as a manor. Then 2 villeins, now 2 bordars. Then as now I plough and 2 acres of meadow. Then I mill. Then worth $16 s$, afterwards and now 155 . Fermeus holds it. The soke (is) in Bercolt [Bergholt.] In the same (vill) Turgis, a freeman, held by commendation only 80 acres as a manor. Then as now 2 villeins, and I bordar. Then and afterwards I plough, now nothing, and 2 acres of meadow. Then worth 16 s., afterwards and now I 5s. The soke (was) in Bercolt [Bergholt]. It is 5 furlongs long, and 3 broad, and pays $6 \frac{1}{2} d$. in geld. These two manors were taken by judgement (derationata sunt) from Ralph Taillebosc and Phin into the King's hand, and afterwards Aubrey received them without livery of seisin (sine liberatione) as the reeve and the Hundred say.

In Canapetuna [ sokeman of the King's manor of Brunwin, a holt $]$, held 4 acres, worth $12 d$.

\section{Hertesmera [Hartismere] Hundret}

(At) Burgata [Burgate] Ulwin, a freeman, held T.R.E. as a manor 5 carucates of land. Then as now 22 villeins and 33 bordars. Then 4 serfs. Then as now 3 ploughs on the demesne. Then and afterwards 15 ploughs (belonging to the men), now 10. And $3 \frac{1}{2}$ acres of meadow. Then wood(land) for 100 swine, now for 40. Churches (Aecclesiae) with 29 acres, and half a plough. Then 7 beasts, now 12. Then 23 swine, now 80. Then 63 sheep, now 176 . Then 40 goats, now 57. And 9 sokemen (held) I 42 acres, and 4 bordars. Then as now 5 ploughs. And $3 \frac{1}{2}$ acres of meadow. Wood(land) for 6 swine. The fourth part of a church with I acre. Then the whole was worth $16 / i$, now I 9 li. and 4 s. It is I league in length and 7 fur- 


\section{THE HOLDERS OF LANDS}

fol. 419.

longs in breadth. And pays 5d. in geld. Ulwin had the soke. Adelalm holds the whole (of this) of Aubrey.

\section{Half Hundret of Cosfort [Cosford]}

In Ialdham [Aldham] Ulwin held T.R.E. $5 \frac{1}{2}$ carucates of land as a manor. Then 7 villeins, now 4. Then 6 serfs, now 2. Then 4 ploughs on the demesne, now 3. Then 6 ploughs belonging to the men, now 4. 7 acres of meadow. Wood(land) for 8 swine. Then as now 2 mills and 3 rounceys. Then 10 beasts, now I 8. Then 80 swine, now 60 . Then 140 sheep, now 6o. A church with 7 acres. Then it was worth $8 l i$, now i 5 li.

In the same (vill) a freeman held 5 acres by commendation only. Saint Edmund (had) the soke. Worth rod. It is 8 furlongs long and 7 broad, and (pays) $5 d$. in geld.

\section{Hertesmera [Hartismere] Hundret}

In Burgata [Burgate] (there was) a freewoman Milda, and in WORDAM [Wortham] (were) 9 freemen, Beso, Alwin, Godwin, Ulviet, Boti, Ordric, Stanart, Godric.

In Strandestuna [Thrandeston] 2 freemen, Fulcard, Alwin. In Metles [Mellis] $4 \frac{1}{2}$ freemen, Leuric, Godric, Ulward, Lewin benne (and) Furcard the half (freeman). In Torham [Thornham] r freeman, Ulmar. In RichingeHALA [Rickinghall] I freeman, Brictmar. In Gislingeham [Gislingham] a freeman, Edric. In WoRDham [Wortham] I freeman, Coleman. In Mrtues [Mellis] I freewoman, Menleva, and she had 14 acres of free land, and T.R.E. she gave that land to Saint Edmund. Altogether the others have 90 acres. Then as now $6 \frac{1}{2}$ ploughs. And 1 acre of meadow. Then as now worth 6os. Adelalm holds the whole under Aubrey. Over these freemen Aubrey's predecessor had soke and commendation T.R.E.

In Gisungreram [Gislingham] (were) 3 freemen, Ulmar, Lestan, Lefquena with 23 acres and I plough, worth 4 s. and $8 d$. The said Adelalm holds under Aubrey.

fol. 4196 .

\section{LAND OF ROBERT GRENON}

\section{Sanfort [SAmford] Hundret and a Half}

(At) Cercesfort [Churchford] Scapi, Harold's thegn, held as a manor I carucate of land T.R.E. Now William de Alno holds it of Robert. Then 6 villeins, now 4 . Then 4 bordars, now 3 . Then 2 serfs, now r. Then 2 ploughs on the demesne, now 1 . Then $I_{2} \frac{1}{2}$ ploughs belonging to the men, now I. 7 acres of meadow, now I mill. Then 2 rounceys, 6 beasts, and 140 sheep, now nothing. Then and afterwards worth 6os., now 40s. It is 6 furlongs long, and 2 broad, and (pays) $4 d$. in geld. Scapi had the soke under Harold.

(At) Stotuna [Stutton] the same Scalpi held T.R.E. 2 carucates of land as a manor. Then 8 villeins, now 5. Then 4 bordars, now 5 . Then 6 serfs, now 3. Then and afterwards 2 ploughs on the demesne, now 1 . Then as now 2 ploughs belonging to the men. 5 acres of meadow. Wood(land) for 16 swine. Then as now I mill, and 2 salt-pans. Half a church having 15 acres. Then 2 rounceys. Then 16 beasts, now 2. Then 40 swine, now 14. Then I 90 sheep, now 35 . Then and afterwards worth 6 li., now 6os. It is 6 furlongs long, and 4 broad, and (pays) $4 d$. in geld. The same William (holds it). The soke (was held) in the same way.

In Brantham [Brantham] I freeman, Mawa (held) by commendation only $5 \frac{1}{2}$ acres worth 12d. The same William (holds it). Harold (had) the soke.

Manesfort [ ] Saint Benet, of Ramsey, ${ }^{325}$ held in demesne T.R.E. Now the same William holds as a manor $1 \frac{1}{2}$ carucates of land. Then as now 2 villeins. Then 4 bordars, now 5. Then and afterwards 2 ploughs on the demesne, now r. Then as now I plough belonging to the men. 3 acres of meadow, and I mill. Then 2 rounceys. Then 5 beasts, now 3. Then 15 swine, now 5. Then as now 30 sheep. Then and afterwards worth 40 s., now 20s. It is 6 furlongs long, and 3 broad, and (pays) $3 \frac{1}{4} d$. in geld. Saint Benet (had) the soke.

fol. 420 .

In Alsildestuna [ ] Alwin, a freeman, (held) in commendation to Aluric, Robert's predecessor, 30 acres of land as a manor T.R.E. Then as now half a plough, worth 4s. Harold (had) the soke. The same William (holds it).

\section{(At) Turchetlestuna [}

Grim, a freeman, held in commendation to Guert I carucate of land as a manor T.R.E. Then as now 2 villeins and 2 bordars. Then and afterwards I plough, now nothing. And 2 parts of a fishery. Then as now I plough belonging to the men. Then worth 40s, now $38 s$. The same William (holds it). This Robert claims by exchange with Hugh de Montfort's land. Harold (had) the soke.

${ }^{325}$ There is no mention of this manor in the Cbronicle or Cartulary of Ramsey (Rolls Ser.). 


\section{A HISTORY OF SUFFOLK}

(At) Brantham [Brantham] the same Grim held 60 acres as a manor T.R.E. Then as now I bordar. Then and afterwards half a plough. Now 2 oxen. I acre of meadow. Then and afterwards worth 10 s. and $8 d$. now 5s. The same William (holds it). This also Robert claims in the same way. Harold (had) the soke.

(At) Hulferestuna [Woolverstone] Aluret held by commendation to Scalpi 80 acres as a manor T.R.E. Now Robert holds it in demesne. Then as now 3 bordars. Then and afterwards I plough on the demesne, now half a plough, and I acre of meadow. Then worth I6s, now IOS.

In Tatistuna [Tattingstone] Trumuin and Ulsi, freemen, (held) by commendation I 20 acres as 2 manors T.R.E. Then as now I bordar. Then and afterwards 2 ploughs, now I, and 2 acres of meadow. Then worth 10s., now $8 s$.

In Stutruna [Stutton] Eatnod, a freeman, held in commendation 60 acres as a manor T.R.E. Then and afterwards I plough, now half a plough and I acre of meadow. Then it was worth Ios., now 8 s.

In Brantham [Brantham] Tela, a freewoman, held in commendation 30 acres as a manor T.R.E. Then as now I bordar and half a plough, and I acre of meadow. Then and afterwards worth 5s., now 3 s. and $6 \frac{1}{2} d$.

In Tatistuna [Tattingstone] Aluric, a freeman, held in commendation 30 acres as a manor, fol. $420 b$.

and 2 bordars. Then and afterwards half a plough, now 2 oxen. And I acre of meadow. Then worth $40 d$., now $42 d$.

In Herchesteda [Harkstead] Aluric, a freeman, held in commendation 30 acres as a manor T.R.E. Then and afterwards half a plough, now 2 oxen, and half an acre of meadow. Then worth 5s., now $42 d$.

\section{In Eduinestuna [}

] Spieta, a freeman, held by commendation 30 acres as a manor T.R.E. Then half a plough. Then worth 5s., now $42 d$.

In this Hundred 7 freemen have on the demesne by commendation to Robert 120 acres. Then as now 3 ploughs. Then worth 20s., now 25s. Harold (had) the soke.

\section{Cosfort [Cosford] Hundret}

In LAtнam [Layham] were 20 acres belonging to Ciresfort [Churchford] demesne, which Scapi held. Worth 3s. William de Alno holds (them).
In Colenes [Colneis] Hundred (was) a freeman with 2 acres of free land. Worth $4 d$. The said William de Alno holds.

\section{LANDS OF PETER DE VALOIGNES}

\section{Brademera [Bradmere] Hundret}

(At) Fachenham [Fakenham] Alestan the thegn held as a manor 5 carucates of land. Then as now 14 villeins, and 7 bordars, and ro serfs. And then as now 5 ploughs on the demesne. And 4 ploughs belonging to the men. 16 acres of meadow. Wood(land) for 8 swine. Then as now 1 mill. Then 4 rounceys, now 3 . And 16 forest mares. Then as now 12 beasts. Then 40 swine, now 20. Then as now 300 sheep. Two churches with 40 acres, and I plough, and half an acre of meadow. To this manor are attached $6 \frac{1}{2}$ sokemen with 30 acres. Then as now I plough. Then as now (it was worth) 13 i. It is I league long, and 8 furlongs broad. And (pays) 2s, in geld.

In the same (vill) 20 freemen over whom Alestan had commendation (held) 80 acres. Then as now 2 ploughs. And 3 acres of meadow. Worth 20s. This (Peter de Valoignes) claims of the King's gift.

In TORP [(Ixworth) Thorpe] a freeman, Sparavoc, (held) 30 acres. $\mathrm{He}$ was Queen Edith's man; and she gave him to Peter; after her death the King granted him to him, as his men say.

In SaPEstuna [Sapiston] (are) 3 freemen with $13 \frac{1}{2}$ acres of land. Among them then as now I plough, and I acre of meadow. This is of the King's gift, and is worth 5 s.

In Barnicham [Barningham] Alestan held I carucate of land as a manor. Then 5 villeins, now 2, and I serf. Then as now I plough on the demesne. Then half a plough belonging to the men, now 2 oxen. And 2 acres of meadow. And then as now I rouncey. Then 30 sheep. Worth 20s. And 6 freemen by fold-soke and commendation (held) 12 acres and half a plough. Worth 5 s.

In WICAM [Wyken ${ }^{328}$ ] Alan held T.R.E. as a manor I carucate of land. Then as now 5 bordars. Then 2 serfs, now I. Then I plough on the demesne, now 2. And 3 acres of meadow. Wood(land) for 8 swine. And 2 oxen belonging to the men. Now I rouncey. Then 3 beasts, now 11 . Then 7 swine, now 13. Then 40 sheep, now 100. And (there are) 2 sokemen with 10 acres. Then as now 2 oxen. Then it was worth 20 s., now 30 s. 


\section{THE HOLDERS OF LANDS}

In the same (vill) 8 freemen under commendation (hold) I carucate of land and II bordars. Then as now 2 ploughs. And 3 acres of meadow. Wood(land) for 2 swine. Then it was worth IOs., now 20s. These he has by livery of seisin (de liberatione) and as (one) estate (pro serra).

(At) Riseurda [Rushford] Alti (and) Ketel, freemen (and) thanes, held T.R.E. 2 carucates of land. Then 2 ploughs on the demesne. And now 4 acres of meadow. Now I rouncey. Then I beast, now 5. Then II sheep, now 80 . And 4 hives of bees. This land these men held T.R.E. as two manors. Then as now it was worth 30 s.

In the same (vill) 8 freemen (have) I carucate of land and 9 acres by commendation. Over 7 (he has) fold-soke, and commendation only over one. Then and afterwards 2 ploughs, now 1. And 4 acres of meadow. Worth ros. It is 6 furlongs long, and 3 furlongs broad. And (pays) $I I \frac{1}{4} d$. in geld.

Saint Edmund has soke over the whole hundred.

fol. $421 b$.

\section{Hertesmera [Hartismere] Hundret}

In WEST TORP [Westhorpe] a freeman under commendation, Alti, (held) 9 acres. Wood(land) for 2 swine. Worth $18 d$.

\section{LAND OF ROGER DE RAMIS}

\section{Babenberga [Babergh] Two Hundrets}

In Bura [Bures] Earl Algar held I carucate of land, Roger now (holds it). And I villein, and 3 bordars, and I serf. AnI I plough on the demesne. And I plough telonging to the men. And 2 acres of meadow. Then half a mill, now none. And then as now I horse, and 30 swine, and 100 sheep. Worth 20 s.

In Lishou [ ] Uluric held under Aluric Camp T.R.E., and they could sell, 30 acres, and 4 bordars, and 3 oxen. Worth 18s. Saint Edmund (has) soke and sac.

\section{Half Hundret of Gepeswiz [Itswich]}

In the town of GePEswiz [Ipswich] Roger has a church, St. George's, and 4 burgesses, and 6 burgages (mansuras) lying waste. One of these (burgages) was adjudged to the use of the Abbot of Ely, and he was seised thereof, as the hundred bears witness. But Roger says that he holds of the King. To the aforesaid church belongs 1 acre of land. The whole is worth IOs. The King has the customs.

\section{Bosemera [Bosmere] Hundret}

In CRofelda [Crowfield] Edric, a freeman, held T.R.E. 20 acres. Then $\mathrm{I}$ plough and (the like) now. Then 4 rounceys, now none. Then 2 beasts. Then 12 swine. And 5 sheep. Now altogether nothing. Then as now worth $40 d$.

In the same (vill) Wicolf, a freeman, held T.R.E. 35 acres which that same Edric held with his land at the time when it was delivered to Roger. Then as now 4 bordars. Wood(land) for 10 swine. And 2 acres of meadow. Worth 8 s.

\section{fol. 422 .}

In Codrham [Coddenham] 3 freemen (held) 30 acres, and I bordar. Then and afterwards I plough, now half a plough. And $1 \frac{1}{2}$ acres of meadow. Then it was worth 6 s., now 5s. And the fourth part of a church and the fourth part of that which belongs to the church. This land Warenger held of Roger, but he disseised him. The King and the Earl (have) soke over the whole.

(At) Estena [? Stonham] a freeman Ailmar held under Edric, Robert Malet's predecessor, by commendation only T.R.E. 60 acres as a manor. Then as now I bordar. Then and afterwards I plough, now none. And 2 acres of meadow. Wood(land) for 30 swine. A church with 14 acres. Then it was worth 20s, now I 5 s.

In the same (vill) a freeman Alwin in the King's soke (held) 90 acres as a manor. Then as now I villein, and I bordar. And then 2 ploughs on the demesne, now I. And 4 acres of meadow. Wood(land) for 20 swine. Then it was worth 40s., now 25s. The King and the Earl (have) the soke.

In the same (vill was) a freeman with 60 acres, and I bordar and I villein. Then and afterwards I plough, now half a plough. Then I plough belonging to the men, now half a plough. Then I acre of meadow. Wood(land) for 20 swine. Then it was worth 20 s., now I5s. The King and the Earl (have) the soke.

In the same (vill was) a freeman with 30 acres, and I bordar. Then and afterwards I plough, now half a plough. Wood(land) for 10 swine. Then it was worth IOs., now 5s. The King and the Earl (have) the soke.

In the same (vill) 8 freemen (held) 30 acres. Two of these were under commendation to a certain man who was himself under commendation to Robert Malet's predecessor, and William (Malet) his father had seisin thereof. All together they had I plough. Worth 5s. All this Milo holds of Roger ; and he took over 4 horses, now 1. Then 3 beasts, now 3 . Then 14 swine, now 36 . Then 36 sheep, now none. It is half a league long, and half (a league) broad. And (pays) $6 d$. in geld. Others hold land therein. The King and the Earl (have) the soke. 


\section{A HISTORY OF SUFFOLK}

In the same (vill) of Estuna [? Stonham] Roger has in demesne 12 freemen with 40 acres in the soke of the King and the Earl. Then and afterwards 2 ploughs, now $1 \frac{1}{2}$ ploughs. And I acre of meadow. Worth I5s.

\section{fol. $422 b$.}

In BRIESETA [Bricett] Anschetill holds of Roger 1 carucate of land as a manor in the soke of the King and the Earl, which Godwin a freeman held T.R.E. Then 2 bordars, now 5. A church with 15 acres. Then as now I plough on the demesne. Now 2 oxen belonging to the men. And 2 acres of meadow. And 42 sheep, and 15 swine. Then it was worth 20 s, now 25s. The whole is I league long, and half (a league) broad. And (pays) $6 \frac{1}{2} d$. in geld. Others hold land therein.

In Langhedana [Langheden] Roger's daughter holds a freeman with 9 acres. Worth $18 d$.

In Codenham [Coddenham] a freeman Alwin holds $I$ acre. Worth $2 d$. And in the same (vill) are 4 acres on the demesne, and they are valued therewith.

\section{Claindune [Claydon] Hundret}

(At) Achreham [Akenham] Godwin the priest, a freeman, held T.R.E. I carucate of land and 20 acres as a manor. Now Roger's daughter holds it (under him). Then on the demesne 2 ploughs, now 3. And 4 acres of meadow. And 2 rounceys, 7 beasts, and 6 swine. Three fourth parts of a church with 12 acres. Then it was worth 24 s., and the like now.

In the same (vill) Godwin a freeman under Gurth held 100 acres as a manor. Then 3 bordars, and now. Then 1 plough, and now. And $2 \frac{1}{2}$ acres of meadow. 'Then it was worth 16 s., now 19 s. and $4 d$.

In the same (vill) Aluric a freeman under commendation to Saxo the predecessor of Peverel (held) 40 acres. Then as now I plough. And I acre of meadow. Then it was worth 6s. and $8 d$., now ros.

In the same (vill) Sunwin a freeman held by commendation to Gurth 36 acres as a manor T.R.E. Then 1 plough. And $1 \frac{1}{2}$ acres of meadow. Worth 6s.

In the same (vill) Turbern the priest, a freeman, held 30 acres as a manor T.R.E. Then I plough. Then I bordar. Then it was worth 5s., now I os. and rod. The King and the Earl (have) the soke and commendation.

In the same (vill) 35 freemen (held) $203 \frac{1}{2}$ acres, and 2 acres of meadow. Then 7 ploughs, now half a plough. Then it was worth 40 s, now 5 li. and 9s. The King and the Earl (have) the soke. It is I league long, and 7 furlongs broad. And pays 20d. in geld.
In Westrefelda [Westerfield] 3 freemen (held) 28 acres. Then and afterwards 1 plough, now none. And I acre of meadow. Worth IOs. The King and the Earl (have) the soke.

fol. 423 .

In Toddenham [Tuddenham] (are) 20 acres on the demesne of Tuddenham and (included) in its valuation.

In Westrefelda [Westerfield] 5 freemen (held) 23 acres and I rood. Then and afterwards I plough, now none. Worth 4s. Girold holds (them).

In the same (vill) I freeman (held) 16 acres. Then and afterwards half a plough, now none. Worth 32d. The King and the Earl (have) the soke. Ernald holds of him (Roger).

In this Hundred are 20 acres which belong to the church of TотDenham [Tuddenham].

Niwetuna [Newton ${ }^{327}$ ] Ernald holds of Roger, which Brictmar a freeman held T.R.E.; 102 acres as a manor T.R.E. Then and afterwards 2 villeins, and 2 bordars, now 4 bordars. Then as now I plough on the demesne. Then and afterwards 2 ploughs belonging to the men, now none. And 2 acres of meadow. And $x$ rouncey. Then 20 swine, now 16 . Then 20 sheep, now I2. Worth 20 s.

In the same (vill) Levesun a freeman under commendation to Stigand held 40 acres as a manor T.R.E. Then and afterwards I plough, now 2 oxen. And I acre of meadow. Then it was worth 20 s, now IOs. Ralph holds of Roger. The King and the Earl (have) soke over the whole.

In Codeham [Coddenham] Roger holds on the demesne 6 freemen with 26 acres in the soke of the King and the Earl. Then and afterwards 2 ploughs, now I. And I acre of meadow. Worth 12s. less $2 d$.

In Helmincham [Helmingham] Leured a freeman (held) 20 acres. Then and afterwards I plough, now none. Worth 3 s. and 1 d. The King and the Earl (have) soke over the whole.

In Estuna [Easton (?)] (are) I 5 acres of demesne land and (they are included) in the valuation. Milo holds of Roger.

In Codeham [Coddenham] Aluric and Boti, freemen under Boti, held $9 \frac{1}{2}$ acres. Then half a plough, now 2 oxen. Worth 3 s. The same Milo (holds of Roger).

\section{Sanfort [SAmford] Hundret and a Half}

In Heinam [Higham] Siric, a freeman, held 30 acres as a manor T.R.E. Then as now half

$$
\text { "zz In Swilland. }
$$




\section{THE HOLDERS OF LANDS}

a plough, and then worth $5 s_{0}$, now $8 s$. Garenger holds it. Harold (had) the soke in Bercolt [Bergholt].

fol. $423^{b}$.

\section{Hundret of Carleforda [Carlford]}

In Tudenham [Tuddenham] Gerold (holds) Aluric the deacon, a freeman under commendation to Saxa, (who held) of the Abbot (of Ely) T.R.E. 12 acres as a manor. 3 bordars. Then as now I plough. 2 acres of meadow. Then I rouncey, and then as now 2 beasts, and II swine, and 40 sheep. Worth 3 s.

And in the same (vill) 2 freemen, 1 under commendation to Saint Etheldreda ${ }^{328}$ and the other under commendation to Harold, (held) 10 acres and half a plough. Worth 2s. This Gerold holds of Roger.

In Grundesbur [Grundisburgh] Raulf holds 20 acres, and they belong to Neutune [Newton] and to its valuation.

In FinLesford [

] (are) 6 acres and I acre of meadow, and they belong to Newton in another Hundred. This Ralph holds.

In Oteleia [Otley] are 4 acres, and they belong to Estuna [Easton] and to its valuation. This Milo de Belefol holds.

\section{Colenesse [Colneis] Hundret}

In KiRketuna [Kirton] were 2 acres. Worth $4 d$.

\section{Losa [Lozs] Hundret}

In UDEBRIGE [Woodbridge] a freeman under commendation of Alwin (held) I I acres, Half an acre of meadow. Worth $27 d$.

\section{XXXVIIII. LANDS OF RANULF BROTHER OF ILGER}

\section{Colenesse [Colneis] Hundret}

In Burg [Burgh (?)] was a freeman Godric under commendation to one himself under commendation to Harold with 16 acres of land. 2 bordars. Half a plough. Half an acre of meadow. Worth 3 s.

And in Tremelaia [Trimley] (were) 2 acres. Worth $4 d$.

In Morestona [Moston ${ }^{329}$ ] (was) a freeman under commendation to Brismer with 4 acres. Worth $12 d$.

398 'a freeman $£$ dric under commendation to St. Etheldreda (held) 8 acres. Worth 20d.'; Inq. El. 151.

In Trimley St. Martin.
In FALTENHAM [Falkenham] the said Brismer held 26 acres T.R.E. as a manor. Then I plough. And I rouncey, 4 beasts, and 40 sheep. Now nothing at all. Then worth 10s., now 5 s.

This Brictmar had several estates (plures terras),

fol. 424 .

and some part was delivered on the King's behalf to Ingelric; and other parts to Ranulf Ilger's brother, and a third part to Ralph Pinel; and with (in) this third part was this aforesaid estate delivered to Ralph as he himself says, and the same appears (?) by the testimony of the Hundred (idem pib\& $\hbar_{0}$. testimoni') that he was seised at the first; but whether he was seised by the King's action (ex parte regis) or not they do not know ; and they say also that Ranulf claimed this land against Ralph; and Roger the Sheriff named to them a set term, that they should both be present,-Ranulf appearing, Ralph was absent; and thereupon the men of the Hundred adjudged that Ranulf was seised, who now holds. But Ralph Pinel denies that he was summoned for that plea.

In Motestuna [Moston] a freewoman Ulveva under commendation to Brictmar (held) Io acres. Then half a plough, now none. Worth 2 s.

In Halmelega [Hemley] (was) a freeman Brictmar, (of whom) Briht (had) half commendation and Saint Etheldreda the other half T.R.E.; now Ranulf holds of the King by livery as part of his demesne. But the Abbot says he ought to hold the half from him. 22 acres. Then I plough, now none. And I bordar. One acre of meadow. And 1 serf. Worth 4 s.

In the same (vill) Ulward a freeman under commendation to Godric T.R.E. held 20 acres of land, and 2 bordars, and I plough, (and) half an acre of meadow. Worth 4 s.

Moreover in the same (vill) a freeman Hardwin ... to one himself under commendation to N[orman], and half under Edric's commendation, T.R.E. (held) 5 acres of land and half a plough, (and) half an acre of meadow. Worth $12 d$.

In the same (vill) a freeman Brihtric, under commendation half to Brihmar and half to Stanmar, T.R.E. (held) 9 acres, and half a plough, (and) half an acre of meadow. Worth $3^{\text {s. A }}$ church with 8 acres; worth $2 s$.

All this Ranulf Ilger's brother holds by livery of the King, and William de Nomore (sic) of him. Saint Etheldreda (has) the soke.

\section{Hundret of Carlaforda [Carlford]}

In Merlesham [Martlesham] Eadwold T.R.E. (held) $2 \frac{1}{2}$ carucates of land as a manor. Then as now 10 villeins and 10 bordars. Then 2 


\section{A HISTORY OF SUFFOLK}

\section{fol. $424 b$.}

serfs. Then as now on the demesne 2 ploughs, and then 5 ploughs belonging to the men, now 4. 12 acres of meadow, now I mill. Wood(land) for 16 swine. Then 3 rounceys, now 5 . Then 24 beasts, now 20 . Then 40 swine, now 27. Then 300 sheep, now 212. Then I6 goats. Then 6 hives of bees, now 12. Then it was worth 40 s., now the like. It is I league long, and 5 furlongs broad, and (pays) $6 d$. in geld.

In the same (vill is) I church with 36 acres.

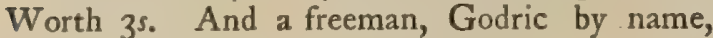
held 16 acres and $I$ bordar, and half a plough, and $I$ acre of meadow. Worth 2 s.

In WALDINGAFELDA [Waldringfield] Brihtmar, a freeman, T.R.E. held I carucate of land as a manor, and I bordar. Then 2 ploughs, now I. And I mill. Then I rouncey. Then 100 sheep, now 27. Then it was worth 20s, now IOS. It is 6 furlongs long and 3 broad and (pays) $5 d$. in geld.

In the same (vill) 5 freemen under commendation half to Brihmar and half to his mother (held) 40 acres and I plough. Worth 45.

In Prestetuna [

] 10 freemen under commendation half to Brihmar and half to Quengeva his mother, and one of them was under half commendation to Saint Etheldreda, held I carucate of land. Now (there are) 9 bordars under them. Then 4 ploughs, now 2. 1 acre of meadow. Then it was worth 20 s., now 10 s. It is 6 furlongs long and 3 broad, and (pays) $6 d$. in geld.

In Haspelega [Haspley] 5 freemen under commendation, like the others, to the same Brihmar, (held) I carucate of land, and 5 bordars, and 3 ploughs. 2 acres of meadow. Then it was worth 30 s., now 20 s. One of these was half Edric's man and half Norman's man. Two of them were under commendation to Quengeva T.R.E. It is 6 furlongs long and 3 broad, and (pays) $5 d$. in geld.

In NEBRUNNA [Newbourn] (were) I 6 freemen under commendation to Brictmar and Quengeva T.R.E. and 2 under half commendation to Saint Etheldreda, ${ }^{330}$ with I carucate and 40 acres of land, and under them I4 bordars. Then 4 ploughs, now 3. $1 \frac{1}{2}$ acres of meadow. Then it was worth 40 s., now 20s. I church with 12 fol. 425 .

acres, worth $16 d$. ; and it was Norman's, witness the Hundred. It is 6 furlongs long and 5 broad, and (pays) $7 \frac{1}{2} d$. in geld.

In Kingeslanda [ ] ${ }^{331}$ (there is) I carucate of land, waste land (guasta terra), worth

s30 ' 2 half freemen, Turketel and Goda'; Inq. El. 149.

${ }^{3} 1$ There was a Kingshall Manor in Clopton; Copinger, Suff. Rec.
25. It is 4 furlongs long and 3 broad, and pays 5 d. in geld. All this W. de Nemore holds of Ranulf, Ilger's brother.

\section{In Aluredestuna [} ] Durand, a freeman, Robert Malet's predecessor, held T.R.E. I carucate and 80 acres of land; now Ivo holds it of Ranulf, brother of Ilger, as a manor. Then as now 7 villeins and 3 bordars. Then on the demesne 2 ploughs, now 1 . Then as now 3 ploughs belonging to the men. 4 acres of meadow, and I mill, and 3 beasts, and 50 sheep. A church with 12 acres, worth $12 d$. Then it was worth 4 li., now 6os. It is 6 furlongs long, and 4 broad, and (pays) Iod. in geld.

And in Gepeswiz [Ipswich] is I vacant burgage (mansura) and another occupied, and it renders $8 d$.

In Haspelega [Haspley] (are) 7 acres and they are (included) in the valuation of Almelega [Almeley].

In Eduluestuna [ ] are 9 acres. Worth 2s.

In Bulges [Boulge] Uluric a villein (holds) 4 acres. Worth $8 d$.

\section{Babenberga [Babergh] Two Hundrets}

In Walingafella [Waldingfield] Uluric King Edward's thegn held I carucate of land; now Ranulf holds it as a manor by gift of King William, with soke and sac. Then as now I villein, and 3 bordars. Then and afterwards 1 plough, now 2 among them all. And 4 acres of meadow. Then as now 2 beasts. Then 12 swine, now 16. Then 20 sheep, now 30. Then and afterwards it was worth $305 .$, now 40 s.

\section{SANFort [SAmFord] HUNDret}

(At) Branham [Brantham] Aluric de Wenhou held 2 carucates of land. Then and afterwards 4 villeins, now 2. Then I bordar, now 8 . Then 2 serfs, now I. Then and afterwards 2 ploughs on the demesne, now r. Then as now I plough belonging to the men. Wood(land) for 12 swine. 5 acres of meadow, and I saltpan, and I mill. Then I rouncey. Then as now 12 beasts, 24 swine, and 60 sheep. Worth 40s. Aluric (had) the soke under Harold. Roger (holds) of Ranulf.

\section{fol. $425 b$.}

\section{LANDS OF ROBERT SON OF CORBUZZO}

\section{Tingou [Thingoe] Hundret}

Brocle [Brockley] Richard holds, which Saiard a freeman under Saint Edmund T.R.E. 


\section{THE HOLDERS OF LANDS}

within the soke of Saint Edmund held, but could not sell ; half a carucate of land. And I plough. And $1 \frac{1}{2}$ acres of meadow. Then worth ros., now 15 s.

\section{Babenberga [Babergh] Two Hundrets}

Somerledetuna [Somerton] Roger holds, which Stakker held under King Edward of glorious memory; 1 carucate of land as a manor in King Edward's soke. Then as now 2 bordars. Then 4 serfs, now I. Then and afterwards 2 ploughs on the demesne, now I. And $3 \frac{1}{2}$ acres of meadow. Now 10 beasts. Then 15 swine, now 8. Then 60 sheep, now 50. Now 5 goats. Then and afterwards it was worth 30 s., now 4 os.

\section{SANFort [SAmFord] Hundret and a haly}

(At) Wenham [Wenham] Auti the thegn held T.R.E. as a manor 3 carucates of land. Then 9 villeins. Afterwards and now 6 . Then and afterwards 4 bordars, now 14 . Then as now I serf. Then and afterwards 2 ploughs on the demesne, now half a plough. Then 5 ploughs belonging to the men, afterwards 4 , now 3 . II acres of meadow. Then wood(land) for 10 swine. Then as now I mill. A church with 20 acres of free land. Then as now half a plough. Then 2 rounceys, 4 beasts, and 20 swine, now nothing except 23 sheep. Then and afterwards worth 6 li., now roos. Auti had soke over his own demesne, and the soke of the villeins was in Bercolt [Bergholt]. Girard holds of this manor 30 acres, worth 5s., and they are (included) in the same valuation.

In Wenham [Wenham] Godwin a freeman held ro acres, and his holding has been added to this manor, and is worth 2s. The soke was in Bercolt [Bergholt]. It is 12 furlongs long, and 6 broad, and (pays) 2s. in geld.

\section{Hundret of Carleford [Carlford]}

In Barchestuna [ ] $]^{332}$ Depekin, a freeman, under commendation to Harold held I carucate of land as a manor. Then 6 bordars, now 4. Then on the demesne I plough, now none. Then 7 ploughs belonging to the men, now none. 5 acres of meadow, and 6 sheep. fol. 426.

Then it was worth 20s, now I2s. It is 6 furlongs long and 4 broad, and (pays) $3 d$. in geld.

\section{Half Hundret of Cosfort [Cosford]}

In WATEFELDA [Wattisfield] I sokeman of Saint Edmund (held) roo acres. Then I plough 83.

moccurs as 'Barkestone' in $134^{6}$; Feud. Aids, v, afterwards half a plough, now none. Worth IOs. Berard the Abbot's man holds (this land) of the Abbot.

\section{Sanfort [Samford] Hundret}

(At) Torintuna [Thorington] ${ }^{333}$ Alwin a freeman of Stigand's T.R.E. (held) 2 carucates of land as a manor. Then and afterwards 6 villeins, now 4 . Then and afterwards 2 bordars, now 5. Then 2 serfs, afterwards and now $\mathbf{I}$. Then as now 2 ploughs on the demesne. Then and afterwards 3 ploughs belonging to the men, now 2. 20 acres of meadow. Then as now I mill. A church (having) 50 acres of free land. Now 1 rouncey, and 6 beasts. Then 4 swine, now 30 , and 20 sheep, and 30 goats. Then as now worth 50s. The same (man) had the soke under Stigand. It is 6 furlongs long and 4 broad, and (pays) $5 d$. in geld. Gifard holds of Robert.

\section{LANDS OF WALTER THE DEACON}

\section{Half Hundret of Cosfort [Cosford]}

(At) Bilestuna [Bildeston] T.R.E. Queen Edith held 6 carucates of land as a manor. Then as now 14 villeins, and 6 bordars, and 8 serfs. And 3 ploughs on the demesne, and 3 ploughs belonging to the men. 20 acres of meadow. Wood(land) for Io swine. And 3 rounceys, io beasts, 40 swine, and 80 sheep. A church with 40 acres, and I plough, and I acre of meadow. Then it was worth 8 li., now roli., but it renders $12 l i$. It is I league long and half a league broad. And pays $5 d$. in geld.

\section{Claindune [Claydon] Hundret}

(At) Suinlanda [Swilland] Queen Edith T.R.E. held 2 carucates and 40 acres of land as a manor. Then as now 6 villeins, and 6 bordars, and I serf. And 2 ploughs on the demesne. And 3 ploughs belonging to the men. 4 acres of meadow. Wood(land) for 6 swine. A church with 5 acres. And 1 rouncey, 8 beasts, and 19 swine. Then 60 sheep, now 100 . Then it fol. $426 b$.

was worth 50s., now 70s. It is 6 furlongs long and 4 broad. And (pays) 20d. in geld. Walter holds (this) in demesne. The Queen (had) the soke.

In Turoluestuna [Thurlston] a freeman (held) 16 acres and 4 bordars. Then as now half a plough. And I acre of meadow. Worth 25. and $8 d$. Half a church with 5 acres.

In Westrefredda [Westerfield] Almar a freeman held 30 acres and 4 bordars. Then as now ${ }^{333}$ In Stoke-by-Nayland. 


\section{A HISTORY OF SUFFOLK}

1 plough. And 2 acres of meadow. Worth 8 s. Turstin holds of Walter as of Tedric's fee. The King and the Earl (have) the soke.

In ACREHAM [Akenham] 2 freemen, Suen and Lewin, (held) 50 acres. Worth 5s. Turstin holds of Walter, and Bernard, as of the same fee.

In Westrefelda [Westerfield] 3 freemen (held) 28 acres. And then half a plough. Worth 36d. Bernard and Almar hold (of Walter). The King and the Earl (have) the soke.

In the same (vill) a freeman (held) 6 acres. Worth 12d. As of the same fee. Norman holds (of Walter). The soke (is) the King's and the Earl's.

\section{Hertesmara [Hartismere] Hundret}

(At) Bachetuna [Bacton], (now held) in demesne, Lewin a freeman under Harold T.R.E. (held) 3 carucates of land and 40 acres. Then I 7 villeins, now 8 . Then 3 bordars, now 12 . Then 2 serfs, now I. Then as now on the demesne 2 ploughs. Then 3 ploughs belonging to the men, now 2. 6 acres of meadow. Wood(land) for 100 swine. Then 9 rounceys, now 8. Then as now 8 beasts. Then 60 swine, now 40. Then 16 sheep, now 100. Then 40 goats, now 36 . A church with 24 acres, worth $3^{5}$. Then worth 8 i., now gli. and Ios. And 40 freemen under commendation to Lewin T.R.E. (held) 80 acres and I bordar. Then 3 ploughs, now 2. I acre of meadow. Then worth 20 s., now $4 l i$. and Ios. The King and the Earl (have) the soke. It is I league long, and 4 furlongs broad. And in geld (pays) $6 d$.

\section{In Caldecota [}

] were 19 acres of the demesne of Bachetuna [Bacton], worth 3 s. and $3 d$. It is 9 furlongs long, and 2 (furlongs) and 5 perches broad. And in geld (pays) $6 d$.

In WestoRP [Westhorpe] Brictric a freeman under commendation (held) 6 acres, worth $12 d$.

\section{fol. 427 .}

\section{Babenberga [Babergh] Two Hundrets}

Melinga [Milden ${ }^{334}$ ] Walter holds in demesne, which Lewin of Bagatona [Bacton], King Edward's thegn, held, 2 carucates of land as a manor. Now Walter holds it, and it belongs to his brother Thederic's fee. Then as now 6 villeins, and 6 bordars, and 4 serfs. Then as now 2 ploughs on the demesne. Then and afterwards 3 ploughs belonging to the men, now I. And 6 acres of meadow. Wood(land) for 6 swine. And 1 mill. Then as now 2 horses. Then 6 beasts, now 7, and 22 swine. Then 40 sheep, now 50. Then 12 goats, now 16. Then and afterwards it was worth Formerly Milding.
$4 l i$, now $6 l i$. It is 6 furlongs long and 4 broad. And (pays) $7 d$. in geld. A church with I 5 acres of free land. Over Io acres which a freeman had, which he could sell, Saint Edmund has soke and sac, and it is worth 2 s.

\section{Stou [STOW] HundReT}

In Dagaworda [Dagworth] William a freeman, of whom Teri the predecessor of Barthetona (sic) had half commendation only, and Gutmund the predecessor of Hugh de Montfort (had) the other half. And he could without their licence sell his land, and had 60 acres and I bordar. Then and afterwards $1 \frac{1}{2}$ ploughs, now 2 oxen. Wood(land) for ro swine, and 3 acres of meadow.

In WELEDANA [

] (were) I5 acres of land belonging to the same freeman, and 2 acres of meadow. Then and afterwards the whole was worth 20s., now 5s. This land Theodric the predecessor of Walter the Deacon had without livery of seisin (sine liberatore), as the Hundred testifies. The King and the Earl (have) soke and sac.

In WATDENa [Wetherden] a freeman within the soke of the Hundred has 5 acres. Worth I2d.

\section{Half Hundret of Gepeswiz [IPswich]}

In the borough Walter has 5 houses, and 3 vacant burgages (mansuras), which the Queen held T.R.E. And they render customs. And are worth $20 d$.

\section{Claindune [Claydon] Hundret}

(At) Henleir [Henley] Uluric a freeman held I carucate of land and 70 acres as a manor T.R.E. Then 2 bordars, now 6 . Then and afterwards 2 ploughs on the demesne, now $x$. Then as now I plough belonging to the men.

fol. $427 b$.

4 acres of meadow. Then 3 rounceys. Then 2 beasts, now 3. Then Io swine, now 2. Then 40 sheep, now 44 . A church with 8 acres. Then it was worth 40 s., and now $48 \mathrm{~s}$. Roger holds of Walter. The King and the Earl (have) the soke.

In the same commendation 6 freemen (held) 36 acres. Then and afterwards $1 \frac{1}{2}$ ploughs, now I plough. Then it was worth $6 s$. and $8 d$, now 75. The same Roger (holds of Walter). The King and the Earl (have) the soke.

In the same (vill) a freeman Suen by name held 40 acres as a manor T.R.E. 'Then as now I plough. And I bordar. Then it was worth IOs., now $18 s$. Walter holds in demesne. It is I league long, and half a league broad. And 


\section{THE HOLDERS OF LANDS}

(pays) 20d. in geld. The King and the Earl (have) the soke.

In Bruntuna [

] Lewin the thegn T.R.E. held I carucate of land and 40 acres as a manor. Then as now 9 bordars, and 2 serfs. Then and afterwards 2 ploughs, now I. Then and afterwards 2 ploughs belonging to the men, now I. 5 acres of meadow. Then I rouncey. Then 20 swine, now 10 . Then 20 sheep, now 16. Then it was worth 4 os., now 30 s. Robert holds of Walter. The King and the Earl (have) the soke.

In Aсненам [Akenham] (were) 4 freemen with 32 acres of land. Then $x$ plough. Worth 5s. Roger holds of Walter. The King and the Earl (have) the soke.

\section{Hundrat of Carleforda [Carlford]}

In WrtTlesham [Witnesham] Lewin, a freeman, T.R.E. held 3 carucates of land. Then as now 10 villeins, and 4 bordars, and 6 serfs, now 5 . Then as now 3 ploughs on the demesne, and 4 ploughs belonging to the men. Io acres of meadow. And 3 rounceys, 8 beasts, 68 swine, 180 sheep, 30 goats, and 7 hives of bees. Then it was worth 6os., now 12 li. It is 8 furlongs long, and 4 broad, and (pays) $5 d$. in geld.

In Finesforda [

]$^{335}$ (now held) in demesne, 26 freemen under commendation to the predecessor of Walter held I carucate of land. Saint Etheldreda had the soke. Then among them (were) 3 ploughs, now 2. 4 acres of meadow. Worth 40s. It is Io furlongs long, and 3 broad, and (pays) rod. in geld.

In Otelega [Otley] on the demesne are 6 acres. Worth $12 d$.

\section{LANDS OF TEHELL DE HERION}

\section{Babrnberga [Babergh] Two Hundrets}

(At) Ilebega [(Brent) Eleigh] Ulward a freeman under Stigand T.R.E. held 3 carucates of land as a manor. Then as now 5 bordars, and 2 serfs. Then as now 2 ploughs on the demesne. And 3 acres of meadow. And 1 mill. And 2 horses at the hall, 6 beasts, 20 swine, and 100 sheep. Then it was worth 40 s., afterwards and now 80 s. It is half a league long, and 4 furlongs broad. And (pays) $3 \frac{1}{2} d$. in geld.

fol. 428 .

\section{RISEBRUGB [RISBRIDGE] HUNDRET}

At Hauerhella [Haverhill] Clarebold held $2 \frac{1}{2}$ carucates of land as a manor T.R.E. Then and afterwards 6 villeins, now 1 . Then and afterwards 4 bordars, now 10 . Then as now Io serfs. Then and afterwards and always 2 ploughs on the demesne. Then as afterwards I plough belonging to the men, now half a plough. Wood(land) for 20 swine. 6 acres of meadow. The third part of a market; in it 10 bordars. To the church (belong) 5 acres. The manor is worth 40 s., and the market $13^{s}$. and $4 d$. It is I league long, and half a league broad. And pays $6 d$. in geld. Others hold (land) therein.

\section{LANDS OF RALPH DE LIMESI}

\section{Babenberga [Babergh] Two Hundrets}

(At) HoKetona [Houghton ${ }^{336}$ ] Huthtrad held under Harold T.R.E. as a manor 2 carucates of land with soke. Then as now I villein, and 2 bordars, and 5 serfs. Then 3 ploughs on the demesne, afterwards and now 4. Then as now half a plough belonging to the men. Wood(land) for 20 swine. And 10 acres of meadow. Then as now I horse at the hall, Then 3 beasts, now none.

Finested A [Fenstead ${ }^{337}$ the same Uthtret T.R.E. held as I carucate of land. Now Ralph holds (this land) as a berewick of Hoketona [Houghton] from Edgar his predecessor. Then as now I plough on the demesne.

Hoketona [Houghton] was then worth 4 li., now Ioos. And Finesteda [Fenstead] then and afterwards was worth 20s., now 30s. But it is included in the roos. The whole is 8 furlongs long, and 4 broad. And pays $4 d$. in geld.

(At) Kanavadisc [Cavendish] Norman held with soke and sac under King Edward as a manor 2 carucates of land. A church with 30 acres of free land. Then as now 5 villeins, and 8 bordars, and 7 serfs. Then 2 ploughs on the demesne, afterwards and now 4. Then as now fol. $428 b$.

3 ploughs belonging to the men. And I mill. And 10 acres of meadow. Then 3 beasts, now 24. Then 40 sheep, now 110 . Then 30 swine, now 50. To this manor belongs KODENHAM [Coddenham ${ }^{238}$ ], a berewick with 2 carucates of land. Then 5 villeins, and afterwards and now 3. Then 4 bordars, and afterwards and now I3. Then and afterwards $2 \operatorname{serfs,~now~} I$. Then 2 ploughs on the demesne, and afterwards and now 1 . And $1 \frac{1}{2}$ ploughs belonging to the men. Then half a mill, afterwards and now none. A church with 20 acres of free land. Then and afterwards the whole was worth roos., now roli.

${ }^{286}$ In Cavendish. $\quad{ }^{37}$ Ibid. $\quad{ }^{289}$ In Boxford. 


\section{A HISTORY OF SUFFOLK}

KANAVADIS [Cavendish] is half a league long, and 4 furlongs broad. And (pays) $10 d$. in geld.

Kodeham [Coddenham] is 6 furlongs long, and 3 broad. And (pays) $3 \frac{1}{2} d$. in geld.

(At) NeuUetona [Newton] the same Uthtret held under Harold with soke and sac 2 carucates of land as a manor. Then as now 3 villeins. Then 7 bordars, and afterwards and now 20. Then 4 serfs, afterwards and now I. Then as now 2 ploughs on the demesne. Then and afterwards 2 ploughs belonging to the men, now $2 \frac{1}{2}$ ploughs. Wood(land) for 6 swine. And 4 acres of meadow. A church with 30 acres of free land. Then $x$ horse, now none. Then 3 beasts, now 8 . Then 17 swine, now 20. Then 60 sheep, now 103. Then 17 goats, now 35. Half a church with 8 acres of free land.

In the same (vill was) a freeman half under Uthtred and half under Saint Edmund by commendation, but wholly in the soke of Saint Edmund. And he could sell without licence. And he had 20 acres. The whole was then worth 40 s., afterwards and now 6os. It is half a league long, and 4 furlongs broad. And (pays) $6 \frac{1}{2} d$. in geld.

In CoRnierda [Cornard] (was) a freeman under Wisgar by commendation only and soke with I carucate of land. Then as now 5 bordars. Then as now I plough on the demesne, and 6 acres of meadow. Wood(land) for 4 swine. Then as now 5 beasts. Then Io swine, now 20. Then 30 sheep, now 60 . Then as now it was worth 20s. It is half a league long, and half a league broad. And (pays) $3 \frac{1}{2} d$, in geld.

\section{Biscopes [Bishops] Hundret}

(At) Bedingafelda [Bedingfield] Aluric a freeman under Harold held as a manor T.R.E. 92 acres. Then 2 bordars, now 4. Then as now I plough on the demesne. And I plough

fol. 429 .

belonging to the men. Wood(land) for 10 swine. And I acre of meadow. Then as now 12 swine, and 20 sheep. The fourth part of a church with 6 acres. Then worth 30s, now $\mathrm{I} 6 \mathrm{~s}$. and $8 d$.

In the same (vill were) 6 freemen. Over all Aluric (had) commendation except over half (a freeman) who was under Robert Malet's predecessor by commendation only; and they had 35 acres and 1 acre of meadow (and) then as now I plough, and were worth $40 d$.

\section{HUNDRET OF LOSA [LOES]}

(At) Framelingaham [Framlingham] Brictmar a freeman under Harold held T.R.E. 50 acres of land as a manor. Then as now 3 bordars, and I serf. And on the demesne I plough. And belonging to the men half a plough. Then and always it was worth 15 s.

\section{Hertesmera [Hartismere] Hundret}

(At) Cranlea [Cranley] Aluric a freeman held 100 acres of land as a manor T.R.E. Then as now Io bordars. And I plough on the demesne. And I plough belonging to the men. Wood(land) for 6 swine. Worth 20s. Aluric had half the soke, and the King the other moiety.

In Hastelea [Hestley] 2 freemen under commendation (held) 10 acres worth $20 \mathrm{~d}$.

In Acolt [Occold] a freeman under commendation (held) 8 acres worth $16 d$. Ralph holds the whole in demesne. The King and the Earl (have) the soke.

In the same (vill) a freeman under commendation to the Abbot of St. Edmunds (held) 2 acres, worth $4 d$. The King and the Earl (have) the soke.

\section{XLIIII. LAND OF ROBERT DE TODENI}

\section{Risebruge [RISBridge] Hundret}

(At) Bradeleia [Bradley] Olf the thegn held as a manor T.R.E., now Roger holds in demesne, 7 carucates of land. Then as now 14 villeins, and 12 bordars, and 6 serfs. And 3 ploughs on the demesne. And 7 ploughs belonging to the men. And I 3 acres of meadow. Wood(land) for 500 swine. Then as now I rouncey. Then 12 beasts, now 18 . Then 60 fol. $429 b$.

swine, now 53. Then 20 sheep, now 63. And 7 goats. And I hive of bees. A church with I 5 acres of free land. Then worth $6 l i$, now $8 l i$. It is $I$ league long, and 7 furlongs broad. And (pays) $6 d$. in geld.

\section{Biscopes [Bishop's] HUNDRET}

At SeILAm [Syleham] Olf held with the soke T.R.E. as a manor $2 \frac{1}{2}$ carucates of land. Then 8 villeins, now 3. Then 12 bordars, now 13 . Now I serf. Then as now 3 ploughs on the demesne. Then and afterwards 12 ploughs belonging to the men, now 4. Wood(land) for I 50 swine. 8 acres of meadow. Then as now I mill. Then 2 rounceys, now I. Then 8 beasts, now 2. Then 80 swine, now 44. Now 7 sheep, and 3 goats, and $\mathbf{I}$ hive of bees. Then worth roos., and the like now.

In the same (vill) 5 freemen (of whom $R$. de Todeni's) predecessor had commendation held 


\section{THE HOLDERS OF LANDS}

30 acres. Then I plough, now half a plough. And I acre of meadow. Worth 5s. A church with 16 acres, worth 2s. It is I league long and 8 furlongs broad. And (pays) $7 \frac{1}{2} d$. in geld. The soke is in Hox [Hoxne] the Bishop's manor.

\section{Blidigga [Blything] Hundret}

(At) Mealla [Mells ${ }^{339}$ ] Manning a freeman held as a manor, and now Robert has in demesne, 3 carucates of land. Then as now 8 villeins. Then as now 12 bordars. Then as now 3 serfs. Then as now 2 ploughs on the demesne. 3 ploughs belonging to the men. Wood(land) for 100 swine. 5 acres of meadow. Then I mill, now none. Then as now 2 rounceys, 7 beasts, 30 swine, 16 sheep. Then it was worth 50 s., now 60 s. It is 10 furlongs long, and 7 broad. And renders $2 d$. in geld.

(At) GoKesford [Yoxford] Manning (held) as a manor, now Robert holds in demesne, 5 carucates of land. Then 12 villeins, now 9. Then 2 bordars, now none. Then as now I serf. Then as now 2 ploughs on the demesne. And 3 belonging to the men. Wood(land) for 30 swine. 20 acres of meadow. Then as now I rouncey, 7 beasts, 30 swine. And then it was worth 40s., now 6os. It is 10 furlongs long, and 7 broad. (And pays) $3 d$. in geld.

fol. 430 .

\section{LAND OF WALTER GIFART}

\section{Perreham [Parham] Half Hundret}

In Blachessala [Blaxhall] a free(man) Codric, ${ }^{340}$ half under commendation to the predecessor of Malet and half to the Abbot of Ely, (held) 10 acres, worth $20 d$. Ralph de Langhetot holds. The soke is the Abbot's.

\section{Plumesgata [Plomesgate] Hundret}

(At) Gliemham [Glemham] Starlinc held I 80 acres ${ }^{341}$ as a manor T.R.E. under commendation half to the Abbot of Ely and half to William Malet, and he (Malet) was seised thereof. Then as now II bordars. And 2 ploughs on the demesne. And I plough belonging to the men. And I acre of meadow. Then as now 2 rounceys. Then 16 swine, now 26. Then 30 sheep, now 50. Then it was worth 40 s., now 6os. And there have been added 24 freemen under commendation with 100 acres. Then as now 3 ploughs. Worth 40 s. It is I league long,

\footnotetext{
In Wenhaston.

sto "Godric'; Ing. El. I 51 .

'11 " $1 \frac{1}{2}$ carucates of land'; Inq. El. 153. This shows that the carucate contained I 20 acres.
}

and half (a league) broad. And pays 20d. in geld.

In Straffort ${ }^{342}$ [Stratford (St. Andrew)] the same Starlinc held I carucate of land as a manor T.R.E. Then as now 5 bordars. And I plough on the demesne. Half a plough belonging to the men. And 4 acres of meadow. And 1 mill. Worth 40 s.

In the same (vill) $13 \frac{1}{2}$ freemen under commendation then as now (held) 64 acres, and $1 \frac{1}{2}$ ploughs. Worth 7s. Ralph de Langhetot holds the whole. The soke (belongs to) the Abbot of Ely.

\section{fol. $430 b$.}

\section{LANDS OF THE COUNTESS OF ALBAMARLE}

\section{Babenberga [Babergh] Two Hundrets}

In Simplinga [Shimpling] Uluric, King Edward's thegn, held 5 carucates of land as a manor. Now the Countess of Albamarle holds it. Then 5 villeins, now 3 . Then and afterwards 4 bordars, now 10. Then as now 6 serfs. Then and afterwards 3 ploughs on the demesne, now 2 . Then as now 3 ploughs belonging to the men. Wood(land) for 8 swine. And Io acres of meadow. Then as now I horse. Then $\mathrm{I} 4$ beasts, now 6 . Then 40 swine, now 24. Then 120 sheep, now 100. A church with 30 acres. In the same (vill) 5 freemen under Uluric by commendation-and Saint Edmund had soke and sac T.R.E., now the Countess has them-(held) I carucate of land, and I bordar, and I serf. Then as now 2 ploughs. And 2 acres of meadow. Then and afterwards it was worth $g l i$. It is $\mathbf{I}$ league long, and half a league broad. And (pays) $5 d$. in geld.

At SCERDACRa [Chadacre ${ }^{343}$ ] the same Uluric T.R.E. held I carucate of land as a manor. Then as now 1 villein, and 3 bordars, and 2 serfs. Then 2 ploughs on the demesne, now none. Then as now I plough belonging to the men. And 3 acres of meadow. Then as now it was worth 6os. It is 4 furlongs long and 2 broad. And (pays) $2 \frac{1}{2} d$. in geld.

\section{Sanfort [Samford] Hundret and a Half}

(At) Belesteda [Belstead] Aluric de Weinhou held 3 carucates and 40 acres of land as a manor. Then as now 12 villeins and 3 bordars. Then 5 serfs, now I. Then 2 ploughs on the demesne, now I. Then 8 ploughs. Afterwards and now 5 , and 6 acrts of meadow. Then wood(land) for 30 swine, now 20. A church with 34 acres of free land. Now 27 swine, and 35 sheep. Then

$$
\text { 31s 'Strattuna'; ibid. } \quad{ }^{313} \text { In Shimpling. }
$$




\section{A HISTORY OF SUFFOLK}

worth 8 ii, now 6li. The same Aluric (had) the soke. It is I league long, and 3 furlongs broad, and (pays) $7 d$. in geld.

(At) Herchesteda [Harkstead] Edith the Fair held 7 carucates of land as a manor T.R.E. Then as now 17 villeins, and 8 bordars. Then I serf. Then 3 ploughs on the demesne. Afterwards and now 2. Then as now 5 ploughs belonging to the men, 8 acres of meadow. Wood(land) for 30 swine. And 1 mill. A church

fol. 431 .

having 24 acres. And 4 beasts, 24 swine, 40 sheep, and 27 goats. Then worth roli., now 14li. It is I league long, and half a league broad, and (pays) $14 d$. in geld.

(At) Gutthuluesforda [Gusford ${ }^{344}$ ] Edith held T.R.E. 2 carucates of land as a manor. Then as now 1 villein and 6 bordars. Then 2 ploughs belonging to the men, now $\mathrm{I}$, and 3 ploughs could be restored. 8 acres of meadow. Then wood(land) for 20 swine. Then I mill. The third part of a church (having) 8 acres. Worth 3 li. It is 8 furlongs long and 3 broad, and (pays) $5 d$. in geld. Edith (had) the soke.

\section{Hundret of Colenesse [Colners]}

In Helmelea [Hemley] I villein with 9 acres; worth $20 d$. And he belongs to Cloptuna [Clopton].

\section{Hundret of Carleforda [Carlford]}

In Clopetuna [Clopton] Burric, a freeman, under Ralph the Staller T.R.E. held I carucate and 20 acres of land as a manor. Then as now II bordars, and on the demesne 2 ploughs. Then 2 ploughs belonging to the men, now I. 4 acres of meadow, and 10 swine, and 35 sheep. Then as now it was worth 40 .

In the same (vill) are 6 acres which Ulwin the priest keeps (servat) and holds. Worth I2d.

In BURg [Burgh] (were) 2 freemen, I under commendation to Saint Etheldreda, ${ }^{345}$ and the other under commendation to Ralph the Earl, with 36 acres, and 2 bordars. Then 2 ploughs, now half a plough. 2 acres of meadow, worth $6 s$.

In Clopetuna [Cloptor] $12 \frac{1}{2}$ freemen under commendation to Burric T'.R.E. (held) 92 acres, and 2 bordars. Then 3 ploughs, now 2. I acre of meadow. Worth 16 s. and $4 d$.

34 In Belstead.

345 ' a freeman under commendation to St. Etheldreda (with) 16 acres, 2 bordars and 1 acre of meadow. Worth 32d.'; Inq. El. 150.

\section{HUNDRET OF WILEFORD [WILFORd]}

In Depebes [Debach] were 3 freemen under commendation to Edric Grim with 20 acres. $^{346}$ I acre of meadow. Then I plough. Worth $3^{\text {s. }}$ A church with 8 acres, worth $16 d$.

In Bulges [Boulge] a freeman (holds) half an acre, worth $2 d$.

\section{HUNDRET OF LOSA [LOES]}

In Mungadena [Monewden] (are) 5 acres and in Caresfella [Charsfield] 3 acres, worth $12 d$.

\section{fol. $43^{1} b$.}

\section{LANDS OF WILLIAM DE ARCIS}

\section{Hundret of Colenessi [Colnets]}

In Helmele [Hemley] I bordar with 5 acres. And they belong to Cloptuna [Clopton], and (are included) in its valuation.

\section{Hundret of Carleford [Carlford]}

In Cloptuna [Clopton] Edmund the priest, a freeman under Saint Etheldreda T.R.E., held I carucate and 22 acres of land as a manor. ${ }^{847}$ And 1 villein, and 7 bordars. Then on the demesne 3 ploughs, now 1 . Then 1 plough belonging to the men, now half a plough. ${ }^{343} 4$ acres of meadow, now I rouncey. Then 4 beasts. Then 40 swine. Then 30 sheep. Now of the whole (stock) nothing (remains). Then it was worth 30s., now Ios. This Bernard de Sancto Audoeno holds of William.

\section{Hundret of Losa [Loes]}

Brantestuna [Brandeston] Edmund the priest, under commendation of Saint Etheldreda, T.R.E. held; and the land which he received with his wife in Brandeston and in Cloptuna [Clopton] he granted to the church with the lady's consent by such agreement that he could not sell nor give away from the church. 60 acres as a manor. And 5 bordars, and 2 serfs. And on the demesne I plough. And belonging to the men I plough. 5 acres of meadow. Wood(land) for 6 swine. ${ }^{349}$

36 " 3 freemen under commendation to St. Etheldreda (with) 20 acres. Of these the Countess of Albemarle has one'; ibid. 148. In the summary of encroachments (ibid. 189) this entry is summarized as 'I acre of meadow in Depepache."

${ }^{317}$ 'held I carucate and Io acres of land, which he could not give or sell, and a villein held 12 acres'; ibid. 150.

348 'Then 2 ploughs belonging to the men, now '; ibid.

348 'Wolth 20s.' ; ibid. 152. 


\section{THE HOLDERS OF LANDS}

To this manor were added 80 acres of land as a manor T.R.E. Then 4 bordars, now 12 bordars. Now among them I plough. Wood(land) for 8 swine. And 4 acres of meadow. And I mill. Now 1 rouncey, 20 swine, 16 sheep, 30 goats, and 3 hives of bees. Then all together it was worth Ioos., now 6os.

This William has as I manor, but T.R.E. there were 2. A church with 12 acres, worth 2s. It is 1 league long, and 3 furlongs broad. And in geld (pays) $5 \frac{1}{2} d$.

\section{fol. 432. \\ XLVIII. LANDS OF DROGO DE BEURERIA}

\section{Hun $D$ Ret of Blidinga [Blything]}

(At) Sudretuna [Sotherton] Rada a freeman held under Harold 2 carucates of land as a manor. Now Franc holds it of Drogo. Then and afterwards 16 bordars, now 19. Then as now 2 serfs. Then and afterwards I plough on the demesne, now 2. Then as now 3 ploughs belonging to the men. And 2 acres of meadow. Wood(land) for 100 swine. A church with 5 acres. And I rouncey. And now I beast. Then 12 swine, now 24, and 25 sheep. Then as now it was worth 40s. It is I league long and half a league broad. And (pays) $1 \frac{3}{4} d$. in geld. Rada, Drogo's predecessor, had soke and sac. To this manor Humphrey de Sancto Bertino added I freeman with 12 acres, over whom his predecessor had commendation T.R.E. Then as now I bordar. And half a plough. Worth 2 .

\section{XLVIIII. LANDS OF HUGH DE GRENTEMESNIL}

\section{half Hundret of Crosfort [Cosford]}

(At) Leiram [Layham] T.R.E. Alfnod held of Harold 3 carucates of land as a manor. Then as now 4 villeins, and 7 bordars. Then 5 serfs, now 6. Then as now 2 ploughs on the demesne, and 2 ploughs belonging to the men. And II acres of meadow. And I rouncey, 15 beasts, 15 swine, 100 sheep, and 19 goats. Then it was worth 70 s., now roos. It is half a league long, and half (a league) broad. And (pays) $4 \frac{1}{2} d$. in geld. Saint Edmund had the soke.

\section{LANDS OF RALPH DE FELGERIS}

\section{(Hartismere Hundret)}

(At) Estutestuna [Stuston] Ulsi a freeman under Gurth's commendation held 2 carucates of land as a manor T.R.E. Then as now 4 villeins, fol. $43^{2} b$.

and 4 bordars. Then on the demesne 2 ploughs, now 1. Then as now I plough belonging to the men. 6 acres of meadow. Then 2 beasts, now I. Then 5 swine. Then worth 60s., now 40 s.

And 3 freemen under Ulsi's commendation (held) 12 acres, worth 2s. The King and the Earl (have) the soke.

In Frondestuna ['Thrandeston] (are) 6 acres, worth $12 d$.

\section{LANDS OF WALTER DE SANCTO WALERICO}

\section{Stou [STOW] HundReT}

In Cratinga [Creeting (St. Peter)] Aluric a freeman T.R.E., under Edric the predecessor of Robert Malet by commendation only, held-and Robert held but was afterwards disseised-I $\frac{1}{2}$ carucates of land. And 2 villeins, and 9 bordars. Then as now $2 \frac{1}{2}$ ploughs on the demesne. Then I plough belonging to the men, afterwards and now half a plough. Then wood(land) for 40 swine, now for none. And I mill. And 6 acres of meadow. And half a church with 10 acres of free land. And 5 beasts, 9 sheep, and 12 swine. Worth roos.

In the same (vill) Walter a freeman under Tholi by commendation held $10 \frac{1}{2}$ acres. Then and afterwards and now half a plough. Worth $3^{\text {s. }}$

\section{Bosemera [Bosmere] Hundret}

In Cratinga [Creeting (All Saints)] a freeman (held) 60 acres T.R.E. under commendation to Robert Malet's predecessor, and his father was seised thereof. Then as now 4 villeins. And half a plough. This is attached to Cratingis [Creeting (St. Peter)] in the Hundret of Stou [Stow] and is included in its valuation.

In the same (vill) 4 freemen by commendation (hold) 7 acres.

In ULEDANA [Olden ${ }^{350}$ ] a freeman under commendation (held) 4 acres. Worth 2s. The King and the Earl (have) the soke.

fol. 433 .

\section{LANDS OF HUMPHREY THE CHAMBERLAIN}

\section{Hundret of Carifforda [Carlford]}

In Otrleia [Otley] Lefleda, a freewoman under commendation to Edric the predecessor of Robert Malet, held $\mathrm{I} \frac{1}{2}$ carucates of land. Then

$$
{ }^{350} \text { In Coddenham. See n. } 2 .
$$




\section{A HISTORY OF SUFFOLK}

as now 3 villeins, and 10 bordars. Then on the demesne 2 ploughs, and now $1 \frac{1}{2}$. Then 3 ploughs belonging to the men, now 2. Wood(land) for 20 swine. 2 acres of meadow. Then as now 2 rounceys. Then 5 beasts. Then 40 swine, and now the like. Then as now roo sheep, and 25 goats, and 6 hives of bees. Then it was worth IOOs., now 6li. William Malet was seised on the day of his death, and afterwards Robert, witness the Hundred.

In the same (vill) Lustwin, under commendation to Edric T.R.E., held I carucate of land as a manor. Then as now I villein and 4 bordars. Then I plough, now $1 \frac{1}{2}$ on the demesne. Then as now I plough belonging to the men. 2 acres of meadow. Wood(land) for 5 swine. Then it was worth 20 s, now 30 s.

In the same (vill) $16 \frac{1}{2}$ freemen under commendation to Lefleda (held) 69 acres. Then 3 ploughs, and now. Then it was worth 20s., now 30s. I church with 20 acres, worth $4^{\text {s. }}$ Of all this was William Malet seised on the day of his death, and Robert afterwards, and the King and the Earl (have) the soke.

In the same (vill) Amund holds; Brithwold, a freeman under commendation to Queen Edith, (held) 30 acres, and I villein, and 4 bordars. Then 1 plough, now $1 \frac{1}{2}$. $x$ acre of meadow. Wood(land) for Io swine. Then it was worth 8 s., now IOs.

In Cloptuna [Clopton] are 20 acres and I bordar. Worth 5s. This Amund holds of Humfrey ( $W$ mfrido).

In Oteleia [Otley] 6 freemen under commendation to Brihtwold (held) 27 acres of land. Then 2 ploughs, now 1 . Then it was worth Ios., and now the like.

In Burg [Burgh] a freeman, under commendation half to the same (Brihtwold) and half to Saint Etheldreda, (held) 24 acres, and half a plough, and half an acre of meadow, worth ros.

\section{HuNDRET OF LOSA [LOes]}

(At) Gretingaham [Cretingham], (which) Amund (now) holds, Brihtmar, under commendation of the Queen, held 83 acres as a manor. fol. $433^{b}$.

Then and now I villein, and I bordar, and I serf. And on the demesne I plough. And belonging to the men half a plough. 4 acres of meadow. A church with 8 acres, worth $16 d$. Then as now 3 rounceys, 3 beasts, 24 swine, 40 sheep, 25 goats, and 4 hives of bees. Then it was worth $20 s_{\text {s, now } 30 s .}$

In the same (vill) 8 whole freemen and 4 half (freemen) under commendation to the same (Queen) (held) 66 acres of land. Then 2 ploughs, now $1 \frac{1}{2}$ ploughs. And I acre of meadow. Then it was worth 20 s., now $3 \mathrm{Is}$.

\section{Hundret of Bosemera [Bosmere]}

In Assa [Ash] Alwin a freeman held 4 acres. Then it was worth $16 d$, now $8 d$.

In Oteleia [Otley] Humfrey holds in demesne a freeman (with) 3 virgates, worth $3^{d}$.

In the same (vill was) a freewoman, Listeva, with $I$ acre, worth $2 d$.

In Brictices HaGA [ ] is wood(land) in which I 6 swine could be pastured T.R.E., now 4. And Amund holds it of Humfrey. And it is attached to (jacet in) Gratingeham [Cretingham].

\section{Claindune [Claydon] Hundret}

(At) Elmingheham [Helmingham] Grimolf, a freemen under commendation to the Queen, held 120 acres of land; and it belongs to (jacet in) the demesne of Oteleia [Otley]. Then as now I villein, and 5 bordars. And I plough belonging to the men. 3 acres of meadow. Wood(land) for 50 swine. And this is (included) in the valuation of Oteleia [Otley].

In the same (vill) on the demesne (were) II freemen under commendation to (Humfrey's) predecessor, except two who were under commendation to Brictuold T.R.E., with 68 acres T.R.E. Then as now 2 ploughs. Worth 20 s.

In the same (vill) Brictuold a freeman held 40 acres T.R.E. Then as now 2 villeins, and 3 bordars. Then as now 2 ploughs. 3 acres of meadow. Worth 20s. Amund holds of Humfrey. The King and the Earl (have) the soke.

\section{fol. 434 .}

In AsSEFELDA [Ashfield] were 2 freemen with 4 acres. Worth $8 d$. The soke (is) the Abbot's.

In Bermesdena [ ]$^{351}$ Anant held 2 freemen ... having 60 acres T.R.E. Then as now I bordar. Then I plough, 2 acres of meadow. Then it was worth 20s., now 30 s. Humfrey holds in demesne. The King and the Earl (have) the soke. And a freeman added (to the estate) holds 4 acres. Worth 2 s.

\section{LANDS OF EUDO SON OF SPIRUIC}

\section{LAcForda [LAckFord] Hundret}

In Ecclingaham [Icklingham] Moruant holds of Eudo (the land) which Anant a free-

${ }^{351}$ Occurs in $15^{\text {th }}$ century 2s 'Bermoundesden ;' Copinger, Suff. Rec. 


\section{THE HOLDERS OF LANDS}

man under Saint Etheldreda T.R.E. held, viz., 2 carucates of land as a manor, but he could not sell it ; now Eudo son of Spiruic holds from Henfrid his predecessor; but the soke and sac are Saint Edmund's. Then and afterwards 7 villeins, now 6 , and 6 bordars, and 1 serf. Then as now 2 ploughs on the demesne. And I plough belonging to the men. And 5 acres of meadow. And 1 mill. Now 84 sheep. Then it was worth 4 li., now 60 s.

\section{Bosemera [Bosmere] Hundret}

(At) WLEDANA [Olden ${ }^{352}$ ] Siric a freeman T.R.E. held as a manor 70 acres, now William (holds). Then as now 2 bordars. Then 2 ploughs, now $I_{\frac{1}{2}}$ ploughs. And 2 acres of meadow. Then 2 rounceys. Now 16 swine. And 28 sheep. Worth 20 s.

In the same (vill) 13 freemen, over 2 Roger's predecessor had commendation, (held) 40 acres and I plough. Worth Ios. The King and the Earl (have) the soke. It is I league long, and 3 furlongs broad. And (pays) Iod. in geld. Others hold land therein.

\section{fol. $434^{b}$.}

At BETEsFort [Battisford] Jarnagot holds, which Kerinc a freeman T.R.E. held; viz., I carucate of land and 20 acres as a manor. Now Jarnagot holds it. And (there were) then as now 5 bordars, and 1 serf. Then 2 ploughs on the demesne, now I. And half a plough belonging to the men. 6 acres of meadow. Then wood(land) for 60 swine, now 10 . Then 2 rounceys. Now 20 swine, II sheep, and 12 goats. Half a church with 20 acres. Worth 25 s.

In the same (vill were) 3 freemen with 20 acres. Over two his predecessor had commendation. Then as now half a plough. Worth 5s. The King and the Earl (have) the soke.

In Codenham [Coddenham] Siric a freeman (held) on the demesne 5 acres, worth $10 d$. The soke (is) the King's.

\section{HUNDRET OF W ANNEFORDA [W ANGFORD]}

Flixtuna [Flixton] Geoffrey holds, which Offa, a freeman under commendation to Stigand, held T.R.E. ; 2 carucates of land as a manor. Then 16 villeins, now 10. Then II bordars, now 14. Then as now 2 serfs. And on the demesne 2 ploughs. Then belonging to the men $13 \frac{1}{2}$ ploughs, now $9 \frac{1}{2}$. Then as now $\mathrm{I}$ rouncey, 2 beasts, 6 swine, and 26 sheep. 12 acres of meadow. Wood(land) for 20 swine. Half a mill. Then worth $40 s$,

$$
\text { w" In Coddenham; see n. } 2 .
$$

now 6os. Half a church with ro acres, worth $16 d$.

In the same (vill) 2 freemen under the same (Stigand's) commendation (held) 30 acres. Then as now $3 \frac{1}{2}$ bordars. And $2 \frac{1}{2}$ ploughs. Wood(land) for 2 swine. $\quad 3 \frac{1}{2}$ acres of meadow. Then worth 75., now 1 os. and $8 d$. It is I league long, and half (a league) broad. And in geld (pays) $20 d$.

\section{Hertesmara [Hartismere] Hundret}

At WEST ToRP [Westhorpe] the said Geoffrey now holds; Ulric Hagana held I carucate of land as a manor T.R.E. Then as now I bordar, and I serf. And on the demesne $I_{2} \frac{1}{2}$ ploughs. Wood(land) for 12 swine. 6 acres of meadow. And 3 rounceys, 2 beasts, 3 I swine, 50 sheep, 15 goats, and 5 hives of bees. Then worth 20 s., now 30 s. And 15 freemen under Ulric's commendation (held) 33 acres. Then as now I plough. Wood(land) for 2 swine. 2 acres of meadow. Worth IOs. Over this fol. 435 .

manor Saint Edmund had T.R.E. soke and sac and commendation; and (Ulric) could not sell or give it away from the church; and over the I 5 freemen and over Ulnoht (sic) Robert Malet's predecessor had commendation, witness the Hundred, and (Ulric) could not sell or give his land away from him.

\section{Half Hundret of Cosfort [Cosford]}

In WeCrSham [Wattisham] a freeman over whom the Abbot of Ely had commendation and soke T.R.E. (held) I carucate of land, and 3 bordars, and I plough, and 3 acres of meadow. Worth 20s. Saint Edmund had the six forfeitures. Jarnacot holds (this land).

\section{LIIII. LANDS OF WILIIIAM DE WATEVILLE}

\section{Risebruge [RIsbridge] Hundret}

(At) Litgata [Lidgate] Stori held as a manor T.R.E. 4 carucates and 60 acres of land. Then as now 9 villeins, and 12 bordars, and I serf. And 2 ploughs on the demesne. Then 3 ploughs belonging to the men, now 2. Io acres of meadow. Wood(land) for 15 swine. Then I rouncey, and 5 beasts, and 25 swine. Then 33 sheep, now I 40. And I 3 goats. Then worth 80 s, and now the like. It is I league long and 8 furlongs broad. And pays $13 \frac{1}{2} d$. in geld. Others hold (land) therein.

\section{Tingoho [Thingoe] Hundret}

(At) Haragrava [Hargrave] Alviet a freewoman held T.R.E. under Saint Edmund, and 


\section{A HISTORY OF SUFFOLK}

could not sell, 4 carucates of land. Then and afterwards 6 villeins, now 8 . Then and afterwards 4 bordars, now 7 . Then 4 serfs, now 2 . Then and afterwards 2 ploughs on the demesne. Then and afterwards 4 ploughs belonging to the men, now 3. Then I horse, now none. Then 2 beasts, now 8. Then 5 swine, now 40. Now I00 sheep. And 4 acres of meadow. Wood(land) for 16 swine. A church with 12 acres fol. $435^{b}$.

of free land. Then and always worth 4 li. It is 8 furlongs long, and 5 broad. And (pays) $7 d$. in geld.

\section{LACHEFORdA [LACKFORD] HUNDRET}

(At) Bertunna [Barton (Mills)] Alued a freeman held 5 carucates of land; and this land William held from the Queen; now Alveve holds from the King. Then ro villeins, now 7. Now 5 bordars. Then 9 serfs. Then 4 ploughs on the demesne, now I. Then as now 3 ploughs belonging to the men, 2 fisheries. 2 acres of meadow. Then I rouncey. And now 2 horses. Then ro beasts, now 5. Then 200 sheep, now 3. Then 40 swine, now 3. Then it was worth $8 l i$, and afterwards $6 i_{\text {. }}$, now 30 s. And it is I league long, and half a league broad. And in geld (pays) 2od. Saint Edmund (has) soke and sac.

\section{LAND OF JOHN SON OF WALERAN}

\section{Babenberga [Babergh] Two Hundrets}

In Bura [Bures] Uluric son of Brictric T.R.E. held 2 carucates of land under King Edward. Then 7 serfs. And I smith. Now 4 serfs. And now 2 bordars. Then as now 2 ploughs on the demesne. Wood(land) for 40 swine. And 4 acres of meadow. Now I mill. Now 2 horses, and 2 beasts. Then 60 sheep, now I40. Then 40 swine, now 20. Now 35 goats. Then it was worth 6os., now 40 s.

In the same (vill) Tosti a freeman under King Edward held I carucate of land. Then I villein, now none. And now 2 bordars, and I serf. Then as now I plough. Wood(land) for 10 swine. And 2 acres of meadow. Then 40 swine, now 20. And 20 sheep. Now 15 goats. Worth 20 s.

In the same (vill were) 2 freemen under Harold. And they could sell. And they had 60 acres, and I plough. Worth 5s. And they were assigned (liberati) to make up the manor. fol. $43^{6}$.

\section{LAND OF HUMPHREY SON OF} AUBREY

\section{Stou [Stow] Hundret}

By reason of the Normandy exchange

In Anehus [Onehouse] Io freemen under Ketel by commendation only (held) 60 acres of land and I bordar. Then 2 ploughs, afterwards and now $\mathrm{x}$. And 3 acres of meadow. Worth Ios. The King and the Earl (have) the soke.

\section{Bosemera [Bosmere] Hundret}

In Codenham [Coddenham] (were) II freemen with 80 acres less 2. Then 2 ploughs, now $1 \frac{1}{2}$ ploughs. And 2 acres of meadow. In Uledana [Olden] (were) 5 freemen with 20 acres. Then as now half a plough. In HaUUngestuna [Hemingstone] (were) 3 freemen with 9 acres. And the whole is worth 30s. The King and the Earl (have) the soke.

In Cadenham [Coddenham] Aluric a freeman (held) 8 acres T.R.E. (included) in the same valuation.

\section{Claindune [Claydon] Hundret}

In Codenham [Coddenham] was a freeman with 4 acres. Worth $8 d$. The soke (is) the King's and the Earl's.

From Belingesfort [Billingford ${ }^{353}$ ] mill 75 . and $4 d$. In EusFort Hundret [Eynsford Hundred] in Norfolk.

\section{LAND OF HUBERT DE MONTE CANESIO}

\section{Hertesmera [Hartismere] Hundret}

(At) Wiuertestuna [Wyverstone] Lewin the Bald held T.R.E. I carucate of land as a manor. Then 4 bordars, now 3. Then 2 ploughs on the demesne, afterwards 1 , now $1 \frac{1}{2}$. And half a plough belonging to the men. And 3 acres of meadow. Then wood(land) for 40 swine, now for 20. A church with 16 acres of land and half a plough. Then as now I rouncey, 3 beasts, 12 goats, and 10 swine. Then as now worth 30 s.

In the same (vill) 6 freemen under Lewin's commendation (held) 37 acres. Then as now fol. $436 b$.

I plough. Worth Ios. All this Richard holds

${ }^{\text {sis }}$ Billingford in Norfolk was held by Humphrey (Dom. Bk. ii, $262 b ;$ V.C.H. Norf. ii, 184). 


\section{THE HOLDERS OF LANDS}

of Hubert. The King and the Earl (have) the soke. It is I league long, and $4 \frac{1}{2}$ furlongs broad. And (pays) $8 d$, in geld.

\section{LAND OF GONDWIN THE CHAMBERLAIN}

Sanfort [Samford] Hundret and a Half

(At) Hzcham [Higham] Asseman a freeman in commendation to Robert son of Wimarc held as a manor I carucate of land. Then as now I villein, and then 3 bordars. Afterwards and now 2. Then 2 ploughs on the demesne. Afterwards nothing, now I plough. Then I plough belonging to the men. Afterwards and now half a plough. 7 acres of meadow. Wood(land) for 10 swine. Then and now I mill. Part of a church with 2 acres. Now 3 beasts, 8 swine, 6 sheep, and 8 goats. Then worth 305 ., now $20 s_{\text {, }}$ but it was (let) to farm for 3 os. It is 8 furlongs long and 6 broad, and (pays) $12 d$. in geld. Others had holdings there. The soke (was) in Bercolt [Bergholt].

\section{LANDS OF SAISSELIN}

\section{Brademera [Bradmere] Hundret}

(At) Torp [(Ixworth) Thorpe] T.R.E. Acolf the thegn held as a manor I carucate of land. Then as now 2 bordars. Then and afterwards 2 ploughs on the demesne, now I. And half a plough belonging to the men. 6 acres of meadow. Then as now $\mathrm{I}$ mill. Then as now 2 beasts. Then ro swine, now 16. Then as now 30 sheep. And (there are) 4 freemen, over whom his (Saisselin's) predecessor had commendation T.R.E. and they have 13 acres and half a plough. Worth 20s.

At Sapestuna [Sapiston] Godman the thegn held T.R.E. half a carucate of land. Then as fol. 437 .

now 2 bordars. And I plough on the demesne. 5 acres of meadow. Then as now a mill. And 2 beasts. Then 3 swine, now 5. Then 20 sheep, now 33. Then as now it was worth 15 s.

In the same (vill) 8 freemen under commendation (held) 24 acres. Worth $3^{\text {s. Saint }}$ Edmund has soke and sac over them and over the whole Hundred.

\section{LANDS OF ROBERT DE VERLI}

\section{Blackebrune [Blackbourn] Hundret}

In Westuna [Weston] Alsi a freeman held T.R.E. I carucate of land as a manor. And
I bordar, and 2 serfs. Then 2 ploughs on the demesne, afterwards none, now 1 . Then as now half a plough belonging to the men. 3 acres of meadow. Then as now I mill. Now I rouncey, 2 beasts, 8 swine, and 50 sheep. And 6 freemen under commendation (held) ro3 acres. Then 2 ploughs, now I. And I acre of meadow. A church with 12 acres and half a plough. This manor was then as now worth 25 s., and the freemen 5 s.

\section{LAND OF RALPH PINEL}

In Reinduna [Raydon] 2 freemen Erniet and Alwort held 40 acres. Then as now half a plough and I bordar. Worth Ios. This land Ralph held by the King's gift, but from it Geoffrey de Magnaville (received) service. The soke (is) in Bercolt [Bergholt].

\section{Half Hundret of Cosfort [Cosford]}

(At) LafHam [Layham] Bricthmar T.R.E. held 40 acres. Then as now I bordar and I serf, and I plough. Worth ros. Saint Edmund (has) the soke.

fol. $437 b$.

\section{LAND OF ISAAC}

\section{Bosemera [Bosmere] Hundret}

(At) Offetuna [Offton] Siric a freeman held T.R.E. 100 acres as a manor. Then as now 2 bordars. And then I plough, now half a plough. A church with $7 \frac{1}{2}$ acres. Then it was worth 20 s, now 30 s. The King and the Earl (have) the soke.

In Sumersham [Somersham] Ulwin a freeman held 60 acres of land as a manor T.R.E. Then I plough. Then it was worth 20s, now 20s. The King and the Earl (have) the soke.

In the same (vill) a freeman, Coleman, (held) 5 acres. Worth 20d. The King and the Earl (have) the soke.

In Hamingestuna [Hemingstone] (are) 4 acres on the demesne, worth $8 d$.

In the same (vill) a freeman (held) half an acre. Worth I $d$. The King and the Earl (have) the soke.

\section{Claindune [Claydon] Hundret}

(At) Hamingestuna [Hemingstone] Leuric a freeman held T.R.E. I carucate of land as a manor. Then as now 2 bordars. Then 2 ploughs, now I. And 4 acres of meadow. Wood(land) for 2 swine. Then as now I rouncey. Then 2 beasts, now I. Then II sheep, now 20. Then 13 swine, now 20. 


\section{A HISTORY OF SUFFOLK}

Then 7 goats. Then it was worth 20s., now 25s. less $8 d$.

In the same (vill) were 3 freemen with 24 acres. Then and afterwards I plough, now half a plough. Worth 5s. The King and the Earl (have) the soke.

\section{Hertesmera [Hartismere] Hundret}

(At) Thorham [Thornham] Leuric, under commendation to Bristric Saint Edmund's reeve, T.R.E. held I carucate of land as a manor. Then as now 2 bordars. Then 2 ploughs, afterwards half a plough, now I plough. 2 acres of meadow. Then wood(land) for 30 swine, now for 20. Then as now 2 rounceys. And the fourth part of a church with $3 \frac{1}{2}$ acres. Then worth 30s., now 20s. Over this land the Abbot had three parts of the soke and the King the fourth part.

In the same (vill) 3 freemen (held) $4 \frac{1}{2}$ acres worth $8 d$. It is 8 furlongs long, and 8 broad. And (pays) $8 \frac{1}{2} d$. in geld.

fol. 438 .

\section{Hundret of Claindune [Claydon]}

In Henleie [Henley] (are) 16 acres of free land belonging to Hamingestuna [Hemingstone] and (included) in its valuation.

\section{HUNDRET OF COSFORT [COSFORD]}

In REDLES [ ] a sokeman held half a carucate of land from Stigand. Then and afterwards I plough, now none, and I acre of meadow. Worth I 8s. To this estate belonged (in bac terra jacebant) I4 acres of wood(land) which William de Burnolville took therefrom and now holds.

\section{LAND OF NORMAN THE SHERIFF}

\section{Half Hundret of Gepeswiz [Ipswich]}

In the borough Norman has 2 burgesses, one in pledge to him (in vadimonio contra eundem), and the other on account of a debt. But the King has his customs.

\section{LXIIII. LAND OF JUICHEL THE PRIEST}

\section{Bosemera [Bosmere] Hundret}

In StANHaM [Stonham] Aluric, a freeman under Edric, Robert Malet's predecessor, held 90 acres as a manor: and Robert was seised thereof. Then as now 6 bordars, and $\mathrm{r}$ serf. And $1 \frac{1}{2}$ ploughs on the demesne. And half a plough belonging to the men. And 2 acres of meadow. Wood(land) for 10 swine. And 7 beasts. Then I swine, now 15. Then 8 sheep, now 40. And (there were) 5 freemen with 24 acres and half a plough. A church with 16 acres and half a plough. Then it was worth 20 s., now 35 s. In the same (vill) a freeman (held) 24 acres. Then I plough. Worth 5s. The King and the Earl (have) the soke. It is $\mathrm{I}$ league and 3 furlongs broad. Others hold (land) therein. And (it pays) $7 \frac{1}{2} d$. in geld.

In Stanham [Stonham] (is) a church with 20 acres which 9 freemen gave thereto for their souls.

\section{Bisopes [Bishop's] HundreT}

In Horam [Horham] Algar, a freeman under Stigand, and 2 others, I (free)man under Bishop Ailmar and the other a (free)man under Edric of Laxfield, held I carucate of land T.R.E. fol. $438 b$.

Then as now 7 bordars, and I serf. And I plough on the demesne. Wood(land) for 24 swine. And 2 acres of meadow. And 1 plough belonging to the men. Then 2 rounceys. Then 8 beasts. Then as now 24 swine. Then 24 sheep. And 1 hive of bees. And 4 freemen (hold) 24 acres, whom he (Juichel) claims by livery of seisin. Then half a plough, now 2 oxen. A church with 22 acres worth $22 d$. Then as now worth 20s. The soke is in Hoxa [Hoxne], the bishop's (manor).

\section{LANDS OF GIROLD THE MARSHAL}

\section{Risebruge [Risbridge] Hundret}

(At) Damardestuna [Denston] T.R.E. Earl Algar held as a berewick of Bademundsfelda [Badmondisfield] 2 carucates of land. Then as now 4 villeins, and I bordar, and 3 serfs. And 2 ploughs on the demesne. Then worth 60 s., now 70 s. Then as now 1 rouncey. Then 2 beasts, now 15. And 24 swine, and 44 sheep.

\section{LANDS OF ROBERT BLUND}

\section{Brademera [Bradmere] Hundret}

(At) Grswortha [Ixworth] Achi held as a manor T.R.E. 3 carucates of land. Then as now 2 bordars. Then 5 serfs, now 2. Then as now 3 ploughs on the demesne. And 1 mill. And 20 acres of meadow. Then 2 rounceys, now $x$. Then as now 5 beasts. Then 40 swine, now 22. Then 8 sheep, now 92. And 3 arpents of vineyard. And I park. Then it was worth 80 s., now 6 li.

In the same (vill) 25 freemen under commendation (had) $2 \frac{1}{2}$ carucates of land. Then 5 


\section{THE HOLDERS OF LANDS}

ploughs, now $3 \frac{1}{2}$ ploughs. And 4 acres of meadow. Then as now it was worth 20 s. Over the whole hundred Saint Edmund (has) sac and soke.

In the same (vill) 5 freemen under commendation (had) I carucate and 80 acres of land. Then 5 ploughs, now 2. And 3 acres of meadow. Then it was worth 30 s, now 20 s. A church with 80 acres of free land and I plough and 1 acre of meadow. Worth 5s. The whole fol. 439 .

is 2 leagues long, and 6 furlongs broad. And pays $22 \frac{3}{4} d$. in geld.

(At) W ALsam [Walsham] T.R.E. Achi held as a manor 2 carucates of land. Then as now 4 bordars. Then 2 ploughs on the demesne, now 3. And half a plough belonging to the men. And 5 acres of meadow. Wood(land) for 20 swine. Then as now I rouncey. Then 3 beasts, now I. Then 40 swine, now 29. Then 5 sheep, now 30. Then it was worth 40 ., now 60 s.

In the same (vill) 20 freemen under commendation (had) I carucate of land. Then as now 2 ploughs. And 2 acres of meadow. Wood(land) for to swine. Then it was worth IOs., now 20 s.

In the same (vill) $3 \frac{1}{2}$ freemen (had) I carucate of land. Then and afterwards $3 \frac{1}{2}$ ploughs, now 2. And $2 \frac{1}{2}$ acres of meadow. Wood(land) for 4 swine. Then as now it was worth 20 s. Half a church with ro acres, and an acre of meadow, worth $8 d$. It is 2 leagues long, and 6 furlongs broad. And (pays) $17 d$. in geld. Others have holdings therein.

(At) Eascefrlda [Ashfield ${ }^{364}$ ] Achi held as a manor T.R.E. 3 carucates of land. Then as now 9 bordars. Then 4 ploughs on the demesne, now 3. And 12 acres of meadow. Wood(land) for 60 swine. Then as now 2 rounceys, and 2 beasts. Then 60 swine, now 15 . Then 25 sheep, now 10. And 10 hives of bees. Then as now it was worth 60 s.

In the same (vill) were 14 freemen under commendation with 80 acres. Then as now I plough. And 4 acres of meadow. Wood(land) for 4 swine. Worth 8 s.

In the same (vill) Ketel a freeman (had) I carucate of land as a manor. Then as now 2 bordars, and 2 serfs. And 2 ploughs on the demesne. And 4 acres of meadow. Wood(land) for 20 swine. And 3 freemen under him (had) 22 acres and half a plough. Then as now 2 rounceys. Then 4 beasts. Then 24 swine, now 23. Then 32 sheep, now 100. Then

34 Fees at both Great and Little Ashfield were held in 1346 by William Criketot, who held also at Ixworth, Walsham, and Langham; Foud. Aids, v, 71,72 .
40 goats, now 12. Then as now it was worth 30s. Over him Robert's predecessor had commendation. William holds (him) of Robert.

In the same (vill) 3 freemen under commendation (had) I carucate of land and 60 acres, and I bordar. Then as now 3 ploughs, and 4 acres of meadow. Wood(land) for 4 swine. fol. 4396 .

Then as now it was worth 30 . These men 2 knights (milites) hold. A church with 9 acres. It is I I furlongs long, and I I broad. And (pays) $5 \frac{1}{2} d$. in geld. Others have holdings therein.

(At) Wrсам [Wyken] Aki held T.R.E. as a manor I carucate of land. Then 3 bordars. Then 3 serfs, now 2. Then as now 2 ploughs on the demesne. And 3 acres of meadow. Wood(land) for 10 swine. Then I rouncey, now 2. Then as now I beast. Then I 2 swine, now 23. Then 25 sheep, now 38 . Then as now it was worth 30 s.

And $5 \frac{1}{2}$ freemen under commendation (had) I carucate of land. Then as now 2 bordars. And under them (were) 2 freemen with 4 acres. Then as now 2 ploughs. And 6 acres of meadow. And the fourth part of a mill. Then it was worth 20 s., now 135 .

In SAPESTUNA [Sapiston] 2 freemen under King Edward (held) 18 acres. Worth $3^{\text {s. }}$

(At) Langham [Langham] Haret a freeman over whom Saint Edmund had commendation T.R.E. held 3 carucates of land. Then I villein. Then as now 3 bordars, and 3 serfs. Then and afterwards 3 ploughs on the demesne, now 2. Then half a plough belonging to the men. 12 acres of meadow. Wood(land) for 6 swine. Then 7 rounceys, now 1 . Then 8 beasts, now 2. Then 30 swine, now I6. Then I 40 sheep, now I2. Then it was worth 8 os., now 60 s.

In the same (vill) 2 freemen under commendation (had) 20 acres. Then half a plough, now 2 oxen. Worth 3 s. It is 7 furlongs long, and 6 broad. And (pays) rod. in geld.

In HEPWORDA [Hepworth] a half freeman (had) 40 acres, and I bordar. Then as now half a plough. And half an acre of meadow. Worth I Os.

In WicA [Wyken] a freeman under commendation (had) 60 acres, and I bordar. Then as now I plough. Worth ios.

In ICsEWRDA [Ixworth] a freeman (had) 40 acres. Then as now I plough. Worth $5^{\text {s. }}$

As to his holding over all these freemen he vouches the King to warrant.

Saint Edmund has soke and sac over the whole of them. 


\section{A HÏSTORY OF SUFFOLK}

fol. 440 .

In ICSEWRDA [Ixworth] Ketel a freeman held 200 acres as a manor. Then as now 2 bordars, and 2 serfs. And 2 ploughs on the demesne and 6 acres of meadow and $I$ mill and under him 6 freemen with 29 acres. Then 2 ploughs, now 1. Then as now it was worth 6os. Over him Angar the Staller had commendation T.R.E. Ralph, Robert's brother, was seised when he died, and Robert received (the holding) from the King.

\section{Half Hundret of Cosfort [Cosford]}

In W ATEFELLA [Whatfield] were 5 freemen. Over one Saint Edmund had commendation, and over all the soke. The predecessor of Robert had neither commendation (nor soke). And they had 60 acres. Then 2 ploughs, now I. Thien as now it was worth $6 \mathrm{~s}$., now 20 s.

In the same (vill) 4 freemen held 63 acres. Then 2 ploughs, now half a plough. Worth Ios. and $8 d$.

\section{Blidinga [Blything] Hundret}

In West Ledestuna [Westleton] Brunar the priest held $27 \frac{1}{2}$ acres T.R.E. Then as now half a plough. Worth 4 s. By reason of exchange.

\section{Hertesmera [Hartismere] Hundret}

In Gisilincham [Gislingham] (are) 30 acres of the demesne land of Walesam [Walsham] which Achi held, and I acre of meadow, worth $6 s$. and $8 d$.

In the same (vill) 3 freemen under Achi's commendation, Algar, Godric, Godwin, (held) 53 acres, and a freeman under them (held) I acre. Then and afterwards 2 ploughs, now half a plough. And I acre of meadow. Wood(land) for 24 swine. Worth $16 s$. Over 2 wives (feminas) of those men the Abbot of Saint Edmunds had half the commendation and half the soke.

\section{Hertesmera [Hartismere] Hundret}

In WEST TORP [Westhorpe] 4 freemen under Achi's commendation T.R.E. (held) $4 \frac{1}{2}$ acres, worth $16 d$.

In Finingaham [Finningham] (are) 2 acres of demesne land of Walsam [Walsham].

In Wiugrthestuna [Wyverstone] 2 freemen under Achi's commendation T.R.E. (held) 30 acres. Then half a plough. Wood(land) for 2 swine. Half an acre of meadow. Worth 5 s. This R. Ovethel holds of Robert Blond.
Stou [STOW] Hundret

In Escefella [Ashfield] belongs (jacet) I bordar with 3 acres; and he renders $12 d$.

fol. 4406 .

\section{LAND OF HERVEY DE BOURGES (BITURICENSIS)}

In ToRnEI [Thorney ${ }^{356}$ ] Euen holds of Hervey I carucate of land which Brictric Blac held under Witgar the predecessor of Richard de Clare, and he might not sell without his licence. Now Hervey holds (it) by the King's gift. Then 6 bordars, afterwards and now 3. Then 2 ploughs, afterwards none, and now I plough. And 4 acres of meadow. Then 2 ploughs belonging to the men, afterwards and now none. Then worth 30s., now $47^{s}$. The King and the Earl (have) the soke.

\section{BOSEMERA [Bosmere] HuINDreT}

Hamingestuna [Hemingstone] Rainald holds of Hervey, which Ulmar a freeman held by commendation only under Edric, Robert Malet's predecessor, T.R.E.; 100 acres of land as a manor. Then as now 6 bordars. And 1 plough on the demesne. Then I plough belonging to the men, now half a plough. And 2 acres of meadow. And (there was) a freeman with 4 acres. The whole is worth 20s. The King and the Earl (have) the soke. Of this land was William Malet seised on the day on which he died, and afterwards Robert Malet his son.

\section{Claindune [Claydon] Hundret}

(At) Pettehaga [Pettaugh] Brictuolt held on the demesne $I$ carucate of land and 30 acres as a manor T.R.E. Robert Malet's predecessor had the commendation. Then as now 5 bordars. Then 2 ploughs on the demesne, afterwards and now I. 3 acres of meadow. Then as now $\mathbf{I}$ rouncey. Then 3 beasts, now I. Then 14 swine, now 8 . Then 32 sheep, now 20. Then it was worth 6os., now 40 s.

In the same (vill) 5 freemen under commendation (held) 18 acres. Then 2 ploughs, now $\mathbf{I}$. A church with $2 \frac{1}{2}$ acres. Worth 5 s. This was set to farm for 3 li. and 15 s.: but the men were thereby ruined (confusi); and now it is appraised at $45^{s}$. It is I league long, and 3 furfol. 441 .

longs broad. And (pays) rod. in geld. The Abbot of Ely (had) half the soke, and Earl Hugh's predecessor half.

In Assefredia [Ashfield] Godman, a freeman under commendation T.R.E. to Robert Malet's

$$
{ }^{365} \text { In Stowmarket. }
$$




\section{THE HOLDERS OF LANDS}

(predecessor), (held) 30 acres as a manor, and I bordar. And then I plough, afterwards none, now half a plough. A church with 4 acres. Worth 10s. Ranulf holds (of Hervey). The soke belonged to the Abbot and to Hugh's predecessor. Of these two manors was William Malet seised on the day of his death.

In the same (vili) a freeman held 2 acres. Worth 4d. The soke (is) the Abbot's.

\section{Perreham [Parham] Half Hundret}

(At) Brutge [ ] Edric, under commendation to Edric, Robert Malet's predecessor, (held) 120 acres as a manor. Then 2 ploughs, afterwards 1, now half. And 4 acres of meadow. Then as now a mill. And the fourth part of a church with 6 acres. 8 swine. Then worth 40 s., now 20s. The Abbot of Ely (has) the soke. And Garner holds of Hervey.

In the same (vill) 8 freemen, added (thereto), (held) 20 acres. Then I plough, afterwards half, now none. Worth 40d. Concerning half of this land Hervey came to an agreement with the Abbot; and afterwards he held of the King. It is 8 furlongs long and 6 broad. And (pays) $40 d$. in geld.

In Beuresham [Beversham] ${ }^{356}$ Aluric, a freeman in the soke and commendation of the Abbot of Ely, held 60 acres as a manor. Then I plough. 3 acres of meadow. Then worth 20s., afterwards and now 5 s.

In the same (vill) 2 freemen under commendation to the aforesaid Aluric (held) Io acres. Then half a plough, afterwards and now none. Worth 2s. The same Garner holds of Hervey, and (Hervey) himself came to an agreement with the Abbot concerning this manor aforesaid.

\section{Biscopes [BISHOP'S] HundRET}

In Cipbenhala [Chepenhall ${ }^{357}$ ] on the demesne a freeman under Harold (had) 60 acres T.R.E. And then as now 2 villeins. And 2 ploughs. And 2 acres of meadow. Wood(land) for 30 swine. Then worth ros., now 20s. This W. son of Gorham held.

In Colestuna [Colston ${ }^{368}$ ] a freeman under commendation to Edric held 30 acres, and 3 borfol. $441 b$.

dars, and half a plough. Then worth IOs, now 20r. And he belongs to Cranesforda [Cransford]. This Warner holds of Hervey.

2s6 The road from Blaxhall to Stratford St. Andrew crosses the Ore at Beversham Bridge.

ist In Fressingfield.

as In Badingham.

\section{Hundret of Colnesse [Colneis]}

In KELEBROC ${ }^{350}$ [Kembrook] Kenold holds of Hervey a freeman, Ulurich, under commendation to Saint Etheldreda, with I4 acres, half a plough, half a mill, I acre of meadow, and 2 bordars. Then worth 5 s., now $9 s^{360}$

\section{Hundret of Carleforda [Carlford]}

In Grundesburg [Grundisburgh] Godric, a freeman T.R.E. under Harold, held I carucate of land as a manor. Then as now $x$ villein and 4 bordars. Then as now I plough on the demesne, and I plough belonging to the men. 3 acres of meadow. Then it was worth 16 s, now the like.

In the same (vill) 3 half freemen, Godwin, Ulwin, Leuric, under commendation to the same (Harold), (held) 7 acres of land. ${ }^{361}$ Then half a plough, now none. Then it was worth 25 , now I $2 d$.

Moreover in the same (vill) on the demesne 2 freemen, Burric and Ailric, under commendation to Aschil the house-carl, T.R.E. (held) 5 acres. Then half a plough, now none. Worth Iod.

In the same (vill) on the demesne Brun, a freeman under commendation to Edric, predecessor of Robert Malet, (held) 20 acres, and these 20 acres he held of Edric. Then I plough, now half a plough. $2 \frac{1}{2}$ acres of meadow. Then it was worth 5 s., now 4 s.

In Belinges [Bealings] on the demesne (were) Io freemen, Blakeman, Alwin, Stanard, Ana, Uluric, Turbert, Edric, Godwin, Alestan, Anund the priest, and of this (last) Halden had commendation, and of the others Saint Etheldreda, with 84 acres. Then 4 ploughs, now 2 ploughs. 8 acres of meadow. Then it was worth 20s., now the like.

In the same (vill) was Ulmar, a freeman, under Halden, the predecessor of Geoffrey de Magnaville, with 100 acres of land on the demesne as a manor, and Ulmar himself has under him 3 villeins. Then on the demesne 2 ploughs, now I, and I plough belonging to the men, and 3 acres of meadow. Then 2 rounceys, now 4 . Then 4 beasts, now 3. Then 16 swine, now 12. Then 80 sheep, now 6o. Then it was fol. 442 .

worth 20 s., now 40 . I church with 20 (?) acres, worth $40 d$. Saint Etheldreda (has) the soke.

In Parva Belinges [Little Bealings] Geoffrey holds; (there were) 2 sokemen, Gladman and Brihtric, over them Godwin had soke and sac and custom, and I Leofsi, of whom Edric had ।

sso 'Kenebroch'; Ing. El. 144.

360 'Worth Ios.'; ibid. ${ }^{361}$ See n. 217. 


\section{A HISTORY OF SUFFOLK}

commendation. These 2 sokemen had 28 acres. Then I plough, now none. I acre of meadow. Worth 2s. And Leofsi held on the demesne 20 acres. Then I plough, now none. 3 acres of meadow, I mill. Worth $3^{\text {s. }}$

In the same (vill) on the demesne Leuric and Brihtric, 2 freemen under commendation to Saint Etheldreda 'T.R.E., (held) 10 acres. Then as now half a plough. Half an acre of meadow. Worth 2s.

Moreover in the same (vill) on the demesne Ulmar and Bond, 2 freemen under commendation to the same Etheldreda T.R.E., (held) 4 acres. Worth $8 d$.

And in the same (vill) on the demesne Hardekin, a freeman under commendation half to Durand, Edric's man, and half to Harold, (held) 3 acres. Worth $6 d$. It is 6 furlongs long and 5 broad, and (pays) $7 \frac{1}{2} d$. in geld.

In Nechemara [ ] on the demesne a freeman, Ulfwin, under commendation to Ingulf the house-carl (held) 3 acres. Worth $6 d$.

In Riscemara [Rushmere] on the demesne a freeman, Brunwin, under commendation to Gurth (held) 30 acres. Then as now I plough. $I$ acre of meadow. Then as now it was worth IOs. It is 8 furlongs long and 7 broad and (pays) $16 d$. in geld.

In Tudeham [Tuddenham] on the demesne are 4 acres, and they lie (sunt) in Belinges [Bealings]. Worth $8 d$.

In the same (vill) a freewoman, Aldeda, under commendation to Edric of Laxfield (held) 6 acres. Worth $12 d$.

In the same (vill) Bernard de Alencun holds 80 acres which Brihtmar, a freeman T.R.E. under commendation to Edric of Laxfield, held as a manor. Then as now 6 bordars and $I$ serf. And 2 ploughs on the demesne. And 4 acres of meadow. Then 2 rounceys, now none. Then 3 swine, now 5. Then 15 sheep, now Io. Then 6 goats, now none. Then it was fol. $442 b$.

worth 20s., now the like. And of this manor was Edric, predecessor of Robert Malet, seised T.R.E. and William Malet at the time when he died; and he could not give his land or sell it to anyone. And 5 freemen under commendation to the said Brihtmar (held) 14 acres. Then half a plough, now none. Then it was worth $4^{\text {s., now }} 3^{\text {s. }}$

In the same (vill) 2 freemen, one under commendation to the predecessor of Ranulph brother of Ilger, and the other under commendation to one himself under commendation to Saint Etheldreda (held) 7 acres. Then half a plough, now none. Worth $16 d$. It is Io furlongs long, and
6 broad, and pays $15 d$. in geld. All this Bernard de Belencun holds of Hervey.

(At) Thisteldena [Thistleton] a freeman, Frana, under commendation to Edric T.R.E., (held) 30 acres of land. Then as now 2 bordars, and I plough. 2 acres of meadow. Worth $8 s$. This Reynold holds of Hervey. But William Malet was seised thereof on the day of his death.

In DERNEFORD [

I I freemen under commendation to Durand, (who was) half Edric's man T.R.E. and half Harold's, (held) 80 acres and 3 bordars. Then 4 ploughs, now 3, and 2 acres of meadow. Then it was worth 4 Os., now 15 s.

In INGOLUESTUNA [ ] 13 freemen T.R.E., now 6, under commendation to the same Durand, (held) I carucate and 4 acres of land. Then 5 ploughs, now I. 5 acres of meadow. Worth Ios.

In the same (vill) I freeman under commendation to the said Durand (held) 12 acres and half a plough. Worth $40 d$. It is 6 furlongs long and 5 broad. And pays $7 \frac{1}{2} d$. in geld. This Peter de Paludel holds of Hervey.

\section{HUNDRET OF WILEFORDA [WILFORD]}

(At) BERDEFELdA [Bredfield] Suarting, under commendation to the predecessor of Robert Malet, held T.R.E. 80 acres and I bordar. Then $\mathbf{I} \frac{1}{2}$ ploughs, now I plough. Then 2 rounceys, now 2, and I beast, and 27 sheep. Then worth 20 s., now 30 s. It is I league and half a furlong long, and 6 furlongs broad. And in geld (pays) $13 \frac{1}{2} d$.

In the same (vill were) $2 \mathrm{I}$ freemen under Swarting's commendation T.R.E. with I carufol. 443 .

cate and 22 acres of land. Then 4 ploughs, now 3. Half an acre of meadow. Then worth 30s., now a like amount.

Moreover in the same (vill) a freeman under commendation to one himself under commendation to Robert Malet's predecessor (held) I 2 acres, Then as now half a plough. Worth 25 . Of this was William Malet seised on the day on which he died.

In WiKhaM [Wickham (Market)] Ranulph now holds, a freeman Atser under Edric's commendation T.R.E. held, 33 acres as a manor, and I bordar. 3 acres of meadow. Then I plough, now none. And 2 freemen under him (held) 8 acres. Then half a plough. Then worth ros., now 6s. And of this in like manner (was William Malet seised).

In Sutruna [Sutton] Arcenbald (now holds), the same Atser held T.R.E., 60 acres as a manor. 


\section{THE HOLDERS OF LANDS}

Then as now 2 bordars. Then and afterwards 1 plough, now half a plough. Half an acre of meadow. Then worth Ios,, now a like amount.

In the same (vill) the said Arcebald holds a freeman (formerly) under Edric's commendation, with 6 acres. Then as now 2 oxen. Then worth 2s., now a like amount. Of this (William Malet was seised) in like manner.

In Horapola [Harpole] Odo holds a freeman ${ }^{368}$ (formerly) under commendation half to Saint Etheldreda and half to Edric with 16 acres. Worth $3^{\text {s. }}$

In BRedefelda [Bredfield] Peter now holds a freeman (formerly) under commendation of Durand of Offetuna [Offton] with 12 acres. 3 oxen, and 23 sheep. Worth 2 s.

In the same (vill) a freeman under commendation of Ailric of Burc [Burgh] (held) 4 acres, worth $8 d$.

In LUDEHAM [Loudham] a half freeman under Swarting's commendation T.R.E. (held) I 5 acres, worth $2 s$.

In Bulgrs [Boulge] (is) a freeman under commendation of Edric Grim with 5 perches of land, worth $4 d$.

In Horepolo [Harpole] a freeman under Edric's commendation (held) 5 acres, and half an acre of meadow. Worth I $2 d$.

\section{HUNDRET OF LOSA [LOES]}

(At) Martele [Martley] Brihtmar, under Harold's commendation, T.R.E. held as a manor 80 acres. Then as now 5 bordars. And on the demesne 2 ploughs. 9 acres of meadow. And I rouncey, I beast, 9 swine, I 7 sheep, and 30 goats. Then it was worth 40 s., now 30 . And 10 freemen and 2 half (freemen) under commendation of the same (Brihtmar) (held) 60 fol. $443^{b}$.

acres. Then as now 2 ploughs. $1 \frac{1}{2}$ acres of meadow. Worth Ios. Robert Malet claims one of these. It is I league long, and half a league broad. And in geld (pays) I I $d$.

(At) Campeseia [Campsey] 2 freemen, Swarting and Edric, under commendation of Edric of Laxfield held 60 acres of land as a manor. Then as now 3 villeins. Then as now 2 ploughs. And half a plough belonging to the men. 8 acres of meadow. 1 mill. And 2 rounceys, 8 swine, 20 sheep, and 3 hives of bees. Then it was worth $20 s_{0}$, now 30s. And 12 freemen under commendation of the same (Edric) (held) $3^{8}$ acres of land. Then 2 ploughs, now I. Then it was worth 8 s, now 10 . It

$$
362 \text { 'Wencling'; Inq. El. } 146 .
$$

is 6 furlongs long, and 4 broad. And in geld pays 7 . William Malet was seised (of it) on the day on which he died.

(At) Renlesham [Rendlesham] Godgeva, a freewoman under commendation half of Saint Etheldreda and half of Edric of Laxfield, held 60 acres as a manor. Then 2 ploughs, now I plough. 2 acres of meadow. And I villein. Then as now worth 20s. And $1 \frac{1}{2}$ freemen (held) 10 acres under commendation of the same (Godgeva ?). And half a plough. (Included) in the same valuation. This Bernard de Alencun holds of Hervey. William (Malet) was seised on the day on which he died. It is I league long, and half a (league) broad. And in geld (pays) $14 d$.

(At) Potesforda ${ }^{363}$ [ ] Odon holds as a manor 80 acres, which Wenning held as a manor under commendation half to Saint Etheldreda and half to Edric. Then as now 2 villeins, and 2 bordars. And 6 acres of meadow. Then 2 ploughs, now I. I rouncey, 4 beasts, and 10 goats. Then as now it was worth 20 .

And in the same (vill) 8 freemen, ${ }^{364}$ of whom 3 forfeited their land to (contra) the Abbot, and the Hundred has not since seen (evidence) that they have redeemed it, and the fourth was the Abbot's man, and the other 4 were under Wenning's commendation, (held) 30 acres. These all (had) half a plough, $\mathrm{I} \frac{1}{2}$ acres of meadow. Then as now it was worth Ios. It is I league long, and half (a league) broad. And in geld fol. 444 .

(pays) $11 d$. William (Malet) was seised of it on the day on which he died.

(At) Glereuinges [Glevering ${ }^{365}$ ] Brihtmar held under commendation to Edric T.R.E. as a manor 40 acres. And I bordar. And I plough. 3 acres of meadow. I mill. And 20 sheep. Then it was worth 8s, now ros.

In the same (vill) I $7 \frac{1}{2}$ freemen under the said Brihtmar's commendation (held) 60 acres. Then 2 ploughs, now I. I acre of meadow. Then it was worth 17s., now 15s. William Malet was seised of it on the day on which he died. It is I league long and half (a league) broad. And in geld pays 22d. This Odo holds of Hervey.

In Delingahou [Dallinghoo] (are) 40 acres, which 3 freemen held, worth 6 s.

In the same (vill) 2 freemen under commendation half of Swarting and half of Bruman (held) 20 acres. Then half a plough. Worth

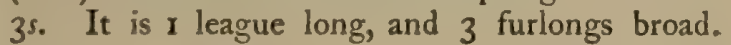
And in geld pays $7 \frac{1}{2} d$.

263 'Potesfort,' 'Pitlesford,' 'Pitesford,' and 'Witlesford'; ibid. $148,180$.

201 ' $8 \frac{1}{3}$ freemen'; ibid. $\quad{ }^{363}$ In Hacheston. 


\section{A HISTORY OF SUFFOLK}

In the same (vill) 2 half (freemen) under Edric's commendation (held) 5 acres, worth $12 d$.

\section{Plumesgate [Plomesgate] Hundret}

(At) Cranesforda [Cransford] Atsur under commendation of Edric of Laxfield held 80 acres of land as a manor. Then as now I bordar. Then 2 ploughs, now I. I acre of meadow. Then 3 rounceys. Then 24 swine, now 1 . And 16 sheep. Then 40 goats. Then it was worth 20 s., now 13 s. and $4 d$.

\section{LANDS OF GILBERT THE CROSSBOWMAN}

\section{Bidinga [Blything] Hundret}

In Estuna [Easton] Elric son of Wlviat, under commendation to Earl Harold, held, and now Gilbert holds of the King as a manor, 2 carucates of land. Then 5 villeins, now 3 . Then as now 5 bordars, and I serf. Then $I \frac{1}{2}$ ploughs on the demesne, now none. Then as now 3 ploughs belonging to the men. Wood(land) for 8 swine. 3 acres of meadow. Then I salt-pan, now none. Then I rouncey, 3 beasts, fol. $444 b$.

and 2 swine, and 80 sheep. Now no stock (nichil). Then it was worth 40s., now 20s. The King and the Earl (have) the soke. Moreover in UgGeceHAla [Uggeshall] (there is) I villein, Uluric, with 20 acres and half a plough, and in Cedestan [Chediston] I villein, Osketel, with 20 acres and half a plough, and they are (included) in the valuation of Estuna [Easton].

The said Gilbert holds in CEDEsTan [Chediston] a freeman Godric (formerly) under commendation to the same (Harold) with 20 acres, and 2 bordars. Half a plough. Half an acre of meadow. Wood(land) for 6 swine. Worth 4 s.

And in Estuna [Easton] (were) 2 freemen, Godric and Osketel, under commendation to the said (Harold) with 20 acres of land. Then as now I plough. Worth 4s. The King and the Earl (have) the soke. Estuna [Easton] is I league long, and half a league broad. And in geld (pays) $6 d$. Others hold land therein.

\section{Hertesmara [Hartismere] Hundret}

(At) Gislincham [Gislingham] Alsi a freemen held 2 carucates of land as a manor, and 2 bordars. Then and afterwards 2 ploughs on the demesne, now 1. And 2 acres of meadow. Wood(land) for 4 swine. Worth 40s. 'This manor belonged in the lifetime of King Edward to the demesne of Abbot Lefstan of Saint Edmund's, and Abbot Lefstan leased it to Alsi and his wife by such an agreement that after their deaths the Abbot should have back his manor and another manor of Alsi's, Eustuna [Euston] by name. The King and the Earl (have) the soke.

In the same (vill) 8 freemen under commendation to Alsi (held) 16 acres. Then I plough, now half a plough. And they are (included) in the above valuation.

In the same (vill) 3 freemen under commendation to the predecessor of Aubrey de Vere (held) 6 acres, worth $12 d$. The King and the Earl (have) the soke. It is I league long and 7 furlongs broad. And (pays) rod. in geld.

\section{fol. 445 .}

\section{LXVIIII. LANDS OF RALPH THE CROSSBOWMAN}

\section{Half Hundret of Ludingaland} [LOTHINGLAND]

(At) Burch [Burgh (Castle)] Bishop Stigand held T.R.E. with the soke 4 carucates of land as a manor. Then as now 10 villeins, and 5 bordars. Then 2 serfs, now none. Then on the demesne 3 ploughs, now 2. Then belonging to the men 4 ploughs, now 3. Io acres of meadow. 3 salt-pans. Then as now 3 rounceys, 6 beasts, 17 swine, and 160 sheep. One church with 10 acres, and I acre of meadow. Then worth I00s, now 106s.

(At) Caldecotan [Caldecot ${ }^{366}$ ] Bund under Gurth's commendation held T.R.E. I carucate of land as a manor. Then I bordar, now 3 . Then I plough, now half a plough. Then worth Ios., now 8 s.

In Earetuna [ ] a freeman Kettle under Ulf's commendation T.R.E. held 40 acres. Then I bordar, now none. Then as now half a plough. Then as now worth 4 s.

In Sumerledestuna [Somerleyton] a freeman Alwold under Gurth's commendation (held) 30 acres. Then half a plough, now none. Wood(land) for 5 swine. Worth 2 s.

\section{LAND OF RAINALD THE BRETON ${ }^{367}$}

\section{Which he Claims of the King in Alms}

\section{Risebruge [Risbridge] Hundret}

In Litgata [Lidgate] 3 freemen held as (a manor) 4 carucates of land. Then 9 villeins,

${ }^{368}$ In Fritton.

${ }^{967}$ Lidgate was given to St. Edmund's by Reynold Stanceberd (?), "who was called "denasez," because he had lost his nose in battle with the elder William "; Add. MS. 14847 , fol. 24. 


\section{THE HOLDERS OF LANDS}

afterwards 7 , now 3 . Then 1 bordar, afterwards 4 , now 6 . Then 3 serfs, afterwards I, now none. Then and afterwards 3 ploughs, now x. Then and afterwards 7 ploughs belonging to the men, now 2. Wood(land) for ro swine. Io acres of meadow. Then 2 swine, now 30 . Then as now 7 sheep. They were then worth 80 s., now 60 s. This land Wateville's men claim as belonging to his fee.

fol. $445^{b}$.

\section{LAND OF ROBERT DE STRATFORD}

\section{SANFort [SAmFord] Hundret}

(At) Bortuna [Boyton ${ }^{368}$ ] Suain Suart held T.R.E. I carucate of land as a manor. Then 2 bordars, now 6 . Then 2 ploughs on the demesne. Then as now I plough belonging to the men. 5 acres of meadow. Then worth 4 os., now 30s. The soke (is) in Bercolt [Bergholt.]

In the same (vill) Brixi, a freeman, held I carucate of land as a manor T.R.E. Then I bordar, now 2. Then as now I plough on the demesne. Now I rouncey and 6 sheep. Worth 20s. It is 7 furlongs long, and 6 broad, and pays $14 d$. in geld. Others have holdings there. The soke (is) in Bercolt [Bergholt].

In Belesteda [Belstead] Turi held 80 acres as a manor. Then as now 3 villeins and 2 bordars. Then I plough on the demesne. Then as now I plough belonging to the men, and 2 acres of meadow, and the fourth part of a church. Worth 23s. The soke (is) in Bercolt [Bergholt].

\section{LAND OF STANARD SON OF ALWI}

\section{Risebruge [Risbridge] Hundret}

In UURsDana [Ousden] Wisgar held 30 acres T.R.E. Then as now 1 bordar. And I plough. And 2 acres of meadow. Worth 20 s.

\section{LAND OF WLMAR}

\section{Risebruge [RIsBridge] Hundret}

In LAFHaM [ ] (are) 24 acres, and half a plough. Worth 4s. Saint Edmund (has) the soke.

In the same (vill) the said Ulmar holds 9 acres which he took in pledge (invadavit) in King William's time from the predecessor of Ralph Pinel for 21s. Worth I $2 d$. Roger the Sheriff had heriot (berret) from his father.

20 In Bergholt and Bentley; Copinger, Suff. Rec. fol. 446.

\section{LXXIIII. LAND OF THE VAVASSORS}

\section{Bosmera [Bosmere] Hundret}

In HaMingEstuna [Hemingstone] (was) a freeman with 20 acres in the King's soke, and 5 bordars. Then as now I plough. Worth 5 s.

In Facheduna [ ] 3 freemen in the King's soke (held) 30 acres. Then as now I plough. Worth 5s.

In the same Hundred. In Betesfort [Battisford] a freeman Durand held 30 acres T.R.E. Now Siward holds it, in the King's soke. Then half a plough, now 2 oxen. And 2 acres (of meadow).

In UlEDANA [Olden ${ }^{369}$ ] 4 freemen, Rabboda, Leuric, Edric, Uluric, (held) 8 acres. Worth $16 d$. These were added to the farm in King William's time, and Roger is warrant thereof to Ulmar the reeve, who added them, and Roger did not know that they were so added, and they used not to belong to any farm.

In the same (vill) a freeman Ulmar (had) the fourth part of an acre. Worth $2 d$. Brictmar the bedel held over him; and he gave security. Ulmar the reeve is surety (fidejussor) (for him).

In the same (vill) a freeman Lewin (held) $2 \frac{1}{2}$ acres. Worth $8 d$.

In Hamigestuna [Hemingstone] a freeman Brictoult (held) 4 acres, worth $8 d$.

In Cratingis [Creeting] a freewoman, Aldith, (held) half an acre, worth $1 d$.

\section{Hundret of Claindune [Claydon]}

In Haminghelanda [Hemingstone (?)] a freeman Alwin under commendation to Gurth (held) 30 acres. Then half a plough. Worth $5 \mathrm{~s}$. Ulmar the reeve conjoined this freeman to the King's farm of Brumfor [Bramford], and Roger the Sheriff is warrant to him for so doing, and he renders every year $5^{5}$. And the King and the Earl (have) the soke.

In Turolwestuna [Thurlston] Rolf held T.R.E., now Aluric his son, a burgess of Gipeswiz [Ipswich] (holds) 12 acres. Worth 2s. The King and the Earl (have) the soke. And of this was Earl Ralph seised when he made forfeiture. The said Aluric holds the church of St. Julian in fol. $446 b$.

the borough of Ipswich with 20 acres of land, worth $40 d$. Of this church Earl Ralph was seised.

In Claindune [Claydon] Alric a freeman held $6 \frac{1}{2}$ acres T.R.E.; now the same Aluric holds.

${ }^{369}$ In Coddenham; n. 2. 


\section{A HISTORY OF SUFFOLK}

Worth 14d. The King and the Earl (have) half the soke, and Saint Etheldreda the other moiety. This Aluric held this land in pawn (in vadimonio), and thereof has no warrant.

The above are in the King's hand.

In WESTREFELDA [Westerfield] 6 freemen, Alwin, Flint, Alwin, Edric, Uleric, Alestan, (held) among them I5 acres and I plough. Worth $30 d$. One of them, Flint by name, gave a pledge for that he said that they gave farm in Gipeswiz [Ipswich] ; and the Sherif proved that he lied; and the same Sheriff is surety (fidejussor). The King and the Earl (have) the soke.

In Turoluestuna [Thurlston] a freeman Godwin under commendation to Stigand (held) 10 acres. Worth 20 d.

In this Hundred the King has 30 freemen with I $47 \frac{1}{2}$ acres, and a church in WIDITUNA [Whitton] with 10 acres. Then as now 3 ploughs. And I acre of meadow. Worth 40s. and $4 d$. These are their names: Aistan, Godric, Godwin, Offa, Rictan, Gadinc, Aluric, Estrat, Aluric, Touilt, Lewin, Aluric, Gunequata, Uluric, Turchetel, Godric, Edied, Dirsi, Brictmar, Leveva, Aluric, Uluric, Norman, Lewric, Saxlef, Alwin, Ulwin, Edric, Sigar. These men the Sheriff holds in hand for the King. The King and the Earl (have) the soke.

In Westrefelda [Westerfield) Aluric the priest held then as now 12 acres, and 2 acres

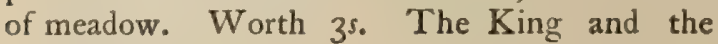
Earl (have) the soke.

In Turuestuna [Thurlston] 2 freemen, Uluric and Ormar, (held) 6 acres. Worth 12d. The soke is the King's. 'The Sheriff keeps (them) in hand for the King.

fol. 447 .

In Codenham [Coddenham] Friebern, a priest, (holds) half an acre in alms. Worth $\mathbf{I} d$.

LXXV. THESE ARE THE FREEMEN OF SUFFOLK WHO REMAIN IN THE KING'S HAND

\section{Brademera [Bradmere] Hundret}

In ToRp [(Ixworth) Thorpe] a freeman (had) 30 acres T.R.E. Then and afterwards half a plough, now 2 oxen. Worth 2s. and 6d. Him Robert Blund held, supposing him to belong to the Abbot's fee, and the same man gave assurance to Robert that he belonged to the Abbot's fee. But the Abbot is not his warrant for this. Now at length Robert has made recognizance that he does not belong to the Abbot's fee, he has remitted him into the King's hand, and has given security thereupon.
In ICSEWRDA [Ixworth] a freeman (had) 12 acres worth 2s. Saint Edmund had half the commendation T.R.E., and soke and sac, and the predecessor of Peter de Valoignes had half the commendation. Over him Richard the man of Robert Blund held, and gave security. Robert is not his warrant.

\section{Hundret of Biscopes [Bishop's]}

In Horan [Horham] a freeman held 6 acres worth 12d. Him Herbert Blacun held in hand for the King by order of Bishop Arfast, but Juchel the priest claims him of the King's gift, and thereof was he seised. And his predecessor had the commendation T.R.E. The soke (is) in Hoxa [Hoxne].

In IsTEDA [Instead ${ }^{370}$ ] (is) a freeman, over whom Bishop Ailmer had commendation, with I $\frac{1}{2}$ acres. And the fourth part of a mill. And I bordar. And then half a plough, now 2 oxen. Worth 2s. This William Malet held, (as did) afterwards Robert his son, supposing it to belong to his father's fee.

\section{fol. $447 b$.}

In Badingafelda [Bedingfield] (are) 2 freemen who remain in the King's hand through respite of the plea between the Bishop of Bayeux and Robert Malet's mother. One was under commendation to Stigand and the other, half under Leuric, Robert Malet's predecessor, and the other moiety (belonged to) Saxo; and they have 40 acres and 3 bordars. Then as now I plough. Wood(land) for 20 swine. Worth 1 os. The soke is in Hoxa [Hoxne].

\section{ENCROACHMENTS (INVASIONES) UPON THE KING}

\section{Risebruge [RISBRIDGE] HuNDRET}

Richard son of Count Gislebert.

In BRAdeleia [Bradley] (were) 4 freemen, Ulwin, Leuric, Ulwin. And they have 15 acres. And the fourth was Bundo; And he has I carucate of land. Then as now 2 ploughs. And 5 acres of meadow. Worth 22s. and 6d. From them his (Richard's) predecessor never had commendation. Malvoisin (malus vicinus) holds the carucate. Saint Edmund (has) the entire soke.

\section{Babenberga [Babergh] Two Hundrets}

In Grotena [Groton] Richard son of Gilbert holds a freeman (formerly) under Robert son of Wimarc, by commendation only, with 60 acres of land. Then 4 bordars, now $\mathbf{I}$. T'ien and afterwards I plough, now none. And

sro In Weybread. 


\section{THE HOLDERS OF LANDS}

I acre of meadow. Then and afterwards worth I Os., now 18s. On this land Roger de Orbec encroached, and holds it under Richard son of Gilbert. And Richard's men claim it as belonging to the fee of Wisgar his predecessor. But according to the testimony of the Hundred it never belonged (to that fee) either by commendation or by soke.

In Kavanadisc [Cavendish] Aluric, brother of the aforesaid Edric and Witgar's man, encroached upon half his brother's land (viz.) 60 acres. fol. 448 .

Now Roger de Saint Germain holds it as of Richard's fee. But it never belonged to the fee by commendation or soke. Then as now there was there $I$ villein and I bordar and I acre of meadow.

In Cornierda [Cornard] Aluric Campo held 2. freemen under commendation only, in Saint Edmund's soke, T.R.E. But after King William came Wisgar encroached (thereon) before the agreement with Richard, who now holds. And (the freemen) had 2 carucates of land and 40 acres. Then and afterwards 4 bordars, now 11. Then 5 serfs, now 4. Then 3 ploughs on the demesne, now 3 between him and the men. Wood(land) for 30 swine. And 8 acres of meadow. Then 3 horses. Now 4 beasts. Now 30 swine. Now I IO sheep. A church with 15 acres of free land. Then and afterwards it was worth 20 s., now it renders $6 \%$. It is 8 furlongs long, and 4 broad. And (pays) $24 d$. in geld, whoever holds therein.

In Saibamus [

] Richard holds a freeman (formerly) under Robert son of Wimarc by commendation, and in Saint Edmund's soke and sac. But Wisgar held him when he made forfeiture. Now Richard his successor holds him. And he had I carucate of land, and 3 bordars and 2 serfs. Then as now I plough. And 7 acres of meadow. Now 50 sheep, and 7 swine. Worth 20 s.

In Kavanadis [Cavendish] Alwold (held) a freeman under Harold by commendation, soke and sac, T.R.E. and after King William came. Now Richard has encroached. And (the freeman) had I carucate of land. Then as now I $\frac{1}{2}$ ploughs. And 2 acres of meadow. Worth 20 .

In the same (vill) Richard of Clare encroached upon a freeman (formerly) under King Edward, But his predecessor had no interest whatever (nichilomnino) in him. And the (freeman) had 1 carucate of land. Then 4 villeins, afterwards and now 2, and 7 bordars. And then and afterwards 2 ploughs, now I. And I plough belonging to the men. And 4 acres of meadow. And now I mill. Wood(land) for Io swine. Worth 20 s. fol. $448 b$.

HUNDRET OF BLACBRUNA [BLACKBOURN]

In Stantuna [Stanton] a freewoman under commendation to Saint Edmund held 30 acres T.R.E. Worth 5 s.

In Gnodassala [Knettishall] Saint Edmund held 30 acres T.R.E. and half a mill. Worth 5 s.

In BEORDEwELLA [Bardwell] (were) the houses (mansiones) of a certain freeman under Saint Edmund.

In the same (vill) half a freeman under Saint Edmund (held) 8 acres. Worth $16 d$.

In the same (vill were) Io acres in the holding of a certain freewoman under Saint Edmund. Worth $20 d$.

And in all this W. de Partenai encroached upon the Abbot's right. And he holds the commendation of one freeman.

\section{Hundret of Bosemera [Bosmere]}

In SUMERSAM [Somersham] (was) a freeman Uluric by name with 12 acres. Worth $4^{\text {s. Of }}$ him was Ralph the Earl seised when he forfeited: and his predecessor had the commendation in Nedesteda [Nettlestead]. On this Ulmar the King's reeve encroached, and he gave security. Roger Bigot is his surety. And (the freeman) is in the King's hands. The King and the Earl (have) the soke.

In BRIEsETA [Bricett] are 20 acres which are attached (jacent) to William de Othoburville's manor, which Anschill held T.R.E. Now a certain woman, (called) Botilt, holds them, and calls Hugh de Hosdenc to warrant. But he is under arrest by the King, and cannot respond. Now these acres are in the King's hand, and Ulmar the reeve has charge of them. Worth $5^{\mathrm{s}}$.

In Belham [Baylham] Queen Edith held T.R.E. and as long as she lived half a church with 12 acres. Afterwards William de Burnolville held it. Now it is in the King's hand. Worth 2s. Of this he (? Ulmar) gave security. Turstin son of Guy is his surety (fide jussor).

\section{HUNDRET OF STOU [STOW]}

In Fineberga [Finborough] (is) a freeman of whom the predecessor of Roger had half commendation. Eustace (had) the other half of the commendation, and afterwards the Count of Moretain held over him. But Roger held him when he left the land, and Robert the crossbowman (arbalistarius) under him. Now Roger Bigot

fol. 449 .

holds him in hand for the King, until proof of right be made. And he has I 5 acres of land. Then half a plough, now none. Worth 3 s. 


\section{A HISTORY OF SUFFOLK}

\section{Hundret of Blidinga [Blything]}

In Wiseta [Wissett], Count Alan's manor, belonged a freeman with 4 acres which are attached to Northala [North Hales], worth $8 d$. This Robert de Curcun encroached upon. This (freeman) Earl Ralph held when he made forfeiture. Of this he gave security.

In the same (vill) was a freeman worth $16 d$. over whom the predecessor of William de Warenne had commendation T.R.E. And he has it as part of his land by reason of the exchange. These two Robert encroached upon with the 4 acres aforesaid.

In WgGessala [Uggeshall] were 2 freemen, Norman and Ketel, with 18 acres and half a plough, worth $3^{\text {s. }}$ This Berengar, Saint Edmund's man, encroached upon; and he is in the King's mercy. He was sick. He could not come to the plea. Now (the lands) are in the Sheriff's custody.

\section{(BAbERgh Two Hundrets)}

In Kanauadisc [Cavendish] Ralph de Limesi holds a freeman (formerly) under Harold (with land) which Edric the deacon, who died with him (i.e. Harold) in the battle, held. And (the freeman) was delivered to Baynard as an estate. Edgar added this to Cavendish after Baynard lost it. Now Ralph de Limesi holds it in the hall demesne.

In Lauen [Lavenham (?)] Aubrey de Vere holds 3 freemen (formerly) under Ulwin, Aubrey de Vere's predecessor, by commendation only, in the soke of Saint Edmund, and (the freemen) have 50 acres. Then among them all were 2 ploughs, now r. Then as now it was worth $6 s$.

In Kodenham [Coddenham ${ }^{371}$ ] Walter de Saint Valery's predecessor held by commendation fol. $449 b$.

only 2 freemen. Now Roger de Ramis holds (them). But the Hundred knows not by what title. Nor was there anyone on his behalf who could say by what title. And (the freemen) have 20 acres of land. Then and afterwards it was worth IOS., now nothing.

\section{Hertesmera [Hartismere] Hundret}

In Eram [Eye] Robert Malet held I freeman Swartric by name, (who was formerly) under commendation to Harold and in his soke, with 120 acres as a manor. Then as now 4 bordars. And I plough on the demesne. And 4 acres of meadow. Wood(land) for 13 swine. Worth 20s.

$$
{ }^{3 n} \text { In Boxford. }
$$

fol. 450 .

CONCERNING THE CLAIMS IN DISPUTE BETWEEN THE BISHOP OF BAYEUX AND ROBERT MALET'S MOTHER

\section{Hertesmera [Hartismere] Hundret}

In Acolt [Occold] Brictere a freeman under Stigand held 20 acres. Then as now I bordar. Worth 40d. This land Stigand gave to Robert Malet's mother; and she afterwards held it of the Queen. Now the bishop holds it $\left(m^{\circ} . e_{0}\right)$.

In the same (vill) Cheric a freeman, half under sub-commendation to the predecessor of Robert Malet and half under commendation to Saxo the predecessor of Ranulph Peverel, held 20 acres and 2 bordars and 1 plough. Worth $40 d$.

\section{Biscopes [Bishop's] Hundret}

In BADIngeFelda [Bedingfield] the aforesaid Brictere and Cheric (held) 40 acres in manner aforesaid. Then I plough, now half a plough. Wood(land) for 40 swine. And a freeman under commendation to Brictred (held) 5 acres. The whole was worth IIs.

\section{Hertesmara [Hartismere] Hundret}

In Aspala [Aspall] 4 freemen, Derulf under commendation to the Abbot of Ely, and Thurstan under commendation to Saxo, and Marculf under commendation to Edric, Robert Malet's predecessor, and Grunulf under sub-commendation to Robert Malet's predecessor, (held) 86 acres and 7 bordars. Then as now 3 ploughs. 2 acres of meadow. They were then as now worth 40s. Of this land William Malet was seised, so the Hundred witnesses, before the Bishop of Bayeux ; and afterwards came Hubert de Port and adjudged the land free and seised the Bishop of this land because the freemen used to hold it; and on the day on which Earl Ralph made forfeiture Robert Malet's mother was seised thereof, so witnesses the Hundred, and up to the date of the plea (held) at Hodiham [Odiham]; now it is held, as the King ordered, in pace Regis between the Bishop and Robert's mother.

IN THE YEAR ONE THOUSAND AND EIGHTY-SIX

FROM THE INCARNATION OF THE LORD, AND THE

TWENTIETH OF THE REIGN OF WILLIAM, WAS THIS

SURVEY (Descriptio) MADE, NOT ONLY THROUGHOUT THESE THREE COUNTIES, BUT ALSO THROUGHOUT THE OTHERS. 


\section{ANCIENT EARTHWORKS}

The gently undulating contours of Suffolk provide no such heights as were chosen for the sites of hill fortresses by a primitive people, and consequently no such strongholds are found in the county. The reason for the paucity of earthworks capable of identification with a very early people must be found in the adaptability of the soil for agriculture; the greater part of the county is under tillage, and it is one of the finest corn-growing districts in England. To the plough, then, may be ascribed the destructive influence that has spared so few of those unrecorded landmarks. Some, indeed, may unknowingly be extant, incorporated into later moated sites. Possibly this may be the case with the works at Chevington and Wattisham, but it can only be suggested by a study of the entrenchments, and in no wise proven.

Similar forces have wrought havoc with the military works raised during the Roman occupation, for excepting the camp on Clare Common we look in vain for any definite earthwork that may be included under Class C. Burgh, Dunwich, and Walton were strongholds for the defence of the Saxon shore; the last two have been swallowed by the sea, and Burgh Castle, in the northern extremity of the county, is a well-defined Roman work, but only a very small part of its earthen defences remains. Suffolk, however, is not entirely denuded of signs of Roman entrenchments, and it is marvellous that after centuries of cultivation five camps of rectangular plan may with care be traced. At Stowlangtoft and Burgh (near Woodbridge) are double entrenchments; at Ashbocking, Bredfield, and Brettenham are traces of single entrenchments; the valla have disappeared, having been ploughed into the fosses, which are abnormally widened and almost filled to the surface in the process, but on these sites are found tesserae, pottery, and oyster-shells.

It is interesting to observe how ancient ramparts have been utilized wherein to build early churches, as may be seen at Burgh St. Peter, South Elmham St. Cross, where it is called the 'Minster Yard,' and Stowlangtoft St. George.

When this district became part of the province of East Anglia the Suthfolc were severely disciplined by foes both at home and from abroad. Their struggles against absorption by the kingdom of Mercia in the $7^{\text {th }}$ century may have led to the construction of those stupendous dykes, the principal of which was known as 'Devil's Dyke' and 'St. Edmund's Dyke,' and although it is beyond our limits-being in Cambridgeshire-it may be suggested that, with the great fosse to the west of the huge vallum, it was made for the protection of the people resident in the country under our consideration against an inland foe. 


\section{A HISTORY OF SUFFOLK}

As a maritime county Suffolk was exposed to the inroads of the Norsemen, and the opposing ramparts of these two peoples were doubtless numerous; but again the arable nature of the ground must be held responsible for the lack of their militant handiwork.

When peace was attained by King Alfred East Anglia was included in that portion of territory allotted to the Danes. To the presence of these settlers may be traced the ship-barrow in the parish of Snape, a great earthen monument which has recently been destroyed.

One class only of early fortified positions is adequately represented, that is the mount and bailey, which perhaps provided the most stupendous artificial works in Suffolk, and thus has better escaped the levelling process. Of this type Haughley is the best preserved and a good example, while Clare is the most stupendous.

Advancing to a later period of the Middle Ages we find a few examples of a defended residence which represent a transitional type, between the feudal castle and the simple moated inclosure. Rushbrooke, Wingfield, and Helmingham may be cited, inasmuch as the last two retain mementos of an ancient custom in the preservation and utilization of their drawbridges.

As in most low-lying districts simple moated areas abound, and in this respect Suffolk is especially remarkable with over five hundred examples. A noteworthy feature is that in West Suffolk the moats generally surround the houses of great families, as of the Drurys of Hawstead; the Tollemaches of Helmingham and Fakenham; the De la Poles of Wingfield, and many others; while those of East Suffolk protected the more modest halls and farmsteads.

Many sites have remains of extensive grouping of moats, as at Braiseworth Hall, Tannington, and Kenton Hall. Others have double moats, one within the other, the smaller around the house and the larger including the surrounding grounds, of which Gisleham is a perfect example.

Within the confines of this county churches have been cinctured by moats, Gedding, South Elmham All Saints, and Wattisham. Religious houses have also been protected by similar defences from marauders; the moat around the great abbey of St. Edmund at Bury has been filled, but fragments of moats may yet be traced at the monastic establishments at Wingfield, Hoxne, Bricett, Bruisyard, Flixton, Redlingfield, and Rumburgh.

Among the miscellaneous works the purpose of one has as yet baffled all antiquaries. The 'Warbanks' have been attributed to various races, and among the different theories expressed are those suggesting them to be the site of a Roman camp and a disused water-course ; the latter may at once be dismissed, but whatever their object it is evident that these trenches provided a defence for a large irregular area.

Tumuli are numerous, yet again, considering the nature of the ground on which they were raised, they are probably but a small fraction of those formerly existing, and these are fast being levelled. Barrows distinctive of each of the four earlier nationalities inhabiting the county have been explored and destroyed. A feature in the East Anglian barrows is the number that were known to be used for the holding of 'Things,' as Hills of Judicature, and in the retention of the name of that on which the people of Bury assembled in the Hundred of Thingoe. 


\section{ANCIENT EARTHWORKS}

The scheme for the classification of these earthworks may be enumerated in full, although no examples of Classes A, B, and $\mathrm{H}$ exist in Suffolk ; it may in part explain those types which are lacking :-

Class A.-Fortresses partly inaccessible, by reason of precipices, cliffs, or water, additionally defended by artificial works, usually known as promontory fortresses.

CLAsS B.-Fortresses on hill-tops with artificial defences, following the natural line of the bill; or, though usually on high ground, less dependent on natural slopes for protection.

Class C.-Rectangular or other simple inclosures, including forts and towns of the Romano-British period.

Class D.-Forts consisting only or a mound with encircling ditch or fosse.

CLAsS E.-Fortified mounds, either artificial or partly natural, with traces of an attached court or bailey, or of two or more such courts.

Crass F.- Homestead moats, such as abound in some lowland districts, consisting of simple inclosures formed into artificial islands by water moats.

Class G.-Inclosures, mostly rectangular, partaking of the form of F, but protected by stronger defensive works, ramparted and fossed, and in some instances provided with outworks.

Class H.-Ancient village sites protected by walls, ramparts or fosses.

Class X.-Defensive works which fall under none of these headings.

Class T.-Tumuli.

In Class $\mathrm{C}$ are seventeen examples, for the most part difficult to trace. It is probable that many others have been utilized for the making of moats at a later period, but if that is the case they have passed beyond recognition in this division.

Of the eight examples in Class $\mathrm{D}$, no one is particularly noteworthy except Orford, and this most probably would have been classified under Class $\mathrm{E}$, but that every vestige of a bailey has been destroyed. The mount at Offton is square, and is evidently of a later date than the type which this division was designed to include.

The eleven examples of Class $E$ are the most interesting earthworks in the county, and include some that are quite typical. At Clare is the largest mount, and a feature is the northern courtyard, which was indubitably an earlier stronghold adapted to the requirements of the mount castle. The destruction of the southern bailey by the railway and station yard is to be regretted. The works at Haughley are in an exceptionally good state, and at Framlingham the scheme of multiplying the courts and increasing the defences exhibits an interesting development.

The Homestead Moats of Class $F$ number five hundred and five. In some of them it would appear that many earlier works are incorporated, especially those of circular or elliptical plan, as in the case of the inner moat at Wattisham Hall.

In Class $G$ the most noteworthy among the eleven examples is at Barrow Hall, where a heavy rampart has lined both the inner and outer sides of a broad moat.

Class $\mathrm{H}$ cannot be said to be represented; possibly the Warbanks surrounded a village site, but further discoveries must be made before it can be determined. Again, at Icklingham, there is said to be the site of an AngloSaxon village; both here and on Cavenham Heath are signs of habitation, but no area can be traced as the borders of a settlement.

Among the eighteen miscellaneous works in Class $\mathrm{X}$ is nothing of moment; the origin and intention of 'Oliver's Ditches' is still enveloped in 


\section{A HISTORY OF SUFFOLK}

mystery, which the name-usually assigned to Cromwell-does not tend to solve.

Fish-ponds, so strongly in evidence in some of the midland counties, are found to a very limited extent in Suffolk, the most extensive being at Redlingfield.

The tumuli at Rougham, the ship-barrow at Snape, and the use of tumuli as judicial seats deserve special attention.

All the works are classified under the name of the parish in which they are situated, and the Roman numerals following represent the sheet of the 25-in. map of the Ordnance Survey whereon they are marked.

\section{SIMPLE INCLOSURES}

\section{(Class C)}

Ashbocking (lxvi, 4).-North-west of the village, $7 \frac{1}{2}$ miles north-west from Woodbridge, is the supposed site of a camp. Faint traces of a rectangular fosse are discernible and indications of Roman occupation have been found.

BRAmfield (xxxix, 6).- ' Castle Yard,' close to Castle Farm and east of Bramfield Park, 3 miles south-south-east from Halesworth, is a circular fosse $270 \mathrm{ft}$. in diameter, now containing water, with the entrance to the interior on the west.

BREDFIELd (1xvii, 8).-Four miles north from Woodbridge is a rectangular site surrounded by a fosse, which continuous ploughing has failed to obliterate although now worn wide and shallow. Many fragments of tiles and pottery and a bronze hair-pin found within the circumvallation tend to identify the work as being in use in the Roman period. The camp is surrounded at some distance by a fosse of oval shape known as 'Oliver's Ditches,' a decidedly later work which indicates the adaptation of the early camp to more modern defence.

Brettenham (lxiv, 3).- In a field south-west of the church, 5 miles north-east from Lavenham, are traces of a rectangular fosse. The ground is under the plough, which has greatly levelled it in recent years, but the outline can be distinctly traced. Roman coins and oyster-shells are found here.

Bungay (viii, I I).-On the north side of the railway are three parts of a rectangular inclosure; the longest part extant is about $200 \mathrm{ft}$. running north-east to south-west, the other sides are at the south-west and the southeast, with a short bank $12 \mathrm{ft}$. long turning at right angles towards the southeast. The greatest height of the rampart is now $2 \mathrm{ft}$., but it is greatly trodden down, and being situated on common land and golf links it is constantly subjected to further mutilation. Flint flakes and arrow-heads have been found on the site.

Burgh (lxvii, 10).-In 'Castle Field,' to the north of St. Botolph's Church, $5 \frac{1}{2}$ miles north-east from Ipswich, is a rectangular outline of double vallum and intermediate fosse ; it is faint from constant ploughing, yet distinct. It covers a piece of undulating ground, the lowest part passing through the camp is occupied by Drabs Lane. The long axis north-west to southeast is $900 \mathrm{ft}$., and the short axis $675 \mathrm{ft}$.; on the south-western side a scarp alone remains towards the west of the church. Within the northern angle of 


\section{ANCIENT EARTHWORKS}

the inner vallum are the traces of a circular mount and fosse, almost levelled, but enough to suggest that the people of a later age availed themselves of the defences of a Roman camp wherein to erect their mount stronghold and their church. Within this area Roman pottery, tesserae and tiles, with the constantly recurring oyster-shells, are frequently found.

Burgh Castre (ii, 5).-Burgh Castle, $3 \frac{1}{2}$ miles south-west-by-west from Yarmouth, is situated on high ground upon the eastern bank of the River Waveney. It is one of the best remaining Roman fortified camps in the country, but so far as its earthworks are to be considered it is included in this

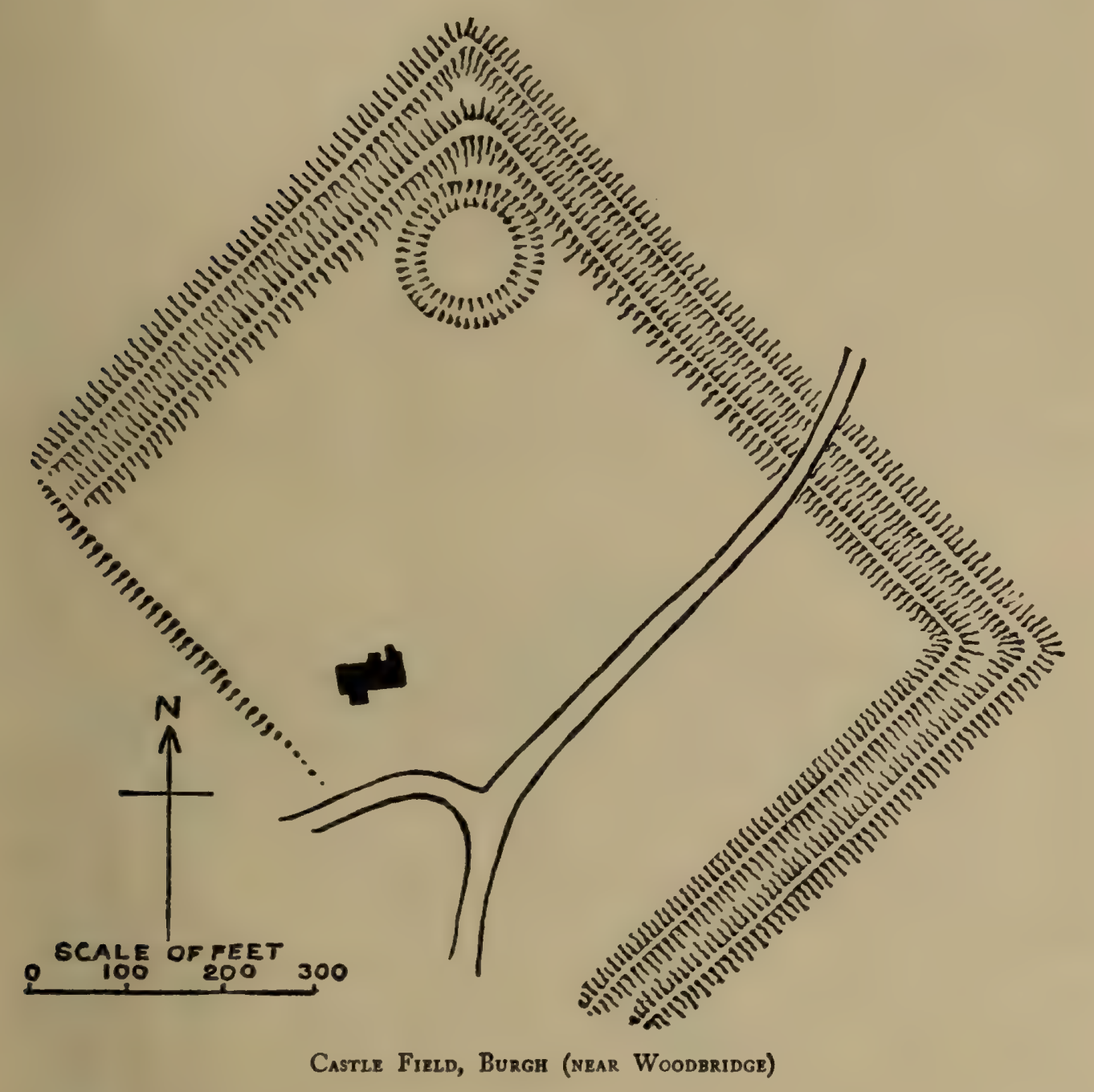

class. The area is $640 \mathrm{ft}$. long by $4 \mathrm{r} 3 \mathrm{ft}$. broad, and the ground within the walls is $4 \mathrm{ft} .8 \mathrm{in}$. above that outside. The terrier of Burgh St. Peter-by which name it was anciently known-for the year I6 i m mentions the Castle Ditch ; this would be the fosse around the outside of the Roman stronghold, which has disappeared on the eastern side under the action of the plough. From the middle of both the northern and southern sides the fosse is seen, gradually deepening until it reaches the level of the marsh by the river. All that is left on the western side is an irregular escarpment $32 \mathrm{ft}$. at its highest point at the north-west. A mound is said to have been discovered inside the south-west corner of the inclosure which has led to two opposing theories as 


\section{A HISTORY OF SUFFOLK}

to whether it was of the Roman period or the mount of a Saxon stronghold within the older lines.

Chevington (xliii, I6).-Chevington Hall Farm, north of the church, $4 \frac{1}{2}$ miles south-west from Bury. Around this farm-house are the remains of an exceedingly strong camp of irregular plan, the western side being angular and the eastern semicircular. The northern side consists of a fosse $60 \mathrm{ft}$. wide and $14 \mathrm{ft}$. deep, gradually increasing in magnitude towards the northwest. At a distance of $250 \mathrm{ft}$. from that angle is the commencement of a heavy vallum, rising $9 \mathrm{ft}$. high from the interior, with a summit $26 \mathrm{ft}$. broad; from this point is an escarpment of $28 \mathrm{ft}$. into a fosse $104 \mathrm{ft}$. wide, and having a counterscarp of $14 \mathrm{ft}$. On the western side is a continuation of the vallum of the same height, but of narrower dimensions, with the same scarp and counterscarp throughout, except at the south-west corner, where the escarpment is $32 \mathrm{ft}$. The normal measurements of vallum and fosse are continued along the south to the margin of a large pond, where they have been destroyed. To the east of the pond the original line of the vallum may yet be traced in a broad semicircular bank $3 \mathrm{ft}$. high; but the fosse has been filled up and a roadway occupies part of its site. This stronghold was afterwards utilized for the protection of a country house of the abbots of Bury which was built within it.

Clare $(1 \times x i, 3)$.-On the north-east of Clare Common, 6 miles east from Haverhill, are extensive remains of a camp, irregularly quadrangular in plan,

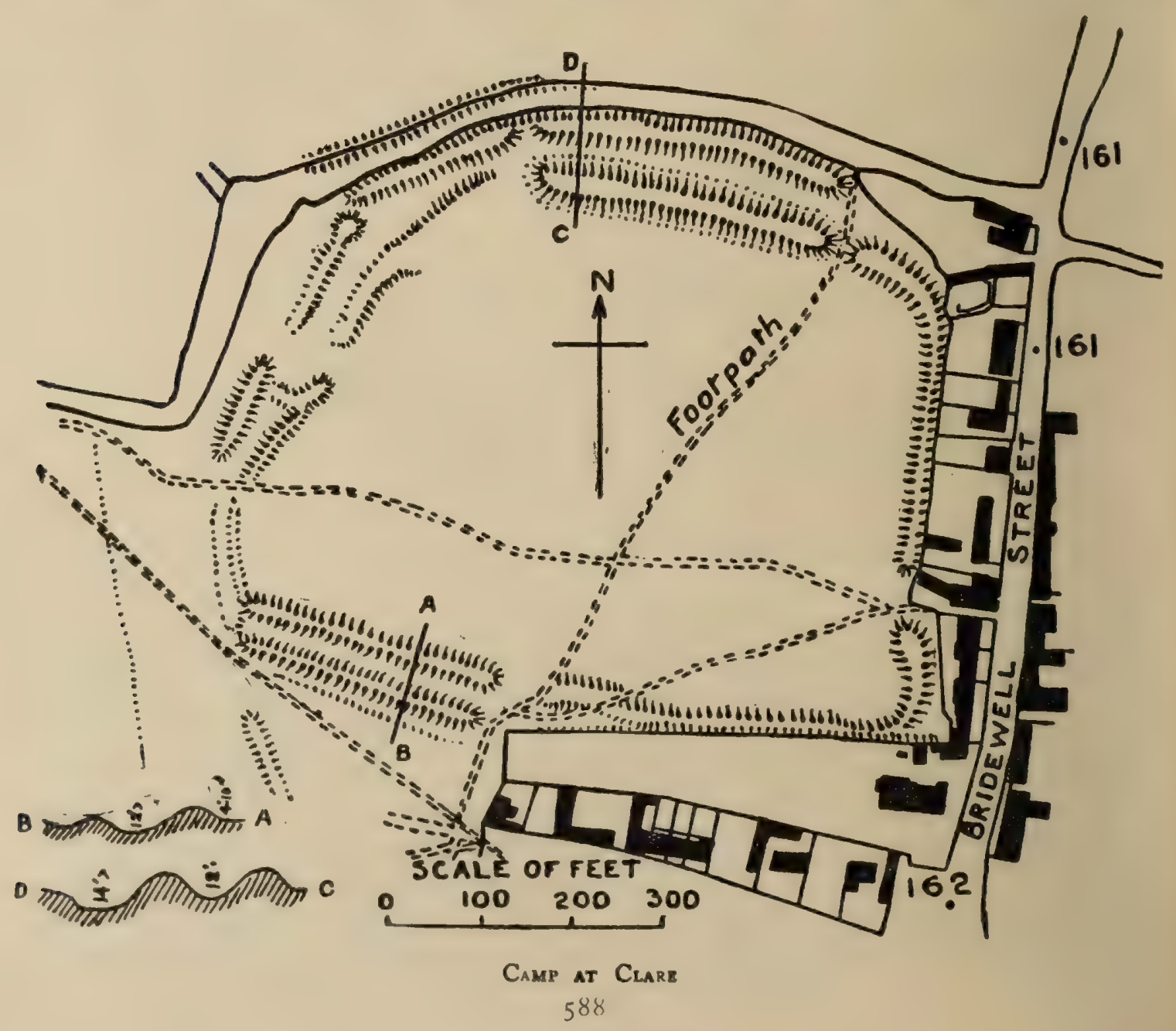




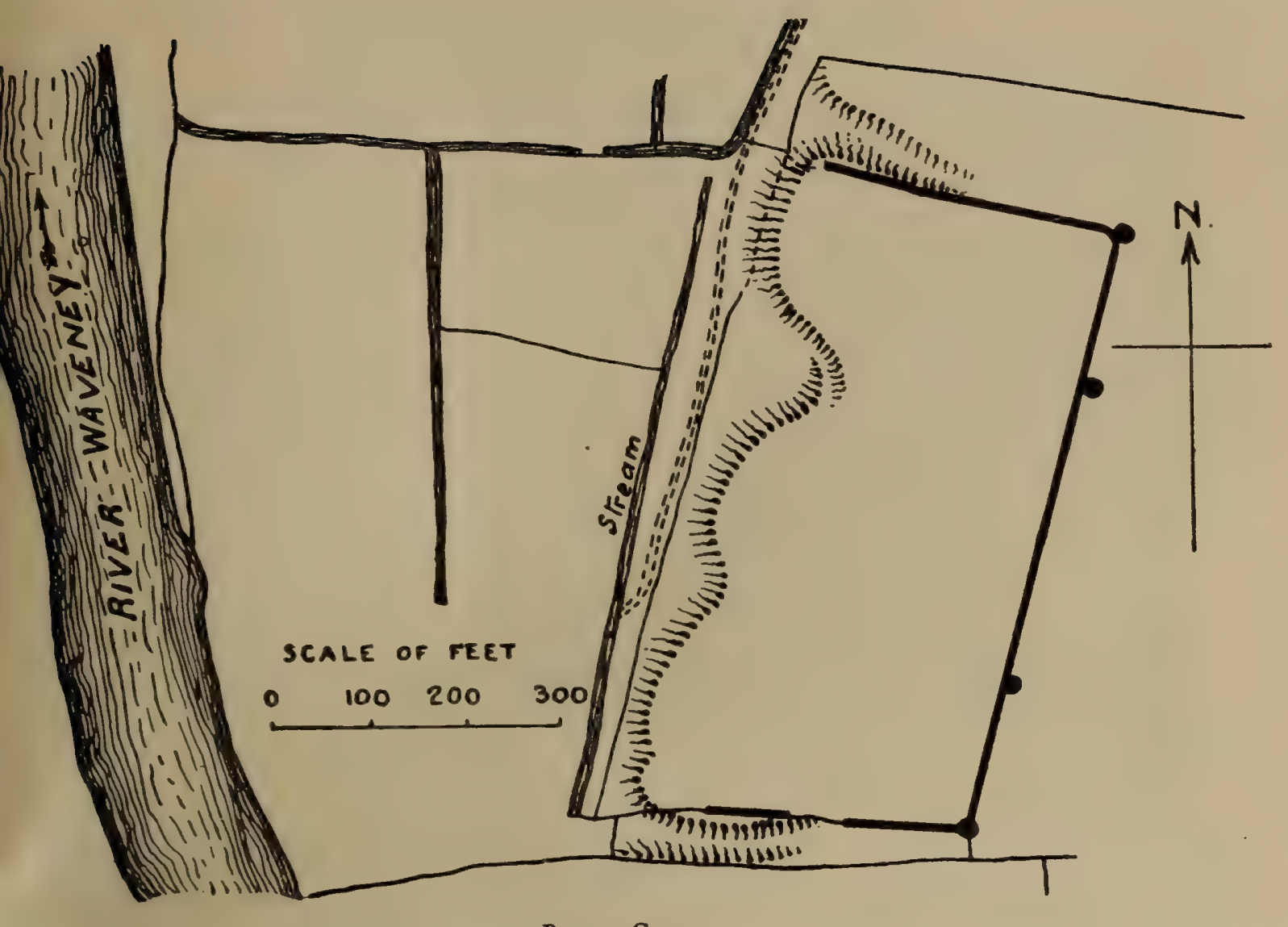

Burgh Casteg

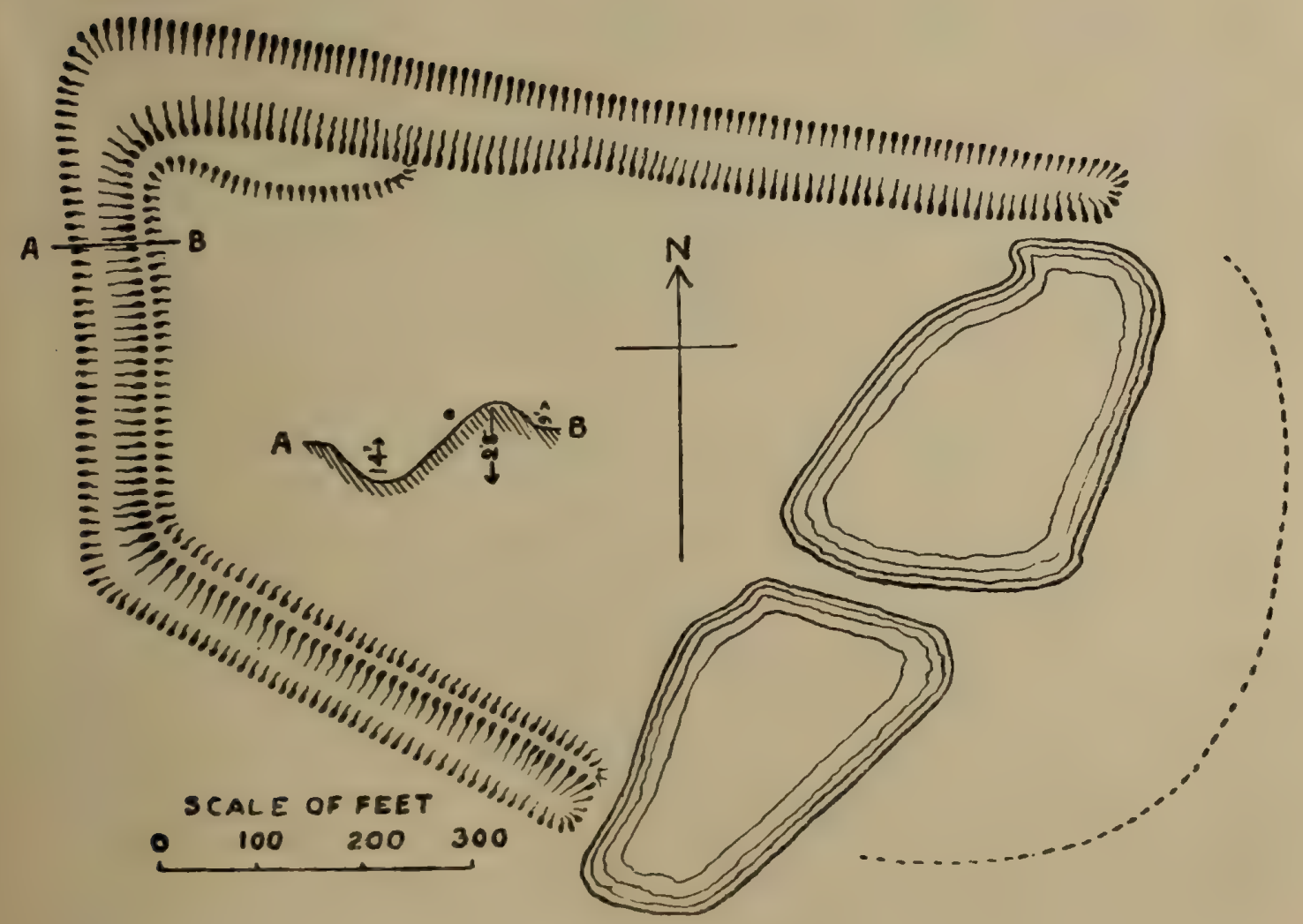

Chevington Hall Farm 


\section{A HISTORY OF SUFFOLK}

of double vallum and double fosse, occupying an eminence overlooking the country and the town. Lying so near to the town the growth of buildings and the common rights of pasturage have combined towards its mutilation. One fairly perfect length, at the south-west, has the rampart rising $4 \mathrm{ft}$. Io in. with a scarp of $12 \mathrm{ft}$. The counterscarp is $6 \mathrm{ft}$. high, and the scarp of the outer vallum is $3 \mathrm{ft}$., while its counterscarp of $2 \mathrm{ft}$. $10 \mathrm{in}$. descends into another shallow fosse; beyond this is a small piece of an outwork. From this corner the rampart is trodden within $2 \mathrm{ft}$. of the ground and the fosse is just visible at 9 in. deep, but due west it is in a slightly better condition, where $5 \mathrm{ft} .4$ in. is the greatest height, and a causeway connecting the two ramparts may be traced. The northern side is the most complete, where there are strong double works, the ramparts rising $9 \mathrm{ft}$. with the counterscarps $12 \mathrm{ft}$. and $14 \mathrm{ft}$. respectively; a cart track now occupies the base of the outer fosse. On the eastern and south-eastern sides the inner rampart alone remains, buildings having caused the destruction of the outer works. Two entrances only can be definitely seen, at the northern side near the east and in the eastern side near the south, both of which show a broadened vallum at one side of the entry.

Fakenham Magna (xxiii, 9).-In Burnthall Plantation, south of Fakenham, $7 \frac{1}{2}$ miles north-north-east from Bury St. Edmunds, is a circular stronghold of rampart and fosse. The entrance is on the west, where the northern end of the rampart broadens for the better defence against the ingress of an enemy.

Finningham (xxxv, 7).-By Stoland Abbey, south of Allwood Green, 7 miles west-by-south from Eye, is a small circular entrenchment, perfect in shape, consisting of a bold rampart and fosse, with the entrance apparently on the north-west.

Haverhill $(1 \mathrm{xx}, 2)$. - The site of Haverhill Castle, north-west of Haverhill, in the extreme south-western corner of the county, was on high ground commanding an extensive stretch of country. Its south-eastern scarp and fosse were preserved until recently, but now the rectangular site can only be traced by the fencing of the ground, a ditch, and part of the fosse, $\mathrm{I} 2 \mathrm{ft}$. deep, containing water. This bleak position is now occupied by Castle Farm.

ICKLINGHAM (xxi, I 5).-On the western side of the Icknield Way, $4 \frac{I}{2}$ miles south-east from Mildenhall, in a field called Camp Close, is a slightly raised plateau with a scarp of $3 \mathrm{ft}$., representing the site of a camp denuded of its defences. Numerous evidences of early occupation abound in its neighbourhood.

North Cove $(x, 9)$. - The site of Wathe, or Wade Hall, north-west of Barnby, 3 miles east from Beccles, was upon a circular entrenched position in the midst of marshes. The rampart rises from $2 \mathrm{ft}$. to $4 \mathrm{ft}$. in height, and the escarpment attains $10 \mathrm{ft}$. in some places. On the northern side the rampart has perished and the counterscarp of the fosse-which is $16 \mathrm{ft}$. wide -varies from $3 \mathrm{ft}$. to $4 \mathrm{ft}$. $6 \mathrm{in}$.; on the southern side are the remains of a revetment, but the whole work is trodden down by cattle.

Soutr Elmham St. Cross (xvii, 14). - West of St. Nicholas village and 33 miles south-east-by-east from Harleston, is a square camp inclosing about $3 \frac{1}{2}$ acres, within which stand the ruins of the ancient minster. The rampart 


\section{ANCIENT EARTHWORKS}

and fosse are now of no great strength, and a great portion of the latter contains water. The escarpment varies from $4 \mathrm{ft}$. on the north-west to $6 \mathrm{ft}$. on the south-west, but the rampart has largely been absorbed in gardening operations.

Stowlangtoft (xxxiv, I 5).-The Church of St. George -7 miles eastby-north from Bury St. Edmunds-is situated within the entrenchments of an oblong camp. The circumvallation consisted of a double vallum and fosse. The works are most clearly defined on the eastern and northern sides of the churchyard; on the east the inner fosse is $3 \mathrm{ft}$. deep and $15 \mathrm{ft}$. wide, the outer one is the same depth, but only $10 \mathrm{ft}$. broad; the depth is retained on the north, but the fosse narrows to $8 \mathrm{ft}$. The road from Pakenham to Stowlangtoft borders, and has destroyed, the southern side of the camp, leaving a scarp only, $6 \mathrm{ft}$. deep. A spear-head and coins have been found here.

Sutron (1xxvii, Io).-In Bussack Wood, 4 miles south-east from Woodbridge, a small circular camp may be traced, of slight elevation with an indication of a fosse on the south-eastern side, which is also just visible on the north.

\section{MOU N T S}

\section{(Class D)}

Burgh (lxvii, I0).-In 'Castle Field,' north of the church, $3 \frac{1}{2}$ miles north-west-by-west from Woodbridge, faint indications of a mount and fosse are discernible within an angle of a Roman camp ; an example of the utilization of early entrenchments by a later people. The whole area being under cultivation the plough has nearly obliterated the works. The description of the earlier entrenchments will be found in Class C.

Сомвs (lvi, ro).-In 'Jack's Grove' plantation, north-west of the village, I miles south-west from Stowmarket, is a small circular mount. A shallow fosse and outer bank remain around the northern half.

Great Ashfield (xxxiv, I6).- ' Castle Hill,' in Parker's Wood, southeast of Hunston, 8 miles north-eastby east from Bury St. Edmunds, is a very rotund mount. It is $130 \mathrm{ft}$. in diameter at the base and rises to a height of $24 \mathrm{ft}$. An irregular circle in plan, it has an oval summit slightly depressedor saucer-shaped-in the middle. A fosse, $18 \mathrm{ft}$. wide and $7 \mathrm{ft}$. deep at its highest part, completely surrounds it.

G R O T ON (lxxiii, I 5).-

'Pytches Mount' is situated in Groton Park, $5 \frac{1}{2}$ miles east from Sudbury. The mount, nearly $200 \mathrm{ft}$. in diameter at the base,

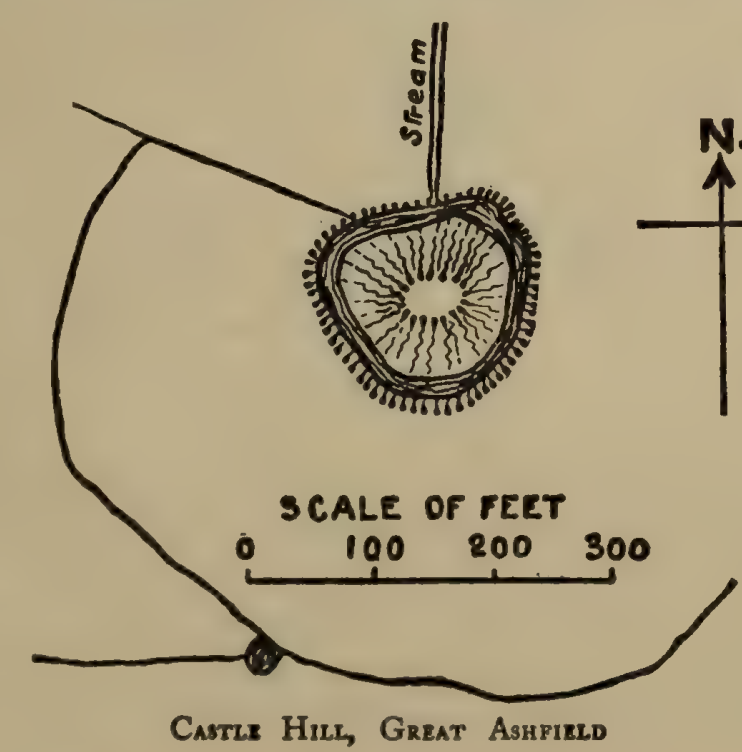

591 


\section{A HISTORY OF SUFFOLK}

rises $20 \mathrm{ft}$. in height, but is mutilated by an excavation through the top. It was formerly surrounded by a fosse, the greater part of which has either been filled in or destroyed by digging for gravel ; it is most in evidence on the north, where the counterscarp is $4 \mathrm{ft}$. 9 in.

Hunston (xxxiv, I6).- South-east of the village, $8 \frac{1}{2}$ miles north-east-byeast from Bury St. Edmunds, is a small mount surrounded by a fosse. The form of the mount has been destroyed by an indiscreet attempt at exploration, and the fosse now contains water.

Offron ( $1 \mathrm{xv}, \mathrm{I} 5$ ).- Site of Offton Castle, 4 miles south from Needham Market. A square area with an abrupt escarpment $14 \mathrm{ft}$. above the water, is surrounded by a moat $35 \mathrm{ft}$. in breadth ; to the east of the entrance on the north the moat narrows to $28 \mathrm{ft}$., apparently by the subsidence and consequent spreading of the mount at this point. The counterscarp of the moat is $6 \mathrm{ft}$. On the south side of the exterior of the moat are evidences of another embanked field inclosure. These works are situated on high ground which rapidly declines on the north and east, allowing of extensive observation of the surrounding country. It has the appearance of an early befossed mount adapted to later mediaeval defence.

ORFORD (1xix, 14).--Orford Castle, at the west end of the town, 9 miles east from Woodbridge, occupies a commanding position on the sea coast, on

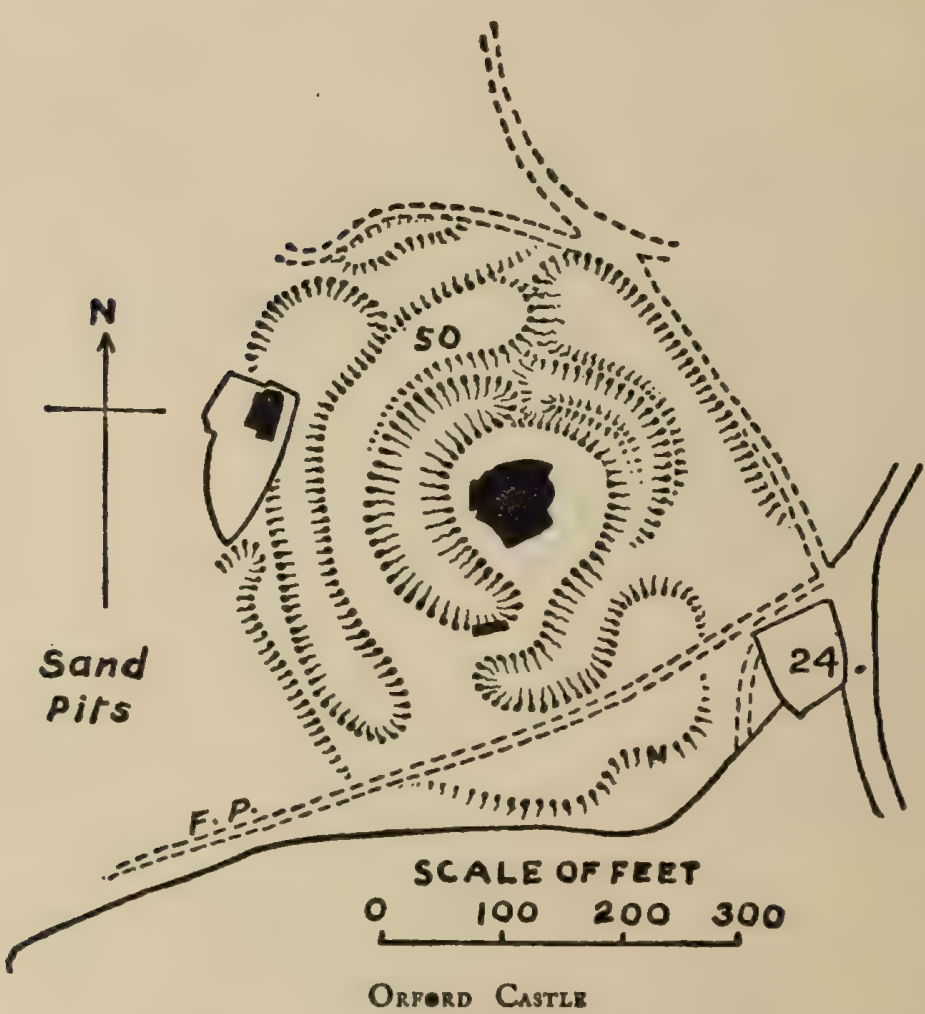
the western bank of the River Ore, protecting the adjacent harbour - now choked and useless-which provided a haven for Flemish mariners when the families of Glanville and Valoines successively held this stronghold. The mount, retaining the polygonal keep, is very irregular in outline, and was surrounded by a double fosse, which sand digging and other encroachments have more or less destroyed, and whatever outer works may have defended a bailey are now beyond recognition, and no plan of a base-court can be traced. The steepest part of the escarpment of the mount is on the west, where it is $34 \mathrm{ft}$. with a counterscarp of $23 \mathrm{ft}$., the fosse at this point is $15 \mathrm{ft}$. wide at the base and $70 \mathrm{ft}$. wide from edge to edge. The entrance is on the south, where a causeway, of which some supporting masonry remains, curves between one end of the fosse abutting upon the concave termination of the other end, by which the approach to the keep was completely covered. A causeway crosses the fosse on the north, and in the north-western depths of 


\section{ANCIENT EARTHWORKS}

the latter rises an intermediate agger. The outer fosse has lost its continuity for reasons stated above, but that it was another strong defence is evident from the remains. ${ }^{1}$

Redisham (xviii, I0)._- Mill Mount,' south-west of the village, 4 miles south by west from Beccles, is a small circular mount $9 \mathrm{ft}$. in height, with a slight depression in the middle of the summit. It is surrounded by a fosse with a counterscarp now measuring $4 \mathrm{ft}$. at its highest point, and a breadth of $\mathrm{I} \circ \mathrm{ft}$. at its broadest part ; but both height and width have been badly trodden by cattle.

\section{MOUNTS WITH ONE OR MORE ATTACHED COURTS (CLASS E)}

Bungay (viii, 6).-The castle of Bungay, on the northern border of the county, $5 \frac{1}{2}$ miles west from Beccles, was situated in a commanding position

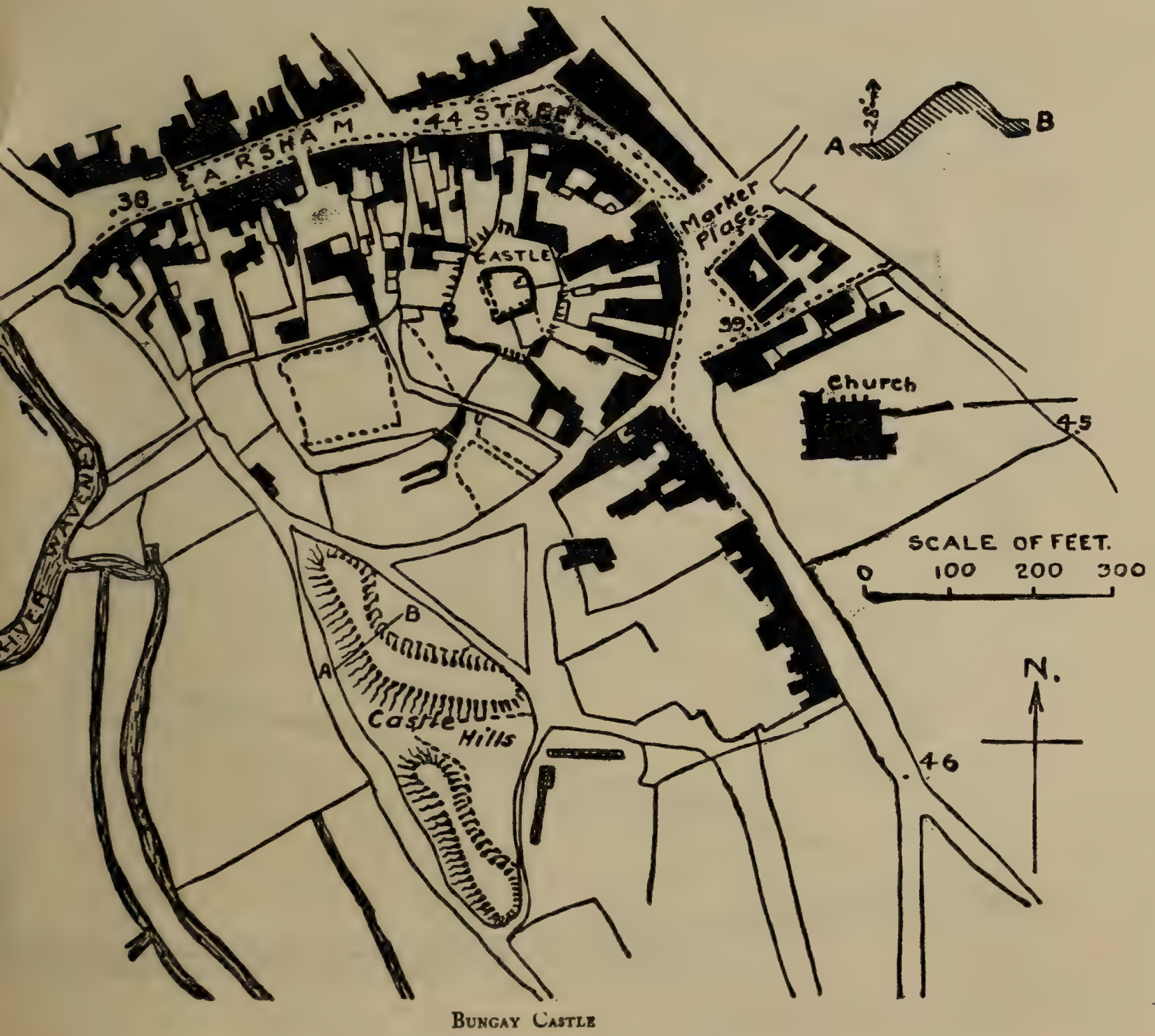

'Compare Pipe R. of 19 Hen. II. ' $\mathrm{Et}$ in operatione magni fossati circa Castellum de Oreford cum Hericia et Brestachia, et in Operatione Pontis lapidii de codum Castello lviii libros ii solidos et viii denarios.' 


\section{A HISTORY OF SUFFOLK}

on the isthmus of a small peninsula formed by the windings of the River Waveney, and covered the ford at this point. The later mediaeval adapta-

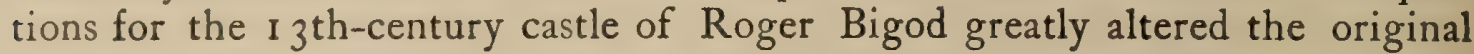
features of the artificial earthen mount. The latter is supported all around by a perpendicular wall of flint which, on the east, is $20 \mathrm{ft}$. high ; this is reduced by the rising of the ground to $8 \mathrm{ft}$. on the north and $9 \mathrm{ft}$. $6 \mathrm{in}$. on the west, with the greater height of $\mathrm{I} 2 \mathrm{ft}$. on the south, increasing towards the east. Between the two flanking towers of the entrance the height is $6 \mathrm{ft}$.

The middle of the mount sustains the ruins of a shell keep within which is a well; around the edge of the flint-built mount another shell surrounded the first, and between the two are two shafts descending into a subterranean chamber $14 \mathrm{ft}$. square and $14 \mathrm{ft}$. high. On the south and southwest of the mount are the massive remains of the vallum formerly surrounding
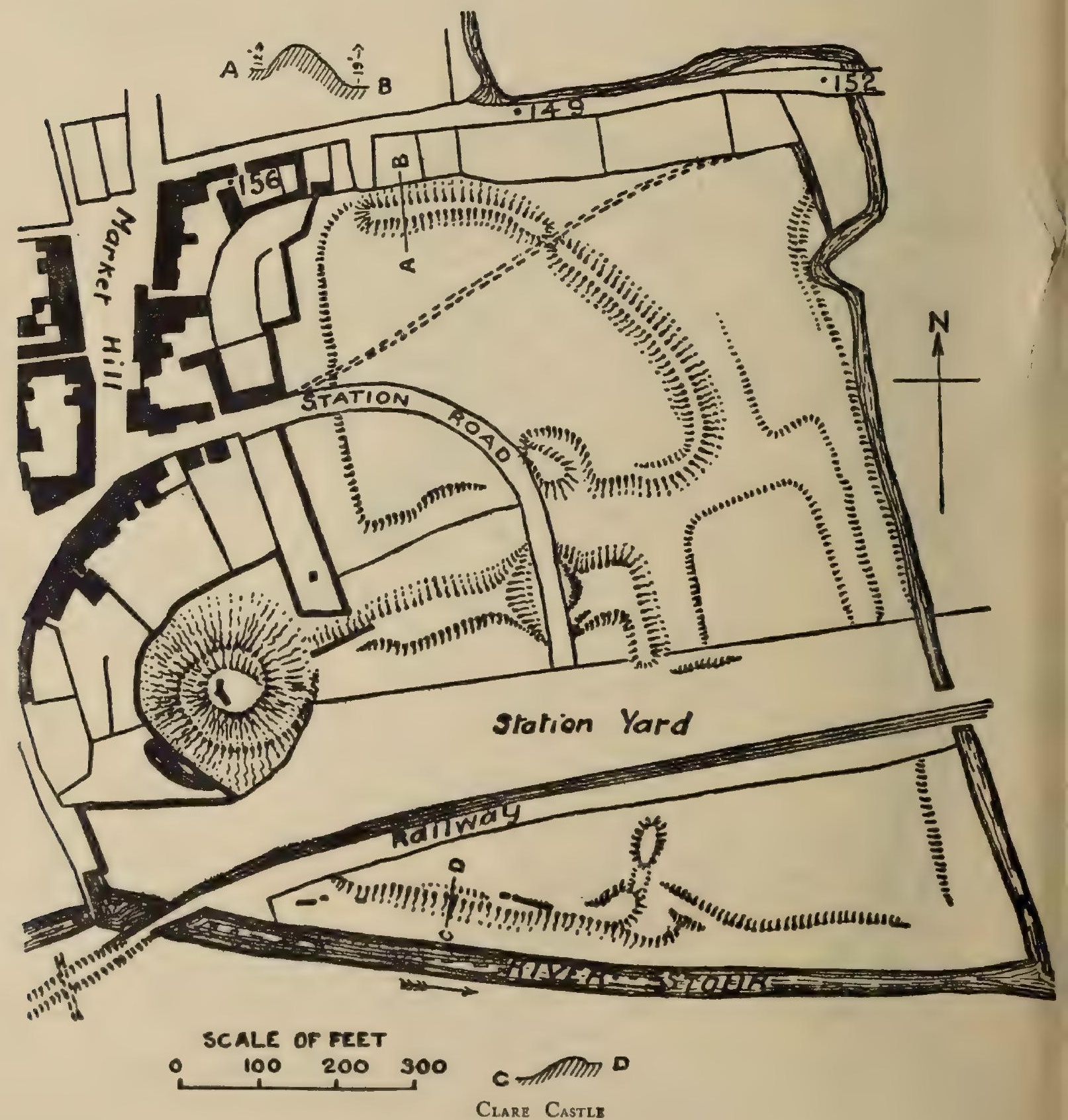


\section{ANCIENT EARTHWORKS}

the two baileys, which were situated on the southern side of the mount. In its present debased state this vallum rises from $\mathrm{r} 0 \mathrm{ft}$. to $\mathrm{I} 8 \mathrm{ft}$. from the base court, and has an escarpment of nearly $30 \mathrm{ft}$.

Clare (1xxi, 7).-Clare Castle, 6 miles east from Haverhill, is situated in the angle formed by the junction of the Rivers Stour and Chilton, on the northern bank of the former, the course of which has been diverted from its original bed, which passed slightly more to the south. The plan of the earthworks was a mount, and two baileys side by side; the former is intact, but the latter have been mutilated by the buildings of the town, a road, and the railway.

The mount is a truncated cone $850 \mathrm{ft}$. in circumference at the base and $100 \mathrm{ft}$. in height, with a level summit $6_{3} \mathrm{ft}$. in diameter, upon which are the remains of the shell keep of the Clares. The fosse of the mount-excepting a small piece containing water at the south-east-has been partially filled up for cottage gardens, but the houses are built to a circuit preserving the course of the original cincture; at the south-east it is quite obliterated by the railway-station yard. The original lines of the northern bailey apparently swept around in a wide curve from the north of the mount to the eastern side, whence it returned westwards to the mount ; the southern base-court is bounded by a vallum running easterly from the mount ; bending to the south for over $600 \mathrm{ft}$. it returned westwards and curved in a northerly direction on to the fosse of the mount, forming a court approximating to an oblong plan. In the northern court there remains the eastern quadrant of a heavy vallum, rising $12 \mathrm{ft}$. from the interior with an escarpment of $14 \mathrm{ft}$., increasing to $19 \mathrm{ft}$. at the north. On the south an inlet is cut resembling a false entrance in a prehistoric work, which is emphasized by the presence of an adjoining mound with a scarp of $14 \mathrm{ft}$. into a fosse $8 \mathrm{ft}$. deep. It is not improbable that the defences of this court were earlier fortifications preceding the mount type and incorporated into a later work. The southern court is certainly of a later period than that already described, and by the remaining fragments of masonry it is evident that the vallum was surmounted by a strong wall which descended the mount and surrounded the whole bailey. This vallum, beginning at the mount, is very broad and $20 \mathrm{ft}$. high, rising to over $22 \mathrm{ft}$. with a very steep scarp; it is separated from the northern bailey by a very broad and shallow fosse-or sunken road-with a counterscarp of $6 \mathrm{ft}$. South of the north-east right angle the vallum is destroyed by the railway, but on the southern side of the line it may again be followed, though in a mutilated state, $9 \mathrm{ft}$. wide at the top with a scarp of $18 \mathrm{ft}$. ; the south side is a scarp with indications of a rampart, $\mathrm{I} O \mathrm{ft}$. to the river bank. Without the eastern side of these works are other embankments to keep the land from inundation by the rivers, possibly for the accommodation of horse; these broad banks are $3 \mathrm{ft}$. and $5 \mathrm{ft}$. in height, and in the midst of the shallow trench which yielded the earth for the banks, a low plateau has been left.

A portion of another vallum lies to the south of the present river; this was possibly raised for the protection of the Priory of Austin Friars, founded here in 1248 .

Eye (xxxvi, 3).-Eye Castle, I I $\frac{1}{2}$ miles north-north-east from Stowmarket. Despite the violent usage meted out to this strong fortification its original 


\section{A HISTORY OF SUFFOLK}

lines may yet be traced. The conical mount with a base diameter of $\mathrm{r} 60 \mathrm{ft}$. is over $40 \mathrm{ft}$. in height on the western side towards the bailey, and higher by I $0 \mathrm{ft}$. on the eastern side by reason of the decline of the land. The basecourt, situated to the west of the mount, is bluntly elliptical, $400 \mathrm{ft}$. long on the east-to-west axis and $250 \mathrm{ft}$. wide from north to south, and its boundaries

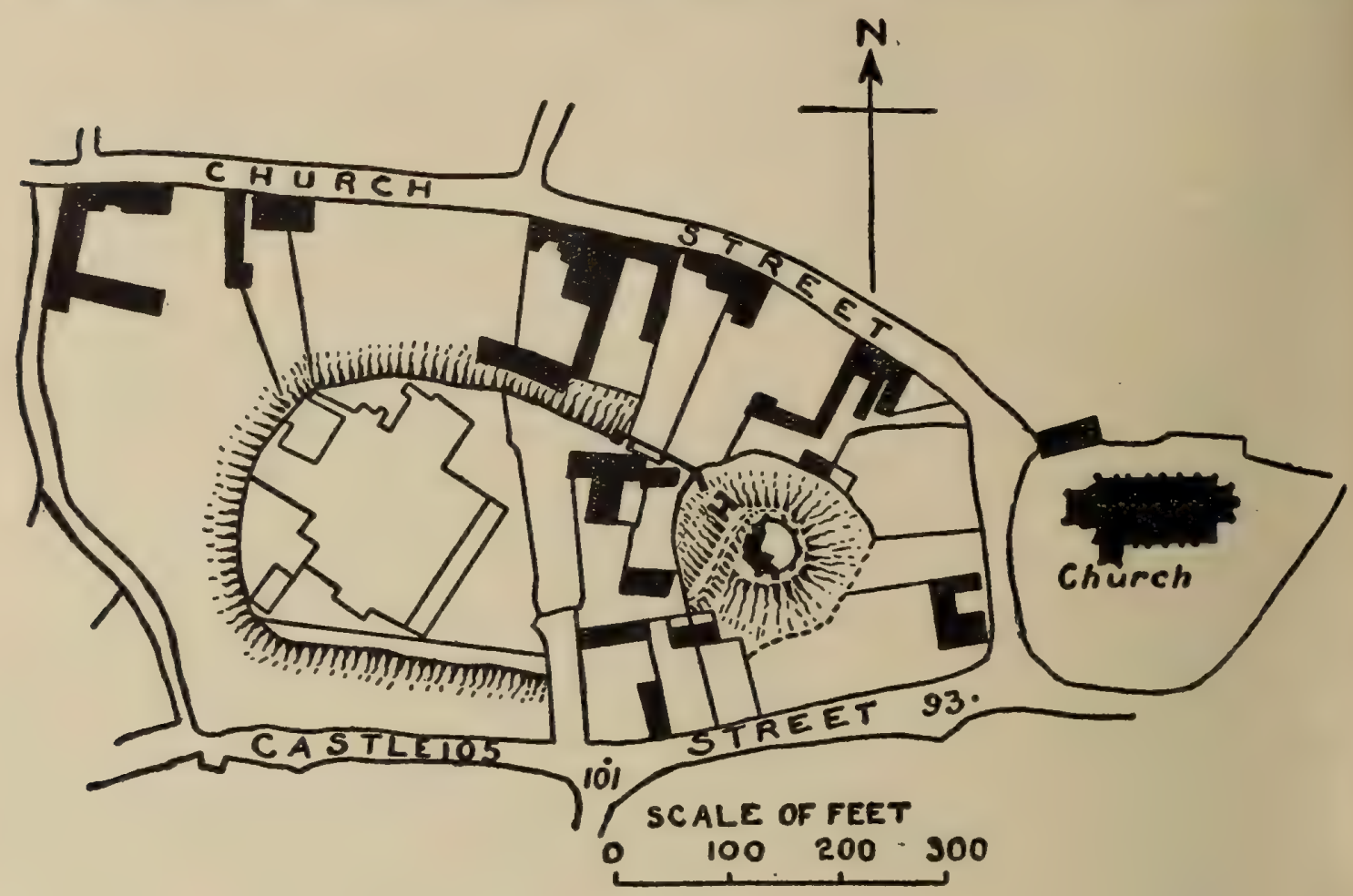

Exe Castux

abutted on the north-west and south-west of the mount ; the junction is now invisible owing to the filling in of the fosse of the latter, buildings and gardens covering its site. The vallum and fosse of the bailey have also been obliterated, leaving a scarp only, $14 \mathrm{ft}$. in height. Within the base-court is a well.

Framlingham (xlix, 9 and 13 ).-Framlingham Castle, 9 miles north from Woodbridge, is traditionally said to have been a stronghold of the East Anglian kings, and to have received the assaults of the Danes, although no history of it is known until it was owned by the Bigods subsequent to the Conquest. The horse-shoe bailey is certainly of an earlier date than the supplementary earthworks to be seen towards the north-west, and although its boundaries have been mutilated on the south-east they can yet be distinctly traced. The mount with its broad, flat, but irregularly outlined summit, surmounted by the walls and towers which formed the shell of the former castle, containing an inner court and a well, varies in height from the unequal base of the fosse; the steepest escarpment is $68 \mathrm{ft}$. on the north. At the north-east the scarp is $38 \mathrm{ft}$. and the counterscarp $25 \mathrm{ft}$., and the height is gradually reduced towards the south-east to $18 \mathrm{ft}$., again increasing as it passes the bridge towards the west, at which point the later alterations have destroyed the original plan. On the north-west the counterscarp of the fosse has been removed and a low-level base-court excavated $44 \mathrm{ft}$. 


\section{A HISTORY OF SUFFOLK}

From the north, eastwards, the fosse of the bailey is a huge excavation, with a scarp of $38 \mathrm{ft}$. and a counterscarp of $25 \mathrm{ft}$., but where the outer fosse branches from that of the mount the base rises and the two sides are brought to a level at the east, where they are nearly twenty feet above the base of the fosse. On the east the fosse has been blocked with earth, and forms a cart track. South of this modern causeway the fosse continues as a large pond for a length of $340 \mathrm{ft}$., beneath a scarp of $18 \mathrm{ft}$., after which it has been filled in and the gardens of cottages cover it beneath a scarp of I $4 \mathrm{ft}$. Another portion of the fosse is seen in the village pond, and yet farther west-on the south side-it is covered by an inn, behind which it is again in evidence with a scarp of $18 \mathrm{ft}$. and a counterscarp of $7 \mathrm{ft}$. The scarp turns north and gradually rises to $48 \mathrm{ft}$. at a point round which it originally amalgamated with the fosse of the mount; now it runs into the branch fosse protecting the southern side of the later quadrangular court. To the west of the bailey is another small angular area with an outer fosse

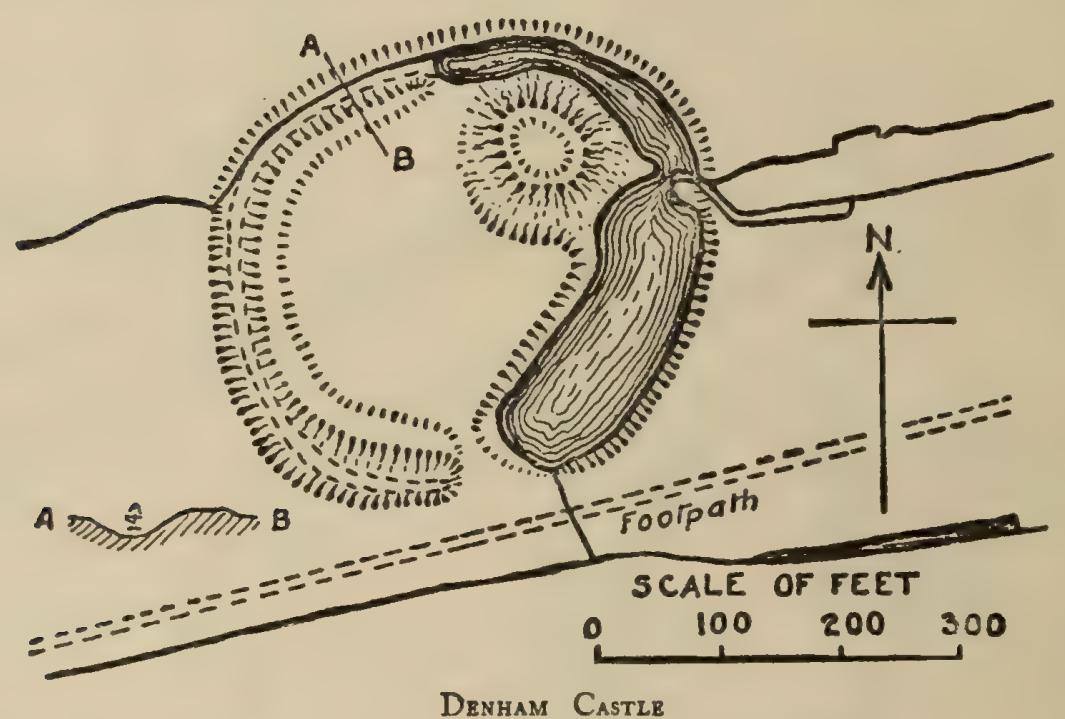

$6 \mathrm{ft}$. deep, access to which from the interior could only have been gained by a bridge. At the north and north-east of these works is a third fosse $18 \mathrm{ft}$. wide and $5 \mathrm{ft}$. deep, apparently of a much later period.

GAZELEY (xliii, IO). - Denham Castle, 'Castle Holes,' is 6 miles south-west by west from Bury St. Ed-

munds. The mount of this castle, roft. in height, with a concave summit, lies within the north-eastern side of the circuit of an oval bailey, the fosse at that point being common to both the keep and the court. The whole work is greatly worn, and the fosse surrounding the mount is now but $4 \mathrm{ft}$. 6 in. deep. One noteworthy feature is the very wide and low bank around the western half of the bailey; it rises $4 \mathrm{ft}$. from the interior, and is $30 \mathrm{ft}$. broad, forming a wide platform whereon the warriors could take their stand behind a palisade. The scarp of this varies; on the north it is $14 \mathrm{ft}$. into a fosse of $9 \mathrm{ft}$. deep; towards the west both the scarp and counterscarp of the fosse are $9 \mathrm{ft}$., which are reduced to $5 \mathrm{ft}$. at the south-west, where the fosse is $42 \mathrm{ft}$. wide. The entrance is on the south, and on its eastern side the vallum, or platform, has been dug away, and the site of it, together with the fosse, now provides a pond $100 \mathrm{ft}$. broad. A slightly raised bank running through the centre of the court has probably been an agricultural division in a post-mediaeval age.

Haughley (xlvi, 14).- - Haughley, or Hagenet, Castle, 28 miles north-northwest from Stowmarket, is the most perfect earthwork of this type in the county. 


\section{ANCIENT EARTHWORKS}

The stupendous artificial conical mount, $2 \mathrm{I} \circ \mathrm{ft}$. in diameter at the base, is $80 \mathrm{ft}$. in height, with a flat summit $80 \mathrm{ft}$. in diameter. The summit, however, is not concentric with the base, but considerably to the north, whereby the escarpment on that side is more abrupt and inaccessible, a feature to be considered as strengthening that side, which lies unprotected by the bailey. Beneath the soil of the top are the foundations of the shell keep of Hugh de Montfort, or one of the succeeding families in the Honour of Hagenet. The fosse surrounding the mount is very deep, and water has been conducted into it from the west, thus turning it into a water moat ;

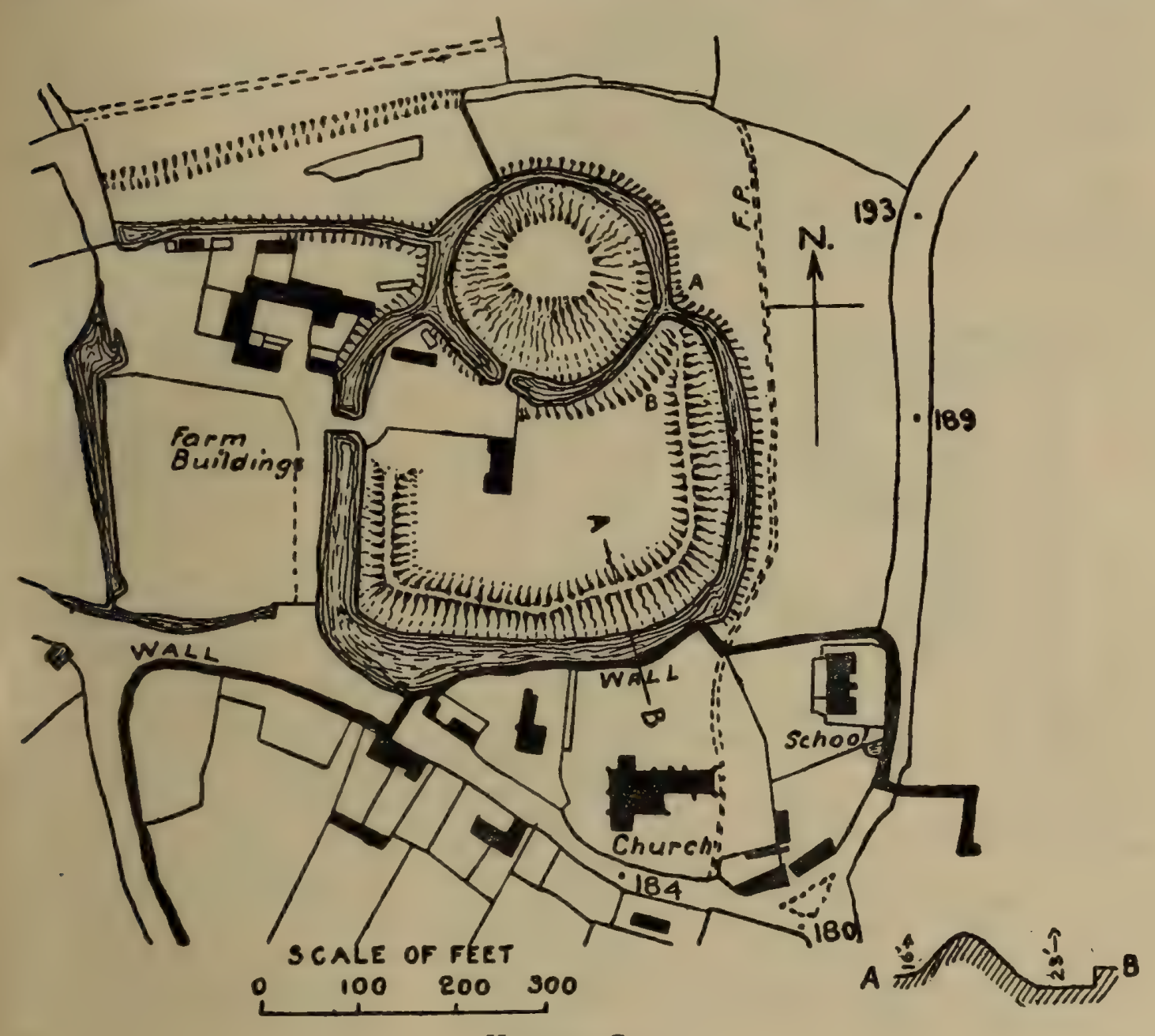

Haughley Castre

this is $\mathrm{r} 2 \mathrm{ft}$. wide at the north and $26 \mathrm{ft}$. on the south and west. The height of the counterscarp is $6 \mathrm{ft}$. on the north-west, increasing to $\mathrm{I} 2 \mathrm{ft}$. at point $\mathrm{A}$, the junction with the fosse of the bailey. On the southern side -dividing the mount from the court-the counterscarp is $20 \mathrm{ft}$. at point $\mathrm{B}$ just within the bailey, decreasing with the fall in the ground to $4 \mathrm{ft}$. at the south-west, but at this point it is worn far below the original height by farmyard use. At the extreme west, between the fosse of the bailey and the cutting for the water supply, the counterscarp is $9 \mathrm{ft}$.

The bailey lies due south, with the mount forming part of its circuit and with nearly half the circumference being within the base-court. The latter is nearly quadrangular, $390 \mathrm{ft}$. wide by $300 \mathrm{ft}$. from north to south; 


\section{A HISTORY OF SUFFOLK}

it is surrounded by a heavy vallum and deep fosse, the latter entering the fosse of the mount just below its east-to-west axis. The vallum of the bailey rises $16 \mathrm{ft}$. from the interior, and has a scarp of $23 \mathrm{ft}$. to the water level; this is at its highest and most perfect part. The counterscarp, $14 \mathrm{ft}$. on the east, declines to $8 \mathrm{ft}$. on the south-east, and is but $4 \mathrm{ft}$. above the water at the west; this is partly on account of the ground sloping down towards the west - as seen in all the above measurements-and partly because the farm traffic has required a lower road level. The width of the bailey fosse averages $24 \mathrm{ft}$. and the width of the vallum $20 \mathrm{ft}$. The cutting for water to the fosse on the west is $9 \mathrm{ft}$. deep, and a ditch on the north of the mount for the overflow of the water, now largely filled up, exhibits no such work as is represented on the Ordnance Survey. On the west of the bailey an oblong area appears to have been moated at a later period.

Ilketshall ST. John (xvii, 4).-The 'Mount,' north-east of the village, 2 miles south-east from Bungay. The circular mount-situated near the ancient road known as Stone Street-is $23 \mathrm{ft}$. in height; it is surrounded

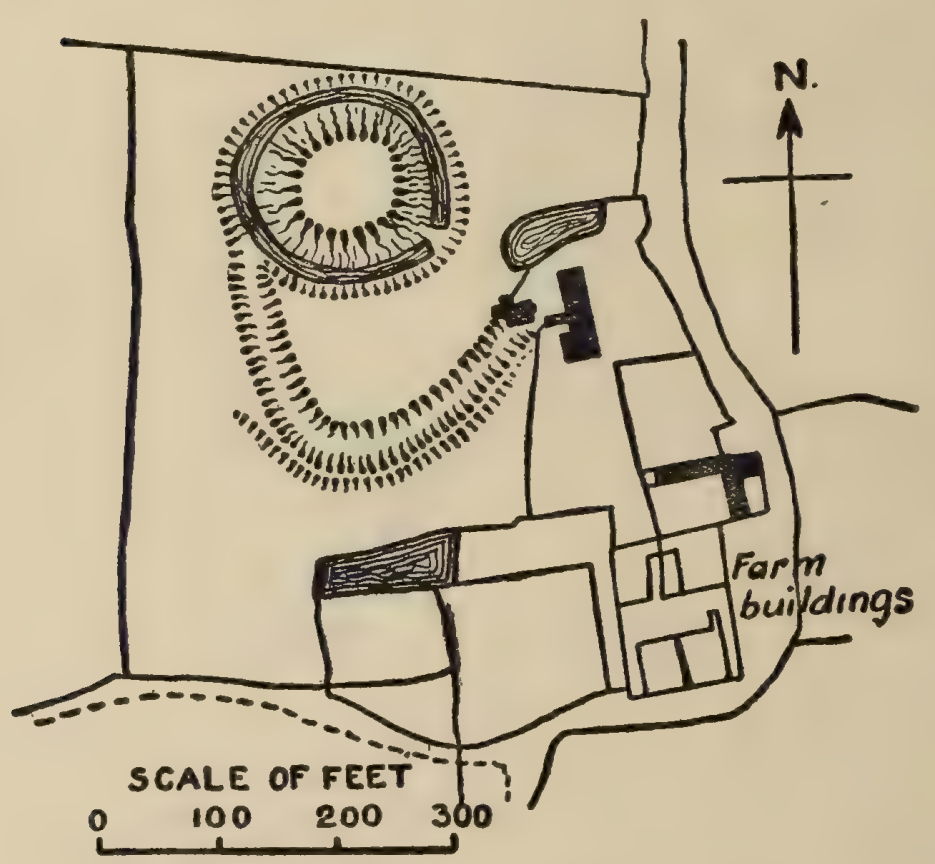

Thв Mount, Ileztshall St. JohN by a fosse $8 \mathrm{ft}$. 6 in. deep, increasing to $\mathrm{II} \mathrm{ft}$. on the north, and attains great breadth on the west. This is situated on the northwestern part of the circuit of a small horse-shoe bailey, the fosse of which enters that of the mount at the south-west, but the eastern junction has been levelled for farm-yard requirements. No rampart remains to the bailey, but around the southern curve and south-eastern side a low revetment surmounts the counterscarp of the fosse, rising from $5 \mathrm{ft}$. on the south-east to $8 \mathrm{ft}$. on the south-west. The land

declines from the north-west to the south-east, and the higher side shows no trace of the outer bank. The fosse, represented as containing water in the Ordnance Survey, only presents this appearance after a heavy rainfall.

Lidgate (liii, 5).- - Lidgate, or Lydgate, Castle, $8 \frac{1}{2}$ miles south-west by west from Bury St. Edmunds, is a mount and bailey fortification differing considerably from the general features of this type. The mount is quadrangular, with a fragment of its rampart $3 \mathrm{ft}$. high remaining on the eastern side and south-eastern corner, and another mound covering foundations. The fosse surrounding it, except at the south where the entrance is situated, is of great strength. The mount has an escarpment of $12 \mathrm{ft}$. at the western angle, $20 \mathrm{ft}$. at the northern angle, and $35 \mathrm{ft}$. on the east; the counterscarp is generally $16 \mathrm{ft}$. From the western angle the fosse of the bailey branches, 


\section{ANCIENT EARTHWORKS}

taking a south-westerly course psst the west end of the church built within the protection of the court; this has a scarp of $24 \mathrm{ft}$. and a counterscarp of $8 \mathrm{ft}$. The whole of the southern side of the bailey has been destroyed, though possibly the site is marked by the cottages built here in a similar manner to the southern half of the eastern side, where cottage gardens occupy the ancient fosse, which, however, still retains a scarp of $\mathrm{I} 2 \mathrm{ft}$. This side of the bailey fosse turns into that of the mount at the eastern angle; but it has also been extended in a northerly direction, inclosing another elongated

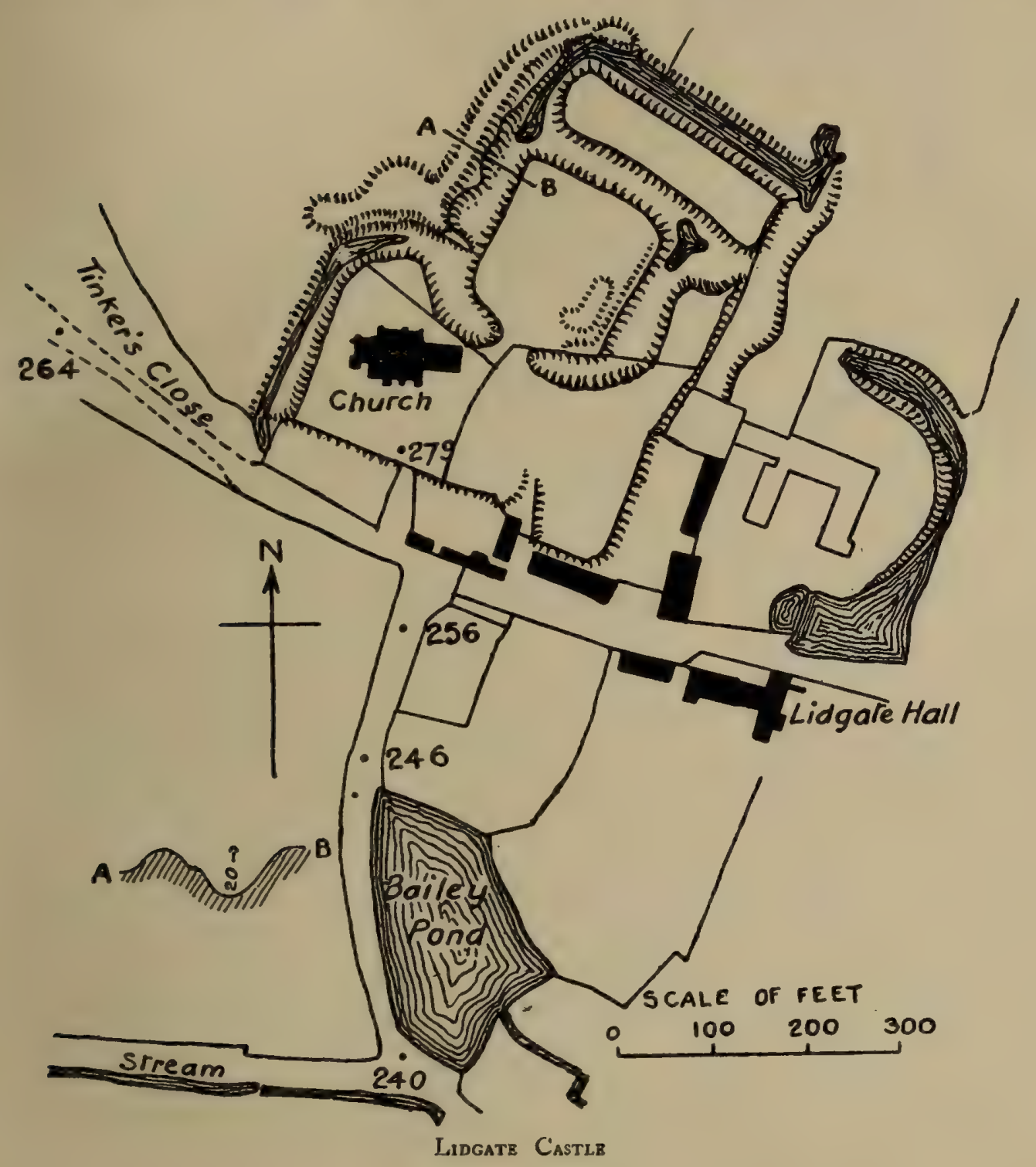

oblong area, apparently of a later period. Outside the western side and northern angle of the fosse is a broad revetment $10 \mathrm{ft}$. high, which expands into two curved platforms $6 \mathrm{ft}$. in height. On the eastern side of these works a portion of another fosse appears to indicate the inclosure of another court; but this may belong to a later age, for these entrenchments point to a stronghold of the mount and bailey type, which were afterwards altered to manorial requirements.

LindSEY (lxxiii, I2).- The 'Mounts,' on the site of Lindsey Castle, 4 miles north-west by north from Hadleigh. The mount, $12 \mathrm{ft}$. in height, 


\section{A HISTORY OF SUFFOLK}

is situated on the southern cincture of the original bailey; this latter is oblong in plan, to which a stream was a natural limit and defence to the eastern side. The strength of this fortification was obviously greatly

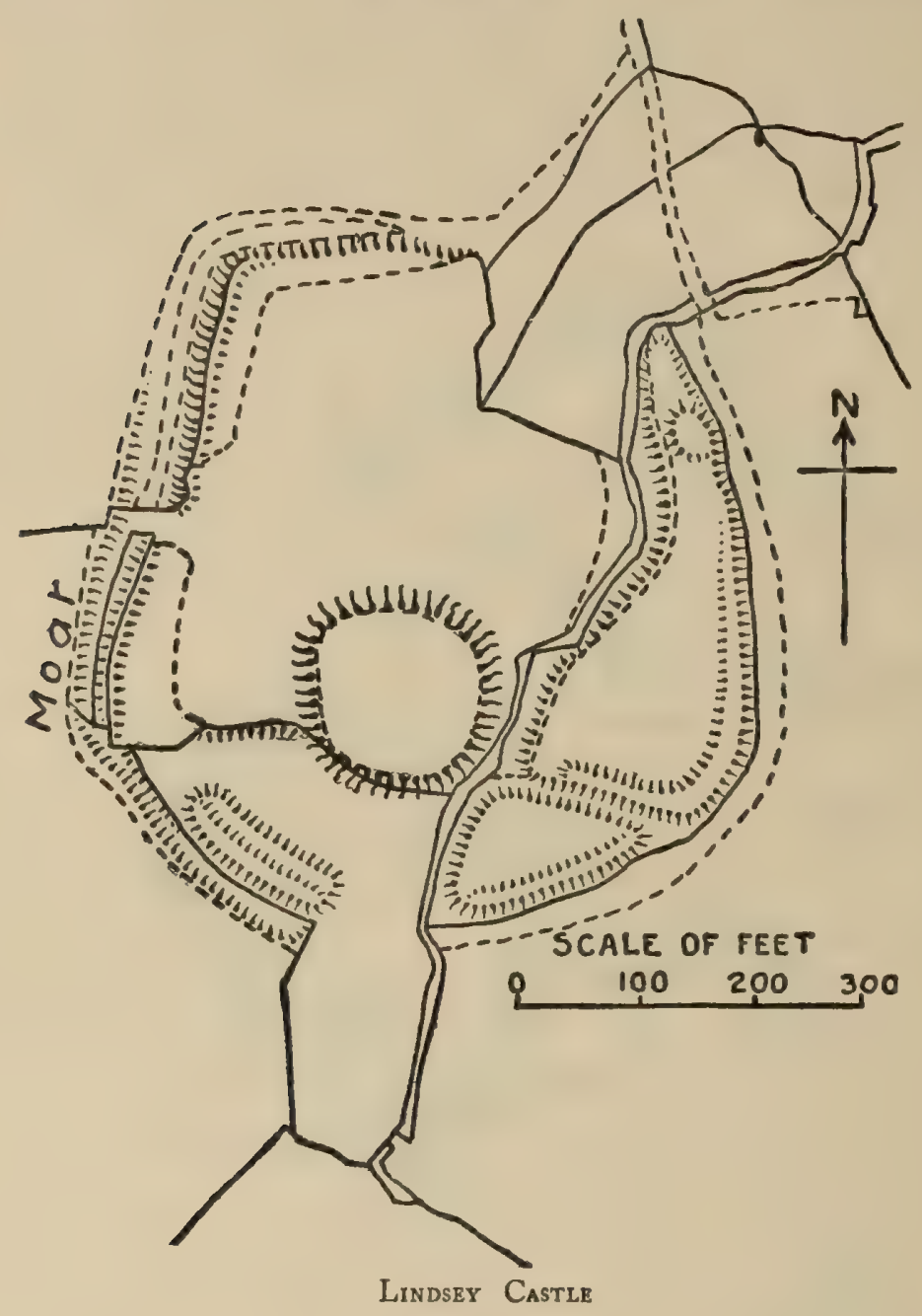
augmented by a series of fosses and ramparts at some subsequent period; thus, east of the stream, and $8 \mathrm{ft}$. above its level, is another irregularly shaped court, on the eastern border of which is a rampart $8 \mathrm{ft}$. high with an escarpment of $12 \mathrm{ft}$.; towards the north this rampart rises into a small mound $27 \mathrm{ft}$. above the stream. On the north, and beyond the curve of the rivulet, is a strong agger rising $\mathbf{I} 2 \mathrm{ft}$. above the water, and with a scarp of $6 \mathrm{ft}$. A fosse divides a small triangular area from the south of the latter court, and this is also ramparted. To the south of the mount another portion of the outworks is seen in a platform for the defenders $5 \mathrm{ft}$. above the ground level, with a rampart $4 \mathrm{ft}$. high and a scarp of $9 \mathrm{ft}$. into a $4 \mathrm{ft}$. fosse.

Minden (1xxiii, 6).-Milden Castle, known as 'Foxburrow Hill,' lies to the south-west of the village, 6 miles north-west from Sudbury. It is situated on ground no higher than the surrounding land except on the southeast, from which side it declines. The works here are so thoroughly mutilated that it is difficult to trace their original extent. The circular mount is situated within the southern part of a small base-court, and by a gentle acclivity reaches a height of $\mathbf{I} 2 \mathrm{ft}$. at the apex; this apparently was originally surrounded by a fosse and revetment, with the vallum and fosse surrounding them. The fosse of the mount remains only on the eastern side, and a fragment of the revetment on the north-east. Of the bailey cincture the rise of the vallum alone is left on the east, the escarpment of the same, about $7 \mathrm{ft}$. deep, at the north-west, and a portion of the fosse on the west. Digging for gravel has almost obliterated any definite formation.

Othey (lxvii, I)._- The Mount,' called Otley Barrow, 7 miles northeast by north from Ipswich. The circular mount, $20 \mathrm{ft}$. in height, has a flat summit, and is surrounded by a fosse nearly three feet deep; this has been almost levelled on the west, though easily to be traced by the depression 


\section{ANCIENT EARTHWORKS}

in the ground; and at the south-west the fosse has been destroyed by a broad clearance, which would appear to have been made for obtaining the supplementary soil required for the formation of the mount, the excavation of the fosse yielding an insufficient amount for that purpose.

Indications of a bailey appear on the northern side of the mount, the fosse having sprung from that of the mount on the eastern and western extremities of the axis, and the 'Gull,' the bed of a winding stream, being utilized for the same purpose on the north and the northeast. Another fosse branches from that of the mount on

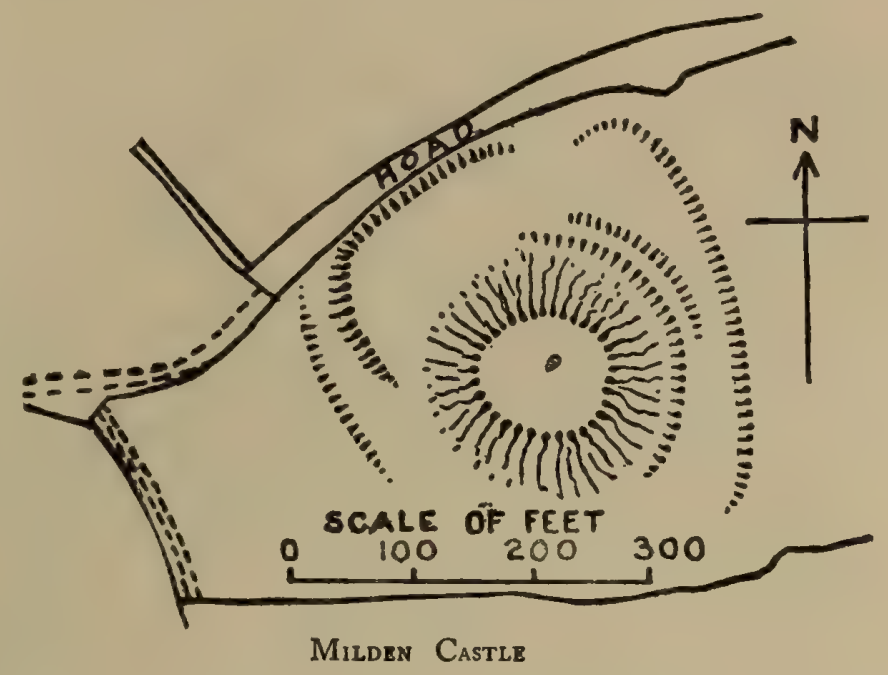
the south side, and eridently formed a large inclosure with the stream as the eastern boundary. This is of a later date, and within the area various mediaeval implements, horse furniture, and jewellery have been found.

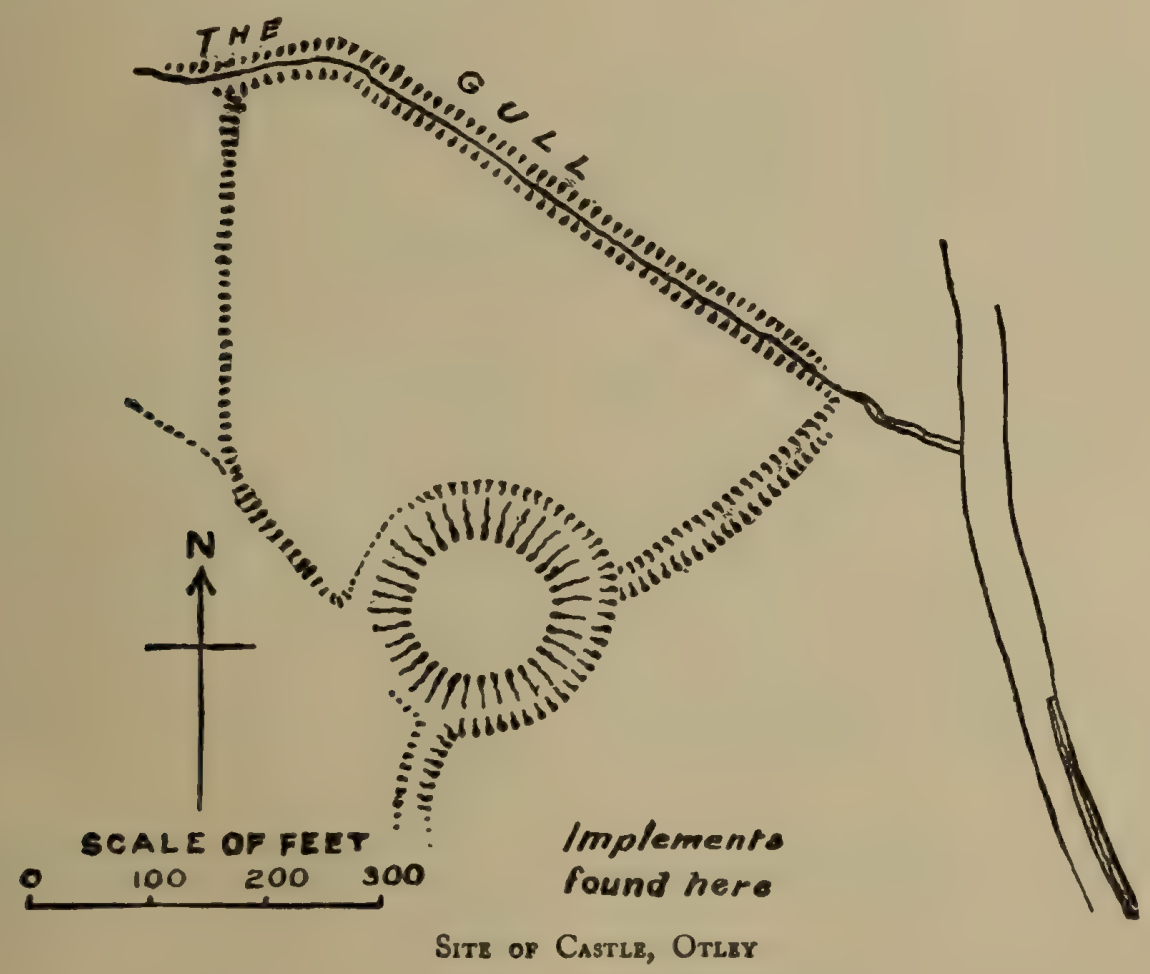




\section{A HISTORY OF SUFFOLK}

\section{HOMESTEAD MOATS}

\section{(Class F)}

Acton (lxiii, I6).-Balesden Hall, I $\frac{1}{2}$ miles south-west from Lavenham, has a narrow moat inclosing a large quadrangular site, partially divided by an intermediate branch extending $300 \mathrm{ft}$. inwards from the south-western side. That part surrounding the grounds adjacent to the Hall would appear to have been the original moatcontaining fish-ponds-and the extension towards the north-west a later addition. On the northeast another square moat surrounds a plot of land in the centre of which is another piece of water.

Acton (lxxii, 3). At Acton Hall, 2 miles east from Melford, north of All Saints' Church, a portion of an elliptical moat remains in the form of a horse-shoe.

Alderton (lxxxiv, 3).-At Alderton Hall, 5 miles north-east from Felixstowe, is the greater part of an oblong moat, with an extension branching from the south-western angle in a westerly direction.

Ashbocking (lxvi, 4).--Ashbocking Hall, 5 miles east from Needham Market, retains but a small portion of its once extensive moat. The east side remains, and it may be traced to a certain extent on the south and west.

Ashbocking (lxvi, 4)-'Feoffee Moat,' northeast of Ashbocking Green, is a remnant of an irregular oblong defence. It is, however, partly filled up, and various cuttings projecting from its main trench disfigure its original plan.

Aspall (xlvii, 8).-At Aspall Hall, I $\frac{1}{4}$ miles north from Debenham, is a strong oval moat.

Athelington (xxxvii, 9).-At Athelington Hall, west of the village and 4 miles south-east from Eye, are two moats in close proximity one to the other. The greater part of a square onethe south-western corner having gone-opens into a small pond at the north-western angle; otherwise it is regularly formed with an entrance on the north. The other moat, to the south-west of the first, is rectangular on the west and circular on the east, with spreading ponds on the north.

Athelington (xxxvii, 10).-The greater part of a small oblong moat is situated to the east of the village.

Bacton (xlvi, 2).-At Redhouse Farm, Earls Green, 5 miles north from Stowmarket, is a very perfect quadrangular moat.

West of the last-mentioned are the remains of a narrow moat at Bacton Old Hall with extensions which probably surrounded other tracts of land.

Bacton (xlvi, 3).-Manor House Farm retains three sides of a quadrangular moat, the south side having been filled up.

At Pulham's Farm, $\frac{1}{4}$ of a mile south of Bacton
Church, a moat-rectangular on the western side but almost circular on the eastern-is still perfect.

One mile south-west of St. Mary's Church another moat, quadrangular in plan with an excrescence surrounding an islet at the western angle, surrounds the site of the ancient rectory.

Bacton (xlvi, 6).-At Bacton Hall, west of Bacton Green, $7 \frac{1}{2}$ miles north-east from Needham Market, is a narrow moat of many angles irregularly surrounding the ancient hall and its grounds.

Bacton (xlvi, 7).-At Kerry's Farm, Cow Green, are pieces of two adjacent rectangular moats.

Also Russell's Hill Moat, south of Cow Green, an oblong moat, clearly traced on the north of a narrow stream by which it was formerly fed with water.

Badingham (xxxviii, 14).-Badingham Hall moat, 5 miles north-east from Framlingham, is an imperfect oblong.

Badingham (xlix, 9).-At Moat Farm, northeast of Brabling Green, is an extensive irregular oblong moat. The south-eastern side is almost destroyed by a roadway.

BaDwell Ash (xxxv, 9).-A fragment of a very broad moat is at Green Farm, Badwell Green, $4 \frac{1}{2}$ miles north-west by north from Haughley.

BaDWELl Ash (xxxv, 13).-At Cutchey's Farm, half a mile east from Great Ashfield, is an oblong moat widening into a pond on the west.

BARDWELL (xxxiv, 2).-To the west of the church of SS. Peter and Paul, $6 \frac{1}{2}$ miles northeast from Bury St. Edmunds, is the greater part of a quadrangular moat.

Barham (lxvi, Io).-One side only of a broad moat remains at Barham Hall Farm, 4 miles south-east from Needham Market.

BARKIng (lxv, 7).-Barking Farm Moat, south-west of Barking Tye, $2 \frac{1}{2}$ miles south-west from Needham Market, has more than half perished ; the remaining portion consists of one side and its two angles.

Barnardiston (lxii, 5).-Two sides of a narrow moat remain at Barnardiston Hall, 5 miles north-west from Clare.

Barnardiston (lxii, 9).-A small moat surrounded the old rectory, north-east of the church, of which three sides remain.

Barningham (xxiii, 8).-In 'Moat Plantation,' 8 miles north-east from Bury St. Edmunds, is a cutting which appears to have formed part of a moat, from the northern angle of which a channel connected it with ponds at the Old Hall. 


\section{ANCIENT EARTHWORKS}

Barsham (ix, 10).-The remains of a moat at Barsham Hall comprise about half of the original. It is situated by the side of a stream from which the water was obtained; it is nearly 2 miles west of Beccles.

Barton Mills (xxi, 13).-Three parts of a narrow moat are extant at Barton Hall, nearly I mile south-east from Mildenhall.

BatTISFORD (lxv, 3).-A large moat is at St. John's Manor House, $2 \frac{1}{2}$ miles west by. south from Needham Market.

Baylham (lxv, 8).-Baylham Hall Moat, 2 miles south from Needham Market, appears to have inclosed two lateral sites with ponds on the eastern side, but it is now levelled to a great extent.

Half a mile west of the latter is the double moat of Taston Hall; a small strong moat is surrounded by a narrow outer one except on the south-eastern side, where the earlier moat is incorporated with the larger.

Becclas (ix, 10).-Roos Hall, the 16th-century manor-house of the Roos family, surrounded by a moat of moderate width, is situated to the west of the town.

Bedfield (xlviii, 7). - At Bedfield House,

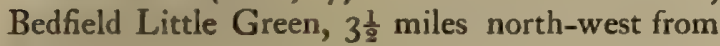
Framlingham, are three parts of a quadrangular moat.

One mile south of Bedfield, at Pipe's Farm, are the remains of the house-moat and another of minor strength which formerly surrounded the grounds.

Bedfield (xlviii, 6).-At Bedfield Hall is a small moat; extending to the west it forms another moat originally inclosing a larger area.

Bedingfield (xxxvi, 12). 'Moated Yards,' 3 miles south-east from Eye, is an oblong area covered by wood and surrounded by a wellformed moat.

BedingField (xlvii, 4).-At Bedingfield House, I mile south by west from the village, three parts of an irregular moat remain.

Bedingrield (xlviii, I).-Bedingfield Hall, $1 \frac{1}{2}$ miles east from the latter, has a strong and well-defined moat inclosing a large area. Except for its eastern side, which curves outwards, it would be oblong in plan. Another rectangular piece of water within the area, called a fish-pond, is probably a portion of an inner moat.

Another moat in this parish is at Flemings Hall, $\frac{1}{4}$ of a mile north-west of the last-mentioned. It is an extensive oblong moat divided into two square areas by a traverse of water.

Benhall (lix, 8).-Manor Farm has a fairly perfect quadrangular moat of varying width, the northern side being $20 \mathrm{ft}$. wide, while at the south-west it is $40 \mathrm{ft}$. The inlet is at the northeast angle.

Beyton (xlv, I0).-At Brook Farm, 5 miles east by south from Bury St. Edmunds, is a perfect oblong moat of considerable width, the inner side of which is of brick masonry.
Blundeston (iv, ro).-At Blundeston Hall, 3 miles north-west from Lowestoft, is a quadrangular moat with a cutting at the north-eastern angle connecting it with a stream.

BoxTED (lxiii, 5).-A moat, irregular both in plan and width, is at Moat Farm, Fenstead End, 7 miles north-west from Sudbury.

BoxTED (lxiii, 9).-Boxted Hall is surrounded by a strong moat of great breadth; the inner site is oblong, but the external bank assumes an oval form. From the southern side a cutting, $50 \mathrm{ft}$. wide, extends some $300 \mathrm{ft}$. in a south-easterly direction to a large pond containing two islets.

BRAdField Combust (liv, I2).-This parish is also known as Bradfield-Manger. The plan of a strong square moat which formerly surrounded a grange of the Abbot of Bury may yet be traced in Bradfield Park, 5 miles south-east from Bury.

Bradfield Combust (lv, 9).-At Sutton Hall, south-east of the village, is a quadrangular moat, the south side of which is in the neighbouring parish of Cockfield.

Bradfield St. Clare (lv, 5).-On the east of St. Clare's Church, I $\frac{1}{2}$ miles east of Bradfield Combust, is a curiously irregular moat; the eastern side is straight and narrow, but the southern and western sides broaden in places to $30 \mathrm{ft}$. and $60 \mathrm{ft}$.

Another moat of quadrangular form, but mutilated on the western side, is at St. Clare's Hall, half a mile east from the last named.

Brampton (xviii, 14). - South-east of Brampton station, $4 \frac{1}{2}$ miles south from Beccles, three moats are at Brampton Hall. The farm-house representative of the old hall stands within a rectangular moat, with banks $4 \mathrm{ft}$ : above the water, and the entrance on the west. The overflow of water finds an exit at the south-east angle and flows into a ditch which, to a certain degree, formed a protection to the orchard.

To the west of this moat a large irregular piece of water, in an artificial excavation, surrounds a small island, standing $6 \mathrm{ft}$. above the water, with the connecting causeway on the north.

Still further westwards a circular moat $8 \mathrm{ft}$. wide cinctures a plot of land $90 \mathrm{ft}$. in diameter, and $9 \mathrm{ft}$. above the water level.

Brampton (xviii, I 5).-At Potash Farm, $I_{4} \frac{1}{4}$ miles north-west from the village, are three sides of a narrow moat.

Half a mile to the south-east of the latter, at Old Potash Farm, the four corners of a quadrangular moat remain; otherwise it has been destroyed.

At the rectory, east of the last named, are fragments of another moat.

BREDFIELD (Ixvii, 8). - Three miles north of Woodbridge is an angular cutting containing water at Moat Farm, and only from the name may this be recognized as the fragment of a moat. 


\section{A HISTORY OF SUFFOLK}

The greater part of another moat may be traced to the north of Bredfield, and south-west of Dallinghoo Hall.

Brent Eleigh (Ixxiii, 2).-Wells Hall, 2 miles south-east from Lavenham, has a wide and almost complete square moat. The south-eastern part is in Milden parish.

Brettenham (lv, 15).-At Water Hill, 5 miles north-east from Lavenham, is a small moat. It has been square, but a road made through the inclosure has destroyed its original symmetry.

Brettenham (lxiv, 3).-At Rose's Farm, west of the village, are three sides of a long oblong moat.

The north and west sides of a moat $20 \mathrm{ft}$. wide, originally surrounding the rectory of Brettenham, remain in good condition; the other sides, which have been filled up, may yet be traced.

Brettrenham (lxiv, 7).-At Popple Farm, west of Brettenham Park, is a fragment of a small moat.

Brockley (liv, 9 and I3). Brockley Hall, $4 \frac{1}{2}$ miles south by west from Bury St. Edmunds, is situated within an oblong moat-almost square -with the entrance on the north. Close to the north-east is a smaller but stronger moat, fed by an adjacent stream; and further to the west of these are the remains of a third moat, the northern side straight, and the eastern forming an arc.

BRockley (liv, ro).-At Gulling Green, east of the rectory, is the fragment of a moat.

Brockley (liv, 13).- Two fragments of a moat are at Glasshouse Farm, Brockley Green.

Brome (xxv, II).-South-east of Brome Church, I $1 \frac{3}{4}$ miles north of Eye, is an oval moat, now dry, and close by the south-western side is another of oblong formation with sundry irregularities where the waters broaden.

BRUISYARD (xlix, 7).-On the site of the convent of Franciscan nuns of St. Clare, $3 \frac{1}{2}$ miles north-east from Framlingham, are the remains of an extensive moat. It is difficult to trace its original plan, but it must have inclosed a large area.

Brundish (xxxvii, I2).-At St. Edmund's Farm, Brundish Street, 5 miles north by west from Framlingham, are portions of moats formerly inclosing three square sites, one side of each being common with one of another.

One and a half miles south-west by west from the latter another very perfect oblong moat, with entrance on the north, is at Brundish Lodge.

BRUNDISH (xxxvii, 15).- North-east of Tannington is the greater part of a strong moat. The north and east sides are $50 \mathrm{ft}$. wide, the south is weak and imperfect, and the west side has been destroyed.

In a field just north of the last, called 'Potash Yard,' is an irregular quadrangular moat. The bridge is on the eastern side, and water is obtained from a stream to the north.
Brundrsh (xxxvii, 16).-At Yewtree Farm, west of the village, are three parts of two adjoining moats, with extensions on the west and east.

Half of another-almost square-moat lies to the south of Brundish Church. On its eastern side are some fish-stews.

Bures St. Mary (Ixxx, 13).--South-east of Bures Green, 5 miles south-east from Sudbury, two sides of a narrow moat are at Moat Farm.

Burgate (xxiv, 16).-At Stubbings Entry, 5 miles west from Eye, is a large irregular moat with an extension towards the east, forming three sides to another moat.

Three sides of a moat remain at Burgate Hall, and to the south-west is a fragment of an adjacent one.

BURGH (lxvii, 6).-Three miles north-west from Woodbridge, at Thistleton Hall, is a complicated triple moat. The smallest surrounds but a limited area, and lies within the eastern side of a large oblong moat, which contains a pond within its south-western angle; the northern side is mutilated and spreads into a large pond. Outside the eastern arm of the large moat, and opposite the smaller inner one, is another of medium size, fed by a channel on the south and a pond for the overflow on the east.

Burgh (lxvii, 7).-Half a mile west from Boulge Park are portions of two moats. That on the north is small and has evidently been square, but a long piece has been levelled. South of this, and close to Moat Farm, are three sides of an oblong moat, the western side having been obliterated.

Buxhall (lv, I2).-At Cockerell's Hall, 4 miles south-west by west from Stowmarket, there was a quadrangular moat. Its original course is now marked by a series of ponds, formed by the filling up of the former cutting at various points.

Buxhall (lvi, 5).-At Fenn Hall, $\frac{1}{2}$ a mile north-west from the village, is an oblong moat.

Buxhall (lvi, 9).- -South-west of Buxhall, at Fasbourn Hall, the north and south sides of a quadrangular moat remain. Within the northeastern angle is a small hillock, probably formed by the clearings from the moat and for no defensive purpose.

Carlton Colville ( $x, 14)$.- South of the village is a small but wide moat, square in plan.

Cavendish (lxii, 12). - A square moat, now drained, lies south-east of Houghton Grove, north-east of Clare.

Cavendish (lxxi, 4).--Houghton Hall, I mile west from Cavendish, has the southern and eastern sides, with the south-west angle, of a quadrangular moat remaining.

The fragment of another moat may be traced at Over Hall, near the rectory.

Cavendish (lxxii, i).-Blacklands Hall moat, north of Cavendish station, is but a long curved channel, graduating from $20 \mathrm{ft}$. wide at the northeastern end to $60 \mathrm{ft}$. wide at the south-west. 


\section{ANCIENT EARTHWORKS}

Charsfield (lviii, 15 ). - Portions of a square

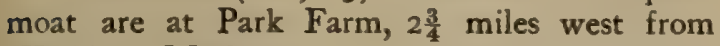
Wickham Market.

A large part of another moat of irregular plan is at Redhouse Farm, $\frac{3}{4}$ of a mile north-west from Charsfield.

Chedrston (xxvii, I I). - Two small oblong moats, now drained, lie in a field called 'The Grove,' $2 \frac{1}{2}$ miles west by north from Halesworth; the larger, at the north-west, measures $200 \mathrm{ft}$. by $150 \mathrm{ft}$., the smaller is $135 \mathrm{ft}$. by $104 \mathrm{ft}$.

Chediston (xxvii, 12).-Chediston Grange, $\frac{3}{4}$ of a mile south of the village, is a strong moat, almost square, with two entrances.

Chevington (lii, 4).-The north-western half of 2 square moat remains at the rectory, $4 \frac{1}{2}$ miles south-west from Bury St. Edmunds.

Chevington (liv, $\mathbf{1}$ ). - A very small length of a moat may be seen at Moat Farm, south of Ickworth Park.

Chizton (lxxii, 16).-Chilton Hall, I mile north-east from Sudbury, has a perfect moat over $40 \mathrm{ft}$. wide.

Claydon (lxvi, 14).-At Claydon Hall, 3 miles north by west from Ipswich, are portions of a moat which, in past ages, must have been a strong barrier against aggressors. The south and east sides only remain, the north-eastern angle being of considerable width.

Cockfreld (liv, 12).-At Oldhall Green, 4 miles north from Lavenham, is a perfect rhomboid moat.

CoCKFIELD (lv, 13).-An oblong moat is at Palmer's Farm, I mile east of the village.

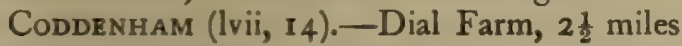
east from Needham Market, has an imperfect oblong moat.

A quarter of a mile north-west from the latter, at Birch Farm, are parts of a moat, but it is difficult to determine its original plan.

Сомвs (lvi, 10).-At Boyton Hall, $1 \frac{1}{2}$ miles south-west from Stowmarket, is a moat bulging out towards the south-west, in plan resembling the shape of a pear. The western part is in the parish of Great Finborough.

Combs (lvi, 14).-At Ebbs Farm, $\frac{3}{4}$ of a mile south-west from the Tannery, are three separate portions of a once extensive moat, which is now divided by a road.

Kimberley Hall, Moats Tye, I mile south from Combs village, has two sides of a narrow moat.

Corton (xlvi, 4).--North-east of the village, 6 miles north by east from Stowmarket, a good rhombic moat remains at Hempnalls Old Hall.

At Potter's Farm, south-east of Cotton, is a narrow moat of oblong form, complete but for the south-west corner.

A right angle of a moat may be seen at the rectory in this parish.

One side of a small moat is in a field southeast of the village.
Cotron (xlvi, 8). - A strong square moat is at Cotton Lodge, I mile south-east from the village.

Cotton Hall Moats, $\mathrm{I} \frac{1}{4}$ miles south-west from the village, are a series of three moats and fragments of another. The largest- to the southof wide span, is of oblong form but for the southeast corner, which is rounded. To the northwest is the northern side and pieces of the western and eastern sides of another. On the north-east of the first is a small square and perfect moat; and the fragments of another inclosure are due north of the first.

Cowlinge (liii, 9).-At Shardelows Farm, 7 miles north by west from Clare, are three sides of a rectangular moat, with an extension towards the south-east.

Cowlinge (liii, I3).-Fairstead Farm, east of the village, has a well-defined moat.

A small but perfect oblong moat lies in a field south-west of Briggs Farm.

At Dowel's Farm, in Beeton's Plantation, west of the village, is a narrow moat nearly square in plan.

In a field at Pound Green, south of Cowlinge, there are portions of a small quadrangular moat.

Cowlingr $(\mathrm{lxi}, 4)$. - At Hobbles Green are three sides of an irregular moat.

Cowlinge (lxii, 1). - A good moat remains at Cowlinge Hall, south-west of Farley Green, quadrangular in form, with the north-eastern side longer than the south-western. It has two entrances on the north-eastern side.

Cratfield (xxvii, 13).-At Moat Farm, Swan Green, 6 miles west by south from Halesworth, the moat is rectangular on the north and west, but from the north-west it makes a sweeping arc, and extends far beyond the southern angle.

Creeting St. Mary (lvii, 9).-At Broadgates Farm, north-east of the village and 2 miles northeast from Needham Market, is a fragment of a moat.

A small portion of another moat is near the schoolhouse.

Two sides of a square moat are at Fox's Farm, I mile east from the village.

Another moat, just east of the last, at Vale Farm, of wide dimensions, surrounds a small area, and extends some $300 \mathrm{ft}$. towards the south.

Creeting St. Peter (lvi, 8).--Roydon Hall, West Creeting Green, 2 miles north from Needham Market, retains a portion of a very wide moat. The north-eastern side with its two angles alone remains; a pond to the west may possibly have formed part of the original moat.

Cretingham (Iviii, 2). - At Moat Farm, $\frac{3}{4}$ of a mile north-east from the village, 3 miles west by south from Framlingham, a moat with an irregular outer bank surrounds a square area, the entrance being on the north.

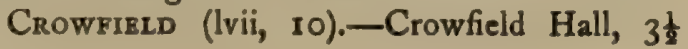




\section{A HISTORY OF SUFFOLK}

miles east-north-east from Needham Market, was taken down in 1829 , but the site is still partially surrounded by portions of the rectangular moat.

Another oblong moat is in Crowfield Park, to the north of the last named, and close to All Saints' Church.

Culpho (lxvii, r3).-A quadrangular moat marks the site of the Abbey Farm, $4 \frac{1}{2}$ miles west from Woodbridge.

Dallinghoo (Ixvii, 4).-Moat Farm, $\frac{3}{4}$ of a mile south-east from the village, 3 miles north from Woodbridge, is a quadrangular moat with the entrance on the west.

Darsham (xxxix, I4).-North-east of Darsham station, $4 \frac{1}{2}$ miles north by east from Saxmundham, is the greater part of a small rectangular moat.

Debenham (xlvii, I I ). - At Ulverston Hall, to the west of Debenham, 12 niles north-west irom Woodbridge, are three portions of a quadrangular moat.

Debenham (xlvii, 15 ).-One mile west from Debenham the western side of 'Esther's Moat' is extant.

Debenham (xlvii, I2).-Two opposite fragments remain of a moat at Blood Hall, northeast of the town.

Close by the latter, at Hill Farm, is part of a moat and an artificial cutting containing water, which probably formed part of a defensive work.

Debenham (xlviii, 13).-One mile east of Debenham is a series of artificial works around Crowe's Hall, a name derived from the family who obtained possession in 1300 . The walls of the Hall rise from the waters of a strong square moat attaining a breadth of $90 \mathrm{ft}$. at its widest part. The entrance is on the west, before which is a fragment of another moat which has been destroyed too far to trace its original plan. At the north-east of the first are three sides of a narrow moat, and indications of another may be seen to the north of the first.

Denham (xxxvi, 4).-T wo miles east by south from Eye, at Denham Hall, is an oblong moat of considerable width, a narrow channel connecting it with another of small dimensions on the south.

Denham (xliii, II).-At Denham Hall, in another parish of the same name as the last, $7 \frac{1}{2}$ miles west by south from Bury St. Edmunds, is a large oblong moat, from the south-western angle of which extends a pond.

Dennington (xxxvii, 12). - Red House, 5 miles north from Framlingham, has the greater part of a narrow moat, square in plan, surrounding a large area. Towards the south of the eastern side cuttings from the moat project both externally and internally. The latter, which apparently inclosed a small area in former times, is probably of an earlier date than the present moat.

Dennington (xxxvii, I6).-A moat with adjacent fish-pond at Moat Farm lies to the east of Brundish village.
Dennington (xxxviii, 13).-Around the site of Dennington Hall is a perfect square moat, with a pond projecting on the south side.

Dennington (xlviii, 3).-At Moat House, south-east of Tannington, 3 miles north-west from Framlingham, are the remains of a rectangular moat.

Dennington (xlviii, 4). - At Pound Farm, $\frac{3}{4}$ of a mile north-west from the village, is a small square moat with an extension from the northwest corner.

At Red House, $\frac{1}{2}$ a mile west from Dennington, are two sides of a small moat.

Immediately to the west of the latter are fragments of another moat.

Dennington (xlviii, 8).-Glebe Farm has a square moat, somewhat irregular, with a wide pond at the northern side.

At Dennington Place, $I \frac{1}{4}$ miles west from the village, is the greater part of a quadrangular moat, fed by a channel on the south.

Between the last two is a well-proportioned oblong moat at Whitehouse Farm.

Dennington (xlix, 5).-Elm Hall, $x$ mile south-east from the village, has a small oblong moat.

DePDEN (liii, I I ). - Three sides of a moat remain at Depden Hall, $6 \frac{1}{4}$ miles south-west from Bury St. Edmunds.

Drinkstone (lv, 3).-Round the site of Drinkstone Hall, $5 \frac{1}{2}$ miles west from Stowmarket, is an oblong moat.

Drinkstone (xlv, 15).-West of Drinkstone Village, 6 miles west by south from Bury St. Edmunds, is an oblong moat.

Earl Soham (xlviii, ro).-Three miles west from Framlingham, at Earl Soham Lodge, is a strong circular moat, which increases in width from $30 \mathrm{ft}$. on the west to $70 \mathrm{ft}$. on the south.

Earl Stonham (xlvii, r 3).-At Moat Farm, south-west of Westwood Hall, $4 \frac{1}{2}$ miles northeast from Stowmarket, is a large oblong moat. The southern side has for the most part been destroyed.

East Bergholt (lxxxvii, 8).-Near Gibbonsgate Farm, 2 miles north-west from Manningtree, a small oblong moat lies close by the River Stour, from which the water is obtained through a short channel.

Easton (lviii, 8).-At Martley Hall, north of Easton, and $2 \frac{1}{2}$ miles south from Framlingham, is an irregular hexagonal moat.

Easton (lix, 5).-Bentries Farm, to the east of Easton Park, has a moat rhombic in plan.

Edwardstone (lxxiii, 14). - At Moat Farm, Mill Green, north-east of the village and 4 miles east by north from Sudbury, is the northern side of a small moat.

Elmsetr (lxxiv, 3).-A very small piece of a moat is left at Elmsett Hall, $4 \frac{1}{2}$ miles north-east from Hadleigh.

The moat at Elmsett Rectory is half of an 


\section{ANCIENT EARTḦWORKS}

ellipse. The northern side is straight, and is in the place of the short axis.

Elmsetr (lxxiv, 7).-The 'Moated House,' south of the village, has but a very small fragment of the moat remaining.

Elmswell (xlv, 8).-At Elmswell Old Hall, west of the village, 5 miles north-west from Stowmarket, is an oblong moat. To the east of it are portions of the northern and eastern sides of a large water-girt area.

EYE (xxxvi, 4).-An irregular oblong moat is at Low Farm, south-west of Denham Hall, nearly 2 miles south-east by east from Eye. The general width is $22 \mathrm{ft}$., but the northern side widens to $75 \mathrm{ft}$. A pond extends from the south-east angle.

Another moat, of oblong form, mutilated at the north-east, is at Kiln Farm, south of Cranley.

Eye (xxxvi, 8).-At King's Farm, south-east of Cranley, 2 miles south-east from Eye, are three sides of a quadrangular moat.

Felsham (lv, Io).- - At Felsham Hall, on the site of the old hall, 5 miles north by east from Lavenham, is a quadrangular moat, the southeastern corner being somewhat curved.

At the Grange, south-west of the village, is a very perfect moat.

Capel Farm, I $\frac{1}{4}$ miles south-west from Felsham, has a double moat, each of them oblong in plan, one of the short sides being common to both moats. The stronger and more perfect is towards the north-east.

Felsham (lv, I I).-A good oblong moat lies south of Lower Green.

At Brook Hall is a fragment of another.

Two pieces of a moat, the original form being lost, are at Valley Farm.

Felsham (lv, 15).-Castle Farm, built on the remains of the old castle, to the west of Hightown Green, is partly surrounded by a moat.

A very long oblong moat, in good condition, lies to the south-west of the last.

Finningham (xxxv, 11 ).-At Finningham Hall, $5 \frac{1}{2}$ miles south-west from Eye, is one perfect side of a moat and other fragments.

Flixton (xvii, 6).-At Boys Hall, east of Flixton Park, $2 \frac{1}{2}$ miles south-west from Bungay, is a curiously-formed moat; the southern side is straight, and $50 \mathrm{ft}$. wide, but the sides branching northwards converge until they meet at a rounded angle on the north; a curved channel passes from the west to the north-east within the area, thus separating the inclosure into two unequal parts.

Around the site of a house of Austin Nuns, now known as Abbey Farm, south-east of Flixton, is the greater part of a moat. The height of the banks above the water averages $4 \mathrm{ft}$. 6 in. high, and the moat is from $16 \mathrm{ft}$. to $22 \mathrm{ft}$. broad. A fish-pond is within the southern side of the inclosure.
Flixton (xvii, 7).-At Starknaked Farm are portions of an irregular moat.

Fornham All Saints (xxxiii, 14).-One and a half miles north-west from Bury St. Edmunds, near Aldridge Cottages, is an irregular oblong moat.

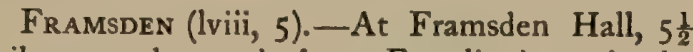
miles west by south from Framlingham, is the north-eastern part of a long oblong moat; a piece of the south-western end also remains.

FRAMSDEN (lviii, 6). - In a field $1 \frac{1}{2}$ miles southeast from Framsden is a small moat approaching an oblong in plan.

Fragments of another are at Moat Farm, northeast of the last.

Framsden (Iviii, 9).-In a field to the south of Bastings Hall is a well-formed square moat.

FRESSINGFIELD (xxvi, 7). - The greater part of a large moat, with a pond, is at Vales Hall, 7 miles north-east from Eye.

Fressingfield (xxvi, 8).-Fressingfield Lodge has a moat, in form oblong with one angle flattened, and a pond joining the northern side.

Another moat to the west of the last apparently had a traverse separating the area inclosed into two portions.

At Hill House, south-west of Fressingfield Lodge, are two pieces of a quadrangular moat.

Fressingfield (xxvi, 12). - At Tithe Farm, south-east of the village, a little more than two sides remain of an oblong moat.

Fressingfield (xxvi, I2).-At the Hall, $7 \frac{1}{2}$ miles north-east by north from Eye, are numerous fragments of moats; but the plan of the lands which they formerly surrounded is past recognition.

Fressingfield (xxvi, 16).-Portions of moats inclosing both a small and a large area, contiguous the one to the other, are at Lambert's Farm, 2 miles south-east from the village.

Fressingrield (xxvii, 5).-On the north side of Whittingham Hall, north of Whittingham Green, is a large square moat, and a portion of another which apparently inclosed a small area along the southern side of the first.

FRessingField (xxvii, 9).-The greater part of an oblong moat is at Moore's Farm, north-east of Whittingham Green.

Gazeley (xliii, 6).- South-east of the village, at Desning Hall, is a fairly perfect moat, and to the west of it is another very broad water-filled trench which may have formed one side of a similar inclosure.

Gedding (lv, 7).-The walls of Gedding Hall, the old mansion of the Buckenhams, 7 miles south-east from Bury St. Edmunds, rise out of the broad moat with which it was once cinctured; portions, however, are now filled up.

Gedding (lv, 7). - The greater part of a moat may be traced around Gedding Church ; on the north-west it has an escarpment of $9 \mathrm{ft}$. and is $16 \mathrm{ft}$. wide, and is continued in a westerly 


\section{A HISTORY OF SUFFOLK}

direction in an adjacent field. On the north it is $27 \mathrm{ft}$. wide, and along the eastern side it is partially filled and turned into a vegetable garden. The southern side is obliterated.

Gisleham (xix, 2).-On the site of Gisleham side of the original moat.

On the opposite side of the road to the last is situated the site of the manor house-erroneously very perfect double moat, the smaller placed almost in the centre of the larger water-girt area ; both of them being nearly square. The inner moat averages $24 \mathrm{ft}$. wide, and its banks rise $4 \mathrm{ft}$. above the water. The outer one, measuring $500 \mathrm{ft}$.

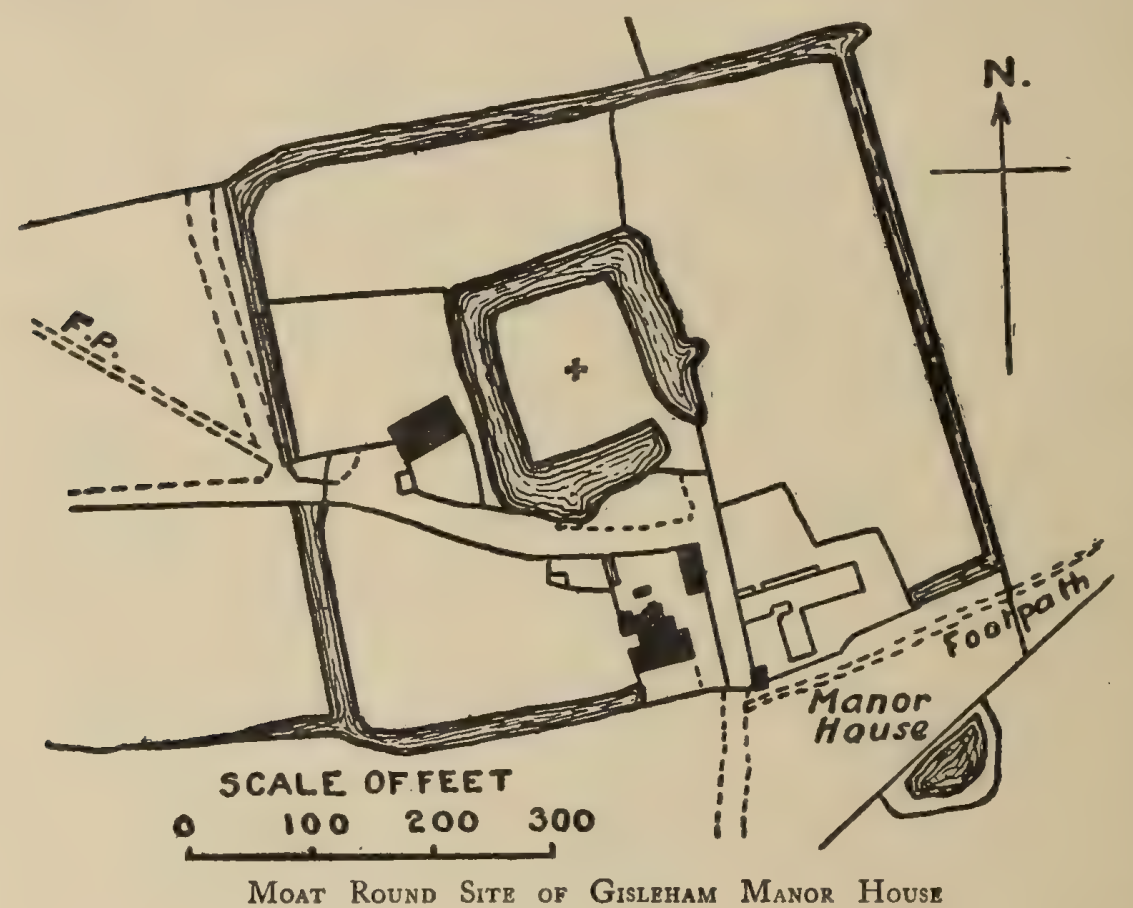
two sides of a large moat. Hall, $5 \frac{1}{2}$ miles east by south from Beccles, is one called the Hall in the Ordnance Survey - within a

the south of the village, and east of Button Haugh Green, is an oblong moat with an intermediate channel dividing the area into two square divisions. The northern side of the western division has gone, and the water is conducted into the moat at its south-western angle.

Grzat Barton (xxxiii, I6).- - At Conyer's Green, Leeds Wood, north-east of Necton Hall, a large part of a moat remains. The eastern and part of the southern sides have been levelled.

Great Bradley $(1 \mathrm{xi}, 3)$.- -At the Hall south of the church, 5 miles north from Haverhill, are

Great BriceTt (or BrisetT) (lxv, 10).-Four miles south-west from Needham Market. Around the site of an alien priory of Augustine Canons, a cell to Nobiliac, are twin circular moats adjoining one another, yet so irregular in outline that the one towards the south-east approaches the figure of a pentagon.

Great Cornard (lxxix, 4). - At Wrong's Farm, southeast of the village, $\mathbf{I} \frac{1}{2}$ miles east from Sudbury, is an irregular quadrangular moat.

GreatFinborough (lvi, I 3). - Three sides of a moat are at Boarded Barn Farm, High Street Green, 3 miles south-west from Stowmarket.

by $520 \mathrm{ft}$., averages $12 \mathrm{ft}$. wide, the banks being about $3 \mathrm{ft}$. 6 in. high.

Grslingham (xxxv, 5).-One angle and a piece of the southern side of a moat remain at Swattersfield Hall, 4 miles west by south from Eye.

GosBeck (lvii, 15).-Two parallel sides of a narrow moat, formerly inclosing a large area, are near Wood House, north-west of St. Mary's Church, $3 \frac{1}{2}$ miles east by north from Needham Market.

Great Ashfield (xxxv, 13).-At Hall Farm, south-east of the village, 9 miles east by north from Bury St. Edmunds, is a square moat; another moat, branching from the two northern corners, surrounded an area with a sweeping curve, and although most of this has been filled in the original course may be easily traced.

South of Great Ashfield an oblong moat lies in a field.

Great Ashfield (xlvi, 1).-Over a mile to
Great Glemham (xlix, 10).-At Fiddler's Hall, 2 miles north-west from Framlingham, are various pieces of moats that would appear to have formed two inclosures, while to the south of them a circular plot of land has its own moat.

Great Thurlow (lxi, 8),-At Sowley Green, 4 miles north-north-east from Haverhill, is a square moat, partly drained.

GREAT ThURLOW (lxi, I I). - A quadrangular moat is at Glebe Farm, south-west of the village, near the vicarage.

Great W aldingrirld (lxxiii, I). - The remains of a moat, spread into ponds until its original form is lost except on the southern side, is at Brandeston Hall, $\mathrm{I} \frac{1}{2}$ miles south from Lavenham.

Great W aldingfield (lxxiii, 9).-At Dyer's Green Farm, south-west of Holbrook Park, are three sides of an oblong moat.

Great Welnetham (liv, 4).-The Hall, 


\section{ANCIENT EARTHWORKS}

3 miles south-east from Bury St. Edmunds, has extensive water-trenches which are now widely disconnected. The largest remaining portion somewhat resembles the letter $S$ in plan, the more northerly part is the most perfect cincture ; but from the southern curve it takes a straight north-westerly direction, growing narrower as it proceeds. Two other lengths, at right angles but with the angle levelled, lie to the north.

Great Wratting (lxi, I2).-At Ganwick Farm, north-east of the village, 2 miles northeast by north from Haverhill, is a small quadrangular moat of greatly varied width.

Groton (lxxiii, I I).-At Moat Farm, Parliament Heath, $5 \frac{1}{4}$ miles east by north from Sudbury, are traces of three sides of a quadrangular moat.

Hacheston (lix, I 3).-At Glevering Hall, half a mile north from Wickham Market, is the greater part of a broad moat.

Hargrave (liii, 3).-At Moat Farm, Hargrave Green, 6 miles south-west from Bury St. Edmunds, are the disconnected fragments of a moat.

Hasketon (lxvii, 15).-The manor house, south-east of the village, I mile north-west from Woodbridge, has a wide moat surrounding a very small area.

Another moat of square plan is at the rectory.

Haughley (xlvi, Io). - A quadrangular moat, partially subdivided by a branch from the southern trench penetrating the inner area, is at Newbell's Farm, $3 \frac{1}{4}$ miles north-west from Stowmarket.

A portion of another rectangular plan is at Wassick's F: rm, to the east of the latter.

Haverhill ( $\mathrm{xx}, 7)$.-At Haverhill Hall, south of the village, is a square moat, of which the eastern side has but a small part remaining. The southern side has spread far beyond its original bounds.

Hawkedon (lxii, 8).-Thurston Hall, 9 miles south-south-west from Bury St. Edmunds, has the south-eastern side of a large moat.

Hawstead (liv, 2).-At Hawstead Lodge,

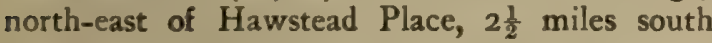
from Bury St. Edmunds, is a narrow moat, widening into a pond at the south-western angle.

Hengrave (xxxiii, Io).-At Hengrave Hall, 3 miles north-west from Bury St. Edmunds, is the south-eastern portion of a large and wide oval moat.

Henham (xxviii, 8).-In Moatyard Covert, north of Henham Park, 4 miles east by north from Halesworth, is an oval moat of great width close to the southern bank of a stream. From its western side it branches out for $200 \mathrm{ft}$., then turns in a northerly direction until it joins the stream. On the south-west of the oval moat is another length of wide entrenchment, also supported by the stream on the north-east. It is possible that this was an early entrenched position afterwards adapted to manorial moats.
Herringfleet (iv, 9).-At Herringfleet Hall, 5 miles north-west from Lowestoft, certain water trenches all but surround a small oblong area.

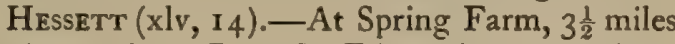
south-east from Bury St. Edmunds, is an oblong moat.

In a field north of the latter is a wide oblong moat, not a far departure from a square plan.

The moat at Hessett Hall is a well-formed square plan. The entrance to the old hall is on the south.

Heveningham (xxxviii, I I).-At Moat Farm, south of the village, and 5 miles south-west from Halesworth, is a well-defined oblong moat ; traces of a subdivision are seen within the north-east part, and ponds are situated on the north-west.

Hintlesham (lxxxi, 4).- - In an angle made by two roads south-west of the village, $5 \frac{1}{2}$ miles west by south from Ipswich, is an irregularly formed moat.

Hitcham (lxiv, 4).-The moat at Stanstead Hall is north of Cook's Green, and 5 miles north-east from Lavenham.

Hiтcham (lxiv, II).-Around the site of Wetherden Hall, north-east of Kettlebaston, $8 \frac{1}{2}$ miles north-east from Sudbury, is a strong square moat. This has evidently been surrounded by another of minor strength, of which one side and a portion of another forming the southern angle are extant.

Hoo (lviii, I I).- - On the site of Goodwin's Place, $3 \frac{1}{2}$ miles south-west from Framlingham, are three sides of an oblong moat.

Another to the north-west of the last, at Hoo Green, is of quadrangular plan ; part of the eastern side has been filled, and an extension branches to the north.

Horham (xxxvii, 5).-Circular towards the north, and angular towards the south, a curiouslyplanned moat lies south-west of the village, 4 miles south-east by east from Eye.

Horham (xxxvii, 6).-East of St. Mary's Church are extensive remains of an elongated moat. The southern portion is destroyed.

HoRningsheath (or Horringer) (xliv, 9).At the site of Little Horringer Hall, $2 \frac{1}{2}$ miles south-west from Bury St. Edmunds, are two sides of a strong rectangular moat.

Hoxne (xxv, 12).-An almost complete oblong moat surrounds the vicarage, except where the south-eastern angle has been levelled. This is 3 miles north-east from Eye.

Hoxne (xxvi, 9).-The western side of a small moat is at Chickering Corner Farm, southeast of the village, close to the road to Stradbroke.

Hoxne (xxvi, 13).-Large pieces of a very irregular moated area are at Park Farm.

College Farm, in the same parish, has a quadrangular moat, outside which is a portion of another defending the western side.

A mile south of Hoxne, at Cross Street, a moat surrounded a religious house, a cell to the 


\section{A HISTORY OF SUFFOLK}

Benedictine priory at Norwich Cathedral. The eastern and the greater part of the northern sides of this moat remain. Another length branches from the north, where also is a broad moat surrounding a very small islet.

Hoxne (xxxvii, 2).-At Thorpe Hall, I mile west from Stradbroke, is a perfect quadrangular moat.

Hundon (lxii, 14).-Pinhoe Hall, south of the village, and nearly 3 miles north-west from Clare, has an elongated oblong moat.

Hunston (xxxiv, 16).- -South-west of the village, $7 \frac{1}{2}$ miles north-east by east from Bury St. Edmunds, the site of Hunston Hall appears to have been surrounded by a moat which is, however, so mutilated that its plan cannot be traced. One angle of another moat, originally inclosing a large area of ground, remains; this is I $2 \mathrm{ft}$. wide, with banks $5 \frac{1}{2} \mathrm{ft}$. deep.

Ilketshall St. ANDrew (xviii, 5).-At Grove Farm, nearly 4 miles south-east from Bungay, and south of the village, are three sides of a small square moat.

About $\frac{3}{4}$ of a mile north-east from the last, a nearly complete, but small square moat, is at Corner Farm.

Ilketshall St. Margaret (xvii, 12). - Southeast of the village, 3 miles south by east from Bungay, at Brookhouse Farm is an oblong moat.

Ilketshall St. Margaret (xvii, r6).-The greater part of a small moat of parallelogram plan lies 2 miles south-east from the village.

Ilketshall St. Margaret (xvii, 16).-At Rookery Farm, north-west of Rumburgh Street village, $4 \frac{1}{2}$ miles south from Bungay, are portions of a moat of parallelogram plan.

Ilketshall St. Margaret (xviii, 9).-Southeast of St. Lawrence Green, and south-west of Back's Green, are the fragments of a moat.

Ixworth (xxxiv, 6).-Disconnected lengths of a moat remain about the ruins of a priory of Austin Canons at Ixworth, 6 miles north-east from Bury St. Edmunds.

IxwORTH THORPE (xxxiv, I).-Six miles north-east from Bury is an irregular oblong moat.

Kedington (lxi, r6).-At Kedington Hall, 2 miles north-east from Haverhill, the position of the moat may be traced.

Kelsale $(1,9)$.-Two sides of an oblong moat are at Church Farm, north of the church, I $\frac{1}{2}$ miles north from Saxmundham.

Kenton (xlvii, 8).-At Moat Farm, west of the village, $5 \frac{1}{2}$ miles south-east from Eye, a circular moat surrounds the house, and another one-approaching an oblong in plan-incloses the first and a larger area of land.

KENTON (xlviii, 5).--Suddon Hall, south-east of the village, has two sides of a square moat.

At Kenton Hall, $1 \frac{1}{2}$ miles north-east from Debenham, is a series of moated areas. Two, small and nearly square, are side by side, and these stand within a wide embracing moat, of which the south-western side includes that side of one of the smaller inclosures.

One side of a moat, with its two angles, may be traced at Kenton Vicarage.

KetTlebaston (lxiv, I I).-An almost complete moat is at Kettlebaston Hall, 8 miles northeast from Sudbury ; its width greatly varies, and the north-western side is extended at both ends.

Kettleburgh (lviii, 4).-A perfect oblong moat (nearly square) is at the site of Kettleburgh Hall, $3 \frac{1}{2}$ miles north-west from Wickham Market.

LANGHAM (xxxiv, 1 2).-In Duffies plantation, to the east of the church, $8 \frac{1}{2}$ miles east by north from Bury St. Edmunds, is the so-called site of a camp. No signs of a military work now remain, neither are there any signs of earthworks in an adjoining field, called 'Castle Ditches'; but that the first site was used for manorial defence is evident by the presence of a moat; this, however, is very unequal in strength. Towards the south is a water ditch $8 \mathrm{ft}$. wide, but the other sides around an oblong area are far broader, the east attaining $24 \mathrm{ft}$.

LavenhaM (lxiv, 9).-The site of the manorhouse moat may be traced in a field north-west of the village, 6 miles north-east from Sudbury.

Lawshall (liv, 10).-At Rowney Farm, south of Butler's Hall, $5 \frac{1}{2}$ miles south from Bury St. Edmunds, are the remains of a large moat, but greatly mutilated.

Lawshall (liv, I 5).- South-west of the rectory is a perfect square moat; the southern side extends eastwards, and turns at right angles towards the north, apparently part of a more extensive moat.

Two sides of a small square moat are at Cooper's Farm, south-east of the last.

Barford's Farm, north of Hart's Green, nearly a mile north-east from Lawshall, has an oblong moat, and traces of another are towards the south.

Lawshall (lxiii, 3).-The greater part of a small square moat is at Newhouse Farm, north of Shimpling Street village, $7 \frac{1}{2}$ miles south from Bury St. Edmunds.

Lawshall (lxiii, 4).-Irregular fragments of a moat are at Trees Farm, Lawshall Green.

LAXField (xxxvii, 4). - A moat, almost triangular in plan, is situated east of Ashfield Green, $6 \frac{1}{2}$ miles south-south-east from Harleston.

LAXFIELd (xxxvii, 8).-Three sides of a rectangular moat are at Wells Corner, 8 miles south-east by east from Eye.

Another small moat, north-west of the last, is at Hall's Farm.

LAXFIELD (xxxviii, 5).-An angular fragment of a moat is at Laurel Farm-until recently called Moat Farm-north-east of the village.

Another may be traced at Yewtree Farm, $\frac{1}{2}$ a mile north-east from Laxfield.

LAXFIELD (xxxviii, IO).-At Boats Hall, west of Ubbeston White House, $6 \frac{1}{2}$ miles south-west from Halesworth, is a nearly square moat. 


\section{ANCIENT EARTHWORKS}

LaYhaM (lxxxi, 5).-Fragments of one side of a moat lie to the south-west of the village, $2 \frac{1}{2}$ miles south from Hadleigh.

Letheringham (lviii, 12).-A strong quadrangular moat, fed by the River Deben flowing close to its western side, is on the site of Letheringham Hall, 2 miles north-west from Wickham -Iarket.

A wide moat surrounding a very small oblong area lies to the south of the village.

Linstead Magna (xxvii, I 4).-A complicated system of moating may be seen at Linstead Hall, 4 miles south-west by west from Halesworth. An oblong moat has been equally divided, and the traverse in part remains; ponds are on the north and the east, and near the south-eastern angle another moat of smaller size has a pond at one corner.

Little Bradley (lxi, 4).-An oblong moat with one corner convex and another concave is at Norley Moat Farm, south of Hobbles Green, 5 miles north-east from Haverhill.

Little Finborough (lvi, I3).-At Moat Farm, 4 miles south-west from Stowmarket, is a moat of rhombic plan, perfect but for a small mutilation on the north-eastern side.

Littre Glemham (lix, I I).-West of the village, and $2 \frac{3}{4}$ miles south-west from Wickham Market, the right angle of a broad moat remains at Moat Farm.

Little Saxham (xliv, 9.)-The moat at Dairy Farm-4 miles south-west by west from Bury St. Edmunds-is of elaborate plan. The old hall appears to have stood between two areas, each of them are three parts surrounded by water; the eastern side, which would have determined whether the two moats here mingled in one, or whether a third moat defended this side, has gone. In the obtuse angle formed by the joining of the two moats on the western side, the waters spread into a lake and contain a small island. Bishop Hervey suggested that these were Saxon entrenchments as opposed to the Danes at Denham Castlc.

Lrtrie Stonham (xlvii, 13).--At Westwood Hall, 4 miles north-east from Stowmarket, the eight fragments of moats indicate four separate inclosures.

Litrte Thurlow (1xi, 7).- 'The Island" is a small square tract of land surrounded by a moat, north-west of the village $3 \frac{1}{2}$ miles north from Haverhill.

Litrle Waldingfield (lxxiii, I and 2).At Nether Hall, north-west of Humble Grove, $4 \frac{1}{2}$ miles north-east from Sudbury, is a portion of a square moat.

Little Welnetham (liv, 4).-Opposite sides of a small moat lie south of Parsonage Lane, $3 \frac{1}{2}$ miles south-east from Bury St. Edmunds.

Litrle Wratting (lxx, 4).-At Great Wilsey's Farm, I mile north-east from Haverhill, is a quadrangular moat.
Long Melford (lxiii, 15).-Kentwell Hall, an ideal example of an Elizabethan house, 4 miles north from Sudbury, stands within a large oblong moat with deeply cut banks. On the north is another long stretch of moat which formerly inclosed a very large area, and between the two is a fish-pond.

Long Melford (lxiii, 16).-At Ford Hall, Bridge Street, is a mutilated square moat.

Long Melford (lxxii, 2).-At Parsonage Farm, west of Cranmore Hills, an oblong moat lies close to the eastern bank of the River Glem, from which one narrow channel supplies the moat with water at the northern angle, while another carries the overflow back to the river from the western angle.

Market Weston (xxiv, 5).-Near the site of Weston Hall, south-east of the village, II $\frac{1}{2}$ miles north-east from Bury St. Edmunds, are two sides of a rectangular moat.

Meluis (xxv, 13).-At Mellis Hall, 3 miles west from Eye, are extensive divisional moats. The most perfect is of oblong plan, from which stretching in a north-easterly direction are various fragments which would seem to have inclosed three distinct areas, one continuous water-trench on the south-east running the whole length of the various works.

Another large quadrangular moat surrounds the rectory.

Melurs (xxxv, 4).-In Moatyard Plantation south-west of the village, $4 \frac{1}{2}$ miles west from Eye, is a square moat with a stream on the western side connecting it with the fragment of another.

Mendham (xvii, I3).-At Oakfield Farm, west of Weston House, $2 \frac{1}{4}$ miles south-east by east from Harleston, are three parts of an oblong moat.

South-east of the last are the remains of a rectangular moat with an extension towards the north.

Mendlesham (xlvi, 4).-A fragment of an irregular moat is at Potter's Farm, 6 miles southwest from Eye, and south-east of another of the same name in the adjoining parish.

Mendeesham (xlvii, 1 ).- - About half of a rectangular moat and other water-trenches are at Mendlesham Lodge, 5 miles north-east from Stowmarket.

Portions of two adjoining square moats at Poplar Farm are in the same parish.

Mendirsham (xlvii, 5). - The site of the old hall is almost surrounded by an oblong moat, the short north side having been levelled.

Another large rectangular moat is immediately to the east of St. Mary's Church.

Metrield (xvii, 13).-On each side of the vicarage -3 miles south-east from Harlestonare fragments of a moat. That on the west is a right angle and portions of two sides; that on the east is the greater part of one of irregular plan. 


\section{A HISTORY}

Méfield (xxvii, 1).-Withersdale Hall, north-west of Metfield, has a moat in plan like a quadrant.

MetField (xxvii, 5).- - Around the site of the old hall, south-west of Metfield Common, $4 \frac{1}{2}$ miles south-east from Harleston, is a strong oblong moat, the north-western corner being exceptionally broad.

Metringham (viii, r 2). - At The Hall, northeast of Mettingham Castle, $1 \frac{1}{2}$ miles east from Bungay, is a T-shaped fragment of a moat.

Mickfield (xlvii, I I). - A small square moat is at Greenwood's Farm, 2 miles west from Debenham.

Mickfield (xlvii, I 4).-At Mickfield Hall, north of the village, $5 \frac{3}{4}$ miles north-east by east from Stowmarket, is a moat approaching a circular form.

At Read's Farm, to the west of the latter, are two sides of a rectangular moat.

Milden (lxxiii, 3).-An irregular rectangular moat is at Moat Farm, 6 miles north-east from Sudbury.

Part of a dry moat remains at the rectory.

Mildenhall (xxi, 5).-Three sides of a parallelogram remain of a moat at Aspall Hall, 2 miles north by west from Mildenhall.

Monewden (lviii, 6). - At Folly Farm, northwest of the village, 5 miles north-west from Wickham Market, is a quadrangular moat with rounded corners.

Monks Eleigh (lxiv, I5).-Manor Farm Moat, $7 \frac{1}{4}$ miles north-east from Sudbury, consists of two sides of an oblong, another water-trench extending $300 \mathrm{ft}$. towards the east, and a pond south of its eastern end.

Monk Soham (xlviii, 5).-At Hill Farm, Monk Soham Green, $2 \frac{1}{2}$ miles north-east from Debenham, are three moated areas adjoining one another; the divisional moats being common many parts of them have been filled up.

Monk Soham (xlviii, 6).- 'The Firs,' north of the village, has a moat of oblong plan, to the south of which are the remains of other moats partly inclosing two rectangular areas.

Naughton (lxv, 13 and 14).-An oblong moat of varied width surrounds Naughton Hall,

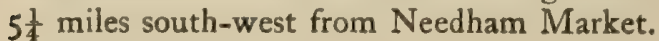

A right angle of another lies on two sides of Naughton Rectory.

It is but a small piece of the moat that is left at Pigeon Hall, south-east of Naughton.

NayLand with Wissington (lxxxvi, 3).A large curved moat makes a complete circuit of the high ground known as Court Knoll, 6 miles south-west from Hadleigh. This possibly marks the fosse of an ancient camp.

Nayland with Wissington (lxxxvi, 6).The moat at Wissington, 7 miles south-west from Hadleigh, covers a large area ; it appears to have formerly been an oblong in plan with a smaller moated square inclosure.

\section{OF SUFFOLK}

Nayland with Wissington (lxxxvi, 5).At Smallbridge, on the northern bank of the River Stour, there remain two sides of a moat, and a wide channel cut from the river supplied the water and at the same time doubled the defence on the western side.

Nedgrng (lxv, 13).-At Fidget's Farm, south-west of Naughton, $5 \frac{1}{2}$ miles south-west from Needham Market, is a rectangular moat.

NorTon (xlv, 4).-Three parts of a moat remain at Norton Hall, east of the village, $7 \frac{1}{2}$ miles east from Bury St. Edmunds.

Nowton (xliv, I 5).-The moat at Nowton Hall, $2 \frac{1}{2}$ miles south from Bury, inclosed two adjacent tracts of land; the cincture of one is nearly complete, the other is almost obliterated.

Occord (xxxvi, I I).- To the north of Occold Hall, 2 miles south from Eye, a quadrangular moat surrounds a plantation.

Occold (xxxvi, 12). - At High House, near the Framlingham road, are three sides of a small square moat, fed by a stream from the west.

Another strong quadrangular moat and long extension on the west is at Benningham Hall.

Offron (lxv, I 4$)$. - A portion of a moat is at Maskeli's Hall, north-west of the village, 8 miles east from Lavenham.

Old Newton (xlvi, I I).-At Rookery Farm, north of the village, $2 \frac{3}{4}$ miles north from Stowmarket, are the remains of two adjoining moated inclosures; the southern and larger has lost its north-eastern angle, and the northern one has its eastern side obliterated. A stream supplies the water from the west.

A fragment of a moat remains at Newton Hall, south-east of the village.

Three fourths of another lie to the south-east of the last, at Pooley's Farm.

OneHouse (lvi, 5).-Three fragments of a moat are round the site of Onehouse Hall, 2 miles west from Stow market.

OtLey (lviii, I3).-A portion of a broad square moat partly surrounds the site of Otley Hall, north-east of the village, $5 \frac{1}{2}$ miles west from Wickham Market. The front portion, with the gatehouse and drawbridge, has been destroyed.

To the west of the latter was a small double moat. The inner one is of oblong plan, and the remains of the outer now cover its northern and western sides at a distance of $25 \mathrm{ft}$.

A moated inclosure adjoining the churchyard of Otley on the north-north-east side, with the entrance near the church, is surrounded by a trench averaging $8 \mathrm{ft}$. deep.

Otrey (lviii, I3).-At Wood Farm, west of the village, 6 miles west from Wickham Market, is a very complete narrow moat.

At Moat Hall to the east of Otley are extensive fragments of moats, so disconnected that it is difficult to trace their original course.

Pakefielo ( $x, 15)$ - - At Pakefield Hall, $2 \frac{9}{4}$ 


\section{ANCIENT EARTHWORKS}

miles south-south-west from Lowestoft, is a large portion of an oblong moat.

Pakenham (xxxiv, 9).-At Redcastle Farm, 4 miles north-east from Bury St. Edmunds, is a square moat, the western side of which is for the most part levelled; a channel from the east conveys the water, and a pond is on the north.

Pakenham (xxxiv, I 4).-At Maulkin's Hall, north-east of Pakenham Street village, is a rhombic-shaped moat, complete but for part of its southern side.

Parham (lix, 6).-The ruined walls of Par-

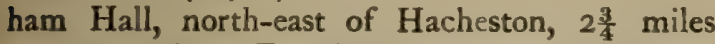
south-east from Framlingham, stand within the northern angle of a moated area. The moat is deep and wide, especially on the south-west, where it attains the proportions of a lake.

Pettaugh (lvii, 7).-Grove Farm, west of the village, $2 \frac{1}{2}$ miles south-south-west from Debenham, had a moat which is now so mutilated that no definite form is seen.

Pettaugh (lvii, 8).-Laffitt's Hall, east of the village, has three sides of an oblong moat.

South of the last, at Abbot's Hall, are fragments of an oblong moat.

PetTistree (lxviii, I).-Pettistree Lodge, nearly a mile south from Wickham Market, stands within the remaining half of an oval moat. To the south of it are various lengths of other moats which appear to have formed a square and to have been prolonged eastwards for additional strength to the principal site.

Playford (lxxvi, I).-Around the site of old Playford Hall, the home of the Felbrigges, $3 \frac{1}{2}$ miles north-east from Ipswich, is a strong moat, nearly square, with the entrance on the south.

Polstrad (lxxx, 4).-At Bower House, southwest of Hadleigh Heath, 3 miles south-west by west from Hadleigh, is a very small piece of a moat.

Preston (lxiv, IO).-One side of a moat, $700 \mathrm{ft}$. long, is at Priory Farm, $6 \frac{1}{2}$ miles northeast from Sudbury.

Two curved sides of another moat at Manor Farm lie to the west of Preston.

RatTlesden (lv, 8).-At Wood Hall, east of the village, $3 \frac{1}{2}$ miles west from Stowmarket, is the greater portion of an oblong moat.

REDE (liv, 5).-At Rede Hall, north of the village, 5 miles south-west from Bury St. Edmunds, moats surrounded two adjacent tracts of land. The northernmost is complete but for part of its western side, and of the southern about half remains.

Redlingfield (xxxvi, 12 ; and xxxvii, 9).Redlingfield Hall, 3 miles south-east from Eye, now a farm-house, contains remains of the house of Benedictine nuns founded here in I120. To this religious house may be ascribed the works remaining upon the site. Extensive moated inclosures may here be traced : two sides of a large moat of rectangular plan, while another area sur- rounded by water branches from the principal moat; within this inclosure are three large fishponds, called 'The Leys,' connected with the waters of the first moat.

RENDHAM (xlix, I 2).-A small fragment of a moat lies to the east of the village, 2 miles north-west from Saxmundham.

Rickinghall Superior (xxxv, 3).-At Facon Hall, north of Allwood Green, 6 miles west from Eye, has been a large moated area which is now mutilated.

Ringshall (lxv, 5).-At Burnthouse Farm, north-east of Wattisham, 4 miles south-west from Needham Market, are three parts of a narrow square moat.

South-west of the latter is a portion of another moat of rectangular plan.

Ringshall (lxv, 6).--At Ringshall Rectory, 3 miles south-west from Needham Market, a square moat, in a perfect state, appears to have stood within a larger one of which two fragments remain. 'The Mount,' on the eastern side, is probably formed from the cleansing of the moat.

Ringshall (lxv, 7).-A very irregular-shaped moat is at Chapel Farm, south-west of Barking Tye.

Rishangles (xxxvi, I6).-An oblong moat at Woodhouse Farm is to the north of the village, 3 miles south-south-east from Eye.

Rishangles (xlvii, 4).-Three parts of a square moat, and portions of another inclosure to the south, are situated at Barnaby's Farm, north of Aspall, 4 miles south-south-east from Eye.

Rougham (xlv, ro).-At Rougham Place, 4 miles east from Bury, is a square moat of considerable width.

Rougham (xlv, I3).-Moat Place, Rougham Green, has a narrow quadrangular moat.

A fragment of another moat remains at the Rectory, Rougham Green.

Rumburgh (xvii, I 5).-A large oblong moat, $3 \frac{1}{2}$ miles south from Bungay, surrounds the site of the Benedictine priory of SS. Michael and John, a cell to St. Mary's Abbey, York, now occupied by St. Michael's Church and a farmhouse.

Rumburgh (xxvii, 4).-At Brookhall Farm, east of Rumburgh Common, $2 \frac{1}{2}$ miles northnorth-west from Halesworth, is the greater part of an oblong moat divided into two unequal parts by a branch of the moat. Two of the angles expand outwardly into ponds.

Rumburgh (xxvii, 4).-Moat Farm, east of Rumburgh Common, 3 miles north-west from Halesworth, has the northern side and a fragment of the southern side of a moat.

Rushirooke (xliv, 16).-The walls of Rushbrooke Hall-3 miles south-east from Bury St. Edmunds-rise from the waters of a moat which averages $35 \mathrm{ft}$. broad. It is a deep cutting, the level of the water being $8 \mathrm{ft}$. below the ground 


\section{A HISTORY OF SUFFOLK}

level; and the sides are in places lined with dressed stone.

Shadingfield (xviii, 7).-At Westend Farm, north-west of the village, 3 miles south from Beccles, is an oblong moat.

To the east of the last are three parts of a larger quadrangular moat, and close to its external bank on the north-east another small one incloses an island, in the midst of which is a square pond.

Shelland (lvi, I).-At New Farm, east of the village, $2 \frac{1}{2}$ miles north-west from Stowmarket, is a portion of an elliptical moat.

Rockylls Hall, north-west of Shelland, has three sides remaining of a large rectangular moat. Near the western angle a branch from the moat penetrates the interior, partly inclosing a pond.

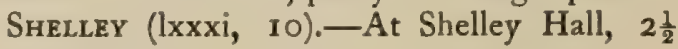
miles south from Hadleigh, a square moat surrounds the fine old Tudor building.

Shimpling (lxiii, 4).-Greentree Farm, east of Shimpling village, 6 miles north from Sudbury, has an oblong moat with a pond at the southwest angle.

Shimpling (lxiii, 7).-Three parts of a moat are at the rectory, to the east of the village.

Shimpling (lxiii, 8).-The quadrangular ' Hunts' Moat' lies in a field $1 \frac{1}{2}$ miles east from the village.

Shothey (lxxxix, 2).-The site of the old hall at Shotley, $2 \frac{1}{2}$ miles north-west from Harwich, shows traces of having once been surrounded by an oblong moat.

SibToN (xxxviii, I6).-North Grange Moat, north of Sibton Abbey, 5 miles south-southwest from Halesworth, consists of two sides of a right angle.

South Elmham All Saints (xvii, r 5).-A network of moats spread around the north, west, and east of the church, 4 miles south-south-west from Bungay. Towards the north-east a large oblong moat is almost complete; from the middle of one side a branch, $300 \mathrm{ft}$. long, takes a southerly course on the north-west of the church, and apparently formed a common side to two moats, one of which possibly surrounded the church. The western end of the branch from the large moat enters the side of a smaller oblong moat, complete but for the eastern angle, and in this area is a pond.

To the south of these, at Meen's Farm, are pieces of six water trenches, which are apparently portions of another group of moats.

At Blackburn's Farm, east of the last, are three sides of a small rectangular moat.

Another, to the south-west of the latter, consists of three-fourths of a quadrangle.

South Elmham St. Cross (xvii, 9).-Threefourths of a rectangular moat remain at the rectory.

Two sides of another, describing a right angle, are at College Farm, north of the village.
South Elmham St. Margaret (xvii, 10).A large quadrangular moat surrounds what is supposed to be the site of the bishop's palace of the ancient East Anglian see; it lies south-west of the village.

The greater portion of another moat is to the east of St. Margaret's Rectory. The waters lie in a broad curved channel of great strength.

South Elmham St. Michael (xvii, I I).A portion of a weak angular moat lies to the west of the church.

South Elmham St. Nicholas (xvii, I4).Three parts of a small square moat are situated on the west of the church.

South Elmham St. Peter (xvii, 7).-At St. Peter's Hall, south of the church, $3 \frac{1}{2}$ miles south from Bungay, are two sides of a square moat with ponds protruding from the two remaining angles.

Southolt (xxxvii, 9).-At Southolt Hall, north-east of the village, $4 \frac{1}{2}$ miles south-east from Eye, is a long oblong moat which has spread inwards, forming a pond by the ancient entrance.

Southolt (xxxvii, 13).-At Paradise Farm are three sides of a square moat.

Spexhall (xxviii, r).- Spexhall Hall moat, north of the village, fully 2 miles north-northwest from Halesworth, retains three parts of its former circuit.

Sproughton (lxxv, 10).-Boss Hall moat, north-east of the village, $1 \frac{1}{2}$ miles west from Ipswich, lies close to the northern bank of the River Gipping ; it is square in plan and the area is divided into two portions.

Stanningfield (liv, 16).-At Great Saxes Farm, south-west of Cross Green, 6 miles southsouth-east from Bury St. Edmunds, is a quadrangular moat.

Stansfizld (lxii, 4).-At Purton Hall, $8 \frac{1}{2}$ miles north-east from Haverhill, is the southern side, with its two angles, of a rectangular moat.

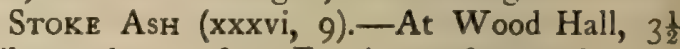
miles south-west from Eye, is a perfect quadrangular moat.

Stoke Ash (xxxvi, 13).-At Colsey Wood, east of Wickham Skeith village, $3 \frac{1}{2}$ miles southwest from Eye, is a rectangular or nearly square moat.

Stonham Aspall (lvii, 6).-Broughton Hall, $3 \frac{1}{2}$ miles south-west from Debenham, has a curved moat.

Stonham Aspall (lvii, 7).-At Morgan's Farm, East End, are three sides of a quadrangular moat, supplied by a channel at the northeast.

To the east of Stonham Aspall there remains a part of an irregularly shaped moat at Lewis Farm.

Stoven (xviii, 16).-At Church Farm, southwest of Middle Green, 5 miles north-east from Halesworth, there remains the greater part of 2 rectangular moat. 


\section{ANCIENT EARTHWORKS}

Stowlangtoft (xxxiv, I 5).-Seven miles east by north from Bury St. Edmunds, immediately to the north of St. George's Churchyard, a small area is inclosed by a moat, the latter averages Io ft. wide except on the west, where it attains a breadth of $30 \mathrm{ft}$.

Another moat of quadrangular plan is to the south-east of the church.

Stowupland (lvi, 4).-Columbine Hall, northeast of Thorney Green, $1 \frac{3}{4}$ miles north-east from Stowmarket, has a large moat of diamondshaped plan, with two adjacent ponds.

Stradbroke (xxvi, i 4).-At 'The Rookery,' Battersea Green, $4 \frac{1}{2}$ miles east by north from Eye, is a straight and wide trench, $900 \mathrm{ft}$. long, in the southern end of which is an islet; from this branch various arms of water towards the east, and other fragments are on the west, the whole area appears to have formerly had a number of moated inclosures.

To the east of the latter, at Hill Farm, there is one square moat and a portion of another adjoining.

Stradbrokr (xxvi, 16).-At Red House, south of Ebden's Corner, $7 \frac{1}{2}$ miles east by north from Eye, is one side and an angle of a rectangular moat.

Stradbroke (xxxvii, 2). - At Stradbroke Hall, 5 miles east from Eye, is a large oblong moat, nearly perfect, with an arm of the moat penetrating the interior area from the north.

STRADBROKE (xxxvii, 3).--South of the church is the southern portion of a quadrangular moat.

Fragments of another of curious and numerous branches lie at Boyton Trust Farm, south-east of the village.

Stradbroke (xxxvii, 4).-A small but strong quadrangular moat is at Whitbread's_Farm, northeast of Ashfield Green.

StradBRoKe (xxxvii, 6). - At Wootten Green, south-west of Ivy Lodge, are the remains of a square moat.

Stradishall (lxii, 2). - At Moat Farm, Farley Green, $6 \frac{1}{2}$ miles north-east from Haverhill, is a four-sided moat with two of its corners rounded.

Stustos (xxv, 7).--Around the site of the Old Hall, $2 \frac{1}{2}$ miles north by west from Eye, are the remains of a broad moat ; and to the south, severed by $a$ road, are the fragments of a double oblong moat.

SUdBuRY (lxxii, II).-One mile north from Sudbury, at Wood Hall, is the greater part of an oblong moat.

Tannington (xxxvii, 15).-At the remains of the old hall, Tannington Green, $7 \frac{1}{2}$ miles south-east from Eye, are the opposite sides and two angles of an oblong moat. Outside the south-western angle the moat turns at right angles inclosing a small square island.

North of the last is another oblong moat inclosing 'The Hoplands.'

1
Tannington (xlviii, 3).-At 'The Chestnuts,' north-east of the village, is the northern portion of a small moat.

To the east of Tannington, at Tannington Lodge, is a heavy oblong moat with a long channel extending in a southerly direction.

Tatringstone (lxxxii, 10).-In Tattingstone Park, $4 \frac{1}{2}$ miles south-south-west from Ipswich, is an irregular quadrangular moat.

ThorNDON (xxxvi, 15).-Fragments of two irregular moats are at Hill House, east of the village, 3 miles south from Eye.

Three sides of an oblong moat are near Thorndon Rectory.

At Hestley Hall, south of Thorndon, are three moated areas. One has three sides of a broad square moat; and the other two appear to have been inclosed in one extended oblong cincture divided in the middle by a water trench. To the east of these a small island-called 'The Mount,' and containing a central pond-is surrounded by a moat.

A mile eastward from the last are the remains of a double moat, close to Rishangles Lodge. The inner one, square and of considerable width, is closely surrounded on three sides by another and narrower moat which at its northern and southern extremities turns outwards at right angles.

Three parts of a square moat in the same parish remain at Rishangles Lodge.

Thorndon (xlvii, 3).-At Lampits, west of Hestley Green, a large tract of land is moated in an intricate manner. An irregular circular moat has portions of other numerous inclosures towards the south and the west ; they are very disconnected, but appear to have provided protection to at least four areas.

South-east of the last are three parts of a small square moat, to the south of which are portions of another inclosure approaching an oblong form, greatly mutilated and spread into irregular ponds.

THORNDON (xlvii, 4).-Buck's Hall moat, extending over the border into the parish of Rishangles, is but a fragment consisting of one side and one angle of a rectangular moat.

Thornham Parva (xxxvi, 5),-In Moathouse Wood, north-west of Thornham Park, $3 \frac{1}{2}$ miles west by south from Eye, is a pentagonal moat with a cutting extending from the northern side.

ThORPE Morizux (lxiv, 2).-Detached fragments of a square moat remain at Moat Farm, $8 \frac{1}{2}$ miles north-east from Sudbury.

At Water Hall, north-west of the last, is a portion of a quadrangular moat.

ThORPB MORIEUX (lxiv, 6).--South-west of the village a piece of a curved moat remains at Thorpe Farm.

Close by the latter, at Manor Farm, the whole of a moat may be traced, the southern and

78 


\section{A HISTORY OF SUFFOLK}

western sides are straight, but the others form one curve.

Thrandeston (xxv, 10). -At Malting Farm, east of the village, 2 miles north-north-west from Eye, is a portion of a moat, so mutilated as to obscure its former plan.

Thrandeston (xxv, 14).-A small quadrangular moat remains at Goswold Hall, north of Yaxley.

ThwaIte (xxxvi, 13). - A quadrangular moat remains in good condition around the site of the old hall, west of the village, $4 \frac{1}{2}$ miles south-west from Eye.

THWarte (xxxvi, 14).-To the west of Willow Farm is a small square moat.

Thwalte (xlvii, 2).-At Brockford Hall, north-west of Brockford Street hamlet, is a long cutting with a broadened part which once formed a side of a moat.

UFFoRd (lxviii, 5).-Ufford Castle, 3 miles north-east from Woodbridge, is an oblong moated site, divided into two unequal portions by a ditch.

Walsham LE Willows (xxxv, 6). - The greater part of a quadrangular moat is at High Hall, north-east of Cranmer Green, $7 \frac{1}{2}$ miles west by south from Eye.

Walsham le Willows (xxxv, 9).-At Crowland Hall is another, of square plan.

W Antisden (lxviii, 4).-Old Yards, 6 miles north-east from Woodbridge, the site of the old hall and its grounds, is surrounded by a moat $6 \mathrm{ft}$. deep, and the area is divided into two parts by a branch of the same; the southern part is rectangular in plan and the northern is semicircular.

WashBrooK (lxxxi, 4).-The moat at Birch House, south of Chattisham, 5 miles south-west from Ipswich, is a small quadrangle, spreading into $a$ pond on the western side, and another pond to the south for receiving the overflow.

WASHBROOK (lxxxii, 1).-At Washbrook Green, west of Copdock, are three sides of an elongated rectangular moat.

Watтisham (lxv, I).-Three disconnected fragments of a moat are at Loose Hall, northwest of the village, $5 \frac{1}{2}$ miles south-west by west from Needham Market.

Wenham, Great (lxxxi, 3).-A circular moat at Vauxhall lies to the west of Birch

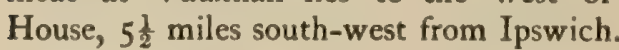

Westhall (xviii, I3).-A fragment of an oblong moat lies to the west of Cox Common, $5 \frac{1}{2}$ miles south-south-west from Beccles.

Westhall (xviii, 14).-At Rookery Farm, south-east of Cox Common, are three sides of a rectangular moat.

Westhall (xxviii, 2).-Moat Yards, Mill Common, are so called from a double moat, one within the other. The innermost is an oblong, nearly square; and the outer, also rectangular, inclosing a larger area, has but two sides left.

WESTHORPE (xxxv, II).-At Moathill Barn, north-west of the village, 7 miles north from Stowmarket, a square moat may be traced, south of which are two water trenches, which may possibly have been another inclosure.

Half a mile to the north of the latter, on the site of the old Westhorpe Hall, is the greater part of a quadrangular moat, fed by a stream from the east, and to the south is another irregular inclosure.

Westleton (xxxix, I0).-Lyenball's Farm, north-east of Darsham, 5 miles south-south-east from Halesworth, has the remains of a double moat, one within the other. The inner moat, a parallelogram, is perfect ; but of the outer one only the northern and western sides are extant, at which sides only $50 \mathrm{ft}$. divide them, but it is evident that at the eastern side a considerably larger tract of land has been inclosed.

Wetherden (xlvi, 5).-One side and an angle of a small moat are at Upper Lodge, south of Wetherden Upper Town, $7 \frac{1}{2}$ miles north-west from Needham Market.

Wetherden (xlvi, 9).-Detached fragments of a moat are at Mutton Hall, north of the village.

Around the site of the old Wetherden Hall, north-east of the village, is an oblong moat.

Wetheringsett CUM BRoCKFord (xlvii, 2). -At Brames Hall, east of the village, $4 \frac{1}{4}$ miles south from Eye, are two-thirds of a large curved moat.

A fragment of another is at Blacksmith's Green.

Wetheringsett CuM Brockford (xlvii, io). -At Green Farm, west of Park Green, is a square moat.

WeYBread (xxvi, 3).-A square moat with its two northern corners rounded surrounds the site of Weybread Hall, 7 miles north-east from Eye.

Weybread (xxvi, 7).-At Church Farm, north-west of Vales Hall, 7 miles north-east from Eye, are the remains of an oblong moat, the interior area being partially divided by a water trench.

Weybread (xxvi, 8). - The moat at Rookery Farm is now represented by two ponds only.

Whatfirld (lxxiv, 2). - Whitehouse Farm Moat, east of the village, 3 miles north from Hadleigh, consists of two sides which once formed part of a quadrangular moat.

WhatField (lxxiv, 5).-At Whatfield Rectory is a very complete and strong oblong moat, with one corner curved.

To the south of the village, another rectangular moat is at Barrard's Hall.

Whepstead (liv, I).-At Doveden Hall, 4 miles south-west from Bury St. Edmunds, is a square moat.

WhePstead (liv, 10).-North-east of Gulling Green, at Manston Hall, three-fourths of a quadrangular moat are extant. 


\section{ANCIENT EARTHWORKS}

To the east of Brockley is a large moat formerly containing a smaller and stronger one, of which two sides remain.

South-west of the last is a small square moat.

Fragments of another are at Gulling Green Farm.

WickhambrooK (liii, 6). - At Badmondisfield Hall, Genesis Green, 8 miles south-west from Bury St. Edmunds, is a strong rhombic-shaped moat ; a channel forming part of another inclosure lies to the north.

W ickнAмBRooK (liii, 10).-An irregularlyshaped and extensive moat remains at 'The Gesyns,' Boyden End.

Wickhambroox (liii, 15).-Giffard's Hall, south of Clopton Green, has an oblong moat; a mound outside its north-eastern angle is modern.

To the south-west of the last is a large, irregular, circular moat, now dry, in Moat Plantation.

Wickham Market (lviii, 16).-One mile west of the town are the remains of moated inclosures which were formerly connected with Thorpe Hall and its grounds. A small piece of a moat is by the site of the hall; to the northeast is an angle of another; and to the south, at the end of a connecting channel, is a quadrangular moat.

WiLBY (xxxvii, 7).- South-east of the village, $6 \frac{1}{2}$ miles south-east by east from Eye, the moat at the rectory remains in a perfect condition. It is oblong in plan with a branch of the moat separating the area into two unequal divisions.

At Church Farm, close to the church, are the remains of a circular moat, and immediately on its eastern arc is part of another rectangular inclosure.

WILBY (xxxvii, 8).-Wilby Hall, east of the village, has the remains of a double rectangular moat, or of two oblongs side by side, the southern of smaller area than the northern.

At Moat Farm, south of Wilby Hall, is one angle of a moat and one side of another.

Wilby (xxxvii, 10).-At Rookery Farm, north-west of Wilby Green, about half of a square moat is left.

Willingham (xviii, 7).-At Moat Farm, 3 miles south from Beccles, an oblong moat may be traced.

Willisham (lxv, I I).-Willisham Hall, 3 miles south-south-west from Needham Market, has a fragment of a moat.

WingFIELD (xxvi, 7).-South-west of Greengate Farm, 6 miles north-east from Eye, is a large portion of an oblong moat.

Wingrield (xxvi, 10). - The remains of a moat at Chickering Hall, $4 \frac{1}{2}$ miles north-east of Eye, have been so greatly mutilated that no form is left in it.
Wingfield (xxvi, i i).-At Abbey Farm, on the site of an ancient religious house, north-east of Wingfield, is an irregular moat and six fragments of other undoubted moated inclosures.

Winston (lvii, 4).-At Park Farm, Winston Green, $1 \frac{3}{4}$ miles south from Debenham, is the greater part of a strong moat inclosing an oval site.

W Issetr (xxvii, 8).-Bleach Farm Moat, east of the village, 2 miles north-north-west from Halesworth, is a complete quadrangle.

Withersfield (lxi, 14).-To the west of

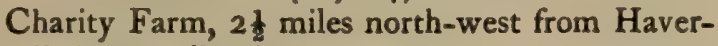
hill, is a small oblong moat.

The remains of another moat at Hall Farm consist only of one long channel.

Witnesham (lxvi, 8). - A strong square moat surrounds the site of old Berghursh House, 5 miles north from Ipswich.

Witnesham (Ixvi, 12). - South-west of the church is a curved side of a once strong moat.

Woolprt (xlv, 12).- 'Lady Well' is the name given to a moat in a field north-east of the rectory of Woolpit, $7 \frac{1}{2}$ miles east by south from Bury St. Edmunds.

Worlington (xx, 16). - South-east of the Bell Inn, $11 \frac{1}{2}$ miles south-east from Bury St. Edmunds, is a large five-sided moat.

Worlingworth (xxxvii, Io).-At ' Honeypots,' north of Fincle Street village, 5 miles south-east from Eye, is a moat almost inclosing two tracts of land-saving the west side-the junction of the three sides forming a pond at the south-west corner.

Worlingworth (xxxvii, II).-At Stanway Green are the remains of two moats; that to the west is small and externally square, but the varying width detracts from the regularity of the interior area.

The other moat, to the east, was apparently also square in plan, but only one side with its two angles is left entire.

Wortham (xxv, 5).-An irregular piece of the moat of Wortham Hall is situated to the north of the village, 5 miles north-west from Eye.

Wrentham (xviii, 16).-At Moat Farm, West End, 5 miles south-south-east from Beccles, are portions of a very weak moat.

Wyuerstone (xxxv, 15).-At Hill Barn, on the site of the old hall, $5 \frac{1}{2}$ miles north from Stowmarket, are curved portions of a moat.

Wyverstone (xlvi, 2).-At Moat Hall, Wyverstone Green, is a small square moat,

YAXLEY (xxxvi, 2).-Portions of three contiguous moats lie to the north of the village, 2 miles west by north from Yaxley.

YOXFORD (xxxix, 13).-One right angle of a moat remains at Cockfield Hall, $5 \frac{1}{2}$ miles south from Halesworth. 


\section{A HISTORY OF SUFFOLK}

\section{MOATED INCLOSURES WITH STRONGER \\ DEFENSIVE WORKS}

(Class G)

BARRow (xliii, 7).-Barrow Hall, north of the village, 6 miles west from Bury St. Edmunds, has extensive remains of strong entrenchments. There is one perfect, large, square moat, with the western side extended northwards, which is evidently part of the inclosure of another area. These moats have been strengthened by inner and outer banks; that within the square moat is a great rampart $20 \mathrm{ft}$. broad, rising $5 \mathrm{ft}$. from the interior with an escarpment of $\mathrm{I} 6 \mathrm{ft}$. to the water. The bank on the outside of the moat is preserved only at the south-west corner and the southern side; this is of the same height, but of less width, than the inner one. Without the northern side another piece is left; but the greater part was destroyed forty years ago. On the western side of the extension the bank is $6 \mathrm{ft}$. high. When in a complete state this must have been one of the strongest homestead defences in the county.

Chevington (xliii, I6).-Although the work around the country house of the abbots of Bury-the site of which is now occupied by Chevington Hall Farm-served the purposes of a moat; it is in fact a very strongly fortified position of an early date, and as such will be found under Class C.

Great Barton (xxxiii, I6).- The site of Necton Old Hall, north-west of the village, $2 \frac{1}{2}$ miles north-east from Bury St. Edmunds, is surrounded by a square moat, now somewhat dilapidated on the north. Outside the southern part of the eastern side is a portion of an agger over $100 \mathrm{ft}$. long, indicating the former defensive additions to the moat.

w Great Thurlow (lxi, 8).-At Wadgell's Farm, north of Sawley Green and east of Little Thurlow, 4 miles north-north-east from Haverhill, are fragments of a once large and strongly fortified moat. Outside the eastern part of the moat are the remains of an earthen bank which gradually decreases towards the north until it is totally lost.

Hawstead (liv, 2).- - Hawstead Place, north-west of the village, $2 \frac{1}{2}$ miles south from Bury, is a strongly defended manor house of a type between a castle and a homestead. The inner quadrangular site is built from the moat to a height of from $5 \mathrm{ft}$. to $8 \mathrm{ft}$. The moat averages $40 \mathrm{ft}$. wide, except on the west, where it is slightly narrower. The outer side of the moat rises $3 \mathrm{ft}$. above the water, and leaving a path around its margin there rises a strong bank surrounding three of its sides $7 \mathrm{ft}$. above the path, making a total height of $\mathrm{r} 0 \mathrm{ft}$. above the water. This agger on the north and east is $14 \mathrm{ft}$. broad and $4 \mathrm{ft} .6 \mathrm{in}$. above the outside ground level.

Helmingham (lvii, I 2). - In Helmingham Park, $3^{\frac{1}{2}}$ miles south by west from Debenham, the Tudor mansion of the Tollemache family is surrounded by a very wide square moat, crossed by two drawbridges. Along the exterior edge of the north-west side a strong vallum provided additional defence. The custom of raising the drawbridge is still observed. Parallel to the south-west side is another moat of oblong plan inclosing a large area of land. 


\section{A HISTORY OF SUFFOLK}

TAnnington (xlviii, 3 ).-Braiseworth Hall, $3^{\frac{1}{2}}$ miles north-west from Framlingham, has a series of moats contained within one large oblong moat, the latter being strengthened by a rampart upon its inner margin; this bank still remains round one third of the whole cincture.

Wattisham $(\mathrm{lxv}, 5)$.-Wattisham Hall, 5 miles south-west from Needham Market, has a double moat. A broad oval fosse $44 \mathrm{ft}$. wide surrounds an area $9 \mathrm{ft}$. above the water, upon which stands the manor house. This is evidently an ancient fortified site long antedating the mediaeval works. A manorial moat was at some later period cut around a large irregular quadrangular area, inclosing the more ancient oval site. This averages $\mathrm{I} 2 \mathrm{ft}$. wide, with banks $3 \mathrm{ft}$. high, and taking an inward curve on the south-east it enters the fosse of the first work; it is probable that at the time the moat was constructed the oval fosse was converted into a moat by the inlet of water. The church and churchyard are situated within the north-west corner of thr manorial moat. Vestiges of banks without the western side may hav, inclosed an orchard, and by the north side of this embankment are the remains of a fish-pond.

Wingfield (xxvi, Io).-Wingfield Castle, 5 miles north-east from Eyte is an ideal example of that type of residence transitional from the feudal caste to the moated manor-house. The walls of the castle and courtyard ri

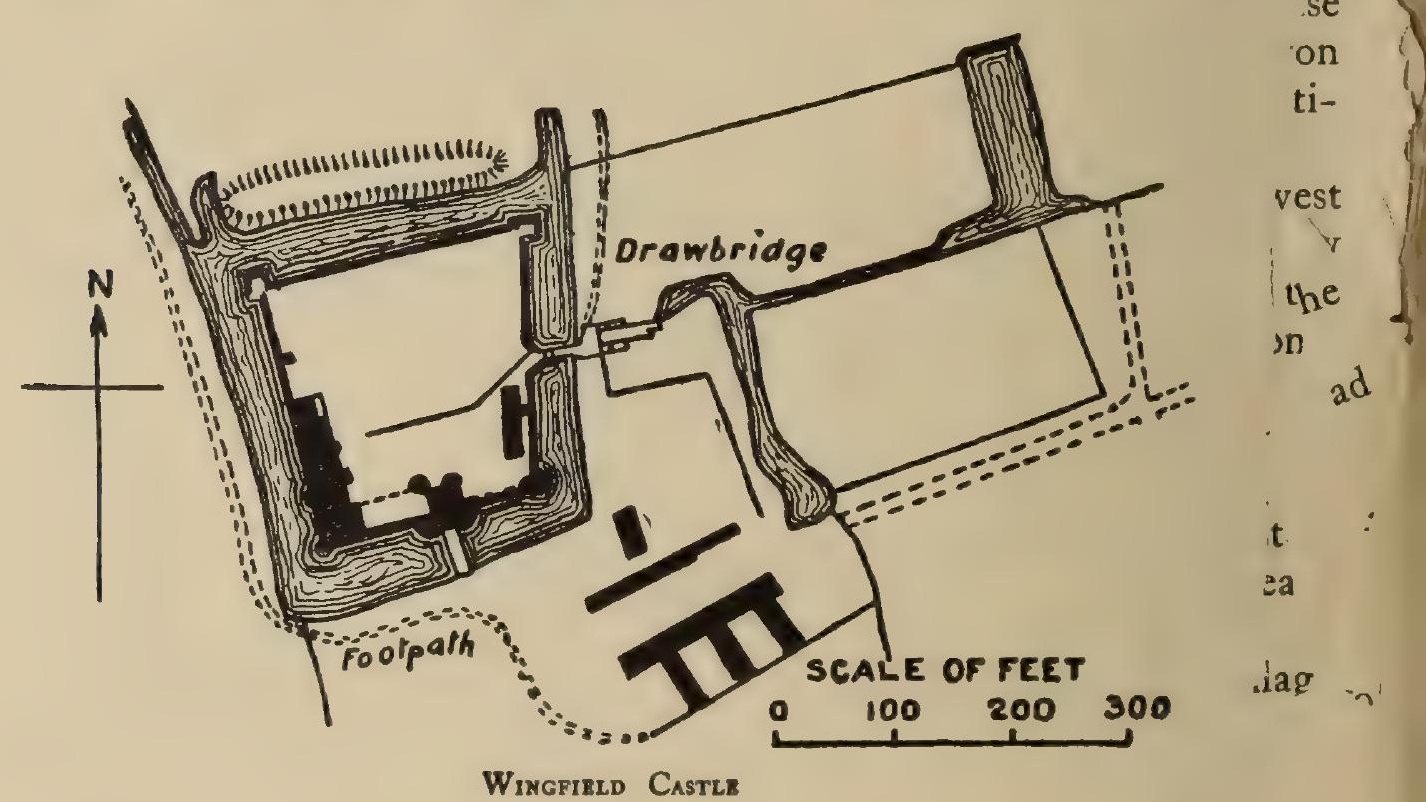

immediately from the waters of the moat, which is from $24 \mathrm{ft}$. to $40 \mathrm{ft}$. broad, and nearly square in plan. The principal entrance is now by a stone bridge, but a drawbridge still spans the eastern side of the moat. Outside the northern margin of the moat is a wide vallum $8 \mathrm{ft} .4 \mathrm{in}$. in height. Indications of other water-girt areas are situated on the east. 


\section{ANCIENT EARTHWORKS}

\section{MISCELLANEOUS EARTHWORKS}

\section{[CLASS X]}

Bredfield (lxvii, 8).- 'Oliver's Ditches,' 4 miles north from Woodbridge, are artificial trenches $8 \mathrm{ft}$. deep; they describe an ellipse around a large area in which is situated the site of a rectangular camp dealt with in Class $\mathrm{C}$; they also extend to the south, taking a serpentine course, and protecting another area. These were evidently excavated for defensive purposes, but their origin is unknown.

Bury St. Edmunds (xliv, II).-In a district called Haberdon, to the south-east of the town and east of Southgate Street, the only remaining earthwork defences of Bury lie in a field. An escarpment facing south-east by south is $14 \mathrm{ft}$. in depth, with a fosse having a counterscarp of $6 \mathrm{ft}$. ; the outer scarp is $5 \mathrm{ft}$. $8 \mathrm{in}$., and is a very gentle slope. Branching from the fosse and facing due south is another entrenchment with a scarp of $2 \mathrm{ft} .4$ in., and a ounterscarp of $\mathrm{I} \mathrm{ft}$. 6 in., with an outer bank $\mathrm{I} \mathrm{ft}$. high. Towards the east 1. has been mutilated by field drainage, and to the north by digging for A avel.

Cavenham (xxxii, 3).- - Black Ditches,' a series of banks and trenches, VImmence on the northern edge of Cavenham Heath, about $\frac{1}{2}$ a mile south11 st of Icklingham, and extend for $\frac{3}{4}$ of a mile towards the south-east. saces of these Ditches again appear on the west side of Long Plantation, and sally terminate on Risby Poor's Heath. Signs of primitive habitations tund here, and tumuli lie to the north.

- Cockfield (1xiii, 4).- 'The Warbanks'; see Lawshall.

i) Coddenham (lxvi, 2). - On the road from Ipswich to Eye, east of dham Market, is 'Stonewalls,' a bank inclosing about ro acres, and at thithnorth-east corner, close to the road, is a high wooded hill known as Thm. con Hill.'

${ }_{1}{ }_{1}$ CRATFIELD (xxxviii, 2). - In a field to the south of the village are broad bf $\mathrm{b}$ s forming three sides of a square.

- ov:EyE (xxxvi, 3).- - North-east of Eye Castle, and west of the River Dove, is a series of fish-ponds of the Benedictine priory founded here by Robert Malet.

Great Welnetham (liv, I 2).-To the east of the hamlet of Sicklesmere, $2 \frac{1}{2}$ miles south by east from Bury St. Edmunds, the base of a rounded slope is scarped to a depth of $8 \mathrm{ft}$., upon which a fragment of a rampart $3 \mathrm{ft}$. high remains. This looks towards the south across the site of the ancient mere-formed by the waters of the River Lark-and confronts another site which has yielded abundant relics of Roman occupation.

Around the north and west sides of the area from which Roman relics have been excavated, and extending far towards the south-west, is a manorial bank.

Havergate Island (lxxviii, 6).-Within the widened waters of the River Ore is a tract of land surrounded by a bank which has been called an ancient 'mud sheep fold,' but the work is preserved to keep the island from inundation. 


\section{A HISTORY OF SUFFOLK}

Icklingham (xxi, 15 and 16 ).- The ancient road known as the Icknield Way crossed Icklingham Heath; here the flint relics, the indications of a camp, and the presence of tumuli point to an early occupation of this spot. Many banks and ditches intersecting the ground have suggested it as the defences of a prehistoric village ; but the earthworks rather have the appearance of mediaeval land boundaries.

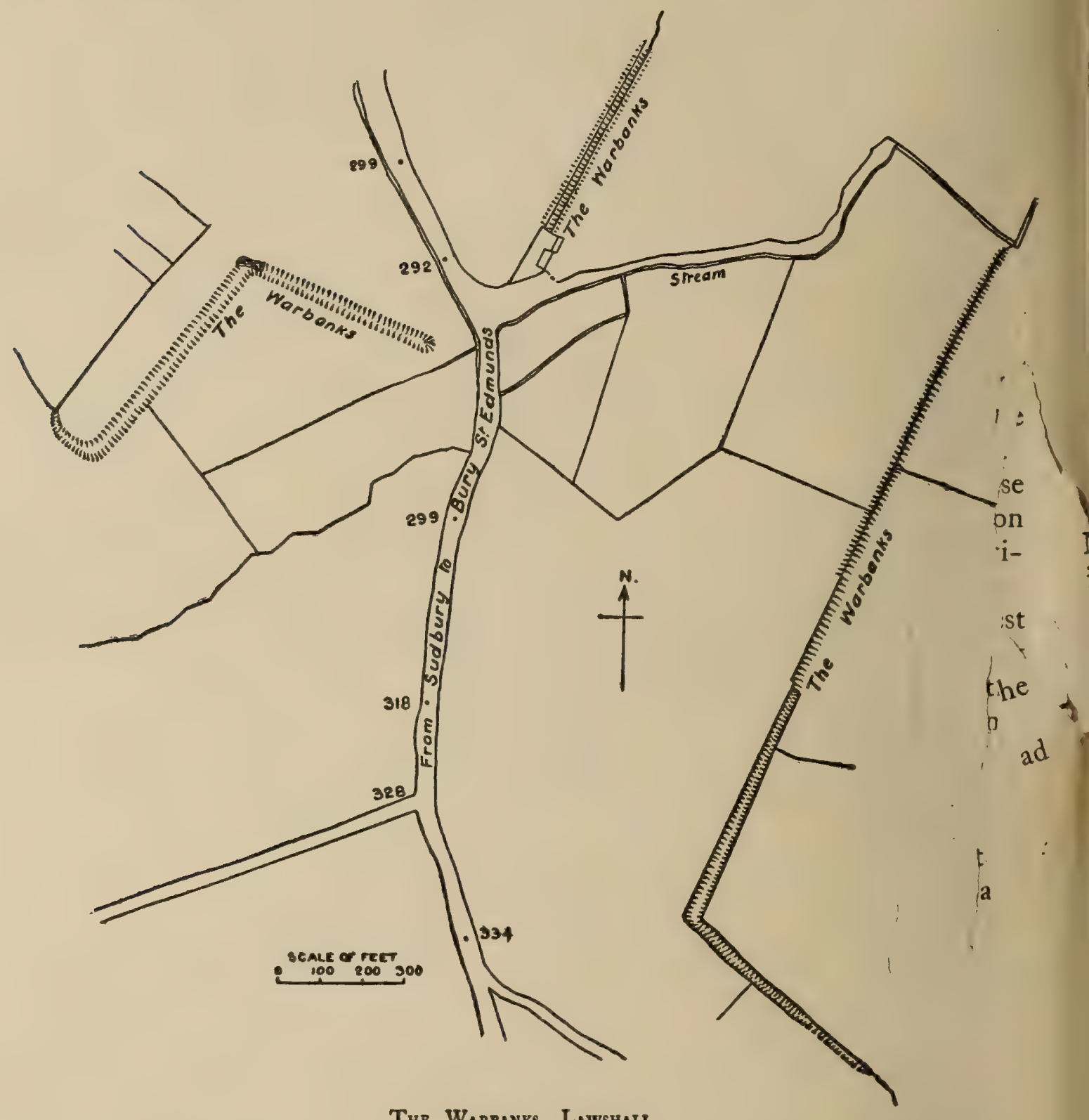

The Warbanks, Lawshall

Langham (xxxiv, I 2).- 'Castle Ditches' is the name given to a field east of the church and north of a moated area, which local tradition asserts to be the site of a village, but all traces of earthworks have been obliterated during the last fifty years.

Lawshall (lxiii, 4).- 'The Warbanks,' also extending into the adjacent parishes of Cockfield and Shimpling. These entrenchments are now in three distinct parts, but they doubtless formed part of one extensive defence. The most northerly portion, north-east of the Greyhound Inn and on the eastern side of the high road between Sudbury and Bury St. Edmunds, 


\section{ANCIENT EARTHWORKS}

consists of a rampart $4 \mathrm{ft}$. high, with an escarpment of $8 \mathrm{ft}$. at the south-west, increasing to $14 \mathrm{ft}$. towards the north-east of this $500 \mathrm{ft}$. of entrenchment. The fosse, $4 \mathrm{ft}$. deep, is towards the north-west. The most perfect part by the roadside was levelled in 1880 . Another portion lying on the west of the road would, if extended, join the first length at right angles; this consists of two lengths of fosse ; that at the north-east is $500 \mathrm{ft}$. long, the other branching from it at an obtuse angle and taking a south-westerly course is $600 \mathrm{ft}$., and finally takes a short curve to the west; in this case the rampart has quite gone, and the ground being under the plough the fosse is only just traceable. The third portion is in a straight line from north-east to south-west, $\mathrm{I}, 800 \mathrm{ft}$. long, when it turns to the south for a distance of $600 \mathrm{ft}$. The southern portion of this is now a fosse only, with an escarpment of $20 \mathrm{ft}$. at its most perfect part, it was placed to the south-east of the rampart, but the latter has been levelled. The middle portion is a scarp only, and the most northerly part is a rampart.

LiNDSEY (lxxiii, I 2).-A portion of one straight side of a manorial bank is behind the ancient chapel on Chapel Farm.

I) Redisham (xviii, Io).-A manorial quadrangular bank lies to the iuth-west of Redisham Church, close to the south side of the road.

th Shimpling (lxiii, 4).-- The Warbanks'; see Lawshall.

Sutton (lxxvi, 4).-To the north of the tumuli at Sutton Haugh, near Woodbridge, is a long entrenchment of bank and fosse, the former $2 \mathrm{ft}$. high 11 the north with a scarp $4 \mathrm{ft} .6$ in. into the ditch on the south; this runs st and west; at the east end it curves to the north, but has here been \$atroyed. At its western end another bank curves from the first at an acute s dle in a northerly direction, with its ditch on the south-eastern side. th cal rumours endow it with venerable antiquity; but it was possibly a fold Nilosure.

Close to the same spot another low bank starts from the west of the $n$ hthernmost barrow, and follows a southerly direction with its fosse on the pme. These are doubtless land boundaries of a far later period than the tak uli between which it takes its course.

of b W ANGFord (xii, 7).-On high chalk land are twenty-five bowl-like pits or oval form, of which the largest is $18 \mathrm{ft}$. in diameter and $5 \mathrm{ft}$. deep.

Woodbridge (1xvii, I 6).- - On the east of the town, alongside the north of the road, a length of bank indicates the ancient road before it was diverted to its present track.

\section{TUMULI}

Ashfield (xlviii, 13).-Near Thorpe Hall is Mill Mount, a flat-topped tumulus with a ditch around its base.

Aldringham with Thorpe ( $1 x, 4$ and 7$)$.- Tumuli are situated on Aldringham Green, south of the vicarage. Another is on 'The Walks,' Aldringham Common, to the west of the railway line.

BARDWELl (xxiii, I I).-A large tumulus is in a field to the north of Bowbeck.

Barton Mills (xxxii, I).-A tumulus is on Chalk Hill north of Chalk Hill Farm. 


\section{A HISTORY OF SUFFOLK}

Belton.

Belton (ii, I3).- 'Mill Hill' is a large tumulus south-west of

Blaxhall (lix, I6).-On the west of Tunstall Heath, south-east of Blaxhall, is a tumulus in which Roman remains were found.

Bucklesham (1xxxiii, 2).-Tumuli are on Bucklesham Heath adjoining Knight's Heath in the next parish, where others are to be seen.

Bury St. Edmunds (xliv, 7).-The 'Thing Houe.' Outside the North Gate of Bury, on the west side of the road to Fornham, and formerly partially isolated by the Teyfen Mere and the marshes of the River Lark, is a tumulus on which the ancient court of judicature of the people of Bury assembled. In charters and documents it is variously spelt 'Dinghowe,' 'Thinghoe,' and 'Thinghowe.' It is possibly a monument to the Danish influence in East Anglia; and as the Dinghowe of St. Edmunds it is mentioned in four Saxon charters. $^{2}$ The name is retained in the 'Thingoe Hundred.' In the latter part of the I $9^{\text {th }}$ century excavations proved it to be a tumulus of three interments. The centre, however, was not reached nor the primary burial discovered. The East Anglian School now occupies the reduced summit.

Chillesford (lxviii, 8).-A tumulus is on the eastern border of Wanti den Heath ; and (lxix, 5) another west of Barness Carr.

Clare $(1 \mathrm{xxi}, 3)$. - The site of a tumulus is in a field to the north of $t$ White Hart Inn.

Culford (xxxiii, 6).-The 'Hill of Health' is a tumulus near the ro north-east of Brockley.

Debenham (xlvii, I6).-A tumulus lies near Brice's Farm. cliffs.

Dunwich ( $\mathrm{xl}, \mathrm{I} 3)$. - A tumulus is in Greyfriars' Wood, close to $t$

Fakenham Magna (xxiii, 9).-On the southern end of Larkhall Hne and south-west of the village is a tumulus.

Flempton (xxxii, I 2).- Two tumuli are at the north-east corner of $\mathrm{Ri}$ ad Poor's Heath.

Fornham St. Geneveve (xxxiii, I 5).- Situated on 'John's Hill; locally known, are a large number of tumuli which have been so dug ove the transplanting of trees that their original form is lost and it is now in sible to number them.

Fritton (ii, I 3).- 'Bell Hill,' a long tumulus close to the railway. The summit has been excavated, leaving two minor hills upon it.

Gazeley (xxxii, I 3).-One tumulus is in a field north of Pin Farm, and two lie in a field east of Kentford.

Gazeley (xxxii, I 4).-A tumulus on the west of Desning Lodge is to the south of the Icknield Way.

Great Barton (xliv, 8).—C Catteshill,' a tumulus used for the judicial assembly of Bury after the Thinghowe had been obtained by the convent of St. Edmund's Abbey.

Great Finborough (lvi, 5).- 'Devil's Hill,' a tumulus on the west of Finborough Hall.

Hadleigh (lxxiv, I 4).-The 'Herst,' long known as Gallows Hill.

Halesworth (xxvii, I 2).-A tumulus lies near the road to Bungay.

'Kemble, Codex Diplomaticus Evi Saxonici, nos. 832, $915,1342,1346$. 


\section{ANCIENT EARTHWORKS}

Helmingham (lvii, I2).-A tumulus with a flat top and surrounded by a ditch is near the village, and other tumuli that have been destroyed near the church have yielded numerous British relics.

Herringswell (xxxii, 5).-A tumulus is on the heath to the west of the village.

Honington (xxiii, 13).- 'Troston Mount,' a tumulus on the eastern side of Broad Mere, west of the village.

Ickirngham (xxi, 7 and I6).- 'Howe Hill,' a tumulus south of Rake Heath, close to the Thetford road ; another lies to the west of Lackford Road Heath and south-east of Bernersfield Farm. On Mitchell's Hill are the remains of a cemetery, and many remains of interments are in the northern part of the parish.

IKEN (1xix, I).-A tumulus is on Iken Heath, west of Oak Covert.

KentFord (xxxii, I 3).-A tumulus lies to the east of Cock and Bull Farm and north-east of Kentford.

KnetTishall (xiv, I 5).-Tumuli are on Knettishall Heath.

LACKFord (xxxii, I 2).- - In Long Belt Wood, between Hall Heath and Intercommon Heath, is a tumulus. Heath.

Levington (lxxxiii, 6 and 7).-Tumuli are situated on Levington

Martlesham (1xxvi, 6, 7, 10, and 12).-Many tumuli are scattered over Martlesham Heath, and others to the south on Brightwell Heath. Another on Waldringfield Heath.

Mildenhall (xxi, 6).-On Warren Hill, north of the road to Bury, a group of bowl-shaped barrows called the 'Three Hills,' $70 \mathrm{ft}$. in diameter s d $9 \mathrm{ft}$. high ; formerly-according to Salmon-these were surrounded by th ches. They were opened in 1875 and the interments were found to be Yumation, and orientated; many implements of iron were unearthed.

Nacton (lxxxiii, 2).-The 'Seven Hills' were a group of tumuli on 5 hight's Heath ; all but three have been levelled, and of those, one situated . In the course $3 / 3$ 'field Comandy soil, of which it is composed, for garden purposes, a quantity oi sin' isottery has been found, but, considered as rubbish, the potsherds have been yet further broken to make a garden path. This tumulus has been of bowl-form, $9 \mathrm{ft}$. high at the apex. Another, in a plantation, covers a large area and is $6 \mathrm{ft}$. high ; and the third, in an adjacent coppice, is of smaller proportions. One of the latter is said to have been explored, but no results were obtained.

Norton (xlv, 3).-A tumulus is in the grounds of Little Haugh Hall, the name of which is suggestive.

Risby (xxxii, I6; and xliii, 3).-Tumuli are upon Risby Poor's Heath and also to the east of it. The remains of another lie near the Newmarket road, north of Barrow Bottom and of the railway.

Rovgham (xlv, 9 and 13 ).- Two Roman tumuli have here been explored. The smaller of them was opened by Prof. Henslow in I 844 , and the contents-as near as possible arranged as when found-are now in the museum at Bury. 'East Low Hill' is a large tumulus $25 \mathrm{ft}$. high, its longer axis lying north and south. A tunnel was pierced from the northern side and $50 \mathrm{ft}$. from the outer edge the tomb was discovered; raised on a platform and covered by a 


\section{A HISTORY OF SUFFOLK}

rounded vault of Roman bricks was a leaden coffin ; this with its contents was deposited in the Fitzwilliam Museum at Cambridge. Two other tumuli near the same spot have been destroyed.

SNAPE $(1 x, 9)$.- Tumuli abound by the side of the Roman road from Aldeburgh, through Snape; this is especially noticeable on Church Common. Several large barrows formerly stood near Snape Priory, but they have been levelled, among them a most interesting ship-barrow, wherein the position of the iron bolts gave the dimensions and form of the original vessel; relics of gold, of glass, and of onyx, of the Norse burial were found; above them the cinerary urn and articles of an early British interment had been placed. These relics are now in the possession of Mr. A. J. Swinburne of Snape Priory.

Sutton (lxxvi, 4).- 'Sutton Haugh' is a name now generally applied to a group of twelve tumuli situated high above the left bank of the River Deben, opposite the town of Woodbridge. These are bowl-shaped barrows; the moct northern is over $40 \mathrm{ft}$. in diameter at the base and rises to $8 \mathrm{ft}$; t the next olie to it is small, being only $4 \mathrm{ft}$. 10 in. in height ; another, with a diameter $78 \mathrm{ft}$. and a height of $7 \mathrm{ft}$. 4 in., has been cut through. One of oval $\mathrm{f}_{\mathrm{r}} \mathrm{nt}^{\circ}$ $80 \mathrm{ft}$. long by $50 \mathrm{ft}$. broad attains a false height of $18 \mathrm{ft}$. by the throwin of the earth in an unsystematic exploration.

Troston (xxii, I 6).- Three tumuli are on Troston Heath, one of ${ }^{\text {att }}$ being called 'Black Hill.'

W ALbERswick (xxxix, 4).-A tumulus is on 'Tinker's Walks,' a artle south of the railway. Age.

WANGForD (xii, 7).-On Wangford Warren are tumuli of th's a group

Westleton (xxxix, 8).-A tumulus lies to the west of Fen Cona d $9 \mathrm{ft}$. $r$ of Newdelights Walks.

Westley (xliv, 6) - -On Shire House Heath, between the rer lumatiol Risby Gate and North Gate of Bury, is a tumulus called Henhowe, $r$ NAC1 made the Hill of Judicature when the local court was transferred frcs light's I hill in 1305 . Other tumuli in the northern part of the paris' dug ove explored; one opened in 1883 was of the Neolithic Age, another ove,ied in I 884 contained a large Celtic cinerary urn, and another at Westley Bottom contained Roman remains.

WORDWELl (xxii, 14).-A tumulus lies in a field to the south of Chalk Lane, west of Culford Heath hamlet.

Worlington (xxxi, 4).-A tumulus is in the midst of a clump of fir trees on the west of the road, north-east of Redlodge Warren. 


\title{
ANCIENT EARTHWORKS
}

\section{N D E X}

\author{
OF THE
}

\section{Parishes IN which Earthworks ake situated, with the LetTer of tha}

\section{Class to Which they Belong}

\begin{tabular}{|c|c|c|c|c|c|c|c|c|c|c|c|c|c|c|}
\hline & & Pari & ith & & & & Class & & & Parial & & & & Clans \\
\hline Acton . & - & - & & - & - & - & $3 F$ & Cavenham & - & - & . & - & - & $\mathbf{X}$ \\
\hline Alderton. & . & & & - . & - & - & $F$ & Charsfield & - & - & . & . & . & $2 \mathrm{~F}$ \\
\hline Aldringham & wit & & & ipe & . & - & $2 T$ & Chediston & . & . & . & . & . & $3 \mathrm{~F}$ \\
\hline Ashbocking & $\cdot$ & . . & - & .. & - & - & $C, 2 \mathrm{~F}$ & Chevington & - & - & - & - & - & $\mathrm{C}, 2 \mathrm{~F}, \mathrm{G}$ \\
\hline Ashfield . & - & . & . & . & . & . & $2 T$ & Chillesford & . & . & . & & . & $2 T$ \\
\hline Aspall . & . & - & . & • & . & - & $F$ & Chilton . & . & . & . & - & * & F \\
\hline Athelington & & - & . & • & - & - & $3 F$ & $\begin{array}{l}\text { Clare . } \\
\text { Claydon : }\end{array}$ & : & . : & . & . & . & C, $\underset{F}{E}, T$ \\
\hline Bacton . & $\cdot$ & - & - & . & - & - & $8 \mathrm{~F}$ & Cockfield & . & . & . & : & i. & $2 F, X$ \\
\hline Badingham & & - & . & • & . & . & $2 F$ & Coddenham & . & . & . & . & . & $2 F, X$ \\
\hline Badwell Ash & & • & & • & . & - & $2 \mathrm{~F}$ & Combs . & • & $\cdot$ & - & · & . & $\mathrm{D}, 3 \mathbf{F}$ \\
\hline Bardwell . & & - & & • & • & - & $\mathrm{F}, \mathrm{T}$ & Cotton . & . & . & . & - & . & $6 \mathrm{~F}$ \\
\hline Barh & - & - & . & • & . & - & $\mathbf{F}$ & Cowlinge & . & - & - & - & - & $7 F$ \\
\hline Barking . & & . & . & . & . & . & $F$ & Cratfield . & & . . & . & . & . & F, X \\
\hline Larnardiston & & • & & • & - & . & $2 \mathrm{~F}$ & g St. & & ary . & - & - & - & $4 F$ \\
\hline pop prningham $^{\text {rnat }}$ & & • & & . & . & . & $\mathbf{F}$ & Creeting St. & Pet & ter. & . & . & - & $F$ \\
\hline Of row. & & - & - & . & . & . & G & gham & - & . . & . & . & . & $\mathbf{F}$ \\
\hline $\begin{array}{l}\text { ham } \\
\text { hallnape Mill }\end{array}$ & & - & . & • & . & . & $\mathbf{F}$ & wfield & - & - & - & - & - & $2 F$ \\
\hline $\begin{array}{l}\text { hallnape Mill } \\
\text { malt }\end{array}$ & & . & & • & . & . & $F, T$ & Culford . & . & - & - & • & - & $\mathbf{T}$ \\
\hline na $\int_{\text {put }}^{\text {ford }}$ & . & - & - & • & - & - & $\mathrm{F}$ & Culpho . & & - & - & • & - & $\mathbf{F}$ \\
\hline Sufputi im . & $\cdot$ & • & : & · & • & . & ${ }_{F}^{2 F}$ & & & & & & & \\
\hline samputt & $\dot{0}$ & . & . & . & 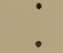 & . & $3_{3 F}^{F}$ & Dallinghoo & - & - & - & - & - & F \\
\hline the out lold & & • & . & . & 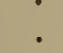 & . & $\begin{array}{l}3 \mathrm{~F} \\
4 \mathrm{~F}\end{array}$ & Darsham. & - & - & - & - & - & F \\
\hline $\mathrm{No}_{\text {outh }}^{\text {outh }}$ & . & . & . & . & . & . & $T$ & Debenham & . & . & . & . & . & $7 \mathrm{~F}, \mathrm{~T}$ \\
\hline mopext 11 & . & • & . & • & - & . & $\mathrm{F}$ & Denham . & . & - & . & . & . & $2 \mathrm{~F}$ \\
\hline & . & - & - & • & - & . & $\mathrm{F}$ & Dennington & & . & . & . & . & I I F \\
\hline & . & - & - & • & . & - & $\mathrm{T}$ & Depden . & . & - & - & . & - & $\mathbf{F}$ \\
\hline$d^{\tan r_{i}}$ & . & • & - & . & • & & $\mathbf{F}$ & Drinkstone & - & . & . & . & . & $2 F$ \\
\hline Boxte & & & & . & . & - & $2 \mathrm{~F}$ & Dunwich & • & - & . & - & - & $T$ \\
\hline Bradfield C & ombr & & & . & . & . & $2 \mathrm{~F}$ & & & & & & & \\
\hline Bradfield St. & $\mathrm{Cla}$ & are & & - & - & . & $2 F$ & oham & & & & & & \\
\hline Bramfield & . & . & . & . & . & . & C & tonhar & & : & . & . & . & $\mathrm{F}$ \\
\hline Brampton & . & . & . & . & . & . & $6 \mathrm{~F}$ & East Bergho & & . & . & . & . & $\mathrm{F}$ \\
\hline Bredfield . & & • & . & • & • & . & $C, 2 F, X$ & Easton & & . & . & . & . & $2 \mathrm{~F}$ \\
\hline Brent Eleig & & - & - & - & . & - & $F$ & Edwardstone & & . & . & . & . & $F$ \\
\hline Brettenham & . & - & - & - & - & - & $C,{ }_{4} \mathrm{~F}$ & Elmsett . & & • & . & . & . & $3 \mathrm{~F}$ \\
\hline Brockley . & - & - & . & • & - & - & $5 F$ & Elmswell & . & - & . & . & . & F \\
\hline Brome & $\cdot$ & • & - & • & - & - & $2 F$ & Eye . . & - & - & - & $\cdot$ & • & $\mathrm{E}, 3 \mathrm{~F}, \mathrm{\gamma}$ \\
\hline $\begin{array}{l}\text { Bruisyard } \\
\text { Brundish. }\end{array}$ & : & . & • & • & & - & $\underset{6 F}{F}$ & & & & & & & \\
\hline lesham & & • & . & . & & ${ }^{\circ}$ & $\mathrm{T}$ & Fakenham & Mag & na . & - & - & & \\
\hline Bun & & - & . & . & . & . & C, E & Felsham. & & - . & . & . & . & $8 \mathrm{~F}$ \\
\hline Bures St. M & Iary & & . & . & . & & $F$ & gham & & - & . & . & . & $\mathrm{C}, \mathrm{F}$ \\
\hline Burgate . & . & & & & . & . & $2 F$ & Flempton & & . & . & . & & $\mathrm{T}$ \\
\hline Burgh (near & $r W$ & ood & lbric & dge) & & . & $C, D, 5$ F & Flixton & & . . & . & . & . & $3 \mathrm{~F}$ \\
\hline Cast & de ( $n$ & lear & & armo & uth) & . & C & Fornham Al & & aints & . & . & . & $F$ \\
\hline Bury St. Ed & dmur & nds & & . . & . & . & $\mathrm{X}, \mathrm{T}$ & Fornham St & & eneve & eve & . & - & $\mathrm{T}$ \\
\hline Buxhall . & & & & • & · & . & $3 F$ & linghar & & - . & - & - & - & E \\
\hline & & & & & & & & & & . & - & - & & $4 F$ \\
\hline & lville & & - & - & - & $\bullet^{\circ}$ & $\mathbf{F}$ & Fressingfield & & . & . & . & . & $9 \mathrm{~F}$ \\
\hline dish & - & & & & - & . & $4 \mathrm{~F}$ & Fritton . & - & - & - & - & - & $T$ \\
\hline & & & & & & & & & & & & & & \\
\hline
\end{tabular}




\section{A HISTORY OF SUFFOLK}

\section{INDEX (centinued)}

Pariah

Gazeley

Gedding

Gisleham

Gislingham

Gosbeck .

Great Ashfield

Great Barton

Great Bradley

Great Bricett

Great Cornard

Great Finborough

Great Glemham

Great Thurlow

Great Waldingfield

Great Welnetham .

Great Wenham

Great Wratting

Groton

Hacheston

Hadleigh .

Halesworth

Hargrave

Hasketon

Haughley

Havergate Island

Haverhill

Hawkedon

Hawstead

Helmingham

Hengrave

Henham .

Herringfleet .

Herringswell

Hessett

Heveningham

Hintlesham .

Hitcham .

Honington

Hoo .

Horham :

Horningsheath

Hoxne

Hundon

Hunston

Icklingham

Iken

Ilketshall St. Andrew

Ilketshall St. John .

Ilketshall St. Margare

Ixworth

Ixworth Thorpe

Kedington

Kelsale

Kentford

Kenton .
Class

E, F, $4 \mathrm{~T}$
$2 \mathrm{~F}$
$2 \mathrm{~F}$
$\mathrm{~F}$
$\mathrm{~F}$
$\mathrm{D}, 3 \mathrm{~F}$
$\mathrm{~F}, \mathrm{G}, \mathrm{T}$
$\mathrm{F}$
$\mathrm{F}$
$\mathrm{F}$
$\mathrm{F}, \mathrm{T}$
$\mathrm{F}$
$2 \mathrm{~F}, \mathrm{G}$
$2 \mathrm{~F}$
$\mathrm{~F}, \mathrm{X}$
$\mathrm{F}$
$\mathrm{F}$
$\mathrm{D}, \mathrm{F}$

F

T

$\mathrm{T}$

F

$2 \mathrm{~F}$

$\mathrm{E}, 2 \mathrm{~F}$

$\mathrm{X}$

C, F

F, G

G, $\mathrm{T}$

F

F

F

$\mathrm{T}$

3F

F

$2 \mathrm{~F}$

$\mathrm{T}$

$2 \mathrm{~F}$

$2 \mathrm{~F}$

$6 \mathrm{~F}$

F

$\mathrm{D}, \mathrm{F}$

C, $\underset{T}{T}, 2$

$2 \mathrm{~F}$

E

$4 \mathrm{~F}$

F

F

F

$\mathbf{F}$

$\mathrm{T}$

$4 \mathrm{~F}$
Parish

Class

Knettishall

Lackford . . . . . . T

Langham . . . . . . F, X

Lavenham

Lawshall .

Laxfield

Layham

Letheringham

Levington

Lidgate

Lindsey

Linstead Magna

Little Bradley

Little Finborough

Little Glemham

Little Saxham

Little Stonham

Little Thurlow.

Little Waldingfield

Little Welnetham

Little Wratting

Long Melford

Market Weston

Martlesham

Mellis

Mendham

Mendlesham

Metfield .

Mettingham .

Mickfield

Milden

Mildenhall

Monewden

Monks Eleigh

$\mathrm{F}$

$6 \mathrm{~F}, \mathrm{X}$

$6 \mathrm{H}$

F

$2 \mathrm{~F}$

$T$

E

E, X

$\mathrm{F}$

F

Fxt

$\mathrm{F}, \mathrm{t}$

F $\mathrm{f}$

Fn

F

$3 \mathrm{~F}$,

$\mathrm{F}$ ath

3 F, rtle

F $n$ I $S$

T MILIS

$3 \mathrm{~F}$ rroup

$5 \mathrm{~F}$ ft.

3 Fies.

$\mathrm{F}$, (matior

${ }^{3}{ }^{\mathrm{F}} \mathrm{N}_{\text {ACI }}$

$\mathrm{F}$, Tht's I

$\mathrm{F}$

Monk Soham

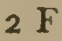

Nacton

$\mathrm{T}$

Naughton

Nayland with Wissington

Nedging

North Cove

Norton

Nowton

$3 \mathrm{~F}$

$3 \mathrm{~F}$

F

C

F, T

Occold

$3 \mathrm{~F}$

Offton

D, F

Old Newton

$3 \mathrm{~F}$

Onehouse

Orford

D

Otley

E, $5 \mathrm{~F}$

Pakefield.

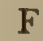

Pakenham

F

Parham

$2 \mathrm{~F}$

$\mathrm{F}$ 


\section{ANCIENT EARTHWORKS}

\section{INDEX (continued)}

\begin{tabular}{|c|c|c|c|c|c|c|c|c|c|c|c|c|c|}
\hline \multicolumn{6}{|c|}{ Pariah } & Class & \multicolumn{5}{|c|}{$\begin{array}{l}\text { Parish } \\
\end{array}$} & \multicolumn{2}{|r|}{ Class } \\
\hline Pettaugh . & • & & - & - & - & $3 \mathrm{~F}$ & Tannington & & - & - & - & & $4 \mathrm{~F}, \mathrm{G}$ \\
\hline Pettistree & - & & - & - & - & $F$ & Tattingstone & . & - & . & . & & $\mathrm{F}$ \\
\hline Playford . & . & & - & - & - & $\mathbf{F}$ & Thorndon & & - & . & - & . & $8 \mathrm{~F}$ \\
\hline Polstead . & - & - & - & - & - & $\mathbf{F}$ & Thornham P & Parva & . & . & - & - & $F$ \\
\hline Preston . & & & - & - & & $2 F$ & Thorp Morie & eux & - & - & - & - & $4 \mathrm{~F}$ \\
\hline & & & & & & & Thrandeston & & - & - & - & & $2 \mathrm{~F}$ \\
\hline Rattlesden & . & & - & . & . & F & Thwaite. & - & - & - & - & - & $3 F$ \\
\hline Rede. & - & & - & - & . & $F$ & Troston . & - & - & - & - & & $\mathrm{T}$ \\
\hline Redisham & - & & - $\cdot$ & $\cdot$ & - & $\mathrm{D}, \mathrm{X}$ & & & & & & & \\
\hline Redlingfield & & & - & - & - & F & Ufford & - & - & - & - & - & $\mathbf{F}$ \\
\hline Rendham & & & . & . & . & F & & & & & & & \\
\hline Rickinghall & Sup & erio & . & . & . & $F$ & Walberswick & & . & . & - & . & $\mathrm{T}$ \\
\hline Ringshall & . & • & - & . & . & $4 F$ & Walsham le & Will & ows & . & . & . & $2 \mathrm{~F}$ \\
\hline Risby. & . & • & - & . & . & $2 T$ & Wangford . & . . & . & - & . & . & $\mathrm{T}, \mathrm{X}$ \\
\hline Rishangles & - & • & . & . & - & $2 F$ & Wantisden & . & . & . & . & . & $\mathrm{F}$ \\
\hline Rougham & - & & - & - & - & $3 \mathrm{~F}, 2 \mathrm{~T}$ & Washbrook & . & . & - & - & . & $2 \mathrm{~F}$ \\
\hline Rumburgh & - & $=$ & - & - & . & $3 \mathrm{~F}$ & Wattisham & . & . & - & . & . & $F, G$ \\
\hline rooke & & & . & - & . & $F$ & Westhall. & . & - & . & . & . & $3 \mathrm{~F}$ \\
\hline & & & & & & & Westhorpe & & . & . & . & & $2 \mathrm{~F}$ \\
\hline $\begin{array}{l}\text { ngfield } \\
\text { land. }\end{array}$ & & • & . & . & . & $2 F$ & Westleton & - & - & - & - & . & $\mathrm{F}, \mathrm{T}$ \\
\hline land. & & • & - & . & · & $2 \mathrm{~F}$ & Westley & . & - & - & . & . & $\mathrm{T}$ \\
\hline at $\mathrm{th}^{2 \mathrm{y}}$ & - & - & - & . & . & F & Wetherden & · . & $\cdot$ & - $\therefore$ & ; & - & $3 \mathrm{~F}$ \\
\hline $\begin{array}{l}\text { pling } \\
\text { populay }\end{array}$ & - & . & . & . & & $3 \mathrm{~F}, \mathrm{X}$ & Wetheringset & tt cur & & & ord & . & $3 \mathrm{~F}$ \\
\hline $\begin{array}{l}\text { populay . } \\
\text { Of th }\end{array}$ & . & . & . & . & & F & Weybread . & - & - & . & . & - & $3 \mathrm{~F}$ \\
\hline Of th & . & - & . & . & . & $\mathrm{F}$ & Whatfield & - & - & - & - & . & $3 \mathrm{~F}$ \\
\hline ha $\left.\right|_{\text {buth }} ^{\text {nape }}$ Elmh & . & in & $\therefore$ & . & . & $T$ & Whepstead . & . . & . & . & . & . & $5 \mathrm{~F}$ \\
\hline mouth Elmh & & & Saint & & . & $4 \mathrm{~F}$ & Wickhambro & & - & . & . & . & $4 \mathrm{~F}$ \\
\hline moth Elmh & am & St. & Cross & & & $C, 2 F$ & Wickham M & larket & . & . & . & . & $F$ \\
\hline Suputh Elmh & lam & St. & Marg & aret & & $2 F$ & Wilby . & . . & . & - & - & - & $5 \mathrm{~F}$ \\
\hline sarputh Elmh & Iam & St. & Mich & ael & & $F$ & Willingham & . & . & . & . & . & $F$ \\
\hline h Elmh & am & St. & Nich & olas & & F & Willisham & . & . & . & . & . & $F$ \\
\hline th outh Elmh & lam & St. & Peter & & . & $F$ & Wingfield & . & . & . & . & . & $3 F, G$ \\
\hline$N_{\text {butholt }}$. & . & . & . . & . & . & $2 F$ & Winston . & . & . & . & . & . & $F$ \\
\hline mipexhall . & . & . & . & . & . & $F$ & Wissett & . & . & . & . & . & $F$ \\
\hline niproughton & & . & . & . & . & F & Withersfield & - & . & . & . & . & $2 F$ \\
\hline - Stanningfiel & & • & . & . & . & F & Witnesham & • & . & . & . & . & $2 F$ \\
\hline Stansfield & $\bullet$ & . & . . & . & . & F & Woodbridge & - & . & . & . & . & $X$ \\
\hline Stoke Ash & . & & . . & . & . & $2 F$ & Woolpit . & - & . & . & . & . & $\mathrm{F}$ \\
\hline Stonham A & spall & & - & . & . & $3 \mathrm{~F}$ & Wordwell & - & - & . & . & . & $T$ \\
\hline Stoven . & & - & . . & . & . & $F$ & Worlington & . & . & . & . & . & $\mathrm{F}, \mathrm{T}$ \\
\hline Stowlangtof & & . & . . & . & . & $\mathrm{C}, 2 \mathrm{~F}$ & Worlingwort & th. & - & . & . & . & $3 \mathrm{~F}$ \\
\hline Stowupland & . & . & . & . & . & F & Wortham & . . & - & - & . & . & $\mathrm{F}$ \\
\hline Stradbroke & . & • & . . & . & . & $8 \mathrm{~F}$ & Wrentham & - & . & . & - & . & $\mathbf{F}$ \\
\hline Stradishall & . & . & - . & . & - & $F$ & Wyverstone & - & - & - & - & - & $2 F$ \\
\hline Stuston . & - & - & - & - & - & F & & & & & & & \\
\hline Sudbury . & . & - & - & - & - & F & Yax & - & - & & & & $\mathrm{F}$ \\
\hline Sutton - & - & & - . & • & & $\mathrm{C}, \mathrm{X}, \mathrm{T}$ & Yoxford. & . & - & . & . & . & E, \\
\hline
\end{tabular}





\section{OCIAL AND ECONOMIC HISTORY}

\section{PART I}

T the time of the Conquest Suffolk was perhaps (excluding Middlesex) the most densely populated county in England. The persons of all classes mentioned in its Domesday Survey number 20,491. Larger numbers are recorded in the case of Lincoln and Norfolk,
creage of these counties is more than proportionately greater. The population was moreover as remarkable for its quality as for its quantity. Of the 12,423 freemen recorded in Domesday, ${ }^{1} 7,460$, or more than half, were in Suffolk. Of socmen, whose status differed from that of freemen mainly in their inability to sell their land without the lord's permission, Suffolk had 1,060. These two classes taken together constituted about the same proportion to the rest of the population in Norfolk as in Suffolk, and the same is true of the disappearing class of serfs who numbered 995 in Norfolk, and 909 in Suffolk. There were, however, about four thousand more villeins and cottars in Norfolk than in Suffolk, where the villeins only numbered 2,8I4, and the cottars (bordarii) 6,226, making together considerably less -nan half of the whole. Throughout England as a whole, and iin most of the separate counties, the villeins and cottars were more than twothirds of the recorded population. Both the larger numbers and the superior status of the men of Suffolk, Norfolk, and Lincolnshire, must be mainly attributed to the accident of geographical position. The successive waves of invasion aturally left a richer deposit of settlers along the eastern coast, and the .efeated race left a smaller remnant in that region to swell the ranks of 'rfdom.

It may be inferred from what has been said that the typical holder of nd in Suffolk was the freeman of small estate. The larger manors of everal hundred acres, cultivated with the assistance of a score of villeins and if one or two serfs, were to be found indeed in all parts of the county, and ccounted for the greater part of the soil, but they by no means dominated very township as in most parts of England, nor did they contain the majority of the cultivators of the soil. There were many small manors which had lone of the economic characteristics associated with the name, containing, as hey did quite commonly, only 30 acres, the usual size of a villein holding

${ }^{1}$ F. W. Maitland, Dom. Bk. and Beyond, 19-20; Ellis, Introd. to Dom. ii, 469-70, 488-90, 5 I I-I4; .. Ballard, The Dom. Surv. $114,264$. 


\section{A HISTORY OF SUFFOLK}

on a large manor, and being cultivated by the labour of the himself, with the help at most of a single cottar. ${ }^{2}$ Apart holdings of freemen and socmen were of every size from hundred or more, but the average holdings were very small, as, and probably smaller than, the average villein holding, though $\mathrm{HC}$ are given of the latter. We may take a rough example from Thin. Hundred, where the villeins and serfs were more numerous than usual. average of eleven manors gives about four carucates to the manor, wit 8 villeins, 7 cottars, and 4 serfs to cultivate it. On these eleven manors the villeins numbered 92 , the bordars 80 , and the serfs 45 . In the same district there were 149 freemen and socmen holding land, the acreage of which wa. a little more than two-thirds of that of the eleven manors. One of these held two carucates, another one, but the average holding was only about twenty-three acres. To assist in the cultivation of their land they had 8 villeins, 84 bordars, and I 3 serfs. ${ }^{3}$

The relations of the freemen and socmen with small holdings to their superior lords presented a great many varieties. Even before the great change effected by the Conquest they had been exhibiting an increasing degree of dependence, and this tendency was now accentuated. Let us take a single township in the midst of a district largely inhabited by freemen : the hundred of Hertesmere. There were no less than five tenants-in-chief interested in Gislingham, and under them forty-one freemen had holdings which varied in size from one acre up to thirty. Before the Conquest seven of the smaller holders had been driven by the insecurity of the times to place themselves under the protection of Ulwin, the lord of the neighbouring manor of Burgate and of much other land in Suffolk. A group of three freemen, who owned 53 acres, and had a freeman under them with I acre, had commended themselves to another neighbouring Saxon lord. Two other groups of six and four, possessing 13 and 10 acres respectively, had commended themselves severally to two freemen of their own township who held 30 acres apiece as manors. But the Conquest had borne heavily upon these small lords of manors. They had lost all their plough-cattle, and were themselves in need of protection. There was a manor of the larger kind in Gislingham. It had 240 acres as against 295 held by the freemen, but it had only two bordars to assist in its cultivation. It was natural that the lord of this manor and the freemen seeking protection should be drawr together. The two small manors and presumably the two groups of dependen freemen commended themselves to the larger manor, and another group of eight freemen owning 16 acres did the same."

The depression in the status of freemen and of socmen which had begu? before the Conquest but was accentuated by that great change was not always due to voluntary commendation. In the new distribution of lordship the rights of small holders were often ignored. Bracton tells us at a later date that at the time of the Conquest freemen who were ejected by stronger people came back and received the same lands to be held in villeinage, and by villein

Maitland, Dom.Bk. and Beyord, $117-18$.

${ }^{3}$ Sufolk Dom. Thingoe Hundred. The Latin text exterded and translated. By John H. The calculations are my own-G. U.

'Dom. Bk. ii, fol. $322 a, b, 440 a, 444 b$. 
offer favour

\section{SOCIAL AND ECONOMIC HISTORY}

hecome for hich were specified and certain." And in the Domesday record villing to find many freemen added to manors, and some paying custom enur ${ }^{\prime}$ 10rd's bailiff where none was paid before. At that time or in the century stsh $\mathrm{h}^{\text {at }}$ followed we find them losing the right to sell or give their land. In aralle of all this, the class of freemen remained a very large one in Suffolk. ttra nearly every village in the county men of free status were living along

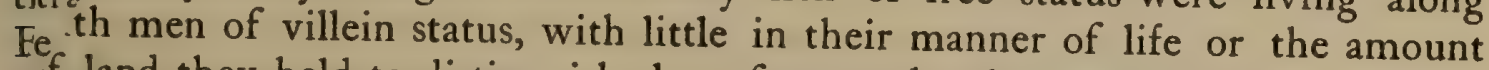
of land they held to distinguish them from each other, and this was a factor of the greatest importance in the social development we are about to trace.

In that development the towns naturally led the way. Suffolk had not, and never acquired, any town of the first rank, but 738 burgesses and 178 poor men are enumerated in six centres of trade and industry exclusive of Bury. At the time of the Conquest Dunwich with its 440 householders was the most flourishing of these, in spite of the fact that the incursions of the sea, which were to prove its destruction, had already begun. Its prosperity, which was maintained for another century, was mainly due to the herring fishery, which was carried on all along the coast from Dunwich to Gorleston and Beccles. The Abbot of Bury had a 'sea-hedge' at Southwold, and derived a rent of 25,000 herrings from his manor there. The herring rents of Beccles and Dunwich were each 60,000 , and many villages several miles inland had to provide a quota of one or two thousand yearly for their lord's use. It was here that industrial influences were first brought to bear on the social life of Suffolk. Ipswich at the time of the Confessor had had $53^{8}$ burgesses, but it had suffered terribly during the Conquest, and in 1087 it had only 210 , of whom 100 were too poor to pay more than a penny of taxation. Of the markets recorded in Domesday an exceptionally large number were in Suffolk. They are mentioned at Eye, Hoxne, Sudbury (where there was also a mint), Beccles, Clare, Haverhill, and Caramhall, besides a fair at Aspall. ${ }^{8}$

Nowhere is the process of transition from serfdom to freedom more clearly displayed than in the early history of Bury St. Edmunds as preserved for us by the admirable Jocelyn de Brakelonde. ${ }^{9}$ Originally the townsmen of Bury held their houses and their land from the abbot on servile conditions. They were obliged to plough a rood of their lord's land for every acre they occupied themselves. At harvest time they must give their services in reaping his crops, and assist along with their oxen in carrying them to the barn. At night they must drive their sheep and cattle into the lord's fold in order that his lands might be enriched with the manure. Once a year each householder must make a journey of 14 miles to Lakenheath, and spend a day catching eels for the cellarer. Before the end of the I 2th century most of these services were redeemed by a bargain profitable to both parties for a money payment. Instead of the eel-catching, which might easily prove unprofitable if the sportsmen were as unwilling as the eels, each holder of 30 acres was to pay a penny (the price of a day's work) and remain at home.

- Vinogradoff, Villainage in England, $12 \mathrm{I}$.

i Dom. Bk. ii, 331, 331b, 404b, $410 a, b$; Maitland, Dom. Bk. and Beyond, 62.

'W. J. Corbett and T. T. Methold, 'Rise and devolution of Manors in Repworth,' Suff. Arch. Inst. vol. x.

- Mon. Bk. il, $3196,379,2866,3696,389,428,3306,418$. 'Mem. of St. Edmund's Abbey (Rolls Ser.), i, 299-305; The Chrom. of Jocelin of Brakelond (ed. Sir E.
Clarke), (1903), $150-16 \mathrm{I}$. 


\section{A HISTORY OF SUFFOLK}

In the same way the service of reaping was commuted for an ann called rep-silver, the carrying service for a tax of $2 d$. on each 30 acre 'aver-peni,' whilst the obligation for bringing cattle to the lord's fold was by a payment of a penny for every cow per year called 'sor-peni.' But Bury became a busy and populous town and the holdings changed har were divided, or sublet, the assignment and collection of these dues beca increasingly difficult. In the uncertainty as to who was liable, it was ea for the richer burgesses to evade payment, and the abbey official foun himself reduced to levying the tax on the poorer householders by distraining such of their movables as lay to his hand. This method of collection led to disturbances and bad feeling in the town, and cannot have yielded much profit to the abbey. When therefore the townspeople offered to compound for rep-silver by the payment of a fixed sum every year, the abbot, "considering the undignified way in which the cellarer used to take distresses in the houses of the poor, and how the old women came out with their distaffs threatening and abusing the cellarer and his men, ordered that 20s. should be given every year to the cellarer at the next portmanmoot before August' by the burgesses through the hands of the bailiff in discharge of rep-silver. A quittance was also given for the payment of sor-peni in consideration of $4 s$. payable at the same term, which was a pure gain to the abbey as the burgesses had for some time successfully repelled the attempts of the cellarer to seize the dunghills before their doors, and each householder had acquired a prescriptive right to use or sell his own.

There was indeed no practical object to be gained by enforcing agricultural service on a body of townsmen, but the comparative ease with which the men of Bury got rid of this element of villeinage was due to their possessing an organization capable of bargaining with the abbot and of standing to the bargain when made. The question was how far should this new organization be allowed to carry its claims to an independent existence. The rights of the town as a borough had been in some sort recognized by previous abbots since the beginning of the 12 th century, and more explicitly by the charter of Abbot Anselm, ${ }^{10}$ but for the most part they were being acquired by the steady encroachments of custom. From the monks' point of view the burgess tenants in Bury were still to be distinguished from the villeins of the abbey only by the few privileges mentioned in the charter, and the new sources of revenue opened up by the growth of the town were entirely at the disposal of their lord. They might be tallaged or their merchandise taxed at his pleasure. The rents of their stalls and shops might be made a rack-rent. Their numbers might be increased by the admission of the abbey's suburban tenants to share all the advantages of the town's trade without bearing any of its burdens. Their markets were to be regarded as in the first place a source of supply to the abbey, which was to have the right of first purchase at a lower price than others. And finally, their municipal officers were to be considered as servants of the abbey. ${ }^{11}$

Such claims involved a complete negation of the rights which the free towns of Western Europe were at this time winning for themselves, and the men of Bury found it impossible to acquiesce in them. Their town was fast

${ }^{10}$ Published by J. H. Round in American Hist. Rev. ii, 688.

"Mem. of St. Edmund's Abbey (Rolls Ser.), i, 279-80, 304. 636 


\section{SOCIAL AND ECONOMIC HISTORY}

not already become, the wealthiest and most populous in

th industry, which was destined to transform the social as already established there, and a little later Bury was its leading cloth manufacturer. ${ }^{12}$ The yearly fair of ated by the merchants of London, ${ }^{13}$ who could buy in its Vicus Francorum the costly wares of Flanders and III wished to replenish his wardrobe and the wardSella with a set of furred robes of scarlet and black nnics, over-tunics, and mantles wrought in the looms of rres, he issued his mandate to William the royal tailor to go - uper person and bargain for them in Bury Fair. ${ }^{15}$ The enterprise such a centre of trade could not flourish if the management of its affairs ere to be controlled from the chapter-house and if every extra shilling of fofit were to be held on sufferance at the will of the abbot.

In point of fact the burgesses had practically established themselves in a certain degree of independence. They chose their own bailiffs, though they might go through the form of presenting them at the abbey, and when the bailiffs had paid a fixed farm of $f_{4} 40$ they considered themselves entitled to let the shops and stalls in the market-place to the best advantage of the town. They would not allow the abbot's servants to be free of toll in the market unless they were selling his produce or buying for his use. If they dealt for their own profit they must belong to their merchant gild. They had, moreover, their borough court or portmanmoot, presided over by those who were nominally the abbot's servants, but who were really their own elected magistrates, and the wardship of minors went not to the lord of the borough, but to the next of kin. ${ }^{16}$ Such was the situation in the time of Abbot Sampson (1 $82-1211$ ), who was statesman enough to perceive the futility of trying to enforce on a vigorously growing community the letter of a legal arrangement that was becoming obsolete. For the sake of pacifying the monks he insisted on the bailiffs receiving the horn of office from the prior, but he left them in unfettered exercise of the office, was ready to meet the townsmen in their attempts to get rid of feudal obligations, and even promoted a compromise by which those tenants of the cellarer who lived outside the town gates might share in one of the chief privileges of the borough. The monks had no sympathy with these concessions. They thought the farm of the town should be raised. When rep-silver and sor-peni were commuted, the convent took it in ill part, and Benedict the sub-prior, answering for all in the chapter, said, "That man, Abbot Ording, who lies there would not have done such a thing for five hundred marks of silver.' ${ }^{17}$

The rights and privileges which in the case of Bury were only conceded partially, implicitly, and with reservations that boded a future of stubborn conflict, were at the same time in the towns that had no lord except the king being achieved much more fully and explicitly by the grant of a royal charter. In the reign of John-a great epoch of municipal enfranchisement-and both in the same year of 1200 , Ipswich and Dunwich received

13 Fulk de St. Edmund, to whom there are many references in Letter Bk. A of the London records.

is Men. (Roll Ser.), i, 278.

16 Cal. Close, $1231-4$, P. 4 .

11 Harl. MS. 27.

"Ibid. i, 300 .

${ }^{16}$ Mem. (Rolls Ser.), i, 277, 281 . 


\section{A HISTORY OF SUFFOLK}

charters as free boroughs with the right of farming the self-government through their own elected magistr jurisdiction in their own courts in accordance with and finally of exercising the powers of a merchant $g$ manner in which the men of Ipswich, with a meth marked their sense of the greatness of the occasion, $s$ their new institutions, has often been told $:^{18}$ the choi coroners, and twelve chief portmen; the assembling c the churchyard of St. Mary at Tower to swear allic, constitution; the separate choice of an alderman and four asi the merchant gild; the making and authorization of a common sua, codification of the customs of the borough in the 'Domesday of Ipswich What we are here concerned with-the social and economic aspects of th new development-find their chief expression in the constitution of th merchant gild as a separate organ of municipal government with officers records and accounts of its own, of which every full burgess was to be a member, but every member of which need not be a full or resident burgess.

Nothing, indeed, could be more significant of the great change which had been brought about by the recognition of the borough as a free selfgoverning community than the terms upon which the most powerful of these foreign burgesses were admitted to a share in its privileges. Foremost in the roll comes Lord Roger le Bigod, Earl of Norfolk and Marshal of England, who was installed as a burgess in the hall of the prior of St. Peter soon after the charter was granted.

He gives to the merchant gild an ox and a bull, two quarters of wheat and two quarters of malt, in order that he and his villeins may be free of toll in the town, viz., on all corn and other things produced on his own estates and on all things bought for the use of his own household and not otherwise. And he shall pay annually for ever at the feast of St. Michael iiiid. for his quay at Ipswich towards the farm of the town, but nevertheless if his villeins are merchants they shall pay to the farm of our lord the king their right and due custom ... and the same day Robert de Vaux knight of the said earl was made a burgess and he gives to the hanse of the gild a quarter of wheat, and in order that he and all the villeins whom he has at Wenham and elsewhere may be free of toll at Ipswich in the manner aforesaid he agrees to give every year . . . iiiis. and two bushels of wheat. ${ }^{19}$

And about the same time the question having arisen how far certain religious houses having lands and tenements in the town ought to be free of toll, a jury declared that the Archbishop and Prior of Canterbury, the Bishop and Prior of Norwich, the Bishop and Prior of Ely, the Abbot of Colchester, and the Abbot of Coggeshall were free to sell their produce or buy for their own use. If their villeins were merchants they must pay toll. The issue involved in this settlement was of vital importance. It was one of the main positions round which the struggle for municipal freedom was then being carried on in many continental towns, and at Bury it remained for more than two centuries one of the bitterest subjects of contention between the abbot and his town. ${ }^{20}$

Having thus made themselves masters in their own house, the burgesses of Ipswich could afford to welcome the outsider into their market, and might

${ }^{10}$ Gross, Gild Merchant, i, 23-6 ; Pollock and Maitland, Hist. of Engl. Law, i, 658, 664 ; Mrs. Green, Town Life, ii, 224-5.

19 Hist. MSS. Com. Rep. ix, App. i, 240 ; Gross, Gild Merchant, ii, 113.

${ }^{20} \mathrm{~F}$. Keutgen, Aemter und Zünfte, 60-3. 


\section{SOCIAL AND ECONOMIC HISTORY}

offer favourable terms to the lords of neighbouring manors who wished to hecome foreign burgesses, or even accept them as full burgesses if they were illing to be 'at scot and lot' with the townsmen. The contribution levied nually upon foreign burgesses varied a little, but was generally $4 d$. and two shels of wheat for the larger proprietors, and $2 d$. and one bushel for a ialler proprietor. Those who desired to be 'at scot and lot' paid an trance fee of four or five shillings to the town, and one or two shillings to e bailiff. In this way the town not only absorbed into its life as a free smmunity the originally alien elements within its own walls, but also became intre of a territory comprising most of the four surrounding hundreds of ere and Claydon, Sampford, Carleford, and Colneis, which owed it a of alleziance. The Priors of Holy Trinity and St. Peter, who had tes both in town and country, became full burgesses in I 244, and their tcessors took a leading part in organizing the religious activities of the erchant gild, whilst during the latter half of the $13^{\text {th }}$ century at least a core of the lords of the landed gentry within a ten-mile radius had attached themselves to Ipswich as out-burgesses, and promised to give aid and counsel in its affairs. ${ }^{21}$ In order to appreciate the civilizing mission of the town we have only to turn our attention to the feudal anarchy by which it was surrounded. In the Hundred Rolls of I 274 we find ourselves treading everywhere the live embers of recent strife. At Bentley, for instance, the homage of Sir Hugh Tollemache and the homage of Holy Trinity of Ipswich present a verdict that the death of Jordan of Copdock was hastened by the assault of Robert of Copdock and of John of Copdock, and the homage of Sir Hugh Tollemache in Copdock agree in this verdict. On the other hand the juries of Sproughton, Belstead, Albemarle, Hintlesham, Capel, Raydon, Brantham, ? Parva Belstead, and John le Barun and his homage in Copdock itself, aeclare that Jordan died a natural death and not from the assault of Robert. ${ }^{22}$ All the townships here mentioned lie in the hundred of Samford within a few miles of Ipswich, and at the very moment when local feeling was running high over this family affair, Sir Hugh Tollemache, John le Barun, and Robert de Copdock paid their first contributions as foreign burgesses of the town.

The earliest detailed accounts of manorial organization in Suffolk belong to the end of the $13^{\text {th }}$ century, but though many changes were in process of realization, the essential framework of the rural economy was sufficiently stable from the IIth to the I $4^{\text {th }}$ century to justify our using these accounts as a starting point for our study of the period. The chief economic features

the manorial system were the communal methods of cultivation and the rents rendered by the villein to his lord. All the arable land of the was divided into several portions (generally three), each of which lay in turn, was sown with two different crops in rotation and then left $w$ again. The holdings of each tenant, and generally of the lord's sesne also, consisted of acre or half-acre strips scattered about these open . $u$ ds, no two of them together, and each divided from a neighbour's strip by 5 parrow balk. No separate access was possible. The whole had to be sughed, sown and reaped at the same time, and after harvest it was turned to a common pasture. Sometimes there was meadowland, distributed in

"The Great Domesday Book in Ipswich Town Hall ; Hist. MSS. Com. Rep. ix, App. i, 240.

For " Hund. R. (Rec. Com.), ii, 175-6. 


\section{A HISTORY OF SUFFOLK}

lots before the hay-harvest and afterwards thrown open, and generally there were pasture and wood in which lord and tenants had common rights. Th demesne, or portion directly under the lord's management, was original cultivated almost entirely by the labour due from his villein tenants. Duri the busiest portion of the year, each holder of a villein tenement had devote several days a week to ploughing, sowing, and reaping his lord's lar. and to carrying the crops. During autumn he was liable to be called up for the additional service of 'boon-days' or precariae. Free tenants a socmen sometimes rendered services of this kind, but they are exceptional al small in proportion to the money rent which represented the bulk of ' obligation. The molman occupied an intermediate position. $\mathrm{He}$ villein who had been freed from the greater part of his services in cons tion of a money rent.

These conditions were common to the whole of England. What peculiar to the eastern counties, and especially to Suffolk, was the lar. number of small freemen who, though they tended to be subordinated to th manorial system, could not be completely absorbed by it, and who by their semi-independent status reacted strongly upon it so as to loosen its structure at a comparatively early date. As the free holdings, never very large, grew smaller by subdivision, the tenants would furnish an easily available source of labour, and thus make the lord more inclined to allow the services of his villeins to be commuted for money. In this way the villein, who very frequently held more land than the free tenant, tended to become assimilated to him in personal status.

It will be well to examine the normal working of the manorial organization in a few typical cases before following the gradual process of its dissolution. The manor of Hadleigh, held by the Prior of Christchu ', Canterbury, of which we have a full account in I 304 , seems to have unuungone surprisingly little change since Domesday. About a hundred acres were held in small holdings by a number of free tenants, about a third of the rest was held by the lord in demesne, and two-thirds was parcelled out among the villein tenants in what had originally been 27 uniform holdings, probably of 24 or 30 acres apiece. The farmhouse of the demesne stood between the high road and the river, surrounded by 4 acres of curtilage, herbage, and a garden in which apples, pears, and grapes were grown. There was a windmill and a water-mill, one for milling cloth, the other for corn, which together brought in annually $\delta_{0} g s .8 d$., a dove-house, and a small quantity of separate pasture, meadow, and wood.

The lord had the right to let out four score sheep on the c. pasture, and to fish the common fishery. The arable land of this dem. various fields amounted to 327 acres valued at $8 d$. an acre. 'And eac. of suitable land can be sown with $2 \frac{1}{2}$ bushels of corn, with $2 \frac{1}{2}$ bushe. siliga, with 2 bushels of peas and beans, and with 4 bushels of oats, 4 bushels of barley. And each plough ought to be yoked with 4 oxen : 4 heifers, and the plough can commonly plough one acre of land at the le [a day].'

Each tenant of a full villein holding at Hadleigh had to plough 6 acr a year for his lord, 3 in winter for corn, and 3 at Lent for oats and barle Five of the 6 acres were called 'gafolearth,' and had to be sowed an 


\section{SOCIAL AND ECONOMIC HISTORY}

harrowed as well as ploughed, the other acre, called 'benearth,' was supposed to be thrown in out of the tenant's goodwill. The tenant also owed seven days work between Michaelmas and Pentecost, in which seven days the lord might expect him to thresh 2 quarters of corn or 4 of barley. During the busy summer months he must provide five days' labour a week. The villein tenants amongst them must reap I 75 acres. They must spread, lift, and toss the dung on the lord's meadow when cut, and each must do four days' carting. For the harvesters food was found. Two men had 2 loaves ( 32 loaves to the quarter of wheat), 6 herrings, a quantity of ' morterell,' 'potage,' and cheese. On the first day they had water to drink, and beer or cider on the second. ${ }^{23}$

The size of these holdings is not given in the Survey. The ordinary virgate of 30 acres is found in Suffolk, but a virgate of 24 would seem to have also been common. In many places some of these full holdings were split up by the lord into half or quarter holdings. This, as we shall see later, was the case at Hadleigh. At Hawstead there were customary holdings of 30,15 , and $7 \frac{1}{2}$ acres; ${ }^{24}$ at Elmswell of 24,12 , and 6 ; and at Soham of 24, I 2,6 , and 3 , each with a proportionate set of customs. ${ }^{25}$ There were also full yardlands of 16 acres each at Lidgate. ${ }^{26}$

An extent taken of twelve Suffolk manors of the Abbot of Bury ${ }^{27}$ about the year 1300 shows that the customary services differed very widely from one manor to another even under the same lord. The amount directly assessed in money varied from nothing to a quarter of the yearly value. The number of acres to be ploughed by the holder of 24 acres varied from 2 to 10 , and the ploughing of an acre was generally valued at $4 d$. Reaping also was valued at $4 d$., but it was more generally merged in the sum of works demanded. If each of these works represented a day, the tenant would have had no time to till his own acres. At Melford, for example, each tenant of a virgate owed 312 works a year, but as these were only valued at 3 a penny, they cannot have represented more than a few hours' labour apiece. The more usual price of a work was a halfpenny, and of a full autumn day's work a penny. Reducing the works to full days at a penny, we find the number of days required from the holder of 24 acres in four different manors was 104 , $69,3^{8}$, and 30 . Sometimes the work is specified in quantity, as the threshing of so many quarters of oats or barley. A couple of hens at Christmas and a dozen eggs at Easter are almost invariably demanded. It seems likely that a great part of these services were being commuted. Their estimated value added to the money payment generally brings up the total rent of the land to something between $4 d$. and $6 d$. an acre, and this was the value set on the demesne land.

The services so far mentioned were villein services. Freemen seem as a rule to have rendered an exclusively money rent. But 48 free tenants at Redgrave rendered amongst them in addition to $\oint_{0} 5 \mathrm{I} 8 \mathrm{~s}$. in money, $8 \frac{1}{2}$ quarters of oats $\left(8 s .6 d_{\text {. }}\right), 8$ hens $\left(8 d_{\text {. }}\right)$, I duck $\left(2 \frac{1}{2} d_{\text {. }}\right), 2$ capons $\left(3 d_{\text {. }}\right), 53$ eggs $\left(1 \frac{1}{2} d_{0}\right), 6$ pinughings ( $1 s .6 d$.), 20 works ( $10 d$.), 6 weedings ( $3 d$.), reapings (I $2 d$.$) , and$ 5 plougi, shares (is. $3 d$.). At Rickinghall i 4 molmen owed besides a money

${ }^{3}$ An extent of tis manor of Hadleigh in Suff. Arch. Inst. xi, pt. $\mathrm{x}$.

"Copy of an extent of Hawstead in 1358 , kindly lent me by Mr. E. Powell.

25 Add. MSS. 13849 . 23 See post, p. 663.

"Reg. Thomas Abbatis, Ha-1. MSS. 230. The manors are Melford, Chevington, Hargrave, Saxham, Fornham, Elmswell, Brockford, Woriingworth, Redgrave, Soham, Rickinghall, and Culford. 


\section{A HISTORY OF SUFFOLK}

rent $33^{\frac{1}{2}}$ quarters of oats at Iod. a quarter, 79 hens, 340 eggs, 89 days' carrying, and 80 mornings' work; while another 40 molmen at the same place had each to do three ploughings, receiving from the lord 4 loaves, 8 herrings, and 24 eggs as food, and also to do among them 140 weeding works. At Fornham Io cottagers who held an acre apiece rendered $\mathrm{r} O d$. for each acre as bedrep-silver and had to weed 30 acres of corn $\left(\frac{1}{2} d\right.$. an acre) and reap 30 acres (at $3 d$. an acre), which works out at the extraordinary rate of is. $8 d$. an acre.

The average value which is assigned to the arable land in the demesne of these twelve manors is $4 d$. an acre. Meadow is commonly valued at is. $6 d$. and pasture at is. Of the wood a portion varying from a seventh to a fifteenth is allowed to be cut each year, and this is valued at from is. $6 d$. to $2 s$. an acre. It appears to be implied in the language of the 'extent' that the demesne in several cases was actually rented out at these prices. This would seem to have been a necessity when the demesne comprised, as in several cases, more than half the land of the manor. Even if all the services due from the villeins had been exacted they would not have sufficed. Such renting out of the demesne must have played a large part in the break-up of the manorial system. Wind and water-mills contributed a not inconsiderable amount to the manorial receipts. The mill of Saxham was worth ros., that of Fornham 20s., that of Rickinghall 30s., and that of Redgrave $\oint_{6} 6 \quad \mathrm{I} 3$ s. The market of Botesdale, which was attached to Redgrave, brought in $f_{0}$, and that of Bungay was valued in 1270 at $f_{0} 6 \mathrm{I}^{\mathrm{s}}$. $4 d$., and its two fairs at $f_{0} 4 \mathrm{r} 3^{s} .4 d^{28}$ The annual value of pleas and perquisites was on the average about I 0 s., but at Melford it was 40 s., and at Redgrave 60 s.

A striking example of the action of the economic forces which were gradually remoulding the status of the population as exhibited in the conditions of land tenure is furnished in the account which the Hundred Rolls give of the manor of Gorleston, which was included in the half-hundred of Lothingland, and was reckoned as 'ancient demesne.' In Edward the Confessor's time, when the Earl Gurth held it, there were twenty villeins attached to the manor, but when the Domesday Survey was made these had been reduced to twelve. ${ }^{29}$ The manor remained in the King's hands from the Conquest till the reign of Henry III, by which time the villeins had again increased to twenty. The total amount of land held by them was $25^{8}$ acres, and it would seem to have been originally divided into lots of 12 acres, since fifteen of the holdings were still of this size, while one was of 24 acres, another of 35 , two others of $8 \frac{1}{2}$ and $4 \frac{1}{2}$, and one of 6 acres. The King's bailiff received $29 s$. $3 d$. as annual rent from these 'bondmen,' but this hardly represented half the value of the land to the King. The villeins also paid $22 s .4 d$. every year in place of the customary services which they owed on the royal demesne. ${ }^{30}$ Before the middle of the I $3^{\text {th }}$ century they had ceased to perform these services, and were giving their whole attention to their own land, much as if they were freemen. What still marked them as villeins was the equality of their holdings, which passed undivided from father to son $\backsim r$ to whatever successor the lord might appoint. There can be no duubt that the holdings were divided into strips, probably of half an acre each, distributed over several large open fields which were cultivated according to a course common to the whole village. But each holding of 12 acres, though

${ }^{2}$ Suckling, Hist. of Suff: i, 120.

${ }^{29}$ Dom. Bk. ii, 283. 


\section{SOCIAL AND ECONOMIC HISTORY}

it might be physically cut up into as many as 24 scattered bits, was legally one, and had usually one holder. The natural tendency to subdivision of holdings with an increase of population, which would have found a wider expression in case of free tenure, had led to two of the holdings being represented by groups of partners, and apparently to the actual subdivision of a third.

During the reign of Henry III this situation underwent an entire revolution. Each of the former holdings is now represented by a number of tenants, several by three or four, others by eight, ten, or a dozen, one by a score. The successors of the original holders have generally retained one or two acres of each holding, and assumed the right of letting out the rest. Many of the new tenants hold only a cottage, a rod of land, or one or two half-acres. The population of Gorleston as a prosperous fishing village has obviously increased, much more than doubled, and at first sight it looks as if small holdings had become universal.

On closer examination of the list, however, a new and still more interesting fact emerges. The strips thus sub-let in any one holding are taken generally each by a separate tenant, but a number of these tenants have also taken strips in other holdings. Sometimes half a dozen of these new tenancies are under the same name, and the name is generally that of a descendant of one of the original holders of 12 acres. A single instance will serve to illustrate the process that has been going on. A certain John Bond was one of the villeins holding 12 acres in the time of Henry III. His son has let 2 acres to Matilda Bond, I acre to Thomas le Palmer and Alicia his wife, and $2 \frac{1}{2}$ acres to Margaret, widow of Roger Ruffi. He has let small plats of land for building purposes to eight persons, who now hold five messuages and four cottages upon them. In John Bond's own occupation there can hardly be left more than five or six of his original 12 acres. But while he has been letting to others he has been entering upon new tenancies himself. $\mathrm{He}$ has three half-acre strips from the holdings of three different neighbours, 3 rods from a fourth, I acre from a fifth, two lots of $I_{2} \frac{1}{2}$ acres each from a sixth and a seventh, and another piece of unspecified size from an eighth, of the original holdings. ${ }^{31} \quad$ The amount of land in his occupation is therefore almost exactly the same as at first. But why should he have abandoned his compact ancestral holding to replace it by this multifarious tenancy of fragments? There seems but one answer possible. The compactness of the ancestral holding was on paper only; the land itself was scattered about the village in probably as many as twenty-four pieces. He has abandoned half of these in order that he might build up a more compact estate round the other half by adding to them the strips of his neighbours that lay on either side of his own in the open fields. And several of his neighbours have been doing the same. So that in place of a few holdings of uniform size held on servile conditions and cultivated on uneconomical principles, we have a great increase of small holdings, the growth of compact holdings affording more scope for enterprise and capital, and in both cases the servile conditions have all but disappeared.

Yet so great is the power of custom that more than three centuries later the framework of the original system is still clearly discernible behind all the changes of tenure and subdivisions of property. In the reign of Elizabeth

"Hund. R. (Rec. Com.), ii, 167-8. 


\section{A HISTORY OF SUFFOLK}

there still assembled at the Court of Ancient Demesne held annually Gorleston eighteen 'Chievers' who represented the original tenants of $\mathrm{te}^{\text {ual }}$ I 2-acre holdings, and who were responsible for the collection of the sami sum of $4 \mathrm{I} s$. for rent and in commutation of service which the king's bailiff had demanded in the $\mathrm{I}^{\text {th }}$ century; and what is more remarkable still is that in one case, and probably in most, the identity of the original holding, now a mere legal figment, is preserved under the name of the last tenant who held it undivided three centuries before. ${ }^{32}$

The accident of being 'ancient demesne' secured to Gorleston a freer play of economic forces which were nevertheless everywhere at work, as will be seen if we take a case where the conditions were entirely different. ${ }^{3 s}$ What the herring fisheries were to Gorleston, the woollen industry was to be to Hadleigh. In another century it would be a flourishing town. In I 305 this development was only in its beginnings, but already the population was rapidly growing, and there was a brisk demand for land. The economic tendency towards the break-up of uniform holdings was the same as it had been half a century earlier at Gorleston. Indeed one of the Hadleigh villeins ventured to dispose of his holding in the same manner as John Bond and the rest had done. He let out a fifth of his land to another, and even sold two plots for messuages. The lord's bailiff acquiesced in this, but when the lord heard of it, he pointed out that the villein had gone beyond his rights and that any disposal of the land required the lord's consent.

At Hadleigh in 1305 the 27 villeins of Domesday were represented by $26 \frac{1}{2}$ holdings, four of which had been converted into a special class of eight half holdings called 'Monday lands,' which were held by those who acted as the lord's overseers and answered for his outgoings. The Monday lands were so called from the day on which labour was required, and they had a special set of services. Of the $22 \frac{1}{2}$ ordinary holdings $3^{\frac{1}{2}}$ had been at an early date split into 'half lands,' and one into 'quarter lands'; so that apart from the eight Monday lands there were 29 villein estates, if we may so call them, in Hadleigh in I 305 . With a few exceptions a uniform set of rents and services was required from each full holding, and half of these from a half land. Each of these 'estates' - whether a whole land, a half land, a quarter land, or a Monday land-bore a name generally derived from a family who had occupied it for generations, and on the side of its obligations to the lord it had a strict legal unity. This, as we have just seen, was insisted upon by the lord for the excellent reason that he might, if this unity of responsibility were broken up, lose the services to which he was entitled. But on the side of possession and use this unity and uniformity had entirely disappeared. Only one of the holdings, a 'half land,' was occupied by a single tenant. Generally there were five or six, sometimes nine or ten, and in one case as many as twenty tenants to a single holding. In many cases-it is almost the rule-several of the co-tenants bear the same family name, and in about a third of the holdings there are among the tenants some who bear the same

Suckling, Hist. of Suff. i, 362 .

${ }^{33}$ From the Subsidy return of 1327 it would appear that both Hadleigh and Gorleston were in the second rank of Suffolk towns. The number of taxpayers (probably about one-tenth of the population), which was 210 at Ipswich and 155 at Bury, 204 at Beccles and 169 at Sudbury, was 73 at Hadleigh and 76 at Gorleston, 74 at Kessingland, and 69 at Orford. It was only 48 at Stowmarket, and 43 at Woodbridge, and 33 at Aldeburgh. 'Suffolk in 1327 ' Suff. Green Bk. no. ix, vol. ii. 


\section{SOCIAL AND ECONOMIC HISTORY}

name as the land. To some extent therefore the subdivision has been a matter of inheritance and family arrangement. But the obvious outsiders are far too numerous for this explanation to be adequate to the $\mathrm{v}^{\text {h }}$ )le situation. Moreover the tendency towards subdivision is not the only influence ai work. The tendency towards aggregation is also observable. As at Gorleston, a great many have tenancies in more than one of the original holdings, some in three or four. It is highly improbable, therefore, that the original uniform holding, which was the legal unit, remained also the economic unit, i.e. that the co-tenants cultivated the original holding in common. Their partnership was only a sharing of a common obligation to the lord. Each occupied separate strips belonging to one of the original sets of strips which made up a villein's holding, and as he prospered he acquired the adjacent strips belonging to another set. ${ }^{34}$ The hypothesis at any rate is a tempting one, and it is strengthened by what we learn of the rest of the prior's land at Hadleigh. Besides his villein tenants he had free tenants, a few of whom owed services, but the great majority of whom paid a purely money rent. Here there is no uniformity in the holdings, but there is much subdivision and aggregation going on, and there are many co-tenancies arising often out of partible inheritance. But the striking thing is that the men whose names appear most often as partners in villein holdings are tenants or co-tenants of the largest amount of free land.

The fact that many freemen were occupying land on a villein tenure seems to show that the special economic conditions originally associated with villein tenure were on the point of passing away. But the prior had still another kind of land at his disposal, i.e. the 300 acres of arable in his demesne, and out of this he was creating new tenancies, some of which suggest further economic developments. Richard the Smith, who is already one of ten co-tenants in one villein holding, one of eight in another, and one of four in a free co-tenancy, builds a forge on the demesne for which he renders a plough-share worth $6 d$. every Christmas, and pays a rent of Iod. for a 'certain way' next to his messuage. Vincent the Fuller, who occupies a third of a former freeman's holding in arable land, pays a rent of $12 d$. for a messuage and $6 d$. for a dye house on a demesne. He also takes a small piece of land, eight perches by two, for which he pays $18 d$., and which is very likely a drying ground for his cloth; and there are two men with foreign names living in cottages of which he is a co-tenant and has probably had built for them. There are three other fullers occupying land in Hadleigh, and a fourth who is co-tenant in cottages. ${ }^{35}$

One more example may be taken, where the circumstances were entirely different from either of the foregoing cases. The village of Hawstead had remained, what it still is, an entirely agricultural community, and at the time of the Conquest its landholders had been mainly freemen, of whom there were thirty occupying some 500 acres among them. They could give and sell their land, but were commended to the abbot and under his jurisdiction. There were also two large estates of two carucates and one carucate respectively and three villeins and twenty-one bordars who helped to cultivate them.

It is probable, however, that the common course of cultivation was still preserved, and that each tenant had access to his strips for the purpose of ploughing, reaping only at fixed times along with all the other tenants. 33 'An Extent of the Manor of Hadleigh,' Suff. Arch. Inst. xi, pt. i. 


\section{A HISTORY OF SUFFOLK}

In 1289 these two holdings were manors in the hands of Thomas Fitz Eustace and William Talmache, except that 80 acres of one of them were inherited by Philip Noel. But what in the meantime has become of the thirty freemen whose holdings on the average were about 17 acres apiece? There is one freeman holding 20 acres, there are two holding 18 , three 15 , and nine others who hold from 3 to 9 acres. These fifteen hold about I 50 acres among them. There are a dozen with only one or two acres, and another dozen who hold messuages without other land. The rest of the 500 acres is in the hands of four men: William de Cramaville, Richard de Saxham, Robert de Ros, and John le Beylham, and the way in which they are held reveals something of the process of their accumulation. John le Beyiham holds 30 acres of arable besides wood and pasture from the abbot direct, and perhaps we may assume that this was his original holding. He has taken over the entire holdings of three freemen, amounting to 12 acres, 5 acres, and 2 acres of arable respectively; and then, no doubt because he found them intermixed with his own acquisitions, he has rented 3 acres from the large manorial holding of William Talmache. Robert de Ros has increased the 40 acres he held from the manor of Thomas Fitz Eustace by 12 acres taken over from Edward de Welnetham and 5 acres from Robert de Beylham; but he has let out 9 acres to William de Cramaville, as well as small plots to others. William de Cramaville holds I 5 acres from the abbot directly, and 7 acres from the inherited estates of Philip Noel, and, besides the 9 acres rented from Robert de Ros, he has acquired a freeman's entire holding of 16 acres. On the other hand he has let out 20 acres to the fourth of our group of accumulators, Robert de Saxham. Robert de Saxham holds 27 from the abbot directly and besides the additional 20 acres rented from William he has taken 15 of Edward de Welnetham's acres and $9 \frac{1}{2}$ of Robert de Beylham's as well as small lots belonging to six other freemen amounting to 21 acres, making a total of 93 acres.

This method of building up an estate must not be thought peculiar to the larger holders. A free tenant of I 5 acres holds land from five different sources; others of 15 and of 9 acres hold land from four sources. In short the evidence points to a universal breaking up and reconstruction of the free holdings, and it cannot be doubted that the resulting distribution of land amongst the freemen exhibited much more inequality than had existed before. The freemen are considerably more numerous than those recorded in Domesday, but four of them hold two-thirds of the land. Another change must be noted. The number of villein holdings has increased. Domesday records three villeins, twenty-one bordars, and two serfs. But in 1289 there were at least a dozen villein tenancies comprising 180 acres on one of the two manors and 32 acres on the other. ${ }^{36}$

The researches of $\mathrm{Mr}$. Edgar Powell ${ }^{87}$ and of $\mathrm{Mr}$. Redstone, ${ }^{88}$ taken together with the Domesday Book of Ipswich, ${ }^{39}$ make it possible to form a

${ }^{36}$ Harl. MSS. 743, printed with some omissions in Cullum's Hist. of Hawsied, 84-8. The account thus given of Hawstead is derived from an Itinerary, a sort of later and lesser Domesday made of the lands of the Abbey of Bury by Solomon de Roff and his colleagues, in the reign of Edward I. Even a brief examination of this important document, which gives details only of free holdings, shows that in many respects Hawstead is a representative case. The numbers of free tenants are everywhere increasing, but the size of most of the holdings is exceedingly small. The round numbers given by this survey are of doubtful accuracy.

${ }^{37}$ The taration of Ipswich for the Welsh War in 1282 in Proc. Suff. Arch. Inst. vol. xii, pt. ii.

39 'The 'Chaucer Malyn Family, Ipjwich,' in Proc. Suff. Arch. Inst.xii. ${ }^{39}$ Black Bk. of Admiralty (Rolls Ser.). 


\section{SOCIAL AND ECONOMIC HISTORY}

fairly complete picture of the condition of the town at the beginning of the I 4 th century. At that time the population must at least have numbered I, 500 , and was probably greater. The subsidy roll of 1282 contains the names of some 280 householders, and in 1377 , in spite of the intervening Black Death, the poll tax returns give the number of persons over fourteen years of age as 1,507 . Although the life of the place centred round the quay and the markets, the agricultural basis of the community had by no means disappeared from view. Live stock and grain were the largest and most widely distributed components in the wealth of the inhabitants. More than a score of the burgesses owned horses, one having as many as eight, others four, and the rest one or two, whilst most of these had also carts or carriages. Some of the more well-to-do had yokes of oxen, a great number had cows, and many even of the poorest kept a pig or two, poultry being rather less common. Wheat, barley, oats, and malt were naturally the most universal form of property. In most cases no doubt they constituted merely a household provision, but the large quantities held in store by the leading burgesses must have been for the purposes of trade, and it is to be noted that several of them possessed a large stock of millstones. But the relations of the town to the agriculture of the district were far closer than is indicated by any list of its inhabitants. The lords of the neighbouring manors had, as we have already seen, received from the first a certain share in its privileges as foreign burgesses. Within a radius of ten miles more than a score of villages sent in their produce free of extra toll to be sold in the town's market. The leading inhabitant, Philip Harneys, supplied a kind of link between the town and this outlying part of its economy, being lord of the manor of Ashe in Bosmere. The inventory of his town movables admirably illustrates the transitional character of urban economic activity at this time. ${ }^{40}$ Of the total of $f_{0}$ I I 7 about $£ 20$ were represented by his furniture, plate, and linen, the contents of his wardrobe, larder, and cellar ; $£_{3} 30$ were invested in white and grey millstones and other stones and in handmills; the rest of his capital was pretty equally divided into three portions, one consisting of farm produce and live stock, another of ships and boats and of the materials for their repair, and the third of merchandise imported for the purpose of trade, such as iron and steel, Scotch hides, timber, and wine. This mingling of interests was common to most of the wealthier burgesses. Less than half a dozen of them had movables to the value of over $f_{6} 5^{\circ}$, and these together with about a score of others whose goods were valued at $£_{0} 20$ and upwards constituted no doubt the ruling class in the borough."

Nearly thirty burgesses had capital invested in ships and boats, the largest amount being $£ 35$ and the smallest 5 s. The boats were valued at

${ }^{10} \mathrm{He}$ possessed in corn and malt 20 marks; in timber and building materials 15 marks; in oxen and swine 5 marks; in horses $3 \frac{1}{2}$ marks ; in white and grey millstones and other stones 40 marks ; in salt $8 \mathrm{~s}$. ; in iron 50s.; in steel 20s.; in pitch 20s.; in boards 40s.; in cups and plate (jocalibus) to marks; in woollen and linen cloth 10 marks; in earthenware 20s.; in fish and herring 10s.; in ships and boats 20

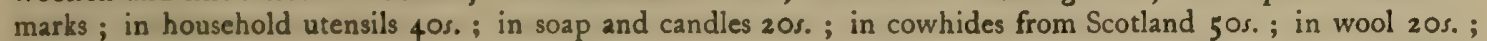
in hand mills 4 marks; in wine 20 marks; in canvas $40 \mathrm{~s}^{2}$; in wine $22 \mathrm{~s}$. ; in fleshmeat I mark; total 6.117. The Tax. of Ipsewich, 11 .

"A fairly exact idea of the relative wealth of Suffolk towns about this time can be obtained from the Subsidy Roll for 1327, which has recently been published by Mr. Hervey in one of his Suffolk Green Books. The taxation of the whole county $\left(\frac{1}{8 \delta}\right)$ amounts to $\oint_{1} 1,082$ 17s.; that of Ipswich to $\oint_{0} 295 \mathrm{~s} .5 \mathrm{~d}$.; that of

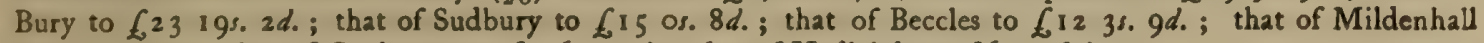

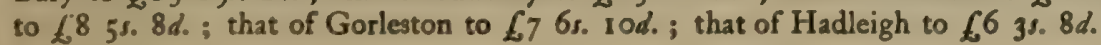




\section{A HISTORY OF SUFFOLK}

from 5 s. to $\oint_{0} \mathrm{I}$, whilst a ship might be worth anything from $\oint_{0} 4$ to $£_{\mathrm{I}} \mathrm{O}$, or in a few cases more. Even if we multiply these sums by fifteen to get somewhere nearer to modern values, it is clear that most of the Ipswich vessels can only have been small coasting craft. The kind of vessel that may have been owned by the largest capitalist is shown by an account of a barge built in I 294 at Ipswich for the king's use. This cost $£_{0} 237$ s., about $f_{0} 7$ of which was spent in timber and boards; $£_{3} 36 s .8 d$. in carpenters' wages; f.3 I Is. 9 d. in iron, $\mathrm{r}, 000$ small nails and the wages of smiths; and about $f_{9} 9$ in pitch, sails, sheets, steadings, coverings, thirty oars and a rudder. A much larger ship built as a man-of-war at the same time cost fig5, and took over twenty-one weeks in building. ${ }^{42}$ This suggests the possibility that as some of the poorer burgesses are stated to have shared the ownership of a small boat, some of the wealthier ones may have been partners in a larger vessel than any that is represented in a single inventory. A little later we certainly find Ipswich shipowners supplying means of transport for the wool of English merchants to Flanders, and Ipswich merchants trading with German goods between Flemish and French ports.

At this time, however, most of the trade of Ipswich with the Continent was carried on in Dutch and Flemish ships, and the prosperity of the town was felt to depend on the presence of the foreign merchant. This is shown by the various provisions of the Domesday code which aim at securing just dealings and speedy settlements in all bargains made between burgesses and strangers. Cases dealt with in the town court under the 'law merchant' in which strangers were involved were not to be adjourned like local cases for a fortnight, but pleaded ' from day to day and from hour to hour as well forenoon as after,' and the bailiffs were armed with special powers of distraint against an Ipswich merchant who proved a defaulter in regard to a bargain made with a foreigner. The preamble of this last ordinance forcibly expresses the sense which the good men of the town had 'of the wickedness and the folly of such buyers men insufficient and of evil feith who be envyous covetise or by defaut of goode advysement . . . haven embrased bargaynes and bought goodys and merchaundysys comyng into the forseid town . . . and wykkydly agens law and good faith in esclandre of the . . good men therin dwellyng han delayed merchaundes of ther payment, wherefore straunge merchaunts oftentyme withdrawen ... and that to the grievous damage of the town and of all the cuntre aboutyn.' 43

The trade both inward and outward was very largely in food and drink and raw material. The grain and wool, the butter, cheese, and beer exported were balanced by wine, almonds, figs and raisins, fish of all kinds both cured and fresh, woad, ashes, copperas and alum, oil, tallow, pitch and salt, the leather and iron of Spain, the timber of Ireland and Norway, and the wines and salt of France. But a trade in manufactured goods was not wanting. The cloth made in the neighbouring towns of Coggeshall, Maldon, Colchester, and Sudbury, as well as that brought from Beverley, Lincoln, and London, was exchanged for the more costly fabrics of Flanders, the silks of Italy, the cutlery of France and Germany. ${ }^{44}$

${ }^{2}$ Hist. MSS. Com. Rep. ix, App. i, 258.

"Dom. of Ipswich. The translation here given was made in the 15 th century.

"Ipswich Dom. Bk. I $8 \mathrm{I}-5$. 


\section{SOCIAL AND ECONOMIC HISTORY}

Amongst the Ipswich burgesses who engaged in this foreign trade the tendency to specialize in one or other branch of commerce had not proceeded very far ; and indeed it was never destined to go as far in Ipswich as in larger centres of trade. The merchant was a combination of grocer, vintner, draper, and ironmonger, and varied his investments according to his opportunities. There were, however, about a dozen traders the bulk of whose capital was invested in mercery, about half a dozen who had a considerable stock of skins, and Thomas le Spicer had spices to the value of 10 marks. ${ }^{45}$ Many burgesses held a quantity of cloth which was evidently in excess of their household requirements, but Hugo Golding, the wealthiest burgess after - Iilip Harneys, was the draper par excellence, having $£_{06} 6$ of a total of $£_{0} 92$ invested in cloth of various kinds. ${ }^{46}$ Richard Topy must also be reckoned as a draper, since $\oint_{0} 20$ out of $\oint_{0} 27$ was in his case represented by cloth; whilst in Roger le Neve with $\oint_{0} 12$ invested in cloth and $\oint_{0} 6$ in mercery we have the type of merchant in whose hands lay most of the English cloth trade at this period. ${ }^{47}$ William Strik ${ }^{48}$ and William Smith possessed stocks of iron of the value of $£_{0} 7$ and $£_{4} 4$ respectively, Bernard the dyer ${ }^{49}$ had imported woad and ashes to the value of $\mathscr{f}_{0} 7 \mathrm{IOs}$., and an alewife held $300 \mathrm{lb}$. of salt worth $\oint_{6} 6$ i 5 s.

There is little sign in the Subsidy Roll of 1282 of the development of handicraft at Ipswich, with a single exception, that of the tanning industry. About a dozen tanners are mentioned with capital varying from Ios. to $f_{0} 7$ (besides the skinners already referred to), four or five shoemakers, a parchment maker, and a glover. There are also enumerated six blacksmiths, one goldsmith, a carpenter, a capper and a maker of catapults. At first sight the cloth industry seems to be very inadequately represented, though the fact that four dyers are named and only two weavers suggests the probability that cloth woven in the country districts was brought to be finished in the town. But it is extremely likely that many of the richer burgesses who are mentioned as having stocks of cloth and wool and fuller's earth gave out materials to the poorer inhabitants who had too little property to find a place on a subsidy roll. This supposition is rendered almost a certainty by the evidence of an ordinance in the Ipswich Domesday Book which forbids any burgess to take as gage of a money debt, or as a pledge for victuals, any cloth or combed wool white or dyed, or flax or hemp or woollen or linen thread from poor weavers, women wool combers or spinners, tailors, tailoresses or laundresses or other poor ' catyvys,' when there is a reasonable suspicion that the goods so offered are the property of some other person..$^{50}$

For the most part, however, Ipswich in the I $4^{\text {th }}$ century was less a centre of industry than a combination of market, town, and port, where half a dozen different currents of trade found a focus. The grain and dairy produce of Suffolk came week by week to Cornhill and Butter Market, on the spot where the old names still survive, and its live-stock and butchers' meat to the Flesh Market or Cowerie, on the site of which Tavern Street grew up, and to the Hen Market or Poultry which ran at right angles to the Flesh Market in the direction of the Tower Ramparts. The wool and skins of many counties came to the Wool Market. In the Fish Market were found

\footnotetext{
is The Tax. of Ipswich, 10.

${ }^{43}$ Ibid. IO.
}

45 Ibid 6.

3 Ibid. 12.

649
"Ibid. 9.

- Dom. Bk. of Ipswich, 133. 


\section{A HISTORY OF SUFFOLK}

the salmon of Suffolk rivers, the shell-fish of its estuaries, the herrings of its coasts, and the cod and mackerel, sturgeon and whale brought by the men of Dunwich or of Gorleston from the North Sea or from Iceland. In the Cloth Market, the Timber Market, and in Mercery Row the foreign merchant met not merely the Ipswich trader, but many others who came from inland towns to bargain with him there. ${ }^{\text {II }}$

The main business of the town was thus to act as a broker between foreigners and upland men, and between these two sets of outsiders and the burgesses. But this function was far too profitable to be effectively retained, as the law required, in public hands. The town's prosperity brought into existence a class of middlemen, and it was from this class that the bailiffs and other town officials were largely drawn. Hence complaints of private brokerage are mingled with denunciations of the abuse of official power. At Ipswich, as at Dunwich, ${ }^{52}$ the conflict between the ruling clique and the rank and file of burgesses led to a temporary suspension of the constitution under Edward I. An Ipswich ordinance of I 319 forbids the dealings of those who act as hosts to merchants and make private sale of their commodities, keeping a fourth part to themselves, and in the same year a number of safeguards were erected against the tyranny of the bailiffs. They were to be openly and annually elected, and to receive a fixed fee. Two sufficient persons of the inferior sort of people were to be elected chamberlains and to check the bailiff's accounts, and four men were to be elected to keep the keys of the Common Hutch where the Common Seal was kept. ${ }^{63}$

While Ipswich was struggling for reform, Bury was still fighting for freedom. After two severe contests in 1264 and 1293 the abbot and his town confronted each other in a drawn battle. The burgesses held the gates, exercised the power of gild merchants and elected their alderman, but the power of taxation and the control of the town courts remained in the hands of the abbot. In I 304 the men of Bury struck another blow for freedom. They held the town by force, compelled all traders to join their gild, levied taxation and convened the courts under the presidency of their alderman. The abbot, however, soon proved too strong for them. The king's judges set aside all their claims. The gild merchant was no longer to levy its fines, and the alderman elected by the town must swear on the high altar of the abbey to preserve all the rights of St. Edmund. The town had to submit, but treasured its grievance against another day of reckoning. ${ }^{64}$

The events of the rising of 1327 were part of a national crisis, and the same immediate cause to which the troubles at Bury must be referred-the paralysis of the central government in the last days of Edward II-produced almost exactly the same situation at St. Albans, where the abbot's villeins secured by intimidation a charter which remained in force five years. ${ }^{65}$ At Bury the revolution had not run its full course till the new king had been nearly two and a half years upon the throne, and the first victorious phase lasted almost exactly twelve months. On I 4 January I 327 a body of several

"V. B. Redstone, 'The Chaucer Malyn Family' in Suff. Arch. Inst. vol. xii.

6s Cal. Pat. 1272-81, pp. 2, 4, 89.

34 Mrs. Green, Town Life in the 15 th Cent. i, 296-7; Hist. MSS. Com. Rep. xiv, App. viii, $25-8$.

${ }_{85} \mathrm{~J}$. A. Froude, 'Annals of an English Abbey,' in Short Studies on Great Subjects, iii ; cf. also situation at Canterbury : Rogers, Six Cents. of Work and Wages. 


\section{SOCIAL AND ECONOMIC HISTORY}

thousand townsmen and their sympathizers gathered at the sound of the tollhouse bell, attacked and plundered the abbey, imprisoned the prior, elected an alderman and assumed full authority over the town and neighbourhood, even setting up, it was said, a block and axe in the market-place.

A fortnight later, the abbot hurrying down from London, where he had been sitting in Parliament, was compelled to sign a charter which conferred on Bury all the rights for which the burgesses were contending. Soon afterwards he escaped again to London and tried to get his grant annulled. This led to a further outbreak of violence in May, and another in October, during which many of the abbey buildings were destroyed and a score of its manor-houses burnt and plundered. It was not till December that the sheriff, backed by the military forces of the Crown, contrived to overpower the to "unnsmien and their allies, three cart-loads of whom were sent to Norwich 1n trial. A number were hanged, others were imprisoned, and over 200 were outlawed. But these proceedings were far from making an end of the matter. Many of the outlaws were still at large, and a body of them entered the town at midnight on 28 August 1328 , were feasted in Moyses Hall, and did not depart till they had routed with slaughter some of the abbot's servants who were sent to capture them. Another body, headed by the two leaders of the revolt, who had contrived to escape from prison, actually succeeded in kidnapping the abbot at Chevington, and after keeping him several days in London by the connivance of the Lord Mayor carried him over to Brabant, whence he did not escape till the following April. ${ }^{56}$

The demands of the townsmen as embodied in the extorted charter had nothing very extravagant about them. The grant of a perpetual commune and a common seal, the free election of their alderman, the full exercise of the powers of a gild merchant, the exemption from tolls, the farm of tallage, the removal of the taint of villeinage from the holdings, the power of admitting new burgesses, the control of the town courts, ${ }^{67}$ - these rights and privileges if permanently secured would certainly have almost entirely emancipated the town from the abbot's authority, but they would not have conferred more freedom upon Bury than royal charters had long ago bestowed on Ipswich and Dunwich. What is worthy of special note, however, is the large measure of support which the burgesses received from other clàsses : from the clergy, the local gentry, and the peasantry on the abbey's estates. It is this which accounts for the determined character of the struggle, and which lends it its real social significance. No less than thirty-two of the clergy were convicted of taking part in the revolution. These were drawn not only from the secular priests of the parish churches, but also from the friars of Babwell, who had an old grudge against the abbey.

The two sections were not free from jealousy of each other. The friars would gladly have secured a foothold in the town, while the secular clergy were anxious to keep it as much as possible to themselves. But they joined in giving the sanction of the Church to the claims of the burgesses and in saving them from the consequences of excommunication. In full array of vestments and banners they took the place of the monks in the processions of Rogation Day. They even seem to have conferred on the movement the

\footnotetext{
* Mem. of St. Edmunds (Rolls Ser.), ii, 327 et seq. ; see also V.C.H. Suff. ii, 62-3.

$"$ Mem. of St. Edmunds (Rolls Ser.), iii, App. A. 


\section{A HISTORY OF SUFFOLK}

character of a sacred crusade. When the abbot appealed to Rome, the parish clergy sent a counter embassy which asked for and claimed to have obtained a grant which rendered the two chief churches of the town independent of the abbey. After the rising was suppressed, the friars sheltered the outlaws at Babwell, and assisted their escape. ${ }^{58}$ A number of local gentry lent important military aid to the townsmen. Some of their names appear as those of witnesses to the charter, and one of them took a leading part in kidnapping the abbot. ${ }^{59}$ But most significant of all, perhaps, was the share of the neighbouring peasantry in this short-lived revolution. According to the monk who chronicles these events, more than twenty thousand men from the country round about thronged into the town to lend their aid in a contest which they conceived to be waged as much on their behalf as on behalf of the liberties of Bury. 'The townsmen promised,' says the chronialer, 'that all those from the country whether villeins or freemen who were wilicial to support their cause should be free of all toll and of all service throughout all England by virtue of charters which they had in their possession.' ${ }^{60}$ No doubt there is some exaggeration in these numbers, but the fact that a score of the manors belonging to the abbey were plundered sufficiently proves that town and country were alike imbued with the revolutionary spirit.

To the student of social history the rising of $I 38 I$ is apt to seem an extraordinary event, which must have been produced by extraordinary causes. To a certain extent this view is justified. The disturbance of the labour market by the Black Death, the struggle between economic forces and legal rights in the matter of land tenure, the evil effects of the Hundred Years' War, culminating in the repetition of the hateful poll-tax, are no doubt the larger and more general causes to which we must look for the explanation of so widespread an insurrection of the people. But these causes are not to be pressed to the same extent as they must be if the troubles of $138 \mathrm{I}$ were phenomena of an entirely new kind suddenly emerging in a time of profound social peace and universal respect for law and order. The truth is, as we have already seen, that during the twenty or thirty years preceding the Black Death, England was already very largely in a state of social anarchy, and if we examine in detail the local events which determine the substance of social history, we find the seeds of 138 I being sown half a century before. The trouble did not spring solely, perhaps not even mainly, from class dissensions of one particular kind-the struggle between peasant and landlord. Fierce family feuds, the faction fights of local parties, the unbridled jealousies of neighbouring ports, the violence and rapacity of swashbucklers and freebooters home from the wars, combined to render law and order the exception rather than the rule. Gorleston and Yarmouth are in a constant state of civil war. ${ }^{61}$ A fleet of privateers from Harwich lays siege to Ipswich for ten weeks, sinking, burning, and pillaging. ${ }^{62}$ Walberswick, aided by a convulsion of nature, captures the river and port of Dunwich, and puts to the sword its protesting customs officers. ${ }^{63}$ The Inquest Rolls of Ipswich between I 330 and I 340 reveal seventeen cases

\footnotetext{
${ }^{58}$ Mem. of St. Edmunds (Rolls Ser.), ii, 335-6, 349.

Ibid. iii, App. A; ii, 35 I.

Ibid. ii, 334.

6I Suckling, Hist. of Suff. i, 364 ; Cal. Pat. 1 $343-5$, p. 323 ; V.C.H. Suff. ii, 204.

${ }^{63}$ Cal. Pat. 1334-8, pp. 2 I 3, 218.

${ }^{63}$ T. Gardiner, Hist. Account of Dunwich, 39-40; Parl. R. ii, 44; V.C.H. Suff. ii, 203-4.
} 


\section{SOCIAL AND ECONOMIC HISTORY}

of murder and manslaughter perpetrated in the neighbourhood of the town. ${ }^{64}$ The knights of the shire carry war into each others' manors. One of them hurls a justice from his bench at Ipswich. Seven other free-lances entrenched in the parish church defy the law at Stowmarket. ${ }^{65}$ The justices are fined heavily for extortion, but make terms with the Exchequer. ${ }^{66}$ The Abbot of Bury, besieged by his Suffolk tenants, cannot collect his rents in Northamptonshire. His bailiffs, when they attempt to exalt the alewives of Mildenhall in the tumbril, have to fly for their lives. Between the regular and secular clergy there is constant and bitter feud. ${ }^{67}$ The monks are accused of 'consorting with notorious criminals, and of committing rape, adultery, highway robbery, perjury, simony, and usury.' ${ }^{68}$

The social discontent of the peasant and artisan class finding expression for the first time through widespread organization in a simultaneous rising in support of a common programme-it is this no doubt that gives the events of $138 \mathrm{I}$ their permanent historical interest. But that this had little relation to the flood of violence let loose by the rising will be evident to anyone who studies the narrative given by $\mathrm{Mr}$. Powell of what happened in East Anglia. ${ }^{69}$ If we subtract from the total of local disturbances in Suffolk all those that were due to a desire to pay off old scores and family feuds, all those that originated in the action of knights, esquires, and well-to-do gentry like Thomas Sampson, whom we shall hear of later); if we allow for the illseeling generated in the recent dispute about the appointment of a new abbot, and in the long-drawn contest between the abbey and the town of Bury; and finally, if we take account of the natural indignation aroused against the ministers of state and their local officials by the exaction of the poll-taxthere will remain very little lawlessness to be laid to the charge of the strictly agrarian movement.

That movement itself was not the fruit of any sudden fit of perversity in the part either of lords or of peasants, but was due to more gradual and eneral causes. For more than two centuries the wealth and population ${ }^{70}$ of e country, in spite of war and pestilence, had been steadily increasing. The 1 produced more, and the growth of an industrial population raised the ue both of food and of raw material. Under this stimulus to improved thods of rural economy the old communal arrangements were gradually indoned in practice, though the legal form associated with them long sured. Status was giving way to contract. A social stability resting on a wasteful uniformity of custom was being displaced by the irregularities and uncertainties which inevitably accompany enterprise and competition. The typical mediaeval holding of from fifteen to thirty acres was being absorbed into larger farms or broken into smaller holdings. The number of labourers with two or three acres had greatly increased. The condition of the labourer

"Hist. MSS. Com. Rep. ix, App. i, 226 ; Suff. Arch. Inst. xii, 192-3.

es Cal. Pat. 1338-40, p. 273 ; 1340-3, p. 313.

${ }^{\circ}$ Ibid. $1340-3$, p. 316 ; $1343-5$, p. 156 ; $1340-3$, pp. 207-8.

- Ibid. 1334-8, pp. 35, 44, 207.

${ }^{68}$ Mem. of St. Edmunds (Rolls Ser.), iii, 65.

6. E. Powell, The Rising in East Anglia, 9-25, 103.

${ }^{70}$ This would seem an inevitable inference from all the local evidence. The poll-tax of 1277 was levied on 2,445 persons in Bury, 1,507 in Ipswich, and on 58,610 in the rest of Suffolk. If we multiply these figures by 2 , and compare them with those of Domesday multiplied by 5 (a very rough method of comparison), the increase indicated is only 25 per cent. It is possible some of the persons enumerated in Domesday appear twice. 


\section{A HISTORY OF SUFFOLK}

had no doubt improved, but this could not satisfy the sons and grandsons of independent cultivators. On the other hand the wealth drawn by the lord from the soil was much greater. The income of Bury Abbey doubled during the $14^{\text {th }}$ century, and it was mainly derived from rent. ${ }^{n}$

A couple of illustrations, one drawn from the history of a manor, and the other from that of an individual, will give point to these generalizations. The manor of Hawstead had on it, as we have seen, in I 280 , a dozen villeins with about two hundred acres among them. In I 358 there were 146 acres held by eleven villeins, of whom only one had a full holding of 30 acres, while four had half holdings, six had quarter holdings, and all of them were paying the full value of their land in money rent of $8 d$. or $9 d$. an acre. They owed, it is true, between them forty-two days of mowing and sixty days of reaping, but these works were reckoned of no value by the lord's bailiff, because they need not be done unless an equivalent was given in money and produce, which included all the milk of the manor for one day. In I 388 the villein tenants have almost disappeared. Two-thirds of their holdings have fallen back into the lord's hands. The harvesting is done by hired labour at $3 d$. and $4 d$. a day with food, the head reaper getting $6 s .8 d$. for the season. The total rent paid has increased nearly fifty per cent. since I 358. The dairy produce brings in nearly as much as the crops. The old communal arrangements linger somewhere in the background no doubt, bu the bailiff's accounts show little sign of them. The Hawstead of 1388 is already in essentials a modern village. ${ }^{72}$

A chance glimpse into the affairs of a typical individual reveals no less vividly the progress of change. Whatever may have been the grievance or the ambition of Thomas Sampson of Harkstead who led the rising in southeast Suffolk, he was no mediaeval peasant confined within the manor that reared him and obliged to till the soil of his lord on servile conditions. When his property fell into the hands of the king he was found to br farming land which is almost unmistakably an aggregate of half a doze peasant holdings of 30 acres each. One of these was at Freston, two Kersey, and four at Harkstead where he lived. The crops of corn, pe oats, and barley standing on these holdings at the time of his death $\mathrm{w}$ such as would have been sown in the common course of cultivation by 1 original customary tenant, and part of the stock in each case was such the ordinary peasant holder would possess; the teams of two, four, six oxen respectively, each ox worth IOs., the cart-horses worth $5^{s .}$ apiece, the tumble-down cart worth $2 s .6 d$., the plough worth is., the half-dozen pigs at Is. apiece, a stack of hay, and a couple of quarters of wheat and malt. No doubt Thomas Sampson had managed to free the tillage of these holdings from some of the old communal restrictions, but in any case tillage was becoming a secondary part of his farming. At Freston he had a herd of fifteen cows, with a bull grazing, and a hundred hogs fattening. At Harkstead a fine flock of 300 sheep worth $\oint_{0} 15$ was producing wool for the neighbouring clothiers. Nor was this the full extent of Sampson's enterprise. When he had sold his wool and produce at Ipswich market he did

\footnotetext{
"V.C.H. Suff. ii, 68-9.

73 These particulars are obtained from a transcript of an Extent of Hawstead for 1358, and a Compotus Roll kindly lent me by Mr. Edgar Powell.
} 


\section{SOCIAL AND ECONOMIC HISTORY}

not bring the money home to hoard, but invested $53^{s}$. $4 d$. (about the value of 24 acres of corn) in the purchase of an eighth share of a Harwich vessel. His domestic possessions, if not luxurious, were much above those of a peasant. The movables in his house were worth $f_{6} 6$. Usually he dined off pewter, but he had a silver dish, six silver cups, and some fine earthenware, and linen for festive occasions. ${ }^{73}$ As a grazier and a woolgrower and a commercial shareholder, Thomas Sampson was a man of the future. Perhaps that was why he was discontented. For he had his roots apparently in the manorial acres of the peasant bondman.

The steady progress of this economic development might be illustrated at great length from the rentals of the abbey. Of these invaluable sources of social history far too many are extant to allow of any detailed account here, but a comparison of two or three of them of different date will be the most instructive way of carrying on our account of land tenure in Suffolk into the iddle of the $15^{\text {th }}$ century. The rental of Elmswell in 1357 , which is one f a number drawn up in the same district at the same time, has a great nany features in common with the survey of Hadleigh taken half a century earlier. The original uniformity of the customary holdings is carefully preserved. There are six of 24 acres each, eleven of $\mathrm{I} 2$ acres, and eight of 6 acres, and each class of holdings of the same size has a uniform set of services and payments in kind or money rents. The tenant of 24 acres renders twenty eggs yearly, the tenant of 12 acres ten eggs, the tenant of 6 acres five eggs, and so on. These uniform holdings, each with the name of an original holder attached to it, are the legal personalities upon which, in the thought of the surveyor, if not in actual law, the obligations of tenancy are laid. In some cases the actual tenant of whole or part of the holding is a descendant of the original holder. But a single tenant of the entire original holding is exceptional. In most cases it is split up as far as occupation and cultivation are concerned into quite irregular portions, each occupied by a different tenant, who holds at the same time similar portions of some of the other original holdings. The amount of land cultivated by the individual tenant might vary from half an acre to 40 acres, and the rents and services that had to be rendered would vary in proportion from tenant to tenant. The spirit of individualism, with the natural accompaniment of wide diversities of economic condition, has already made considerable encroachment upon the ormities of a semi-communal tenure in Elmswell and elsewhere by the I 357 , but the rental still sticks to the old uniformities as the basis of its v. Thus of one of the original uniform holdings we are told John Jake'eld formerly 24 acres. Of these, W. Warde now holds 12 , W. Jake:n., 5 a. I r., W. Jakeman, jun., 5 a. I r., T. de Lane 3 roods, and so on; and the rents and services to be rendered for the whole 24 acres by the eight tenants are stated in the mass as being practically identical with those demanded from each of the other lots of 24 acres. How the tenants are to pportion the burden among them is not stated..$^{7}$

If we turn from this set of rentals to one drawn up for Rickinghall in 387 we find a very significant change. The tradition of a number of

${ }^{73} \mathrm{E}$. Powell, The Rising in East Anglia, 143.

" B.M. Add. MSS. 14849. The extents in this MSS. are those of Elmswell, Culford, Fornham, Redave, Wortham, Burgate, Palgrave, Westhorpe, Rickinghall, Worlingworth, and Soham. 


\section{A HISTORY OF SUFFOLK}

uniform customary holdings is still clearly preserved, and the names of the original holders still attach to their land, i.e. to their sets of half-acre strips scattered about the large fields of the manor which were once, and to some extent no doubt still continue to be, cultivated in common. But the place of the original uniform holding as the formal unit of tenancy is taken by the actual holding of each individual tenant. Thus Reginald Aylmer is said to hold 4 a. 3 r. I 2 p. of the original 'Aylmer' holding, I a. 3 r. of the Gorchold holding, and similar fragments of eleven other holdings distinguished by family names, making up a total of about 22 acres. And what is perhaps even more significant of an entire change in the point of view taken by the lord of the manor is that Reginald Aylmer (and each of the other tenants) has a set of rents and services which has been calculated to fit his particular case, though no doubt the original uniform set of rents and services has been used as a basis of the calculation. Money rents are nominally still the lesser part of the tenant's obligations, but the various payments in kind and servic demanded are generally valued in money, and seem to be open to com mutation. ${ }^{75}$

We are specially fortunate in being able to compare this rental with another taken at Rickinghall in 1433 which marks a further stage in the development we have been tracing. Services and payments in kind seem to have largely disappeared. The bounds of each portion of land held by a tenant are carefully defined, and it seems to be becoming the custom to assess each separately at a money rent. Still more interesting is the evidence afforded of the tendency of the strips held by each tenant to draw together into large fields for the obvious purpose of realizing in some way a more individualized cultivation. Hitherto we have been led to assume this process to have been going on because it afforded the only rational explanation of the facts. And here we have actual proof that the assumption was justified. In some cases as many as half a dozen different portions of land held by one tenant are bracketed together in the rental as 'one piece'; and in a great many other cases where the bracketing has not been done by the surveyor we can do it for ourselves with the help of the exact boundaries given in the survey. Thus a certain John Chapman holds twenty-nine separately specified pieces of customary land, many of which are less than half an acre in extent, so that the whole is only 25 acres. But these pieces are not isolated each from the others. Fifteen of them are found grouped together in twos threes, making up six fields of from 2 acres to 4 acres apiece, and these 1 plots represent more than two-thirds of the total holding. We may be sure that this aggregation means in some way or other a partial with from the old common course of cultivation to which the system of quarter acre strips was adapted. ${ }^{76}$

In these examples, which may perhaps be taken as representing the more rural districts, the process under observation is comparatively slow Where the industrial population gathered it was much more rapid. Milder hall was the most productive manor possessed by the abbey. It was r Mildenhall Heath that the Prior of Bury was beheaded in $138 \mathrm{I}$. It happens that the extant bailiff's accounts for the manor begin in that ve. year, and the one striking feature in them is the system of leases whi

$$
{ }^{78} \text { B.M. Add. MSS. } 14849 \text {. }
$$$$
{ }^{76} \text { Ibid. } 14850 .
$$ 


\section{SOCIAL AND ECONOMIC HISTORY}

appears to have gradually displaced other kinds of tenure since the time of the pestilence. A few are for forty years, but most are for ten or six years, and it is noteworthy that the six-year leases are those last granted. The land so leased is not mainly demesne land. It belongs largely to villein tenements that have fallen into the lord's hands, and the process of consolidation already described had taken place even earlier at Mildenhall. The land held by John Kelsynd on a ten years' lease includes for example ' 3 acres of Frere's, Hayward's, and Willway's tenements in Bradinhawfield, I acre of Holmes' tenement in Suttonfield, 5 acres of Zabulo's tenement in one piece at Lambwash,' and the rent of the whole $22 \frac{1}{2}$ acres is $3 \mathrm{I} s$. I $d$., or nearly Is. $5 d$. an acre, an extremely high rent for land not stated to be meadow or pasture. ${ }^{77}$

The lord's power to insist on this new economic rent must have been a more serious grievance than his persistence in claiming the old servile rents, but the real social danger arose from the juxtaposition of the two situations which made either seem more intolerable. The revolutionary doctrine looked both ways. It repudiated the labour rents, and fixed a maximum for money rents. Four years after the rising the fifteen villeins on the manor of Littlehaw in Thurston were still acting up to these principles with the support of the clergy in their parish, who had helped them to form an association for the purpose, the collections for which amounted to the large sum of $f_{0} 6$ a year. In the strength of this actual support they had persisted in withdrawing their services, claiming to be free from all except the rent of $4 d$. an acre. The services due from a holder of 24 acres included three hens, fifteen eggs, two days' ploughing, four half-days' mowing, two half-days' hoeing, six days' reaping, and one day's carrying. He must pay a fine on entry, on the marriage of son or daughter, and a heriot was claimed on his death. In spite of citations from Domesday the villeins lost their case, and were fined $\oint_{0} 3{ }^{78}$

This exceedingly interesting case naturally prompts the inquiry as to how far the rising of $13^{8} \mathrm{I}$ was due to deliberate propaganda or based on preconcerted plans. The references of some of those who took part in it to a ' Great Society,' implies an attempt at some large form of organization, and though this was probably of a vague and temporary character arising out of the stress of the crisis and not outlasting it, it could scarcely have come into existence at all unless some foothold had been supplied here and there by local organization. And in view of the part in the rising taken by the clergy, it is difficult to reject the idea that in some cases such a local foothold was furnished by the parish gilds.

The history of the gild goes, of course, much further back than the beginning of the I $4^{\text {th }}$ century, but at that period it enters on an entirely new phase, and more especially after the middle of the century gilds began to multiply at a rapid rate both in town and country. By the middle of the I $5^{\text {th }}$ century there can have been few populous parishes in Suffolk without one.

The returns made to the royal inquiry of 1389 have been very imperfectly preserved, but those relating to Suffolk are exceptionally numerous,

$n$ Add. Rolls. 53116.

${ }^{78}$ Powell, The Rising in East Anglia, 64-5; cf. an article on 'The Sandling' in Suff. Arch. Inst. x, 61-2, by Mr. Redstone, who gives several interesting cases of the exaction of merchet and heriot in the 15 th cent. In 29 Hen. IV Matilda Bond is charged with destroying two plates, one kettle, and other utensils which the bailiff had seized for non-performance of service of ploughing. 


\section{A HISTORY OF SUFFOLK}

there being thirty-eight for the whole county, of which nineteen belong to Bury. Many of the Bury gilds undoubtedly owed their origin to the religious character of the town as a place of pilgrimage. Two at least were distinctly clerical in composition, and one of these-the Gild of the Clerks of Glemsford-was a survival from an earlier period of gild creation, the other-the Gild of St. Nicholas-having ordinances dated 1282 . Of the rest, two claimed an origin in time whereof there was no memory; and five had no date assigned to them. The dates of the remaining ten are spread over the I 4 th century two claiming 80 years of existence, one 70 , one 60 , two 40 , and one 30 , whilst the other three were of recent origin. The local distribution of the score of gilds recorded as existing in 1389 outside Bury is very remarkable. No less than eleven of them were to be found in the hundred of Lackford, where some of the most terrible scenes of the rising were enacted, and all the rest except the two gilds of Beccles belonged to the south-western district, of which Bury is the centre. All of them had come into existence during the thirty years which intervened between the coming of the pestilence and the insurrection. ${ }^{79}$

Whether the rapid spread of this ostensibly religious institution had (as the government undoubtedly feared) any direct and conscious connexion with the social and political aspirations of the peasants or not remains uncertain, but it is quite clear that it furnishes an unmistakable indication of social development and of comparative economic prosperity. The gild has been very aptly called a co-operative chantry, and the multiplication of gilds represents one of the main elements of social progress-the advance made by the associative principle, not so much in displacing as in supplementing the narrower ties of the family. This influence is naturally most active in towns and in such industrial districts as West Suffolk was coming to be at the end of the $14^{\text {th }}$ century. But in the century that followed, gilds, and even in many cases gildhalls, sprang up all over rural Suffolk. A list : of some I 20 , taken by Mr. Redstone from wills and from the returns of $f_{t}$ the Royal Commission at the time of the suppression, represents practically every part of the county. The primary objects of these fraternities were in all cases religious. The performance of due obsequies for the departed and the continual care for the welfare of their souls came first, and with these objects were closely associated the provision of religious consolations for the living, the enlargement and adornment of churches, the endowment of altar lights and services. But wherever fuller ordinances have come down to us, we almost invariably find some form of charitable provision for the sick, the disabled and the poor of the fraternity. The fund for these purposes was provided only in part by the regular contributions of members which were not large (there was a halfpenny fraternity at Beccles), and was supplemented largely by the bequests of the more well to do-gifts of land or corn or cattle as well as of money. The score of Suffolk gilds reported on at the Reformation as possessing property, held it mostly in the form of ready money, amounting to $£_{9}$ or $£_{0}$ ro in some cases. But it is not unlikely that the gilds had been selling their property in view of spoliation. The administration of real estate thus held in joint ownership was not only a valuable educational experience for the villagers, but afforded them the oppor-

79 V. B. Redstone, 'Chapels, Chantries, and Gilds in Suffolk,' in Proc. of Suff. Arch. Inst. xii. 


\section{SOCIAL AND ECONOMIC HISTORY}

tunity, if they were so disposed, of lending capital to poorer members. The accounts belonging to the opening of the 16 th century of the gild at Bardwell illustrate the operation of loans of live stock. The gild let out in one year eight cows, and 4 neats at $\mathrm{I} g d$. each, also four wethers. It may be added that this gild had at the time I 34 members, nearly half of whom were women, there being thirty-three married couples, and that its officers included an alderman, a chaplain, a cook, a minstrel, and a guardian of lights. ${ }^{80}$

Another aspect of gild activity that cannot be overlooked was the provision of annual pageants. These were usually the work of the Corpus Christi gilds. In I 325 we find the priors of Holy Trinity and of St. Peter's, Ipswich, assisting the town authorities to organize a series of Corpus Christi celebrations which were to represent the merchant gild on its religious side, and which culminated in the ceremonial washing of the feet of thirteen poor men. In the $15^{\text {th }}$ century some forty trades took part in the procession, marshalled in a dozen groups under the banners of as many patron saints. ${ }^{81}$ j similar annual procession took place at Bury. The ordinances of the Neavers' Gild for I 477, which constitute the only definite and detailed account ve possess of a Suffolk craft guild before the Reformation, provide that half the fines are to go to the maintenance of the pageant of the Ascension of our Lord God and of the gifts of the Holy Ghost ... among other pageants in the feast of Corpus Christi. ${ }^{82}$

Bungay too, had its Corpus Christi celebrations. In I 5 I 5 five men of Bungay were brought before the Star Chamber for having riotously broken down five pageants - heaven pageant, the pageant of all the world, paradise pageant, Bethlehem pageant, and hell pageant. The motive for this assault was not an outburst of iconoclastic zeal. The malcontents considered the pageants to be worn out, and were anxious to bear their part in renewing the symbols of eternity.

The multiplication of gilds had not the effect of checking bequests by individuals for the endowment of chantries, obits, and lights, which had probably never been so numerous as they were in the last half of the $15^{\text {th }}$ :entury. The 'briefe certyficatt' drawn up in 1548 enumerates over three hundred [of these] endowments, varying in value from $2 d$. yearly for a light to $£ 5$ or $£_{0} 6$ for a chantry and three or four hundred pounds for a college of clergy. ${ }^{83}$ The College of St. John the Baptist, founded by Edmund, Earl of March, and Ulton, Lord of Wigmore and Clare, at Stoke by Clare, in I 4I 9, consisted of I dean, 6 canons, 8 vicars, 4 clerks, I verger, I porter, 3 choristers, and 2 priests, was worth yearly $£_{3} 383$ i 4 s. $8 d$. and had a free school attached to it. ${ }^{84}$

But if the gilds did not displace the chantries they absorbed a certain number of them. Their immortal character as corporations seemed to offer security for the perpetual performance of religious services desired by pious testators. Thus all members of the gild of the Purification of Our Lady at Bury were required to swear on entry to fulfil the wills of John Smith and Margaret Odham, which were read at the annual dinner, and after the dinner all members were to kneel and say the De Profundis ... for the souls of

* A 'Pre-Reformation Village Gild,' Proc. Suff. Arch. Inst. xi.

81 V. B. Redstone, op. cit. 8.

Hist. MSS. Com Rep. xiv, App. viii, 134.

V. B. Redstone, op. cit. $4^{8}$; V.C.H. Suff. ii, 145.

${ }^{3}$ V. B. Redstone, op. cit. 74 ; V.C.H. Suff. ii, 29. 


\section{A HISTORY OF SUFFOLK}

these founders. A similar trust was reposed in municipal corporations. ${ }^{85}$ By a will made in I 509 William Godell, merchant of Southwold, provided for a priest to go to Rome to sing for him in five different churches for a whole year. His wife was to have a Requiem Mass sung in Southwold Church for thirty days, giving alms each day to twelve poor men or women. His executors were to keep his yearday for twenty years at the cost of 20 s. per year, and finally after his wife's death the bailiffs and commonalty of Southwold were to find a priest for sixteen years next following to sing for his soul and the souls of his friends. ${ }^{86}$ At Eye in 1479 and 1488 there were two legacies left to the townspeople on condition of their carrying out certain religious observances, one of which was that the sacristan or some other honest man should perambulate the streets of the borough with the little bell known as the 'sowlebell.' At the same time a bequest was made to St. Peter's Gild at Eye to endow a chantry priest on condition of the gild buying land for a similar purpose, and the parish priest has left a pleasant account of how he urged his congregation from the pulpit to complete the bargain he had negd tiated on the instalment system: "How saye now saide I unto them 1 I have bought a ground for you so that ye maye stonde in the church yard anc see it,... if it be a bargaine because it for the comon wele speake all Una Voce and seye ye this was a godly hearinge every man, woman and childe saide yea yea, dyverse men gave $\mathbf{x}$ marke a peice women fower marke $\mathbf{x x}^{\text {s. }}$ and $\mathrm{xl}^{d}$. $\mathrm{x}^{1}$. So that $\mathrm{I}$ gathered on Candlemas daye above $\mathrm{xx}^{l i .}{ }^{28}$

The important part played by Suffolk men at the time of the Reformation was no accident. Nowhere in England were the forces of economic and social progress more active. If the future development of English industry and commerce had been revealed in general terms to one of the numerous political speculators of those times, and the local details left to his imagination, he would very probably have placed Manchester at Lavenham or Hadleigh and Liverpool at Ipswich. As far as Ipswich was concerned, this forecast was indeed frequently made in the days of Elizabeth. But the development of the textile manufacture of Suffolk which has been traced in detail elsewhere had already almost attained its highest point, and the economic future of the county down to our own day was to depend increasingly on the favourable conditions under which its agriculture was carried on. Those conditions were no new or sudden achievement. The germs of them, as we have seen, are to be found in the Domesday Survey, and their steady growth can be followed through the intervening centuries. The story that is to follow of the development of high farming in modern Suffolk derives all its meaning from its continuity with the past.

\section{PART II}

When Tusser in I 557 published his Five Hundred Points of Good Husbandry, ${ }^{88}$ the forwardness of the county in agricultural improvements was already noteworthy, and the progressive movement had well begun which was to lead Young in 1794 to place Suffolk in the forefront of scientific farming. Tusser wrote his poem during his residence at Brantham in

${ }^{85}$ Gasquet, Parish Life, 269.

"Hist. MSS. Com. Rep. x, App. iv, 528.
${ }^{86}$ Gardner, Hist. Account of Dunwich, 248.

${ }^{88}$ Engl. Dial. Soc. Publ. I 878 , p. 140. 


\section{SOCIAL AND ECONOMIC HISTORY}

Suffolk, and drew from his experience there and in his native county of Essex material for his praise of inclosures. The effect of inclosure upon the condition of the labourer and the improvement of husbandry struck him as extremely favourable, and he urged other counties to take example in the matter by Suffolk and Essex :-

\footnotetext{
Mast, covert, close pasture, and wood,

And other things needful as good,

All these do enclosure bring,

Experience teacheth no less.

More plenty of mutton and beef,

Corn, butter, and cheese of the best,

More wealth anywhere (to be brief),

More people more handsome and great,

Where find ye? (go search any coast)

Than there where enclosure is most.
}

phe surveys hereinafter quoted bear ample testimony to the truth of this poetic statement, both as to the large amount of inclosed land, and the fact hat inclosure was going on steadily all through the 16 th and 17 th centuries. During the latter period the Privy Council issued frequent orders for pressing on the draining of land on the north-west, and the reclaiming of sea-lands on the eastern coasts; the numerous Inclosure Acts at the beginning of the I $9^{\text {th }}$ century dealt chiefly with the commons and wastes.

Cullum points out in his History of Harested ${ }^{89}$ that during the reign of James I land-rents in Suffolk became almost double what they had been at the close of Elizabeth's reign, yet during the latter the foundations of advance were laid; the progress of agriculture in Suffolk was but a wave of the same tide of prosperity which swept over the whole country.

'Yet will the farmer think his gains very small,' wrote Harrison, ${ }^{90}$ ' if he has not six or seven years' rent lying by him, therewith to purchase a new lease ; besides a fair garnish of pewter on his cupboard, three or four featherbeds, so many coverlets and carpets of tapestry, a silver salt, a bowl for wine (if not a whole nest), a dozen of spoons to furnish up the suit.'

The prosperity of the cloth-making population during the 16 th century may be regarded as the primary reason for the prosperity of the agricultural population, to whom they looked for their food supply. "This country hath evermore had sufficient to feed the populous number of their own inhabitants.' ${ }^{91}$ A certain amount of corn was carried to foreign markets, but the trade in dairy produce with London had scarcely begun.

Another factor to be considered in the advance in agricultural prosperity is the setting free of large areas of soil by the dissolution of the monastic establishments and the sale or re-grant of their lands; church property in Suffolk was very extensive, and the Dissolution came at the right moment for the introduction of a more individual and progressive system of cultivation than was possible under semi-feudal arrangements. Where property continued to be held under the Church, or by collegiate bodies, the I 8 th century (as in the case of Framlingham, presently to be considered) found the land still making totally inadequate returns to its owners. At the end of the reign of

Op. cit. 212.

${ }^{11}$ Reyce, Breviary of Suff. (ed. Hervey), 29.

Ibid. 213 ; Harrison, Descr. of Britait, 189. 


\section{A HISTORY OF SUFFOLK}

Elizabeth the eastern parts of the county, 'High Suffolk,' consisted chiefly of pasture and meadow lands, with enough tillage only to supply local requirements. Central Suffolk was the great corn-growing district; Western Suffolk, with its poorer soil, almost entirely given up to sheep farming..$^{92}$ The condition of the manor of Mettingham in the extreme north-east of the county may be taken as a typical example. A survey was made in $1562^{93}$ for Sir Nicholas Bacon, keeper of the Great Seal, who in I 57 I became bailiff of Bury (his native place) under grant of Queen Elizabeth.94 Sir Nicholas purchased the estate from Sir Anthony Denny, to whom it had been granted on the abolition of the College of Priests in I 54I ${ }^{95}$ The Dennys do not, however, appear to have exercised their rights as lords of the manor. The soil of the estate was good, and proximity to the River Waveney made the timber especially valuable, as it could so easily be conveyed to London in large keels or barges. ${ }^{96}$ The customary tenants upon the land had originally held by inheritance, and the fines, arbitrable between them and their lord according to the quantity and quality of their lands, had stood at $\frac{1}{12}$ for ever acre; but this had of late been altered, apparently on the initiative of the tenants during the interregnum. They also asserted an unsupported right to crop and shred the trees growing in the hedgerows, and to take timber without assignment from their grounds for the necessary repair of their buildings. The old manorial perquisites of weyves, estreyes, and the goods of felons and fugitives had so diminished as "scarce to countervail the charge of the court." ' ${ }^{86}$ The free tenants held by 'service of suit to the lord's court, yielding of releases after the death of their ancestors and payment of rents.'

It appears from the survey that the demesne consisted of 365 acres in the lord's hands, i.e. 277 of pasture, 64 of arable, and 24 of meadow, of a total annual value of $\oint_{5} 5^{\circ}$ I $5 \mathrm{~s} .2 \mathrm{~d}$. In the main the property is composed of 'closes' of meadow, pasture, and arable, but a certain amount still lies in the open fields of the place (e.g. 'there are lying in divers pieces in the campus called Mettingham field 23 acres of arable land '). ${ }^{96 \mathrm{~b}}$ The meadow is held at rents of $6 s$. and $6 s .8 d$. an acre, the 30 acres called The Dairy Park, attached to the farm called 'Le Darye,' and included with the house, garden, and apple orchard, at $8 s$. an acre. The pasture is worth $2 s .8 d ., 3^{s .} 3^{d}$., and $4 s$. an acre, the arable uniformly $2 s$. an acre when inclosed, Is. $4 d$. when lying in pieces in the open fields. The tenants' holdings fall into two groups of large (over 30 acres) and small. The largest farm contains 2 I 5 acres of pasture, 30 of arable, and 15 of meadow, on a lease of twenty-one years, and at a rent of $\oint_{0} 146 s .8 d$. There are six others holding I $30, I_{1} 3,104,88,5$, and 32 acres respectively, all on the same twenty-one years' lease.

Amongst the small tenants we find John Wyard's holding to consist in all of 20 acres, including nine pieces of arable land lying in the common fields, four pieces lying in the East field containing 6 acres and some roods, and five pieces lying in the West field containing 5 acres and some roods, in all 12 acres of $16 s$. total value; this, with the addition of a close of arable containing 8 acres at $2 s$. per acre, is rented to him on a twenty-one years' lease. ${ }^{97}$

Reyce, Breviary of Suff. (ed. Hervey), 29.

Hist. MSS. Com. Rep. xiv, App. viii, 139.

${ }^{86}$ B.M. Add. MSS. 14850 , fol. 15 I. 152.

662

${ }^{3}$ Add. MS. 14850.

${ }^{9}$ Suckling, Hist. of Suff. i, 168.

${ }^{96 b}$ Ibid. fol. 154. ${ }^{87}$ Ibid. fol. 158. 


\section{SOCIAL AND ECONOMIC HISTORY}

Only one of the smaller tenants holds on a yearly tenancy. John Berye's holding is described as ' a close of pasture in five different pieces' at 3 s. an acre, and it is rented with an acre of fen at $2 s .8 d$. (the usual price of fen land) under a forty years' lease dating from Henry VIII, at the rent of 4Os. and two capons.97a

The surveyor comments on the bad repair of the tenements and farms, although the tenants are bound to keep them in good and sufficient reparation, at their own charges, in all things except timber. Speaking generally, an examination of the component parts of the various farms and holdings shows them to be in the main compactly and conveniently arranged, made up of various adjacent inclosures, and in most cases including a dwellinghouse. Tiaces of the older system are few, and in course of disappearing, as is clear from a reference to 'various bits of arable land newly inclosed,' which form part of one holding.

As might be expected from the comparative poverty of the soil, and the prevalence of sheep-farming, as well as from the greater distance from convenient waterways, and proximity to the fen-country with its povertystricken population dependent entirely upon fishing and fowling, agricultural progress in the western part of the county is less marked than in the east. A survey of an estate at Lidgate, ${ }^{98}$ at a date of twenty years after the Mettingham survey, shows the existence of a much more primitive condition of things. The manor is divided for the most part into full yard-lands of 16 acres, held by copy of court roll and heritable at a rent of Ios. (in a few cases $7 s$. to $8 s$., or I 3 s. with a dwelling). It will be remembered that arable in Mettingham, even in the open field, was worth is. $4 d$. an acre. Each tenement bears the name of some previous owner; the names of its holders for two or three generations back are also given, so that a process of consolidation which is in progress is clearly of very recent date. For many of the holdings are no longer confined to a single person. For example, Edmond Halles holds six separate parcels of land :-

I. A copyhold tenement heritable, called Gyll's with I 6 acres of ground, late William Cator's and sometime William Gyll's, and before Adam Gyll's ; rent 13 s.

2. A full yard of copyhold land heritable, called Griggs', sometime knit with the tenement Griggs', late William Cator's, and sometime William Griggs' ; rent Ios.

3. A copyhold cottage with a garden adjoining, containing by estimation half a rood, and one piece of land in Oakefield ' at . . . gappe,' containing one acre and a half late in the tenure of Steven Halles; rent is. $4 d$.

4. A copyhold pightell of pasture called Morryes pightell containing 2 roods, late Steven Halles'; rent $6 d$.

5. A full yard of copyhold land called Collers Knights, containing I 6 acres, late in the tenure of John Webbe; rent $8 s$.

6. One tenement and a half yard of copyhold land called Fletcher's, with a cottage called a three-acre-ling thereto annexed, containing together II acres, and one piece of land called a way, long 6 poles, broad I I poles, late William Almer's, before John Fuller's; rent $9 s$.

פa B.M. Add. MSS. 14850 , fol. 159.

${ }^{20}$ Ibid. 22058 , fol. 32. 


\section{A HISTORY OF SUFFOLK}

Before him these parcels were in the hands of four different owners; two only, judging by the evidence of names, came to him in the ordinary course of inheritance.

Another owner, William Almer, holds twelve separate parcels, of which five are full yard-lands of 16 acres; evidently in his case the accumulation of property had begun in the preceding generation, for of his parcels five had been taken over by his father from other men and passed on to him; the other seven he has himself acquired.

The survey does not describe the constituent parts of the full yard-lands; of the remaining holdings two are small closes of 3 acres, rented one at $7 d$. and the other at $\mathrm{I} 2 d$. and a capon, the inclosure dating from I 547 at latest; another is described as ' 3 acres of the demesne, lying in the fitid in two pieces.' Rents in kind are frequently mentioned; a yard-land of the usual extent pays $3^{s .} \mathrm{I} d$., $\frac{3}{4} \mathrm{lb}$. of pepper, and an arrow tipped with iron. By a survey of the demesne of the same manor taken seven years later, ${ }^{98 a}$ it is clear that the larger copyhold tenants of the earlier survey are in many cases also leasehold tenants of the demesne on six-year leases; their total holdings must thus often have been of considerable size; e.g. one George Taylor holds by copy four full yards of 16 acres each, and also leases 37 acres of the demesne. These last are made up of three closes of pasture, containing 10, 7, and 3 acres respectively, rented at $4 s$. the acre; a piece of meadow also rented at 4 s. the acre, and various pieces of arable in the field, i.e. a piece of 3 acres in Bishopshall field at is. $8 d$. the acre, and another piece of 5 acres in the same field; this description suggests that while the accumulation of $\frac{1}{2}$-acre strips had in course of years resulted in pieces of 3 and 5 acres, these two pieces were not contiguous, and would in time no doubt become two separate inclosures. A comparison of land-rents at the close of the century between east and west shows the rent of pasture uniformly $4 s$. , arable in the open field Is. $8 d$. in Lidgate, $\mathrm{I} s .4 d$. in Mettingham, meadow in Mettingham 6s. and 6s. 8d., in Lidgate $4 s$, an acre.

Cullum's account of land values in the manor of Hawstead, near Bury and in the corn-growing district, is valuable, as covering a larger number of years than the surveys already quoted. In $1500,{ }^{99}$ when the lands of the manor were measured, none were let for more than Is. $6 d$. an acre, pasture and arable not distinguished in value. In 1536 arable was is. an acre, meadow-land is. $8 d$. Fifty years later 40 acres of meadow and pasture were worth $5 s$. an acre, wheat was at $8 s$. a comb, barley at $6 s .8 d$., rye $5^{s}$. The increase still continued to be rapid. In I $6 \circ 3{ }^{100} \mathrm{Hawstead} H$ all, with I 26 acres of land, was let for $£_{4} 40$ and 10 combs of wheat; whereas in 1589 it had been let for $\oint_{2} 0$ and 20 combs of wheat, 10 of oats, and 3 loads of wheat-straw. In 16 I $5,{ }^{101}$ the houses, barns, and lands called Hawstead Park were let for twelve years at the following rents : every acre of pasture not ploughed $9 s^{s}$, every acre of meadow I 7 s., every acre of arable half the corn that should grow on the same (after the first two years, 70 acres). In $1633^{102}$ the rent of pasture had risen to I $3^{s} .8 d$. an acre on a twenty-one years' lease. Various clauses in the leases on this manor, cited by Cullum, throw an interesting light on economic development. ${ }^{108}$

${ }^{88 a}$ B.M. Add. MSS. 22058 , fol. 42.
Ibid. 209 .
${ }^{99}$ Cullum, Hist. of Howsted, 197.

${ }^{102}$ Ibid. 214.

664
${ }^{100}$ Ibid. 207.

103 Ibid. 198. 


\section{SOCIAL AND ECONOMIC HISTORY}

The leases of date 1572 show a special care for the timber on the estate, the tenants being permitted to crop, and lop and shred only such trees as had been used to these processes, and none other; they are allowed as they will or not to improve the ground by clearing it of bushes and briars, and they may break up and put in tillage any pasture ground except the wooded borders.

The conditions as to clearing the ground of thorns gradually became more stringent, though a very large amount of 'terra et pastura dumosa et boscalis' must have remained unimproved through many successive tenancies. ${ }^{104}$ In these earlier leases it is noticeable that the condition of the tillage is that chiefly looked to.

From $1593^{105}$ onwards another clause is to be noted; the breaking up of pasture for tillage is penalized more or less severely, sometimes with a money fine, sometimes with the forfeiture of the whole or some large part of the crop.

Whenever the import of grain to foreign markets had raised corn to a high price, the farmer might have been tempted to break up pastures and to sacrifice the certain profits of grass for the precarious ones of tillage, which would probably cease when foreign demands grew less. ${ }^{106}$

About $1620^{107}$ the clauses about the clearing of thorns and briars drop out as self-evident, now that the price of land is so high, and in their place appears a provision for manuring and improving its condition, "the great cattle to be foddered in winter with hay on the pasture.'

The leases show a distinct advance in conditions favourable to the liberty of action of the tenant; a clause providing that the landlord might re-enter and re-possess upon twenty days' (later extended to forty days') default of payment, only after a legal demand of the rent, first appears in Hawstead in Elizabeth's reign. ${ }^{108}$ In a lease of ${ }_{1} 682$ the allowance of 'carte-boote and plough-boote' to the tenant is made for the last time. ${ }^{109}$

Reyce (I6I 8) ${ }^{110}$ graphically describes the course of husbandry in the midSuffolk district, where 'in the heaviest grounds scarce six horses of good strength can furnish one plough'; and the husbandmen who 'in the latter end of March beginning to break up their lands to fallow, do never cease until by twy-fallowing, try-fallowing, compossing and sometimes four-fallowing, they have sown their rye, mislin and wheat, or else have laid up their land for barley which in March or April following they sow in those lands thus summer-tilled.' ${ }^{\prime \prime \prime}$ He goes on to condemn the practice of the farmer who, being almost at the end of his lease, and 'having respect only for his own profit, taketh a second and a third crop.' 112 As the custom of granting long leases extended itself, while the old methods of cultivation requiring frequent fallow years were still pursued, the clauses of the leases referring to the last few years of occupation were necessarily stringent ; the tenant is required to leave the arable land to pasture one whole year before the end of the lease, or in other cases to give his successor access to a stipulated quantity of the fallow in the ploughing season previous to the expiration of his own term. ${ }^{113}$

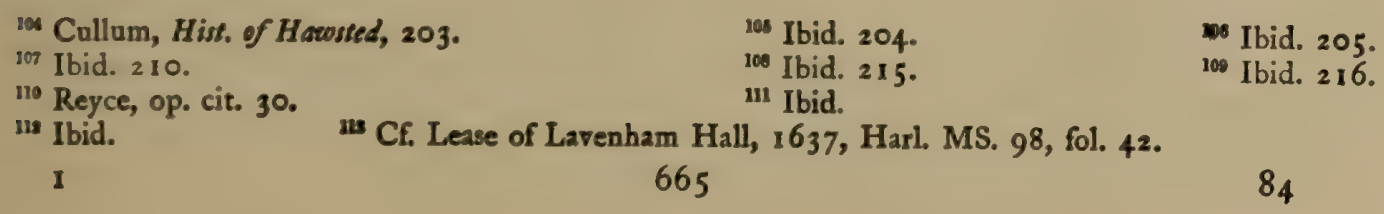




\section{A HISTORY OF SUFFOLK}

But it was impossible for the old personal relation between the lord of the manor and the customary tenant to give place to the impersonal relation involved in the payment of fixed money rents to pass away entirely, without even at this late date some difficulties arising. Even as late as 1597, on the sale of the manor of Monk Soham, ${ }^{114}$ an item of 'I 4 days' divers works to be done upon the demesne in harvest at $\mathrm{I} 2 d$. a day,' figures as one of the assets of the property, 'which at Io years' purchase amounteth to $£_{1} 4^{\prime}$ '; also I $5^{s .} 9 d$. of palfrey silver and $26 \mathrm{~s} .8 \mathrm{~d}$. of knowledge money due to every lord at his first entrance into the manor, and amounting at five years' purchase to $f_{0} 6$ I $3^{s .} 4 d$. The barter of ancient rights could not always be effected with such an exact computation of their value. A curious and typical case is exemplified in the history of the same manor. ${ }^{115}$ Upon the surrender of some portion of the land about 1595 , a dispute arose about the fine, whether or not it were certain, i.e. ' 4 s. the acre for Molland and 2s. the acre for Workland according to the pretended prescription.' ${ }^{116}$ The Court Rolls showed, it was alleged, that fines had been taken at several rates, sometimes $4 s$., sometimes $3 s .4 d$., sometimes $2 s$. an acre; there was, therefore, no prescribed fine, and further, 'it is not known at this day which land is molland and which is workland,' in the copies land being taken up by the names of so many acres of molland and workland generally, without specifying how much of each sort. 'Of late time,' the statement concludes, 'since about primo Elizabeth, no fine is set down in the Court Rolls, but the steward left the copyholder to compound with the lord himself.' ${ }^{117}$ But from the close of the century the most striking feature of the agrarian records is the eagerness for the acquisition of landed property, by advantageous purchase or by less questionable methods. Reyce (I6I8) complains ${ }^{118}$ that in this latter age, "through the immoderate desire of the next bordering lords,' the very highways are 'straitened and narrowed in many places.' In the same year a commission was appointed to adjust the boundaries of the freehold and copyhold lands of one John Haughfen, lying at Slaughden End in Sudbourne.

The defendant held certain copyhold lands under the manors of Sudbourne, Dunningworth, and Staverton-cum-Bromeswell, and was accused of having defaced the ancient abuttalls and boundaries of these freeholds, and under colour of certain deeds of feoffment claimed the same as his own freehold property, and refused to the lord of the manor, Sir John Stanhope, his due of rent. ${ }^{119}$

The extraordinarily complicated condition of Haughfen's property may perhaps be urged in extenuation, if not as an excuse, for his attempt to enrich himself at his neighbour's expense. By a survey of I 577 brought forward in evidence, he owned partly in bond, partly as freehold, thirty-five pieces of land (farmed jointly by two tenants), thirty-four of which are between I acre I rood and $\frac{1}{2}$ a rood in size, while one is 2 acres 2 roods.

The surveyor of the manor of Ixworth in 16 I $6{ }^{120}$ complains to the lord that "the revenue of the manor is much diminished by late encroachments made by the lord of Wyken, and by inclosures and intrusions upon

114 Add. MS. 23959, fol. 34.

${ }^{116}$ Ibid. fol. 40.

118 'Molland,' land in villeinage with largely commuted services; ' workland ' with services uncommuted.

1117 Add MS. 23959, fol. 4 I.

119 B.M. Add. MS. 21054 .

118 Breviary, 53.

${ }^{190}$ Harl. MS. 98, fol. 28. 


\section{SOCIAL AND ECONOMIC HISTORY}

your land and profit as is conceived made by the lord of Stowlangtoft. . . . Besides it is confessed by the foreman of the homage and others that many hold lands within your manor for which they have no evidence to show.' A survey of the same manor in 1627 concludes its summary of property with the words, ${ }^{121}$ ' Land intruded upon \& concealed 316 acres.' To meet the difficulties which arose from the conflict of ancient custom with modern conditions much readjustment was necessary. In a survey of Mendlesham (undated) ${ }^{198}$ a contrast is drawn between the 'ancient free rents of assize yearly-whereby ariseth yearly divers reliefs,' and the 'new free rents' reserved by the lord of the manor and yearly payable for lands and tenements by him sold free, namely, some to the tenants and their heirs for ever, some leased for a thousand years.

The sale of portions of the demesne land of Monk Soham ${ }^{198}$ in 1599 gave the steward an opportunity of breaking it up afresh into such convenient properties as would find a ready market. The lords of Framlingham abandoned the ancient method by which the revenues of their manor were collected, as part of their service, by the Coliar-holders (who paid a uniform rent of $2 \frac{1}{2} d$. an acre), and employed a bailiff in their stead. ${ }^{124}$ Lords of the manor began to take stock of their properties with a view to ' reasonable improvements' to be effected when the leases fell in. The survey of the Ixworth property (circa I 625) ${ }^{125}$ gives an insight into the direction in which improvement was expected. All the farms which consist of stocking grounds and inclosures of meadow and pasture are to have their rents raised ( $£_{4} 40-$ $£_{5} 0, £_{2} 8-40, \& c$.). On the rents of farms consisting largely of arable no advance could be made (i.e. a large farm of 180 acres of arable inclosed and 340 acres in the open field, and 23 acres of meadow to pay as before $\{22$ I Is. 4d.) A lease of II acres for ninety-nine years, dating from 23 Henry VIII, will be worth on renewal a rental of $f, 65^{5}$. instead of $5^{\text {s. }}$ as heretofore. The value of timber is so high that on one wood alone an increased profit of $\oint_{0} 7$ per annum (a yield of $6 d$. per pole on coppice of seven years' growth) is anticipated. The benefit of fairs and markets at Ixworth has doubled in value, and is to be rented at $£_{0} 5$ instead of $£_{0} 2$ Ios. per annum. The popularity with the gentry of fishing (as also of hawking, hunting, fowling, and keeping swans) 'which this manor as doth the whole county affordeth most plentifully' has made it worth while to preserve the fisheries on the river and in the moats and ponds, hitherto neglected, and to ask for them a rent of $£_{0} 6 \mathrm{~s} .8 \mathrm{~d}$. a year.

Finally (although at this date the anticipation seems unwarrantable) the profits upon weyves, estreyes, and felons' goods, copyholders and the perquisite of court, estimated at $£ 200$, but bringing in nothing, may be made to yield $£ 5^{\circ}$ per annum. The farmers of the forest sheepwalks are alleged to be making undue profits. The farmers sell I 50 full grown wethers for $£_{\mathrm{II}}$, $£_{12}$, and $£_{1}{ }_{3}$ a score, and buy in so many 'tegge' for half the money, which in three or four years will again yield double the price paid for them; the profit on such sales amounting to $f_{5} 50$ or $f_{0} 60$ a year. The wethers produce $3 \mathrm{lb}$. of wool apiece, above 77 tod in all, at $£ 28$ the tod, and besides

${ }^{1 n}$ Harl. MS. 98, fol. 368.

in Add. MS. 23959, fol. 47.
is Harl. MS. 98, fol. 118. Date from internal evidence.
13 Ibid. 2296, fol. 132 .

13 MS. Hist. of Framlingham (Add. MS. 33247), fol. 388-91.

667 


\section{A HISTORY OF SUFFOLK}

this the profits from the ewe-flock and lambs are very considerable. Yet for all this they pay but $£_{2} 8$ a year rent.

The intermission of manorial courts from 1643 to 1650 during the Civil War and the unsettled state of the lordship of the manors led to great confusion in many cases about the ownership of the land. The Act of Charles II which converted all tenures into free and socage had considerable effects in those parts of Suffolk where the ancient services remained intact, and many manors were lost to their former owners. ${ }^{126}$ The historian of Framlingham, while lamenting this effect of the 'sacred laws of liberty,' holds out the warning that even the rights remaining are threatened by the extravagant demands of lords of manors and stewards for fines and fees on the admission of copyhold tenants. ${ }^{127}$

With regard to the personnel of the farmers under these prosperous conditions Reyce's statement may well be believed: "Whilst many of the better sort, as having passed their uttermost period do suffer an utter declination, these only (the yeomanry of the county) do arise and do lay such strong sure and deep foundations that from thence in time are derived many noble and worthy families.' ${ }^{128}$ Of the position of the agricultural labourer in the middle of the $17^{\text {th }}$ century, interesting evidence is afforded by agreements between Paul D'Ewes (father of Simonds D'Ewes the diarist) and a shepherd, a ploughman, and a labourer employed on his estate in I628-9. ${ }^{129}$ John Tillot, the shepherd, is bound over to keep his master's flocks well and safely, to make good any that are missing, and if any die to bring him the skins. $\mathrm{He}$ is also to make amends for any corn bitten or spoiled by the sheep, and to bring any stray sheep to Stowlangtoft pound.

If any man do sow any ground, and the stifts of the field are broken, and may not be duly taken and fed as heretofore they have been used, then the said Tillot to feed off the said corn and to drive his sheep upon that part of the ploughed land. And to forbid any particular man to sow his ground or any part thereof whereby the sheep-walk may be hindered.

$\mathrm{He}$ is also to keep the 'conies' from destroying the corn and to stop their runs, but to kill none upon the warren; and to mend gaps in the hedges when need arises.

In consideration of these services Paul D'Ewes agrees to give pasture for fifty ewes yearly, in money for wages 50 s. yearly, in corn 7 combs, and 2 bushels of rye, and 7 combs and 2 bushels of barley, part of the corn grown on the estate; also a fleece at every shearing and a sucking lamb.

To the ploughman, ${ }^{130}$ one Bartholomew Peirson, D'Ewes lets the house called Dutchman's House at the rent of $f_{0} 2$ Ios. per annum, the yards and a close of pasture belonging to it at $f_{4} 4$ additional ; Chandler's meadow, containing I I acres, and certain fields lately divided at $f_{0} 8$ Ios. in all; with all the profits derived therefrom, as part and parcel of his wages; with the sum of $\oint_{5} 5$ in money paid half-yearly, to make a total of $\oint_{2} 20$. Peirson for his part agrees to serve Paul D'Ewes as his ploughman and servant for one year, and to do no other work for any man whatsoever. He is also bound to maintain and keep at his own charges one other able and sufficient ploughman or husbandman, as his servant, to be used solely in D'Ewes' interest. Both men are to be 'careful, diligent, and painful' in the work which their master

${ }_{188}$ MS. Hist. of Framlingham (Add. MS. 33247 ), fol. 391 .

${ }^{198}$ Reyce, Breviary of Suff. $5^{8}$. ${ }_{199}$ Harl. MS. 98, fol. 3 I.

เง Ibid. fol. 399 . 668

180 Ibid. fol. 32 . 


\section{SOCIAL AND ECONOMIC HISTORY}

or his bailiff may assign to them, and to make good any loss or wilful default due to mishandling or neglect of the cattle. Peirson is obliged to buy all his rye, barley, or malt from his master, at the price obtaining in Bury market, and to accept it in part payment of his wages.

The agreement with the husbandman, ${ }^{131}$ Thomas Palfrey, closely resembles the foregoing, except that Palfrey and his hired man (whose maintenance is to be wholly at Palfrey's expense) are to occupy themselves 'in and about the folding and manuring of the ground and all other their master's works of husbandry and labour whatsoever.' Palfrey's remuneration is to stand at $f_{0} 83^{s .} 4 d$. in money, and $f_{0} \mathrm{I} 3 \mathrm{I} 6 s$. in house and land rent. $\mathrm{He}$ is to have 4 combs of rye at $8 d$. a comb, and 5 combs of barley at $6 s$. $8 d$. a comb at

ie next harvest. His wife is to malt as much rye as her master requires her for his own use, 'she having for her pains a comb of rye, the said il. aul D'Ewes to find straw and carriage.'

of $f_{1 .}$ The wages of servants and labourers appointed by the justices of peace $P_{i}$ Bury Quarter Sessions in 1682 stand at the following rates :- ${ }^{132}$
A bailiff in husbandry
$£$ s. $d$.
A chief husbandman or carter . . . . .
A second hind or husbandman or common servant above
eighteen years
fourth under eighteen
600 per annum
500 ,
A fourth under eighteen years. . . 2100
The best hired servants with meat and drink for harvest I 20
An ordinary harvest man. . . . . . o I8 0

\section{For Day Labourers}

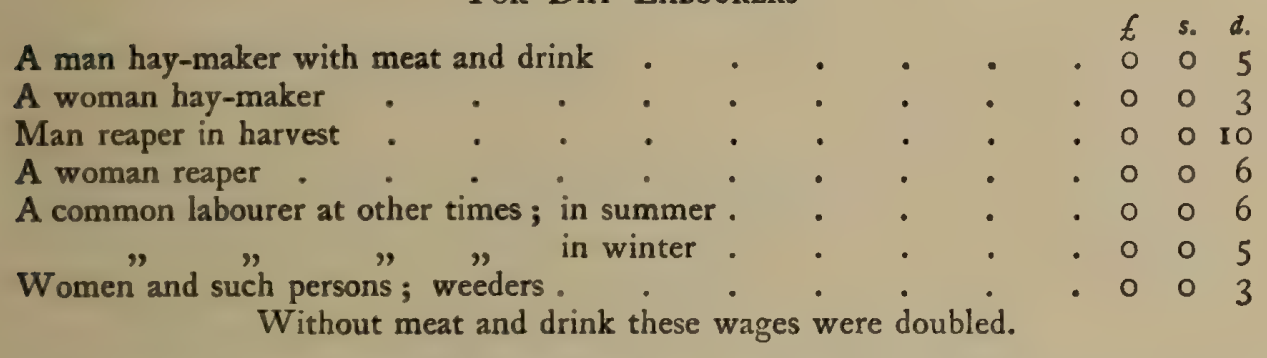

At Friston in the south-east of the county in 1684 the payment for such rural labours as setting a hedge was $2 d$. a rod, for a staked hedge $I d$. a rod. ${ }^{133}$ In 1694 the gardener at the Hall received $\oint_{0} 12$ a year. The wages of the men employed in that typically East Anglian labour of cutting sluices and mending forelands and sea-walls were is. $6 d$. per day, reed-cutting (for thatch) in the rivers also $1 s .6 d$. a day. ${ }^{134}$ In $175^{136}$ carpenter's work was paid at Is. Iod. a day, a bricklayer and his labourer received together $3^{s .} 4 d$. a day; a bricklayer and his boy $3^{\text {s. a day. }{ }^{136}}$

The rent of land at Friston at the close of the 17th century stood according to the rotation of crops at :-

Rye ground
Pasture and barley
Pasture and rye
Pasture and wheat
Barley, wheat, pasture
Pasture, hemp, or corn
Turnips .

in Harl. MS. 98, fol. 30.

in Ibid. fol. 152 .

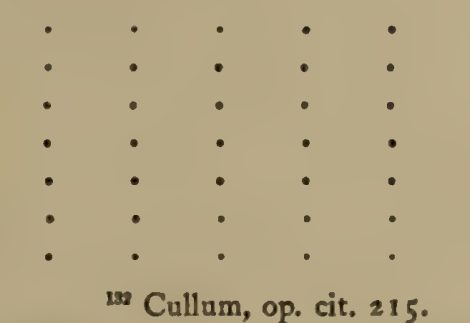

w3 Ibid. fol. 264 .
196 Ibid. fol. 266.

3s. $4 d$. per acre

IOs. "

5s. I3. "d."

IOS. "

IOS.

IOS. " " 137

138 Add. MS. 22249 , fol. 158. 


\section{A HISTORY OF SUFFOLK}

A turnip crop first occurs in the Friston records in $1694:{ }^{198}$ Cullum ${ }^{139}$ mentions their cultivation at Hawstead in 1700 , some thirty years before it was to become general all over England. ${ }^{140}$ With these signs of enterprise may be compared the condition of property in Framlingham, ${ }^{141}$ where under the lordship of Pembroke College the 'coliar holders' are found in 17 I 2 paying rents of $2 \frac{1}{2} d$. per acre and where the customs 'having no foundation in reason, conscience or law' include the payment of tithe in kind or by compounds of totally inadequate value. The tenth and seventh lamb or 4 s.; if under seven, each $\frac{1}{2} d$. The tenth or seventh pig or $2 s$.; if under seven, each $\frac{1}{2} d$. Or as at Saxtead, for 'every gast or grazing beast $2 d$., for every skep of bees $\frac{1}{2} d .{ }^{\prime}{ }^{142}$

During the 16 th century agriculture in Suffolk was but the handmaidf of the dominant industry of cloth-making, but with the slow decay of $t^{\text {s }}$ cloth-trade throughout the succeeding century it began itself to take the for most place : the export of cloth to the foreign market gradually yielded importance to the export of dairy produce for consumption in Londoi. The Privy Council answered the petitions of distressed cloth workers with futile attempts to coerce the dying trade into activity by well-directed legislation; the Suffolk landowners were more concerned to press forward Acts for the draining of the fens and the reclamation of sea-board, ${ }^{143}$ and so to increase the grazing capacity of their properties. ${ }^{144}$

The hearth tax returns ${ }^{145}$ at this period (1662-8) show Suffolk to have had a population of approximately I42,000, which by 1700 increased to I 72, I I O. But East Bergholt, Hadleigh, Halesworth, Woodbridge, with their long lists of empty houses bear witness to decaying trade no less than do Aldeburgh, Dunwich, Gorleston, Southwold, and Walberswick to encroaching seas and dwindling fisheries.

The Civil War may for a time have hampered agricultural activities : so rich a source of supply as Suffolk was not likely to be overlooked where troops were to be fed : the direct exaction of ship-money, which in the last reign had pressed very heavily upon the small farmer, ${ }^{146}$ was replaced by the seizure for the use of the Parliamentary army of 'billingers of barley' and the commandeering of hundreds of tons of cheese. ${ }^{147}$ But in 1722 when Defoe made his tour ${ }^{148}$ High Suffolk was full of rich feeding grounds and large farms, employed in making the best butter and (in his opinion) the worst cheese in England, and in fattening great quantities of beef and mutton, turkeys, fowls and geese for the London market. ${ }^{140}$

From the middle of the 18 th century with the wider introduction of turnips and clover crops, and the consequent avoidance of the necessity of leaving the fields to fallow, the cultivation of the arable entered on a fresh stage.

Cullum ${ }^{150}$ notices the provision in leases from 1732 onwards for the improvement of the soil by the use of manures, e.g. the tenant of Pinford End

\footnotetext{
${ }^{139}$ Add. MS. 22249 , fol. 144 : for date of entry cf. fol. $13,147$.

${ }^{140} \mathrm{Cf}$. Defoe, Tour in Eastern Counties, 120.

${ }^{141}$ MS. Hist. of Framlingham (Add. MS. 33247 ), fol. 452.

${ }^{14}$ Ibid. fol. 377.

ius Suff. Green Books, no. xi, vol. I3, p. 29.

${ }^{246}$ Cal. S.P. Dom. $1648-9$, p. 382 .

${ }^{148}$ Tour in the Eastern Counties, 110.
${ }^{148}$ Cal. S.P. Dom. $163 \mathrm{I}-3$, p. 115 ; $1638-9$, p. 326.
${ }^{145}$ Suckling, Introd. 27.
147 Ibid. I650, p. 590.
${ }^{149}$ Ibid. 120 et seq.

${ }^{139}$ Cullum, op. cit. 2 I8.
}

sn

he

e-

in 


\section{SOCIAL AND ECONOMIC HISTORY}

Farm is to be allowed 2s. for every wagon-load of dung or cinder-ash which he should bring from Bury to lay on the lands. This allowance was, however, only once claimed in 2 I years, and in other cases the tenant was more prudently given no option in the matter. This period of agriculture in Suffolk is marked by a further considerable rise in the value of land.

The largest estate in the county, [writes Arthur Young in 1794,] is supposed not to exceed $f 8,000$, or $f^{8,500}$ a year .... there are three or four other estates which rise above $£ 5,000$ a year, and about 30 others which are about $£ 3,000$ a year and upwards. Under this are numbers of all sizes, but the most interesting circumstance is of a different complexion. I mean the rich yeomanry as they were once called being numerous, farmers occupying their own lands of a value rising from $\oint_{0}$ roo to $£_{400}$ a year : a most valuable set of men who having the means and the most powerful inducements to good husbandry carry agriculture to a high degree of perfection. ${ }^{111}$

The farms of largest size were to be found in the south-east sand district, one of the best cultivated in England and a most profitable one to farm in. The light soils were best understood : in the district of strong wet loam farms were smaller and the fortunes made upon them 'comparatively inconsiderable. ${ }^{\text {'158 }}$

The gentry, like Arthur Young himself, took a leading part in the cultivation of experimental crops and the improvement of grass lands.

Land rents in Young's day were as follows :-

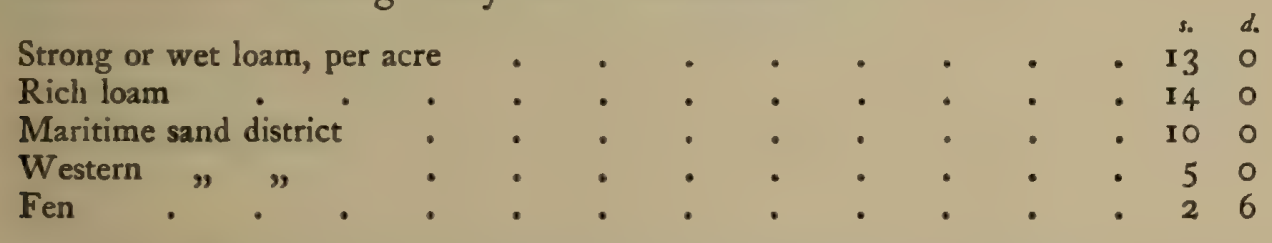

In some districts were tracts letting at 20s. to 25 s. per acre, and at even higher rents, meadow land being highest of all..$^{163}$ In few counties had the value of long leases been more conclusively proved; the tenant-farmer, secure in the investment of his money, had been active in the conversion of warren and sheep walks into cultivated inclosures. In 1798, 100,000 154 acres of uninclosed waste still remained. A further obstacle to agricultural progress also existed in some districts; the greater part of the county was freehold, but copyholds were still numerous and extensive, and often included peculiar rights of commonage and pasture. ${ }^{165}$ Young quotes an instance at Troston on the borders of the western sand district, where open field lands, on which the course consisted of one crop to two fallows, were left to weeds for the flock of one farmer, he being by prescription the only person able to keep sheep, and having even the right of sheep-feeding in many inclosed pastures and meadows after the hay harvest. ${ }^{156}$ Numerous Inclosure Acts at the close of the 18 th and early in the I gth century to a great extent obviated these difficulties. For example, the parish of Coney Weston was inclosed by Act of Parliament in 1777 , and the land-rents immediately doubled. ${ }^{167}$ The drainage of the fens was also pressed forward, and 14,000 acres in Burnt Fen alone brought under cultivation. ${ }^{168}$

\footnotetext{
1s1 Ger. Vicev of Agric. of County of Suff. (1794), Sect. iv, p. 14.

158 Young, op. cit. 15.

155 Ibid. 14. 186 Ibid. 15.

${ }^{157}$ Ibid. 54. 158 Ibid. 13.

${ }^{154}$ Ibid. 19. 


\section{A HISTORY OF SUFFOLK}

The woods of Suffolk alone show any appreciable decrease in 1798 on the valuation of former surveys ${ }^{159}$ : there was no longer any scarcity of timber as in the preceding century, and the ship-building industry had declined.

There is some direct evidence that improved agriculture brought about a shifting of population. Between 1770 and 1783 the population of Hawstead increased by one-fifth, the farmers employed double the number of hands, and bestowed on the land double the former amount of cultivation. ${ }^{160}$

If the agrarian history of Suffolk shows it in the I6th century in the forefront of the agricultural counties of England owing to the numbers of its inclosures, in the $17^{\text {th }}$ century through its growing trade with London in corn and dairy-produce, in the 18 th for the practice of scientific farming, to the I 9 th belongs characteristically the growth of its most important modern industry, the manufacture of agricultural implements and milling machinery.

Already in Arthur Young's day much fertility in inventions of this kind had been shown: he mentions numerous experimental drills and ploughs which had been employed in various parts of the county, and a machine called the Bear for cleansing river-bottoms. ${ }^{161}$ The detailed history of the growth of the industry belongs elsewhere. ${ }^{162}$

The reigns of Elizabeth and James I, with their comparative security and growing prosperity, probably represent the golden age as regards the life of the Suffolk gentry: the evil days of the Civil War had not yet fallen on them : the attractions of London had not given rise to the complaint of a later date that Suffolk reaped no benefit of the revenues drawn from her soil. ${ }^{163}$

Reyce writes of the great hospitality and neighbourliness, of the 'frequent interlacing in marriage' of the county families, 'a practice much used at this day,' also of their improvidence and lack of foresight. ${ }^{164}$ 'The multiplicity of curious buildings' strikes him, a great contrast to the low houses, thick stcine walls, small windows, and round hearth with a hole in the roof to carry off the smoke, which the insecurity of life and property had formerly rendered necessary. The Suffolk houses of his day, three or four stories high, had thin walls of brick, stone, or timber, large light windows, square lofty rooms, many small chimneys, roofs 'square and so slender that they are enforced often to repair' ${ }^{165}$ - houses many of which at the present time are in the occupation of tenant-farmers. ${ }^{166}$

The scarcity of timber ${ }^{167}$ (in part owing to the custom which now prevailed of using nothing but oak in house-building ${ }^{168}$ ) obliged them to be 'spare of stuff,' and 'that workman that can do his work with most beauty and least charge (albeit not so strong) he is most required.' ${ }^{169}$ People began to set store by the nature of the soil, the healthiness of the situation, the beauty of the prospect: all these things have a definite market value in the many descriptions of property in Suffolk which belong to this period. Many rich

\footnotetext{
169 Young, op. cit. 47.

${ }^{160}$ Cullum, op. cit. 168.

161 Young, op. cit. 31 .

${ }^{268}$ See V.C.H. Suff. ii, 281 et seq.

$16 s$ Young, App. to Gen. Surv. of Agric. (1 794), 85.

265 Ibid. 50.

167 Reyce, Breviary, 33.

${ }^{16}$ Cf. Suckling, Hist. of Suff. ii, 222.

14 Breviary, 60.

${ }^{268}$ Harrison, Descr. of Engl. (ed. Withington), 197.

${ }^{260}$ Reyce, Breviary, 50.
} 


\section{SOCIAL AND ECONOMIC HISTORY}

merchants who had made their money in the cloth-fairs of Antwerp or the markets of the Levant bought land in Suffolk and settled down to found a family. Such, for example, was Sir Thomas Kytson, 'the merchant,' citizen and mercer of London, who bought the manor of Hengrave in $152 \mathrm{I}$ from the Duke of Buckingham, and on the dissolution of Bury Abbey added to his already extensive estates the manors of Risby, Westley, Chevington, Hargrave, and the Fornhams, for which he paid $f_{0} 3,7$ Io Is. $8 d_{0}$. ${ }^{170}$ Between I 525 and 1538 Kytson built Hengrave Hall, with its gateway, one of the most beautiful specimens of the architecture of the period. ${ }^{171}$ John Eldred, citizen of London, bought the manor of Great Saxham in $1597 ;{ }^{178}$ Hakluyt gives the record of his voyages to Tripoli and Babylon. Thomas Spring, known as the rich clothier, who died in $15 \mathrm{IO}$, owned large estates in Lavenham. ${ }^{173}$ Fuller estimates the former prosperity of the cloth trade by the 'many marbles richly inlaid with brass to the memory of clothiers in foregoing ages,' which he observed in the churches of Suffolk, adding (168I), ' and not one in these later seasons.' 174 In I6 I 3 Sir John Suckling, father of the poet, bought the manor and advowson of Barsham for $£_{4}, 000$, 'confident that ere long lands will have a better and a higher price.' ${ }^{175}$

In some cases the fine monastic buildings were taken over and adapted for private use. An interesting example is Mettingham Castle, which, from 1393 till the Dissolution, had been occupied by the master and priests of Raveningham College, Norfolk. ${ }^{176}$ When Sir Nicholas Bacon came into possession of the property by purchase in 1562 , the dwelling house had fallen into complete disrepair owing to thefts of lead from the roof. The parlour, a room $25 \mathrm{ft}$. by $18 \mathrm{ft}$., which possessed a large bay window, glazed, opening into a little court, is described as 'very fair, sealed with wainscot, carved with knops fair gilt hanging down, and with two fair benches of wainscot and the floor boarded with oak. And the arms of the last master of the college round about the same parlour, fair gilt.' ${ }^{177}$ A few ruins and a freestone chimney also remained of an earlier feudal castle. The orchards, divided into sundry parts with quickset hedges and set with divers fruit trees, pears, apples, and warden plums, are carefully detailed, as well as the 'friday ponds,' and the river well replenished with pike, perch, roach, tench, and other kinds of fish, where the monks had been accustomed to boat and fish at their pleasure. Sir Nicholas succeeded also to their swannery (the birds marked in the bill with $\mathbf{M}$ for Mettingham), and the woods abounding in all kinds of wild fowl and very commodious for hawking, pheasants, and partridges; besides which, the warren of conies, black and grey, only needed careful preserving to afford him good sport. This passion for sport is thoroughly typical of the social life of the period, and there is ample evidence to show that the gentry of Suffolk appreciated to the full the peculiar advantages of their county in this respect.

Although Suffolk was never a battle-ground during the Civil War, the houses of the gentry suffered considerably at the hands of the soldiery who were arbitrarily quartered upon them. Some idea of their conduct may

${ }^{370}$ Gage, Thingoe Hund. 182.

$13 \mathrm{Kirby}$, Suff. Traveller, 225.

${ }^{773}$ Suckling, Hist. of Suff. i, 37 .

17 Add. MS. 14850 , fol. 151.
${ }^{17 n}$ Ibid. 213.

${ }^{174}$ Fuller, Worthies, 159.

${ }^{176}$ lbid. 175. in Ibid. 107. 


\section{A HISTORY OF SUFFOLK}

be gathered from the Wentworth Papers. ${ }^{178}$ Somerleyton House was more than once occupied by the Parliamentary troops.

Upon the 14th day of March, I642, being Tuesday, Colonel Cromwell's troop and Captain Fountain with his troop and divers others to the number of 140 , came to Somerleyton Hall in the morning, and there they quartered that night and a great part of them all Wednesday and Thursday till afternoon.

Valuing the quartering of 100 men-because some of them went away in the morning-for two days as abovesaid, at $8 d$. the man, comes to : .

Item, their horses eat in that time-as by good proof is made manifest35 comb of oats : the price of them 5 s. the comb, comes to. - .

Item, their horses eat and stroyed off the chamber and out of the barns at least 4 comb of wheat besides rye : the price of such wheat then, at least i $6 \mathrm{~s}$. the comb, comes to

Item, their horses eat and stroyed at least 3 loads of grey peas in the straw, all which were very well worth

Item, they shot out of the sacks and gave to their horses 9 bushels of barley: then being $2 s$. the bushel comes to

$$
\begin{array}{rrr}
6 & s & d \\
3 & 6 & 8 \\
8 & 15 & 0 \\
3 & 4 & 0 \\
4 & 0 & 0 \\
0 & 18 & 0 \\
\hline 20 & 3 & 8
\end{array}
$$

Sum of this free quarter.

Besides at least 5 loads of good hard-land hay, eaten and stroyed, worth $f 5$ at least. For goods, horses and arms seized or taken thus we inform and account :-

The I $5^{\text {th }}$ day of March I 642 Colonel Cromwell's quarter-master took away from Somerleyton Hall, the house of Sir John Wentworth, Knight, six muskets worth 20s. the musket, which comes to $f_{6} 6$; and their bandeliers and two rests valued at $6 \mathrm{s.} 8 d$. ; and one fowling-piece well worth 225. , and 12 head-pieces valued at 95 . the piece, comes to $f, 58$ s.

So the total of these arms comes to $£ 12$ I6s. $8 d$.

More, at the same time, from the same place, was taken, but by whom we know not; in gold f, 160 .

Suffolk was assessed for the maintenance of the army at $£_{0} I, 250$. Soldiers were quartered freely upon the townships, where they pillaged the shops of their stock-in-trade, and gave no recompense. ${ }^{179}$ The inhabitants of Somerleyton were compelled to maintain eight foot soldiers at a payment of $5^{\text {s. a }}$ week for each. The volunteer soldiers of the trained bands were called up weekly for exercise, providing their own arms, matches, powder, and bullets. ${ }^{180}$

At the close of the century the records of social life in Suffolk regain once more their peaceful character. From the Friston Papers may be gathered interesting glimpses of the almost paternal relations existing between the large landowners and the townspeople, who are their tenants. Sir Henry Johnson and his son-in-law and successor in the estate, Lord Strafford, are consulted on every imaginable subject, from the supply of ordnance for the defence of Aldeburgh, ${ }^{181}$ to the troubles of an aged fisherwoman almost seventy years old; ${ }^{182}$ or the disposal of brandy casks blown ashore after being sunk by smugglers with bags of stones; ${ }^{183}$ they appoint a new schoolmaster at a salary of $f_{0} 14$ a year to succeed another whose wife has an alehouse 20 miles distant from Aldeburgh, and who is in consequence too often absent from his post; ${ }^{184}$ they lend the newspapers for perusal at the same 'White Lion,' on condition that they are kept clean and returned every

178 Suckling, op. cit. ii, 48 .

181 Add. MSS. 22249 , fol. 45.

104 Ibid. fol. 69.
170 Ibid. ii, 67.

${ }^{188}$ Ibid. fol. 106.
180 Ibid. ii, 50.

${ }^{183}$ Ibid. fol. 97 . 


\section{SOCIAL AND ECONOMIC HISTORY}

Monday morning $(1738){ }^{185}$ they give permission for the erection of posts and rails at either end of the Market Place, where wagons and carts break up the pavement, on the understanding that a passage is left open for the Friston coach, or those of any other gentlemen coming to town. ${ }^{186}$

During the I 8 th century the interest of social life centres mainly about the towns. The Dutch wars had for a time checked the prosperity of the shipping industry. Defoe ${ }^{187}$ points out how Ipswich in particular had suffered by the diminution of the collier fleets plying between Newcastle and London, which its harbour had once entertained, and which had often been built in its yards. Dutch 'fly-boats,' taken in the war, thrust themselves into the coaltrade, and Ipswich men dropped gradually out of it. ${ }^{188}$ The thinness of the population, owing to this, and, according to another witness, ${ }^{189}$ also to the passing of the cloth trade to the north and west of England, became a byword : 'Ipswich a town without people.' But already in Defoe's day things had begun to mend : large quantities of corn grown in the surrounding district were continually shipped from its quays to London, and also to Holland..$^{190}$ If the wealthy manufacturers had deserted it never to return, people of another class 'scrambled' for houses in the town. ${ }^{191}$

There ${ }^{192}$ is a great deal of very good company in this town and though there are not so many of the gentry here as at Bury, yet there are more here than in any other town in the county : the company you meet with are generally persons well-informed on the world and who have something very solid and entertaining in their society. This may happen by their frequent conversing with those who have been abroad, and by their having a remnant of gentlemen and masters of ships among them who have seen more of the world than the people of an inland town are likely to have seen.

Living in Ipswich was particularly cheap, and access to London easy, the coach going through in one day. Woodbridge also was 'full of cornfactors and butter-factors,' some of them very considerable merchants.

Bungay about 1700 was the subject of an unsuccessful experiment: Mr. King, an apothecary of the town, tried to bring it forward as a spa, pointing out that the chalybeate spring in the old castle possessed valuable properties: he built a bath-house at Earsham (just across the Norfolk border), planted a vineyard, and made walks; but though the Suffolk gentry for many - years resorted to the bath-house, little came of the enterprise. ${ }^{193}$

Reyce in his Breviary had written a century earlier of the condition of the Suffolk cottage :-

'The mean person and the poor cottager thinks he doth very well if he can compass in his manner of building to raise his frame low, cover it with thatch, and to fill his wide panels (after they are well splinted and bound) with clay or culme enough well-tempered ... over which to bestow a cast of hair, lime, and sand made into mortar and laid thereon rough or smooth.' ${ }^{194}$ In Arthur Young's day the Suffolk cottage was still built of lath and plaster, or wattle and clay, and was, he adds, deficient in warmth and every convenience of life. ${ }^{195}$ Crabbe's unflinching pen has left a picture of the conditions of life in the lowest stratum of society, as he saw it in his native town of

${ }^{285}$ Add. MSS. 22249 , fol. I 3.

188 Ibid. 84.

100 Defoe, op. cit. 94.

w Suckling, op. cit. i, 128.
186 Ibid. fol. Ior.

189 Kirby, Suff. Traveller (ed. 1784), 51.

${ }^{191} \mathrm{Kirby}$, op. cit. 5 I.

19 Breviary, 5 I. 675
${ }^{187}$ Tour in the Eastern Counties, 83 .

198 Defoe, op. cit. 95. 1 Young, op. cit. (ed. I 797), 1 I. 


\title{
A HISTORY OF SUFFOLK
}

Aldeburgh-a description of an old warehouse let out as a shelter to beggars and vagabonds : ${ }^{196}$

\author{
Where'er the floor allows an even space, \\ Chalking and marks of various games have place; \\ Boys, without foresight, pleased in halters swing- \\ On a fix'd hook men cast a flying ring; \\ While gin and snuff their female neighbours share, \\ And the black beverage in the fractured ware.
}

But some few of the Suffolk landlords, intent on improvement, turned their attention to the condition of their tenants' dwellings; ${ }^{197}$ and the $\mathrm{I} 8$ th century saw the introduction of a new system of Poor Law, which endeavoured to deal more effectually than the old with the vagabond population, and to control the education of pauper children.

Suffolk, as an industrial county, had from an early date experience of the problem of poor relief. Between I5I4 and I569 the town councils throughout England were active in forwarding measures for the relief of the poor. The lead which London had given was closely followed by Ipswich. In I 55 I two persons were nominated by the bailiffs ' to inquire into the poor of every parish and thereof to make certificate.' ${ }^{198}$ In 1556 eight burgesses were appointed to frame measures for the ordering and maintenance of poor and impotent people, for providing them with work, and for suppressing vagrants and idle persons: licensed beggars were supplied with badges. Compulsory taxation for the benefit of the poor was adopted, and the rate levied according to the value of house-property-punishments being inflicted for non-payment. In 1569 Christ's Hospital, the counterpart of Bridewella house of correction, an asylum for the aged, and a training-school for the young-was erected. Bury also possessed a house of correction; the regulations for food compare favourably with the workhouse dietary of a later date : the inmates were supplied with two principal meals a day, dinner and supper, and on days when meat was eaten everyone was to have eight ounces of rye bread, a pint of porridge, a quarter of a pound of meat, and a pint of beer : on fast days one-third of a pound of cheese, and one or two herrings instead of meat. All were to rise at four in the summer, and five in winter, and to work till seven with intervals for morning and evening prayer.

The Bury Articles of I $57 \mathrm{I}-5{ }^{199}$ reflect the prevalent opinion that idle persons were a menace to the prosperity of town life. 'Item that every artificer and labourer suspected of loitering do weekly declare to one of the constables of the ward every Sunday in the morning where he wrought every day in the said week, and the said constable to inquire immediately the truth thereof.

'If any labourer shall not be provided of work on the Sunday for the week following, then the curate or constable to move the parish for work.'

No poor persons were allowed to keep their children at home when they were of an age for service.

The history of the Poor Law in Suffolk during the 16 th and 17 th centuries is closely bound up with the history of the cloth industry.

${ }^{106}$ Borough (ed. 1834), 296.

${ }^{197}$ Young, loc. cit.

198 Cf. Bacon, Ann. of Ipswich, 1 26-235, quoted E. M. Leonard, Early Hist. of Engl. Poor Relief, 42.

${ }^{100}$ Hist. MSS. Com. Rep. xiv, App. viii, I 39. 


\section{SOCIAL AND ECONOMIC HISTORY}

Those who, under the newly inaugurated system of poor relief, had to provide work for the unemployed naturally turned their attention to spinning, and an industry already carried on by the women and children in cottages all over the county was represented in the cloth centres by a considerable amount of semi-pauperized labour. ${ }^{200}$ The children of Christ's Hospital, Ipswich, were taught to card and spin wool at an early age : under an order of I 590 every clothier was compelled to have at least half his wool carded, spun, woven, and shorn by the poor of the town; for the other half he might procure labour outside if he wished. ${ }^{201}$ The Bury Articles ${ }^{202}$ already quoted ensure that the work thus compulsorily provided should be properly carried out. Every spinner was, if possible, to be provided with $6 \mathrm{lb}$. of wool every week, and to bring home the same every Saturday night. If the task was not completed the clothier had liberty to inform the constable, that punishment might be inflicted.

The spinners, probably owing to the fact that the industry was to such a great extent carried on in scattered homes, never seem to have been organized, and were peculiarly liable to oppression, 'not only through low wages, but also through payment in kind and the exaction of arbitrary fines.' ${ }^{203}$ Throughout the 17 th century the regulation of the spinners' wages was one of the problems of poor-law administration. When the cloth sales began to fail, and the looms to stand idle, they were the first to suffer. In vain the Privy Council instructed the justices of Suffolk to urge upon the clothiers the necessity of finding work for the poor. With exhausted capital and cloth to the value of thousands of pounds returned upon their hands, they were compelled to reduce the numbers of their workpeople. In I629 the Privy Council replied to a question of the Suffolk justices that a tax might permissibly be levied on the inhabitants of a parish for their lands per acre 'to employ the poor.' ${ }^{204}$ In East Bergholt, one of the chief clothing towns, the sum raised for poor relief had to be doubled. ${ }^{205}$ In 1630 malting was prohibited in the county in order to increase the supply of barley for the poor. ${ }^{206}$ The Orders in Council for the sale of corn under cost price are too numerous to be detailed here. To the growing depression of the cloth trade must be added such minor causes of distress as the frequency of disastrous fires (hardly a town in Suffolk appears to have escaped) and of epidemics of plague and small pox. The long struggle of the coast towns (where fire was but too apt to follow in the wake of tempest) against the invading sea was drawing to a close in defeat. Southwold, Blythburgh, Walberswick, Dunwich, in particular, were in a pitiable condition of poverty, while the decay of the fisheries followed inevitably upon the shifting and silting of their havens. A petition of the inhabitants in $1652{ }^{207}$ speaks of 'our poor town of Walberswick, now one of the poorest towns in England, not being able to repair our Church or Meeting place, which at the first was reared up by the Inhabitants at their only Cost and Charge, and the many poor widows and fatherless and motherless children and at this present not above one man living in the town that has $\oint_{5} 5$ per year of his own.'

\footnotetext{
200 V.C.H. Suff. ii, 258.

sos Ibid.

1 Hist. MSS. Com. Rep. xiv, App. viii, 139.

200 V.C.H. Suff. ii, $258 . \quad{ }^{20}$ E. Leonard, Early Engl. Poor Relief, p. 178. ${ }^{203}$ V.C.H. Suff. ii, 266.

$n$ E. M. Leonard, Early Engl. Poor Relief, p. 179.

${ }^{207}$ Gardner, Hist. of Dunwich, 176.
} 


\section{A HISTORY OF SUFFOLK}

In 1637 the Assizes were ordered to be held at Ipswich instead of Bury, on account of the plague, and Ipswich Fair on St. James's Day was discontinued lest the influx of pedlars and people might infect the town. ${ }^{208}$ In 1665 the Corporation of Bury, "conceiving it very necessary in these dangerous times of God's visitation timely to provide a pest-house,' set apart for the purpose the great barn called Almoners' Barn, as they had no other use for it that year. ${ }^{.09}$

In the latter part of the reign of Charles II Suffolk stood twelfth among the counties of England in the average amount of its poor rate. ${ }^{210}$ Cullum ${ }^{211}$ gives some details of the sums of money expended on the relief of the poor in Hawstead over a term of years :

\begin{tabular}{|c|c|c|c|c|c|c|c|c|c|c|c|c|c|c|c|c|}
\hline & & & & & & & RAISI & D B & LLECTION & & & & & & & \\
\hline & & & & & & $t^{6}$ & $\begin{array}{l}s \\
18\end{array}$ & $\begin{array}{l}d, \\
0\end{array}$ & I676 & - & - & - & & & $6_{8}$ & 2 \\
\hline 1672 & . & . & . & . & . & . 4 & 7 & 0 & 1680. & . & . & . & . & . & . 10 & 15 \\
\hline $1672-4$ & . & . & - & - & • & . 13 & 19 & 3 & I68I. & . & - & . & - & - & - I3 & 8 \\
\hline 675. & . & . & - & . & & . 16 & 3 & 8 & & & & & & & & \\
\hline
\end{tabular}

Under the latter year occurs the account for a pauper's funeral. ${ }^{212}$

Laid out for woollen and bread for Edward Goodwin's burial .

For a cheese for the funeral

For beer at the funeral

Beside this may be placed the provision of clothing for another pauper, 'Mother Codnam,' in 1701. ${ }^{213}$

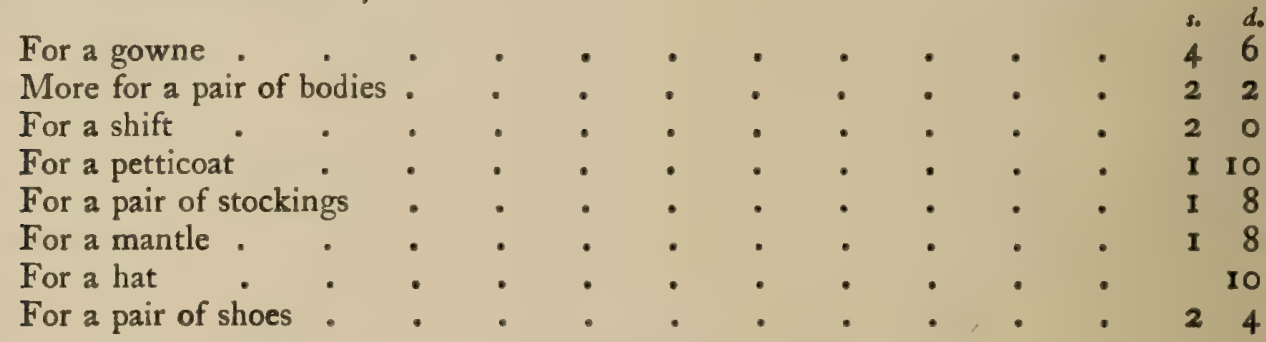

The expenditure upon poor relief in Hawstead continued very small till well on in the 18 th century. For some years after 1724 it did not exceed $£_{1} 10$ a year; till $1735, f_{0} 30$. By 1767 it had reached $£_{0} 100$, and by 1774 fi 150.214

In Glemsford, a parish of 2,400 population, the poor rates rose from $£_{0} 678$ in 1772 to $f_{0} 1,100$ in 1792 , and $£_{0} 2,129$ in 1796.215

The feeling appears to have been general that the reorganization of poor relief which took place all over Suffolk about this time led to an increase of dependence on parochial support. ${ }^{216}$ But at the same time this very reorganization had been rendered necessary by the working of economic causes. Suffolk a second time had passed through the severe trial of the decay of a staple industry, though one less acutely felt than at the first owing to her advance in agricultural prosperity. The making of the new draperies, 'bays, says and calimancoes,' introduced into Suffolk by Dutch refugees in

${ }^{200}$ Cal. S.P. Dom. 1637, pp. 282-3.

${ }^{909}$ Min. Bks. of Corp. of Bury, Hist. MSS. Com. Rep. xiv, App. viii, 145.

110 Rogers, Hist. of Agric. and Prices, iv, I 22.

11 Cullum, op. cit. 162. "13 Suckling, Hist. of Suff. i, 358.

"16 Young, op. cit. (ed. 1797), 18.

"14 Cullum, op. cit. 186.

${ }^{116}$ Cullum, op. cit. 168. 


\section{SOCIAL AND ECONOMIC HISTORY}

the reign of Elizabeth, ${ }^{217}$ at first subservient to, had gradually replaced the older industry. Side by side, as a dependent industry, must be placed the production of yarn, the new draperies requiring long wool which had to be combed before it was spun, instead of short carded wool. This combing and spinning employed many poor persons, who fed the Norwich and London markets as well, producing more than could be made up in Suffolk. It was said that while $84 \mathrm{lb}$. of wool, the amount required for a cloth of the old stout texture, gave employment to but fourteen people, forty or fifty were engaged upon working up the same quantity into the flimsier materials.

But the period of revival was but a brief one, for towards the close of the $17^{\text {th }}$ century the fabrics brought in by the East India Company came into serious competition with the new draperies, ${ }^{218}$ and as time went on they followed the old to the manufacturing towns of the north and west of England. In 1722 Defoe ${ }^{219}$ comments on the poverty of Sudbury, the centre of the revived industry: "They have a great manufacture of says and perpetuanas, and multitudes of poor people are employed in working them; but the number of the poor is almost ready to eat up the rich.'

But while the weaving industry steadily declined, a very large quantity of yarn continued to be spun for weavers without the county, especially in Norwich. The earnings were extremely low, from $3 d$. to $4 d$. a day, ${ }^{220}$ and the trade subject to frequent depression. ${ }^{221}$ The spinners could not live upon their pittances, and the deficiency had to be made up out of the rates. Arthur Young estimates their number, women and children, at about $36,000 .{ }^{.29}$

Enough has been said to show that the undoubted increase of poverty in certain parts of Suffolk was due to well-defined economic causes. Towards the middle of the century several districts within the county applied to Parliament for the 'power of incorporating themselves and of regulating the employment and maintenance of the poor by certain rules not authorized by existing poor laws.' ${ }^{223}$

Several Acts of Parliament were passed, and between 1756 and $178 \mathrm{I}^{223 \mathrm{a}}$ the hundred of Colneis and Carlford; Blything, Mutford, and Lothingland; Wangford; Loes and Wilford; Samford; Bosmere and Claydon; Cosford (with the parish of Polsted); Hartismere, Hoxne and Thredling; and Stow were incorporated. They were permitted under the Act to borrow funds to a limited amount for the purpose of building Houses of Industry, ${ }^{224}$ and these were erected (in all but the Hartismere district, where smaller local houses in several parishes took the place of a central house) at Nacton (1757), ${ }^{225}$ Bulcamp ( 1765$),{ }^{226}$ Oulton ( 1767$),{ }^{227}$ Shipmeadow (I 766), ${ }^{228}$ Melton ( I 765), ${ }^{229}$ Tattingstone (1 766), ${ }^{230}$ Barham ( I 766), ${ }^{231}$ Semer (1 780), ${ }^{232}$ Onehouse (178 I) ${ }^{233}$ The erection of the workhouses led to rioting and the attempted destruction of the buildings by the classes they were intended to benefit. ${ }^{23}$ In other ranks of society the movement found supporters among those who considered the spirit of the French Revolution not altogether absent from the English

217 V.C.H. Suff. ii, 267.

200 V.C.H. Suff. ii, 270.

In Ibid. (1804), 232.

mas Ibid. 76 et seq.

$m$ Ibid. 78 .

31 Ibid. 81 ns Ibid. 269. 119 Tour in the Eastern Counties (ed. Cassell), 100.

ml Young, Gen. View of Agric. (1794), 50.

ss Young, App. to Gen. View of Agric. (1794), 75.

st Ibid. 76.

Ibid.

ws Ibid. 82 .

Ibid. 79 .

ss Ibid. 83 .

21 Ibid. 77 .

230 Ibid. 80 .

su Ibid. 92. 


\section{A HISTORY OF SUFFOLK}

poor, and needing the chastening influence of restraint and enforced industry; many people, however, not least the poet Crabbe, regarded the innovation with horror and were in full sympathy with his denunciation ${ }^{234 a}$ of the

\section{- Pauper palace, which they hate to see, ... \\ A prison with a milder name \\ Which few inhabit without dread or shame.'}

Both points of view appear to have been justified to a certain extent by immediate consequences.

An inquiry into the state of the workhouse at Melton in $\mathrm{I}_{79} \mathrm{I}^{285}$ disclosed fearful conditions of neglect and inhumanity, especially in the treatment of the sick. On the other hand the general report of the Suffolk workhouses appended to Arthur Young's treatise and published in 1793 (by which time Melton had a new governor) speaks of the improvement in morality and the superior good order noticeable in the incorporated as compared with the other districts, "less of drivers riding on their waggons, tippling in alehouses, and smaller immoralities and improprieties; the poor respectful and civil to their superiors, the children less prone to steal wood and turnips.' 286

It is significant that the spinning (especially hemp-spinning for coarser textiles, which was more remunerative than yarn-spinning, being paid at the rate of $6 d$. a day ${ }^{237}$ ) was found to be the most productive employment for the workhouse inmates. An attempt to employ them in agriculture met with little result-a few ' let out for husbandry' earned $6 d$. a day by weeding. ${ }^{238}$ The inmates of Oulton workhouse made nets for the Lowestoft herring fisheries, the merchants furnishing twine to be braided by the yard.

The workhouses are described as clean and, airy, and, by implication, the cottage homes of the poor as filthy, airless, and slovenly; the food, 'good brown bread,' cheese of the county, 'excellent small-beer home-brewed from the best malt,' ${ }^{239}$ was at least so far more plentiful than the ordinary diet of the class to which the inmates belonged that at Semer a large number of deaths occurred among them owing to too much meat having been allowed to those who came in after suffering extreme poverty. ${ }^{240}$ Yet the deathrate in these first years owing to epidemics of 'putrid fever' and smallpox was enormous; in I 78 I 130 inmates of the Bulcamp workhouse, where the average number of inmates was 203 , died of a 'putrid fever,' which also carried off one-third of the inhabitants of Blythburgh. ${ }^{241}$ The administration of out-relief appears to have been so indiscriminate as to lead to abuses as great as those which existed under the old system. ${ }^{242}$

According to the evidence taken before the Poor Law Commission of I 83 I, Suffolk, with a population by the last census (I 82 I) of 270,542 , had an average poor rate of $17 s$. $10 \frac{1}{2} d$. per head..$^{243}$

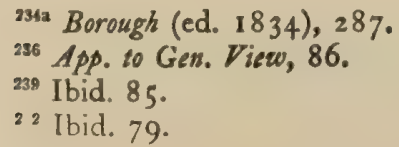

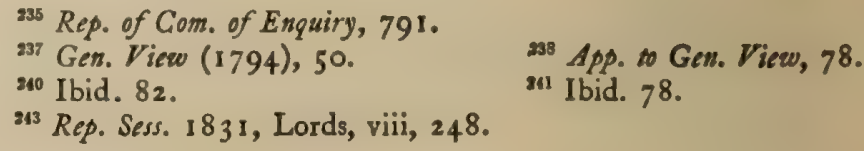




\title{
SOCIAL AND ECONOMIC HISTORY
}

\section{TABLE OF POPULATION, I80I To I90I}

\author{
Introductory Notes
}

AREA

The county taken in this table is that existing subsequently to 7 \& 8 Vict., chap. 6I (I 844 ). By this Act detached parts of counties, which had already for parliamentary purposes been amalgamated with the county by which they were surrounded or with which the detached part had the longest common boundary ( $2 \& 3$ Will. IV, chap. $64-1832$ ), were annexed to the same county for all purposes; some exceptions were, however, permitted.

By the same Act (7 \& 8 Vict., chap. 6r) the detached parts of counties, transferred to other counties, were also annexed to the hundred, ward, wapentake, \&c. by which they were wholly or mostly surrounded, or to which they next adjoined, in the counties to which they were transferred. The hundreds, \&c. in this table also are given as existing subsequently to this Act.

As is well known, the famous statute of Queen Elizabeth for the relief of the poor took the thenexisting ecclesiastical parish as the unit for Poor Law relief. This continued for some centuries with but few modifications; notably by an Act passed in the thirteenth year of the reign of Charles II which permitted townships and villages to maintain their own poor. This permission was necessary owing to the large size of some of the parishes, especially in the north of England.

In 1801 the parish for rating purposes (now known as the civil parish, i.e. 'an area for which a separate poor rate is or can be made, or for which a separate overseer is or can be appointed') was in most cases co-extensive with the ecclesiastical parish of the same name; but already there were numerous townships and villages rated separately for the relief of the poor, and also there were many places scattered up and down the country, known as extra-parochial places, which paid no rates at all. Further, many parishes had detached parts entirely surrounded by another parish or parishes.

Parliament first turned its attention to extra-parochial places, and by an Act (20 Vict., chap. 19-1857) it was laid down (a) that all extra-parochial places entered separately in the 1851 census returns are to be deemed civil parishes, $(b)$ that in any other place being, or being reputed to be, extra-parochial, overseers of the poor may be appointed, and $(c)$ that where, however, owners and occupiers of two-thirds in value of the land of any such place desire its annexation to an adjoining civil parish, it may be so added with the consent of the said parish. This Act was not found entirely to fulfil its object, so by a further Act (31 \& 32 Vict., chap. I 22r 868) it was enacted that every such place remaining on 25 December 1868, should be added to the parish with which it had the longest common boundary.

The next thing to be dealt with was the question of detached parts of civil parishes, which was done by the Divided Parishes Acts of 1876,1879 , and 1882 . The last, which amended the one of 1876 , provides that every detached part of an entirely extra-metropolitan parish which is entirely surrounded by another parish becomes transferred to this latter for civil purposes, or if the population exceeds 300 persons it may be made a separate parish. These Acts also gave power to add detached parts surrounded by more than one parish to one or more of the surrounding parishes, and also to amalgamate entire parishes with one or more parishes. Under the 1879 Act it was not necessary for the area dealt with to be entirely detached. These Acts also declared that every part added to a parish in another county becomes part of that county.

Then came the Local Government Act, 1888 , which permits the alteration of civil parish boundaries and the amalgamation of civil parishes by Local Government Board orders. It also created the administrative counties. The Local Government Act of 1894 enacts that where a civil parish is partly in a rural district and partly in an urban district each part shall become a separate civil parish ; and also that where a civil parish is situated in more than one urban district each part shall become a separate civil parish, unless the county council otherwise direct.

Meanwhile, the ecclesiastical parishes had been altered and new ones created under entirely different Acts, which cannot be entered into here, as the table treats of the ancient parishes in their civil aspect.

\section{Population}

The first census of England was taken in I 801 , and was very little more than a counting of the population in each parish (or place), excluding all persons, such as soldiers, sailors, \&c., who formed no part of its ordinary population. It was the de facto population (i.e. the population 


\section{A HISTORY OF SUFFOLK}

actually resident at a particular time) and not the de jure (i.e. the population really belonging to any particular place at a particular time). This principle has been sustained throughout the censuses.

The Army at home (including militia), the men of the Royal Navy ashore, and the registered seamen ashore were not included in the population of the places where they happened to be, at the time of the census, until $184 \mathrm{I}$. The men of the Royal Navy and other persons on board vessels (naval or mercantile) in home ports were first included in the population of those places in 1851 . Others temporarily present, such as gipsies, persons in barges, \&c. were included in 1841 and perhaps earlier.

\section{General}

Up to and including 1831 the returns were mainly made by the overseers of the poor, and more than one day was allowed for the enumeration, but the $1841-1901$ returns were made under the superintendence of the registration officers and the enumeration was to be completed in one day. The Householder's Schedule was first used in 184r. The exact date of the censuses are as follows:-

$\begin{array}{lccl}\text { 10 March, 1801 } & \text { 30 May, 1831 } & 8 \text { April, 1861 } & 6 \text { April, 1891 } \\ 27 \text { May, 181 } & \text { 7 June, 1841 } & 3 \text { April, 1871 } & \text { 1 April, 1901 } \\ 28 \text { May, 1821 } & \text { 31 March, I851 } & 4 \text { April, 1881 } & \end{array}$

\section{Notes Explanatory of the Table}

This table gives the population of the ancient county and arranges the parishes, \&c. under the hundred or other subdivision to which they belong, but there is no doubt that the constitution of hundreds, \&c. was in some cases doubtful.

In the main the table follows the arrangement in the $184 \mathrm{I}$ census volume.

The table gives the population and area of each parish, \&c. as it existed in 1801, as far as possible.

The areas are those supplied by the Ordnance Survey Department, except in the case of those marked ' $e$,' which were calculated by other authorities. The area includes inland water (if any), but not tidal water or foreshore.

+ after the name of a civil parish indicates that the parish was affected by the operation of the Divided Parishes Acts, but the Registrar-General failed to obtain particulars of every such change. The changes which escaped notification were, however, probably small in area and with little, if any, population. Considerable difficulty was experienced both in 189 I and I $90 \mathrm{I}$ in tracing the results of changes effected in civil parishes under the provisions of these Acts; by the Registrar-General's courtesy, however, reference has been permitted to certain records of formerly detached parts of parishes, which has made it possible approximately to ascertain the population in 1901 of parishes as constituted prior to such alterations, though the figures in many instances must be regarded as partly estimates.

* after the name of a parish (or place) indicates that such parish (or place) contains a union workhouse which was in use in (or before) $185 \mathrm{I}$ and was still in use in $190 \mathrm{I}$.

$\ddagger$ after the name of a parish (or place) indicates that the ecclesiastical parish of the same name at the 1901 census was co-extensive with such parish (or place).

$\$$ after the name of a parish (or place) indicates that the civil parish of vie same name at the I gor census was co-extensive with such parish (or place).

$O$ in the table indicates that there is no population on the area in question.

- in the table indicates that no population can be ascertained.

The word 'chapelry' seems often to have been used as an equivalent for 'township' in 184I, which census volume has been adopted as the standard for names and descriptions of areas.

The figures in italics in the table relate to the area and population of such subdivisions of ancient parishes as chapelries, townships, and hamlets. 


\section{SOCIAL AND ECONOMIC HISTORY}

\section{TABLE OF POPULATION}

$1801-1901$

\begin{tabular}{|c|c|c|c|c|c|c|c|c|c|c|c|c|}
\hline 一 & $\begin{array}{c}\text { Acre- } \\
\text { age }\end{array}$ & 1801 & $18 \mathrm{II}$ & $182 \mathrm{I}$ & 1831 & $\mathrm{I} 84 \mathrm{I}$ & 1851 & $186 x$ & 1871 & $188 I$ & I8gr & IgOI \\
\hline $\begin{array}{l}\text { Ancient or Geographical } \\
\text { County }{ }^{1}\end{array}$ & 952,710 & 214,404 & 233,875 & 270,542 & 296,317 & 315,073 & 337,235 & 336,290 & 0348,118 & 356,128 & 369,150 & 381,752 \\
\hline
\end{tabular}

\begin{tabular}{|c|c|c|c|c|c|c|c|c|c|c|c|c|}
\hline Parish & $\begin{array}{l}\text { Acre- } \\
\text { age }\end{array}$ & I8OI & I8II & 1821 & $183 \mathrm{I}$ & $184 \mathrm{I}$ & I85I & $186 \mathrm{I}$ & $187 x$ & $188 \mathrm{I}$ & I89I & Igor \\
\hline \multicolumn{13}{|l|}{ Babergh Hundred } \\
\hline Acton $t t$. . & $2,8 \mathrm{II}^{\circ}$ & 461 & 470 & 555 & 565 & 555 & 539 & $55^{8}$ & 548 & 579 & 607 & 591 \\
\hline Alpheton $\ddagger \$$ & 1,222 & 204 & 208 & 264 & 309 & $32 \mathrm{I}$ & 370 & 298 & 290 & 249 & 234 & 244 \\
\hline Assington $t$. . & $2,986^{\circ}$ & $47 i$ & 478 & 533 & 641 & 778 & 776 & 747 & 746 & 735 & 588 & 560 \\
\hline $\begin{array}{l}\text { Boxfond (part } \\
\text { of }+8)\end{array}$ & $1,325^{\circ}$ & 636 & 702 & 743 & 874 & 889 & 898 & 806 & 743 & 659 & 659 & 581 \\
\hline Boxted $\uparrow:$ : & $1,367^{\circ}$ & 171 & 173 & 196 & 239 & 200 & 201 & 192 & 194 & 181 & 163 & 187 \\
\hline Brent Eleigh $\$$ \& . & 1,684 & 243 & 255 & 298 & 290 & 289 & 260 & 228 & 219 & 229 & 221 & 182 \\
\hline $\begin{array}{l}\text { Bures St. Mary } \\
\text { (part of } \dagger^{3}\end{array}$ & 2,516 & 702 & 710 & 837 & 996 & 984 & $I, 144$ & 1,036 & 910 & 868 & 906 & 810 \\
\hline Cavendish $t$. & $3,354^{\circ}$ & 1,042 & I,074 & 1,215 & 1,214 & 1,353 & $\mathbf{I}, 394$ & I,30I & $\mathbf{1}, 388$ & I, I 49 & 1,045 & 902 \\
\hline Chilton $+t^{4}$ & $979^{\circ}$ & 79 & - & 97 & 108 & 98 & 151 & 149 & 260 & 284 & 297 & 271 \\
\hline Cockfield $\$ \S$. & 3,626 & 739 & 829 & 897 & 1,023 & 951 & 988 & 992 & 980 & 931 & 926 & 854 \\
\hline 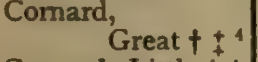 & $1,567^{\circ}$ & 535 & 510 & 656 & 819 & 938 & 857 & 904 & 877 & 803 & 866 & 863 \\
\hline Cornard, Little $\dagger+$ & $1,657^{\circ}$ & 279 & 239 & 297 & 345 & 396 & 380 & 404 & 429 & 385 & 330 & 282 \\
\hline Edwardstone $\dagger \ddagger$. & $1,872^{\circ}$ & 362 & 374 & 416 & 503 & 495 & 479 & 462 & 473 & $43^{8}$ & 420 & 416 \\
\hline Glemsford $t \pm$. . & $2,295^{\circ}$ & 1,215 & $I, 148$ & 1,275 & $\mathbf{I}, 470$ & 1,366 & 1,626 & 1,932 & 2,251 & 2,490 & $2,45^{8}$ & 2,016 \\
\hline Groton $t \downarrow$ & $1,571^{\circ}$ & 516 & 545 & 597 & 577 & 624 & 589 & 554 & 506 & 467 & 463 & 394 \\
\hline Hartest $t \quad{ }^{\circ}$ & $1,964^{\circ}$ & 646 & 705 & 740 & $76 I$ & 812 & 832 & 744 & .720 & 616 & 609 & 537 \\
\hline Lavenham $\neq \delta$. & 2,898 & $\mathbf{I}, 776$ & $x, 711$ & I, 898 & 2,107 & 1,871 & 1,811 & 1,823 & I,886 & 1,838 & I, 908 & 2,018 \\
\hline Lawshall $\$$ \& & 2,930 . & 554 & 717 & 837 & 885 & 925 & 908 & 903 & 870 & 799 & 770 & 664 \\
\hline Melford, Long $\downarrow \downarrow$ & $5,185^{\circ}$ & 2,204 & 2,068 & 2,288 & 2,514 & 2,597 & 2,587 & 2,870 & 3,046 & 3,293 & 3,253 & 3,080 \\
\hline Milden \pm 8 : & $\mathrm{I}, 343$ & 130 & 141 & 167 & 177 & 186 & 165 & 159 & 170 & 179 & 160 & 152 \\
\hline Monks Eleigh $¥ \S$. & 2,099 & 542 & 560 & 713 & 733 & 732 & 722 & 678 & 720 & 577 & 547 & 553 \\
\hline Nayland $+I$. & $94 i^{\circ}$ & 881 & 933 & 1,019 & 1,047 & I, I I 4 & 1,153 & $I, 061$ & 980 & 901 & 882 & 792 \\
\hline $\begin{array}{l}\text { Newton near } \\
\text { Sudbury } t \downarrow\end{array}$ & $2,197^{\circ}$ & 354 & 310 & 343 & 432 & 443 & 499 & 529 & 477 & 442 & 427 & 334 \\
\hline Polstead $\dagger$. & $3,402^{*}$ & 655 & 699 & 900 & 960 & 989 & 943 & 922 & 853 & 820 & 749 & 672 \\
\hline Preston $t+.$. & $1,931^{\circ}$ & 309 & 272 & 320 & 321 & 406 & 386 & 348 & 354 & 300 & 305 & 284 \\
\hline Shimpling $t+$ & $2,698^{\circ}$ & 44 I & 393 & 450 & 496 & 517 & 470 & 500 & 584 & $49 \mathrm{I}$ & 464 & 410 \\
\hline Somerton $t t$ & $1,040^{\circ}$ & 117 & 187 & 156 & 141 & 143 & 136 & 153 & 168 & 116 & 125 & 103 \\
\hline Stanstead $\dagger \ddagger \cdot$ & $1,162^{\circ}$ & 258 & 284 & $34 \mathrm{I}$ & 353 & 387 & 412 & 382 & 399 & 369 & 368 & 326 \\
\hline $\begin{array}{l}\text { Stoke by } \\
\text { Nayland }+\end{array}$ & $5,277^{\circ}$ & 1,041 & 1,242 & 1,393 & I, 447 & 1,362 & 1,406 & 1,275 & I, I 74 & 1,150 & 1,084 & 948 \\
\hline $\begin{array}{l}\text { Waldingfield, } \\
\text { Great }+ \pm^{4}\end{array}$ & $2,423^{\circ}$ & 564 & 577 & 711 & 679 & 676 & 659 & 622 & 585 & 587 & 569 & 462 \\
\hline $\begin{array}{l}\text { Walding field, } \\
\text { Little }+\ddagger\end{array}$ & $1,574^{\circ}$ & $33^{8}$ & 347 & 386 & 403 & 420 & 404 & 412 & 391 & 415 & 406 & 340 \\
\hline $\begin{array}{l}\text { Wiston, or } \\
\text { Wissington } \dagger \ddagger\end{array}$ & $1,485^{\circ}$ & 220 & 218 & 246 & 249 & 252 & 256 & 254 & 222 & $19 x$ & 127 & 153 \\
\hline
\end{tabular}

1 Ancient County.-There were no changes in the area of this County under the provisions of the Act $7 \& 8$ Vict. cap. 6r. Unfortunately the parts of Thetford St. Mary and Thetford St. Cuthbert in Suffolk were not distinguished at the earlier Censuses, neither was the part of Brandon in Norfolk; consequently Brandon is shown in the Table as entirely in Suffolk and the parts of Thetford St. Mary and Thetford St. Cuthbert are ignored in this Table. In the ${ }_{38} 8 \mathrm{~g}$ Census Volume a part of Gorleston Ancient Parish is said to be in Norfolk Ancient County and a part of Great Yarmouth Ancient Parish in Suffolk Ancient County. The figures given for Gorleston Parish are exclusive of those for the part in Norfolk Arcient County, which was first shown in 189I; the part in Norfolk is known to have been enumerated in Runham Parish in 188r. None of Great Yarmouth is shown in this Table.

The area is taken from the Igor Census Volume, and necessarily does not exactly correspond with the population.

The population given in the Table for 1821 excludes 979 Militia, who could not be distributed to the places to which they belonged. (See also notes to Rushford, Mendham.)

2 Boxford is situated partly in Babergh Hundred and partly in Cosford Hundred.

- Bures St. Mary Ancient Parish.-The remainder is in Essex (Hinckford Hundred).

- Chiltow. - A portion of Chilton is supposed to have been included in Great Corrard in 184r. The 1818 volume states that the population of Chilton is included with that of Great Waldingfield in that year. 


\section{A HISTORY OF SUFFOLK}

TABLE OF POPULATION, 1801-1901 (continued)

\begin{tabular}{|c|c|c|c|c|c|c|c|c|c|c|c|c|}
\hline PARISB & $\begin{array}{l}\text { Acre- } \\
\text { age }\end{array}$ & 1801 & I8II & 1821 & $183 I$ & $184 \mathrm{I}$ & 5851 & $186 \mathrm{I}$ & 1871 & $188 \mathrm{I}$ & I89I & 1901 \\
\hline \multicolumn{13}{|l|}{$\begin{array}{l}\text { Blackbourn } \\
\text { Hundred }\end{array}$} \\
\hline Ashfield, Great $\ddagger \S$ & 1,548 & 270 & 294 & 345 & 408 & 396 & 455 & 408 & 459 & 398 & 362 & 375 \\
\hline Badwell Ash $\ddagger \S$. & 1,858 & 348 & 360 & 427 & 490 & 458 & 478 & 527 & 520 & 445 & 454 & 356 \\
\hline Bardwell $\pm \$$ & 3,183 & 556 & 553 & 687 & 799 & 826 & 893 & 882 & 806 & 756 & 734 & 668 \\
\hline Barnham $\S^{\circ}$. & $5,29 \mathrm{I}$ & 303 & 325 & 369 & 384 & 412 & 445 & 475 & 434 & 459 & 454 & 382 \\
\hline Barningham $\S$. & 1,620 & 316 & 349 & 424 & 514 & 508 & 499 & 489 & 446 & 421 & 403 & 399 \\
\hline Coney Weston $\S$. & $\mathbf{I}, 35 \mathrm{I}$ & 198 & 221 & 261 & 255 & 244 & 266 & 254 & 209 & 198 & 178 & 230 \\
\hline Culford : - & $2,22 \mathrm{I}$ & 244 & 239 & 291 & 327 & 352 & 348 & 346 & 298 & 299 & 364 & 309 \\
\hline Elmswell \$ $\$$ & 2,089 & 451 & 478 & 628 & 694 & 671 & 779 & 759 & 754 & 761 & 781 & 858 \\
\hline Euston...+ & $3,659^{\circ}$ & 198 & 160 & 164 & 202 & 255 & 242 & 225 & 221 & 234 & 219 & 211 \\
\hline $\begin{array}{l}\text { Fakenham } \\
\text { Magna } \dagger\end{array}$ & $2,155^{\circ}$ & 157 & 177 & 214 & 204 & 213 & 229 & I96́ & 176 & 190 & 182 & 161 \\
\hline Hepworth $\mp \S$. & 1,693 & 449 & 443 & 523 & 542 & 582 & 582 & 594 & 614 & 527 & 439 & 392 \\
\hline Hinderclay $\pm \S$. & $\mathbf{I}, 488$ & 335 & 334 & 403 & 405 & 387 & 394 & 388 & 324 & 306 & 312 & $26 r$ \\
\hline Honington $\$ \S$. . & $\mathrm{I}, 20 \mathrm{I}$ & 176 & 209 & 250 & 248 & 273 & 331 & 363 & 315 & 308 & 259 & 236 \\
\hline Hopton $\neq \S$ & $\mathbf{I}, 397$ & 433 & $44 I$ & 524 & 581 & 623 & 674 & 643 & 604 & 555 & 474 & 488 \\
\hline Hunston $\ddagger \S$. . & 960 & 143 & 165 & 178 & 185 & 162 & 142 & 172 & $15^{8}$ & 134 & 130 & 127 \\
\hline Ingham $\S$ & 1,830 & 160 & 155 & 185 & $22 \overrightarrow{6}$ & 208 & 233 & 236 & 242 & 284 & 292 & 252 \\
\hline Ixworth $\$$. . & 2,304 & 827 & 846 & 952 & $I, 06 I$ & 1,064 & 1,189 & 1,074 & 1,057 & $I, 004$ & $95 \mathrm{I}$ & 856 \\
\hline Knettishall \& . . & 1,059 & 49 & 60 & 70 & 67 & 79 & 80 & 84 & 83 & 76 & 69 & 59 \\
\hline Langham $+\S$ & 970 & 207 & 214 & 268 & 264 & 293 & $28 \mathrm{r}$ & 242 & $2 \infty$ & 204 & 175 & 154 \\
\hline Livermere Parva $\$$ & I,437 & 89 & 142 & 187 & 185 & 172 & 174 & 167 & 179 & 166 & 145 & 140 \\
\hline Norton $\ddagger \S$. & 2,460 & 533 & 565 & $69 \mathrm{I}$ & 802 & 879 & 927 & 948 & 886 & 746 & 762 & 742 \\
\hline $\begin{array}{l}\text { Rickinghall } \\
\text { Inferior } \neq 8\end{array}$ & $\mathbf{I}, 981$ & 427 & 400 & 428 & 465 & 432 & 460 & 437 & 388 & 367 & 362 & $3^{81} \mathrm{I}$ \\
\hline Rushford (part of $)^{3}$ & 1,250 & - & - & 一 & - & 34 & 54 & 36 & 20 & 26 & 58 & 46 \\
\hline $\begin{array}{l}\text { Rymer, Extra } \\
\text { Par. } \dagger\end{array}$ & $121^{\circ}$ & - & 一 & - & - & 15 & 14 & 19 & 32 & 25 & 23 & 7 \\
\hline Sapiston $\neq \$$ & 1,282 & 207 & 258 & 242 & 234 & 255 & 255 & 255 & 222 & 263 & 233 & 211 \\
\hline $\begin{array}{l}\text { Stanton, All Saints, } \\
\text { with St. John the } \\
\text { Baptist United } \\
\text { Parishes \$ } \$\end{array}$ & 3,319 & 728 & 816 & 939 & 1,035 & 1,029 & 1,082 & 1,045 & 918 & 842 & 791 & 778 \\
\hline $\begin{array}{l}\text { Stowlangtoft } \ddagger \S . \\
\text { Stow, West } \delta\end{array}$ & $\mathrm{I}, 478$ & 162 & 163 & 172 & 204 & 183 & 186 & 204 & 196 & 178 & 177 & 158 \\
\hline $\begin{array}{l}\text { Extra Par. } \\
\text { Chimney Mills }\end{array}$ & $\begin{array}{r}2,941 \\
8\end{array}$ & 168 & 170 & I79 & 266 & $\begin{array}{r}273 \\
6\end{array}$ & $\begin{array}{r}308 \\
7\end{array}$ & $\begin{array}{r}238 \\
10\end{array}$ & $\begin{array}{r}217 \\
6\end{array}$ & $\begin{array}{r}188 \\
8\end{array}$ & $\begin{array}{r}193 \\
8\end{array}$ & $\begin{array}{r}193 \\
4\end{array}$ \\
\hline Thelnetham $t \pm$. & $1,773^{\mathrm{e}}$ & 444 & 445 & 512 & 553 & $56 \mathrm{I}$ & 552 & $5^{16}$ & 421 & 384 & $35 I$ & 315 \\
\hline Thorpe by & 1,065 & 122 & 107 & 148 & 128 & 142 & 136 & 139 & 135 & 145 & I3I & 115 \\
\hline Troston $\ddagger \S .$. & 1,779 & 247 & 293 & $37 \mathrm{I}$ & 399 & 409 & 427 & 322 & 354 & 309 & 268 & 235 \\
\hline $\begin{array}{l}\text { Walsham le } \\
\text { Willows } \ddagger \S\end{array}$ & 2,817 & 993 & 948 & 1,081 & 1,167 & 1,265 & I,297 & $\mathbf{I}, 290$ & 1,277 & $\mathbf{I}, \mathbf{I} 8 \mathrm{I}$ & $\mathbf{1}, 033$ & 1,038 \\
\hline Wattisfield $\ddagger \S$. & 1,530 & 520 & 521 & 596 & 592 & 6or & 603 & 615 & 562 & $48 \mathrm{I}$ & 434 & 408 \\
\hline $\begin{array}{l}\text { Weston, } \\
\text { Market } \dagger \ddagger\end{array}$ & $1,083^{\circ}$ & 273 & 270 & 332 & 312 & 330 & 317 & 303 & 285 & 294 & 237 & 246 \\
\hline Wordwell §. . & 2,310 & 40 & 45 & 48 & 69 & 66 & 56 & 65 & 60 & 44 & 45 & 42 \\
\hline \multicolumn{13}{|l|}{$\begin{array}{l}\text { Blything } \\
\quad \text { Hundred }\end{array}$} \\
\hline $\operatorname{tam} \pm \S$ & 725 & 221 & 264 & 315 & 362 & $40 \mathrm{I}$ & 467 & 471 & 485 & 524 & 577 & 573 \\
\hline$x^{2}, 0$ & 2,560 & 178 & 201 & 224 & 208 & 194 & 223 & 212 & 196 & 207 & 204 & 216 \\
\hline Blythburgh * $\ddagger \S$ & 4,325 & 886 & 774 & 1,048 & 983 & 837 & 1,118 & 832 & 861 & 821 & 746 & 646 \\
\hline Blythford $t+$ & $947^{\circ}$ & 163 & 163 & 163 & I97 & 223 & 194 & 193 & 189 & 195 & 166 & 140 \\
\hline Bramfield $\ddagger \S$. & 2,601 & $55 ?$ & $55^{2}$ & 630 & 667 & 746 & 740 & 649 & 653 & 628 & 535 & 535 \\
\hline Brampton $\ddagger \S$ & 2,074 & 236 & 251 & 255 & 289 & 322 & 281 & 310 & 280 & 298 & 308 & 274 \\
\hline Chediston $t$. & $2,378^{\circ}$ & 368 & 345 & 427 & 409 & 433 & 434 & 418 & 401 & 362 & 363 & 283 \\
\hline Cookley $\S \quad$ : & $\mathbf{I}, 727$ & 264 & 268 & 274 & 287 & 324 & 275 & 252 & 249 & 212 & 205 & 185 \\
\hline Cove, South $\mp \&$ & 1,212 & I3I & I 35 & 186 & 183 & I94 & 194 & $\times 87$ & 170 & 157 & 137 & 158 \\
\hline Cratfield + \pm . & $2,085^{\circ}$ & $55 \mathrm{I}$ & 651 & 717 & 692 & 720 & 673 & 604 & 564 & 495 & 467 & $39^{2}$ \\
\hline Darsham $\ddagger \S$. & 1,594 & $42 \mathrm{I}$ & 387 & 487 & 513 & 528 & 462 & 409 & 472 & 434 & 365 & 379 \\
\hline Dunwich $¥ \S$ & I, I93 & 184 & 208 & 200 & 232 & 237 & 294 & 227 & 234 & 250 & 213 & 157 \\
\hline Easton Bavents $\S$. & 323 & 17 & 18 & 24 & 16 & II & 3 & 7 & 6 & 13 & 18 & 16 \\
\hline Frostenden $\ddagger \S$. & $\mathrm{I}, 322$ & 266 & 324 & 390 & 373 & 428 & $45^{6}$ & 409 & $43 I$ & 386 & 417 & 405 \\
\hline Halesworth $\dagger$. & $1,445^{\circ}$ & 1,676 & 1,810 & 2,166 & 2,473 & 2,662 & 2,662 & $2,52 \mathrm{I}$ & 2,437 & 2,498 & 2,324 & 2,266 \\
\hline Henstead (part of) ${ }^{6}$ & I,959 & 227 & 233 & 268 & 269 & 280 & 279 & 534 & 552 & 537 & 488 & 455 \\
\hline
\end{tabular}


TABLE OF POPULATION, 180I-rgor (continued)

\begin{tabular}{|c|c|c|c|c|c|c|c|c|c|c|c|c|}
\hline PARISH & $\begin{array}{l}\text { Acre- } \\
\text { age }\end{array}$ & 1801 & $18 I I$ & 1821 & $183 x$ & $I 84 I$ & $185 x$ & I86 $x$ & 1871 & $x 881$ & I8gr & IgOI \\
\hline \multicolumn{13}{|l|}{$\begin{array}{c}\text { Blything Hundred } \\
\text { (cont.) }\end{array}$} \\
\hline Heveningham $\neq \S$. & $\mathbf{1}, 669$ & 305 & 322 & $4 \mathrm{II}$ & 423 & 417 & 422 & 354 & 351 & 316 & 312 & $29 I$ \\
\hline Holton t t & $\mathbf{I}, \mathbf{I} 30^{\circ}$ & 328 & 399 & 399 & 435 & 541 & 516 & 470 & 429 & $44 I$ & 490 & .506 \\
\hline Huntingfield $\$$ & 2,146 & 373 & 403 & 386 & 400 & 397 & 411 & 369 & $36 \mathrm{I}$ & 357 & 378 & 306 \\
\hline Knoddishall $\$ \$$ & 1,850 & 286 & 309 & 316 & 315 & 397 & 432 & 442 & 442 & 448 & $44 I$ & 479 \\
\hline $\begin{array}{l}\text { Leiston cum } \\
\text { Sizewell } \ddagger \S\end{array}$ & 4,987 & 823 & 867 & 954 & 1,070 & I, 177 & 1,580 & 2,227 & 2,252 & 2,439 & 2,616 & 3,259 \\
\hline Linstead Magna $\$$. & 1,325 & 93 & 134 & 103 & 110 & 92 & 100 & 115 & 113 & 123 & 91 & 96 \\
\hline Linstead Parva ${ }^{\circ}$. & $554^{\circ}$ & 134 & 132 & 164 & 186 & 205 & 200 & 227 & 165 & 159 & 125 & 120 \\
\hline $\begin{array}{l}\text { Middleton with } \\
\text { Fordley } \$ \$\end{array}$ & 2,04 II & 488 & 564 & 564 & 580 & 599 & 620 & $5^{89}$ & 526 & 503 & 520 & 497 \\
\hline $\begin{array}{l}\text { North Hajes, or } \\
\text { Covehithe } \$\end{array}$ & $1,45^{8}$ & I 80 & 169 & 169 & 182 & I 86 & 195 & 192 & 182 & 173 & 162 & 189 \\
\hline Peasenhall $t+$. & $1,995^{\circ}$ & 532 & 633 & 746 & 773 & 845 & 820 & 875 & 930 & 863 & 781 & 698 \\
\hline Reydon 8. & 2,729 & 317 & 278 & 325 & 338 & 433 & 337 & 294 & 275 & 307 & 352 & 453 \\
\hline Rumburgh \& & $\mathbf{I}, 538$ & $35^{8}$ & 409 & 445 & 421 & 435 & 432 & 405 & 391 & 346 & 378 & 316 \\
\hline Sibton $+t$ & $2,86 I^{\circ}$ & $42 I$ & 503 & 569 & 498 & 564 & 501 & 489 & 509 & 483 & 495 & 435 \\
\hline Sotherton \&., & 1,095 & I68 & 164 & 178 & 196 & 222 & 252 & 187 & 157 & I 80 & 159 & 177 \\
\hline Southwold $\neq \$$. & 612 & 1,054 & 1,369 & 1,676 & 1,875 & 2,186 & 2,109 & 2,032 & 2,155 & 2,107 & 2,311 & 2,800 \\
\hline Spexhall $+\ddagger$ & $I, 4^{8} 4^{\prime}$ & 140 & 130 & 172 & 197 & 215 & 196 & 181 & 203 & 204 & 191 & 175 \\
\hline Stoven $\$ \$$ & 806 & 125 & 117 & 116 & I 12 & 127 & 172 & 161 & 187 & 131 & 115 & 116 \\
\hline Theberton $\$ 8$ : & $2,00 I$ & 430 & 440 & 557 & 537 & 580 & 591 & 541 & 526 & 593 & $54 I$ & 490 \\
\hline Thorington $\neq \oint^{7}$ & $1,44^{8}$ & 125 & 143 & 158 & 159 & 157 & 161 & 123 & 133 & 104 & 104 & 98 \\
\hline Ubbeston $1+$ & $1,212^{\circ}$ & 177 & 192 & 181 & 199 & 243 & 208 & 206 & 202 & 189 & 165 & 146 \\
\hline Uggeshall \$ & I,494 & 335 & 328 & 308 & 303 & 295 & 293 & 272 & 235 & 250 & 235 & 228 \\
\hline Walberswick \& $\$$ & 1,985 & 229 & 244 & 263 & 279 & 339 & 357 & 315 & 303 & 289 & 270 & 304 \\
\hline Walpole $\$$ & 1,675 & 494 & 492 & 605 & 658 & 615 & 563 & 540 & 426 & 394 & 393 & 348 \\
\hline Wangford :- & 2,700 & 593 & 622 & 746 & 792 & 818 & 814 & 862 & 789 & 757 & 727 & 716 \\
\hline Wangford $\$$ & 897 & 477 & 502 & 615 & 636 & 690 & 713 & 701 & 647 & 606 & 565 & 576 \\
\hline Henham Hamlet & 1,803 & 116 & 120 & 131 & 156 & 128 & 101 & 161 & 142 & 151 & 162 & 140 \\
\hline Wenhaston $\S$ & 2,401 & 578 & 710 & 887 & 1,070 & 1,094 & 1,004 & 948 & 914 & 877 & 832 & 792 \\
\hline Westhall $\neq \$$. & 2,318 & 373 & 441 & 440 & 442 & 412 & 496 & 468 & 474 & $43 I$ & 391 & 413 \\
\hline Westleton $\$ \S$. & 6,122 & $66 r$ & 713 & 788 & 884 & 897 & 993 & 940 & 899 & 835 & 807 & 755 \\
\hline Wisset $t+$ & $2,259^{\circ}$ & 349 & 374 & 435 & 419 & 470 & 490 & 427 & 413 & 394 & 376 & 327 \\
\hline Wrentham \$ \$. & 2,334 & 822 & 750 & 995 & 1,022 & $\mathbf{I}, 020$ & 1,026 & $I, 05 I$ & 1,019 & 980 & 1,018 & 1,019 \\
\hline Yoxford $\$ 9$ & 2,730 & 851 & $1, \infty 07$ & $I, 073$ & 1,149 & 1,251 & 1,272 & I, I I I I & $\mathbf{I}, \mathbf{1} 48$ & 1,060 & $\mathbf{I}, 047$ & 988 \\
\hline \multicolumn{13}{|l|}{$\begin{array}{c}\text { Bosmere and Clay- } \\
\text { don Hundred }\end{array}$} \\
\hline Akenham 8 : & I,OI 7 & 105 & 117 & 120 & 119 & 117 & I3I & 94 & 84 & 115 & 116 & 104 \\
\hline Ashbocking \& \& & $I, 4 I 3$ & 186 & 237 & 248 & 234 & 321 & 314 & 324 & 320 & 316 & 289 & 289 \\
\hline Badley $\$ 8$ & 1,078 & 82 & 81 & 84 & 82 & 83 & 74 & 70 & 84 & 77 & 83 & 77 \\
\hline Barham $\$ \S^{8}$. & 1,802 & 352 & 539 & 845 & 825 & 576 & 776 & 568 & 509 & 470 & $45^{8}$ & 449 \\
\hline Barking + t & $3,164^{\circ}$ & 1,900 & 1,685 & 1,761 & 1,957 & $\mathbf{1}, 879$ & $\mathbf{1}, 856$ & I,, 850 & $\mathbf{I}, 842$ & $1,84 I$ & 1,730 & $\mathbf{I}, 657$ \\
\hline Battisford $\ddagger \$$ & 1,581 & 290 & 320 & $42 \mathrm{I}$ & 436 & 520 & 496 & 504 & 495 & 435 & 399 & 390 \\
\hline Baylham $\neq 8$. & 1,357 & 232 & 224 & 237 & 238 & 275 & 310 & 327 & 275 & 256 & 288 & 255 \\
\hline $\begin{array}{l}\text { Blakenham, } \\
\text { Great } \$ \$\end{array}$ & 875 & 120 & 127 & 162 & 192 & 180 & 244 & 291 & 236 & 300 & 276 & 305 \\
\hline $\begin{array}{l}\text { Blakenham, } \\
\text { Little } \S\end{array}$ & $I, 070$ & I I5 & 102 & 120 & 102 & 119 & I39 & 146 & I 44 & 173 & I 59 & 156 \\
\hline Bramford (part of) & 3,140 & 762 & 784 & 855 & 874 & 833 & 953 & 982 & $I, 165$ & $\mathbf{r}, \mathbf{1 6} 63$ & $I, I 40$ & $\mathbf{I}, 200$ \\
\hline Bricett, Great $\$ \$$. & 926 & 224 & 224 & 290 & 284 & 214 & 236 & 207 & 257 & 243 & 245 & 202 \\
\hline Claydon $8:$. & 975 & 305 & 316 & 328 & 402 & 418 & 540 & 501 & 563 & 530 & 562 & 549 \\
\hline Coddenham : :- & 4,464 & 903 & 993 & 1,192 & 1,273 & 1,309 & 1,457 & 1,256 & 1,237 & 1,171 & I,094 & I,016 \\
\hline Coddenham 8 & 2,733 & 653 & 725 & 847 & 913 & 924 & 1,047 & 903 & 835 & 815 & 801 & 705 \\
\hline $\begin{array}{l}\text { Crowfield Par. } \\
\text { Chap. } \$\end{array}$ & 1,731 & 250 & 268 & 345 & 360 & 385 & 410 & 353 & 402 & 356 & 293 & 311 \\
\hline $\begin{array}{l}\text { Creeting All } \\
\text { Saints }+\end{array}$ & & 279 & 244 & 271 & 294 & 286 & 301 & 333 & 317 & 300 & 321 & 301 \\
\hline Creeting St. Mary † & $3,115^{\circ}$ & 122 & 165 & 167 & 129 & 196 & 224 & 202 & 203 & 237 & 308 & $3 I 4$ \\
\hline $\begin{array}{l}\text { Creeting St. } \\
\text { Olave }+\end{array}$ & & 36 & 26 & 35 & 44 & 30 & 50 & $4 I$ & 38 & 45 & 47 & $2 I$ \\
\hline Flowton \pm 8. & 492 & 121 & 118 & I 50 & 185 & 179 & 178 & I5I & 156 & 168 & I 50 & 129 \\
\hline Gosbeck \$8 & $\mathbf{I}, 475$ & 284 & 266 & 308 & 319 & 316 & 3 II & $30 I$ & 290 & 302 & 288 & 203 \\
\hline Helmingham $\neq 8$ & 2,454 & 235 & 267 & 325 & 286 & 284 & 287 & 320 & 290 & 339 & 353 & 332 \\
\hline Hemingstone \$ 8 & 1,449 & 253 & 265 & 322 & 342 & 381 & 388 & 395 & 342 & 298 & 279 & 239 \\
\hline
\end{tabular}

7 Thorington includes No-where House, formerly Extra Parochial.

8 Barham.-The workhouse contained 429 persons in $183 \mathrm{I}$ and only 183 in $184 \mathrm{r}$.

9 Bramford is situated partly in Bosmere and Claydon Hundred and partly in Ipswich Borough. The population is entirely sbown in Bosmere and Claydon Hundred, 180r-1831. 


\section{A HISTORY OF SUFFOLK}

TABLE OF POPULATION, 1801-I901 (continued)

\begin{tabular}{|c|c|c|c|c|c|c|c|c|c|c|c|c|}
\hline Parish & $\begin{array}{l}\text { Acre- } \\
\text { age }\end{array}$ & $180 x$ & $18 I I$ & 1821 & 1831 & 1841 & 1851 & I86I & 1871 & I88I & I89r & Igor \\
\hline \multicolumn{13}{|l|}{$\begin{array}{c}\text { Bosmere and Clay- } \\
\text { don Hundred } \\
\text { (cont.) }\end{array}$} \\
\hline Henley $\pm \S$. & $\mathbf{I}, 235$ & 250 & 248 & $24 I$ & 305 & 329 & 326 & 293 & 287 & 248 & 220 & 208 \\
\hline Mickfield $+\S$. & $\mathbf{I}, 274$ & 173 & 219 & 246 & 257 & 263 & 256 & 259 & 243 & 255 & 224 & 199 \\
\hline Nettlestead $t$. & $1,028^{\circ}$ & 87 & 97 & 85 & 74 & 98 & 81 & 105 & 114 & 99 & 62 & 74 \\
\hline $\begin{array}{c}\text { Offton with Little } \\
\text { Bricett } t \ddagger\end{array}$ & $1,561^{\circ}$ & 264 & 283 & 328 & 399 & 417 & 410 & 394 & 376 & 348 & 357 & 326 \\
\hline Ringshall $\neq \&$ & 2,135 & 257 & 290 & 304 & 337 & 356 & 371 & 359 & 304 & $33 I$ & 286 & 243 \\
\hline Somersham $\dagger \ddagger$ & $1,027^{\circ}$ & 298 & 337 & 377 & 446 & 485 & 422 & 366 & 372 & 403 & 354 & 362 \\
\hline Stonham Aspall $¥ \S$ & 2,474 & 578 & 619 & 633 & 612 & 772 & 814 & 694 & 701 & 725 & 720 & 647 \\
\hline Stonham, Earl $\ddagger \S$ & $2,55^{\circ}$ & 575 & 620 & 677 & 757 & 878 & 860 & 752 & 685 & 633 & 612 & 574 \\
\hline Stonham Parva $\neq \$$ & $\mathrm{I}, 202$ & 257 & 258 & 3 II & 329 & 368 & 402 & 391 & 336 & 309 & 346 & 310 \\
\hline Swilland $\ddagger \S$ & 956 & 184 & 237 & 195 & 272 & 270 & 267 & 243 & 259 & 213 & 214 & 190 \\
\hline $\begin{array}{l}\text { Westerfield (part } \\
\text { of) }\end{array}$ & 466 & 59 & - & - & 74 & 55 & 49 & 64 & 69 & 59 & 83 & 63 \\
\hline $\begin{array}{l}\text { Whitton cum Thurl- } \\
\text { ston (part of ) }\end{array}$ & 497 & - & - & - & - & II 2 & 124 & 159 & 128 & 154 & 143 & 182 \\
\hline Willisham $\dagger \ddagger$. & $927^{\circ}$ & 154 & 159 & 173 & 224 & 217 & 213 & 186 & 204 & 199 & 144 & 123 \\
\hline \multicolumn{13}{|l|}{ CarlfordHundred } \\
\hline Bealings, Great $\ddagger \S$ & 1,036 & 218 & 279 & 339 & 367 & 377 & 377 & 338 & $34 \mathrm{I}$ & 287 & 337 & 291 \\
\hline Bealings, Little, $\ddagger \S$ & 798 & 277 & 269 & 262 & 272 & 322 & 315 & 278 & 245 & 236 & 225 & 231 \\
\hline Brightwell $\S^{12}$. & $\mathrm{I}, \mathrm{I} 14$ & 46 & 53 & 73 & 86 & $8 I$ & 73 & 81 & 67 & 68 & 60 & 81 \\
\hline Burgh $+\S$. & 1,242 & 222 & 248 & 250 & 252 & 266 & 296 & 271 & 271 & 256 & 220 & 211 \\
\hline Clopton $\mp \$$. . & 2,098 & 389 & 377 & 413 & 468 & 389 & 390 & 407 & 382 & 382 & 358 & 317 \\
\hline Culpho\$. . . & 726 & 73 & 55 & 55 & 64 & 70 & 63 & 56 & $5 \mathrm{I}$ & 60 & 67 & 71 \\
\hline Foxhall \$ & 1,850 & 150 & $15^{8}$ & 217 & 190 & 200 & 176 & 190 & 213 & $25 \mathrm{I}$ & 213 & 194 \\
\hline Grundisburgh $\ddagger \S$. & 1,909 & $64 I$ & 734 & 815 & 835 & 874 & $80 I$ & 836 & 824 & 813 & 822 & 715 \\
\hline Hasketon $\pm \S$ & $I, 680$ & 360 & 493 & 530 & 517 & 508 & 503 & 483 & $43^{8}$ & 484 & 414 & $46 \pi$ \\
\hline Kesgrave $\dagger$. & 900 & 73 & 64 & 102 & Ior & 88 & 86 & 93 & 88 & 98 & 90 & 74 \\
\hline Martlesham $\ddagger \S$. & 2,631 & 269 & 317 & 413 & 440 & 510 & 477 & 465 & 454 & 498 & 472 & 459 \\
\hline Newbourn $+\xi$ is & 909 & 142 & 153 & I $8 \mathrm{I}$ & 176 & 163 & $22 \mathrm{I}$ & 168 & $16 i$ & $14 \mathrm{I}$ & 129 & 114 \\
\hline Otley $\neq \S$ & 2,168 & 415 & 507 & 629 & 616 & 647 & 616 & 615 & 625 & 630 & 525 & 530 \\
\hline Playford $\dagger$. . & 1,296 & 216 & 189 & 264 & 299 & 253 & 260 & 275 & 258 & 239 & $24 \mathrm{I}$ & 238 \\
\hline $\begin{array}{l}\text { Rushmere (part } \\
\text { of) }{ }^{13}\end{array}$ & $\mathrm{I}, 523$ & 287 & 360 & 437 & 568 & $34 \mathrm{I}$ & 424 & $43^{8}$ & 375 & 401 & 416 & 427 \\
\hline Tuddenham $\neq \S$. & I, 274 & 205 & 301 & 308 & 369 & 423 & 425 & 394 & 390 & 358 & 374 & 356 \\
\hline Waldringfield $\ddagger \S$. & 902 & 118 & 132 & 163 & 166 & 174 & 169 & 205 & 228 & 270 & 284 & 278 \\
\hline Witnesham $\ddagger \S$. . & 2,046 & 387 & 448 & 515 & 562 & 543 & 575 & 634 & 534 & 515 & 488 & $46 I$ \\
\hline \multicolumn{13}{|l|}{ Colneis Hundred } \\
\hline Bucklesham $\ddagger \S$. & 1,826 & 186 & 221 & 269 & 274 & 255 & 318 & 362 & $32 \mathrm{I}$ & 321 & 289 & 263 \\
\hline Falkenham $\ddagger \S$. & $\mathrm{I}, 75 \mathrm{I}$ & 219 & 239 & 285 & 297 & 290 & 271 & 270 & 272 & 274 & 258 & 244 \\
\hline Felixstowe $\$$ & 1,932 & 259 & 348 & 385 & 363 & 552 & 691 & 673 & 760 & 864 & $1,5^{84}$ & 2,720 \\
\hline Hemiey $\pm \S$. & 740 & 66 & 66 & 80 & 69 & 71 & 63 & 63 & 76 & 97 & 94 & 68 \\
\hline Kirton $\neq \S$. & $\mathrm{I}, 854$ & 376 & 455 & 578 & 624 & 607 & 546 & $54 I$ & 615 & 627 & $54 \mathrm{I}$ & 515 \\
\hline Levington §. . . & 1,026 & 165 & 191 & 205 & 228 & 214 & 241 & 228 & 169 & 167 & 175 & 160 \\
\hline Nacton $^{14}$ & 3,438 & $46 I$ & 756 & 769 & 712 & 765 & 810 & 660 & 676 & 604 & 599 & 528 \\
\hline $\begin{array}{l}\text { Stratton Hall } \\
\text { Extra Par. } \$\end{array}$ & 505 & - & - & - & - & IO & 6 & 22 & I9 & 24 & 16 & 47 \\
\hline Trimley St. Mar- & 2,154 & 256 & 319 & 436 & 514 & 486 & 574 & 582 & 588 & $6 \mathrm{II}$ & 597 & $64 \mathrm{r}$ \\
\hline Trimley St. Mary ${ }^{t+}$ & $I, 925$ & 330 & 346 & 379 & 401 & 430 & 394 & 385 & $4 I I$ & 418 & 499 & 644 \\
\hline Walton \&. . . & 2,021 & 628 & 643 & 783 & 887 & 907 & 897 & 988 & 1,016 & 1,272 & 1,923 & 3,095 \\
\hline \multicolumn{13}{|l|}{ Cosford Hundred } \\
\hline Aldham $\dagger \pm$. . . & $I, 744^{\circ}$ & 197 & 251 & 292 & 318 & 293 & 307 & 267 & 234 & 238 & 233 & 242 \\
\hline $\begin{array}{l}\text { Bildeston or } \\
\text { Bilston } t+\end{array}$ & $1,420^{\circ}$ & 744 & 762 & 814 & 836 & 857 & 818 & 788 & 808 & 782 & 744 & 792 \\
\hline
\end{tabular}

10 Westerfield is situated partly in Bosmere and Claydon Hundred and partly in Ipswich Borough. The population is entirely shown in Ipswich Borough in I8II and I82I.

${ }_{11}$ Whitton cum Thurlston is situated partly in Bosmere and Claydon Hundred and partly in Ipswich Borough, The population is entirely shown in Ipswich Borough, 180I-183I.

12 The populations of Brightwell and Newbourn for I80I are estimated.

18 Rushmere Ancient Parish is situated partly in Carlford Hundred and partly in Ipswich Borough. The population is entirely shown in Carlford Hundred, 1801-1831.

14 Nacton includes Alnesbourn Priory and Purdis Farm. These two places became separate Civil Parishes under the Act 20 Vict. cap. 19, having been previously Extra Parochial. 


\section{SOCIAL AND ECONOMIC HISTORY}

TABLE OF POPULATION, 180I-I90I (continued)

\begin{tabular}{|c|c|c|c|c|c|c|c|c|c|c|c|c|}
\hline PARISB & $\begin{array}{l}\text { Acre- } \\
\text { age }\end{array}$ & 1801 & $I 81 \mathrm{I}$ & 1821 & 1831 & 1841 & $185 I$ & 1861 & 1871 & I88I & $189 \mathrm{I}$ & Igur \\
\hline \multicolumn{13}{|l|}{$\begin{array}{c}\text { Cosford Hundred } \\
\text { (cont.) }\end{array}$} \\
\hline \multicolumn{13}{|l|}{ Boxford (part } \\
\hline $\begin{array}{l}\text { Hadleigh } \\
\text { Hamlet } \S\end{array}$ & 427 & I54 & 186 & 201 & 214 & 232 & 204 & 180 & 198 & 205 & I9I & 183 \\
\hline Brettenham $\dagger \ddagger$ ? & $1,55^{\circ}$ & 228 & 292 & 280 & 366 & 367 & 401 & 426 & 406 & 316 & 354 & 294 \\
\hline Chelsworth $\ddagger \S$. & 877 & 234 & 269 & 311 & 346 & 284 & 255 & 273 & 276 & 245 & 227 & 199 \\
\hline Elmsett $+\ddagger$ & $1,973^{\circ}$ & 324 & 345 & 371 & 437 & 446 & 433 & 459 & 425 & 432 & 434 & 361 \\
\hline Hadleigh $t \neq$ & $4,288^{\circ}$ & 2,332 & 2,592 & 2,929 & 3,425 & 3,679 & 3,716 & 3,606 & 3,575 & 3,237 & 3,224 & $3,24 I$ \\
\hline Hitcham $t$. & $4,117^{\circ}$ & 746 & 866 & 965 & 1,022 & 1,065 & I,037 & 99 I & 974 & 897 & 856 & 7 il \\
\hline Kersey $\ddagger \S$. & 1,510 & 513 & 616 & 621 & 700 & 787 & 714 & 604 & 570 & 495 & 482 & 482 \\
\hline Kettlebaston $\dagger \ddagger$ & $1,063^{\circ}$ & 145 & 186 & 190 & 202 & 203 & 189 & 198 & 174 & 164 & I 33 & 133 \\
\hline Layham $\downarrow \pm$ & $2,488^{\circ}$ & $47 I$ & 493 & 595 & 552 & 549 & 577 & 534 & 542 & 537 & $52 \mathrm{I}$ & 442 \\
\hline Lindsey $\uparrow \ddagger$. & $1,246^{\circ}$ & 170 & 212 & 232 & 250 & 290 & 326 & 316 & 270 & 224 & 253 & 221 \\
\hline Naughton $+t$. & $854^{\circ}$ & 120 & 125 & 155 & 187 & I37 & 134 & 155 & 149 & 159 & I 43 & 145 \\
\hline Nedging $\dagger \ddagger \quad$. & $837^{\circ}$ & 143 & $18 i$ & 203 & 214 & 195 & 183 & $17 \mathrm{I}$ & 177 & 173 & 188 & 159 \\
\hline Semer* $+t$. & $1,248^{\circ}$ & 203 & 395 & $43 I$ & 429 & 370 & $55^{8}$ & 429 & 414 & 356 & 344 & 292 \\
\hline Thorpe Morieux $t t$ & $2,457^{\circ}$ & 271 & 305 & 369 & 412 & 418 & 414 & 447 & 449 & 416 & 385 & 370 \\
\hline Wattisham $\dagger$. & $1,298^{\circ}$ & 154 & 167 & 193 & 202 & 240 & 220 & 220 & 210 & 184 & 183 & 177 \\
\hline Whatfield $\dagger \ddagger$ & $1,570^{\circ}$ & 235 & 268 & 326 & 377 & 394 & 380 & 340 & 339 & 322 & 326 & 299 \\
\hline \multicolumn{13}{|l|}{$\begin{array}{l}\text { Hartismere } \\
\text { Hundred }\end{array}$} \\
\hline Aspall $\ddagger \S$. . & 843 & 87 & 94 & 109 & 126 & 132 & 143 & 156 & 150 & 151 & 139 & I1 6 \\
\hline Bacton + \pm & $2,204^{\circ}$ & $5^{85}$ & 610 & 715 & 758 & 800 & 901 & 733 & 659 & 642 & 639 & 580 \\
\hline Braiseworth $\ddagger \S$ & 730 & 105 & 126 & 170 & 156 & 151 & 171 & 164 & 160 & 159 & 119 & II 3 \\
\hline Brome \& . . & 908 & 278 & 287 & 324 & 377 & 328 & 314 & $29 I$ & 296 & 261 & 274 & 297 \\
\hline Burgate $\$ \$$. & 2,067 & 296 & 303 & 344 & 343 & 369 & 350 & 359 & 299 & 287 & 273 & 229 \\
\hline Cotton $t^{+}$. & $1,92 i^{\circ}$ & $44 I$ & 435 & 527 & 585 & 545 & 571 & 542 & 536 & 506 & 479 & 422 \\
\hline Eye $\$ \S^{16}$ & 4,410 & $\mathbf{I}, 734$ & 1,893 & 1,882 & 2,313 & 2,493 & 2,587 & 2,430 & 2,396 & 2,296 & 2,064 & 2,004 \\
\hline Finningham $+\ddagger$ & $1,242^{\circ}$ & 373 & 383 & 435 & 497 & 480 & $57 I$ & 542 & 431 & 420 & 414 & 353 \\
\hline Gislingham $\ddagger \S$ & 2,271 & 473 & 519 & 620 & 660 & 669 & 696 & 623 & 595 & 552 & 494 & 438 \\
\hline Mellis $\neq \S$ & 1,365 & 371 & 422 & 447 & 513 & 532 & 610 & 598 & 490 & $47 I$ & 413 & $45 \mathrm{I}$ \\
\hline Mendlesham $\ddagger 8$ & 3,960 & $1,05 I$ & 1,093 & 1,250 & 1,233 & 1,340 & I, 442 & 1,316 & I, 243 & I, I 26 & $\mathbf{I}, \mathbf{1} 38$ & $96 I$ \\
\hline Oakley \&. ? & 1,304 & 298 & 324 & 403 & 365 & 355 & 336 & 332 & 300 & 276 & 260 & 228 \\
\hline Occold $\$ \&$. & 1,508 & 397 & 433 & 461 & 518 & 578 & 620 & 570 & $55^{8}$ & 522 & 514 & 435 \\
\hline Palgrave $\$$ \$ & 1,504 & 580 & 601 & 654 & 760 & 730 & 740 & 739 & 695 & 748 & 776 & 726 \\
\hline Red grave $\$:-$ & 3,392 & 1,095 & 1,221 & 1,297 & $I, 367$ & 1,352 & $x, 382$ & 1,266 & 1,157 & 1,109 & $95^{8}$ & 900 \\
\hline Redgrave \& & 2,123 & 530 & 646 & 713 & 712 & 719 & 756 & 686 & 578 & 557 & 503 & 501 \\
\hline $\begin{array}{l}\text { Botesdale } \\
\text { Hamlet } \S\end{array}$ & 1,269 & 565 & 575 & 584 & 655 & 633 & 626 & 580 & 579 & 552 & 455 & 399 \\
\hline Redlingfield $\ddagger \S$ & 1,060 & 212 & $2 I_{4}$ & 222 & 235 & 240 & 251 & 203 & 189 & 187 & 175 & 165 \\
\hline $\begin{array}{l}\text { Rickinghall } \\
\text { Superior } \ddagger \S\end{array}$ & 1,414 & 565 & 568 & 705 & 774 & 768 & 734 & 742 & 656 & 570 & 498 & 485 \\
\hline Rishangles $\pm \S$. & 721 & 192 & 176 & 208 & 242 & $26 r$ & 279 & 229 & 199 & 190 & 152 & 155 \\
\hline Stoke Ash $\$ 8$. & 1,215 & 275 & 294 & 330 & 392 & 423 & 392 & 371 & 334 & 310 & 228 & 231 \\
\hline Stuston $\$ 8$. & 802 & 180 & 192 & 208 & 212 & 252 & $24 I$ & 232 & 213 & 190 & 194 & 216 \\
\hline Thorndon $¥ \$$. & 2,723 & 526 & 580 & 638 & 696 & 732 & 725 & 674 & 701 & 639 & 618 & $55^{\circ}$ \\
\hline Thornham & 1,368 & 295 & 300 & 342 & 380 & 374 & 322 & 282 & 273 & 285 & 275 & 198 \\
\hline Thornham Parva $\S$ & 685 & 123 & 122 & I 39 & 206 & 203 & 155 & 124 & I44 & 134 & 136 & 116 \\
\hline Thrandeston $\ddagger \S$ & 1,386 & 305 & 306 & 330 & $35^{8}$ & 373 & 397 & 364 & 310 & 282 & 285 & 271 \\
\hline Thwaite $\$ \&$ & 833 & 129 & 116 & II 2 & 175 & 176 & 179 & 147 & 151 & I 46 & 122 & 105 \\
\hline Westhorpe $\$ 5$ & 1,337 & 199 & 230 & 234 & 263 & 264 & 240 & 227 & 212 & 213 & 216 & I I I \\
\hline Wetheringsett $\$ \&$. & 3,812 & $85 I$ & 854 & 937 & 1,001 & 1,065 & I, IOI & 1,072 & $\mathbf{I}, 063$ & 1,034 & 967 & 812 \\
\hline Wickham Skeith $¥ \S$ & $\mathrm{I}, 782$ & 442 & 516 & 523 & 556 & 574 & 613 & 564 & 555 & 505 & 439 & 413 \\
\hline Wortham $\$ \delta$ & 2,740 & 784 & 832 & 935 & 1,016 & 1,116 & 1,086 & $96 \mathrm{I}$ & 1,015 & 948 & 852 & 776 \\
\hline Wyverstone $\ddagger \$$ & 1,558 & 243 & 227 & 260 & 316 & $34^{8}$ & 329 & 302 & 300 & $26 I$ & 245 & 238 \\
\hline Yaxley $\$ \&$ & I,257 & 382 & 394 & 425 & 478 & 507 & 550 & 510 & 462 & 371 & 335 & 339 \\
\hline \multicolumn{13}{|l|}{ Hoxne Hundred } \\
\hline Athelington $\ddagger$ \& & 494 & 70 & 83 & 100 & 129 & 111 & 117 & 115 & 129 & II 8 & 106 & 87 \\
\hline Badingham $\$ \S$ & 3,209 & 607 & 667 & 816 & 866 & 864 & 794 & 749 & 707 & 672 & 598 & $55^{8}$ \\
\hline Bedfield $\ddagger 8$ & 1,270 & 295 & 336 & 319 & 323 & 358 & 372 & 415 & $45 \mathrm{I}$ & 375 & 357 & 317 \\
\hline Bedingfield $\$ 8$. & 1,805 & 252 & 252 & 318 & 332 & 336 & 312 & $32 \mathrm{I}$ & 353 & 332 & 299 & 298 \\
\hline Brundish \& . & 2,126 & 330 & 384 & 427 & 478 & 525 & 510 & 451 & 426 & 368 & 377 & 326 \\
\hline
\end{tabular}




\section{A HISTORY OF SUFFOLK}

TABLE OF POPULATION, I80I-IgOI (continued)

\begin{tabular}{|c|c|c|c|c|c|c|c|c|c|c|c|c|}
\hline PARISB & $\begin{array}{l}\text { Acre- } \\
\text { age }\end{array}$ & 1801 & 1811 & 1821 & 1831 & $184 \mathrm{I}$ & 1851 & $I 86 \mathrm{I}$ & 1871 & I88I & $189 \mathrm{r}$ & 1901 \\
\hline \multicolumn{13}{|l|}{$\begin{array}{c}\text { Hoxne Hundred } \\
\text { (cont.) }\end{array}$} \\
\hline Carlton $t^{-}$. & $543^{\circ}$ & 108 & $12 \mathrm{I}$ & 126 & 130 & 133 & 128 & I16 & 118 & 94 & I 46 & II 8 \\
\hline Denham $\ddagger \S$. & 1,282 & 219 & 247 & 259 & 276 & 313 & 318 & 282 & 259 & 300 & 272 & 192 \\
\hline Dennington $\ddagger \xi$ & 3,267 & 726 & 818 & 938 & 1,000 & 979 & 1,047 & 895 & 885 & 789 & 718 & 652 \\
\hline Fressingfield $\$$. & 4,618 & I, 044 & 1,064 & 1,231 & $1,35^{2}$ & 1,456 & I,49I & 1,325 & 1,319 & 1,147 & 1,086 & 1,005 \\
\hline Horham $\ddagger \S$. & 1,456 & 394 & 426 & 423 & 464 & 442 & 436 & 396 & 398 & 339 & 328 & 287 \\
\hline Hoxne $t+$. & 4,185 & 972 & 948 & 1,066 & I, 243 & 1,333 & 1,262 & 1,218 & 1,090 & 1,000 & 938 & 838 \\
\hline Kelsale $\dagger^{17}$. . & $3,047^{\circ}$ & 988 & $\mathrm{I}, \mathrm{O} 2 \mathrm{I}$ & 1,060 & 1,103 & 1,126 & 1,157 & $I, 084$ & 1,017 & 973 & 892 & 842 \\
\hline Laxfield $\neq \S$. & 3,719 & 1,008 & 1,003 & $1,1,5^{8}$ & 1,158 & I, I 72 & 1,147 & 1,031 & 1,018 & 886 & 905 & 827 \\
\hline $\begin{array}{l}\text { Mendham } \\
\qquad \text { (part of) }+18\end{array}$ & 2,155 & 541 & 546 & 835 & $55 \mathrm{I}$ & 566 & 586 & $55^{8}$ & 544 & 500 & 450 & 397 \\
\hline Metfield $t \pm 19$ & $2,162^{\circ}$ & $55^{8}$ & 6II & 682 & 733 & 702 & 651 & 663 & 670 & 584 & 500 & 413 \\
\hline Monk Soham $\ddagger \S$. & 1,619 & 329 & 325 & 388 & 433 & 404 & 448 & 442 & 470 & 400 & 315 & 244 \\
\hline Saxtead $\S \cdot$. & 1,209 & 391 & 390 & 453 & 505 & 447 & $44 \mathrm{I}$ & 448 & 383 & 338 & 352 & 270 \\
\hline Southolt § & $82 I$ & $21 I$ & 192 & 203 & 193 & 211 & 209 & 193 & 165 & I34 & 152 & 126 \\
\hline Stradbroke $\$ 8^{20}$ & 3,796 & 1,215 & 1,277 & $\mathbf{I}, 400$ & $\mathbf{I}, 527$ & 1,637 & 1,822 & $\mathbf{I}, 537$ & 1,513 & 1,202 & 1,069 & 1,016 \\
\hline Syleham $\ddagger \S$ & 1,615 & 257 & 285 & 360 & $39 I$ & 399 & 374 & 357 & 337 & 280 & 234 & $24 I$ \\
\hline Tannington $\S$ & 1,638 & 202 & 214 & 209 & 264 & 252 & 243 & 246 & 240 & 206 & 167 & 146 \\
\hline Weybread $\ddagger \$$. & 2,501 & 662 & 680 & 680 & 708 & 771 & 745 & 713 & 670 & 647 & 638 & $57 \mathrm{I}$ \\
\hline Wilby $\dagger \pm$ : & $1,844^{\circ}$ & 443 & 378 & 576 & 649 & 623 & 620 & 560 & 568 & 469 & 396 & 331 \\
\hline Wingfield $\ddagger \S$. & 2,495 & 521 & 555 & 578 & 668 & 668 & 654 & 593 & 581 & 463 & 466 & 387 \\
\hline Withersdale ${ }^{\prime}$ : & $880^{\circ}$ & 115 & 170 & 168 & 194 & 184 & 199 & 225 & 220 & $15 \overline{8}$ & 164 & 140 \\
\hline Worlingworth \& . & 2,473 & 653 & 595 & 685 & 729 & 786 & $8 \mathrm{II}$ & 740 & 761 & 643 & 574 & 552 \\
\hline \multicolumn{13}{|l|}{ LackfordHundred } \\
\hline Barton Mills $\neq \S$ & $\mathbf{I}, 888$ & 305 & 376 & 523 & 591 & 640 & 642 & 531 & 536 & 468 & 407 & 444 \\
\hline Brandon $\S$. & 6,783 & I, 148 & 1,360 & 1,770 & 2,065 & 2,002 & 2,215 & 2,218 & 2,248 & 2,309 & 2,334 & 2,327 \\
\hline Cavenham $\ddagger \S$. & 2,352 & 190 & 230 & 261 & $26 \mathrm{I}$ & 277 & 283 & 229 & 210 & I 86 & 185 & 147 \\
\hline $\begin{array}{l}\text { Elveden, or } \\
\text { Elden }+\S\end{array}$ & 5,508 & 134 & 174 & 277 & 248 & 240 & 238 & 193 & 285 & 310 & 233 & 459 \\
\hline Eriswell $\neq \S$. & 6,658 & 295 & 295 & 346 & 403 & 501 & 524 & 473 & 407 & $44 \mathrm{I}$ & 402 & 352 \\
\hline Exning * $\S^{21}$ & 4,987 & 566 & 590 & 695 & 9 I 7 & 1,259 & 1,556 & $\mathrm{I}, 348$ & $I, 528$ & $\mathrm{I}, 79 \mathrm{I}$ & 2,757 & 3,814 \\
\hline $\begin{array}{l}\text { Freckenham } \neq \S^{22} . \\
\text { Herringswell } \$ \S\end{array}$ & 2,610 & 256 & 307 & 366 & 427 & 495 & 477 & 476 & 421 & 371 & $34 I$ & 320 \\
\hline $\begin{array}{l}\text { Herringswell } \$ \$ \\
\text { Icklingham-All }\end{array}$ & 2,242 & 126 & I 53 & 215 & 239 & 219 & 225 & 203 & 173 & 193 & 200 & 178 \\
\hline $\left.\begin{array}{l}\text { Saints, and St. } \\
\text { James United } \\
\text { Parishes } \delta\end{array}\right\}$ & 6,762 & 335 & 364 & 424 & 473 & 525 & 652 & 625 & 529 & 425 & 375 & 339 \\
\hline Lakenheath $\S$. & 11,33 I & 745 & 844 & I, 042 & I,209 & I, 579 & 1,864 & I,797 & 1,880 & $\mathbf{I}, 877$ & 1,825 & $\mathbf{I}, 637$ \\
\hline $\begin{array}{l}\text { Mildenhall St. } \\
\text { Andrew * } \S\end{array}$ & 16,767 & 2,283 & 2,493 & 2,974 & 3,267 & 3,731 & 4,374 & 4,046 & 3,862 & 3,764 & 3,732 & 3,567 \\
\hline $\begin{array}{l}\text { Newmarket St. } \\
\text { Mary } \$\end{array}$ & 234 & 1,307 & $\mathbf{I}, 431$ & 1,810 & 2,134 & 2,143 & 2,298 & 2,002 & 2,368 & 2,730 & 2,543 & 2,825 \\
\hline $\begin{array}{l}\text { Santon Down- } \\
\text { ham } \neq \S\end{array}$ & 3,921 & 57 & 78 & 79 & 66 & 68 & 70 & $8 I$ & 84 & 101 & 68 & 93 \\
\hline Tuddenham $\neq \S$ & 2,664 & 268 & 276 & 316 & 388 & 428 & 479 & 413 & 400 & 377 & 329 & 335 \\
\hline Wangford \& & 3,285 & 43 & 33 & 63 & 53 & 46 & 33 & 50 & 54 & 56 & 50 & 38 \\
\hline Worlington $\ddagger \S$ & 2,003 & 326 & 340 & 360 & 368 & 351 & 391 & 349 & 274 & 293 & 248 & 249 \\
\hline \multicolumn{13}{|l|}{ Loes Hundred } \\
\hline eston $t t$ & $1,224^{\circ}$ & 287 & 415 & 458 & 569 & 55 & 508 & 469 & 420 & 401 & $4 \llbracket 3$ & 347 \\
\hline & 1,978 & 250 & 262 & 321 & $35^{6}$ & 364 & 375 & 385 & 369 & 383 & 337 & 270 \\
\hline Campsey Ash $\ddagger \$$. & 1,825 & 327 & 326 & 342 & 392 & 374 & 371 & 379 & 374 & 383 & 340 & 345 \\
\hline ield $\neq \S$. & 1,358 & 4 II & 465 & 549 & 558 & 551 & 511 & 484 & 457 & 430 & 411 & 412 \\
\hline Cretingham $\ddagger \$$ & 1,649 & 246 & 349 & 375 & 387 & $4 I I$ & 423 & 343 & 328 & 303 & 298 & 256 \\
\hline Earl Soham $\ddagger \S$ & 1,977 & 563 & 574 & 64 & 762 & 741 & 729 & 745 & 683 & 607 & 572 & 551 \\
\hline Easton \$ \&.. & 1,484 & 304 & 354 & $37 \mathrm{I}$ & 362 & 415 & 404 & 400 & 366 & 415 & 418 & 378 \\
\hline Eyke $\$ \& \cdot \cdot$ & 2,784 & 308 & 337 & 396 & 485 & 502 & 529 & 486 & 465 & 380 & 489 & 418 \\
\hline
\end{tabular}

17 The population of Kelsale for $\mathbf{r} 80 \mathrm{r}$ is estimated. in 1821

18 Mendham. - The remainder is in Norfolk (Earsham Hundred). The entire population is shown in Suffolk

19 The population of Metfield for I8or is estimated.

20 Stradbroke. - The decrease in the population in $188 \mathrm{I}$ is mainly due to the closing of the workhouse and the removal of the paupers to Eye workhouse.

${ }_{21}$ Exning. - The increase in population in Igor is partly due to large sewerage and other works in progress at the date of the Census.

22 Freckenham. - The decrease of population in $187 \mathrm{I}$ is ascribed to migration-principally to Durham. 


\section{SOCIAL AND ECONOMIC HISTORY}

TABLE OF POPULATION, 180I-I90I (continued)

\begin{tabular}{|c|c|c|c|c|c|c|c|c|c|c|c|c|}
\hline Parish & $\begin{array}{l}\text { Acre- } \\
\text { age }\end{array}$ & I80I & I8II & 1821 & $183 I$ & $184 I$ & $185 \mathrm{I}$ & I86I & $187 \mathrm{I}$ & $188 \mathrm{x}$ & I89I & 1901 \\
\hline \multicolumn{13}{|l|}{$\begin{array}{c}\text { Loes Hundred } \\
\text { (con!.) }\end{array}$} \\
\hline Framlingham $\S^{29}$. & 4,688 & 1,854 & $I, 965$ & 2,327 & 2,445 & 2,523 & 2,450 & 2,252 & 2,569 & 2,518 & 2,525 & 2,526 \\
\hline Hacheston $\S$. . & 1,779 & 543 & 468 & 534 & 549 & 518 & 510 & 526 & 476 & 435 & 436 & 442 \\
\hline $\mathrm{HoO} \S$. · . & 1,217 & 124 & 148 & 174 & 186 & 211 & 195 & 182 & 181 & 164 & 182 & 158 \\
\hline Kenton $\$ \xi$ : & 1,229 & 243 & 237 & 252 & $26 \mathrm{I}$ & 287 & 301 & 308 & 289 & 254 & 258 & 242 \\
\hline Kettleburgh $\ddagger \S$ & $I, 446$ & 272 & 275 & 360 & 388 & 355 & 348 & 359 & 312 & 290 & 284 & 262 \\
\hline Letheringham \& & 1,153 & 138 & 129 & 175 & I 74 & 164 & 206 & 208 & 173 & 202 & 207 & 160 \\
\hline Marlesford $+\$$. & 1,301 & 315 & $38 i$ & 436 & 433 & 424 & 428 & 412 & 410 & 334 & 375 & 354 \\
\hline Monewden $+t$ & $1,088^{\circ}$ & 157 & 180 & 188 & 207 & 220 & 220 & 223 & 226 & 220 & 203 & 152 \\
\hline Rendlesham $+\S$ & 2,036 & 216 & 225 & 249 & 261 & 325 & 359 & 359 & 345 & 354 & 355 & 283 \\
\hline Woodbridge $\S^{24}$ & $I, 100$ & 3,020 & 4,332 & 4,060 & 4,769 & 4,954 & 5,161 & 4,513 & 4,525 & 4,544 & 4,480 & 4,640 \\
\hline \multicolumn{13}{|l|}{$\begin{array}{l}\text { Mutford and } \\
\text { Lothingland } \\
\text { Hundred }\end{array}$} \\
\hline Ashby $\$$. . & $I, 105$ & 42 & 39 & 34 & 42 & 53 & 50 & 70 & 95 & 110 & 88 & 89 \\
\hline Barnby $\$$. & 1,093 & 188 & 235 & 262 & 303 & 296 & 294 & 270 & 285 & 260 & 313 & 311 \\
\hline Belton $\$ \$$ & 2,057 & 350 & 389 & 385 & 424 & 465 & 489 & 516 & 582 & 624 & 752 & $8_{36}$ \\
\hline Blundeston 8 & $\mathrm{I}, 583$ & 386 & 355 & 448 & 517 & 592 & 663 & 664 & 716 & 714 & 741 & 737 \\
\hline Bradwell $\$ \&$ & 2,340 & I99 & 225 & 272 & 257 & 270 & $34 I$ & 387 & 389 & 540 & 542 & 534 \\
\hline Burgh Castle $\$ \S$ & 1,496 & 189 & 217 & 239 & 270 & 327 & 344 & 458 & 409 & 518 & 469 & 527 \\
\hline Carlton Colville $\$ \$$ & 2,828 & 497 & 527 & 714 & 745 & 785 & 845 & 946 & 990 & 1,309 & 1,826 & 2,375 \\
\hline Corton $\ddagger \S$. . & 1,178 & 242 & 294 & 375 & 410 & 442 & 559 & 530 & 594 & 562 & 577 & 618 \\
\hline Flixton \&. & 604 & 41 & 37 & 34 & 39 & 23 & 33 & 37 & 52 & 60 & 97 & 76 \\
\hline Fritton $\mathrm{f} \&$ & 1,483 & 174 & 178 & {$[74$} & 170 & 223 & 215 & 209 & 221 & 253 & 297 & 270 \\
\hline Gisleham $\neq \$$ & $\mathrm{I}, 34 \mathrm{I}$ & 198 & 201 & 222 & 262 & 254 & 310 & 267 & 284 & 301 & 287 & 306 \\
\hline Gorleston & $2,175^{\circ}$ & 1,728 & 2,471 & 2,967 & 3,420 & 3,779 & 3,999 & 4,472 & 6,653 & 9,008 & 11,589 & 13,586 \\
\hline Gunton 4. & 825 & 36 & 89 & 87 & 63 & 77 & 77 & 73 & 76 & 88 & 59 & 90 \\
\hline Herringfleet $\ddagger \S$ & 1,305 & 160 & 200 & 168 & 183 & 197 & 179 & 210 & 230 & 224 & 187 & 257 \\
\hline Hopton $¥ \S$. & 1,29 I & 202 & 225 & 274 & 260 & $25 \mathrm{I}$ & 331 & 297 & 309 & 320 & 304 & 293 \\
\hline Kessingland $\ddagger \S$ & 1,679 & 475 & 529 & 579 & 666 & 658 & 777 & 872 & 958 & 1,229 & 1,275 & 1,420 \\
\hline Kirkley $\ddagger \ddagger$ & $539^{\circ}$ & 177 & 305 & 337 & 374 & 433 & 799 & I, I 29 & 1,626 & $2,94 I$ & 4,223 & 6,468 \\
\hline Lound +8 & 1,263 & 332 & 375 & 416 & 425 & 412 & 439 & 466 & 422 & 440 & 403 & 377 \\
\hline Lowestoft + . & $1,485^{\circ}$ & 2,332 & 3,189 & 3,675 & $4,23^{8}$ & 4,647 & 6,781 & 9,534 & 13,620 & 16,755 & $19,1.16$ & 23,372 \\
\hline Mutford $\$$ & I. 597 & 290 & 330 & 387 & 373 & 415 & 435 & 386 & 379 & 394 & 420 & 409 \\
\hline Oulton $* \$ 8$ & $1,86 \mathrm{I}$ & 522 & 475 & 704 & 809 & 660 & 742 & 747 & 864 & 1,202 & 1,314 & 1,860 \\
\hline Pakefield $\$ 8$ & 688 & 282 & 328 & 349 & 472 & 495 & 718 & 768 & 875 & 884 & I,010 & 1,425 \\
\hline Rushmere \& \& & $76 \mathrm{r}$ & 127 & 122 & $\mathrm{II}_{4}$ & 114 & 134 & II 6 & I2I & 136 & 145 & 154 & 147 \\
\hline Somerleyton $\S$. & 1,372 & 240 & 277 & 349 & 419 & 504 & 627 & $62 I$ & 599 & 597 & 569 & 54 I \\
\hline \multicolumn{13}{|l|}{$\begin{array}{l}\text { Plomesgate } \\
\text { Hundred }\end{array}$} \\
\hline Aldeburgh \$. . & 1,629 & 804 & 1,066 & 212 & $\mathrm{I}, 34 \mathrm{I}$ & 1,557 & $\mathbf{I}, 627$ & $\mathbf{I}, 72 \mathbf{I}$ & 1,990 & 2,106 & 2,159 & 2,405 \\
\hline Benhall $\$ 8$. & 2,165 & 533 & 481 & 710 & 668 & 749 & 713 & 678 & 644 & 623 & 588 & 536 \\
\hline axhall \$ई & 2,018 & 373 & 429 & 474 & 525 & 576 & 577 & $5^{89}$ & 546 & 513 & 567 & 536 \\
\hline Bruisyard $\pm \$$ & 1,138 & 225 & 223 & 269 & 292 & 296 & $25^{8}$ & 222 & 261 & 239 & 252 & 220 \\
\hline Chillesford \& \& & 1,852 & 154 & 137 & 140 & 179 & 220 & 203 & 214 & 221 & 233 & $24 I$ & 216 \\
\hline ford $\$ \S^{25}$. & 1,202 & 210 & 234 & 294 & 323 & 303 & 309 & 284 & 226 & 184 & 172 & 181 \\
\hline Farnham $\ddagger \S$ & I, 199 & 216 & 186 & 213 & 216 & 186 & 195 & 184 & 172 & 185 & 185 & 136 \\
\hline Friston $\S$. & 1,737 & 299 & 374 & 452 & 466 & 455 & 500 & 432 & 400 & 385 & 459 & $43 I$ \\
\hline Glemham, Great § & $I, 918$ & 384 & 353 & 413 & 399 & 370 & 349 & 354 & 320 & 344 & 282 & 312 \\
\hline Glemham, Little $\S$ & $I, 285$ & 319 & 299 & 349 & 361 & 333 & 318 & 325 & 268 & 271 & $28 \mathrm{I}$ & 243 \\
\hline $\begin{array}{l}\text { Havergate Island } \\
\text { Extra Par. } \$\end{array}$ & & - & - & & & 12 & 8 & 6 & 4 & 6 & 4 & \\
\hline Hazlewood \& & $\mathrm{I}, 740$ & 93 & 110 & 99 & 90 & 108 & 102 & 91 & 88 & 85 & I 4 I & 107 \\
\hline Iken $\$$. . & 2,662 & 282 & 298 & 363 & 382 & 342 & 321 & 336 & 290 & 324 & 316 & 279 \\
\hline Orford $\S .$. & 2,702 & 751 & & & & $(1,028$ & 1,045 & 948 & 1,022 & 1,147 & 987 & 885 \\
\hline $\begin{array}{l}\text { Gedgrave Extra } \\
\text { Par. } \S\end{array}$ & 1,809 & 71 & 737 & 1,119 & I,302 & 69 & 53 & 60 & 57 & 66 & 67 & $5^{8}$ \\
\hline Parham \& : . & 2,215 & 399 & 389 & 448 & 502 & 514 & 532 & 470 & 477 & 446 & 477 & 375 \\
\hline Rendham $\$ \$$. & 1,736 & 367 & 429 & 452 & 449 & 412 & 453 & 384 & 368 & 367 & 336 & 284 \\
\hline
\end{tabular}

Framlingham.-The increased population in $187 x$ is mainly due to the opening of the Albert Middle-class College since $186 \mathrm{r}$.

${ }_{24}$ Woodbridge includes the Manor of Kingston. The decline in population in 1821 is attributed to the disuse of the barracks.

${ }^{25}$ Cransford. - The increased population in 1821 is explained in the Census Volume for that year as being due to the low wages paid to single men and the absolute want of employment, which is said to produce early marriages. parocbial relief being thereby procured. 


\section{A HISTORY OF SUFFOLK}

TABLE OF POPULATION, I80I-I90I (continued)

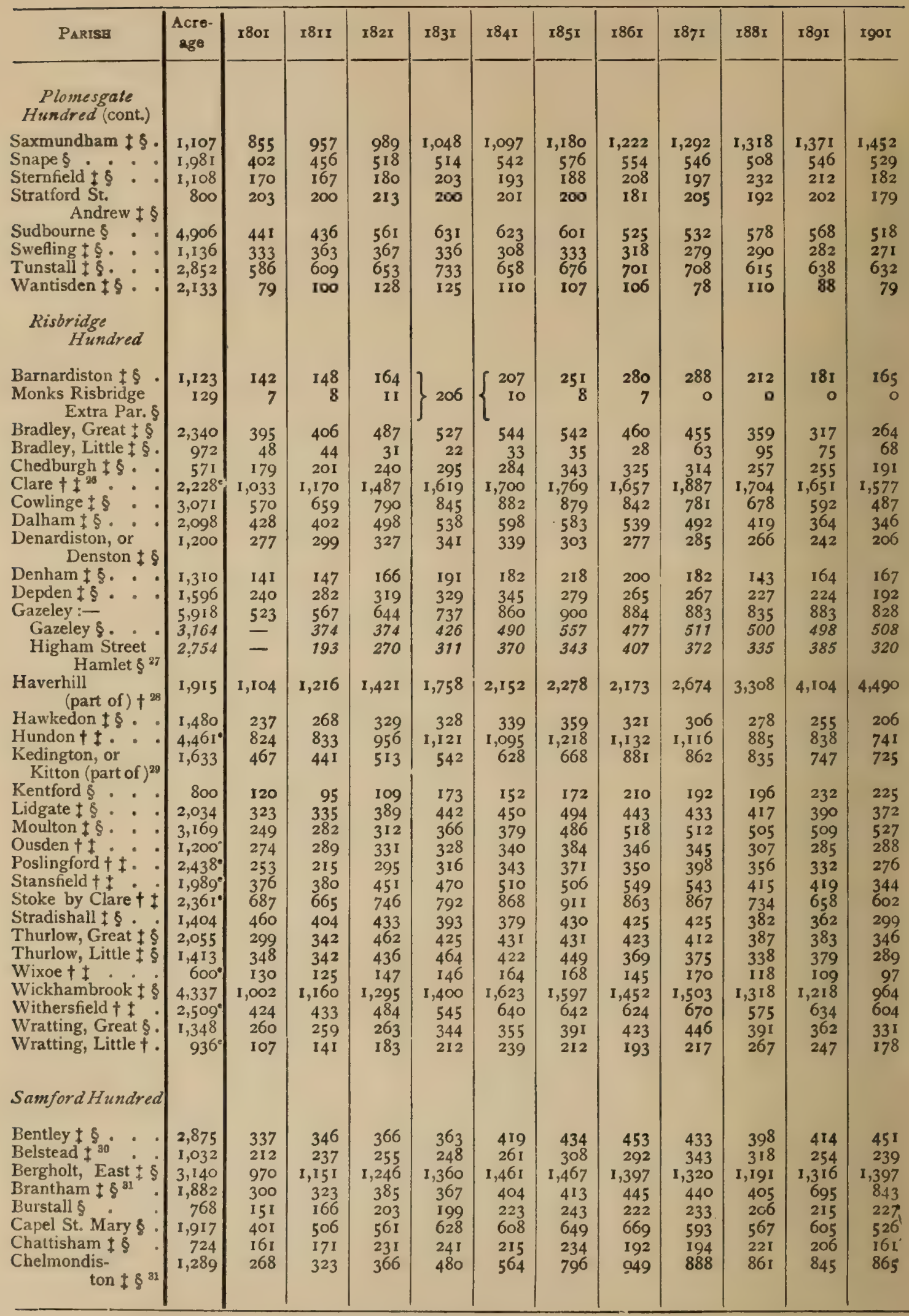

26 The population of Clare for $180 \mathrm{r}$ is estimated.

97 Higham Street may be in Lackford Hundred.

2 Haverhill. - The remainder is in Essex (Hinckford Hundred)

20 Kedington, - The remainder is in Essex (Hinckford Hundred).

so Belstead.-A small part is in Ipswich Borough; none shown there.

1 The populations of Brantham, Cholmondiston, and Harkstead for I80r are estimated. 


\section{SOCIAL AND ECONOMIC HISTORY}

TABLE OF POPULATION, 1801-1901 (continued)

\begin{tabular}{|c|c|c|c|c|c|c|c|c|c|c|c|c|}
\hline Parise & $\begin{array}{l}\text { Acre- } \\
\text { age }\end{array}$ & $280 x$ & $18 \pi x$ & $x 82 x$ & $183 x$ & $184 x$ & $185 I$ & $186 \pi$ & $187 x$ & 1881 & $189 \mathrm{r}$ & Igor \\
\hline \multicolumn{13}{|l|}{$\begin{array}{l}\text { Samford } \\
\text { Hundred (cont.) }\end{array}$} \\
\hline Copdock $\dagger$. . . & $954^{\circ}$ & 225 & 288 & 278 & 310 & 299 & 349 & 341 & $34 \mathrm{I}$ & $32 \mathrm{I}$ & 322 & 340 \\
\hline Erwarton \& . . & 1,306 & 195 & 155 & 157 & 179 & 199 & $\begin{array}{l}349 \\
247\end{array}$ & 243 & $\begin{array}{l}341 \\
187\end{array}$ & $\begin{array}{l}3<1 \\
174\end{array}$ & $\begin{array}{l}522 \\
183\end{array}$ & $\begin{array}{l}340 \\
200\end{array}$ \\
\hline Freston 18 . & 1,460 & 142 & 148 & 189 & 183 & 224 & 250 & 256 & 263 & 274 & 265 & 254 \\
\hline Harkstead $\$ \delta^{312}$ & 1,740 & 214 & 240 & 301 & 329 & $33^{8}$ & $34 I$ & 380 & 372 & 360 & 371 & 388 \\
\hline Higham $\$ \S^{\circ}$. & 900 & 202 & 237 & 262 & 260 & 259 & 292 & 229 & 219 & 176 & 194 & 177 \\
\hline Hintlesham $+\downarrow$ & $2,828^{\circ}$ & 419 & 510 & 562 & 578 & 583 & 584 & 613 & 543 & 569 & 575 & 569 \\
\hline Holbrook $\neq \$$ & 2,054 & 447 & 477 & 641 & 762 & 747 & 857 & 903 & 821 & 779 & 774 & 720 \\
\hline $\begin{array}{l}\text { Holton St. } \\
\text { Mary } \ddagger \$^{82}\end{array}$ & 848 & 190 & 196 & 213 & 194 & 187 & 192 & 167 & 167 & 169 & 176 & 144 \\
\hline Raydon $\$ 8 . ?$ & 2,374 & 367 & 422 & 501 & 559 & 592 & 555 & 561 & 558 & 524 & $54 \mathrm{I}$ & 505 \\
\hline Shelley $\dagger \neq$. & $928^{\circ}$ & 137 & 136 & 130 & 142 & 139 & 138 & 142 & 130 & 121 & 112 & 125 \\
\hline Shotley $\pm \varnothing$. & 2,04 I & 284 & 319 & 339 & 410 & 464 & 505 & 582 & 628 & 622 & 580 & $75^{\circ}$ \\
\hline $\begin{array}{r}\text { Sproughton (part } \\
\text { of) }\end{array}$ & 2,181 & 353 & 442 & 506 & 524 & 569 & 565 & 583 & 589 & 587 & 525 & 637 \\
\hline $\begin{array}{l}\text { Stratford St. } \\
\text { Mary } \ddagger \S\end{array}$ & 1,503 & 502 & 573 & 614 & 630 & 647 & 673 & 655 & 658 & 506 & 522 & 510 \\
\hline Stutton $\div 8$ & 2,299 & 406 & 420 & 475 & 475 & 492 & 455 & $53 \mathrm{I}$ & $53 I$ & 528 & 542 & 522 \\
\hline Tattingstone * $\ddagger \S$ & $1,67 \mathrm{I}$ & 620 & 519 & 665 & 666 & 628 & 597 & 626 & 585 & 535 & 515 & 558 \\
\hline Washbrook + & $1,443^{\circ}$ & 278 & 289 & 377 & 418 & 506 & 514 & $45 \mathrm{I}$ & $42 \mathrm{I}$ & 346 & 326 & 282 \\
\hline Wenham, Great $\$ \S$ & I, I33 & 170 & 156 & 205 & 181 & 198 & 269 & 260 & 282 & 234 & 228 & 184 \\
\hline Wenham, Little ${ }^{31}$ & 940 & 64 & 69 & 90 & 88 & 87 & 72 & 95 & 115 & 65 & 56 & 65 \\
\hline Wherstead $\neq 8$. & 2,142 & 237 & 223 & 242 & 233 & 238 & 238 & 245 & 255 & 264 & 315 & 287 \\
\hline Woolverstone \& & 960 & $24 I$ & 263 & 269 & 235 & 246 & 241 & 239 & 245 & 243 & 309 & 349 \\
\hline \multicolumn{13}{|l|}{ Siow Hundred } \\
\hline Buxhall $\neq \&$. . & 2,560 & 385 & 415 & 457 & 466 & 533 & 560 & 536 & 488 & 476 & 424 & 402 \\
\hline Combs $t \pm$. & $2,745^{\circ}$ & 662 & 723 & 736 & 950 & 1,064 & $\mathbf{I}, \mathbf{1} 48$ & 1,243 & $\mathbf{I}, 278$ & $\mathrm{I}, \mathrm{I} 74$ & $\mathbf{I}, \mathbf{1} 69$ & I, I 88 \\
\hline $\begin{array}{c}\text { Creeting St. Peter, } \\
\text { or West } \\
\text { Creeting } \S^{35}\end{array}$ & I, $35^{8}$ & 106 & 123 & 169 & 166 & 213 & 255 & 248 & 224 & 239 & 248 & 231 \\
\hline $\begin{array}{l}\text { Finborough, } \\
\text { Great }+\ddagger\end{array}$ & $\mathrm{I}, 63 \mathrm{I}^{\circ}$ & 325 & 333 & 392 & $42 I$ & 467 & 436 & 419 & 406 & 413 & 462 & 412 \\
\hline $\begin{array}{l}\text { Finborough, } \\
\text { Little }+t^{35}\end{array}$ & $367^{\circ}$ & 64 & 68 & 70 & 73 & 64 & 64 & 62 & 72 & 66 & 59 & 57 \\
\hline Harleston $\$$ & 612 & 87 & 97 & 94 & 89 & 90 & 80 & 65 & 43 & 76 & 78 & 64 \\
\hline Haughley $\$ \S$ : & 2,566 & 592 & 700 & 854 & 908 & 916 & 971 & 987 & 947 & $88 \mathrm{I}$ & 859 & 789 \\
\hline Newton, Old $\$ 8$ & 2,372 & $45 I$ & $5 \pi$ & 577 & 679 & 712 & 792 & 718 & 762 & 685 & 672 & 619 \\
\hline Onehouse * $8:$ & 926 & 180 & 356 & 420 & 358 & 303 & 432 & 336 & 336 & 336 & 318 & 314 \\
\hline Shelland $\ddagger$ \& & 551 & 90 & 109 & 104 & 126 & 109 & 9 I & 99 & 97 & 94 & 90 & 89 \\
\hline Stowmarket :- & 2,158 & $I, 88 I$ & 2,113 & 2,359 & 2,759 & 3,136 & 3,404 & 3,639 & 4,146 & 4,106 & 4,384 & $4,20 I$ \\
\hline $\begin{array}{l}\text { Stowmarket } \\
\text { Township } \S\end{array}$ & 999 & 1,761 & 2,006 & 2,252 & 2,672 & 3,043 & 3,306 & 3,563 & 4,097 & 4,052 & 4,339 & 4,162 \\
\hline Gipping & 1,159 & 120 & 107 & 107 & 87 & 93 & 98 & 76 & 49 & 54 & 45 & 39 \\
\hline Stowupland \& & 2,886 & 709 & 720 & 836 & 826 & 903 & 966 & 986 & 1,097 & 1,170 & $I, 240$ & 1,326 \\
\hline Wetherden $\$ 8$. & 1,856 & 346 & 382 & 468 & 487 & 515 & $54 \mathrm{I}$ & 479 & 445 & 489 & 452 & 400 \\
\hline \multicolumn{13}{|l|}{$\begin{array}{l}\text { Thedwestry } \\
\text { Hundred }\end{array}$} \\
\hline Ampton $¥ \$$ & 736 & 75 & 71 & II7 & I10 & 147 & 131 & 131 & 120 & 97 & 136 & $12 \mathrm{I}$ \\
\hline Barton, Great $\$ \$$. & 3,764 & 523 & 569 & 702 & 778 & 774 & 855 & 848 & 878 & 819 & 766 & 645 \\
\hline Beyton $\ddagger \S$. & 644 & 231 & 248 & 238 & 330 & 384 & 394 & 360 & 363 & 342 & $33^{8}$ & $35 \mathrm{I}$ \\
\hline $\begin{array}{l}\text { Bradfield Com- } \\
\text { bust }+ \pm\end{array}$ & $818^{\circ}$ & 125 & I 37 & 146 & 154 & 192 & 203 & 173 & 166 & 155 & 130 & 123 \\
\hline $\begin{array}{l}\text { Bradfield } \\
\text { St. Clare } \neq \$\end{array}$ & $I, 427$ & I3I & I5I & 201 & 226 & 240 & 214 & 233 & 233 & 250 & 216 & 165 \\
\hline $\begin{array}{l}\text { Bradfield } \\
\text { St. George } \nmid \ddagger\end{array}$ & I, $984^{\circ}$ & 354 & 370 & 409 & 489 & 479 & 486 & 427 & 493 & 443 & 388 & 417 \\
\hline Drinkstone $\$ 8$. & 2,196 & 369 & 344 & 456 & 469 & 505 & 543 & 496 & 492 & 463 & 396 & $3^{82}$ \\
\hline Felsham +1. & $1,630^{\circ}$ & 301 & 295 & 389 & $40 \mathrm{I}$ & 398 & 402 & 394 & 358 & $33 I$ & 374 & 360 \\
\hline $\begin{array}{l}\text { Fornham } \\
\text { St. Geneveve } \$\end{array}$ & 688 & 116 & 111 & 144 & 73 & 70 & 57 & 64 & 89 & 95 & 100 & 92 \\
\hline
\end{tabular}

Ma See note 3r, ante. The populations of Holton St. Mary and Little Werham for 180r are estimated. Spronghion is situated partly in Samford Hundred and partly in Ipswich Borough. The population is entirele shown in Samford Hundred, $1801-1831$.

i4 See note 32 , ante.

w Creting St. Peter and Littls Finborough. -The populations for $180 \mathrm{r}$ are estimated. 


\section{A HISTORY OF SUFFOLK}

TABLE OF POPULATION, 180I-IgOI (continued)

\begin{tabular}{|c|c|c|c|c|c|c|c|c|c|c|c|c|}
\hline Parist & $\begin{array}{l}\text { Acre- } \\
\text { age }\end{array}$ & 1801 & $18 \mathrm{II}$ & 1821 & $183 \mathrm{r}$ & $184 \mathrm{I}$ & 1851 & 1861 & $187 \mathrm{I}$ & $188 \mathrm{I}$ & r8gr & IgOI \\
\hline \multicolumn{13}{|l|}{$\begin{array}{l}\text { Thedwestry } \\
\text { Hundred (cont.) }\end{array}$} \\
\hline $\begin{array}{l}\text { Fornham } \\
\text { St. Martin } \S\end{array}$ & $\mathrm{I}, 294$ & 160 & 174 & 222 & 276 & 294 & 322 & 350 & 328 & 310 & 280 & 282 \\
\hline Gedding $t+$ ? & $521^{\circ}$ & 108 & II3 & 144 & 147 & 173 & 163 & 150 & 150 & 102 & 93 & 100 \\
\hline Hessett $+t^{t}$. . & $1,568^{\circ}$ & 323 & 343 & $\begin{array}{l}144 \\
393\end{array}$ & 428 & 417 & 487 & 454 & 437 & 428 & $\begin{array}{r}93 \\
353\end{array}$ & 381 \\
\hline Livermere Magna $\S$ & 1,555 & 259 & 239 & $25 \mathrm{I}$ & 336 & 320 & 301 & 290 & 295 & 275 & 224 & 211 \\
\hline Pakenham $\neq \S$. & $3,7 \mathrm{II}$ & $68 \mathrm{I}$ & 793 & 928 & 979 & 1,102 & 1,134 & 1,130 & 1,033 & 959 & 945 & 886 \\
\hline Rattlesden $\ddagger \S$. & 3,299 & 814 & 849 & 1,032 & 1,113 & 1,141 & I,20I & 1,117 & I, 104 & 1,040 & 980 & 894 \\
\hline Rougham $\neq \S$ & 3,977 & 607 & 626 & 778 & 868 & 969 & 1,079 & 988 & 884 & 816 & 835 & 849 \\
\hline Rushbrooke $\S$. & 1,063 & 122 & 148 & 194 & 177 & 175 & 184 & 185 & 139 & 135 & 136 & 134 \\
\hline Stanningfield $\dagger \ddagger$. & $1,455^{\circ}$ & 248 & 263 & 290 & 306 & 327 & 320 & $35 \mathrm{I}$ & 337 & 268 & 301 & 258 \\
\hline Thurston $\$ \$$. & 2,223 & 354 & 360 & 377 & 462 & 599 & 759 & 740 & 671 & 695 & 644 & 600 \\
\hline Timworth $\$$. . & 1,375 & 149 & 166 & 210 & 216 & 212 & $24 I$ & 222 & 182 & 179 & 186 & 146 \\
\hline Tostock $\ddagger \S$. & 952 & 220 & 252 & 281 & 283 & 367 & 348 & 382 & 362 & 354 & 298 & 286 \\
\hline $\begin{array}{l}\text { Welnetham, } \\
\text { Great } \dagger \ddagger\end{array}$ & $1,493^{\circ}$ & 222 & 266 & 399 & 422 & 514 & 552 & 504 & 523 & 440 & 362 & 357 \\
\hline Welnetham, Little $\$$ & 599 & 142 & 527 & 176 & 180 & 206 & 178 & I 94 & 204 & 156 & I 74 & 138 \\
\hline Woolpit $\ddagger \S$. & $1,88 \mathrm{I}$ & 625 & 669 & 801 & 880 & 942 & 1,071 & 1,008 & 995 & $\mathbf{I}, 034$ & 1,018 & 863 \\
\hline \multicolumn{13}{|l|}{$\begin{array}{l}\text { Thingoe } \\
\text { Hundred }\end{array}$} \\
\hline Barrow \pm 8 . . & 2,677 & 614 & 645 & 755 & 856 & 995 & 1,120 & 1,030 & 940 & 910 & 952 & 967 \\
\hline Brockley $t \pm$. & $1,565^{\circ}$ & 253 & 261 & 276 & 319 & 380 & 378 & 340 & 347 & 316 & 279 & 243 \\
\hline Chevington $\ddagger \&$. & 2,445 & 445 & 490 & 590 & 573 & 624 & 600 & 621 & 636 & 556 & 545 & 457 \\
\hline Flempton $\$$. & 947 & $\begin{array}{r}443 \\
99\end{array}$ & 128 & 129 & 188 & 210 & 247 & 190 & 176 & 178 & 187 & 162 \\
\hline $\begin{array}{l}\text { Fornham } \\
\text { All Saints } 8\end{array}$ & 1,705 & 236 & 282 & 305 & 310 & 336 & $35^{8}$ & 381 & 375 & 424 & 395 & 333 \\
\hline $\begin{array}{l}\text { Hardwick } \\
\text { Extra Par. }\end{array}$ & 114 & - & - & - & - & 19 & 36 & 25 & 25 & 19 & 19 & 25 \\
\hline Hargrave t. & $1,108^{\circ}$ & 324 & 313 & 360 & 394 & 457 & 489 & 520 & 480 & 420 & 370 & 326 \\
\hline Hawstead $\$ . .$. & 2,304 & 392 & 409 & 404 & 414 & 457 & 520 & 446 & 427 & 321 & 325 & 297 \\
\hline Hengrave $\S$. & 897 & 196 & 178 & 168 & 238 & 228 & 240 & 219 & 200 & 199 & 189 & 222 \\
\hline Horningsheath $\S$. & 2,212 & 543 & 523 & 539 & 586 & 597 & 670 & 670 & 691 & 662 & 599 & 525 \\
\hline Ickworth § . . & 1,258 & 67 & 68 & 82 & 43 & 62 & 71 & 65 & 115 & 95 & 92 & 100 \\
\hline Lackford $\ddagger \S$. . & 2,338 & 162 & 128 & 163 & 193 & 193 & 216 & 197 & 181 & 175 & 193 & 178 \\
\hline Nowton $\ddagger \S$. . & 1,165 & 170 & 167 & 171 & 137 & 171 & 187 & 186 & 178 & 180 & 234 & 201 \\
\hline Rede $\ddagger \S$. & 1,239 & 161 & 202 & 239 & $23 I$ & $24 I$ & 247 & 245 & 231 & 224 & 204 & 182 \\
\hline Risby $\ddagger \S$ & 2,818 & 266 & 277 & 293 & 332 & 360 & $43 I$ & 427 & 423 & $44 \mathrm{I}$ & 400 & $35 I$ \\
\hline Saxham, Great $\ddagger \S$ & I, 450 & 226 & 276 & 260 & 260 & 271 & 293 & 270 & 247 & 239 & 189 & 199 \\
\hline Saxham, Little $\ddagger \S$ & 1,320 & 194 & 192 & 202 & 198 & 230 & 191 & 171 & 183 & 173 & 159 & 159 \\
\hline Westley $\&$ & 1,240 & 88 & 99 & 124 & 132 & I 44 & 118 & 140 & 172 & 160 & 158 & 152 \\
\hline Whepstead $\dagger \pm$. & $2,670^{\circ}$ & 546 & 635 & 664 & 618 & $68 \mathrm{I}$ & 652 & 677 & 648 & 625 & 502 & 472 \\
\hline \multicolumn{13}{|l|}{$\begin{array}{l}\text { Thredling } \\
\text { Hundred }\end{array}$} \\
\hline $\begin{array}{l}\text { Ashfield with } \\
\text { Thorpe t } 8\end{array}$ & $\mathrm{I}, 5^{80}$ & 252 & 248 & 309 & 375 & 343 & 327 & 306 & 322 & 227 & 194 & 214 \\
\hline Debenham $\ddagger \S$ & 3,322 & 1,215 & I, 224 & 1,535 & 1,629 & $\mathbf{1}, 667$ & 1,653 & $\mathbf{I}, 488$ & 1,349 & 1,179 & 1,219 & 1,182 \\
\hline Framsden $\ddagger \S$. & 2,862 & 684 & 573 & 702 & 642 & 829 & 828 & 811 & 797 & 785 & 734 & 585 \\
\hline Pettaugh $\ddagger \S$. . & 807 & 204 & 216 & 254 & 284 & 266 & 288 & 275 & 240 & 196 & $22 \mathrm{I}$ & 201 \\
\hline Winston $\ddagger \S$. & 1,509 & $26 \mathrm{i}$ & 298 & 366 & 398 & 399 & 392 & 352 & 299 & 297 & 285 & 289 \\
\hline \multicolumn{13}{|l|}{$\begin{array}{l}\text { Wangford } \\
\text { Hundred }\end{array}$} \\
\hline Barsham $t t$. & $1,871^{\circ}$ & 162 & 173 & 192 & 182 & 250 & 207 & 239 & 217 & 305 & 299 & 251 \\
\hline Beccles $\pm \delta^{*}$. . & 2,017 & 2,788 & 2,979 & 3,493 & 3,862 & 4,086 & 4,398 & 4,266 & 4,844 & 5,721 & 6,669 & 6,898 \\
\hline $\begin{array}{l}\text { Bungay Holy } \\
\text { Trinity }+ \pm\end{array}$ & $\mathrm{I}, 332^{\circ}$ & 903 & 1,098 & 1,313 & 1,663 & $1,86 I$ & $I, 86 I$ & $\mathbf{I}, 809$ & 1,957 & 1,863 & 1,872 & 1,698 \\
\hline $\begin{array}{l}\text { Bungay St. } \\
\text { Mary }+\ddagger\end{array}$ & $75^{\circ}$ & I,446 & 1,730 & 1,977 & 2,071 & 2,248 & 1,980 & I,996 & 1,875 & 1,729 & 1,709 & 1,636 \\
\hline Cove, North $\neq 8$. & 1,242 & 178 & 193 & 219 & 218 & 219 & 200 & 200 & 238 & 230 & 234 & 240 \\
\hline Ellough $\ddagger \delta$. & 1,109 & 157 & 147 & 155 & 146 & 155 & 133 & 126 & 127 & 153 & $\begin{array}{l}-34 \\
140\end{array}$ & 127 \\
\hline Flixton $\pm \$$ & 1,774 & 219 & 199 & 209 & 206 & 192 & 210 & 165 & 217 & 176 & 168 & 193 \\
\hline $\begin{array}{l}\text { Henstead (part } \\
\text { of }{ }^{86}:-\end{array}$ & & & & & & & & & & & & \\
\hline $\begin{array}{l}\text { Hulverstreet } \\
\text { Hamlet }\end{array}$ & - & 128 & 176 & 241 & 297 & 293 & 280 & - & - & - & - & - \\
\hline
\end{tabular}

36 See note 6, ante. 


\section{SOCIAL AND ECONOMIC HISTORY}

TABLE OF POPULATION, I80I-1901 (continued)

\begin{tabular}{|c|c|c|c|c|c|c|c|c|c|c|c|c|}
\hline PARISH & $\begin{array}{l}\text { Acre- } \\
\text { age }\end{array}$ & $180 x$ & I8II & 1821 & 1831 & 1841 & 1851 & 1861 & 1871 & $188 x$ & $189 \mathrm{I}$ & rgor \\
\hline \multicolumn{13}{|l|}{$\begin{array}{c}\text { Wangford } \\
\text { Hundred (cont.) }\end{array}$} \\
\hline Homersfield $\$$. . & $\mathbf{1}, 00 ;$ & 147 & 153 & 201 & 233 & 291 & 248 & 208 & 178 & 144 & 160 & 139 \\
\hline $\begin{array}{l}\text { Ilketshall St. } \\
\text { Andrew }+\S\end{array}$ & 1,718 & 368 & 404 & 472 & 512 & 548 & 565 & 515 & 465 & 472 & 484 & 373 \\
\hline Ilketshall St. John & 755 & $5^{I}$ & 62 & 66 & 72 & 71 & 72 & 77 & 87 & 73 & 93 & 72 \\
\hline $\begin{array}{l}\text { Ilketshall St. } \\
\text { Lawrence } \dagger\end{array}$ & $1,073^{\circ}$ & 113 & I 74 & 255 & 242 & 221 & 203 & 202 & 244 & 205 & 226 & 188 \\
\hline $\begin{array}{l}\text { Ilketshall St. } \\
\text { Margaret } \ddagger \S\end{array}$ & 2,097 & 295 & 289 & 269 & 309 & 315 & 306 & 326 & 295 & 286 & 268 & 250 \\
\hline Mettingham $\$ \S$. & 1,392 & 270 & 293 & 349 & 406 & 409 & $3^{82}$ & 387 & 348 & 366 & 325 & 318 \\
\hline Redisham \$. . . & 737 & $13^{8}$ & 145 & 156 & 179 & 165 & 152 & 182 & 165 & 181 & 169 & 117 \\
\hline Ringsfield $t \ddagger$. & $1,666^{\circ}$ & 194 & 226 & 280 & 315 & 311 & 287 & 324 & 338 & 285 & 309 & $32 I$ \\
\hline Shadingfield $\ddagger \S$. & $I, 403$ & 157 & 150 & 189 & 198 & 177 & 214 & 209 & 201 & 164 & 159 & 155 \\
\hline Shipmeadow $* \$ \S$ & 823 & 442 & $3^{87}$ & 339 & 383 & 265 & 515 & 334 & 287 & 214 & 223 & 245 \\
\hline Sotterley $\&$ & 1,597 & 254 & 255 & 287 & 243 & 223 & 227 & 231 & 219 & 268 & 246 & $22 I$ \\
\hline $\begin{array}{l}\text { South Elmham } \\
\text { All Saints }\end{array}$ & $I, 64 I$ & 192 & $18 \mathrm{I}$ & 239 & 239 & 224 & 232 & 197 & 190 & 216 & $24 I$ & 233 \\
\hline $\begin{array}{l}\text { South Elmham, St. } \\
\text { Cross or Sand- } \\
\text { croft } \S\end{array}$ & 1,310 & 203 & 214 & 233 & 234 & $25^{8}$ & 253 & 238 & 234 & 216 & 222 & 189 \\
\hline $\begin{array}{l}\text { South Elmham } \\
\text { St. James } \$ \$\end{array}$ & 1,315 & 243 & 264 & $35 \mathrm{I}$ & 263 & 289 & 269 & 294 & 268 & 232 & 201 & 187 \\
\hline $\begin{array}{l}\text { South Elmham } \\
\text { St. Margaret } 8\end{array}$ & 595 & I 86 & 191 & 181 & 169 & I 8 I & 182 & 152 & I43 & 145 & 123 & I 2 I \\
\hline $\begin{array}{l}\text { South Elmham } \\
\text { St. Michael § }\end{array}$ & 827 & 107 & II 2 & 128 & 147 & 145 & 150 & 156 & 139 & 127 & 116 & 84 \\
\hline $\begin{array}{l}\text { South Elmham } \\
\text { St. Nicholas }\end{array}$ & - & 93 & 97 & 9I & IOI & 90 & 94 & 103 & 80 & - & 一 & 一 \\
\hline $\begin{array}{l}\text { South Elmham } \\
\text { St. Peter } \S\end{array}$ & 570 & 129 & I3I & I39 & 122 & 9 I & 97 & 88 & 76 & 77 & 79 & 93 \\
\hline Weston $\$ 8:$ & 1,567 & 170 & I5I & 179 & 233 & 211 & 243 & $26 r$ & 250 & 265 & 253 & 217 \\
\hline Willingham $\$$ & 1,027 & 136 & 153 & 170 & 158 & 156 & 160 & 142 & 155 & 159 & 115 & 138 \\
\hline Worlingham $\ddagger \S$. & 1,672 & 168 & 177 & 22 I & 202 & 208 & I 74 & 192 & 200 & 184 & 198 & 181 \\
\hline \multicolumn{13}{|l|}{ Wilford Hundred } \\
\hline Alderton $\$ \S$. & 2,575 & 425 & 494 & 566 & 575 & 620 & 630 & 634 & 557 & 533 & 527 & 469 \\
\hline Bawdsey $+\varnothing$ & 1,636 & 344 & 409 & 414 & 454 & 468 & 478 & 426 & 402 & 432 & $46 \mathrm{I}$ & 400 \\
\hline Boulge $\S$ : . . & 545 & 39 & 35 & 44 & 55 & 45 & 39 & 39 & 42 & 64 & 48 & 57 \\
\hline Boyton $\ddagger 8$. . & 1,530 & 201 & 218 & 208 & 247 & 239 & 320 & 254 & 270 & $27 I$ & 223 & 198 \\
\hline Bredfield $\$$. . & I, 107 & 334 & 407 & 402 & 466 & 468 & 462 & 454 & 429 & 432 & 375 & 345 \\
\hline Bromeswell $\pm \S$. & 1,787 & 143 & 143 & 185 & I 78 & 200 & 226 & 210 & 219 & 210 & 236 & 214 \\
\hline Capel St. Andrew $\S$ & 2,330 & 162 & 158 & 157 & 190 & 222 & 202 & 231 & 209 & 190 & 183 & 164 \\
\hline Dallinghoo ${ }^{38}$. & 1,574 & $2+6$ & 280 & 303 & 354 & 346 & $3^{85}$ & 370 & 332 & $30 \mathrm{I}$ & 260 & 239 \\
\hline Debach $\S$ & 464 & 117 & II 4 & 113 & 133 & $12 \mathrm{I}$ & 104 & 144 & I 38 & I 2 I & 140 & 140 \\
\hline Hollesley $\$ \&$ & 3,987 & $46 i$ & 489 & 575 & 604 & 590 & 578 & 603 & 602 & 511 & 607 & $55 \mathrm{I}$ \\
\hline Melton § : . & 1,417 & 501 & 788 & $86 I$ & 863 & 980 & 1,039 & $\mathbf{I}, 084$ & $\mathbf{I}, 237$ & 1,400 & I, 5 IO & 1,640 \\
\hline Pettistree $\S^{39}$ & 1,779 & $24 I$ & 267 & 260 & 276 & 303 & 297 & 290 & 277 & 275 & 250 & 262 \\
\hline Ramsholt $\ddagger \S$ & 1,804 & 152 & 132 & 174 & 215 & 192 & 203 & 186 & 163 & 138 & 157 & 105 \\
\hline Shottisham $\ddagger \S$. & 1,134 & 161 & 196 & 235 & 280 & 283 & 372 & 317 & 329 & 277 & 257 & 209 \\
\hline Sutton $\ddagger \&$ & $5,44^{8}$ & 425 & 440 & 577 & 680 & 707 & 732 & 618 & 600 & 567 & 500 & 495 \\
\hline Ufford $88^{\circ}$ & 1,163 & $45^{\circ}$ & $54 \mathrm{I}$ & 629 & $66 \mathrm{I}$ & 673 & 725 & 656 & 570 & 554 & 532 & 545 \\
\hline $\begin{array}{l}\text { Wickham } \\
\text { Market * } \ddagger \S\end{array}$ & I, 186 & 896 & 906 & 1,015 & 1,202 & $\mathbf{I}, 400$ & 1,697 & $\mathbf{I}, 57 \mathrm{I}$ & $I, 54 I$ & I,469 & $\mathbf{1}, 537$ & 1,417 \\
\hline \multicolumn{13}{|l|}{$\begin{array}{l}\text { Bury St. Ed- } \\
\text { munds Borough }\end{array}$} \\
\hline St. James . & 1,331 & 3,565 & 3,780 & 4,769 & 5,942 & 6,269 & 6,668 & 6,714 & 7,885 & $9,44 \mathrm{I}$ & 9,968 & 9,979 \\
\hline St. Mary * $\downarrow$ & 1,616 & 4,090 & 4,206 & 5,230 & 5,494 & 6,269 & 7,232 & 6,604 & 7,043 & 6,670 & 6,662 & 6,276 \\
\hline
\end{tabular}

3; The area and the population (188I-IgoI) of South Elmham St. Nicholas are included with those of Suth Elmham All Saints.

${ }_{83}$ Dalling hoo is said to be partly in Loes Hundred, but is wholly entered in Wilford Hundred. It includes Dallinghoo Wield, formerly Extra Parochial, but now (Igor) a Civil Parish, containing no population.

99 Pertistres includes the Manor of Bing.

10 Ufford includes the Manor of Sogenhoe. 


\section{A HISTORY OF SUFFOLK}

TABLE OF POPULATION, I80I-IgOI (continued)

\begin{tabular}{|c|c|c|c|c|c|c|c|c|c|c|c|c|}
\hline PARISH & $\begin{array}{l}\text { Acre- } \\
\text { age }\end{array}$ & $180 \mathrm{~T}$ & 1811 & $182 \mathrm{I}$ & $188^{1}$ & $184 \mathrm{I}$ & $185 \mathrm{I}$ & I86I & 1871 & 188x & $189 \mathrm{r}$ & Igor \\
\hline \multicolumn{13}{|l|}{ Ipswich Borough } \\
\hline $\begin{array}{l}\text { Bramford } \\
\quad \text { (part of })^{41}\end{array}$ & 139 & - & - & - & - & 48 & 44 & 37 & 35 & 176 & 268 & 756 \\
\hline $\begin{array}{l}\text { St. Clement } \S^{48} \\
\text { Warren Houses }\end{array}$ & $\begin{array}{r}1,434 \\
69\end{array}$ & $\stackrel{2,424}{-}$ & 3,305 & $\stackrel{4,424}{-}$ & $\stackrel{4,779}{-}$ & $\begin{array}{r}5,945 \\
28\end{array}$ & $\begin{array}{r}7,025 \\
25\end{array}$ & $\begin{array}{r}7,061 \\
26\end{array}$ & $\begin{array}{r}7,632 \\
20\end{array}$ & $\begin{array}{r}8,976 \\
12\end{array}$ & $\begin{array}{r}10,063 \\
22\end{array}$ & $\begin{array}{r}12,537 \\
17\end{array}$ \\
\hline St. Helen $\ddagger \S^{43}$. & 223 & 327 & 848 & 781 & 961 & 1,352 & 2,593 & 2,748 & 3,662 & 4,207 & 4,335 & 4,703 \\
\hline St. Lawrence $\pm \&$. & 7 & 469 & 494 & 503 & 565 & 570 & 590 & 502 & 424 & 480 & 432 & $26 i$ \\
\hline St. Margaret 44. & I,3 I 4 & 1,923 & 2,705 & 3,214 & 4,300 & 4,539 & 5,892 & 8,108 & 9,537 & 12,027 & 13,596 & $16,75^{I}$ \\
\hline $\begin{array}{l}\text { Cold Dunghills } \\
\text { Extra Par. }{ }^{45}\end{array}$ & - & 35 & - & & & 66 & 57 & 44 & 29 & - & & \\
\hline $\begin{array}{l}\text { Globe Lane, or } \\
\text { George Street } \\
\text { Extra Par. }{ }^{46}\end{array}$ & - & - & - & - & 一 & 17 & 12 & 29 & 69 & - & - & - \\
\hline $\begin{array}{l}\text { St. Mary at the } \\
\text { Elms } \dagger t\end{array}$ & $11^{\circ}$ & 447 & 441 & 634 & 778 & 851 & 1,051 & 1,178 & 1,205 & I,III & 952 & 898 \\
\hline $\begin{array}{l}\text { St. Mary at the } \\
\text { Quay } \$ 47\end{array}$ & 17 & 810 & 573 & 773 & 1,039 & 988 & 1,045 & 1,017 & 1,013 & 948 & 913 & 862 \\
\hline $\begin{array}{l}\text { Shire Hall Yard } \\
\text { Extra Par. } \$\end{array}$ & 3 & - & - & - & - & 94 & 171 & 305 & 294 & 294 & 266 & 249 \\
\hline St. Mary Stoke $\ddagger$ & 1,464 & 385 & 568 & 752 & 789 & 992 & 2,055 & 2,518 & 3,080 & 3,306 & 4,099 & 5,417 \\
\hline $\begin{array}{l}\text { St. Mary at the } \\
\text { Tower } \ddagger \S\end{array}$ & 16 & 688 & 810 & 914 & $95 \mathrm{I}$ & 967 & 995 & 984 & 930 & 787 & 656 & 484 \\
\hline St. Matthew 40 & 657 & $\mathbf{I}, 206$ & I,353 & 1,722 & 2,204 & 3,458 & 5,086 & 6,216 & 7,424 & 9,912 & 12,482 & 14,168 \\
\hline St. Nicholas $t+$ & $27^{\circ}$ & 758 & 832 & 1,086 & 1,313 & 1,698 & I, 94 I & $\mathbf{I}, 9 \mathrm{I} \mathbf{2}$ & 1,913 & $\mathrm{I}, 947$ & 1,848 & 1,887 \\
\hline $\begin{array}{l}\text { St. Peter } \$ \delta \text { (part } \\
\text { Rushmere } \\
\text { of) }\end{array}$ & 167 & 986 & I, I 25 & 1,567 & 1,646 & 2,420 & 2,868 & 3,639 & 4,121 & 4,754 & 5,776 & 5,584 \\
\hline $\begin{array}{l}\text { Wicks Ufford } \\
\text { Hamlet }\end{array}$ & 662 & - & - & 一 & - & 223 & 254 & 240 & 238 & 229 & 252 & 601 \\
\hline $\begin{array}{c}\text { Sproughton (part } \\
\text { of) }\end{array}$ & 257 & - & - & - & 一 & 16 & 15 & 15 & 28 & 34 & 58 & 51 \\
\hline $\begin{array}{l}\text { St. Stephen } \\
\text { Felaws Houses } \\
\text { Extra Par. }\end{array}$ & 19 & $\left\{\begin{array}{l}422 \\
-\end{array}\right.$ & $\frac{416}{-}$ & $\underline{561}$ & $\underline{530}$ & $\begin{array}{r}503 \\
30\end{array}$ & $\begin{array}{r}522 \\
31\end{array}$ & $\begin{array}{r}679 \\
25\end{array}$ & $\begin{array}{r}610 \\
20\end{array}$ & \} 611 & 594 & 556 \\
\hline $\begin{array}{l}\text { Westerfield } \\
\text { (part of) }\end{array}$ & 630 & 187 & 248 & 289 & 253 & 269 & 275 & $26 I$ & 245 & 258 & 284 & 283 \\
\hline $\begin{array}{l}\text { Whitton cum } \\
\text { Thurlston (part } \\
\text { of) }\end{array}$ & 982 & 210 & 200 & 255 & 346 & 310 & 352 & 406 & 414 & 477 & 537 & 565 \\
\hline \multicolumn{13}{|l|}{ Sudbury Borough } \\
\hline All Saints ${ }^{54}$ & & 800 & 958 & 1,129 & I, I5I & 1,262 & $I, 25 I$ & 1,350 & 1,235 & I,07I & - & - \\
\hline St. Gregory $\dagger^{54}$. & & $I, 041$ & 998 & $I, 160$ & 1,710 & I,893 & 2,030 & 2,781 & 3,069 & 4,779 & 6,323 & 6,414 \\
\hline $\begin{array}{l}\text { St. Bartholomew } \\
\text { Extra Par. } \dagger\end{array}$ & $1,093^{\circ}$ & & & - & & & & & & & & \\
\hline St. Peter ${ }^{54}$. & & $\mathrm{I}, 442$ & 1,515 & $1,66 \mathrm{I}$ & 1,816 & 1,926 & $I, 941$ & 1,880 & 1,825 & - & - & - \\
\hline
\end{tabular}

41 See note 9, ante.

4 See note 45 , post.

48 Ipswich St. Margaret includes the Suffolk county gaol, which, however, is partly in St. Helen and St. Siephen Parishes.

14 See notes 43,45 , and 46 .

45 Cold Dunghills was returned (1811-183I) partly in St. Clement and partly in St. Margaret Parishes. It was added to St. Margaret prior to the $188 \mathrm{I}$ Census, in the area of which Parish its acreage is included.

46 Globe Lane (or George Street) includes High Street in I86I and $187 \mathrm{I}$. Prior to the I88I Census George Street was added to St. Matthew Parish and High Street to St. Margaret. The area of George Street is included in that of St. Matthew and that of High Street in St. Margaret's.

47 St. Mary-at-the-Quay includes, in 1831 , I70 persons in Extra Parochial houses. These houses were not included in 1811 and 1821 .

$\begin{array}{lll}48 \text { See note } 46 \text {, ante. } & \text { "See note } 13 \text {, ante. } \\ 53 \text { See note ro, ante. } & \text { See note } I I, \text { ante. }\end{array}$

54 The population of Sudbury St. Peter included with that of St. Gregory, 1881-190x; and that of Sudbury All Saints with that of St. Grogory in $189 \mathrm{I}$ and rgor. 


\title{
SOCIAL AND ECONOMIC HISTORY
}

\author{
General Notes
}

I. The Parishes in the Hundreds of Blything, Bosmere and Claydon, Carlford, Colneis, Loes, Mutford and Lothingland, Samford, Thingoe, Wangford, and Wilford were united by Act in or about 1764 for the purpose of collecting the poor in each hundred in a single workhouse. Loes and Wilford Hundreds maintained their poor together prior to $18 \mathrm{I} \mathbf{I}$.

2. The following Municipal Boroughs and Urban Districts were co-extensive at the 1901 Census with one (or more) places mentioned in the Table :-

Municipal Borough, or Urban District

Aldeburgh M.B.

Beccles M.B.

Bury St. Edmunds M.B.

Eye M.B.

Felixstowe and Walton U.D.

Leiston cum Sizewell U.D.

Saxmundham U.D. .

Southwold M.B.

Stowmarket U.D.

Woodbridge U.D.

\section{Place}

Aldeburgh Parish (Plomesgate Hundred).

Beccles Parish (Wangford Hundred).

Bury St. Edmunds : St. James and St. Mary Parishes.

Eye Parish (Hartismere Hundred).

Felixstowe and Walton Parishes (Colneis Hundred).

Leiston cum Sizewell Parish (Blything Hundred).

Saxmundham Parish (Plomesgate Hundred).

Southwold Parish (Blything Hundred).

Stowmarket Township (Stow Hundred).

Woodbridge Parish (Loes Hundred). 


$\begin{aligned} & \text { DA The Victoria history of the } \\ & 670 \quad \text { county of Suffolk } \\ & \text { S9V6 } \\ & \text { V.1 }\end{aligned}$
Acendle cor z care tor corse to be rebound.

$$
\begin{gathered}
\text { For use in } \\
\text { the Library } \\
\text { ONLY }
\end{gathered}
$$

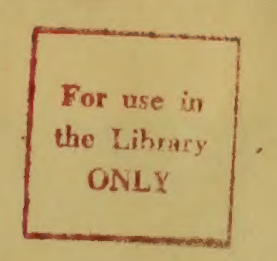




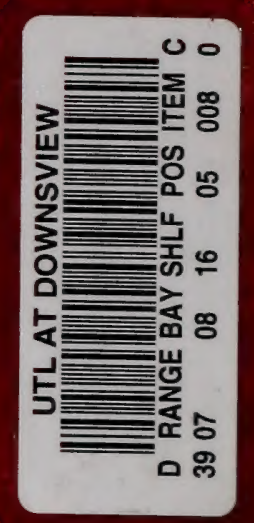

